\title{
PUNÇÃO EM LAJES LISAS COM ARMADURA DE CISALHAMENTO E PILAR DE CANTO REENTRANTE
}

ELAINE JARICUNA PEREIRA DE ALBUQUERQUE

TESE DE DOUTORADO EM ESTRUTURAS E CONSTRUÇÃO CIVIL DEPARTAMENTO DE ENGENHARIA CIVIL E AMBIENTAL

\section{FACULDADE DE TECNOLOGIA} UNIVERSIDADE DE BRASÍLIA 
UNIVERSIDADE DE BRASÍLIA

FACULDADE DE TECNOLOGIA

DEPARTAMENTO DE ENGENHARIA CIVIL E AMBIENTAL

\author{
PUNÇÃO EM LAJES LISAS COM ARMADURA DE \\ CISALHAMENTO E PILAR DE CANTO REENTRANTE
}

ELAINE JARICUNA PEREIRA DE ALBUQUERQUE

ORIENTADOR: GUILHERME SALES S. A. MELO

TESE DE DOUTORADO EM ESTRUTURAS E CONSTRUÇÃO CIVIL

PUBLICAÇÃO: E.TD - 002 A/15

BRASÍLIA/DF: AGOSTO - 2015 


\title{
UNIVERSIDADE DE BRASÍLIA
}

FACULDADE DE TECNOLOGIA

DEPARTAMENTO DE ENGENHARIA CIVIL E AMBIENTAL

\author{
PUNÇÃO EM LAJES LISAS COM ARMADURA DE \\ CISALHAMENTO E PILAR DE CANTO REENTRANTE
}

ELAINE JARICUNA PEREIRA DE ALBUQUERQUE

TESE DE DOUTORADO SUBMETIDA AO DEPARTAMENTO DE ENGENHARIA CIVIL E AMBIENTAL DA FACULDADE DE TECNOLOGIA DA UNIVERSIDADE DE BRASÍLIA, COMO PARTE DOS REQUISITOS NECESSÁRIOS PARA A OBTENÇÃO DO GRAU DE DOUTOR EM ESTRUTURAS E CONSTRUÇÃO CIVIL.

\section{APROVADA POR:}

Prof. Guilherme Sales S. de A. Melo, PhD (UnB) (Orientador)

Prof. Marcos Honorato de Oliveira, Dr. (UnB) (Examinador Interno)

Prof. Yosiaki Nagato, Dr. (UnB)

(Examinador Interno)

Prof. Américo Campos Filho, Dr. (UFRGS)

(Examinador Externo)

Prof. Dênio Ramam Carvalho de Oliveira, Dr. (UFPA)

(Examinador Externo)

BRASÍLIA/DF, 07 DE AGOSTO DE 2015. 


\section{FICHA CATALOGRÁFICA}

\begin{tabular}{|l|}
\hline ALBUQUERQUE, ELAINE JARICUNA PEREIRA DE \\
Punção em Lajes Lisas com Armadura de Cisalhamento e Pilar de Canto Reentrante \\
[Distrito Federal] 2015. \\
xxxviii, 379 p., $297 \mathrm{~mm}$ (ENC/FT/UnB, Doutora em Estruturas e Construção Civil, \\
$\begin{array}{ll}\text { 2015). Tese de Doutorado - Universidade de Brasília. Faculdade de Tecnologia. } \\
\text { Departamento de Engenharia Civil e Ambiental. }\end{array}$ \\
\begin{tabular}{ll} 
1. Punção & 2. Lajes Lisas \\
3. Pilar de Canto Reentrante & 4. Armadura de Cisalhamento \\
I. ENC/FT/UnB & II. Título (Doutor) \\
\hline
\end{tabular}
\end{tabular}

\section{REFERÊNCIA BIBLIOGRÁFICA}

ALBUQUERQUE, E. J. P. (2015). Punção em Lajes Lisas com Armadura de Cisalhamento e Pilar de Canto Reentrante. Tese de Doutorado em Estruturas e Construção Civil, Publicação E.TD - 002 A/15, Departamento de Engenharia Civil e Ambiental, Universidade de Brasília, Brasília, DF, 379 p.

\section{CESSÃO DE DIREITOS}

AUTOR (A): Elaine Jaricuna Pereira de Albuquerque.

TÍTULO: Punção em Lajes Lisas com Armadura de Cisalhamento e Pilar de Canto Reentrante. [Distrito Federal] 2015.

GRAU: Doutor $\quad$ ANO: 2015

É concedida à Universidade de Brasília permissão para reproduzir cópias desta tese de doutorado e para emprestar ou vender tais cópias somente para propósitos acadêmicos e científicos. $\mathrm{O}$ autor (a) reserva outros direitos de publicação e nenhuma parte dessa tese de doutorado pode ser reproduzida sem autorização por escrito do autor (a).

Elaine Jaricuna Pereira de Albuquerque

Rua Doutor Werneck 104, Torre I, ap. 1105, Villa Albuquerque.

CEP: 79.060-300

e-mail: elaine_jari@hotmail.com 


\section{DEDICATÓRIA}

Dedico esse trabalho aos meus pais, Paulo e

Quintina e aos meus irmãos, Ridley e Rondinelle. 


\section{AGRADECIMENTOS}

Primeiramente agradeço a DEUS, por ter me dado forças e iluminar meu caminho ao longo dessa jornada. Ao Professor Guilherme Sales S. A. Melo pelas orientações, sugestões, discursões e cobranças fundamentais para a realização desse trabalho, agradeço também pela confiança depositada em mim, por ter possibilitado e incentivado o doutorado sanduíche. Ao Professor Yosiaki Nagato pelas orientaçãos, sugestões e contribuições durante os ensaios. Ao Professor Paul E. Regan pela idealização do tema dessa pesquisa, orientações na elaboração das séries de ensaios, questionamentos e sugestões. Ao professor Pinho Ramos pelas orientações, discursões e sugestões durante o doutorado sanduíche na Universidade NOVA de Lisboa em Portugal. Ao professor Válter Lúcio e sua família, Luíza e Rita, pelas orientações nesse trabalho além da atenção e carinho sua e de sua família tornando minha estadia em Portugal a melhor possível. Ao Professor e amigo Marcos Honorato pela paciência, pelas valiosas orientações e sugestões durante discursões que foram fundamentais para finalizar esse trabalho. Ao Professor e amigo Maurício, que em algumas reuniões em Brasília contribuiu com suas indagações e sugestões. Aos queridos amigos que ajudaram na execução dos ensaios: Galileu, Wanderley, Nívia, Wallison, Ramon, Alejandro, Marília, Erwin, Gelson, Eduardo, Fabiano, Filipe, Leonardo, Henrique e Wagner cuja participação foi fundamental para a conclusão deste trabalho. Aos amigos conquistados no PECC que contribuíram com sugestões ou apoio no desenvolvimento da pesquisa: Elisandra, Fernanda, Maria Cláudia, Agno, Carlos, Uchôa, Yina, Dyorgge e Nazaré. Aos amigos conquistados na Universidade NOVA de Lisboa: Dinarte, André, Micael, Leonardo, Hugo, Mariana, Jorne, Pedro Maques, e em especial ao Mamede que me ajudou na modelagem computacional das lajes dessa pesquisa. Aos técnicos, Leandro, Pedro, Júlio, Adelmo e Magno do Laboratório de Estruturas pela colaboração no período de ensaios. Aos técnicos Severo, Woshington e Valderi do Laboratório de Materiais e Artur do Laboratório de Mecânica. A Concrecon pelo fornecimento do concreto utilizado nessa pesquisa. A empresa Cervenka que disponibilizou uma licença para utilização do programa ATENA. Ao CNPq e CAPES pela ajuda financeira. Aos meus pais e irmãos, pelo apoio, incentivo e amor. À secretária do

PECC e amiga, Eva pelo apoio junto ao programa. À minha família, aos amigos de Boa Vista e aos amigos conquistados em Brasília que sempre torceram por esse trabalho. 


\title{
RESUMO
}

\section{PUNÇÃO EM LAJES LISAS COM ARMADURA DE CISALHAMENTO E PILAR DE CANTO REENTRANTE}

\author{
Autora: Elaine Jaricuna Pereira de Albuquerque \\ Orientador: Guilherme Sales S. de A. Melo \\ Programa de Pós-graduação em Estruturas e Construção Civil \\ Brasília, agosto de 2015.
}

Ligações laje-pilar em lajes lisas podem romper por punção para uma carga inferior à correspondente de flexão, devido às altas tensões advindas do momento fletor e do esforço cortante, e por isso tem sido muito estudadas. No entanto, dentre os tipos de ligação lajepilar (pilar interno, de borda ou de canto), as ligações com pilares de canto reentrante não havia ainda sido estudado com profundidade, principalmente no caso de momentos desbalanceados em uma ou duas direções.

Nesta pesquisa foram analisadas experimentalmente 12 (doze) ligações lajes lisas / pilar, com pilar quadrado de canto reentrante com $300 \mathrm{~mm}$ de lado, com espessura de $180 \mathrm{~mm}$, e as principais variáveis investigadas foram a presença de armadura de cisalhamento disposta radialmente, a taxa de armadura de flexão na região do pilar, que variou de 0,8 a $2,1 \%$, a presença de armadura de torção no bordo, e o desbalanceamento dos momentos nas duas direções, com excentricidades variando de 267 a $504 \mathrm{~mm}$. Durante os ensaios foram monitoradas as deformações nas armaduras de flexão, cisalhamento e torção; deformações no concreto; deslocamentos verticais; padrão de fissuração; cargas últimas; rotações das lajes e modos de ruptura.

Os resultados experimentais foram comparados com uma proposição para a determinação das resistências esperadas pelas normas NBR 6118 (2014), Eurocode 2 (2004) e ACI 318 (2014), e pelas recomendações do MC2010 (2013), pois as lajes lisas com pilares reentrantes não são abordados por estas normas e recomendações. Também foi realizada uma simulação numérica utilizando o software ATENA, que emprega o método dos elementos finitos para efetuar análises tridimensionais não lineares em estruturas de concreto armado.

Palavras-chave: laje lisa, punção, pilar de canto reentrante, armadura de cisalhamento e armadura de torção. 
ABSTRACT

PUNCHING OF FLAT SLAB WITH SHEAR REINFORCEMENT AND REENTRANT CORNER COLUMN

Author: Elaine Jaricuna Pereira de Albuquerque

Supervisor: Guilherme Sales S. de A. Melo

Programa de Pós-graduação em Estruturas e Construção Civil

Brasília, August of 2015.

In failure slab-column connection failure of flat slabs is observed high stresses are originated by that of bending and shearing efforts, which can cause failure by punching with a load lower than the bending. The types of slab-column connection, internal, edge, corner and re-entrant corner can appear in any deck. However the connection slab-column of reentrant corner is not discussed by any research as the other cases, its mechanical model and its behavior with unbalanced moments in one or both directions are unknown. In this research were analyzed experimentally 12 flat slabs with thickness of $180 \mathrm{~mm}$, supported by a square column with sides of $300 \mathrm{~mm}$ and molded with machined concrete with average strength of $45 \mathrm{MPa}$. The experimental results were: strain in bending, shear and torsion reinforcement; concrete strains; vertical displacement; map of cracking; ultimate loads; rotations of the slabs and failure modes. The variables were: eccentricity, bending reinforcement ratio, amount of shear reinforcement and torsion reinforcement. Strength of punching shear get in the tests was compared with the strength provided by the NBR 6118 code (2014), Eurocode 2 (2004), ACI 318 (2014) and MC2010 (2013), but all the standards had to be adapted because they do not cover punching in slabs with reentrant corner column. Also a numerical simulation was made using the ATENA software designed to make non-linear three-dimensional analysis of reinforced concrete structures. Thus, the data monitored in the laboratory ware correlated with the results from finite element modeling. Some of the major contributions of this study were to show the general behavior of the slab connection with reentrant corner column with respect to displacements, strains, cracking, failure mode and failure surface; analyze the behavior and the adapted codes; and show how to treat this type of connection.

Keywords: flat slab, punching shear, re-entrant corner column, shear reinforcement, torsional reinforcement. 


\section{SUMÁRIO}

1 INTRODUÇÃ 0 ................................................................................................... 1

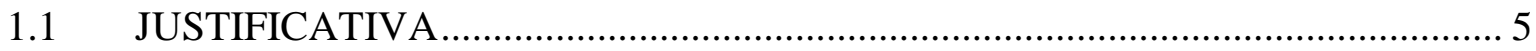

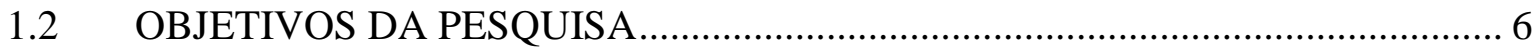

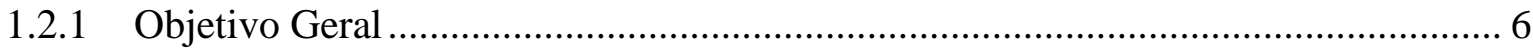

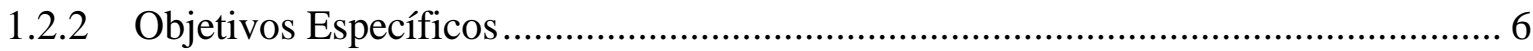

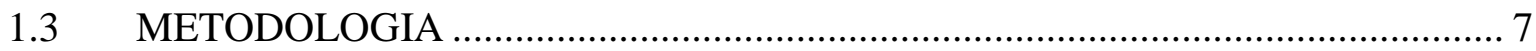

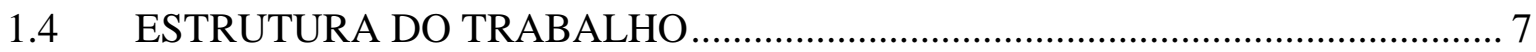

2 REVISÃO BIBLIOGRÁFICA ………….......................................................9

2.1 CONCEITOS FUNDAMENTAIS ……………………………………......... 10

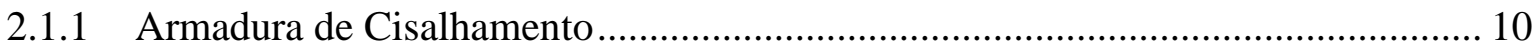

2.2 TRABALHOS EXPERIMENTAIS CONSIDERADOS PARA O ESTUDO DO FENÔMENO DE PUNÇÃO EM LAJES LISAS DE CONCRETO ARMADO COM

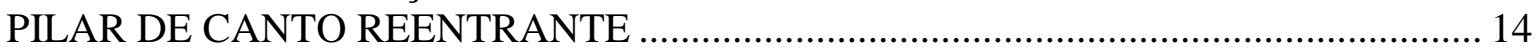

2.2.1 CARES TECHNICAL APPROVAL REPORT TA7 5041 (2012) .......................... 16

2.3 PRESCRIÇÕES NORMATIVAS PARA RESISTÊNCIA À PUNÇÃO ................ 20

2.3.1 NBR 6118 (2014) - Projeto de Estruturas de Concreto - Procedimento................... 20

2.3.2 Eurocode 2 (2004) - Design of Concrete Structures …………………………..... 26

2.3.3 ACI 318 (2014) - Building Code Requirements for Structural Concrete ............... 33

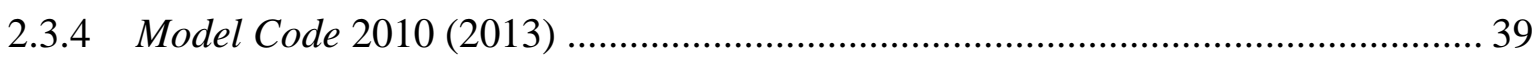

3 PROGRAMA EXPERIMENTAL .................................................................... 47

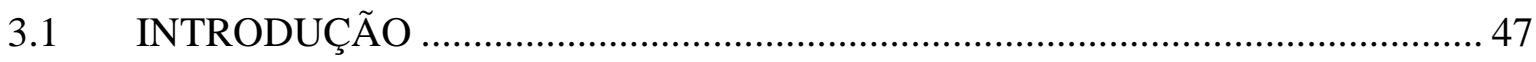

3.2 CARACTERÍSTICAS DAS LAJES ENSAIADAS ………………………….... 48

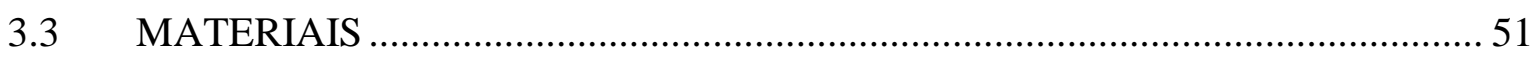

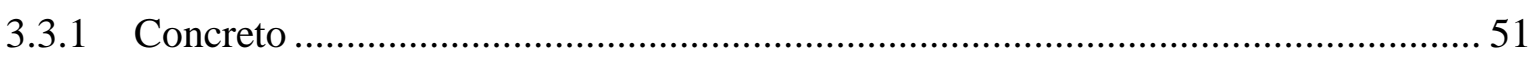

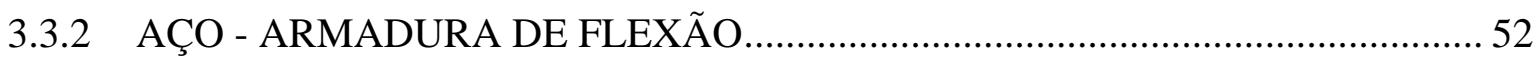

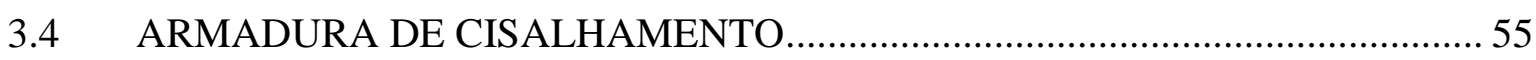

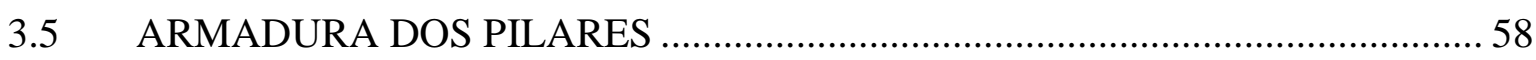

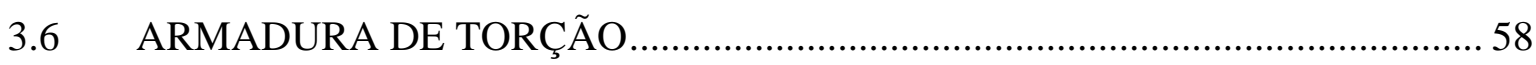

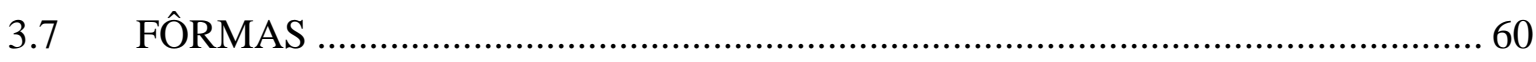

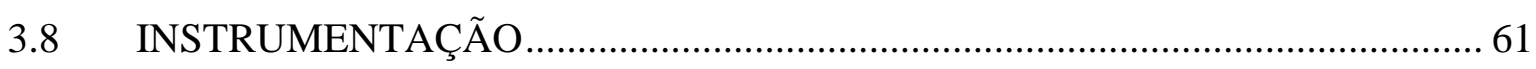

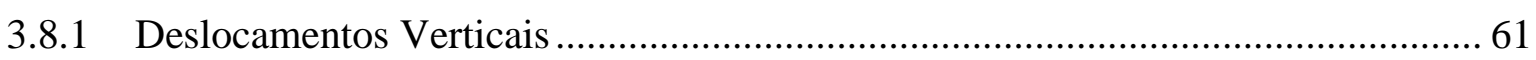

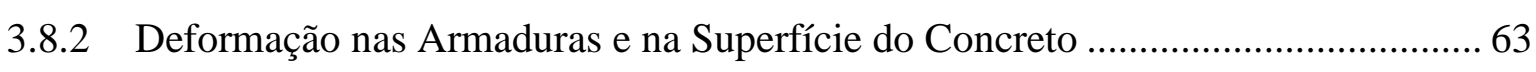

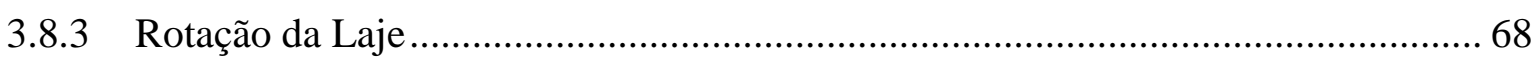




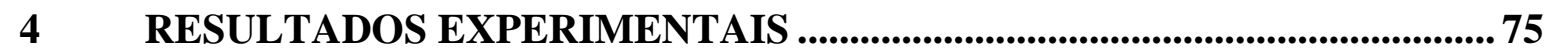

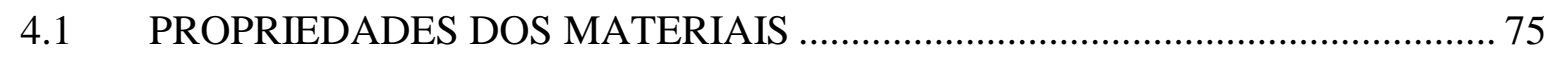

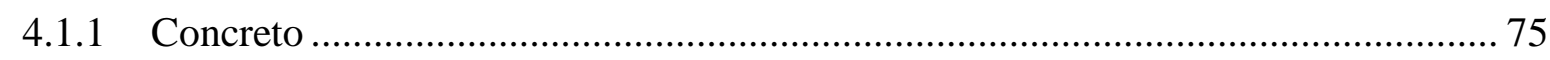

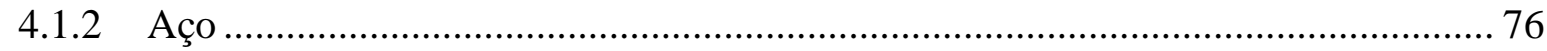

4.1.3 CARGAS DE RUPTURA DAS LAJES ENSAIADAS .................................... 79

4.1.4 RESISTÊNCIA À FLEXÃO DAS LAJES DE CONCRETO ARMADO ............. 79

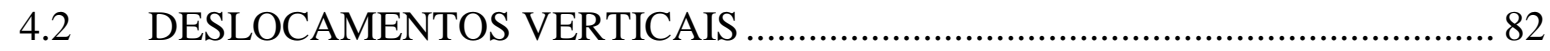

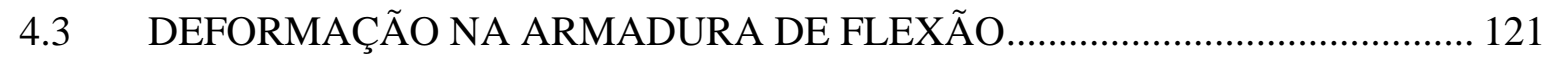

4.4 DEFORMAÇÃO NA ARMADURA DE CISALHAMENTO (STUDS) .............. 139

4.5 DEFORMAÇÃO NA ARMADURA DE TORÇÃO ............................................ 144

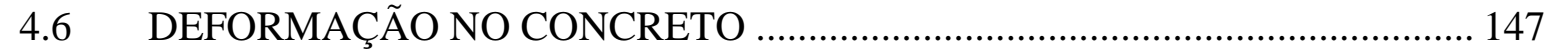

4.7 RESUMO DOS RESULTADOS EXPERIMENTAIS .................................... 152

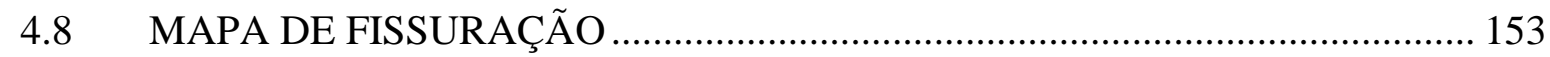

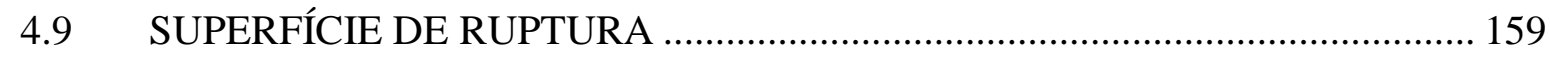

5 ANÁLISE DOS RESULTADOS EXPERIMENTAIS ....................................... 166

5.1 COMPARAÇÃO ENTRE OS RESULTADOS EXPERIMENTAIS DAS LAJES 168

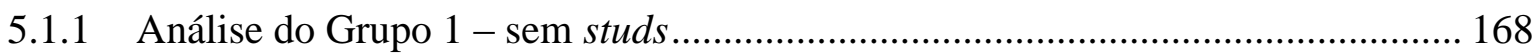

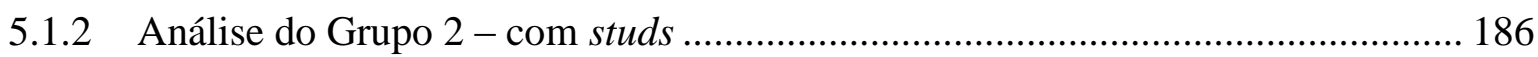

5.1.3 Análise do Grupo 3 - com estribos .................................................................. 193

5.1.4 Análise do Grupo 4 - sem e com studs ............................................................... 197

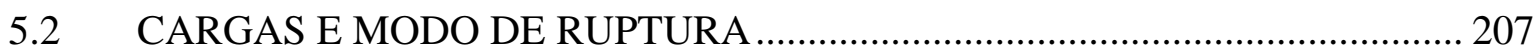

6 ANÁLISE NUMÉRICA (SOFTWARE ATENA 3D).................................. 211

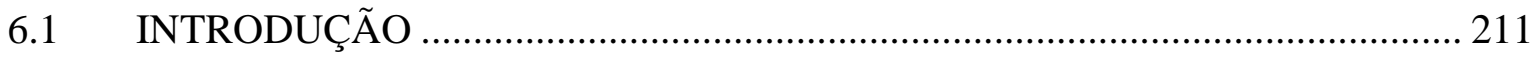

6.2 MODELOS CONSTITUTIVOS DO CONCRETO ............................................ 211

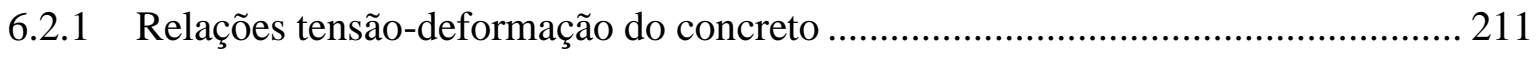

6.2.2 Comportamento do concreto à tração ................................................................. 213

6.2.3 Comportamento do concreto à compressão ....................................................... 214

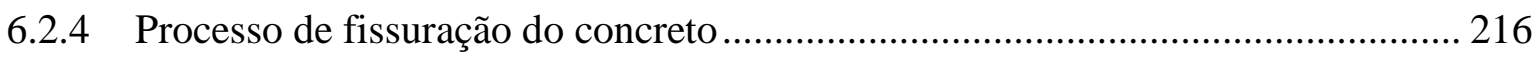

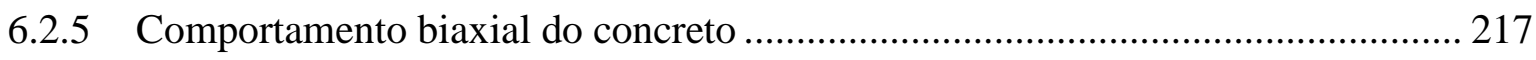

6.2.6 Modelo de fissuração do concreto...................................................................... 219

6.2.7 Comportamento do concreto após fissuração .................................................... 221

6.3 MODELOS CONSTITUTIVOS DAS ARMADURAS DE AÇO....................... 222

6.3.1 Relações tensão-deformação do aço .............................................................. 222 


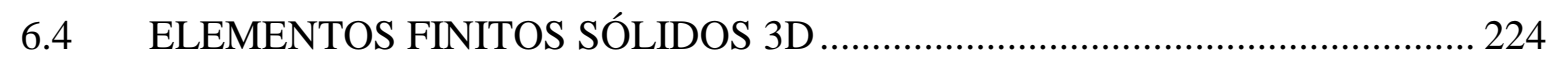

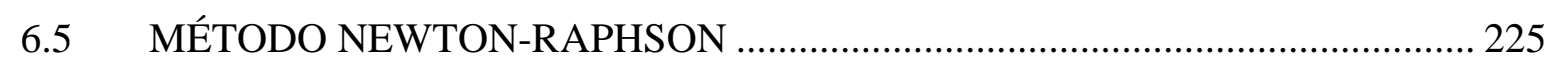

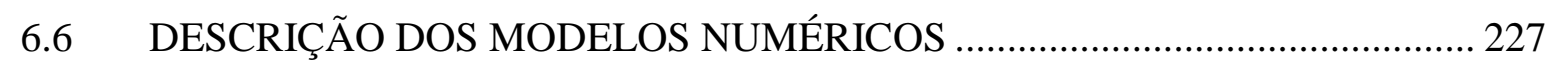

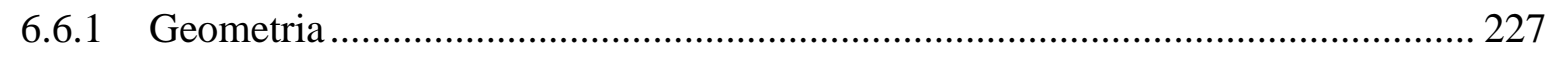

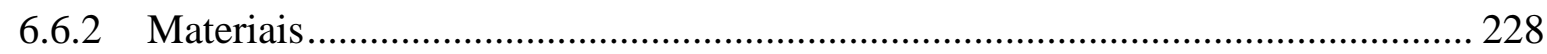

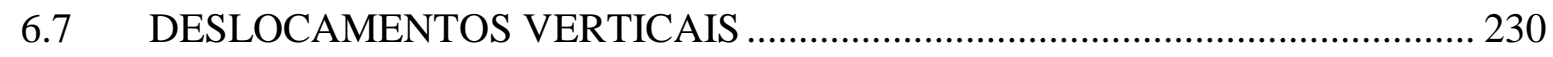

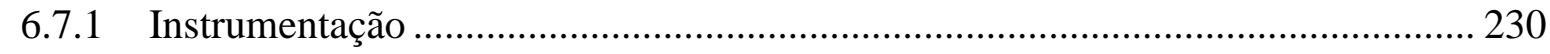

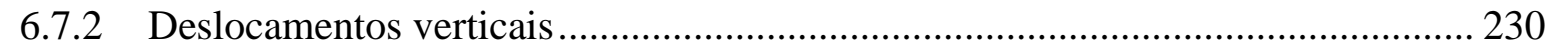

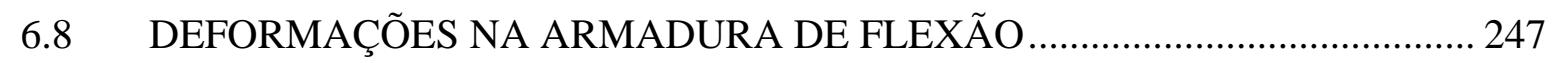

6.9 DEFORMAÇÃO DA ARMADURA DE CISALHAMENTO ............................ 263

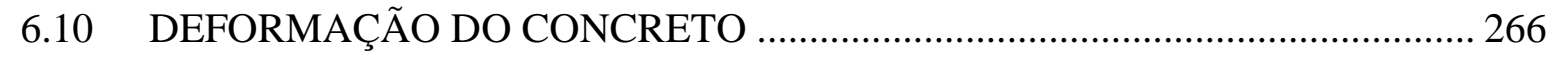

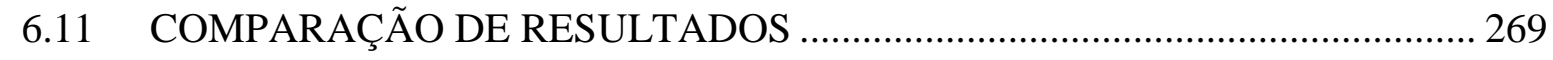

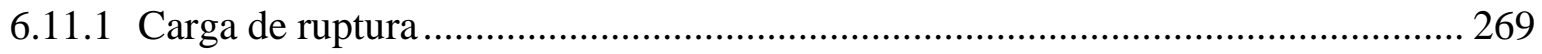

7 ANÁLISE DAS EXPRESSÕES NORMATIVAS.............................................. 273

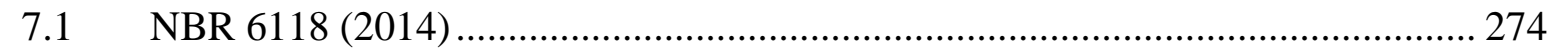

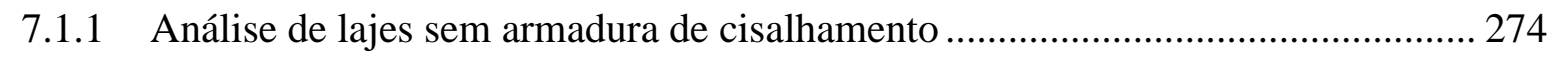

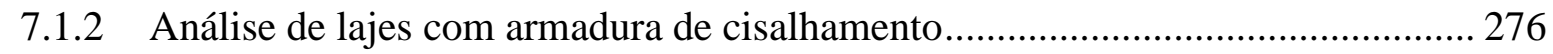

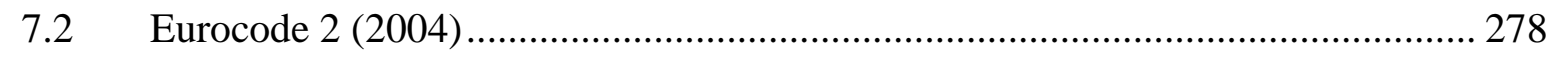

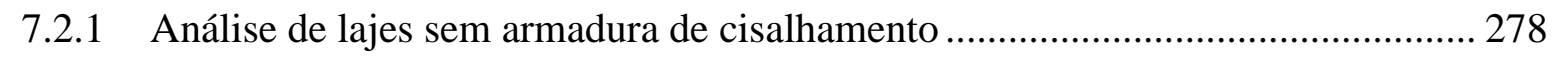

7.2.2 Análise de lajes com armadura de cisalhamento.............................................. 280

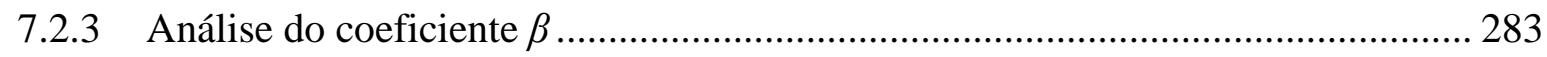

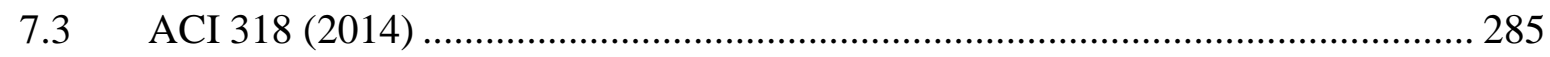

7.3.1 Análise de lajes sem armadura de cisalhamento ............................................ 285

7.3.2 Análise de lajes com armadura de cisalhamento................................................... 286

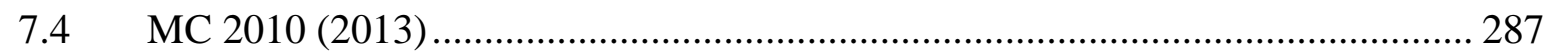

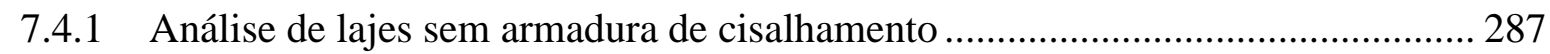

7.4.2 Análise de lajes com armadura de cisalhamento................................................. 290

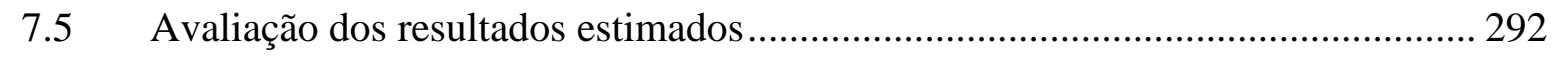

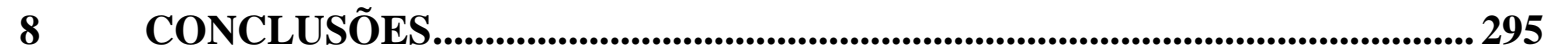

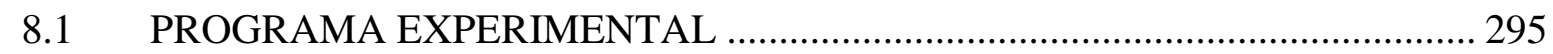

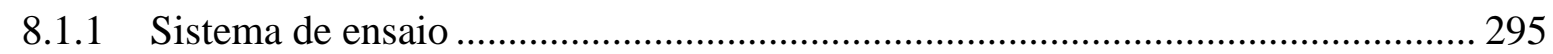

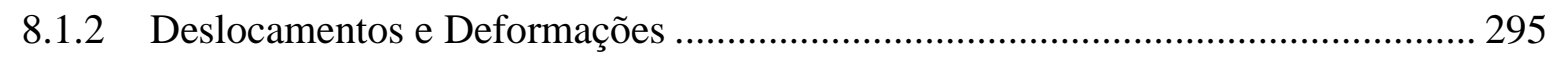

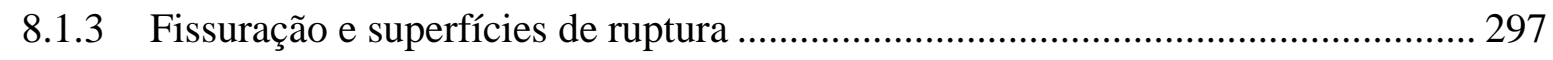

8.1.4 Influência das variáveis nas cargas de ruptura ................................................... 298

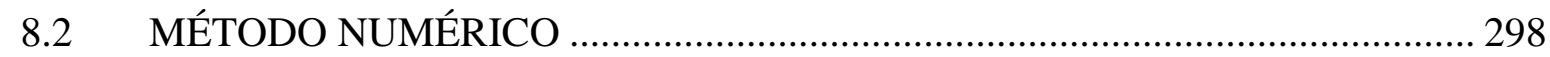




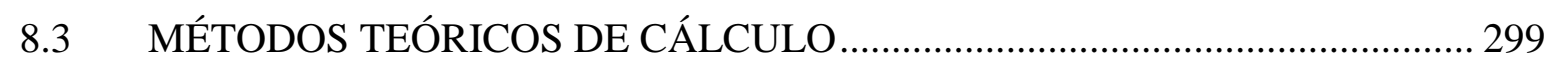

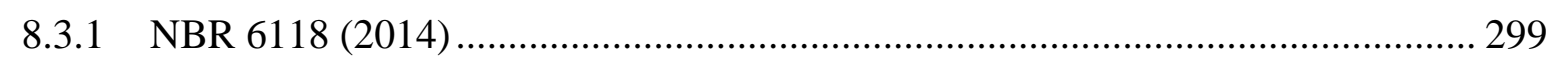

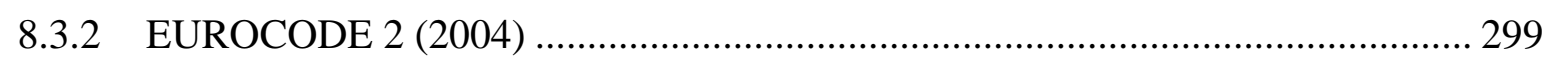

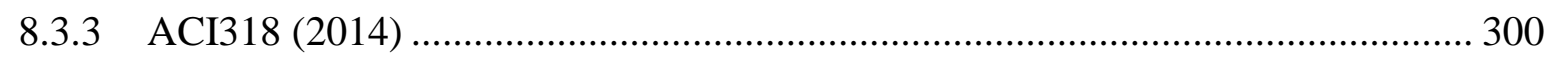

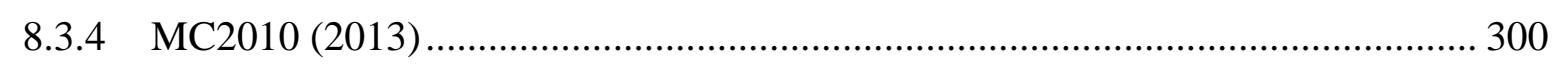

8.4 SUGESTÕES PARA TRABALHOS FUTUROS …………………………….... 301

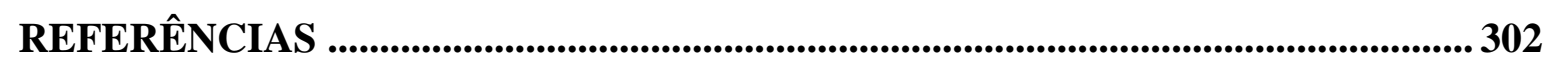




\section{LISTA DE TABELAS}

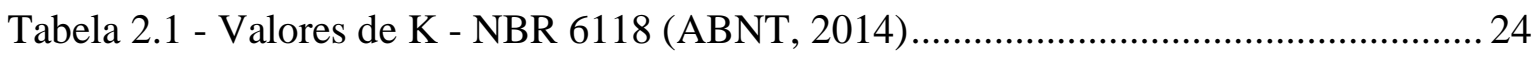

Tabela 2.2 - Valores de k para pilares retangulares - Eurocode 2 (2004) .......................... 29

Tabela 2.3 - Rotação da laje em torno do pilar na zona externa à ruptura........................... 43

Tabela 3.1 - Identificação e características das lajes ensaiadas ........................................ 50

Tabela 4.1 - Propriedades mecânicas do Concreto........................................................... 76

Tabela 4.2 - Propriedades mecânicas do aço utilizado nas lajes ........................................ 77

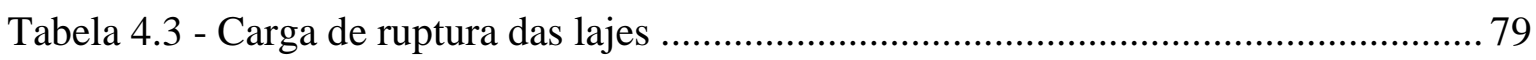

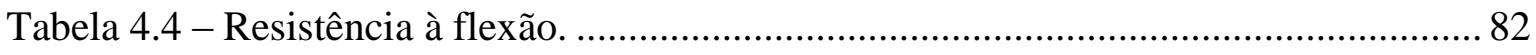

Tabela 4.5 - Resultados experimentais (deslocamentos e deformação do concreto)........ 152

Tabela 4.6 - Resumo dos resultados experimentais (deformação da armadura de flexão).

Tabela 4.7 - Resultados experimentais (deformação da armadura de cisalhamento)....... 153

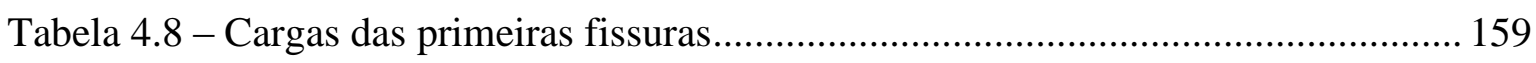

Tabela 4.9 - Resumo dos resultados experimentais (deformação da armadura de flexão).

Tabela 5.1 - Grupos e seus parâmetros analisados. ........................................................... 166

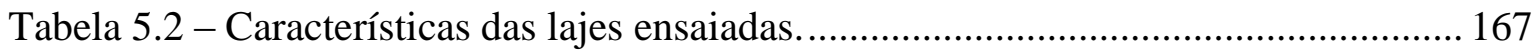

Tabela 5.3 - Características das lajes L01 e L04. ........................................................... 168

Tabela 5.4 - Características das lajes L08, L12 e L07 ................................................... 172

Tabela 5.5 - Características das lajes L06, L08, L07 e L04.. ....................................... 176

Tabela 5.6 - Características das lajes L05 e L01........................................................... 180

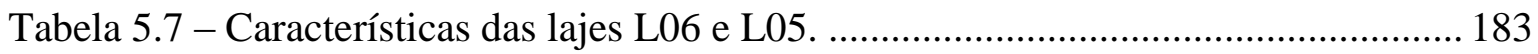

Tabela 5.8 - Características das lajes L02, L09 e L03 .................................................. 186

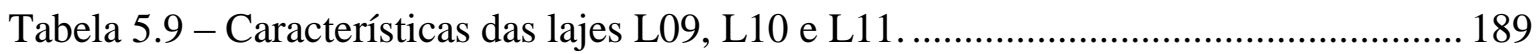

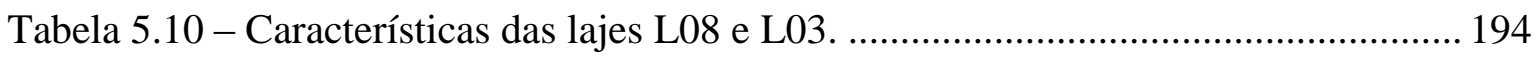

Tabela 5.11 - Características das lajes L02, L09, L04 e L03......................................... 197

Tabela 5.12 - Características das lajes L05, L01 e L10 .................................................. 200

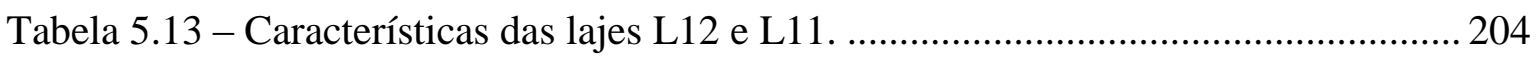

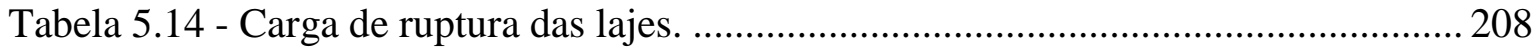

Tabela 5.15 - Resumo das resultados experimentais analisados.................................... 210

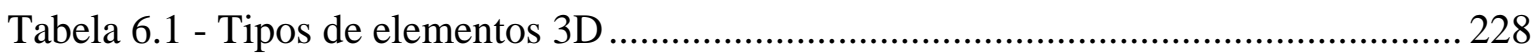


Tabela 6.2 - Parâmetros de entrada no ATENA

Tabela 6.3 - Cargas das primeiras fissuras.

Tabela 6.4 - Cargas de ruptura das lajes obtidas experimentalmente e numericamente... 270

Tabela 7.1 - Características das lajes sem armadura de cisalhamento. 273

Tabela 7.2 - Características das lajes com armadura de cisalhamento. 273

Tabela 7.3 - Critérios de avaliação $V_{u} / V_{\text {NORMA }}$

Tabela 7.4 - Previsão da carga de ruptura para lajes sem armadura de cisalhamento pela NBR 6118 (2014)

Tabela 7.5 - Previsão da carga de ruptura dos casos testados para lajes sem armadura de cisalhamento.

Tabela 7.6 - Previsão da carga de ruptura para lajes com armadura de cisalhamento pela NBR 6118 (2014).

Tabela 7.7 - Previsão da carga de ruptura do CASO1 testado para lajes com armadura de cisalhamento.

Tabela 7.8 - Previsão da carga de ruptura do CASO2 testado para lajes com armadura de cisalhamento.

Tabela 7.9 - Previsão da carga de ruptura das lajes sem armadura de cisalhamento pelo EC2 (2004).

Tabela 7.10 - Previsão da carga de ruptura dos casos testados para lajes sem armadura de cisalhamento.

Tabela 7.11 - Previsão da carga de ruptura das lajes com armadura de cisalhamento pelo EC2 (2004). 280

Tabela 7.12 - Previsão da carga de ruptura do CASO 1 testado para lajes com armadura de cisalhamento.

Tabela 7.13 - Previsão da carga de ruptura do CASO 2 testado para lajes com armadura de cisalhamento.

Tabela 7.14 - Previsão da carga de ruptura do CASO 3 testado para lajes com armadura de cisalhamento. 282

Tabela 7.15 - Previsão da carga de ruptura do CASO 4 testado para lajes com armadura de cisalhamento.

Tabela 7.16 - Comparação dos coeficientes $\beta$.

Tabela 7.17 - Previsão da carga de ruptura para lajes sem armadura de cisalhamento pelo ACI 318 (2014) 
Tabela 7.18 - Previsão da carga de ruptura dos casos testados para lajes sem armadura de cisalhamento.

Tabela 7.19 - Previsão da carga de ruptura para lajes com armadura de cisalhamento pelo ACI (2014)

Tabela 7.20 - Previsão da carga de ruptura do CASO 1 testado para lajes com armadura de cisalhamento. 287

Tabela 7.21 - Previsão da carga de ruptura para lajes sem armadura de cisalhamento pelo MC 2010 (2013) utilizando o nível de aproximação II

Tabela 7.22 - Previsão da carga de ruptura pelo MC 2010 (2013) utilizando o nível de aproximação II.

Tabela 7.23 - Previsão da carga de ruptura pelo MC 2010 (2013) utilizando o nível de aproximação III.

Tabela 7.24 - Previsão da carga de ruptura dos casos testados para lajes sem armadura de cisalhamento.

Tabela 7.25 - Previsão da carga de ruptura pelo MC2010 (2013) utilizando o nível de aproximação II

Tabela 7.26 - Previsão da carga de ruptura do Caso 1 testado para as lajes com armadura de cisalhamento.

Tabela 7.27 - Previsão da carga de ruptura pelo MC2010 (2013) utilizando o nível de aproximação III.

Tabela 7.28 - Previsão da carga de ruptura do Caso 1 testado para as lajes com armadura de cisalhamento.

Tabela 7.29 - Previsão da carga de ruptura pelas normas. 


\section{LISTA DE FIGURAS}

Figura 1.1 - Sistemas estruturais em lajes lisas (FERREIRA, 2010) 1

Figura 1.2 - Exemplos de colapsos estruturais surgidos por esforços de punção.................. 3

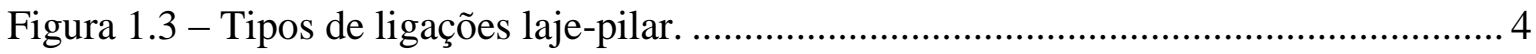

Figura 1.4 - Ruptura por punção em laje-lisa (modificado - Mirzaei, 2010) ........................ 4

Figura 1.5 - Perspectivas das superfícies de ruína devidas à punção em ligações laje -pilar

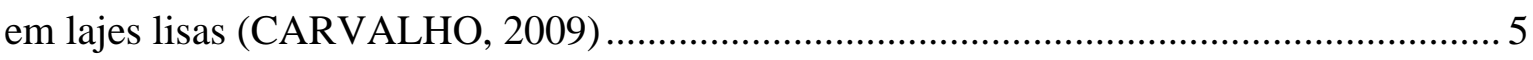

Figura 2.1 - Esquema de ruptura por punção para lajes lisas de concreto armado sem

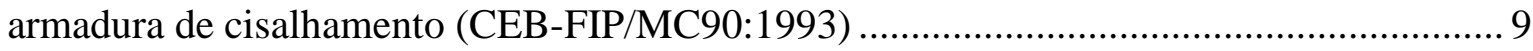

Figura 2.2 - Tipos de armaduras de cisalhamento para lajes lisas (FERREIRA, 2010)...... 11

Figura 2.3 - Detalhes do sistema de armaduras DSA - $\left(\right.$ PEIKKO $\left.^{\circledR}, 2012\right)$......................... 12

Figura 2.4 - Detalhes do sistema de armaduras - (ANCON, 2012) .................................. 13

Figura 2.5 - Arranjos para a distribuição das armaduras de cisalhamento - (NBR 6118,

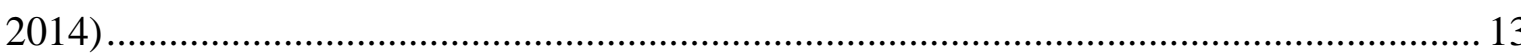

Figura 2.6 - Ancoragem de double-headed studs em lajes lisas (FERREIRA, 2010)......... 14

Figura 2.7 - Distribuição de cisalhamento devido a transferência de momento (CARES

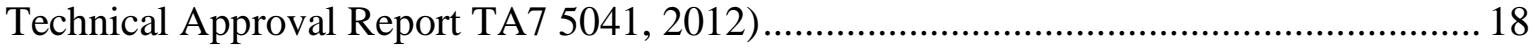

Figura 2.8 - Dimensões e cargas das lajes ensaiadas - (CARES Technical Approval Report TA7 5041, 2012)

Figura 2.9 - Ensaios de validação do SHEARFIX na Universidade de Cambridge -

Inglaterra (CARES Technical Approval Report TA7 5041, 2012)

Figura 2.10 - Canto reentrante; ensaios em escala real na Universidade de Cambridge -

Inglaterra (CARES Technical Approval Report TA7 5043, 2013)

Figura 2.11 - Perímetros críticos $u_{0}$ e $u$ para pilares internos, de borda e de canto -

NBR 6118 (ABNT, 2014)

Figura 2.12 - Perímetro crítico $u$ para áreas carregadas perto do canto reentrante............. 21

Figura 2.13 - Perímetro crítico reduzido $u^{*}$ com pilar de canto reentrante......................... 22

Figura 2.14 - Disposição da armadura de punção em planta e perímetro crítico $u$ ' - NBR 6118 (ABNT, 2014).

Figura 2.15 - Disposição da armadura de punção - NBR 6118 (ABNT, 2014) ................... 23

Figura 2.16 - Perímetro crítico $u$ ' para pilar de canto reentrante. ....................................... 23 
Figura 2.17 - Perímetro crítico reduzido fora da armadura de cisalhamento para pilar de canto reentrante

Figura 2.18 - Modelo para verificar a ruptura por punção no estado limite último -

Eurocode 2 (2004)

Figura 2.19 - Perímetro crítico $u_{1}$ ao redor de áreas carregadas - Eurocode 2 (2004) ....... 27

Figura 2.20 - Perímetro crítico $u_{1}$ para áreas carregadas perto da borda ou do canto -

Eurocode 2 (2004) 27

Figura 2.21 - Perímetro crítico para áreas carregadas perto do canto reentrante. 27

Figura 2.22 - Armadura de borda - Eurocode 2 (2004) 28

Figura 2.23 - Perímetro crítico externo à armadura de cisalhamento - Eurocode 2 (2004) 32

Figura 2.24 - Perímetro $u_{\text {out }}$ para pilar de canto reentrante

Figura 2.25 - Localização da seção crítica e suposta distribuição das tensões de cisalhamento para pilar interno - ACI 318 (2014).

Figura 2.26 - Localização da seção crítica para o pilar de canto reentrante.

Figura 2.27 - Dimensões de $b_{1}$ e $b_{2}$ do perímetro crítico $b_{0}$ 37

Figura 2.28 - Dimensões de $b_{1}$ e $b_{2}$ para o perímetro $b_{\text {out }}$ 37

Figura 2.29 - Representação dos parâmetros de um segmento reto do perímetro crítico... 38 Figura 2.30 - Perímetros críticos em torno de pilares ou área carregada - Model Code 2010

Figura 2.31 - Altura efetiva da laje - Model Code 2010 (2013) ......................................... 39

Figura 2.32 - Localização do perímetro crítico para o pilar de canto reentrante. 39

Figura 2.33 - Redução do perímetro crítico $b_{1, \text { red }}$ - Model Code 2010 (2013)

Figura 2.34 - Resultante da força de cisalhamento: (a) posição com relação ao centróide da área carregada; (b) perímetro crítico do centróide aproximado e a encentricidade entre a força de cisalhamento resultante e o centróide do perímetro crítico - Model Code 2010 (2013)

Figura 2.35 - Armadura de cisalhamento ativa na ruptura - Model Code 2010 (2013)...... 42

Figura 2.36 - Dimensões da área carregada ou analisada - Model Code 2010 (2013). ...... 45

Figura 2.37 - Dimensões da área carregada ou analisada em mm para o caso particular da ligação laje-pilar de canto reentrante. 45

Figura 2.38 - Perímetro crítico fora da armadura de cisalhamento - Model Code 2010 46

Figura 2.39 - Perímetro crítico fora da armadura de cisalhamento. 46 
Figura 3.1 - Modelo hipotético caracterizando a situação estudada .....

Figura 3.2 - Relação entre a região da laje de ensaio e um pórtico equivalente.................. 48

Figura 3.3 - Geometria básica de todas as lajes (em $\mathrm{mm})$. ................................................ 48

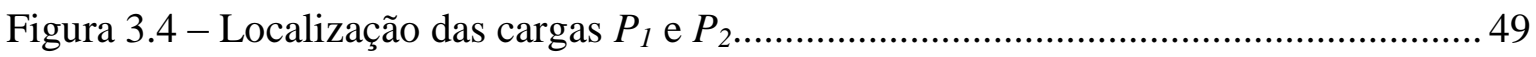

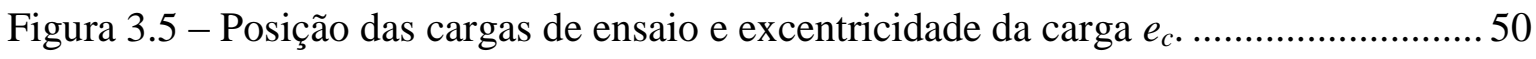

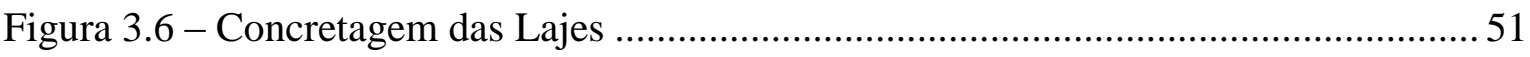

Figura 3.7 - Armadura superior de flexão das lajes com taxa de armadura 2,1\% ............. 53

Figura 3.8 - Armadura superior de flexão das lajes com taxa de armadura 1,3\% .............54

Figura 3.9 - Armadura superior de flexão das lajes com taxa de armadura 0,9\% ............. 54

Figura 3.10 - Armadura inferior de flexão para todas as lajes........................................... 55

Figura 3.11 - Detalhes do sistema de armaduras de cisalhamento. ..................................... 55

Figura 3.12 - Studs com trilhos utilizados na pesquisa..................................................... 56

Figura 3.13 - Projeto das armaduras de cisalhamento com dimensões em mm. ................56

Figura 3.14 - Detalhes das armaduras de cisalhamento................................................ 57

Figura 3.15- Distribuição dos studs das lajes L02, L03, L09, L10 e L11.......................... 57

Figura 3.16 - Projeto de armadura dos pilares. ................................................................. 58

Figura 3.17 - Projeto da armadura de torção na laje L03 .................................................. 59

Figura 3.18 - Projeto da armadura de torção na laje L08 ................................................. 59

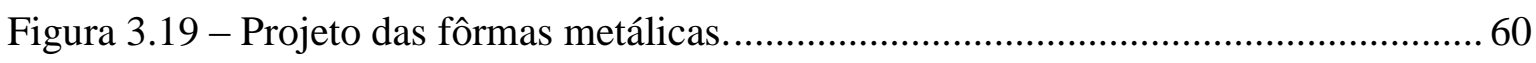

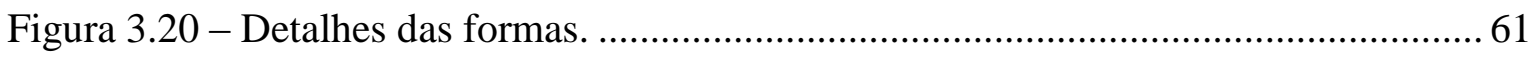

Figura 3.21 - Posicionamento dos LVDT's, potenciômetro, escalas e defletômetros nas

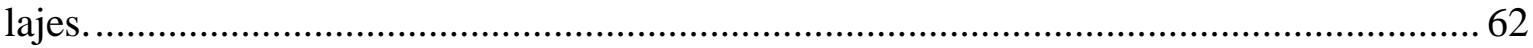

Figura 3.22 - LVDT's utilizados para medir os deslocamentos verticais..........................62 62

Figura 3.23 - Potenciômetro, escala e defletômetro utilizados nas lajes. ........................... 63

Figura 3.24- Procedimento de colagem dos extensômetros.............................................. 64

Figura 3.25- Posicionamento dos extensômetros nas armaduras superior (a) e inferior (b)

(Série 1)

Figura 3.26-Posicionamento dos extensômetros nas armaduras de flexão superior (Série 2).

Figura 3.27-Posicionamento dos extensômetros nas armaduras de flexão superior (Série 3).

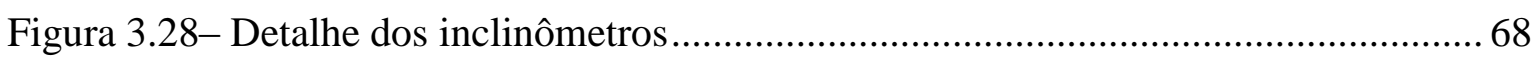

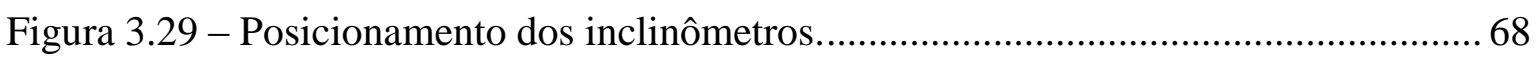

Figura 3.30 - Sistema de ensaio: vista superior. …......................................................... 70 


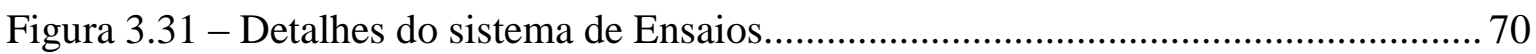

Figura 3.32 - Sistema de ensaio: vista superior. ................................................................ 71

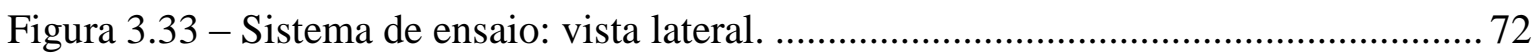

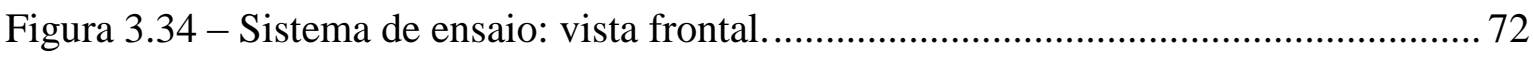

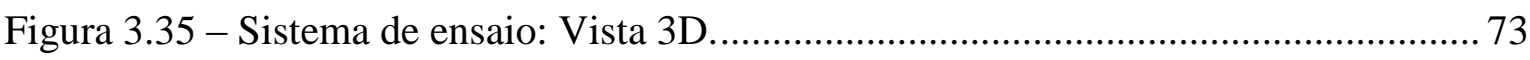

Figura 3.36 - Foto do sistema de ensaio da laje L12. ...................................................... 73

Figura 3.37-Sistema de aquisição de dados ...................................................................... 74

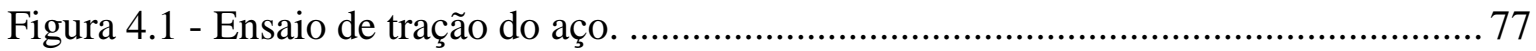

Figura 4.2 - Tensão x deformação das barras de 10,0 mm (Série 3) .................................. 78

Figura 4.3 - Tensão x deformação das barras de 12,5 mm (Série 3) ................................... 78

Figura 4.4 - Tensão x deformação das barras de 16,0 mm (Série 3) .................................... 78

Figura 4.5 - Largura efetiva de uma laje lisa (EUROCODE 2 2004) ................................ 79

Figura 4.6 - Linha de ruptura admitida para cálculo de resistência à flexão da laje............ 80

Figura 4.7 - Capacidade de flexão de acordo com o CSA Standard A23.3-94 (1994) -

(Birkle, 2004) 80

Figura 4.8 - Posicionamento dos LVDT's, potenciômetro, escalas e defletômetros nas lajes

Figura 4.9 - Deslocamentos verticais na direção S-N da laje L01 ..................................... 83

Figura 4.10 - Deslocamentos verticais na direção O-L da laje L01 .................................... 83

Figura 4.11 - Deslocamentos verticais na direção SO-NE da laje L01 ................................ 84

Figura 4.12 - Deslocamentos verticais na direção NO-SE da laje L01 ............................... 84

Figura 4.13 - Deslocamentos verticais na direção S-N da laje L02 …................................ 84

Figura 4.14 - Deslocamentos verticais na direção O-L da laje L02 .................................. 85

Figura 4.15 - Deslocamentos verticais na direção SO-NE da laje L02 ............................... 85

Figura 4.16 - Deslocamentos verticais na direção NO-SE da laje L02 ............................... 85

Figura 4.17 - Deslocamentos verticais na direção S-N da laje L03 …................................ 86

Figura 4.18 - Deslocamentos verticais na direção O-L da laje L03 ..................................... 86

Figura 4.19 - Deslocamentos verticais na direção SO-NE da laje L03 …............................ 86

Figura 4.20 - Deslocamentos verticais na direção NO-SE da laje L03 …............................ 87

Figura 4.21 - Deslocamentos verticais na direção S-N da laje L04 .................................... 87

Figura 4.22 - Deslocamentos verticais na direção O-L da laje L04 .................................. 87

Figura 4.23 - Deslocamentos verticais na direção SO-NE da laje L04 .............................. 88

Figura 4.24 - Deslocamentos verticais na direção NO-SE da laje L04 ............................... 88

Figura 4.25 - Deslocamentos verticais na direção S-N da laje L05 ................................... 88 
Figura 4.26 - Deslocamentos verticais na direção O-L da laje L05 ................................... 89

Figura 4.27 - Deslocamentos verticais na direção SO-NE da laje L05 ................................ 89

Figura 4.28 - Deslocamentos verticais na direção N0-SE da laje L05 ................................ 89

Figura 4.29 - Deslocamentos verticais na direção S0-NE da laje L05 ................................ 90

Figura 4.30 - Deslocamentos verticais na direção S-N da laje L06 .................................... 90

Figura 4.31 - Deslocamentos verticais na direção 0-L da laje L06 ..................................... 90

Figura 4.32 - Deslocamentos verticais na direção S0-NE da laje L06 ................................ 91

Figura 4.33 - Deslocamentos verticais na direção N0-SE da laje L06 ............................... 91

Figura 4.34 - Deslocamentos verticais na direção S0-NE da laje L06 ................................ 91

Figura 4.35 - Deslocamentos verticais na direção S-N da laje L07 ................................... 92

Figura 4.36 - Deslocamentos verticais na direção 0-L da laje L07 ...................................... 92

Figura 4.37 - Deslocamentos verticais na direção S0-NE da laje L07 ................................ 92

Figura 4.38 - Deslocamentos verticais na direção NO-SE da laje L07 .............................. 93

Figura 4.39 - Deslocamentos verticais na direção S0-NE da laje L07 ................................ 93

Figura 4.40 - Deslocamentos verticais na direção S-N da laje L08 ................................... 93

Figura 4.41 - Deslocamentos verticais na direção O-L da laje L08 ................................... 94

Figura 4.42 - Deslocamentos verticais na direção SO-NE da laje L08 ............................... 94

Figura 4.43 - Deslocamentos verticais na direção NO-SE da laje L08 ............................... 94

Figura 4.44 - Deslocamentos verticais na direção SO-NE da laje L08 .............................. 95

Figura 4.45 - Deslocamentos verticais na direção S-N da laje L09 .................................... 95

Figura 4.46 - Deslocamentos verticais na direção O-L da laje L09 ................................... 95

Figura 4.47 - Deslocamentos verticais na direção SO-NE da laje L09 .............................. 96

Figura 4.48 - Deslocamentos verticais na direção NO-SE da laje L09 .............................. 96

Figura 4.49 - Deslocamentos verticais na direção SO-NE da laje L09 ............................... 96

Figura 4.50 - Deslocamentos verticais na direção S-N da laje L10 ................................... 97

Figura 4.51 - Deslocamentos verticais na direção O-L da laje L10 .................................... 97

Figura 4.52 - Deslocamentos verticais na direção SO-NE da laje L10 ................................ 97

Figura 4.53 - Deslocamentos verticais na direção NO-SE da laje L10 ............................... 98

Figura 4.54 - Deslocamentos verticais na direção SO-NE da laje L10 ............................... 98

Figura 4.55 - Deslocamentos verticais na direção S-N da laje L11 .................................. 98

Figura 4.56 - Deslocamentos verticais na direção O-L da laje L11 ................................... 99

Figura 4.57 - Deslocamentos verticais na direção SO-NE da laje L11 .............................. 99

Figura 4.58 - Deslocamentos verticais na direção NO-SE da laje L11 ............................... 99

Figura 4.59 - Deslocamentos verticais na direção SO-NE da laje L11 ............................. 100 
Figura 4.60 - Deslocamentos verticais na direção S-N da laje L12 ................................. 100

Figura 4.61 - Deslocamentos verticais na direção O-L da laje L12 ….............................. 100

Figura 4.62 - Deslocamentos verticais na direção SO-NE da laje L12 ............................. 101

Figura 4.63 - Deslocamentos verticais na direção NO-SE da laje L12 ............................ 101

Figura 4.64 - Deslocamentos verticais na direção SO-NE da laje L12 ............................. 101

Figura 4.65 - Carga x deslocamento da laje L01 …........................................................ 102

Figura 4.66 - Carga x deslocamento da laje L01 …......................................................... 102

Figura 4.67 - Carga x deslocamento da laje L01 ............................................................. 102

Figura 4.68 - Carga x deslocamento da laje L02 ........................................................... 103

Figura 4.69 - Carga x deslocamento da laje L02 …........................................................ 103

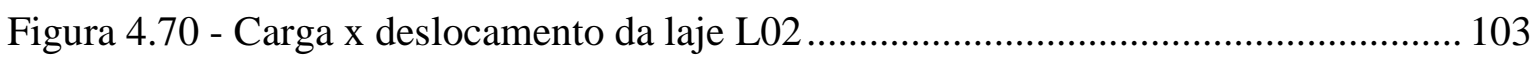

Figura 4.71 - Carga x deslocamento da laje L03 …......................................................... 104

Figura 4.72 - Carga x deslocamento da laje L03 …......................................................... 104

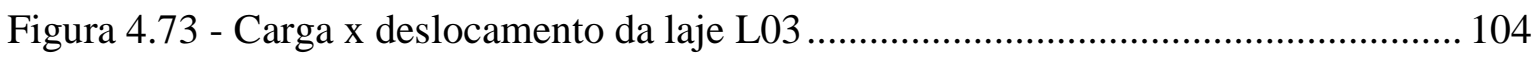

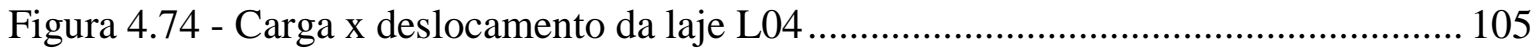

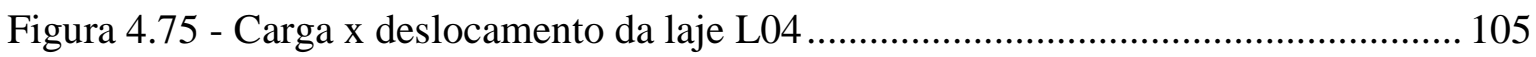

Figura 4.76 - Carga x deslocamento da laje L04 …........................................................ 105

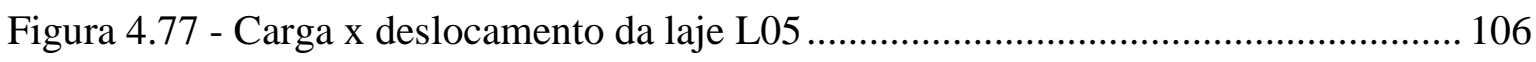

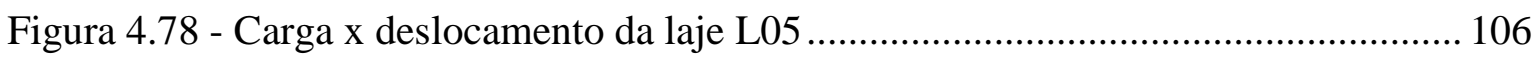

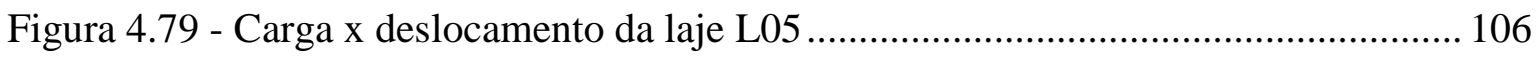

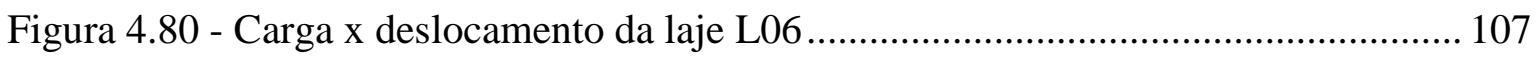

Figura 4.81 - Carga x deslocamento da laje L06 …........................................................ 107

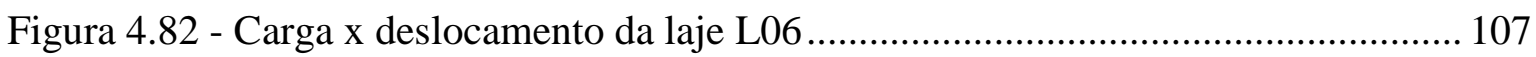

Figura 4.83 - Carga x deslocamento da laje L07 ............................................................ 108

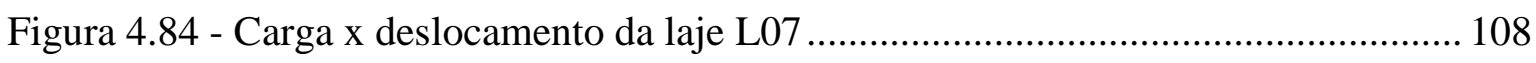

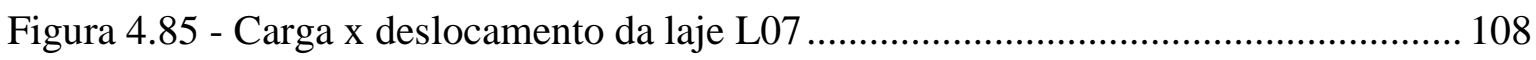

Figura 4.86 - Carga x deslocamento da laje L08 …........................................................ 109

Figura 4.87 - Carga x deslocamento da laje L08 ........................................................... 109

Figura 4.88 - Carga x deslocamento da laje L08 …......................................................... 109

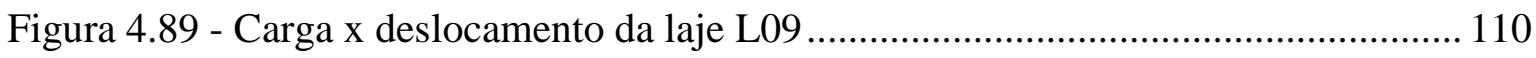

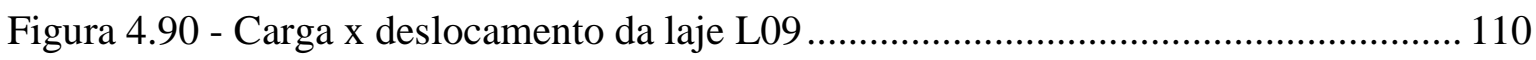

Figura 4.91 - Carga x deslocamento da laje L09 …..................................................... 110

Figura 4.92 - Carga $x$ deslocamento da laje L10 ........................................................... 111

Figura 4.93 - Carga x deslocamento da laje L10 ......................................................... 111 
Figura 4.94 - Carga x deslocamento da laje L10 ............................................................ 111

Figura 4.95 - Carga x deslocamento da laje L11 …....................................................... 112

Figura 4.96 - Carga x deslocamento da laje L11 ............................................................... 112

Figura 4.97 - Carga x deslocamento da laje L11 ............................................................ 112

Figura 4.98 - Carga x deslocamento da laje L12 …....................................................... 113

Figura 4.99 - Carga x deslocamento da laje L12 ........................................................... 113

Figura 4.100 - Carga x deslocamento da laje L12 ........................................................... 113

Figura 4.101 - Carga x rotação da laje L01 na direção S-N e NE-SO .............................. 115

Figura 4.102 - Carga x rotação da laje L02 na direção S-N e NE-SO .............................. 115

Figura 4.103 - Carga x rotação da laje L03 na direção S-N e NE-SO .............................. 115

Figura 4.104 - Carga x rotação da laje L04 na direção S-N e NE-SO ............................... 116

Figura 4.105 - Carga x rotação da laje L05 na direção S-N e NE-SO ............................... 116

Figura 4.106 - Carga x rotação da laje L06 na direção S-N e NE-SO ............................... 116

Figura 4.107 - Carga x rotação da laje L07 na direção S-N e NE-SO ............................... 117

Figura 4.108 - Carga x rotação da laje L08 na direção S-N e NE-SO .............................. 117

Figura 4.109 - Carga x rotação da laje L09 na direção S-N e NE-SO .............................. 117

Figura 4.110 - Carga x rotação da laje L10 na direção S-N e NE-SO .............................. 118

Figura 4.111 - Carga x rotação da laje L11 na direção S-N e NE-SO .............................. 118

Figura 4.112 - Carga x rotação da laje L12 na direção S-N e NE-SO .............................. 118

Figura 4.113 - Carga x deslocamento do ponto 17 das lajes do Grupo 1 ......................... 119

Figura 4.114 - Carga x deslocamento do ponto 18 das lajes do Grupo 1 ......................... 120

Figura 4.115 - Carga x deslocamento do ponto 17 das lajes do Grupo 2 ........................ 120

Figura 4.116 - Carga x deslocamento do ponto 18 das lajes do Grupo 2 ......................... 120

Figura 4.117 - Posicionamento dos extensômetros nas armaduras superior (a) e inferior

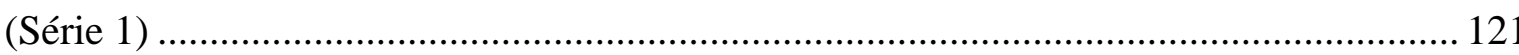

Figura 4.118 - Posicionamento dos extensômetros nas armaduras superior (Série 2) ..... 121

Figura 4.119 - Posicionamento dos extensômetros nas armaduras superior (Série 3) ..... 122

Figura 4.120 - Deformação na armadura de flexão da laje L01 …................................... 122

Figura 4.121 - Deformação na armadura de flexão da laje L01 …................................... 122

Figura 4.122 - Deformação na armadura de flexão da laje L02 ...................................... 123

Figura 4.123 - Deformação na armadura de flexão da laje L02 ..................................... 123

Figura 4.124 - Deformação na armadura de flexão da laje L03 ...................................... 123

Figura 4.125 - Deformação na armadura de flexão da laje L03 ...................................... 124

Figura 4.126 - Deformação na armadura de flexão da laje L04 ...................................... 124 
Figura 4.127 - Deformação na armadura de flexão da laje L04 ...................................... 124

Figura 4.128 - Deformação na armadura de flexão da laje L05 ...................................... 125

Figura 4.129 - Deformação na armadura de flexão da laje L06 ........................................ 125

Figura 4.130 - Deformação na armadura de flexão da laje L07 ....................................... 125

Figura 4.131 - Deformação na armadura de flexão da laje L08 ....................................... 126

Figura 4.132 - Deformação na armadura de flexão da laje L08 …................................... 126

Figura 4.133 - Deformação na armadura de flexão da laje L09 ....................................... 126

Figura 4.134 - Deformação na armadura de flexão da laje L09 ...................................... 127

Figura 4.135 - Deformação na armadura de flexão da laje L10 ...................................... 127

Figura 4.136 - Deformação na armadura de flexão da laje L10 ...................................... 127

Figura 4.137 - Deformação na armadura de flexão da laje L11 ....................................... 128

Figura 4.138 - Deformação na armadura de flexão da laje L11 ...................................... 128

Figura 4.139 - Deformação na armadura de flexão da laje L12 ...................................... 128

Figura 4.140 - Deformação na armadura de flexão da laje L12 ...................................... 129

Figura 4.141 - Carga x deformação na armadura de flexão da laje L01 ............................ 129

Figura 4.142 - Carga x deformação na armadura de flexão da laje L01 ........................... 129

Figura 4.143 - Carga x deformação na armadura de flexão da laje L01 ........................... 130

Figura 4.144 - Carga x deformação na armadura de flexão da laje L01 ........................... 130

Figura 4.145 - Carga x deformação na armadura de flexão da laje L02 ........................... 130

Figura 4.146 - Carga x deformação na armadura de flexão da laje L02 ........................... 131

Figura 4.147 - Carga x deformação na armadura de flexão da laje L02 ........................... 131

Figura 4.148 - Carga x deformação na armadura de flexão da laje L02 ........................... 131

Figura 4.149 - Carga x deformação na armadura de flexão da laje L03 ........................... 132

Figura 4.150 - Carga x deformação na armadura de flexão da laje L03 ........................... 132

Figura 4.151 - Carga x deformação na armadura de flexão da laje L03 ........................... 132

Figura 4.152 - Carga x deformação na armadura de flexão da laje L03 ........................... 133

Figura 4.153 - Carga x deformação na armadura de flexão da laje L04 ........................... 133

Figura 4.154 - Carga x deformação na armadura de flexão da laje L04 ........................... 133

Figura 4.155 - Carga x deformação na armadura de flexão da laje L04 ............................ 134

Figura 4.156 - Carga x deformação na armadura de flexão da laje L04 ........................... 134

Figura 4.157 - Carga x deformação na armadura de flexão da laje L05 ........................... 134

Figura 4.158 - Carga x deformação na armadura de flexão da laje L06 ........................... 135

Figura 4.159 - Carga x deformação na armadura de flexão da laje L07 ........................... 135

Figura 4.160 - Carga x deformação na armadura de flexão da laje L08 .......................... 135 
Figura 4.161 - Carga x deformação na armadura de flexão da laje L08 ............................ 136

Figura 4.162 - Carga x deformação na armadura de flexão da laje L09............................ 136

Figura 4.163 - Carga x deformação na armadura de flexão da laje L10 ............................ 136

Figura 4.164 - Carga x deformação na armadura de flexão da laje L11 ........................... 137

Figura 4.165 - Carga x deformação na armadura de flexão da laje L12 ........................... 137

Figura 4.166 - Carga x deformação na armadura de flexão da laje L12 ........................... 137

Figura 4.167 - Linha utilizada para análise de deformações na armadura de flexão........ 138

Figura 4.168 - Deformações na $1^{\mathrm{a}}$ camada de studs da laje L02 .................................... 139

Figura 4.169 - Deformações na $2^{\mathrm{a}}$ camada de studs da laje L02 .................................... 140

Figura 4.170 - Deformações na $3^{\text {a }}$ camada de studs da laje L02 .................................... 140

Figura 4.171 - Deformações na $1^{\mathrm{a}}$ camada de studs da laje L03 ..................................... 140

Figura 4.172 - Deformações na $2^{\mathrm{a}}$ camada de studs da laje L03 ..................................... 141

Figura 4.173 - Deformações na $3^{\text {a }}$ camada de studs da laje L03 .................................... 141

Figura 4.174 - Deformações na $4^{\mathrm{a}}$ camada de studs da laje L03 .................................... 141

Figura 4.175 - Deformações na $1^{\mathrm{a}}$ camada de studs da laje L09 ..................................... 142

Figura 4.176 - Deformações na 2 $2^{\mathrm{a}}$ camada de studs da laje L09 .................................... 142

Figura 4.177 - Deformações na $1^{\mathrm{a}}$ camada de studs da laje L10 ...................................... 142

Figura 4.178 - Deformações na $2^{\mathrm{a}}$ camada de studs da laje L10 ..................................... 143

Figura 4.179 - Deformações na $1^{\mathrm{a}}$ camada de studs da laje L11 .................................... 143

Figura 4.180 - Deformações na $2^{\mathrm{a}}$ camada de studs da laje L11 .................................... 143

Figura 4.181 - Pontos instrumentados na armadura de torção da laje L08 ....................... 145

Figura 4.182 - Deformações nos pontos superiores dos estribos na direção SE-NO ....... 145

Figura 4.183 - Deformações nos pontos laterais dos estribos na direção SE-NO ............ 145

Figura 4.184 - Deformações nos pontos inferiores dos estribos na direção SE-NO......... 146

Figura 4.185 - Deformações nos pontos superiores dos estribos na direção NE-SO ....... 146

Figura 4.186 - Deformações nos pontos laterais dos estribos na direção NE-SO ............ 146

Figura 4.187 - Deformações nos pontos inferiores dos estribos na direção NE-SO......... 147

Figura 4.188 - Deformações na superfície do concreto da laje L01 ................................. 148

Figura 4.189 - Deformações na superfície do concreto da laje L02 …............................. 148

Figura 4.190 - Deformações na superfície do concreto da laje L03 …............................. 148

Figura 4.191 - Deformações na superfície do concreto da laje L04 …............................. 149

Figura 4.192 - Deformações na superfície do concreto da laje L05 …............................ 149

Figura 4.193 - Deformações na superfície do concreto da laje L06 …............................. 149

Figura 4.194 - Deformações na superfície do concreto da laje L07 ................................ 150 
Figura 4.195 - Deformações na superfície do concreto da laje L08 …............................ 150

Figura 4.196 - Deformações na superfície do concreto da laje L09 …............................. 150

Figura 4.197 - Deformações na superfície do concreto da laje L10 ................................. 151

Figura 4.198 - Deformações na superfície do concreto da laje L11 ................................. 151

Figura 4.199 - Deformações na superfície do concreto da laje L12 …............................ 151

Figura 4.200 - Configuração de fissuras da laje L01 …................................................... 154

Figura 4.201 - Configuração de fissuras da laje L02 ….................................................. 154

Figura 4.202 - Configuração de fissuras da laje L03 ….................................................. 154

Figura 4.203 - Configuração de fissuras da laje L04 …................................................... 155

Figura 4.204 - Configuração de fissuras da laje L05 …….............................................. 155

Figura 4.205 - Configuração de fissuras da laje L06 …….............................................. 155

Figura 4.206 - Configuração de fissuras da laje L07 ………........................................... 156

Figura 4.207 - Configuração de fissuras da laje L08 ….................................................. 156

Figura 4.208 - Configuração de fissuras da laje L09 ….................................................... 156

Figura 4.209 - Configuração de fissuras da laje L010 …................................................. 157

Figura 4.210 - Configuração de fissuras da laje L011 ....................................................... 157

Figura 4.211 - Configuração de fissuras da laje L012 …................................................ 157

Figura 4.212 - Fissuras na borda reentrante da laje L06............................................... 158

Figura 4.213 - Planos de corte das lajes L02 e L03 .......................................................... 159

Figura 4.214 - Planos de corte das lajes L09, L10 e L11 ................................................ 160

Figura 4.215 - Superfície de ruptura da laje L01 ........................................................ 160

Figura 4.216 - Superfície de ruptura da laje L02 ......................................................... 160

Figura 4.217 - Superfície de ruptura da laje L03 ........................................................... 161

Figura 4.218 - Superfície de ruptura da laje L04 ........................................................ 161

Figura 4.219 - Superfície de ruptura da laje L05 ......................................................... 161

Figura 4.220 - Superfície de ruptura da laje L06 ............................................................ 162

Figura 4.221 - Superfície de ruptura da laje L07 ........................................................... 162

Figura 4.222 - Superfície de ruptura da laje L08 .......................................................... 162

Figura 4.223 - Superfície de ruptura da laje L09 ............................................................ 163

Figura 4.224 - Superfície de ruptura da laje L10 ............................................................ 163

Figura 4.225 - Superfície de ruptura da laje L11 ........................................................ 163

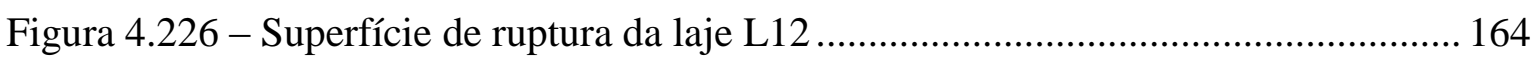

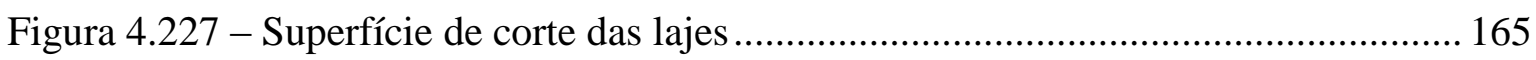

Figura 5.1 - Gráfico de carga de ruptura x excentricidade das lajes L01 e L04............... 168 
Figura 5.2 - Gráfico de deslocamentos verticais na direção S-N das lajes L01 e L04. .... 169 Figura 5.3 - Gráfico de delocamentos verticais x carga das lajes L01 e L04 nos pontos 1, 4, 8 e 10. 169

Figura 5.4 - Gráfico de delocamentos verticais x carga das lajes L01 e L04 nos pontos 12, 13,14 e 15 170

Figura 5.5 - Gráfico de deformações na armadura de flexão das lajes L01 e L04. 170

Figura 5.6 - Deformações na superfície do concreto das lajes L01 e L04. 171

Figura 5.7 - Gráfico de carga de ruptura x excentricidade das lajes L08, L12 e L07. 172

Figura 5.8 - Gráfico de deslocamentos verticais na direção S-N das lajes L08, L12 e L07.

Figura 5.9 - Gráfico de delocamentos verticais x carga das lajes L08, L12 e L07 nos pontos $1,4,8$ e 10 .

Figura 5.10 - Gráfico de delocamentos verticais x carga das lajes L08, L12 e L07 nos

pontos $12,13,14$ e 15 .

Figura 5.11 - Gráfico de deformações na armadura de flexão das lajes L08, L12 e L07. 174

Figura 5.12 - Deformações na superfície do concreto das lajes L08, L12 e L07.

Figura 5.13 - Gráfico de carga de ruptura x taxa de armadura de flexão média das lajes L06, L08, L07 e L04

Figura 5.14 - Gráfico de deslocamentos verticais na direção S-N das lajes L06, L08, L07 e L04. 177

Figura 5.15 - Gráfico de delocamentos verticais x carga das lajes L06, L08, L07 e L04 nos pontos $1,4,8$ e 10 . 177

Figura 5.16 - Gráfico de delocamentos verticais x carga das lajes L06, L08, L07 e L04 nos pontos $12,13,14$ e 15 .

Figura 5.17 - Gráfico de deformações na armadura de flexão das lajes L06, L08, L07 e L04.

Figura 5.18 - Deformações na superfície do concreto das lajes L06, L08 e L07. 179

Figura 5.19 - Gráfico de carga de ruptura x taxa de armadura de flexão média das lajes L05 e L01.

Figura 5.20 - Gráfico de deslocamentos verticais na direção S-N das lajes L05 e L01... 180 Figura 5.21 - Gráfico de delocamentos verticais x carga das lajes L05 e L01 nos pontos 1, 4,8 e 10 . 181

Figura 5.22 - Gráfico de delocamentos verticais x carga das lajes L05 e L01 nos pontos 12, 13,14 e 15 . 181 
Figura 5.23 - Gráfico de deformações na armadura de flexão das lajes L05 e L01. 182

Figura 5.24 - Gráfico de carga de ruptura x excentricidade das lajes L06 e L05.

Figura 5.25 - Gráfico de deslocamentos verticais na direção S-N das lajes L06 e L05. .. 183

Figura 5.26 - Gráfico de delocamentos verticais x carga das lajes L06 e L05 nos pontos 1,

4,8 e 10 . 184

Figura 5.27 - Gráfico de delocamentos verticais x carga das lajes L06 e L05 nos pontos 12, 13,14 e 15 184

Figura 5.28 - Gráfico de deformações na armadura de flexão das lajes L06 e L05. 185

Figura 5.29 - Deformações na superfície do concreto das lajes L06 e L05. 185

Figura 5.30 - Gráfico de carga de ruptura x área de armadura de cisalhamento das lajes L02, L09, e L03.

Figura 5.31 - Gráfico de deslocamentos verticais na direção S-N das lajes L02, L09 e L03.

Figura 5.32 - Gráfico de delocamentos verticais x carga das lajes L02, L09 e L03 nos

pontos $1,4,8$ e 10 .

Figura 5.33 - Gráfico de delocamentos verticais x carga das lajes L02, L09 e L03 nos pontos $12,13,14$ e 15

Figura 5.34 - Gráfico de deformações na armadura de flexão das lajes L02, L09 e L03. 188

Figura 5.35 - Deformações na superfície do concreto das lajes L02 e L03.

Figura 5.36 - Gráfico de carga de ruptura x excentricidade e armadura de cisalhamento das lajes L09, L10, e L11. 190

Figura 5.37 - Gráfico de deslocamentos verticais na direção S-N das lajes L09, L10, e L11.

Figura 5.38 - Gráfico de delocamentos verticais x carga das lajes L09, L10, e L11 nos pontos $1,4,8$ e 10 .

Figura 5.39 - Gráfico de delocamentos verticais x carga das lajes L09, L10, e L11 nos pontos $12,13,14$ e 15 . 192

Figura 5.40 - Gráfico de deformações na armadura de flexão das lajes L09, L10 e L11. 192

Figura 5.41 - Deformações na superfície do concreto das lajes L09, L10 e L11.

Figura 5.42 - Gráfico de deslocamentos verticais na direção S-N das lajes L08 e L03... 194 Figura 5.43 - Gráfico de delocamentos verticais x carga das lajes L08 e L03 nos pontos 1, 4,8 e 10 . 195

Figura 5.44 - Gráfico de delocamentos verticais x carga das lajes L08 e L03 nos pontos 12, 13,14 e 15 . 195 
Figura 5.45 - Gráfico de deformações na armadura de flexão das lajes L08 e L03. 196

Figura 5.46 - Gráfico de deslocamentos verticais na direção S-N das lajes L02, L09, L04 e L03.

Figura 5.47 - Gráfico de delocamentos verticais x carga das lajes L02, L09, L04 e L03 nos pontos $1,4,8$ e 10 . 198

Figura 5.48 - Gráfico de delocamentos verticais x carga das lajes L02, L09, L04 e L03 nos pontos $12,13,14$ e 15 .

Figura 5.49 - Gráfico de deformações na armadura de flexão das lajes L02, L09, L04 e L03.

Figura 5.50 - Deformações na superfície do concreto das lajes L02, L04 e L03.

Figura 5.51 - Gráfico de carga de ruptura x taxa de armadura de flexão média das lajes L05, L01 e L10.

Figura 5.52 - Gráfico de deslocamentos verticais na direção S-N das lajes L05, L01 e L10.

Figura 5.53 - Gráfico de delocamentos verticais x carga das lajes L05, L01 e L10 nos

pontos $1,4,8$ e 10 .

Figura 5.54 - Gráfico de delocamentos verticais x carga das lajes L05, L01 e L10 nos pontos $12,13,14$ e 15

Figura 5.55 - Gráfico de deformações na armadura de flexão das lajes L05, L01 e L10. 203

Figura 5.56 - Deformações na superfície do concreto das lajes L05, L01 e L10. 203

Figura 5.57 - Gráfico de carga de ruptura x taxa de armadura de flexão média das lajes

L12 e L11.

Figura 5.58 - Gráfico de deslocamentos verticais na direção S-N das lajes L12, e L11. . 205 Figura 5.59 - Gráfico de delocamentos verticais x carga das lajes L12 e L11 nos pontos 1, 4,8 e 10.

Figura 5.60 - Gráfico de delocamentos verticais x carga das lajes L12 e L11 nos pontos 12, 13,14 e 15 206

Figura 5.61 - Gráfico de deformações na armadura de flexão das lajes L12 e L11. 206

Figura 5.62 - Deformações na superfície do concreto das lajes L12 e L11. 207

Figura 5.63 - Posição dos atuadores utilizados no ensaio das lajes. 209 Figura 6.1 - Diagrama de tensão-deformação uniaxial do concreto - adaptado de Červenka et al (2010) 212

Figura 6.2 - Lei de abertura de fissuras exponencial, desenvolvida por Hodijk. Adaptado de Červenka et al (2010). 
Figura 6.3 - Diagrama tensão de compressão x deformação. Červenka et al (2010).

Figura 6.4 - Processo de fissuração do concreto no diagrama tensão-deformação do concreto. Adaptado de Červenka et al (2010).

Figura 6.5 - Diagrama de ruptura biaxial do concreto. Adaptado de Červenka et al (2010).

Figura 6.6 - Estado de tensões e deformações do fixed crack model. Adaptado de Červenka et al (2010).

Figura 6.7 - Estado de tensões e deformações do rotated crack model. Adaptado de Červenka et al (2010).

Figura 6.8 - Redução da resistência à compressão com presença de fissuração no material. Červenka et al (2010).

Figura 6.9 - Exemplos de simulação de armaduras no ATENA 3D, à esquerda: armadura distribuída; à direita: armadura discreta. Červenka et al (2010). 222

Figura 6.10 - Diagrama tensão-deformação do aço, bilinear, adotado nos modelos simulados. Adaptado de Červenka et al (2010).

Figura 6.11 - Geometria dos elementos finitos possíveis de modelar no ATENA 3D. Em cima: à esquerda - tetraedro; à direita - brick. Em baixo: elemento wedge. Adaptado Červenka (2010). 224

Figura 6.12 - Método de Newton-Raphson. Červenka et al (2010). 226

Figura 6.13 - Exemplo da modelagem da laje no Atena 3D (Laje L01). 227

Figura 6.14 - Exemplo da laje com pontos monitorados inseridos no programa Atena 3d

(Laje L01). 230

Figura 6.15 - Pontos monitorados no programa ATENA 3D ........................................ 230

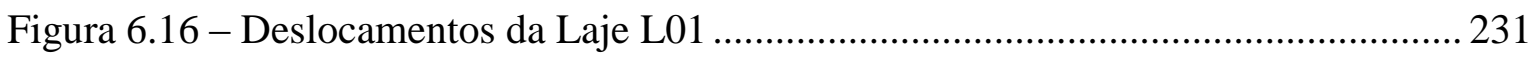

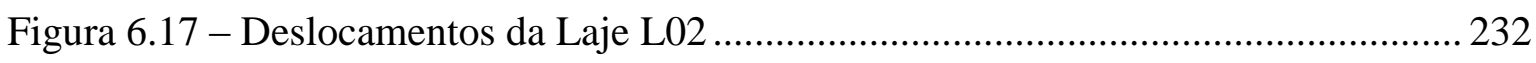

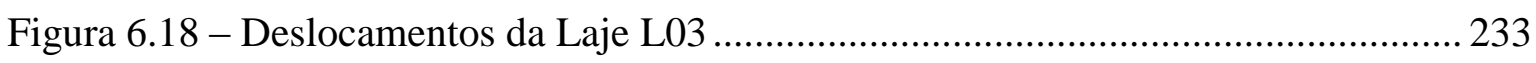

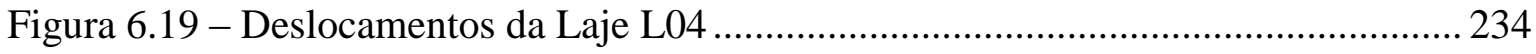

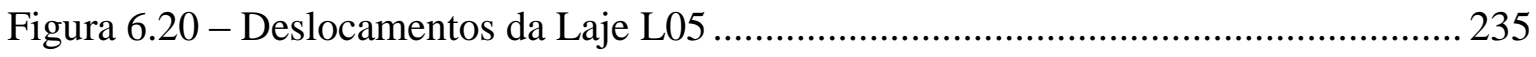

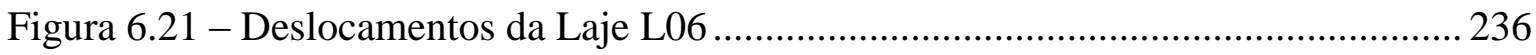

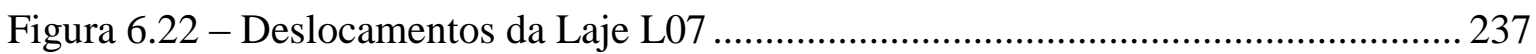

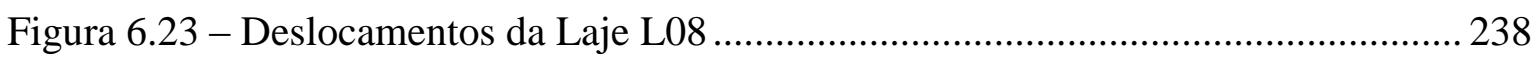

Figura 6.24 - Deslocamentos da Laje L09 …........................................................... 239

Figura 6.25 - Deslocamentos da Laje L10 ….......................................................... 240

Figura 6.26 - Deslocamentos da Laje L11 …............................................................... 241 
Figura 6.27 - Deslocamentos da Laje L12

Figura 6.28 -Fissuras e deformada (m) da laje L04 obtida numericamente (vista em 2D)

Figura 6.29 -Fissuras e deformada (m) da laje L02 obtida numericamente (vista em 2D)

Figura 6.30 -Fissuras e deformada (m) da laje L04 obtida numericamente (vista em 3D)

Figura 6.31 -Fissuras e deformada (m) da laje L02 obtida numericamente (vista em 3D)

Figura 6.32 - Configuração de fissuras da laje L04 para ensaio experimental (esquerda) e numérico (direita)

Figura 6.33 - Configuração de fissuras da laje L02 para ensaio experimental (esquerda) e numérico (direita) 246

Figura 6.34 - Pontos de deformações monitorados no programa ATENA 3D das lajes L01, L02, L03 e L04.... 247

Figura 6.35 - Deformações na armadura de flexão da Laje L01 248

Figura 6.36 - Deformações na armadura de flexão da Laje L02 249

Figura 6.37 - Deformações na armadura de flexão da Laje L03 250

Figura 6.38 - Deformações na armadura de flexão da Laje L04 251

Figura 6.39 - Pontos de deformações monitorados no programa ATENA 3D das lajes L05 e L06 252

Figura 6.40 - Deformações na armadura de flexão da Laje L05 253

Figura 6.41 - Deformações na armadura de flexão da Laje L06 254 Figura 6.42 - Pontos de deformações monitorados no programa ATENA 3D das lajes L07 e L08

Figura 6.43 - Deformações na armadura de flexão da Laje L07 256

Figura 6.44 - Deformações na armadura de flexão da Laje L08 257

Figura 6.45 - Pontos de deformações monitorados no programa ATENA 3D das lajes L09, L10 e L11 258

Figura 6.46 - Deformações na armadura de flexão da Laje L09 259

Figura 6.47 - Deformações na armadura de flexão da Laje L10 ..................................... 260

Figura 6.48 - Deformações na armadura de flexão da Laje L11 ..................................... 261

Figura 6.49 - Deformações na armadura de flexão da Laje L12 262 
Figura 6.50 - Pontos de deformações na armadura de cisalhamento monitorados no programa ATENA 3D das lajes L02, L03, L09, L10 e L11_........................................... 263

Figura 6.51 - Deformações na armadura de cisalhamento da Laje L02 ........................... 264

Figura 6.52 - Deformações na armadura de cisalhamento da Laje L03 ........................... 264

Figura 6.53 - Deformações na armadura de cisalhamento da Laje L09 ........................... 265

Figura 6.54 - Deformações na armadura de cisalhamento da Laje L10 ........................... 265

Figura 6.55 - Deformações na armadura de cisalhamento da Laje L11 ........................... 266

Figura 6.56 - Pontos de deformações monitorados no programa ATENA 3D das lajes L02

e L04.

Figura 6.57 - Deformações na superfície do concreto da Laje L02 ................................. 267

Figura 6.58 - Deformações na superfície do concreto da Laje L04 .................................. 267

Figura 6.59 - Corte da laje para análise de tensões e deformações.................................... 268

Figura 6.60 - Distribuição das tensões principais (MPa) na laje L04 (corte NO-SE). ..... 268

Figura 6.61 - Distribuição das tensões principais (MPa) na laje L02 (corte NO-SE). ..... 268

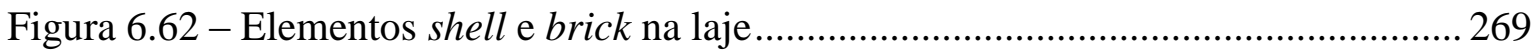

Figura 6.63 - Avaliação da previsão dos resultados para lajes sem armadura de cisalhamento.

Figura 6.64 - Avaliação da previsão dos resultados para lajes com armadura de cisalhamento.

Figura 6.65 - Número do passo de carga x limite de convergência (Laje L04).

Figura 6.66 - Número do passo de carga x limite de convergência (Laje L02).

Figura 7.1 - Perímetro crítico $u$ para áreas carregadas perto do canto reentrante.

Figura 7.2 - Perímetro crítico reduzido pilar de canto reentrante

Figura 7.3 - Perímetro fora da armadura de cisalhamento reduzido para pilar de canto reentrante.

Figura 7.4 - Perímetro crítico fora da armadura de cisalhamento para pilar de canto reentrante.

Figura 7.5 - Localização da seção crítica para o pilar de canto reentrante.

Figura 7.6 - Localização da seção crítica para o pilar de canto reentrante.

Figura 7.7 - Avaliação da previsão dos resultados para lajes sem armadura de cisalhamento.

Figura 7.8 - Avaliação da previsão dos resultados para lajes com armadura de cisalhamento. 


\section{LISTA DE SÍMBOLOS}

$a$ - Altura da distribuição de tensões na zona comprimida;

$A_{c}$ - Área da seção crítica do perímetro distante a $0,5 \cdot \mathrm{d}$ do pilar;

$A_{s}, A_{v}$ - Área da seção transversal das armaduras de flexão tracionadas;

$A_{s w}$ - Área de armadura de cisalhamento por perímetro de studs;

$b$ - Largura de faixa de laje;

$b_{0}$ - Comprimento de um perímetro crítico à d/2 da face do pilar;

$b_{0, \text { out }}$ - Perímetro crítico fora da armadura de cisalhamento;

$b_{1}$ - Projeção da seção crítica no eixo principal, na direção do momento;

$b_{1, \text { red }}$ - Perímetro crítico básico reduzido;

$b_{2}$ - Projeção da seção crítica perpendicular a $b_{1}$;

$b_{e f}$ - Largura efetiva da laje para o cálculo do momento resistente;

$b_{s}$ - Largura da faixa carregada ou analisada para o cálculo de $m_{s d}$;

$b_{s r}$ - Limitação da largura $b_{s}$;

$b_{u}$ - Diâmetro de um círculo com a mesma área da região dentro do perímetro crítico;

$b_{w}$ - Largura da seção de concreto considerada para o cálculo de $\rho$;

$C$ - Força resultante das tensões de compressão no concreto;

$C_{1}, c_{1}$ - Dimensão do pilar perpendicular à borda livre ou uma das dimensões do pilar do canto reenrante;

$C_{2}, c_{2}$ - Dimensão do pilar paralela à borda livre ou uma das dimensões do pilar do canto reenrante;

$c_{A B}$ - Distância entre o eixo centroide do perímetro crítico e o lado da seção crítica paralelo à transferência de momento;

$c_{C D}$ - Distância entre o eixo centroide do perímetro crítico e o lado da seção crítica paralelo à transferência de momento; 
$d$ - Média aritmética das alturas úteis da armadura em direções ortogonais entre si;

$d_{g}$ - Diâmetro máximo do agregado;

$d_{\text {ensaio }}$ - Altura útil medida depois dos cortes das lajes;

$d_{\text {proj }}$ - Altura útil de projeto;

$d_{x}, d_{y}$ - Altura útil da armadura nas duas direções ortogonais;

$d_{v}$ - Altura útil efetiva;

$e$ - Excentricidade do carregamento (M/V) em relação ao eixo do pilar;

$e_{E, 1}$ - Excentricidade da carga em relação ao centroide de $u$, excentricidade relativa;

$e_{u}$ - Excentricidade resultante da força de cisalhamento com respectivo centroide do perímetro crítico;

$E$ - Módulo de elasticidade do concreto;

$E_{0}$ - Módulo de elasticidade inicial;

$E_{c}$ - Módulo de elasticidade secante;

$E_{c m}$ - módulo de elasticidade médio calculado;

$E_{s}$ - Módulo de elasticidade do aço;

$f_{b d}$ - Tensão de flexão para barras nervuradas;

$f_{c k}$ - Resistência característica do concreto;

$f_{c}^{\prime e f}$ - Tensão efetiva de compressão;

$f_{c m}$ - Resistência à compressão média do concreto;

$f_{c, \text { neo }}$ - Resistência à compressão de cilindros 10 x $20 \mathrm{~cm}$ utilizando neoprene;

$f_{c, r e t}$ - Resistência à compressão de cilindros 10 x $20 \mathrm{~cm}$ retificados;

$f_{c t}$ - Resistência à tração média do concreto;

$f_{c t m}$ - Tensão média à tração do concreto;

$f_{t}^{\prime}, f_{t}$ - Tensão efetiva de tração do concreto;

$f_{t}^{\prime e f}$ - Tensão de tração do concreto; 
$f_{y}, f_{y s}$ - Tensão de escoamento do aço da armadura de flexão;

$f_{y w}$ - Tensão de escoamento do aço da armadura de cisalhamento;

$f_{y w, e f f}$ - Tensão de escoamento efetiva do aço da armadura de cisalhamento;

$F_{s d}$ - Força ou reação concentrada de cálculo;

$G$ - Módulo de elasticidade transversal do material;

$G_{F}$ - Energia de fratura;

$h$ - Espessura da laje;

$J_{c}$ - Momento polar de inércia da seção crítica na direção perpendicular à borda;

$k$ - Parâmetro de forma;

$k, K$ - Coeficiente que considera a relação entre as dimensões do pilar; Efeito de escala;

$k_{d g}$ - Parâmetro que depende do diâmetro máximo do agregado;

$L_{d}$ - Dimensão do elemento finito quando a fissura se propaga na direção paralela a este;

$L_{t}^{\prime}, L_{t}$ - Orientação da fissura;

$M_{E d}$ - Momento de cálculo;

$M_{s d}$ - Momento fletor de cálculo perpendicular à borda da ligação;

$M_{u}$ - Momento fletor calculado em relação ao centro do pilar;

$M_{u, f a c e}$ - Momento fletor resistente na face interna do pilar;

$M_{R, f a c e}$ - Momento fletor resistente na face interna do pilar;

$m_{R d}$ - Resistência à flexão média de projeto por unidade de comprimento numa faixa carregada (para a direção considerada);

$m_{s d}$ - Momento médio atuante por unidade de comprimento da armadura de flexão numa faixa;

$P_{1}, P_{2}$ - Cargas aplicadas no ensaio;

$P_{e q}$ - Peso próprio do equipamento sobre a laje;

$P_{\text {fiss }}$ - Carga total de primeira fissura; 
$P_{\text {laje }}$ - Peso próprio da laje;

$P_{u}$ - Carga total aplicada pelo sistema (sem considerar o peso próprio);

$q$ - Vetor de carga total aplicada;

$r_{e c}$ - Fator de redução da tensão de resistência à compressão quando se está no estado tração-compressão (tração numa direção principal e compressão na outra);

$r_{e t}$ - Fator de redução da resistência à tração na direção principal 1;

$r_{s}$ - Corresponde à distância do centro do pilar até ao raio onde o momento fletor é nulo;

$s_{0}$ - Distância do pilar à primeira camada de armadura de cisalhamento;

$s_{r}$ - Espaçamento radial da armadura de cisalhamento;

$s_{t}$ - Espaçamento circunferencial dos studs no perímetro externo dos studs;

$t$ - Espessura efetiva do tubo de parede fina;

$u, u_{0}, u_{1}$ - Perímetro crítico, distante a $2 \cdot d$ do pilar;

$u_{0}$ - Perímetro crítico, distante a $2 \cdot \mathrm{d}$ do pilar (NBR6118);

$u_{0}$ - Perímetro do pilar (EC2);

$u^{*}, u_{1}{ }^{*}, u_{1, \text { red }}$ - Perímetro crítico reduzido distante a $2 \cdot \mathrm{d}$ do pilar;

$u_{\text {out }}$ - Perímetro crítico afastado $1.5 \mathrm{~d}$ da última camada de armadura de cisalhamento;

$u_{\text {out,eff }}$ - Soma dos trechos do perímetro mínimo externos às armaduras de cisalhamento, com perímetro externo da armadura de cisalhamento colocado a uma distância não superior a $1,5 \mathrm{~d}$

$V_{c}$ - Força resistente ao cisalhamento nominal fornecida pelo concreto;

$V_{E d}$ - Esforço normal de cálculo;

$V_{f c, r e t}$ - Força resistente utilizados os resultados da resistência a compressão dos cilindros retificados, com elementos shell na região afastada $2 h$ da face do pilar, e brick no restante da laje e pilar; 
$V_{f c, r e t, a b}$ - Força resistente em que foram utilizados os resultados da resistência à compressão dos cilindros retificados, com elementos todos brick;

$V_{f l e x}$ - Carga de ruptura por flexão na ligação;

$V_{M E F}$ - Resistência à punção obtida com o programa de análise não linear, ATENA.

$V_{N o r m a}-$ Resistência à punção obtida com as expressões da norma;

$V_{R, c}$ - Valor de projeto da resistência à punção de uma laje sem armadura de punção ao longo da seção de controle considerada;

$V_{R, c s}$ - Valor de projeto da resistência à punção de uma laje com armadura de punção ao longo da seção de controle considerada para uma ruptura por tração diagonal dentro da região das armaduras de cisalhamento;

$V_{R, m a ́ x}$ - Valor máximo de cálculo da força resistente ao cisalhamento ao longo da seção de controle considerada para uma ruptura por compressão diagonal;

$V_{R, \text { out }}$ - Valor máximo de cálculo da força resistente ao cisalhamento ao longo da seção de controle considerada para uma ruptura por tração diagonal fora da região das armaduras de cisalhamento;

$V_{s}$ - Força resistente ao cisalhamento ao cisalhamento nominal fornecida pela armadura de cisalhamento;

$V_{u}$ - Carga de ruptura experimental na ligação com o pilar de borda;

$V_{u, g d}$ - Carga de ruptura obtida numericamente utilizando somente os gráficos de carga $\mathrm{x}$ deslocamento;

$T$ - Força resultante das tensões de tração na armadura;

$w$ - Abertura de fissura;

$w_{c}$ - Abertura da fissura quando a tensão efetiva de resistência à tração é nula;

$W_{l}, W_{p}$ - Módulo de Resistência Plástica em função do perímetro crítico $u_{1}$;

$z$ - Braço interno de alavanca; 
$z_{1}$ - Braço de alavanca entre o ponto de aplicação da carga e o eixo transversal que passa pelo centro do pilar;

$z_{2}$ - Braço de alavanca entre o centro de gravidade da área e o eixo transversal que passa pelo centro do pilar.

\section{LETRAS GREGAS}

$\alpha, \alpha_{v}$ - ângulo de inclinação entre o eixo da armadura de punção e o plano da laje;

$\alpha_{1}$ - Relação entre a tensão de compressão média na seção retangular e a resistência do concreto especificado;

$\alpha_{s}$ - fator para cálculo de $V_{c}$ em função do tipo de ligação;

$\beta$ - Relação do lado maior e lado menor da coluna, carga concentrada, ou área de reação;

$\beta c$ - Razão entre a maior e a menor dimensão do pilar;

$\delta_{\text {final }}$ - Deslocamento máximo medido;

$\delta_{\text {comp. }}$ - Deslocamento comparativo em um mesmo nível de carregamento;

$\varepsilon_{1}, \varepsilon_{2}$ - Deformações principais para os eixos 1 e 2 ;

$\varepsilon_{s}, \varepsilon_{c}$ - Deformação do aço e do concreto;

$\varepsilon_{c r}$ - Deformação de abertura de fissura antes da tensão de resistência à tração ser nula;

$\varepsilon_{d}$ - Deformação limite por compressão do concreto onde a resistência do concreto é nula;

$\varepsilon_{f}$ - Deformação da armadura de flexão;

$\varepsilon_{f l, m a ́ x}$ - Primeira deformação máxima;

$\varepsilon_{f 2, \text { máx }}$ - Segunda deformação máxima;

$\varepsilon_{\text {stud }}$ - Deformação na armadura de cisalhamento;

$\varepsilon_{y}$ - Deformação da armadura de flexão;

$\varepsilon^{e q}$ - Deformação uniaxial equivalente;

$\phi$ - Fator de redução da tensão; 
$\phi_{f}$ - Diâmetro da armadura de flexão;

$\phi_{t}$ - Diâmetro da armadura de torção;

$\phi_{w}$ - Diâmetro da armadura de cisalhamento;

$\gamma$ - Fator de correção da dimensão do elemento finito;

$\gamma_{c}$ - Coeficiente de segurança do concreto;

$\gamma_{v}$ - Coeficiente de transferência de momento fletor pela excentricidade da força cortante;

$\gamma_{f}$ - Parcela do momento desbalanceado transferido por flexão;

$\kappa$ - Fator que leva em consideração o efeito de escala;

$\kappa_{e}$ - Coeficiente de redução do perímetro crítico;

$\kappa_{\text {sys }}$ - Coeficiente em função do tipo de armadura de cisalhamento;

$\kappa_{\psi}$ - Parâmetro que depende de deformações (rotações) da laje;

$\lambda$ - Fator de modificação, em função do tipo do concreto;

$\psi$ - Rotação da laje em relação ao plano horizontal;

$\rho$ - Taxa geométrica de armadura passiva de flexão;

$\rho_{x}, \rho_{y}$ - são as taxas de armadura nas duas direções ortogonais;

$\sigma$ - Tensão nominal;

$\sigma_{c 1}, \sigma_{c 2}$ - Tensões principais no concreto;

$\sigma_{c}^{e f}-$ Tensão efetiva;

$\sigma_{c i}$ - Tensão do concreto;

$\sigma_{s w}$ - Tensão cuja armadura de cisalhamento tem capacidade para mobilizar;

$\sigma_{t}^{e f}-$ Tensão à tração do concreto;

$\tau$ - Tensões de cisalhamento na face da fissura;

$\tau_{R d 1}, \tau_{R d 2}$ - Tensão de cisalhamento resistente de cálculo; 
$\tau_{s d}$ - Tensão de cisalhamento solicitante de cálculo;

$\nu_{E d}$ - Tensão atuante na ligação;

$v_{R d, m a ́ x}-$ Valor de cálculo máximo da resistência ao cisalhamento ao longo da seção considerada;

$\nu_{R d, c}$ - Valor de cálculo da resistência ao cisalhamento sem armadura de punção ao longo da seção considerada.

\section{ABREVIATURAS E SIGLAS}

D - Defletômetro.

E - Escala;

EC - Esmagamento do concreto;

EE - Extensômetro das armaduras de torção;

EF - Extensômetro das armaduras de flexão longitudinais superiores;

EI - Extensômetro das armaduras de flexão longitudinais inferiores;

ES - Extensômetro das armaduras de cisalhamento;

EXP - Resultados experimentais;

FP - Flexão seguida por punção;

L, LVDT - Transformador diferencial variável linear;

MEF - Método dos elementos finitos;

P - Potenciômetro;

P - Punção;

PF - Punção seguida por flexão. 


\section{INTRODUÇÃO}

A ligação direta entre pilar e lajes de concreto armado é uma alternativa cada vez mais frequente nos projetos de construção civil no Brasil. Diversos fatores podem indicar a conveniência da utilização de um modelo estrutural tipo laje lisa (lajes apoiadas diretamente em pilares sem capitéis, segundo a NBR 6118:2014), o que pode gerar tensões de cisalhamento significativas na região da laje ao redor do pilar. A Figura 1.1 mostra o sistema estrutural em lajes lisas.

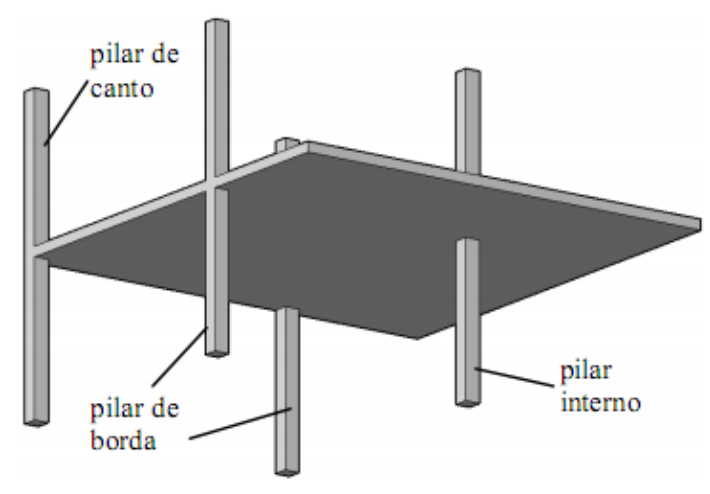

(a) lajes lisas maciças

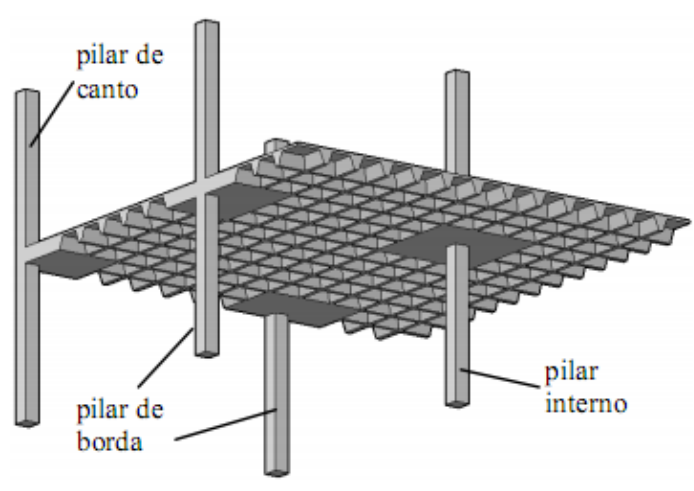

(b) lajes lisas nervuradas

Figura 1.1 - Sistemas estruturais em lajes lisas (FERREIRA, 2010)

Entre as possíveis vantagens deste tipo de estrutura podem-se citar:

- Simplificação na execução das formas e do cimbramento: devido à ausência de vigas ocorre uma diminuição dos recortes, ocasionando uma maior agilidade no processo construtivo;

- Simplificação na concretagem: maior facilidade no lançamento, adensamento e desforma do concreto, reduzindo a possibilidade de ocorrência de falhas de concretagem;

- Melhoria da qualidade final e diminuição da quantidade de material de revestimento: com a simplificação das formas, das armaduras e da concretagem, é possível obter estruturas com melhor acabamento, o que pode até dispensar o uso de revestimentos. Quando houver necessidade de revestimento, a superfície a ser revestida é menor, a preparação é facilitada e também as dificuldades para revestir as superfícies planas são menores. 
- Simplificação das instalações prediais: o projeto e a execução de instalações prediais elétricas e hidráulicas são facilitados e a qualidade aumentada, pois diminui a quantidade de curvas e a necessidade de contornar vigas ou perfurá-las.

- Maior flexibilidade de layout: liberdade na definição de espaços internos e facilidade na realização de reformas e modificações futuras, pois as divisórias não estão condicionadas à localização das vigas.

Algumas desvantagens podem ser observadas no uso de pavimentos de edifícios em lajes lisas, fazendo com que a sua utilização tenha que ser bem estudada e comparada com outros tipos de pavimentos de edifícios, antes de sua adoção.

Com base nos resultados disponíveis na literatura, quando comparadas às lajes usuais apoiadas em vigas, as lajes lisas podem apresentar maiores deslocamentos verticais (flechas) para um mesmo vão. A estabilidade global da estrutura pode diminuir devido à ausência de vigas, sendo necessário vincular a laje a núcleos rígidos ou paredes estruturais para reduzir os deslocamentos horizontais.

Na região de ligação laje-pilar são observadas elevadas tensões originadas pelos esforços de flexão e de cisalhamento, que podem provocar ruptura por punção da laje com uma carga inferior à carga última de flexão. A ruptura por punção está associada à formação de um cone podendo ocorrer sem aviso e de forma frágil.

De acordo com Melo (1990), o primeiro acidente registrado de ruptura por punção foi o caso do edifício Prest-o-Lite, em Indianápolis (1911), onde as lajes se desligaram completamente dos pilares, ocorrendo o colapso progressivo de toda a estrutura, provocando várias mortes.

Outros casos de acidentes estruturais devido à ruptura por punção têm sido registrados, como por exemplo, o colapso por puncionamento em um edifício de 16 pavimentos, em 1971, situado na Avenida Commonwealth, Boston - Massachusetts, Estados Unidos (Figura 1.2a); o colapso parcial do edifício Pipers Row Car Park, localizado na cidade de Wolverhampton na Inglaterra em 1997 (Figura 1.2b); o colapso do edifício garagem no Tropicana Cassino em 2003, localizado em Atlantic City, Estados Unidos (Figura 1.2c); a ruptura ocorrida no pátio de estacionamento na cidade Smith Dundas em 2011, Nova Zelândia (Figura 1.2d). 


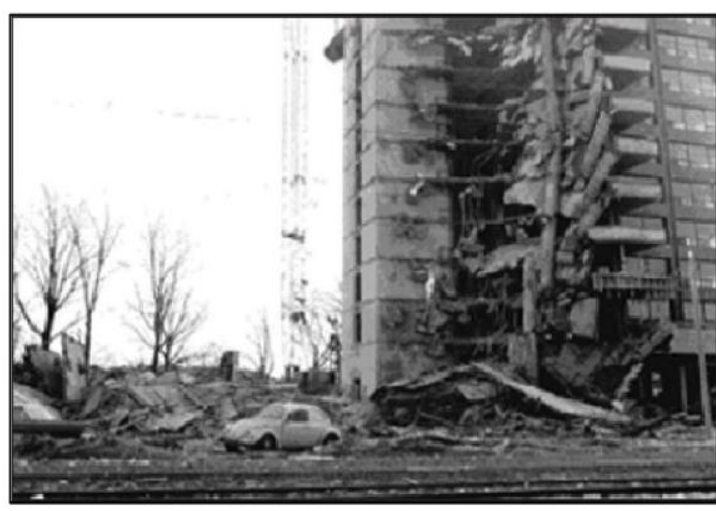

(a) Edifício de apartamentos em Boston, Massachusetts, Estados Unidos em 1971 -. KING (2004).

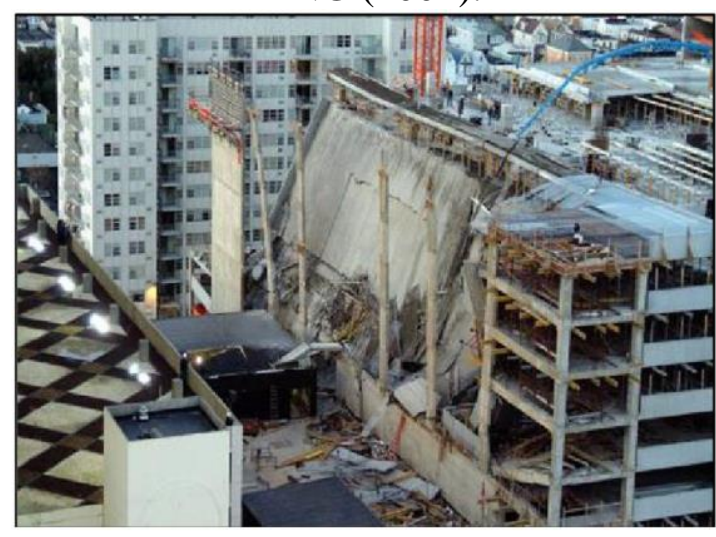

(c) Colapso em edifício garagem, Atlantic City - Estados Unidos (2003).

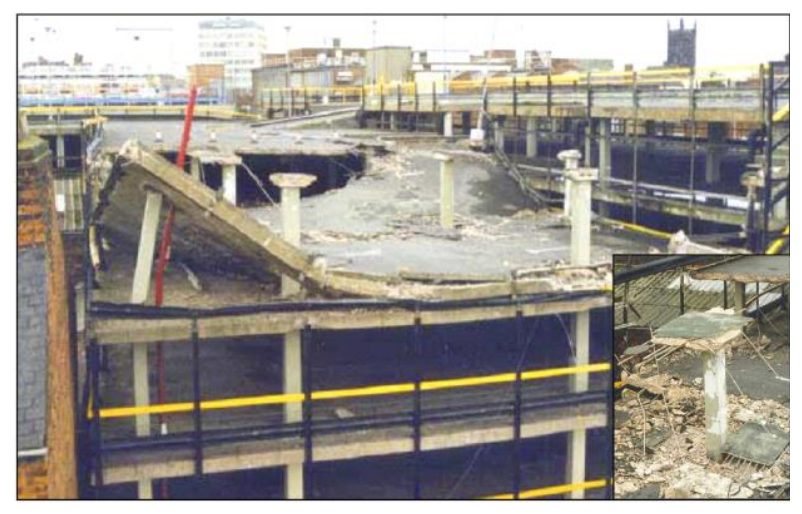

(b) Colapso parcial do edifício Pipers Row Car Park, Wolverhampton - WOOD (1997).

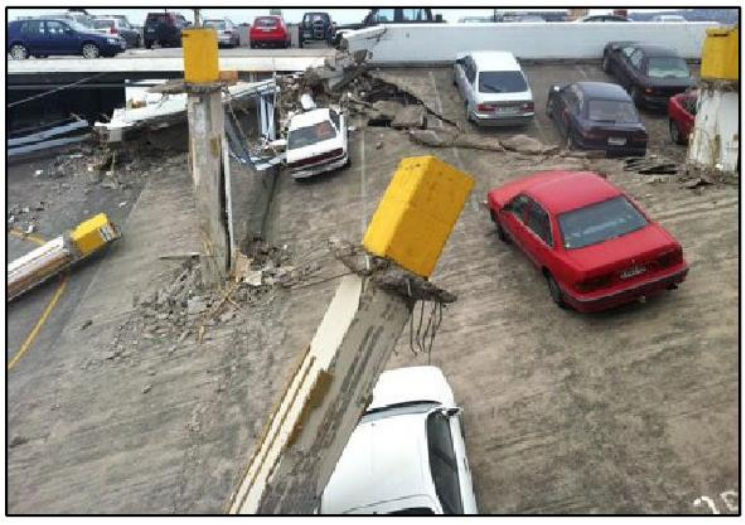

(d) Pátio de estacionamento, Smith Dundas Nova Zelândia (2011).

Figura 1.2 - Exemplos de colapsos estruturais surgidos por esforços de punção

A resistência ao cisalhamento é um fator importante no dimensionamento deste tipo de estrutura, sendo frequentemente um fator condicionante para a escolha da espessura da laje, da geometria dos pilares, da resistência à compressão do concreto, do uso de capitel ou a utilização armadura de cisalhamento.

Entre os fatores que interferem na resistência à punção podem ser relacionados: resistência à compressão do concreto; altura útil da laje e relação entre os lados do pilar (ou diâmetro no caso de pilar circular) e a altura útil da laje; relação entre os lados dos pilares, aberturas na laje próximas aos pilares; excentricidades do carregamento; perímetro de contato entre a laje e o pilar; armadura de flexão; armadura de cisalhamento.

Existem várias posições das ligações laje-pilar (interno, borda, canto e canto reentrante) como mostra a Figura 1.3, mas a ligação laje-pilar de canto reentrante não é abordada por 
nenhuma pesquisa como os demais casos, sendo ainda desconhecido seu modelo mecânico e seu comportamento com momento desbalanceado em uma ou em duas direções.

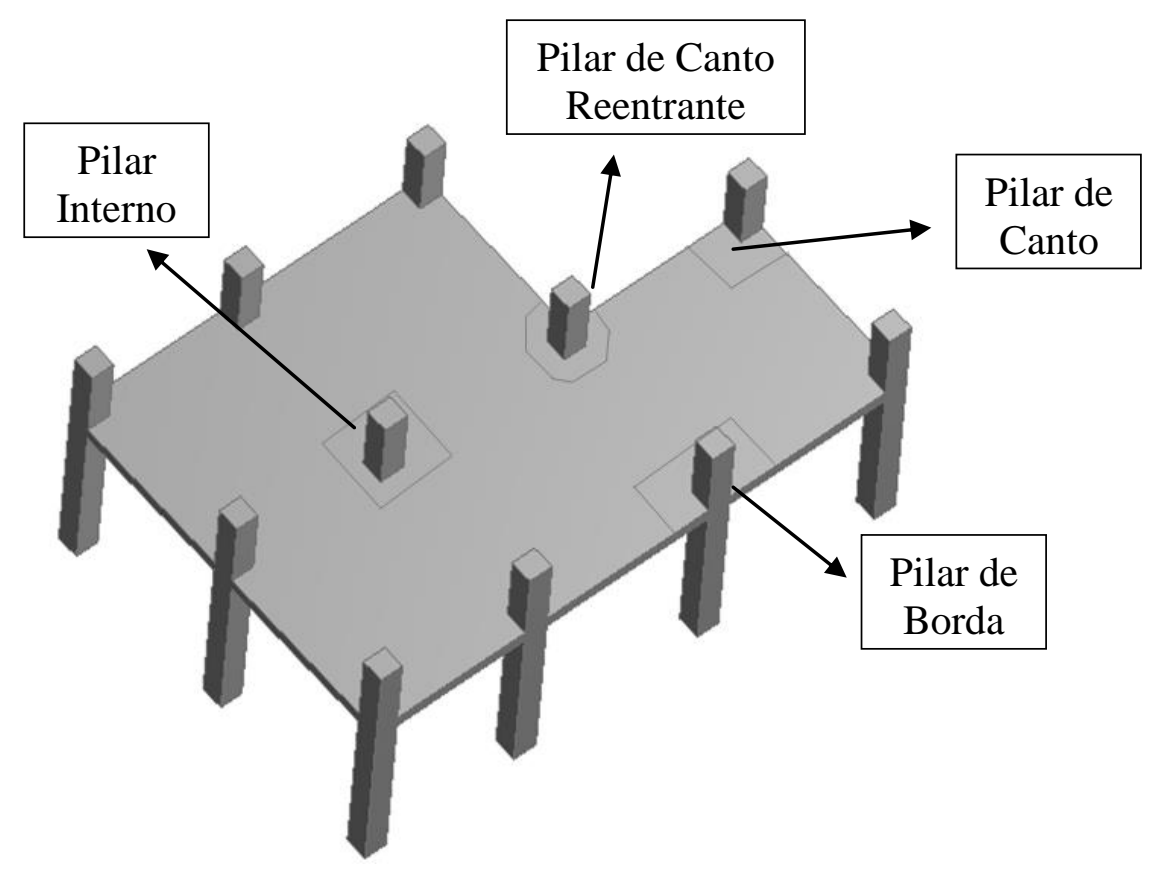

Figura 1.3 - Tipos de ligações laje-pilar.

Para o sistema de lajes lisas o dimensionamento é realizado considerando a resistência à punção nas conexões entre a laje e o pilar, pois a ruptura devida à punção, esquematizada na Figura 1.4, pode se desenvolver de forma frágil, onde a armadura de flexão pode não atingir sua tensão de escoamento, gerando assim limitação quanto à ductilidade da laje.

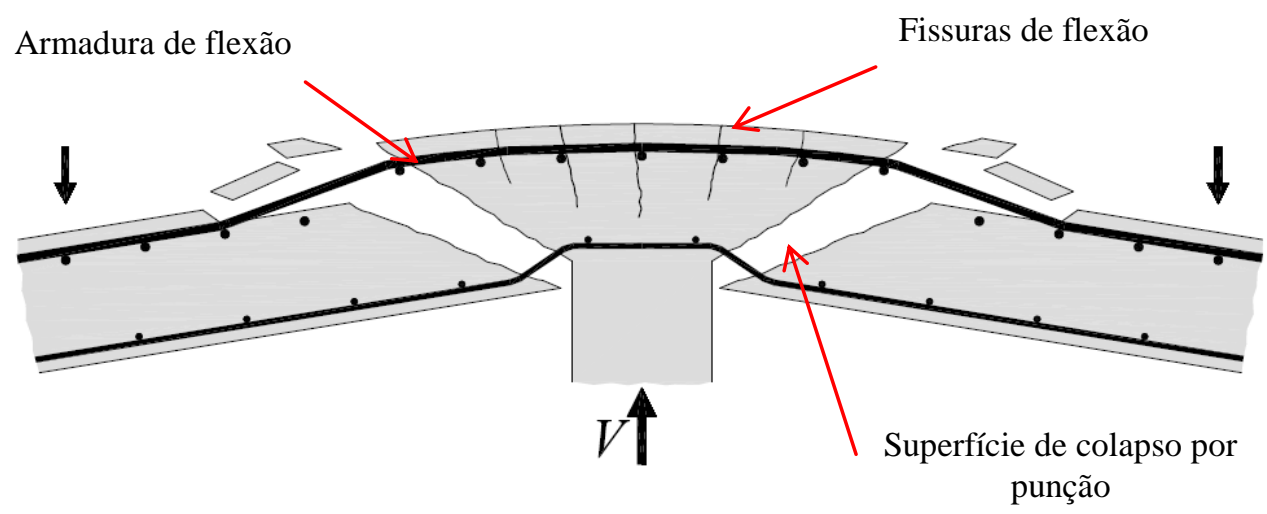

Figura 1.4 - Ruptura por punção em laje-lisa (modificado - Mirzaei, 2010)

A Figura 1.5 apresenta o aspecto da superfície de ruptura devido à punção em diferentes tipos de ligações laje-pilar. 


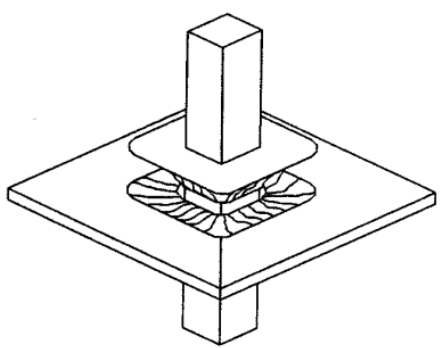

(a) Pilar interno

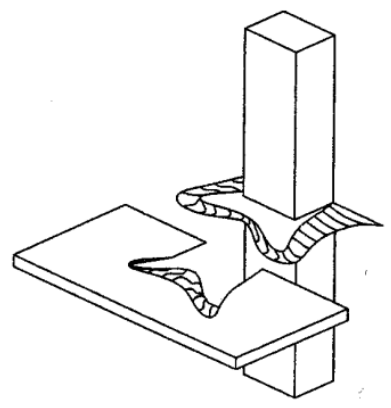

(b) Pilar de borda

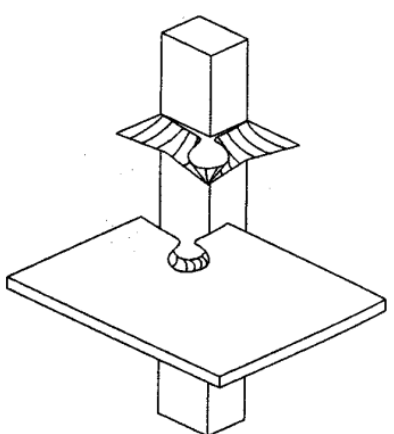

(c) Pilar de canto

Figura 1.5 - Perspectivas das superfícies de ruína devidas à punção em ligações laje pilar em lajes lisas (CARVALHO, 2009)

\subsection{JUSTIFICATIVA}

Esta pesquisa é relevante para a comunidade científica internacional, pois não existe nenhum trabalho publicado no meio científico que trate da ligação laje-pilar de canto reentrante, podendo assim contribuir para no futuro estabelecer um modelo mecânico que possa representar o comportamento à punção desse tipo de ligação.

O estudo de punção com armadura de cisalhamento vem sendo desenvolvido por alguns pesquisadores no mundo todo, com importantes descobertas, sobretudo na influência de studs sobre a carga de ruptura. A transferência de momento em uma ou em duas direções ainda é pouco compreendido, necessitando de modelos teóricos mais embasados para o projeto de lajes lisas de concreto armado.

Há ainda a necessidade de mais pesquisas experimentais que levem a uma melhor compreensão do mecanismo de ruptura das ligações laje-pilar, e o presente estudo pretende dar sua contribuição nesse sentido para o caso de pilar de canto reentrante.

As ligações internas, de borda e de canto recebem tratamento pelas normas com modelos de cálculo para capacidade a punção, mas ligações laje-pilar de canto reentrante ainda não são abordadas em nenhuma norma. 


\subsection{OBJETIVOS DA PESQUISA}

\subsubsection{Objetivo Geral}

O presente trabalho visa contribuir para o avanço do conhecimento acerca do fenômeno de punção em lajes lisas, considerando o histórico de casos de acidentes relacionados ao fenômeno da punção. Para isto, buscar-se-á avaliar experimentalmente os mecanismos resistentes nas lajes lisas de concreto armado com pilar de canto reentrante, com e sem armadura de cisalhamento. Serão variáveis neste trabalho: excentricidade de carga, taxa de armadura de flexão, quantidade e disposição da armadura de cisalhamento e armadura de torção. A partir de estudo experimental, complementado por uma análise computacional, será observada a influência destes parâmetros sobre o comportamento das lajes dessa pesquisa. Desta maneira, pretende-se contribuir com os estudos desse fenômeno com a obtenção de dados que auxiliem na previsão de como poderá ocorrer à ruptura por punção, na caracterização da superfície de ruptura e na identificação dos tipos de ruptura.

\subsubsection{Objetivos Específicos}

- Obtenção e apresentação de resultados experimentais a partir da realização de ensaios com lajes lisas de concreto armado com pilar de canto reentrante;

- Verificar o sistema da armadura de cisalhamento ensaiada para analisar o desempenho em relação às expectativas do projeto estrutural.

- Avaliar o desempenho do tipo de conexão em estudo para diferentes quantidades de armadura de cisalhamento;

- Verificar a viabilidade de utilizar o software ATENA (destinado a efetuar análises tridimensionais não lineares em estruturas de concreto armado) para representar o comportamento de lajes com pilares de canto reentrante, confrontando os resultados que o programa fornece com os resultados obtidos experimentalmente.

- Verificar a validade de utilizar recomendações normativas de projeto sobre ruptura por punção adaptadas para o caso de conexões entre lajes e pilares de cantos reentrantes. 


\subsection{METODOLOGIA}

Foram construídas doze lajes lisas com pilar de canto reentrante, variando-se características como a utilização e quantidade de armadura de cisalhamento do tipo stud, a utilização da armadura de torção, a excentricidade da carga aplicada e a taxa de armadura de flexão. As doze lajes foram moldadas, instrumentadas e ensaiadas no Laboratório de Estruturas da Universidade de Brasília (LABEST - UnB), onde foram registradas as características de cada laje no decorrer dos ensaios.

Após os ensaios, os resultados foram tratados considerando a deformação específica no concreto e nas armaduras, deslocamentos verticais, rotações, fissuração, modos e cargas de ruptura. Essas cargas foram comparadas com estimativas utilizando expressões das normas: NBR 6118 (2014), Eurocode 2 (2004), ACI 318 (2014) e MC2010 (2013), mediante algumas adaptações já que as normas não tratam o caso de punção em lajes com pilar reentrante.

Posteriormente foi utilizado um programa com base em elementos finitos de análise não linear para simular as lajes dessa pesquisa e então realizar algumas análises comparando os resultados obtidos com o programa e os resultados experimentais.

\subsection{ESTRUTURA DO TRABALHO}

O presente trabalho é composto de oito capítulos, incluindo esta indrodução, cujos conteúdos são apresentados sucintamente a seguir:

No Capítulo 2 é apresentada a revisão bibliográfica com aspectos gerais sobre o comportamento das lajes lisas de concreto armado, além da metodologia de cálculo proposta pelas normas: NBR 6118 (2014), Eurocode 2 (2004), ACI 318 (2014) e MC2010 (2013).

No Capítulo 3 apresenta-se o programa experimental, onde são descritas as lajes ensaiadas nessa pesquisa, as variáveis estudadas, a instrumentação e os procedimentos de ensaio.

No Capítulo 4 são apresentados os resultados experimentais obtidos nos ensaios quanto às deformações nas armaduras de flexão e cisalhamento, deformações no concreto, deslocamentos verticais, fissuração, rotações das lajes, cargas últimas e modos de ruptura. 
No Capítulo 5 é apresentada a análise dos resultados experimentais em grupos formados pela semelhança de variáveis existentes nas lajes ensaiadas.

No Capítulo 6 são descritos e analisados os resultados obtidos com o programa de análise não linear ATENA.

No Capítulo 7 são apresentadas as previsões segundo as normas adaptadas e analisada a variação de parâmetros em cada norma utilizada para comparar com os resultados experimentais.

No Capítulo 8 são apresentadas as conclusões e sugestões para trabalhos futuros.

São apresentadoas ainda as Referências Bibliográficas e um apêndice com o cálculo das cargas de ruptura segundo as normas adaptadas para o caso do pilar de canto reentrante. 


\section{REVISÃO BIBLIOGRÁFICA}

O fenômeno de punção pode ser caracterizado como um modo de ruptura que ocorre por cisalhamento em elementos delgados submetidos a carga ou reação concentrada aplicada transversalmente, que provoca elevadas tensões de cisalhamento em torno de regiões relativamente pequenas, podendo resultar em ruptura frágil. Nas lajes lisas, esta situação é típica na região da ligação laje-pilar. Procura-se minimizar essas tensões atuantes na região próxima ao pilar com o uso de drop panel ou capitéis na região onde ocorrem os maiores esforços de cisalhamento. Outra forma de evitar à punção é o aumento da capacidade resistente da laje, utilizando-se concreto de alta resistência e armadura de cisalhamento. A Figura 2.1 apresenta a superfície de ruptura devido à punção em lajes lisas sem armadura de cisalhamento nos casos de carregamento simétrico. Segundo o CEB-FIP MC90 (1993) a superfície de ruptura tem formato tronco-cônica e se desenvolve a partir da extremidade da área carregada até a face oposta da laje, seguindo uma inclinação normalmente entre $25^{\circ} \mathrm{e}$ $30^{\circ}$.

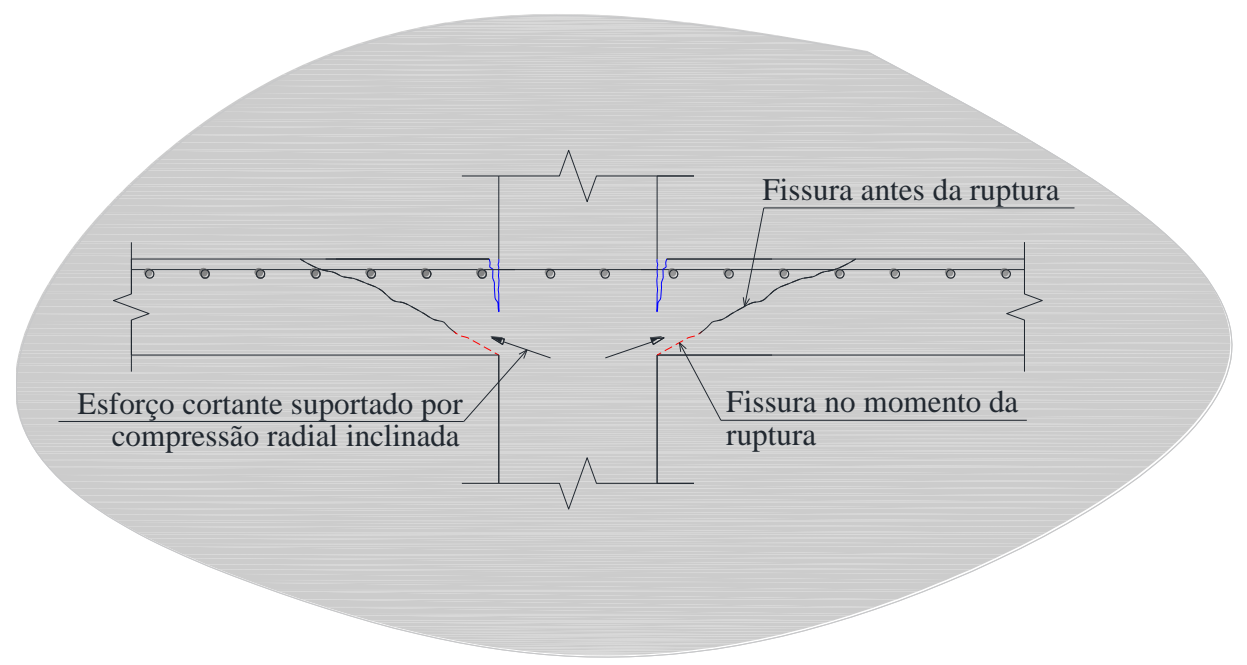

Figura 2.1 - Esquema de ruptura por punção para lajes lisas de concreto armado sem armadura de cisalhamento (CEB-FIP/MC90:1993) 


\subsection{CONCEITOS FUNDAMENTAIS}

\subsubsection{Armadura de Cisalhamento}

Para se evitar a ruptura por punção, muitas vezes é necessário aumentar a resistência da ligação laje-pilar. Soluções comuns como capitéis e "drop panels" podem ser indesejáveis do ponto de vista arquitetônico ou construtivo, e, por isso, o uso de armaduras de cisalhamento para evitar a punção, ou simplesmente, armaduras de punção, vem crescendo bastante. Essa alternativa, favorável do ponto de vista da ductilidade, pode contribuir para a mudança do tipo de ruptura previsto.

A capacidade resistente da ligação aumenta significativamente, tanto que, de acordo com Gomes (1991), a resistência das lajes com armaduras de punção pode chegar ao dobro da resistência das lajes sem essas armaduras. Esse aumento proporcionado pelas armaduras, entretanto, é limitado pela tensão de esmagamento da biela de concreto na face do pilar. Dessa forma, a tensão resistente da ligação tem uma parcela referente à armadura de punção e outra referente ao concreto (não apenas à biela, mas também para o caso de tração diagonal, com mecanismos de transferência como o engrenamento dos agregados).

A parcela de resistência do concreto corresponde a cerca de $75 \%$ da resistência da laje sem armadura de punção, segundo os estudos de Regan e Braestrup (1985), com base nos trabalhos de Dilger e Ghali (1981), Langohr et al. (1976) e Seible et al. (1980), dentre outros. Nas lajes com armadura de cisalhamento, a parcela resistente do concreto sofre redução em consequência, principalmente, das maiores deformações e aberturas de fissuras relacionadas ao trabalho da armadura de cisalhamento. Já a parcela da armadura depende de vários parâmetros, como a disposição e os espaçamentos dos elementos, a eficiência das ancoragens, além da própria área de aço. Podem ser utilizados estribos ou conectores tipo pino (studs), que são modelos mais usuais dentre outras possibilidades. A Figura 2.2 mostra detalhes de alguns dos principais tipos de armaduras de cisalhamento utilizadas em lajes lisas. 

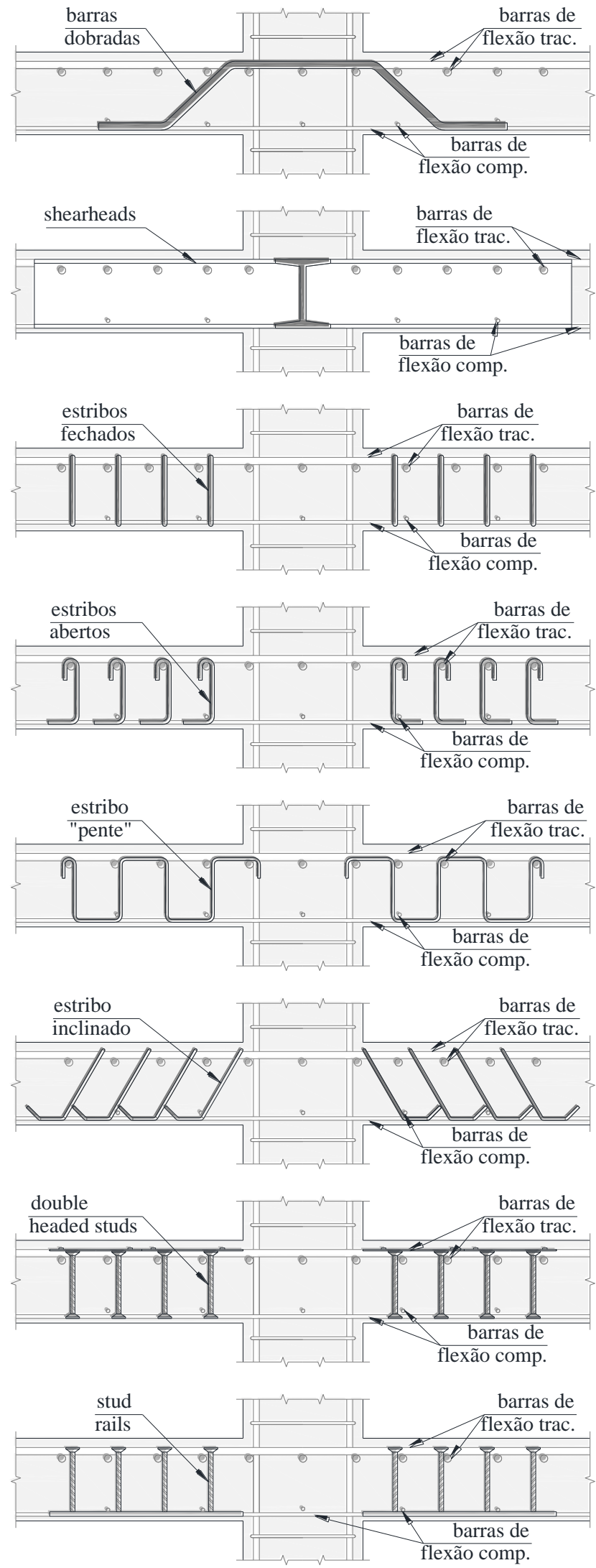

a) Barras dobradas

b) Estribos fechados

c) Estribos abertos e) Estribo inclinado

f) Single-headed studs on rails

g) Double-headed studs

h) Shearheads

Figura 2.2 - Tipos de armaduras de cisalhamento para lajes lisas (FERREIRA, 2010) 
Apesar dos estribos serem escolhidos com maior frequência no Brasil, a garantia de sua ancoragem requer cuidados essenciais. $\mathrm{O}$ estribo deve envolver tanto a armadura de flexão superior quanto a inferior, o que dificulta e pode atrasar o processo executivo. Rupturas nessas ligações provocam escorregamento e já comprometem a eficiência da armadura, como mencionado por Dilger e Ghali (1981).

Mais efetivos em termos de ancoragem e de instalação mais precisa, os conectores tipo pino têm apresentado bom desempenho no aumento da resistência da ligação laje-pilar, como comprovado experimentalmente por Dilger e Ghali (1981), Mokhtar et al. (1985), Elgabry e Ghali (1987) e Ferreira (2010). Dependendo do fabricante deste tipo de armadura, pode-se posicioná-la antes ou depois da montagem das armaduras de flexão, tendo para tal, chapas ou barras delgadas de aço apenas para permitir sua fixação. A Figura 2.3 mostra detalhes das armaduras do sistema DSA (double headed studs attached to a steel shape) da empresa PEIKKO $^{\circledR}$ e a Figura 2.4 apresenta detalhes do sistema de armaduras contra punção da empresa ANCON. Segundo Ghali (1989), numa mesma situação, esse tipo de armadura requer uma menor área de aço que os estribos, o que também significa economia. Por tudo isso, os conectores tipo pino vêm sendo cada vez mais empregados em diversos países.
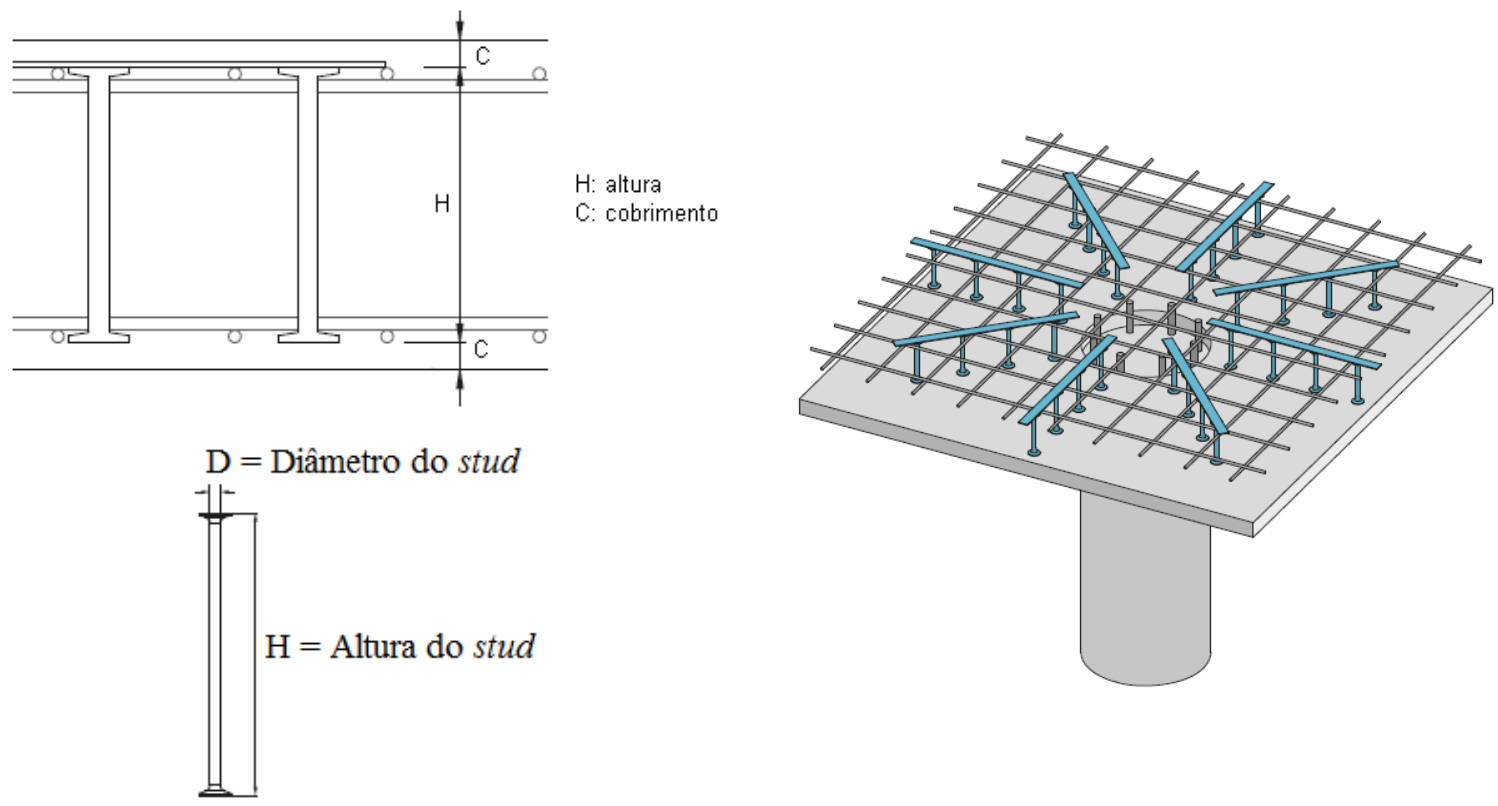

(a) Detalhe dos studs

(b) Laje lisa reforçada com DSA

Figura 2.3 - Detalhes do sistema de armaduras DSA - $\left(\right.$ PEIKKO $\left.^{\circledR}, 2012\right)$ 


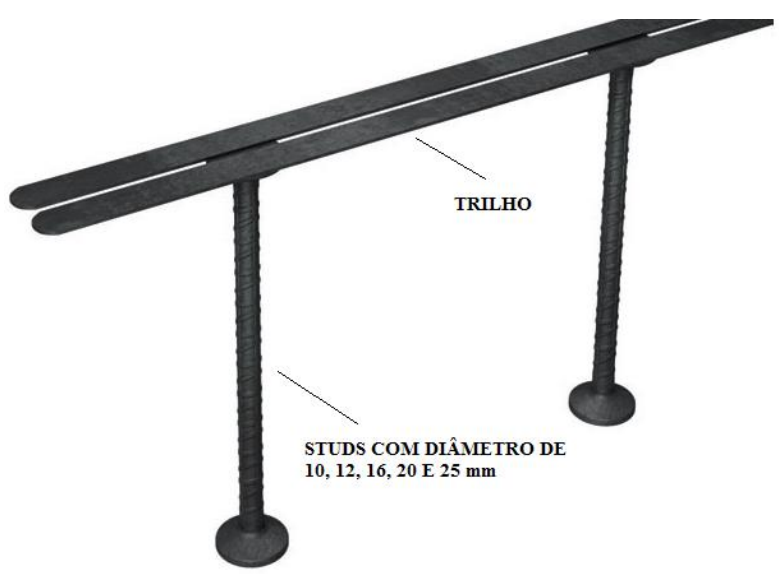

(a) Componentes do sistema

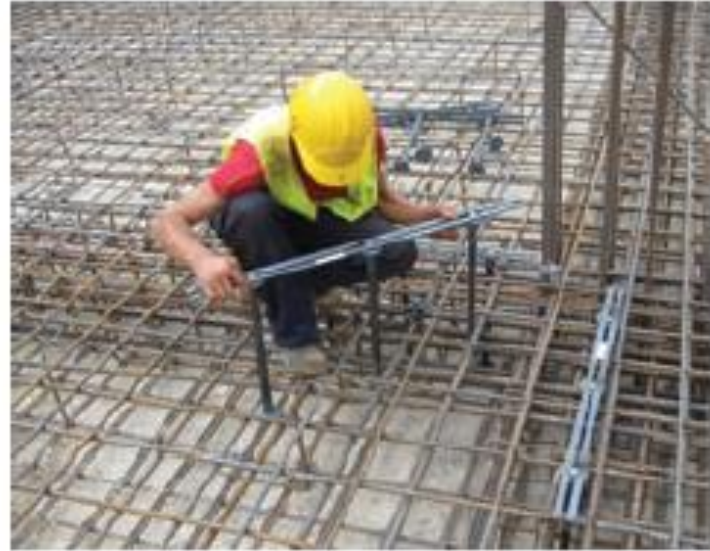

(b) Posicionamento dos studs

Figura 2.4 - Detalhes do sistema de armaduras - (ANCON, 2012)

Por questões construtivas, muitas vezes é mais simples concentrar as armaduras de cisalhamento em faixas ortogonais, em um arranjo "em cruz" (Figura 2.5b) do que em radial devido à interferência entre as armaduras de flexão e de cisalhamento na região da ligação laje-pilar. Tanto o arranjo adotado para a distribuição das armaduras quanto o tipo e quantidade de armadura de cisalhamento influenciam significativamente na resistência à punção de lajes lisas.

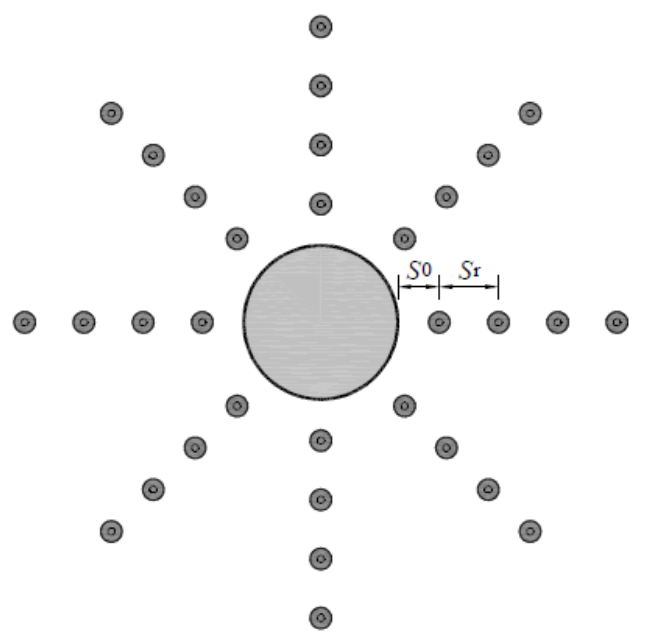

(a) Distribuição radial

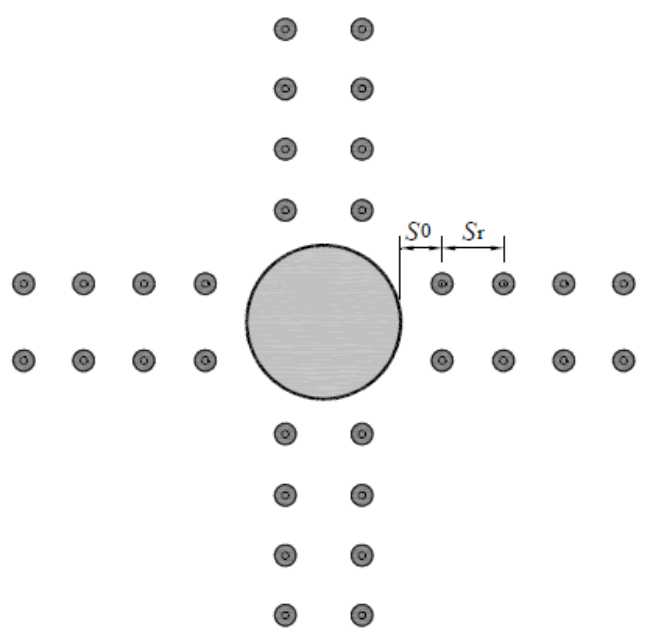

(b) Distribuição "em cruz"

Figura 2.5 - Arranjos para a distribuição das armaduras de cisalhamento - (NBR 6118, 2014)

Para o espaçamento entre camadas $\left(\mathrm{s}_{\mathrm{r}}\right)$, é sugerido pelas normas que a distância máxima adotada seja de $0,75 \cdot d$. Segundo Ferreira (2010), essa limitação para o máximo espaçamento entre camadas parece justificável uma vez que, se for considerado que o 
comprimento das armaduras de cisalhamento é aproximadamente igual à altura útil da laje (d), ao se espaçar as armaduras com valores de $s_{r}=d$ a tendência seria que o ângulo da superfície de ruptura fosse $45^{\circ}$ e, com tal inclinação, a superfície de ruptura poderia não cruzar nenhuma das armaduras de cisalhamento. A Figura 2.6 apresenta a ruptura por punção assumindo-se uma inclinação de $45^{\circ}$ para a superfície de ruptura onde é possível perceber que, se a primeira camada estiver muito próxima da face do pilar e se as demais camadas estiverem muito afastadas é possível que as armaduras não sejam eficientes.

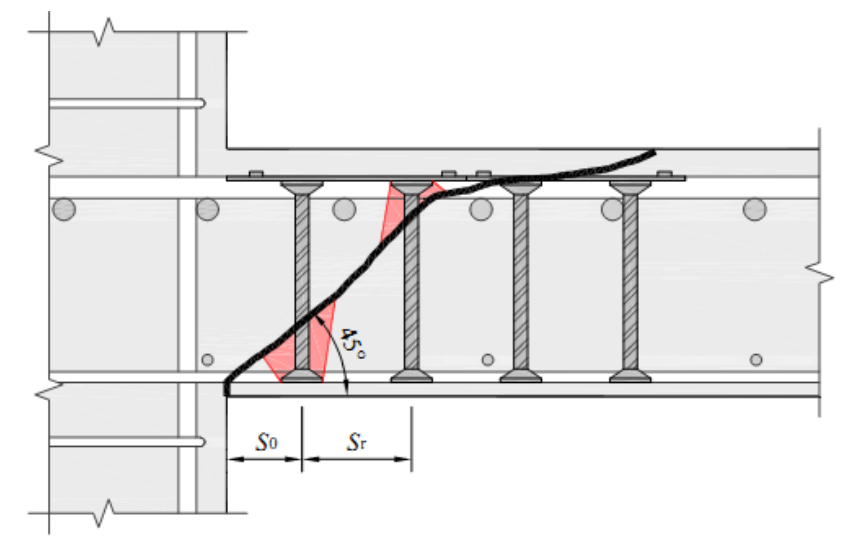

Figura 2.6 - Ancoragem de double-headed studs em lajes lisas (FERREIRA, 2010)

Ferreira (2010) cita que outro parâmetro que pode influenciar o desempenho de uma conexão laje-pilar é o comportamento da região onde as armaduras de cisalhamento serão utilizadas. A correta definição das dimensões da região onde é necessária a utilização de armadura de cisalhamento é fundamental para evitar rupturas bruscas na parte externa à região com armadura de cisalhamento.

\subsection{TRABALHOS EXPERIMENTAIS CONSIDERADOS PARA O ESTUDO DO FENÔMENO DE PUNÇÃO EM LAJES LISAS DE CONCRETO ARMADO COM PILAR DE CANTO REENTRANTE}

Durante a realização desta pesquisa foram encontradas várias publicações sobre o estudo do fenômeno de punção para pilares internos, de borda e de canto, considerando a investigação quanto a vários parâmetros. No entanto, foi encontrada apenas um trabalhoexperimental sobre punção em lajes lisas de concreto armado com pilar de canto reentrante (CARES, 2012 e CARES,2013). Neste Capítulo são citados alguns trabalhos 
relevantes para o estudo do fenômeno de punção e que podem contribuir para a análise dos resultados desta pesquisa e será descrita a pesquisa da CARES.

A primeira pesquisa experimental relativa ao fenômeno de punção foi realizada por Lord (1910) que estudou o fenômeno da punção por meio de prova de carga em um edifício de 11 andares até o estado limite de serviço. Em seguida Talbot (1913), ensaiou 197 sapatas, 114 sob muros e 83 sob pilares verificando-se que 20 romperam por punção. A partir dos resultados experimentais Talbot propôs um cálculo de resistência ao cisalhamento de ligações laje-pilar baseado apenas na resistência do concreto, sem levar em conta a influência da armadura de flexão. Talbot constatou que a armadura de flexão tem influência sobre a resistência à punção e concluiu que a superfície de ruptura é troncocônica com faces inclinadas com um ângulo de aproximadamente $45^{\circ}$.

Graf (1933) concluiu que a resistência à punção das lajes aumentava pouco com o aumento da resistência à compressão do concreto e confirmou que a fissuração devido à flexão diminui a resistência da ligação laje-pilar.

Kinnunen e Nylander (1960) realizaram ensaios com lajes circulares, sendo os primeiros a apresentar uma teoria racional, com um modelo mecânico, sobre lajes submetidas à punção, considerando o caso específico de lajes com armadura de flexão circular. Kinnunem (1963) estendeu o modelo mecânico para lajes com armaduras de flexão ortogonais, considerando os efeitos de pino e de membrana da armadura.

A transferência de momentos nas ligações laje-pilar foi inicialmente estudada com maiores detalhes por Moe (1961), onde foram ensaiadas 43 lajes e feito um estudo estatístico dos resultados de 260 lajes e sapatas, concluindo-se que a transferência de momento reduz a resistência da ligação e que a resistência à punção está relacionada com a resistência à flexão.

$\mathrm{Na}$ Universidade de Brasília os ensaios envolvendo o estudo de punção em lajes lisas de concreto armado foram realizados por Oliveira (1998), Coelho (1999), Trautwein (2001), Barreto (2002), Albuquerque (2010), Feliciano (2011), Barbosa (2012), em dissertações de mestrado, e nas teses de doutorado por Ferreira (2010), Oliveira (2013) e Albuquerque (2014). Trabalhos envolvendo lajes lisas protendidas foram realizados por Corrêa (2001), Alves (2002), Villaverde (2003) e Oliveira (2008) em dissertações de mestrado, e nas teses de doutorado por Melo (2005), Carvalho (2005), Silva (2005), Villaverde (2008) e Gomes 
(2010). Foram desenvolvidos, além dos já citados, trabalhos envolvendo punção em lajes com furos por Souza (2004) em dissertação de mestrado e por Borges (2004) e Souza (2008) em teses de doutorado. Alternativas para evitar a punção foram analisadas por Lima (2012), Nicacio (2013) e Santos (2014) que utilizaram fibras como reforço; Moraes Neto (2013) utilizando lajes lisas reforçadas com fibras, e Lima Neto (2012) o qual utilizou capitéis. Todos estes trabalhos trataram do estudo da ruptura de lajes lisas de concreto armado ou protendido à punção, com ou sem armadura de cisalhamento, sob a orientação do professor Guilherme Sales Soares de Azevedo Melo.

\subsubsection{CARES TECHNICAL APPROVAL REPORT TA7 5041 (2012)}

$\mathrm{Na}$ aplicação de double-headed studs em relação a dimensionamento em projetos, CARES (UK Certification Authority for Reinforcing Steels) tem usado as equações básicas do Eurocode 2 para determinar a resistência à punção sem considerar os coeficientes de segurança, com a resistência à compressão do concreto substituída por $f_{c}$. Assim, para conexão entre a laje de concreto armado comum e pilar de centro sem transferência de momento:

i) Resistência da laje sem armadura:

$$
V_{R, c}=v_{R, c} \cdot u_{1} \cdot d
$$

ii) Resistência no perímetro $\boldsymbol{u}_{1}$ devido à armadura de cisalhamento:

$$
V_{R, s}=\frac{1,5 \cdot d}{s_{r}} \cdot A_{s w} \cdot f_{y w, e f f}
$$

iii) Resistência no perímetro $\boldsymbol{u}_{1}$ em lajes com armadura de cisalhamento:

$$
V_{R, c s}=0,75 \cdot V_{R, c}+V_{R, s} \leq 2 \cdot V_{R, c}
$$

iv) Resistência no perímetro $u_{\text {out }}$, afastado 1,5.d da última camada de armadura de cisalhamento:

$$
V_{R, \text { out }}=v_{R, c} \cdot u_{\text {out }} \cdot d
$$

v) Resistência máxima da conexão conhecendo a dimensão e forma do pilar, espessura da laje efetiva e resistência do concreto:

$$
V_{R, \text { máx }}=0,24 \cdot\left(1-\frac{f_{c}}{250}\right) \cdot u_{0} \cdot d
$$


onde:

$d=$ Altura útil da laje.

$u_{0}=$ Perímetro a $2 \mathrm{~d}$ do pilar.

$u_{0, \text { out }}=\sum s_{t}+3 \pi \cdot d$, onde $s_{t}$ é o espaçamento circunferencial dos studs no perímetro externo dos studs $\leq 2 \cdot d$.

$s_{r}=$ espaçamento radial do perímetro dos studs.

$$
V_{R, c}=0,18 \cdot\left(100 \cdot \rho_{l} \cdot f_{c}\right)^{1 / 3} \cdot(1+\sqrt{200 / d}) \leq 0,36 \cdot\left(100 \cdot \rho_{l} \cdot f_{c}\right)^{1 / 3}
$$

$A_{s w}=$ área de armadura de cisalhamento por perímetro de studs.

$f_{y w, e f f}=1,15 \cdot(250+0,25 \cdot d)$

A resistência calculada prevista é então:

$$
V_{\text {calc }}=\min \left\langle V_{R, c s} ; V_{R, \text { out }} ; V_{R, \text { máx }}\right\rangle \geq V_{R, c}
$$

e deve ter uma probabilidade de $95 \%$ de ser conseguida em ensaio.

Embora o EC2 não apresente regra para ligação laje pilar de canto reentrante (interno), no tratamento básico para cargas excêntricas pode ser incluído esse caso e a Figura 2.7 ilustra tal extensão para pilar quadrado com transferência de momento em x e y igual.

Ao longo do processo de certificação do sistema Ancon SHEARFIX de armadura de cisalhamento para punção pela CARES, foram ensaiadas na Universidade de Cambridge três lajes com dimensões mostradas na Figura 2.8. Duas das lajes foram reforçadas com diferentes arranjos de studs e a terceira sem armadura de cisalhamento. A Figura 2.9 e a Figura 2.10 mostram a armadura de uma das lajes ensaiadas.

A relação de carga última experimental com a carga prevista calculada com base nas equações (2.1) a (2.7), foi 1,05 para laje sem armadura de cisalhamento e 1,0 e 1,19 para lajes com armadura de cisalhamento. A maior carga das lajes foi com armadura de cisalhamento que suportou uma carga 1,78 vezes a capacidade de carga calculada da laje sem armadura de cisalhamento.

Em ambos os ensaios, as medidas de deformações mostraram que a média das tensões nos studs na região crítica atingiu $f_{y w, e f f}$ e os studs individuais atingiram o escoamento, apesar 
de ter utilizado a espessura da laje o mínimo da permitida pelo EC2 em lajes com armadura de cisalhamento.

O valor $\beta$ obtido da análise estrutural de laje usado em projeto para punção não é recomendado pelo EC2 para pilar de canto reentrante e para transferência de momento.

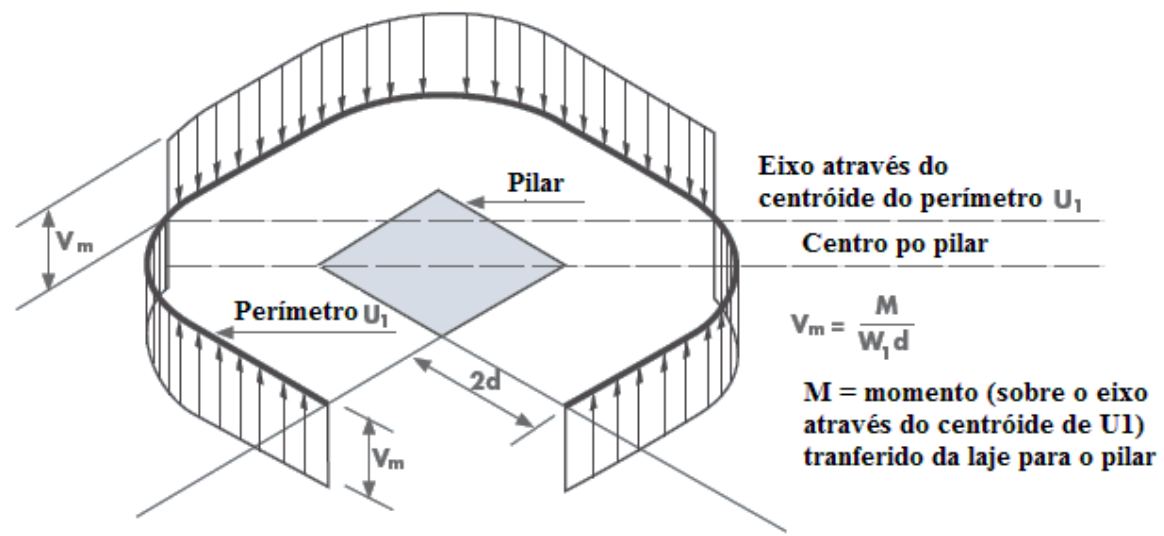

Figura 2.7 - Distribuição de cisalhamento devido a transferência de momento (CARES Technical Approval Report TA7 5041, 2012)

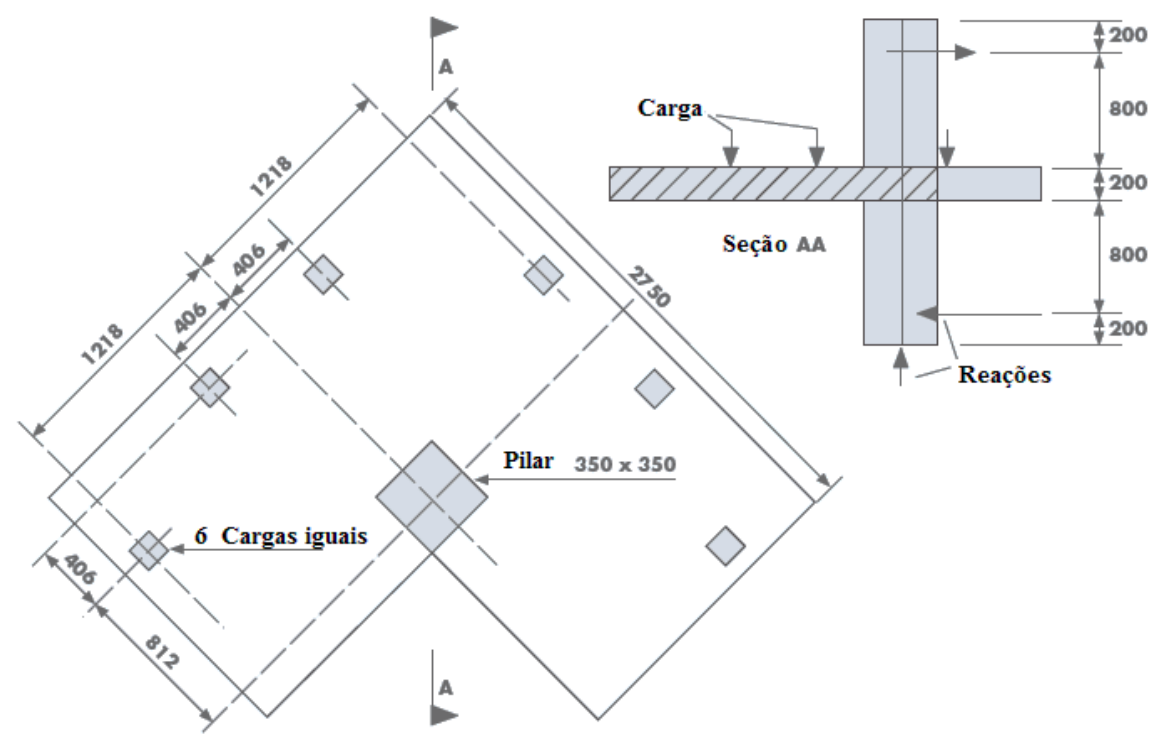

Figura 2.8 - Dimensões e cargas das lajes ensaiadas - (CARES Technical Approval Report TA7 5041, 2012) 


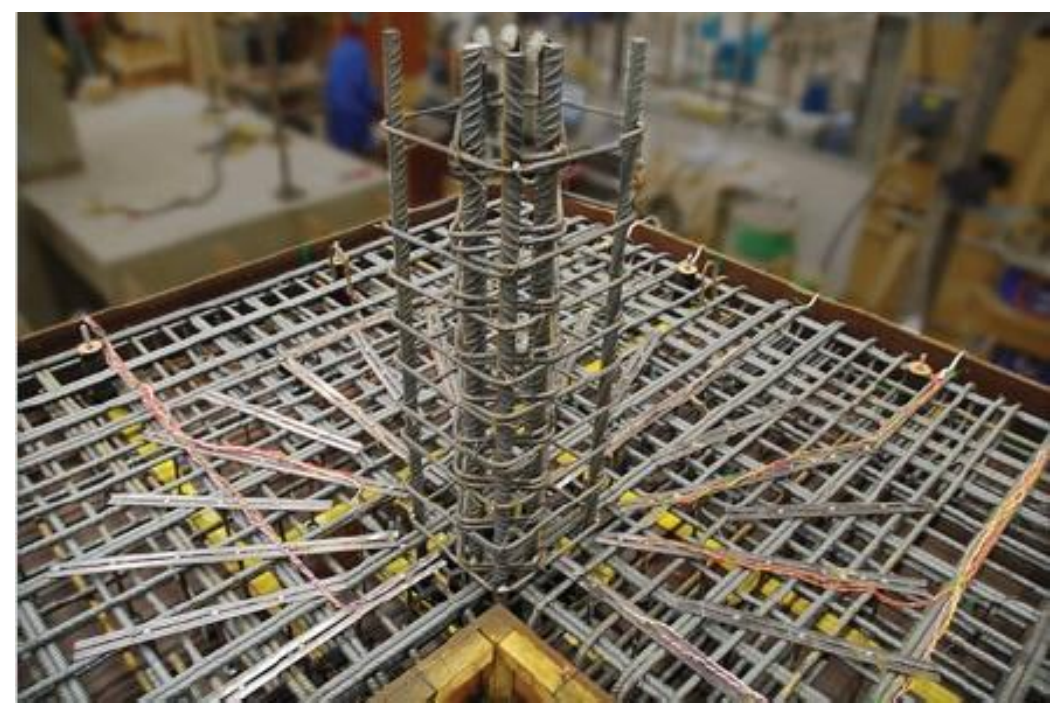

Figura 2.9 - Ensaios de validação do SHEARFIX na Universidade de Cambridge Inglaterra (CARES Technical Approval Report TA7 5041, 2012)

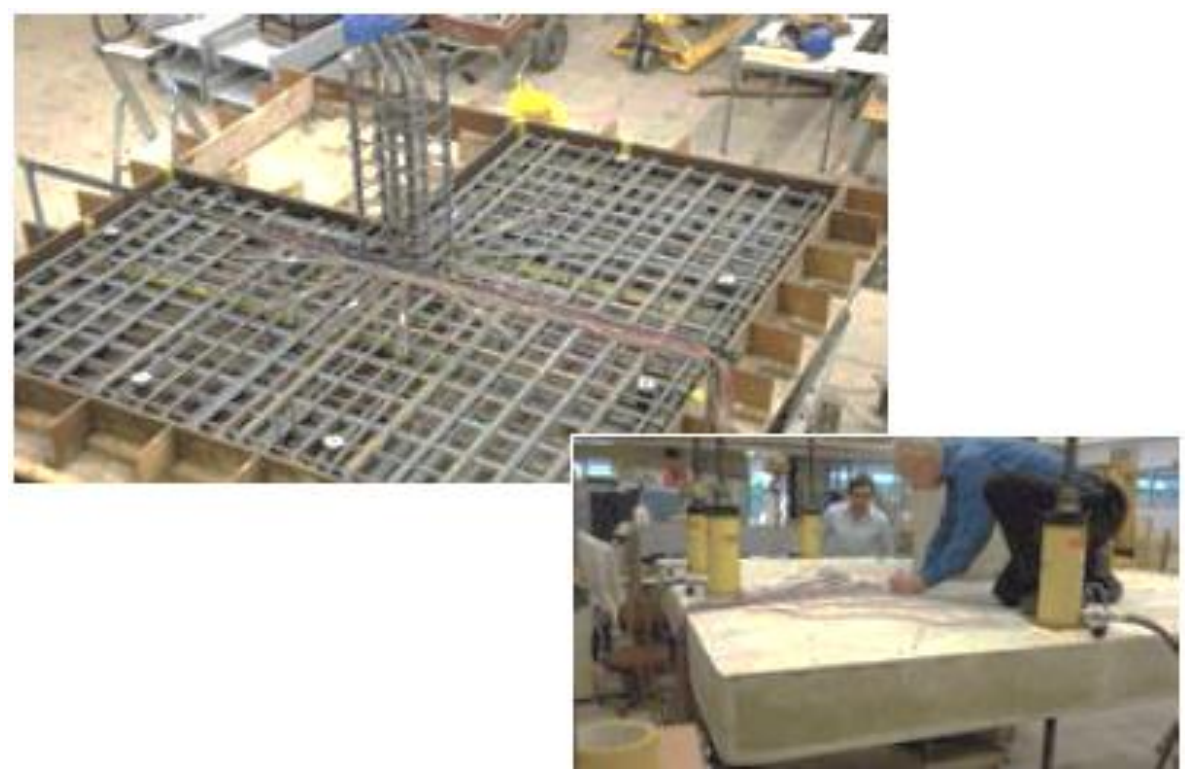

Figura 2.10 - Canto reentrante; ensaios em escala real na Universidade de Cambridge Inglaterra (CARES Technical Approval Report TA7 5043, 2013) 


\subsection{PRESCRIÇÕES NORMATIVAS PARA RESISTÊNCIA À PUNÇÃo}

\subsubsection{NBR 6118 (2014) - Projeto de Estruturas de Concreto - Procedimento.}

O modelo empírico de cálculo adotado pela NBR 6118 (ABNT, 2014) é baseado no método da superfície crítica. Compara-se a tensão de cisalhamento atuante em cada uma das superfícies críticas perpendiculares ao plano médio da laje com a tensão resistente correspondente. Compara-se também a tensão solicitante máxima com a capacidade resistente da ligação, dada pela resistência do concreto à compressão diagonal.

O modelo de cálculo da NBR 6118 (ABNT, 2014) propõe a verificação do cisalhamento em duas ou mais superfícies críticas definidas no entorno de áreas com carregamento concentrado.

Na primeira superfície crítica, (perímetro crítico $u_{0}$ ) do pilar ou da carga concentrada, deve ser verificada indiretamente a tensão de compressão diagonal do concreto através da tensão de cisalhamento.

$\mathrm{Na}$ segunda superfície crítica, (perímetro crítico $u$ ) afastada $2 . d$ do pilar ou carga concentrada, deve ser verificada a capacidade da ligação à punção, associada à resistência à tração diagonal. Caso haja necessidade, a ligação deve ser reforçada por armadura transversal.

A terceira superfície crítica, (perímetro crítico $u$ '), apenas deve ser verificada quando for necessária a utilização da armadura transversal.

A tensão solicitante nas superfícies críticas dos perímetros críticos $u_{0}$ e $u$ para pilar interno com carregamento simétrico é dada por:

$$
\tau_{s d}=\frac{F_{s d}}{u \cdot d}
$$

onde:

$$
d=\left(d_{x}+d_{y}\right) / 2
$$

$d$ é a altura útil da laje ao longo do perímetro $u$, externo ao perímetro $u_{0}$ da área de aplicação da força e deste distante $2 \cdot d$ no plano da laje;

$d_{x}$ e $d_{y}$ são as alturas úteis nas duas direções ortogonais; 
$u_{0}$ é o perímetro do pilar;

$u \cdot d$ é a área da superfície crítica;

$F_{s d}$ é a força ou a reação concentrada de cálculo.

A força $F_{s d}$ pode ser reduzida da força distribuída aplicada na face oposta da laje, dentro do perímetro considerado na verificação, $u_{0}$ ou $u$. A Figura 2.11 ilustra a disposição dos perímetros $u_{0}$ e $u$ para pilares com diferentes posicionamentos em relação à laje.
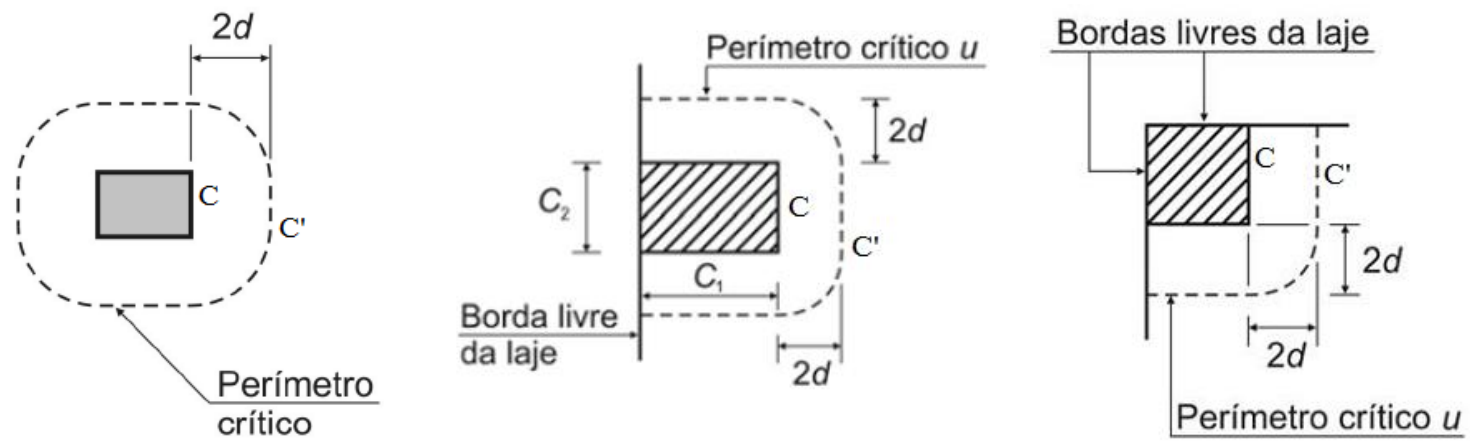

Figura 2.11 - Perímetros críticos $u_{0}$ e $u$ para pilares internos, de borda e de canto -

NBR 6118 (ABNT, 2014)

Como a NBR 6118 (ABNT, 2014) não aborda o caso de pilar com canto reentrante sugerese utilizar o perímetro crítico $u$ normal ou reduzido semelhante ilustrado na Figura $2.12 \mathrm{e}$ Figura 2.13 respectivamente.

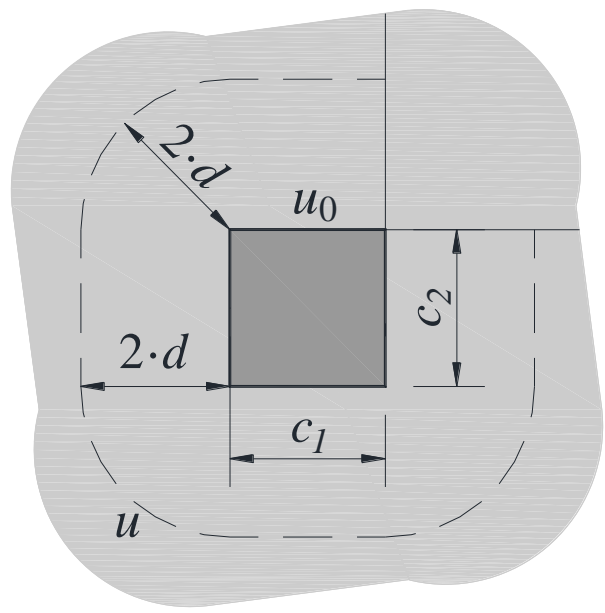

Figura 2.12 - Perímetro crítico $u$ para áreas carregadas perto do canto reentrante. 


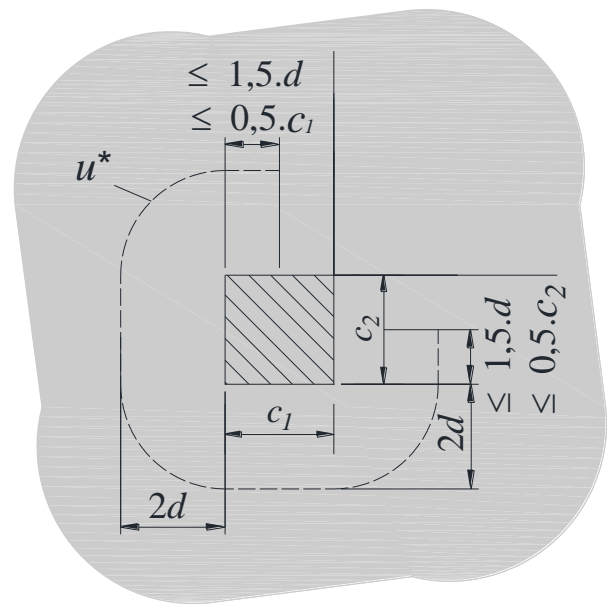

Figura 2.13 - Perímetro crítico reduzido $u^{*}$ com pilar de canto reentrante.

Quando for necessária a utilização de armadura transversal deve-se estendê-la em perímetros paralelos a $u$ até que em um perímetro crítico $u$ ' afastado $2 . d$ do último perímetro de armadura, não seja mais necessária armadura de cisalhamento, isto é, $\tau_{s d} \leq \tau_{R d 1}$. A Figura 2.14 e Figura 2.15 mostram detalhes do perímetro crítico $u$ ' externo às armaduras de cisalhamento considerado pela NBR 6118 (ABNT, 2014).
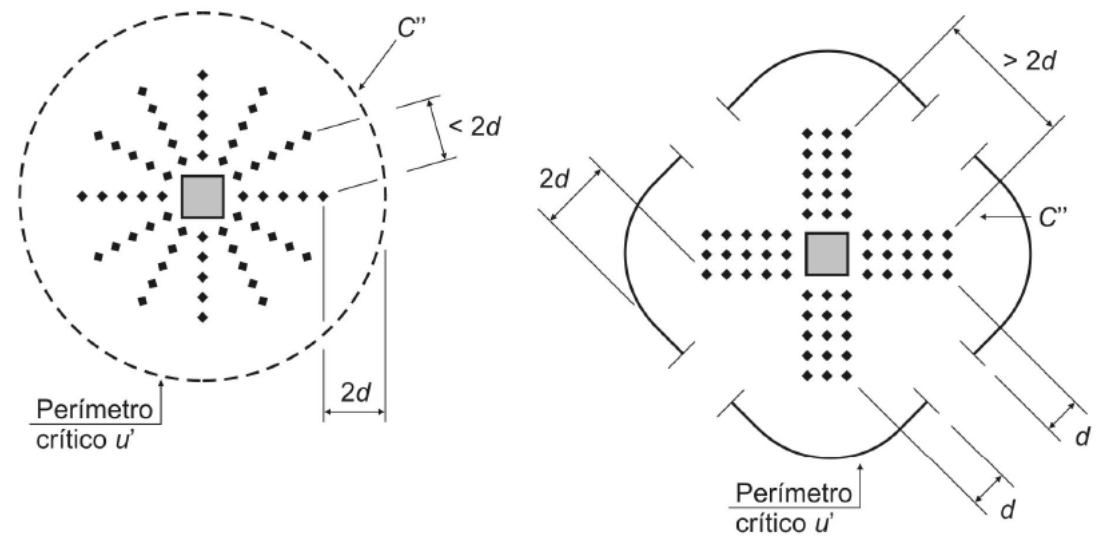

Figura 2.14 - Disposição da armadura de punção em planta e perímetro crítico $u$ ' - NBR 6118 (ABNT, 2014) 


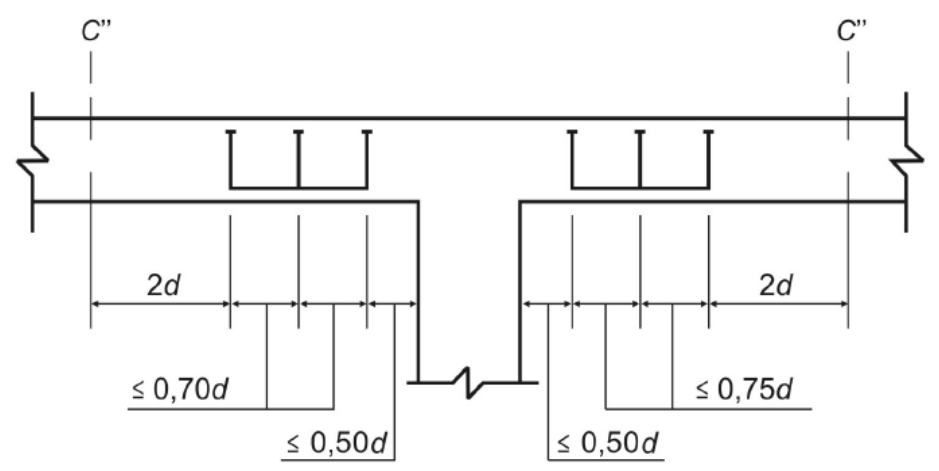

Figura 2.15 - Disposição da armadura de punção - NBR 6118 (ABNT, 2014)

O perímetro crítico $u$ ' considerado para pilar de canto reentrante, adotado como mostra Figura 2.16.

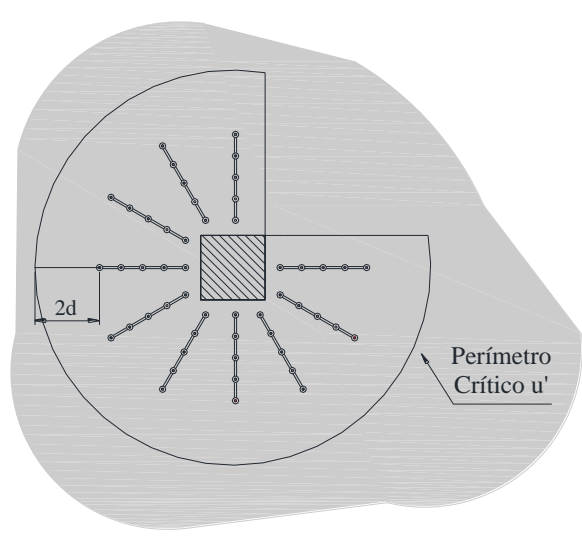

Figura 2.16 - Perímetro crítico $u$ ’ para pilar de canto reentrante.

Além do perímetro crítico reduzido $u^{*}$, pode-se utilizar também o perímetro fora da armadura de cisalhamento reduzido $u_{\text {red }}^{\prime}$ (Figura 2.17), tendo em vista que o mapa de fissuração das lajes mostra que as fissuras que caracterizavam a ruptura não atingem as bordas reentrantes, finalizavam antes.

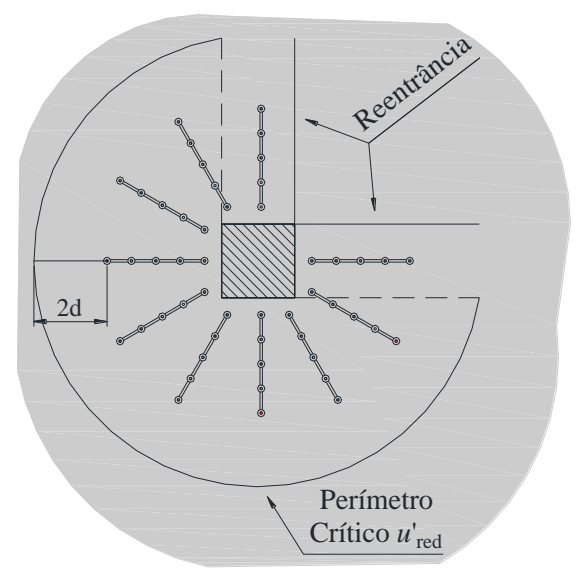

Figura 2.17 - Perímetro crítico reduzido fora da armadura de cisalhamento para pilar de canto reentrante. 
No caso em que, além da força vertical, existe também a transferência de momento da laje para o pilar, o efeito de assimetria deve ser considerado de acordo com a expressão:

$$
\tau_{s d}=\frac{F_{s d}}{u \cdot d}+\frac{K \cdot M_{s d}}{W_{p} \cdot d}
$$

onde:

K é o coeficiente que fornece a parcela de $M_{s d}$ transmitida ao pilar por cisalhamento, que depende da relação $c_{1} / c_{2}$.

O coeficiente $\mathrm{K}$ assume os valores indicados na Tabela 2.1.

Tabela 2.1 - Valores de K - NBR 6118 (ABNT, 2014)

\begin{tabular}{|c|c|c|c|c|}
\hline $\mathrm{c}_{1} / \mathrm{c}_{2}$ & 0,5 & 1,0 & 2,0 & 3,0 \\
\hline $\mathrm{K}$ & 0,45 & 0,60 & 0,70 & 0,80 \\
\hline
\end{tabular}

onde:

$\mathrm{C}_{1}$ é a dimensão do pilar paralela à excentricidade da força;

$\mathrm{C}_{2}$ é a dimensão do pilar perpendicular à excentricidade da força;

$W_{p}$ é o módulo resistente da seção crítica e pode ser calculado desprezando a curvatura dos cantos do perímetro crítico, através da expressão:

$$
W_{p}=\int_{0}^{u}\left|e_{i}\right| \cdot d l
$$

onde:

$d l$ é o comprimento infinitesimal no perímetro crítico $u$;

$e_{i}$ é a distancia de $d l$ ao eixo que passa pelo centro do pilar e sobre a qual atua o momento fletor $M_{s d}$.

Para evitar uma ruptura por compressão diagonal do concreto na superfície crítica do perímetro $u$ (perímetro do pilar ou ponto de carregamento multiplicado pela espessura da laje) uma verificação deve ser feita para lajes com ou sem armadura de punção: 


$$
\tau_{s d} \leq \tau_{R d 2}=0,27 \cdot \alpha_{v} \cdot f_{c d}
$$

onde:

$$
\alpha_{v}=\left(1-\frac{f_{c k}}{250}\right)
$$

$\tau_{s d}$ é a tensão atuante ou de projeto;

$\tau_{R d 2}$ é a tensão resistente;

Para evitar uma ruptura por punção da laje na superfície crítica do perímetro $u$ (perímetro crítico $u$ multiplicado pela espessura da laje) em elementos estruturais ou trechos sem armadura de punção deve ser feita uma nova verificação:

$$
\tau_{s d} \leq \tau_{R d 1}=0,13 \cdot\left(1+\sqrt{\frac{20}{d}}\right) \cdot\left(100 \rho \cdot f_{c k}\right)^{1 / 3}
$$

onde:

$$
\rho=\sqrt{\rho_{x} \cdot \rho_{y}}
$$

$d$ é a altura útil da laje ao longo do perímetro crítico $u$ da área de aplicação da força, em centímetros;

$\rho$ é a taxa geométrica de armadura de flexão aderente (armadura não aderente deve ser desprezada);

$\rho_{x}$ e $\rho_{y}$ são as taxas de armadura nas duas direções ortogonais.

Para evitar uma ruptura por punção da laje na superfície crítica do perímetro $u$ (perímetro crítico $u$ multiplicado pela espessura da laje) em elementos estruturais ou trechos com armadura de punção deve ser feita uma nova verificação:

$$
\tau_{s d} \leq \tau_{R d 1}=0,10 \cdot\left(1+\sqrt{\frac{20}{d}}\right) \cdot\left(100 \cdot \rho \cdot f_{c k}\right)^{1 / 3}+1,5 \cdot \frac{d}{s_{r}} \cdot \frac{A_{s w} \cdot f_{y w d} \cdot \operatorname{sen} \alpha}{u \cdot d}
$$


onde:

$$
s_{r} \leq 0,75 \cdot d
$$

$s_{r}$ é o espaçamento radial entre linhas de armadura de punção, não maior do que 0,75 .d;

$A_{s w}$ é a área da armadura de punção num perímetro completo paralelo ao perímetro crítico $u$;

$\alpha$ é o ângulo de inclinação entre o eixo da armadura de punção e o plano da laje;

$u$ é o perímetro crítico.

$f_{y w d}$ é a resistência de cálculo da armadura de punção, não maior do que $300 \mathrm{MPa}$ para conectores ou $250 \mathrm{MPa}$ para estribos (de aço CA50 ou CA60). Para lajes com espessura maior que $15 \mathrm{~cm}$, esses valores podem ser os seguintes valores máximos, sendo permitida interpolação linear:

— $250 \mathrm{MPa}$, para lajes com espessura até $15 \mathrm{~cm}$;

- $435 \mathrm{MPa}\left(f_{y w d}\right)$, para lajes com espessura maior que $35 \mathrm{~cm}$.

\subsubsection{Eurocode 2 (2004) - Design of Concrete Structures}

O Eurocode 2 (2004) define que a punção pode resultar de um carregamento concentrado ou de uma reação atuante em uma área relativamente pequena de uma laje ou fundação. A Figura 2.18 apresenta um modelo para verificar a ruptura por punção no estado limite último.

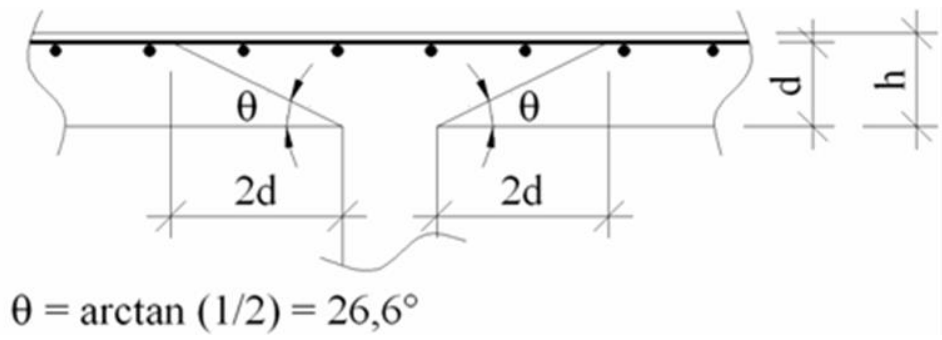

Figura 2.18 - Modelo para verificar a ruptura por punção no estado limite último -

Eurocode 2 (2004) 
A verificação da resistência à punção é feita em torno de um perímetro crítico $u_{1}$ tomado a uma distância $2 \cdot d$ da área carregada e deve ser constituído de modo a minimizar o seu comprimento. A Figura 2.19 e Figura 2.20 mostram detalhes dos perímetros crítico adotados pelo Eurocode 2 (2004).
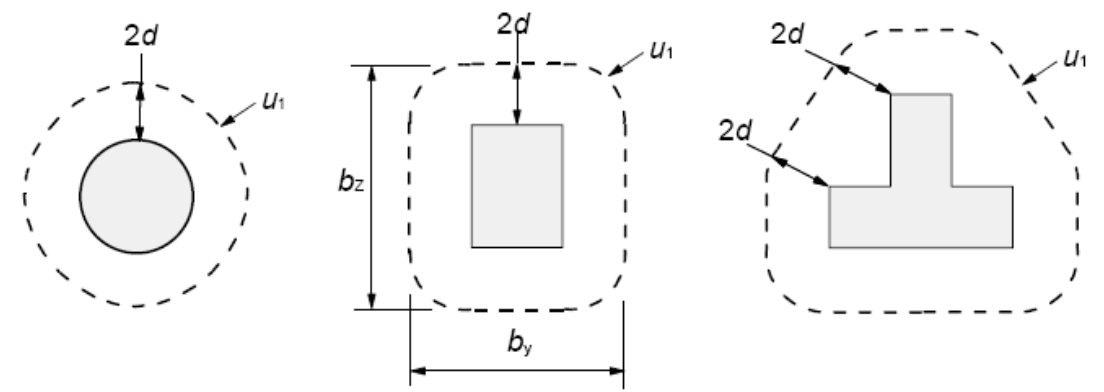

Figura 2.19 - Perímetro crítico $u_{1}$ ao redor de áreas carregadas - Eurocode 2 (2004)
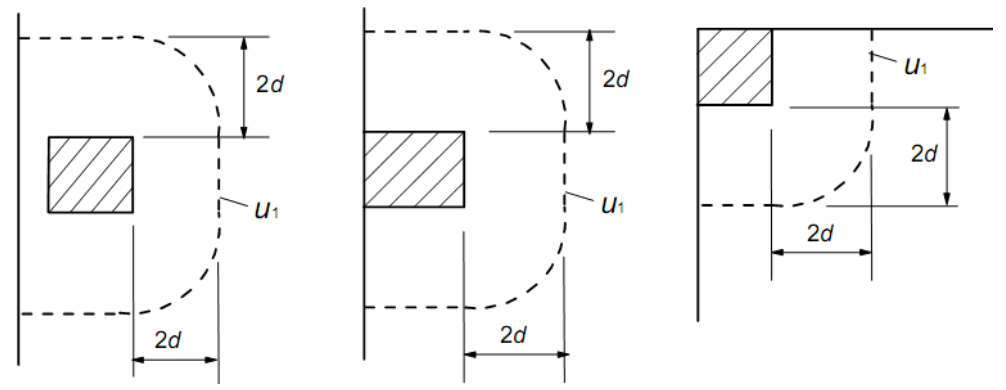

Figura 2.20 - Perímetro crítico $u_{1}$ para áreas carregadas perto da borda ou do canto -

Eurocode 2 (2004)

O Eurocode 2 (2004) não prevê como seria definido o perímetro crítico $u_{1}$ para pilares de canto reentrante. Sugere-se por meio dessa pesquisa o perímetro crítico como mostrado na Figura 2.21.

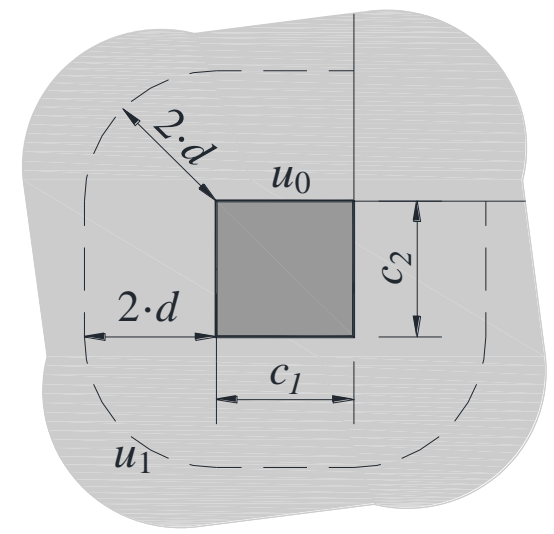

Figura 2.21 - Perímetro crítico para áreas carregadas perto do canto reentrante. 
Para áreas carregadas situadas próximo ou em uma borda ou canto, a uma distância menor do que $d$, armaduras especiais nas bordas devem ser sempre previstas. Ao longo de uma borda livre, uma laje deve normalmente conter armadura longitudinal e transversal, geralmente dispostas como mostrado na Figura 2.22.

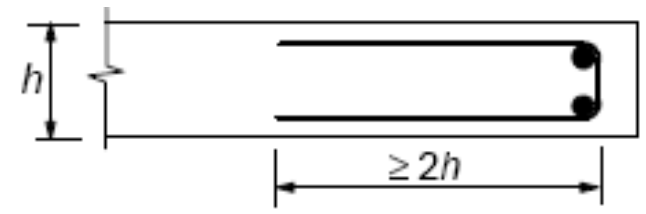

Figura 2.22 - Armadura de borda - Eurocode 2 (2004)

2.3.2.1 As verificações a serem feitas são:

a) Verificação no perímetro do pilar ou área carregada. A máxima tensão de cisalhamento não deve exceder:

$$
v_{E d}<v_{R d, m a ́ x}
$$

onde:

$v_{E d}$ é a tensão atuante na ligação;

$v_{R d, m a ́ x}$ é o valor de cálculo máximo da resistência ao cisalhamento ao longo da seção considerada.

b) Verificação da necessidade de armadura de punção. Não será necessária armadura de punção se:

$$
v_{E d}<v_{R d, c}
$$

onde:

$v_{R d, c}$ é o valor de cálculo da resistência ao cisalhamento sem armadura de punção ao longo da seção considerada.

c) No caso de $v_{E d}$ exceder o valor de $v_{R d, c}$ para a seção de controle considerada deverá adotar-se uma armadura de punção.

O valor da máxima tensão de cisalhamento quando a reação for excêntrica com relação ao perímetro crítico é: 


$$
v_{E d}=\beta \cdot \frac{V_{E d}}{u_{i} \cdot d}
$$

onde:

$$
\beta=1+k \cdot \frac{M_{E d}}{V_{E d}} \cdot\left(\frac{u_{1}}{W_{1}}\right)
$$

$d$ é a profundidade média efetiva da laje, que pode ser tomada como $\left(d_{y}+d_{z}\right) / 2$;

$d_{y}$ e $d_{z}$ correspondem às profundidades efetivas nos eixos y e $\mathrm{z}$ da seção de controle;

$u_{i}$ é o comprimento do perímetro crítico considerado;

$u_{1}$ é o comprimento do perímetro crítico distante $2 \mathrm{~d}$ da face do pilar, em $\mathrm{mm}$;

$u_{1}=4 \cdot c+3 \cdot \pi \cdot d$, para um pilar de canto reentrante quadrado;

$M_{E d}$ é o momento de cálculo;

$V_{E d}$ é o esforço normal de cálculo;

Para simplificar: $e=\frac{M_{E d}}{V_{E d}}$;

$e$ é a excentricidade do carregamento;

k é o coeficiente definido em EC2 em função da razão das dimensões do pilar retangular. Este coeficiente representa a proporção do momento que foi assumido um valor de 0,6, correspondente a um pilar quadrado interno, e é dado pela Tabela 2.2:

Tabela 2.2 - Valores de k para pilares retangulares - Eurocode 2 (2004)

\begin{tabular}{|c|c|c|c|c|}
\hline $\mathrm{c}_{1} / \mathrm{c}_{2}$ & 0,5 & 1,0 & 2,0 & 3,0 \\
\hline $\mathrm{k}$ & 0,45 & 0,60 & 0,70 & 0,80 \\
\hline
\end{tabular}


$W_{1}$ é momento estático do perímetro crítico $u_{1}$ em relação ao eixo passando por $e_{1}$, ou seja, Módulo de Resistência Plástica em função do perímetro crítico $u_{1}$ :

$$
W_{i}=\int_{0}^{u_{i}}\left|e_{i}\right| \cdot d l
$$

$d l$ é o comprimento elementar do perímetro;

$\boldsymbol{e}_{i}$ é a distância de $d l$ ao eixo em torno do qual atua o momento $M_{E d}$.

O cálculo detalhado de $W_{1}$ para pilares de canto reentrante será mostrado no Anexo 1.

\subsubsection{Cálculo da resistência à punção}

O Eurocode 2 (2004) define que a resistência à punção de uma laje com armadura de cisalhamento deve ser o menor valor entre $V_{R, \text { máx }}, V_{R, c s}$ e $V_{R, o u t}$, mas não menor que $V_{R, c}$ :

- $\quad V_{R, \text { máx }}$ é a resistência máxima para uma determinada dimensão de pilar, altura útil e resistência à compressão do concreto;

- $\quad V_{R, c}$ é a capacidade resistente de uma laje similar, mas sem armadura de cisalhamento.

- $\quad V_{R, c s}$ é a resistência máxima advinda da combinação da armadura de cisalhamento e do concreto;

- $\quad V_{R, \text { out }}$ é a resistência da laje na região externa às armaduras de cisalhamento;

a) Resistência máxima:

$$
V_{R, \text { máx }}=\left[\frac{0,3}{\gamma_{c}} \cdot f_{c d} \cdot\left(1-\frac{f_{c d}}{250}\right)\right] \cdot u_{0} \cdot d
$$

onde:

$\gamma_{c}=1,4$ é o coeficiente de ponderação do concreto. 
$f_{c}$ é a resistência a compressão do concreto;

$u_{0}$ é o perímetro do pilar;

b) Para lajes sem armadura de cisalhamento:

$$
V_{R, c}=\frac{0,18}{\gamma_{c}} \cdot\left(100 \cdot \rho \cdot f_{c k}\right)^{\frac{1}{3}} \cdot\left(1+\sqrt{\frac{200}{d}}\right) \cdot u_{1} \cdot d
$$

onde:

$\rho=\sqrt{\rho_{x} \cdot \rho_{y}}$ é a taxa de armadura média da laje, devendo ser calculada em uma largura igual com tamanho do pilar mais $3 \cdot d$ para cada lado;

c) Para lajes com armadura de cisalhamento a resistência máxima advinda da combinação da armadura de cisalhamento e do concreto:

$$
\begin{gathered}
V_{R, c s}=0,75 \cdot V_{R, c}+V_{R, s} \\
V_{R, s}=\left(1,5 \cdot \frac{d}{s_{r}}\right) \cdot A_{s w} \cdot f_{y w, e f f}
\end{gathered}
$$

onde:

$S_{r}$ é o espaçamento radial das camadas (ou perímetro) de armadura de cisalhamento.

$A_{s w}$ é a área (vertical) da armadura de cisalhamento por camada.

$f_{y w, e f f}=1,15 \cdot(250+0,25 \cdot d)$, no qual o 1,15 substitui $\gamma_{\mathrm{s}}$.

d) Resistência da laje na região externa à armadura de cisalhamento:

$$
V_{R, \text { out }}=\frac{0,18}{\gamma_{c}} \cdot\left(100 \cdot \rho \cdot f_{c k}\right)^{\frac{1}{3}} \cdot\left(1+\sqrt{\frac{200}{d}}\right) \cdot u_{\text {out }} \cdot d
$$

onde:

$\kappa=1+\sqrt{\frac{200}{d}} \leq 2,0$ 
$u_{\text {out }}=\beta \cdot V_{E d} /\left(v_{R d, c} \cdot d\right)$

$u_{\text {out }}$ é o perímetro crítico para o qual não é necessário armadura de cisalhamento.

$u_{\text {outeff }}$ é a soma dos trechos do perímetro mínimo externos às armaduras de cisalhamento, com perímetro externo da armadura de cisalhamento colocado à uma distância não superior a 1,5d, conforme ilustrado na Figura 2.23.

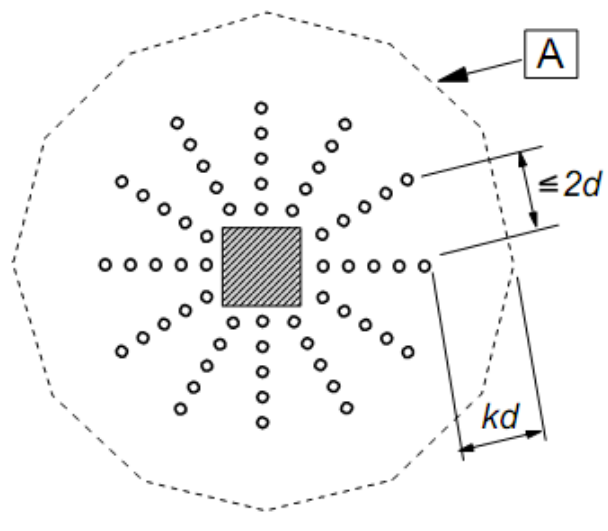

A - Perímetro $u_{\text {out }}$

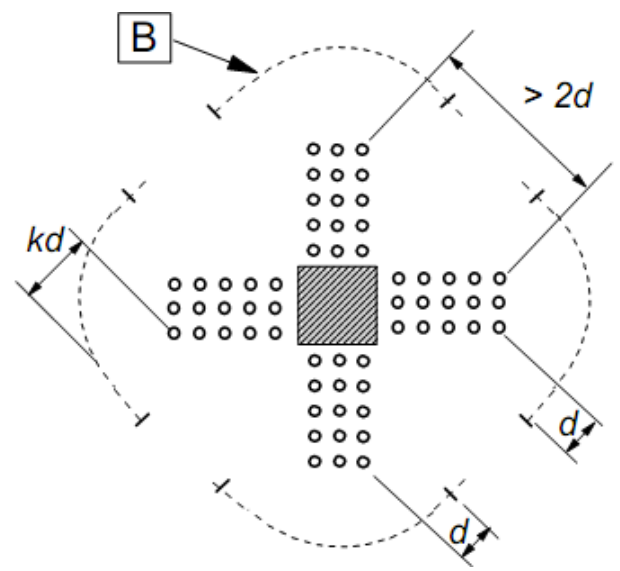

B - Perímetro $u_{\text {out }, \text { eff }}$

Figura 2.23 - Perímetro crítico externo à armadura de cisalhamento - Eurocode 2 (2004)

Para pilares de canto reentrante sugere-se o perímetro poligonal $u_{\text {out }}$ como mostra a Figura 2.24.

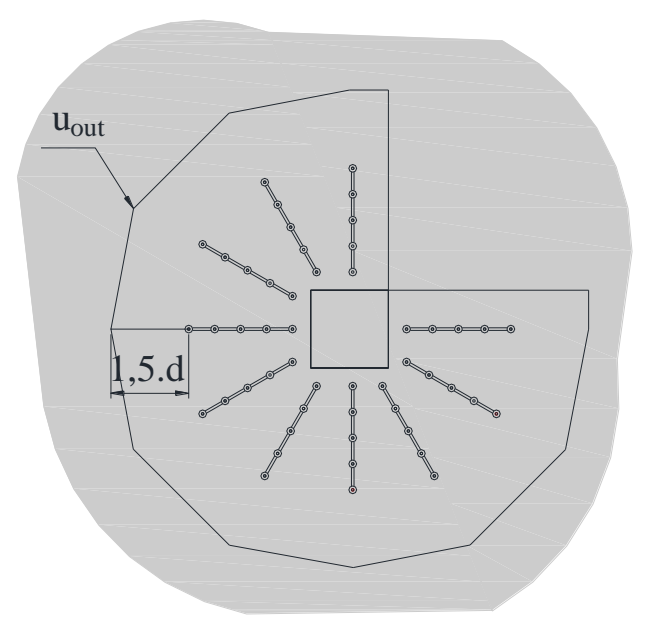

Figura 2.24 - Perímetro $u_{\text {out }}$ para pilar de canto reentrante 


\subsubsection{ACI 318 (2014) - Building Code Requirements for Structural Concrete}

O ACI 318 (2014) adota um perímetro crítico localizado a uma distancia de 0,5.d das faces do pilar para o cálculo da resistência à punção com superfície de ruptura cruzando a armadura de cisalhamento. Para superfície de ruptura externa à região armada ao cisalhamento o perímetro crítico é considerado à uma distância igual à $0,5 . d$ da última camada de armadura transversal.

Para colunas quadradas ou retangulares, cargas concentradas, ou áreas de reação, são permitidas seções críticas com quatro lados retilíneos.

A suposta distribuição das tensões de cisalhamento para pilares internos e a disposição da seção crítica para pilares internos e de canto reentrante estão ilustradas na Figura 2.25.

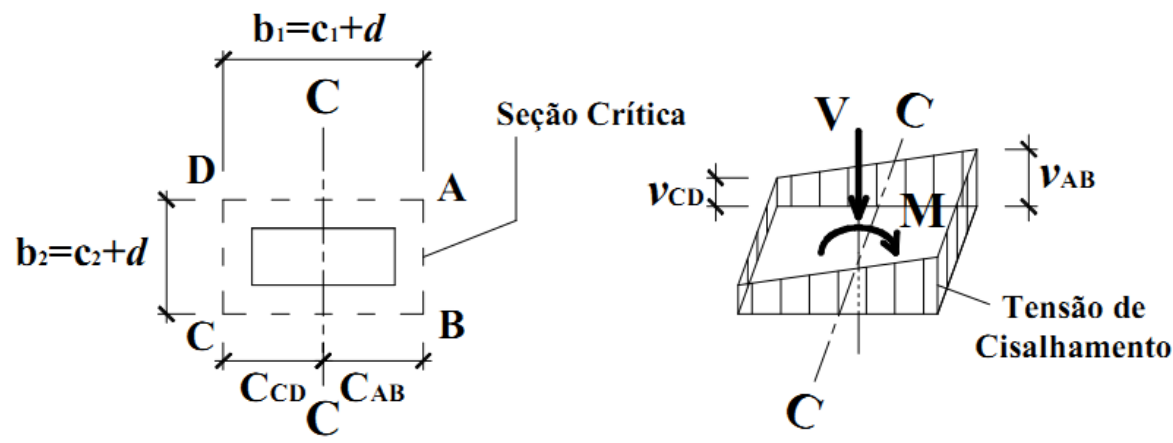

Figura 2.25 - Localização da seção crítica e suposta distribuição das tensões de cisalhamento para pilar interno - ACI 318 (2014)

O ACI 318 (2014) não prevê como seria definida a seção crítica para pilares de canto reentrante. Por isso sugere-se por meio dessa pesquisa a seção crítica mostrada na Figura 2.26 com o momento atuando na direção oposta à reentrância.

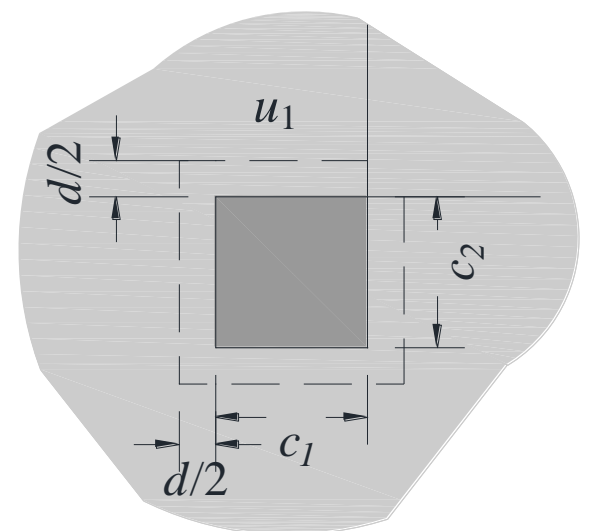

Figura 2.26 - Localização da seção crítica para o pilar de canto reentrante. 
- Resistência à punção de acordo com o ACI 318 (2014), para lajes sem armadura de cisalhamento.

Para lajes não protendidas e sapatas, a resistência a punção sem armadura de cisalhamento, $V_{R, c}$ deve ser o menor valor entre as equações $2.28,2.29$ e 2.30 :

$$
V_{R, c}=0,17 \cdot\left(1+\frac{2}{\beta}\right) \cdot \sqrt{f_{c}^{\prime}} \cdot b_{0} \cdot d
$$

onde $\beta$ é a relação do lado maior e lado menor da coluna, carga concentrada, ou área de reação.

$$
V_{R, c}=0,083 \cdot\left(\frac{\alpha_{s} \cdot d}{b_{0}}+2\right) \cdot \sqrt{f_{c}^{\prime}} \cdot b_{0} \cdot d
$$

onde $\alpha_{\mathrm{s}}$ é 40 para coluna interna, 30 para coluna de borda e 20 para coluna de canto.

(c)

$$
V_{R, c}=0,33 \cdot \sqrt{f_{c}^{\prime}} \cdot b_{0} \cdot d
$$

onde:

$f_{c}^{\prime}$ é a resistência à compressão do concreto, e é limitada em no máximo $69 \mathrm{MPa}$;

$b_{0}$ é o comprimento de um perímetro crítico à $d / 2$ da face do pilar;

$d$ é a altura útil da laje;

A tensão de tração média do concreto, $f_{c t}$ é dada por:

$$
f_{c t}=1 /\left(6,7 \cdot \sqrt{f_{c k}}\right) \leq 1,0
$$

Para lajes de concreto armado com armadura de cisalhamento existem três possíveis posições da superfície de ruptura: superfície de ruptura passando pela armadura de cisalhamento $\left(V_{R, c s}\right)$; superfície de ruptura fora da região das armaduras de cisalhamento $\left(V_{R, \text { out }}\right)$; e ruptura por esmagamento da biela nas proximidades do pilar $\left(V_{R, \max }\right)$. 


$$
V_{R, c s}=V_{R, c}+V_{R, s}
$$

O dimensionamento de qualquer seção de concreto ao cisalhamento, incluindo o dimensionamento de uma ligação laje-pilar à punção, deve satisfazer à seguinte condição:

$$
v_{u} \leq \phi \cdot v_{n}
$$

onde:

$\phi$ é o fator de redução da tensão.

$\nu_{u}$ é a tensão de cisalhamento máxima devido à $M_{u}$ e $V_{u}$;

$v_{n}$ é a tensão de cisalhamento resistente nominal.

Para a tensão de cisalhamento resultante da transferência de momento, a excentricidade de cisalhamento deve ser considerada variável de forma linear sobre o centroide das seções críticas.

Para ligações laje-pilar que realizam transferência de momentos e não apresentam armadura de cisalhamento:

$$
\phi \cdot v_{n}=\frac{\phi \cdot V_{R, c}}{b_{0} \cdot d}
$$

Para membros com armadura de cisalhamento diferente de shearheads:

$$
\phi \cdot v_{n}=\frac{\phi \cdot\left(V_{R, c}+V_{R, s}\right)}{b_{0} \cdot d}
$$

Onde $V_{R, c}$ não deve exceder $0,25 \cdot \lambda \cdot \sqrt{f_{c}^{\prime}} \cdot b_{0} \cdot d$

A contribuição da armadura de cisalhamento, quando se tem estribos verticais, é dada pela expressão: 


$$
V_{R, s}=\frac{A_{v} \cdot f_{y} \cdot d}{s_{r}}
$$

onde:

$A_{v}$ é a área de armadura de cisalhamento por camada;

$f_{y}$ é a tensão específica de escoamento do aço;

$S_{r}$ é o espaçamento entre camadas sucessivas da armadura de cisalhamento.

A força de cisalhamento majorada $V_{u}$ e o momento majorado desequilibrado $M_{u}$ são determinados a partir do eixo centroidal c-c da seção crítica. $O$ valor máximo de tensão de cisalhamento majorado pode ser calculado por:

$$
v_{u}(A B)=\frac{V_{u}}{A_{c}}+\frac{\gamma_{v} \cdot M_{u} \cdot c_{A B}}{J_{c}}
$$

$\mathrm{ou}$

$$
v_{u}(A B)=\frac{V_{u}}{A_{c}}-\frac{\gamma_{v} \cdot M_{u} \cdot c_{C D}}{J_{c}}
$$

onde:

$V_{u}$ é a força de cisalhamento majorada;

$M_{u}$ é o momento majorado desequilibrado;

$c_{A B}$ é a distância do centroide da seção crítica até o ponto de máximo do cisalhamento;

$\gamma_{v}$ é o coeficiente de transferência de momento fletor pela excentricidade da força cortante.

Cálculo de $\gamma_{v}$, fração do momento transferido por excentricidade do cisalhamento da seção crítica é:

$$
\gamma_{v}=1-\frac{1}{1+(2 / 3) \cdot \sqrt{b_{1} / b_{2}}}
$$

onde:

$b_{1}$ é a projeção do perímetro crítico no eixo principal, na direção do momento. 
$b_{2}$ é a projeção do perímetro crítico perpendicular a $b_{1}$.

A Figura 2.27 e Figura 2.28 mostram como sugestão as projeções $b_{1}$ e $b_{2}$ para a seção crítica $b_{0}$ e perímetro $b_{\text {out }}$ (fora da armadura de cisalhamento) respectivamente no caso de pilar de canto reentrante.

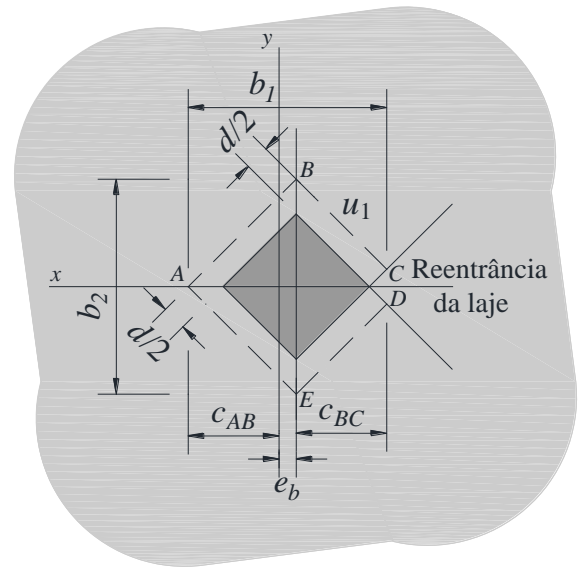

Figura 2.27 - Dimensões de $b_{1}$ e $b_{2}$ do perímetro crítico $b_{0}$.

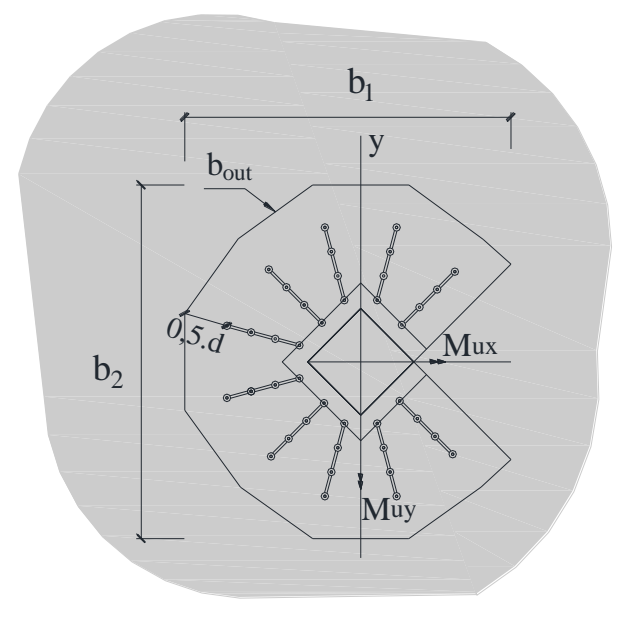

Figura 2.28 - Dimensões de $b_{1}$ e $b_{2}$ para o perímetro $b_{\text {out }}$.

Para colunas internas $A_{c}$ e $J_{c}$ podem ser calculados como de acordo com o ACI 318 (2014):

$A_{c}$ é a área de concreto da seção crítica assumida:

$$
A_{c}=2 d \cdot\left(c_{1}+c_{2}+2 d\right)
$$

$J_{c}$ é a propriedade da seção crítica assumida, análoga ao momento polar de inércia: 


$$
J_{c}=\frac{d \cdot\left(c_{1}+d\right)^{3}}{6}+\frac{\left(c_{1}+d\right) \cdot d^{3}}{6}+\frac{d \cdot\left(c_{2}+d\right) \cdot\left(c_{1}+d\right)^{2}}{6}
$$

De acordo com o ACI 421.1R (1999), o perímetro crítico é geralmente composto por linhas retas. Os valores de $A_{c}, I_{x}, I_{y}$ podem ser determinados pela soma da contribuição de cada segmento, conforme apresentado nas Equações 2.42 a 2.44, nas quais $x_{i}, y_{i}, x_{j}, y_{j}$ são as coordenadas dos pontos $i$ e $j$ nas extremidades de cada segmento cujo comprimento é igual a $l$, conforme apresentado na Figura 2.29.

O momento polar de inércia em relação ao eixo $e_{b 0}$ (centroide do perímetro crítico) pode ser aproximado para o momento de inércia pela equação dada abaixo:

$$
\begin{gathered}
A_{c}=d \cdot \sum l \\
I_{y}=d \cdot \sum\left[\frac{l}{3} \cdot\left(x_{i}^{2}+x_{i} \cdot x_{j}+x_{j}^{2}\right)\right] \\
I_{x}=d \cdot \sum\left[\frac{l}{3} \cdot\left(y_{i}^{2}+y_{i} \cdot y_{j}+y_{j}^{2}\right)\right]
\end{gathered}
$$

onde:

$l=$ comprimento do segmento da seção crítica, em mm.

$x_{i}$ e $x_{j}$ coordenadas do segmento do perímetro crítico, em mm (Figura 2.29).

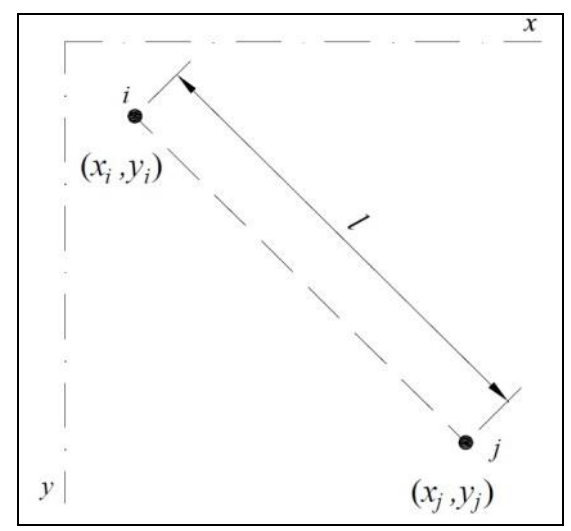

Figura 2.29 - Representação dos parâmetros de um segmento reto do perímetro crítico. 


\subsubsection{Model Code 2010 (2013)}

$\mathrm{Na}$ determinação da carga resistente à punção o perímetro crítico $b_{0}$ é assumido a uma distância equivalente a metade da altura útil efetiva $\left(0,5 \cdot d_{v}\right)$ como mostra a Figura $2.30 \mathrm{e}$ Figura 2.31. A avaliação da capacidade resistente à punção é dada pela equação 2.45.

(a)

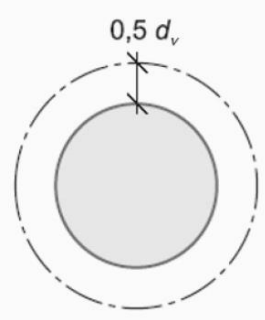

(b)

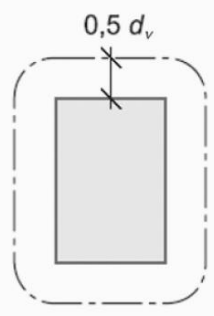

(c)

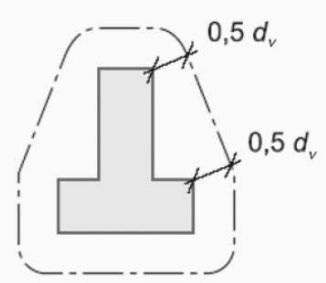

(d)

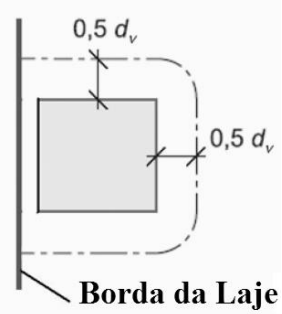

Figura 2.30 - Perímetros críticos em torno de pilares ou área carregada - Model Code 2010 (2013)

Para pilar de canto reentrante foi considerado o perímetro crítico $b_{0}$ como mostra a Figura 2.32, tendo em vista que a norma não prevê qual seria o perímetro para esse tipo de ligação.

(a)

(b)
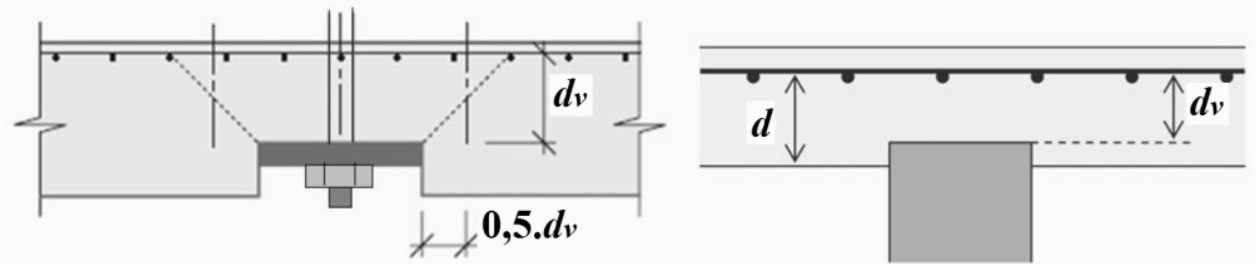

Figura 2.31 - Altura efetiva da laje - Model Code 2010 (2013)

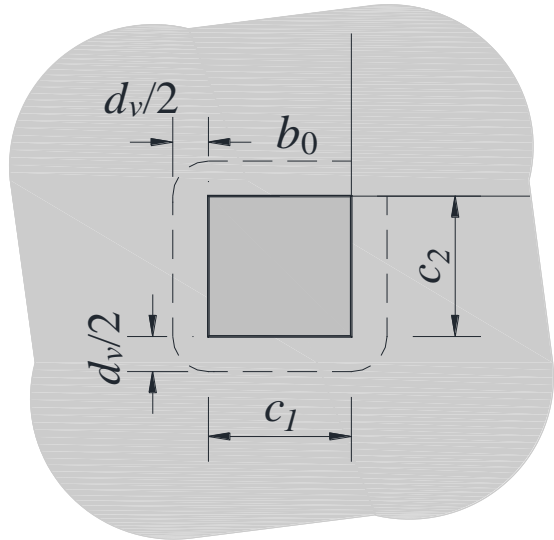

Figura 2.32 - Localização do perímetro crítico para o pilar de canto reentrante. 
A resistência à punção $V_{R d}$ para lajes com armadura de cisalhamento segundo o Model Code 2010 (2013) é calculada como:

$$
V_{R d}=V_{R d, c}+V_{R d, s}
$$

onde:

$V_{R d, c}$ é a resistência do concreto em conjunto com a armadura longitudinal;

$V_{R d, s}$ é a resistência à punção advinda das armadurad de cisalhamento;

A resistência à punção atribuída ao concreto $V_{R d, c}$ é:

$$
V_{R d, c}=\kappa_{\psi} \cdot \frac{\sqrt{f_{c}}}{\gamma_{c}} \cdot b_{0} \cdot d_{v}
$$

onde:

$f_{c}$ é a resistência à compressão do concreto em $\mathrm{MPa}$.

$d_{v}$ é a altura efetiva da armadura de flexão para as direções $\mathrm{x}$ e y;

$b_{0}$ é o perímetro crítico;

$\gamma_{c}$ é o coeficiente de ponderação do concreto.

O parâmetro $\kappa_{\psi}$ depende de deformações (rotações) da laje como mostra a equação a seguir:

$$
\kappa_{\psi}=\frac{1}{1,5+0,9 \cdot \psi \cdot d \cdot \kappa_{d g}} \leq 0,6
$$

onde:

$\psi$ : rotação da laje em torno do pilar na região de ruptura;

$\kappa_{d g}$ é um parâmetro em função do diâmetro máximo do agregado;

Existem evidências que a resistência à punção é influenciada pelo diâmetro máximo do agregado $\left(d_{g}\right)$. Se $d_{g}$ é menor que $16 \mathrm{~mm}$ o valor de $k_{d g}$ é assumido como:

$$
\kappa_{d g}=\frac{32}{16+d_{g}} \geq 0,75
$$

$d_{g}$ em mm. 
Para distribuição da tenão de cisalhamento não uniforme deve-se utilizar o perímetro crítico reduzido:

$$
b_{0}=\kappa_{e} \cdot b_{1, r e d}
$$

onde:

$b_{1, \text { red }}$ é o perímetro crítico assumindo que o comprimento reto não ultrapasse $3 \cdot d_{v}$ para cada bordo (Figura 2.33);

$\kappa_{e}$ é um coeficiente de excentricidade ou fator de redução do perímetro crítico assumindo 0,9 para pilares internos; 0,7 para pilares de bordo e 0,65 para pilares de canto;

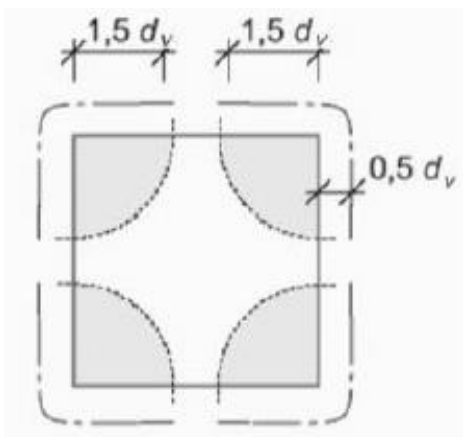

Figura 2.33 - Redução do perímetro crítico $b_{1, \text { red }}$ - Model Code 2010 (2013)

O coeficiente de excentricidade pode ser determinado em função da transferência do momento do pilar para a laje:

$$
\kappa_{e}=\frac{1}{1+e_{u} / b_{u}}
$$

onde:

$e_{u}$ é a excentricidade resultante da força de cisalhamento com centroide do perímetro crítico (Figura 2.34);

$b_{u}$ é o diâmetro de um círculo com a mesma superfície da região dentro do perímetro crítico. 
(a)

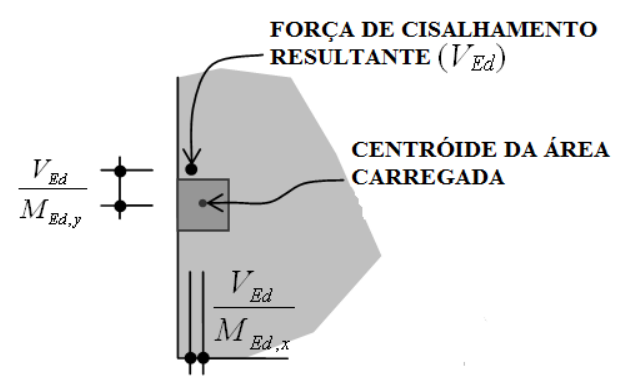

(b)

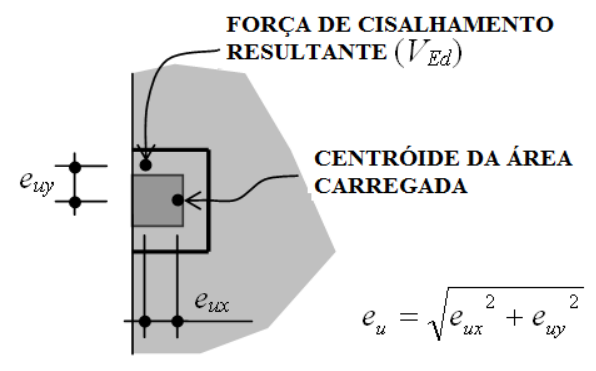

Figura 2.34 - Resultante da força de cisalhamento: (a) posição com relação ao centróide da área carregada; (b) perímetro crítico do centróide aproximado e a encentricidade entre a força de cisalhamento resultante e o centróide do perímetro crítico - Model Code 2010

A contribuição da armadura de cisalhamento é calculada:

$$
V_{R d, s}=\sum A_{s w} \cdot \kappa_{e} \cdot \sigma_{s w d} \cdot \operatorname{sen} \alpha
$$

com:

$$
\sigma_{s w d}=\frac{E_{s} \cdot \psi}{6} \cdot\left(\operatorname{sen} \alpha+\frac{f_{b d}}{f_{y w d}} \cdot \frac{d}{\phi_{w}}\right) \leq f_{y w d}
$$

onde:

$A_{s w}$ é a área da seção transversal da armadura de cisalhamento ancorada adequadamente que intercepta a superfície de ruptura (superfície cônica com ângulo de $45^{\circ}$ ) dentro da zona delimitada por $0,35 \cdot d_{v}$ e $d_{v}$ a partir da área carregada (Figura 2.35);

$\sigma_{s w}$ é a tensão cuja armadura de cisalhamento tem capacidade para mobilizar;

$\alpha$ é o ângulo entre as armaduras de cisalhamento e a laje;

$\phi_{w}$ é o diâmetro da armadura de cisalhamento;

$f_{y w d}$ é a tensão de escoamento da armadura de cisalhamento;

$f_{b d}$ é a tensão de flexão para barras nervuradas pode ser assumido como $3 \mathrm{MPa}$.

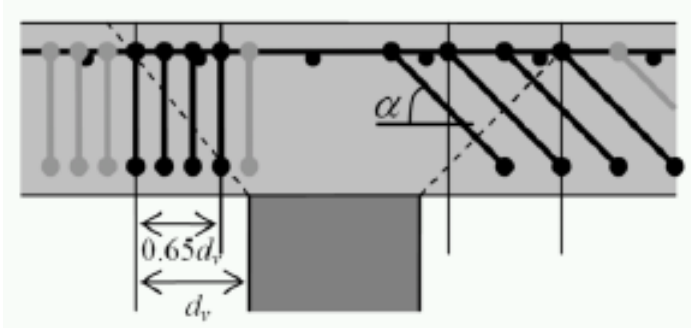

Figura 2.35 - Armadura de cisalhamento ativa na ruptura - Model Code 2010 (2013) 
Em lajes com armadura de cisalhamento a resistência mínima da armadura de cisalhamento de ser:

$$
\sum A_{s w} \cdot \kappa_{e} \cdot f_{y w d} \geq 0,5 \cdot V_{E d}
$$

A resistência à punção máxima é limitada pela resistência ao esmagamento do concreto ou área carregada:

$$
V_{R d, \max }=\kappa_{s y s} \cdot \kappa_{\psi} \cdot \frac{\sqrt{f_{c}}}{\gamma_{c}} \cdot b_{0} \cdot d_{v} \leq \frac{\sqrt{f_{c}}}{\gamma_{c}} \cdot b_{0} \cdot d_{v}
$$

O coeficiente $\kappa_{s y s}$ é 2,8 para studs, 2,4 para estribos com comprimento de ancoragem suficiente e 2,0 pode ser adotado para outros casos.

Para definir a rotação da laje $\psi$ em relação ao plano, é necessário definir o nível de aproximação que se deseja. Quanto maior o nível de aproximação melhor é a previsão estimada por essa norma. O nível I é utilizado para uma laje plana regular, projetada de acordo com uma análise elástica sem redistribuição significativa de forças internas; o nível II é utilizado nos casos em que há redistribuição significativa do momento de flexão; o nível III é utilizado quando se utiliza uma análise elástica-linear para dimensionar a armadura de flexão e obter os momentos de flexão; o nível IV calcula a rotação com base numa análise não linear da estrutura.

Na Tabela 2.3 serão apresentadas as expressões para cálculo da rotação da laje na zona exterior à ruptura de acordo com o nível de aproximação.

Tabela 2.3 - Rotação da laje em torno do pilar na zona externa à ruptura.

\begin{tabular}{|c|c|c|}
\hline Nível de Aproximação & $\psi$ (Rotação) & Equação \\
\hline I & $\psi=1,5 \cdot \frac{r_{s}}{d} \cdot \frac{f_{y d}}{E_{s}}$ & $(2.55)$ \\
\hline II & $\psi=1,5 \cdot \frac{r_{s}}{d} \cdot \frac{f_{y d}}{E_{s}} \cdot\left(\frac{m_{s d}}{m_{R d}}\right)^{1,5}$ & $(2.56)$ \\
\hline III & $\psi=1,2 \cdot \frac{r_{s}}{d} \cdot \frac{f_{y d}}{E_{s}} \cdot\left(\frac{m_{s d}}{m_{R d}}\right)^{1,5}$ & $(2.57)$ \\
\hline IV & Calculado com o programa de análise não linear & $(2.58)$ \\
\hline
\end{tabular}


onde:

$r_{s}$ é a distância do centro do pilar até ao raio onde o momento fletor é nulo, sendo este valor aproximadamente $0,22 \cdot L_{x}$ ou $0,22 \cdot L_{y}$ em lajes regulares em que a razão dos vãos está entre 0,5 e 2,0;

$E_{s}$ é o módulo de elasticidade do material das armaduras longitudinais.

$m_{R d}$ é a resistência à flexão média de projeto por unidade de comprimento numa faixa carregada (para a direção considerada).

No nível de aproximação II o valor de $m_{s d}$ (momento médio atuante por unidade de comprimento da armadura de flexão numa faixa) recomendado corresponde a:

- Para pilares internos:

$$
m_{s d}=V_{E d} \cdot\left(\frac{1}{8}+\frac{\left|e_{u, i}\right|}{2 \cdot b_{s}}\right)
$$

- Para pilares de borda:

Quando o cálculo considera a armadura de flexão paralela a borda:

$$
m_{s d}=V_{E d} \cdot\left(\frac{1}{8}+\frac{\left|e_{u, i}\right|}{2 \cdot b_{s}}\right) \geq \frac{V_{E d}}{4}
$$

Quando o cálculo considera a armadura de flexão perpendicular a borda:

$$
m_{s d}=V_{E d} \cdot\left(\frac{1}{8}+\frac{\left|e_{u, i}\right|}{b_{s}}\right)
$$

- Para pilares de canto:

$$
m_{s d}=V_{E d} \cdot\left(\frac{1}{8}+\frac{\left|e_{u, i}\right|}{b_{s}}\right) \geq \frac{V_{E d}}{2}
$$

- Para pilares de canto reentrante sugere-se utilizar (ver Figura 2.37):

$$
m_{s d}=V_{E d} \cdot\left(\frac{1}{8}+\frac{\left|e_{u, i}\right|}{2 \cdot\left(b_{s} / 2+b_{s r} / 2\right)}\right)
$$

onde o termo $\left|e_{u, i}\right|$ refere-se à excentricidade da força de cisalhamento resultante com respectivo controle de perímetro básico na direção investigada. 
A largura da faixa carregada ou analisada para o cálculo de $m_{s d}$ é:

$$
b_{s}=1,5 \cdot \sqrt{r_{s, x} \cdot r_{s, y}} \leq L_{\min }
$$

Próximo dos bordos da laje, a largura da faixa é limitada a $b_{s r}$ segundo a Figura 2.36. O mesmo valor para $r_{s}$ como que para o Nível I de aproximação pode ser adotada.

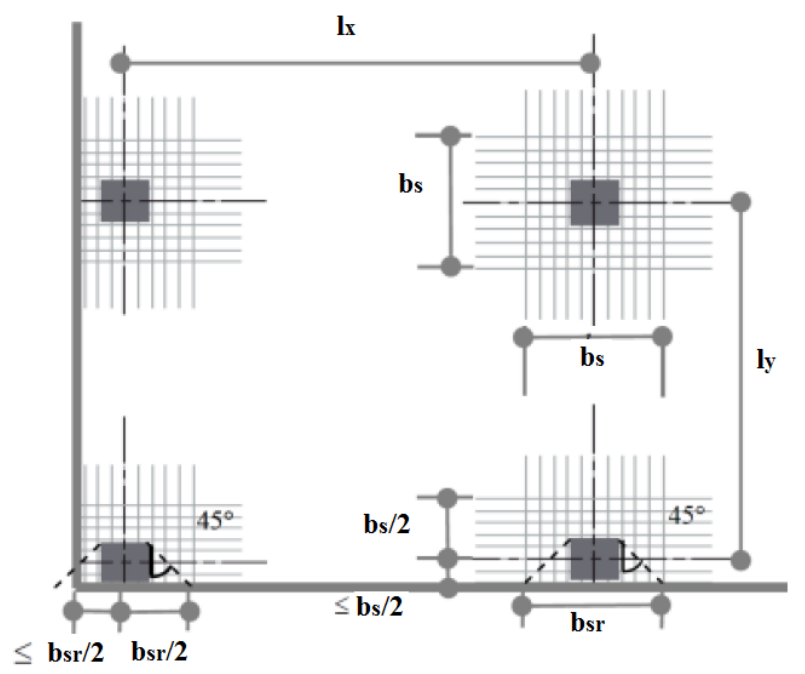

Figura 2.36 - Dimensões da área carregada ou analisada - Model Code 2010 (2013).

Como o Model Code 2010 (2013) não aborda o caso de lajes com pilar de canto reentrante foram utilizadas algumas considerações para adaptar à norma o caso. Ao utilizar o nível III para verificação da resistência a punção foram consideradas as relações de $V_{\text {flex }} / m_{s d}$, extraídas do software SAP200 com $G$ (módulo de elasticidade transversal do material) não reduzido, e um $m_{R d}$ considerando um $\rho$ (taxa de armadura de flexão) na menor direção para uma faixa de $1,25 \mathrm{~m}$ que corresponde a $b_{s} / 2+b_{s r} / 2$ (Figura 2.37).

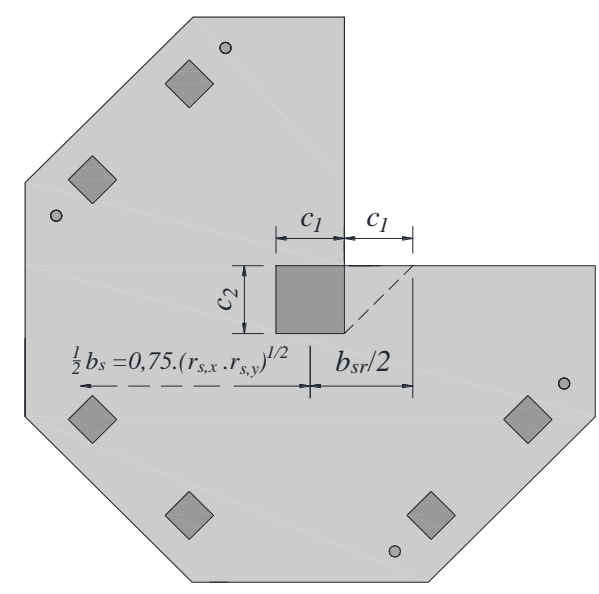

Figura 2.37 - Dimensões da área carregada ou analisada em mm para o caso particular da ligação laje-pilar de canto reentrante. 
A resistência à punção fora da armadura cisalhamento pode ser determinada como na expressão a seguir em um perímetro crítico com a distância máxima efetiva de $3 \cdot d_{v}$ entre dois elementos de reforço de cisalhamento (Figura 2.38):

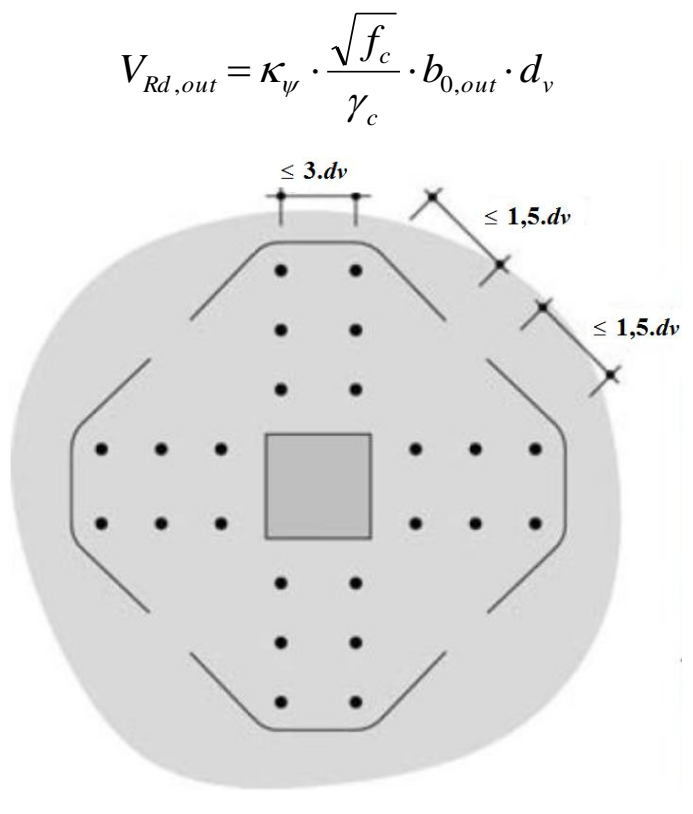

Figura 2.38 - Perímetro crítico fora da armadura de cisalhamento - Model Code 2010 (2013)

O perímetro crítico afastado $0,5 \cdot d$ da última camada de armadura de cisalhamento, $b_{0, \text { out }}$, para o pilar de canto reentrante foi adotado como mostra a Figura 2.39, tendo em vista que a norma não sugere qual seria o perímetro para esse tipo de ligação.

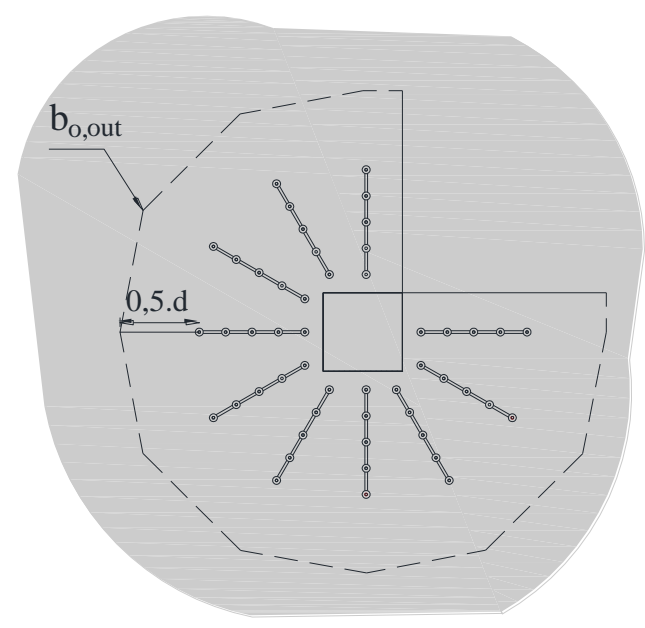

Figura 2.39 - Perímetro crítico fora da armadura de cisalhamento 


\section{PROGRAMA EXPERIMENTAL}

\subsection{INTRODUÇÃO}

Simular o comportamento de um pavimento de lajes lisas de uma edificação em proporções reais em um laboratório não é uma tarefa fácil e demanda custos relativamente altos. Diante disso muitos pesquisadores adotam lajes que representam uma parte ou componente de um elemento estrutural, tentando reproduzir o comportamento da estrutura quando esta é submetida a diferentes níveis de carregamento. O uso dessas lajes busca analisar a influência da distribuição do carregamento, o efeito de carregamentos laterais ou o efeito de forças de membrana existentes na laje, devido ao confinamento que o pavimento como um todo proporciona. Dependendo do tipo de análise desejada podem ser necessários ensaio em laje de maiores dimensões com procedimentos de ensaio mais complexos, envolvendo lajes com tamanho, geometria e disposição de carregamentos bem específicos.

Existem vários trabalhos que tratam de ligações laje-pilar interno, de canto e de borda, com armadura de cisalhamento e momento desbalanceado, mas estudos e pesquisas que tratem ligações de lajes e pilar de canto reentrante ainda não existem ou estão em desenvolvimento. A Figura 3.1 apresenta a idealização das lajes de ensaio desta pesquisa. Já a Figura 3.2 mostra um exemplo de um pavimento em planta com canto reentrante e a relação da área analisada e um pórtico equivalente.

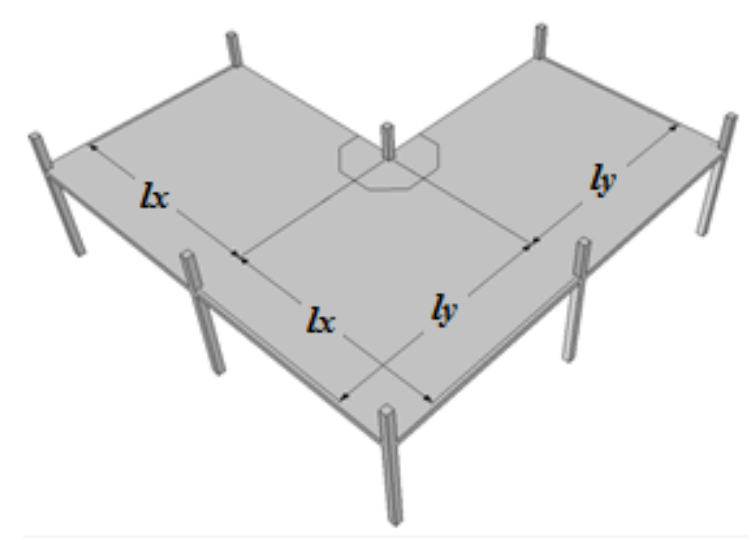

(a) Pavimento em lajes lisas

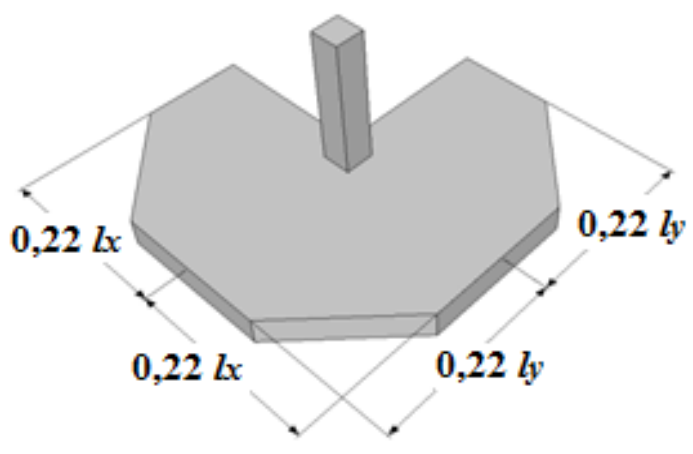

(b) Laje com pilar reentrante

Figura 3.1 - Modelo hipotético caracterizando a situação estudada 


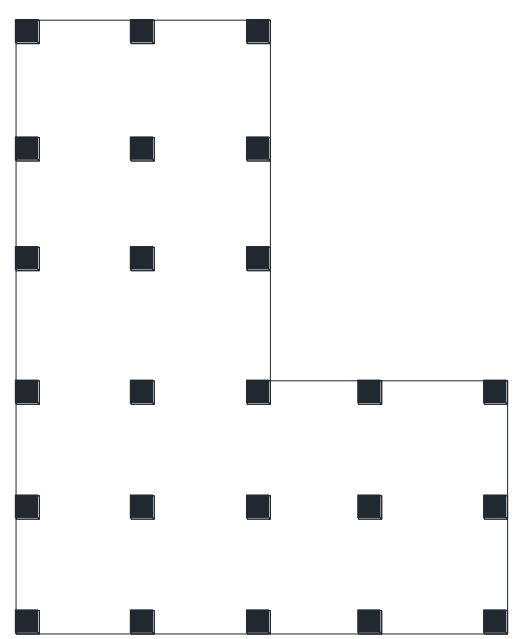

(a) Pavimento com canto reentrante

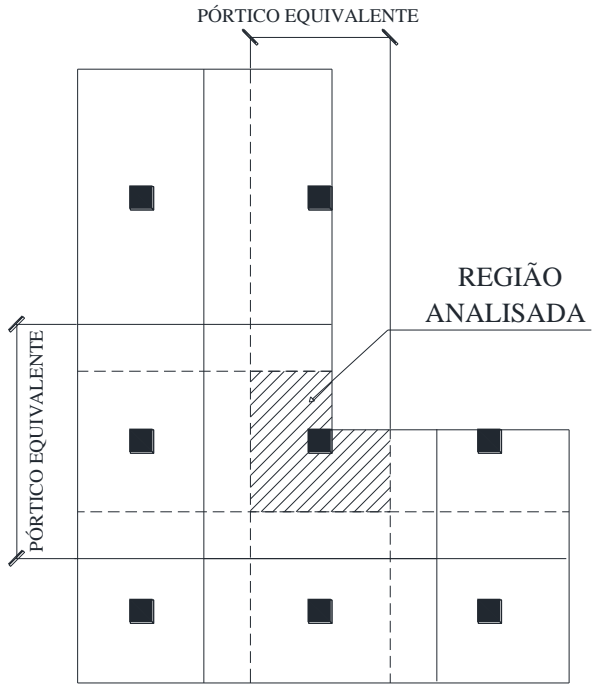

(b) Região do modelo de laje analisado

Figura 3.2 - Relação entre a região da laje de ensaio e um pórtico equivalente.

\subsection{CARACTERÍSTICAS DAS LAJES ENSAIADAS}

Foram ensaiadas 12 lajes de concreto armado com as características geométricas indicadas na Figura 3.3, tendo elas espessura igual a $180 \mathrm{~mm}$ e sendo apoiadas em um pilar quadrado com lados iguais a $300 \mathrm{~mm}$. As dimensões das lajes foram escolhidas de modo a simular a situação real de uma ligação laje-pilar com cantos reentrantes e que respeitasse as dimensões da laje de reação e do pórtico de ensaio do Laboratório de Estruturas da Universidade de Brasília.

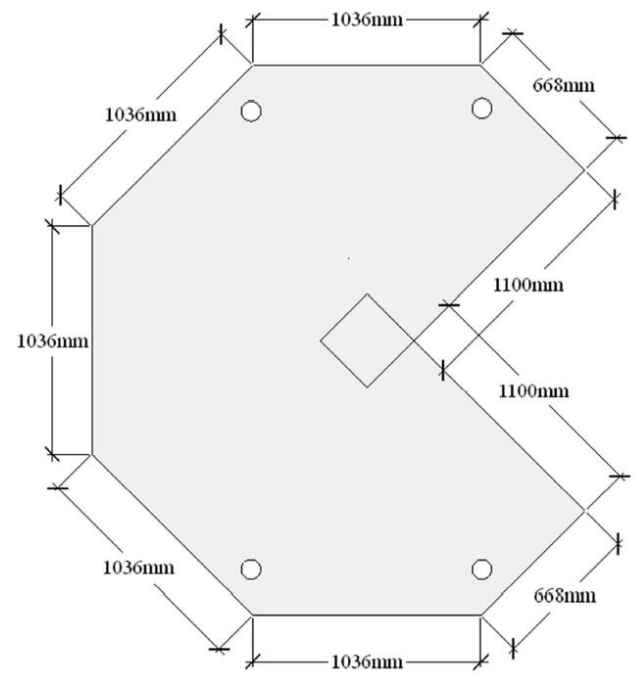

(a) Vista superior

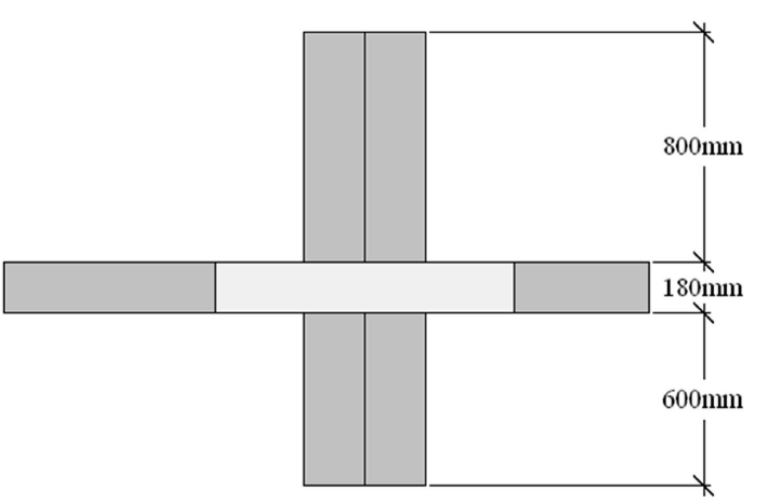

(b) Vista lateral

Figura 3.3 - Geometria básica de todas as lajes (em mm). 
As lajes foram divididas em três séries de ensaios em função da concretagem. Nas lajes da Série 1, duas delas possuíam armadura de cisalhamento e duas não, todas com taxa de armadura de flexão igual a 2,1\%. Na Série 2 a taxa de armadura foi $0,9 \%$ em duas lajes e $1,3 \%$ para os outras duas, nenhuma delas tendo armadura de cisalhamento, sendo a principal variável a relação de carregamento. Já na Série 3 a taxa de armadura foi 1,3\% em uma laje sem armadura de cisalhamento e 2,1\% para as demais, sendo que essas possuíam armadura de cisalhamento, variando-se ainda a relação de carregamento.

A excentricidade nas lajes ensaiadas variou de acordo com a relação de carga $P_{2} / P_{1}$ situadas como na Figura 3.4. A Figura 3.5 mostra a posição das cargas em planta e em vista lateral.

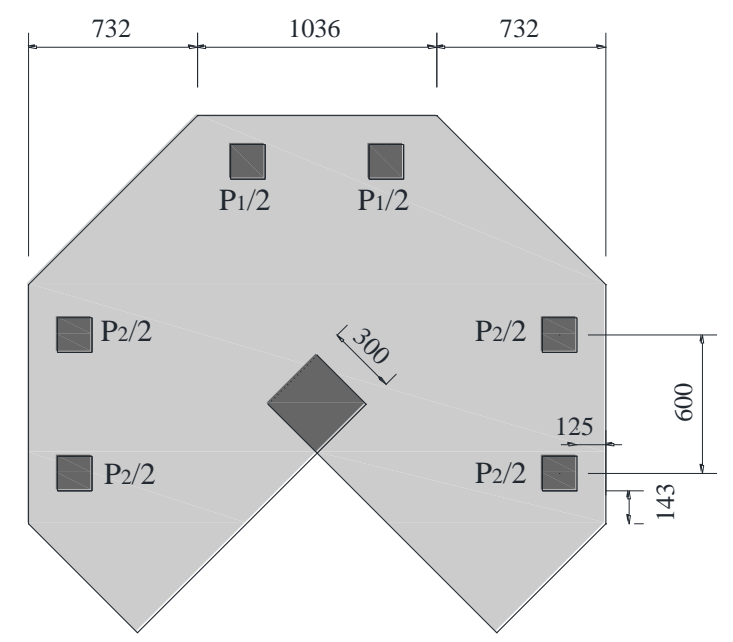

Figura 3.4 - Localização das cargas $P_{1}$ e $P_{2}$.

A Tabela 3.1 apresenta algumas características das lajes ensaiadas e um resumo das principais variáveis de ensaio.

Os valores da taxa de armadura apresentados na Tabela 3.1 foram calculados segundo a Equação 3.1.

$$
\rho=\frac{A_{s}}{A_{c}}=\frac{A_{s}}{b_{w} \cdot d}
$$

onde

$A_{s}$ é a área de aço da armadura de flexão na faixa $b_{w}=c+2 \cdot(3 d)$;

$b_{w}$ é a largura da seção de concreto considerada para o cálculo;

$d$ é a altura útil da laje;

$c$ é o lado do pilar quadrado. 


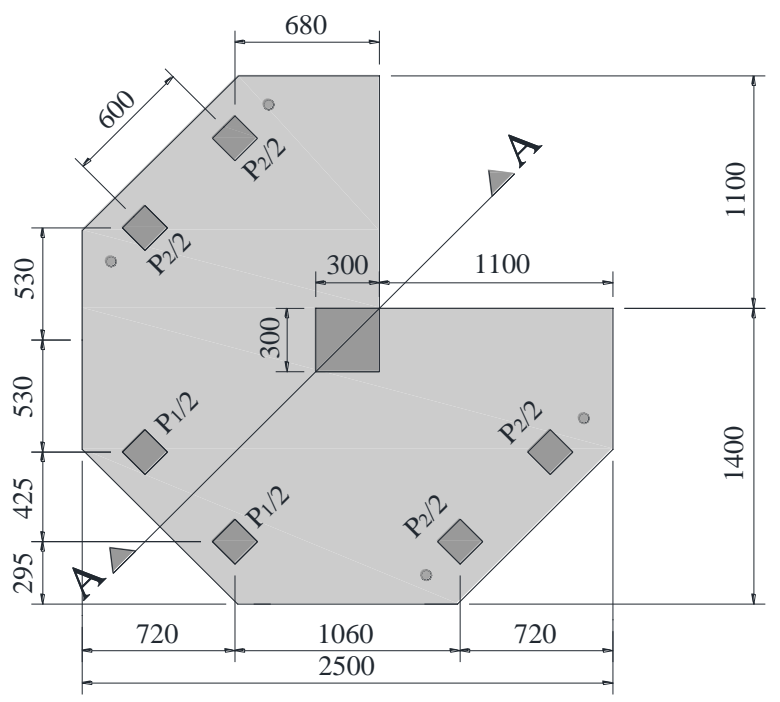

Planta
Corte A-A

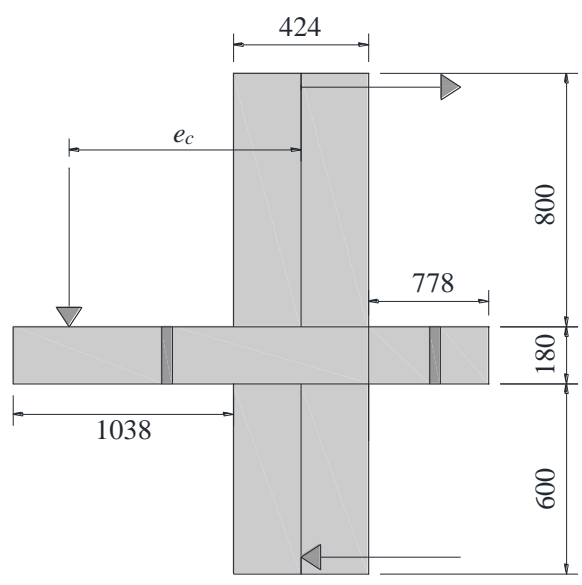

Seção A-A

Figura 3.5 - Posição das cargas de ensaio e excentricidade da carga $e_{c}$.

Tabela 3.1 - Identificação e características das lajes ensaiadas

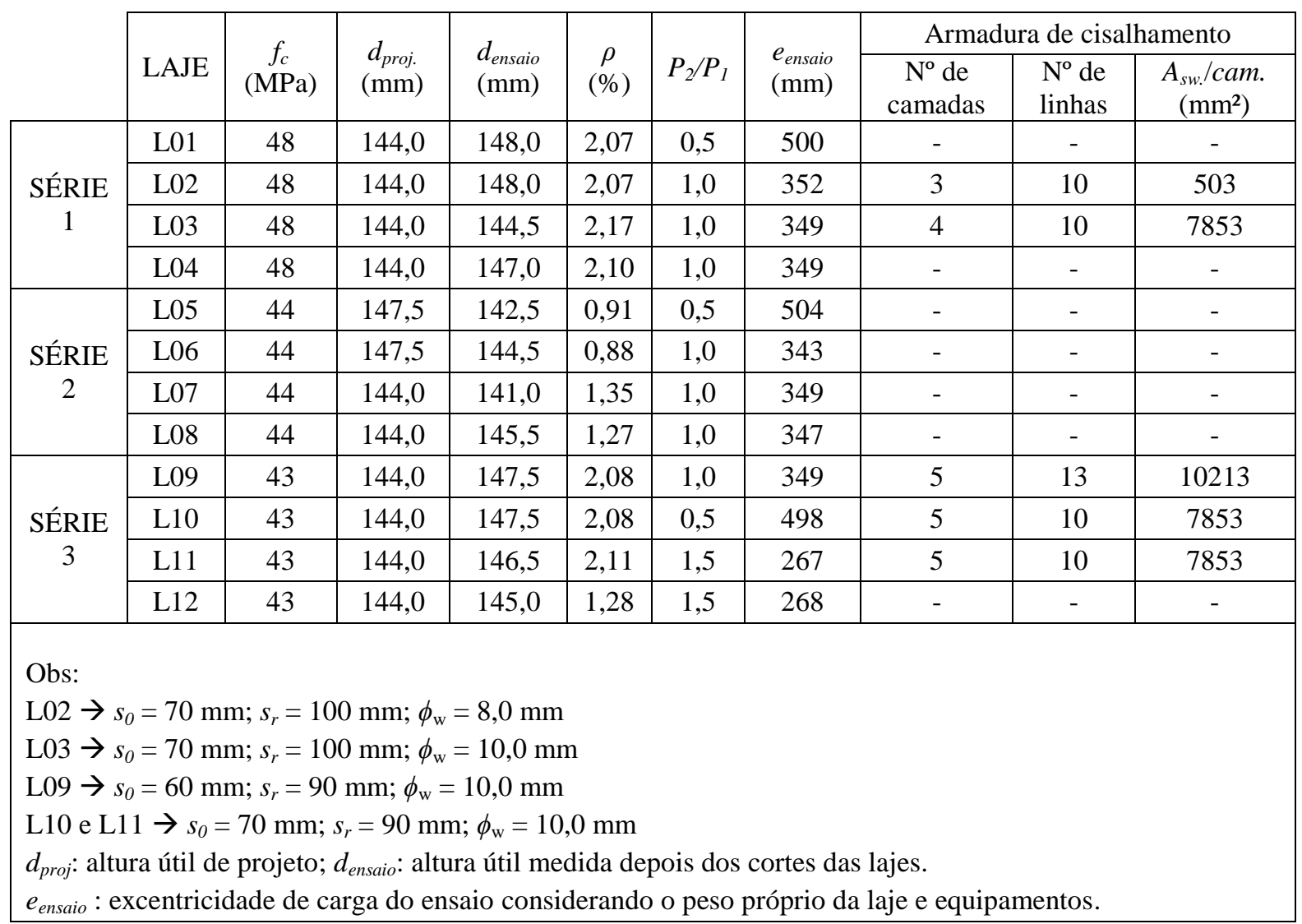




\subsection{MATERIAIS}

\subsubsection{Concreto}

O concreto utilizado nessa pesquisa foi fornecido pela empresa CONCRECON, Concreto e Construções Ltda, em três etapas que foram chamadas aqui de séries de concretagem. A $1^{\mathrm{a}}$ série de concretagem foi realizada dia 25/08/2011, a $2^{\text {a }}$ dia 04/10/2012 e $3^{\text {a }}$ dia 09/04/2013.

$\mathrm{Na}$ dosagem do concreto foram utilizados $50 \% \mathrm{CPV}+50 \% \mathrm{CP}$ III, brita $0(9,5 \mathrm{~mm})$, areia artificial originada de calcários e areia natural rosa quartzosa.

As lajes foram concretadas monoliticamente com concreto usinado. A Figura 3.6 apresenta detalhes do processo de concretagem das lajes.

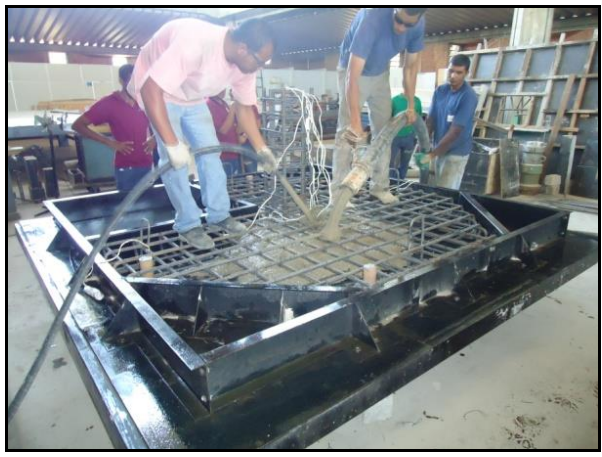

(a) Concretagem com a bomba

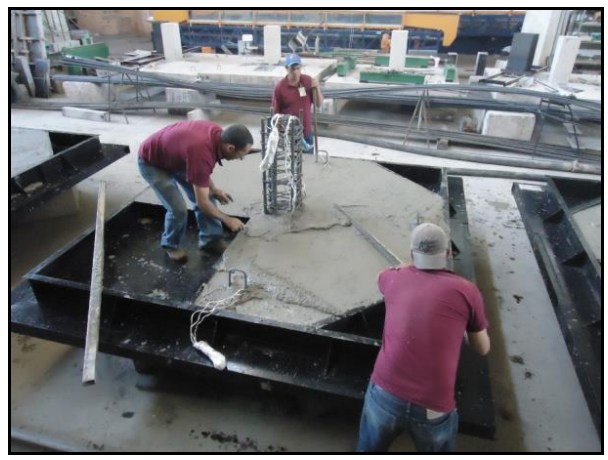

(b) Sarrafeamento

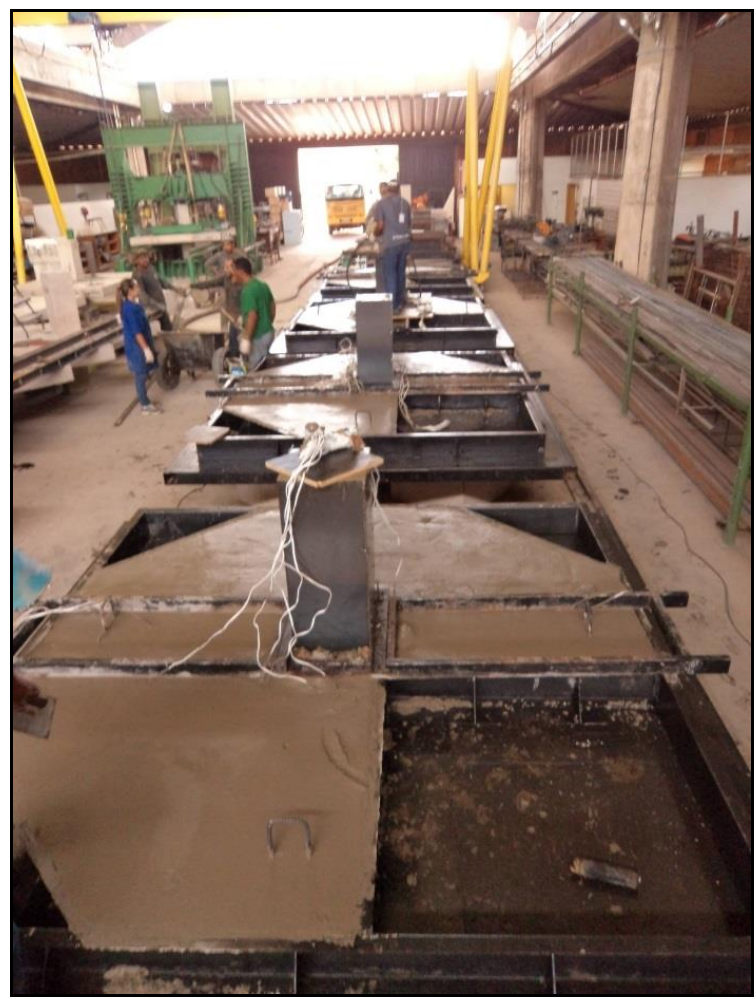

(c) Final da concretagem

Figura 3.6 - Concretagem das Lajes

Em cada concretagem foram moldadas quatro lajes. Antes de iniciar a mesma era feita a verificação da consistência com ensaio de abatimento de tronco de cone apresentando o resultado de $12,0 \mathrm{~cm} \pm 2 \mathrm{~cm}$ de abatimento. 
Foram moldados 36 corpos de prova com $100 \mathrm{~mm}$ de diâmetro e $200 \mathrm{~mm}$ de altura, os quais foram utilizados para a determinação das propriedades mecânicas do concreto (resistência à tração, resistência à compressão e módulo de elasticidade do concreto).

Para todas as lajes foram concretadas inicialmente a parte inferior do pilar, seguida da concretagem da laje. Depois se colocou a fôrma da parte superior do pilar e por último a parte superior do pilar foi concretada.

Cerca de 5 horas após o término da concretagem, iniciou-se processos de cura das peças e dos corpos de prova. O processo adotado, tanto para as lajes como para os corpos de prova, foi o mesmo. Foram colocados tecidos de algodão sobre toda a superfície de concreto que estivesse exposta, os quais foram molhados inicialmente a cada 3 horas nos primeiros 3 dias de cura e 2 vezes por dia durante outros 4 dias. Logo após a molhagem das lajes e dos corpos de prova, estes elementos foram cobertos por uma lona plástica, que teve a função de auxiliar a retenção da umidade em torno das peças de concreto.

\subsubsection{AÇO - ARMADURA DE FLEXÃO}

Foi adotado um cobrimento de $20 \mathrm{~mm}$ para as barras na face superior e de $10 \mathrm{~mm}$ para as armaduras na face inferior. A armadura de flexão das lajes ensaiadas foi composta por barras de alta aderência de aço CA-50, dispostas na parte superior das lajes nas duas direções (armadura principal). A armadura de flexão foi constituída de barras com diâmetro de 16 mm distribuídas de acordo com a taxa de armadura de cada laje, sendo que em ambas as direções foram feitos ganchos em $180^{\circ}$ com o objetivo de garantir a ancoragem das armaduras de flexão.

Inicialmente foi utilizada uma taxa de armadura de flexão alta $(2,1 \%)$, com as barras mais ou menos uniformemente espaçadas em cada direção e o espaçamento nas duas direções foi escolhido para dar praticamente momentos resistentes iguais apesar das diferentes alturas úteis $d_{x}$ e $d_{y}$. O espaçamento variou para algumas medidas locais para evitar sobreposições com a armadura de cisalhamento. Depois, com as deformações dos primeiros ensaios conhecidas, pôde-se trabalhar variando o arranjo das principais barras e possivelmente a relação de aço principal. 
Com isso foram utilizadas três diferentes taxas de armadura de flexão. A Figura 3.7, Figura 3.8 e Figura 3.9 apresentam a distribuição da armadura de flexão para taxa de armadura de $2,1 \%, 1,3 \%$ e $0,9 \%$ respectivamente. Na Figura 3.10 é apresentado o projeto geral das armaduras inferiores das lajes. Em todas as lajes a armadura inferior foi composta por barras de alta aderência de aço CA-50 com diâmetro de 12,5 mm.

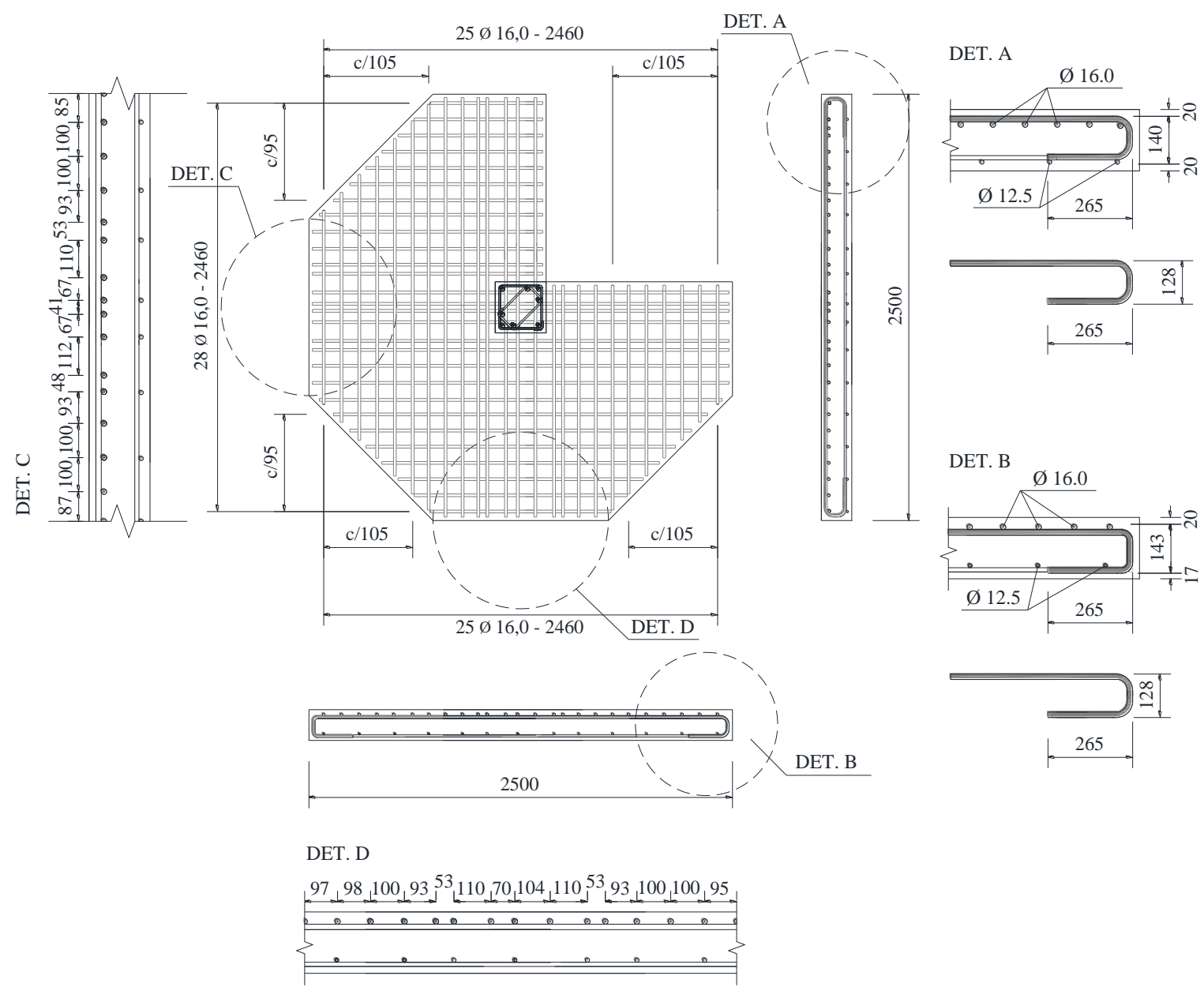

Figura 3.7 - Armadura superior de flexão das lajes com taxa de armadura 2,1\%. 

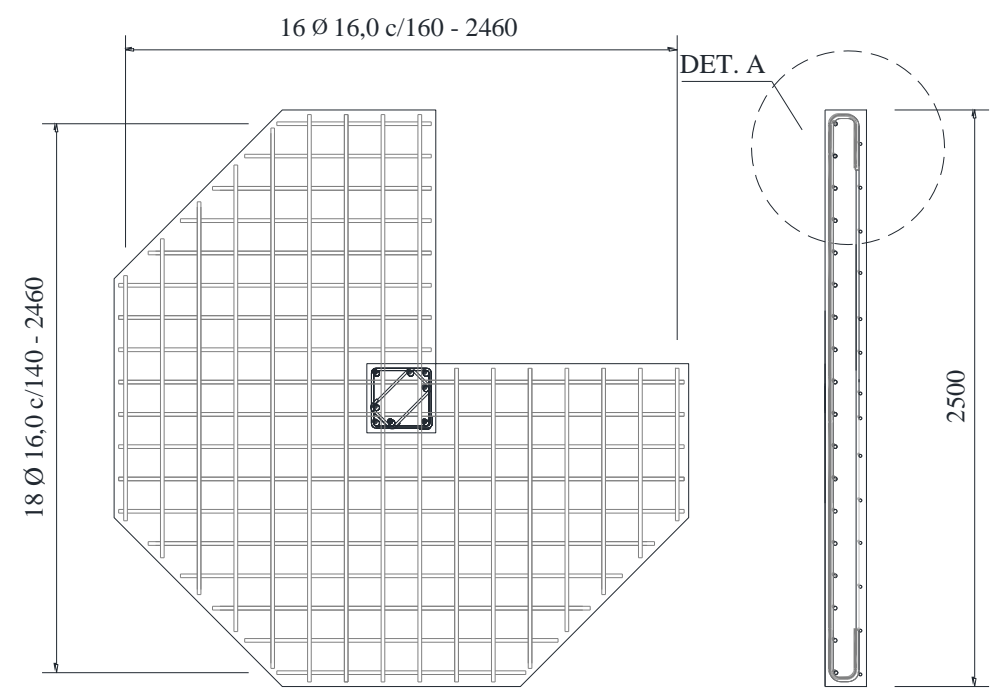

DET. A Ø 16.0
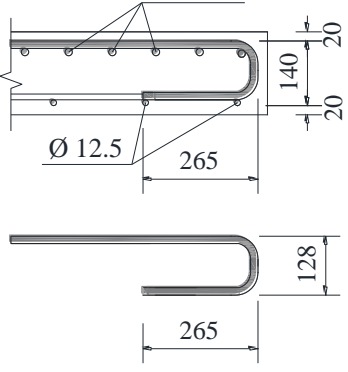

DET. B

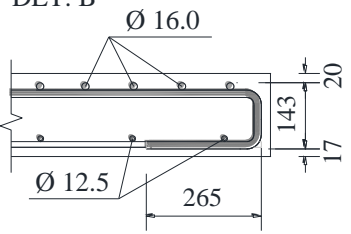

DET. B

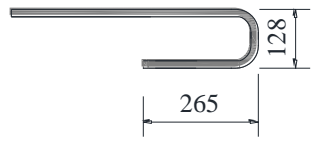

Figura 3.8 - Armadura superior de flexão das lajes com taxa de armadura 1,3\%.

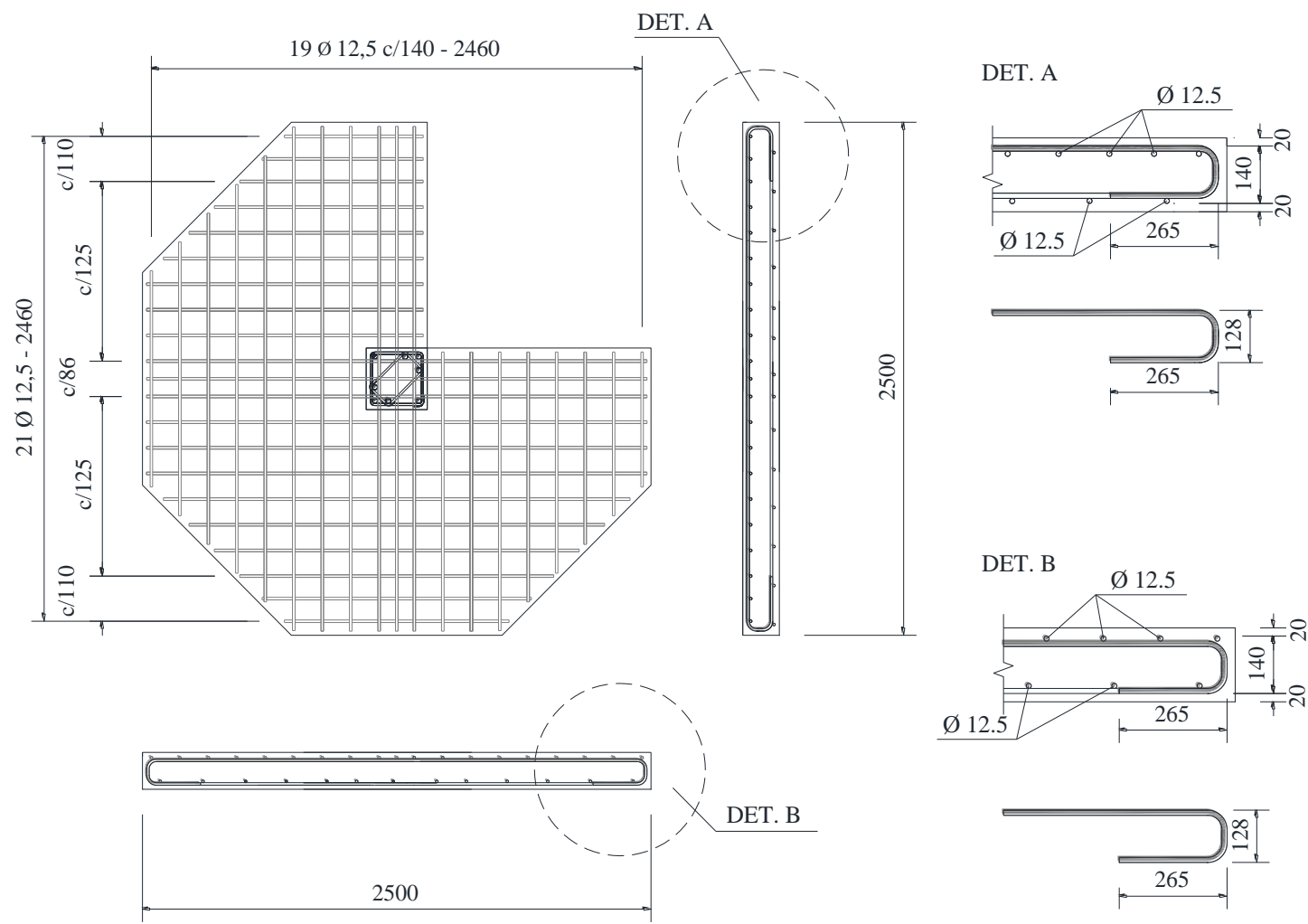

Figura 3.9 - Armadura superior de flexão das lajes com taxa de armadura 0,9\%. 


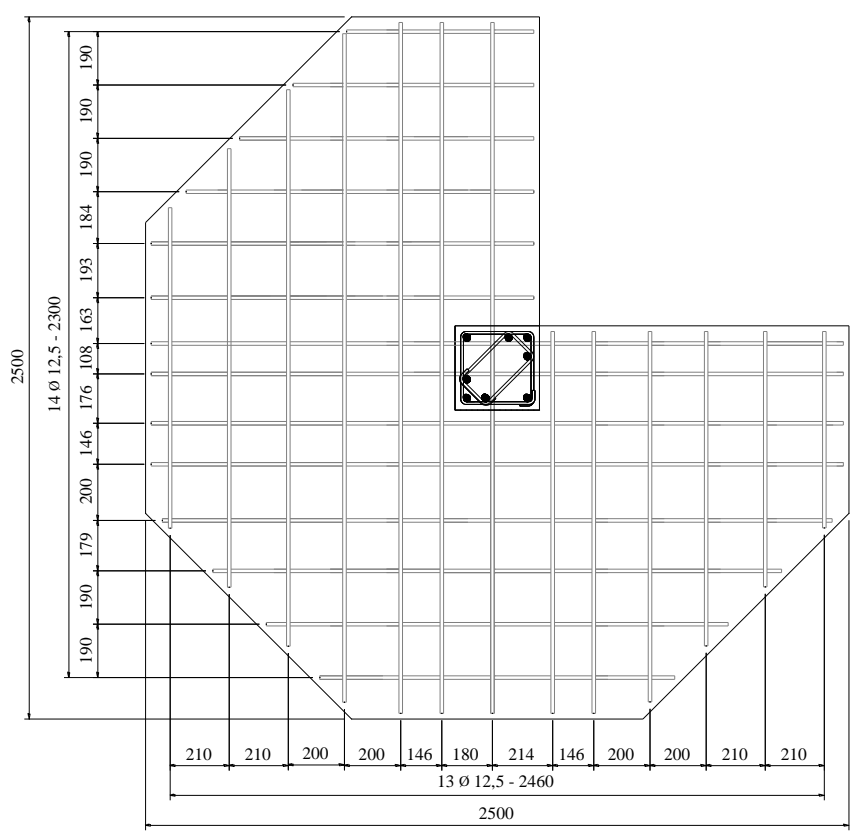

Figura 3.10 - Armadura inferior de flexão para todas as lajes

\subsection{ARMADURA DE CISALHAMENTO}

As armaduras de cisalhamento utilizadas nessa pesquisa foram os double headed studs que caracterizam-se por possuírem como ancoragem duas pastilhas (chapas circulares de aço), com diâmetro igual a $3 \cdot \phi_{w}$, onde $\phi_{w}$ é o diâmetro da barra do stud. Tais armaduras foram posicionadas depois da montagem das armaduras de flexão, com chapas ou barras delgadas de aço, para sua fixação. A Figura 3.11 mostra detalhes das armaduras utilizadas nessa pesquisa.

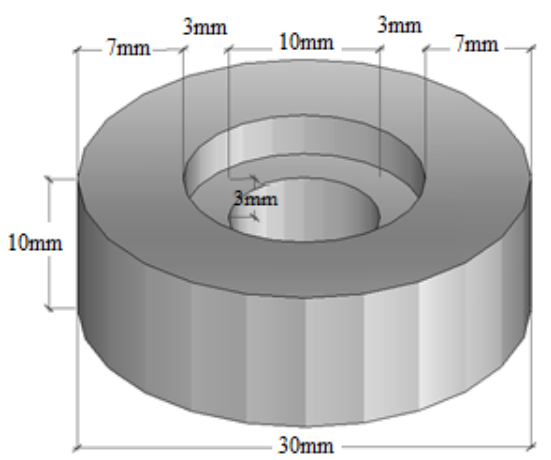

(a) Detalhe do furo nas pastilhas

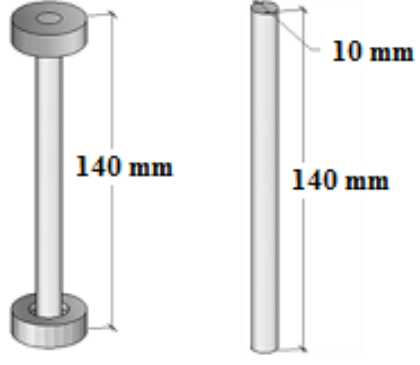

(b) Detalhe final da peça

(Trefilado Ø 1 1/4" L - 10 mm)

Figura 3.11 - Detalhes do sistema de armaduras de cisalhamento. 
As armaduras utilizadas nas lajes L02 e L03 foram fabricadas por profissionais da Universidade de Brasília e nas lajes L09, L10 e L11 por profissionais da área de metalurgia da cidade de Brasília. A Figura 3.12 mostra os studs utilizados na pesquisa e a Figura 3.13 o projeto da armadura de cisalhamento com o diâmetro $\phi$ variando em 8 e $10 \mathrm{~mm}$. Nas lajes em que foram empregadas armaduras de cisalhamento, adotou-se 3, 4 ou 5 camadas de studs com distribuição radial (Figura 3.15).
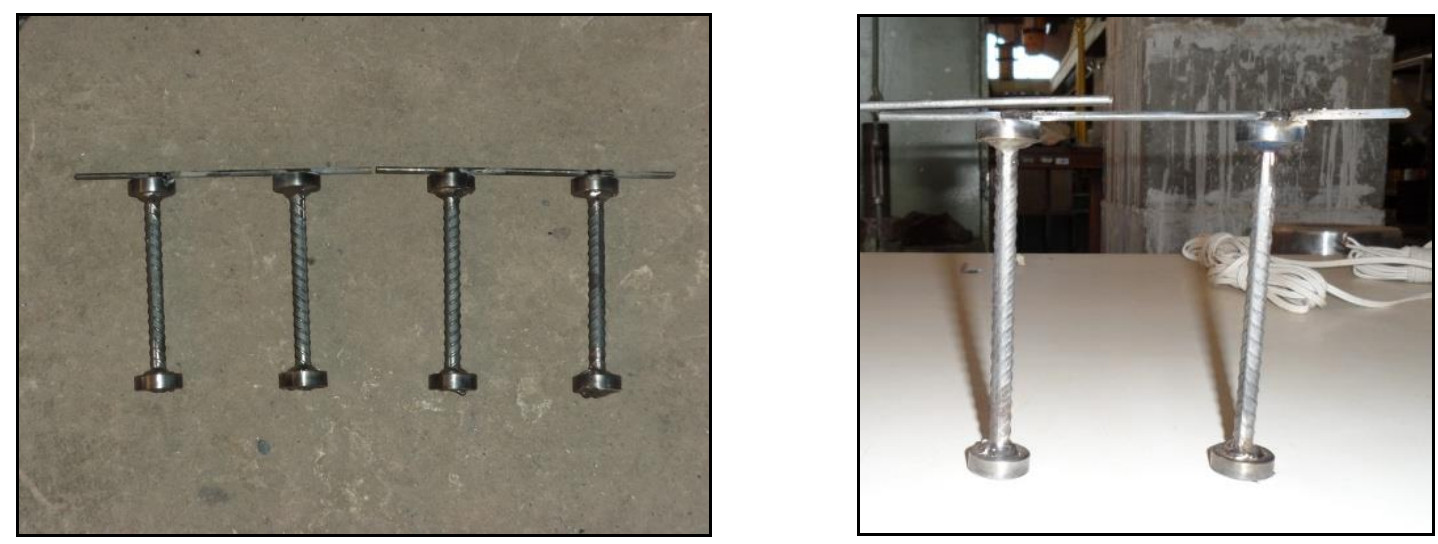

Figura 3.12 - Studs com trilhos utilizados na pesquisa.
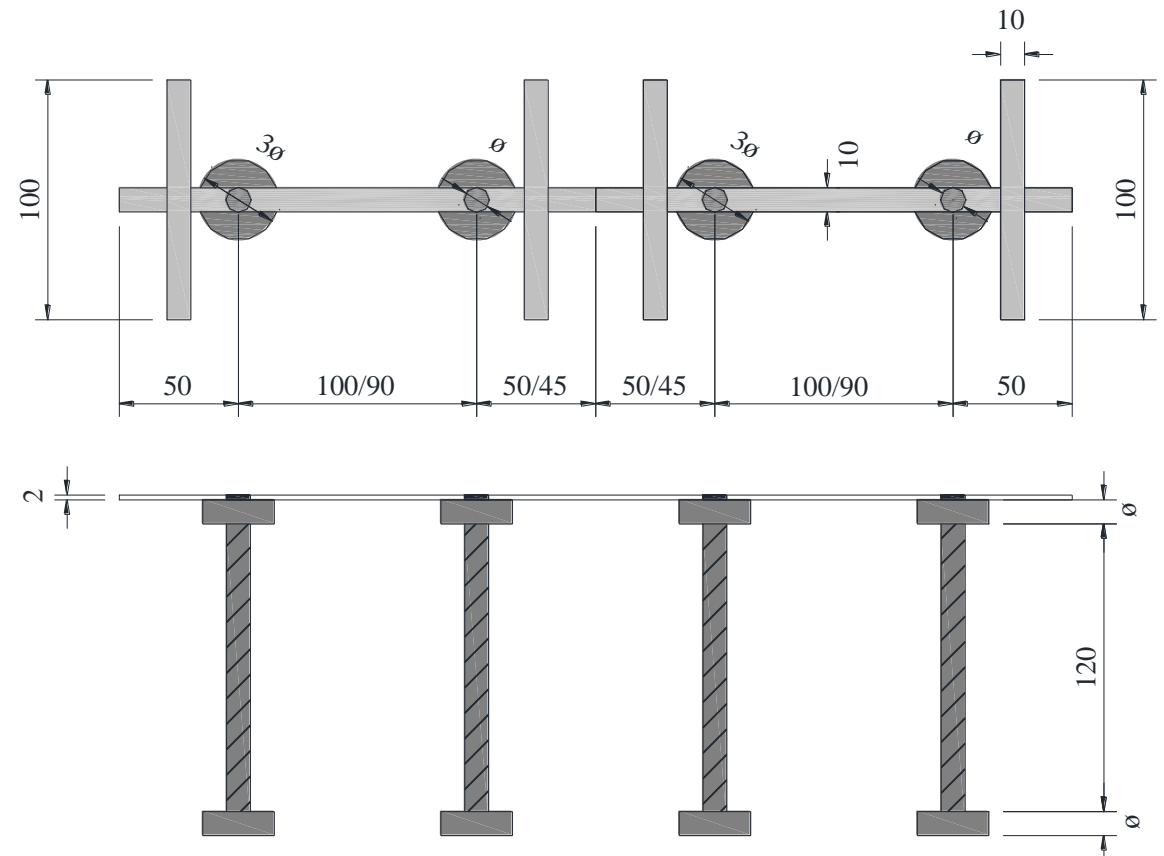

Figura 3.13 - Projeto das armaduras de cisalhamento com dimensões em mm. 


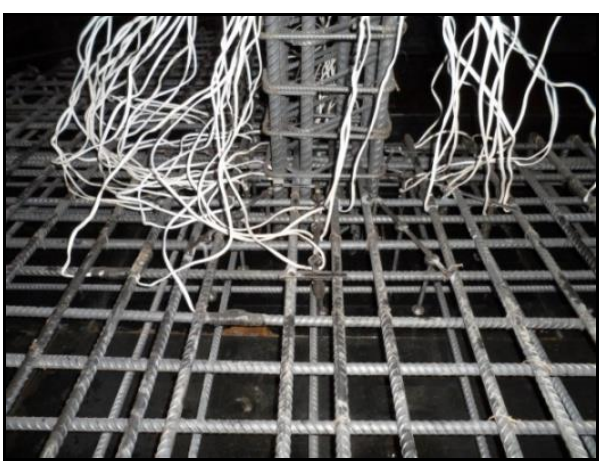

(a) Laje L02

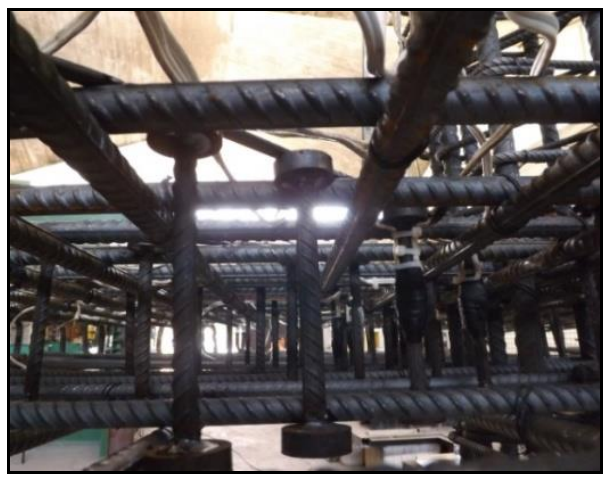

(c) Laje L10

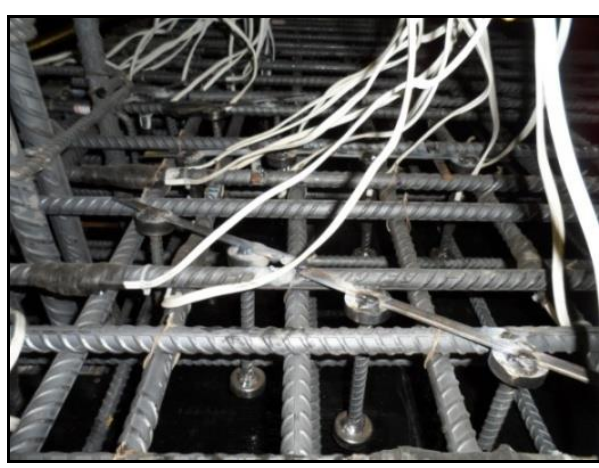

(b) Laje L03

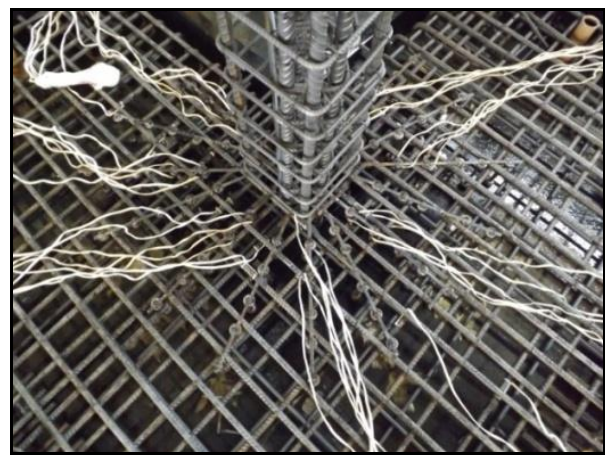

(d) Laje L09

Figura 3.14 - Detalhes das armaduras de cisalhamento.

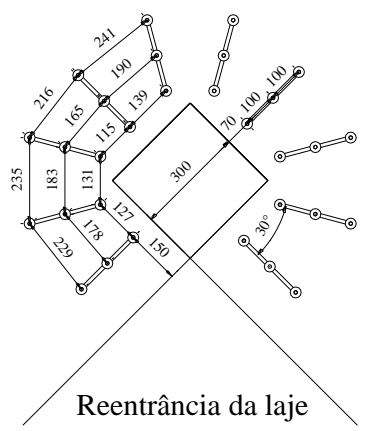

(a) Laje L02

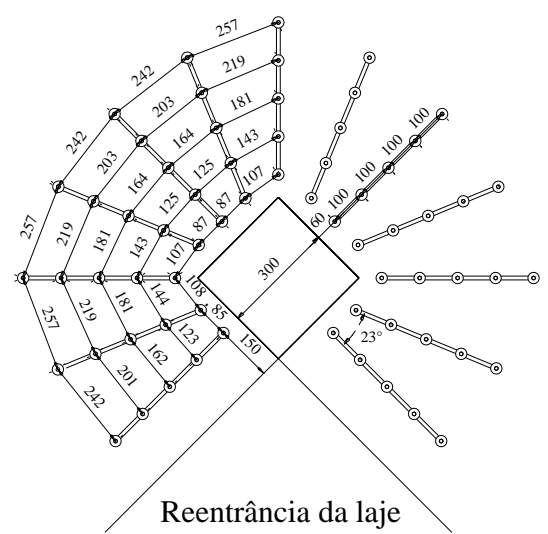

(c) Laje L09

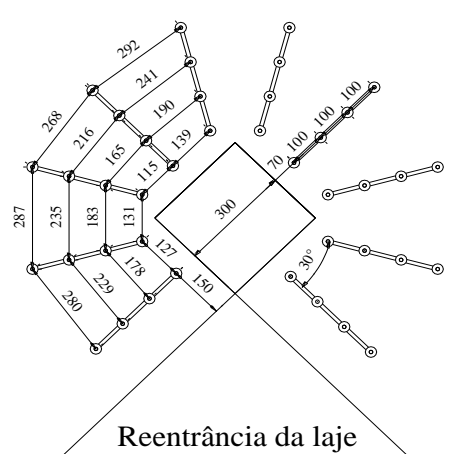

(b) Laje L03

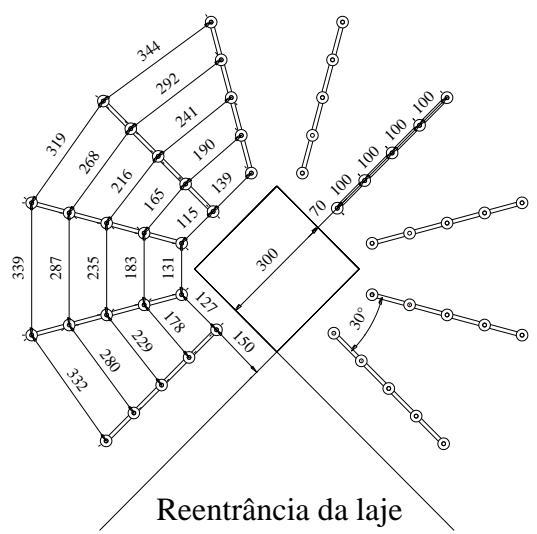

(d) Laje L10 e L11

Figura 3.15- Distribuição dos studs das lajes L02, L03, L09, L10 e L11. 


\subsection{ARMADURA DOS PILARES}

A armadura dos pilares foi composta por barras de alta aderência de aço CA-50 com 25 $\mathrm{mm}$ de diâmetro na direção longitudinal e por dois tipos de estribos de $10 \mathrm{~mm}$ de diâmetro espaçados a cada $100 \mathrm{~mm}$. Para a armadura longitudinal dos pilares foram utilizadas barras dobradas em "U" e em "L" para compor a armadura, a fim de se evitar a possibilidade de uma ruptura localizada por problemas de ancoragem. Ressalta-se que o dobramento destas barras não seguiu as recomendações da NBR 6118 (2014), uma vez que isso inviabiliza o uso de barras de $25 \mathrm{~mm}$ de diâmetro nestes pilares. Alguns detalhes das armaduras utilizadas nos pilares podem ser observados na Figura 3.16.

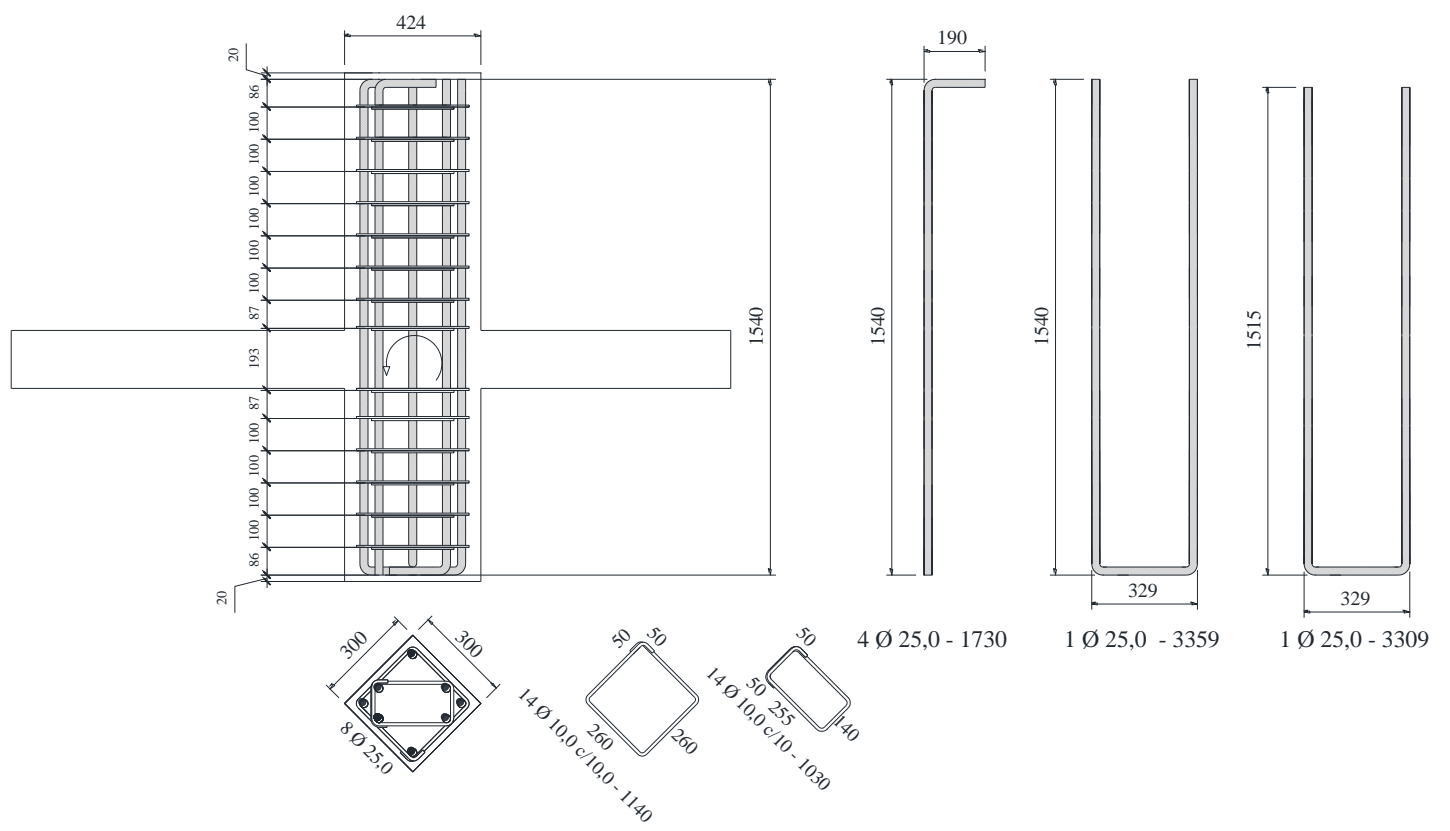

Figura 3.16 - Projeto de armadura dos pilares.

\subsection{ARMADURA DE TORÇÃO}

O detalhamento das bordas das lajes nos cantos chanfrados é potencialmente significante como também é provável que afete o momento a ser transferido para o pilar.

A laje L03 foi escolhida dentre as lajes da primeira série de concretagem para utilizar armadura de torção porque ela possuía maior momento de transferência e maior capacidade de punção.

A armadura de torção utilizada foi constituída de estribos de $10 \mathrm{~mm}$ localizadas nos cantos reentrantes das lajes L03 e L08. Foram adicionadas barras com diâmetro de 12,5 mm com 
finalidade de assegurar a posição e servir de suporte dos estribos. O detalhamento e posicionamento dos estribos da laje L03 podem ser visualizados na Figura 3.17 e da laje L08 na Figura 3.18.
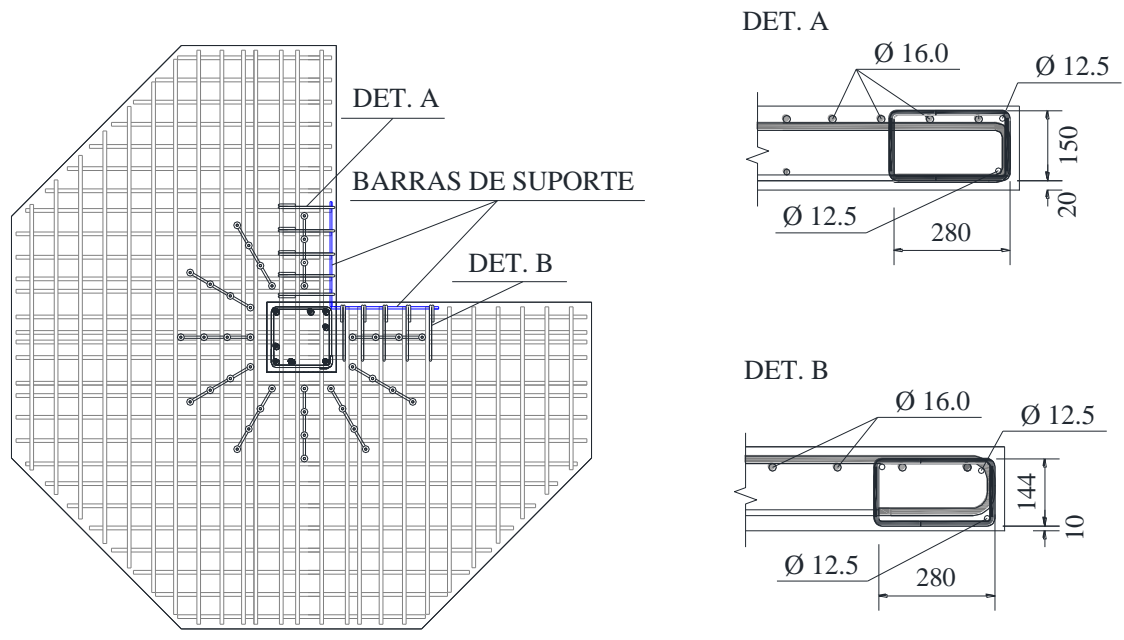

DET. ESTRIBOS:
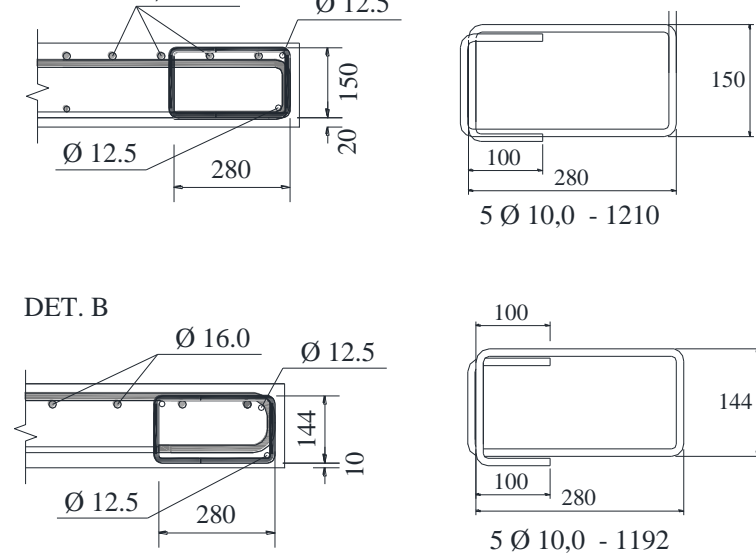

Figura 3.17 - Projeto da armadura de torção na laje L03.

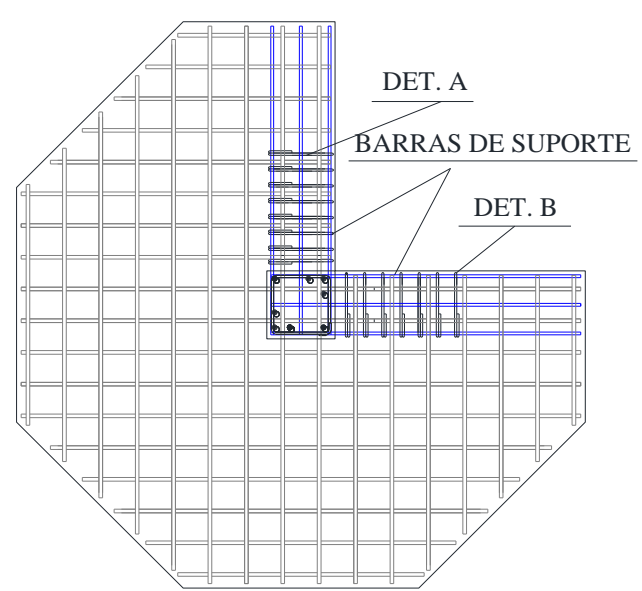

DET. A

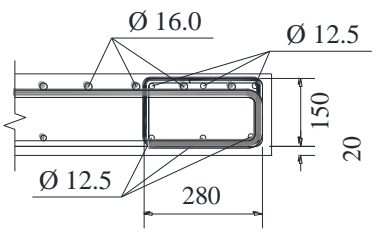

DET. B

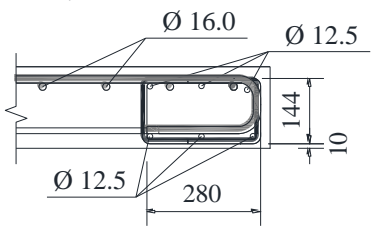

DET. ESTRIBOS:
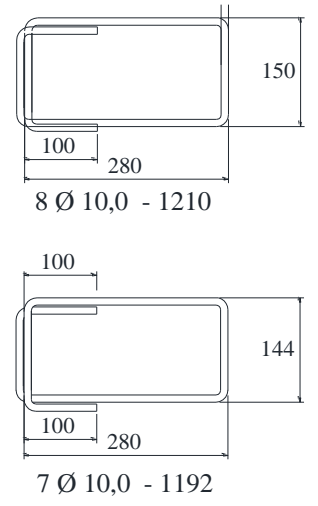

Figura 3.18 - Projeto da armadura de torção na laje L08. 


\subsection{FÔRMAS}

As fôrmas utilizadas para as lajes de ligação foram confeccionadas em estrutura metálica no Laboratório de Estruturas da Universidade de Brasília.

Necessitou-se de peças metálicas inseridas internamente nas quatro fôrmas quadradas existentes, para adaptá-las e obter a geometria das lajes a serem ensaiados. Tais peças foram compostas por quatro perfis metálicos dobrados com comprimentos de $1035 \mathrm{~mm}$ e $1100 \mathrm{~mm}$ e altura de $180 \mathrm{~mm}$ fixados com chapas soldadas e parafusos ligados às chapas que compõe o fundo da forma. A Figura 3.19 ilustra como foi idealizado o projeto das fôrmas.

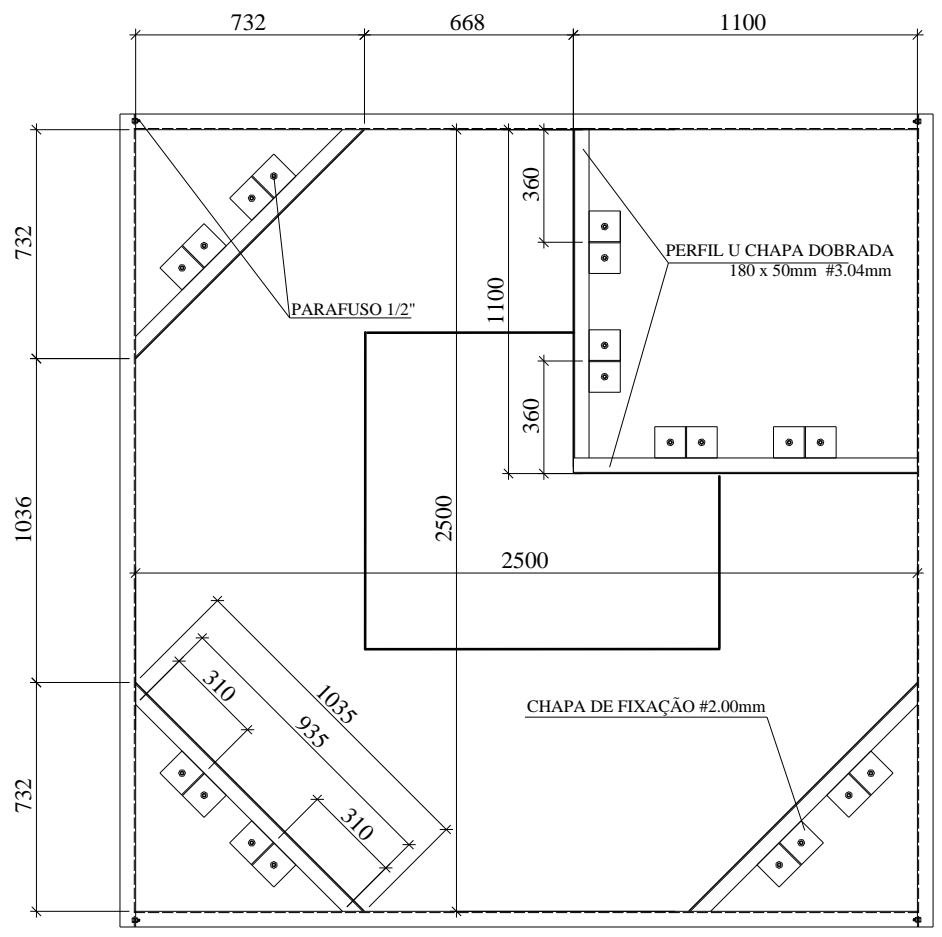

Figura 3.19 - Projeto das fôrmas metálicas.

As fôrmas dos pilares para a primeira série foram produzidas em madeira e para as outras séries em estrutura metálica, ambos os tipos em duas partes, uma para a parte inferior do pilar e outra para a parte superior, de modo a se adequarem à fôrma metálica. A Figura 3.20 apresenta detalhes das fôrmas construídas. 


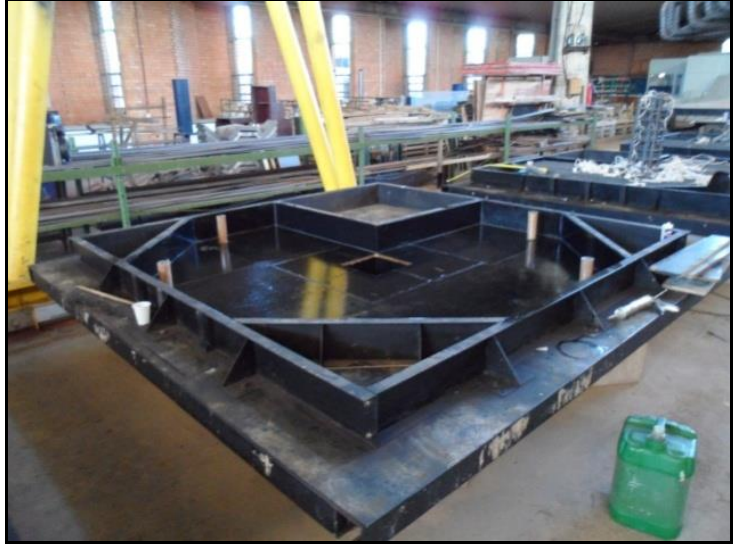

(a) Forma das lajes

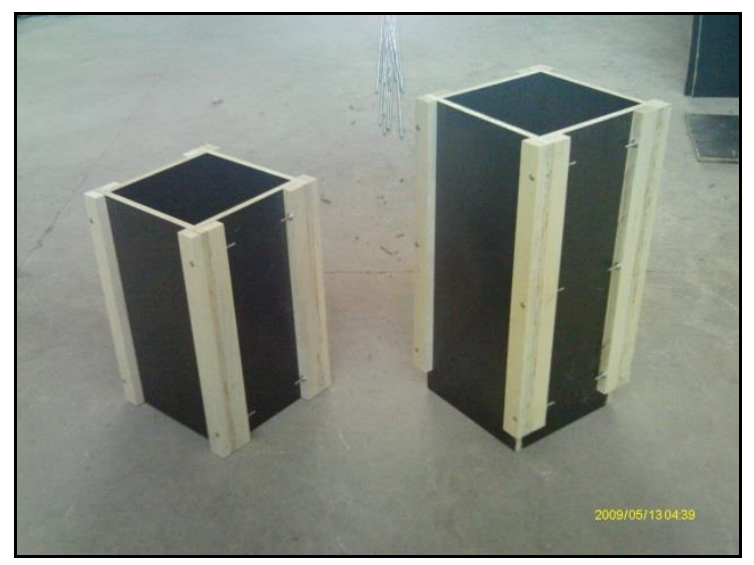

(b) Formas de madeira dos pilares

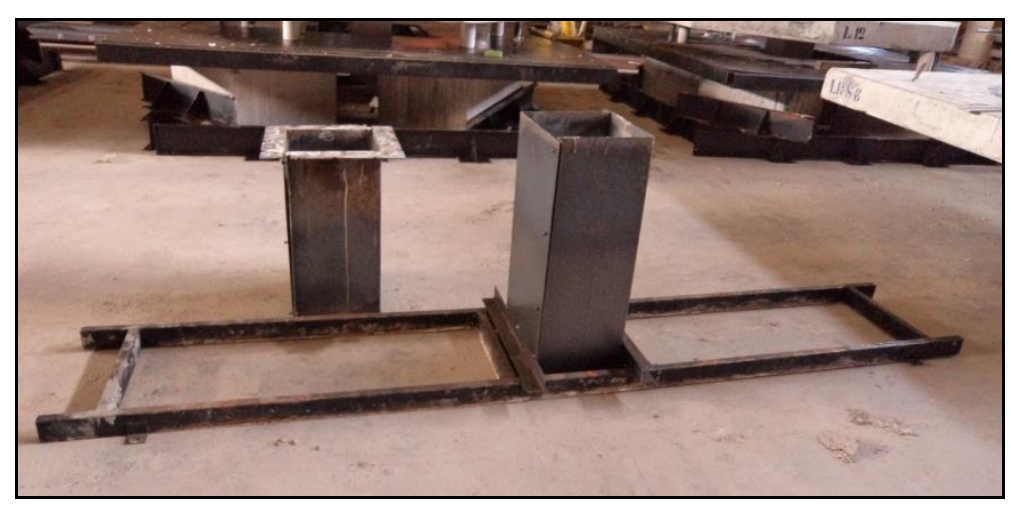

(c) Formas metálicas dos pilares

Figura 3.20 - Detalhes das formas.

\subsection{INSTRUMENTAÇÃO}

\subsubsection{Deslocamentos Verticais}

Os deslocamentos verticais das lajes foram medidos em 24 pontos indicados na Figura 3.21. Os pontos de 1 ao 15 foram medidos por transdutores de deslocamento linear (LVDT's) fabricados pela empresa HBM e o ponto $16 \mathrm{com}$ um transdutor potenciométrico (Figura 3.23) fabricado pela GEFRAN. Os LVDT's (Figura 3.22) foram posicionados abaixo da laje em contato com a superfície inferior e o potenciômetro posicionado na parte superior da laje. Além desses, foram monitorados os pontos 17 e 18 utilizando duas escalas graduadas em milímetros (Figura 3.23) posicionadas em um suporte metálico próximo das extremidades das lajes. Os pontos monitorados de 1 a 18 foram os mesmos em todas as lajes para permitir a comparação dos resultados.

Nas Séries 2 e 3 foram adicionados os pontos de 19 a 24 monitorados com defletômetros analógicos fabricados pela empresa Huggenberger AG (Figura 3.23) localizados nas 
bordas da laje na parte superior com o intuito de conhecer os deslocamentos verticais por toda a extensão da laje e para calcular a rotação da mesma pois os inclinômetros utilizados nas primeiras 4 lajes não funcionaram de maneira correta.

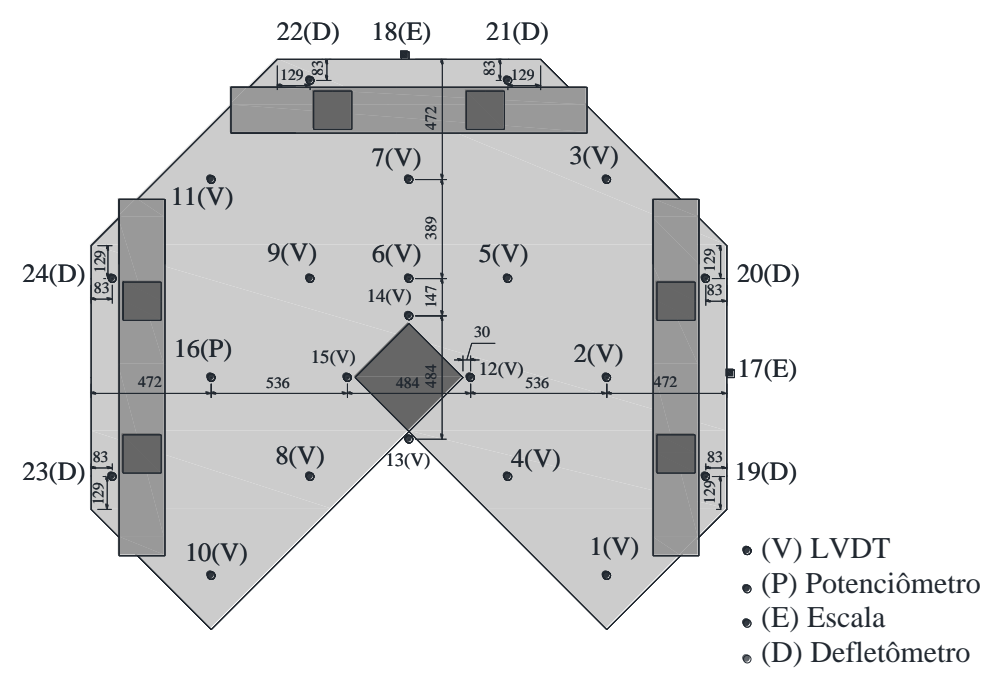

Figura 3.21 - Posicionamento dos LVDT's, potenciômetro, escalas e defletômetros nas lajes.

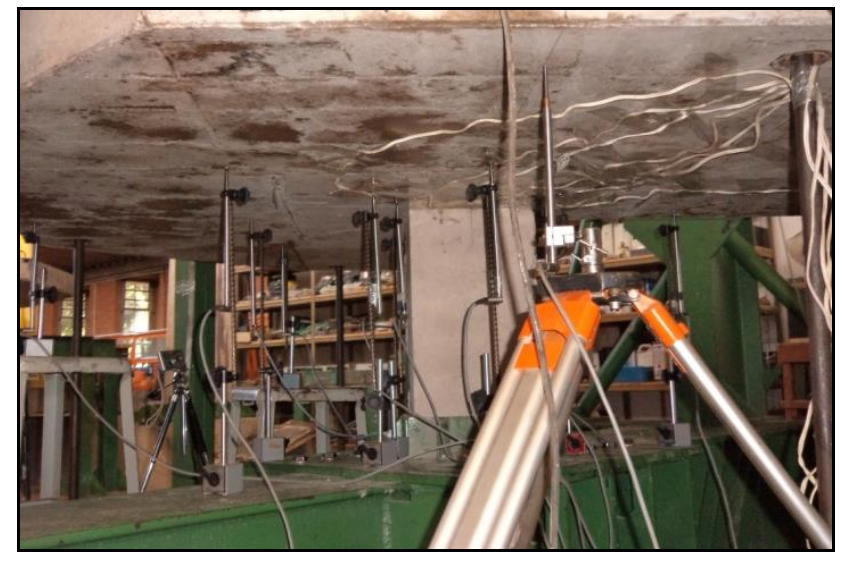

(a) Sistema de suporte dos LVDT's

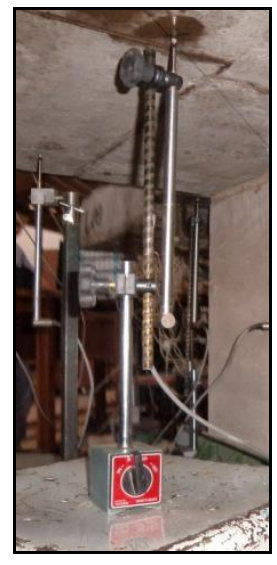

(b) Detalhe dos LVDT's

Figura 3.22 - LVDT's utilizados para medir os deslocamentos verticais. 


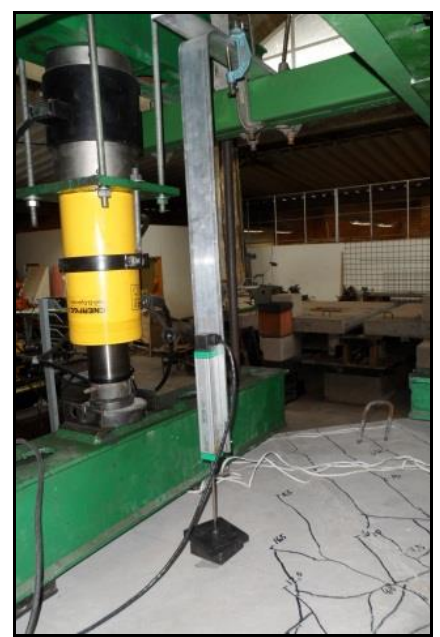

(a) Sistema de suporte do Potenciômetro

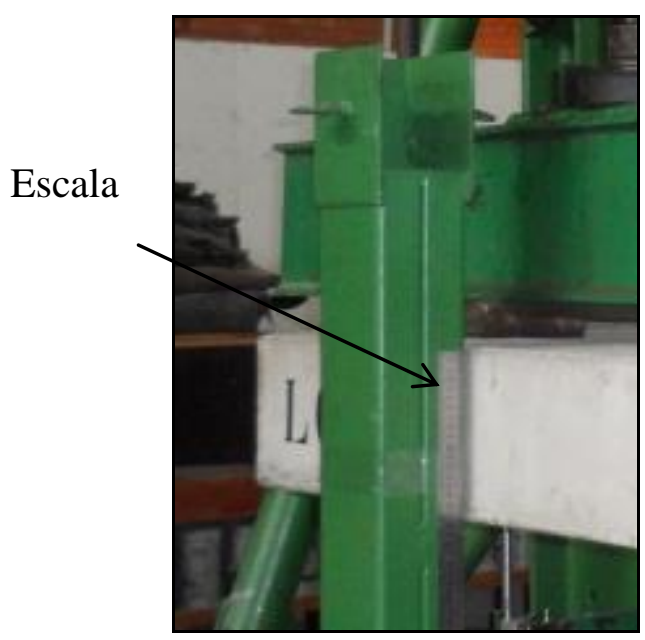

(b) Detalhe da Escala

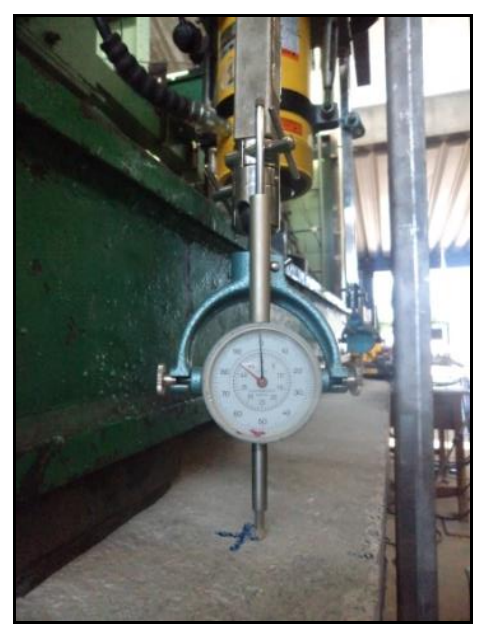

(c) Detalhes do Defletômetro

Figura 3.23 - Potenciômetro, escala e defletômetro utilizados nas lajes.

\subsubsection{Deformação nas Armaduras e na Superfície do Concreto}

Foram medidas as deformações nas armaduras de flexão, armaduras de cisalhamento e na superfície do concreto, a fim de acompanhar o comportamento das lajes durante todas as fases de carregamento. As medições destas deformações foram feitas utilizando-se extensômetros elétricos de resistência. Nas armaduras de flexão e de cisalhamento foram utilizados extensômetros do tipo KFG-5-120-C1-11, medindo $(9,4$ x 2,8) mm, fabricados pela empresa Kyowa Electronic Instruments. Para as barras com dois extensômetros por seção, a deformação apresentada para cada barra consiste da média aritmética dos resultados registrados nos pares de extensômetros. 
As barras de aço e o concreto foram devidamente preparados para receber a fixação dos extensômetros. As barras foram limadas e lixadas com o objetivo de eliminar as mossas na região de fixação, com o devido cuidado para não danificar a seção nominal.

Com a superfície lisa foi feita uma limpeza com álcool etílico com o objetivo de retirar todos os resíduos presentes na superfície de instrumentação das barras. Posteriormente os extensômetros foram colados um a um com cola SUPER BONDER (adesivo instantâneo de cianoacrilato), dispostos diametralmente opostos (quando utilizado dois extensômetro por ponto) e na mesma seção da barra.

Após a fixação dos extensômetros, cada terminal (ponta) foi soldado à ponta de um cordão flexível paralelo, preso à barra por braçadeiras plásticas. Depois de soldados os terminais, a região da solda foi protegida contra atrito e choques mecânicos por uma camada de resina epóxi que também funciona como isolamento elétrico. Uma camada de silicone envolveu o conjunto para proporcionar uma proteção mecânica e por fim o conjunto foi envolvido com uma fita isolante de auto fusão. Na Figura 3.24 são apresentadas algumas etapas do procedimento de colagem dos extensômetros nas barras de aço.

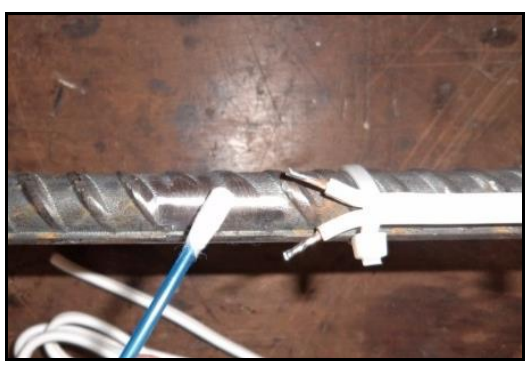

(a) Limpeza da superfície lixada

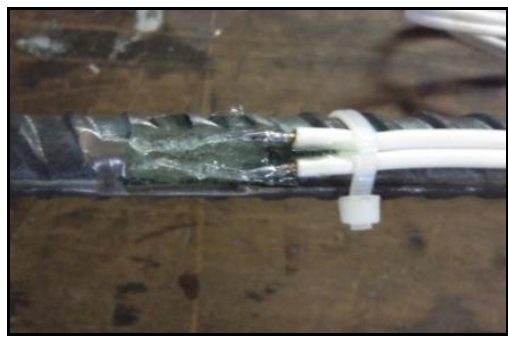

(d) Proteção e isolamento com resina epóxi

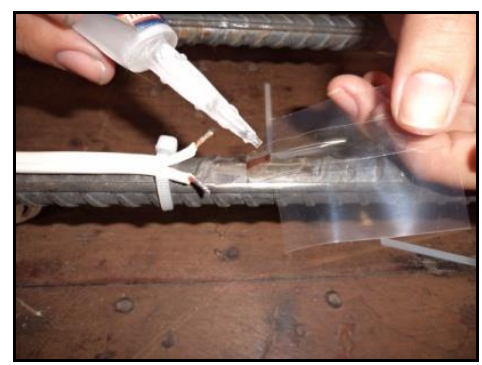

(b) Colagem dos extensômetros

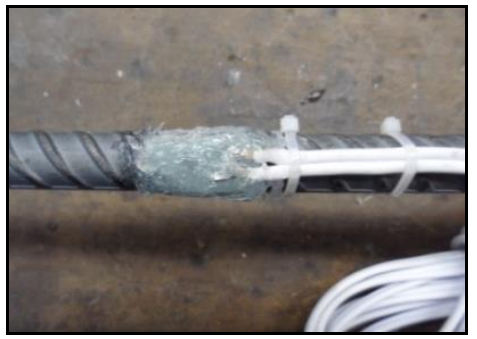

(e) Proteção mecânica com silicone

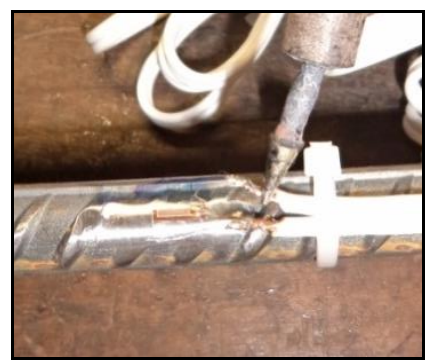

(c) Soldagem dos terminais dos extensômetros

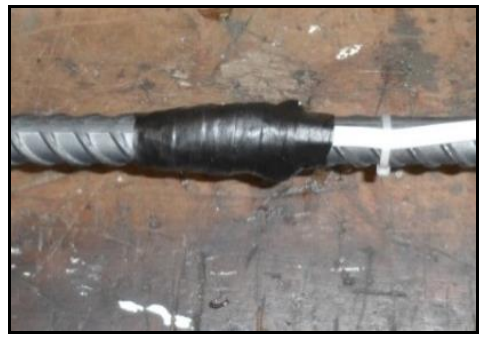

(f) Proteção mecânica com fita isolante de auto-fusão

Figura 3.24- Procedimento de colagem dos extensômetros. 
Na Série 1 foram instrumentadas 11 barras na armadura de flexão superior em uma direção e 11 na direção ortogonal. A armadura de flexão inferior composta por barras de 12,5 mm de diâmetro contou com dois pontos instrumentados, distribuídos em duas barras ortogonais que interceptavam o pilar. A Figura 3.25 mostra o posicionamento dos pontos de instrumentação das barras de flexão comprimidas e tracionadas monitoradas com o intuito de verificar o comportamento quanto à torção nas bordas internas das lajes.

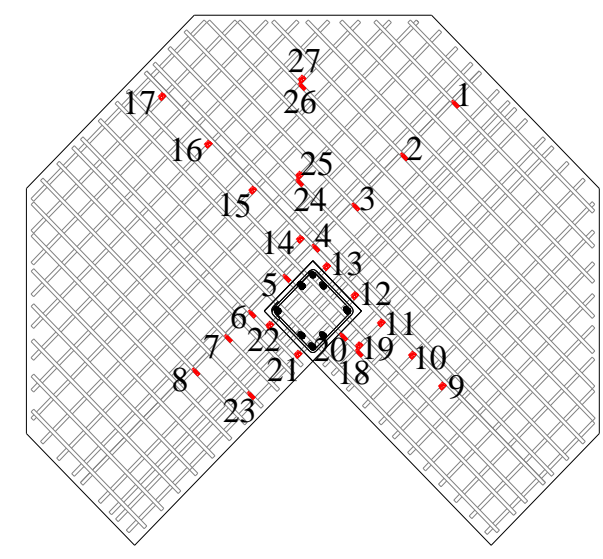

(a) Lajes L01, L02, L03 e L04

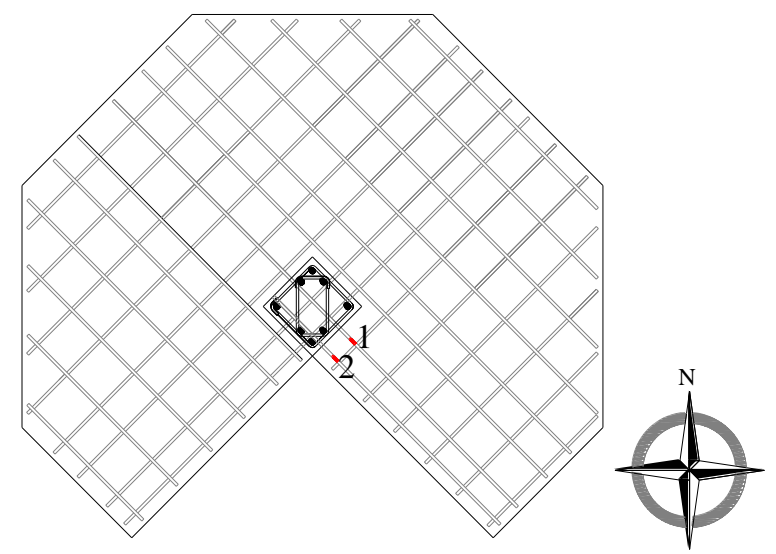

(b) Lajes L01, L02, L03 e L04

Figura 3.25- Posicionamento dos extensômetros nas armaduras superior (a) e inferior (b) (Série 1).

Na Série 2 e Série 3 foram utilizados pontos de instrumentação diferentes em função das taxas de armadura e carregamento como na mostra na Figura 3.26 e Figura 3.27.

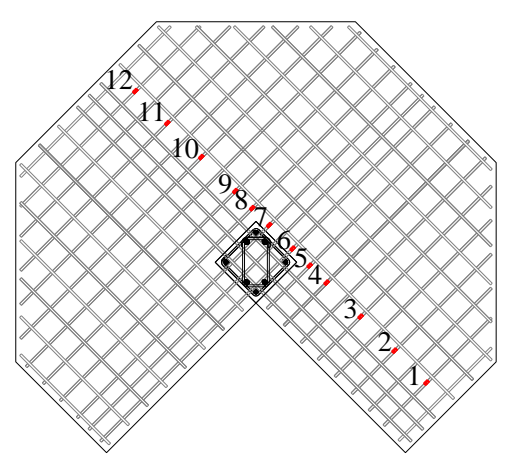

(a) Laje L05 e L06

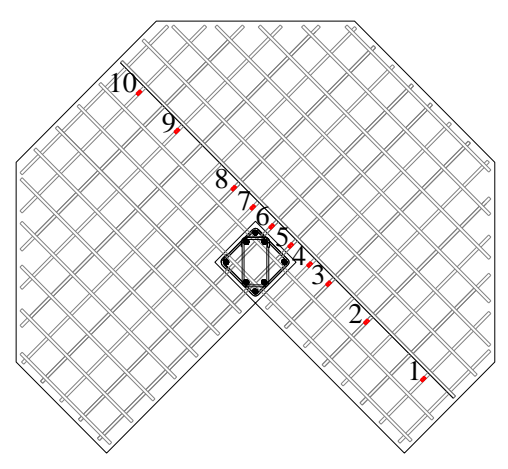

(b) Laje L07

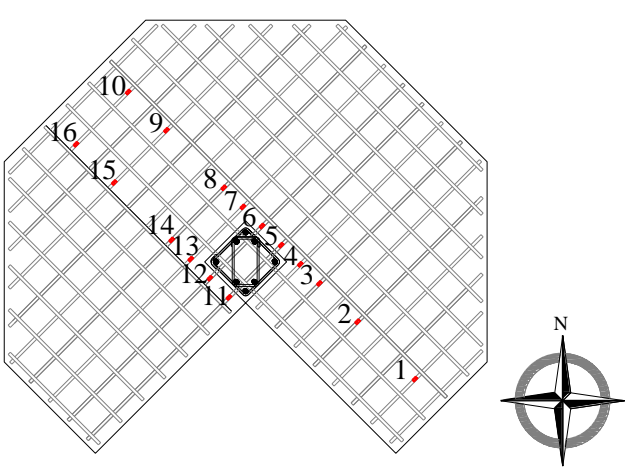

(c) Laje L08

Figura 3.26-Posicionamento dos extensômetros nas armaduras de flexão superior (Série 2). 
12

11

10

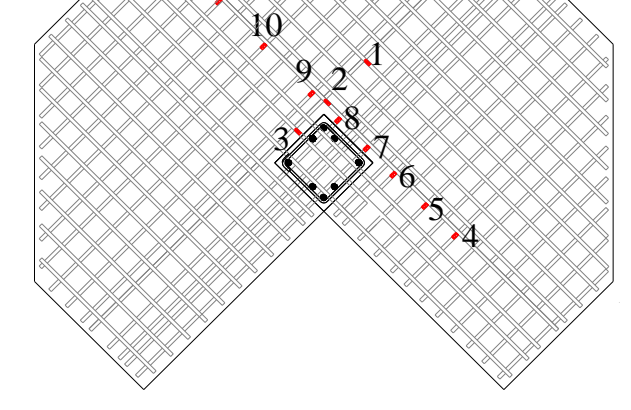

(c) Lajes L09, L10 e L11
10.

16.

15.

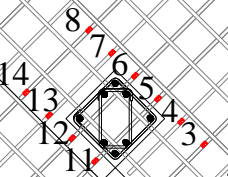

2.

1.

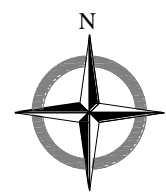

(a) Laje L12

Figura 3.27-Posicionamento dos extensômetros nas armaduras de flexão superior (Série 3).

Existem divergências quanto ao número de camadas de armadura de cisalhamento que realmente contribui para o aumento da resistência à punção de lajes lisas de concreto armado. A norma americana ACI 318 (2014) admite que apenas a primeira camada contribua, enquanto que a norma Europeia Eurocode2 (2004) considera que duas camadas contribuem efetivamente para a resistência à punção de lajes lisas de concreto armado. Ambas consideram que estas armaduras não atingem a tensão de escoamento do aço. Logo, o monitoramento dos studs é essencial a fim de se compreender melhor o comportamento de cada laje ensaiada.

As lajes L02 e L03 da Série 1 apresentavam 3 e 4 camadas de studs respectivamente com um total de 10 linhas distribuídas na laje. Todas as camadas de studs foram instrumentadas em linhas alternadas. A Figura 3.26 apresenta os studs nos quais as deformações foram monitoradas durante os ensaios.

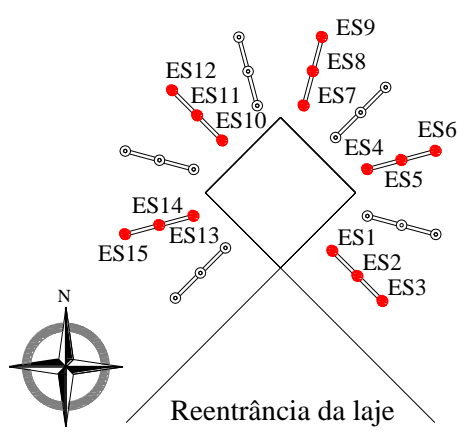

(a) Laje L02

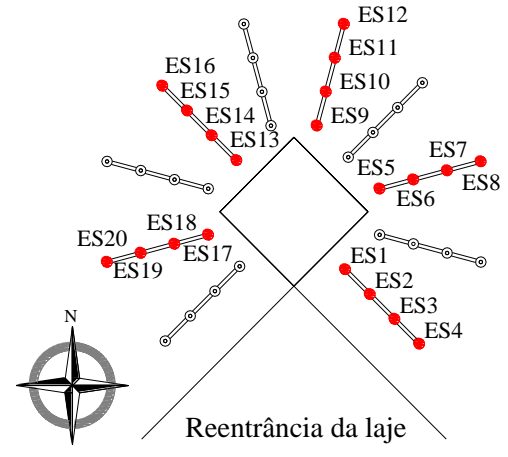

(b) Laje L03

Figura 3.26 - Posicionamento dos extensômetros nos studs (Série 1) 
Na Série 2 não foi utilizada armadura de cisalhamento e na Série 3 as lajes L09, L10 e L11 apresentaram cinco camadas com apenas as duas primeiras instrumentadas em linhas intercaladas como mostra a Figura 3.27.

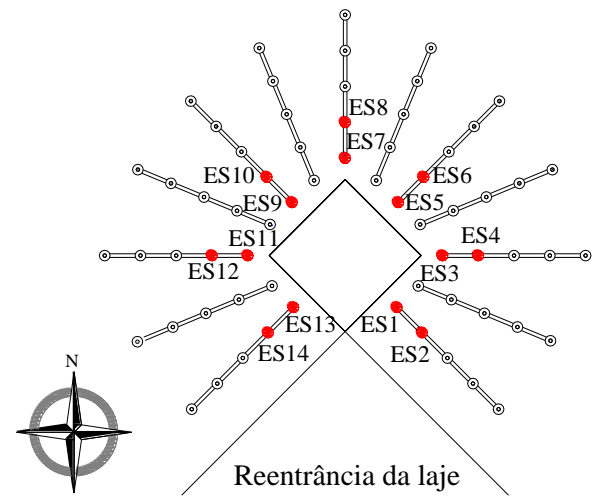

(a) Laje L09

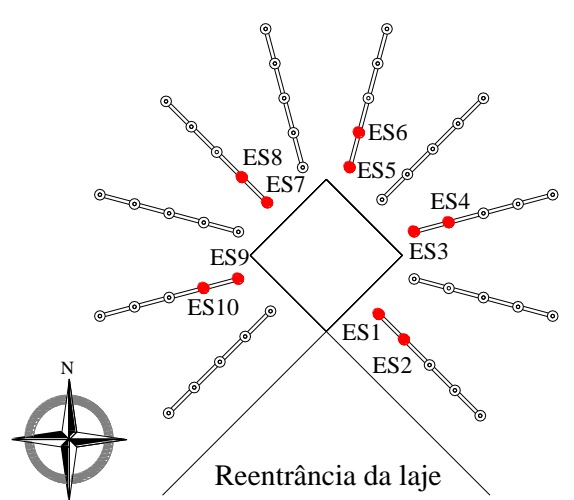

(b) Lajes L10 e L11

Figura 3.27 - Posicionamento dos extensômetros nos studs (Série 3)

As deformações na superfície do concreto também foram monitoradas, a fim de se verificar a possibilidade de ruptura por flexão, porém causada por esmagamento do concreto. Para tal, foram utilizados extensômetros do tipo KC-70-120-A1-11 posicionados segundo dois eixos das lajes.

A posição de máxima deformação na superfície do concreto na região adjacente ao pilar é desconhecida. Assim, foram monitorados extensômetros nos pontos próximo ao pilar posicionados a $25 \mathrm{~mm}$ da face destes como mostram a Figura 3.28.

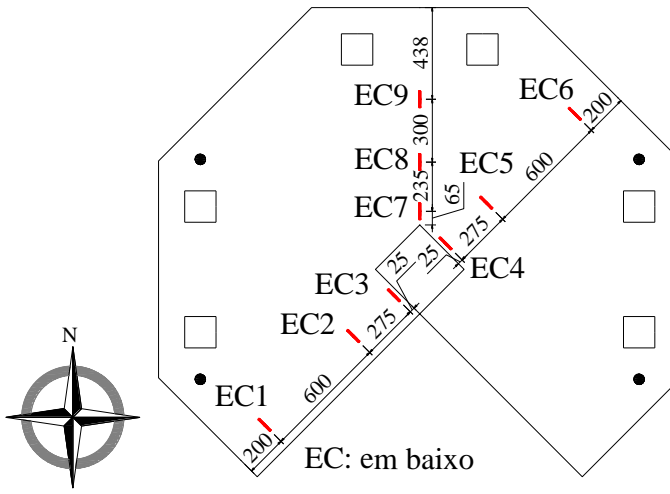

(a) Lajes L01 à L04

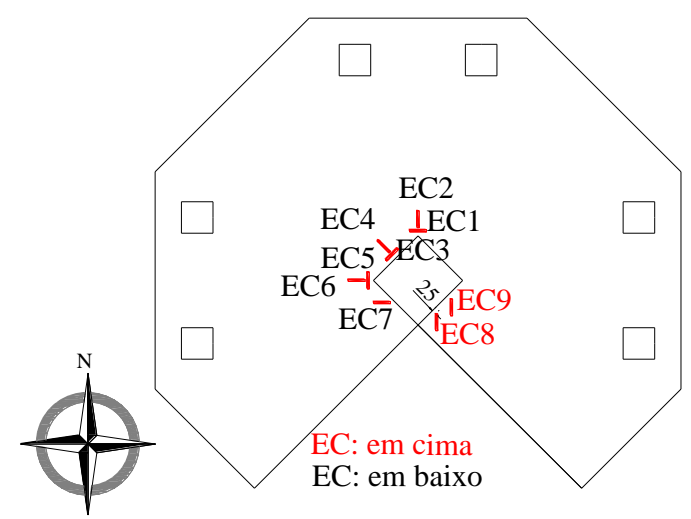

(b) Lajes L05 à L12

Figura 3.28 - Posicionamento dos extensômetros na superfície concreto 


\subsubsection{Rotação da Laje}

A rotação das lajes foi monitorada na Série 1 com dois inclinômetros, um de bolha e outro de pêndulo construído na Universidade de Brasília. Os dois inclinômetros foram posicionados nas proximidades dos pilares das lajes, na superfície superior da mesma para monitorar as rotações no seu eixo de simetria e no eixo ortogonal ao de simetria. A Figura 3.28 mostra os inclinômetros utilizados nessa pesquisa e a Figura 3.29 apresenta detalhes do posicionamento nas lajes.

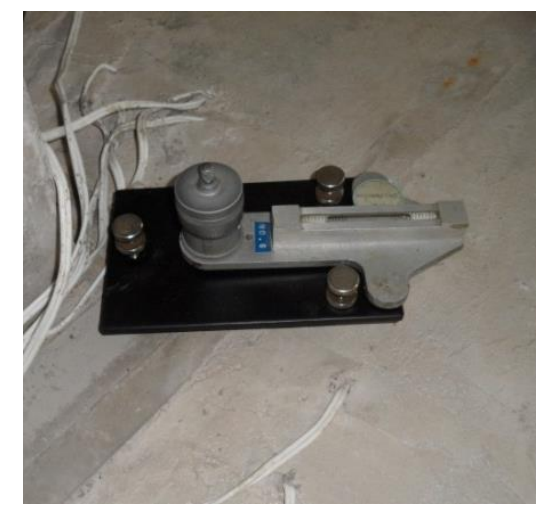

(a) Inclinômetro de bolha

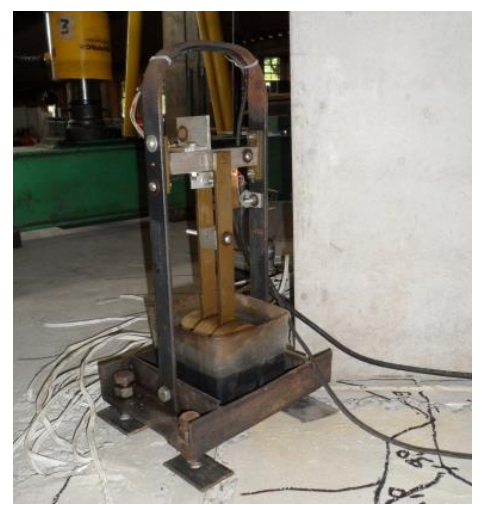

(b) Inclinômetro de pêndulo

Figura 3.28- Detalhe dos inclinômetros

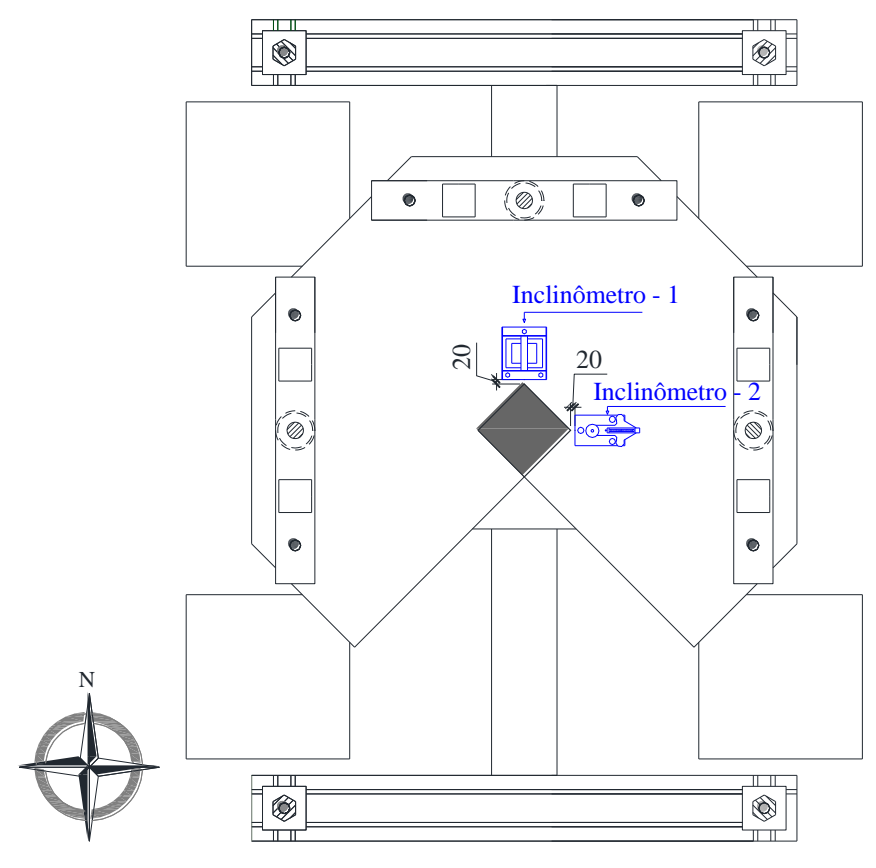

Figura 3.29 - Posicionamento dos inclinômetros. 
Os inclinômetros utilizados não apresentaram resultados satisfatórios, motivo pelo qual não foram utilizados nas Séries 2 e 3. Para suprir a falta dos mesmos, foram utilizados os defletômetros analógicos próximos aos bordos das lajes para calcular sua rotação.

\subsection{SISTEMA DE ENSAIO}

Os ensaios das lajes foram realizados no pórtico de reação existente no laboratório de Estruturas da Universidade de Brasília com necessidade de adaptação para restringir a translação dos segmentos do pilar cuja capacidade é de $2.000 \mathrm{kN}$.

Foram utilizados três atuadores hidráulicos da marca ENERPAC, todos com capacidade de $1000 \mathrm{kN}$; três conjuntos de células de carga e indicadores digitais fabricados pela Kratos Equipamentos Industriais Ltda. com capacidade de $1000 \mathrm{kN}$ e com precisão de $1 \mathrm{kN}$; três rótulas de aço, posicionadas entre o êmbolo dos atuadores hidráulicos e as vigas metálicas, com o objetivo de compensar a rotação provocada pelo deslocamento do bordo da laje devido a aplicação das cargas; duas bombas hidráulicas para acionamento dos atuadores hidráulicos; três vigas metálicas rígidas para distribuição do carregamento aplicado pelos cilindros hidráulicos em duas chapas de aço, totalizando 6 pontos de aplicação de carga; 4 tirantes de aço com $\phi=32 \mathrm{~mm}$ da DYWDAG 1040, usados como dispositivos de reação para os carregamentos aplicados pelos atuadores na direção L-O do sistema de ensaios; conexões metálicas de aço acopladas ao pórtico de reação do laboratório para a restrição da translação dos segmentos de pilar. Na Figura 3.30 é possível observar detalhes da configuração de ensaio das lajes e na Figura 3.31 são apresentados equipamentos e acessórios utilizados durante os ensaios das lajes. 


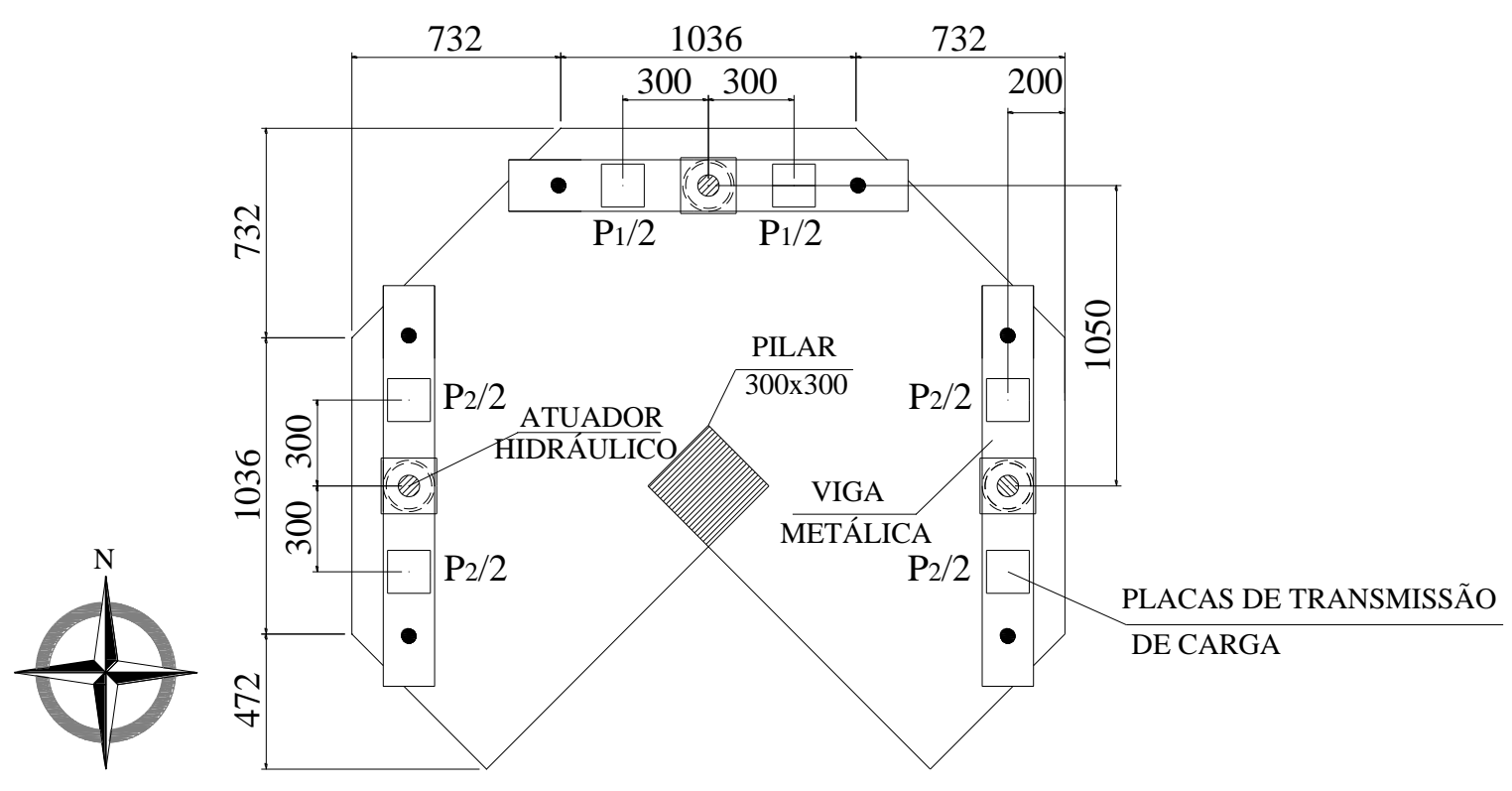

Figura 3.30 - Sistema de ensaio: vista superior.

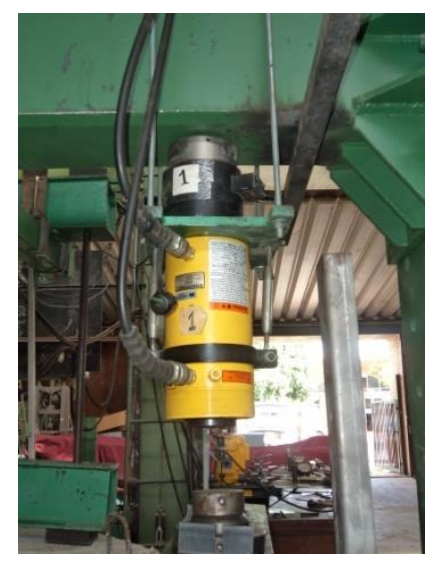

(a) Atuador hidráulico e célula de carga

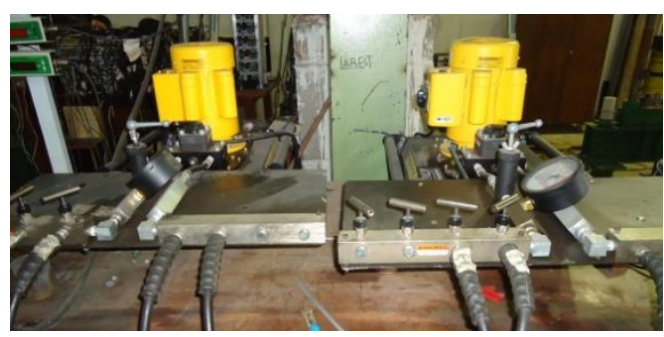

(c) Bombas hidráulicas

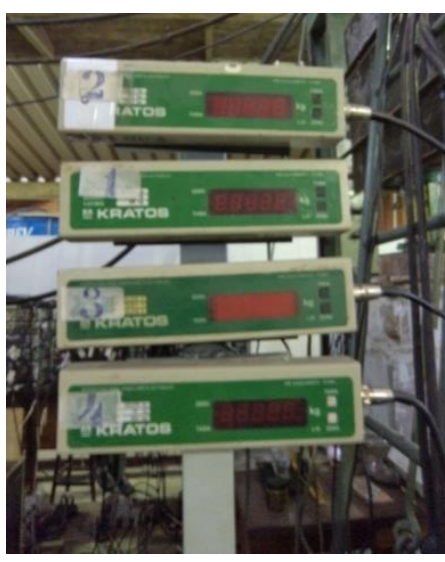

(b) Indicadores das células de carga

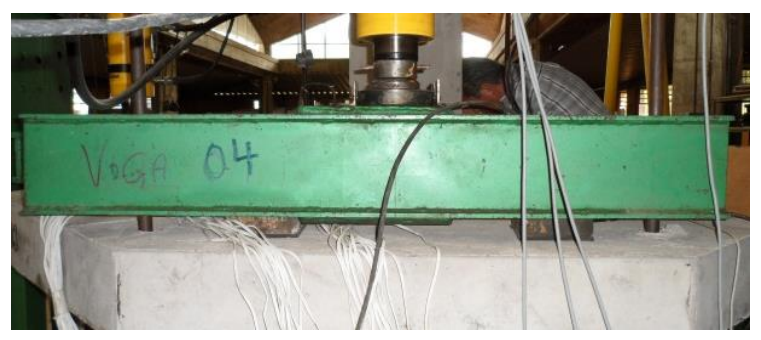

(d) Viga metálica de distribuição

Figura 3.31 - Detalhes do sistema de Ensaios. 
O sistema utilizado para aquisição de dados dos LVDT's e dos extensômetros nas armaduras de flexão e de cisalhamento e na superfície de concreto foi composto por 10 módulos do sistema de aquisição Spider8, modelos SR30 e SR55, fabricados pela empresa HBM, interligados em cascata e ligados a dois computadores. Dois módulos de aquisição ADS2000, fabricados pela empresa brasileira Lynx Tecnologia Eletrônica S.A., cada um ligado a um computador, foram utilizados nos ensaios de algumas lajes que possuíam grande número de canais a serem monitorados.

O software de aquisição de dados utilizado para os módulos Spider8 foi o CATMAN versão 4.5 e para os módulos $A D S 2000$ utilizou-se o software de aquisição de dados AqDados 7.

A Figura 3.32 e a Figura 3.33 mostram uma vista superior e lateral do sistema desenvolvido para o ensaio das lajes desta pesquisa. Na Figura 3.34 e na Figura 3.35 apresentam-se uma vista frontal e uma vista em 3D do projeto. Na Figura 3.36 é possível ver como ficou este sistema no laboratório durante o ensaio da laje L12. Detalhes do sistema de aquisição de dados podem ser vistos na Figura 3.37.

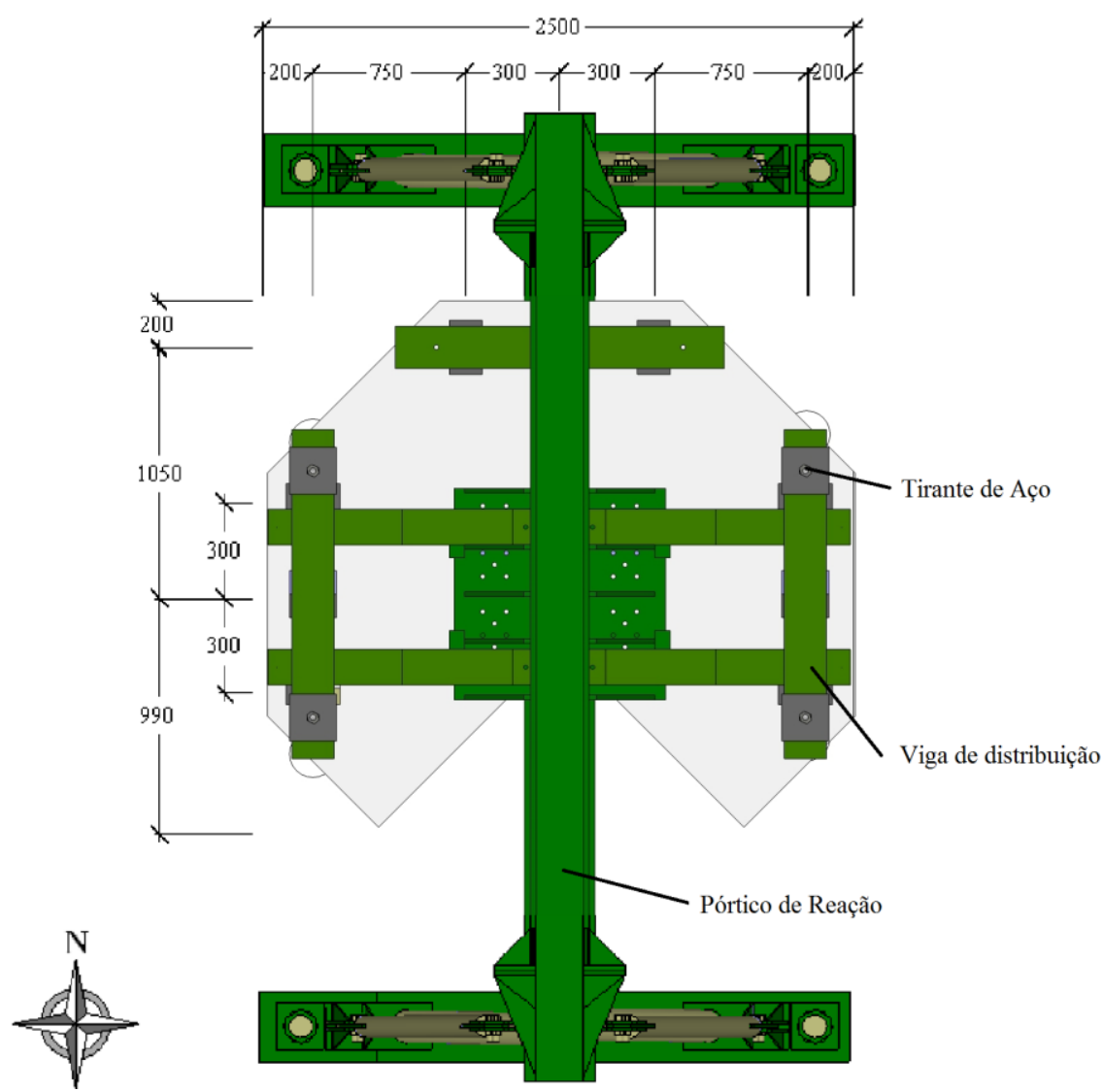

Figura 3.32 - Sistema de ensaio: vista superior. 


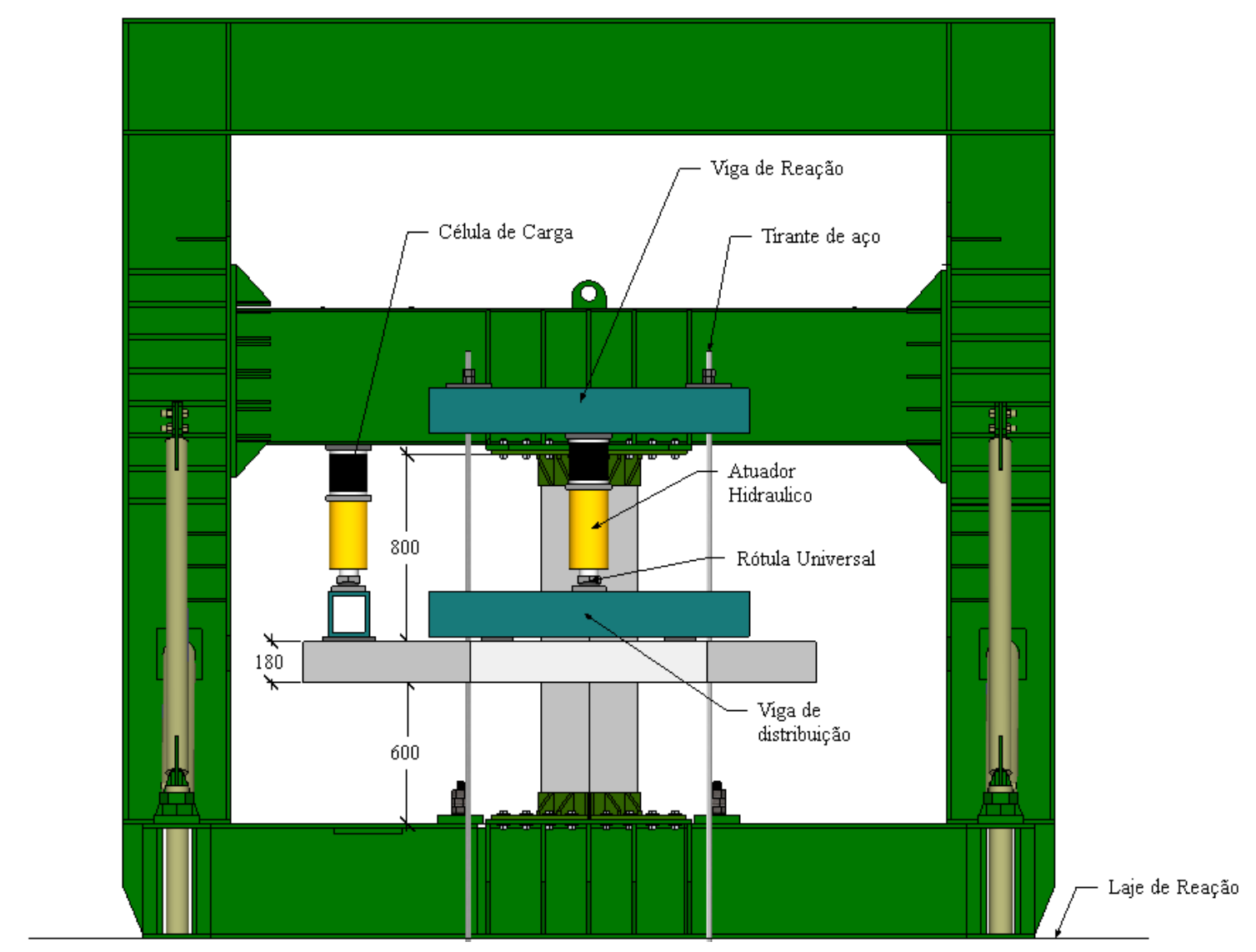

Figura 3.33 - Sistema de ensaio: vista lateral.

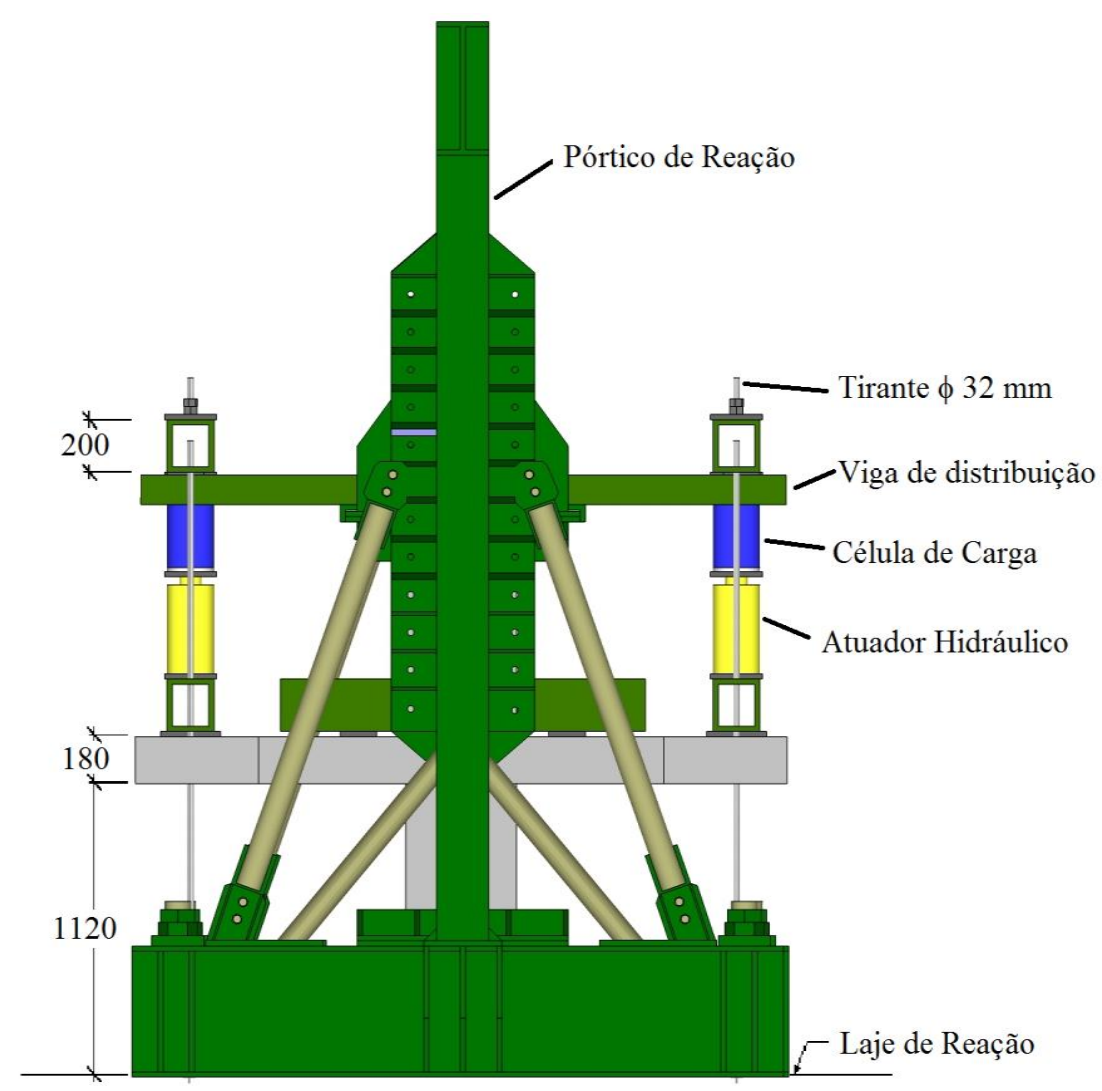

Figura 3.34 - Sistema de ensaio: vista frontal. 


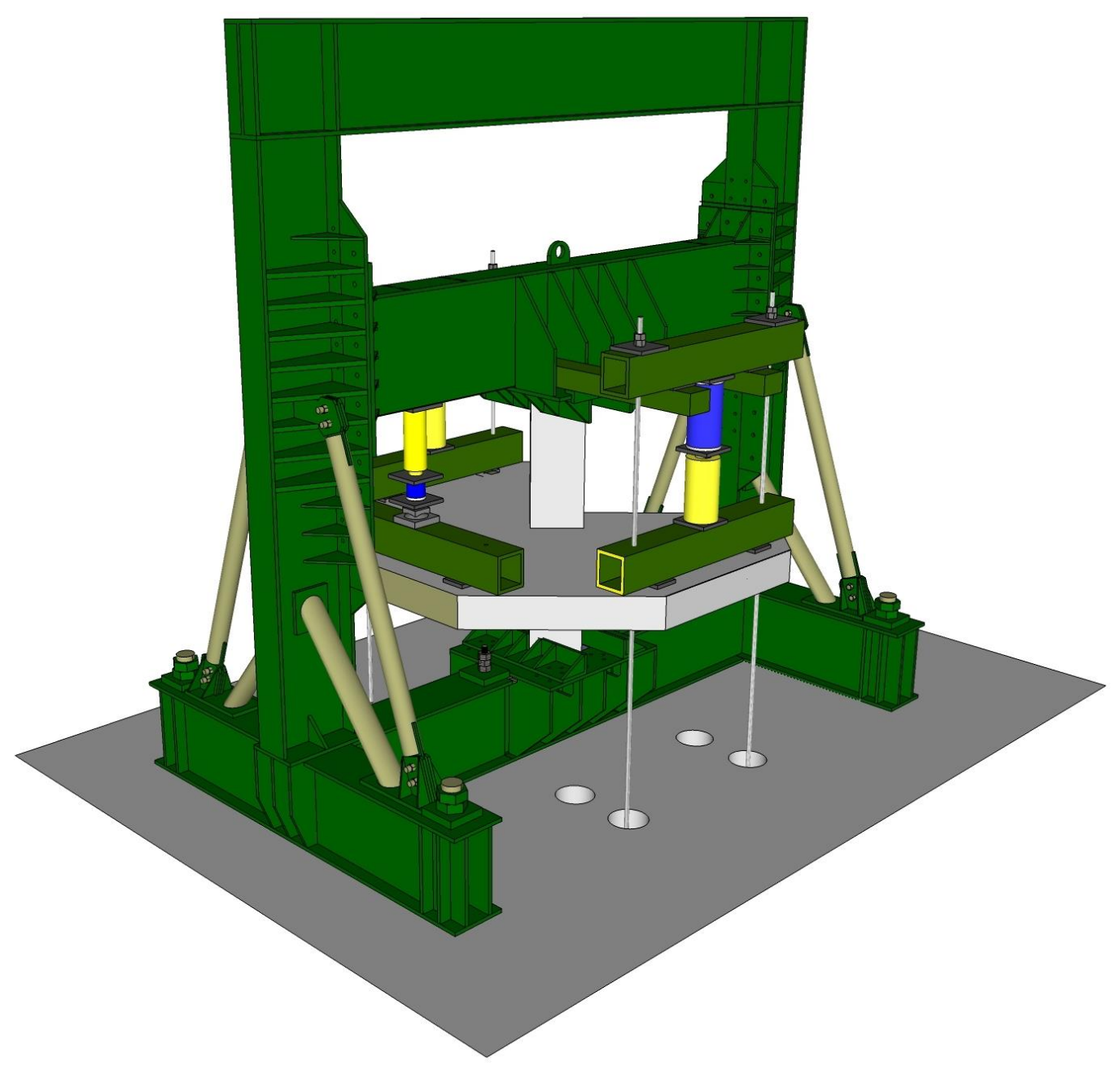

Figura 3.35 - Sistema de ensaio: Vista 3D.

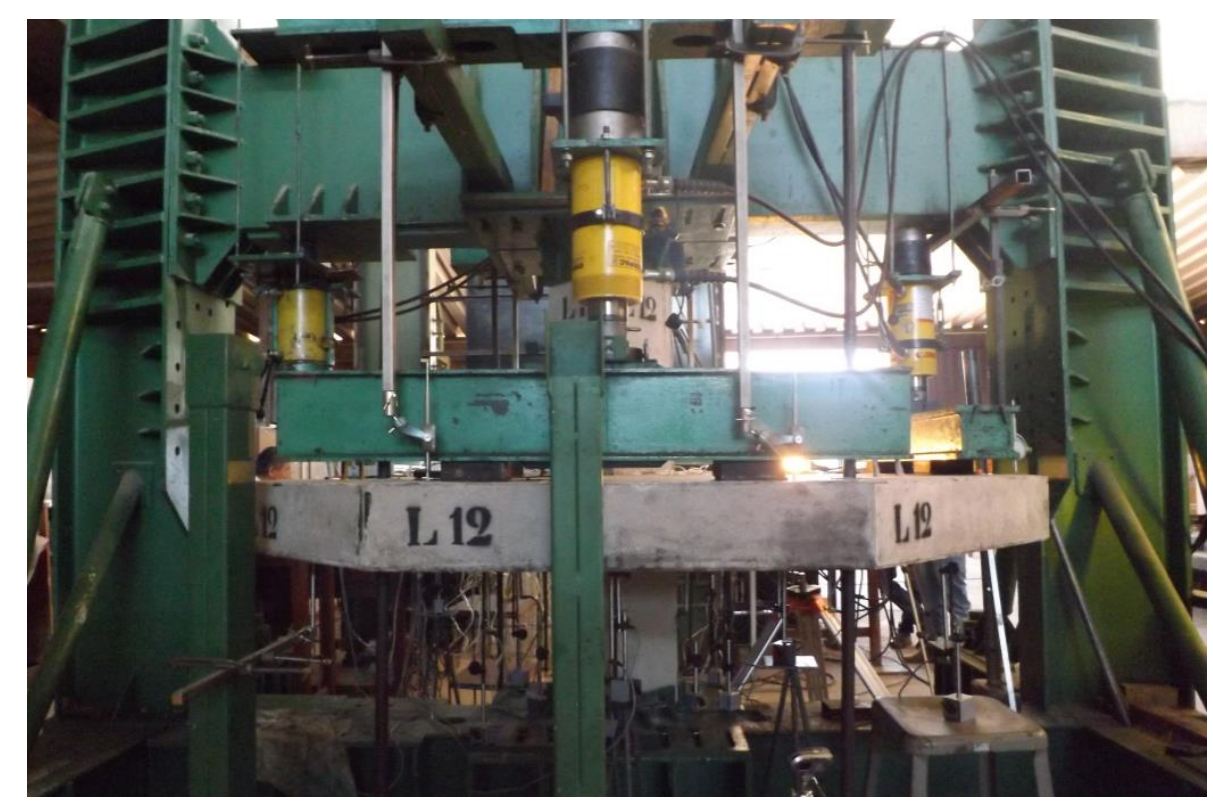

Figura 3.36 - Foto do sistema de ensaio da laje L12. 


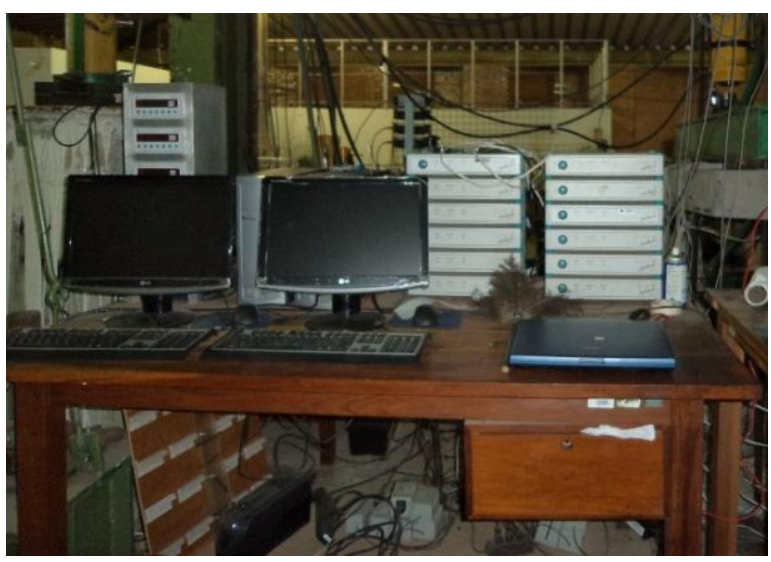

(a) Módulos Spider8

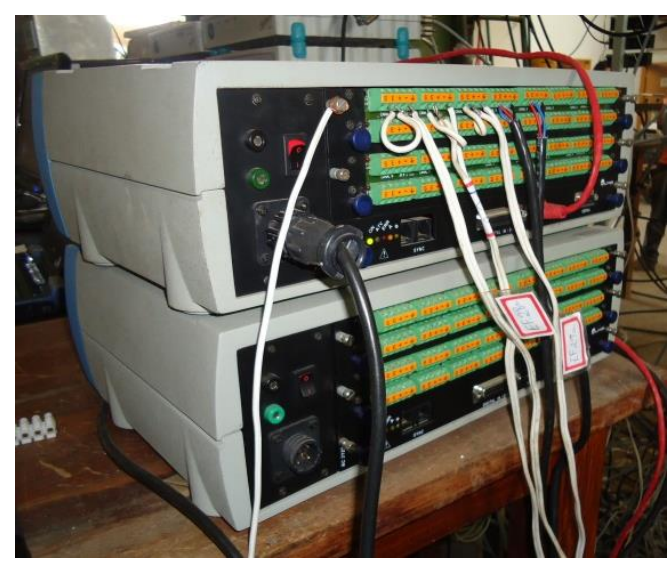

(b) Módulos ADS2000

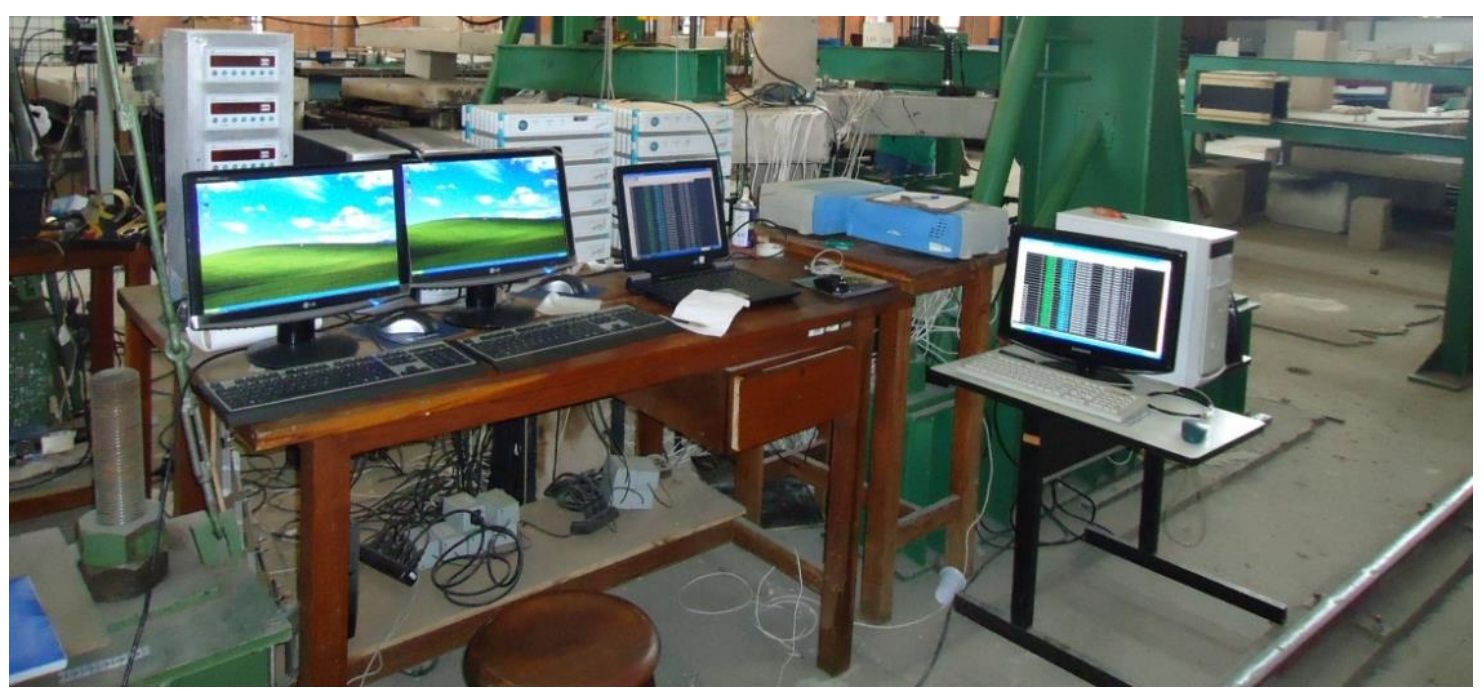

(c) Vista do sistema interligado

Figura 3.37- Sistema de aquisição de dados 


\section{RESULTADOS EXPERIMENTAIS}

Neste capítulo serão apresentados os resultados experimentais obtidos na realização dos ensaios descritos no Capítulo 3, como: deslocamentos verticais; deformações na superfície do concreto; deformações nas armaduras de flexão e de cisalhamento; mapeamento das fissuras de flexão visíveis durante os ensaios e a localização da superfície de ruptura de cada laje. Inicialmente serão apresentados os ensaios de caracterização do concreto e do aço e os resultados referentes às cargas de ruptura observadas ao final de cada ensaio.

\subsection{PROPRIEDADES DOS MATERIAIS}

\subsubsection{Concreto}

Para a confecção das doze lajes propostas, foram realizadas três concretagens, com quatro lajes em cada.

Para cada concretagem foram moldados 36 corpos de prova cilíndricos medindo $100 \mathrm{~mm} \mathrm{x}$ $200 \mathrm{~mm}$ utilizados nos ensaios de caracterização do concreto quanto a resistência à compressão, resistência à tração e módulo de elasticidade tangente inicial.

Os ensaios de compressão simples seguiram as recomendações da norma NBR 5739 (2014), os ensaios de compressão diametral atenderam as exigências da NBR 7222 (2011) e para os ensaios de determinação do módulo de elasticidade tangente inicial utilizou-se a norma NBR 8522 (2008).

Nos ensaios para obtenção de módulo de elasticidade foram rompidos seis corpos de prova para cada série de concretagem (3 tomados como referência $f_{c, \text { ret }}$ e 3 para determinar o módulo de elasticidade). Já para obtenção da resistência à tração do concreto $f_{c t}$ foram ensaiados três corpos de prova por compressão diametral representando cada série de concretagem. Além desses foram realizados ensaios de compressão utilizando três corpos de prova para cada série de concretagem em que a regularização dos topos dos mesmos foi feita com almofada de neoprene, $f_{c, \text { neo }}$. Na Tabela 4.1 apresenta um resumo das propriedades mecânicas do concreto utilizado na pesquisa. 
Tabela 4.1 - Propriedades mecânicas do Concreto.

\begin{tabular}{|c|c|c|c|c|}
\hline LAJES & $f_{c, \text { neo }}$ & $f_{c t}(\mathrm{MPa})$ & $f_{c, \text { ret }}(\mathrm{MPa})$ & $E(\mathrm{GPa})$ \\
\hline L01 & \multirow{4}{*}{58} & \multirow{4}{*}{3,4} & \multirow{4}{*}{48} & \multirow{4}{*}{29,4} \\
\hline L02 & & & & \\
\hline L03 & & & & \\
\hline L04 & & & & \\
\hline L05 & \multirow{4}{*}{43} & \multirow{4}{*}{3,1} & \multirow{4}{*}{44} & \multirow{4}{*}{30,1} \\
\hline L06 & & & & \\
\hline L07 & & & & \\
\hline L08 & & & & \\
\hline L09 & \multirow{4}{*}{51} & \multirow{4}{*}{3,5} & \multirow{4}{*}{43} & \multirow{4}{*}{32,9} \\
\hline $\mathrm{L} 10$ & & & & \\
\hline L11 & & & & \\
\hline L12 & & & & \\
\hline \multicolumn{5}{|c|}{$\begin{array}{l}\text { Obs: } \\
f_{c, \text { neo }}=\text { Resistência à compressão de cilindros } 10 \text { x } 20 \mathrm{~cm} \text { utilizando neoprene. } \\
f_{c, \text { ret }}=\text { Resistência à compressão de cilindros } 10 \text { x } 20 \mathrm{~cm} \text { retificados utilizados } \\
\text { como referência para os ensaios de módulo de elasticidade. }\end{array}$} \\
\hline
\end{tabular}

Os resultados de $f_{c, \text { neo }}$ quando comparado com $f_{c, \text { ret }}$ e submetidos aos critérios de validação do sistema de capeamento com neoprene, utilizando o processo ASTM C1231/C (2000), nota-se que nem todos os resultados podem ser validados e que a dureza do neoprene necessária para utilizar nesse concreto cuja resistência ultrapassa $40 \mathrm{MPa}$ deveria ser maior. Com isso, optou-se por utilizar a resistência à compressão do concreto $f_{c}=f_{c, r e t}$.

\subsubsection{Aço}

Foram utilizadas barras de aço CA50 nas armaduras de flexão e cisalhamento das lajes. Para caracterização das propriedades mecânicas do aço foram utilizadas três amostras para cada diâmetro de barra, com comprimento de aproximadamente $50 \mathrm{~cm}$.

Utilizou-se uma prensa EMIC DL30000 e o software Tesc versão 3.04 para a realização dos ensaios de tração axial no Laboratório de Ensaio de Materiais da Universidade de Brasília, seguindo as recomendações da norma NBR 6892 (2002). A Figura 4.1 apresenta detalhes do esquema de ensaio utilizado. 


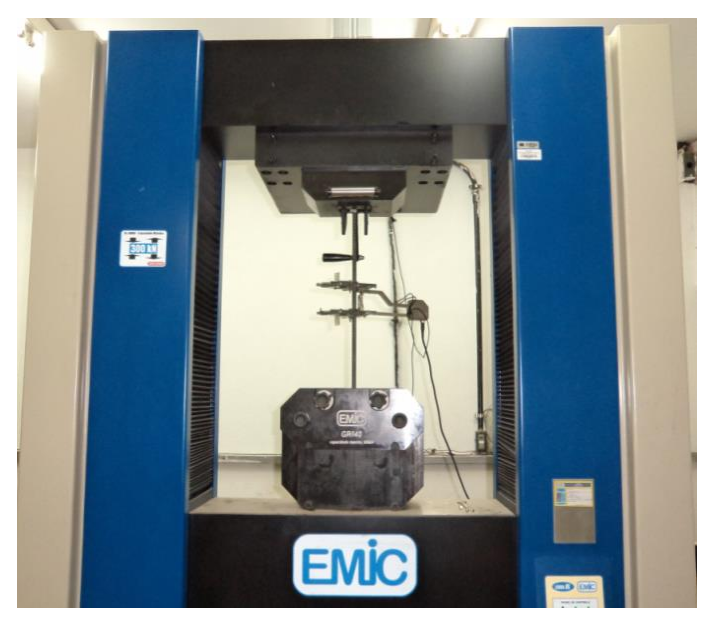

Figura 4.1 - Ensaio de tração do aço.

As propriedades do aço foram obtidas a partir da média dos resultados de três corpos de prova referentes às diversas bitolas utilizadas nas lajes. Na Tabela 4.2 são apresentados os resultados dos ensaios das barras utilizadas na execução das armaduras de flexão. As propriedades do aço foram obtidas a partir da média dos resultados de três corpos de prova referentes às diversas bitolas utilizadas nas lajes. Na Tabela 4.2 são apresentados os resultados dos ensaios das barras utilizadas na execução das armaduras de flexão. Os valores do módulo de elasticidade são afetados pelo fato de se medir a deformação com apenas um extensômetro removível, e não dois diametralmente opostos como seria desejável para a obtenção da deformação média que eliminaria uma eventual flexão da amostra. A Figura 4.2, Figura 4.3 e Figura 4.4 apesentam os gráficos de tensão $\mathrm{x}$ deformação dos aços utilizados na Série 3.

Tabela 4.2 - Propriedades mecânicas do aço utilizado nas lajes

\begin{tabular}{|c|c|c|c|c|c|c|c|c|c|c|c|c|c|}
\hline \multirow[b]{2}{*}{ LAJE } & \multirow{2}{*}{$\begin{array}{l}\text { Lote } \\
\text { (Aço) }\end{array}$} & \multicolumn{3}{|c|}{$\varnothing 8,0 \mathrm{~mm}$} & \multicolumn{3}{|c|}{$\varnothing 10,0 \mathrm{~mm}$} & \multicolumn{3}{|c|}{$\varnothing 12,5 \mathrm{~mm}$} & \multicolumn{3}{|c|}{$\varnothing 16,0 \mathrm{~mm}$} \\
\hline & & $\begin{array}{c}f_{\mathrm{ys}} \\
(\mathrm{MPa})\end{array}$ & $\begin{array}{c}E_{\mathrm{s}} \\
(\mathrm{GPa})\end{array}$ & $\begin{array}{c}\varepsilon_{\mathrm{ys}} \\
(\%)\end{array}$ & $\begin{array}{c}f_{\mathrm{ys}} \\
(\mathrm{MPa})\end{array}$ & $\begin{array}{c}\mathrm{E}_{\mathrm{s}} \\
(\mathrm{GPa})\end{array}$ & $\begin{array}{c}\varepsilon_{\mathrm{ys}} \\
(\% 0)\end{array}$ & $\begin{array}{c}f_{\mathrm{ys}} \\
(\mathrm{MPa})\end{array}$ & $\begin{array}{c}\mathrm{E}_{\mathrm{s}} \\
(\mathrm{GPa})\end{array}$ & $\begin{array}{c}\varepsilon_{\mathrm{ys}} \\
(\% 0)\end{array}$ & $\begin{array}{c}f_{\mathrm{ys}} \\
(\mathrm{MPa})\end{array}$ & $\begin{array}{c}\mathrm{E}_{\mathrm{s}} \\
(\mathrm{GPa})\end{array}$ & $\begin{array}{c}\varepsilon_{\mathrm{ys}} \\
(\% 0)\end{array}$ \\
\hline L01 & \multirow{3}{*}{1} & \multirow{3}{*}{587} & \multirow{3}{*}{187} & \multirow{3}{*}{3,13} & \multirow{3}{*}{560} & \multirow{3}{*}{197} & \multirow{3}{*}{2,84} & \multirow{3}{*}{576} & \multirow{3}{*}{201} & \multirow{3}{*}{2,87} & \multirow{3}{*}{558} & \multirow{3}{*}{192} & \multirow{3}{*}{2,91} \\
\hline $\begin{array}{l}\mathrm{L} 02 \\
\mathrm{I} 23\end{array}$ & & & & & & & & & & & & & \\
\hline $\begin{array}{l}\text { L03 } \\
\text { L04 }\end{array}$ & & & & & & & & & & & & & \\
\hline L05 & \multirow{4}{*}{2} & \multirow{4}{*}{599} & \multirow{4}{*}{193} & \multirow{4}{*}{3,10} & \multirow{4}{*}{528} & \multirow{4}{*}{207} & \multirow{4}{*}{2,55} & \multirow{4}{*}{561} & \multirow{4}{*}{189} & \multirow{4}{*}{2,97} & \multirow{4}{*}{570} & \multirow{4}{*}{196} & \multirow{4}{*}{2,90} \\
\hline L06 & & & & & & & & & & & & & \\
\hline L07 & & & & & & & & & & & & & \\
\hline L08 & & & & & & & & & & & & & \\
\hline L09 & \multirow{4}{*}{3} & \multirow{4}{*}{ - } & \multirow{4}{*}{ - } & \multirow{4}{*}{ - } & & & & & & & & & \\
\hline L10 & & & & & 520 & 007 & 55 & 530 & 100 & 267 & 572 & 200 & 275 \\
\hline L11 & & & & & $5 \angle 8$ & 201 & 2,כग & טנכ & 198 & $2,0 /$ & $5 / 2$ & 208 & 2,13 \\
\hline L12 & & & & & & & & & & & & & \\
\hline
\end{tabular}




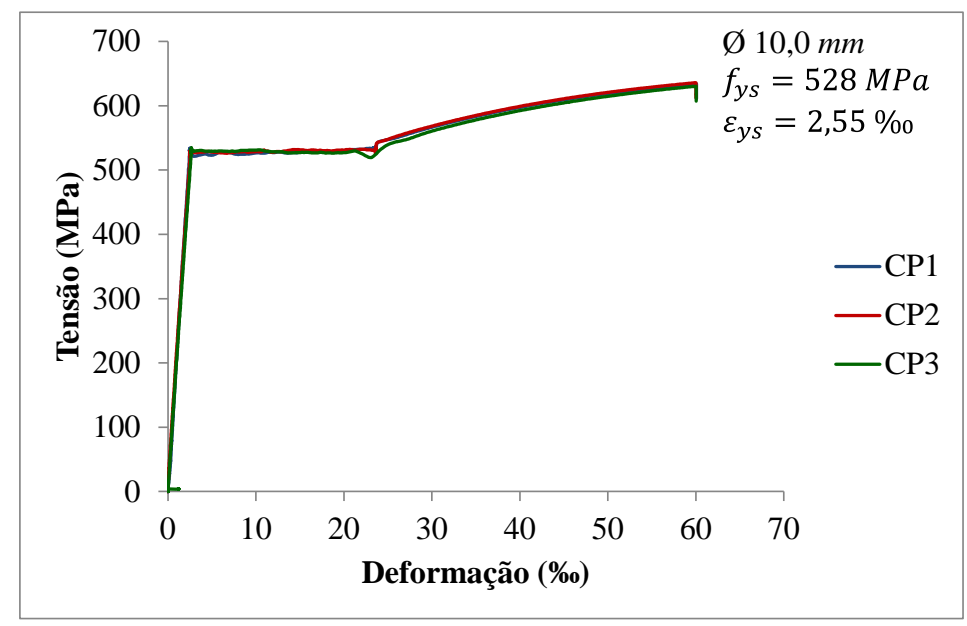

Figura 4.2 - Tensão x deformação das barras de 10,0 mm (Série 3)

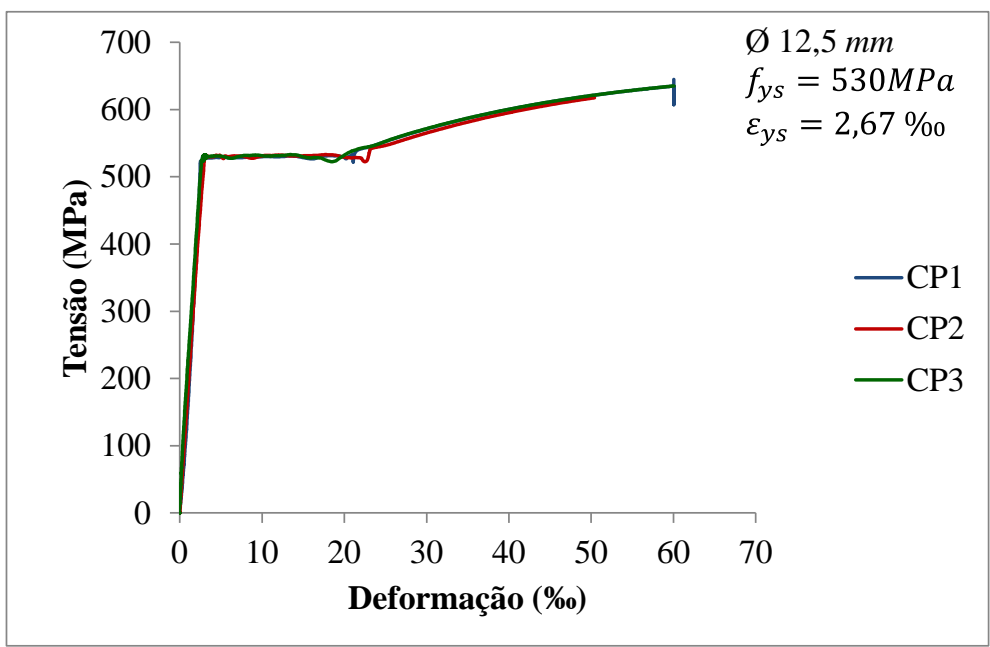

Figura 4.3 - Tensão x deformação das barras de 12,5 mm (Série 3)

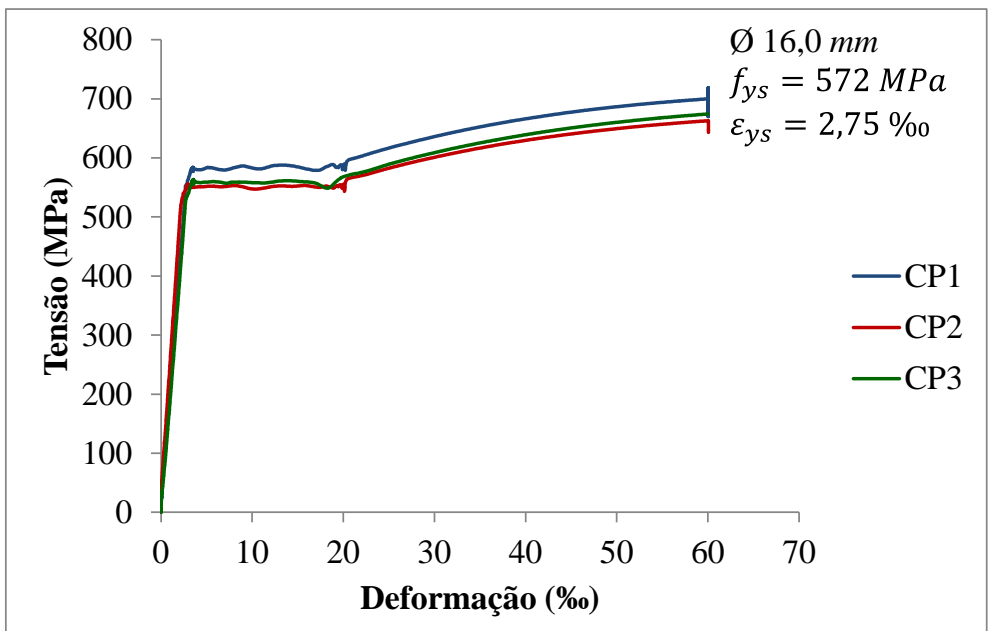

Figura 4.4 - Tensão x deformação das barras de 16,0 mm (Série 3) 


\subsubsection{CARGAS DE RUPTURA DAS LAJES ENSAIADAS}

A Tabela 4.3 apresenta as cargas últimas $V_{u}$ considerando o peso próprio da laje e dos equipamentos.

Tabela 4.3 - Carga de ruptura das lajes

\begin{tabular}{|c|c|c|c|c|c|}
\hline LAJES & $d(\mathrm{~mm})$ & $\rho(\%)$ & $P_{2} / P_{l}$ & $e(\mathrm{~mm})$ & $V_{u}(\mathrm{kN})$ \\
\hline L01 & 148,0 & 2,07 & 0,5 & 500 & 325 \\
\hline L02 & 148,0 & 2,07 & 1,0 & 352 & 513 \\
\hline L03 & 144,5 & 2,17 & 1,0 & 349 & 575 \\
\hline L04 & 147,0 & 2,10 & 1,0 & 349 & 372 \\
\hline L05 & 142,5 & 0,91 & 0,5 & 504 & 250 \\
\hline L06 & 144,5 & 0,88 & 1,0 & 343 & 282 \\
\hline L07 & 141,0 & 1,35 & 1,0 & 349 & 358 \\
\hline L08 & 145,5 & 1,27 & 1,0 & 347 & 345 \\
\hline L09 & 147,5 & 2,08 & 1,0 & 349 & 550 \\
\hline L10 & 147,5 & 2,08 & 0,5 & 498 & 500 \\
\hline L11 & 146,5 & 2,11 & 1,5 & 267 & 640 \\
\hline L12 & 145,0 & 1,28 & 1,5 & 268 & 345 \\
\hline
\end{tabular}

\subsubsection{RESISTÊNCIA À FLEXÃO DAS LAJES DE CONCRETO ARMADO}

As armaduras perpendiculares a uma borda livre, necessárias à transmissão de momentos fletores da laje para um pilar de borda ou canto, devem ser colocadas numa largura efetiva $b_{e}$ correspondente à faixa resistente por flexão na ligação laje-pilar representada na Figura 4.5 .

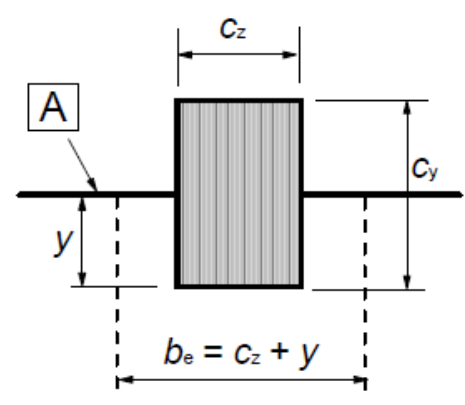

(a) Pilar de bordo

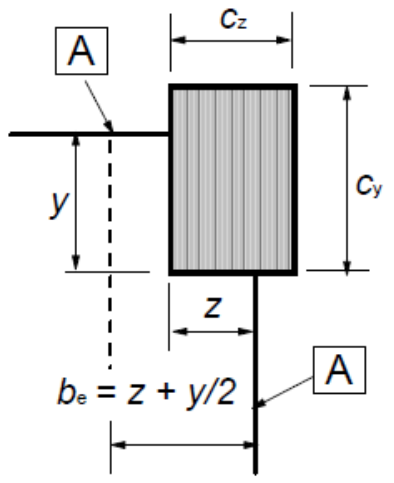

(b) Pilar de canto

Figura 4.5 - Largura efetiva de uma laje lisa (EUROCODE 2 2004) 
Para o cálculo da resistência à flexão dessa pesquisa foi considerada duas faixas A-A (Figura 4.6) onde supostamente ocorreria o escoamento de todas as barras perpendiculares ao longo dessa largura de acordo com os pontos de aplicações e relações entre $\mathrm{P}_{2}$ e $\mathrm{P}_{1}$. As armaduras perpendiculares a uma borda livre, necessárias à transmissão de momentos fletores da laje para um pilar de canto reentrante devem ser colocadas numa largura efetiva $b_{e}$ (Figura 4.6).

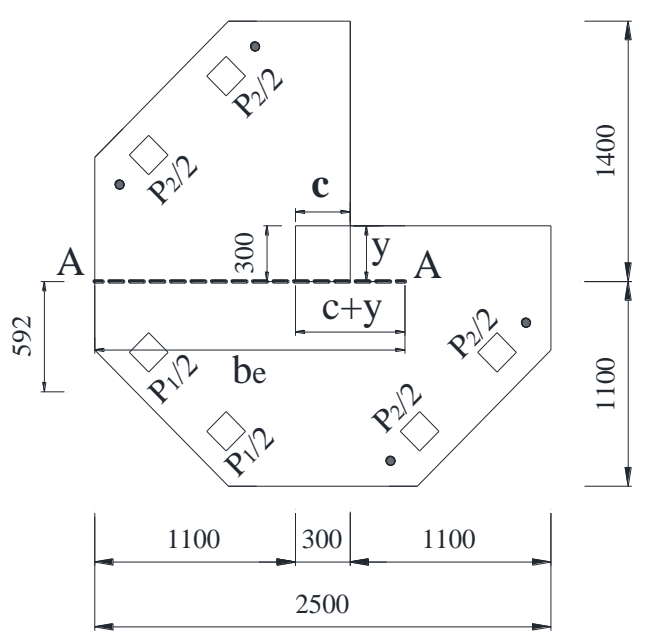

(a) Faixa 1

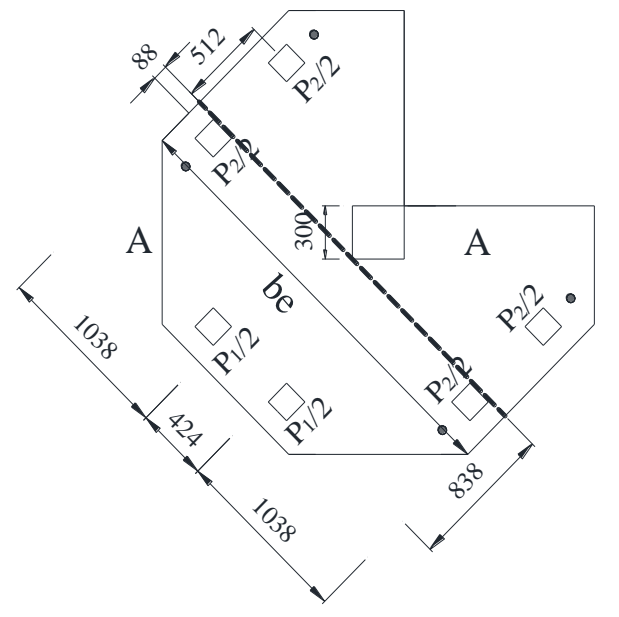

(b) Faixa 2

Figura 4.6 - Linha de ruptura admitida para cálculo de resistência à flexão da laje.

A distância média a partir de uma carga para o potencial de escoamento da linha AA é 592 mm e o momento é $m_{s}=\left(P_{1}+P_{2}\right) \cdot 0,592$.

Os momentos não serão uniformes em toda $\mathrm{AA}$, aqueles da direita do pilar devem ser menores do que da esquerda, mas a largura necessária para resistir esse momento é apenas 1,70 m com algumas armaduras de torção, desde que a resistência à flexão seja alta o suficiente.

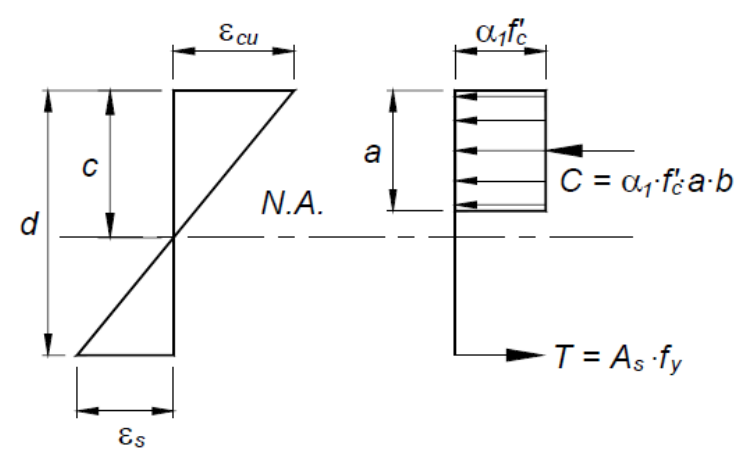

Figura 4.7 - Capacidade de flexão de acordo com o CSA Standard A23.3-94 (1994) (Birkle, 2004) 
Para o cálculo da capacidade do momento resistente por comprimento da laje tem-se:

$$
\begin{aligned}
& m_{R}=\frac{T \cdot(d-0,4 \cdot a)}{b} \\
& a=\frac{A_{s} \cdot f_{y}}{\alpha_{1} \cdot f_{c}^{\prime} \cdot b}
\end{aligned}
$$

onde:

$T$ é a força resultante das tensões de tração na armadura;

$C$ é a força resultante das tensões de compressão no concreto;

$d$ é a altura útil da seção transversal;

$\boldsymbol{a}$ é a altura da distribuição de tensões na zona comprimida considerada $0,8 \cdot c$;

$A_{s}$ é a área de aço da armadura;

$f_{y}$ é a tensão de escoamento no aço;

$\alpha_{1}$ é a relação entre a tensão de compressão média na seção retangular e a resistência do concreto especificado;

$f_{c}^{\prime}$ é a tensão de compressão no concreto;

$b$ é a largura de uma faixa de laje;

Considerando uma distribuição retangular de tensões (Figura 4.7) e o coeficiente $\alpha_{1}=0,85$ pela NBR 6118 (2014), a resistência à flexão média por unidade de comprimento na faixa de apoio pode ser considerada:

$$
m_{R}=\rho \cdot d^{2} \cdot f_{y d} \cdot\left(1-\frac{\rho \cdot f_{y d}}{2,13 \cdot f_{c d}}\right)
$$

Para o cálculo da relação carga de flexão e momento solicitante $V_{\text {flex }} / m_{s}$ foi utilizado o método analítico para duas faixas A-A ilustrada na Figura 4.6 considerando as relações de carga $P_{2} / P_{1}$ de cada laje. A Tabela 4.4 mostra as resistências à flexão das lajes. 
Tabela 4.4 - Resistência à flexão.

\begin{tabular}{|c|c|c|c|c|c|c|c|c|c|c|c|c|}
\hline \multirow[b]{2}{*}{ LAJES } & \multirow[b]{2}{*}{$P_{2} / P_{1}$} & \multirow[b]{2}{*}{$\begin{array}{c}f_{c} \\
(\mathrm{MPa})\end{array}$} & \multirow[b]{2}{*}{$\begin{array}{c}f_{y} \\
(\mathrm{MPa})\end{array}$} & \multirow[b]{2}{*}{$\begin{array}{c}V_{u} \\
(\mathrm{kN})\end{array}$} & \multicolumn{4}{|c|}{ FAIXA 1} & \multicolumn{4}{|c|}{ FAIXA 2} \\
\hline & & & & & $\begin{array}{c}m_{R} \\
(\mathrm{kN} \cdot \mathrm{m} / \mathrm{m})\end{array}$ & $V_{\text {flex }} / m_{s}$ & $\begin{array}{l}V_{\text {flex }} \\
(\mathrm{kN}) \\
\end{array}$ & $V_{u} / V_{\text {fex }}$ & $\begin{array}{c}m_{R} \\
(\mathrm{kN} \cdot \mathrm{m} / \mathrm{m})\end{array}$ & $V_{f l e x} / m_{s}$ & $\begin{array}{l}V_{\text {flex }} \\
(\mathrm{kN})\end{array}$ & $V_{u} / V_{\text {flex }}$ \\
\hline L01 & 0,50 & 48 & 558 & 325 & 133 & 3,83 & 509 & 0,6 & 159 & 3,51 & 560 & 0,6 \\
\hline L02 & 1,00 & 48 & 558 & 513 & 133 & 4,31 & 573 & 0,9 & 159 & 5,02 & 800 & 0,6 \\
\hline L03 & 1,00 & 48 & 558 & 575 & 129 & 4,31 & 557 & 1,0 & 155 & 5,02 & 778 & 0,7 \\
\hline L04 & 1,00 & 48 & 558 & 372 & 132 & 4,31 & 568 & 0,7 & 158 & 5,02 & 794 & 0,5 \\
\hline L05 & 0,50 & 44 & 561 & 250 & 59 & 3,83 & 225 & 1,1 & 75 & 3,51 & 263 & 0,9 \\
\hline L06 & 1,00 & 44 & 561 & 282 & 60 & 4,31 & 257 & 1,1 & 76 & 5,02 & 382 & 0,7 \\
\hline L07 & 1,00 & 44 & 570 & 358 & 80 & 4,31 & 344 & 1,0 & 102 & 5,02 & 512 & 0,7 \\
\hline L08 & 1,00 & 44 & 570 & 345 & 83 & 4,31 & 357 & 1,0 & 106 & 5,02 & 531 & 0,7 \\
\hline L09 & 1,00 & 43 & 572 & 550 & 134 & 4,31 & 575 & 1,0 & 160 & 5,02 & 804 & 0,7 \\
\hline L10 & 0,50 & 43 & 572 & 500 & 134 & 3,83 & 511 & 1,0 & 160 & 3,51 & 563 & 0,9 \\
\hline L11 & 1,50 & 43 & 572 & 640 & 132 & 4,59 & 609 & 1,1 & 159 & 6,39 & 1016 & 0,6 \\
\hline L12 & 1,50 & 43 & 572 & 345 & 83 & 4,59 & 380 & 0,9 & 105 & 6,39 & 674 & 0,5 \\
\hline
\end{tabular}

\subsection{DESLOCAMENTOS VERTICAIS}

Os deslocamentos verticais das lajes foram monitorados em 18 pontos ao longo dos eixos destes elementos utilizando-se 15 LVDT's, um potenciômetro e duas escalas. Em todas as lajes esses pontos foram os mesmos a fim de permitir a comparação direta entre os resultados observados.

A leitura dos deslocamentos foi feita no decorrer dos ensaios pelo sistema de aquisição de dados descrito no Capítulo 3, em intervalos entre cada passo de carga. Próximo ao final dos ensaios optou-se por interromper a leitura, tanto dos deslocamentos verticais como das fissuras de flexão, a fim de não comprometer a carga última das lajes e manter a integridade dos LVDT's perante a ocorrência de ruptura por punção. Na Série de concretagem 2 e 3 foram adicionados mais seis pontos monitorados por defletômetros posicionados próximo às bordas da laje (Figura 4.8).

Da Figura 4.9 à Figura 4.64 são apresentados os deslocamentos verticais das lajes para diferentes passos de carga até aquele mais próximo à ruptura, já os gráficos de carga $\mathrm{x}$ deslocamento são apresentados da Figura 4.65 à Figura 4.99. 


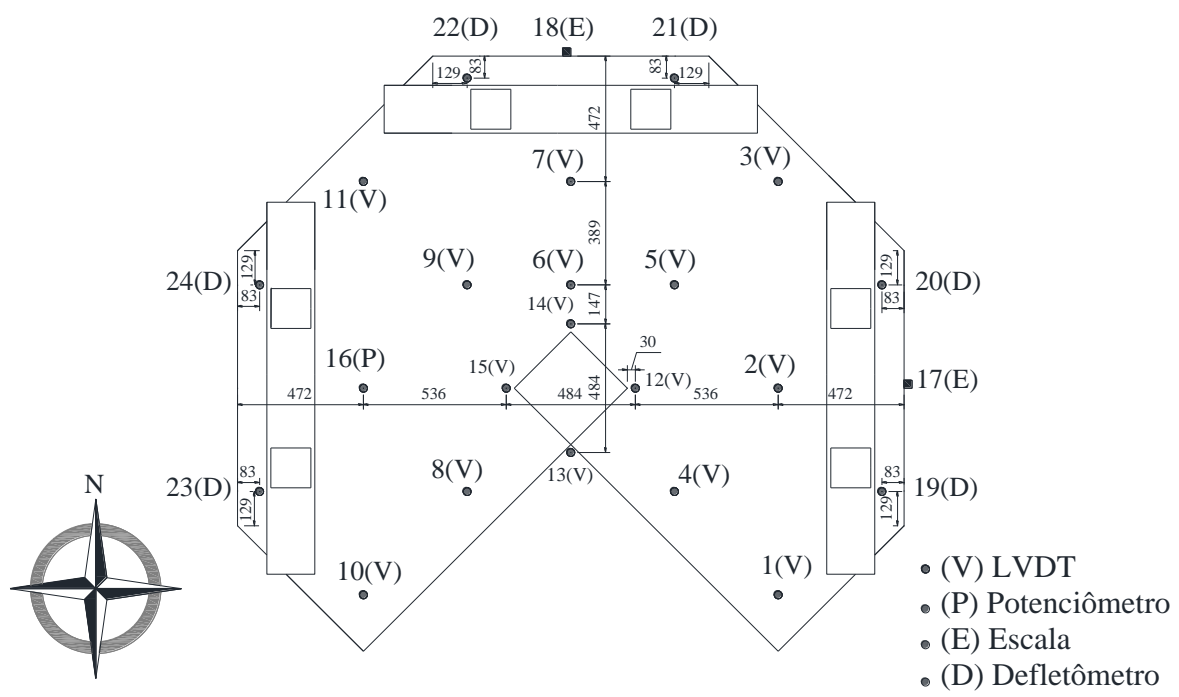

Figura 4.8 - Posicionamento dos LVDT's, potenciômetro, escalas e defletômetros nas lajes

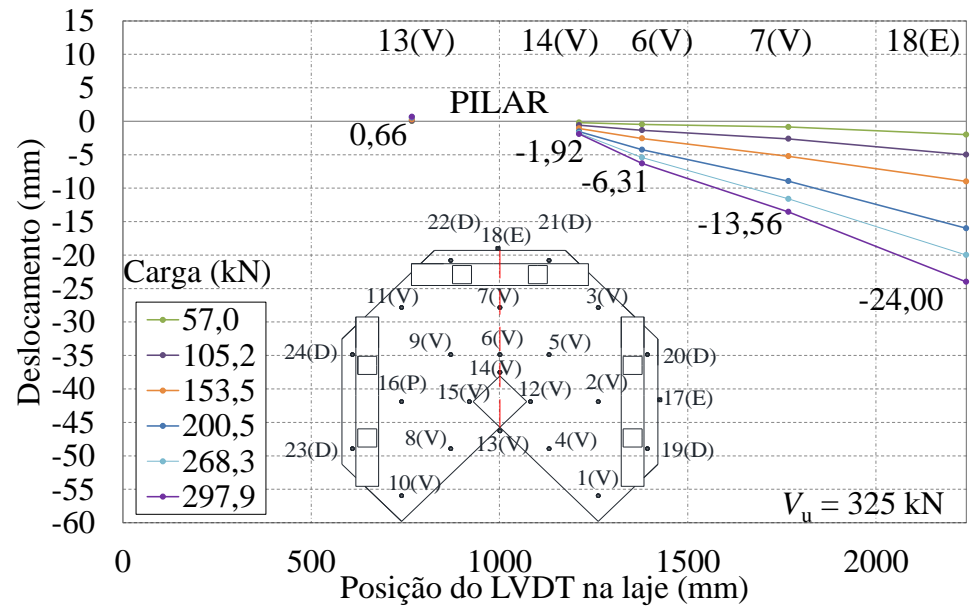

Figura 4.9 - Deslocamentos verticais na direção S-N da laje L01

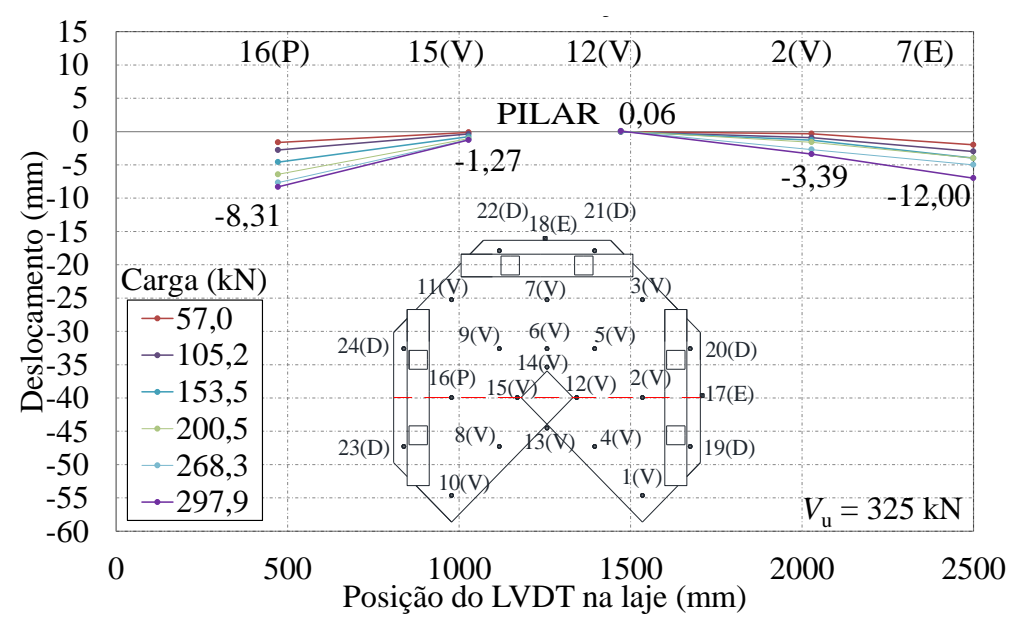

Figura 4.10 - Deslocamentos verticais na direção O-L da laje L01 


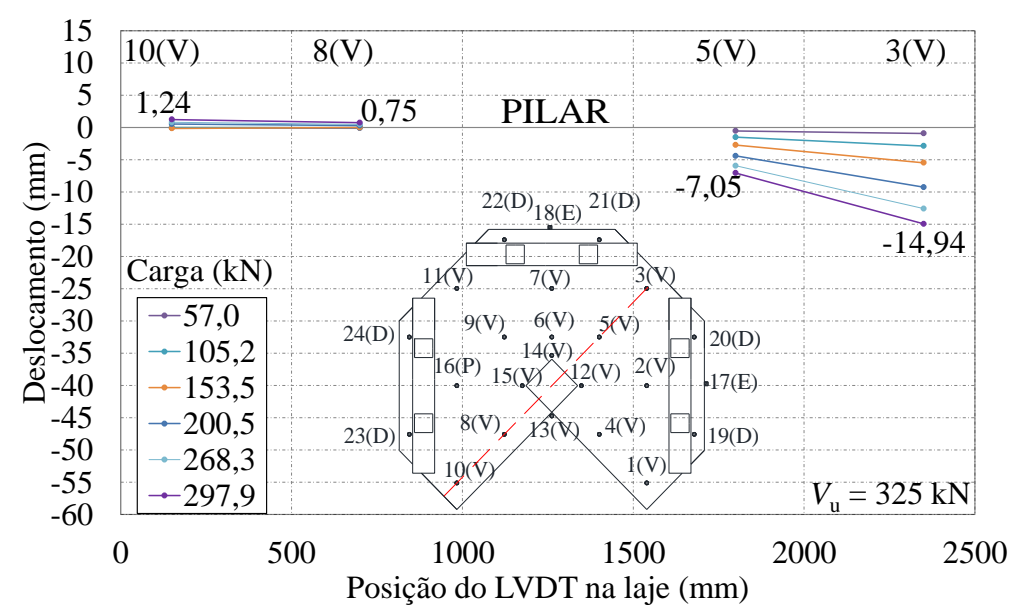

Figura 4.11 - Deslocamentos verticais na direção SO-NE da laje L01

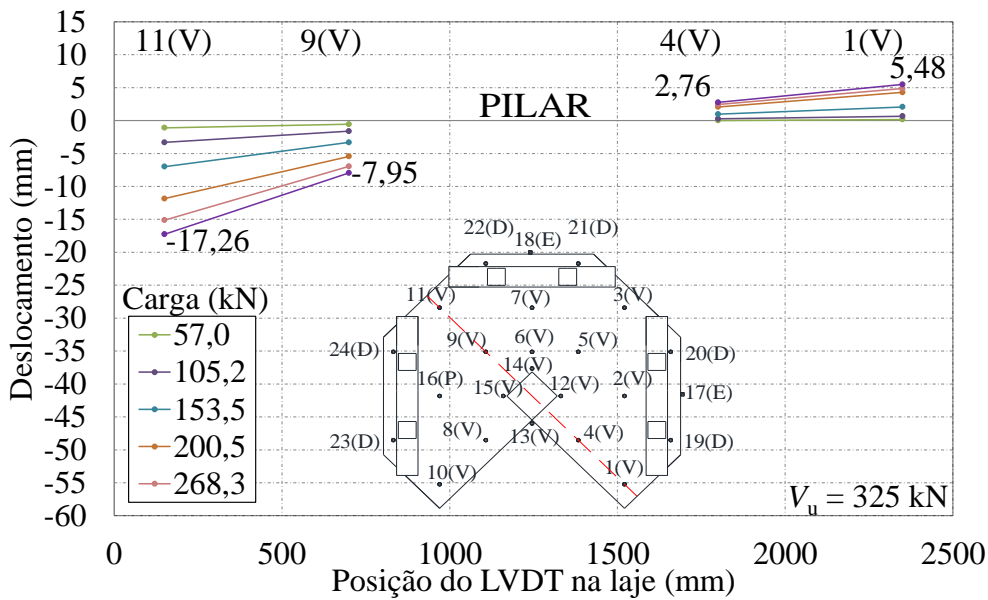

Figura 4.12 - Deslocamentos verticais na direção NO-SE da laje L01

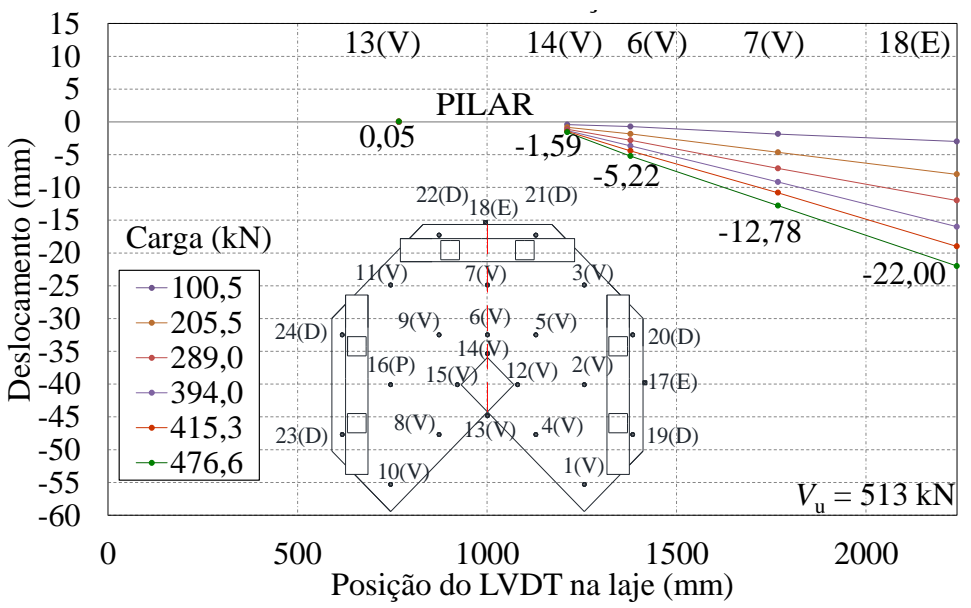

Figura 4.13 - Deslocamentos verticais na direção S-N da laje L02 


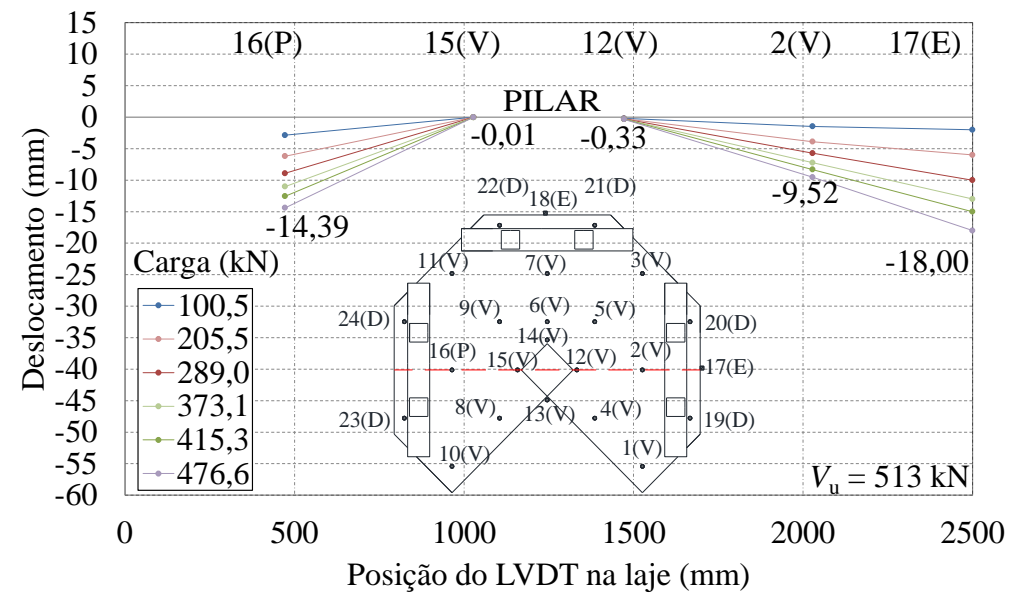

Figura 4.14 - Deslocamentos verticais na direção O-L da laje L02

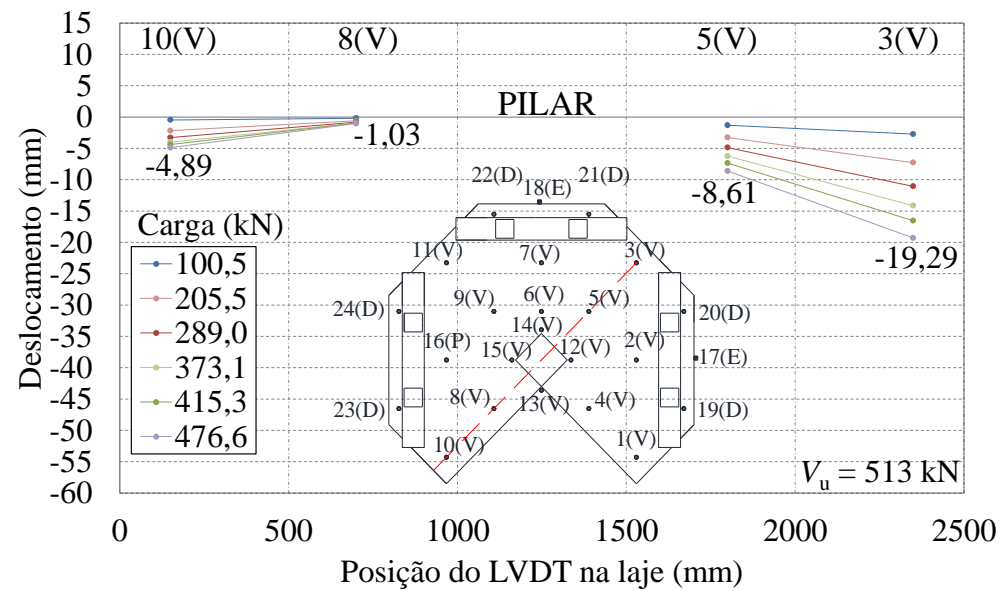

Figura 4.15 - Deslocamentos verticais na direção SO-NE da laje L02

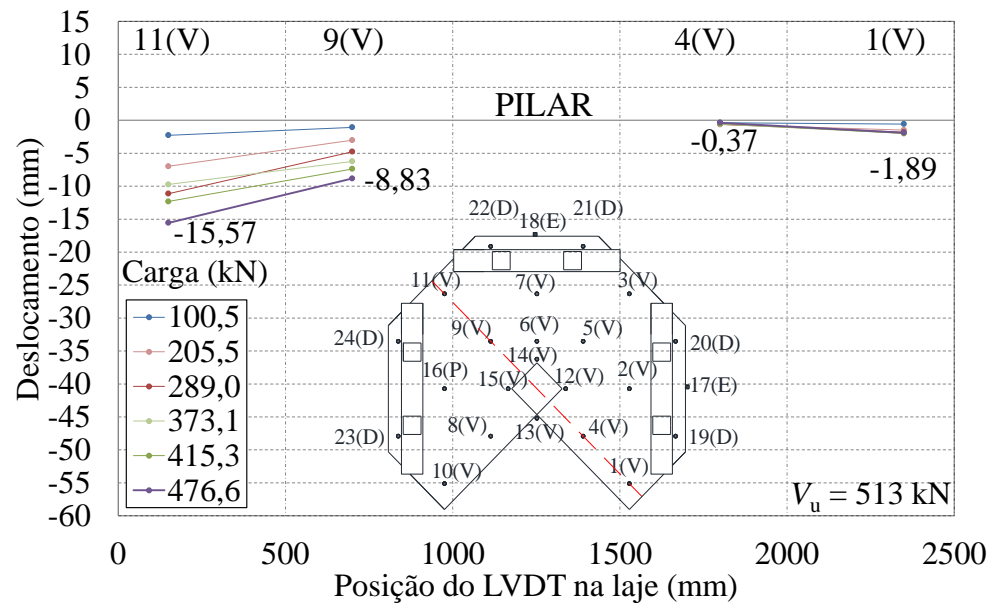

Figura 4.16 - Deslocamentos verticais na direção NO-SE da laje L02 


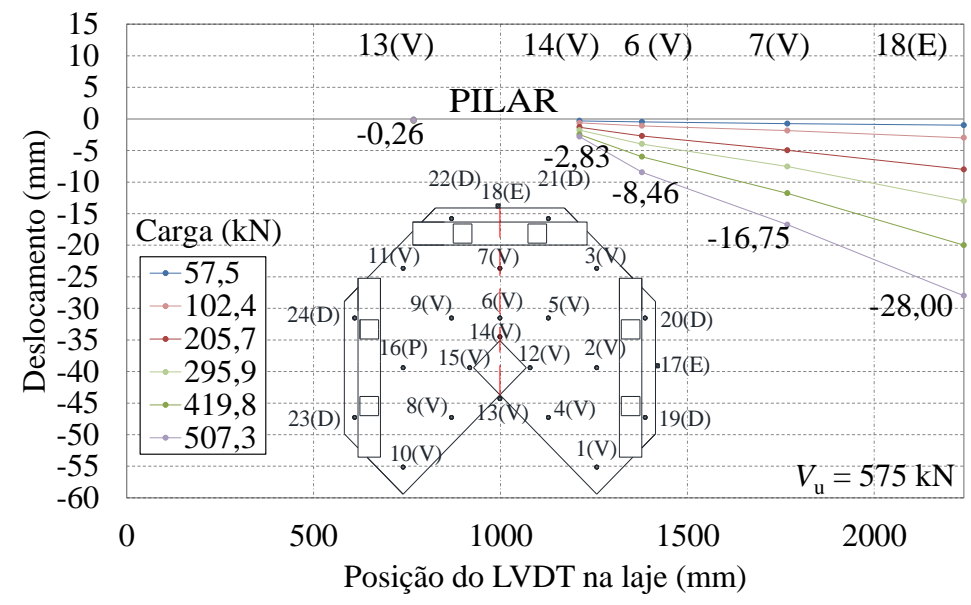

Figura 4.17 - Deslocamentos verticais na direção S-N da laje L03

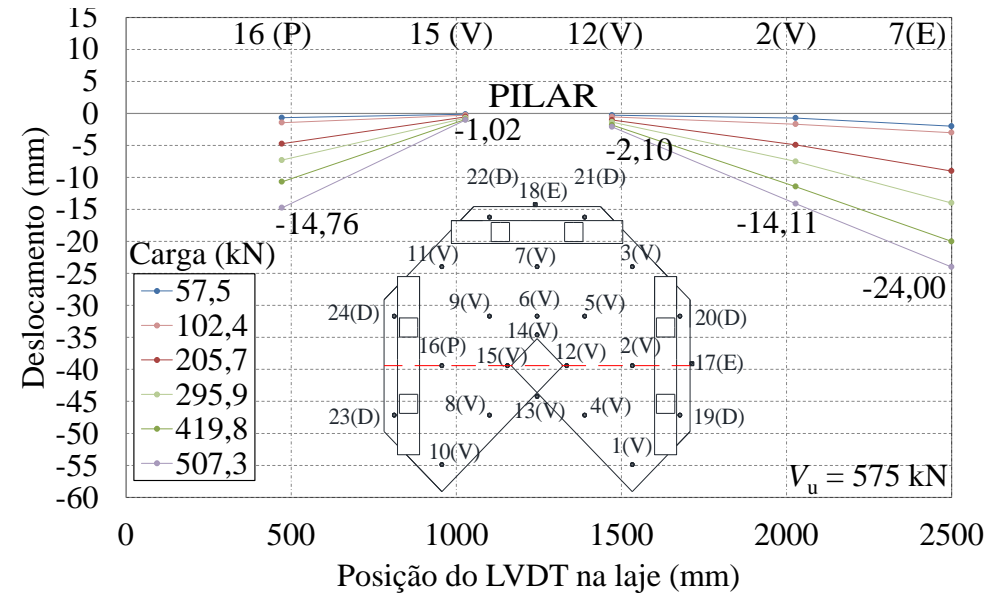

Figura 4.18 - Deslocamentos verticais na direção O-L da laje L03

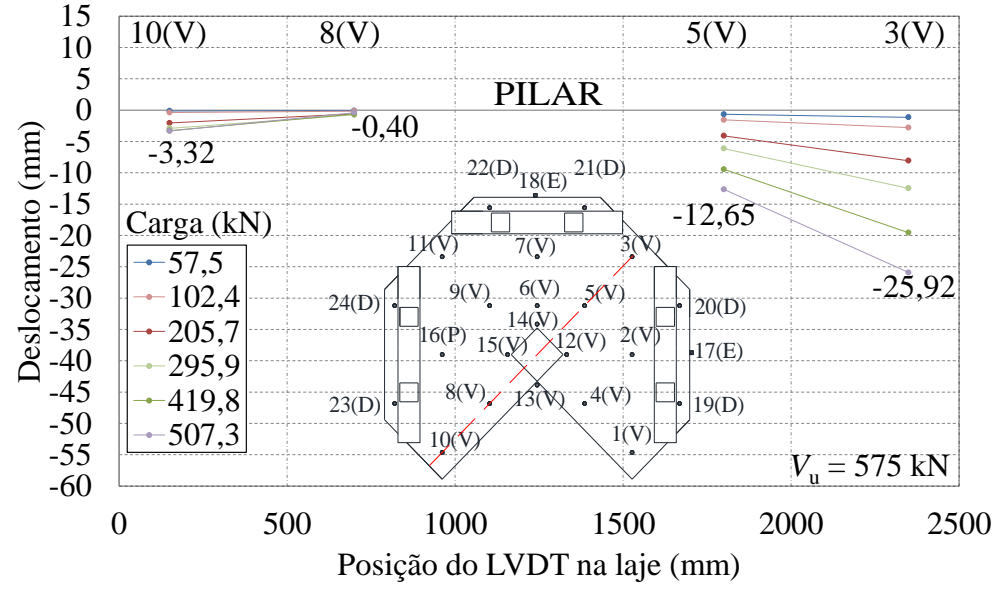

Figura 4.19 - Deslocamentos verticais na direção SO-NE da laje L03 


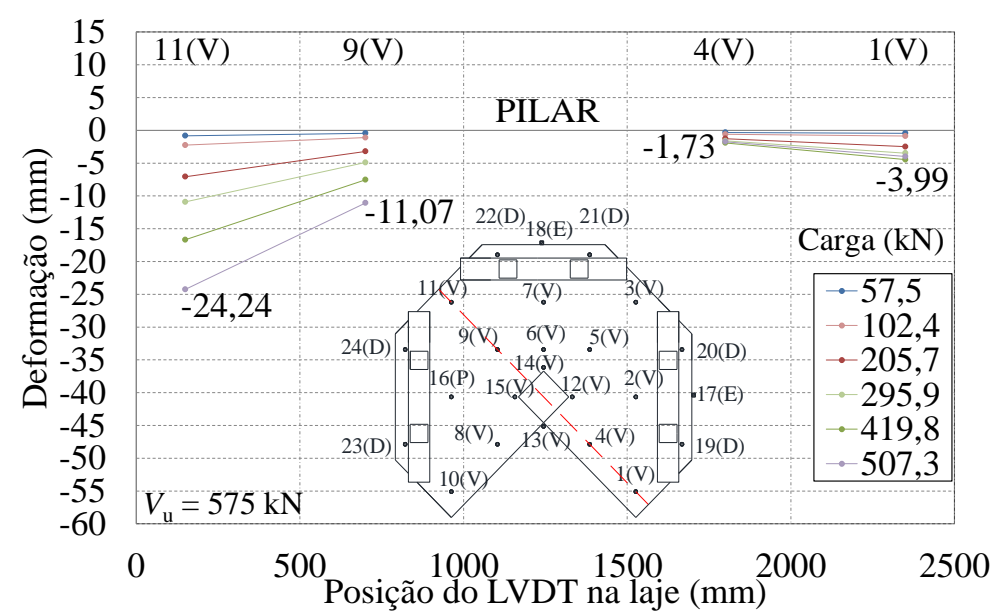

Figura 4.20 - Deslocamentos verticais na direção NO-SE da laje L03

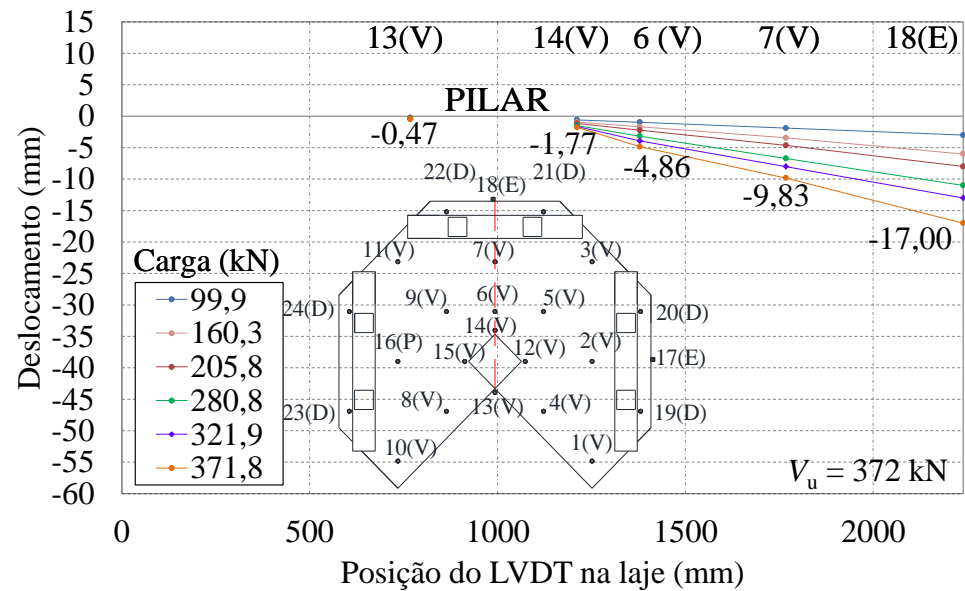

Figura 4.21 - Deslocamentos verticais na direção S-N da laje L04

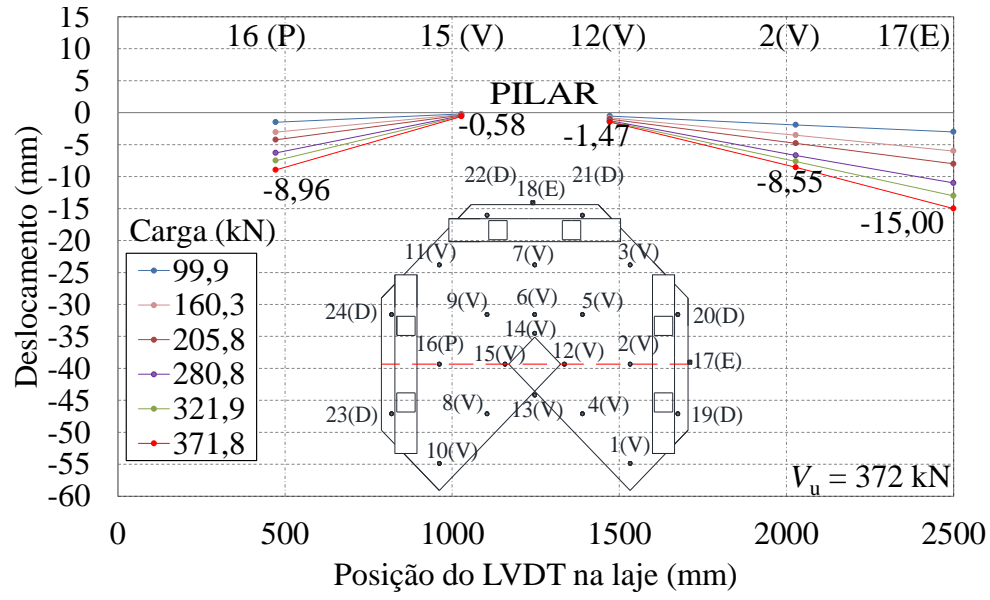

Figura 4.22 - Deslocamentos verticais na direção O-L da laje L04 


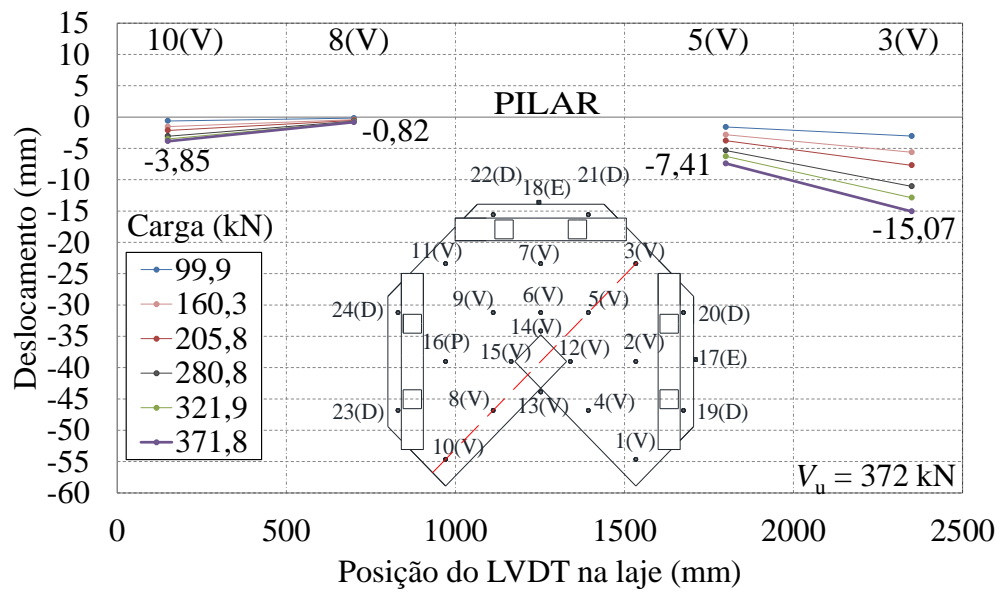

Figura 4.23 - Deslocamentos verticais na direção SO-NE da laje L04

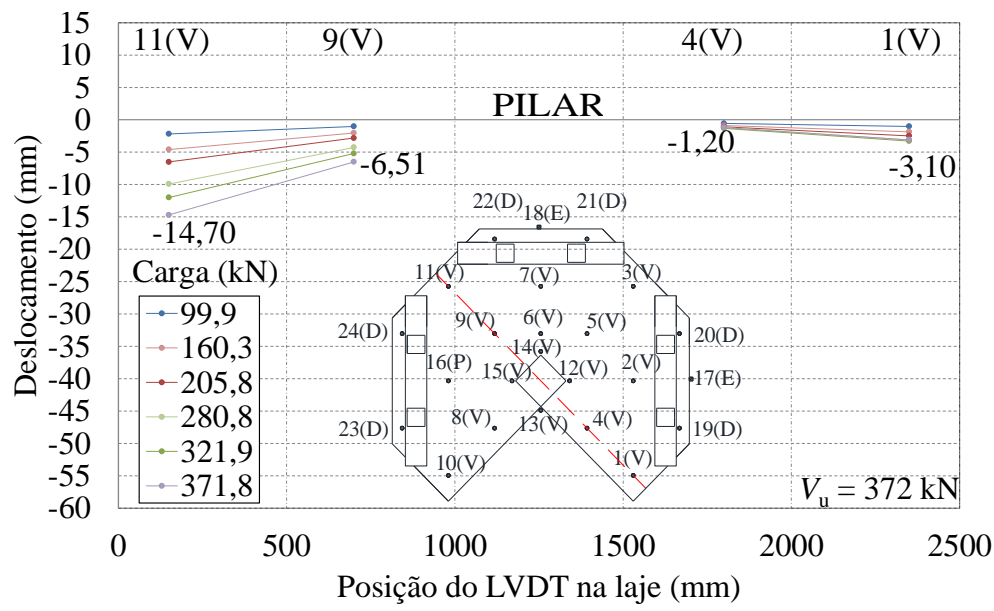

Figura 4.24 - Deslocamentos verticais na direção NO-SE da laje L04

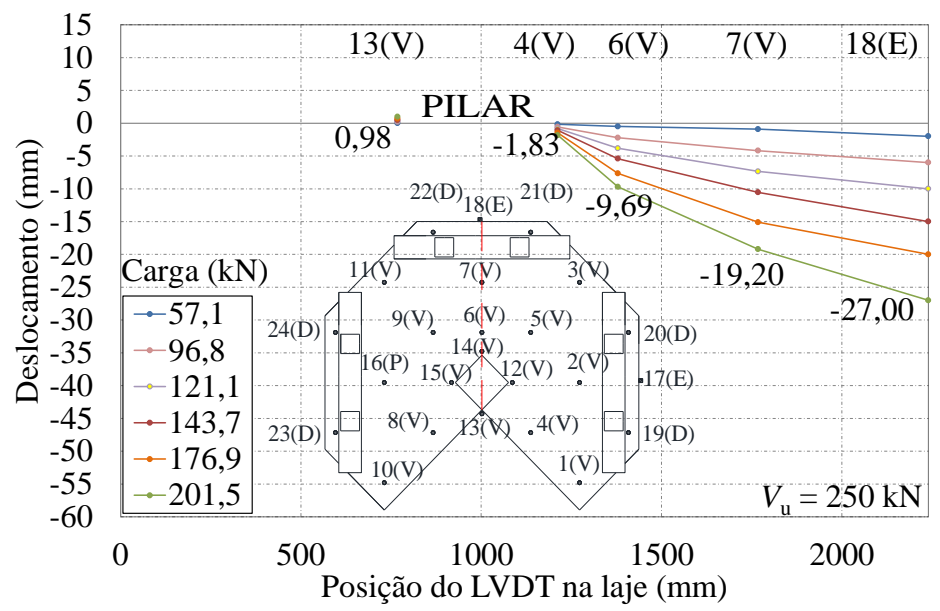

Figura 4.25 - Deslocamentos verticais na direção S-N da laje L05 


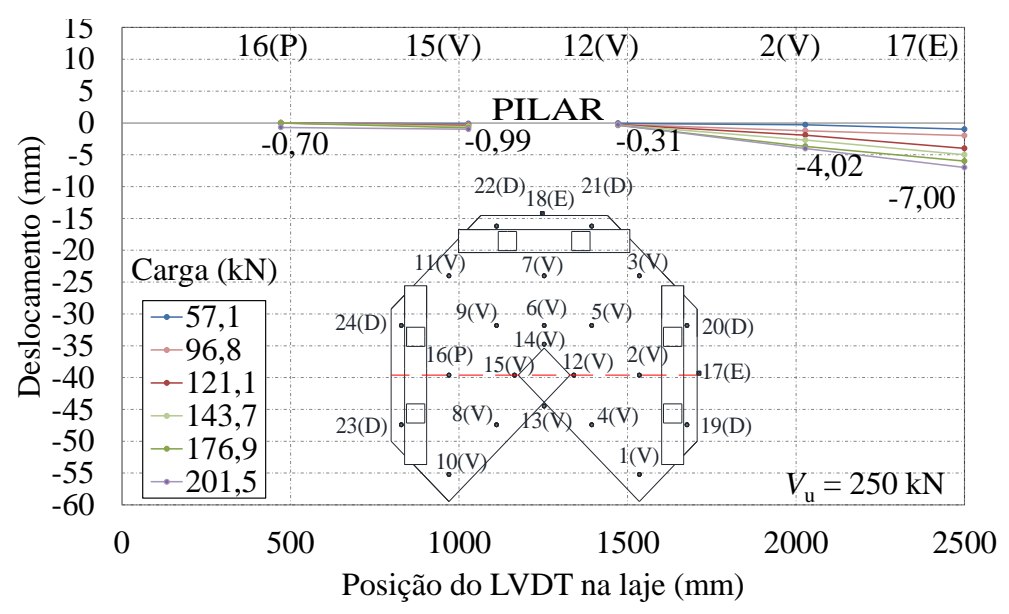

Figura 4.26 - Deslocamentos verticais na direção O-L da laje L05

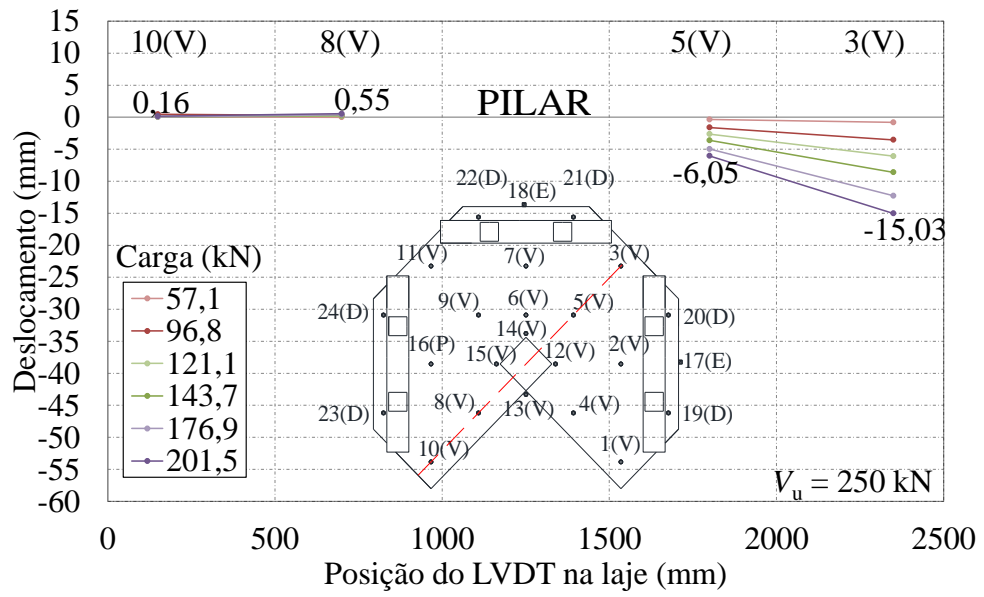

Figura 4.27 - Deslocamentos verticais na direção SO-NE da laje L05

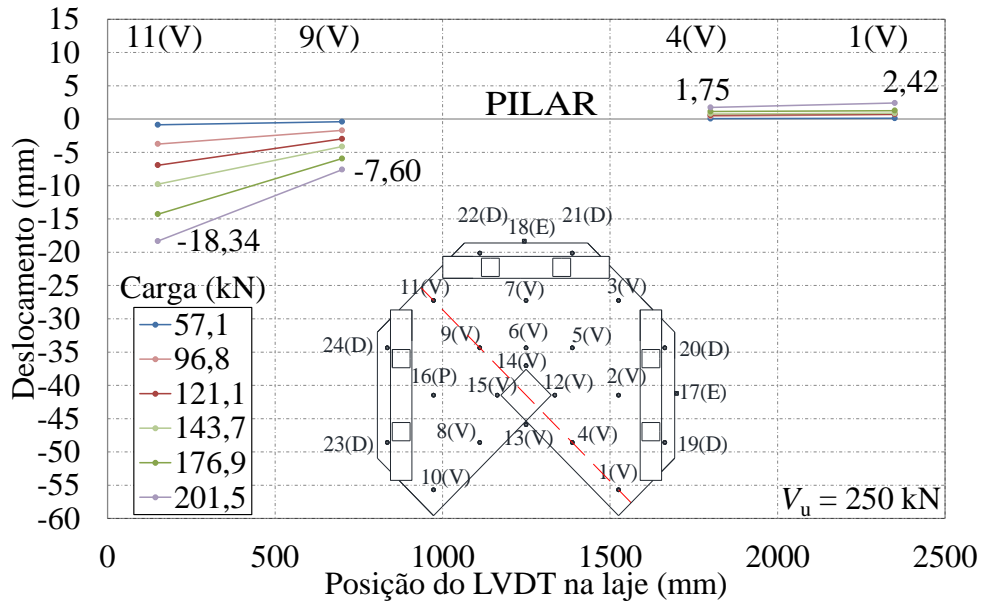

Figura 4.28 - Deslocamentos verticais na direção N0-SE da laje L05 


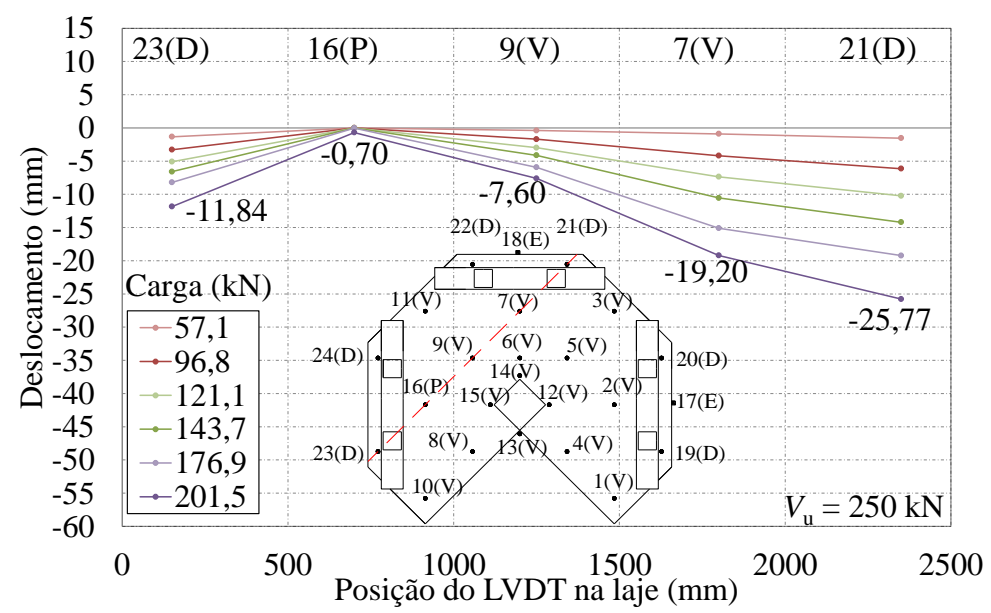

Figura 4.29 - Deslocamentos verticais na direção S0-NE da laje L05

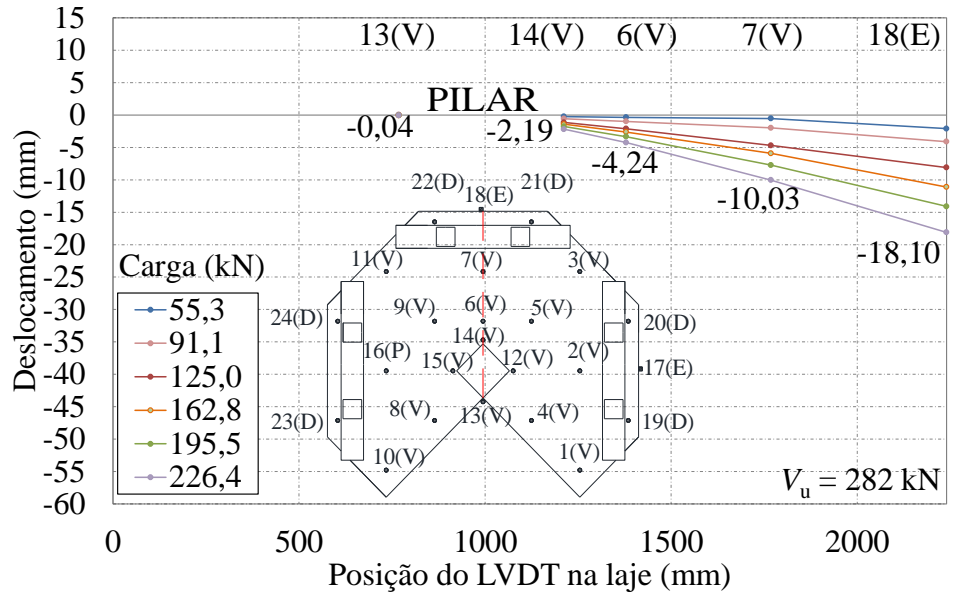

Figura 4.30 - Deslocamentos verticais na direção S-N da laje L06

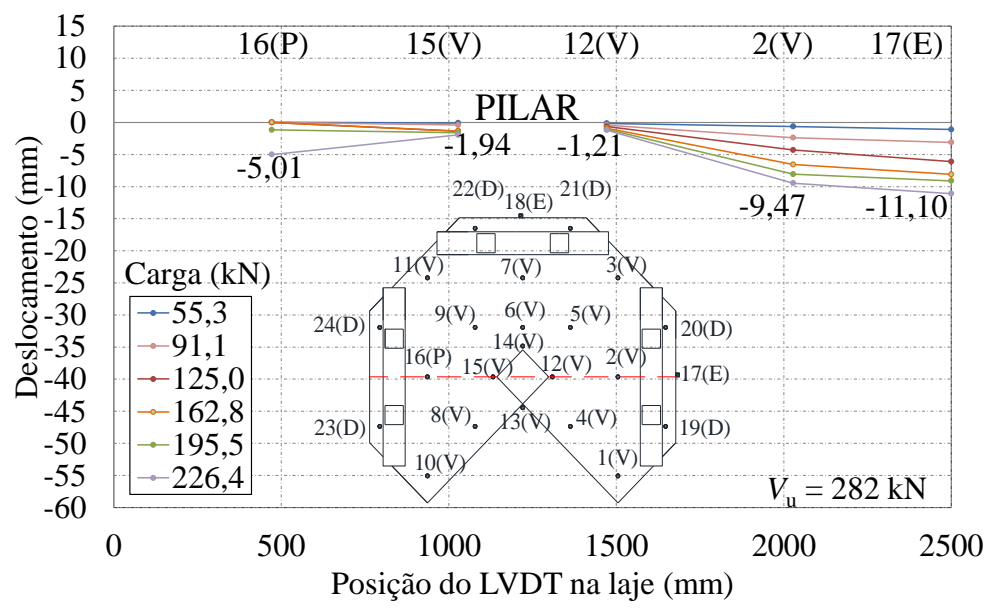

Figura 4.31 - Deslocamentos verticais na direção 0-L da laje L06 


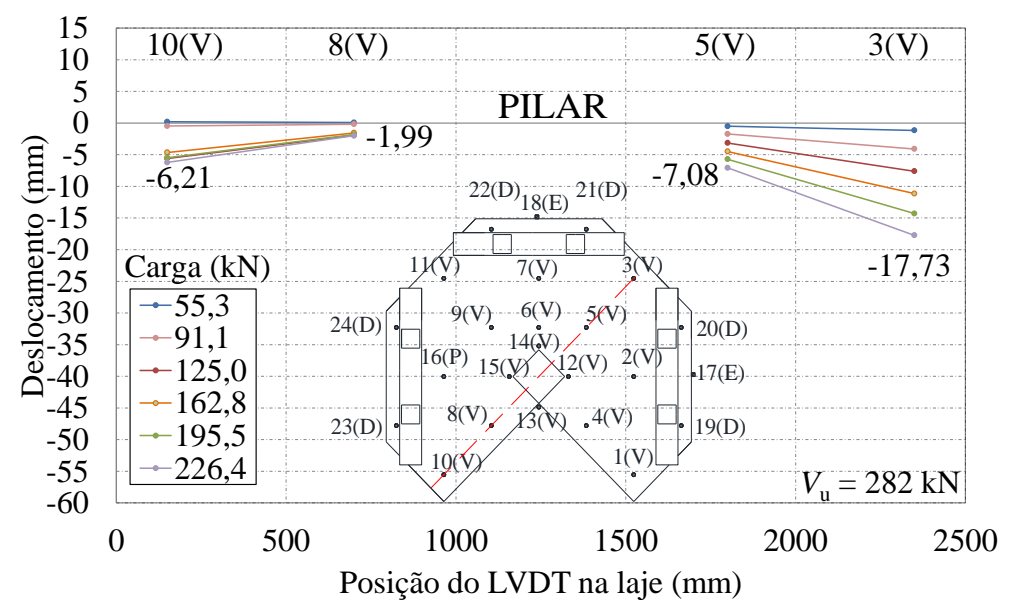

Figura 4.32 - Deslocamentos verticais na direção S0-NE da laje L06

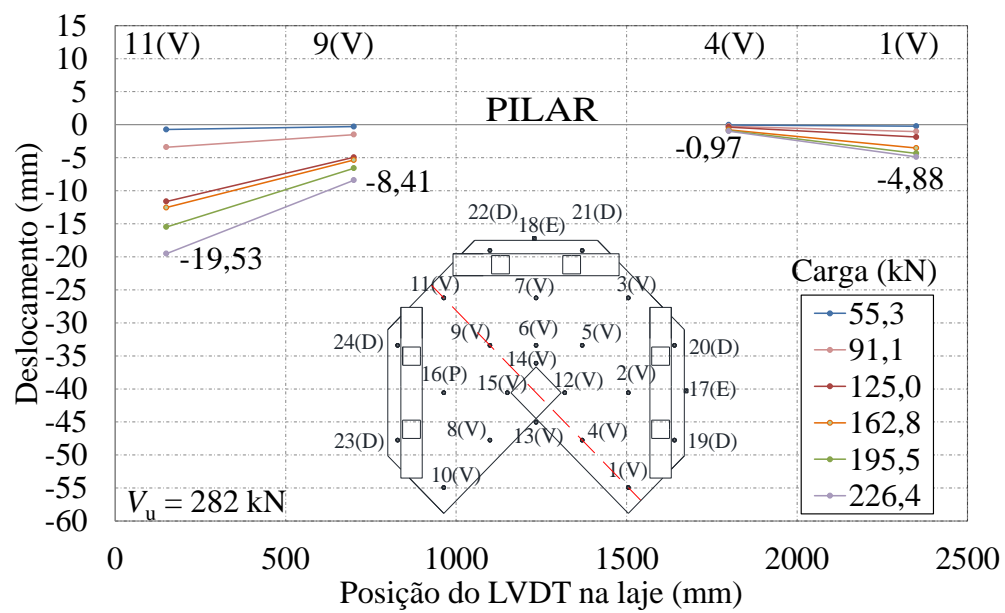

Figura 4.33 - Deslocamentos verticais na direção N0-SE da laje L06

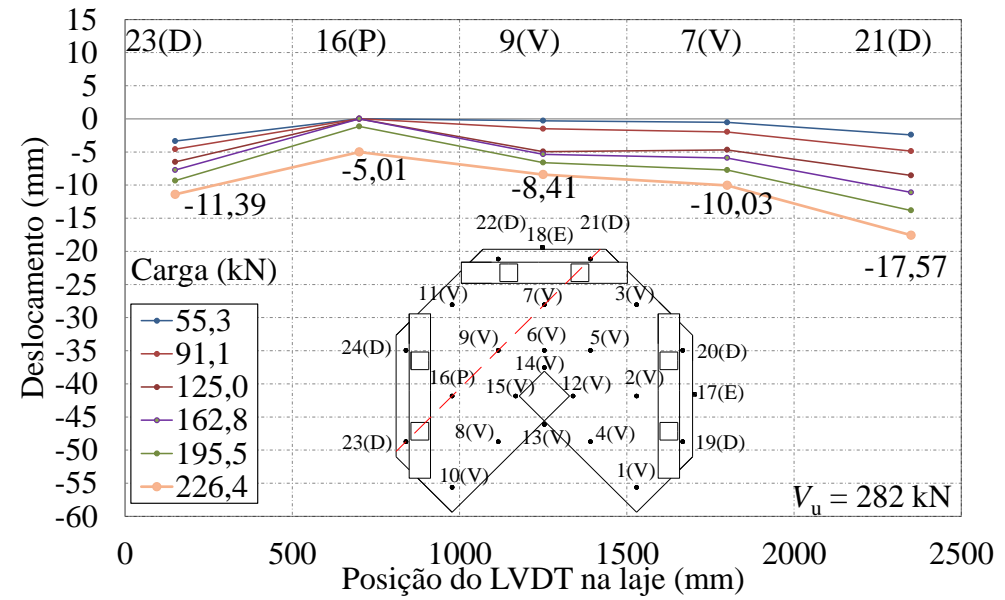

Figura 4.34 - Deslocamentos verticais na direção S0-NE da laje L06 


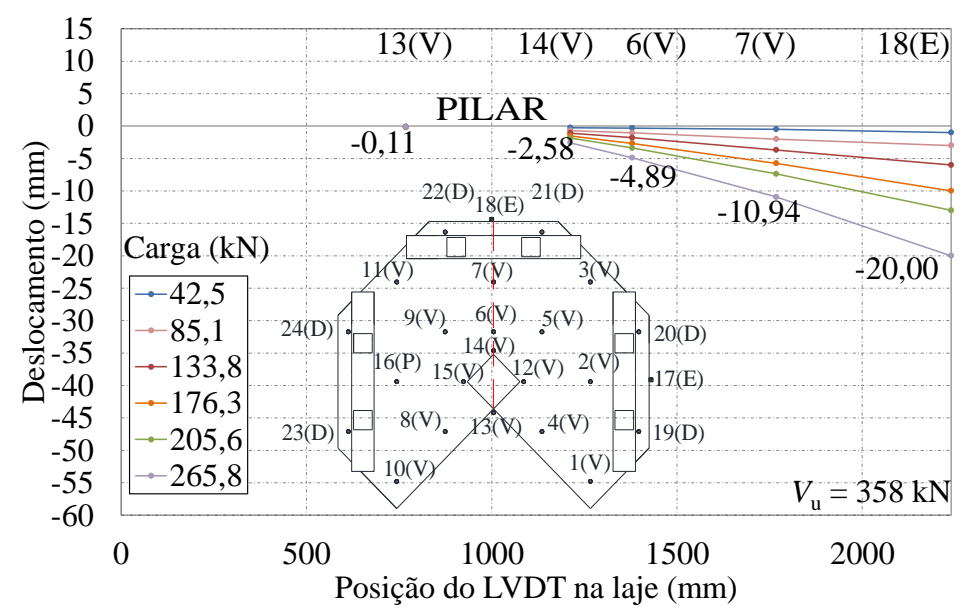

Figura 4.35 - Deslocamentos verticais na direção S-N da laje L07

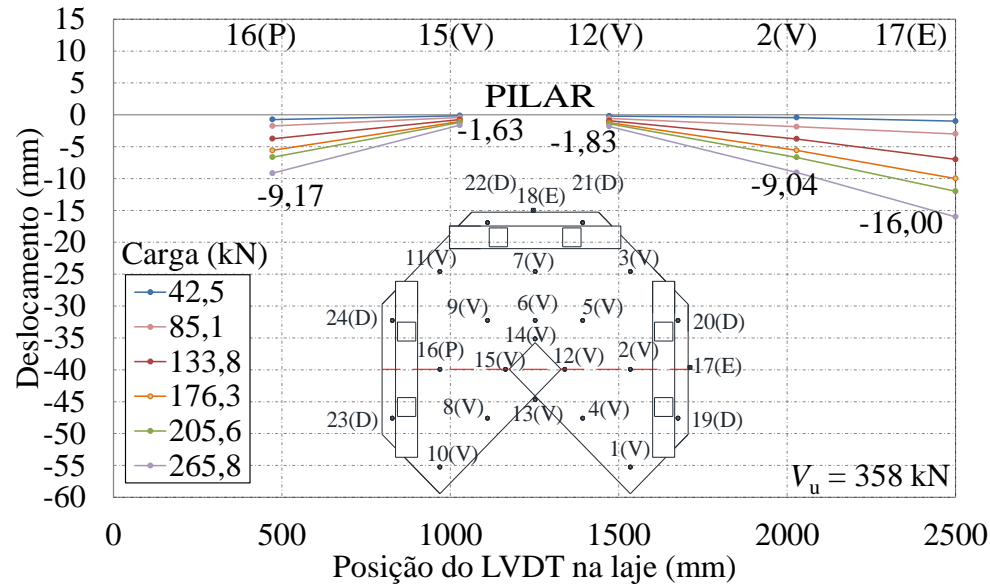

Figura 4.36 - Deslocamentos verticais na direção 0-L da laje L07

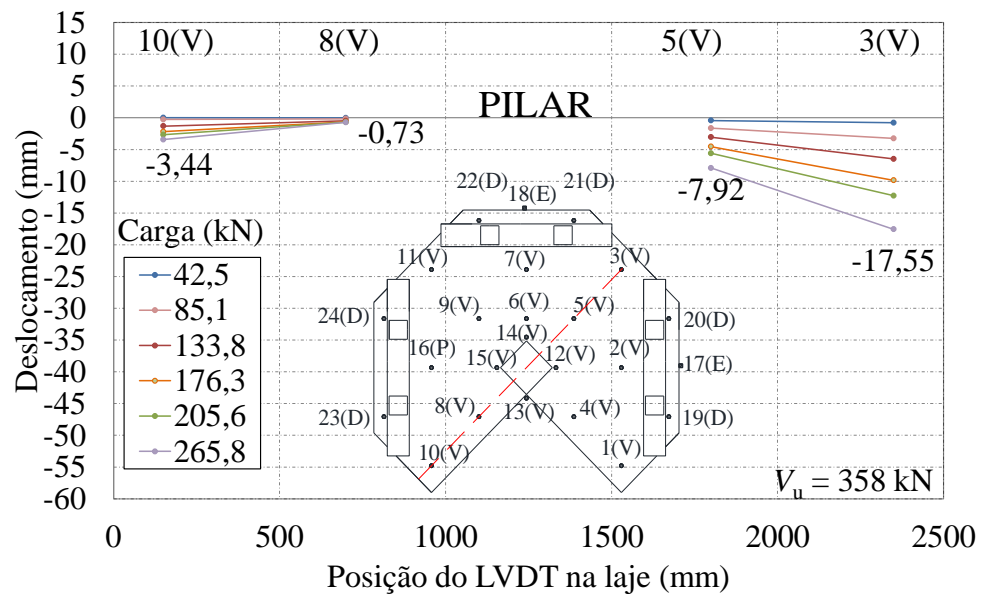

Figura 4.37 - Deslocamentos verticais na direção S0-NE da laje L07 


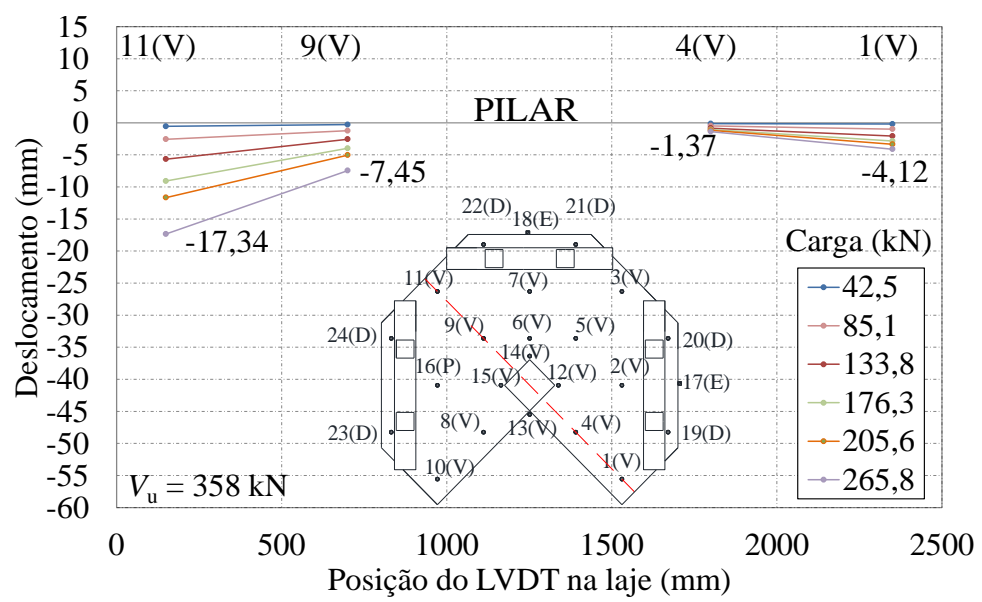

Figura 4.38 - Deslocamentos verticais na direção NO-SE da laje L07

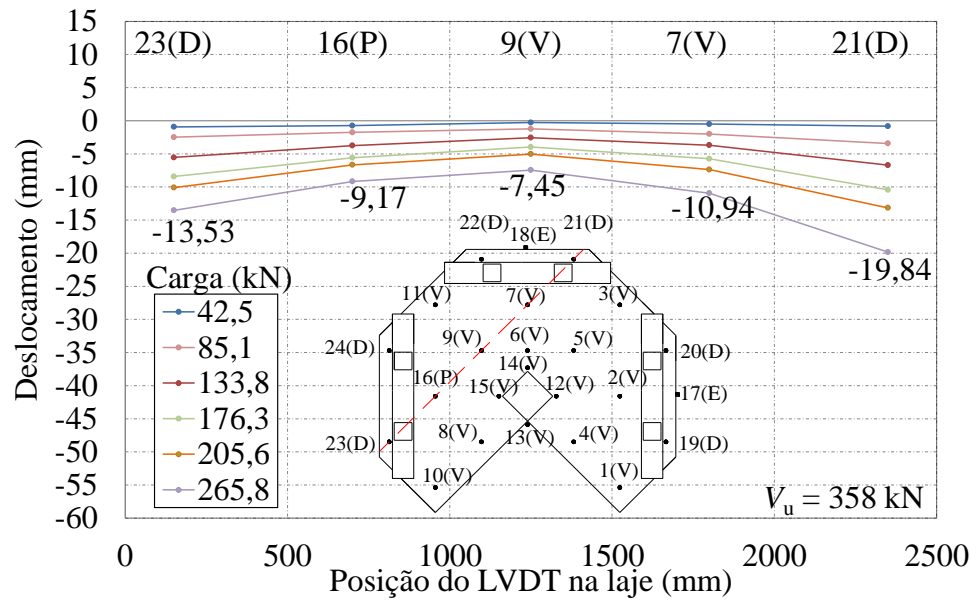

Figura 4.39 - Deslocamentos verticais na direção S0-NE da laje L07

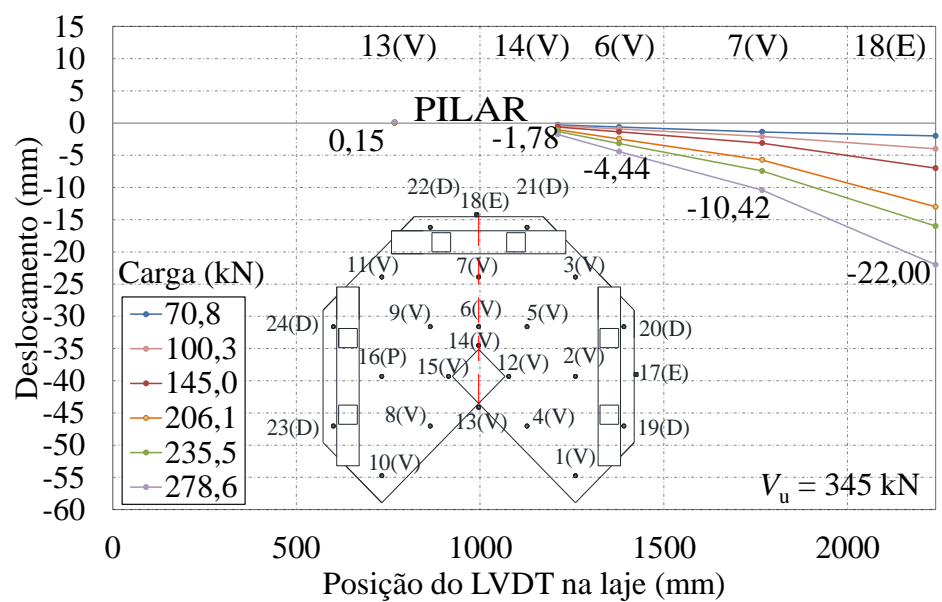

Figura 4.40 - Deslocamentos verticais na direção S-N da laje L08 


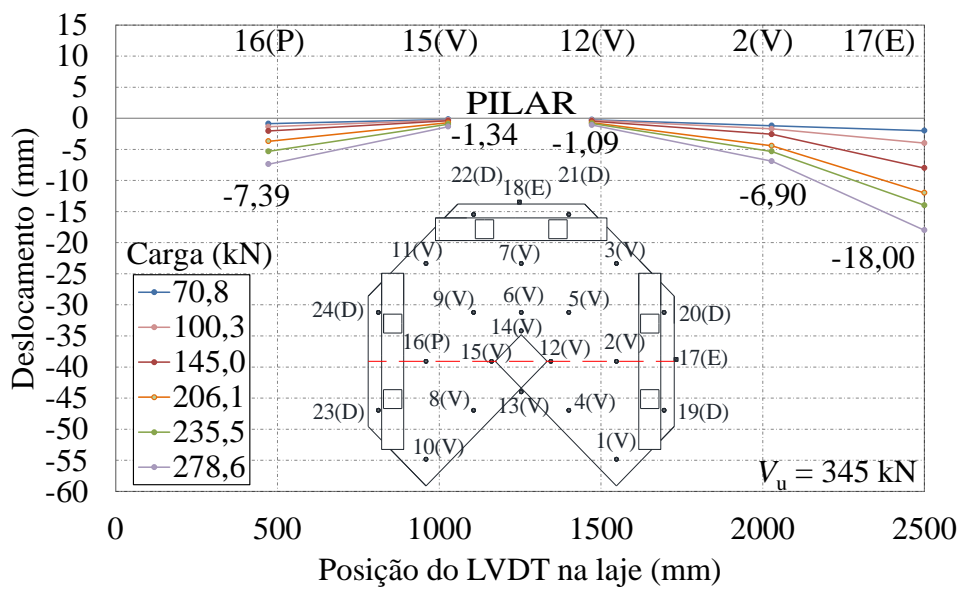

Figura 4.41 - Deslocamentos verticais na direção O-L da laje L08

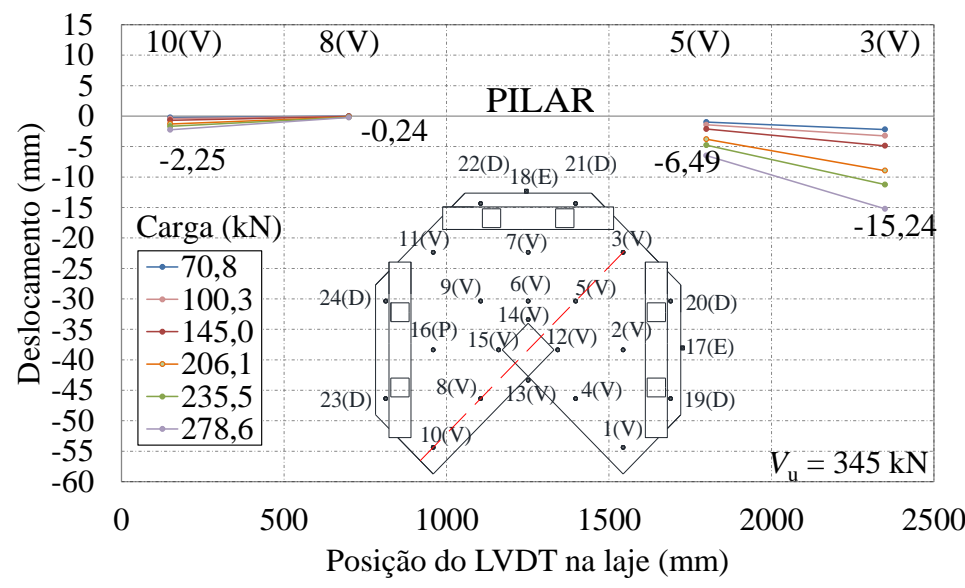

Figura 4.42 - Deslocamentos verticais na direção SO-NE da laje L08

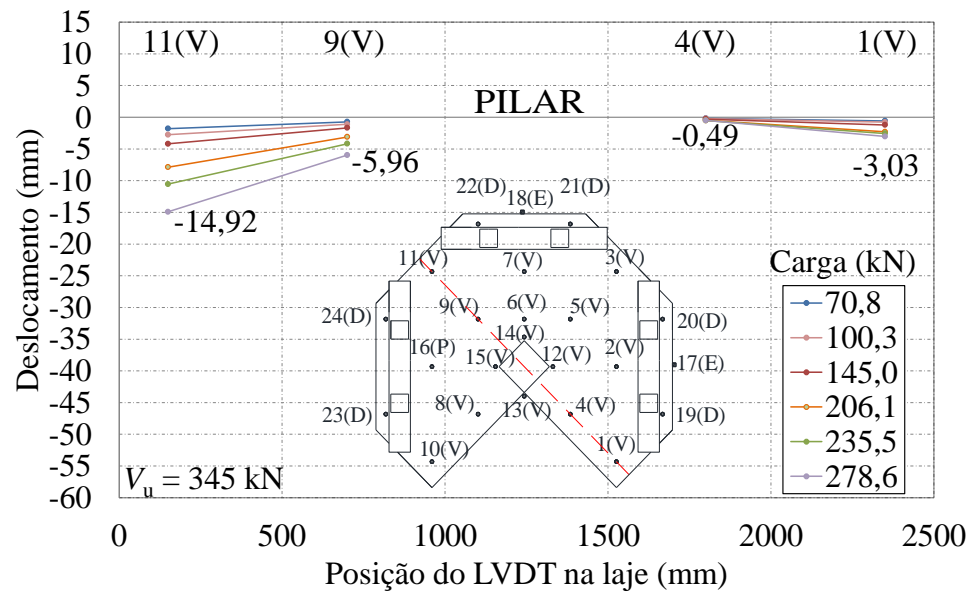

Figura 4.43 - Deslocamentos verticais na direção NO-SE da laje L08 


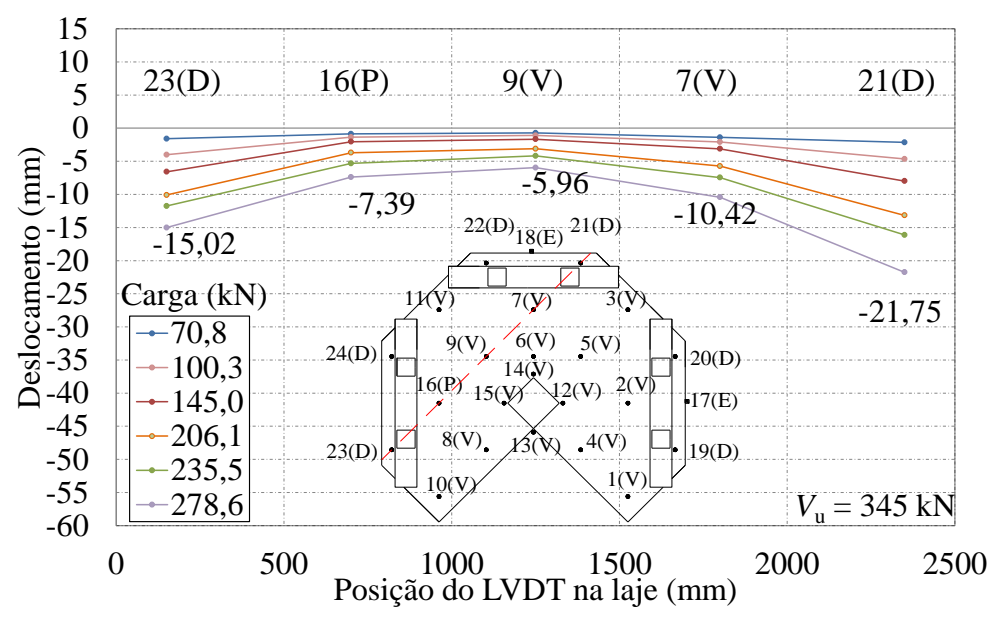

Figura 4.44 - Deslocamentos verticais na direção SO-NE da laje L08

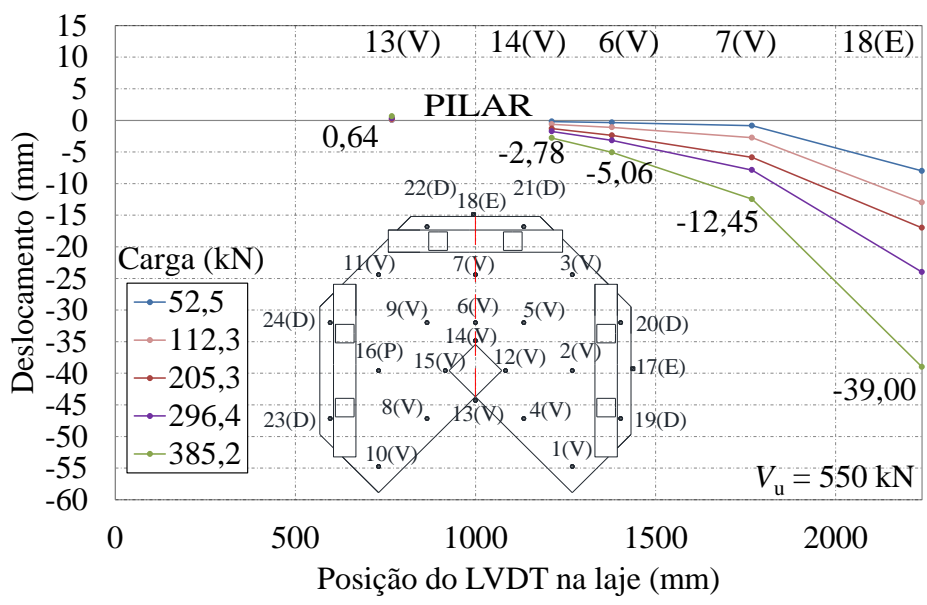

Figura 4.45 - Deslocamentos verticais na direção S-N da laje L09

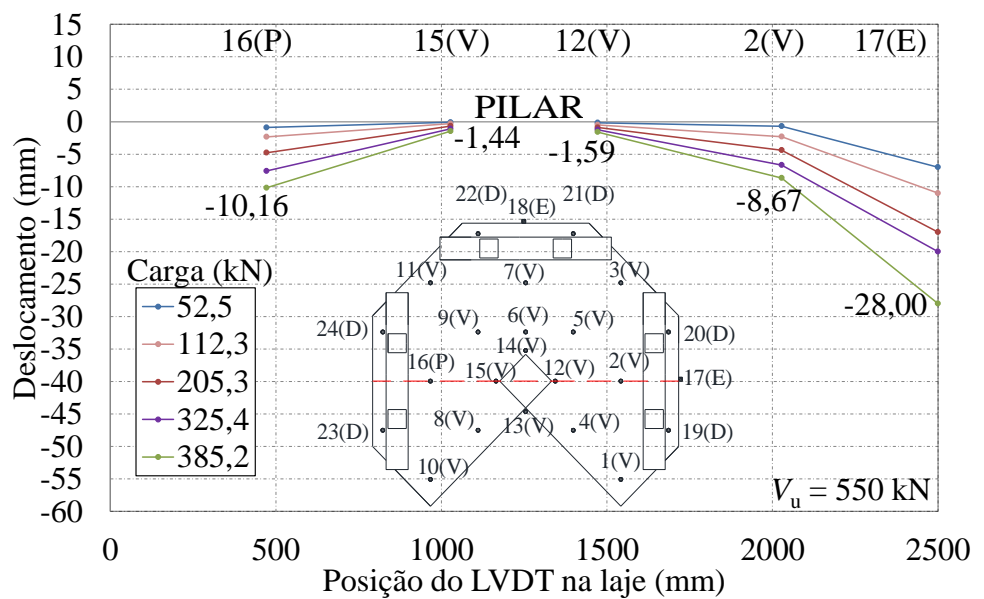

Figura 4.46 - Deslocamentos verticais na direção O-L da laje L09 


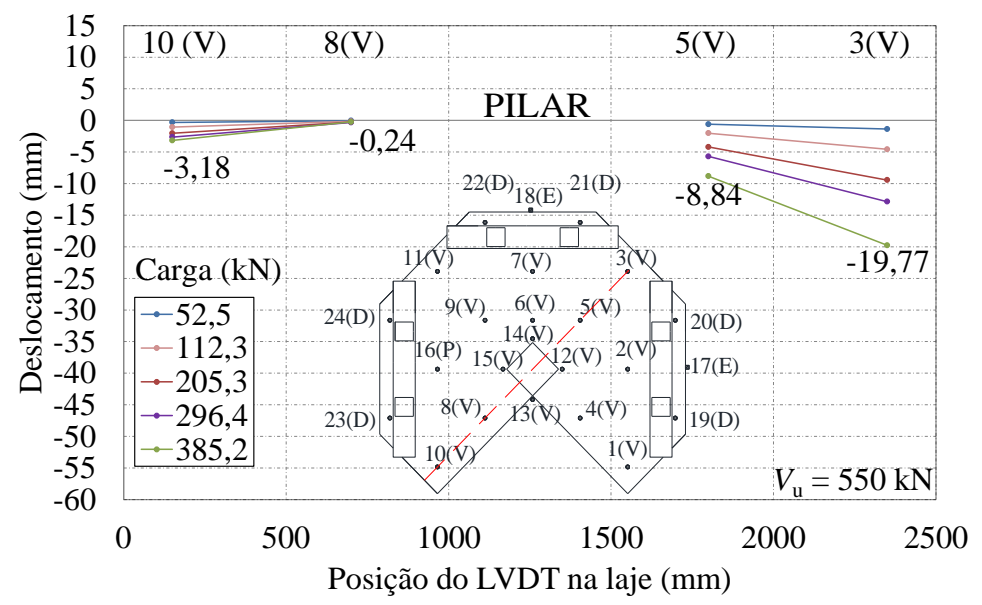

Figura 4.47 - Deslocamentos verticais na direção SO-NE da laje L09

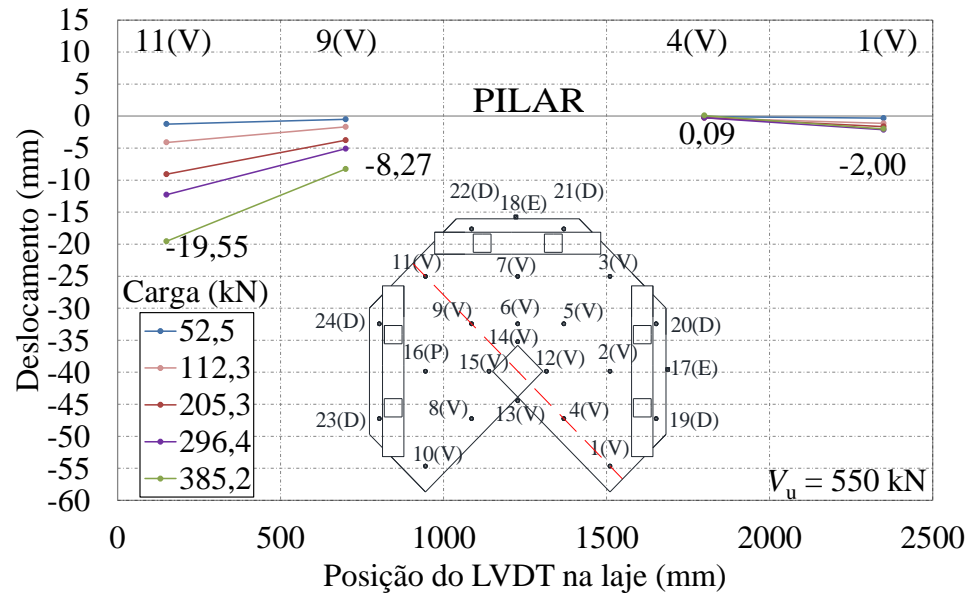

Figura 4.48 - Deslocamentos verticais na direção NO-SE da laje L09

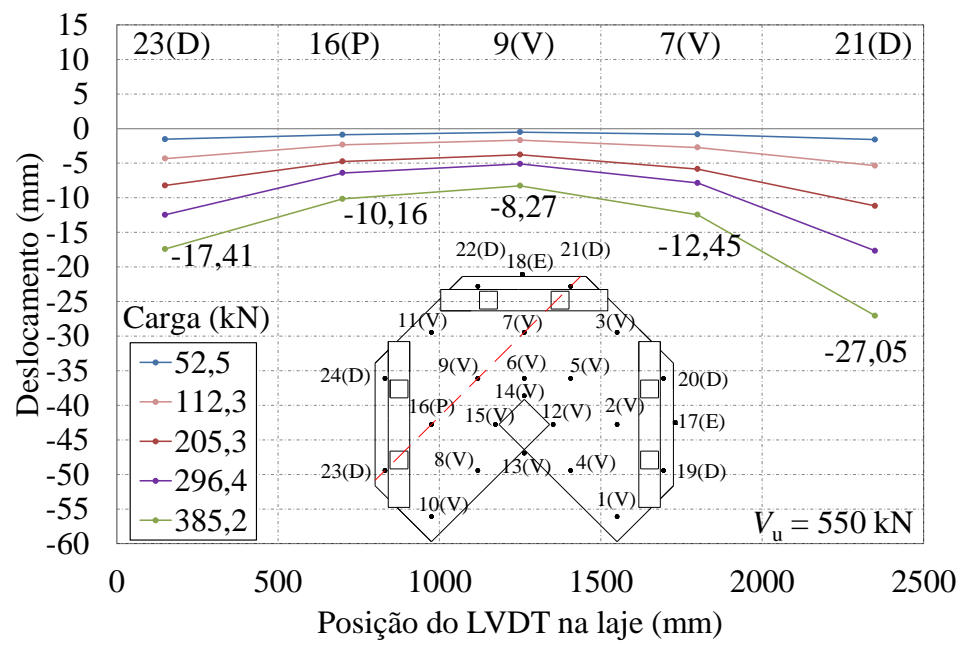

Figura 4.49 - Deslocamentos verticais na direção SO-NE da laje L09 


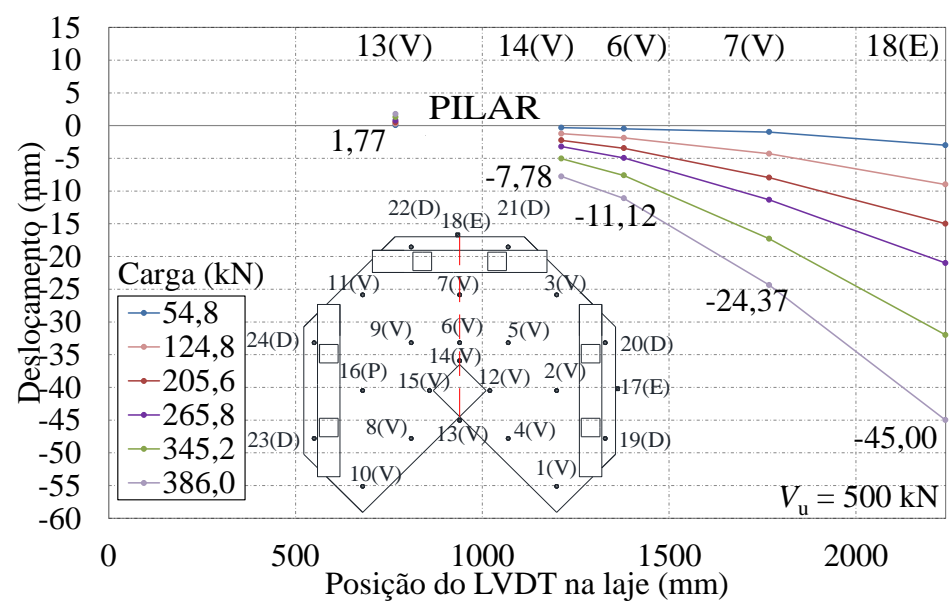

Figura 4.50 - Deslocamentos verticais na direção S-N da laje L10

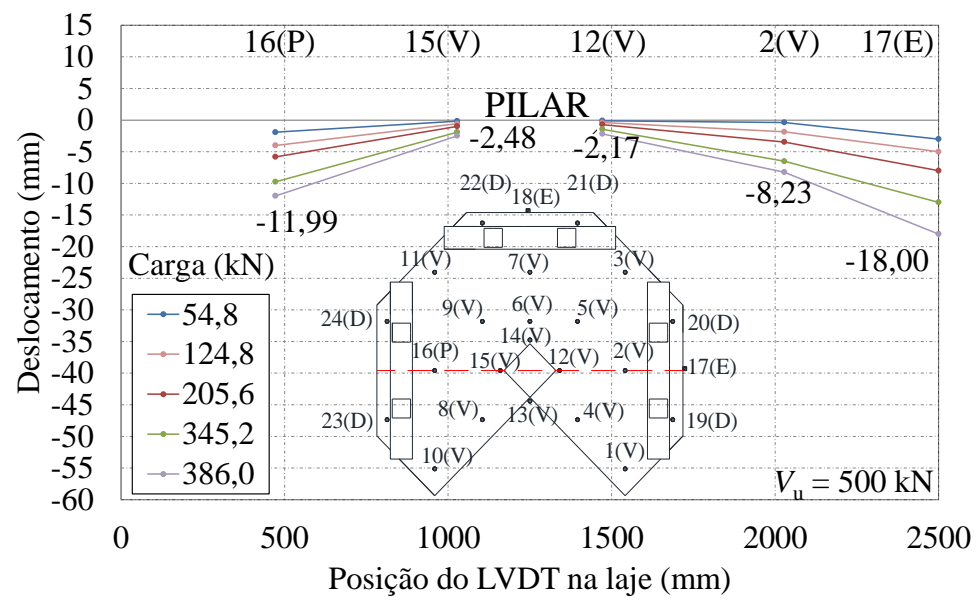

Figura 4.51 - Deslocamentos verticais na direção O-L da laje L10

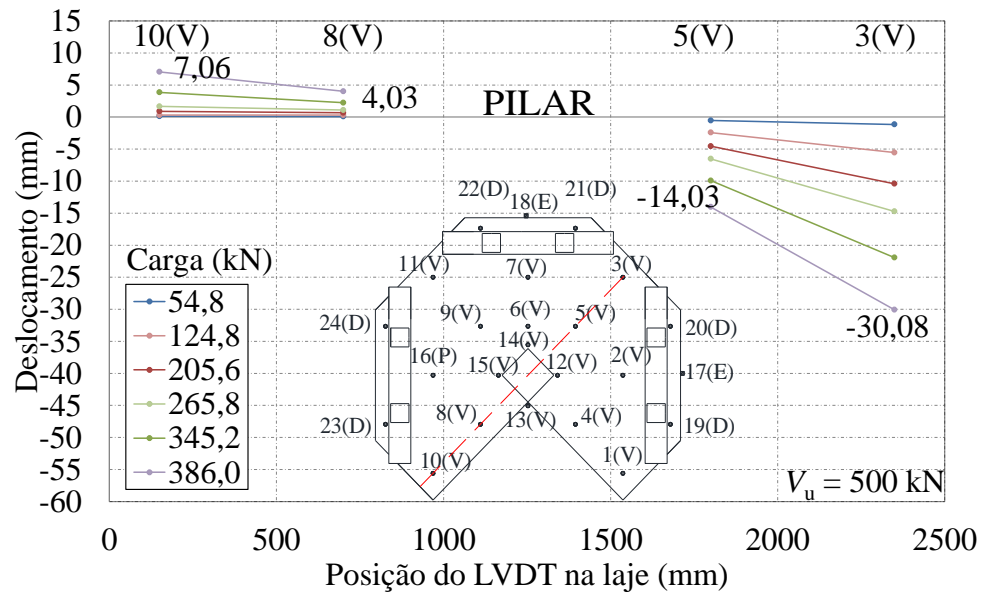

Figura 4.52 - Deslocamentos verticais na direção SO-NE da laje L10 


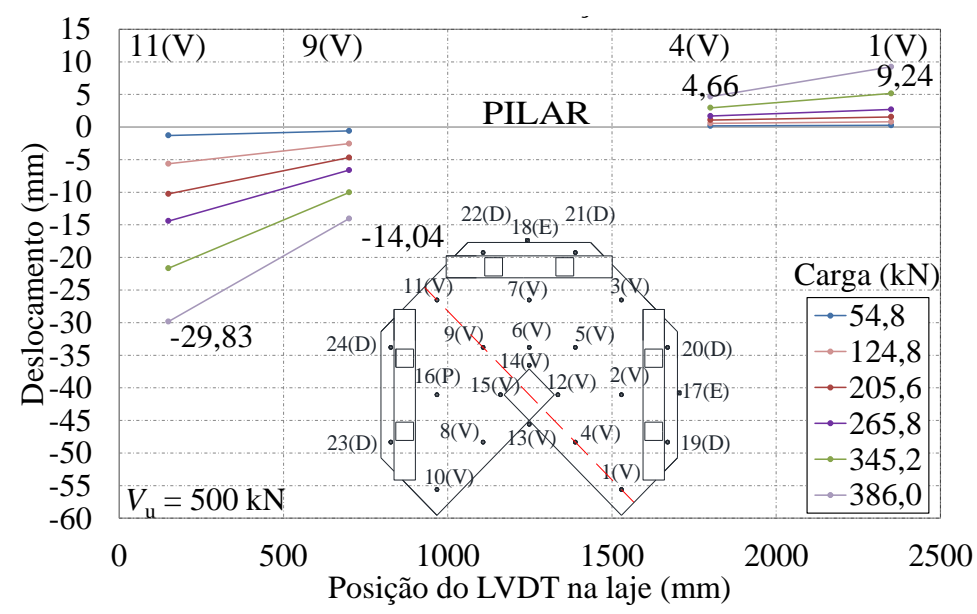

Figura 4.53 - Deslocamentos verticais na direção NO-SE da laje L10

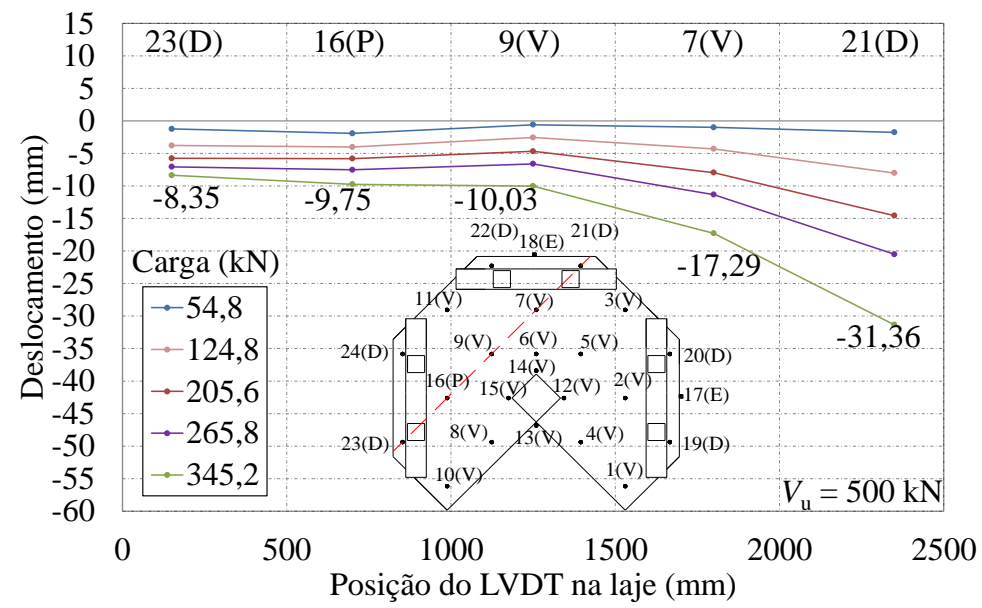

Figura 4.54 - Deslocamentos verticais na direção SO-NE da laje L10

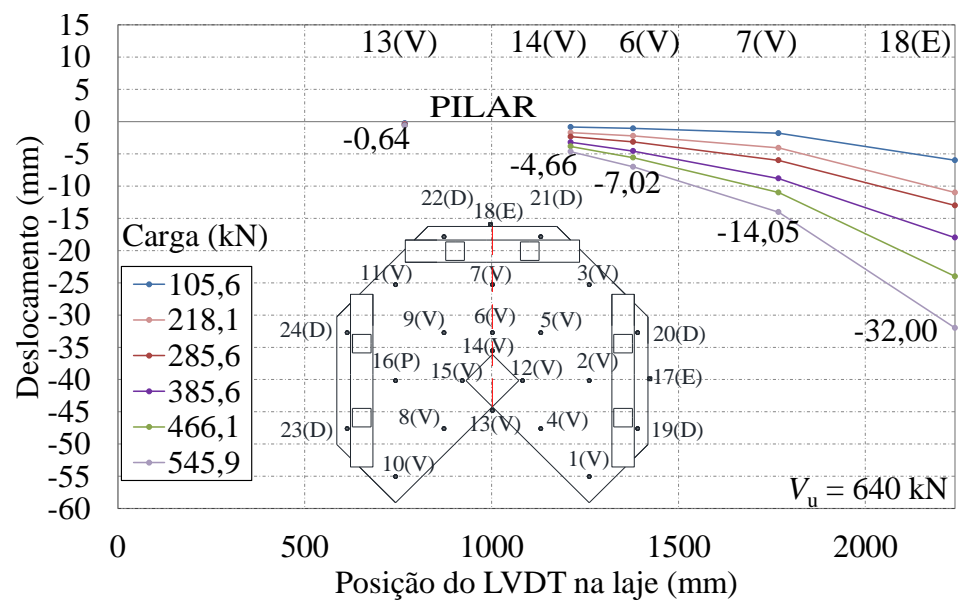

Figura 4.55 - Deslocamentos verticais na direção S-N da laje L11 


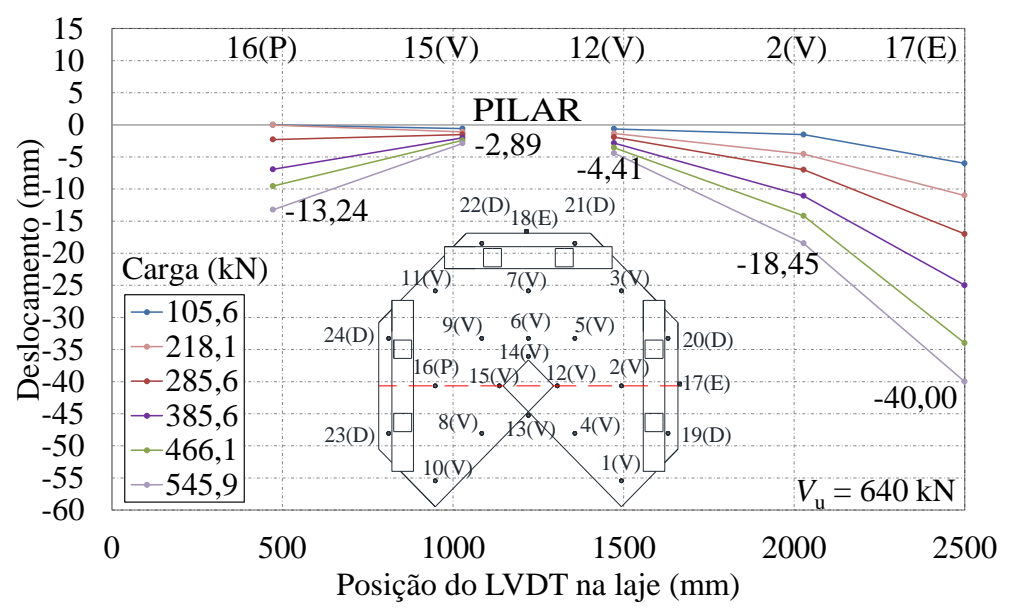

Figura 4.56 - Deslocamentos verticais na direção O-L da laje L11

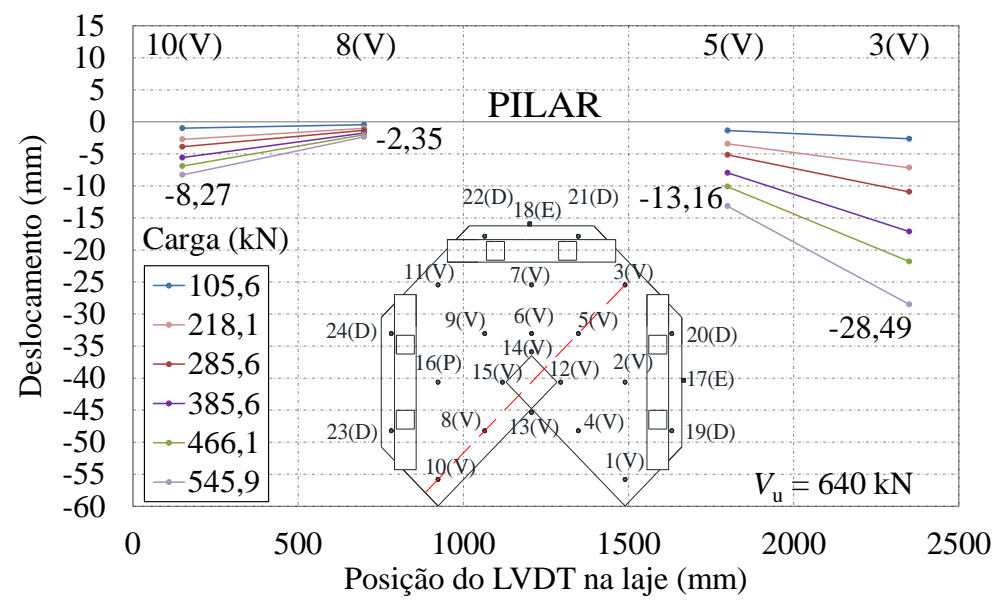

Figura 4.57 - Deslocamentos verticais na direção SO-NE da laje L11

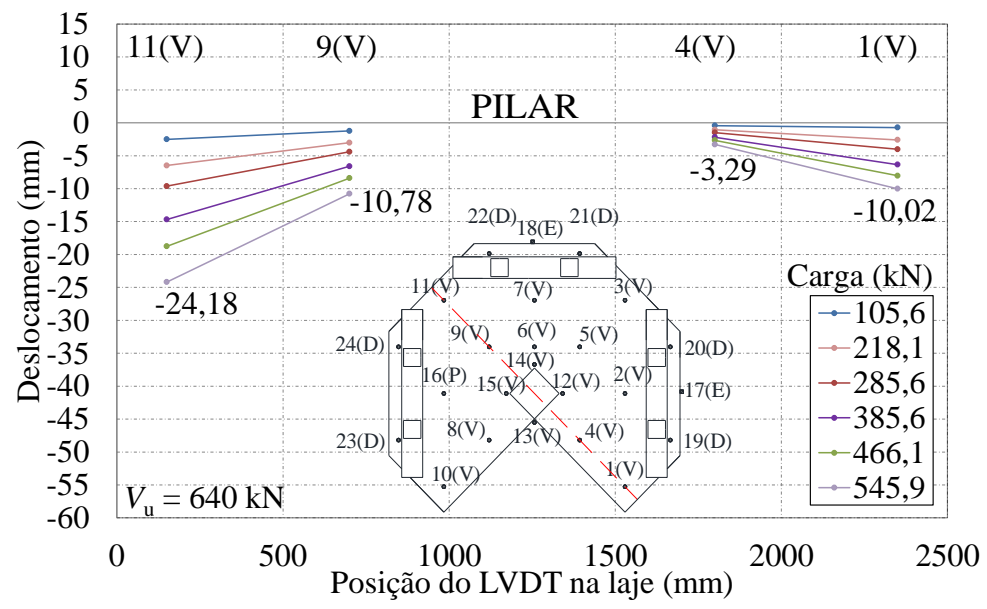

Figura 4.58 - Deslocamentos verticais na direção NO-SE da laje L11 


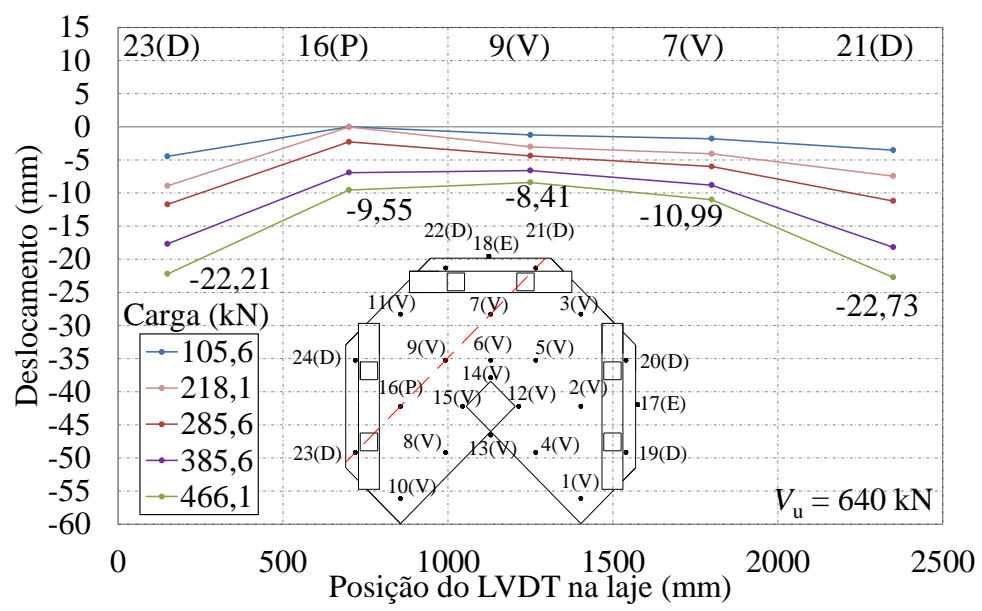

Figura 4.59 - Deslocamentos verticais na direção SO-NE da laje L11

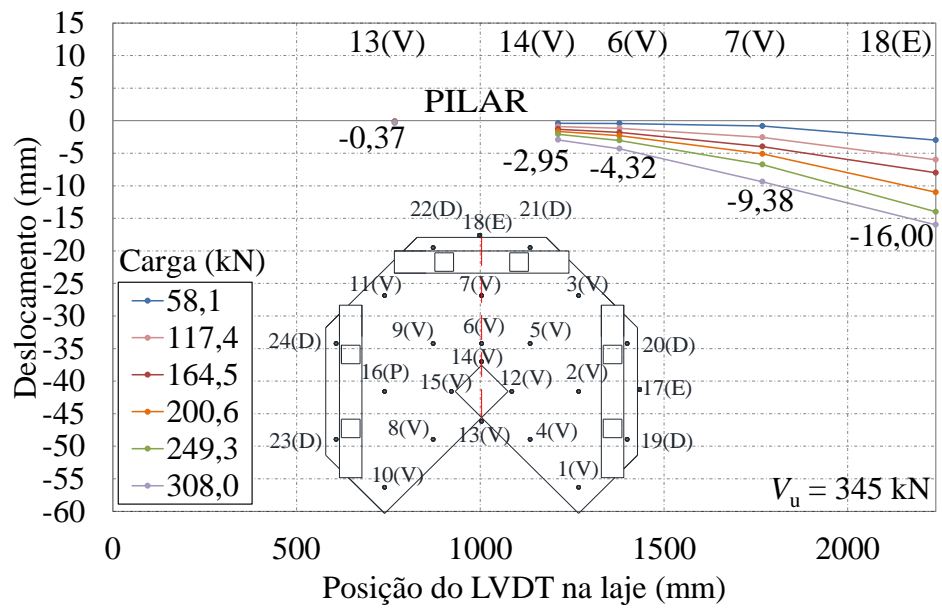

Figura 4.60 - Deslocamentos verticais na direção S-N da laje L12

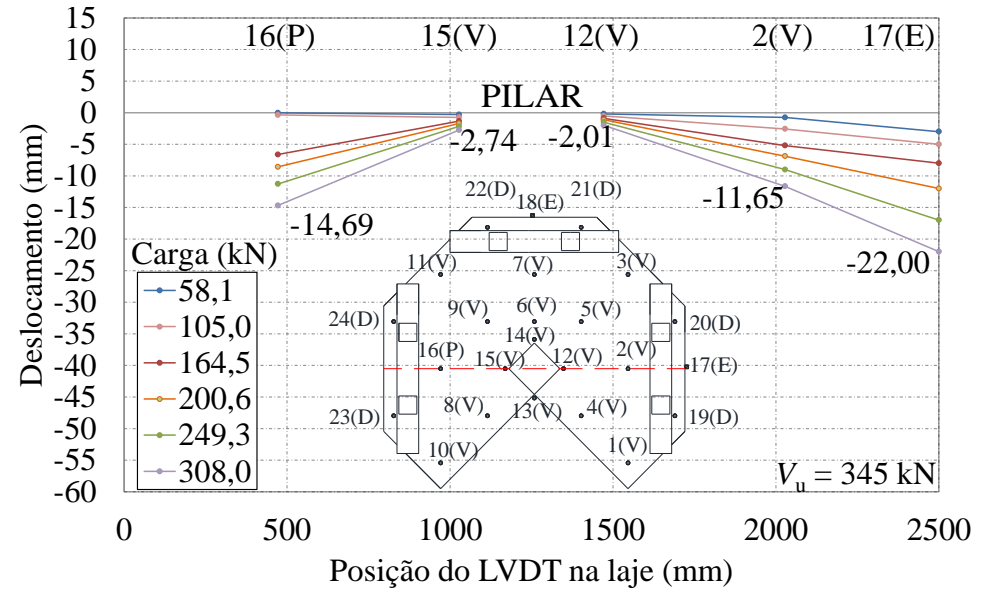

Figura 4.61 - Deslocamentos verticais na direção O-L da laje L12 


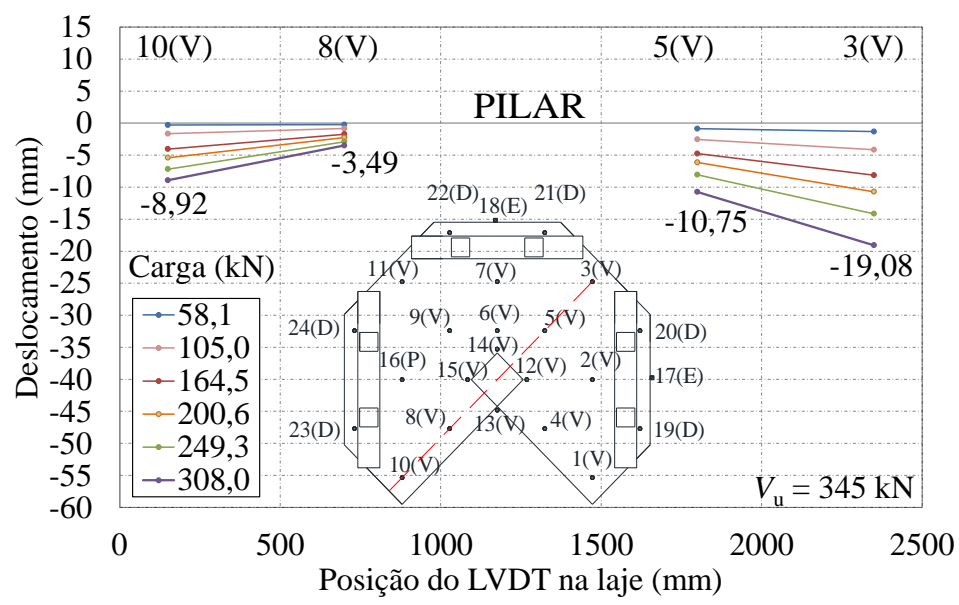

Figura 4.62 - Deslocamentos verticais na direção SO-NE da laje L12

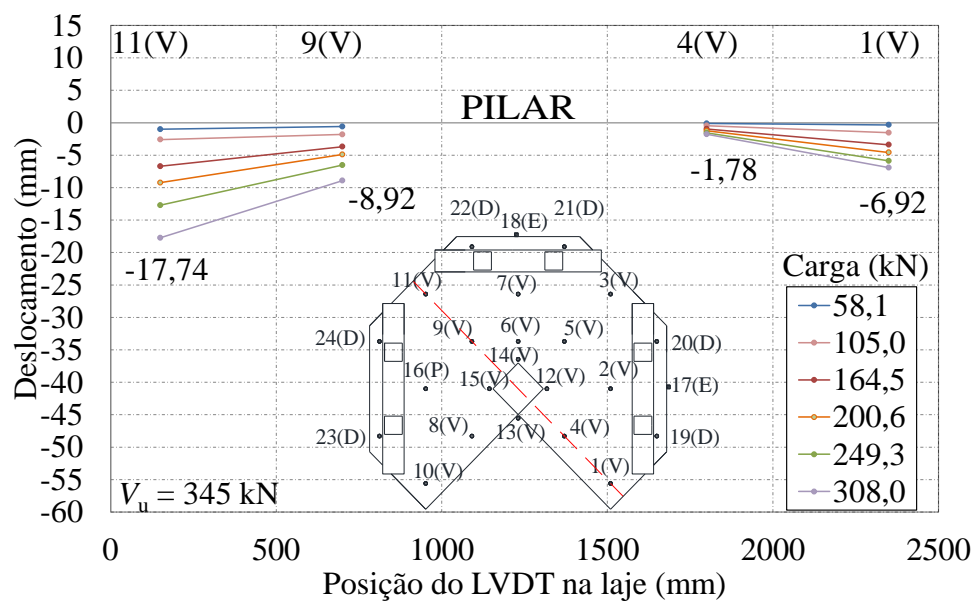

Figura 4.63 - Deslocamentos verticais na direção NO-SE da laje L12

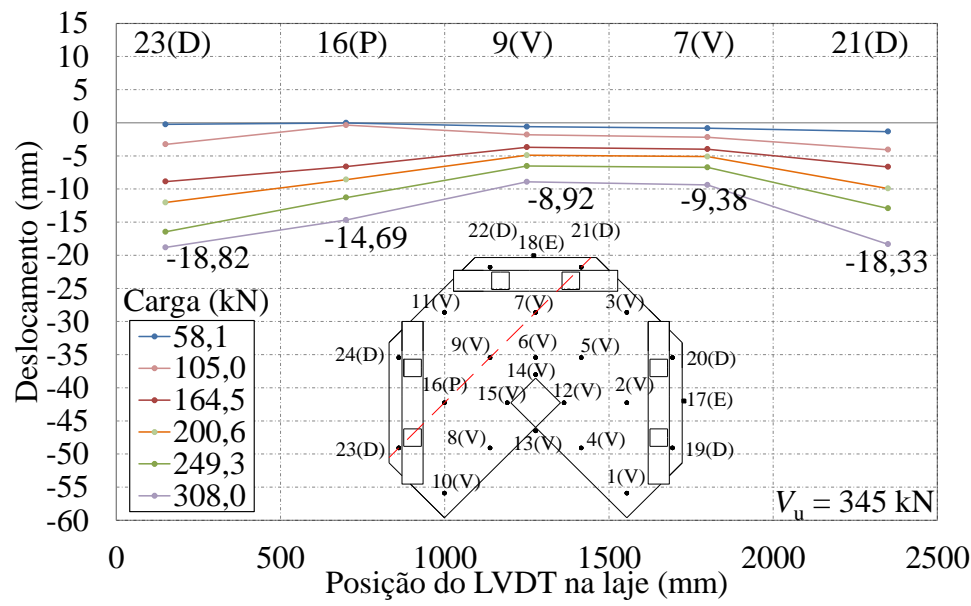

Figura 4.64 - Deslocamentos verticais na direção SO-NE da laje L12 


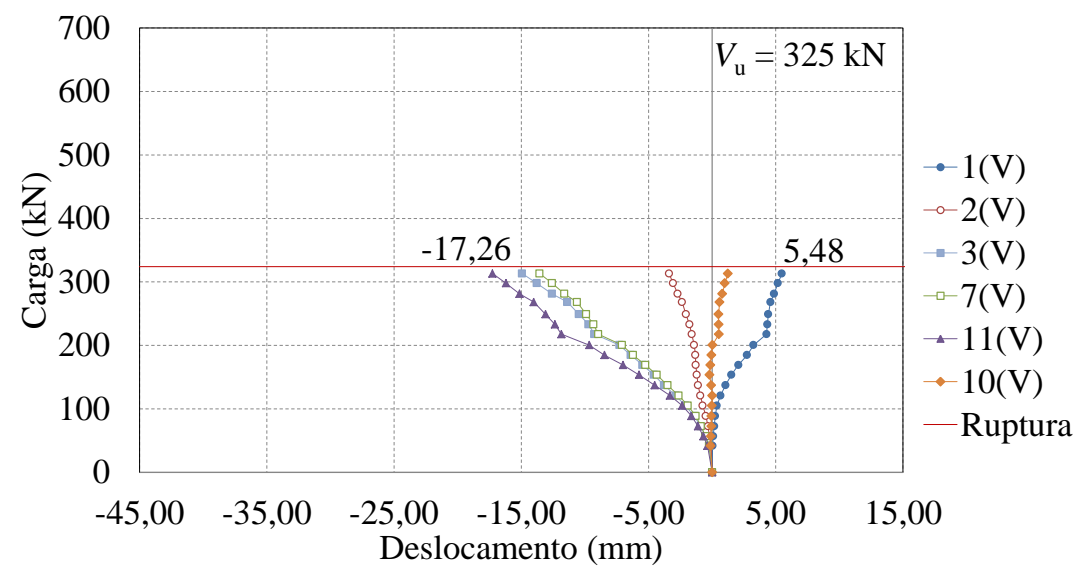

Figura 4.65 - Carga x deslocamento da laje L01

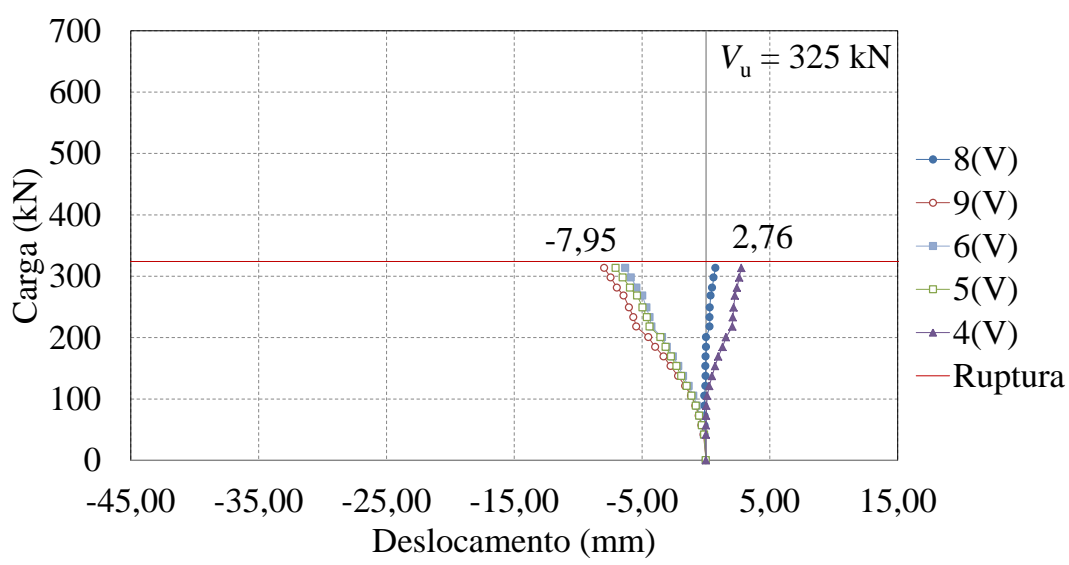

Figura 4.66 - Carga x deslocamento da laje L01

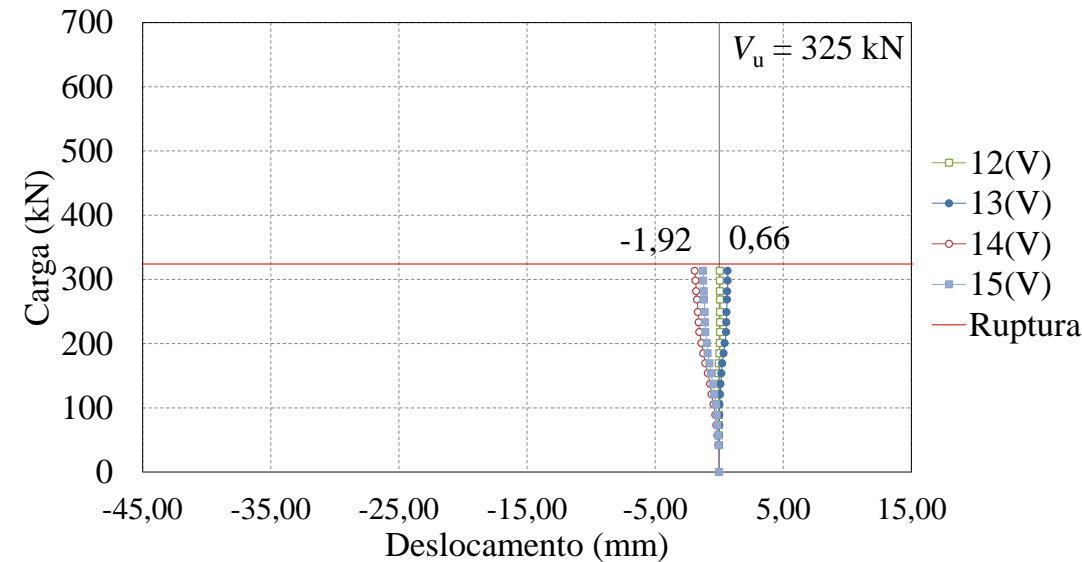

Figura 4.67 - Carga x deslocamento da laje L01 


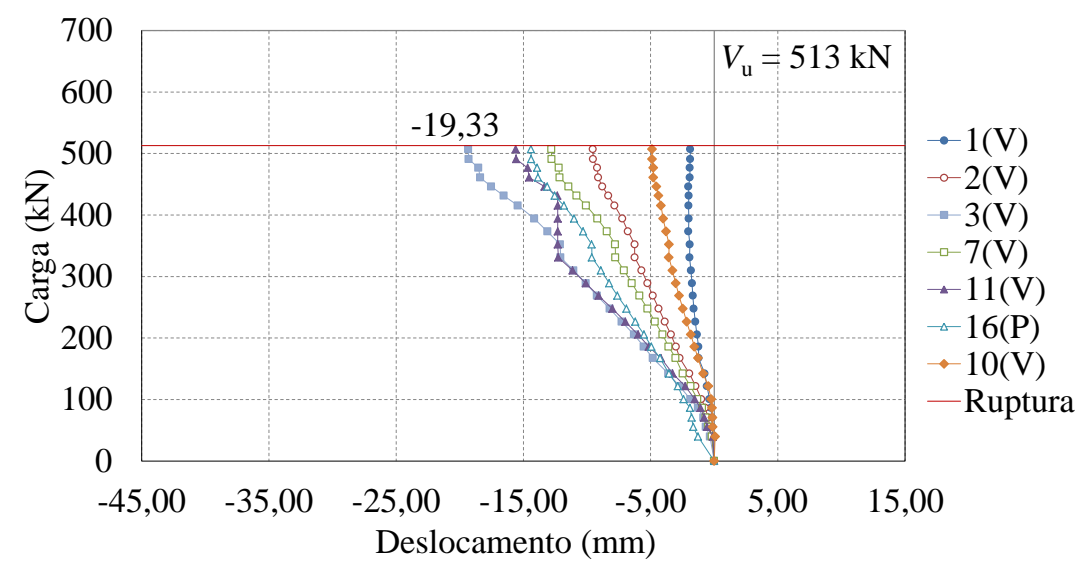

Figura 4.68 - Carga x deslocamento da laje L02

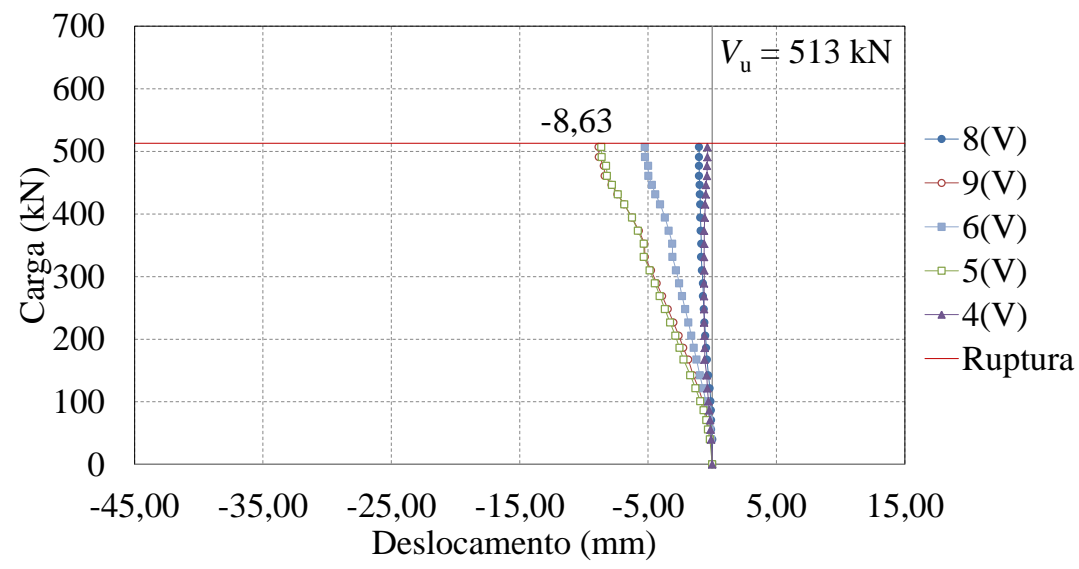

Figura 4.69 - Carga x deslocamento da laje L02

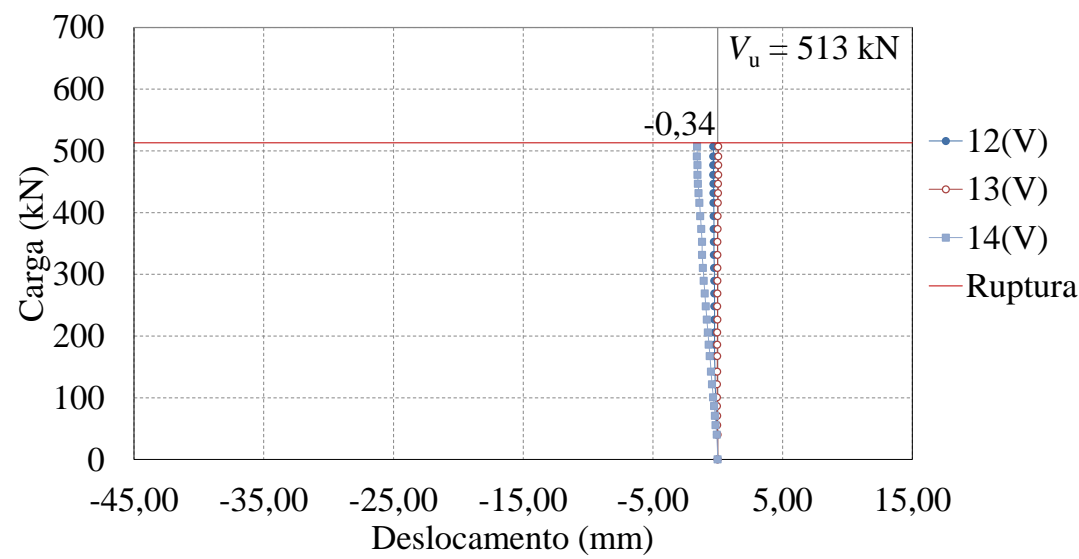

Figura 4.70 - Carga x deslocamento da laje L02 


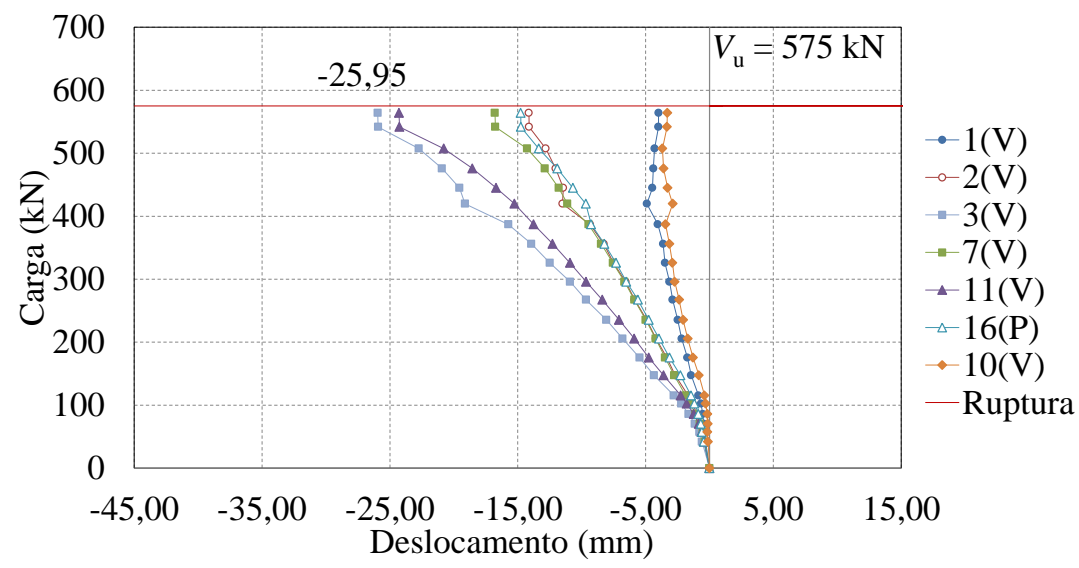

Figura 4.71 - Carga x deslocamento da laje L03

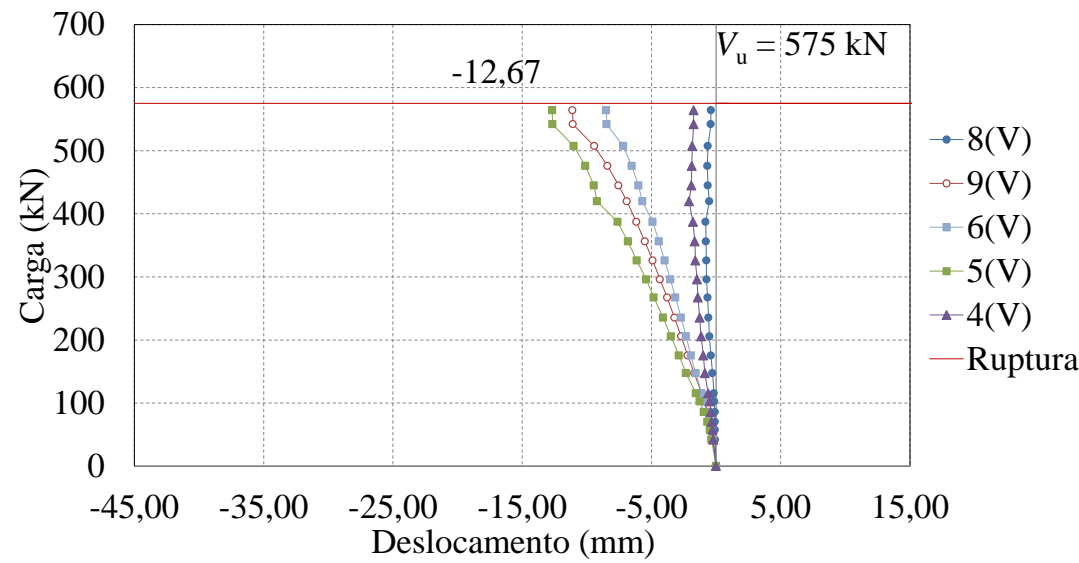

Figura 4.72 - Carga x deslocamento da laje L03

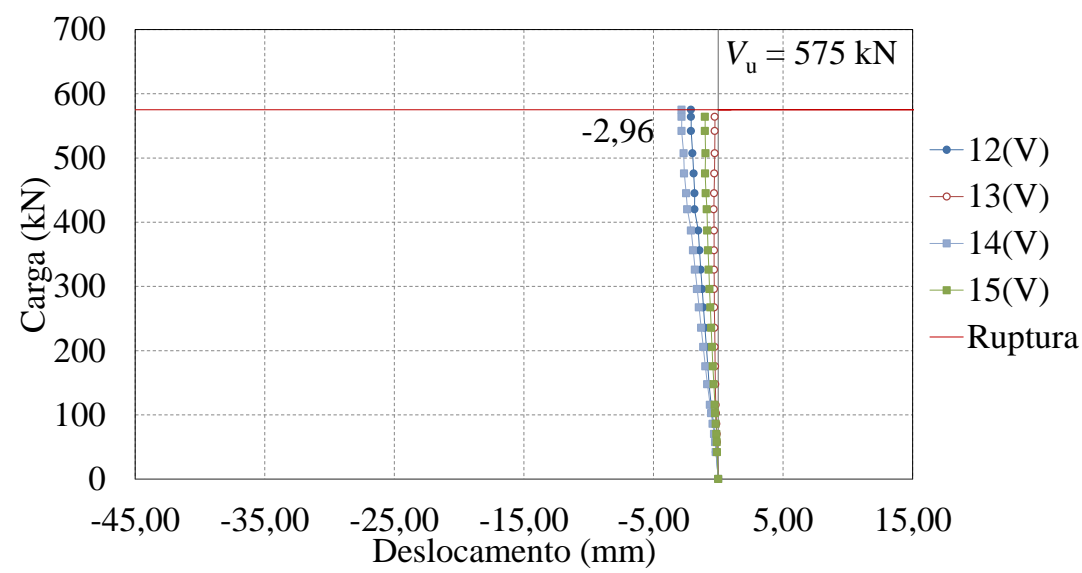

Figura 4.73 - Carga x deslocamento da laje L03 


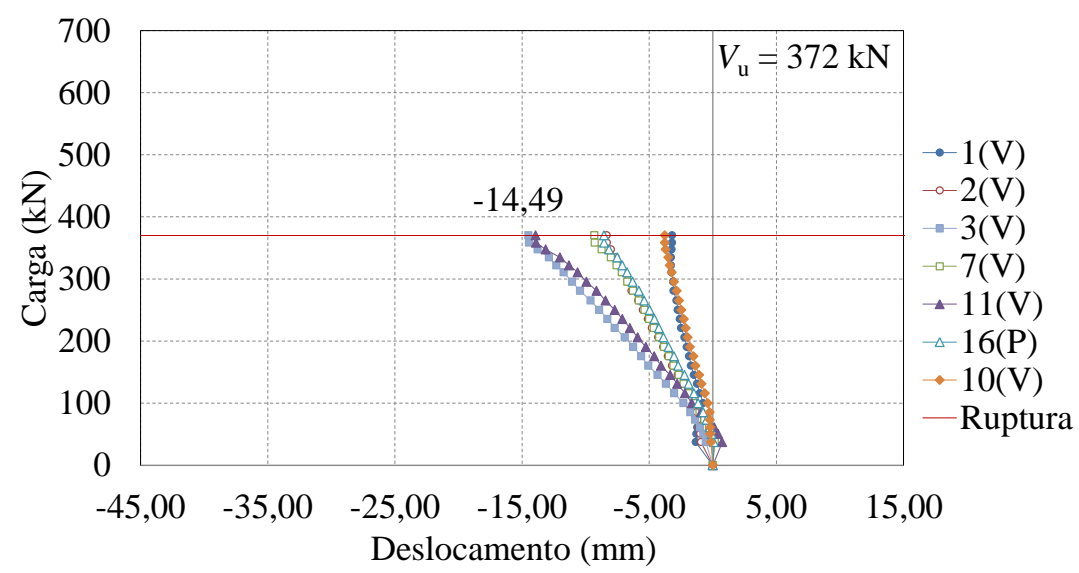

Figura 4.74 - Carga x deslocamento da laje L04

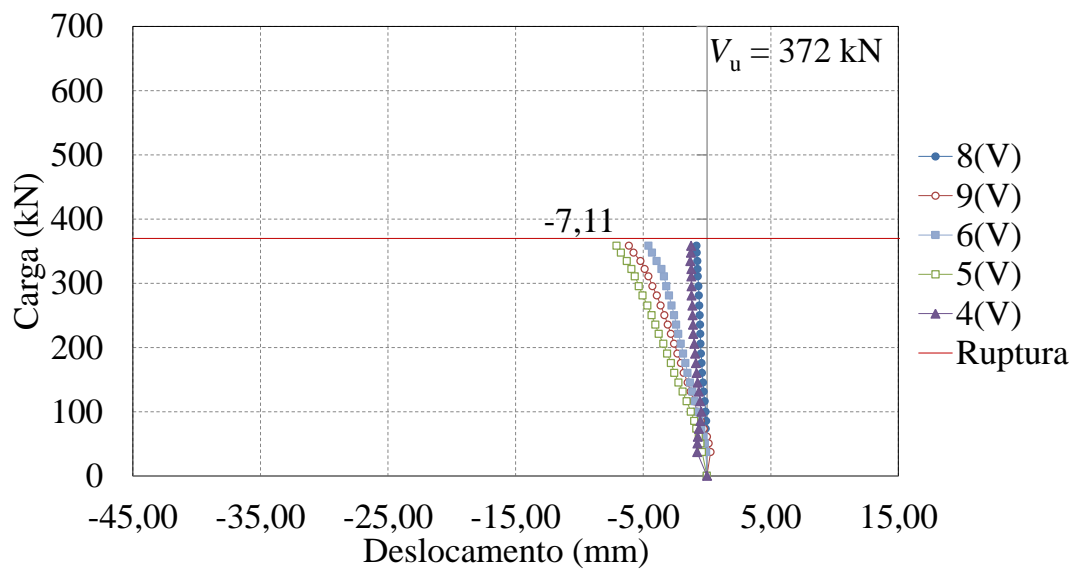

Figura 4.75 - Carga x deslocamento da laje L04

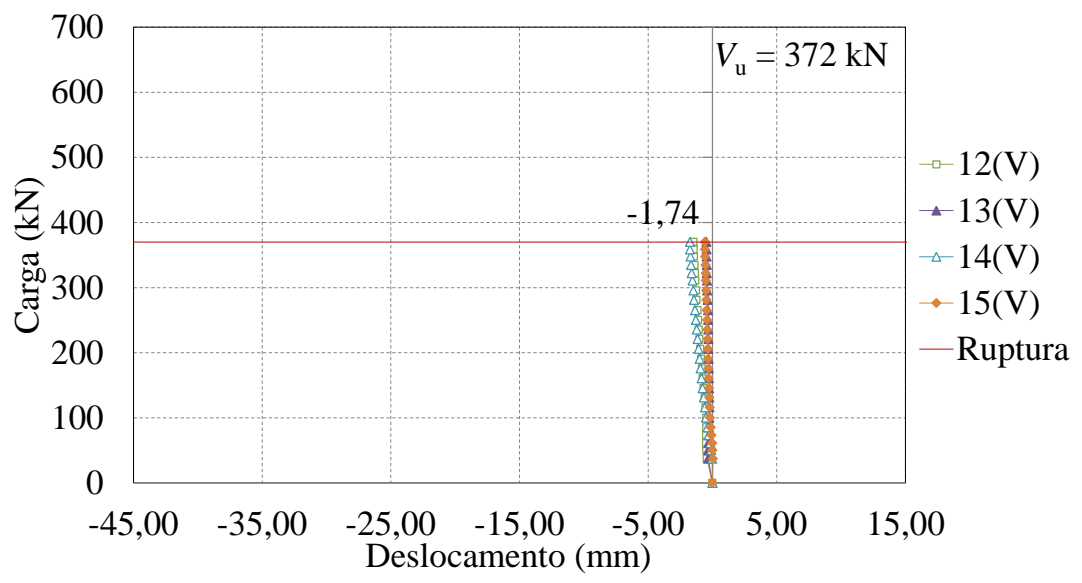

Figura 4.76 - Carga x deslocamento da laje L04 


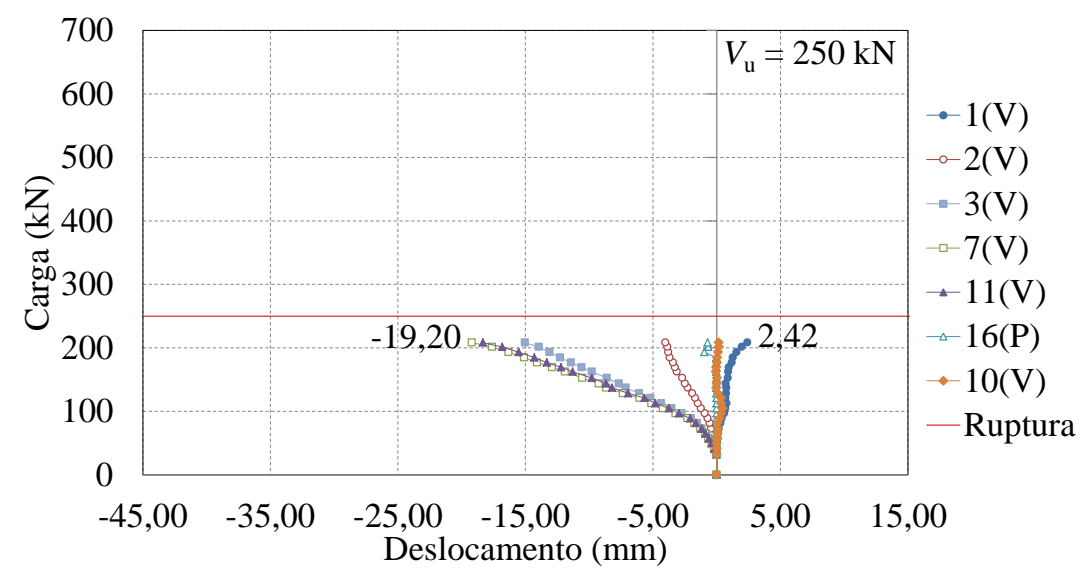

Figura 4.77 - Carga x deslocamento da laje L05

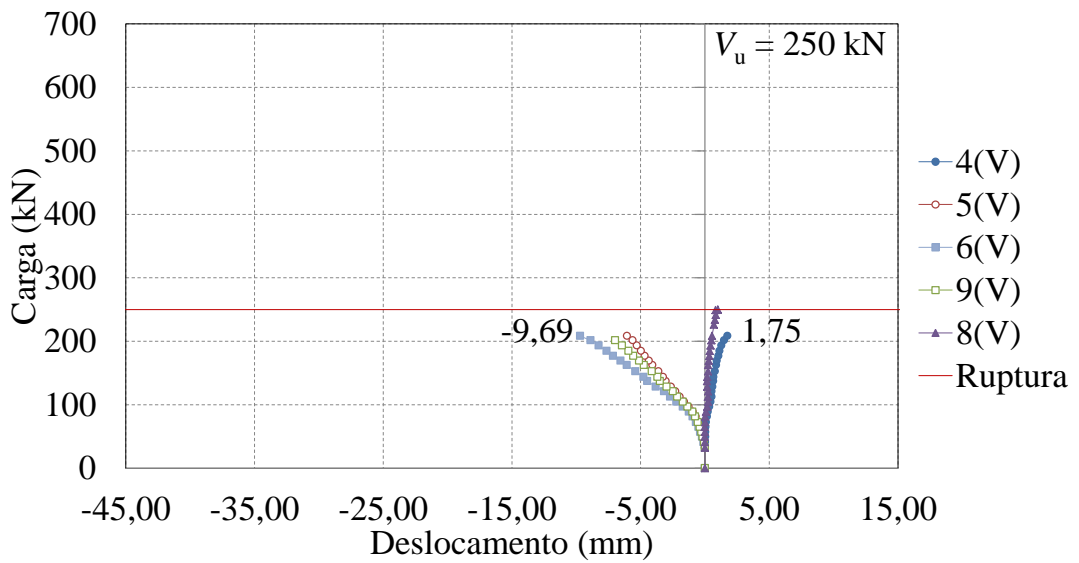

Figura 4.78 - Carga x deslocamento da laje L05

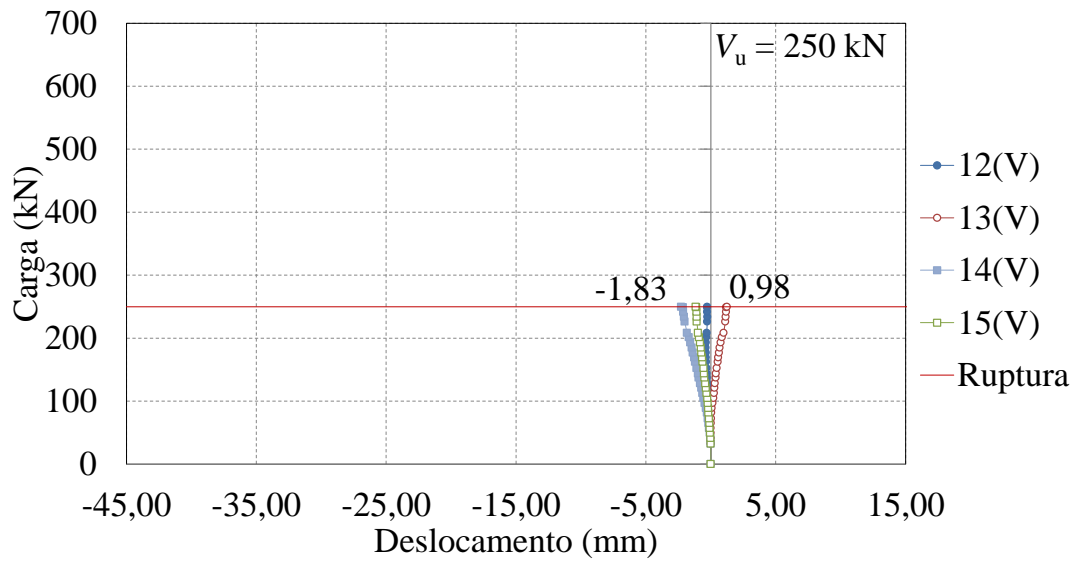

Figura 4.79 - Carga x deslocamento da laje L05 


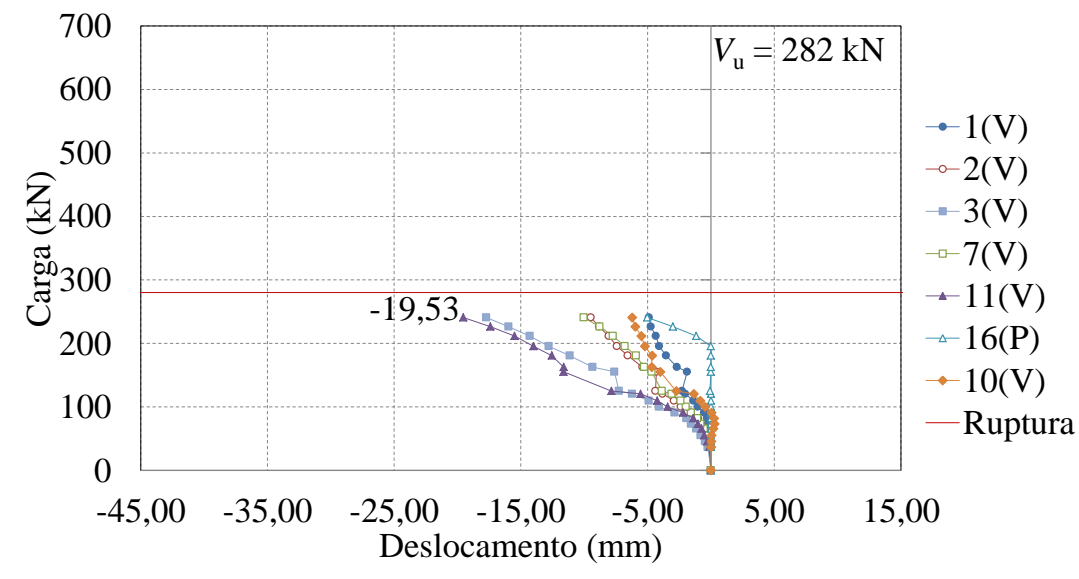

Figura 4.80 - Carga x deslocamento da laje L06

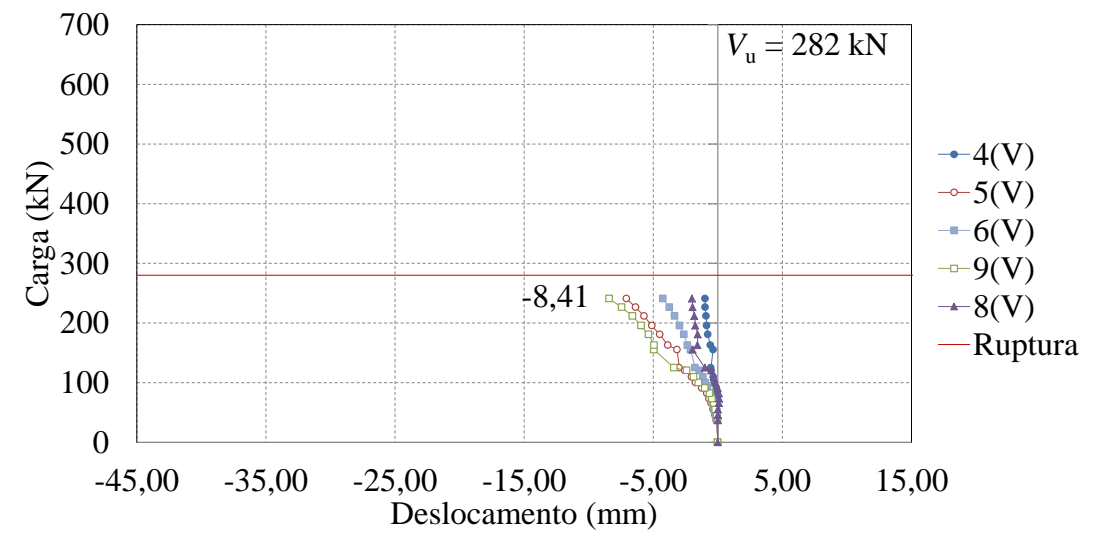

Figura 4.81 - Carga x deslocamento da laje L06

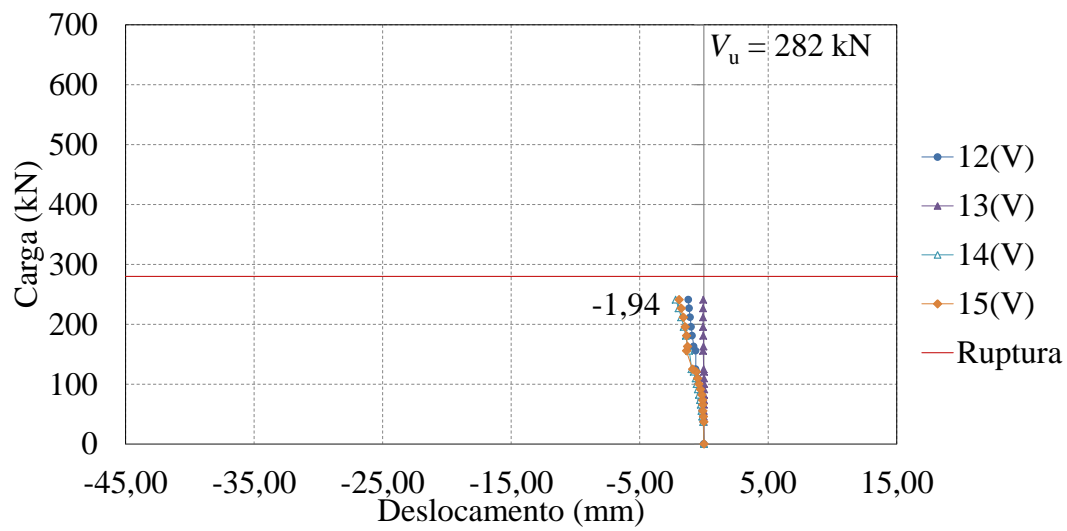

Figura 4.82 - Carga x deslocamento da laje L06 


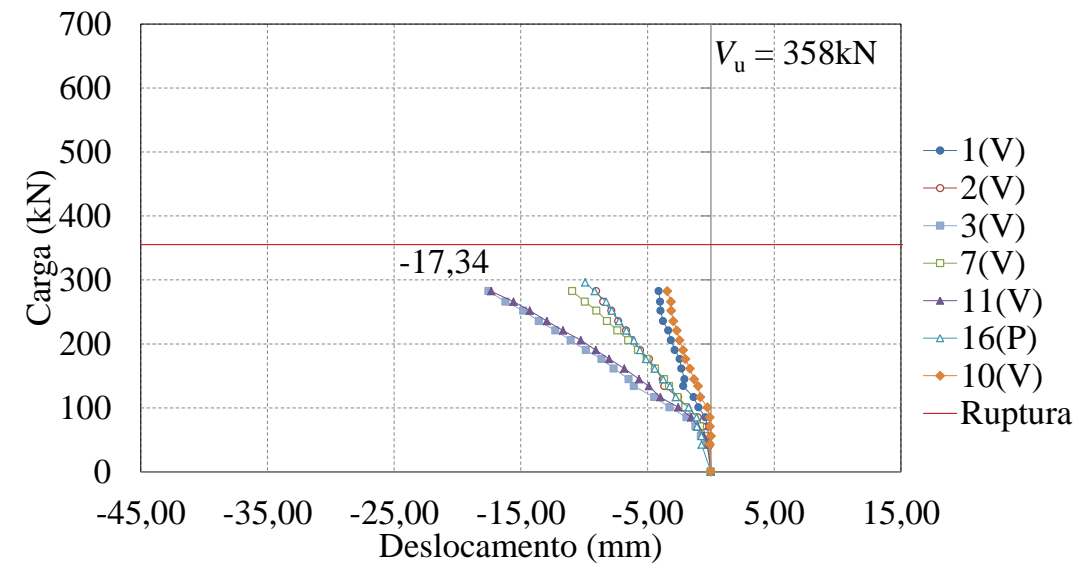

Figura 4.83 - Carga x deslocamento da laje L07

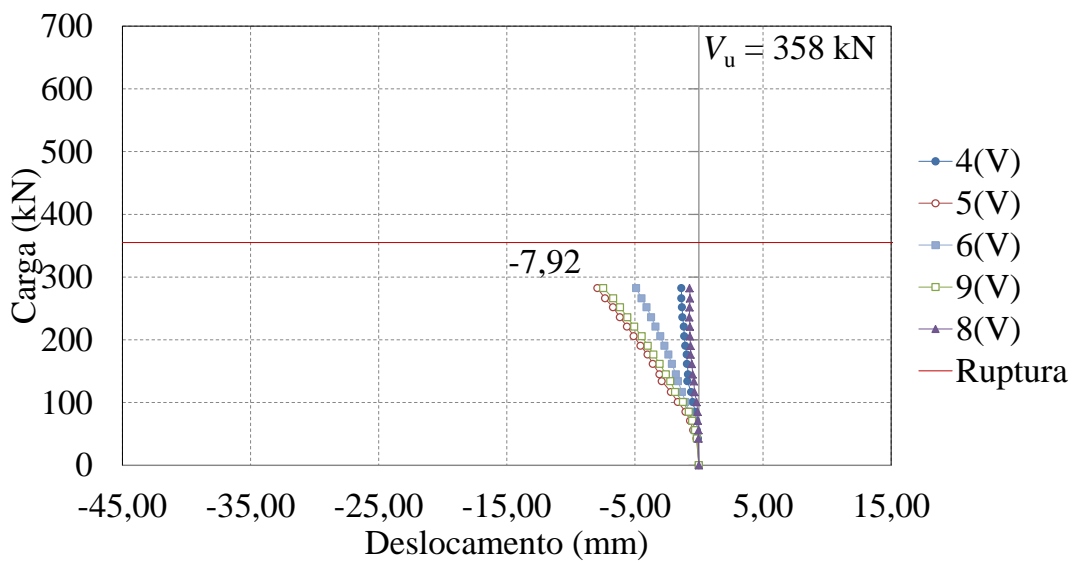

Figura 4.84 - Carga x deslocamento da laje L07

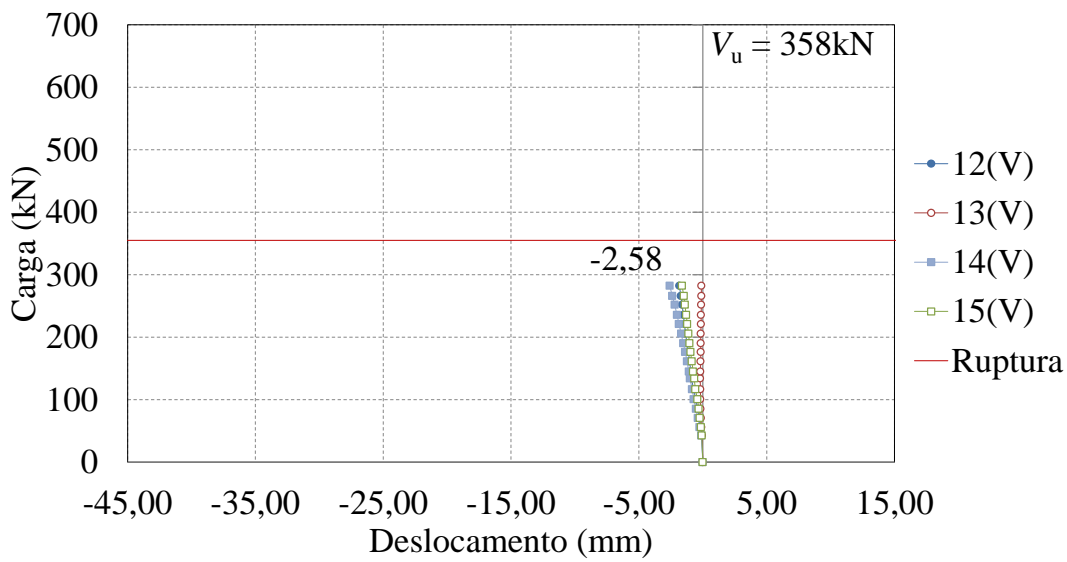

Figura 4.85 - Carga x deslocamento da laje L07 


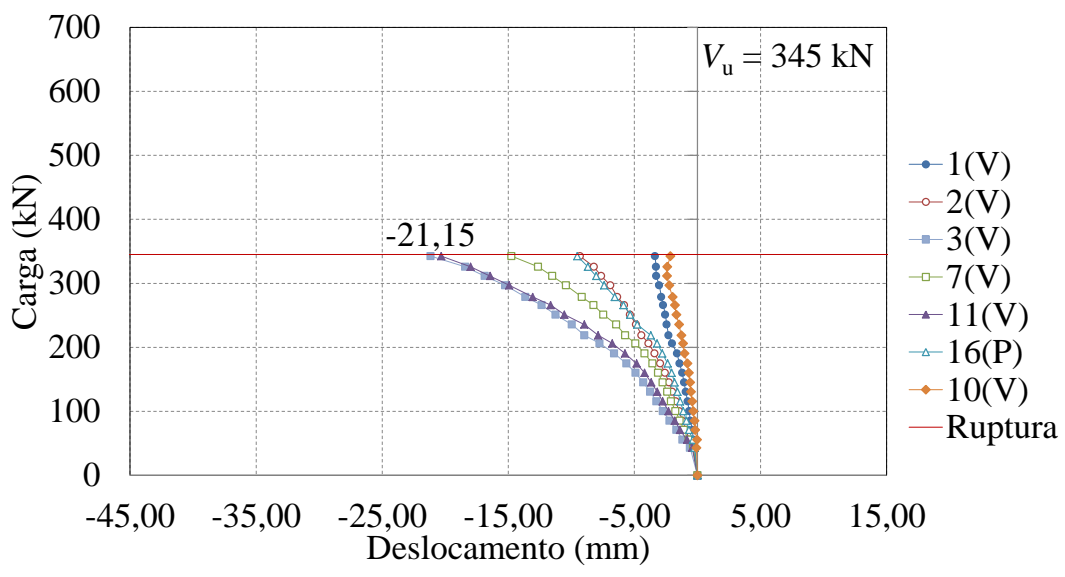

Figura 4.86 - Carga x deslocamento da laje L08

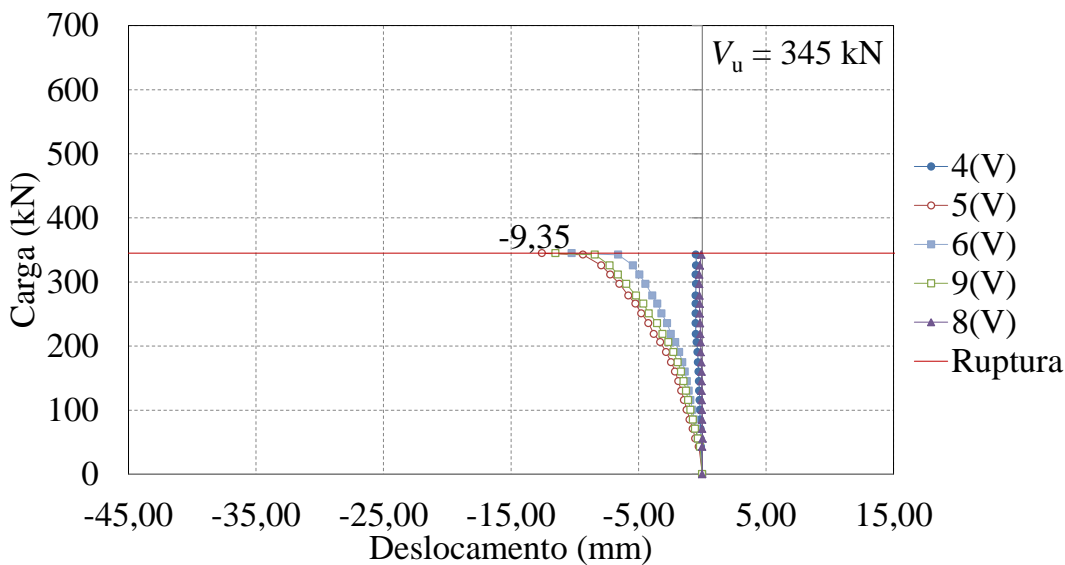

Figura 4.87 - Carga x deslocamento da laje L08

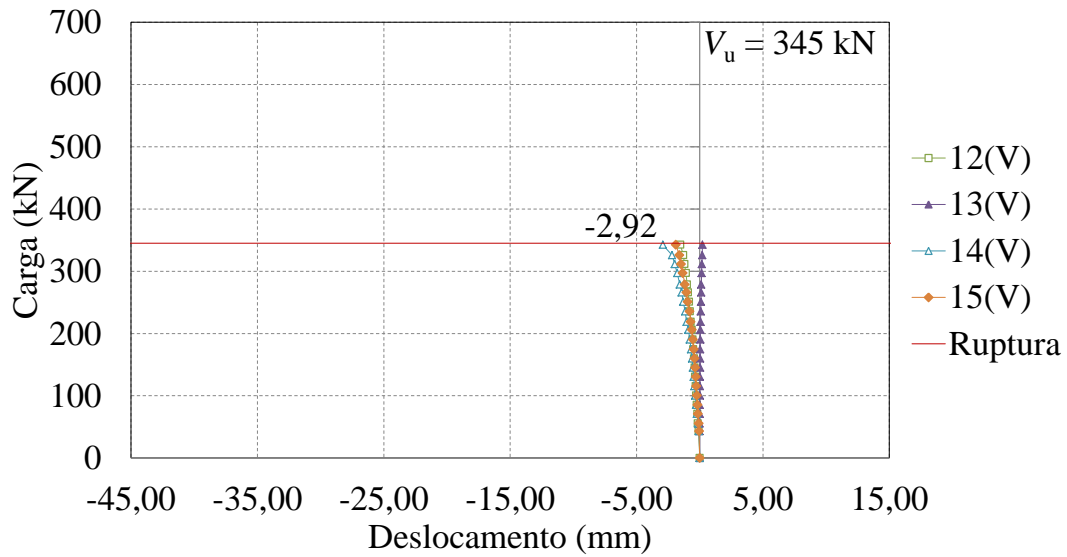

Figura 4.88 - Carga x deslocamento da laje L08 


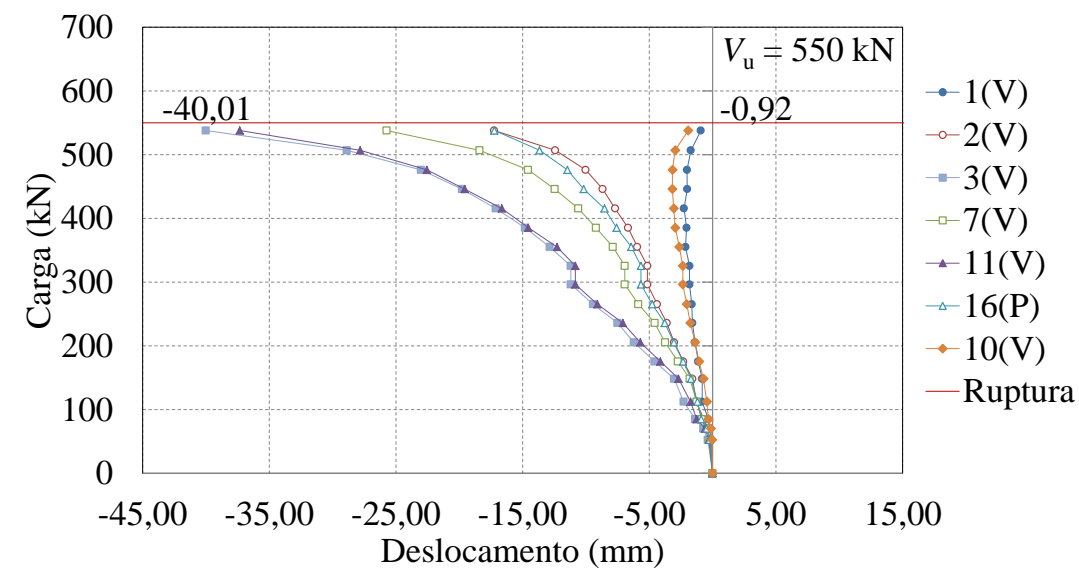

Figura 4.89 - Carga x deslocamento da laje L09

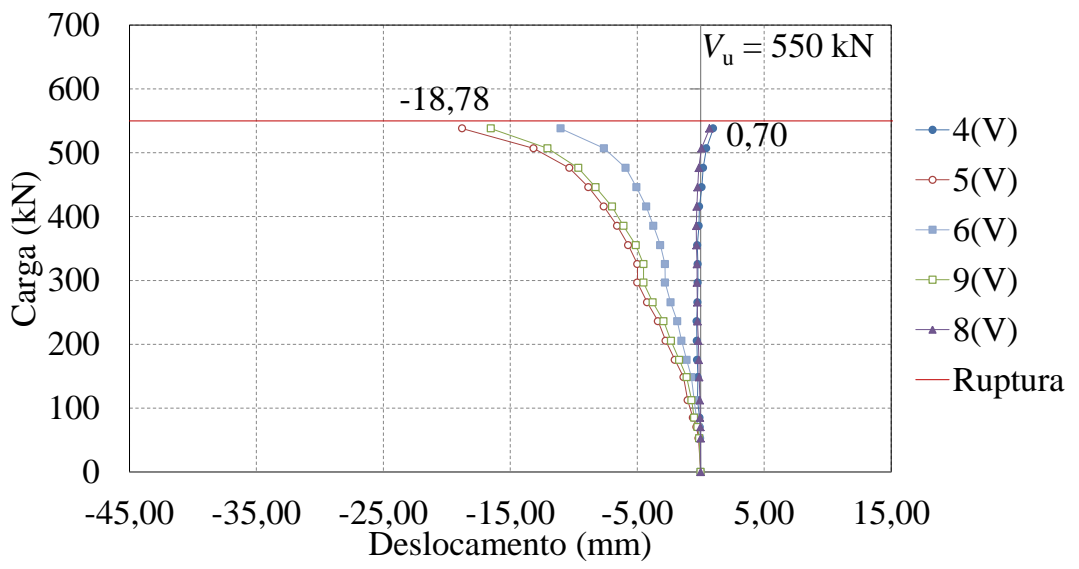

Figura 4.90 - Carga x deslocamento da laje L09

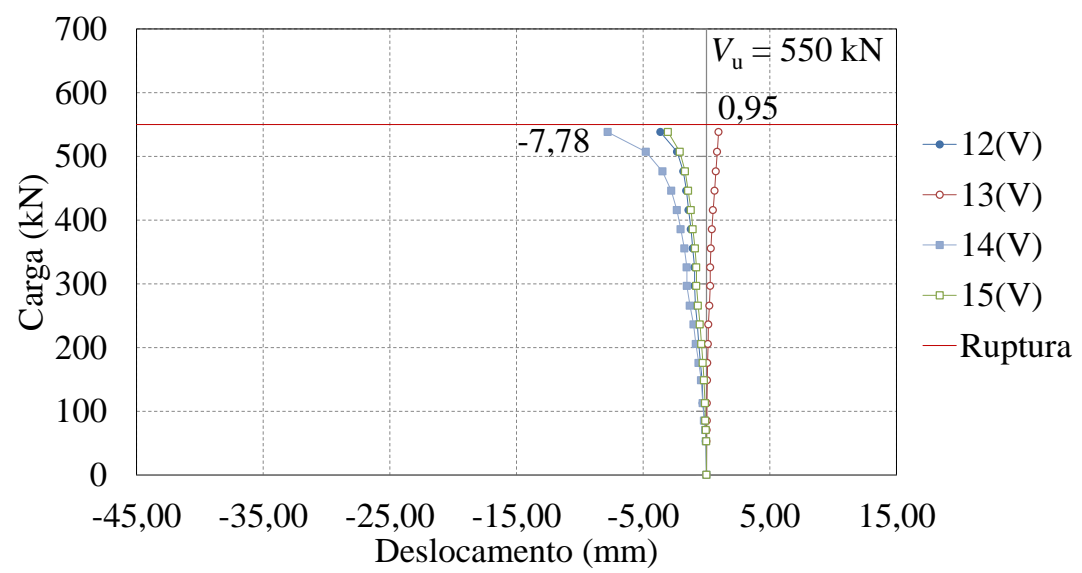

Figura 4.91 - Carga x deslocamento da laje L09 


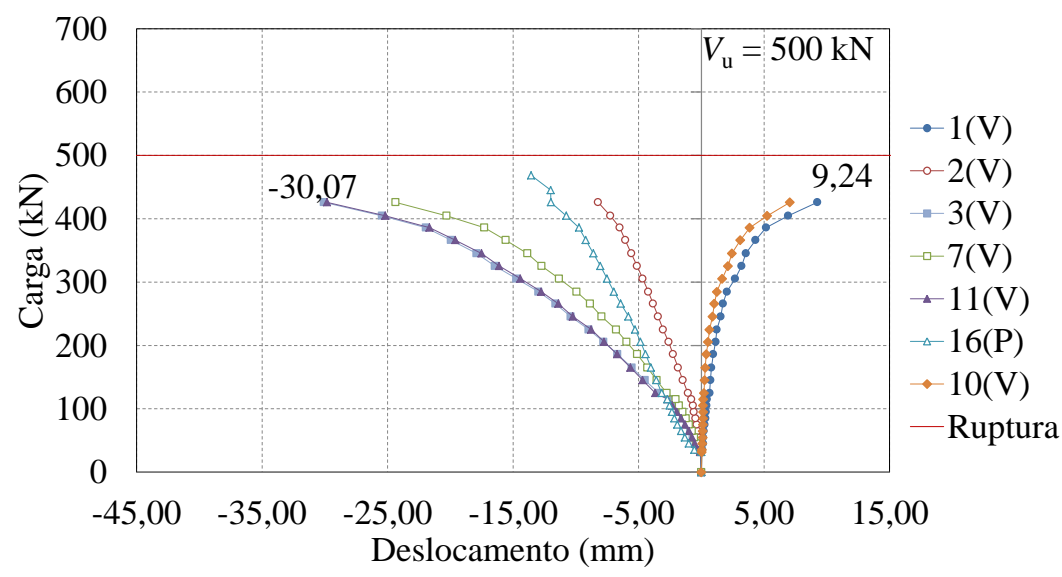

Figura 4.92 - Carga x deslocamento da laje L10

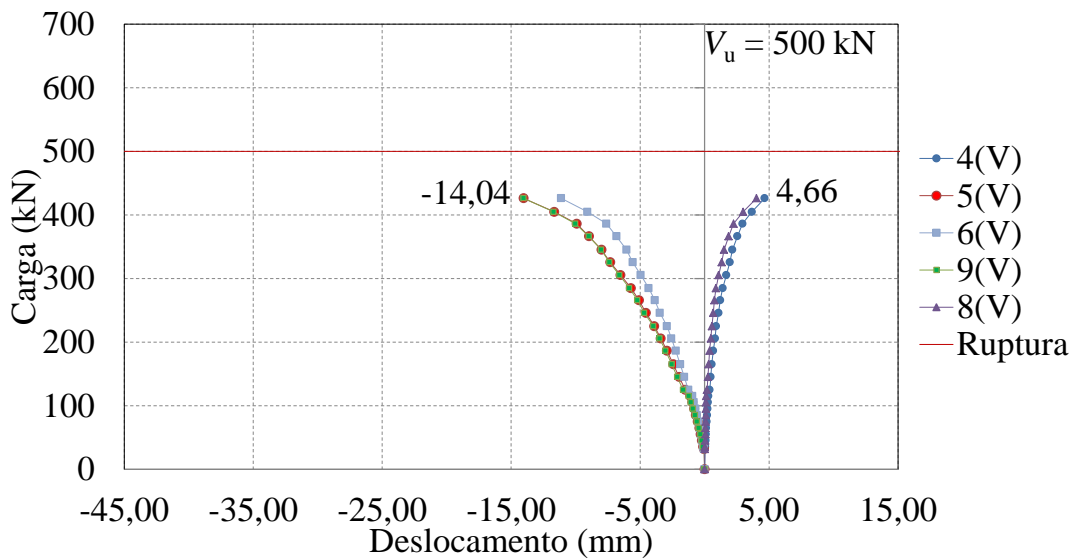

Figura 4.93 - Carga x deslocamento da laje L10

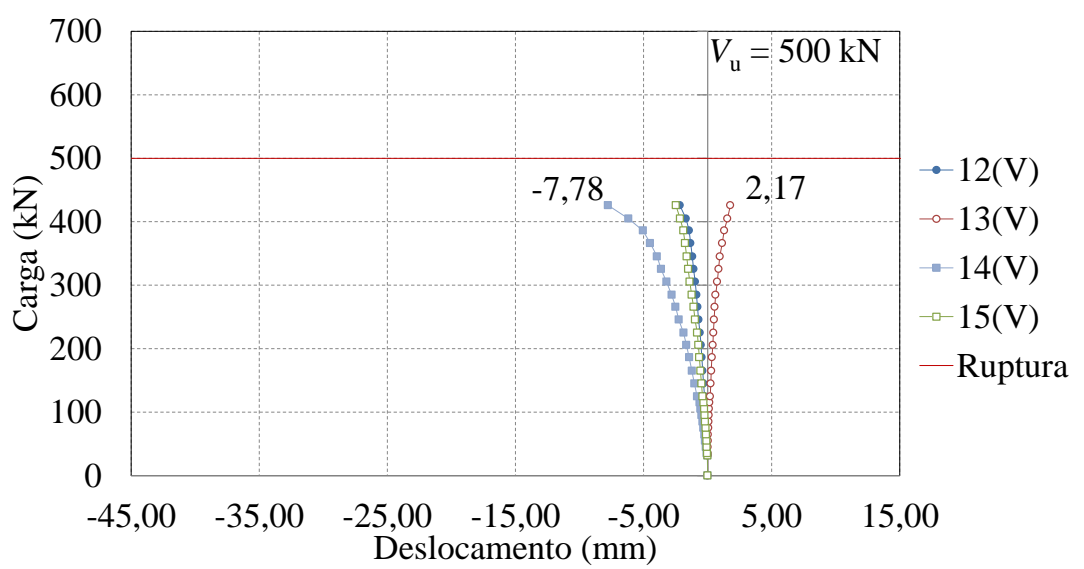

Figura 4.94 - Carga x deslocamento da laje L10 


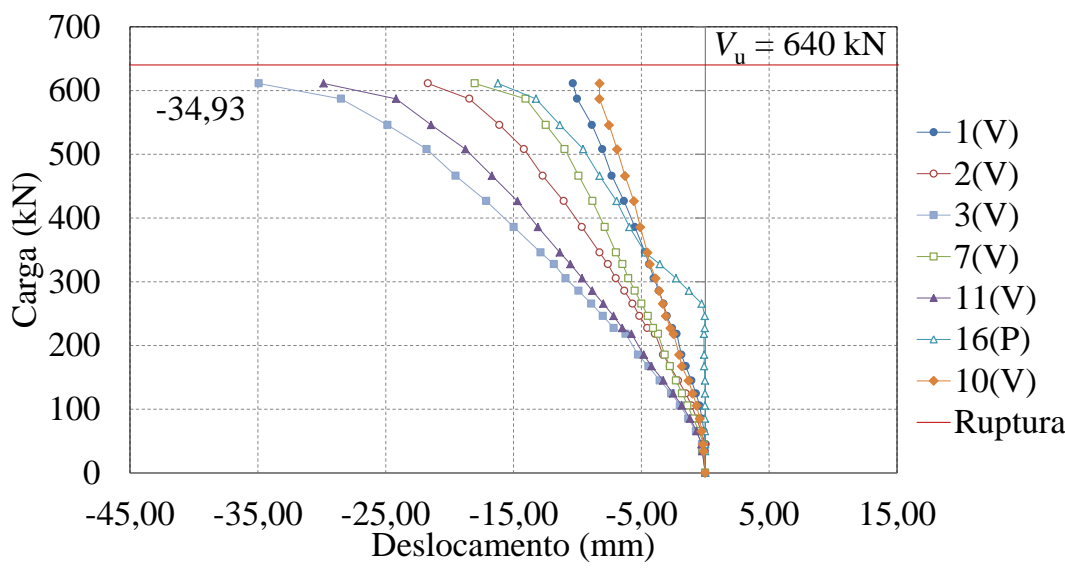

Figura 4.95 - Carga x deslocamento da laje L11

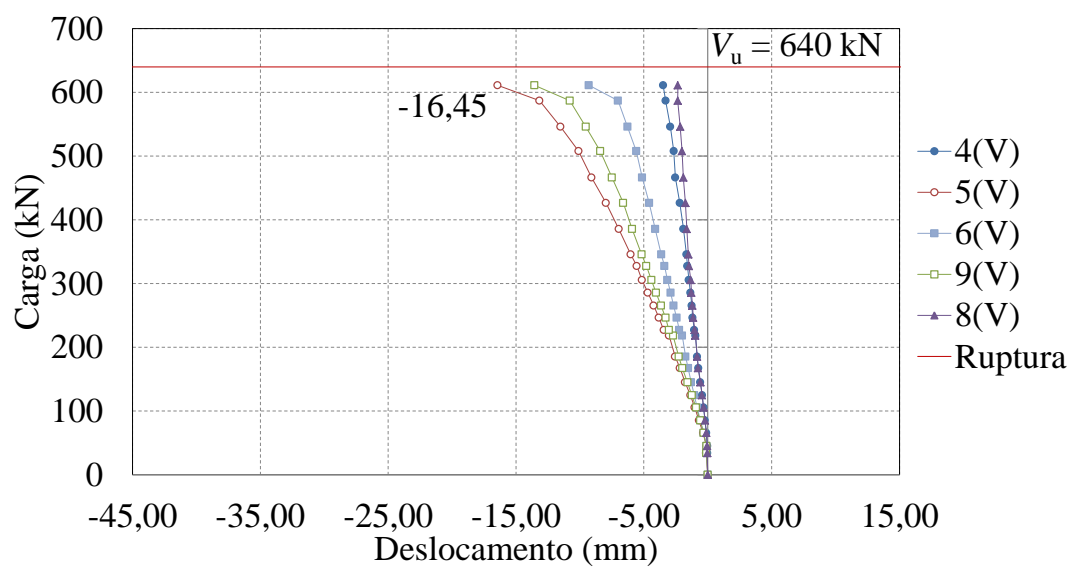

Figura 4.96 - Carga x deslocamento da laje L11

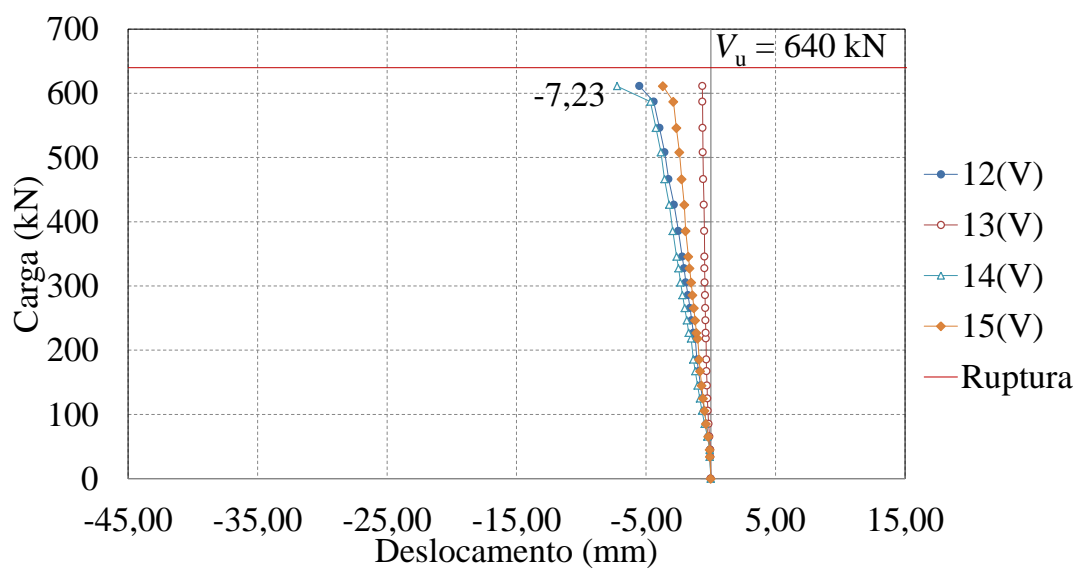

Figura 4.97 - Carga x deslocamento da laje L11 


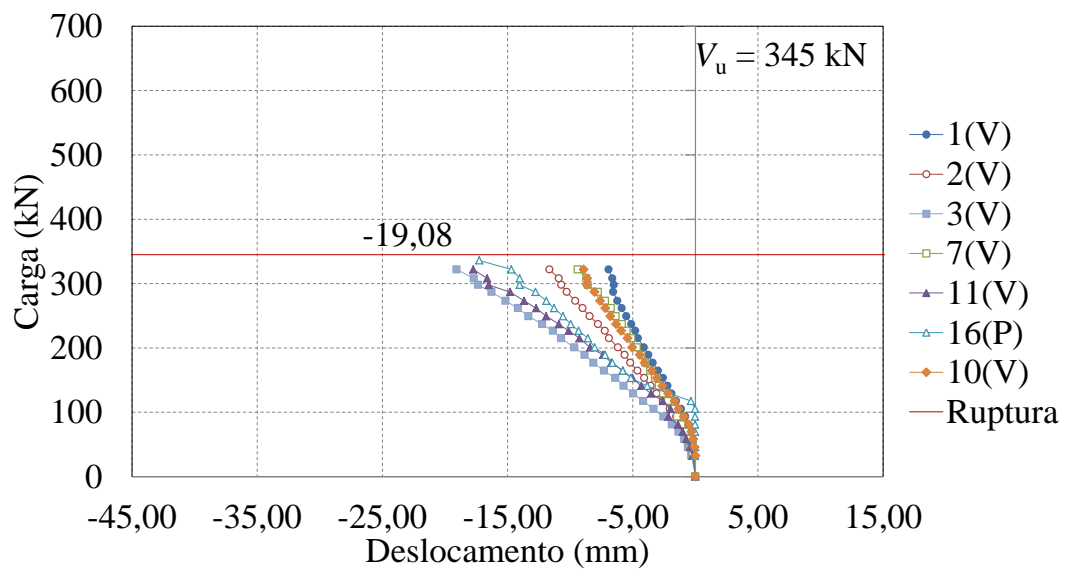

Figura 4.98 - Carga x deslocamento da laje L12

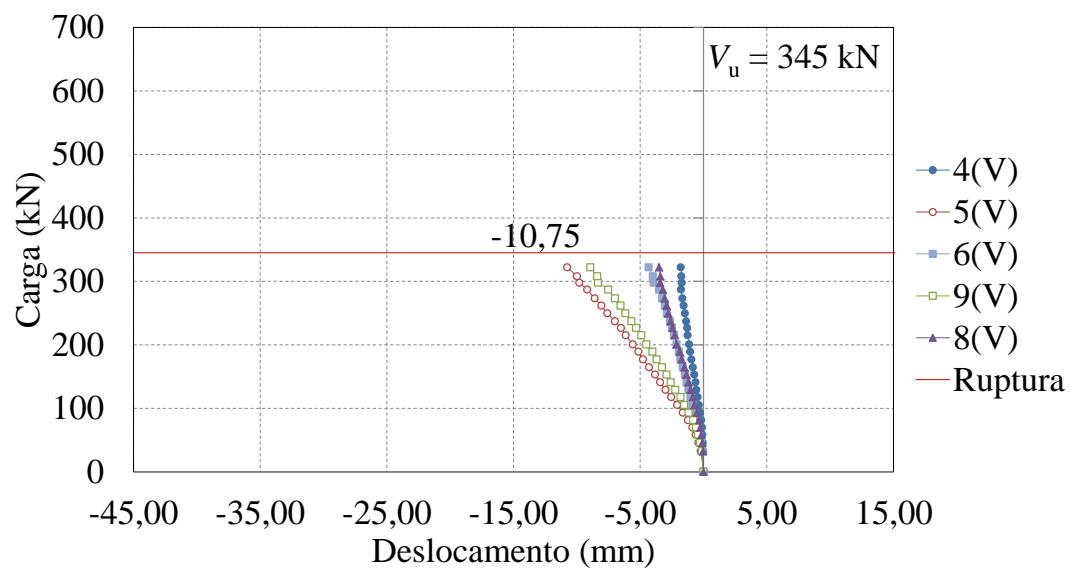

Figura 4.99 - Carga x deslocamento da laje L12

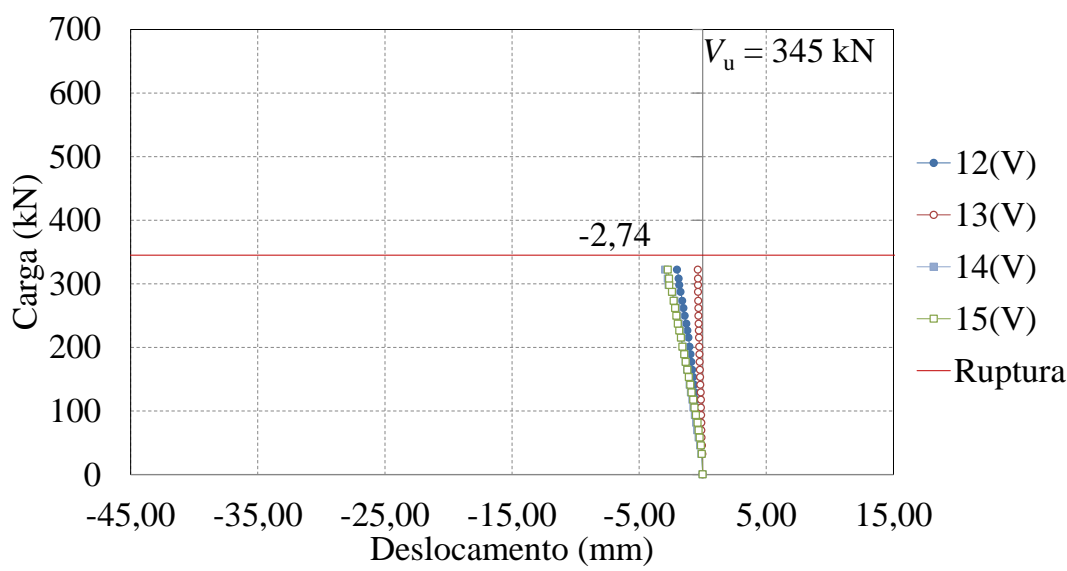

Figura 4.100 - Carga x deslocamento da laje L12 
Os gráficos de deslocamentos das lajes mostram que apesar do ensaio não ter sido com aplicação de carga contínua, o comportamento é efetivamente contínuo do início da aplicação de cargas até à ruptura das lajes. Próximo à ruptura, enquanto as deformações das lajes aumentavam foi necessário reduzir a velocidade de aplicação da carga para a retirada dos LVDT's apoiados na parte inferior e em seguida aumentava-se a velocidade de carga novamente.

Acredita-se que as leituras do potenciômetro (ponto 16) das Lajes L05 e L06 não são confiáveis, pois tiveram leituras baixas e incoerentes com o esperado que divergem do padrão ilustrado pelos gráficos na direção SO-NE.

$\mathrm{O}$ comportamento dos gráficos carga $\mathrm{x}$ deslocamento mostra pequenos deslocamentos ascendentes atingindo cerca de máximo $10 \mathrm{~mm}$ nos pontos $1,4,8$ e 10 próximo ao bordo reentrante nas Lajes 01,05 e 10 com relação $P_{2} / P_{1}=0,5$.

A relação de carga x deslocamento mostra que no ponto 14 , próximo ao canto interno do pilar, o deslocamento aumenta com o incremento de carga, tornando-se relativamente grande, imediatamente antes da carga máxima de ruptura da laje. No ponto 12 e 15, perto do canto do pilar, os deslocamentos são sempre menores, cerca de metade daqueles no ponto 14, para a maior parte das cargas. Já no ponto13 localizado no canto externo do pilar, na reentrância, o deslocamento é praticamente nulo, tendendo a levantar o bordo nos casos com momentos maiores (L01, L05 e L10).

Os resultados das medições nos pontos 14, 12 e 13 mostram que a superfície de ruptura começa no canto interno do pilar e avança ao longo das faces da reentrância com o aumento das cargas. Nas lajes com maiores transferências de momento $\left(\mathrm{P}_{2} / \mathrm{P}_{1}=0,5\right)$ apresentavam efeitos relacionados aos esforços de torção caracterizados pela intensidade de deslocamentos no ponto 13.

Serão apresentados a seguir gráficos carga x rotação das lajes nas direções S-N (eixo de simetria que vai do canto interno da coluna até o bordo da laje) e NE-SO da Figura 4.101 à Figura 4.112. 


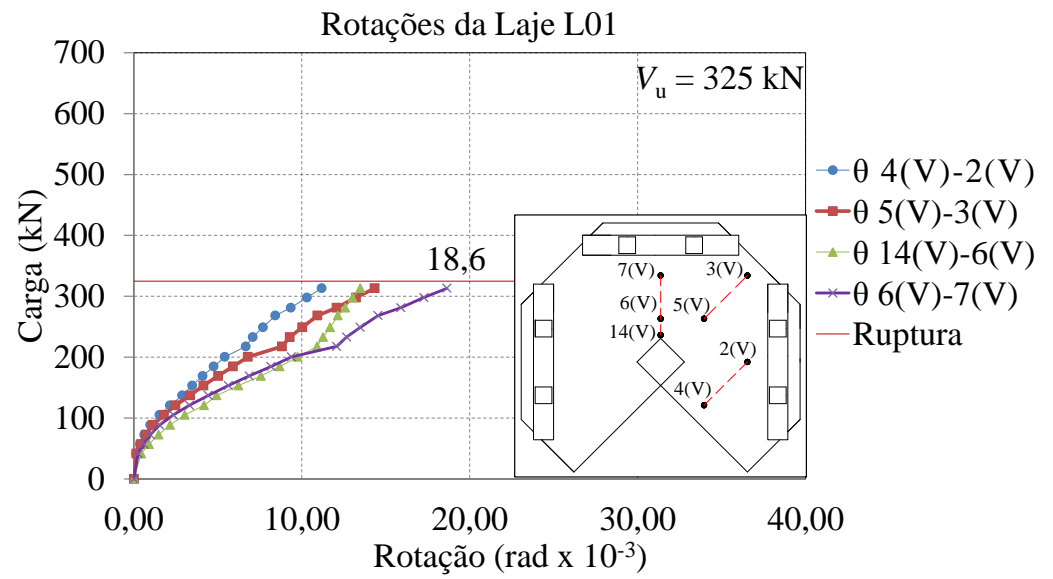

Figura 4.101 - Carga x rotação da laje L01 na direção S-N e NE-SO

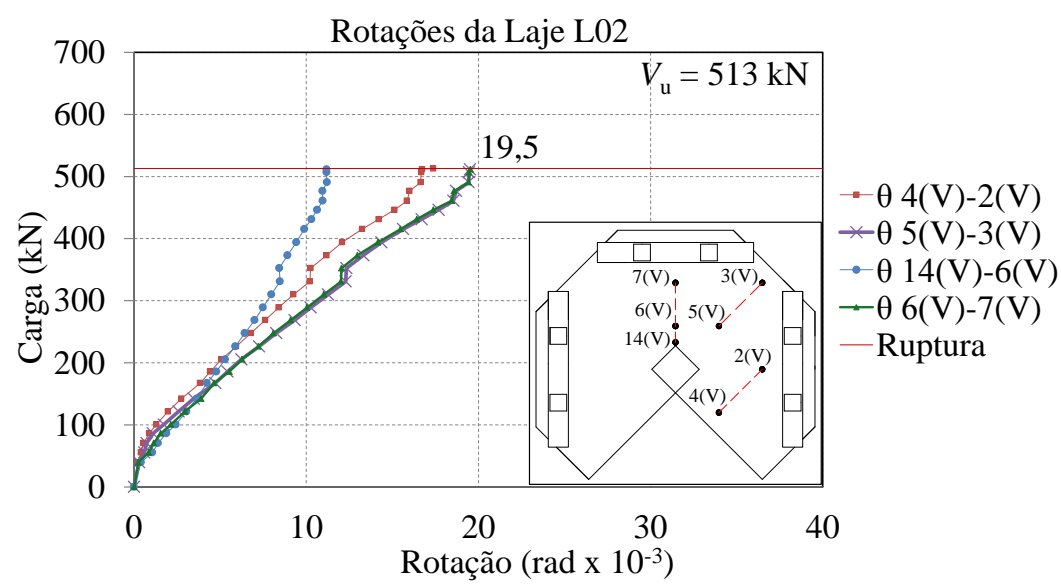

Figura 4.102 - Carga x rotação da laje L02 na direção S-N e NE-SO

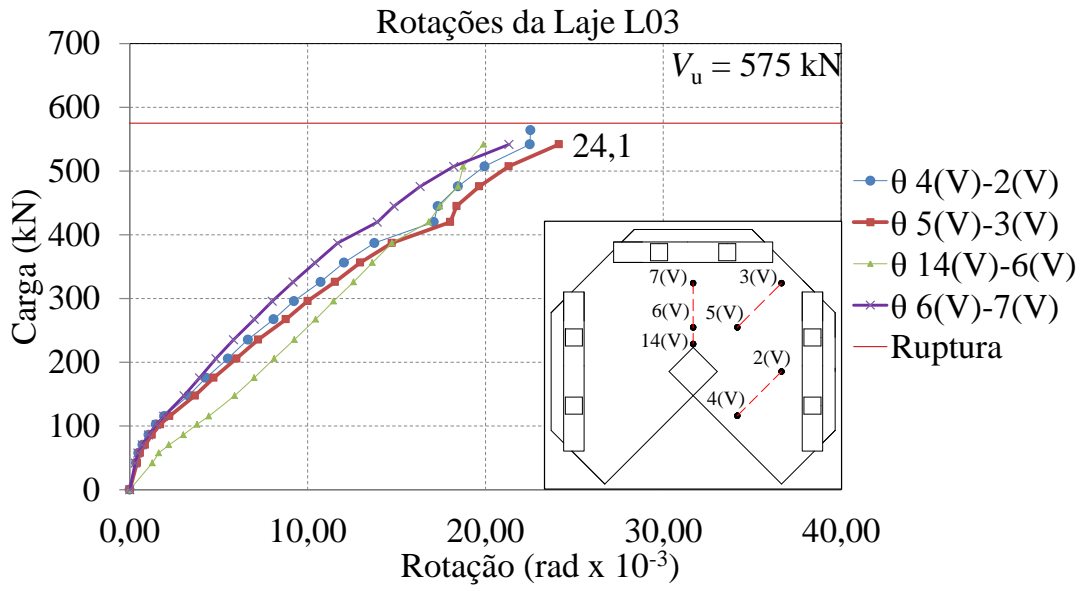

Figura 4.103 - Carga x rotação da laje L03 na direção S-N e NE-SO 


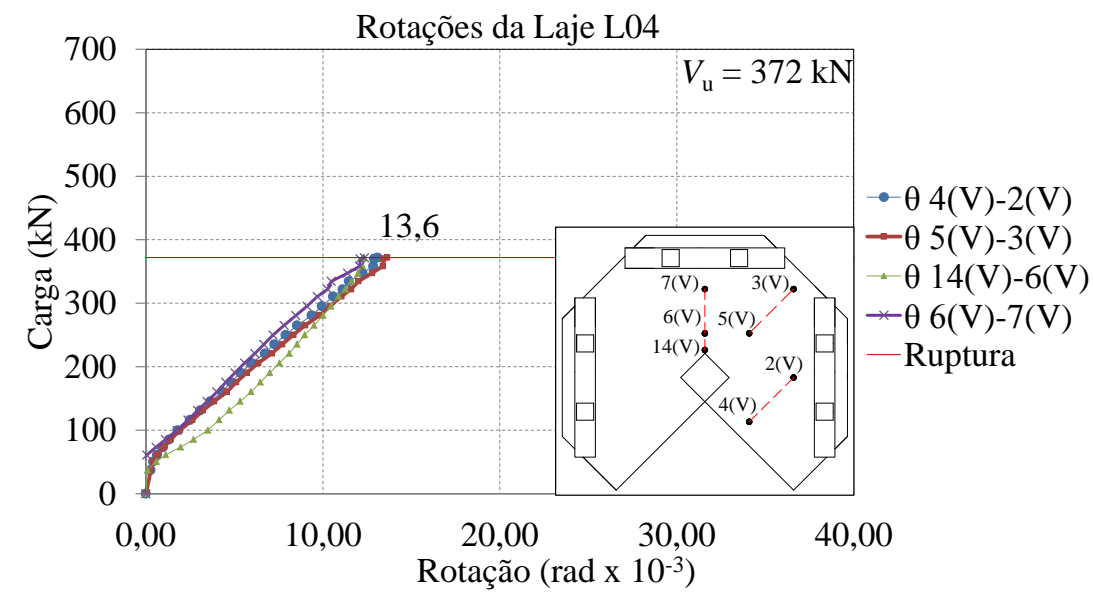

Figura 4.104 - Carga x rotação da laje L04 na direção S-N e NE-SO

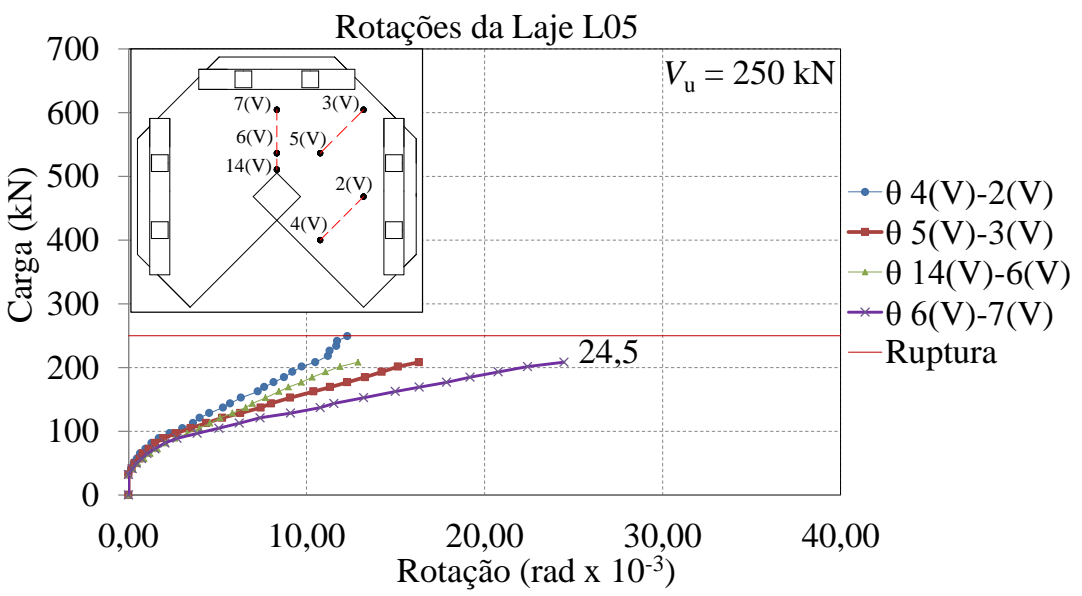

Figura 4.105 - Carga x rotação da laje L05 na direção S-N e NE-SO

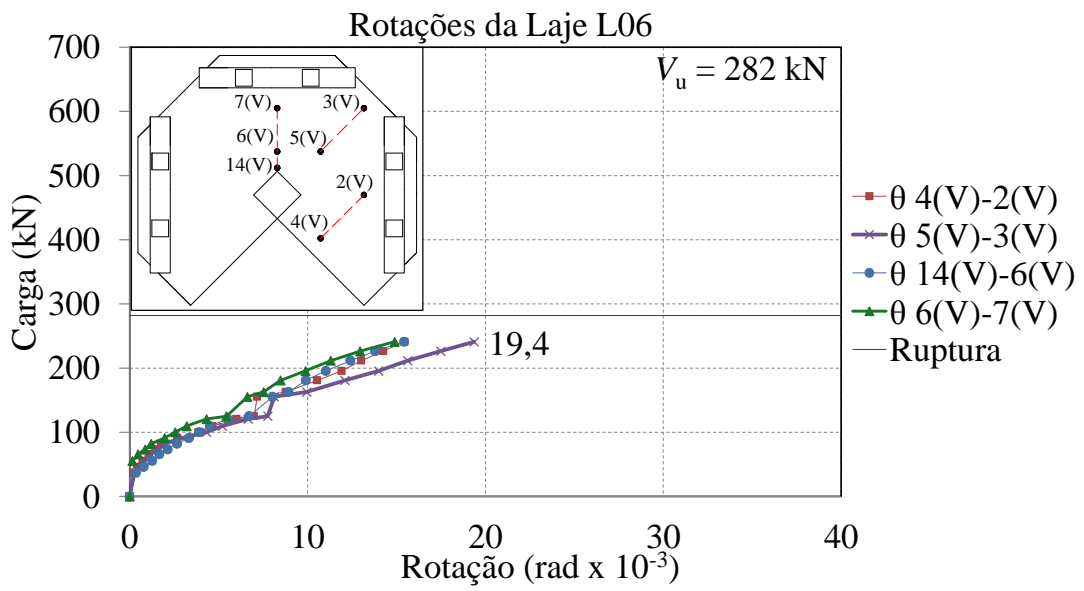

Figura 4.106 - Carga x rotação da laje L06 na direção S-N e NE-SO 


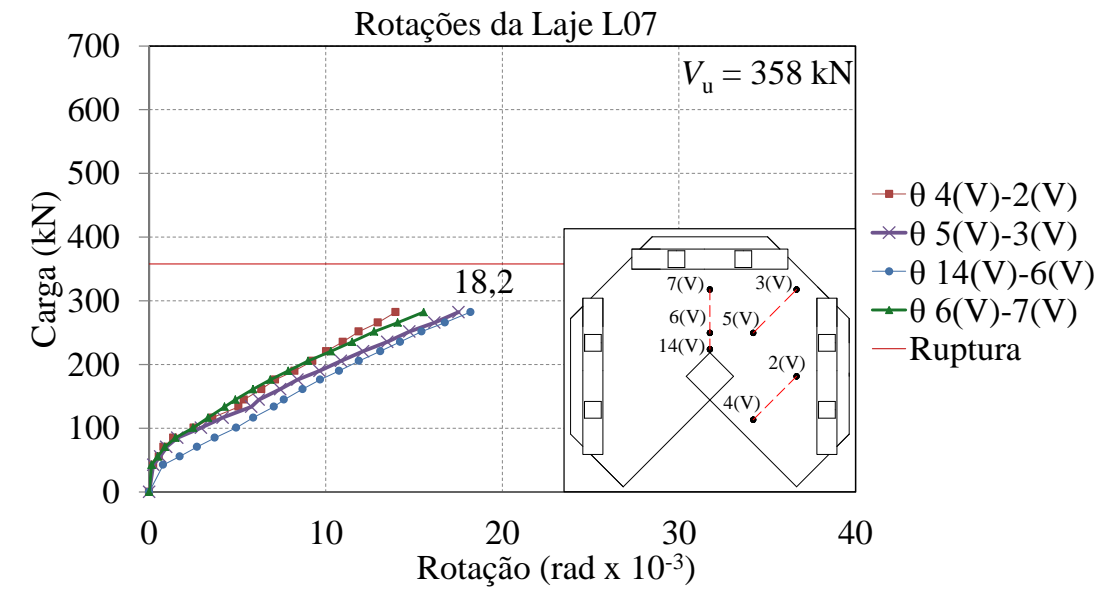

Figura 4.107 - Carga x rotação da laje L07 na direção S-N e NE-SO

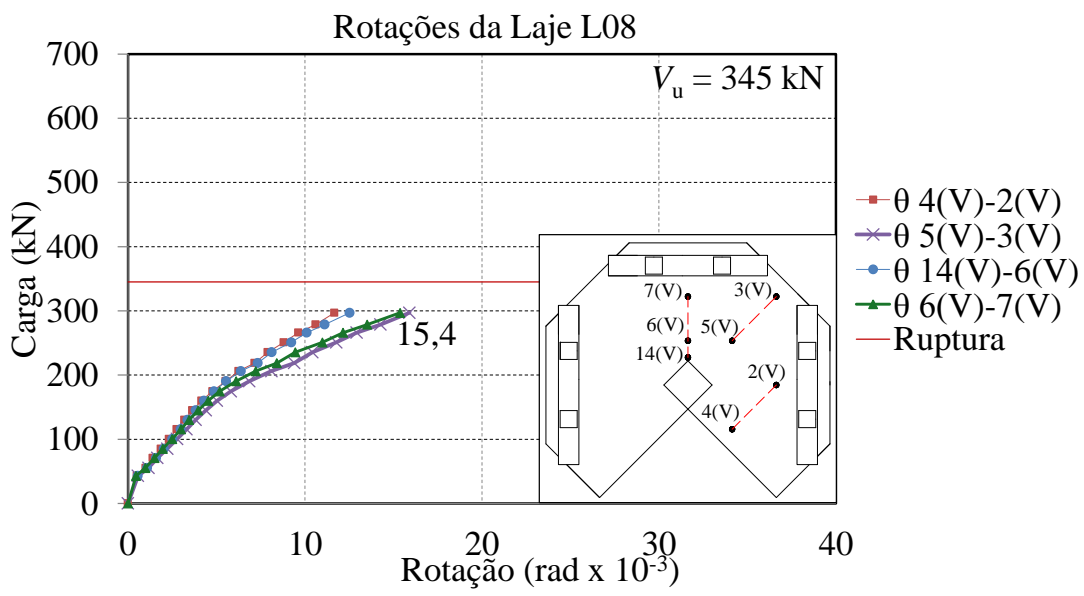

Figura 4.108 - Carga x rotação da laje L08 na direção S-N e NE-SO

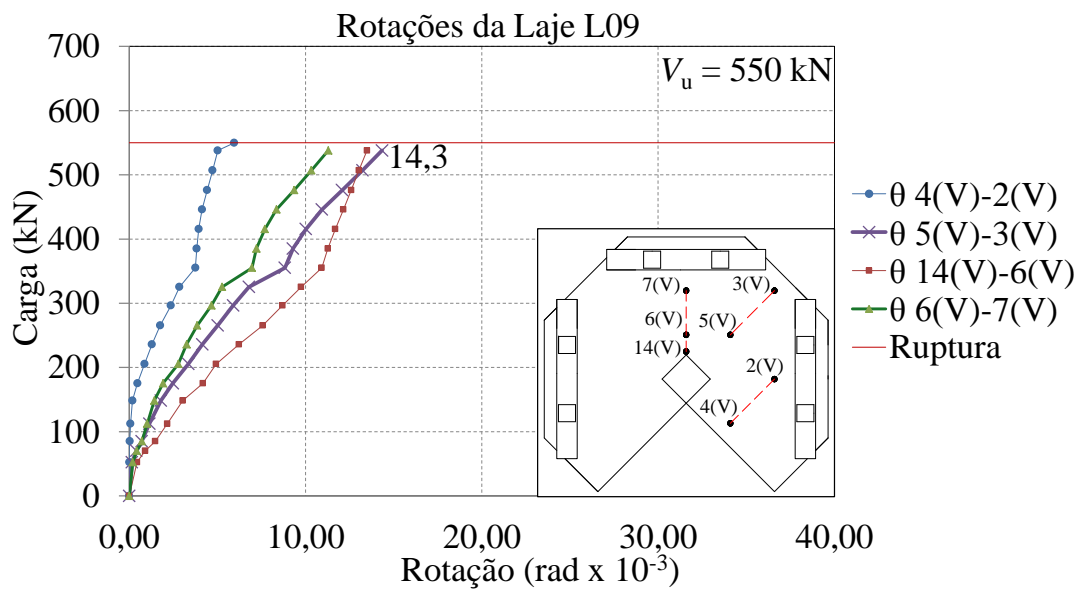

Figura 4.109 - Carga x rotação da laje L09 na direção S-N e NE-SO 


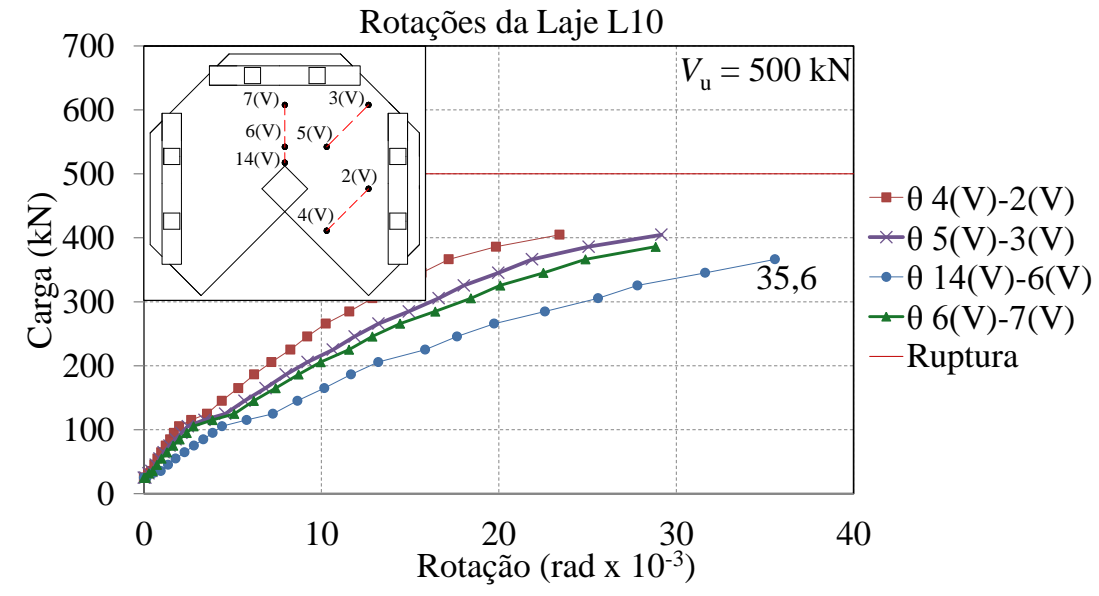

Figura 4.110 - Carga x rotação da laje L10 na direção S-N e NE-SO

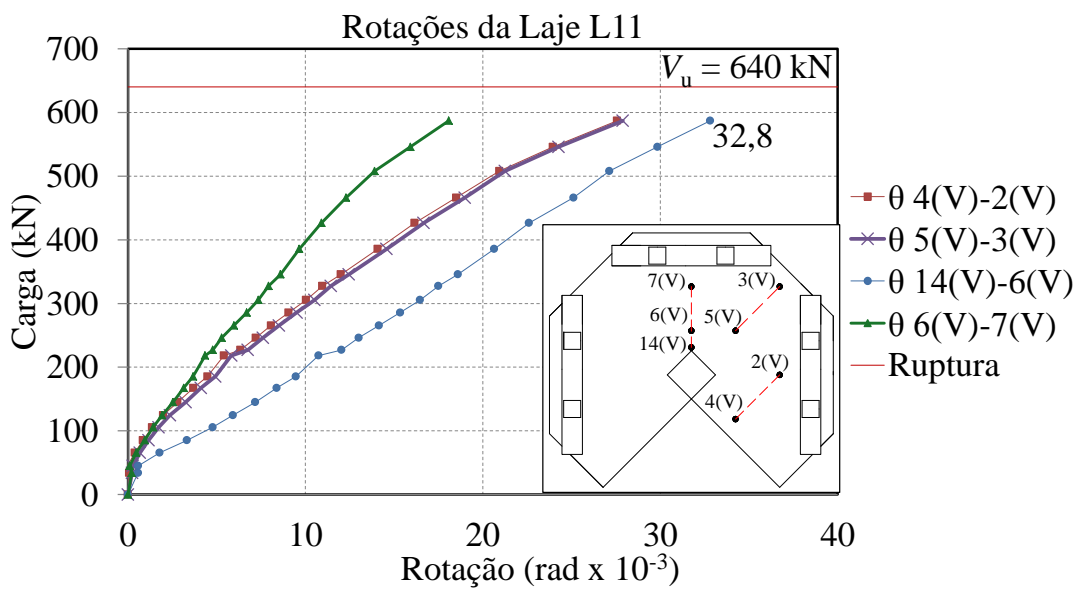

Figura 4.111 - Carga x rotação da laje L11 na direção S-N e NE-SO

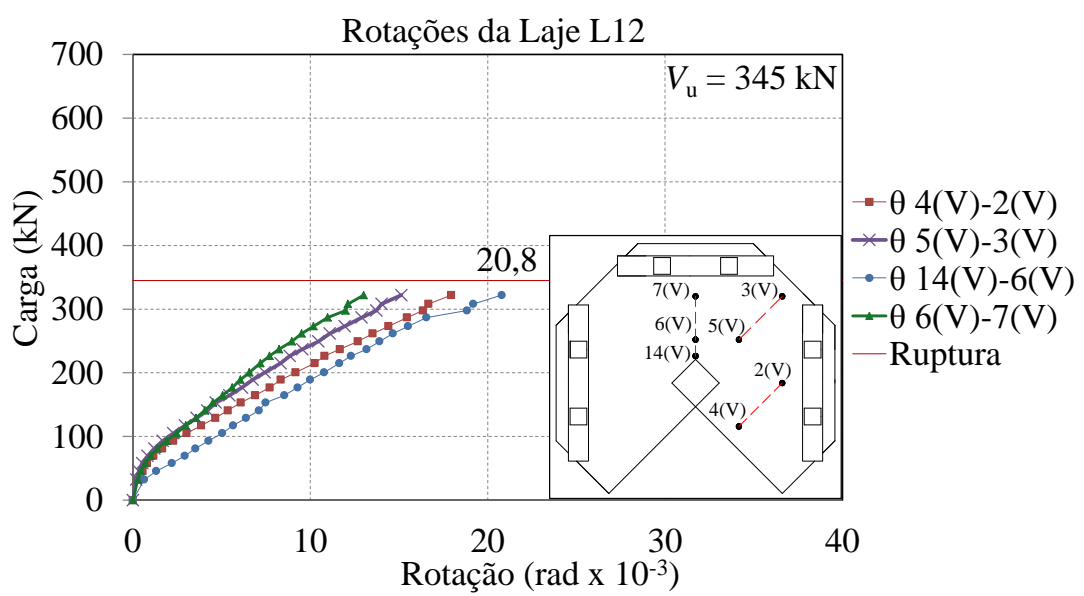

Figura 4.112 - Carga x rotação da laje L12 na direção S-N e NE-SO 
Com os gráficos apresentados pode-se observar nos pontos 14, 6 e 7 que as rotações máximas ocorreram sempre nos pontos mais próximos aos pilares (entre os pontos 14 e 6), e as rotações reduziam em direção às bordas da laje.

As intensidades das rotações no eixo de simetria (S-N) $\theta_{14,6}$ e $\theta_{6,7}$ são similares, para valores baixos de cargas $(100 \mathrm{kN})$, e para valores maiores de carga, as rotações máximas localizam-se entre esses pontos variando com as eventuais fissuras que surgem no decorrer do carregamento, ou seja, com o aumento do momento no sentido oposto a reentrância.

As outras rotações foram feitas em torno de um eixo perpendicular ao bordo reentrante em duas seções. A rotação $\left(\theta_{4,2}\right)$, medida a $150 \mathrm{~mm}$ a partir da borda reentrante, apresentou valores sempre menores do que a rotação $\left(\theta_{5,3}\right)$ localizada paralela à $\theta_{4,2}$ mais para o interior da laje, pois a excentricidade atua mais na região dos pontos 5 e 3 do que dos pontos 4 e 2 .

A Figura 4.113 e Figura 4.114 apresentam uma comparação entre as lajes do Grupo 1 (sem armadura de cisalhamento) para os deslocamentos médios calculados a partir das leituras nos pontos mais ao bordo das lajes (pontos 17 e 18) medidos com escalas. Já a Figura 4.115 e Figura 4.116 apresentam uma comparação entre as lajes do Grupo 2 (com armadura de cisalhamento) para os deslocamentos médios calculados a partir das leituras nos pontos mais ao bordo das lajes (pontos 17 e 18) medidos com escalas.

Como estas lajes possuíam excentricidades e taxas de armadura de flexão $\rho$ diferentes, pode-se observar que o comportamento carga x deslocamento variou.

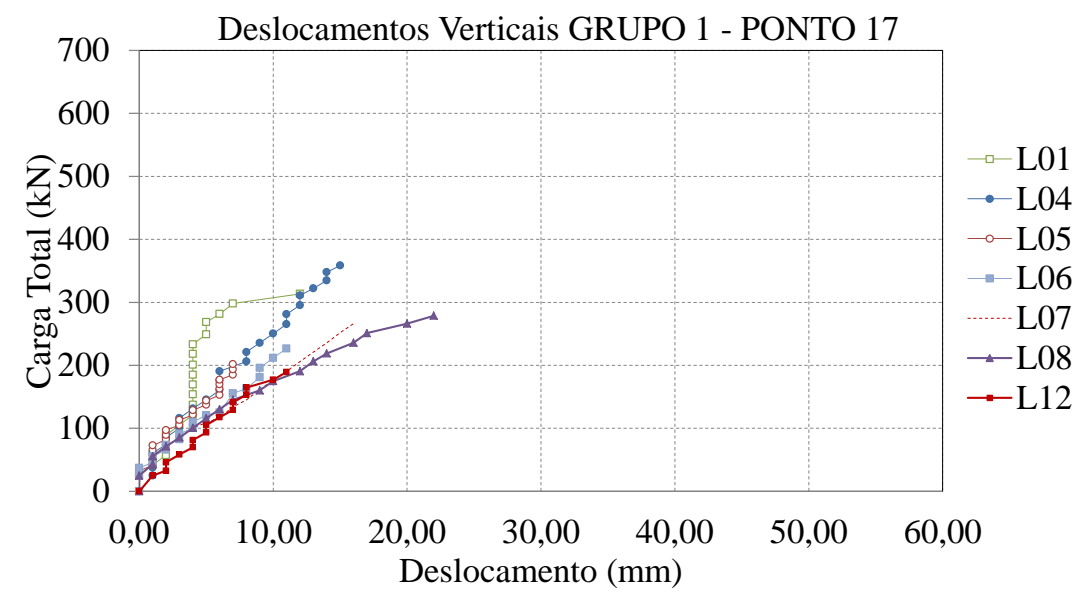

Figura 4.113 - Carga x deslocamento do ponto 17 das lajes do Grupo 1 


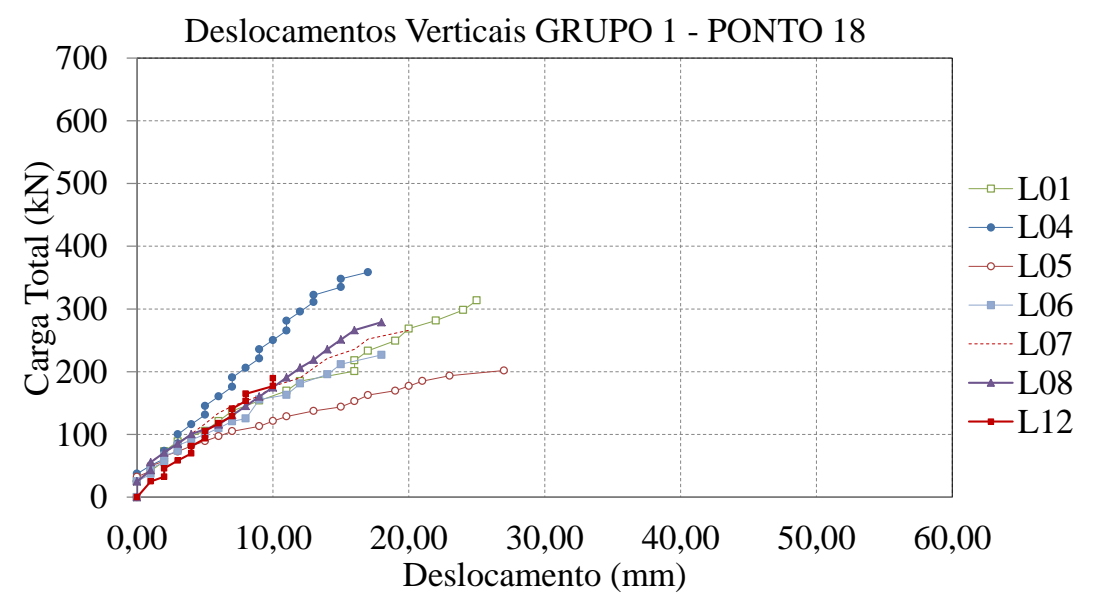

Figura 4.114 - Carga x deslocamento do ponto 18 das lajes do Grupo 1

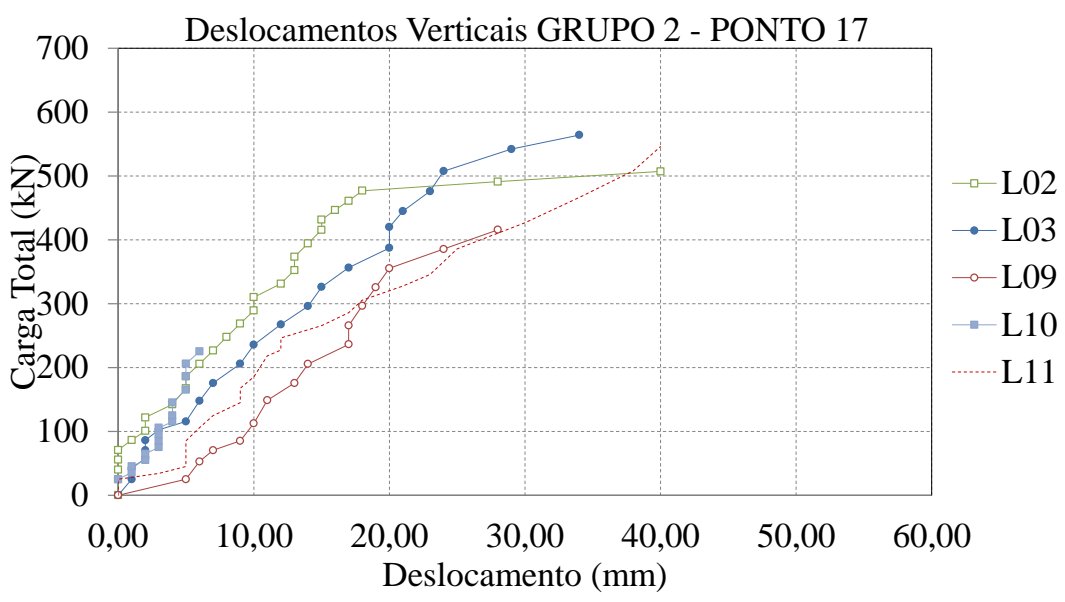

Figura 4.115 - Carga x deslocamento do ponto 17 das lajes do Grupo 2

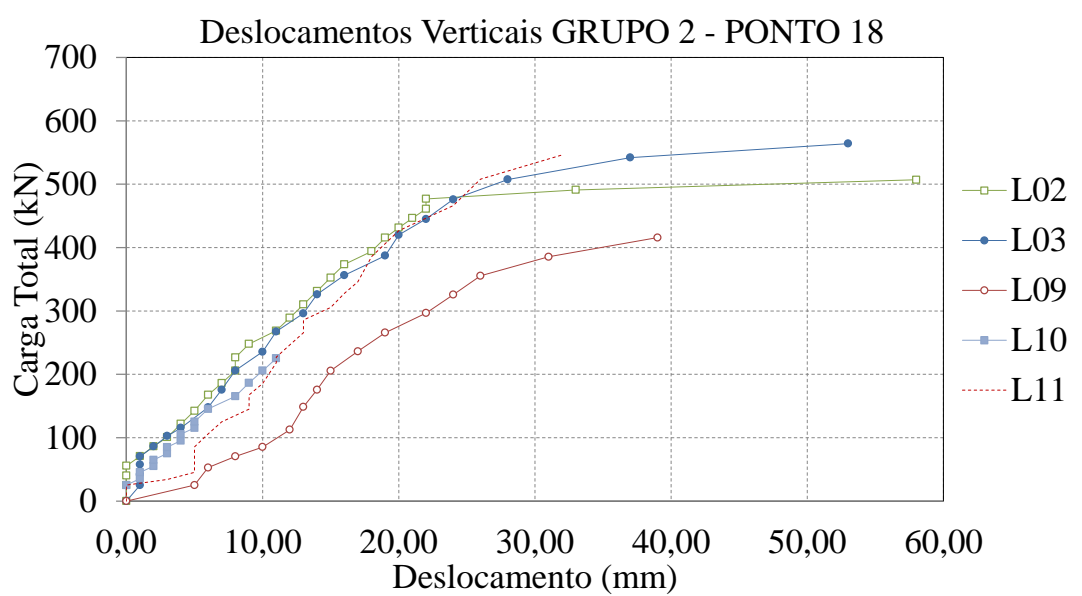

Figura 4.116 - Carga x deslocamento do ponto 18 das lajes do Grupo 2 


\subsection{DEFORMAÇÃO NA ARMADURA DE FLEXÃO}

As deformações na armadura de flexão foram monitoradas em pontos diferentes para cada taxa de armadura e série de concretagem como descrito no Capítulo 3.

Da Figura 4.120 até a Figura 4.140 serão apresentados gráficos das deformações nas armaduras de flexão posicionadas na parte superior e inferior da laje (quando houver armadura inferior instrumentada) em função da posição de cada barra, para diferentes estágios de carregamento. Esses gráficos permitem avaliar a distribuição dos esforços de flexão ao longo da seção transversal da laje, facilitando a visualização do quão próximo de uma ruptura por flexão, devido ao escoamento das armaduras, cada laje chegou. Já da Figura 4.120 até a Figura 4.140 serão apresentadas as curvas de carga x deformação para as armaduras de flexão.

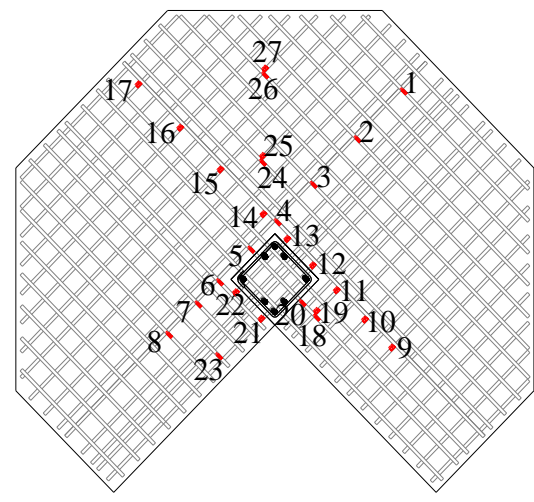

(a) Lajes L01, L02, L03 e L04

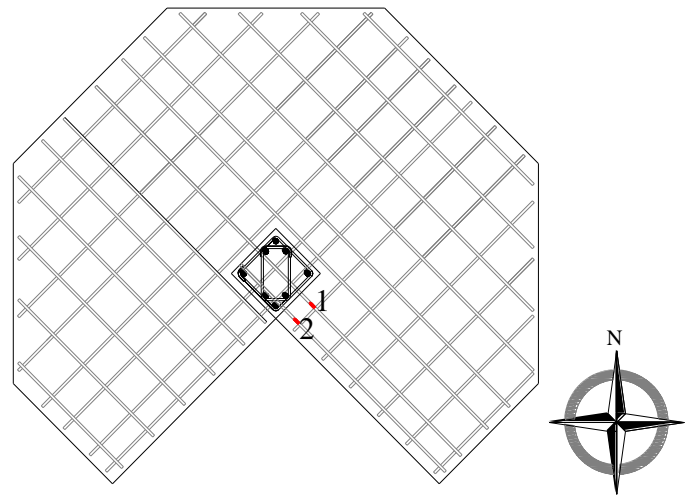

(b) Lajes L01, L02, L03 e L04

Figura 4.117 - Posicionamento dos extensômetros nas armaduras superior (a) e inferior (Série 1)

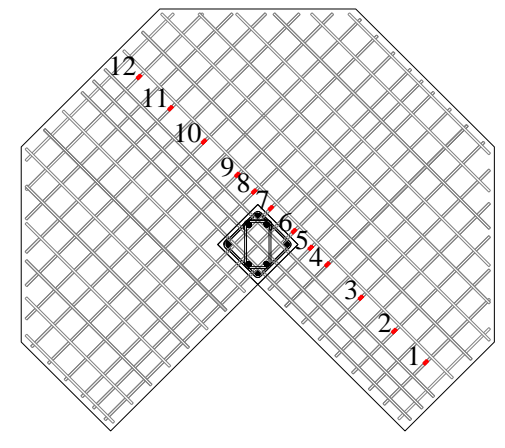

(a) Laje L05 e L06

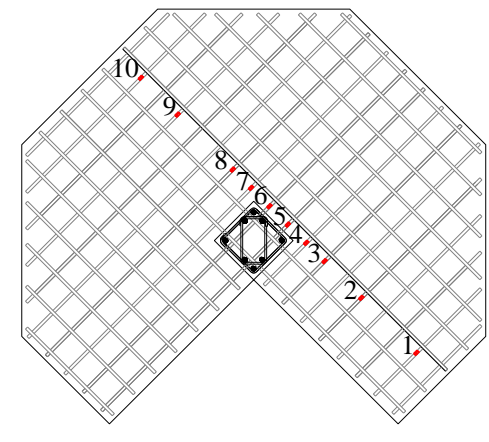

(b) Laje L07

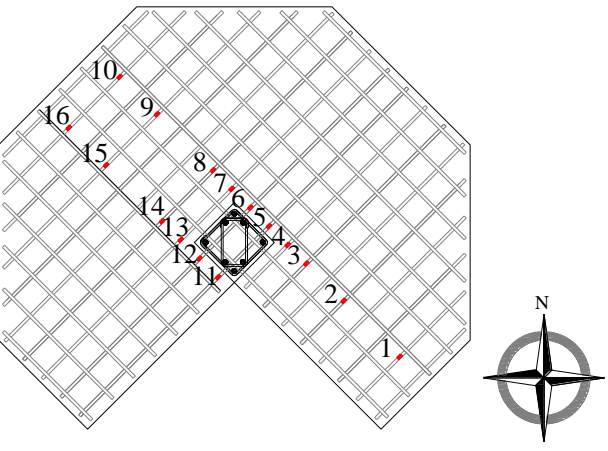

(c) Laje L08

Figura 4.118 - Posicionamento dos extensômetros nas armaduras superior (Série 2) 


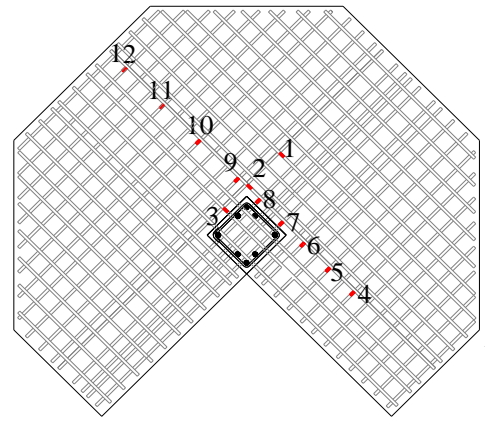

(c) Lajes L09, L10 e L11

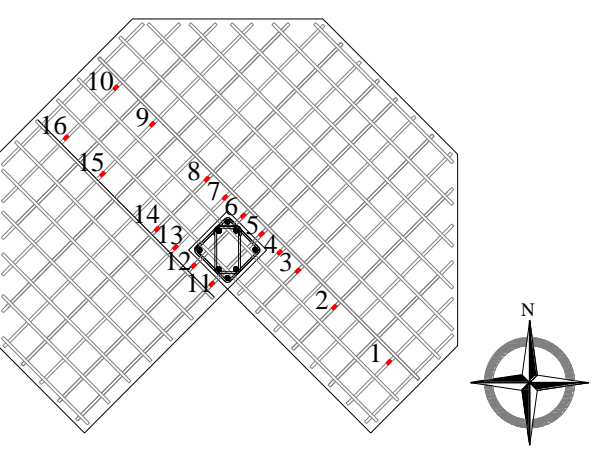

(a) Laje L12

Figura 4.119 - Posicionamento dos extensômetros nas armaduras superior (Série 3)
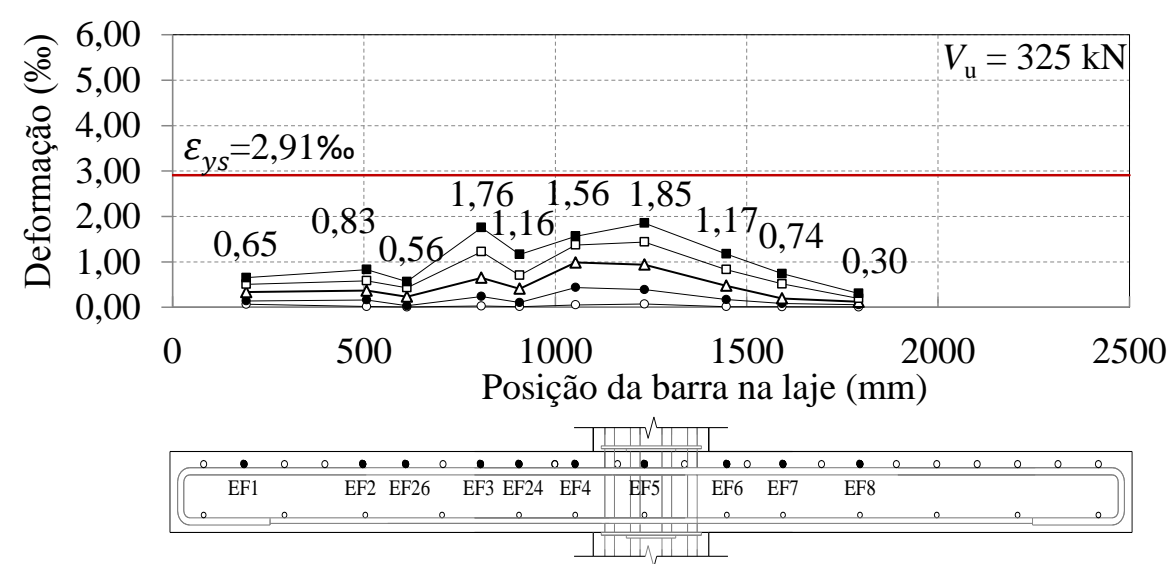

Figura 4.120 - Deformação na armadura de flexão da laje L01

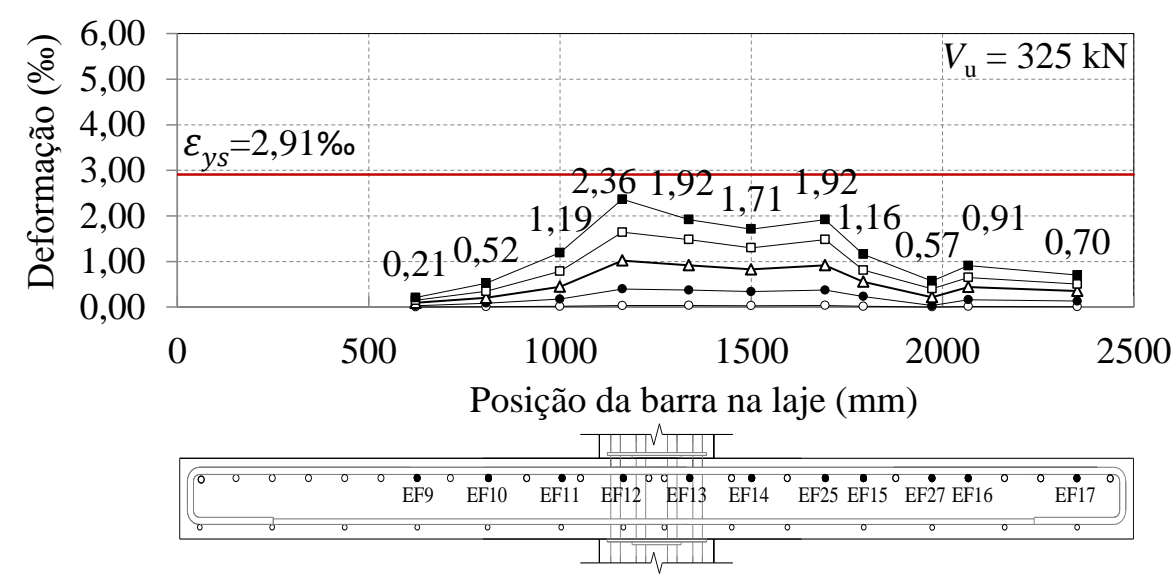

Figura 4.121 - Deformação na armadura de flexão da laje L01 

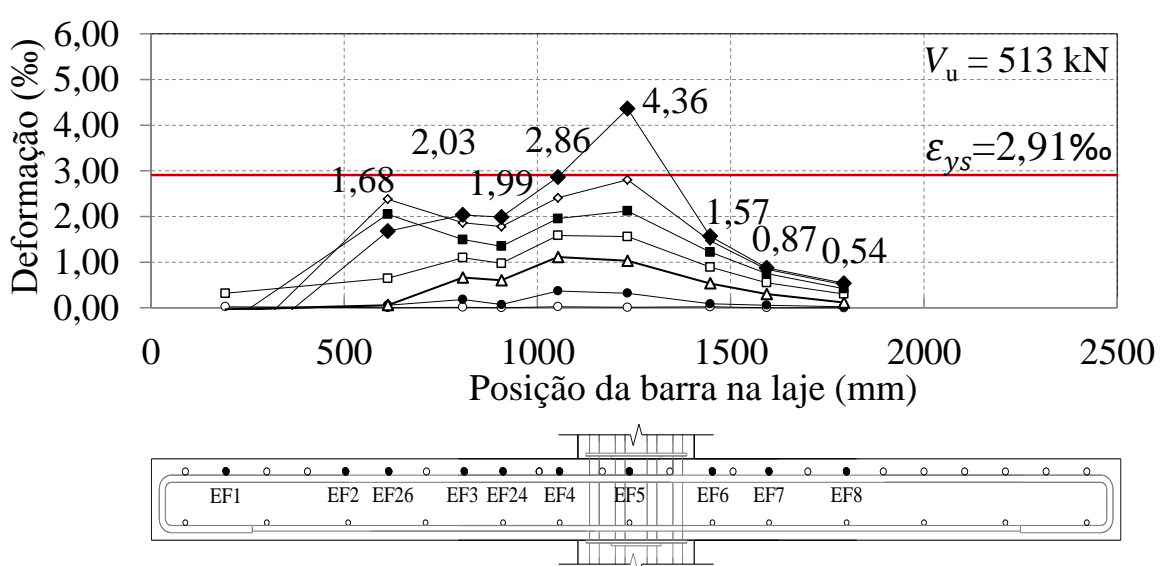

Figura 4.122 - Deformação na armadura de flexão da laje L02

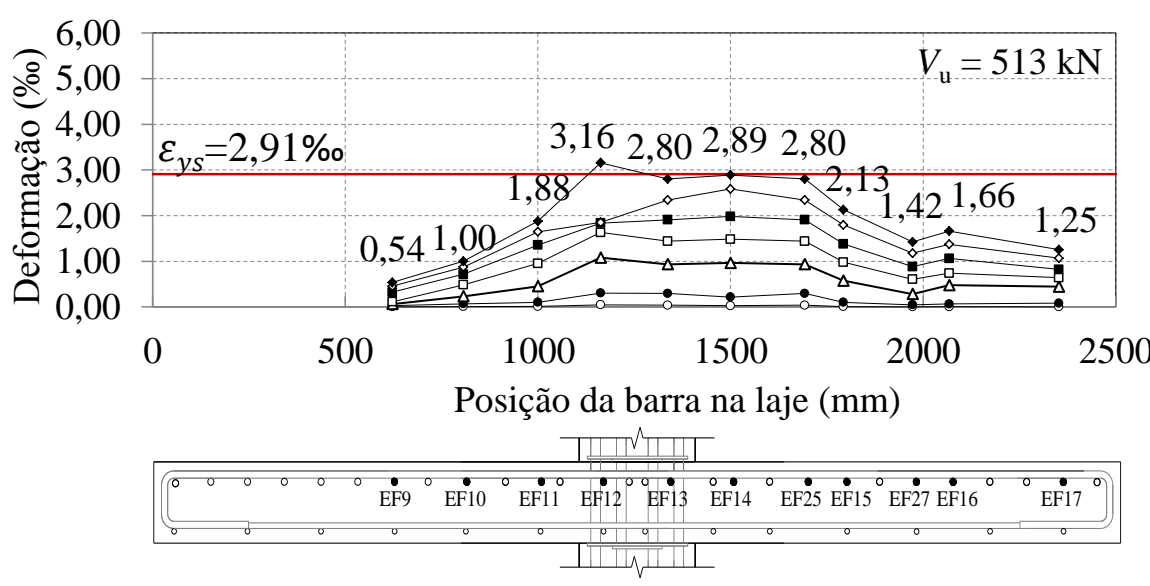

Figura 4.123 - Deformação na armadura de flexão da laje L02

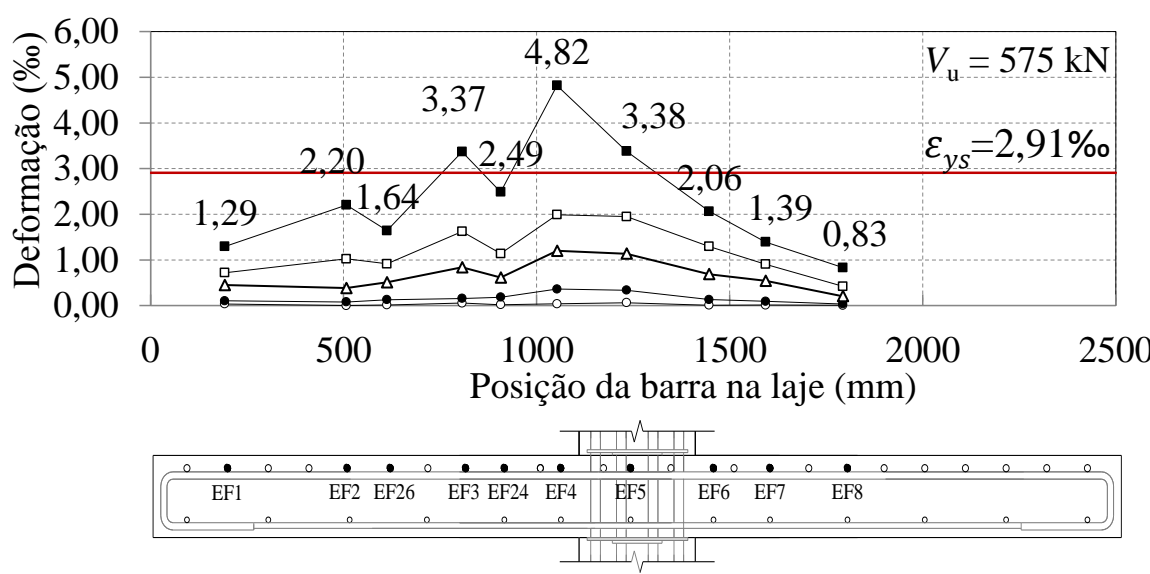

Figura 4.124 - Deformação na armadura de flexão da laje L03 


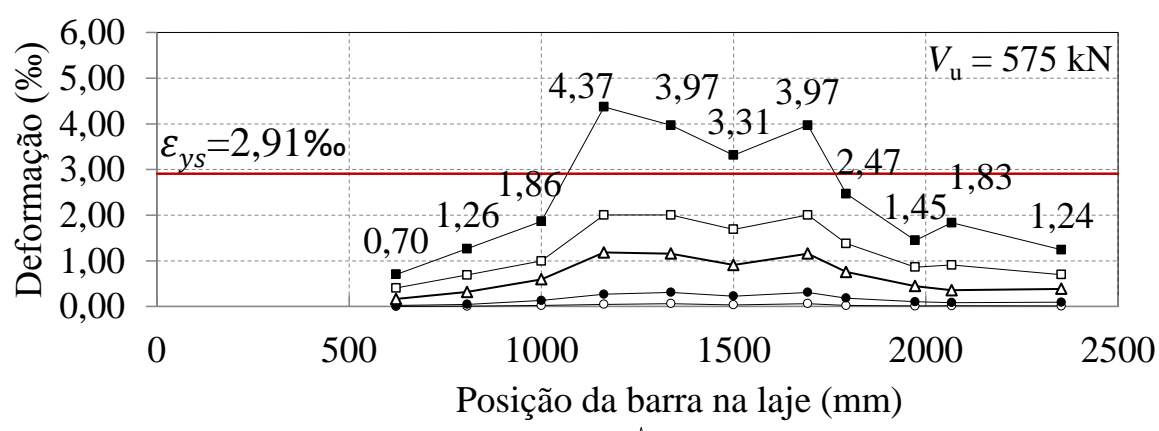

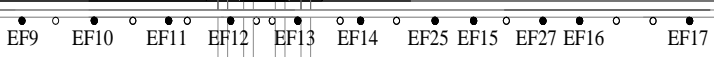

पापाप

Figura 4.125 - Deformação na armadura de flexão da laje L03
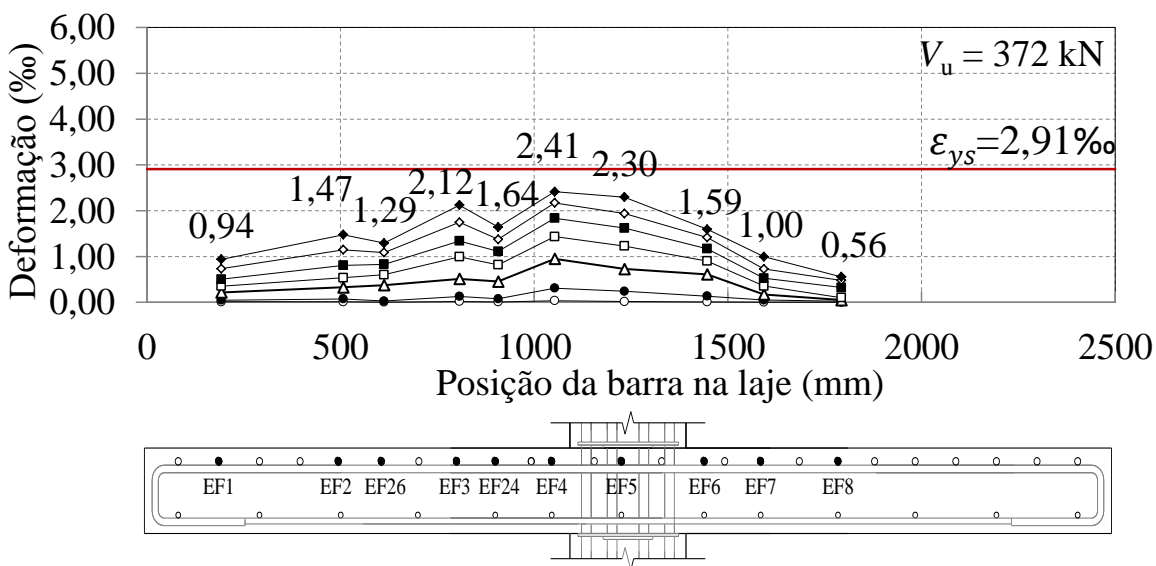

Figura 4.126 - Deformação na armadura de flexão da laje L04

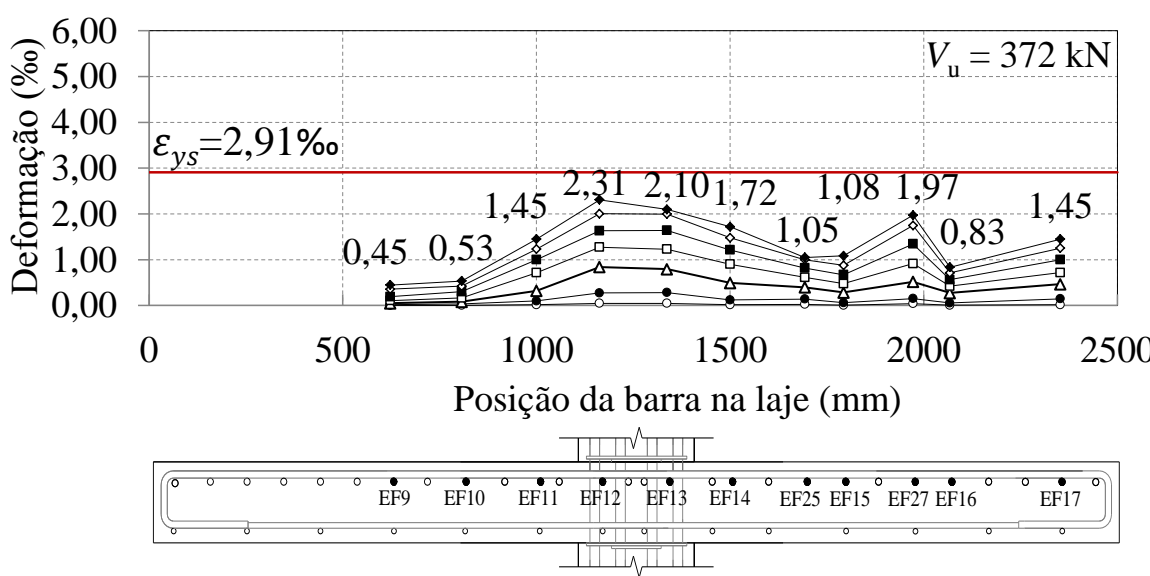

Figura 4.127 - Deformação na armadura de flexão da laje L04 

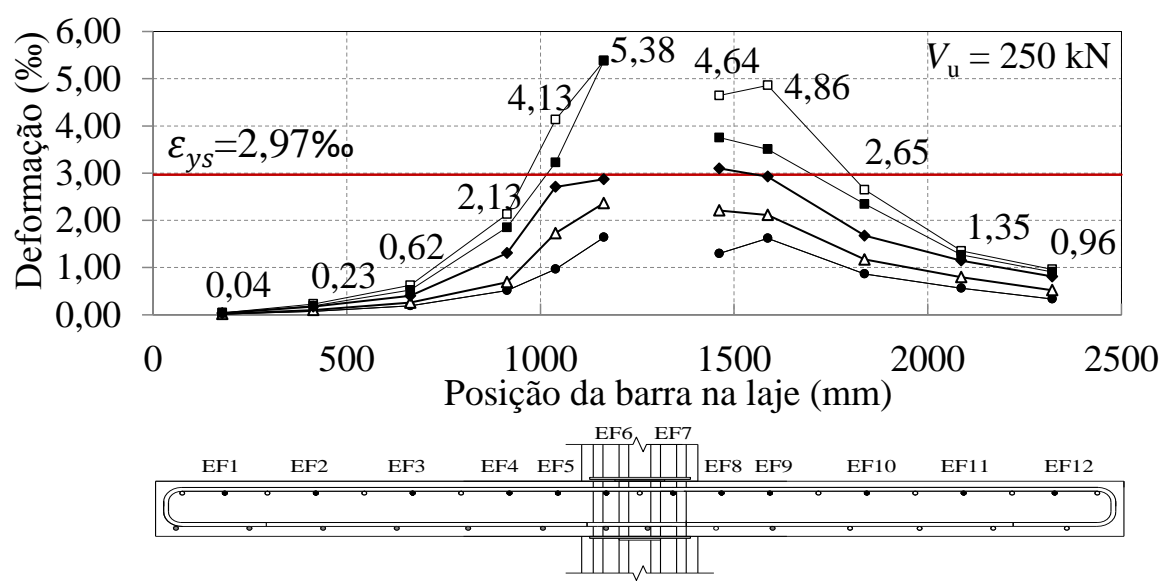

Figura 4.128 - Deformação na armadura de flexão da laje L05

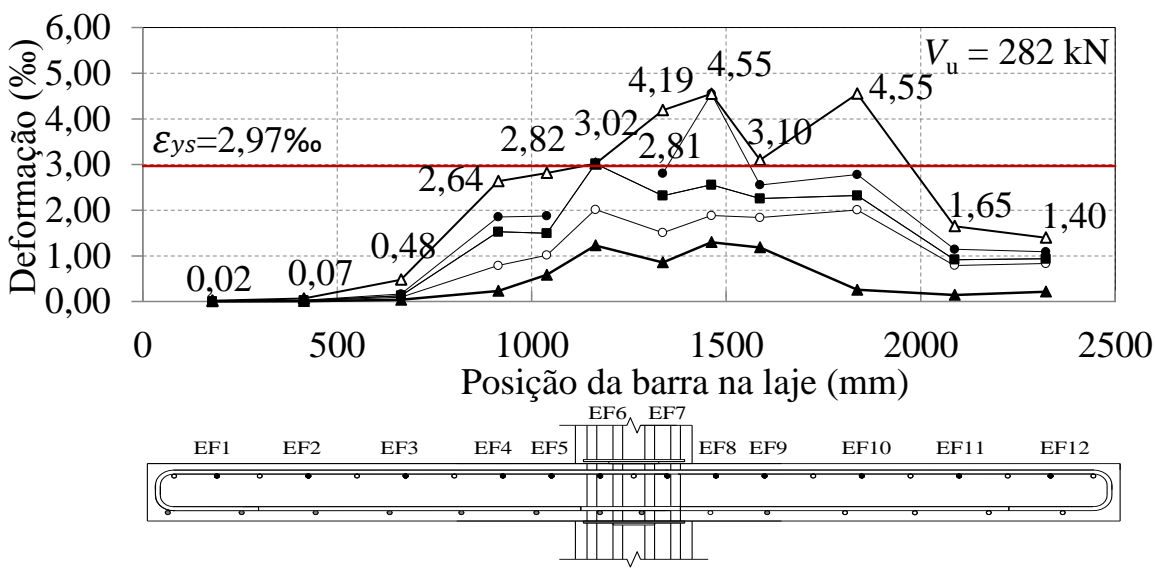

Figura 4.129 - Deformação na armadura de flexão da laje L06

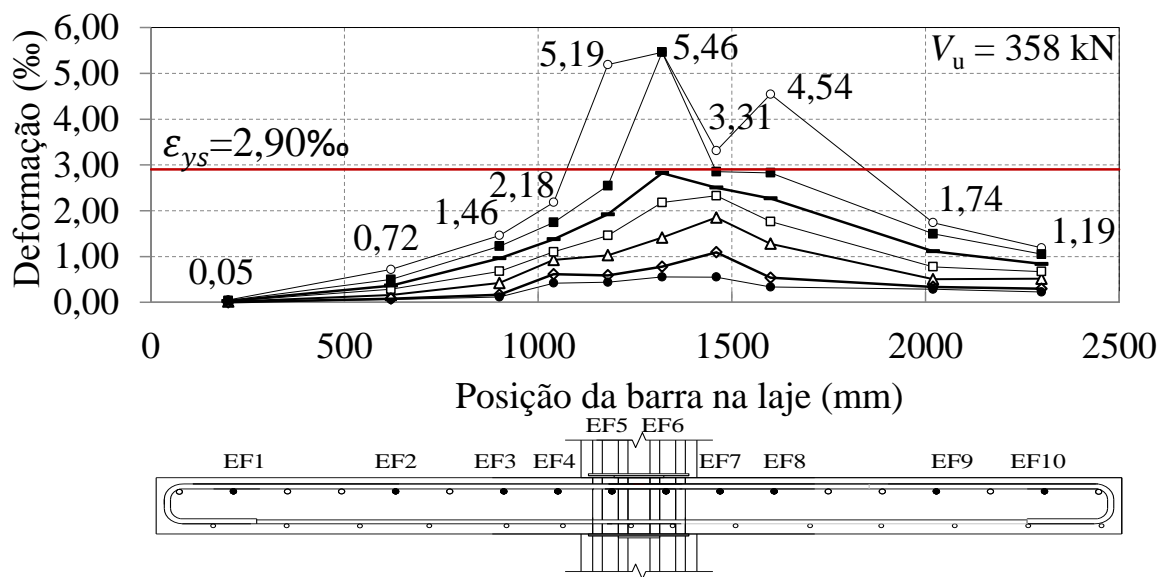

Figura 4.130 - Deformação na armadura de flexão da laje L07 


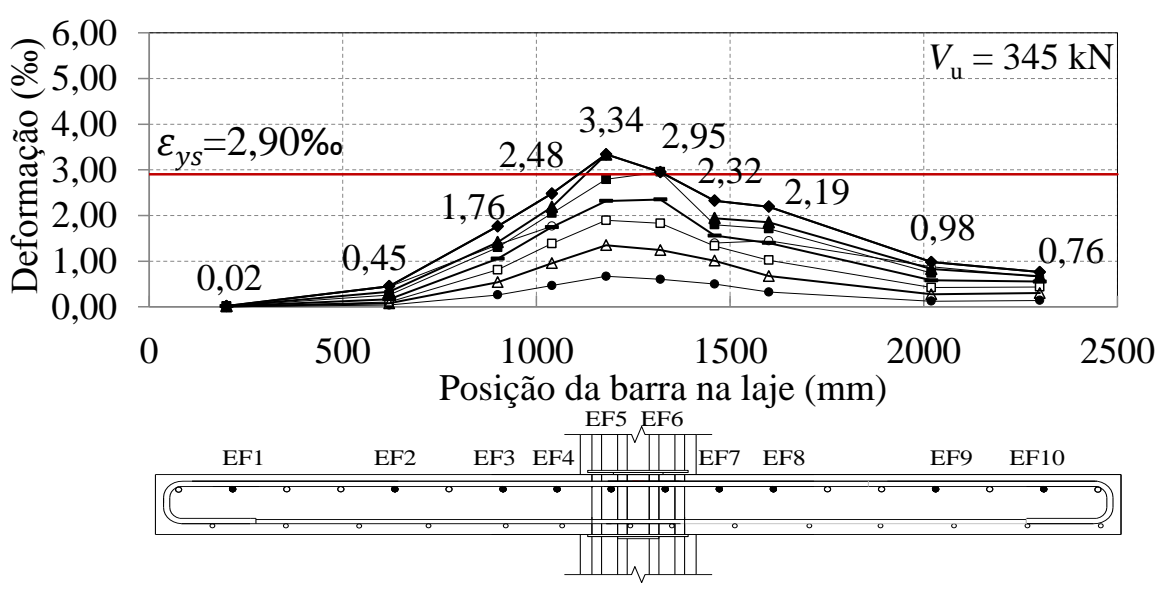

Figura 4.131 - Deformação na armadura de flexão da laje L08

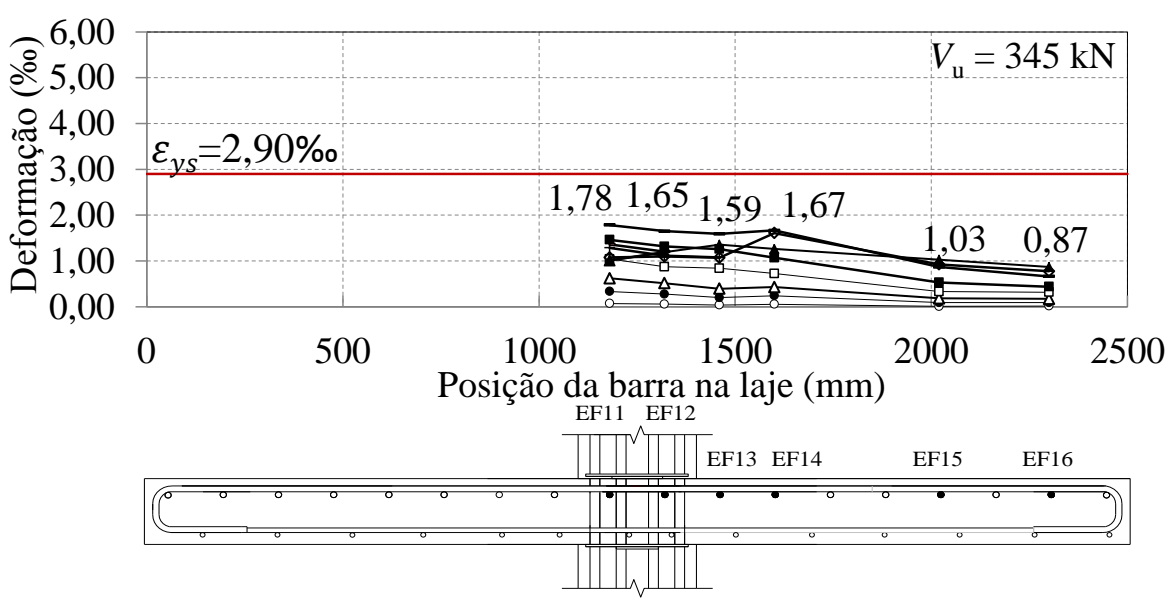

Figura 4.132 - Deformação na armadura de flexão da laje L08

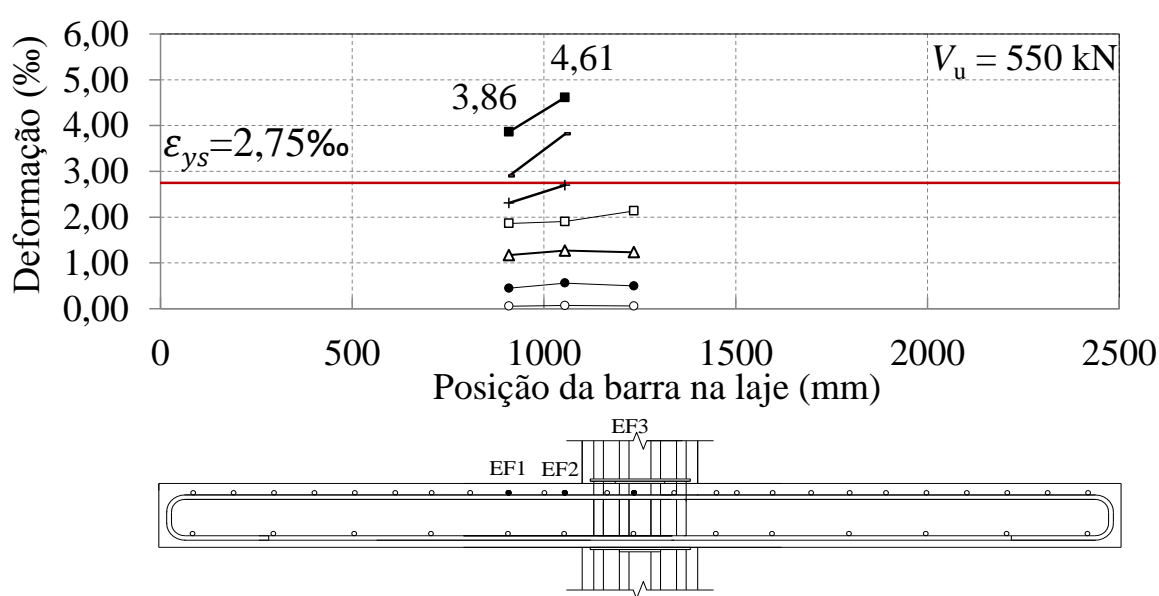

Figura 4.133 - Deformação na armadura de flexão da laje L09 


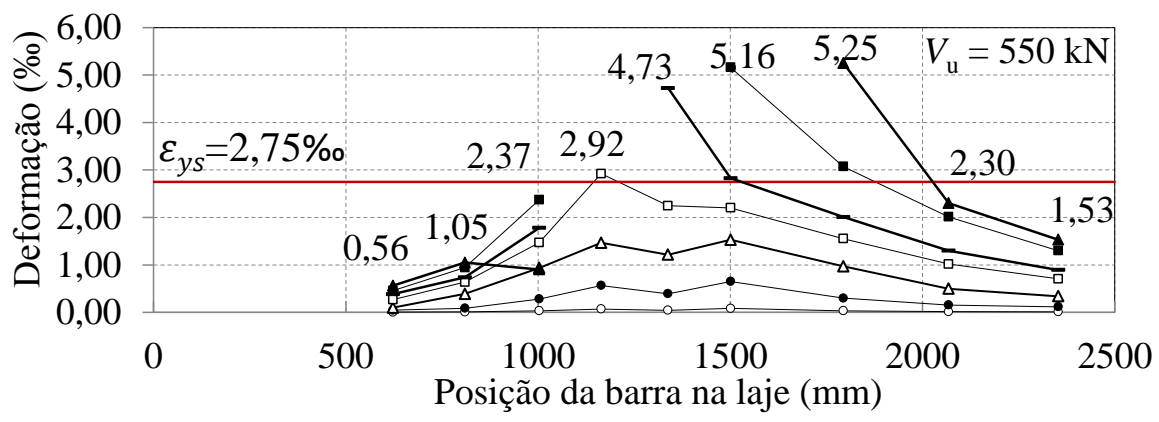

EF7 EF8

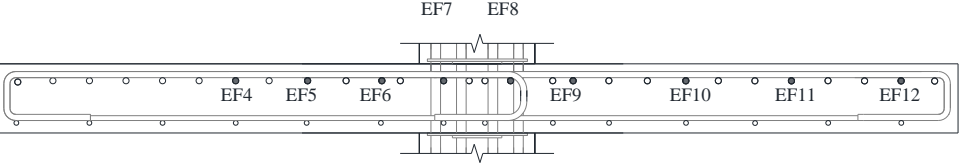

Figura 4.134 - Deformação na armadura de flexão da laje L09
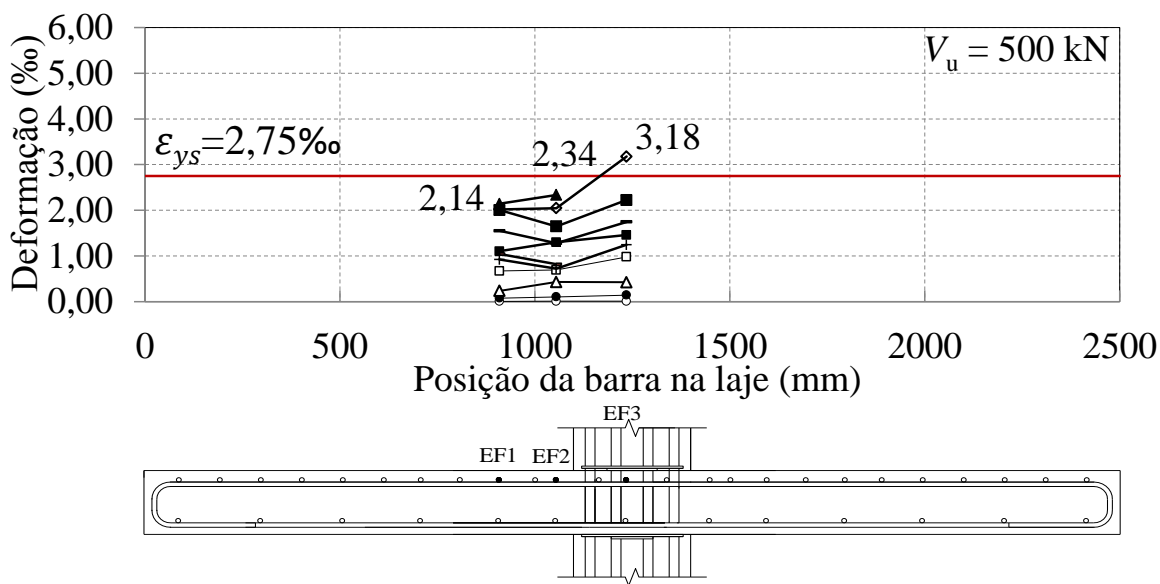

Figura 4.135 - Deformação na armadura de flexão da laje L10

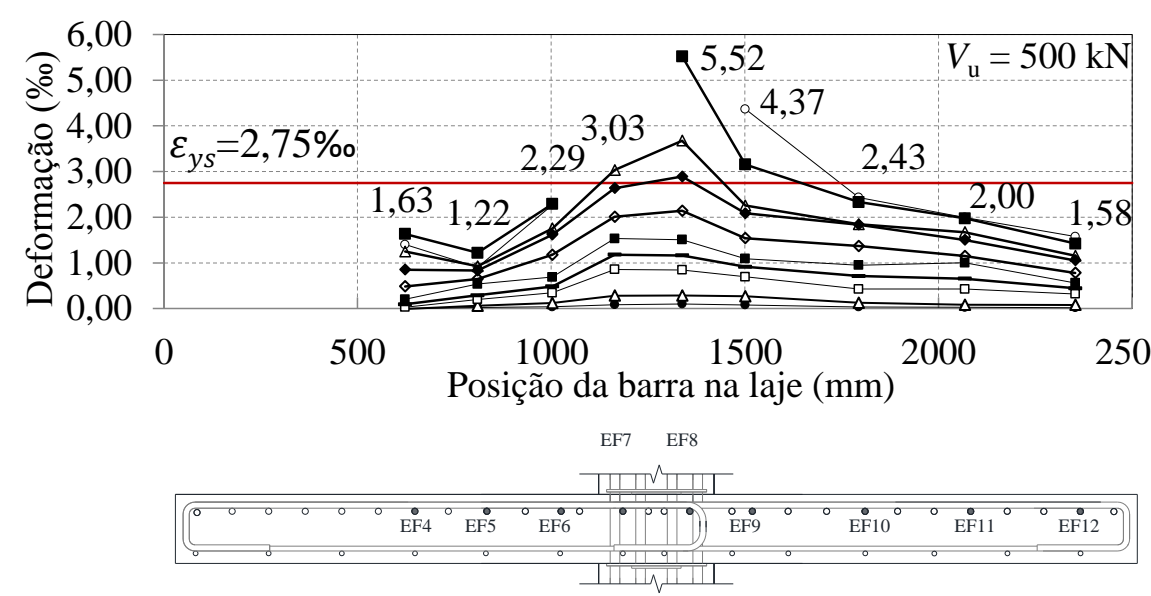

Figura 4.136 - Deformação na armadura de flexão da laje L10 

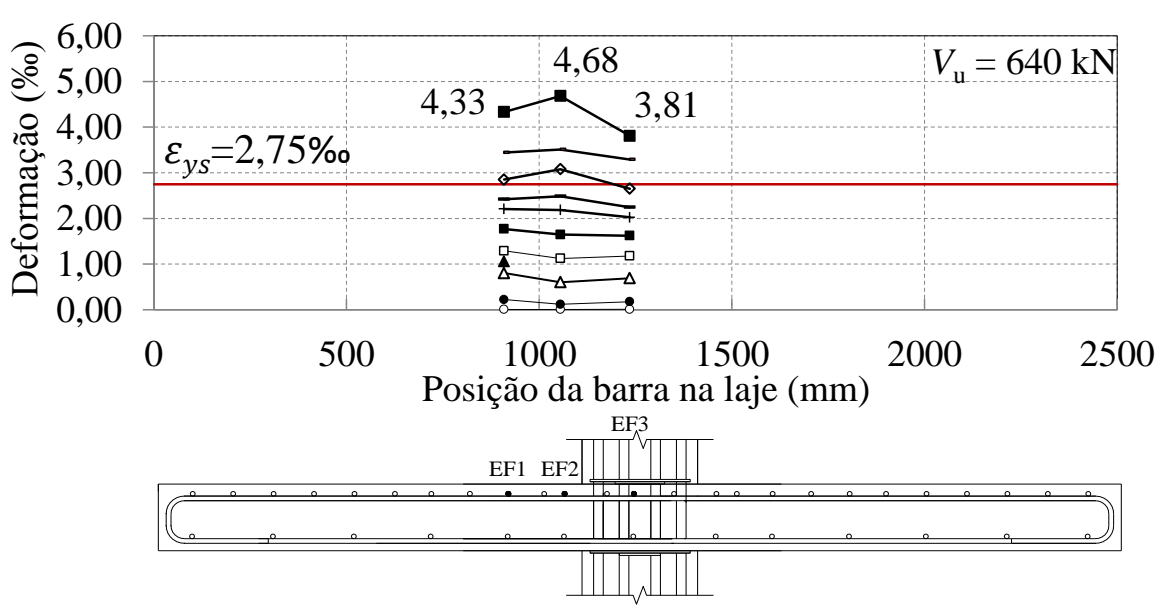

Figura 4.137 - Deformação na armadura de flexão da laje L11

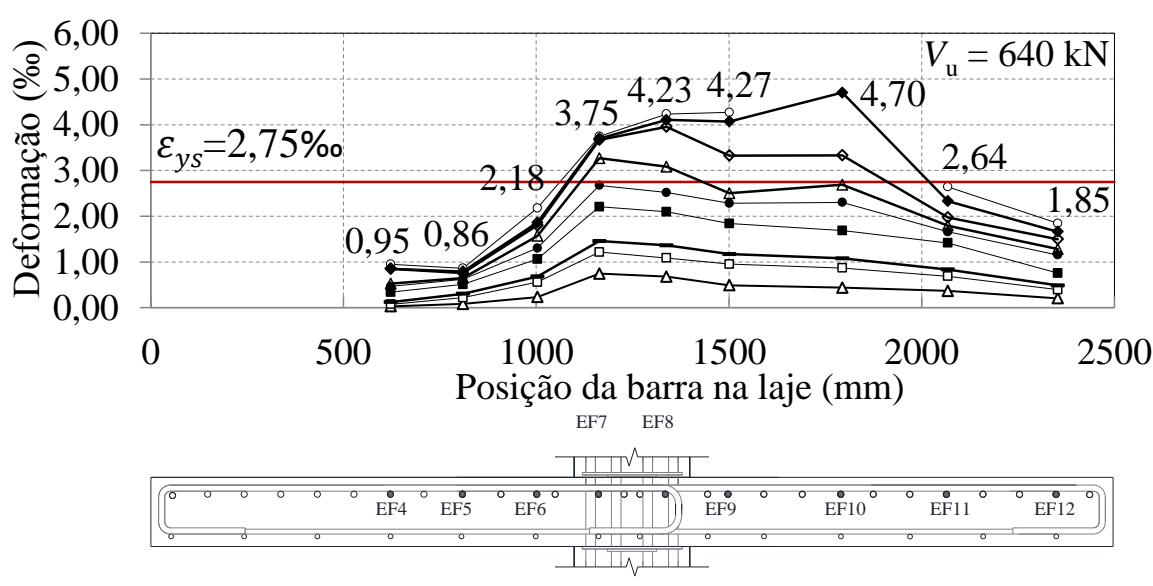

Figura 4.138 - Deformação na armadura de flexão da laje L11

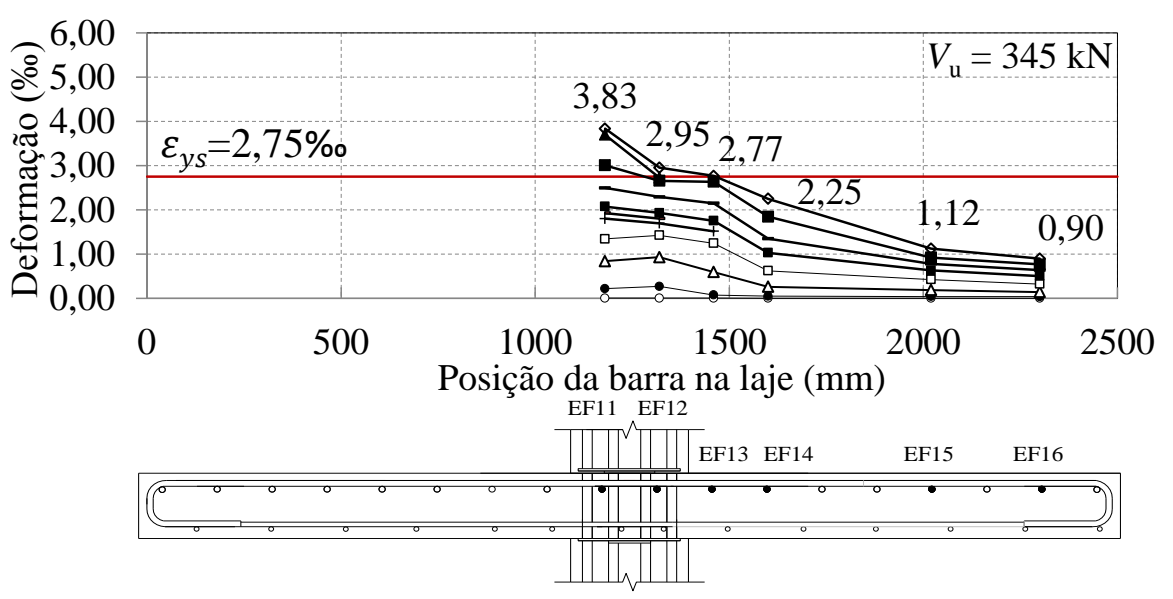

Figura 4.139 - Deformação na armadura de flexão da laje L12 


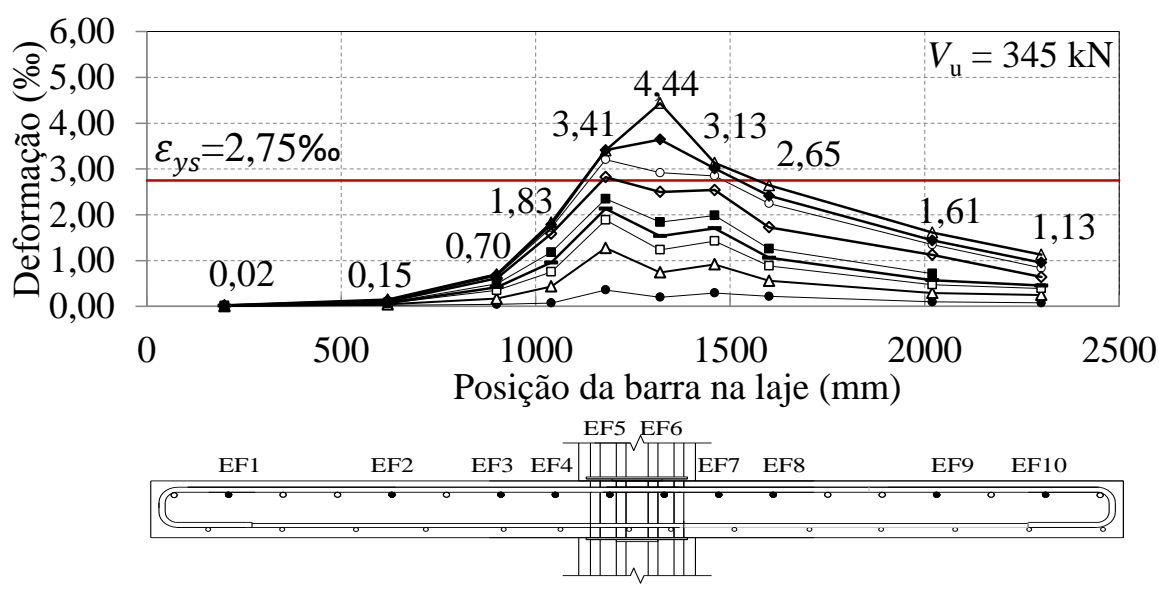

Figura 4.140 - Deformação na armadura de flexão da laje L12

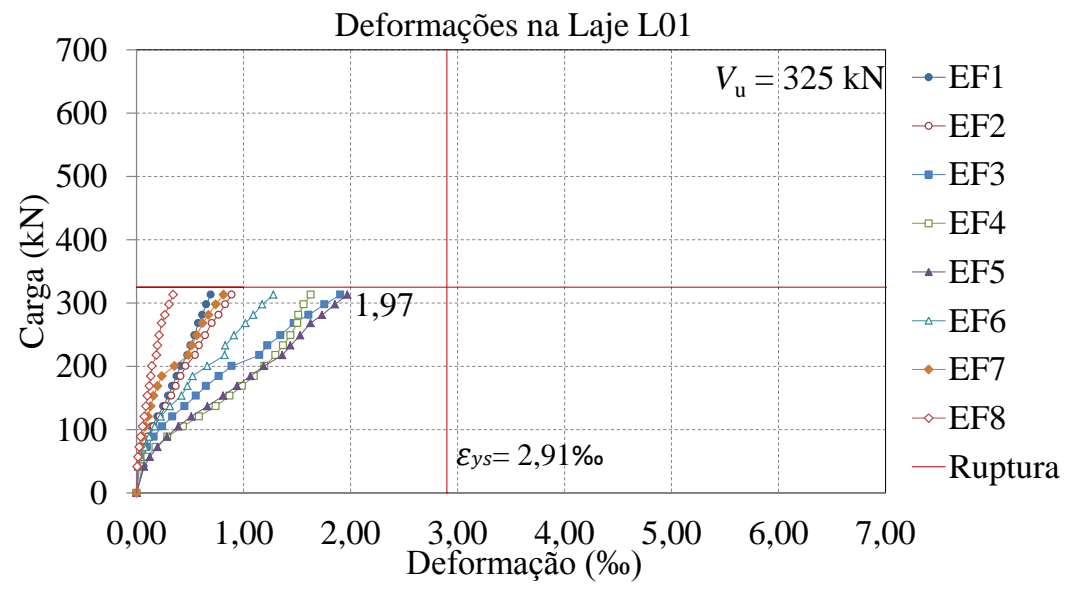

Figura 4.141 - Carga x deformação na armadura de flexão da laje L01

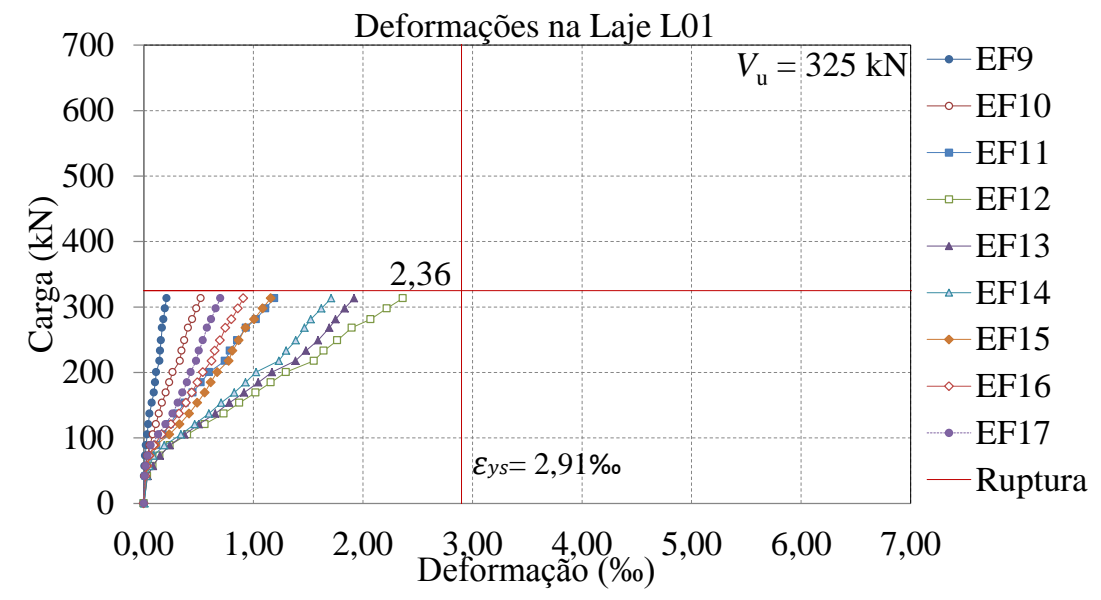

Figura 4.142 - Carga x deformação na armadura de flexão da laje L01 


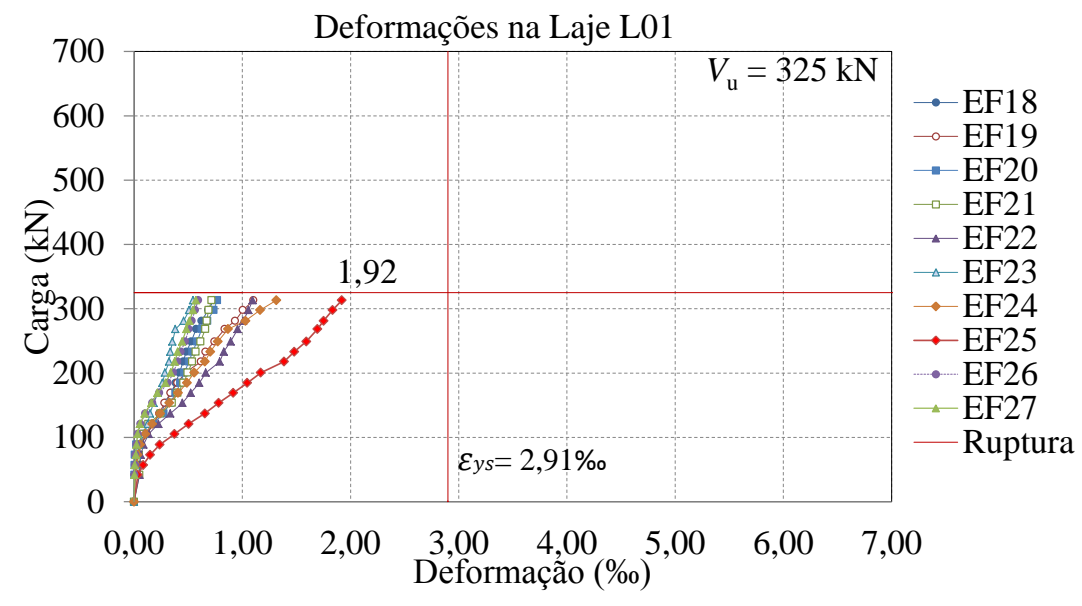

Figura 4.143 - Carga x deformação na armadura de flexão da laje L01

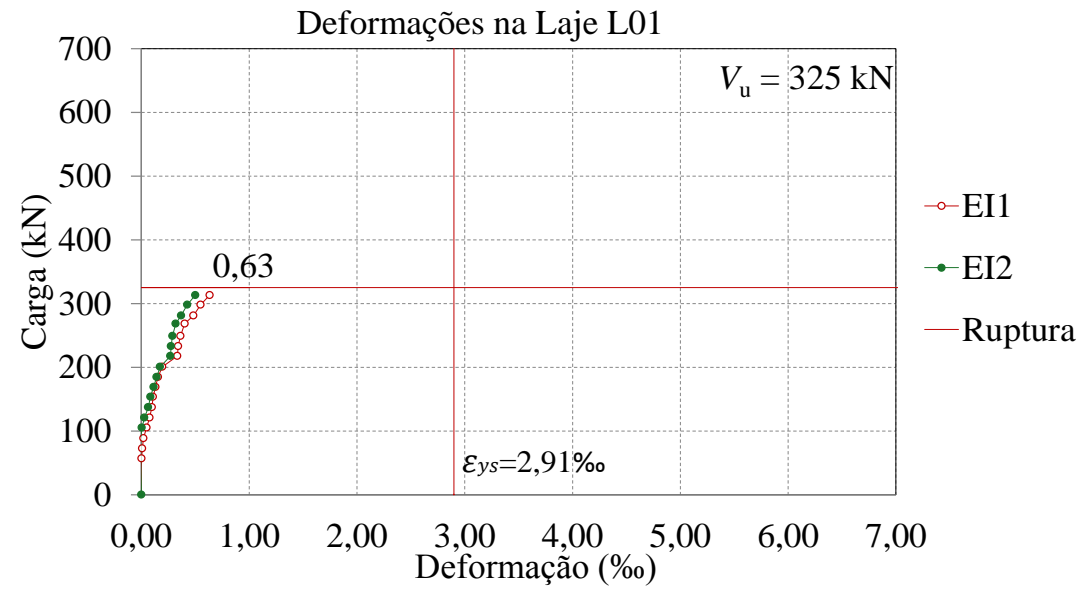

Figura 4.144 - Carga x deformação na armadura de flexão da laje L01

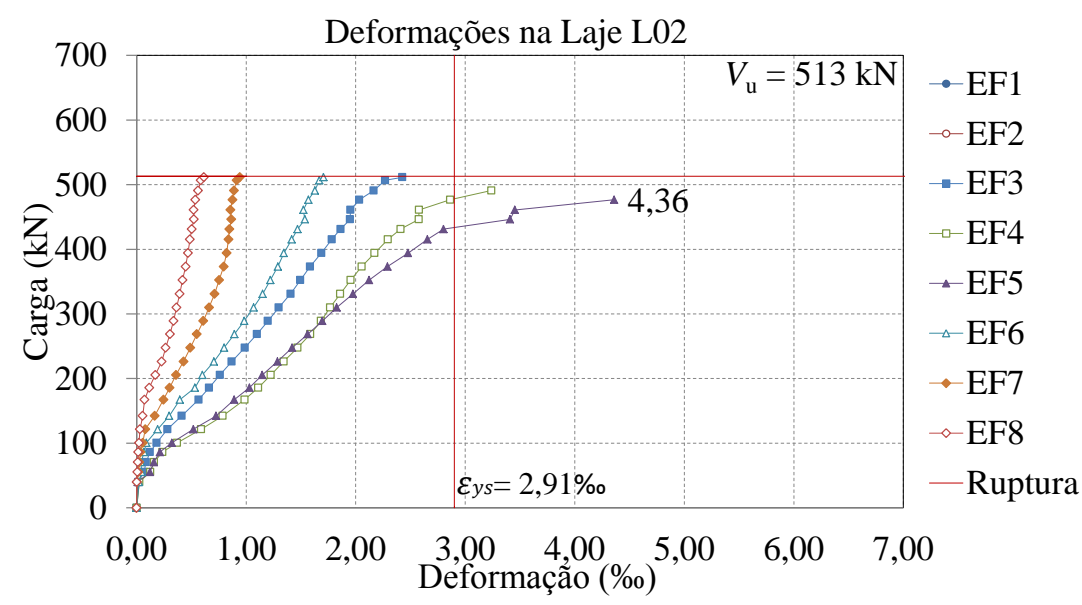

Figura 4.145 - Carga x deformação na armadura de flexão da laje L02 


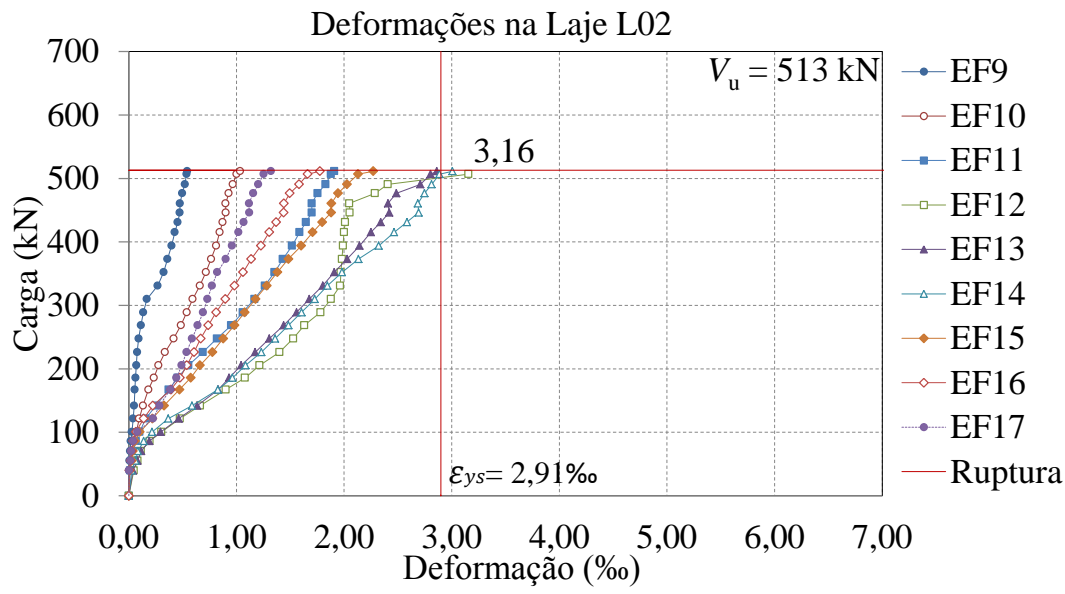

Figura 4.146 - Carga x deformação na armadura de flexão da laje L02

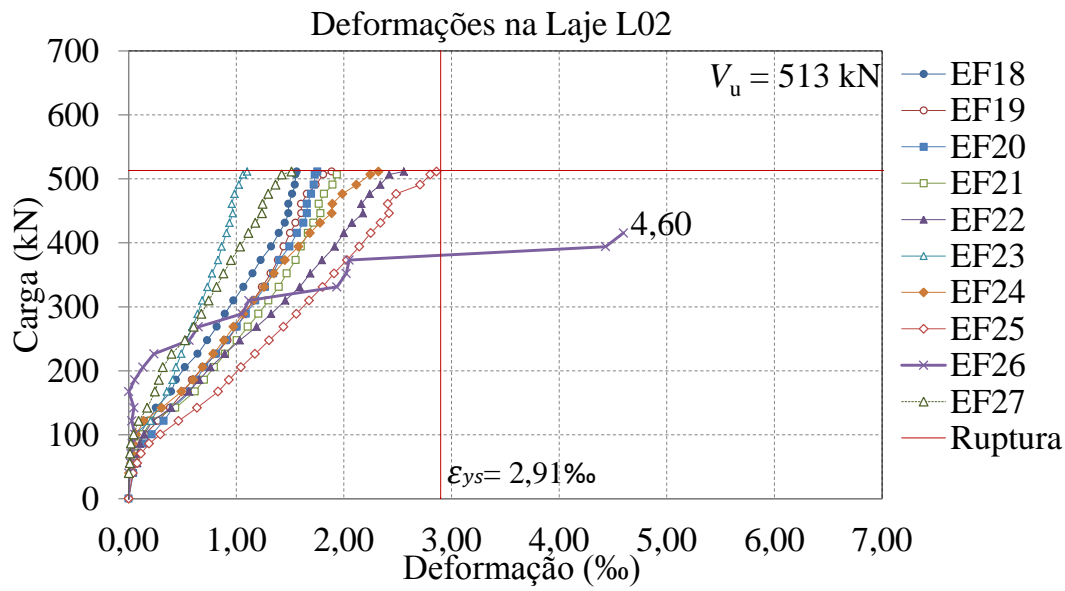

Figura 4.147 - Carga x deformação na armadura de flexão da laje L02

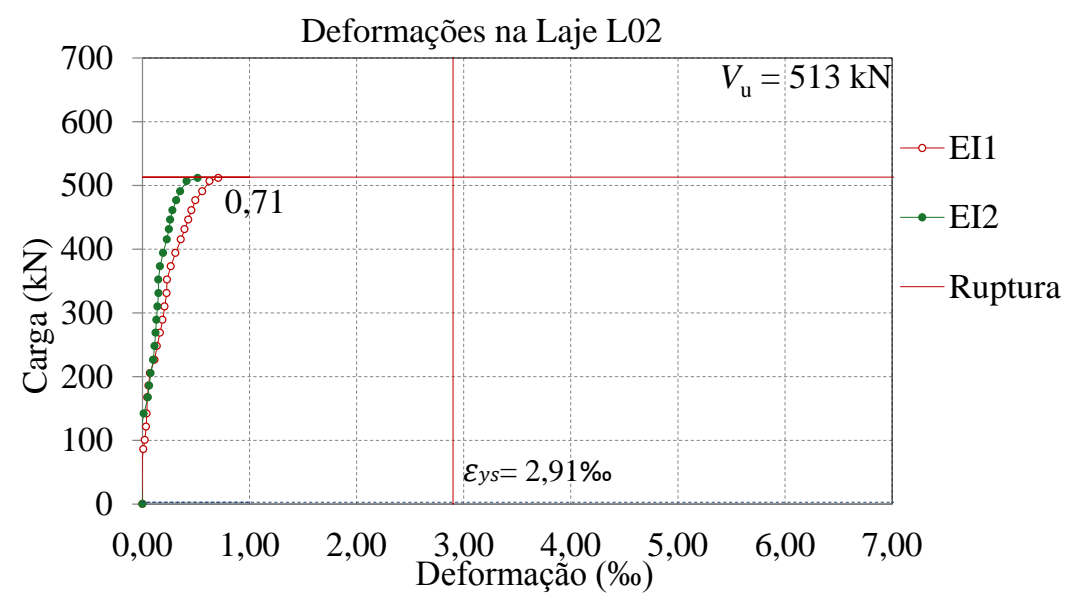

Figura 4.148 - Carga x deformação na armadura de flexão da laje L02 


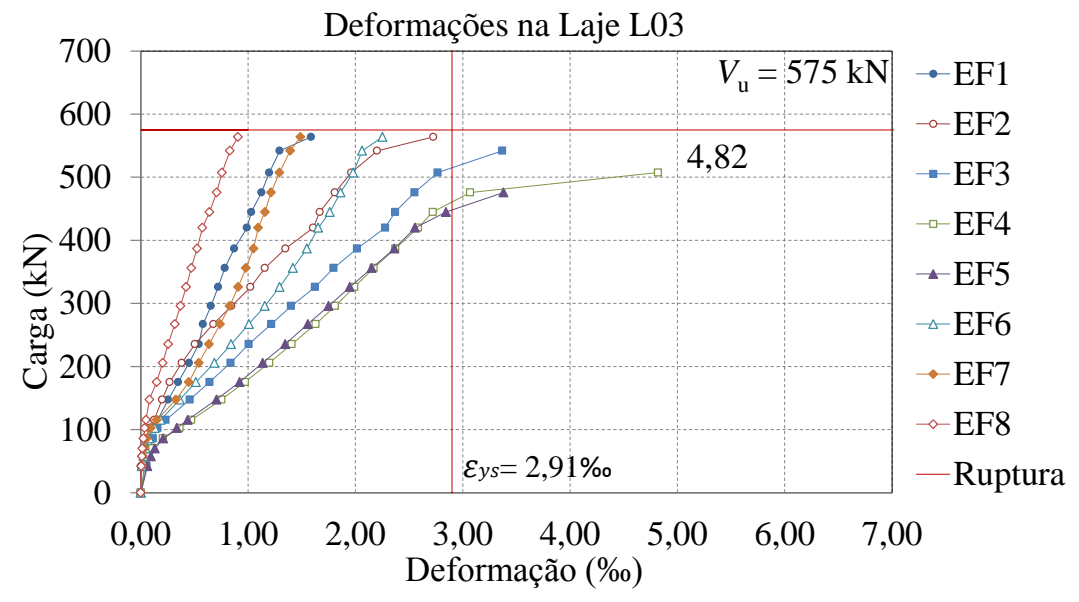

Figura 4.149 - Carga x deformação na armadura de flexão da laje L03

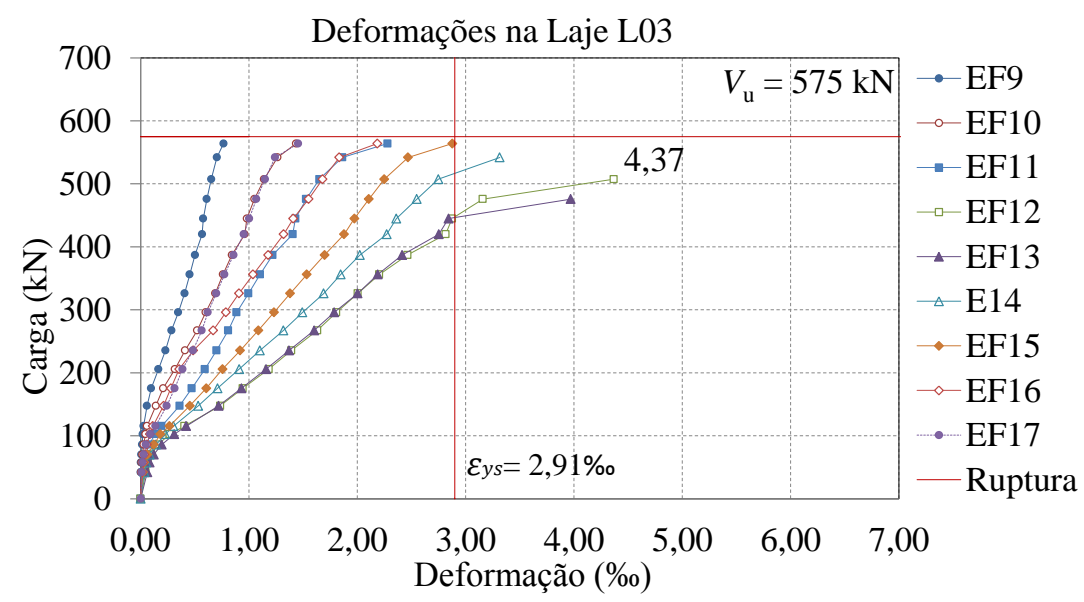

Figura 4.150 - Carga x deformação na armadura de flexão da laje L03

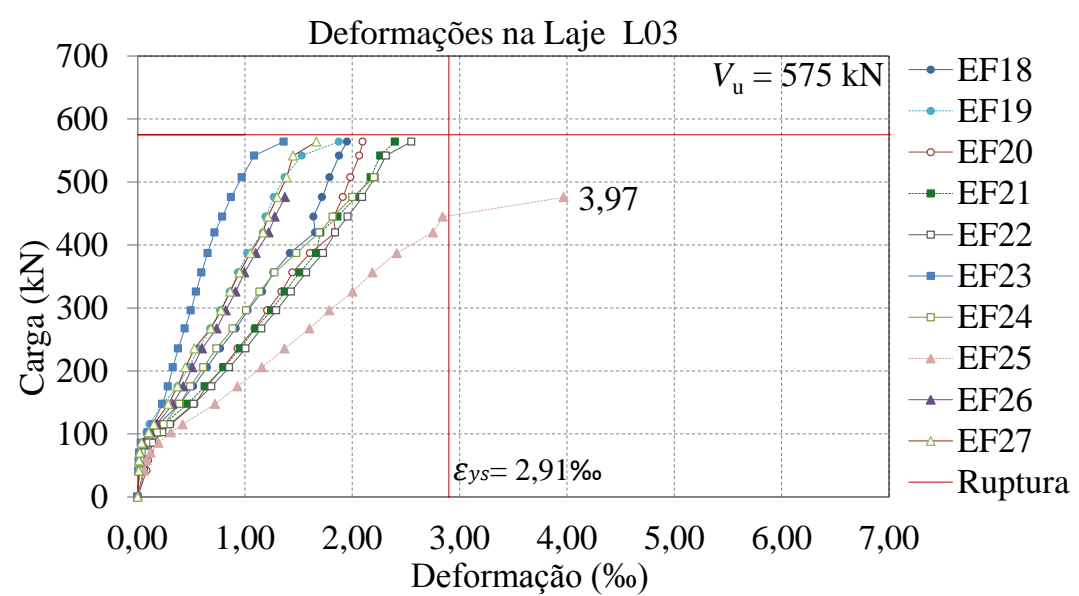

Figura 4.151 - Carga x deformação na armadura de flexão da laje L03 


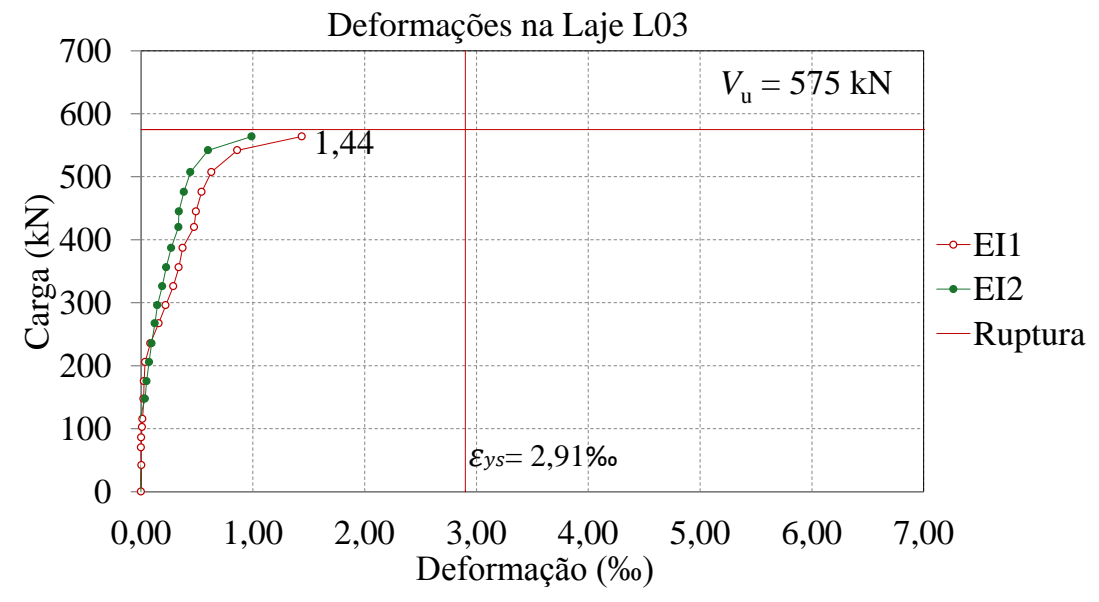

Figura 4.152 - Carga x deformação na armadura de flexão da laje L03

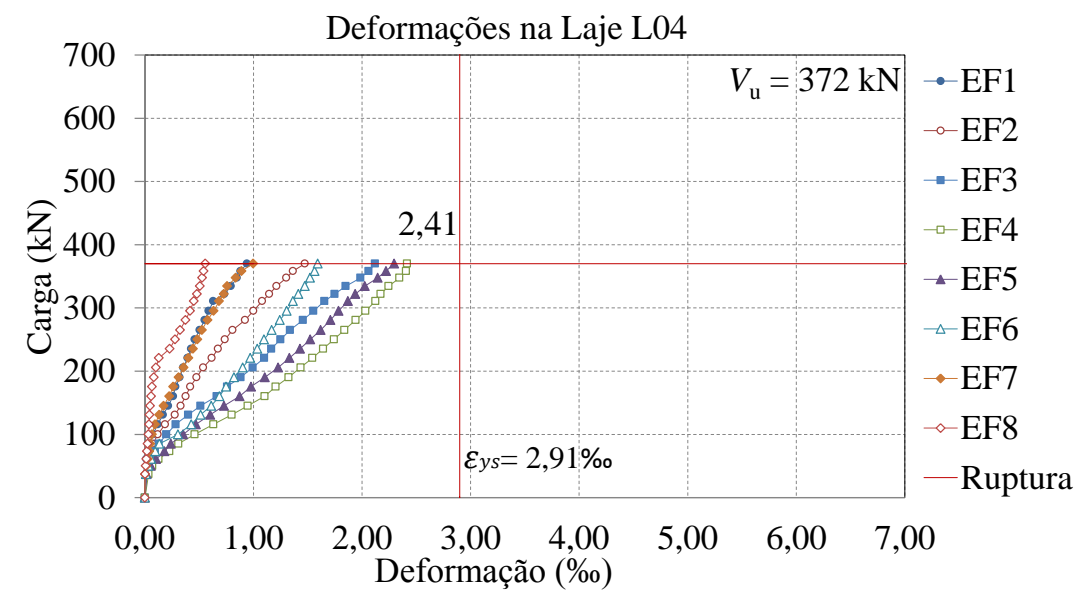

Figura 4.153 - Carga x deformação na armadura de flexão da laje L04

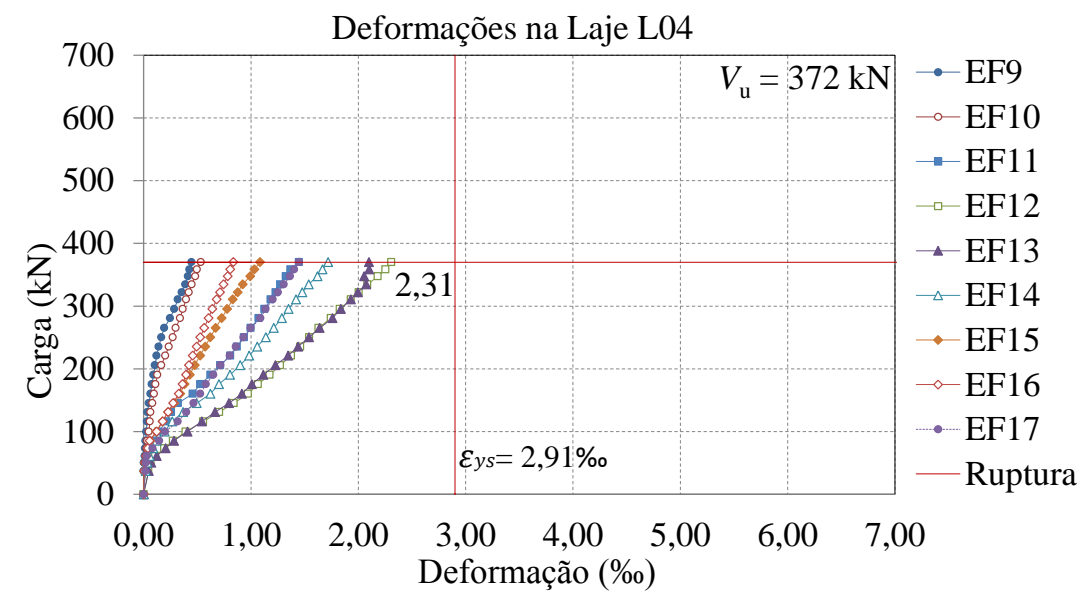

Figura 4.154 - Carga x deformação na armadura de flexão da laje L04 


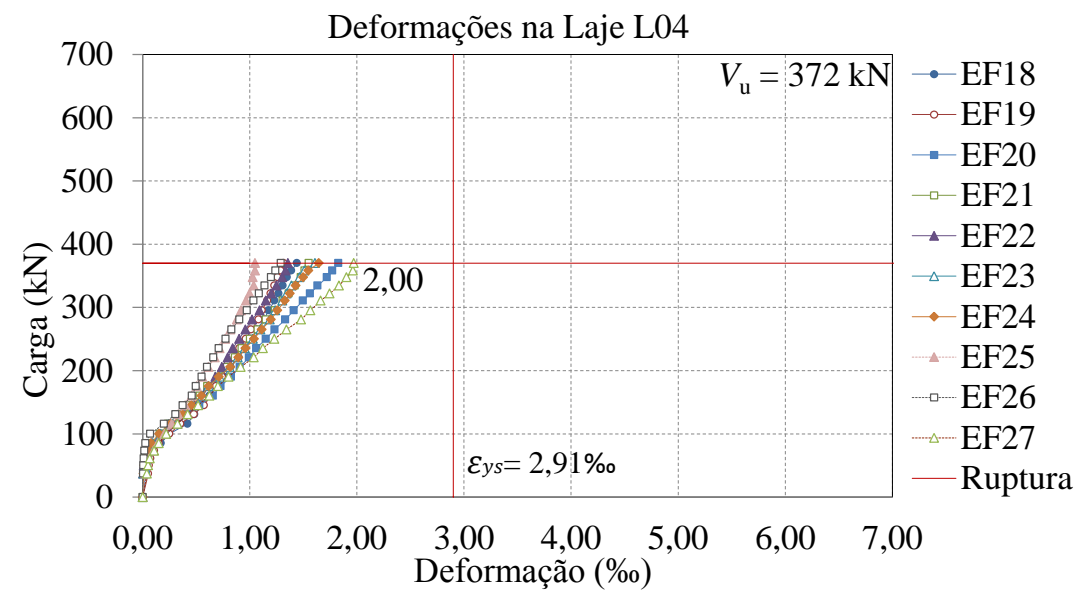

Figura 4.155 - Carga x deformação na armadura de flexão da laje L04

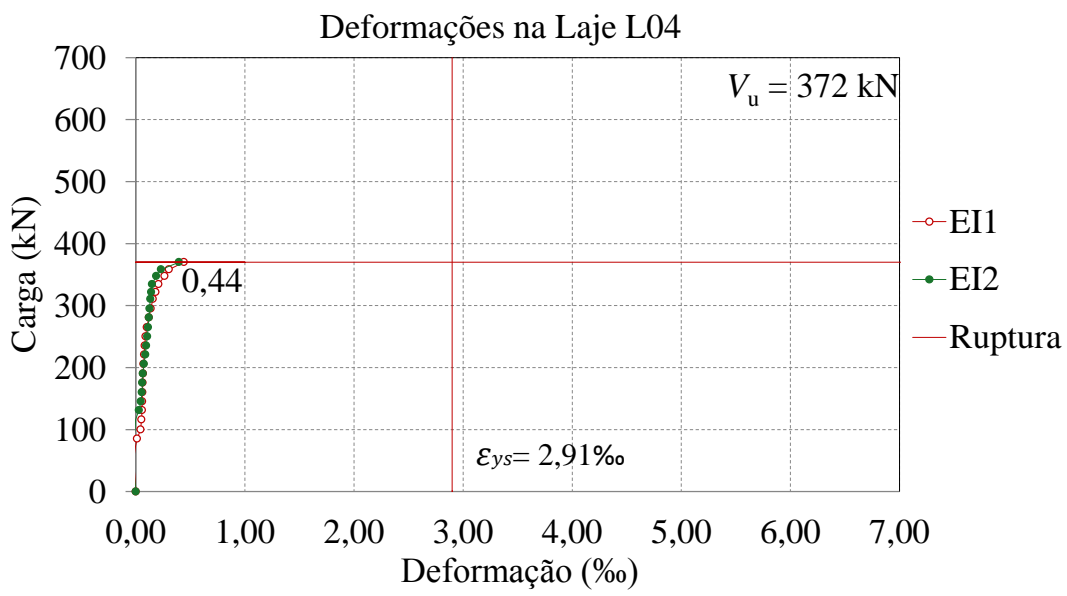

Figura 4.156 - Carga x deformação na armadura de flexão da laje L04

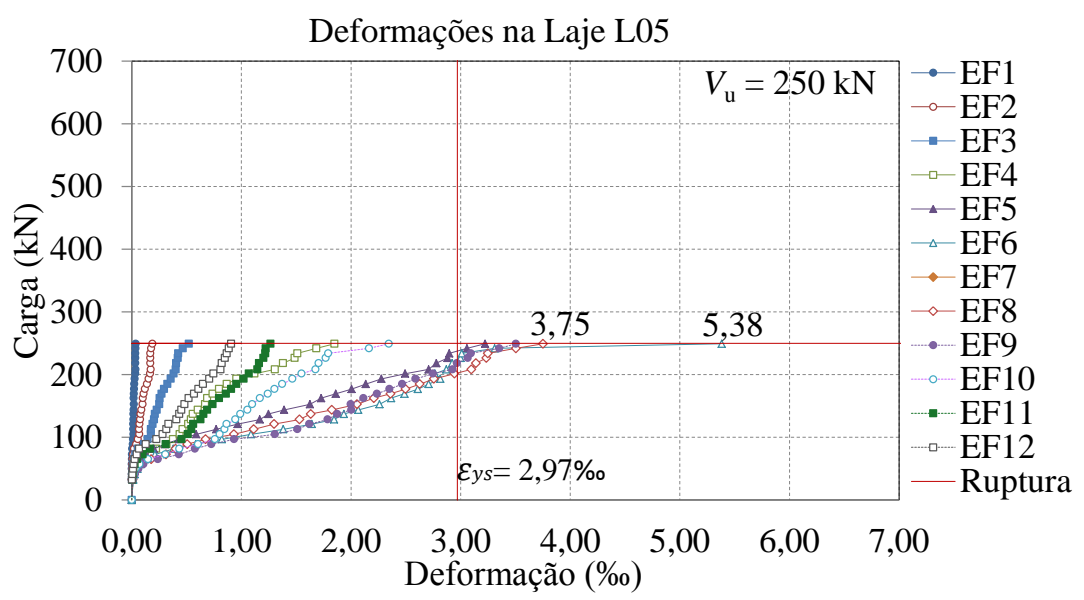

Figura 4.157 - Carga x deformação na armadura de flexão da laje L05 


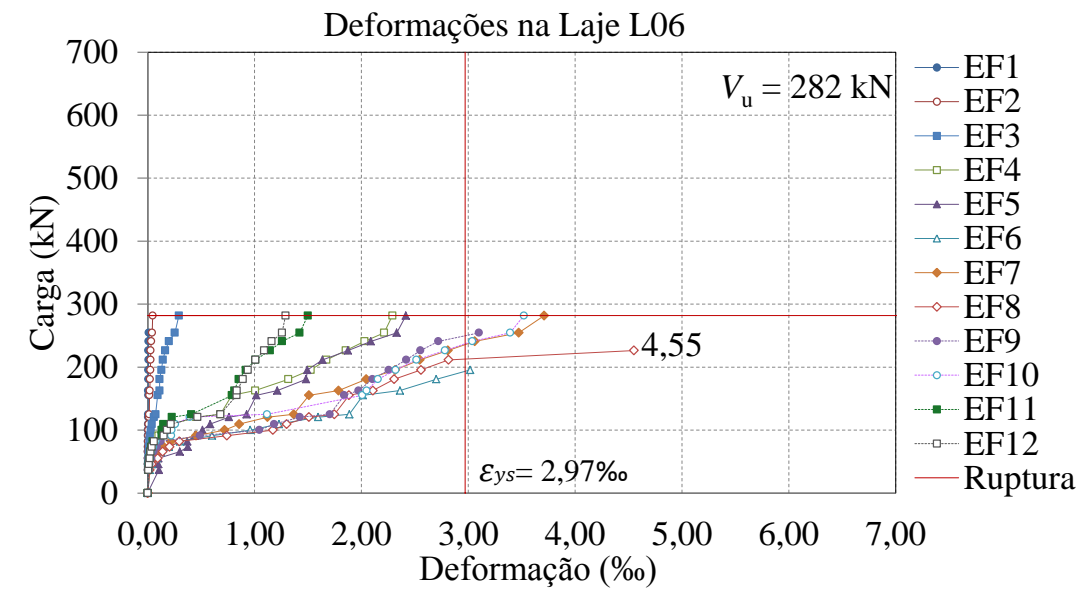

Figura 4.158 - Carga x deformação na armadura de flexão da laje L06

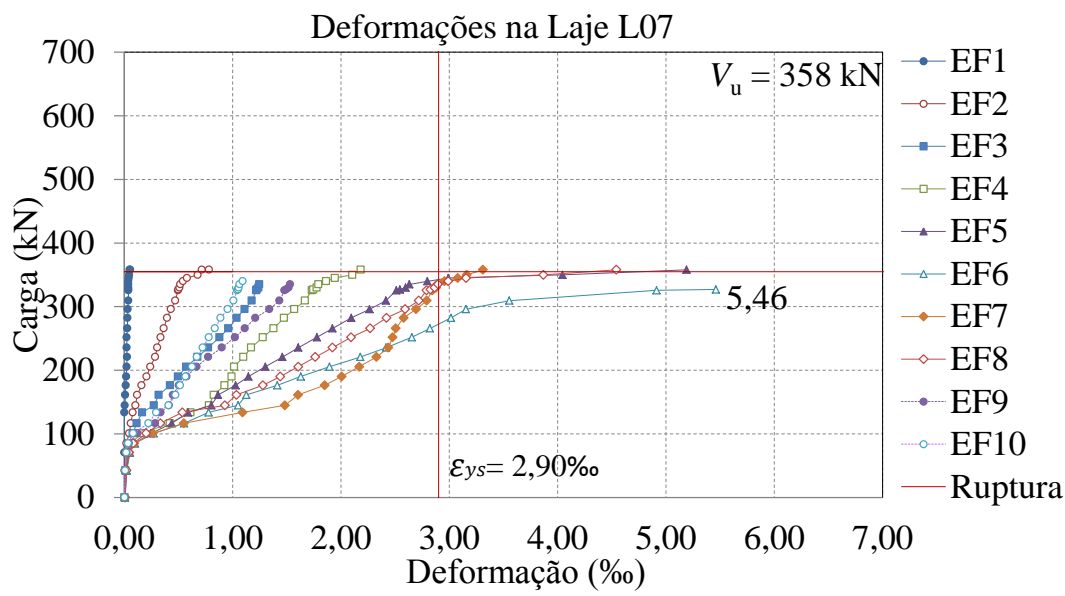

Figura 4.159 - Carga x deformação na armadura de flexão da laje L07

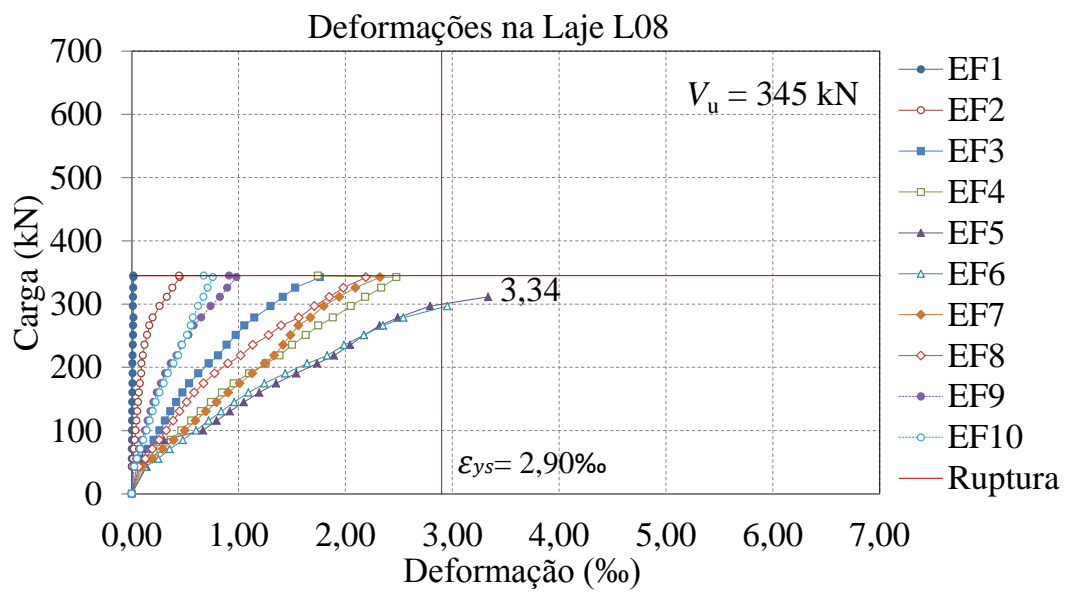

Figura 4.160 - Carga x deformação na armadura de flexão da laje L08 


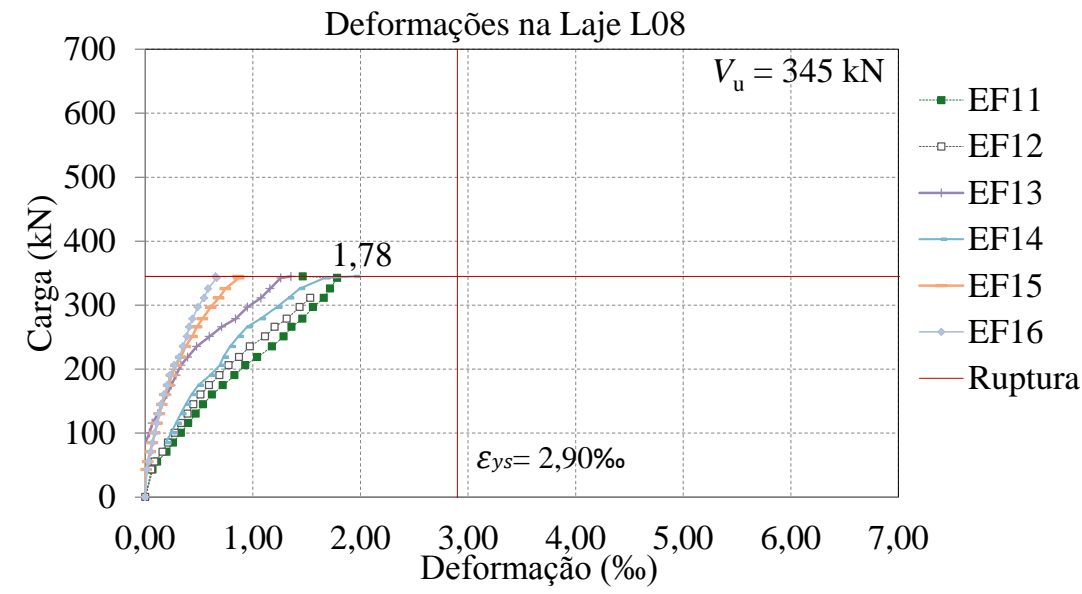

Figura 4.161 - Carga x deformação na armadura de flexão da laje L08

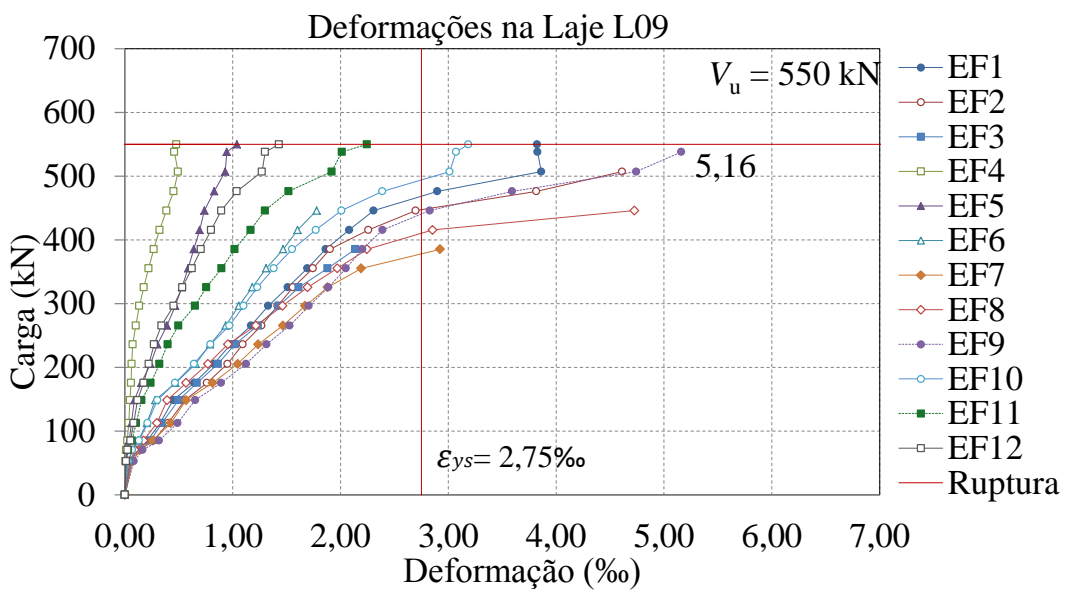

Figura 4.162 - Carga x deformação na armadura de flexão da laje L09

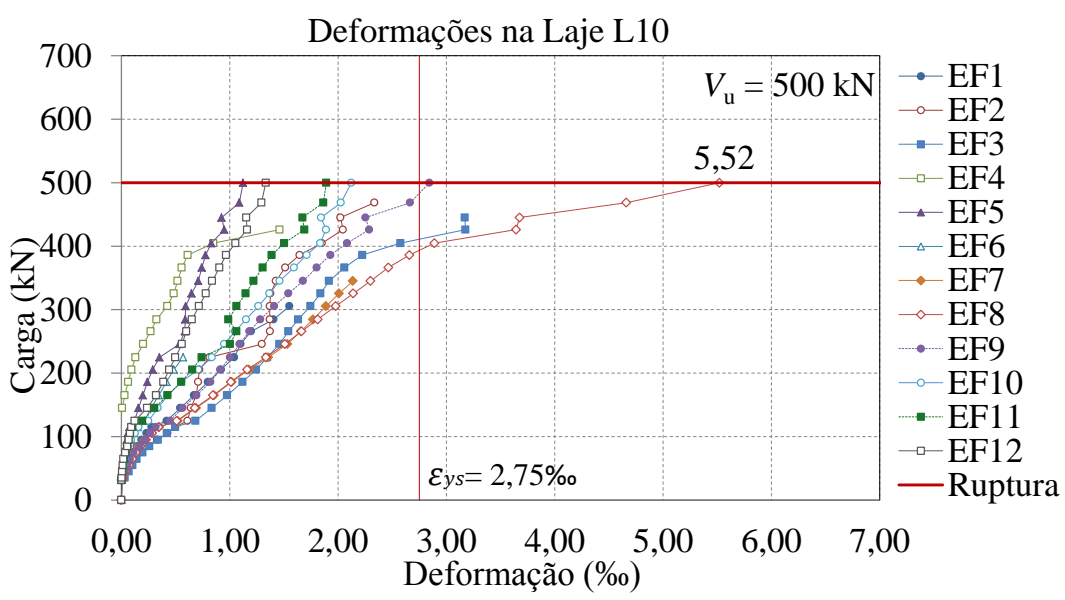

Figura 4.163 - Carga x deformação na armadura de flexão da laje L10 


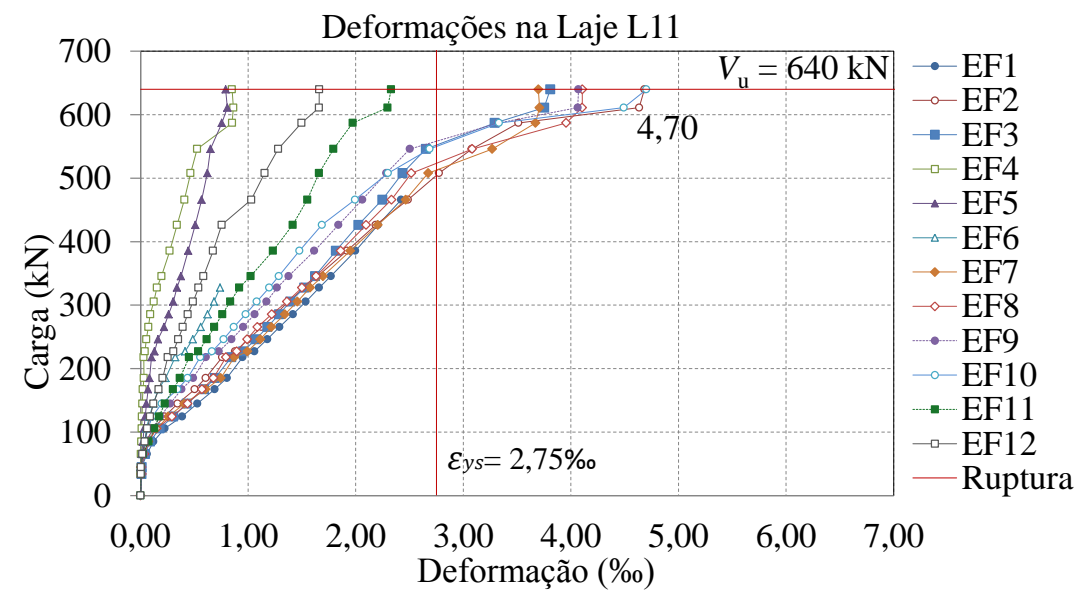

Figura 4.164 - Carga x deformação na armadura de flexão da laje L11

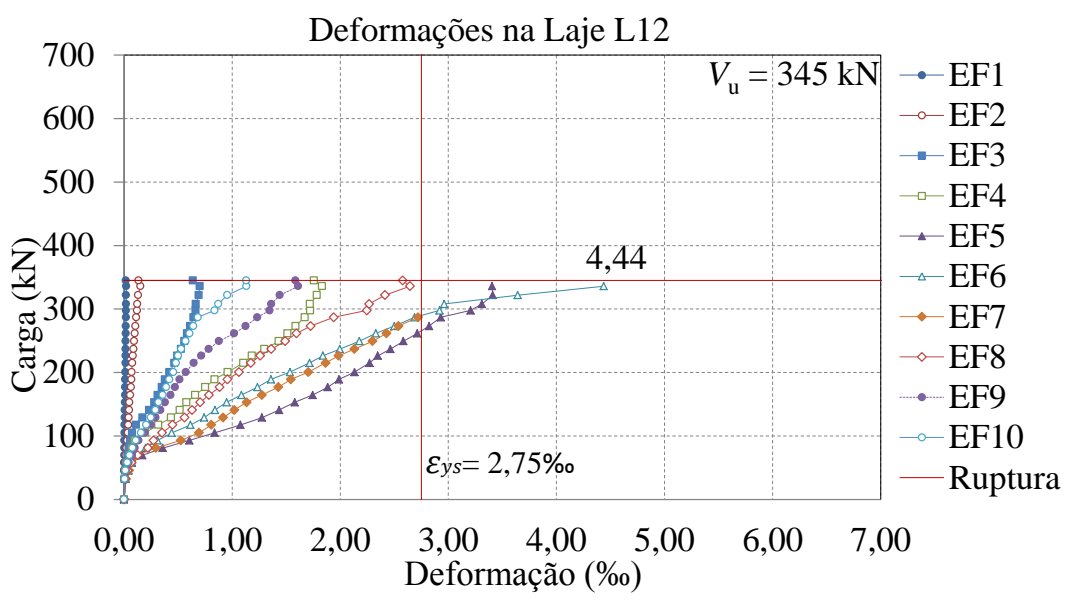

Figura 4.165 - Carga x deformação na armadura de flexão da laje L12

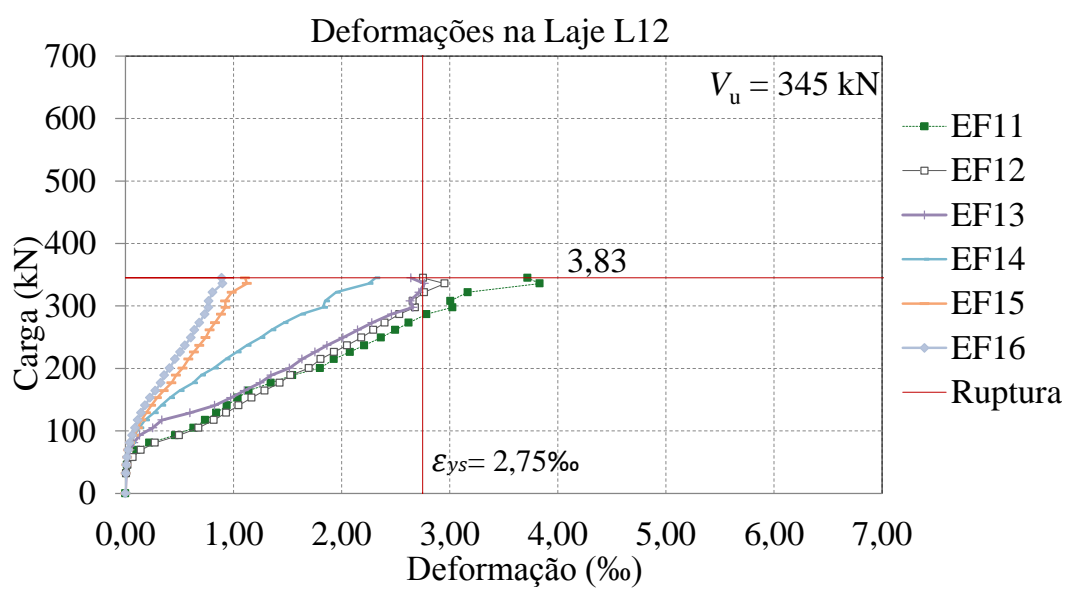

Figura 4.166 - Carga x deformação na armadura de flexão da laje L12 
Os gráficos mostram a distribuição de tensões nas direções NE-SO e SE-NO, respectivamente, em dois tipos: barras de linhas desenhadas através das faces internas dos pilares relacionando posicionamento dos pontos na laje $\mathrm{x}$ deformação $\mathrm{e}$ carga $\mathrm{x}$ deformações.

As barras inferiores monitoradas nas quatro primeiras lajes mostram com as deformações o efeito da torção, por isso foi monitorada a armadura de torção na laje L08.

A concentração da armadura de flexão próxima ao pilar mostrou eficiência no aumento da transferência de momento resistente, porém menos que a armadura de torção.

No geral, as deformações nas lajes são baixas e aumentaram de forma linear. Poucos pontos instrumentados entraram em incidência com os pontos localizados próximos à face interna do pilar das lajes atingindo as deformações máximas exceto nas lajes L01 e L04 que possuíam taxa de armadura de flexão realtivamente alta de $2,1 \%$ e não possuíam reforço ao cisalhamento.

Para a análise das deformações na armadura de flexão foram observados os pontos monitorados na linha A-A da Figura 4.167.

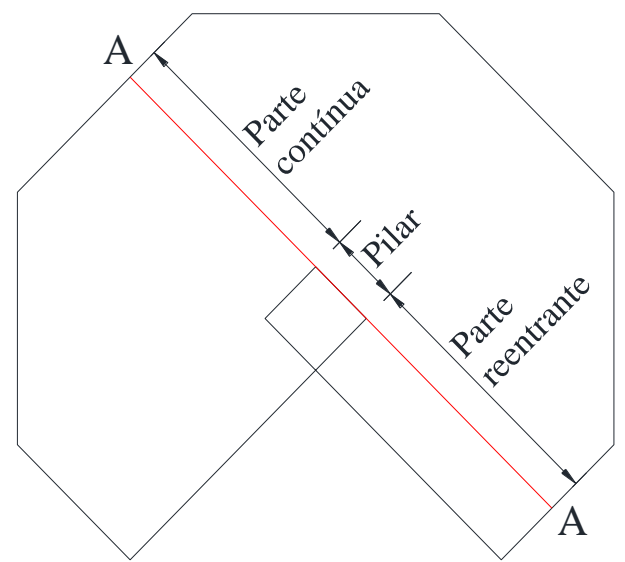

Figura 4.167 - Linha utilizada para análise de deformações na armadura de flexão.

Pode-se notar em todas as lajes que as deformações máximas estão localizadas em pontos próximos à face interna do pilar. As deformações próximas à borda reentrante da laje diminuem com o aumento da distância a partir do pilar, atingindo valores próximos à zero (parte reentrante na Figura 4.167). Para o lado onde a laje é contínua (parte contínua na Figura 4.167) a diminuição da deformação é mais gradual. Esses comportamentos indicam que o momento fletor não é contínuo na linha A-A e que os momentos na parte reentrante 
da linha são menores que os momentos localizados na parte contínua, ou seja, esse comportamento é similar ao encontrado em pilares de borda e de centro respectivamente.

\subsection{DEFORMAÇÃO NA ARMADURA DE CISALHAMENTO (STUDS)}

Foram utilizadas armaduras de cisalhamento nas lajes L02 e L03 com três e quatro camadas de studs e nas lajes L09, L10 e L11 com cinco camadas dispostos de forma radial em todos os casos. Nas lajes L02 e L03 foram instrumentados cinco linhas de studs da armadura de cisalhamento alternadamente. Já nas lajes L09, L10 e L11 foram instrumentadas apenas as duas camadas mais próximas do pilar também alternadamente tendo em vista que da terceira camada em diante as deformações foram relativamente baixas nas lajes L02 e L03. Foram posicionados dois extensômetros diametralmente opostos na barra de cada stud. O resultado da deformação de cada stud para cada passo de carga foi obtido pela média dos resultados registrados nos dois extensômetros. Os gráficos das deformações na armadura de cisalhamento, juntamente com os valores de carga no momento da ruptura serão apresentados nas figuras que se seguem (Figura 4.168 à Figura 4.180).

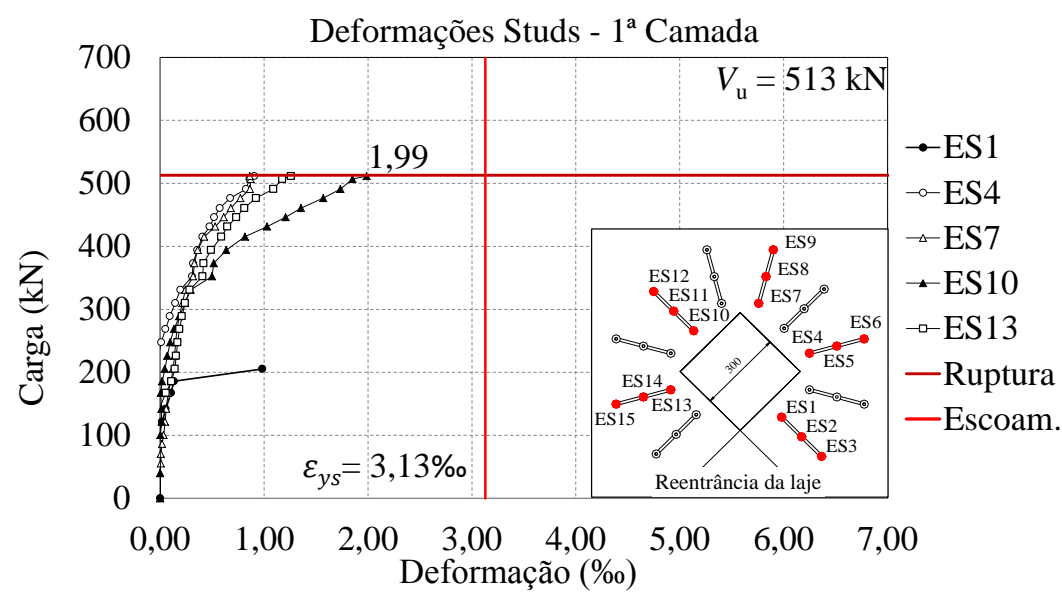

Figura 4.168 - Deformações na $1^{\mathrm{a}}$ camada de studs da laje L02 


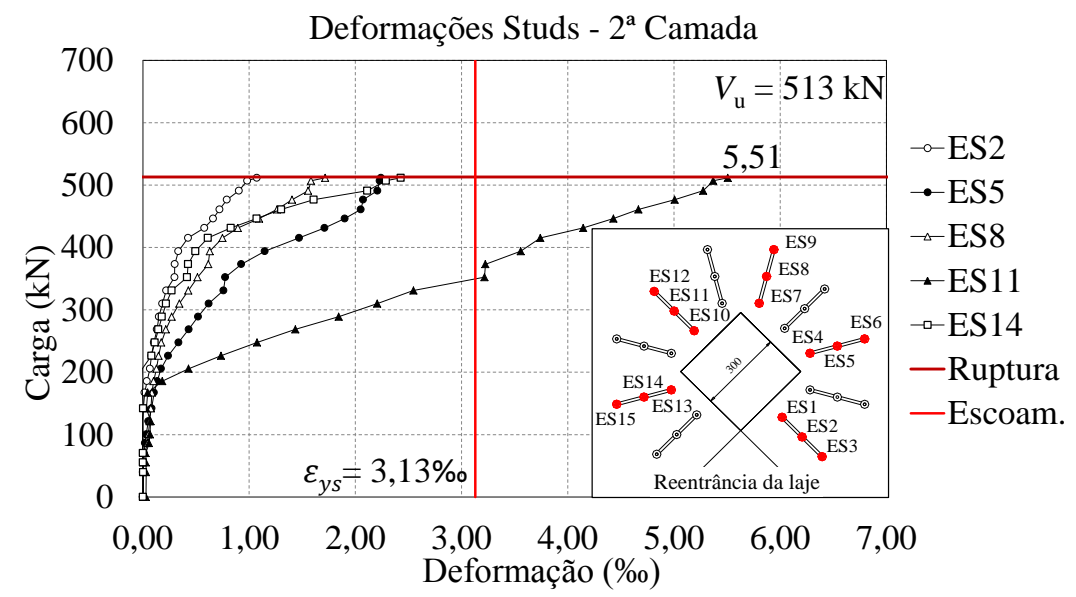

Figura 4.169 - Deformações na $2^{\text {a }}$ camada de studs da laje L02

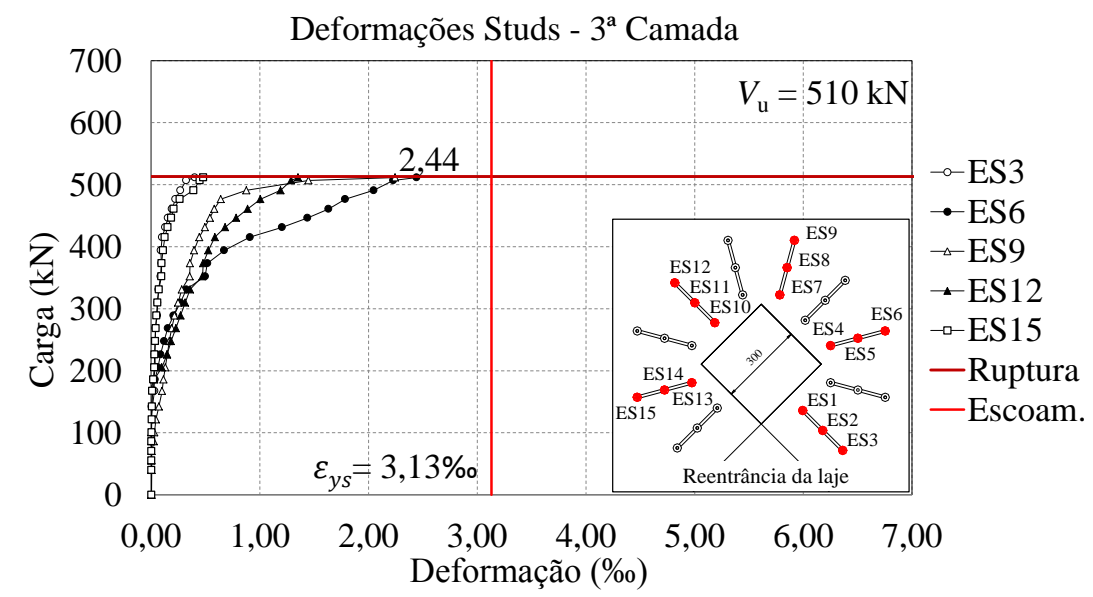

Figura 4.170 - Deformações na $3^{\mathrm{a}}$ camada de studs da laje L02

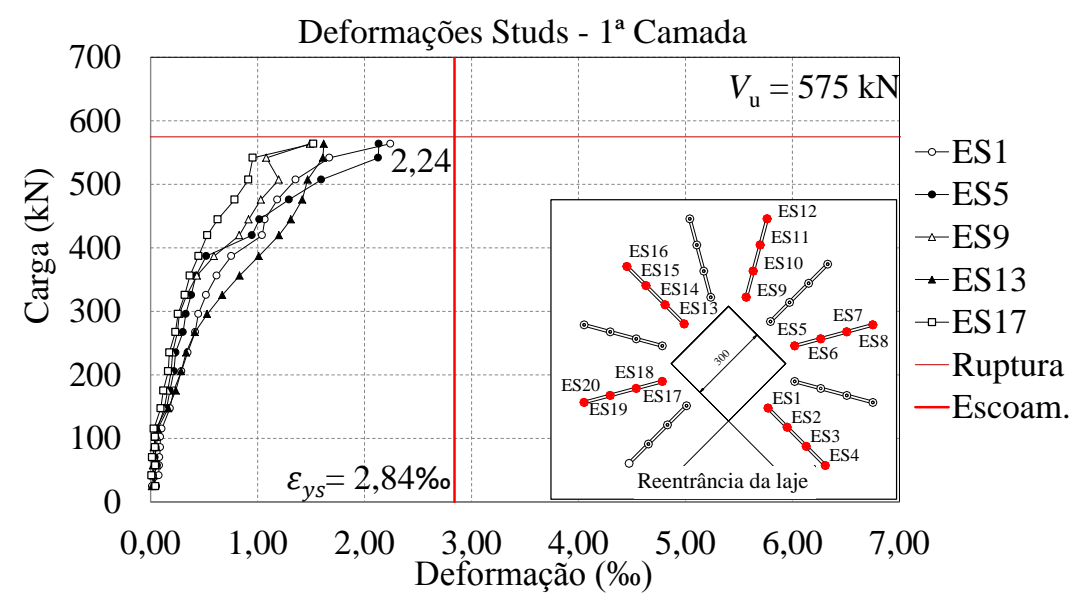

Figura 4.171 - Deformações na $1^{\text {a }}$ camada de studs da laje L03 


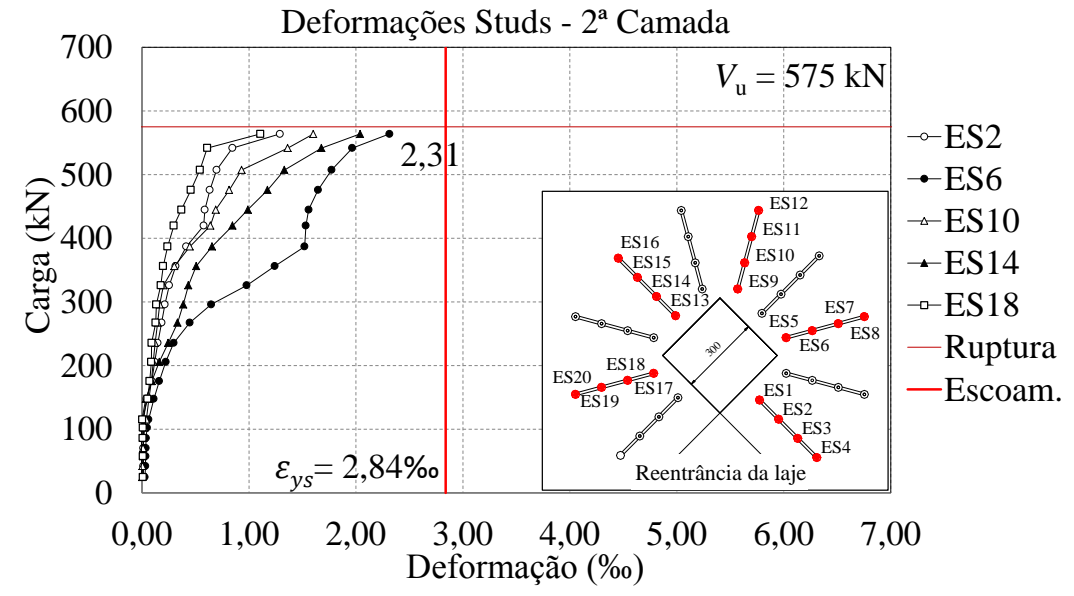

Figura 4.172 - Deformações na $2^{\mathrm{a}}$ camada de studs da laje L03

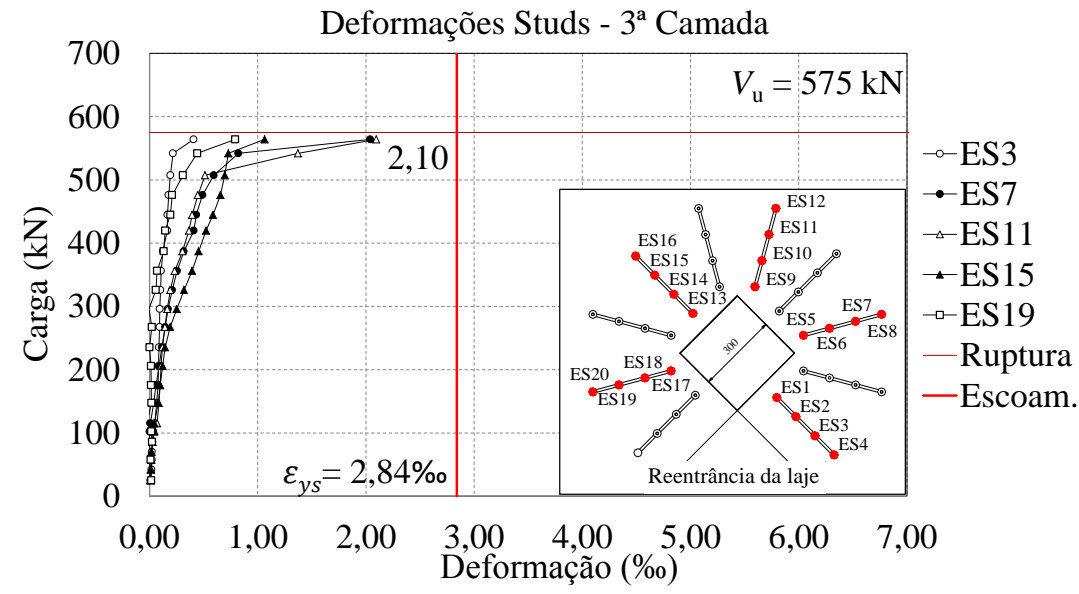

Figura 4.173 - Deformações na $3^{\text {a }}$ camada de studs da laje L03

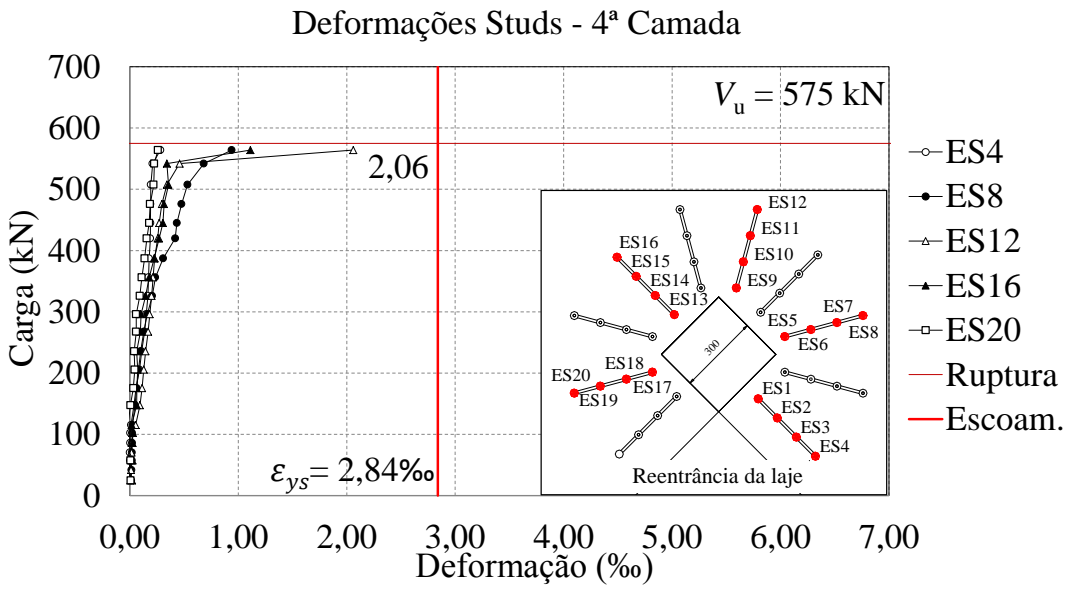

Figura 4.174 - Deformações na $4^{\mathrm{a}}$ camada de studs da laje L03 


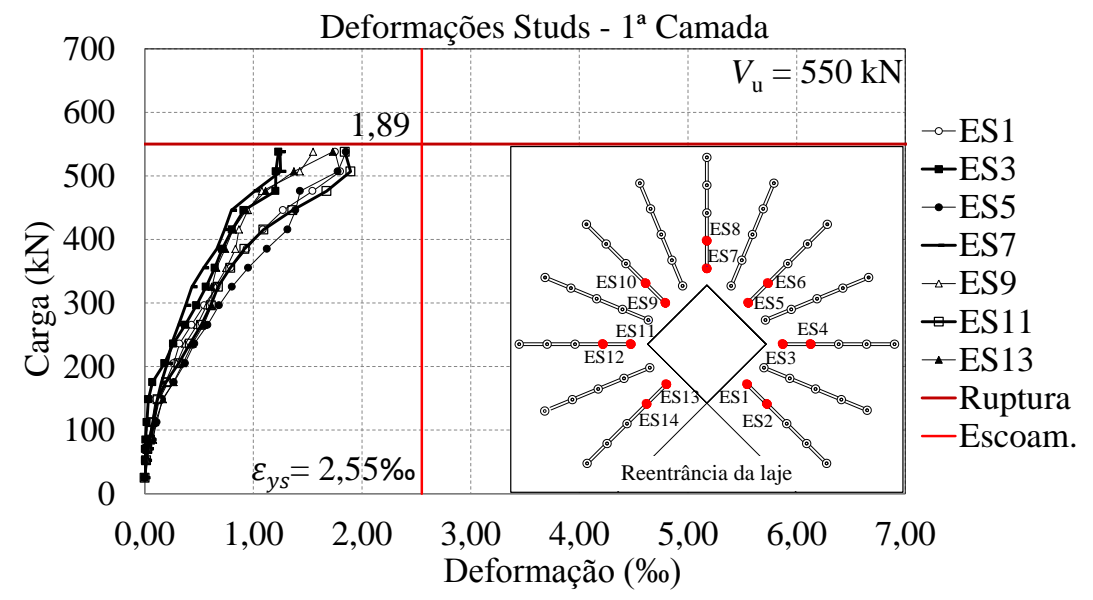

Figura 4.175 - Deformações na $1^{\text {a }}$ camada de studs da laje L09

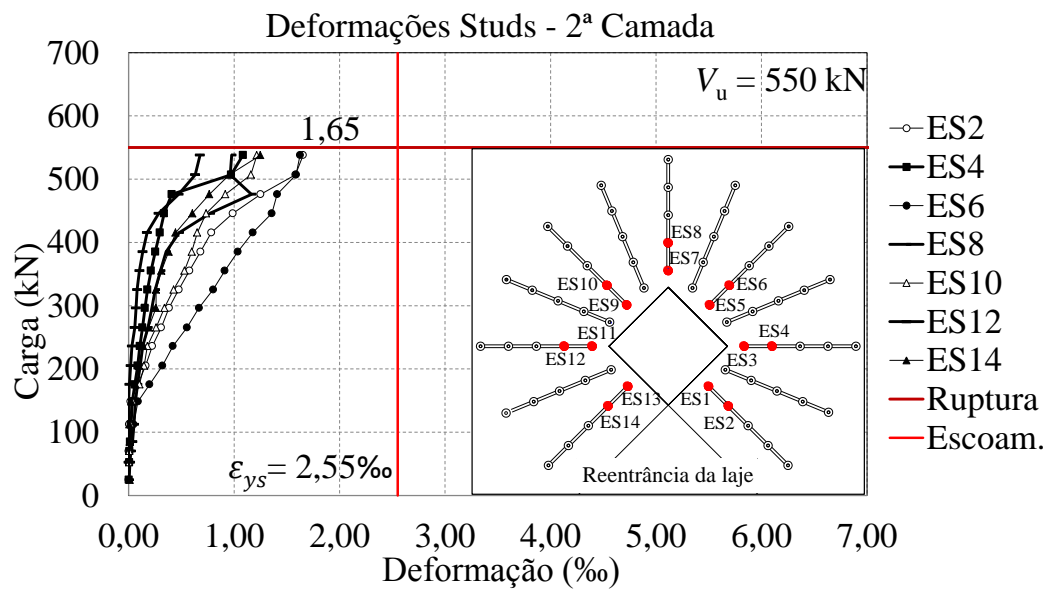

Figura 4.176 - Deformações na 2a camada de studs da laje L09

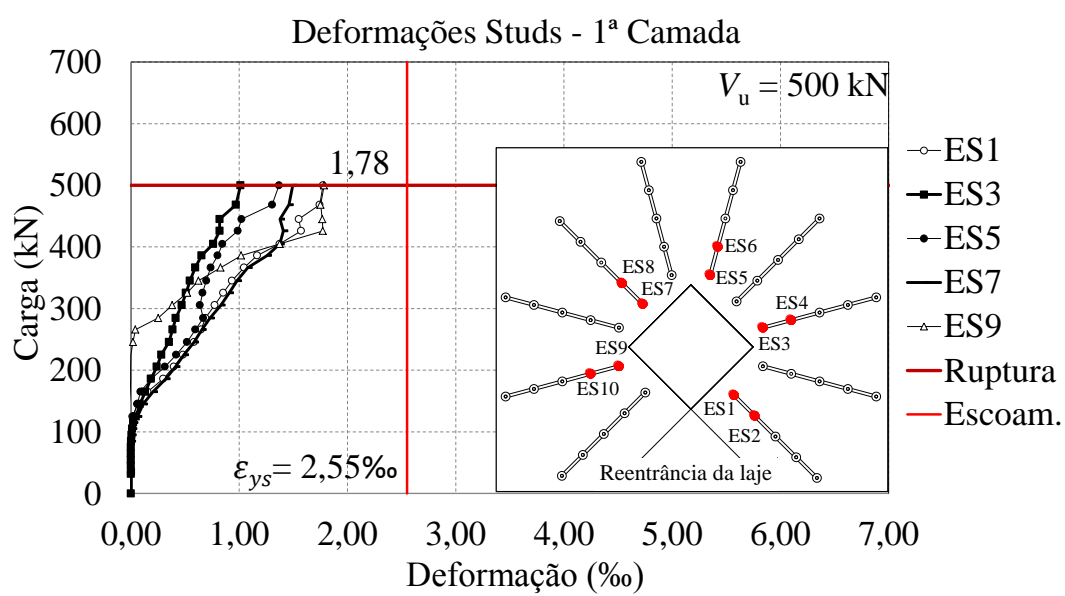

Figura 4.177 - Deformações na $1^{\text {a }}$ camada de studs da laje L10 


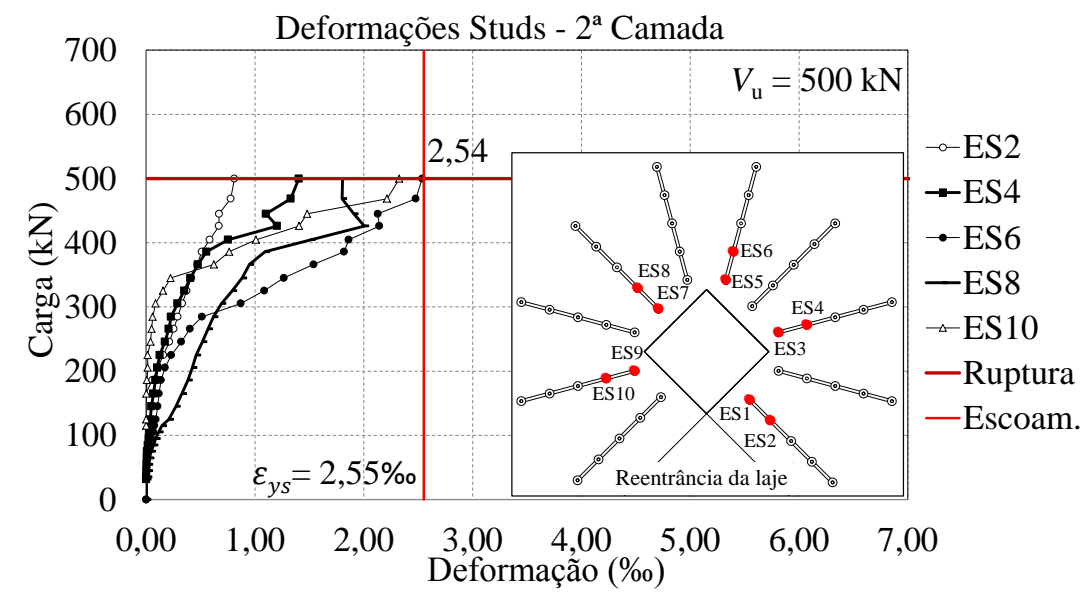

Figura 4.178 - Deformações na $2^{\mathrm{a}}$ camada de studs da laje L10

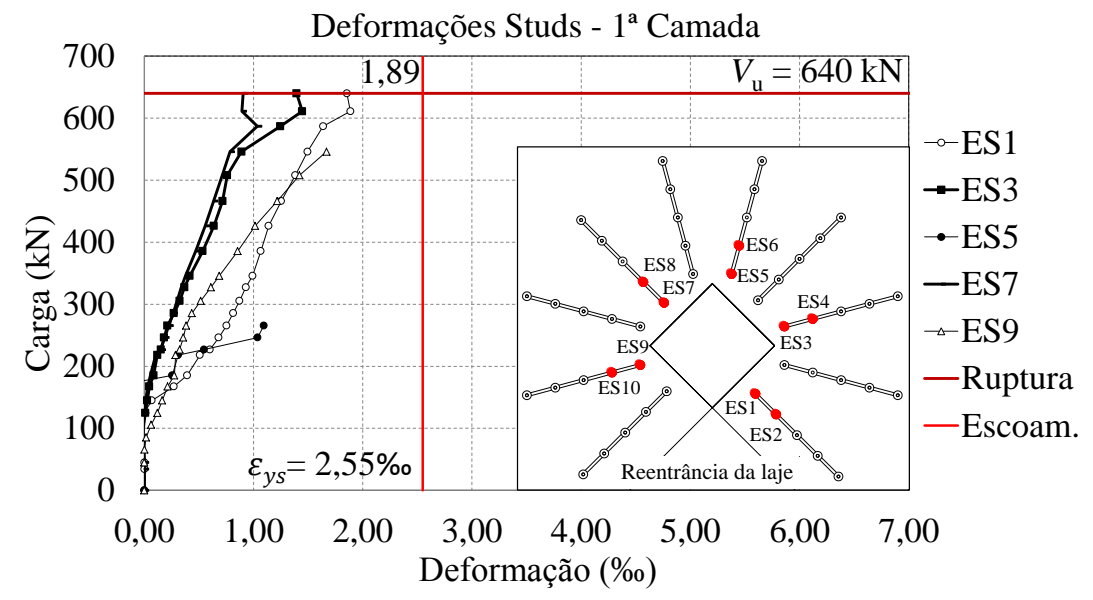

Figura 4.179 - Deformações na $1^{\mathrm{a}}$ camada de studs da laje L11

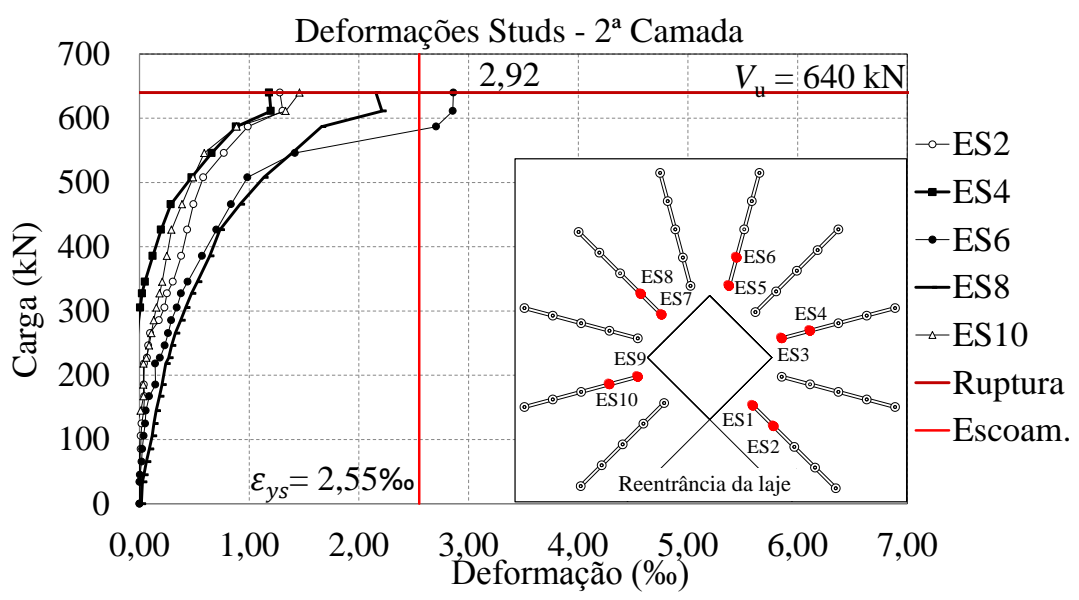

Figura 4.180 - Deformações na $2^{\mathrm{a}}$ camada de studs da laje L11

A armadura de cisalhamento foi instrumentada com dois strain gages em cada ponto. Nas primeiras duas lajes foram monitoradas todas as camadas a fim de conhecer quais 
perímetros eram mais solicitadas, já nas próximas lajes foram monitoradas apenas as duas primeiras camadas.

Pode-se observar que as deformações foram baixas e as barras que se aproximaram ou atingiram o escoamento estavam localizadas nas linhas mais próximas do eixo de simetria em direção à excentricidade. Nas linhas próximas às bordas reentrantes as deformações foram baixas, em torno de $25-60 \%$ de $\varepsilon_{y s}$.

As deformações dos studs foram mais baixas no primeiro perímetro que no segundo, com excessão da laje L09 que possuía mais linhas de studs que as demais lajes, conseguindo redistribuir melhor as tensões na região dos dois primeiros perímetros.

Ao observar os resultados da laje L03 que também possuía armadura de torção, notou-se que mesmo com os estribos a armadura de cisalhamento próximo à reentrância ainda atingiu deformações consideráveis nas duas primeiras camadas, com os extensômetros ES1 e ES2 atingindo valores maiores que 2,0 \% e 1,0 \% respectivamente.

\subsection{DEFORMAÇÃO NA ARMADURA DE TORÇÃO}

Foram dispostas armaduras de torção nas lajes L03 e L08, mas apenas na laje L08 tiveram pontos monitorados, como mostra a Figura 4.181. Foram instrumentados três pontos em cada estribo com dois extensômetros diametralmente opostos na barra. O resultado da deformação de cada ponto para cada passo de carga foi obtido pela média dos resultados registrados dos dois extensômetros. Os gráficos das deformações na armadura de cisalhamento, juntamente com os valores de carga no momento da ruptura serão apresentados nas figuras que se seguem (Figura 4.182 à Figura 4.187). 

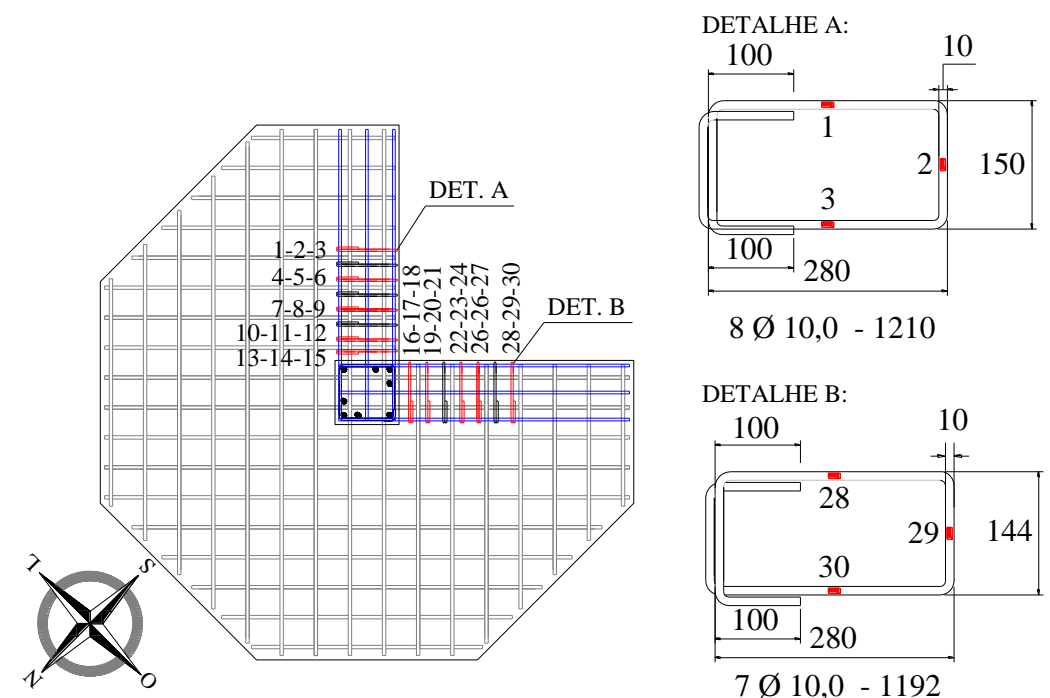

$8 \varnothing 10,0-1210$

DETALHE B:

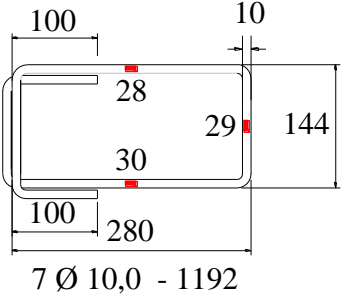

Figura 4.181 - Pontos instrumentados na armadura de torção da laje L08

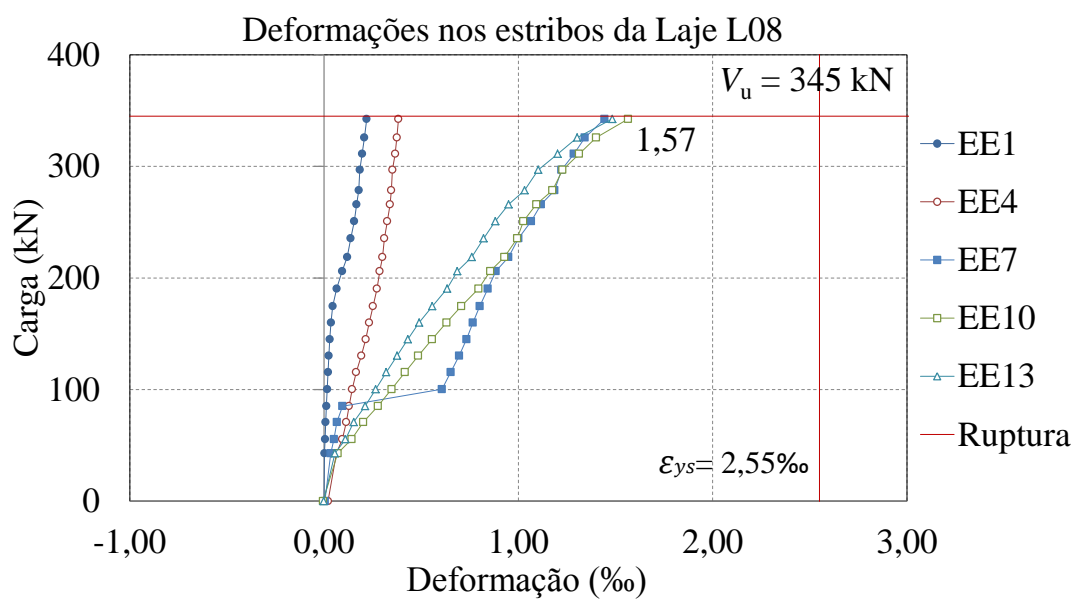

Figura 4.182 - Deformações nos pontos superiores dos estribos na direção SE-NO

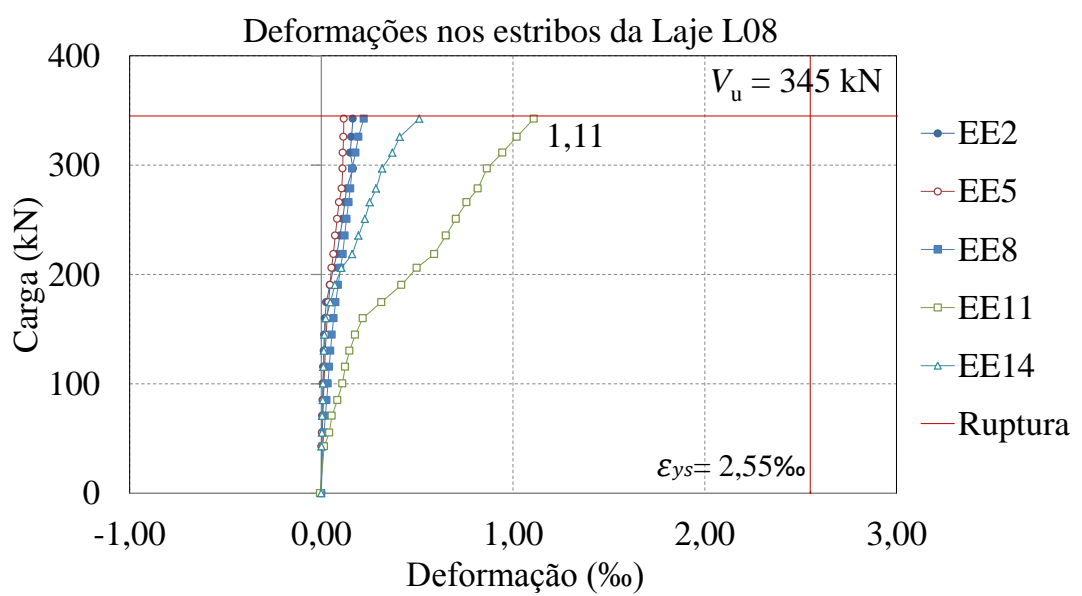

Figura 4.183 - Deformações nos pontos laterais dos estribos na direção SE-NO 


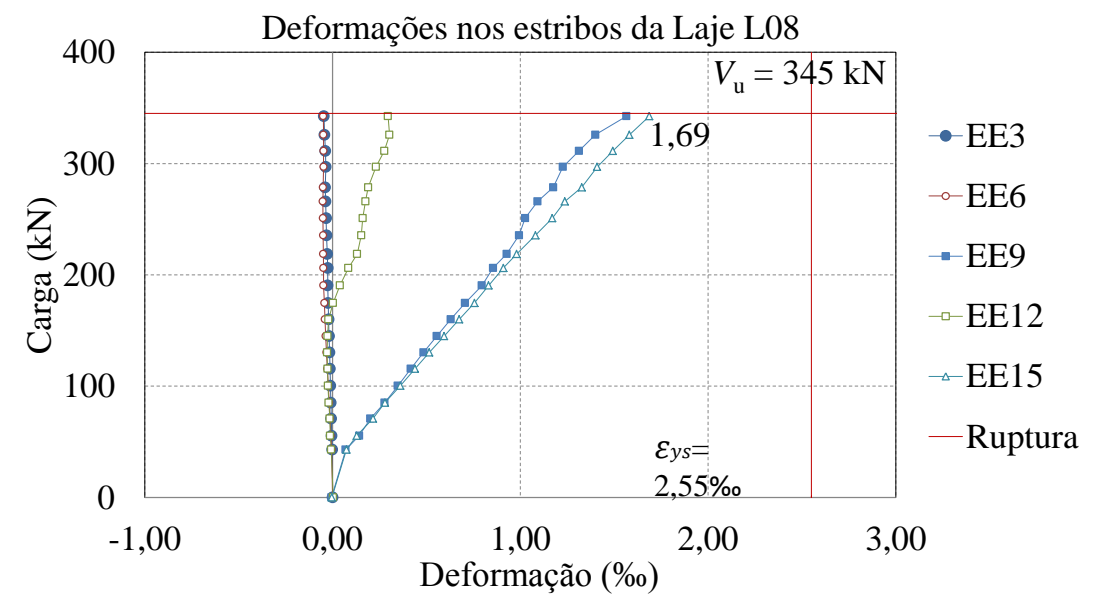

Figura 4.184 - Deformações nos pontos inferiores dos estribos na direção SE-NO

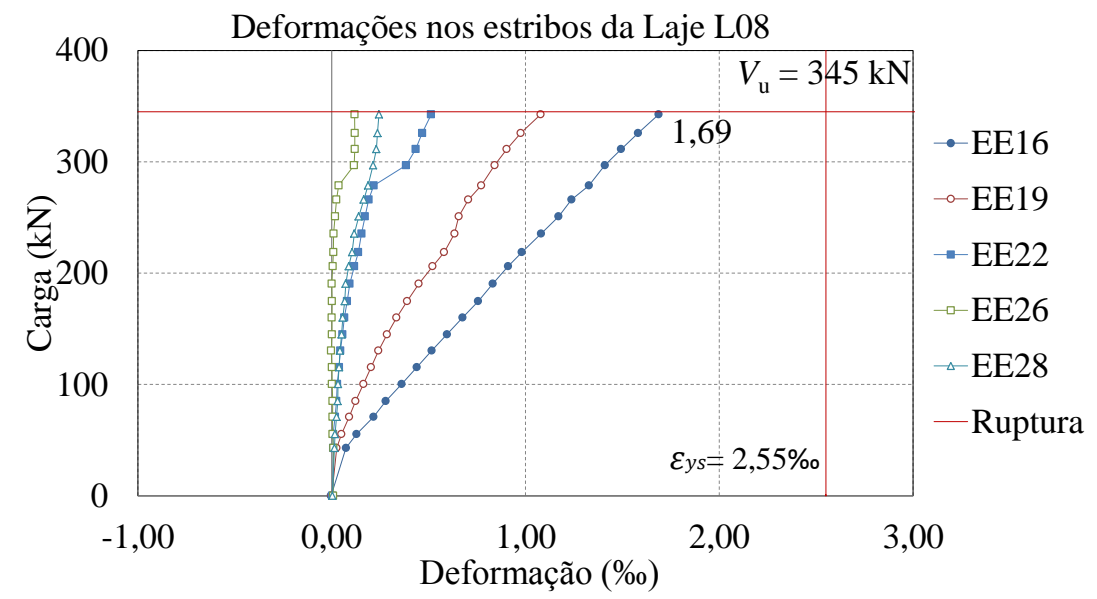

Figura 4.185 - Deformações nos pontos superiores dos estribos na direção NE-SO

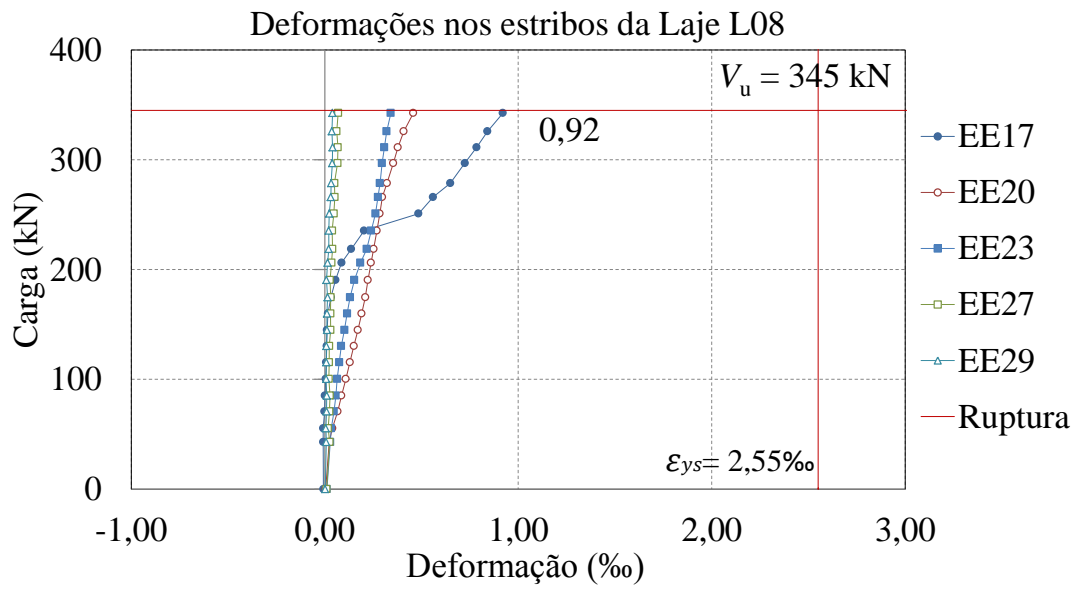

Figura 4.186 - Deformações nos pontos laterais dos estribos na direção NE-SO 


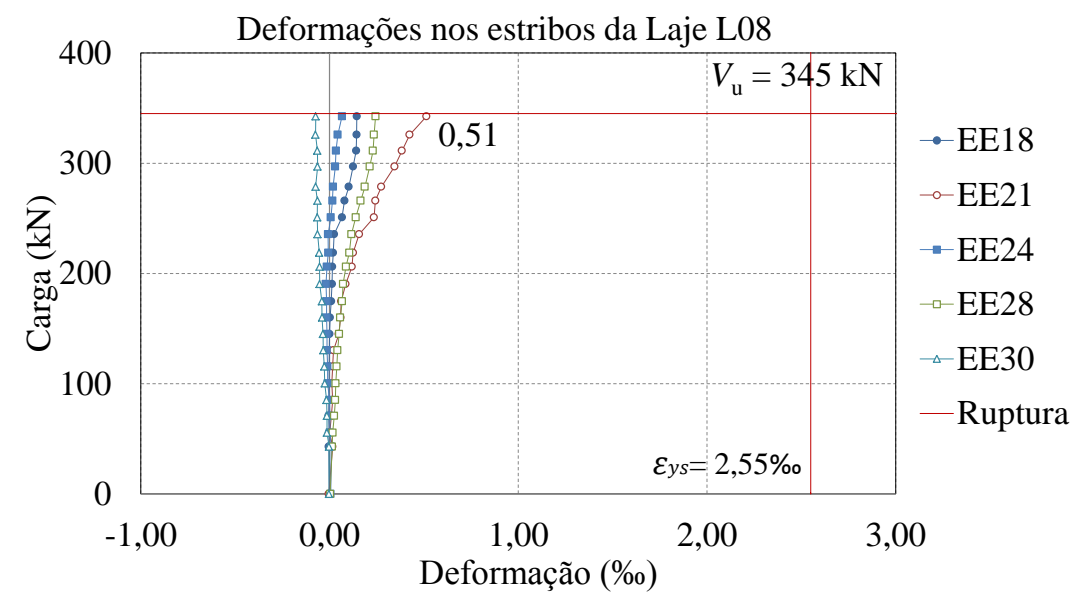

Figura 4.187 - Deformações nos pontos inferiores dos estribos na direção NE-SO

Com os gráficos pode-se notar que em uma das direções (pontos de monitorados de 1 à 15), ocorreram deformações acima de 1,0 \%o nos quarto primeiros estribo, contando a partir do pilar. Já na outra direção (pontos monitorados de 16 à 30) as deformações foram acima de 1,0 \%o nos dois primeiros estribos apenas. Contudo, pode-se reduzir a quantidade de estribos, mas para definir exatamente a eficiência e a que distância eles devem ser distribuídos seria necessário mais ensaios.

\subsection{DEFORMAÇÃO NO CONCRETO}

As deformações no concreto foram obtidas através de extensômetros elétricos de resistência posicionados na superfície inferior e superior das lajes. Na Série 1 foram monitorados extensômetros somente na face inferior das lajes próximo às faces dos pilares e nos eixos das lajes e dispostos de modo que registrassem as deformações tangenciais $(\mathrm{EC} 1, \mathrm{EC} 2, \mathrm{EC} 3, \mathrm{EC} 4, \mathrm{EC} 5$ e EC6) e radiais $(\mathrm{EC} 7, \mathrm{EC} 8$ e EC9) em relação às faces do pilar. Nas Séries 2 e 3 foram monitorados extensômetros na face inferior e superior de cada laje de modo que registrassem as deformações tangenciais (EC1, EC3 e EC5) e radiais (EC2, EC4, EC6, EF7, EC8 e EC9) em relação às faces do pilar.

A seguir são apresentados os resultados de deformação obtidos através dos extensômetros posicionados nas superfícies de concreto inferiores e superiores das lajes e os respectivos valores da carga no momento do registro das deformações (Figura 4.188 à Figura 4.199). 


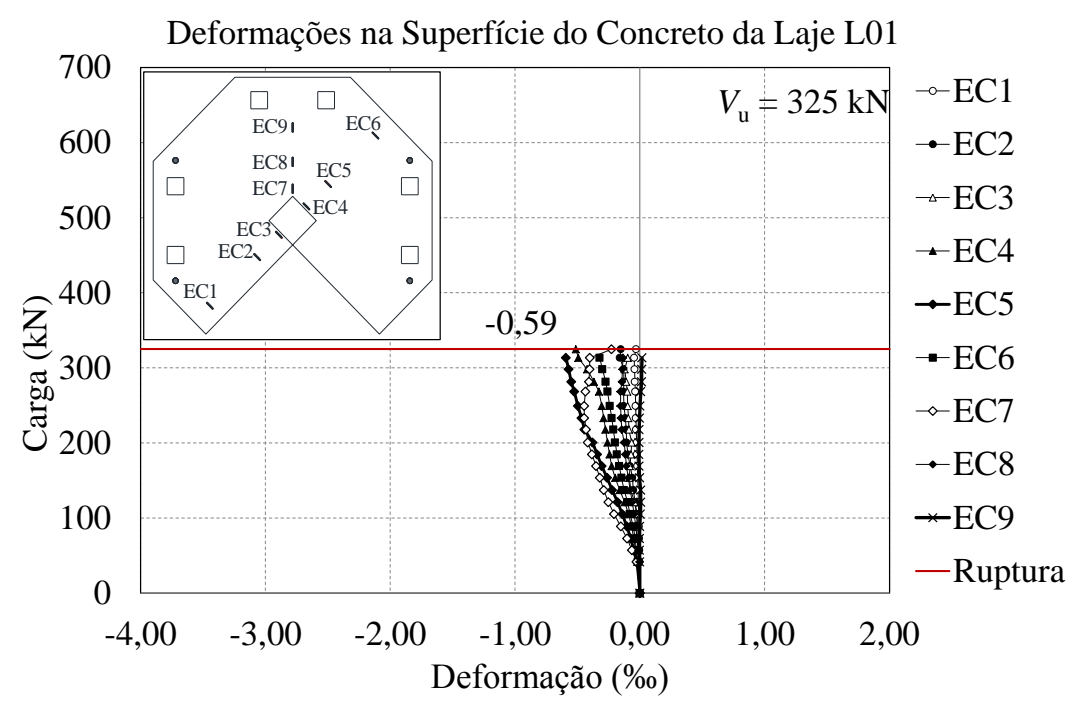

Figura 4.188 - Deformações na superfície do concreto da laje L01

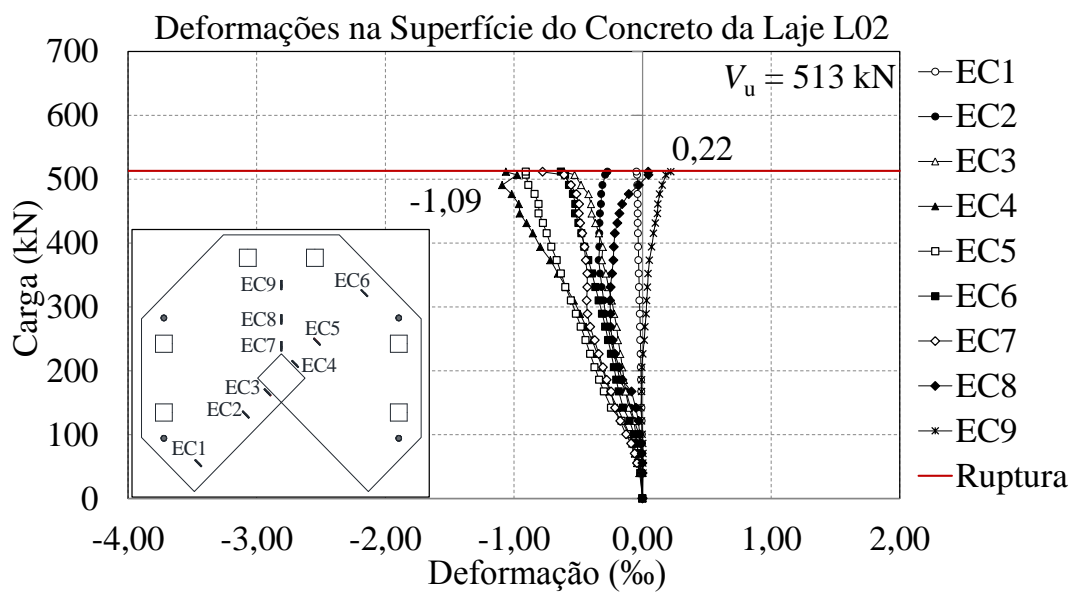

Figura 4.189 - Deformações na superfície do concreto da laje L02

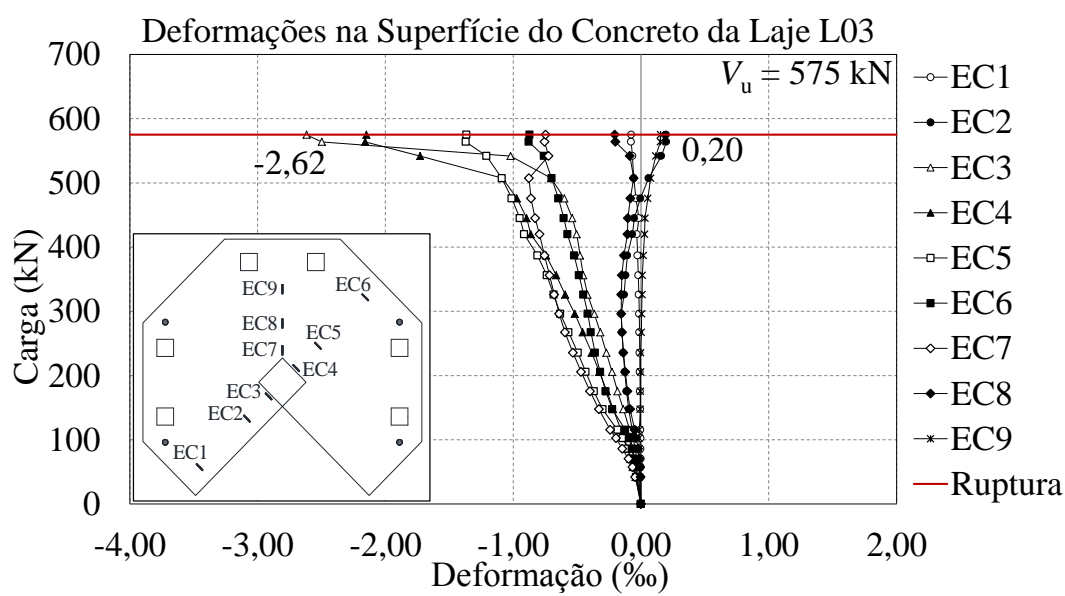

Figura 4.190 - Deformações na superfície do concreto da laje L03 


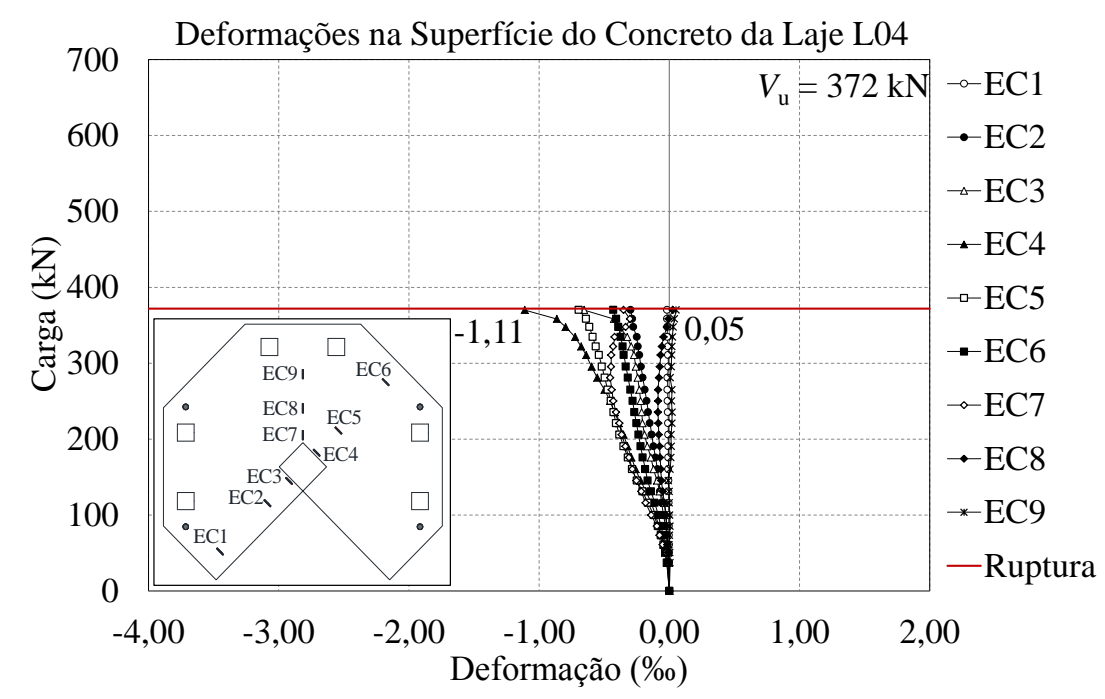

Figura 4.191 - Deformações na superfície do concreto da laje L04

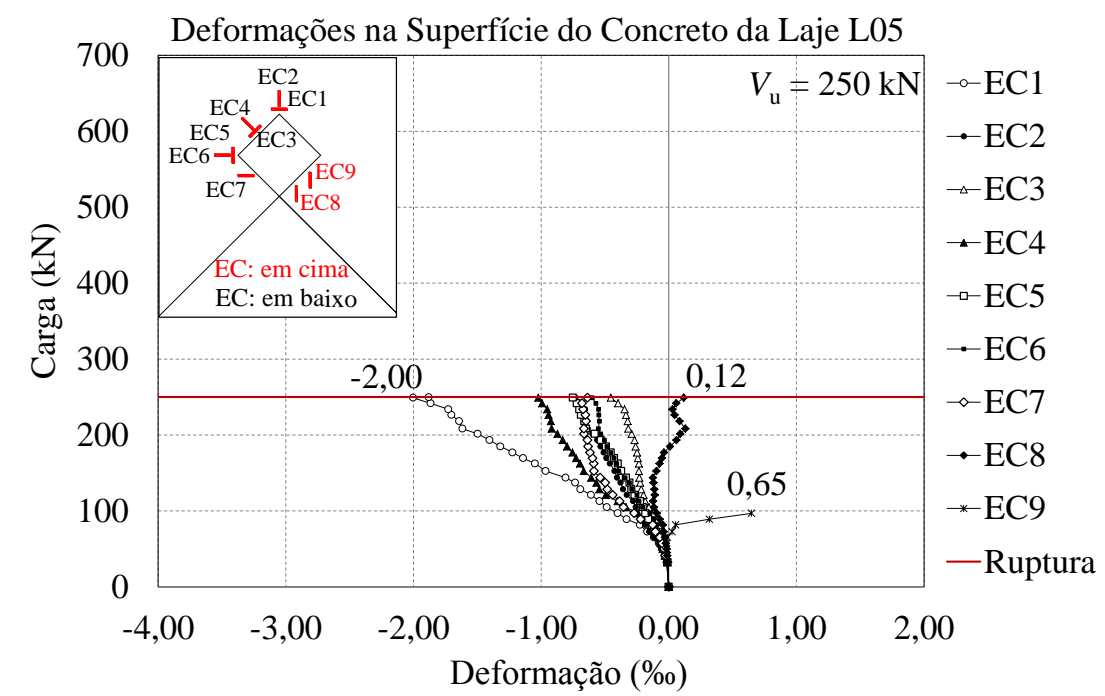

Figura 4.192 - Deformações na superfície do concreto da laje L05

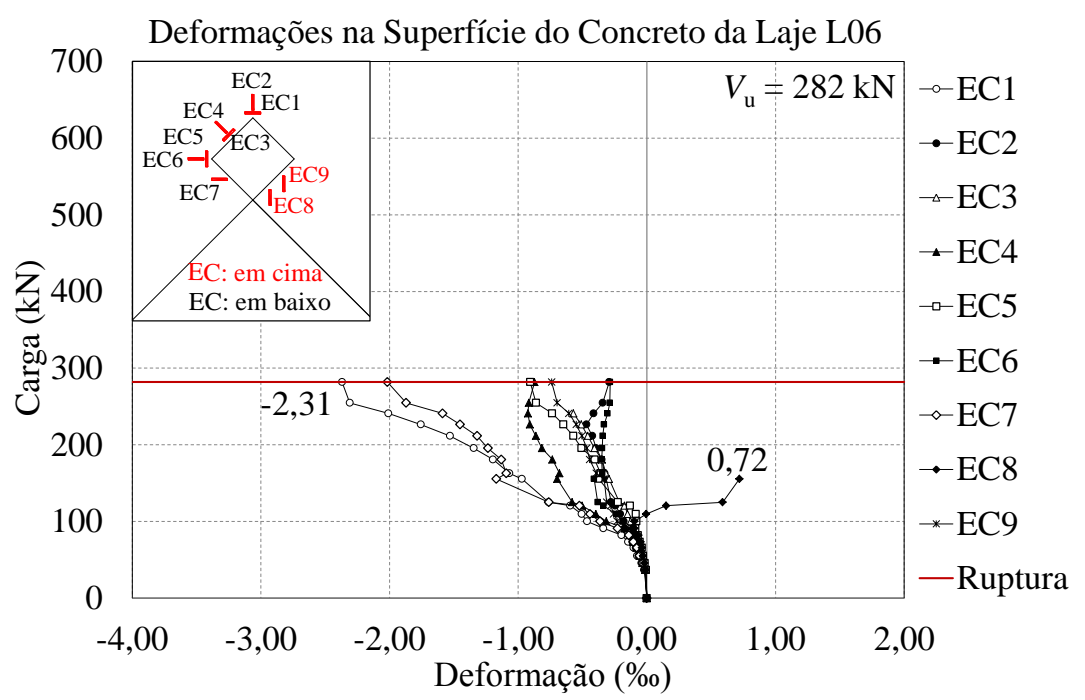

Figura 4.193 - Deformações na superfície do concreto da laje L06 


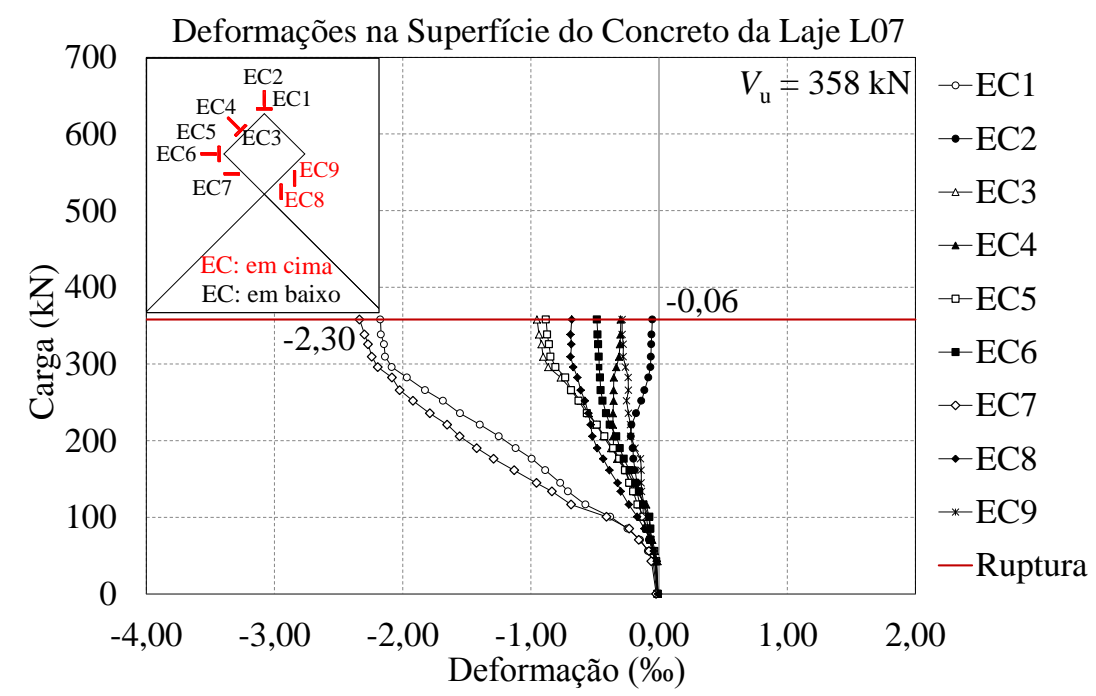

Figura 4.194 - Deformações na superfície do concreto da laje L07

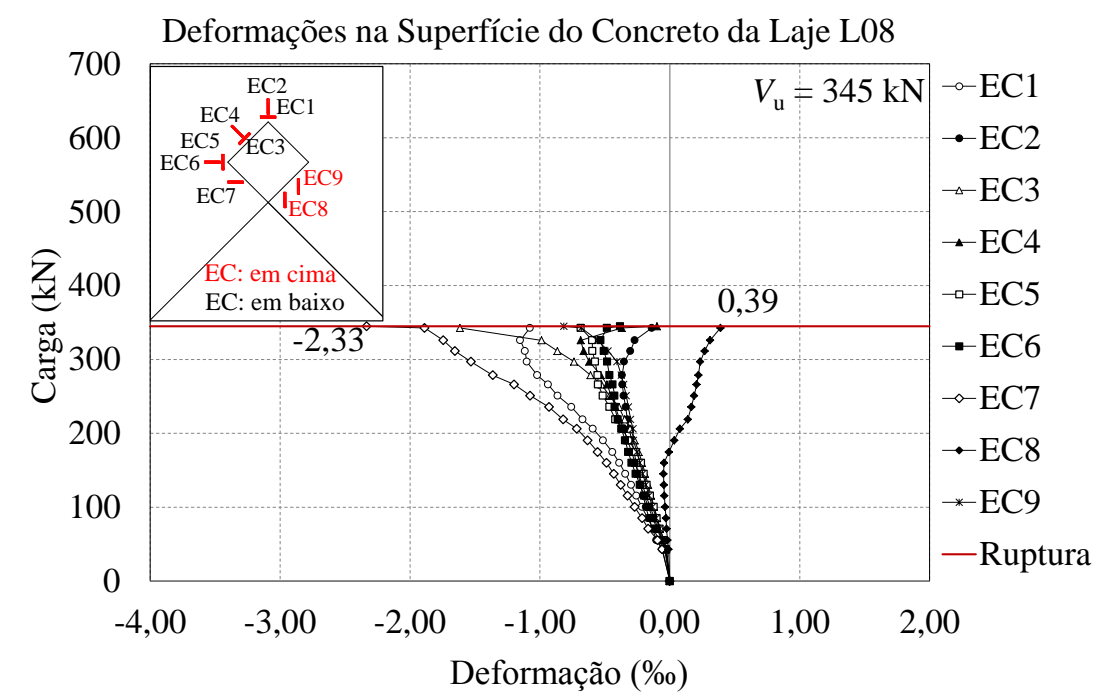

Figura 4.195 - Deformações na superfície do concreto da laje L08

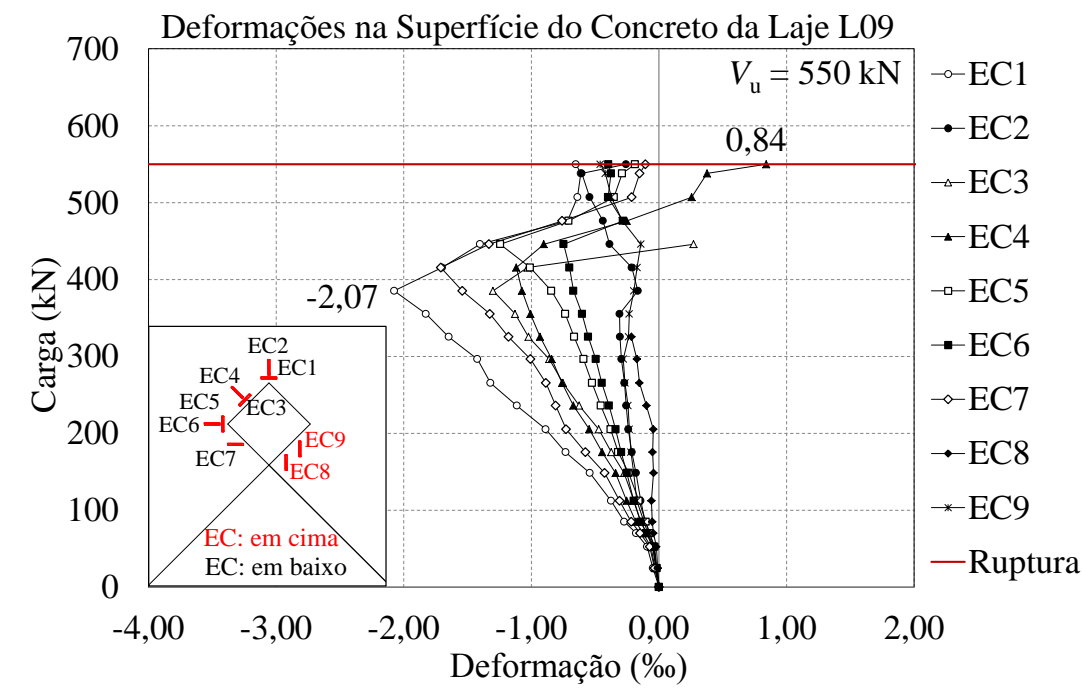

Figura 4.196 - Deformações na superfície do concreto da laje L09 


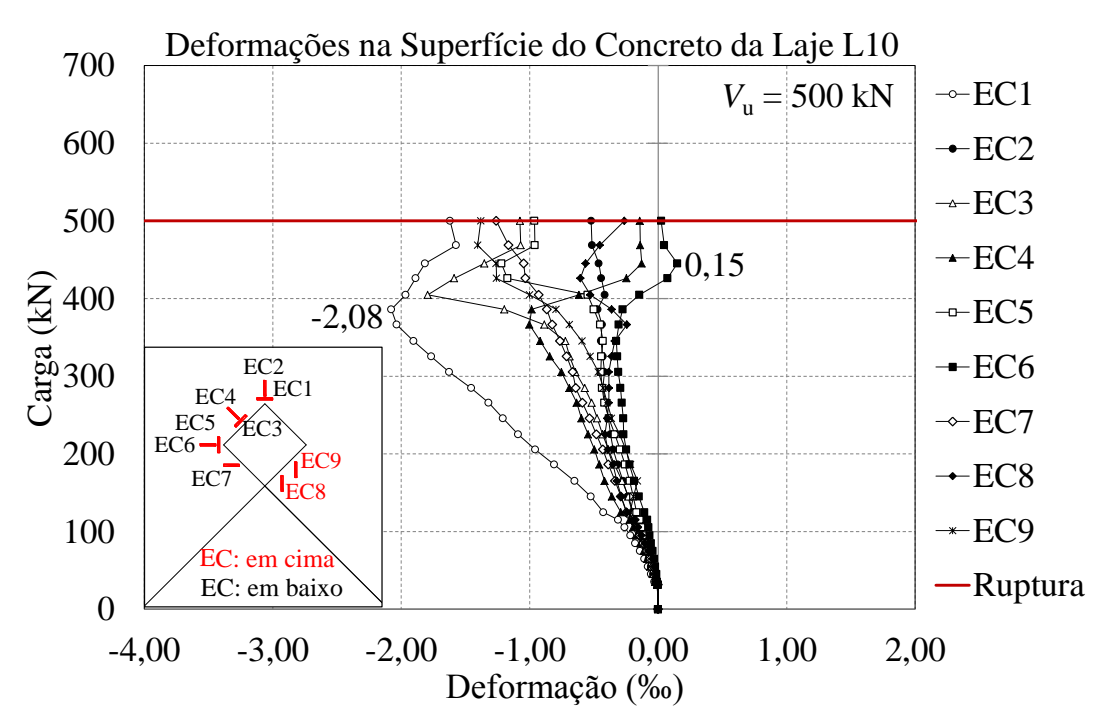

Figura 4.197 - Deformações na superfície do concreto da laje L10

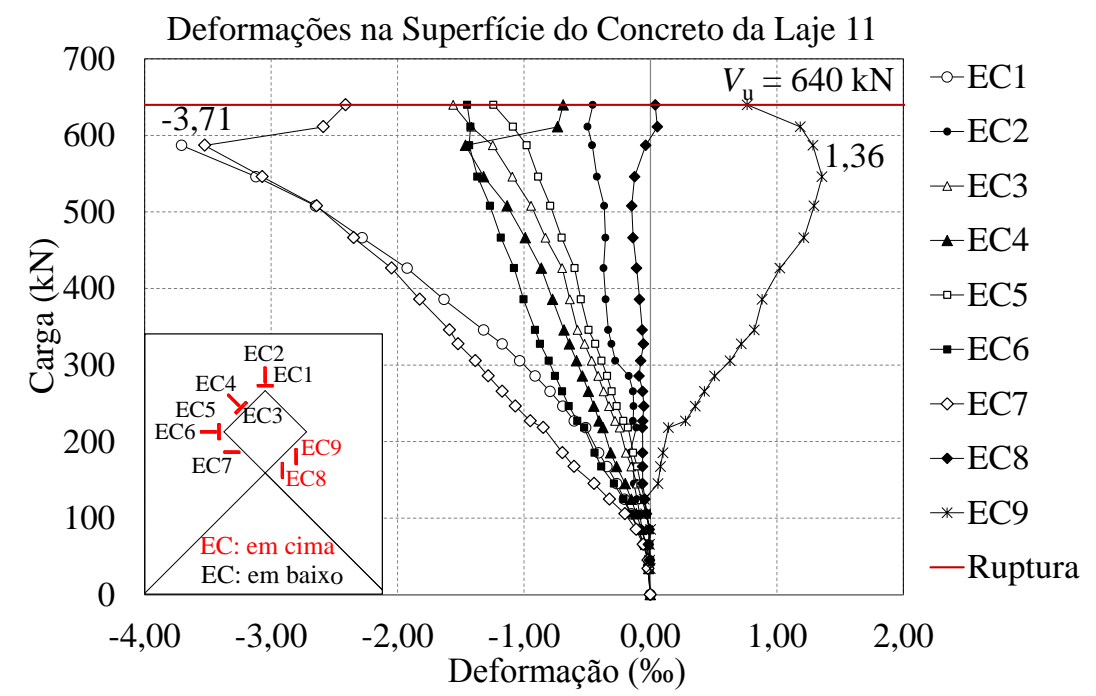

Figura 4.198 - Deformações na superfície do concreto da laje L11

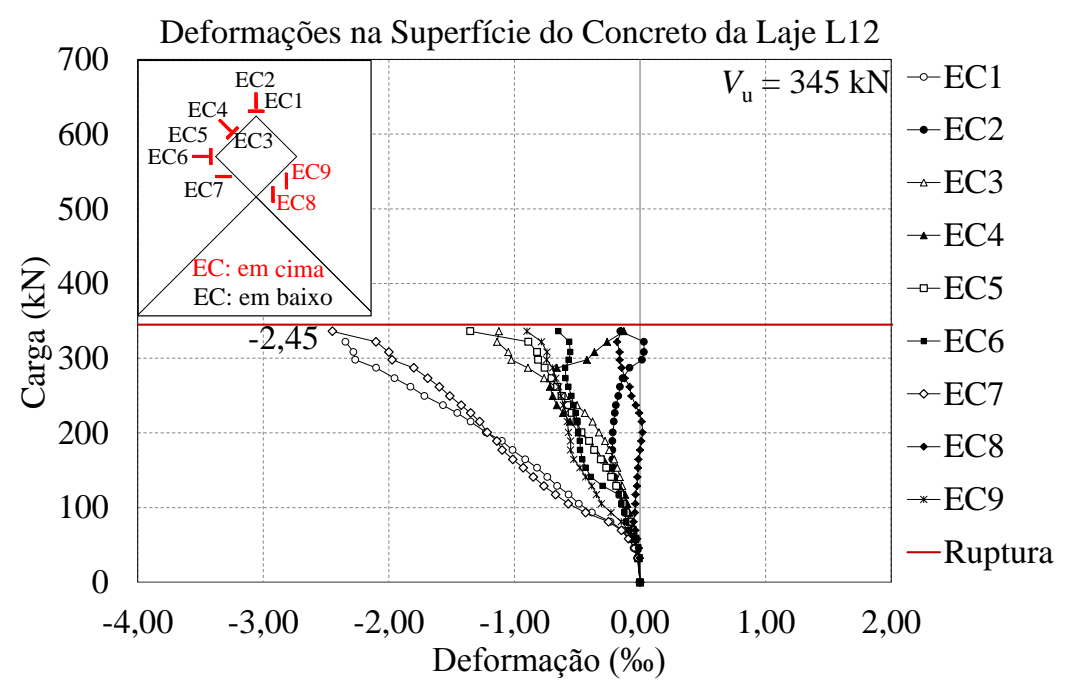

Figura 4.199 - Deformações na superfície do concreto da laje L12 
Na Série 1 de ensaios apenas a laje L03 teve deformações relevantes, acima de 2,5\%, nos pontos próximos ao pilar mostrando que o concreto se aproximou da ruptura. Já nas lajes das Séries 2 e 3 que tiveram instrumentação diferente, mostraram que o concreto é mais solicitado nos pontos tangenciais ao pilar próximo ao eixo de simetria mas somente a laje L11 tive deformações acima de 3,0 \%. A laje L11 foi à única que apresentou o ponto EC9 (situado na superfície superior do concreto próximo a reentrância) tracionado desde o início do carregamento até a ruptura por ter menor transferência de momento; o que possibilitou também o concreto ser mais solicitado antes da ruptura com a ocorrência de esmagamento na superfície inferior do mesmo.

\subsection{RESUMO DOS RESULTADOS EXPERIMENTAIS}

Será exposto aqui um resumo dos resultados de deslocamentos máximos e deformações do concreto na Tabela 4.5, deformações das armaduras de flexão na Tabela 4.5; e deformações das armaduras de cisalhamento na Tabela 4.6 para diferentes níveis de carga, próximo a ruptura.

Tabela 4.5 - Resultados experimentais (deslocamentos e deformação do concreto).

\begin{tabular}{|c|c|c|c|c|c|c|c|c|c|}
\hline Laje & Camada & $\begin{array}{c}f_{c} \\
(\mathrm{MPa})\end{array}$ & $\begin{array}{c}V_{u} \\
(\mathrm{kN})\end{array}$ & $\begin{array}{l}3(\mathrm{~V}) \\
(\mathrm{mm})\end{array}$ & $\begin{array}{l}7(\mathrm{~V}) \\
(\mathrm{mm}) \\
\end{array}$ & $\begin{array}{l}11(\mathrm{~V}) \\
(\mathrm{mm})\end{array}$ & $\begin{array}{r}17(\mathrm{E}) \\
(\mathrm{mm})\end{array}$ & $\begin{array}{l}18(\mathrm{E}) \\
(\mathrm{mm}) \\
\end{array}$ & $\begin{array}{c}\varepsilon_{c} \\
\left(10^{-6}\right) \\
\end{array}$ \\
\hline L01 & 0 & \multirow{4}{*}{48} & 325 & $-24,8$ & $-22,0$ & $-24,5$ & $-22,0$ & $-57,0$ & $-0,59$ \\
\hline L02 & 3 & & 513 & $-24,4$ & $-16,7$ & $-21,4$ & $-40,0$ & $-58,0$ & $-1,09$ \\
\hline L03 & 4 & & 575 & $-32,9$ & $-23,0$ & $-33,4$ & $-34,0$ & $-53,0$ & $-2,62$ \\
\hline L04 & 0 & & 372 & $-15,8$ & $-10,5$ & $-15,4$ & $-15,0$ & $-17,0$ & $-1,11$ \\
\hline L05 & 0 & \multirow{4}{*}{44} & 250 & $-15,03$ & $-19,2$ & $-18,3$ & $-7,0$ & $-27,0$ & $-2,00$ \\
\hline L06 & 0 & & 282 & $-17,7$ & $-10,0$ & $-19,5$ & $-11,1$ & $-18,1$ & $-2,31$ \\
\hline L07 & 0 & & 358 & $-17,6$ & $-10,9$ & $-17,3$ & $-16,0$ & $-20,0$ & $-2,30$ \\
\hline L08 & 0 & & 345 & $-21,2$ & $-14,7$ & $-20,3$ & $-18,0$ & $-22,0$ & $-2,33$ \\
\hline L09 & 2 & \multirow{4}{*}{43} & 550 & $-40,0$ & $-25,7$ & $-37,3$ & $-28,0$ & $-39,0$ & $-2,07$ \\
\hline L10 & 2 & & 500 & $-30,1$ & $-24,4$ & $-29,8$ & $-18,0$ & $-45,0$ & $-2,08$ \\
\hline L11 & 2 & & 640 & $-34,9$ & $-18,0$ & $-29,9$ & $-40,0$ & $-32,0$ & $-3,71$ \\
\hline L12 & 0 & & 345 & $-19,1$ & $-9,4$ & $-17,7$ & $-22,0$ & $-16,0$ & $-2,45$ \\
\hline
\end{tabular}


Tabela 4.6 - Resumo dos resultados experimentais (deformação da armadura de flexão).

\begin{tabular}{|c|c|c|c|c|c|}
\hline Laje & $\rho(\%)$ & $\begin{array}{c}\varepsilon_{y} \\
(\mathrm{MPa})\end{array}$ & $V_{u}(\mathrm{kN})$ & $\begin{array}{l}\varepsilon_{f l, m a ́ x} \\
\left(10^{-6}\right)\end{array}$ & $\begin{array}{l}\varepsilon_{f 2, \text { máx }} \\
\left(10^{-6}\right)\end{array}$ \\
\hline L01 & 2,07 & 2,91 & 325 & $+2,22$ & $+1,85$ \\
\hline L02 & 2,07 & 2,91 & 513 & $+4,36$ & $+2,75$ \\
\hline L03 & 2,17 & 2,91 & 575 & $+2,88$ & $+2,84$ \\
\hline L04 & 2,10 & 2,91 & 372 & $+2,41$ & $+2,31$ \\
\hline L05 & 0,91 & 2,97 & 250 & $+3,75$ & $+3,50$ \\
\hline L06 & 0,88 & 2,97 & 282 & $+4,55$ & $+2,81$ \\
\hline L07 & 1,35 & 2,90 & 358 & $+5,19$ & $+4,73$ \\
\hline L08 & 1,27 & 2,90 & 15 & $+3,57$ & $+3,34$ \\
\hline L09 & 2,08 & 2,75 & 550 & $+5,25$ & $+4,74$ \\
\hline L10 & 2,08 & 2,75 & 500 & $+5,52$ & $+3,18$ \\
\hline L11 & 2,11 & 2,75 & 640 & $+4,70$ & $+4,68$ \\
\hline L12 & 1,28 & 2,75 & 345 & $+4,44$ & $+3,83$ \\
\hline
\end{tabular}

Tabela 4.7 - Resultados experimentais (deformação da armadura de cisalhamento).

\begin{tabular}{|l|c|c|c|c|c|c|c|}
\hline Laje & Camada & $\begin{array}{c}f_{y} \\
(\mathrm{MPa})\end{array}$ & $V_{u}(\mathrm{kN})$ & $\begin{array}{c}\varepsilon_{s c 1, \max } \\
\left(10^{-6}\right)\end{array}$ & $\begin{array}{c}\varepsilon_{s c 2, \max x} \\
\left(10^{-6}\right)\end{array}$ & $\begin{array}{c}\varepsilon_{s c 3, m a ́ x} \\
\left(10^{-6}\right)\end{array}$ & $\begin{array}{c}\varepsilon_{s c 4, m a ́ x} \\
\left(10^{-6}\right)\end{array}$ \\
\hline L02 & 3 & 3,13 & 513 & $+1,99$ & $+5,51$ & $+2,44$ & - \\
\hline L03 & 4 & 2,84 & 575 & $+2,24$ & $+2,31$ & $+2,10$ & $+2,06$ \\
\hline L09 & 2 & 2,55 & 550 & $+1,89$ & $+1,65$ & - & - \\
\hline L10 & 2 & 2,55 & 500 & $+1,78$ & $+2,54$ & - & - \\
\hline L11 & 2 & 2,55 & 640 & $+1,89$ & $+2,92$ & - & - \\
\hline
\end{tabular}

\subsection{MAPA DE FISSURAÇÃO}

Durante os ensaios o carregamento foi aplicado em passos de carga variando de $5,0 \mathrm{kN}$ a 15,0 kN dependendo da previsão da carga de ruptura para cada laje. Após a aplicação de cada passo de carga foram feitos intervalos para registro das deformações do aço, do concreto e leitura das flechas através do sistema de aquisição de dados e acompanhamento da fissuração de cada laje. As primeiras fissuras a surgir na laje foram fissuras de flexão, localizadas na região em torno do pilar. Nas Figura 4.200 à Figura 4.211 são apresentados os mapas de fissuração das 12 lajes após a realização dos ensaios. 

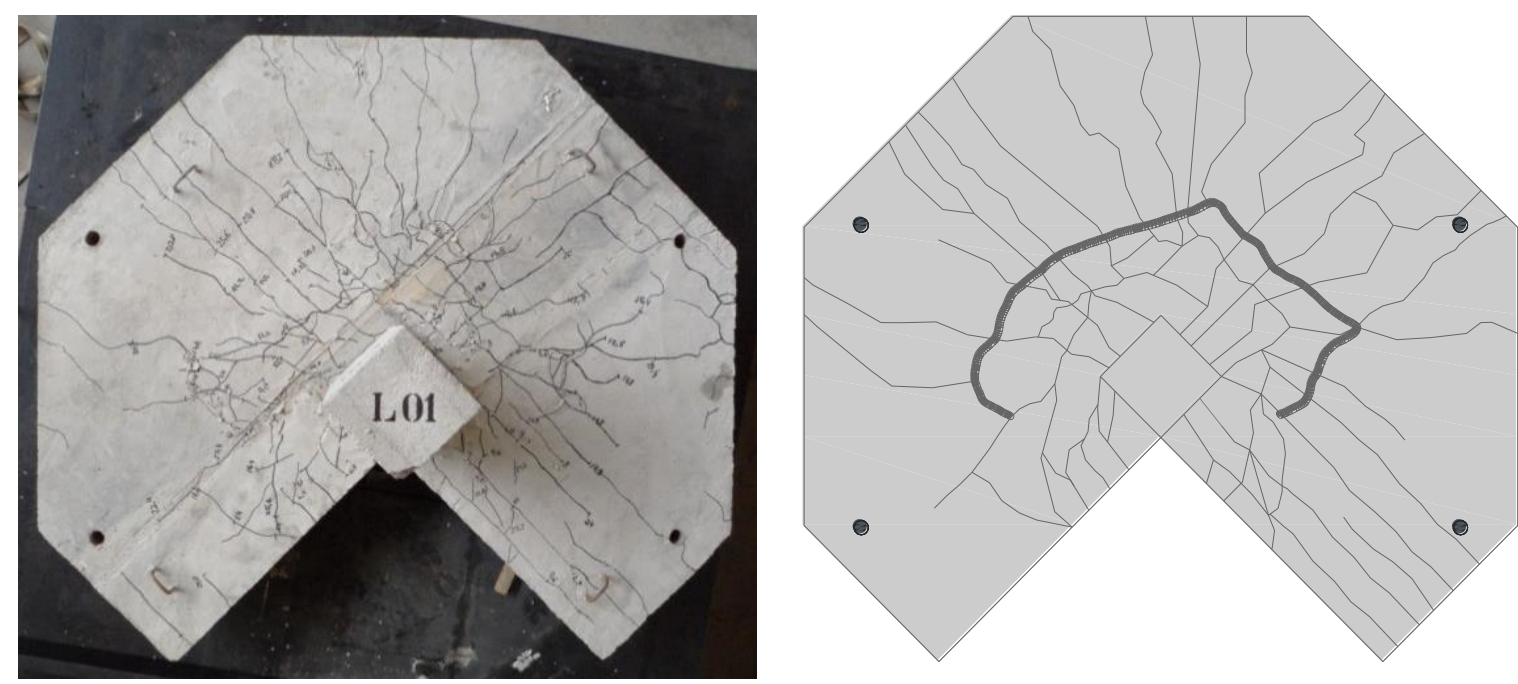

Figura 4.200 - Configuração de fissuras da laje L01
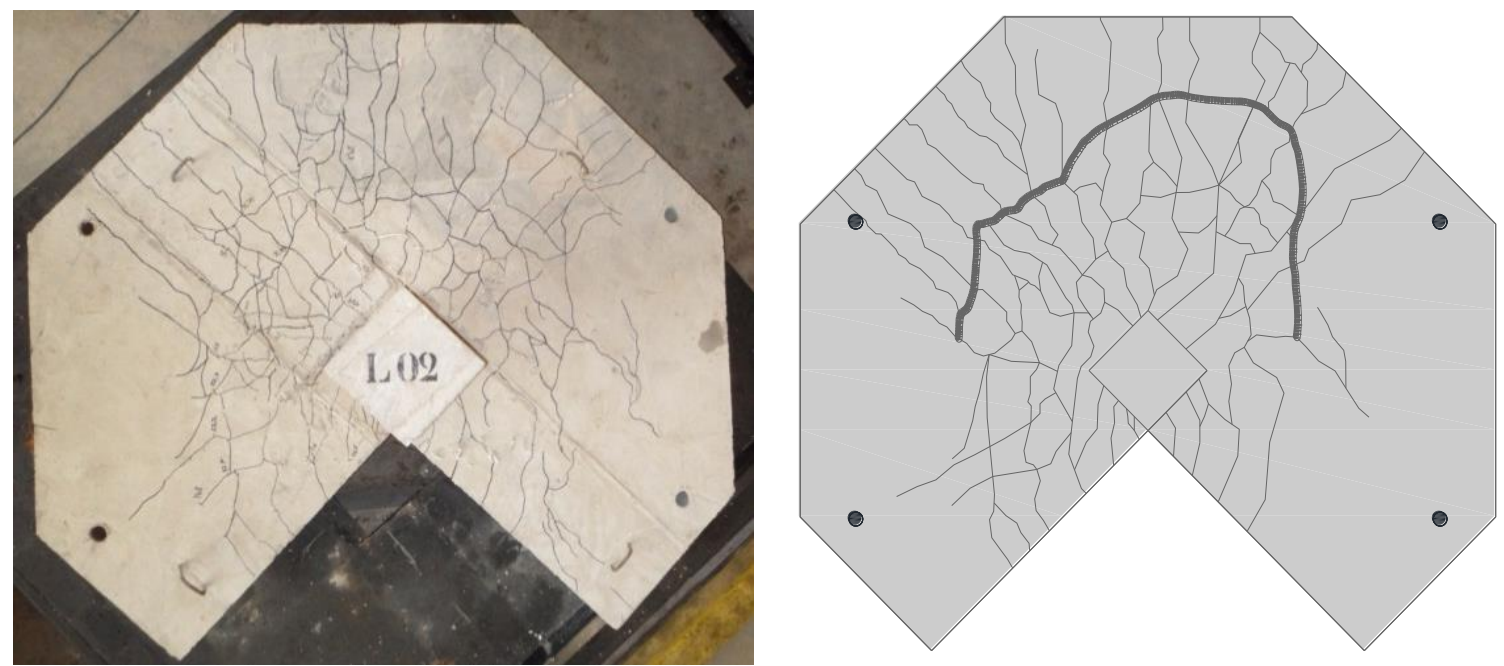

Figura 4.201 - Configuração de fissuras da laje L02
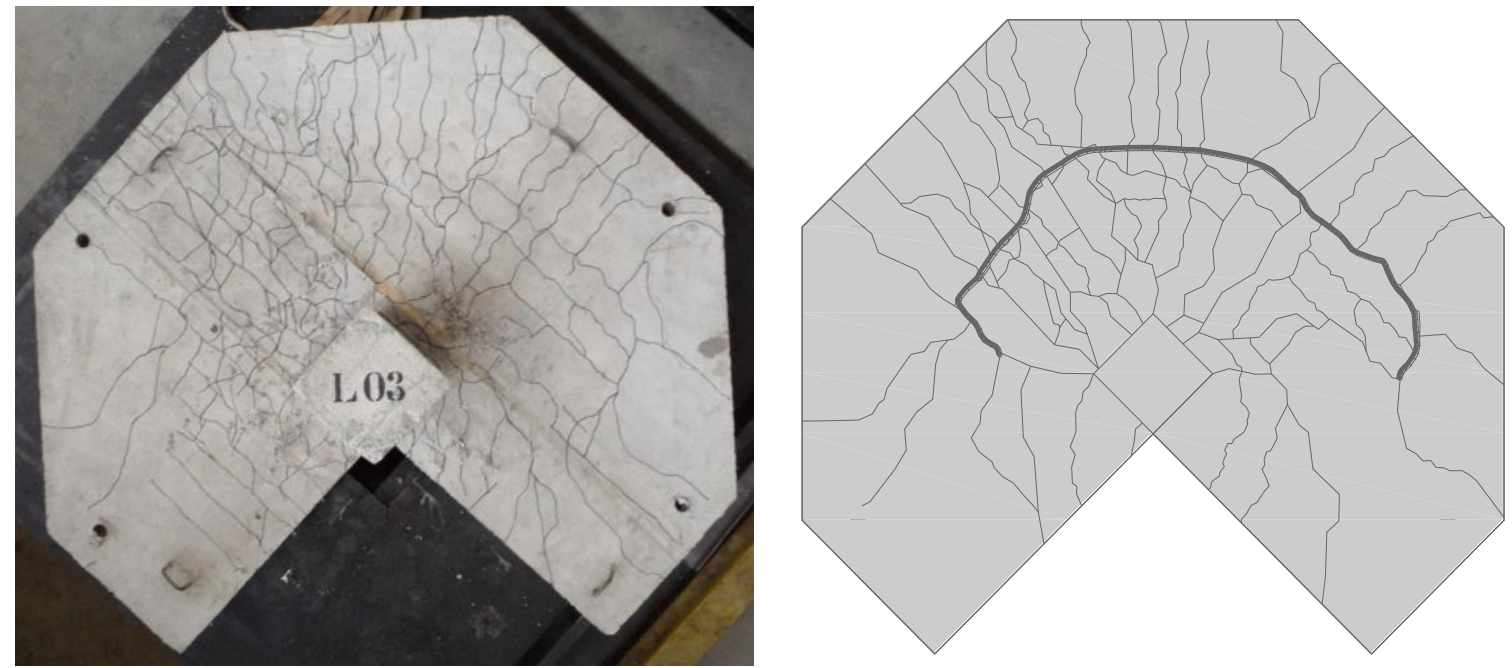

Figura 4.202 - Configuração de fissuras da laje L03 

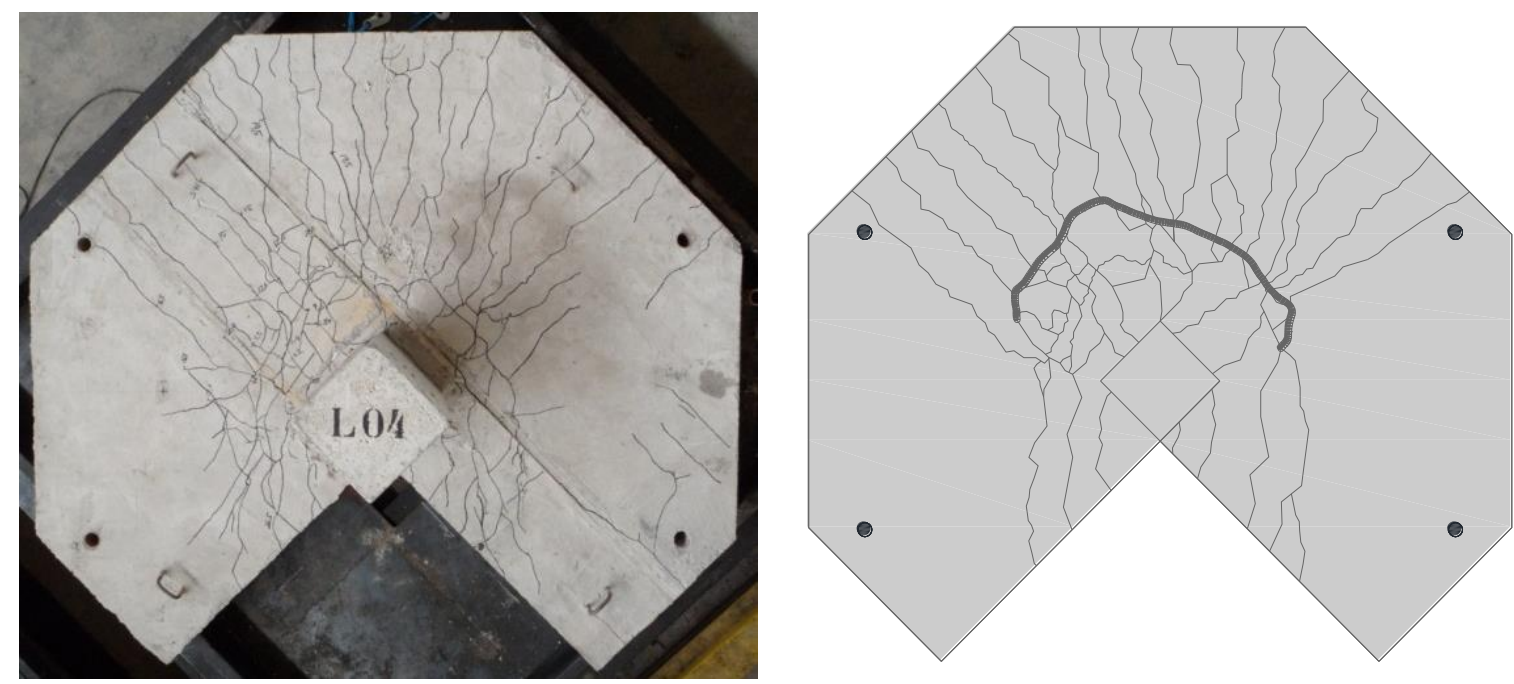

Figura 4.203 - Configuração de fissuras da laje L04
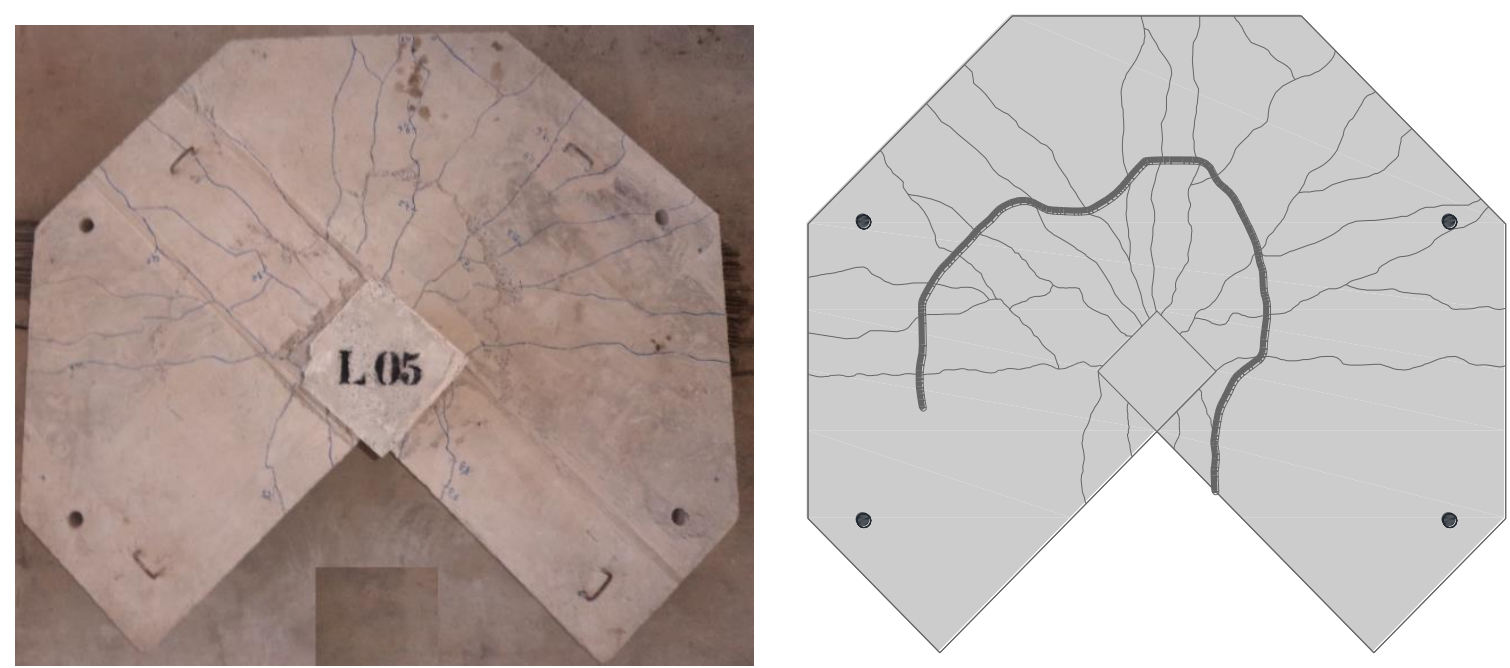

Figura 4.204 - Configuração de fissuras da laje L05
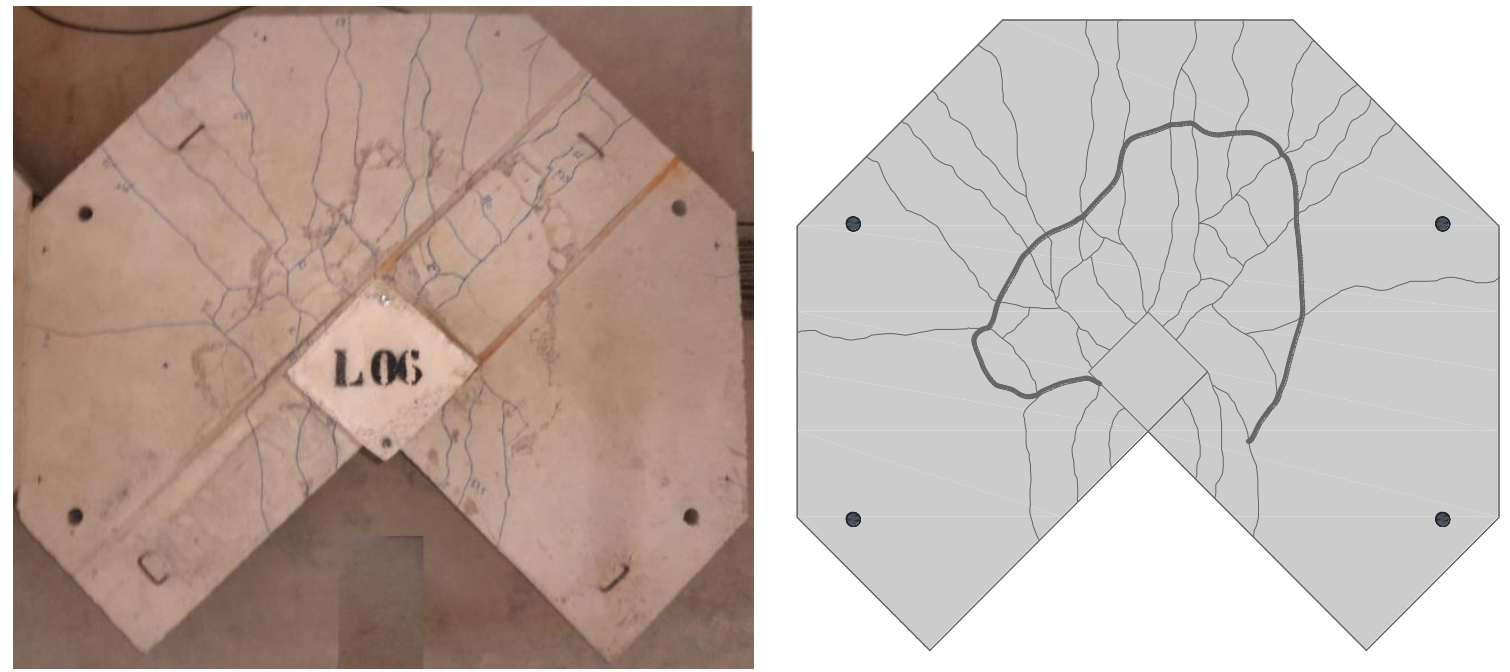

Figura 4.205 - Configuração de fissuras da laje L06 

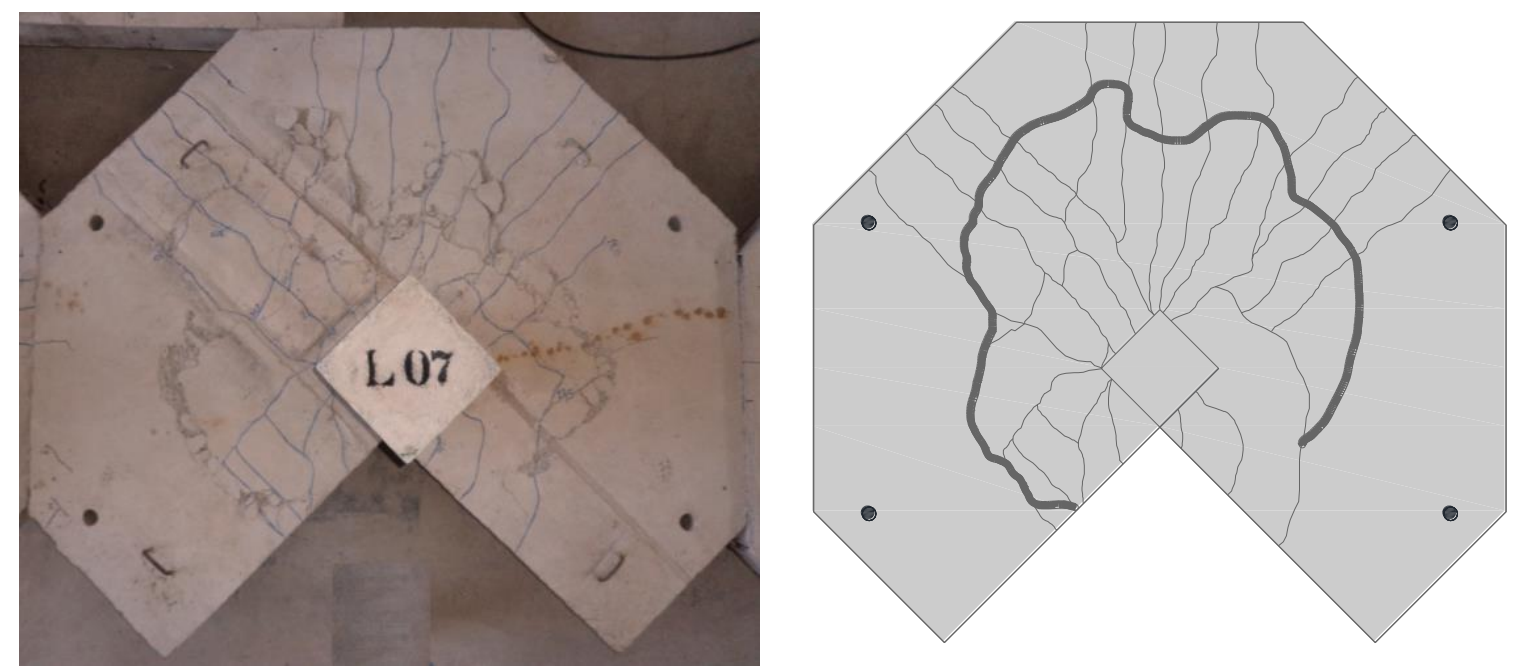

Figura 4.206 - Configuração de fissuras da laje L07
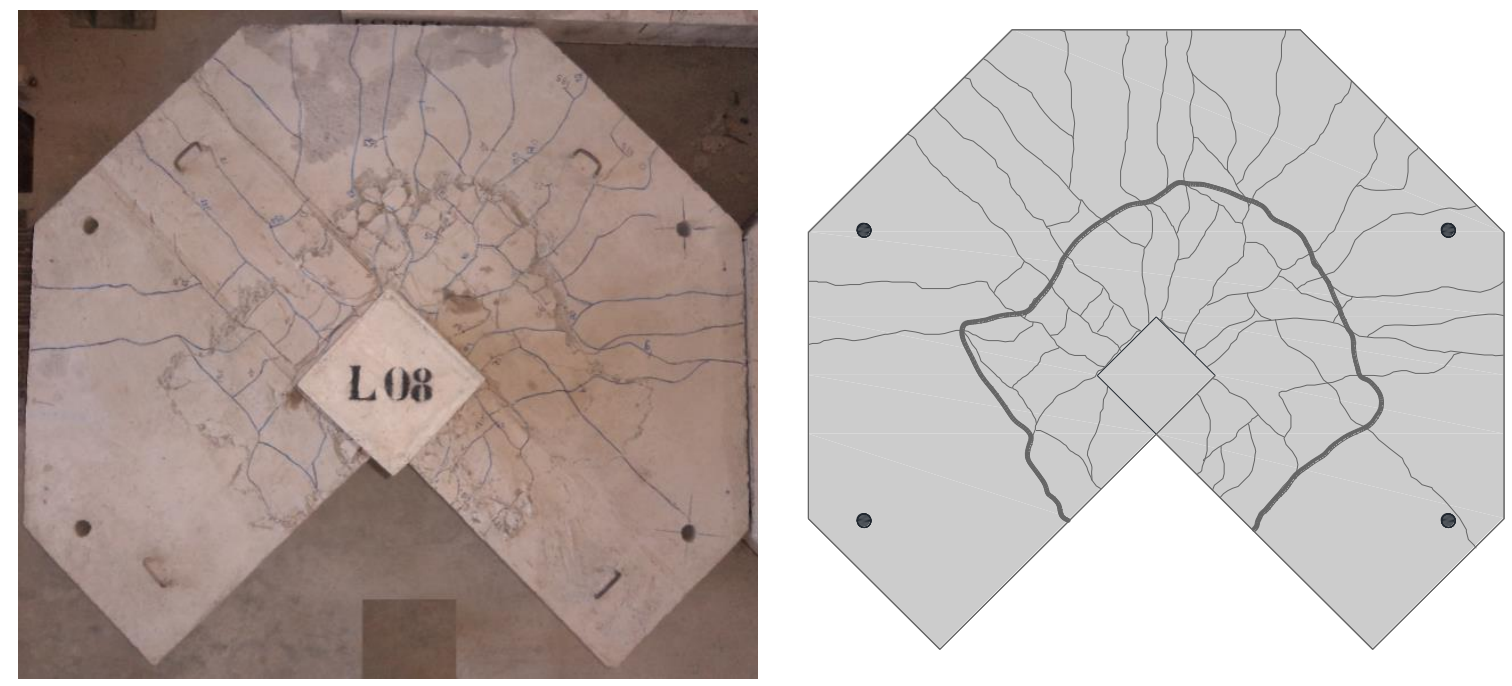

Figura 4.207 - Configuração de fissuras da laje L08
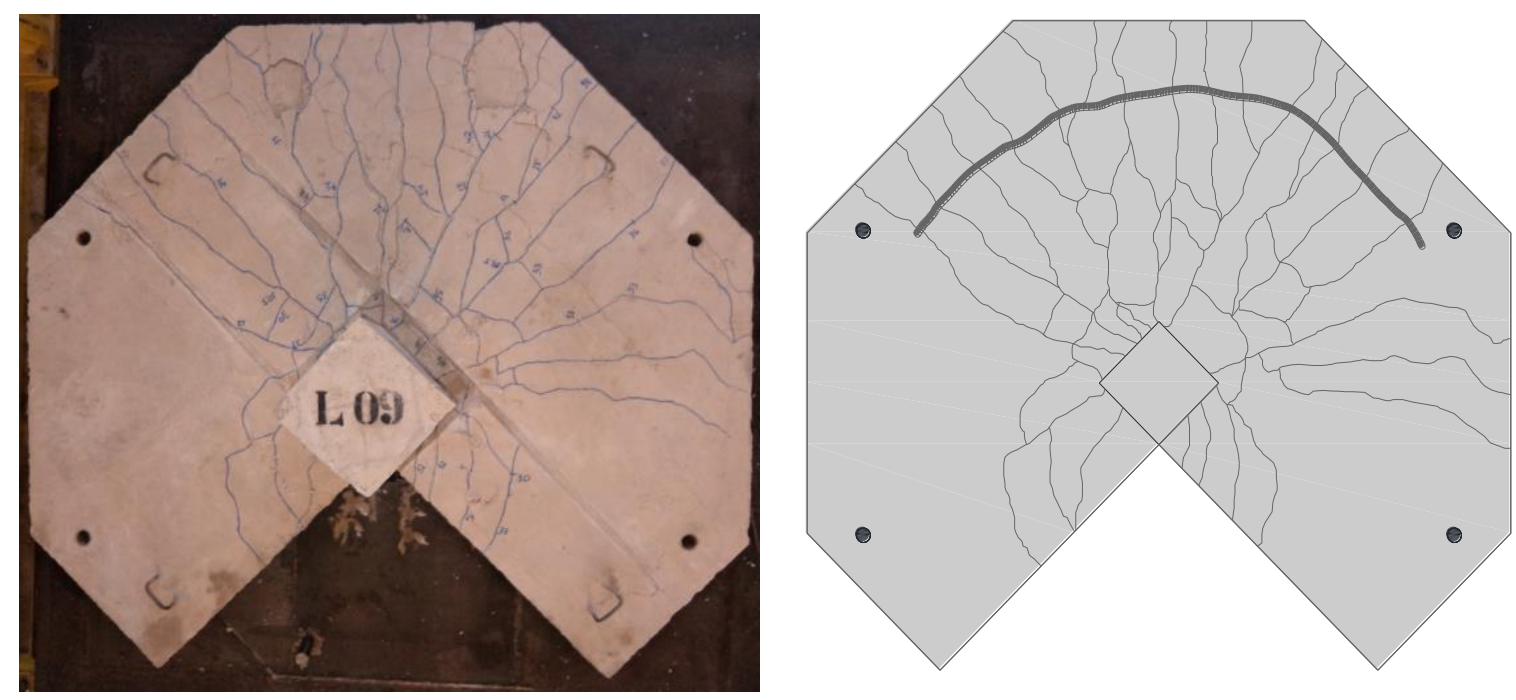

Figura 4.208 - Configuração de fissuras da laje L09 

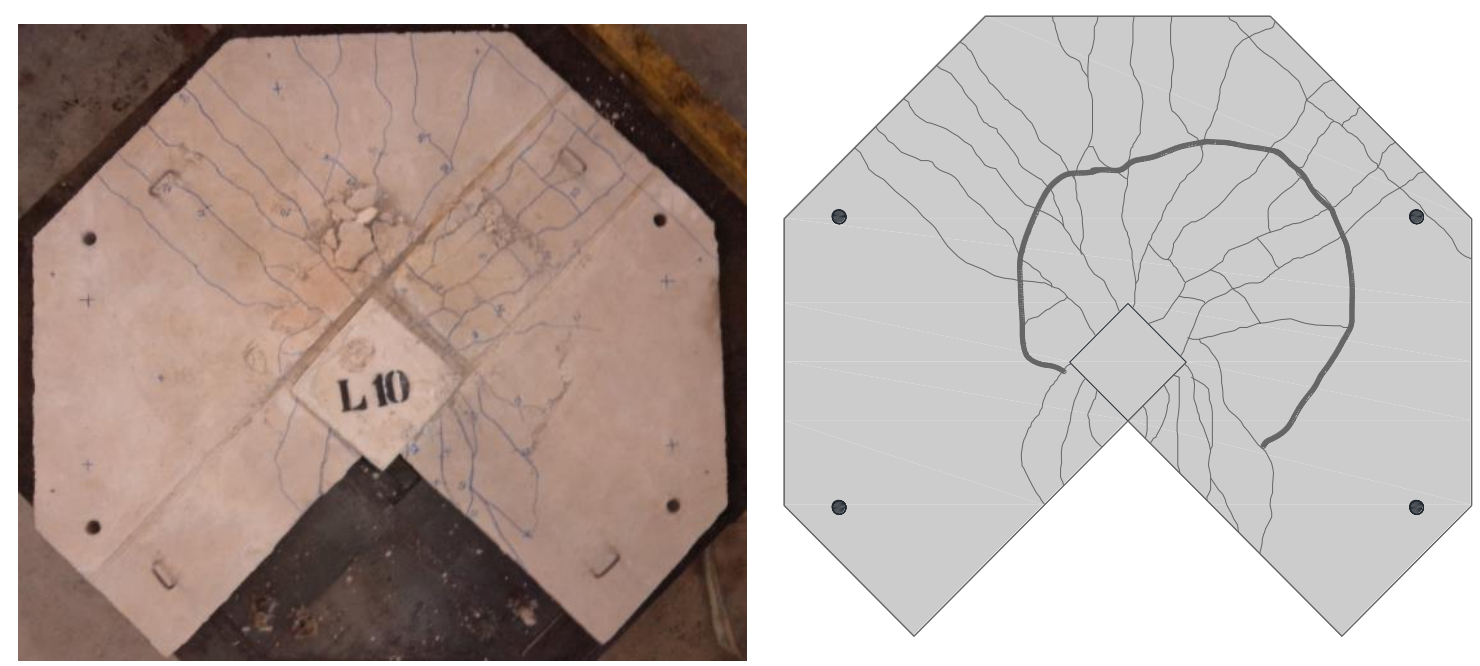

Figura 4.209 - Configuração de fissuras da laje L010
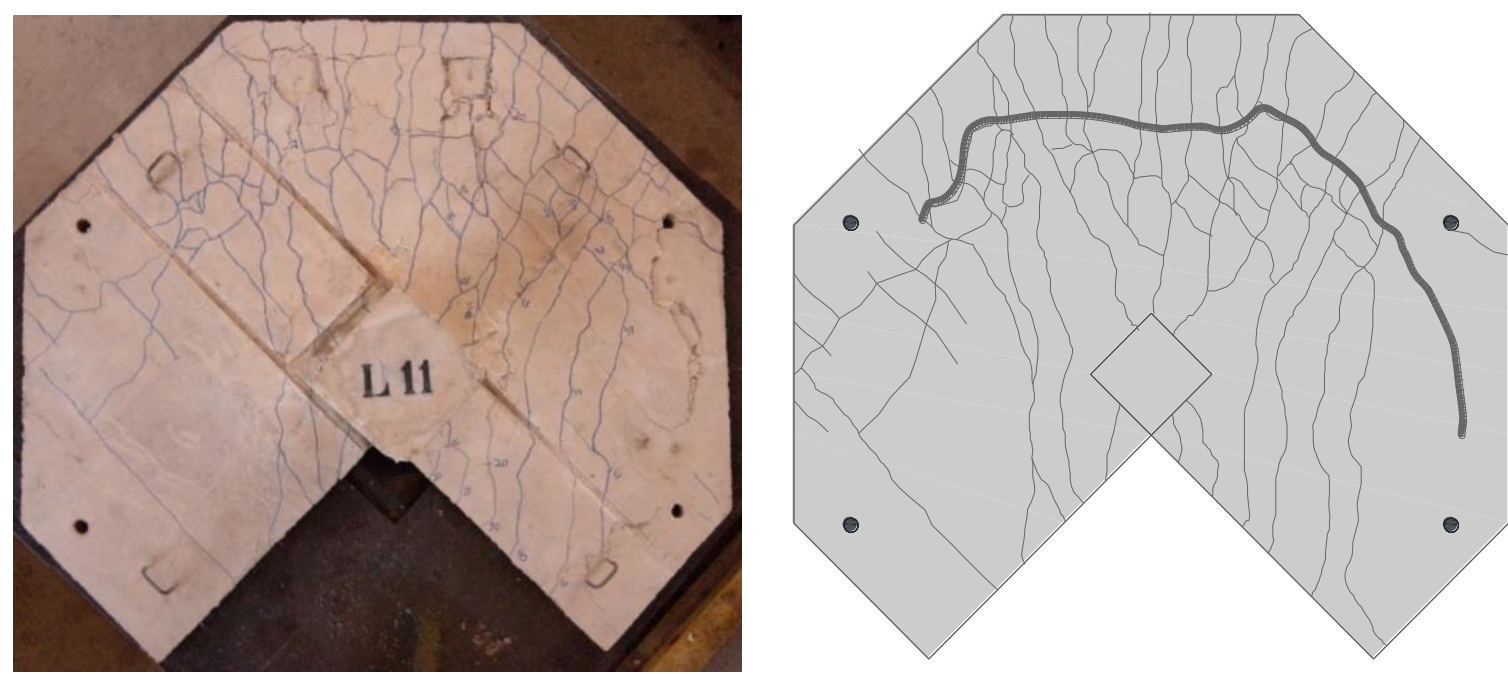

Figura 4.210 - Configuração de fissuras da laje L011
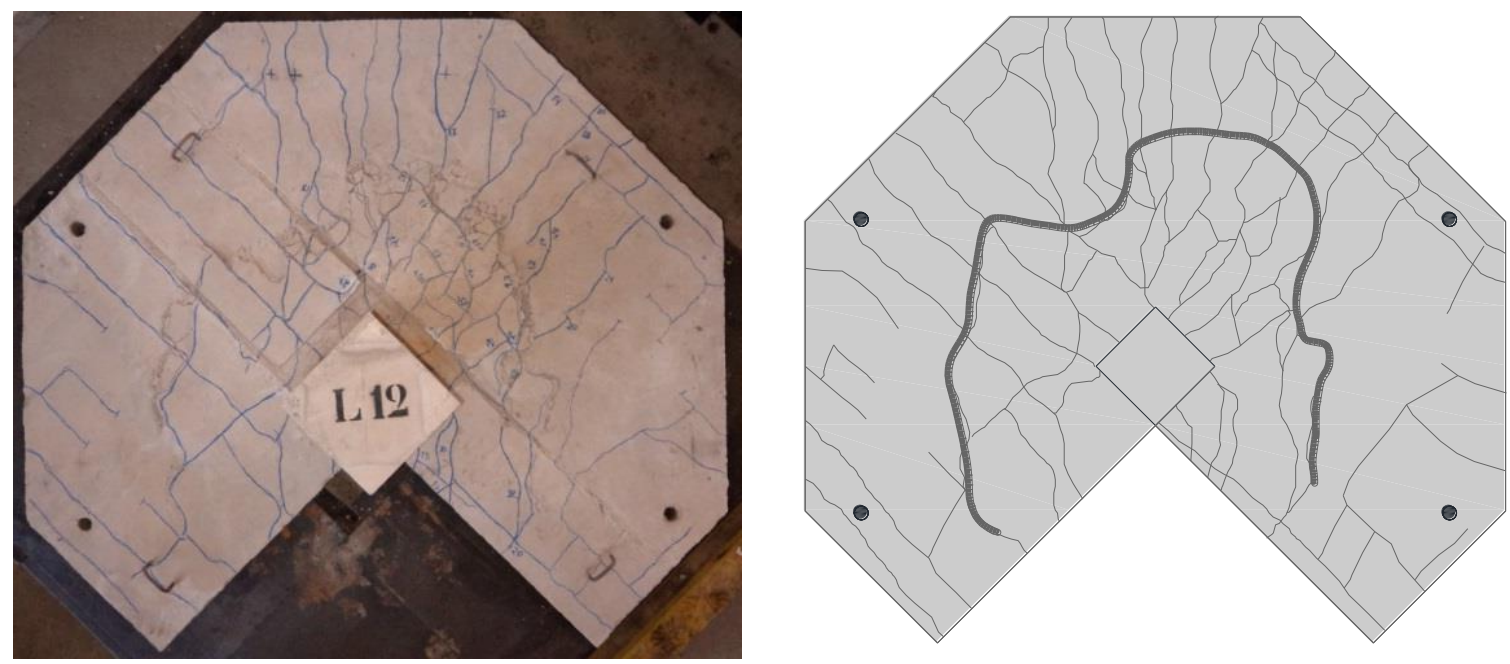

Figura 4.211 - Configuração de fissuras da laje L012 
Apenas com o padrão de fissuração é difícil definir onde ocorre a superfície de ruptura, principalmente nas lajes com taxas de armaduras de flexão maiores. Contudo, notaram-se sinais de uma superfície de ruptura na superfície superior das lajes sem armadura de cisalhamento cerca dentro do perímetro $\mathrm{u}_{0}(2 . \mathrm{d})$ e formação de cone mais evidente.

O padrão de fissuração geral iniciou-se no vértice do pilar, oposto à reentrância, seguindo com fissuras radiais em direção à borda norte da laje. Nas bordas leste e oeste a fissuração teve menor ocorrência. Surgiram fissuras nas faces do pilar próximas à reentrância que seguiram para a face da borda reentrante com um ângulo de $45^{\circ}$ aproximadamente (fissuras de torção) como mostra a Figura 4.212.

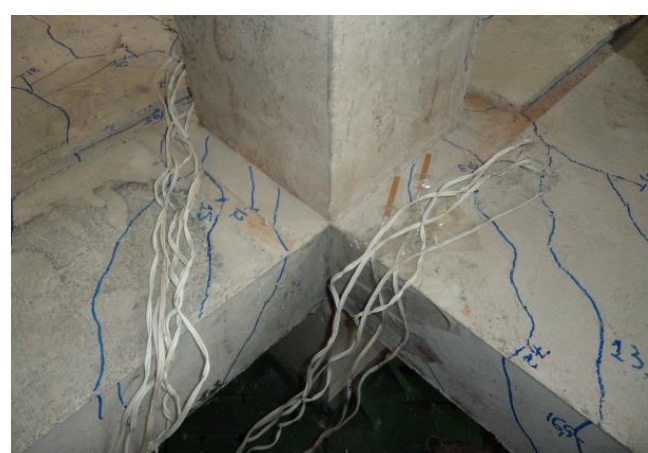

(a) Vista superior

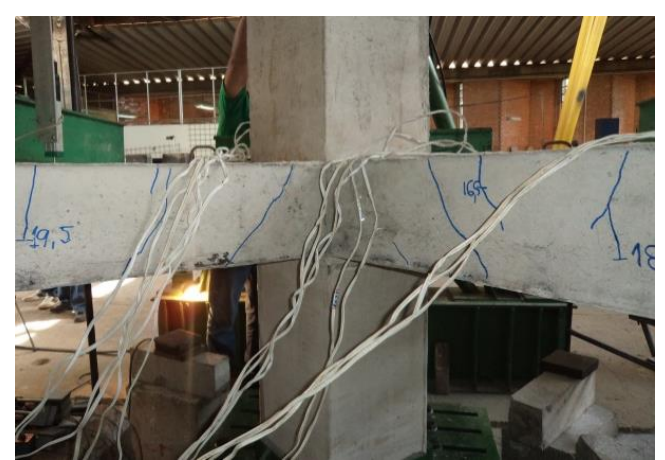

(b) Vista lateral

Figura 4.212 - Fissuras na borda reentrante da laje L06.

Pode-se perceber com as lajes L08 e L07, que a presença de armadura de torção fez com que as fissuras fossem mais distribuídas. Ao comparar as lajes L04 e L06, observou-se que quanto maior a taxa de armadura de flexão mais fissuras superficiais surgiram. A laje L03 por possuir armadura de torção e maior taxa de armadura de flexão apresentou-se mais fissurada em sua superfície superior, pois foi possível a distribuição de tensões entre as armaduras de flexão, cisalhamento e torção. Comparando as lajes L01 e L10, com apenas a armadura de cisalhamento como variável, pode-se perceber que a presença da mesma fez com que reduzisse as fissuras superficiais tendo em vista que a transferência de momento era relativamente alta $(e=500 \mathrm{~mm})$. As fissuras nas lajes L11 e L12, com menor excentricidade, apresentaram-se distribuição mais vertical com maior ocorrência de fissuras nas bordas leste e oeste.

A Tabela 4.8 apresenta o valor das cargas em que ocorreram as primeiras fissuras observadas nos gráficos de carga x deslocamento. Esses valores não são precisos, mas servem para dar uma idéia do nível de carga em que ocorreram essas primeiras fissuras. 
Tabela 4.8 - Cargas das primeiras fissuras

\begin{tabular}{|l|c|c|c|}
\hline Laje & $V_{u}(\mathrm{kN})$ & $V_{\text {fis }}(\mathrm{kN})$ & $\%$ de $V_{u}$ \\
\hline L01 & 325 & 70 & 22 \\
\hline L02 & 513 & 90 & 18 \\
\hline L03 & 575 & 90 & 16 \\
\hline L04 & 372 & 70 & 19 \\
\hline L05 & 250 & 80 & 32 \\
\hline L06 & 282 & 90 & 32 \\
\hline L07 & 358 & 85 & 24 \\
\hline L08 & 345 & 70 & 20 \\
\hline L09 & 550 & 90 & 16 \\
\hline L10 & 500 & 90 & 18 \\
\hline L11 & 640 & 100 & 16 \\
\hline L12 & 345 & 80 & 23 \\
\hline
\end{tabular}

\subsection{SUPERFÍCIE DE RUPTURA}

Todas as lajes ensaiadas foram cortadas para que fosse possível observar a sua superfície de ruptura. O corte foi executado pela empresa LOCBRAS Locadora de Ferramentas Elétricas Ltda. A Figura 4.213 e Figura 4.214 mostram os planos onde foram executados os cortes das lajes. As superfícies de ruptura das lajes podem ser vista da Figura 4.215 à Figura 4.226. É possível notar que quase todas as lajes apresentaram a superfície de ruptura fora da região com as armaduras de cisalhamento com exceção da laje L10.

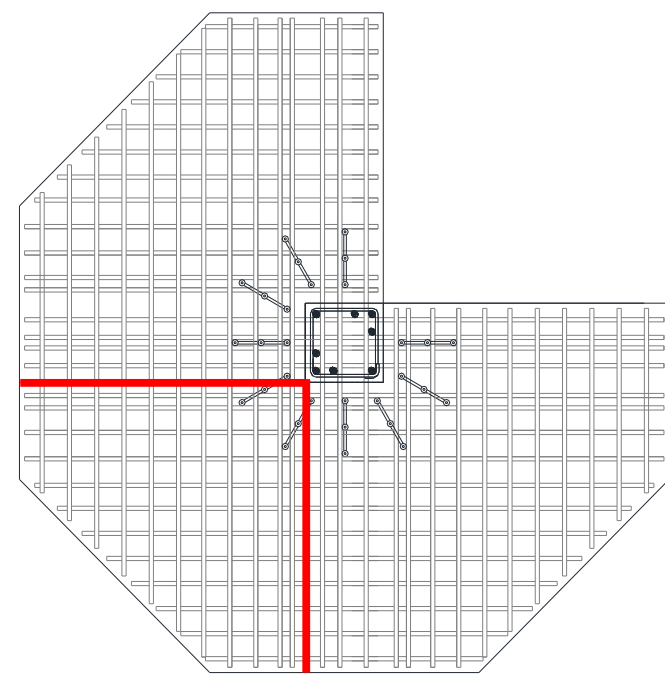

(a) L02

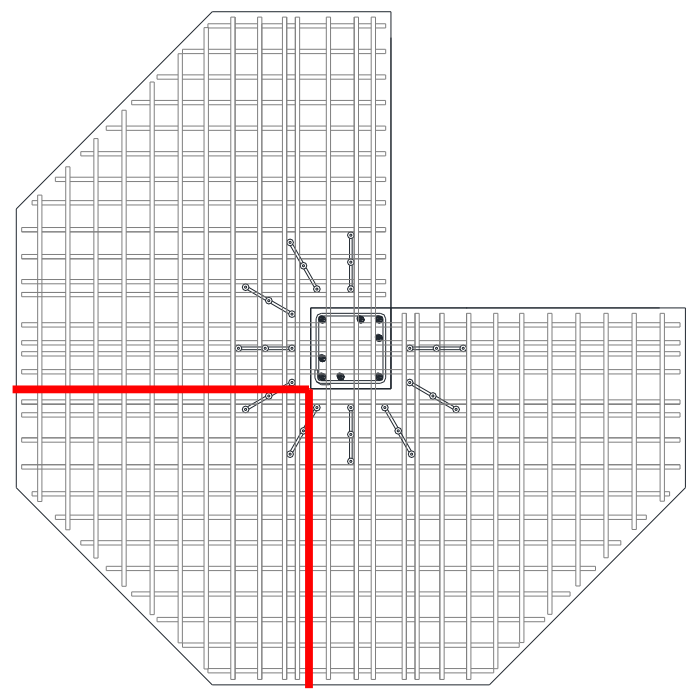

(b) L03

Figura 4.213 - Planos de corte das lajes L02 e L03 


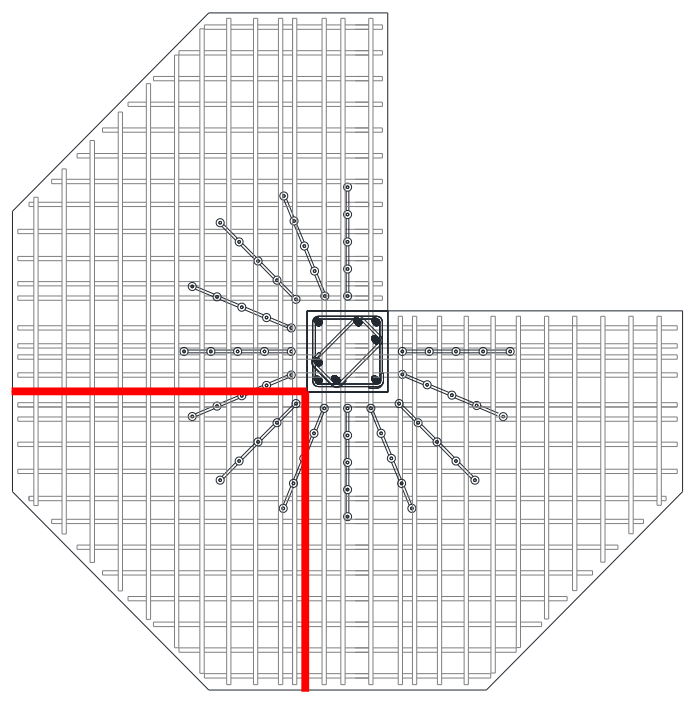

(a) L09

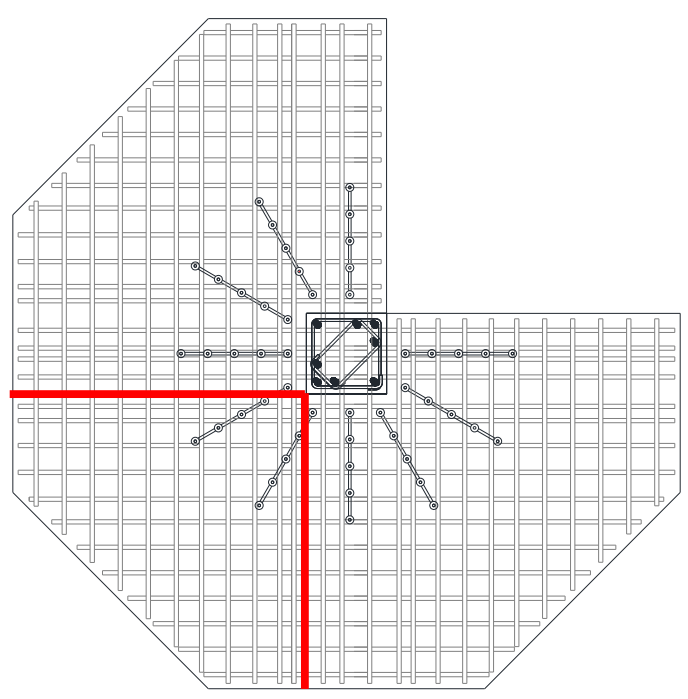

(b) L10 e L11

Figura 4.214 - Planos de corte das lajes L09, L10 e L11
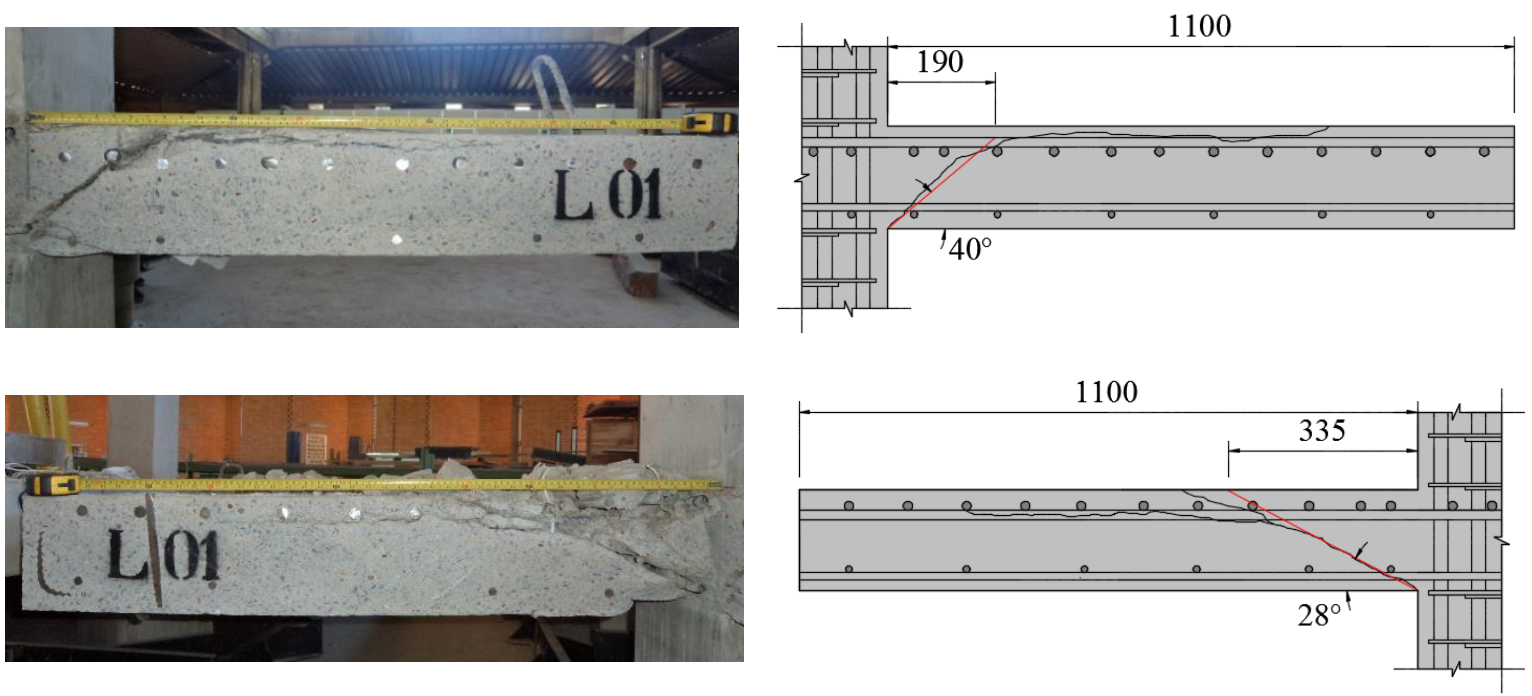

Figura 4.215 - Superfície de ruptura da laje L01
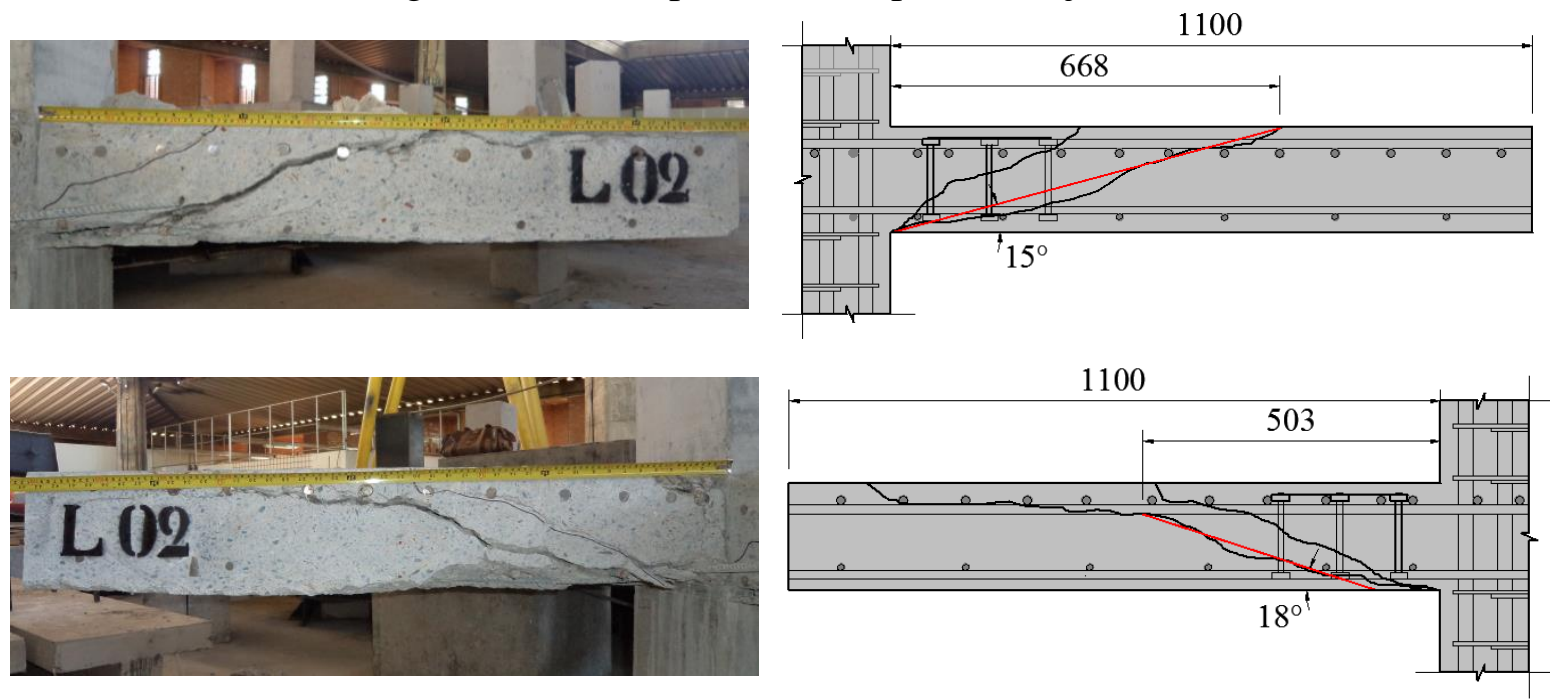

Figura 4.216 - Superfície de ruptura da laje L02 

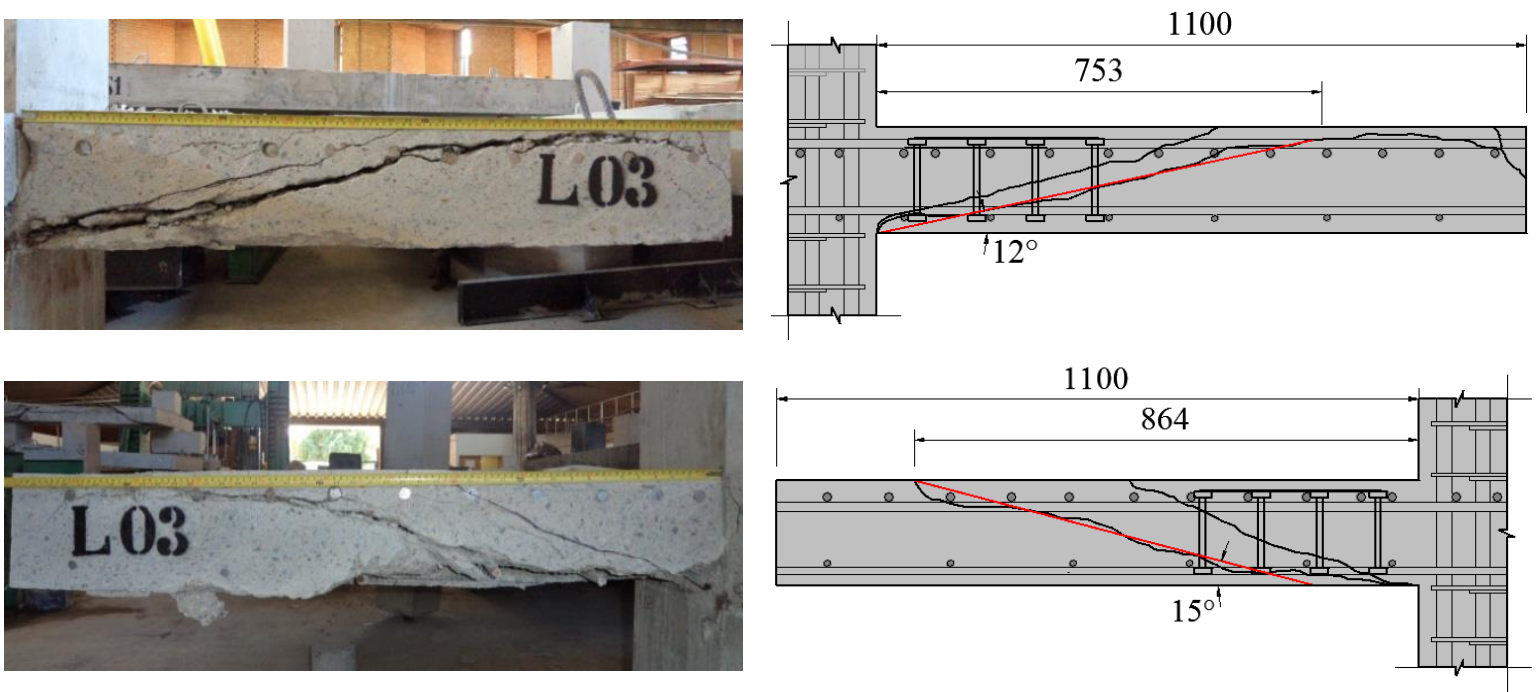

Figura 4.217 - Superfície de ruptura da laje L03
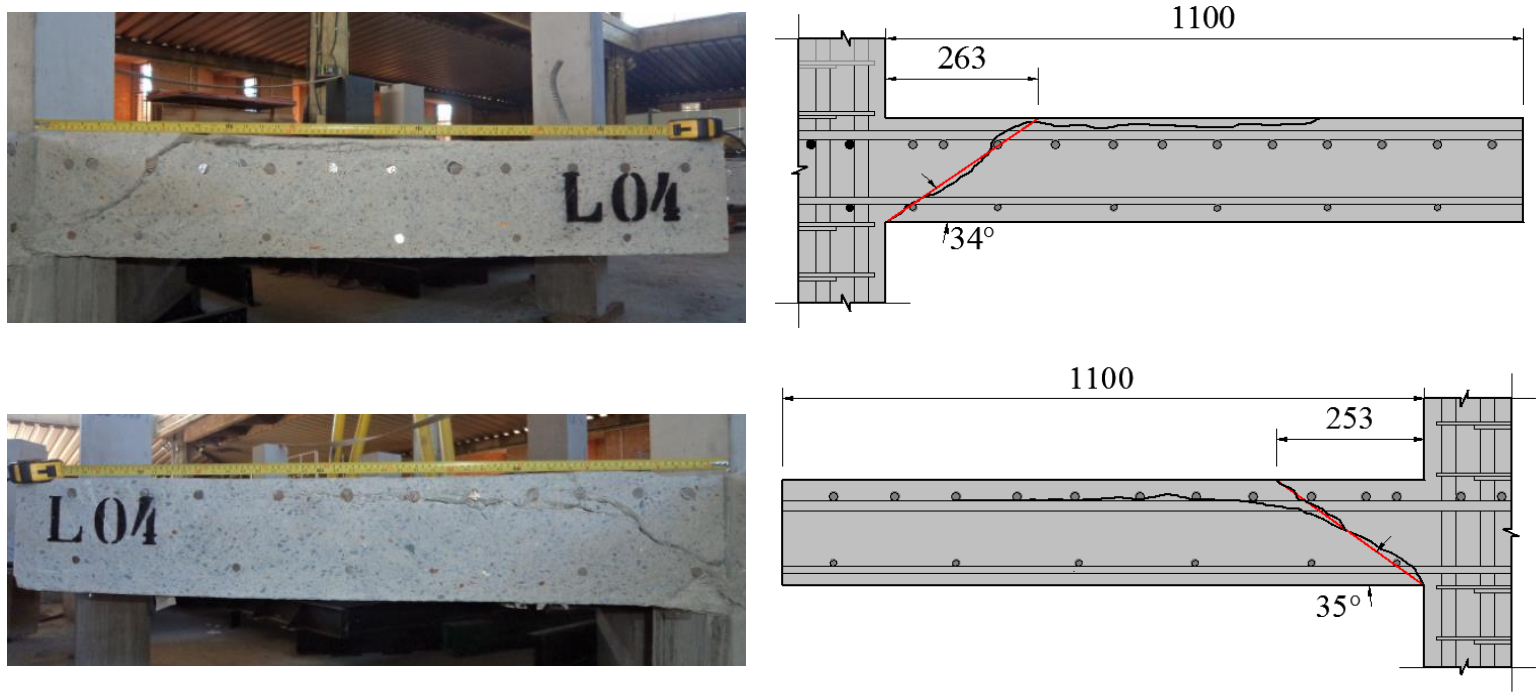

Figura 4.218 - Superfície de ruptura da laje L04
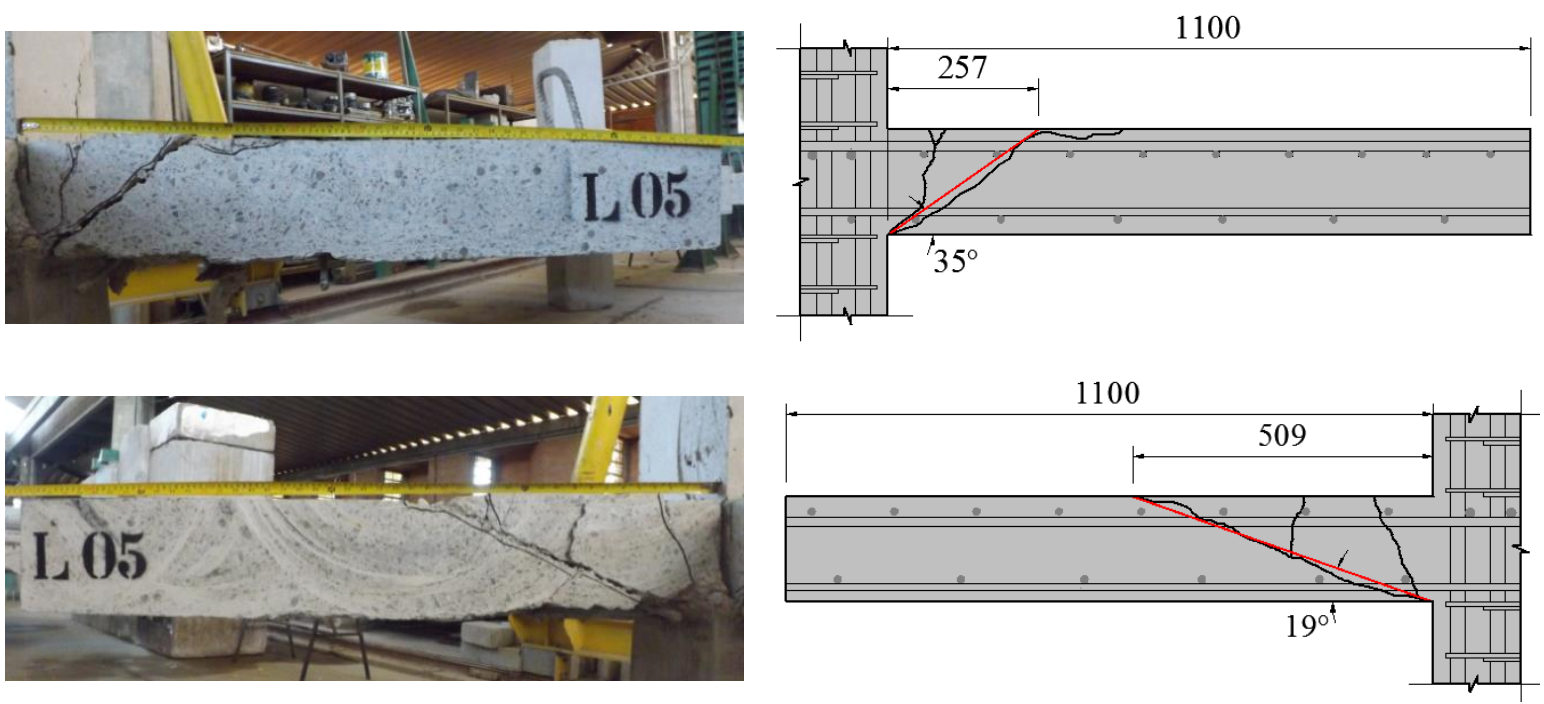

Figura 4.219 - Superfície de ruptura da laje L05 

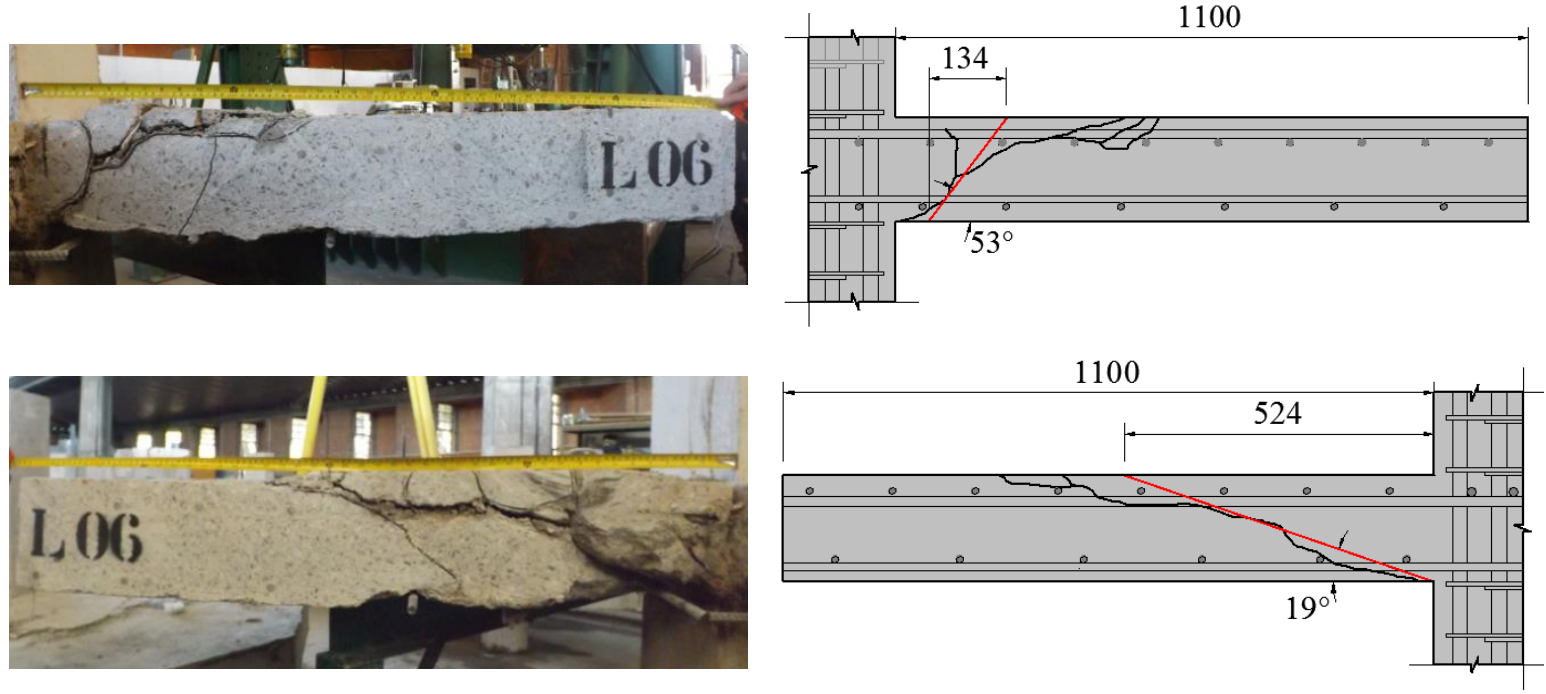

Figura 4.220 - Superfície de ruptura da laje L06
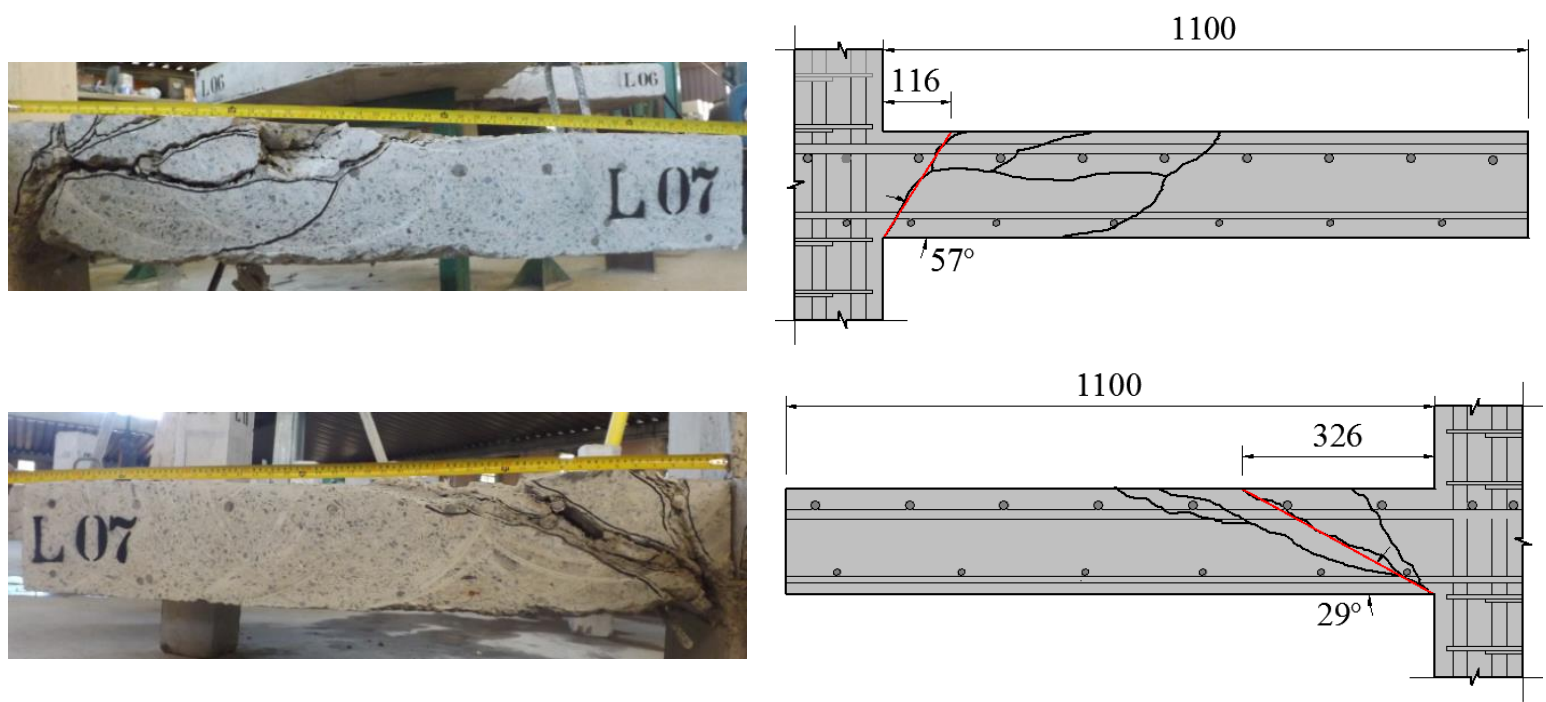

Figura 4.221 - Superfície de ruptura da laje L07
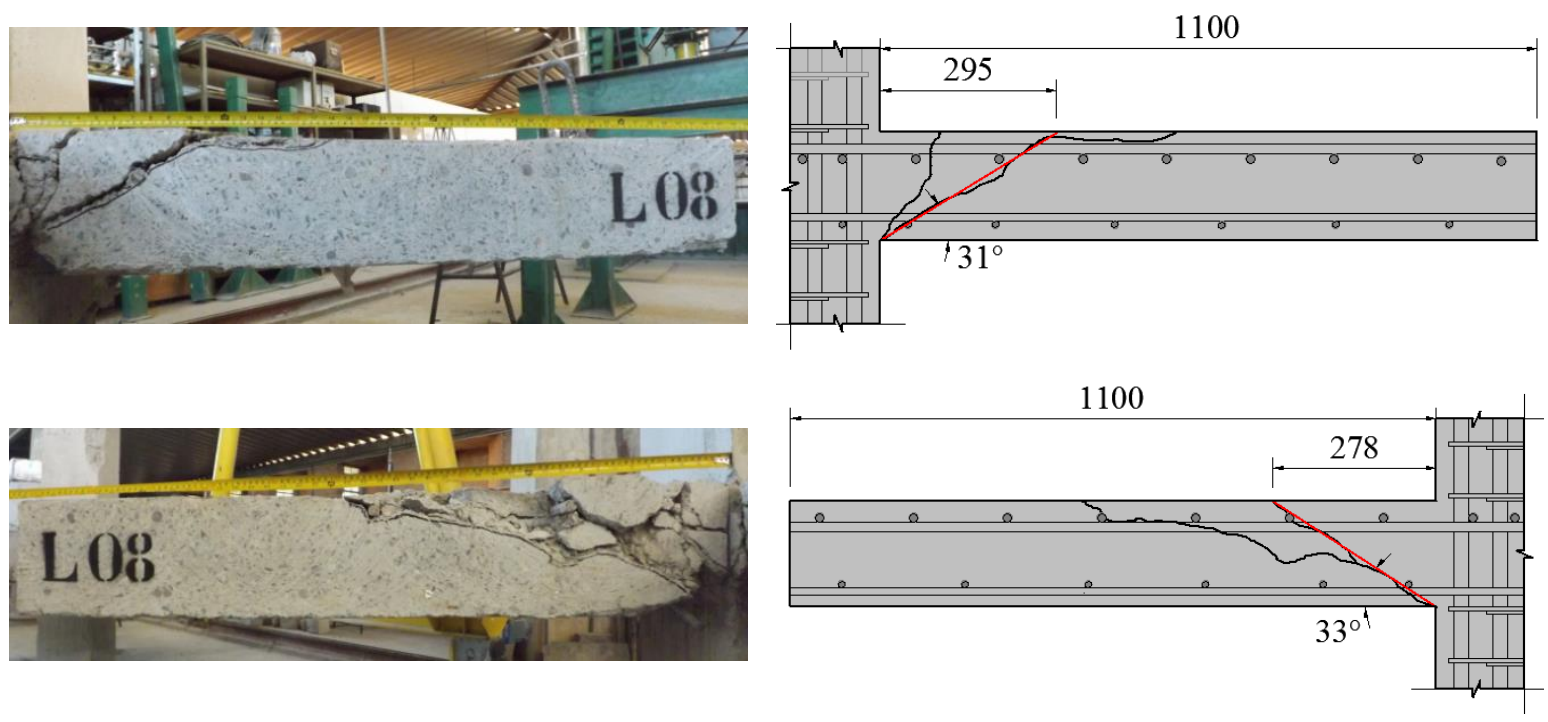

Figura 4.222 - Superfície de ruptura da laje L08 

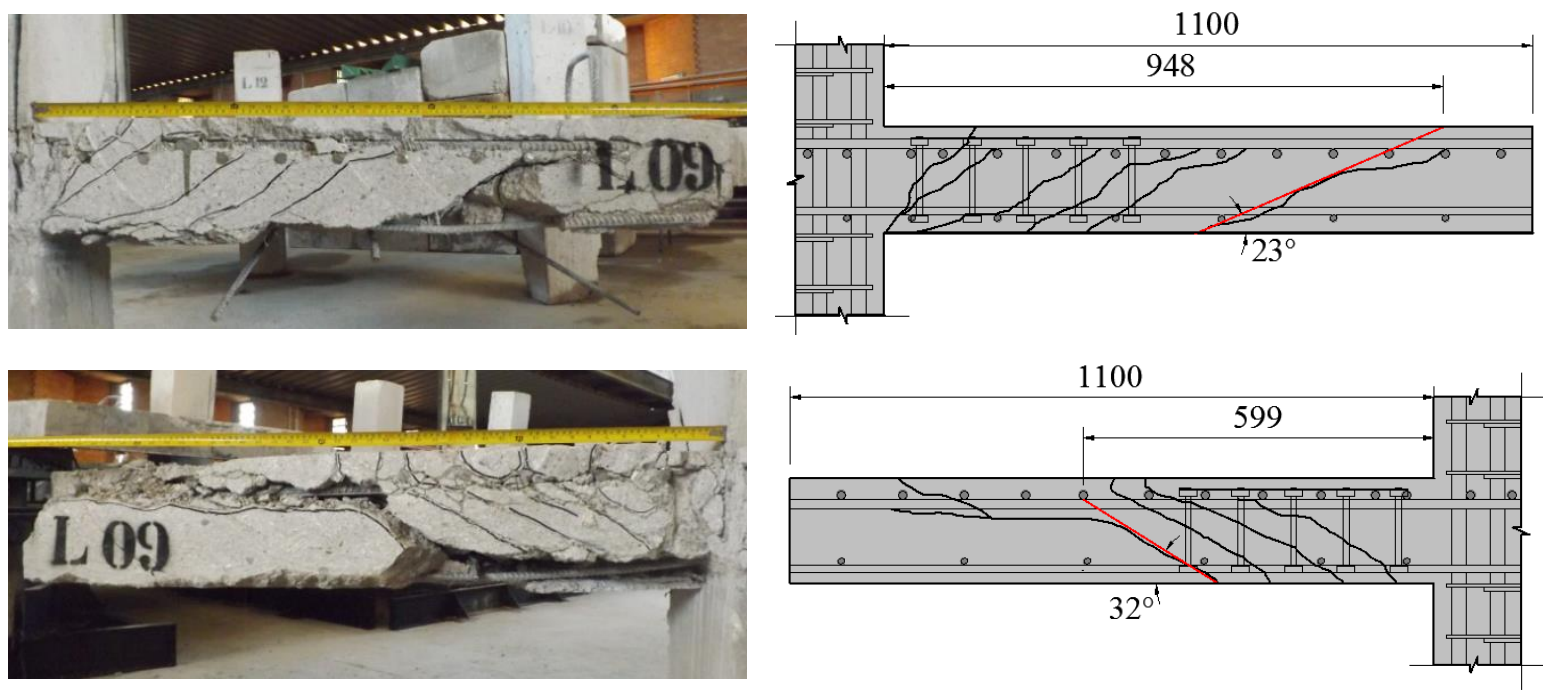

Figura 4.223 - Superfície de ruptura da laje L09
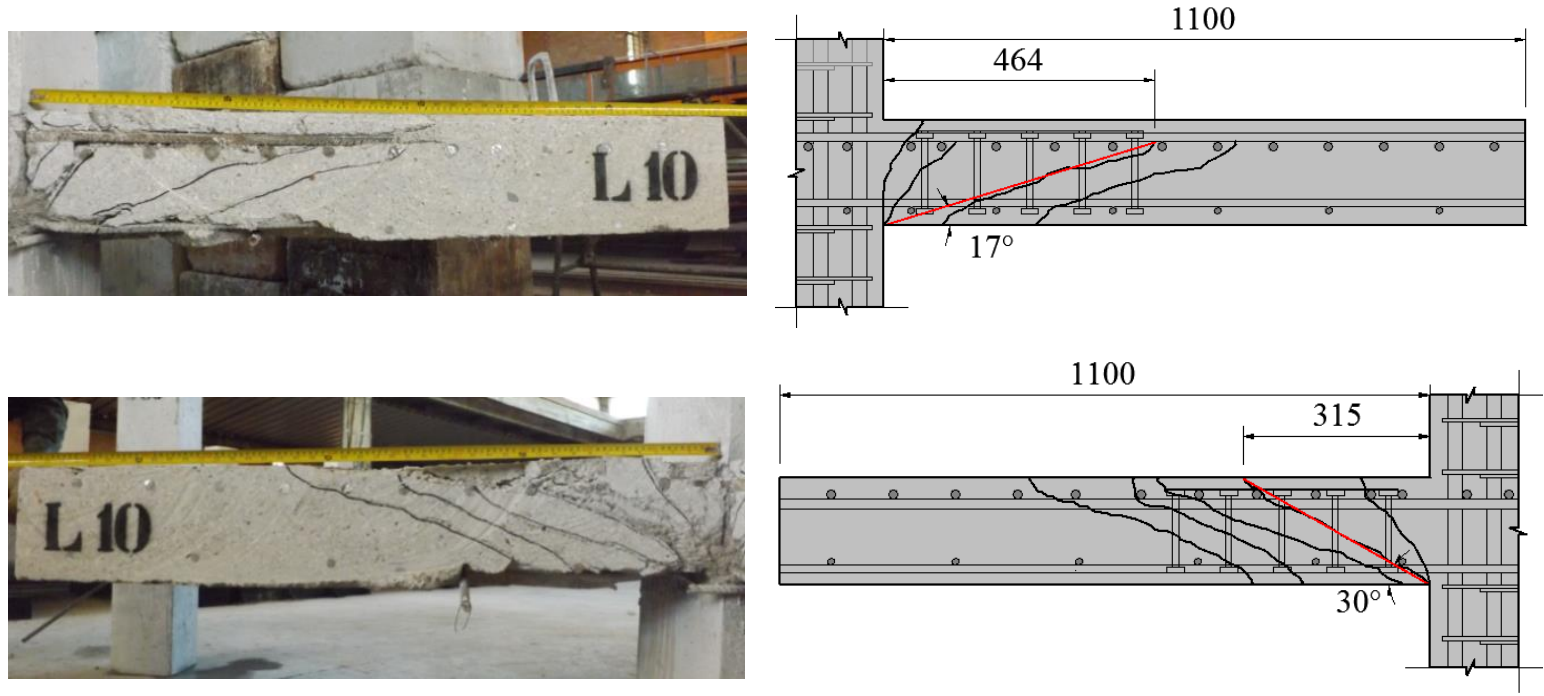

Figura 4.224 - Superfície de ruptura da laje L10
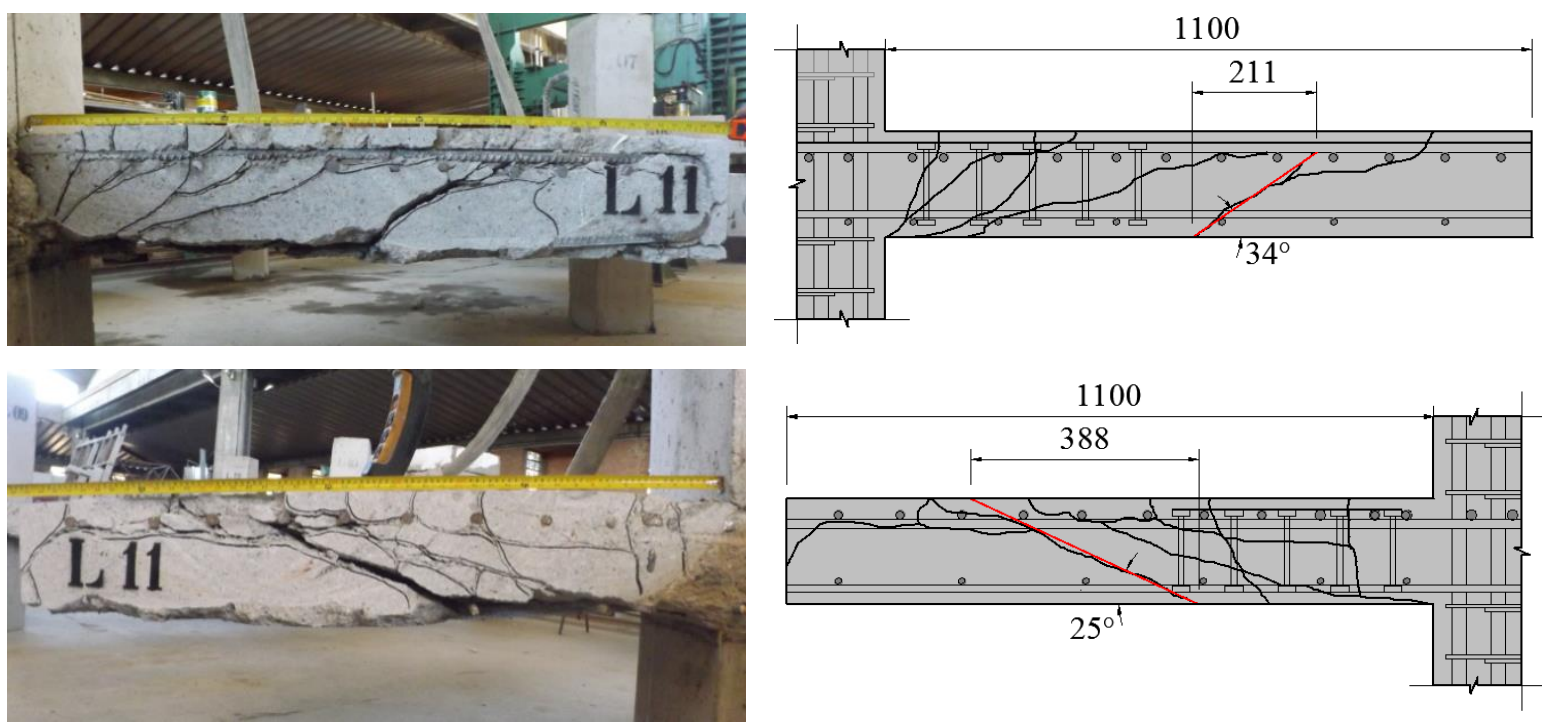

Figura 4.225 - Superfície de ruptura da laje L11 

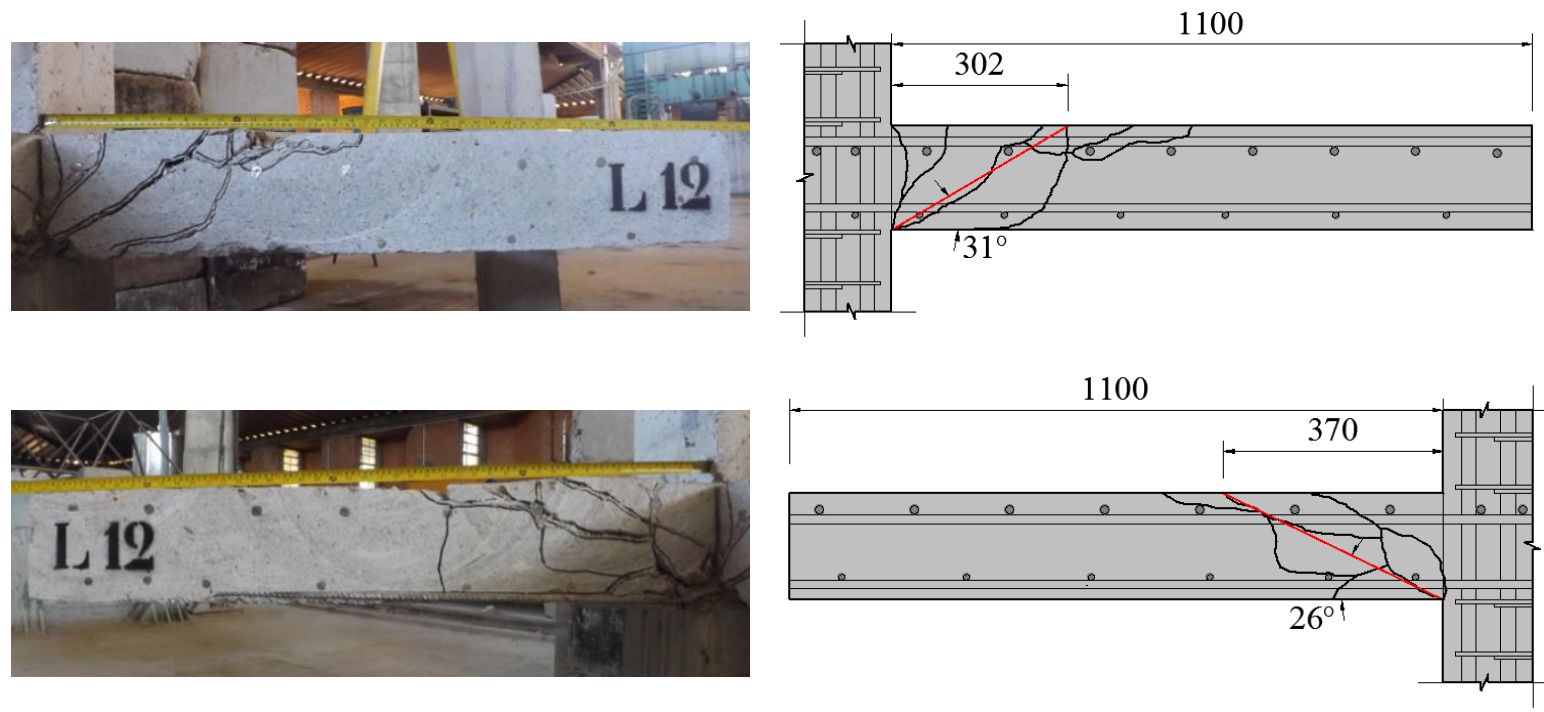

Figura 4.226 - Superfície de ruptura da laje L12

A Tabela 4.9 mostra o resumo das inclinações nas duas direções de todas as lajes de acordo com a Figura 4.227.

Tabela 4.9 - Resumo dos resultados experimentais (deformação da armadura de flexão).

\begin{tabular}{|l|c|c|c|c|c|}
\hline Laje & $V_{u}(\mathrm{kN})$ & $\rho(\%)$ & $\mathrm{e}(\mathrm{mm})$ & $\theta_{\text {direita }}\left({ }^{\circ}\right)$ & $\theta_{\text {esquerda }}\left({ }^{\circ}\right)$ \\
\hline L01 & 325 & 2,07 & 500 & 40 & 28 \\
\hline L02 & 513 & 2,07 & 352 & 15 & 18 \\
\hline L03 & 575 & 2,17 & 349 & 12 & 15 \\
\hline L04 & 372 & 2,10 & 349 & 34 & 35 \\
\hline L05 & 250 & 0,91 & 504 & 35 & 19 \\
\hline L06 & 282 & 0,88 & 343 & 53 & 19 \\
\hline L07 & 358 & 1,35 & 349 & 57 & 29 \\
\hline L08 & 345 & 1,27 & 347 & 31 & 33 \\
\hline L09 & 550 & 2,08 & 349 & 23 & 32 \\
\hline L10 & 500 & 2,08 & 498 & 17 & 30 \\
\hline L11 & 640 & 2,11 & 267 & 34 & 25 \\
\hline L12 & 345 & 1,28 & 268 & 31 & 26 \\
\hline
\end{tabular}




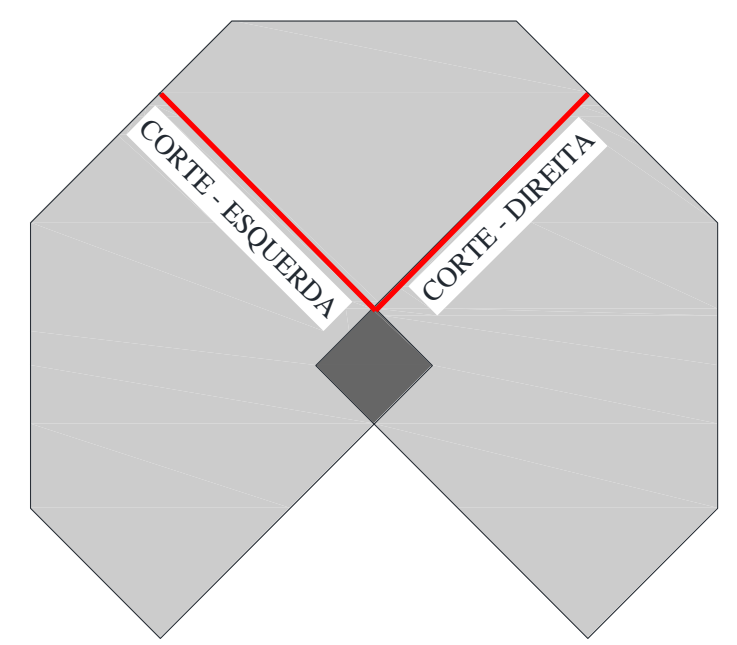

Figura 4.227 - Superfície de corte das lajes

A partir de uma superfície inclinada (vista do corte) que se inicia na face inferior do pilar até atingir a armadura de flexão superior que continua ao longo do cobrimento, a fissura da superfície de ruptura apresentou inclinação variada para as lajes analisadas, mas com mesmo comportamento.

A fissura atinge uma circunferência em média de $30^{\circ}$ de inclinação na maioria dos casos (L01, L04, L05, L08, L11, L12). As lajes L06 e L07 tiveram inclinações em torno de $30^{\circ}$ de diferença entre as duas faces cortadas, com a laje L06 apresentando inclinações de $53^{\circ} \mathrm{e}$ $19^{\circ} \mathrm{em}$ cada face, e a laje $\mathrm{L} 07$ apresentando $57^{\circ}$ e $29^{\circ}$ em cada face.

As lajes L09 e L10 apresentaram superfície de ruptura com inclinação aproximadamente de $20^{\circ}$ em uma direção e $30^{\circ}$ na outra.

Já nas lajes L02 e L03, a fissura atinge uma circunferência, cerca de $15^{\circ}$ de inclinação, e continua ao longo do cobrimento.

Para as lajes com armadura de cisalhamento, foi possível definir se a ruptura dessas lajes ocorreu dentro ou fora dessa armadura. Dentre as cinco lajes que possuíam armadura de cisalhamento apenas a laje L10 teve a ruptura dentro da armadura. 


\section{ANÁLISE DOS RESULTADOS EXPERIMENTAIS}

Para a análise dos resultados foram feitos três grupos em função de parâmetros variáveis: Grupo 1 - Sem armadura de cisalhamento: foram comparadas entre si as lajes L01, L04, L05, L06, L07, L08 e L12, tendo como variável de ensaio a relação $\mathrm{P}_{2} / \mathrm{P}_{1}$, a taxa de armadura de flexão e armadura de torção; Grupo 2 - Com armadura de cisalhamento: foram comparadas entre si as lajes L02, L03, L09, L10 e L11, tendo como variável de ensaio a relação $\mathrm{P}_{2} / \mathrm{P}_{1}$, o número de camadas e o número de linhas da armadura de cisalhamento; Grupo 3 - Com armadura de torção: foram comparadas entre si as lajes L03 e L08, tendo como variável de ensaio a taxa de armadura de flexão e o número de camadas da armadura de cisalhamento; Grupo 4 - Sem e com armadura de cisalhamento: foram comparadas entre si todas as lajes. A Tabela 5.1 mostra o resumo dos grupos formados para as análises. Para auxiliar nas análises dos grupos a Tabela 5.2 apresenta o resumo das características de todas as lajes ensaiadas.

Tabela 5.1 - Grupos e seus parâmetros analisados.

\begin{tabular}{|c|c|c|c|}
\hline GRUPOS & LAJES & EM COMUM & VARIÁVEL DE ENSAIO \\
\hline \multirow{5}{*}{$\begin{array}{l}\text { GRUPO } 1 \\
(\text { Sem } s t u d s)\end{array}$} & L01 e L04 & Taxa de armadura de flexão $2,1 \%$ & Relação $\mathrm{P}_{2} / \mathrm{P}_{1}$ \\
\hline & L08, L12 e L07 & Taxa de armadura de flexão $1,3 \%$ & Relação $\mathrm{P}_{2} / \mathrm{P}_{1}$ e Armadura de torção \\
\hline & $\begin{array}{c}\text { L06, L08, L07 } \\
\text { e L04 } \\
\end{array}$ & Relação $\mathrm{P}_{2} / \mathrm{P}_{1}=1,0$ & $\begin{array}{c}\text { Taxa de armadura de flexão e } \\
\text { Armadura de torção }\end{array}$ \\
\hline & L05 e L01 & Relação $\mathrm{P}_{2} / \mathrm{P}_{1}=0,5$ & Taxa de armadura de flexão \\
\hline & L06 e L05 & Taxa de armadura de flexão $0,9 \%$ & Relação $\mathrm{P}_{2} / \mathrm{P}_{1}$ \\
\hline \multirow{2}{*}{$\begin{array}{l}\text { GRUPO } 2 \\
(\text { Com studs) }\end{array}$} & L02, L09 e L03 & $\begin{array}{c}\text { Armadura de cisalhamento, Relação } \\
\mathrm{P}_{2} / \mathrm{P}_{1}=1,0 \text { e Taxa de armadura de } \\
\text { flexão } 2,1 \%\end{array}$ & $\begin{array}{l}\text { Número de camadas de armadura de } \\
\text { cisalhamento }\end{array}$ \\
\hline & L09, L10 e L11 & $\begin{array}{l}\text { Armadura de cisalhamento e Taxa } \\
\text { de armadura de flexão } 2,1 \%\end{array}$ & $\begin{array}{l}\text { Número de camadas de armadura de } \\
\text { cisalhamento e Relação } \mathrm{P}_{2} / \mathrm{P}_{1}\end{array}$ \\
\hline $\begin{array}{c}\text { GRUPO } 3 \\
\text { (Com estribos) } \\
\end{array}$ & L08 e L03 & $\begin{array}{c}\text { Relação } \mathrm{P}_{2} / \mathrm{P}_{1}=1,0 \text { e Armadura de } \\
\text { torção }\end{array}$ & $\begin{array}{c}\text { Taxa de armadura de flexão e } \\
\text { Armadura de cisalhamento }\end{array}$ \\
\hline \multirow{3}{*}{$\begin{array}{c}\text { GRUPO } 4 \\
(\text { Com e Sem studs) }\end{array}$} & \begin{tabular}{|} 
L02, L09, L04 \\
e L03
\end{tabular} & $\begin{array}{c}\text { Relação } \mathrm{P}_{2} / \mathrm{P}_{1}=1,0 \text { e } \\
\text { Taxa de armadura de flexão }\end{array}$ & Armadura de cisalhamento \\
\hline & L05, L01 e L10 & Relação $\mathrm{P}_{2} / \mathrm{P}_{1}=0,5$ & $\begin{array}{c}\text { Taxa de armadura de flexão e } \\
\text { Armadura de cisalhamento }\end{array}$ \\
\hline & L12 e L11 & Relação $\mathrm{P}_{2} / \mathrm{P}_{1}=1,5$ & $\begin{array}{l}\text { Taxa de armadura de flexão e } \\
\text { Armadura de cisalhamento }\end{array}$ \\
\hline
\end{tabular}


Tabela 5.2 - Características das lajes ensaiadas.

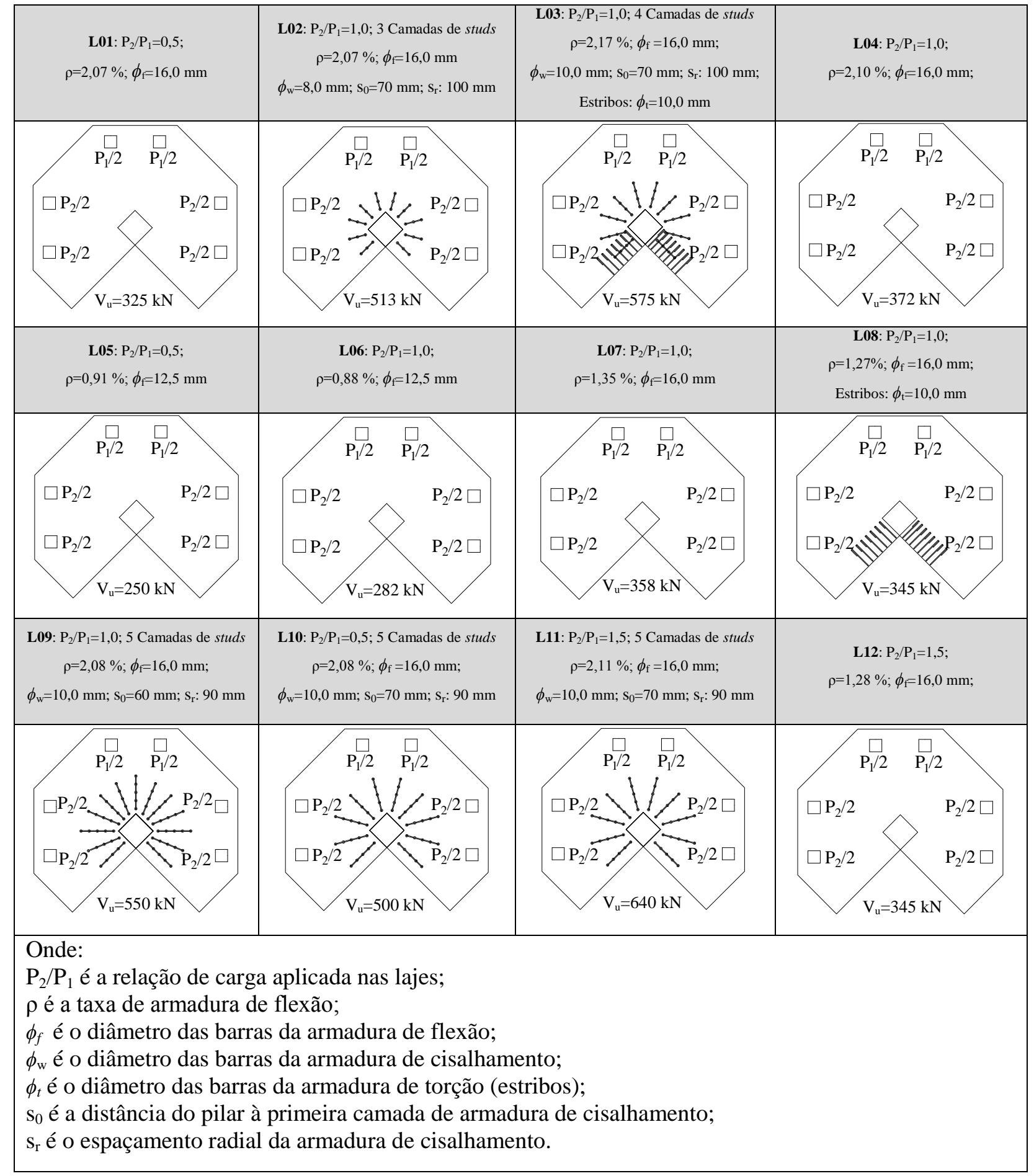




\subsection{COMPARAÇÃO ENTRE OS RESULTADOS EXPERIMENTAIS DAS LAJES}

Para as análises a seguir, as lajes foram ordenadas em função da taxa de armadura de flexão, da menor para a maior. Serão utilizados os resultados experimentais de deslocamentos, deformação na armadura de flexão e deformação na superfície do concreto para entender o comportamento das lajes e definir o tipo de ruptura das mesmas.

\subsubsection{Análise do Grupo 1 - sem studs}

\subsubsection{Lajes L01 (325 kN) e L04 (372 kN)}

A Tabela 5.3 apresenta o resumo das características das lajes L01 e L04.

Tabela 5.3 - Características das lajes L01 e L04.

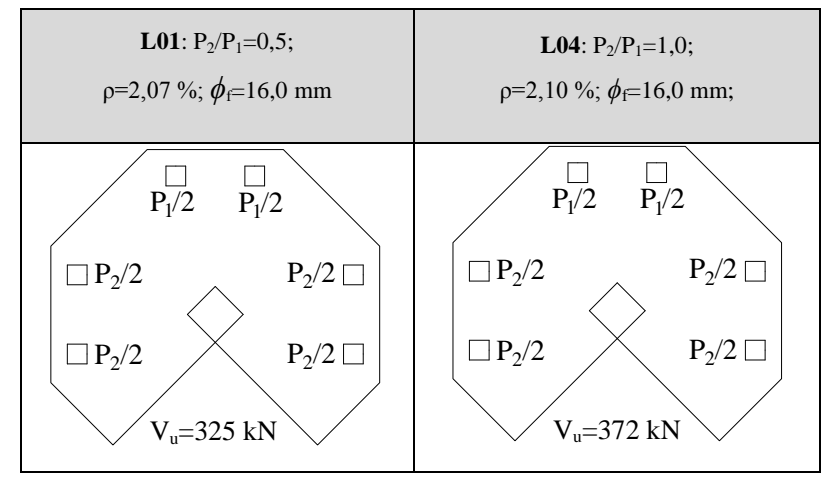

A Figura 5.1 mostra o gráfico da taxa de armadura de flexão em relação à carga de ruptura das lajes L01 e L04 mostrando que é proporcional o aumento da carga quando se aumenta a taxa de armadura de flexão. A laje L04 apresentou carga de ruptura maior por ter menor excentricidade de carga.

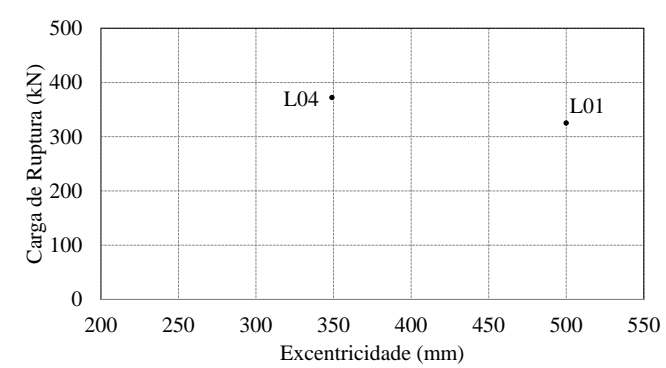

Figura 5.1 - Gráfico de carga de ruptura x excentricidade das lajes L01 e L04.

A Figura 5.2 apresenta o gráfico de deslocamentos das lajes L01 e L04 em relação a posição dos LVDT's onde se pode observar o comportamento em dois momentos: nível de 
carga em torno de $200 \mathrm{kN}$ e nível de carga próximo à ruptura. Em ambos os casos o comportamento foi semelhante, com a L01 mais flexível, apresentando maiores deslocamentos em relação a L04, pois a excentricidade do carregamento aplicado era maior.
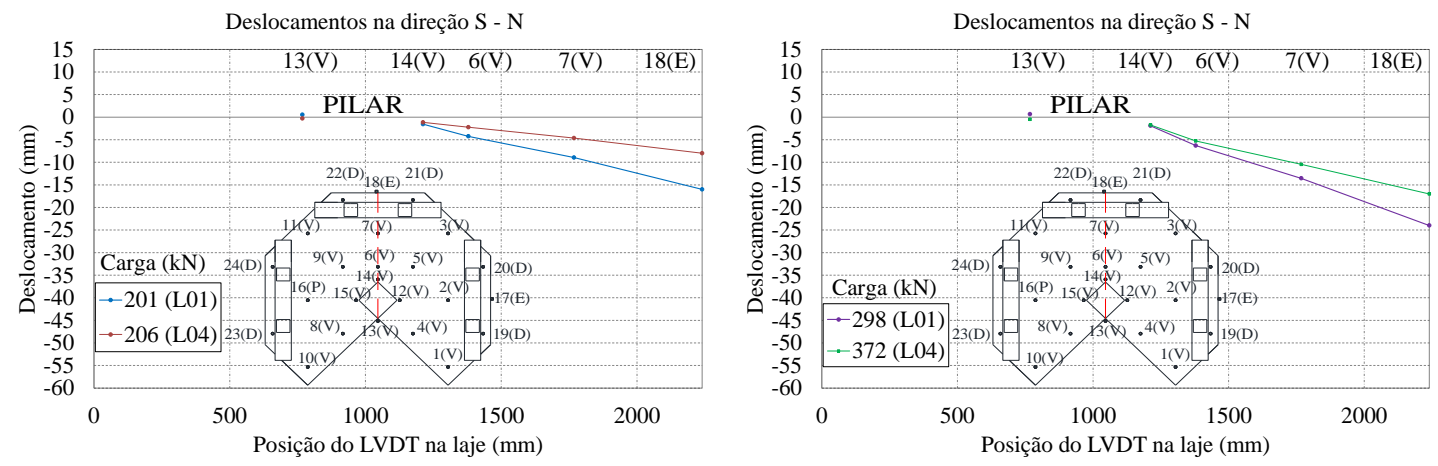

Figura 5.2 - Gráfico de deslocamentos verticais na direção S-N das lajes L01 e L04.

Na Figura 5.3 são apresentados os deslocamentos nos pontos 1, 4, 8 e 10 localizados próximo aos bordos reentrantes, e na Figura 5.4 os deslocamentos nos pontos 12, 13, 14 e 15 localizados próximo os cantos do pilar.
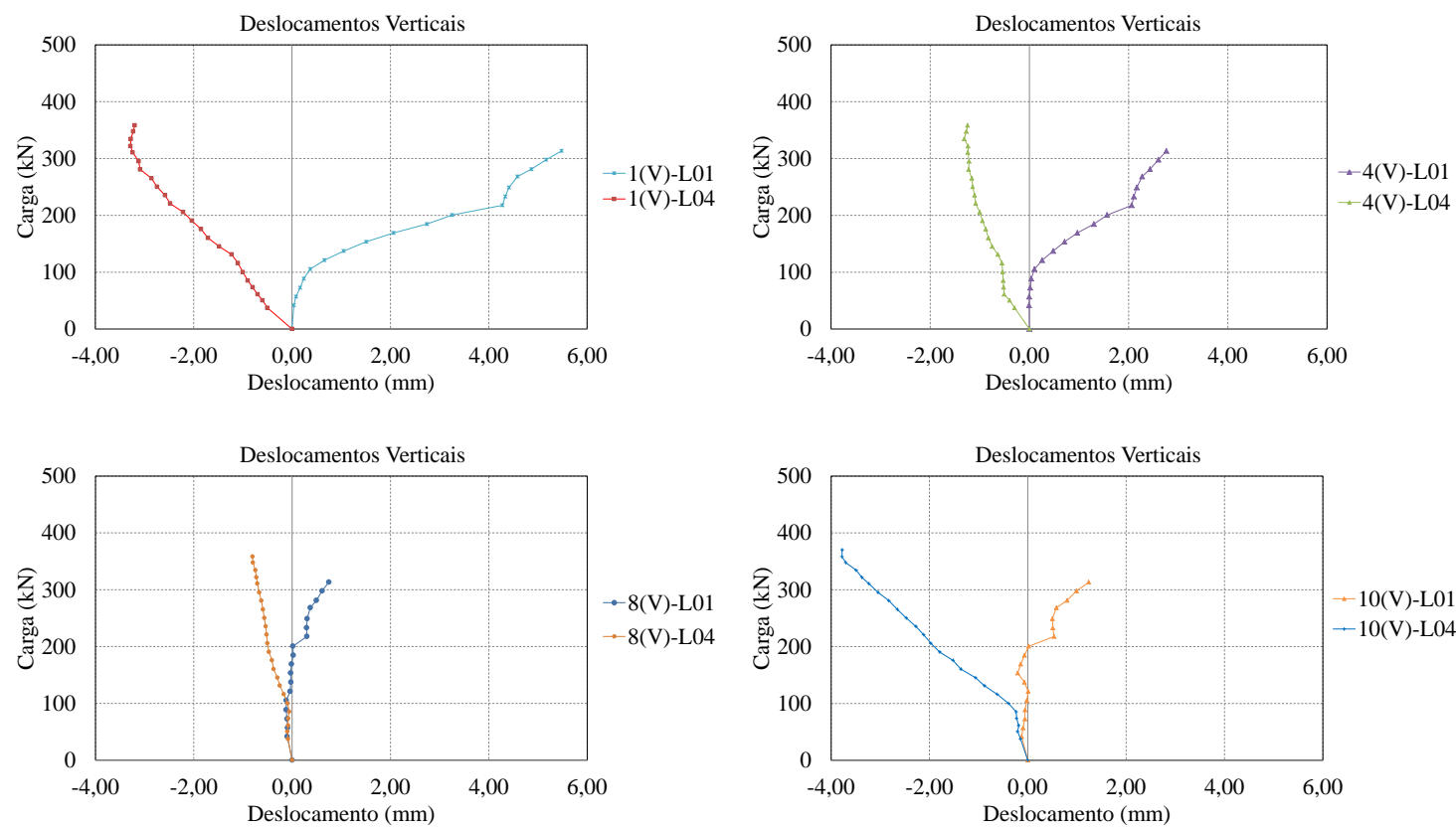

Figura 5.3 - Gráfico de delocamentos verticais x carga das lajes L01 e L04 nos pontos 1, 4, 8 e 10.

Com esses gráficos pode-se observar dois comportamentos distintos devido às diferentes excentricidades do carregamento, a laje L04 apresenta deslocamentos descendentes e a laje L01 comportamento ascendente por ter o maior tranferência de momento ( $e=500 \mathrm{~mm}$ ). 

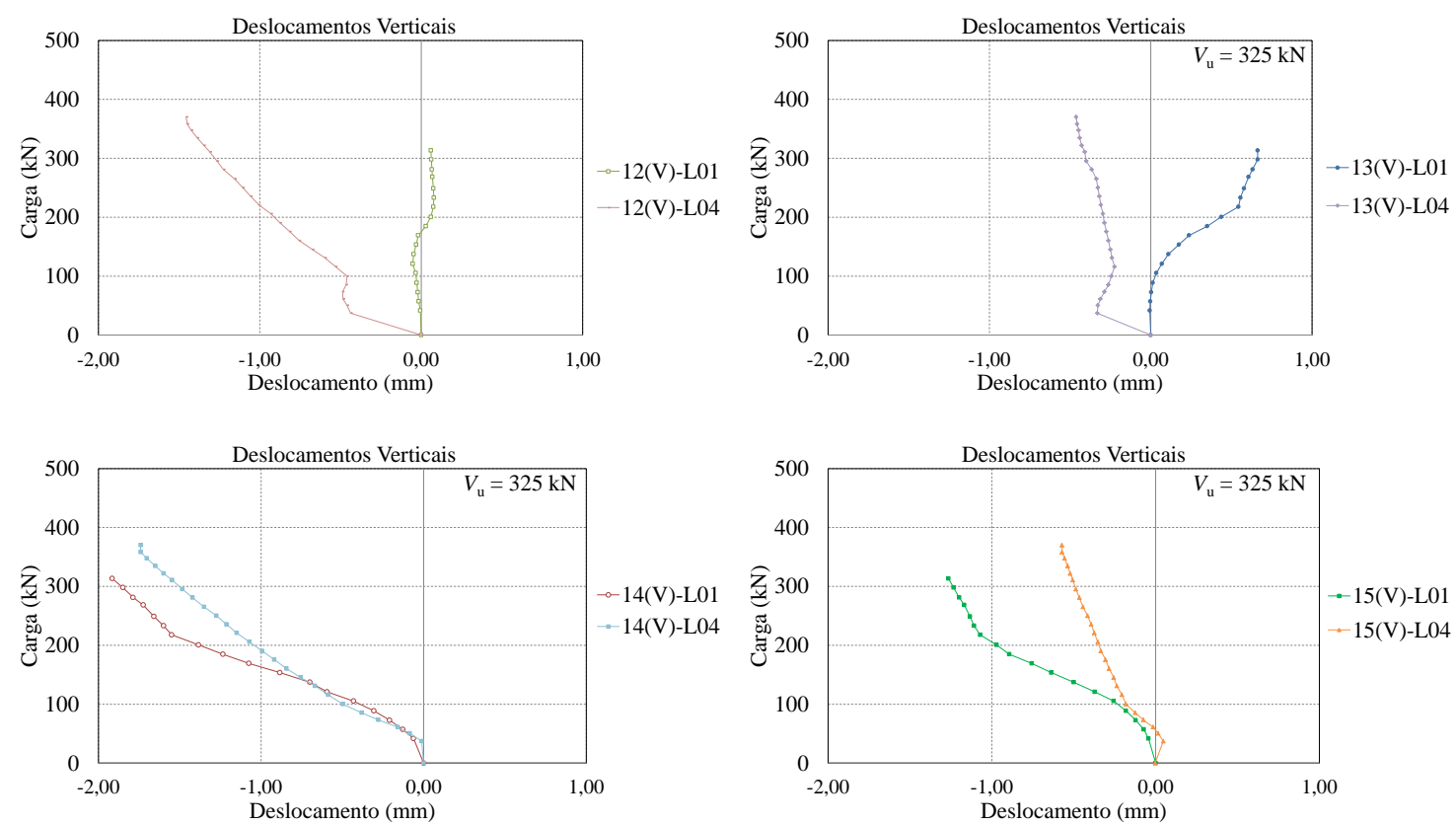

Figura 5.4 - Gráfico de delocamentos verticais x carga das lajes L01 e L04 nos pontos 12, 13,14 e 15.

Os pontos monitorados próximo ao pilar mostram que as duas lajes tiveram comportamento diferente e no ponto 13 (localizado no canto do pilar na reentrância da laje) observa-se uma ascendência na laje L01 e uma descendência na laje L04 por causa da diferença do momento atuante. Na Figura 5.5 são apresentadas as deformações na armadura de flexão em função do posicionamento na laje.

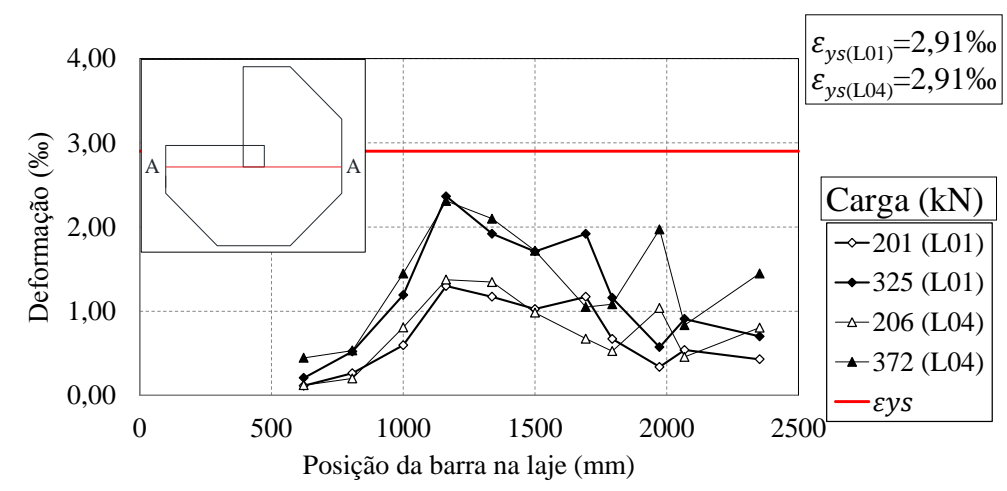

Figura 5.5 - Gráfico de deformações na armadura de flexão das lajes L01 e L04.

Com o gráfico anterior pode-se notar que o momento fletor não é contínuo na linha A-A (Figura 4.167) e os momentos na parte esquerda da linha são menores que os momentos localizados na parte direita por se localizarem próximo a reentrância. Pode-se notar que as lajes L01 e L04 tiveram comportamento semelhante com deformações abaixo do nível de 
escoamento de no máximo 2,4 \%o e 2,3\%o respectivamente, pelo fato de ter uma elevada taxa de armadura de flexão.

Na Figura 5.6 são comparadas as deformações na superfície do concreto das lajes L01 e L04 onde se pode notar que as deformações foram relativamente baixas nos pontos monitorados em ambas as lajes com a L04 deformando mais, pelo fato da excentricidade ser menor comparada à L01. Pode-se notar a formação do cone de punção na superfície de ruptura, indicando que possivelmente houve deformações maiores em pontos não monitorados, uma vez que, espera-se que em uma situação de ruptura por punção haja níveis de deformação no concreto maiores que os registrados.

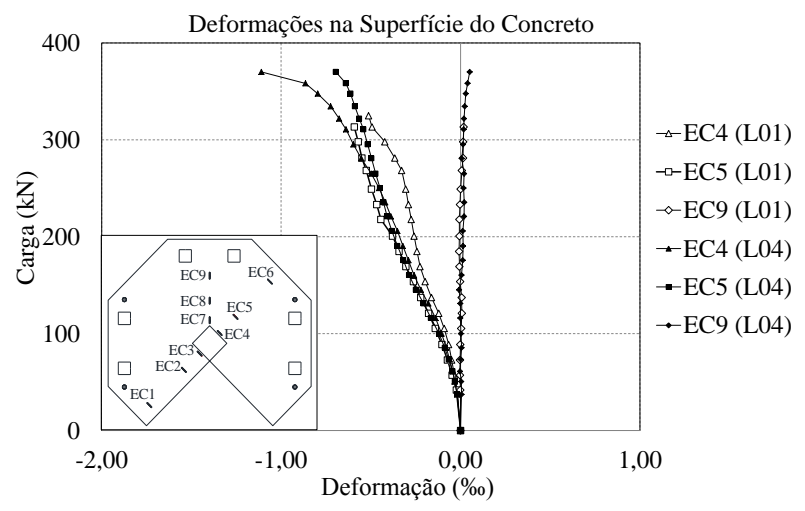

Figura 5.6 - Deformações na superfície do concreto das lajes L01 e L04.

Quanto às cargas de ruptura, pode-se dizer que a laje L04 apresentou maior carga de ruptura $(372 \mathrm{kN})$ e sofreu menores deslocamentos enquanto que a L01 apresentou menor carga de ruptura $(325 \mathrm{kN})$ com deslocamentos maiores por possuir taxa de armadura de flexão menor e pela maior excentricidade de carga.

\subsubsection{Lajes L08 (345 kN), L12 (345 kN) e L07 (358 kN)}

A Tabela 5.4 apresenta o resumo das características das lajes L08, L12 e L07. 
Tabela 5.4 - Características das lajes L08, L12 e L07.

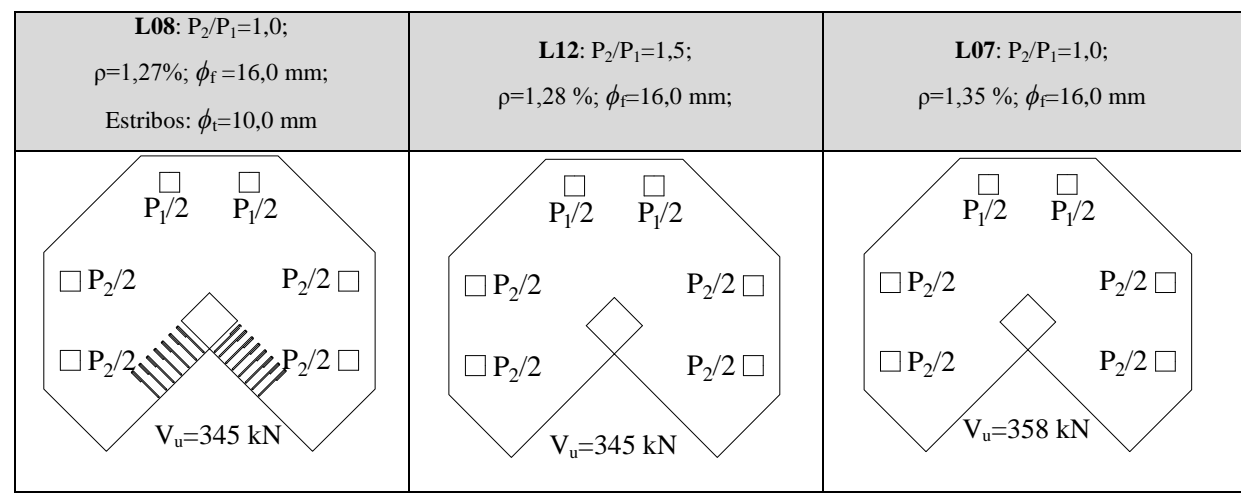

A Figura 5.7 mostra o gráfico da excentricidade em relação à carga de ruptura das lajes L08, L12 e L07 mostrando que as cargas de ruptura foram próximas devido as excentricidades serem próximas. Já em relação a armadura de torção, não houve influência da presença de tal armadura na capacidade de carga da laje L08.

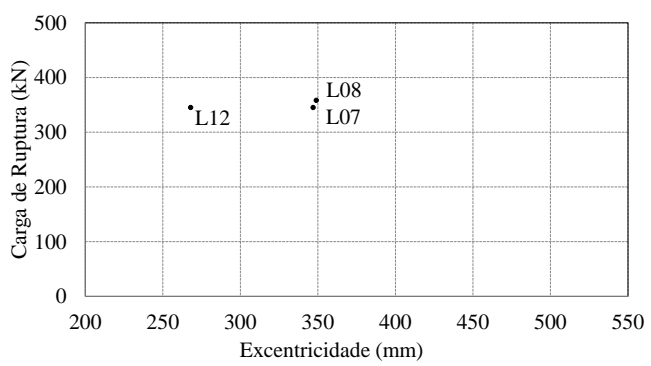

Figura 5.7 - Gráfico de carga de ruptura x excentricidade das lajes L08, L12 e L07.

A Figura 5.8 apresenta o gráfico de deslocamentos das lajes L08, L12 e L07 em relação a posição dos LVDT's onde se pode observar o comportamento em dois momentos: com o nível de carga em torno de 200 kN e nível de carga próximo à ruptura.
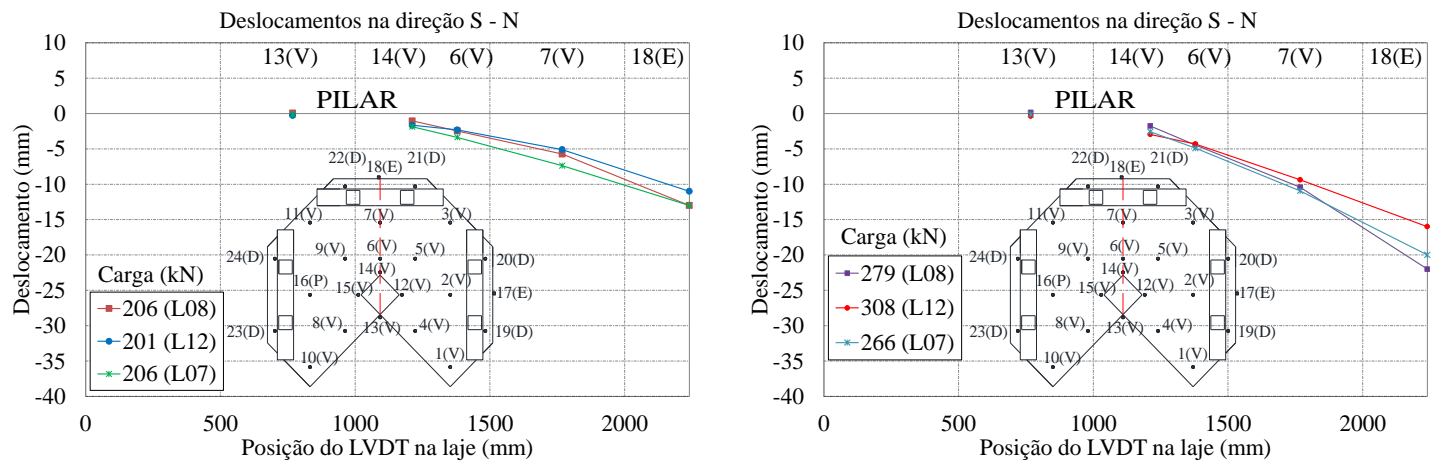

Figura 5.8 - Gráfico de deslocamentos verticais na direção S-N das lajes L08, L12 e L07. 
Em ambos os casos analisados o comportamento foi semelhante, com a L12 mais rígida, apresentando menores deslocamentos em relação às demais. Já próximo à ruptura, a laje L08 apresentou maiores deslocamentos no eixo de simetria da laje, o que não acontece na borda reentrante por existir armadura de torção, garantindo uma maior rigidez nessa região e apresentando menores deslocamentos. Na Figura 5.9 são apresentados os deslocamentos nos pontos 1, 4, 8 e 10 localizados próximo aos bordos reentrantes, e na Figura 5.10 os deslocamentos nos pontos 12, 13, 14 e 15 localizados próximo os cantos do pilar.
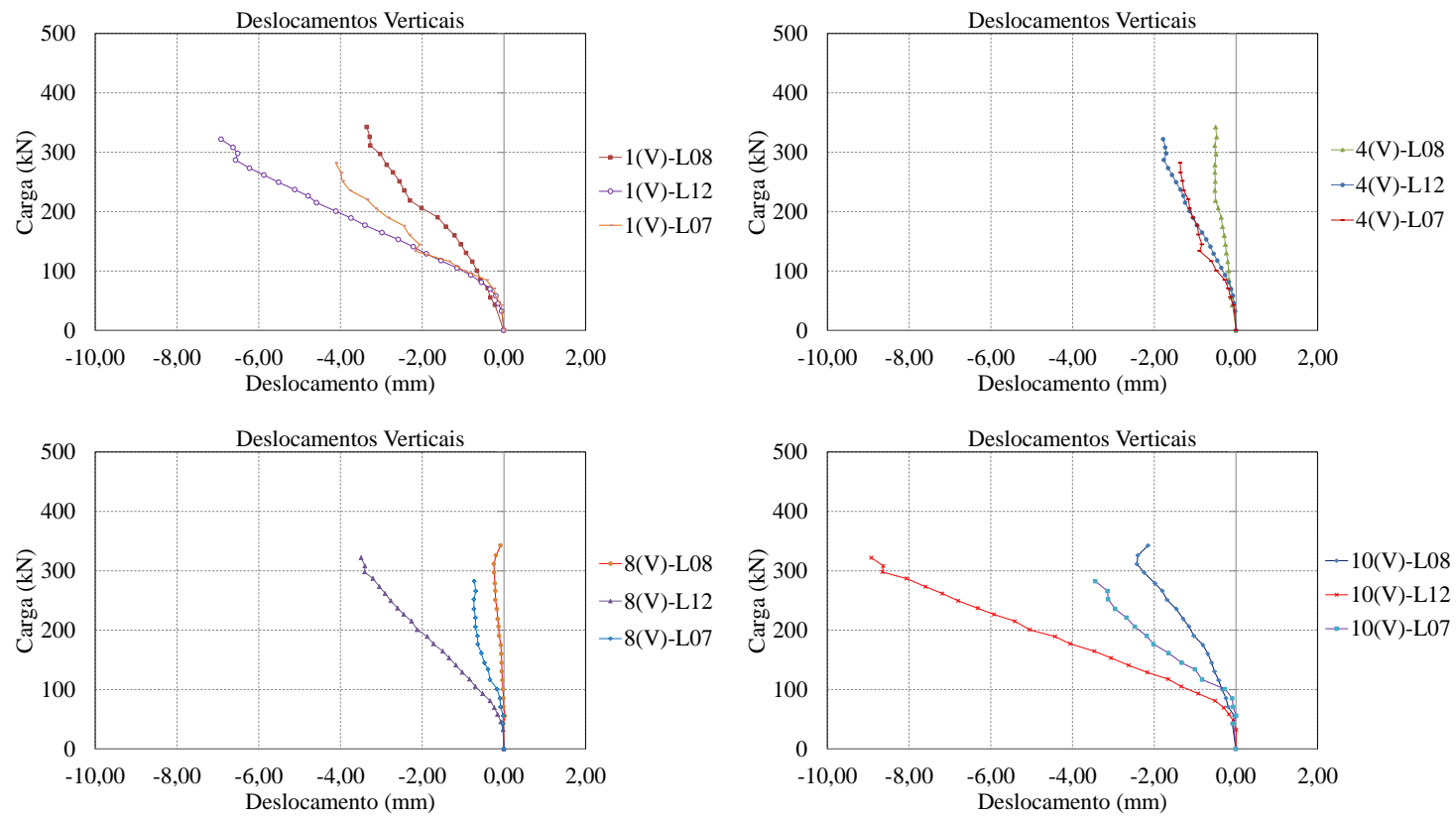

Figura 5.9 - Gráfico de delocamentos verticais x carga das lajes L08, L12 e L07 nos pontos $1,4,8$ e 10 .

Com esses gráficos pode-se observar comportamentos semelhantes para todas as lajes; a laje L12 por ter menor transferência de momento na ligação apresentou deslocamentos muito maiores nas bordas reentrantes em relação às demais lajes. 

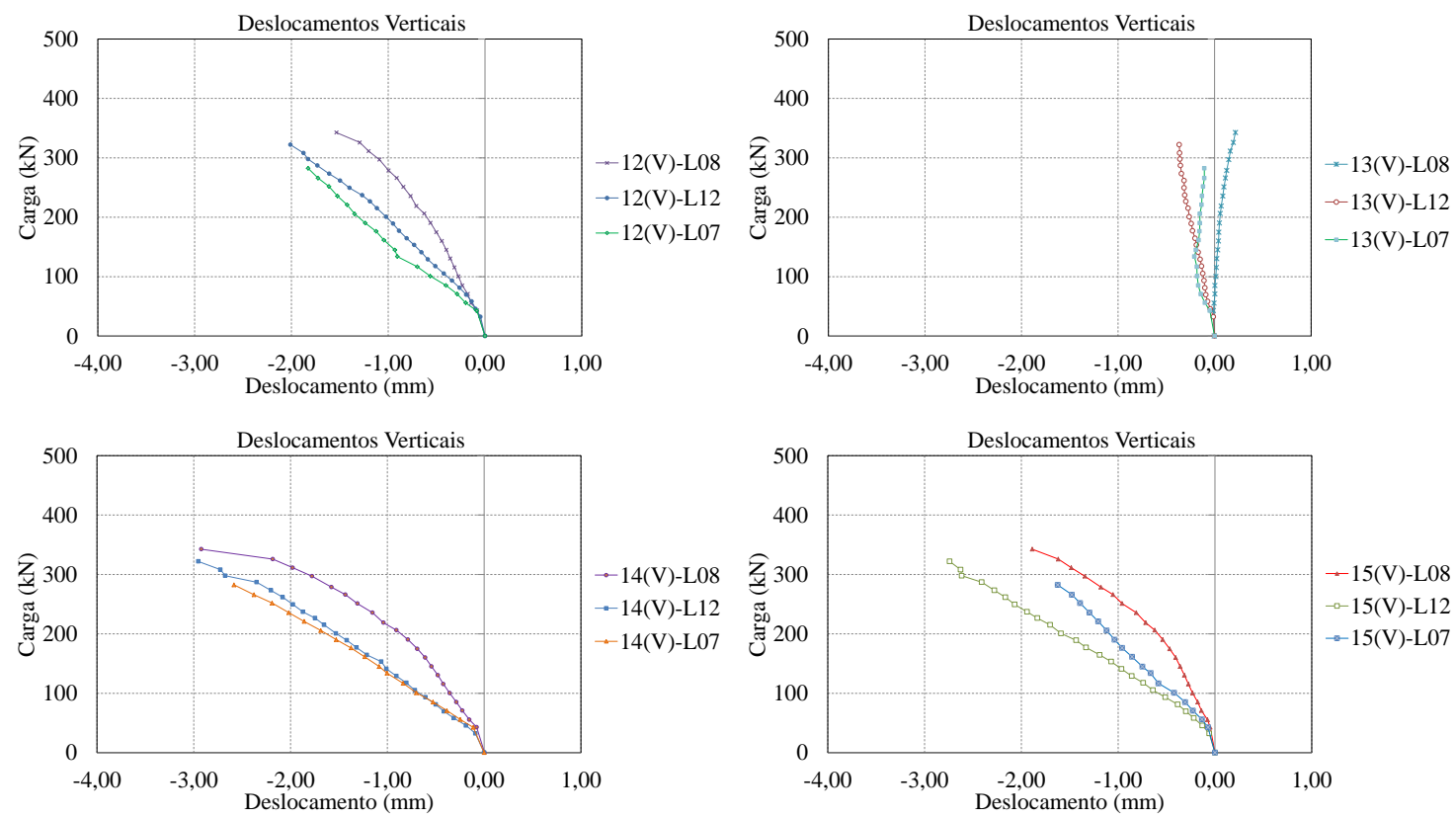

Figura 5.10 - Gráfico de delocamentos verticais x carga das lajes L08, L12 e L07 nos pontos $12,13,14$ e 15 .

Os pontos monitorados próximo ao pilar mostram que as lajes analisadas tiveram comportamento semelhante com exceção do ponto 13 (localizado no vértice do pilar na reentrância da laje) em que se observa uma ascendência na laje L08 devido à presença da armadura de torção e uma descendência nas demais lajes. Na Figura 5.11 são apresentadas as deformações na armadura de flexão em função do posicionamento na laje.

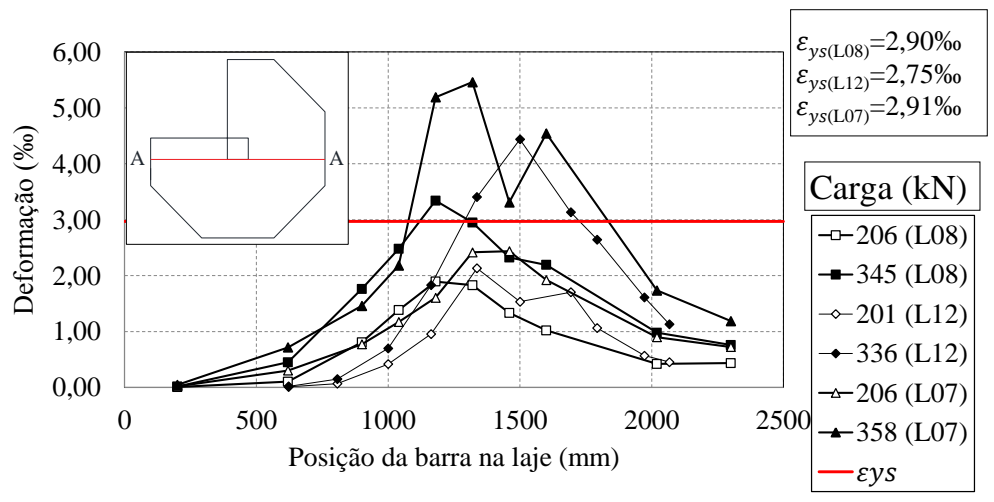

Figura 5.11 - Gráfico de deformações na armadura de flexão das lajes L08, L12 e L07.

Nota-se que na laje L07 mais barras alcançaram a deformação de escoamento que a laje L08 que possuía armadura de torção e a laje L12 que possuía menor transferência de momento, tornando-a mais frágil. A laje L08 apresentou menores deformações devido a 
presença de armadura de torção, que possibilitou a redistribuição de tensões para tais armaduras fazendo com que a armadura de flexão fosse menos solicitada.

As lajes L12 e L07 apresentaram deformações altas de no máximo 4,4 \%o e 5,5 \%o respectivamente em relação à laje L08 que pareceu ser mais rígida e a armadura de torção não permitiu que a armadura de flexão atingisse deformações maiores como nas outras lajes.

Na Figura 5.12 são comparadas as deformações na superfície do concreto em que se pode notar na laje L08 comparada com a L07 a influência da armadura de torção fazendo com que o ponto EC8 (situado na superfície superior da laje na borda reentrante) tracionasse e as deformações na superfície inferior situados na parte interna foram semelhantes.

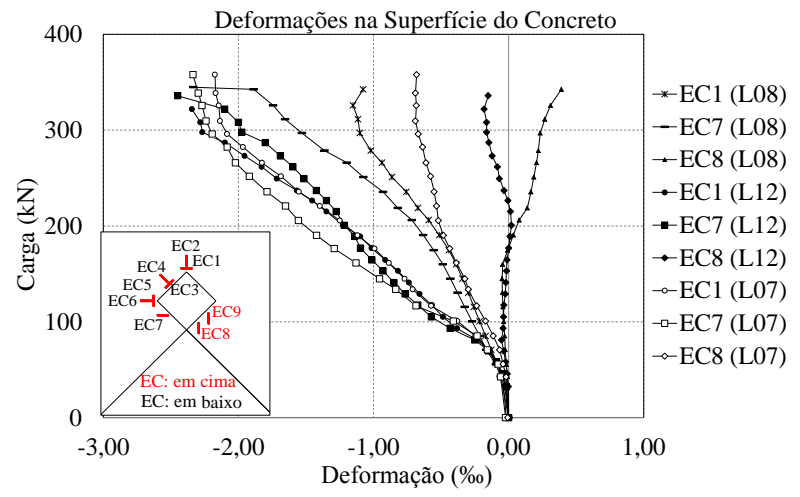

Figura 5.12 - Deformações na superfície do concreto das lajes L08, L12 e L07.

Quanto às cargas de ruptura, pode-se dizer que a laje L07 apresentou maior carga de ruptura $(358 \mathrm{kN})$ e deslocou mais enquanto que a L08 e L12 apresentaram mesma carga de ruptura $(345 \mathrm{kN})$ com deslocamentos menores.

\subsubsection{Lajes L06 (282 kN), L08 (345 kN), L07 (358 kN) e L04 (372 kN)}

A Tabela 5.5 apresenta o resumo das características das lajes L06, L08, L07 e L04. 
Tabela 5.5 - Características das lajes L06, L08, L07 e L04..

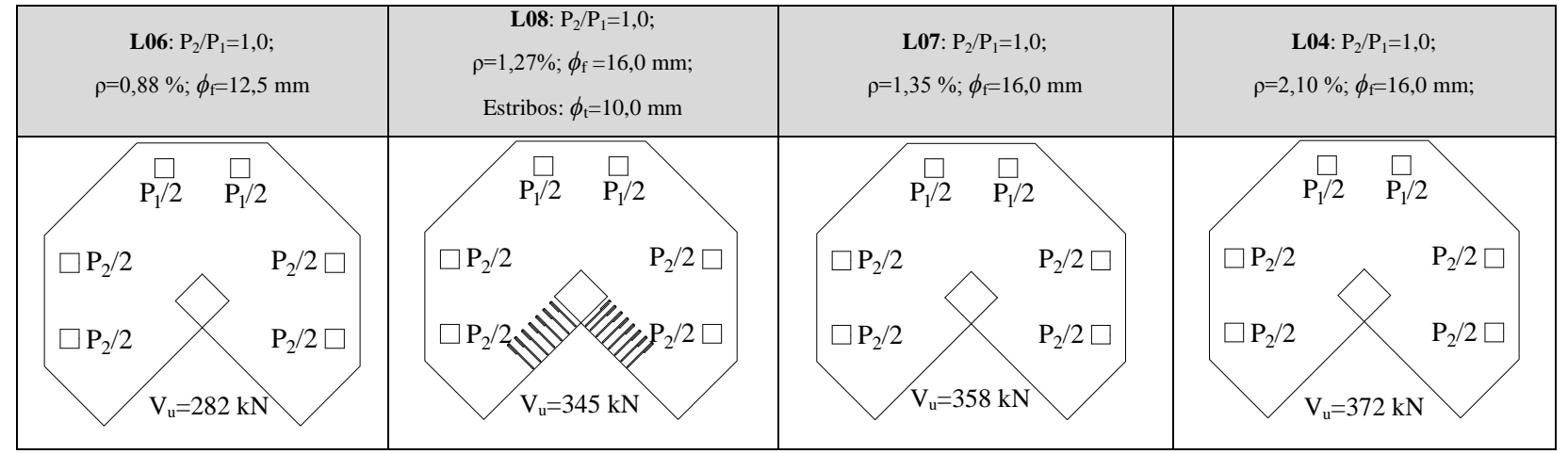

A Figura 5.13 mostra o gráfico da taxa de armadura de flexão em relação à carga de ruptura das lajes L06, L08, L07 e L04 mostrando que quanto maior a taxa de armadura de flexão maior a carga de rutura da laje mesmo que seja uma diferença pequena.

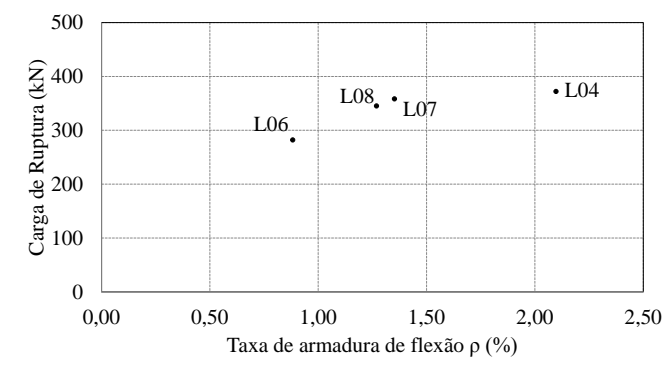

Figura 5.13 - Gráfico de carga de ruptura x taxa de armadura de flexão média das lajes

$$
\text { L06, L08, L07 e L04. }
$$

Pode-se observar com a Figura 5.14 que a laje com maiores deslocamentos próxima à ruptura foi a L08 no ponto 18 com deslocamento em torno de $22 \mathrm{~mm}$. Para um mesmo nível de carga a laje L04 apresenta menores deslocamentos, isso pode ser atribuído à maior quantidade de armadura de flexão, enquanto que para as outras lajes, à medida que se reduz a taxa de armadura de flexão torna-se menor a carga de ruptura da laje e maiores seus deslocamentos, devido à maior ductilidade. 

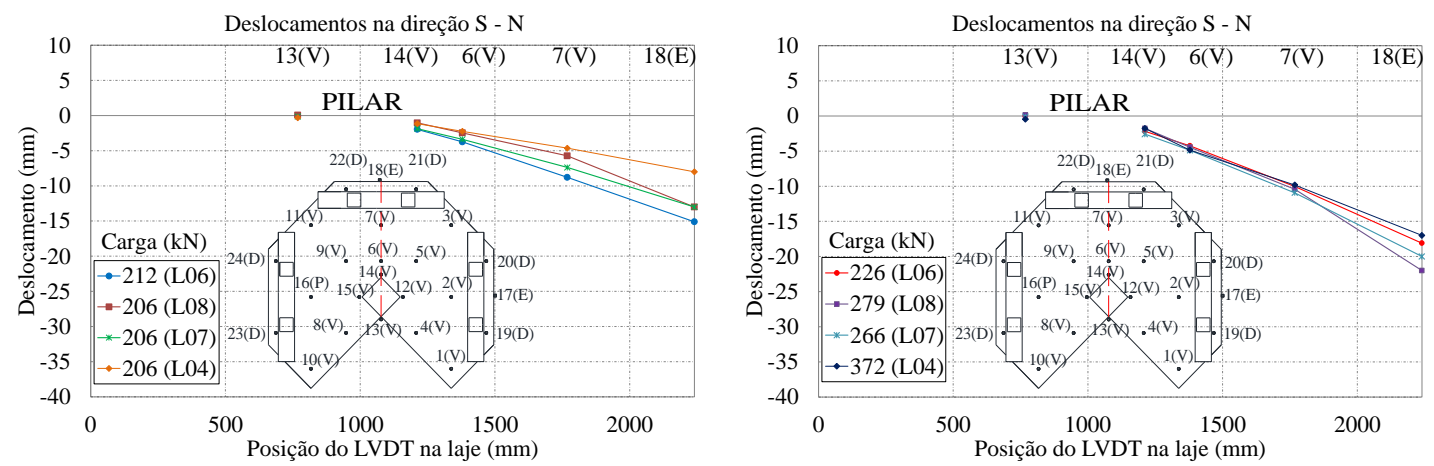

Figura 5.14 - Gráfico de deslocamentos verticais na direção S-N das lajes L06, L08, L07 e L04.

Nos pontos 1, 4, 8 e 10, localizados nos bordos reentrantes da laje, pode-se notar com a Figura 5.15 que as quatro lajes analisadas tiveram o mesmo comportamento descendente devido à excentricidade com $350 \mathrm{~mm}$, tendo a laje L06 apresentado os maiores deslocamentos por ter menor taxa de armadura de flexão.
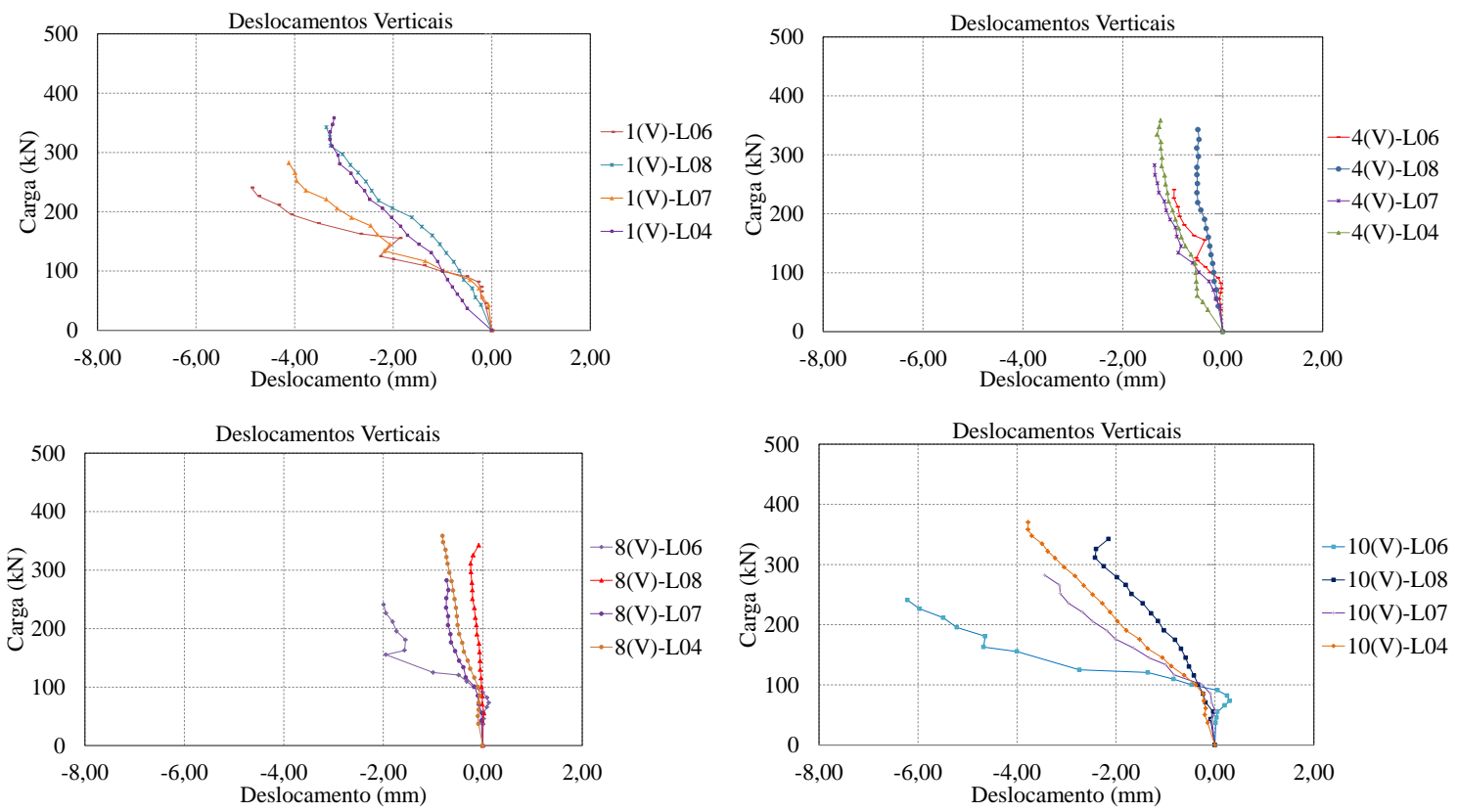

Figura 5.15 - Gráfico de delocamentos verticais x carga das lajes L06, L08, L07 e L04 nos pontos $1,4,8$ e 10 .

Nos pontos 12, 13, 14 e 15, localizados nos vértices do pilar, mostram mesmo comportamento, com exceção da laje L08 que subiu no ponto 13 localizado no canto reentrante do pilar (Figura 5.16). 

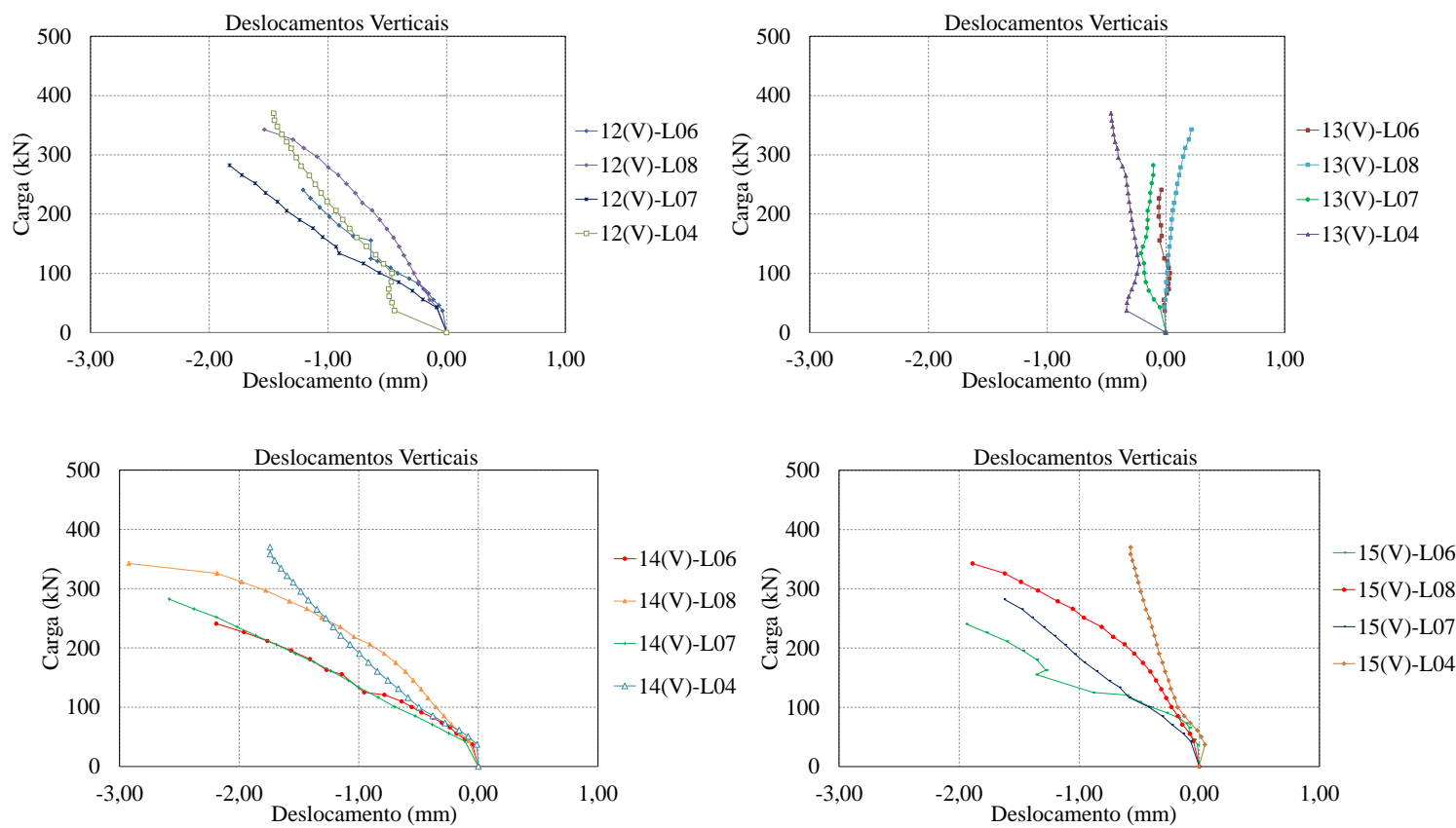

Figura 5.16 - Gráfico de delocamentos verticais x carga das lajes L06, L08, L07 e L04 nos pontos $12,13,14$ e 15 .

Esses comportamentos observados na Figura 5.17 indicam que o momento não é contínuo na linha A-A e que os momentos na parte esquerda da linha são menores que os momentos localizados na parte direita por se localizarem próximo a reentrância.

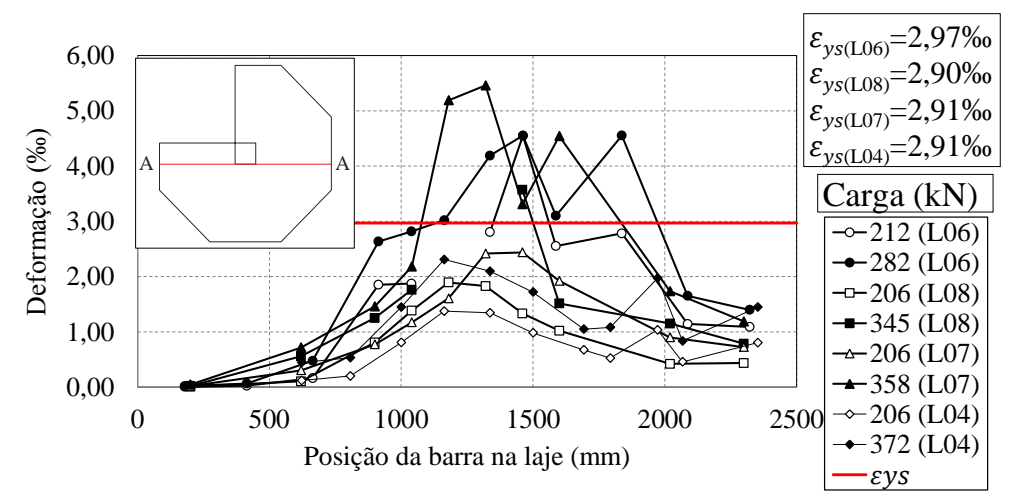

Figura 5.17 - Gráfico de deformações na armadura de flexão das lajes L06, L08, L07 e L04.

Pode-se notar que na laje L04 nenhuma barra escoou e nas lajes L07, L08 e L06 escoaram 1, 2 e 5 barras respectivamente. Na laje L07 escoou a barra 6 à uma carga correspondendo $80 \%$ da carga de ruptura; na laje L08 escoaram as barras 5 e 6 numa mesma carga correspondendo $90 \%$ da carga de ruptura da laje; e na laje L06 escoaram as barras 6, 7, 8, 9 e 10 com uma carga correspondo $70 \%, 90 \%, 75 \%, 95 \%$ e $90 \%$ da carga de ruptura respectivamente. A laje L08 por possuir armadura de torção nas bordas reentrantes apresentou menores deformações nas barras quando comparada a laje L07, que possui a 
mesma taxa de armadura de flexão. A laje L07 apresentou deformações superiores à deformação de escoamento, com valores em torno de 5,00 \%o, nos pontos 4, 5, 6, 7 e 8 .

As deformações na superfície do concreto (Figura 5.18) atingiram tensões de compressão de no máximo 2,33 \%. A laje L04 apresentou deformação de no máximo 1,11 \%o, mas não será utilizada aqui para comparar com as demais por ter pontos monitorados diferentes. Comparando as lajes L07 e L08 notam-se apenas deformações de alongamento na L07 e na laje L08 deformações de alongamento e encurtamento (na ordem de 0,4 \%). Essas deformações de encurtamento estão associadas com o efeito de torção que provoca efeitos de tração nesses pontos, visto que a laje L08 possui armadura de torção. Quando comparadas as lajes L06 e L07 nota-se um comportamento semelhante com exceção do ponto EC8 que se acredita que não funcionou bem, havendo um possível destacamento do extensômetro da superfície do concreto.

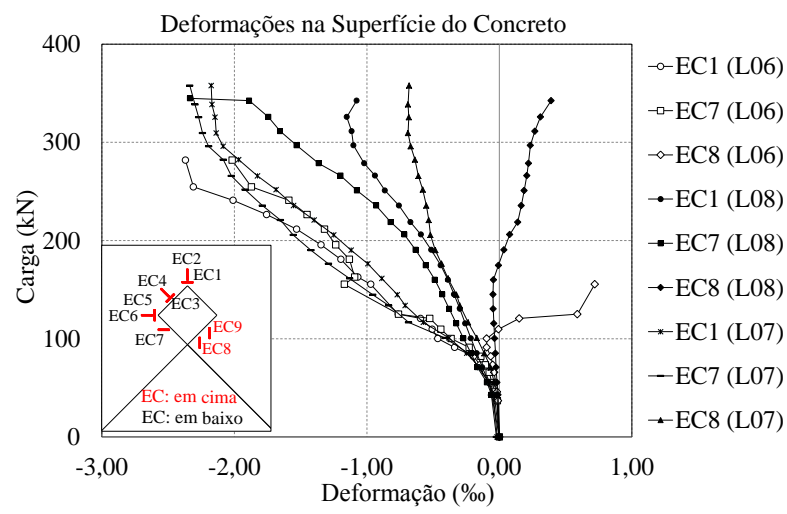

Figura 5.18 - Deformações na superfície do concreto das lajes L06, L08 e L07.

Quanto às cargas de ruptura, pode-se dizer que a laje L04 apresentou maior carga de ruptura $(372 \mathrm{kN})$ e deslocou menos enquanto que a L06 apresentou menor carga de ruptura $(282 \mathrm{kN})$ com deslocamentos maiores por possuir taxa de armadura de flexão menor.

\subsubsection{Lajes L05 (250 kN) e L01 (325 kN)}

A Tabela 5.6 apresenta o resumo das características das lajes L05 e L01. 
Tabela 5.6 - Características das lajes L05 e L01.

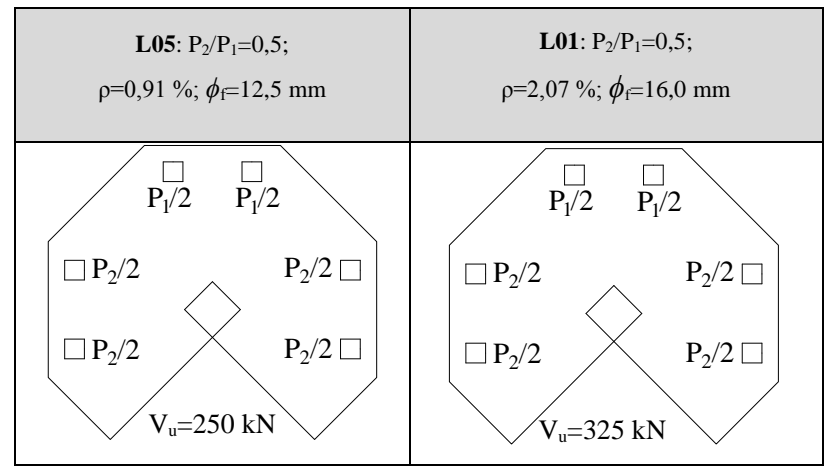

A Figura 5.19 mostra o gráfico da taxa de armadura de flexão em relação à carga de ruptura das lajes L05 e L01 mostrando que é quanto maior a taxa de armadura de flexão maior a carga de ruptura da laje.

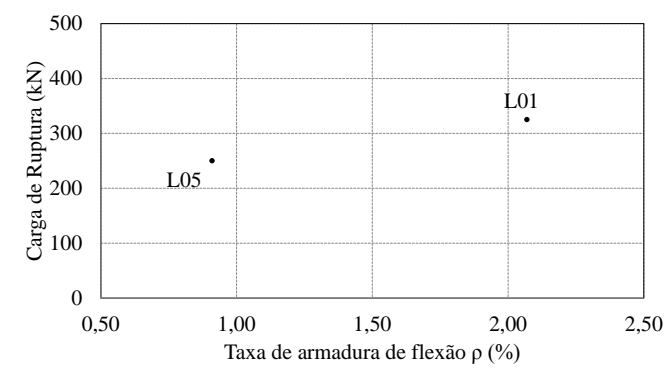

Figura 5.19 - Gráfico de carga de ruptura x taxa de armadura de flexão média das lajes

$$
\text { L05 e L01. }
$$

A Figura 5.20 apresenta o gráfico de deslocamentos das lajes L01 e L05 em relação à posição dos LVDT's com a carga de aproximandamente de $200 \mathrm{kN}$ onde se pode observar que a laje L05 apresentou maiores deslocamentos em relação à laje L01 com maior taxa de armadura de flexão.

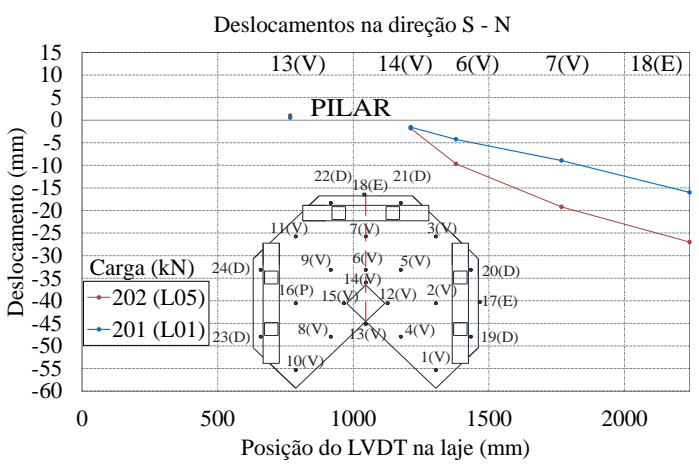

Figura 5.20 - Gráfico de deslocamentos verticais na direção S-N das lajes L05 e L01. 
Na Figura 5.21 são apresentados os deslocamentos nos pontos 1, 4, 8 e 10 localizados próximo aos bordos reentrantes, e na Figura 5.22 os deslocamentos nos pontos 12, 13, 14 e 15 localizados próximo os cantos do pilar.
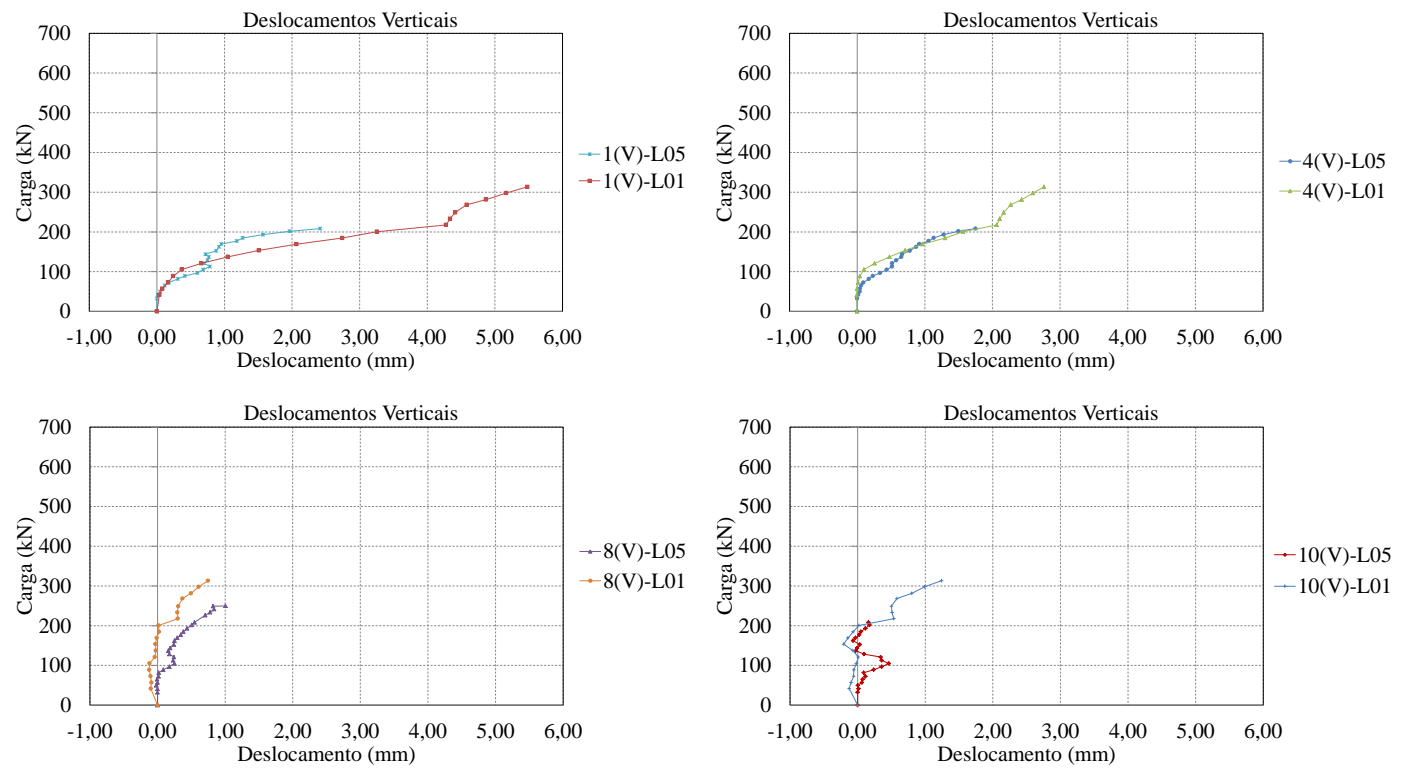

Figura 5.21 - Gráfico de delocamentos verticais x carga das lajes L05 e L01 nos pontos 1, 4,8 e 10.

Com esses gráficos pode-se observar um mesmo comportamentos com deslocamentos ascendentes pois ambas as lajes possuíam excentricidades em torno de $500 \mathrm{~mm}$ mas a laje L05 deslocou-se mais pela menor taxa de armadura de flexão.
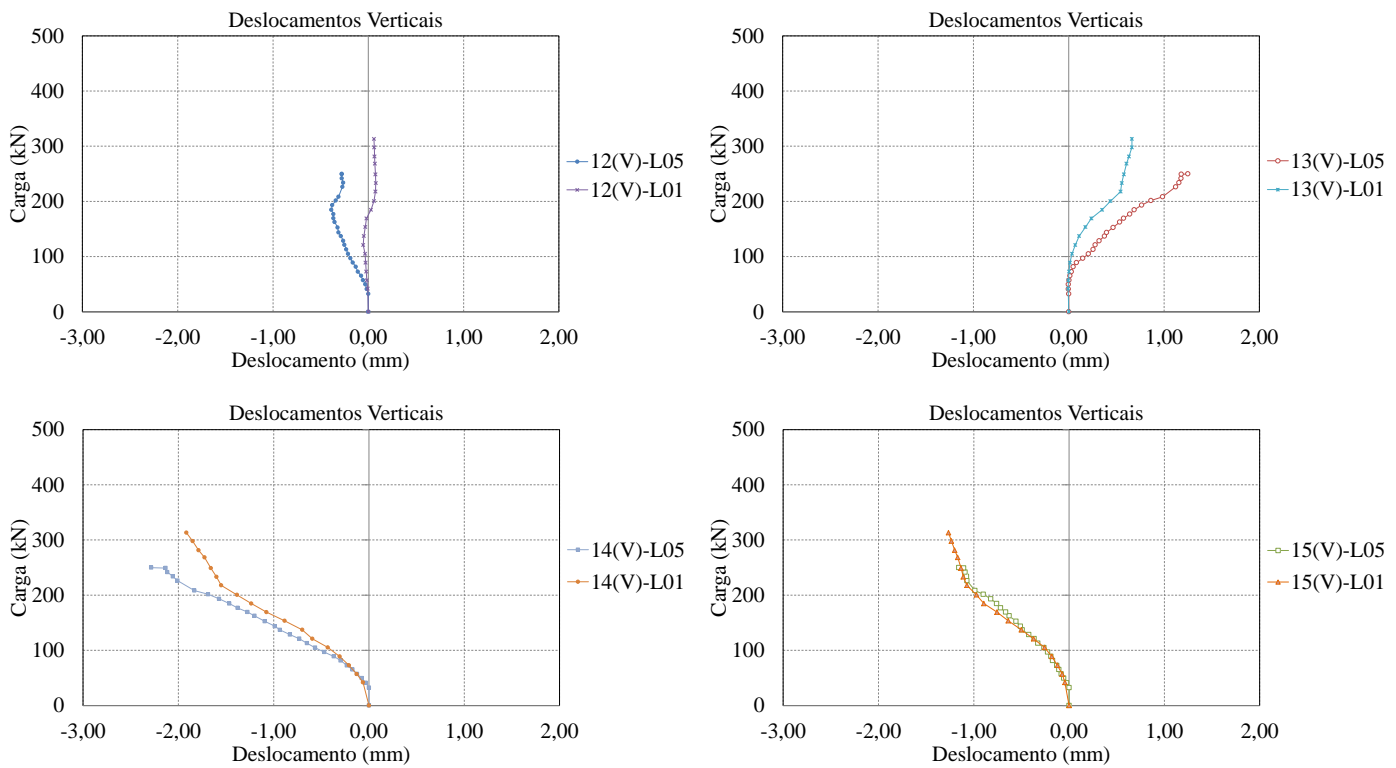

Figura 5.22 - Gráfico de delocamentos verticais x carga das lajes L05 e L01 nos pontos 12, 13,14 e 15. 
Os pontos monitorados próximo ao pilar mostram que as lajes analisadas tiveram comportamento semelhante e no ponto 13 (localizada no canto do pilar na reentrância da laje) observa-se uma ascendência em ambas as lajes pela tranferência de momento ser relativamente alta. Na Figura 5.23 são apresentadas as deformações na armadura de flexão em função do posicionamento na laje.

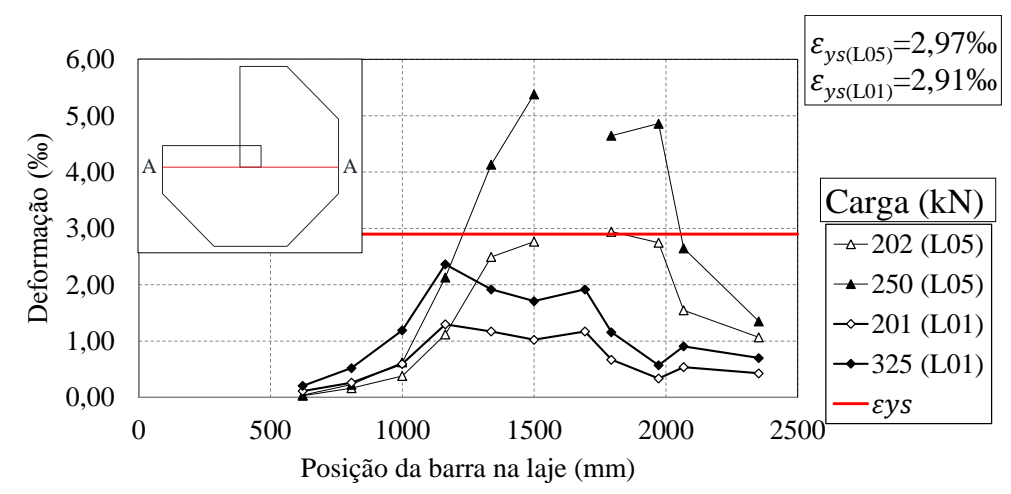

Figura 5.23 - Gráfico de deformações na armadura de flexão das lajes L05 e L01.

Apenas a laje L05 apresentou deformações altas, com 4 barras atingindo a tensão de escoamento.

As deformações na superfície do concreto das lajes L01 e L05 tiveram os pontos monitorados diferentes, por isso não servirão para conclusões consistentes.

Quanto às cargas de ruptura e padrão de fissuração, pode-se dizer que a laje L01 apresentou maior carga de ruptura $(325 \mathrm{kN})$ e deslocou menos enquanto que a L05 com carga de ruptura de $250 \mathrm{kN}$ e deslocamentos maiores por possuir taxa de armadura de flexão menor.

\subsubsection{Lajes L06 (282 kN) e L05 (250 kN)}

A Tabela 5.7 apresenta o resumo das características das lajes L06 e L05. 
Tabela 5.7 - Características das lajes L06 e L05.

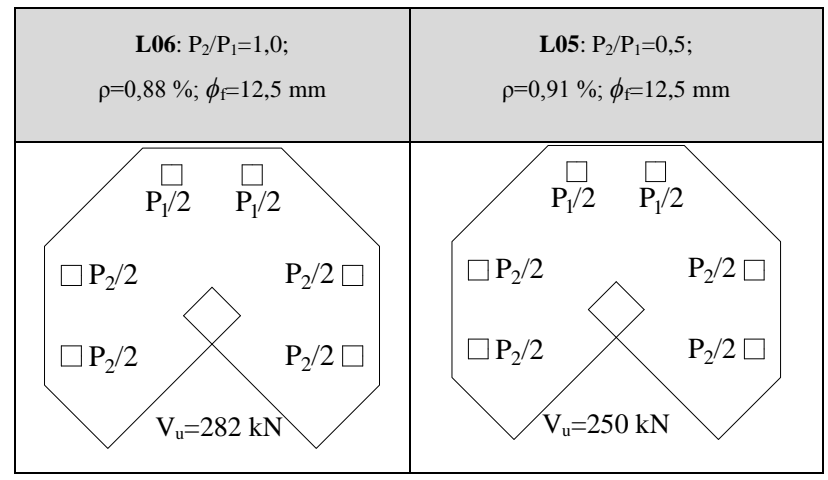

A Figura 5.19 mostra o gráfico da taxa de armadura de flexão em relação à carga de ruptura das lajes L06 e L05 mostrando que quando maior a excentricidade menor a carga de ruptura pelo fato da laje L05 ter uma maior transferência de momento.

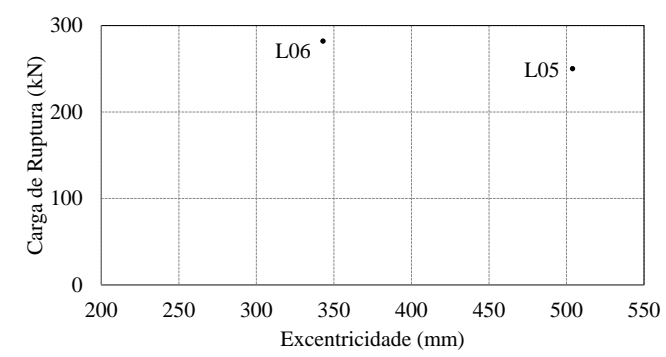

Figura 5.24 - Gráfico de carga de ruptura x excentricidade das lajes L06 e L05.

A Figura 5.20 apresenta o gráfico de deslocamentos das lajes L06 e L05 em relação à posição dos LVDT's com a carga de aproximandamente de $200 \mathrm{kN}$ onde se pode observar que a laje L05 apresentou maiores deslocamentos em relação à laje L06 por ter maior excentricidade.

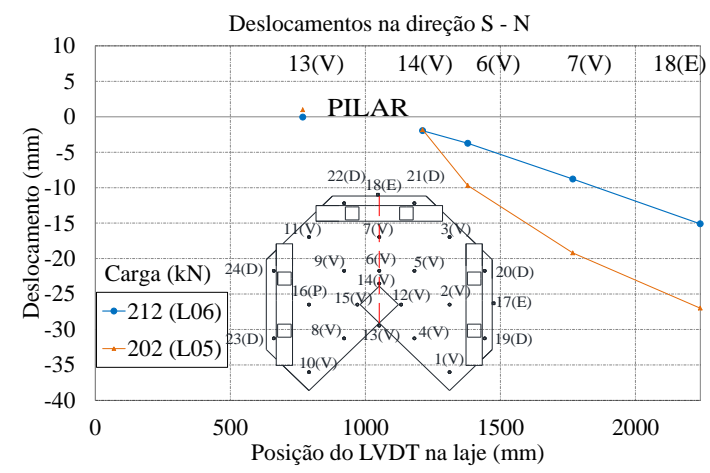

Figura 5.25 - Gráfico de deslocamentos verticais na direção S-N das lajes L06 e L05. 
Na Figura 5.21 são apresentados os deslocamentos nos pontos 1, 4, 8 e 10 localizados próximo aos bordos reentrantes, e na Figura 5.22 os deslocamentos nos pontos 12, 13, 14 e 15 localizados próximo os cantos do pilar.
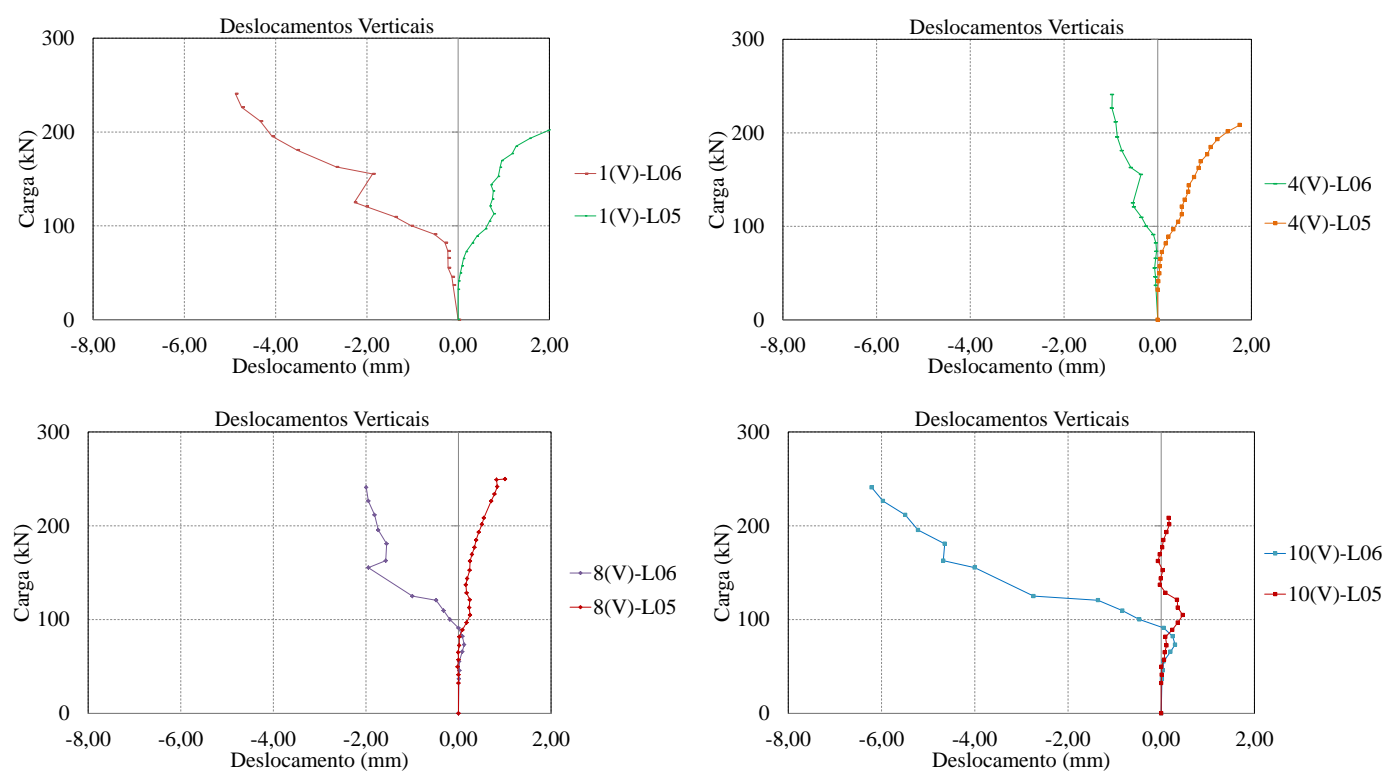

Figura 5.26 - Gráfico de delocamentos verticais x carga das lajes L06 e L05 nos pontos 1,

$$
4,8 \text { e } 10 \text {. }
$$

Com esses gráficos pode-se observar comportamentos diferentes com deslocamentos ascendentes na laje L05 com excentricidade em torno de $500 \mathrm{~mm}$ e a laje L06 com deslocamentos descendentes com excentricidade menor, em torno de $350 \mathrm{~mm}$.
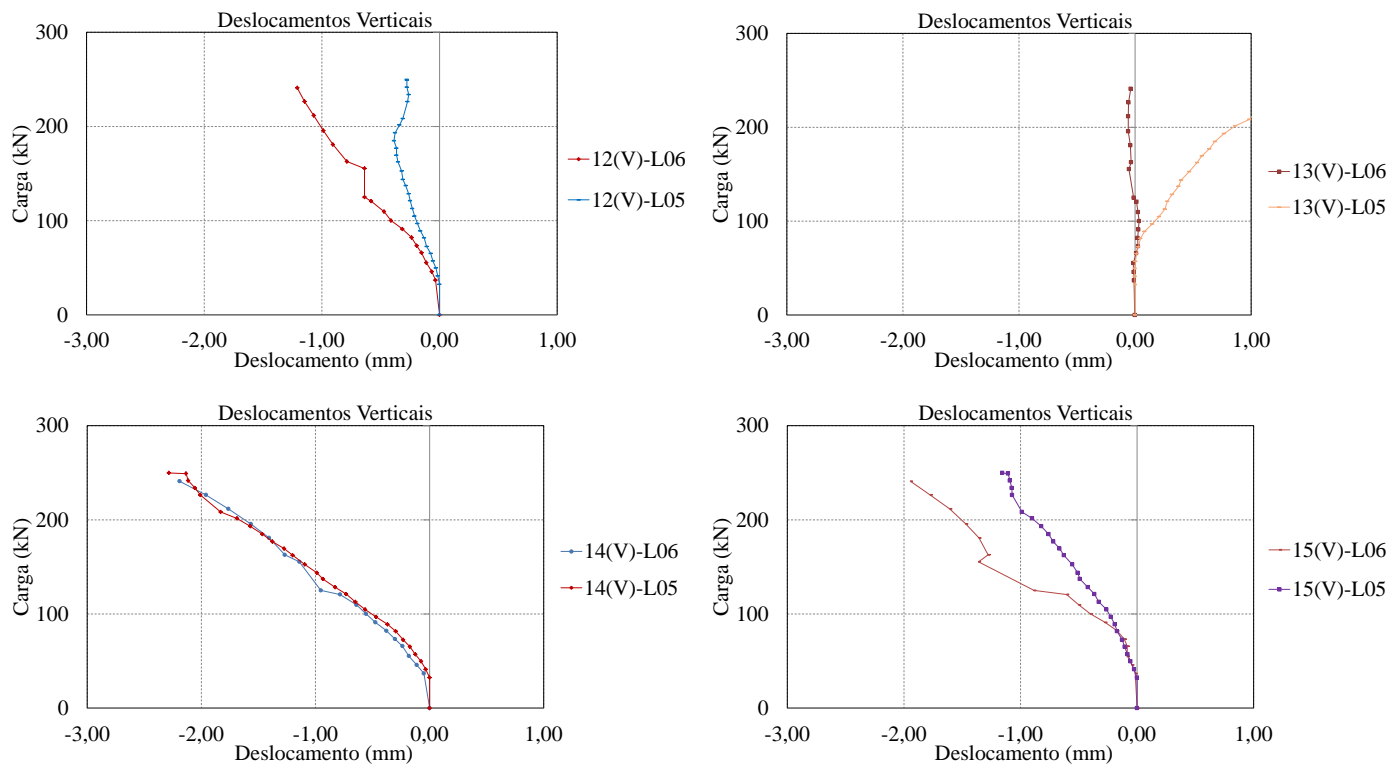

Figura 5.27 - Gráfico de delocamentos verticais x carga das lajes L06 e L05 nos pontos 12, 13,14 e 15. 
Os pontos monitorados próximo ao pilar mostram que as lajes analisadas tiveram comportamento semelhante com exceção do ponto 13 (localizada no canto do pilar na reentrância da laje) observa-se uma ascendência na laje L05 pela tranferencia de momento ser alta (excentricidade de $500 \mathrm{~mm}$ ). Na Figura 5.23 são apresentadas as deformações na armadura de flexão em função do posicionamento na laje.

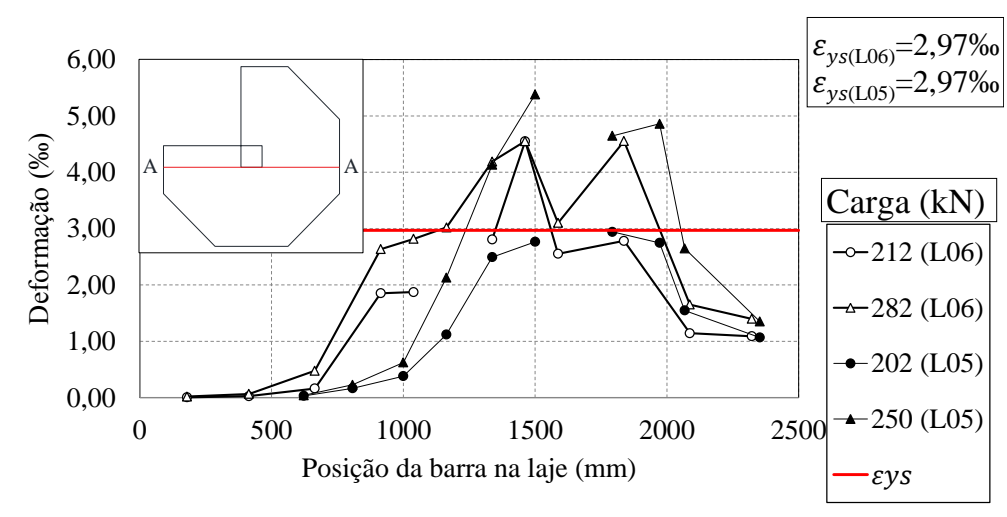

Figura 5.28 - Gráfico de deformações na armadura de flexão das lajes L06 e L05.

Ambas as lajes apresentaram deformações altas, tanto a L06 como a L05 tiveram 4 pontos dos 12 monitorados deformações acima da $\varepsilon_{y}$.

Em relação à deformação na superfície do concreto nota-se com a deformação máxima em ambas as lajes foi no ponto EC1 tangencial ao pilar e oposto a reentrância. O ponto EC8 da laje L06 provavelmente descolou da superfície.

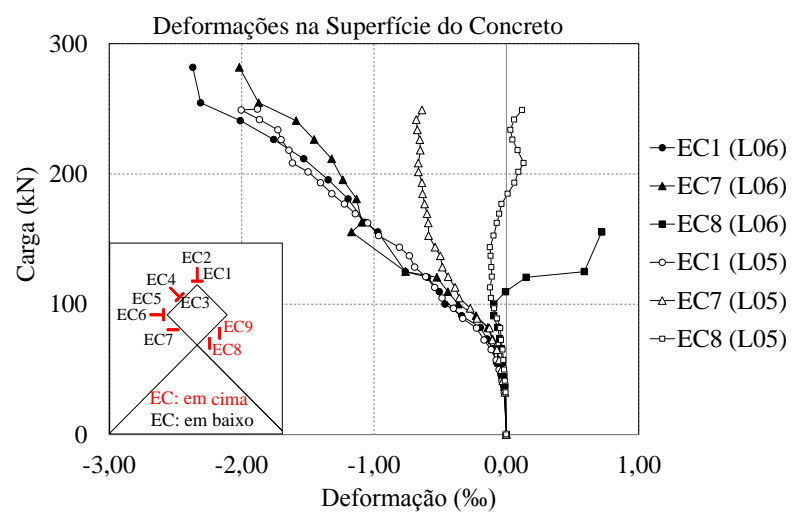

Figura 5.29 - Deformações na superfície do concreto das lajes L06 e L05.

Quanto às cargas de ruptura, pode-se dizer que a laje L06 apresentou maior carga de ruptura $(282 \mathrm{kN})$ e deformou menor enquanto que a L05 com carga de ruptura de $250 \mathrm{kN}$ deslocou mais por possuir maior excentricidade. 


\subsubsection{Análise do Grupo 2 - com studs}

\subsubsection{Lajes L02 (513 kN), L9 (550 kN) e L03 (575 kN)}

A Tabela 5.8 apresenta o resumo das características das lajes L02, L09 e L03.

Tabela 5.8 - Características das lajes L02, L09 e L03.

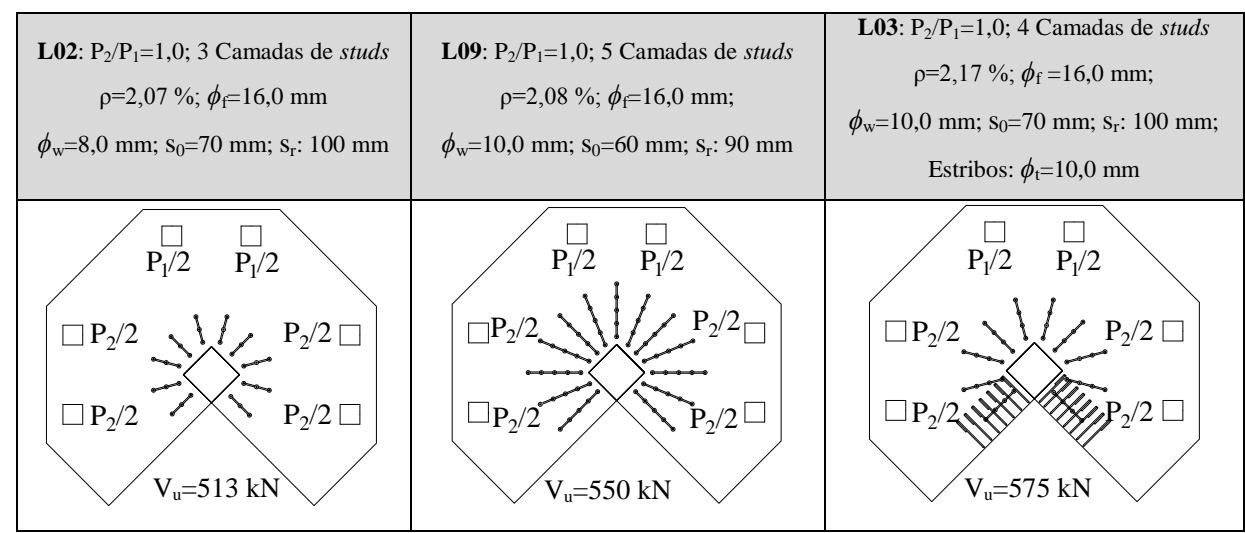

A Figura 5.30 (a) mostra o gráfico da taxa de armadura de flexão em relação à carga de ruptura das lajes L02, L09 e L03 mostrando que é quanto maior a taxa de armadura de flexão maior a carga de ruptura da laje mesmo que seja uma diferença pequena. A Figura 5.30 apresenta o gráfico da área de armadura de cisalhamento em relação à carga de ruptura das lajes L02, L09 e L03 mostrando que quando compara-se as lajes L03 com a laje L02 nota-se que quanto maior a área de armadura de cisalhamento maior a carga de ruptura da laje, o que não acontece quando compara-se as lajes L03 e L09 pois tem-se uma maior área de armadura de cisalhamento radial na laje L09 porém menor taxa de armadura de flexão, por isso a mesma apresentou menor carga de ruptura.

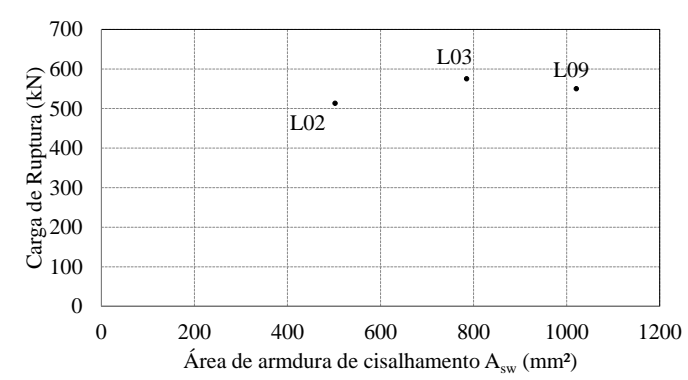

Figura 5.30 - Gráfico de carga de ruptura x área de armadura de cisalhamento das lajes L02, L09, e L03. 
Pode-se observar com a Figura 5.31 que a laje com maiores deslocamentos foi a L09 no ponto 18 com deslocamento em torno de $39 \mathrm{~mm}$. Para um mesmo nível de carga as lajes L02 e L03 apresentaram menores deslocamentos, isso pode ser atribuído à menor quantidade de armadura de cisalhamento comparado a L09.
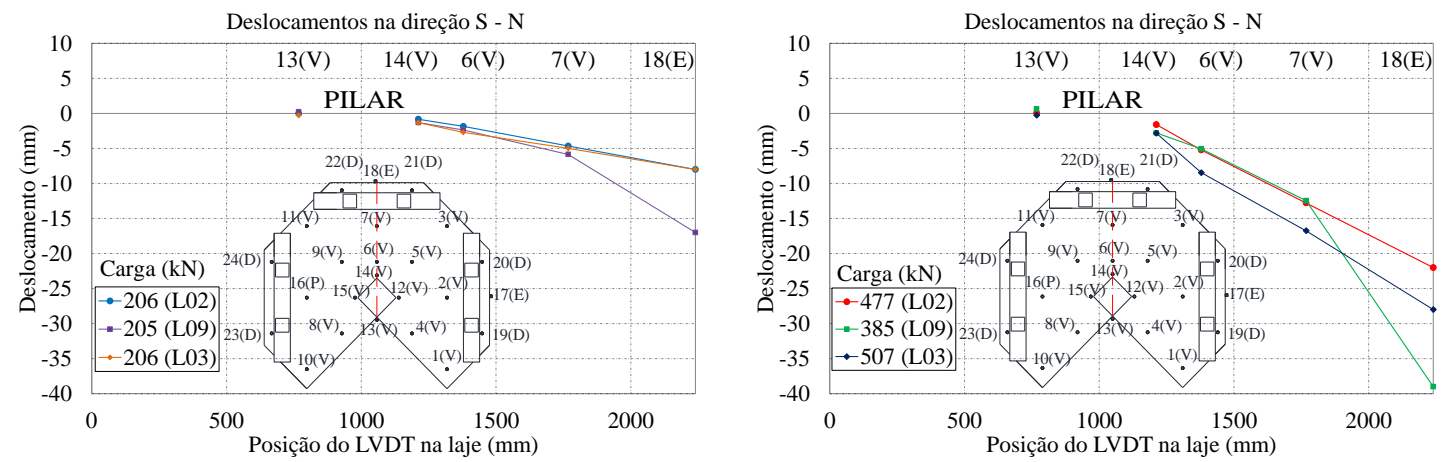

Figura 5.31 - Gráfico de deslocamentos verticais na direção S-N das lajes L02, L09 e L03.

Nos pontos 1, 4, 8 e 10, localizados nos bordos reentrantes da laje, pode-se notar com a Figura 5.32 que as três lajes tiveram o mesmo comportamento com um "alívio" dos deslocamentos em um determinado nível de carga, mas apenas a laje L09 apresentou valores de deslocamentos positivos nos pontos 4 e 8 .
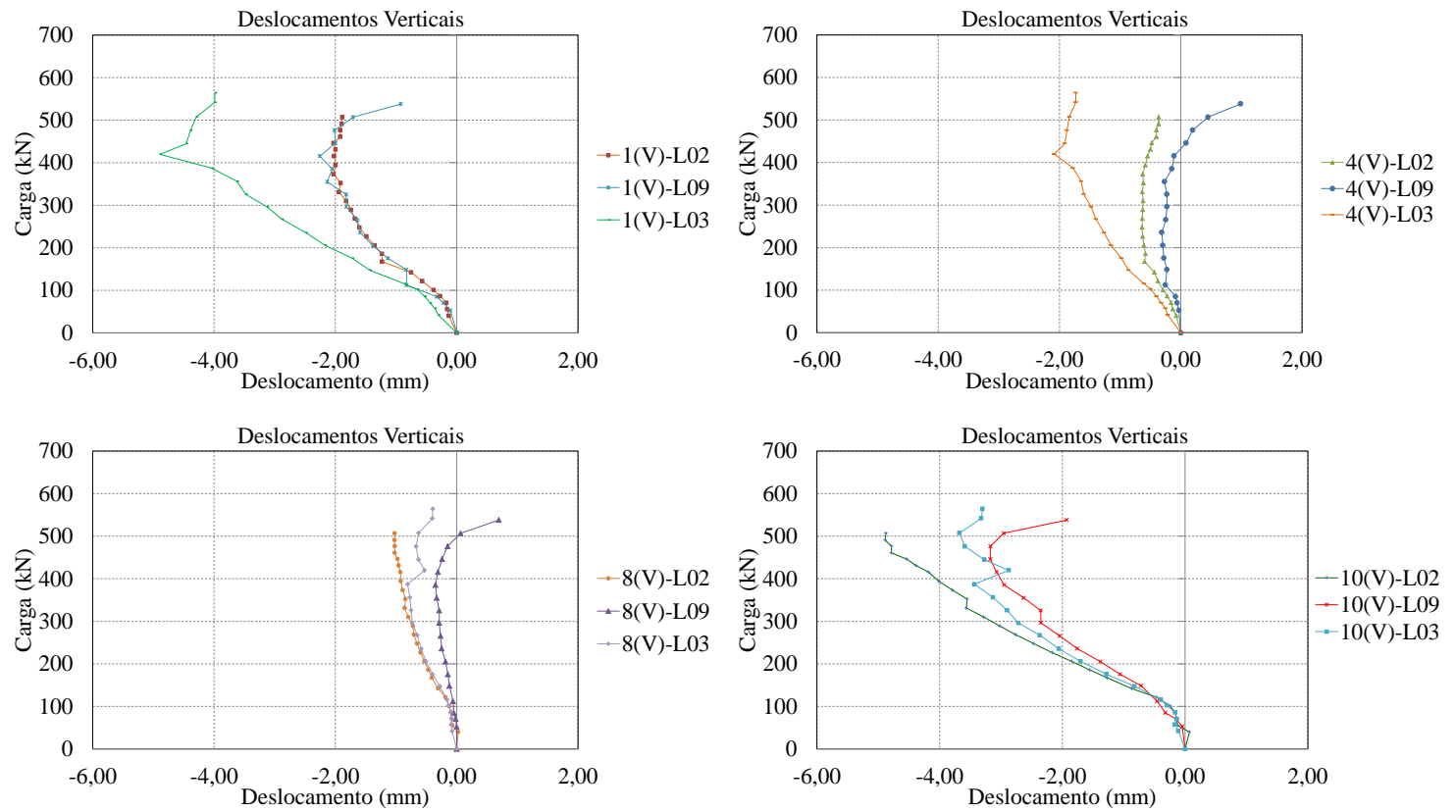

Figura 5.32 - Gráfico de delocamentos verticais x carga das lajes L02, L09 e L03 nos pontos $1,4,8$ e 10 .

Nos pontos 12, 13, 14 e 15, localizados nos vértices do pilar, mostram deslocamentos descentes em sua maioria com exceção da laje L09 que apresentou deslocamento 
ascendente no ponto 13 da ordem de 1,5 mm aproximadamente (Figura 5.33). Nesse caso observa-se que a área de armadura de cisalhamento e o número de camadas da mesma influenciaram no comportamento ascendente no canto reentrante.
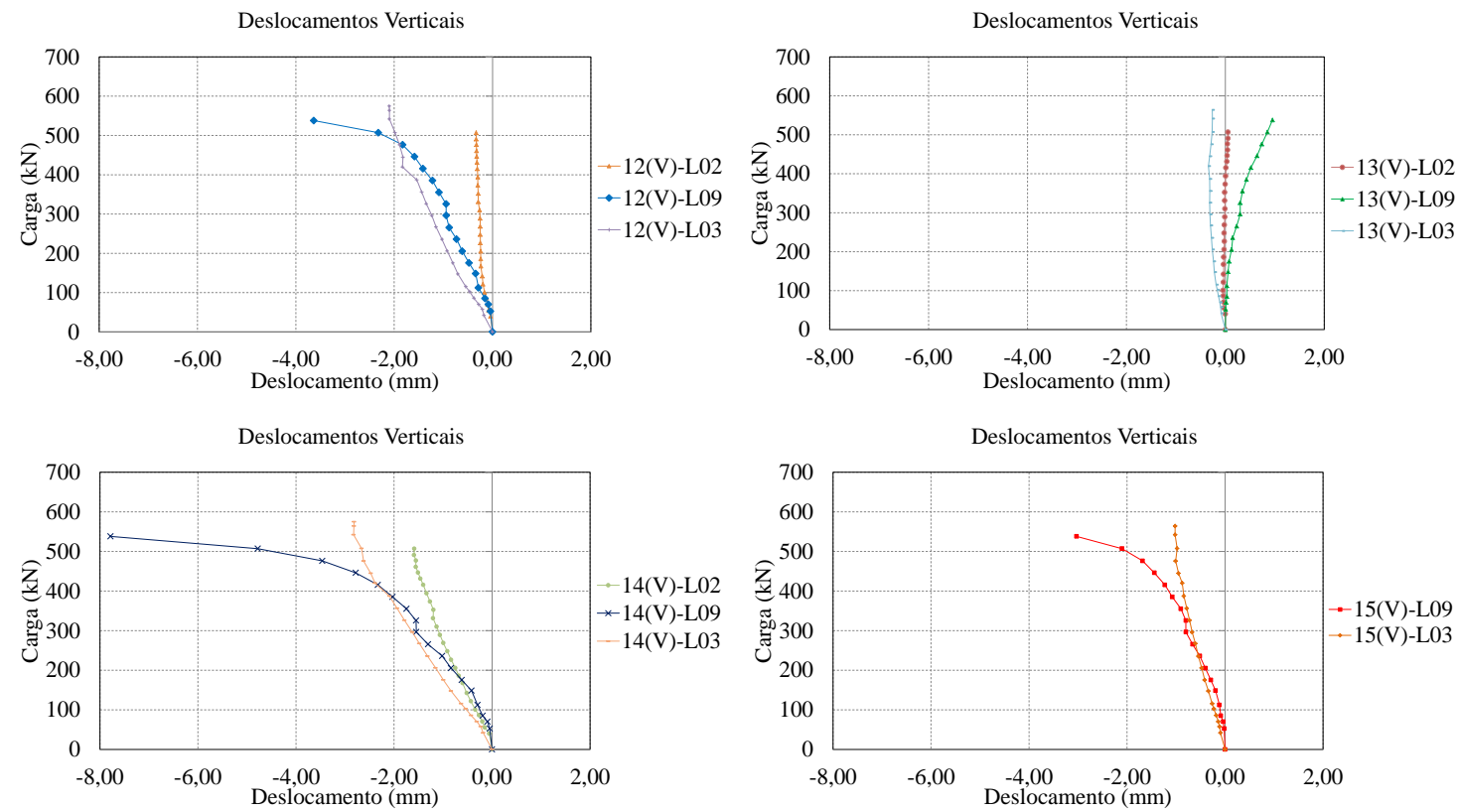

Figura 5.33 - Gráfico de delocamentos verticais x carga das lajes L02, L09 e L03 nos pontos $12,13,14$ e 15 .

A Figura 5.34 mostra que na laje L02 escoaram as barras 12 e 14 na carga ruptura; na laje L09 escoaram as barras 7, 8, 9 e 10 com uma carga correspondente a 70 \%, $75 \%, 80 \%$, e $90 \%$ da carga de ruptura respectivamente; e na laje L03 escoaram as barras 12, 13, 14 e 15 com uma carga correspondente a $90 \%, 75 \%, 95 \%$, e $75 \%$ da carga de ruptura respectivamente. Com o aumento da área da armadura de cisalhamento, foi maior a solicitação da armadura de flexão fazendo com que a laje L09 apresentasse maiores deformações na armadura de flexão.

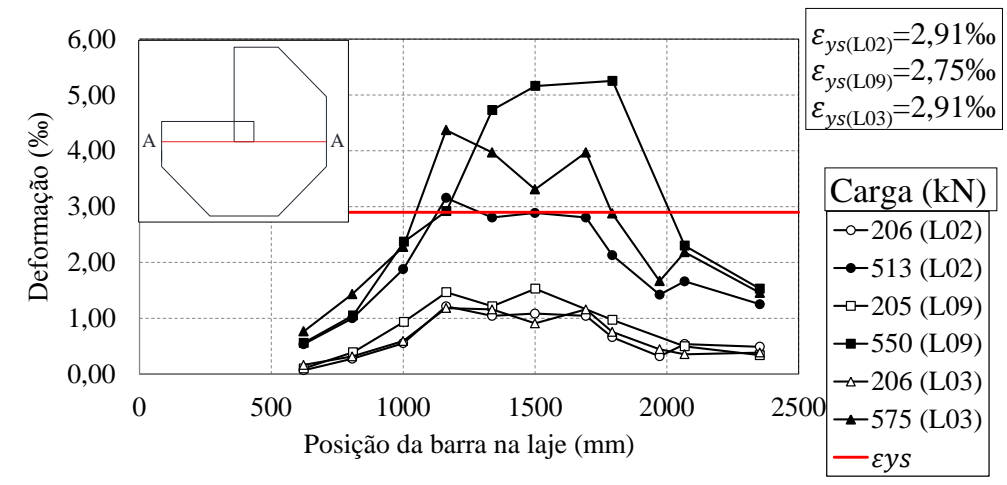

Figura 5.34 - Gráfico de deformações na armadura de flexão das lajes L02, L09 e L03. 
As deformações na superfície do concreto (Figura 5.35) atingiram tensões de compressão de no máximo 2,60\%. Vale ressaltar que os pontos monitorados na laje L09 foram diferentes das demais e não será comparado aqui. As lajes em análise apresentaram deformações de encurtamento com intensidades na ordem de 0,20 \% ambas as lajes diferenciaram-se pela intensidade das deformações na ruptura, ou seja, a laje L02 deformou menos por ter menor área de armadura de cisalhamento.

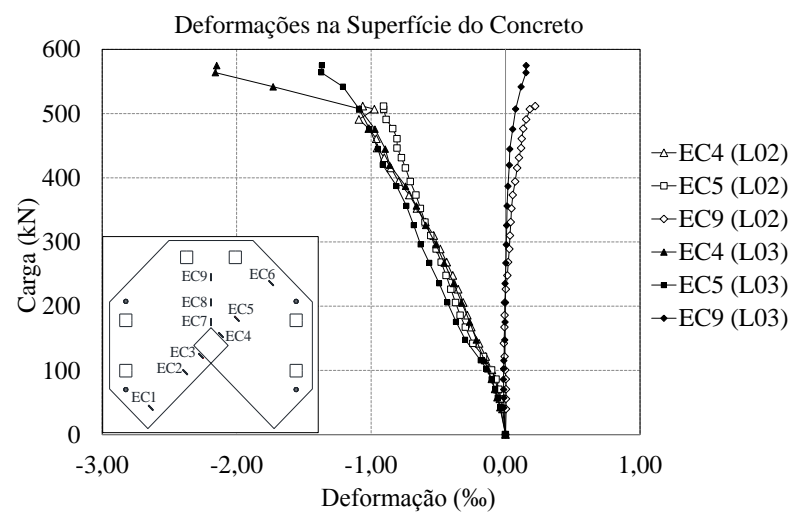

Figura 5.35 - Deformações na superfície do concreto das lajes L02 e L03.

Quanto às cargas de ruptura, pode-se dizer que a laje L03 apresentou maior carga de ruptura $(575 \mathrm{kN})$ por ter maior taxa de armadura de flexão e deslocou menos, enquanto que a L09 apresentou uma carga de ruptura de $550 \mathrm{kN}$ com deslocamentos maiores por possuir maior quantidade de armadura de cisalhamento. Já a laje L02 apresentou menor carga de ruptura entre as lajes analisadas $(513 \mathrm{kN})$ e menores deslocamentos.

\subsubsection{Lajes L09 (550 kN), L10 (500 kN) e L11 (640 kN)}

A Tabela 5.9 apresenta o resumo das características das lajes L09, L10 e L11.

Tabela 5.9 - Características das lajes L09, L10 e L11.

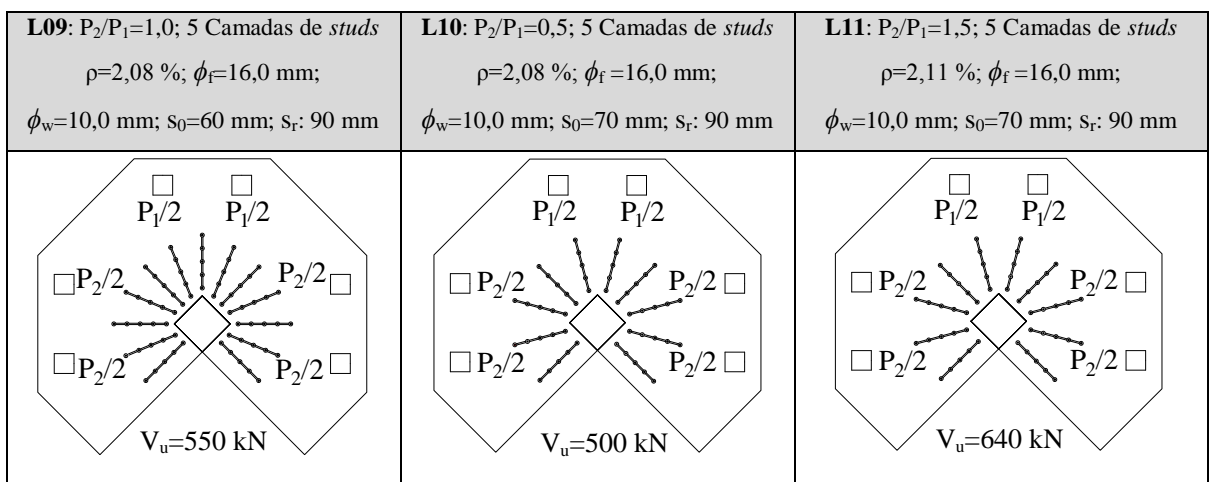


A Figura 5.36 mostra o gráfico da excentricidade em relação à carga de ruptura e o gráfica da área de armadura de cisalhamento em relação a carga de ruptura das lajes L09, L10 e L11. Pode-se notar que quanto mais armadura de cisalhamento maior a carga de ruptura, porém a excentricidade influencia mais na carga de ruptura, ou seja, a laje L09 tem maior carga de ruptura que as lajes L10 e L11 por possuir mais armadura de cisalhamento, contudo a laje L11 apesar de ter menos armadura de cisalhamento possui menor excentricidade e por isso tem maior carga de ruptura, assim como a laje L10 com maior excentricidade tem menor capacidade de carga que as demais.

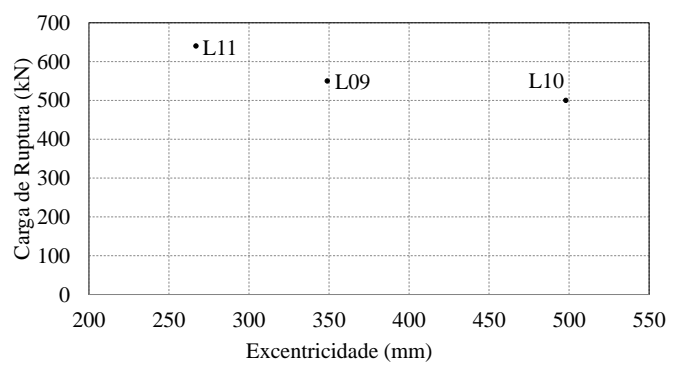

(a) $e(\mathrm{~mm}) \times V_{u}(\mathrm{kN})$

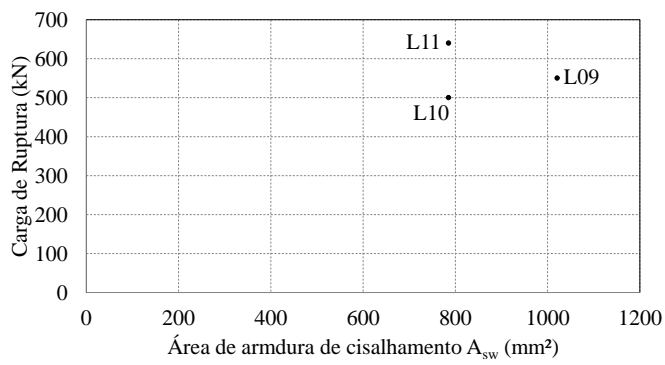

(b) $A_{s w}\left(\mathrm{~mm}^{2}\right) \mathrm{x} V_{u}(\mathrm{kN})$

Figura 5.36 - Gráfico de carga de ruptura x excentricidade e armadura de cisalhamento das lajes L09, L10, e L11.

A Figura 5.37 apresenta o gráfico de deslocamentos das lajes L09, L10, e L11 em relaçao a posição dos LVDT's onde se pode observar o comportamento em dois momentos: com o nível de carga em torno de $200 \mathrm{kN}$ e o nível de carga próximo à ruptura. No primeiro caso a laje L011 apresentou-se mais rígida e as demais com deslocamentos similares entre si (diferenciando-se em $2 \mathrm{~mm}$ ), ou seja, para valores de carga relativamente baixos a influência da taxa de armadura de flexão interfere mais que a excentricidade; já no segundo caso, próximo a ruptura a laje L10 apresentou-se muito mais flexível que as demais, com deslocamento máximo medido de $45 \mathrm{~mm}$ por ter maior tranferência de momento. 

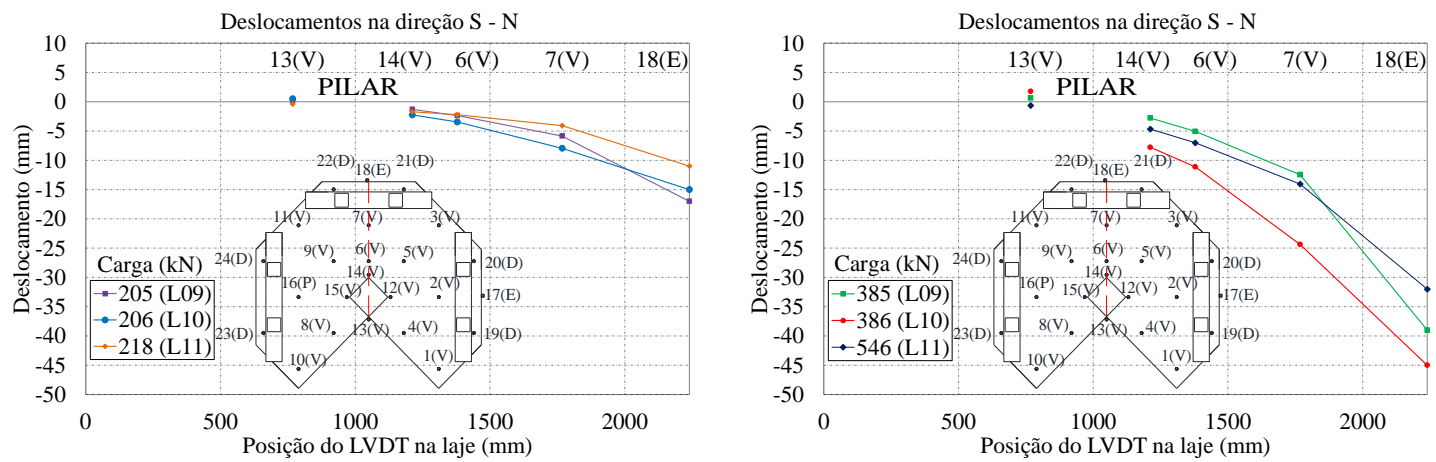

Figura 5.37 - Gráfico de deslocamentos verticais na direção S-N das lajes L09, L10, e L11.

Na Figura 5.38 são apresentados os deslocamentos nos pontos 1, 4, 8 e 10 localizados próximo aos bordos reentrantes, e na Figura 5.39 os deslocamentos nos pontos 12, 13, 14 e 15 localizados próximo aos vértices do pilar.
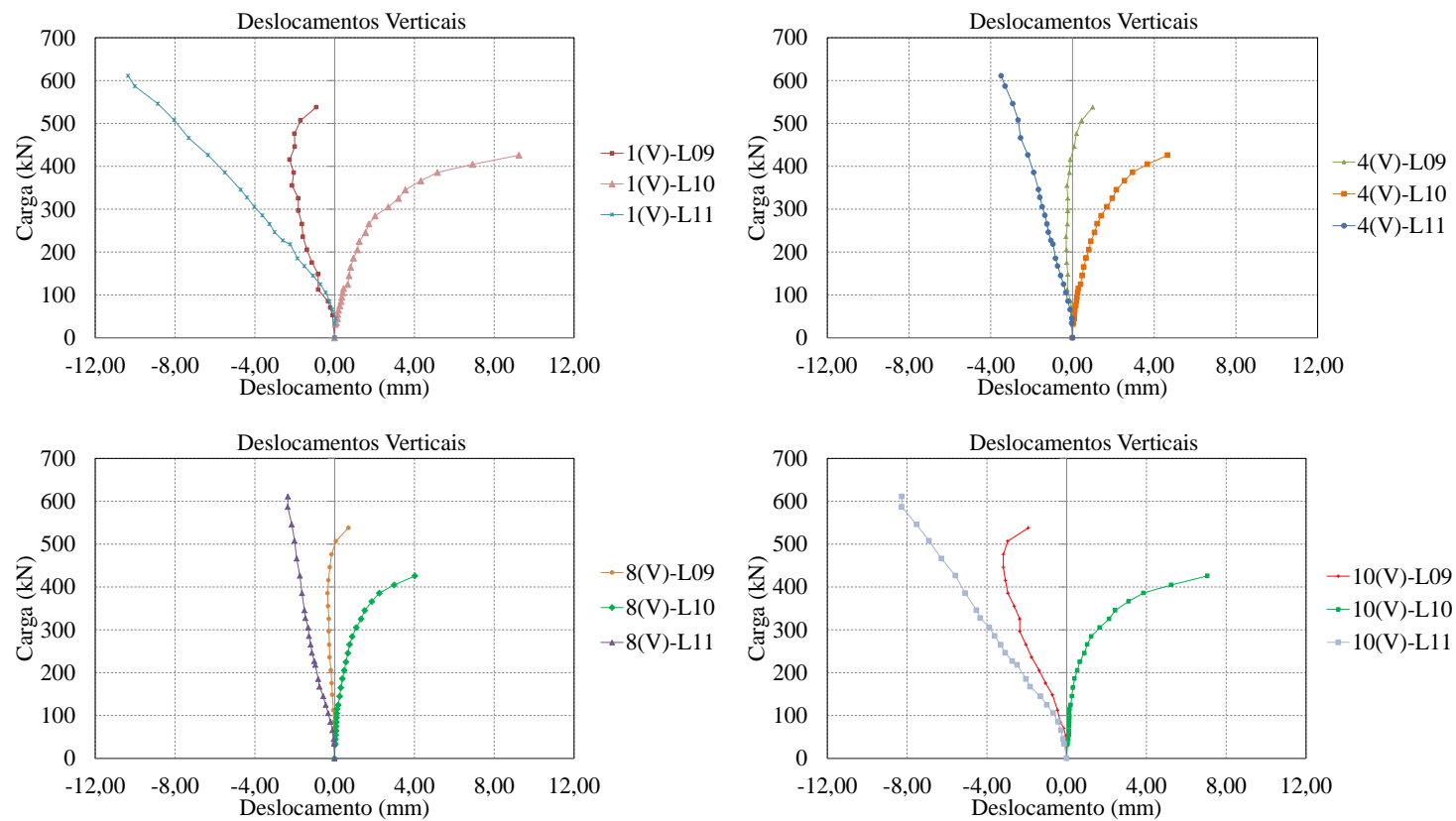

Figura 5.38 - Gráfico de delocamentos verticais x carga das lajes L09, L10, e L11 nos pontos $1,4,8$ e 10 .

Com esses gráficos pode-se observar comportamentos diferentes devido a diferença de excentricidade das três lajes, com a L10 deslocando-se para cima por possuir maior excentricidade e a L11 deslocando-se para baixo com grandes deslocamentos, ou seja, a medida que a excentricidade aumenta os deslocamentos deixam de ser negativos e passam a ser positivos dependendo da magnitude da excentricidade. 

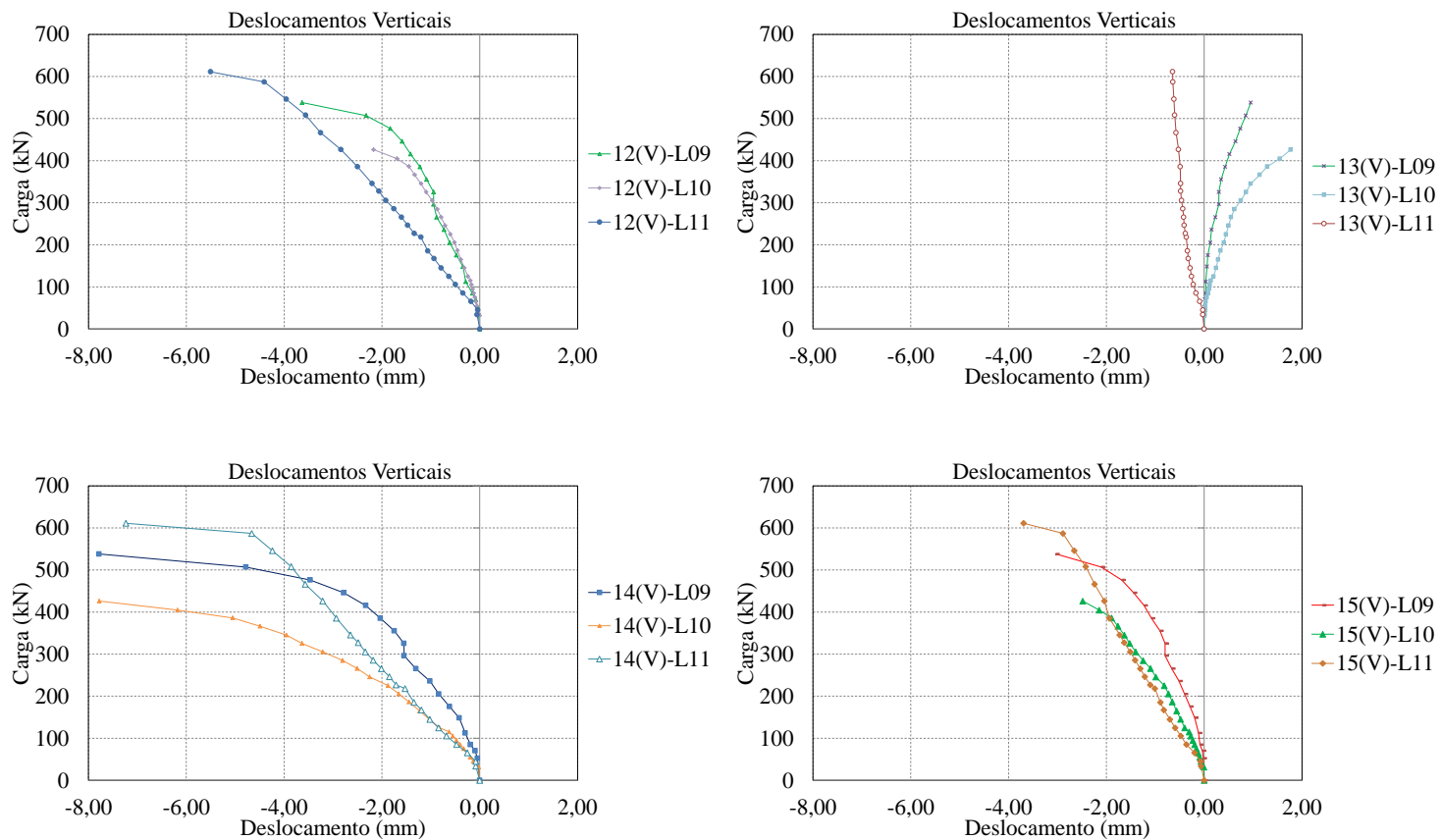

Figura 5.39 - Gráfico de delocamentos verticais x carga das lajes L09, L10, e L11 nos pontos $12,13,14$ e 15 .

Os pontos monitorados próximo ao pilar mostram que as lajes tiveram comportamento semelhante e no ponto 13 (localizado no vértice do pilar na reentrância da laje) observouse uma ascendência nas lajes L09 e L10, o que não ocorreu com a laje L11 por ter menor intensidade na tranferência de momento para a ligação. Na Figura 5.40 são apresentadas as deformações na armadura de flexão em função do posicionamento na laje.

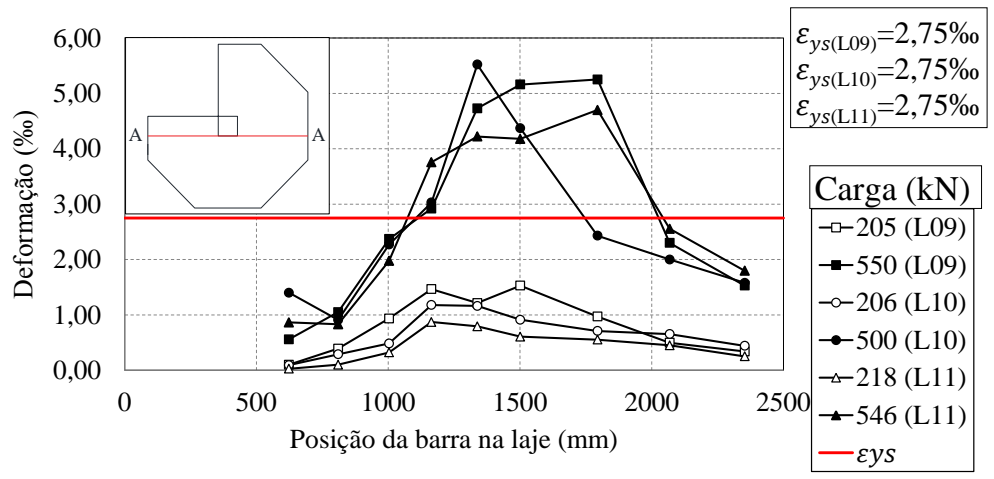

Figura 5.40 - Gráfico de deformações na armadura de flexão das lajes L09, L10 e L11.

Pode-se notar que quanto maior a área da armadura de cisalhamento maior a solicitação da armadura de flexão (L09), ultrapassando o limite de escoamento antes da ruptura; no entanto, a excentricidade também influencia na solicitação da armadura de flexão, aumentando tal solicitação à medida que diminui a transferência de momento (L11). As 
lajes L09, L10 e L11 apresentaram deformações máximas de 5,16 \%o, 5,52 \%o e 4,70 \%o respectivamente.

As deformações na superfície do concreto (Figura 5.41) mostram que o comportamento foi semelhante quando se trata de compressão, mesmo variando a excentricidade, com tendência à tração ao aproximar-se da ruptura.

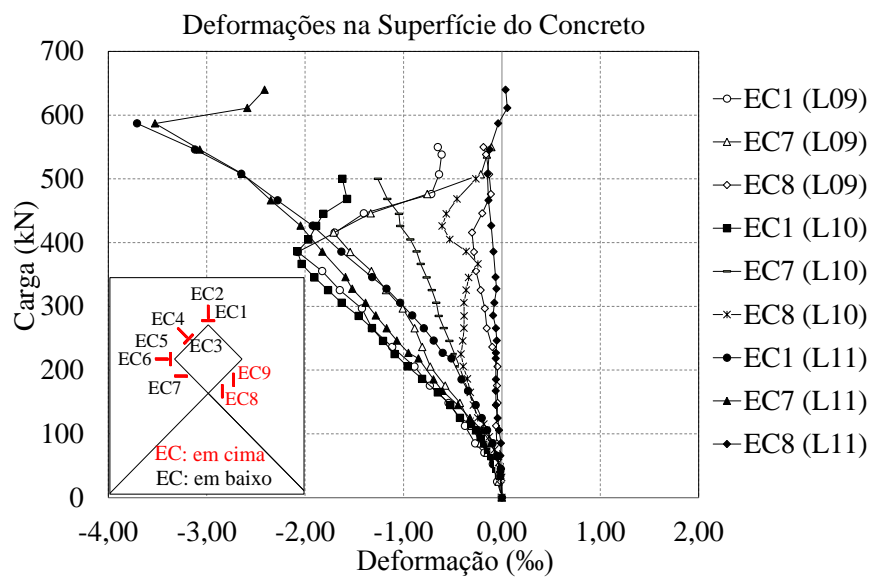

Figura 5.41 - Deformações na superfície do concreto das lajes L09, L10 e L11.

Quanto às cargas de ruptura pode-se dizer que a laje L11 apresentou maior carga de ruptura $(640 \mathrm{kN})$ e deslocou menos; enquanto que as lajes L09 e L10 apresentaram menores cargas de ruptura, $500 \mathrm{kN}$ e $550 \mathrm{kN}$ respectivamente.

\subsubsection{Análise do Grupo 3 - com estribos}

\subsubsection{Lajes L08 (345 kN) e L03 (575 kN)}

A Tabela 5.10 apresenta o resumo das características das lajes L08 e L03. 
Tabela 5.10 - Características das lajes L08 e L03.

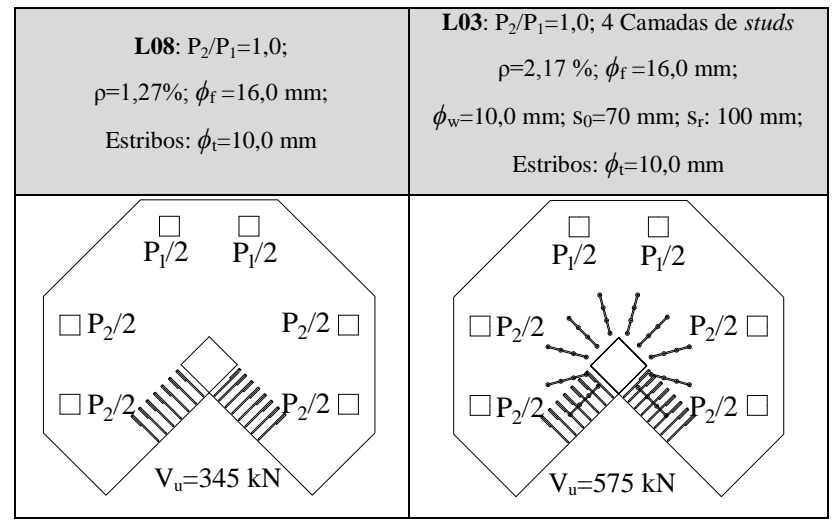

A laje L03 apesar de possuir armadura de torção teve uma menor carga de ruptura em relação a laje L03 que possuia armadura de cisalhamento e maior taxa de armadura de flexão.

A Figura 5.42 apresenta o gráfico de deslocamentos das lajes L08 e L03 em relação à posição dos LVDT's onde se pode observar o comportamento em dois casos: com o nível de carga em torno de 200 kN e o nível de carga próximo à ruptura. No primeiro caso a laje L08 apresentou maiores deslocamentos pois não possui armadura de cisalhamento como na laje em comparação. Já no segundo caso, a laje L03 apresentou maiores deslocamentos, ou seja, deslocou mais antes de romper (dúctil).
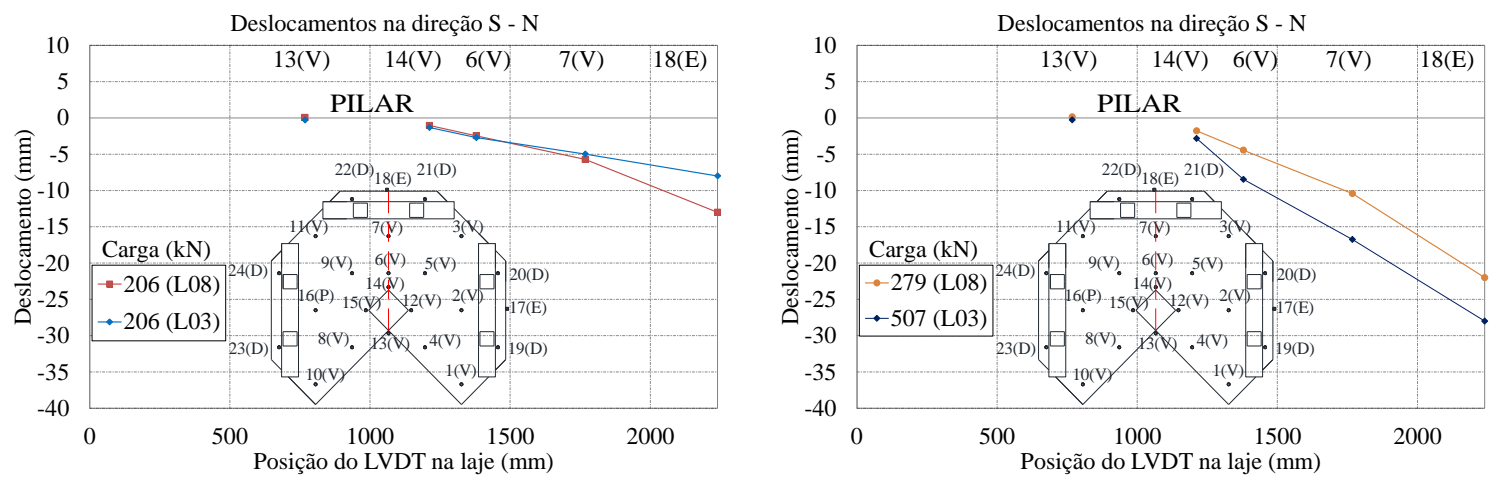

Figura 5.42 - Gráfico de deslocamentos verticais na direção S-N das lajes L08 e L03.

Na Figura 5.43 são apresentados os deslocamentos nos pontos 1, 4, 8 e 10 localizados próximo aos bordos reentrantes, e na Figura 5.44 os deslocamentos nos pontos 12, 13, 14 e 15 localizados próximo os cantos do pilar. 

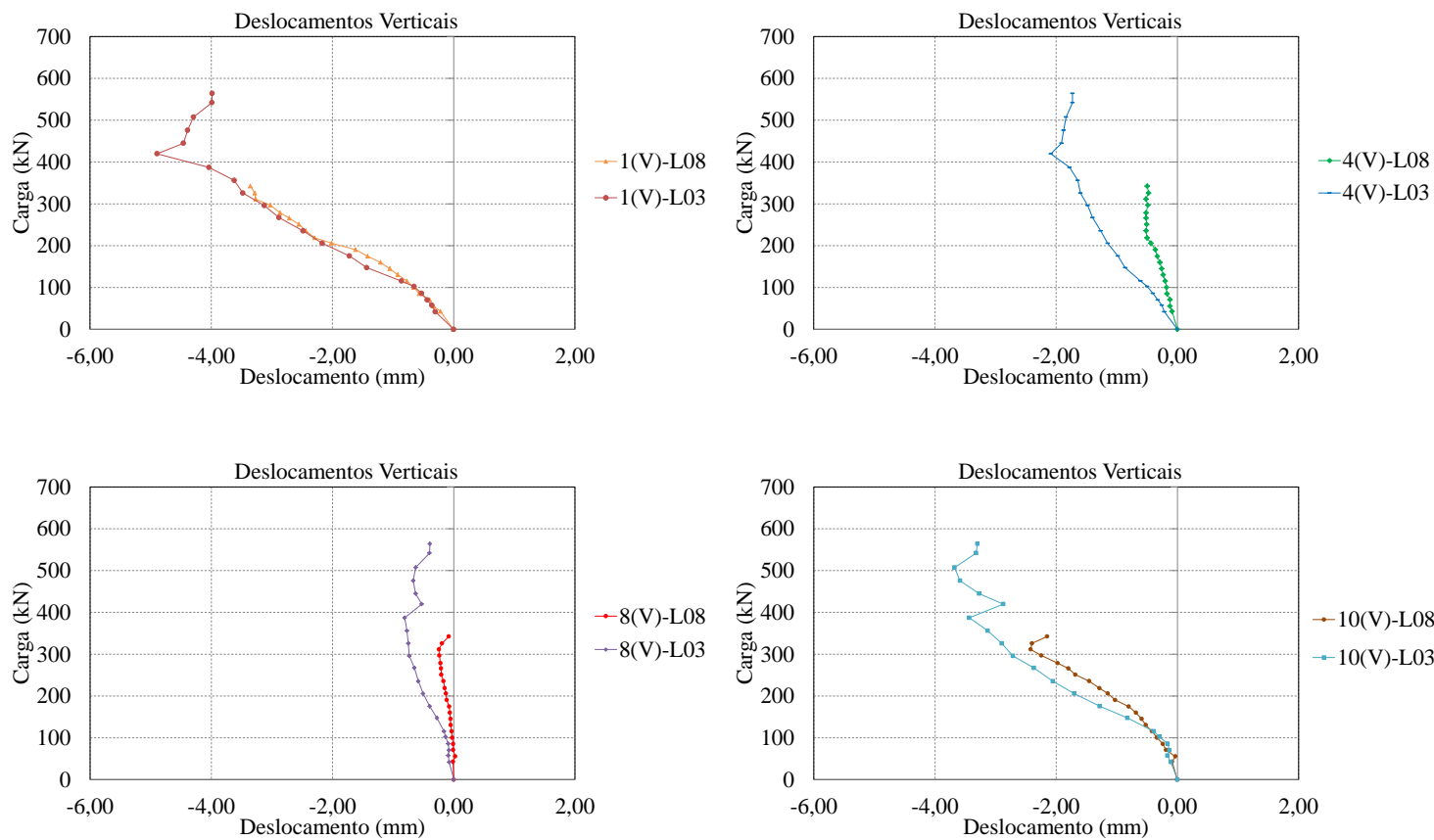

Figura 5.43 - Gráfico de delocamentos verticais x carga das lajes L08 e L03 nos pontos 1, 4,8 e 10.

Com esses gráficos pode-se observar o mesmo comportamento descendente, mas a presença da armadura de torção faz com que as bordas reentrantes da laje tendam a subir e a armadura de cisalhamento age minimizando essa tendência.
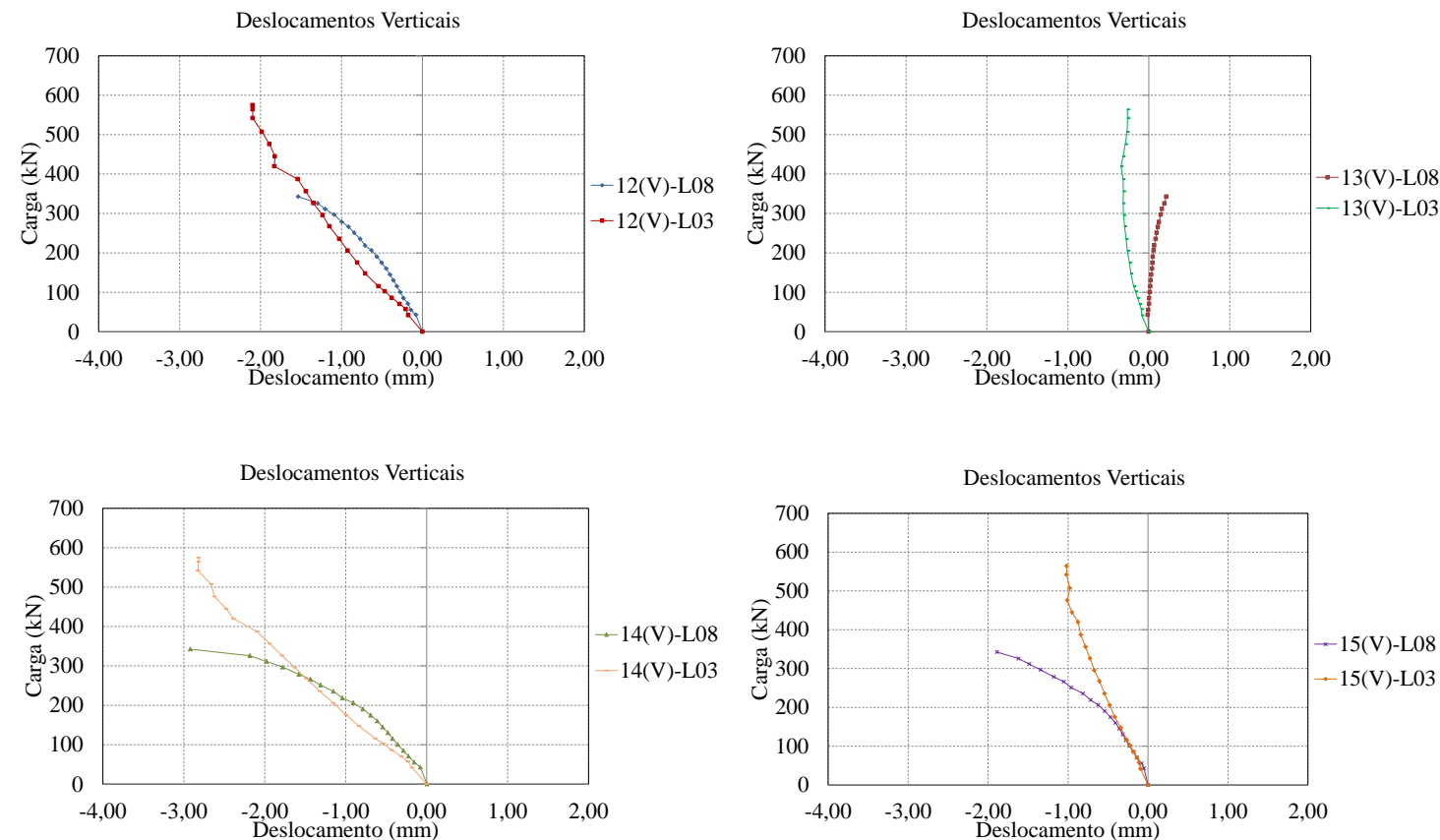

Figura 5.44 - Gráfico de delocamentos verticais x carga das lajes L08 e L03 nos pontos 12,

\section{3,14 e 15 .}


Os pontos monitorados próximo ao pilar mostram que as duas lajes analisadas tiveram comportamento diferente e no ponto 13 (localizada no canto do pilar na reentrância da laje) observa-se uma ascendência na laje L08 e uma descendência na laje L03. Na Figura 5.45 são apresentadas as deformações na armadura de flexão em função do posicionamento na laje.

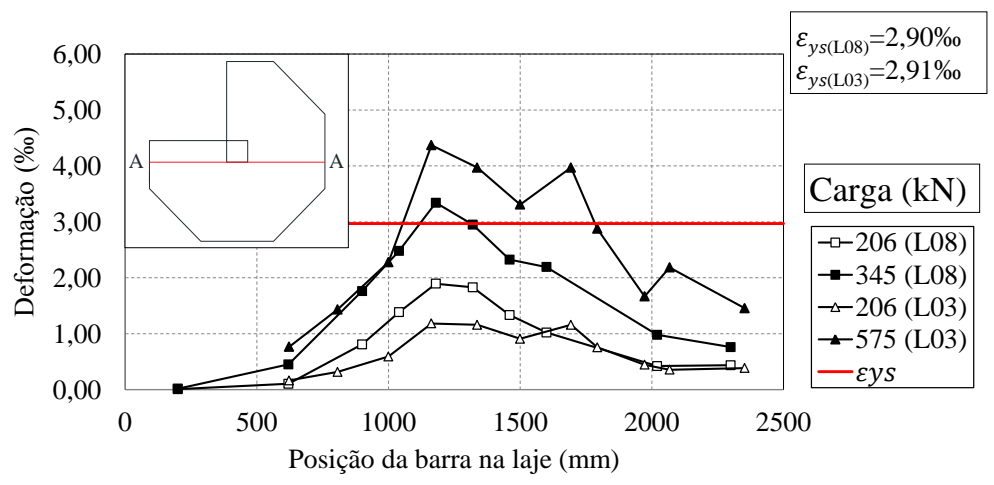

Figura 5.45 - Gráfico de deformações na armadura de flexão das lajes L08 e L03.

Com o gráfico anterior pode-se notar que o momento não é contínuo na linha A-A (Figura 4.167) e os momentos na parte esquerda da linha são menores que os momentos localizados na parte direita por se localizarem próximo a reentrância. A armadura de flexão da laje L03 trabalha mais que a L08 pela presença da armadura de cisalhamento.

Pode-se notar que em ambas as lajes houve barras que atingiram a deformação de escoamento com valores máximos entre 3,34 \%o e 4,37 \%o nas lajes L08 e L03 respectivamente. As lajes L08 e L03 não foram comparadas aqui pela diferença de pontos monitorados, mas foram comparadas com outras lajes em outros grupos.

Em relação às deformações na superfície do concreto, os pontos monitorados foram diferentes e não será possível uma comparação entre as lajes L03 e L08.

Quanto às cargas de ruptura, pode-se dizer que a laje L03 apresentou maior carga de ruptura $(575 \mathrm{kN})$ e deslocou mais enquanto que a L08 apresentou menor carga de ruptura (345 kN) com deslocamentos menores pela ausência da armadura de cisalhamento. 


\subsubsection{Análise do Grupo 4 - sem e com studs}

\subsubsection{Lajes L02 (513 kN), L09 (550 kN), L04 (372 kN) e L03 (575 kN)}

A Tabela 5.11 apresenta o resumo das características das lajes L02, L09, L04 e L03.

Tabela 5.11 - Características das lajes L02, L09, L04 e L03.

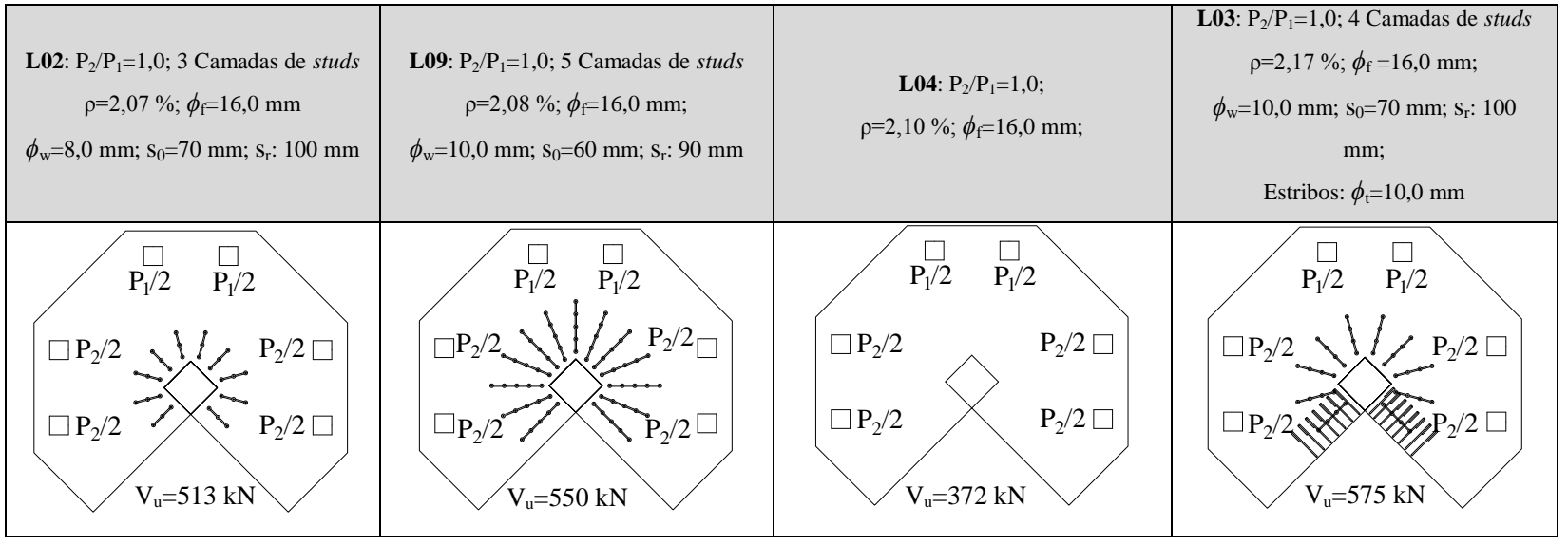

Diante das lajes analisadas pode-se observar que quanto maior a área de armadura de cisalhamento maior a carga de ruptura da laje.

Pode-se observar com a Figura 5.46 que a laje com maiores deslocamentos foi a L09 no ponto 18 com deslocamento em torno de $39 \mathrm{~mm}$. Para um mesmo nível de carga a laje L09 apresentou 17,0 $\mathrm{mm}$ de deslocamentos enquanto que as demais apresentaram o mesmo deslocamento de $8,0 \mathrm{~mm}$, isso pode ser atribuído à maior quantidade de armadura de cisalhamento na laje L09, além da taxa de armadura de flexão menor comparada as lajes L03 e L04.
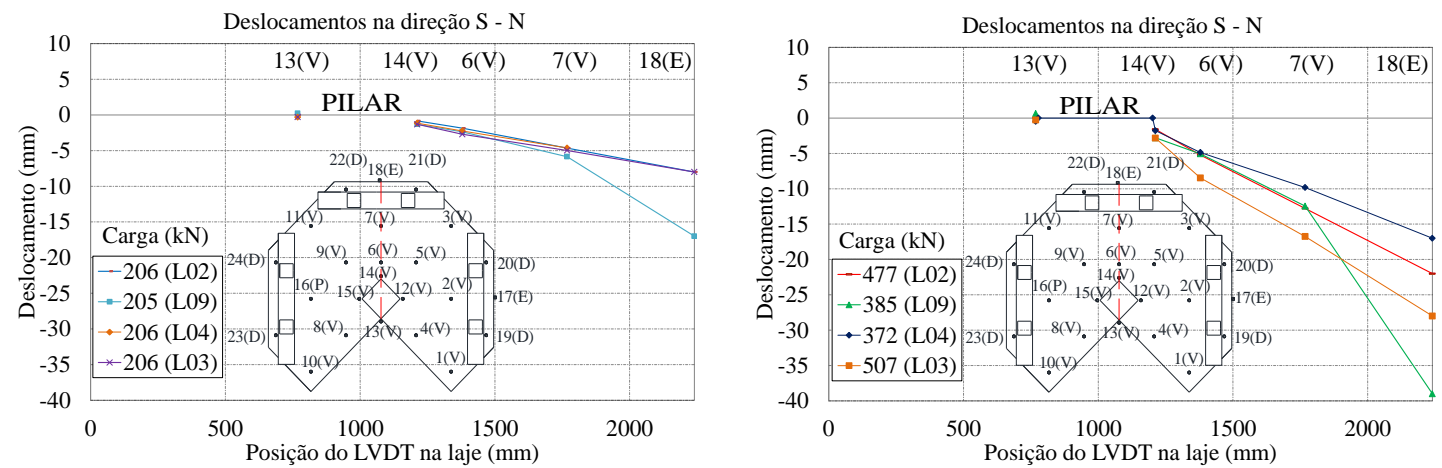

Figura 5.46 - Gráfico de deslocamentos verticais na direção S-N das lajes L02, L09, L04 e L03. 
Nos pontos 1, 4, 8 e 10, localizados nos bordos reentrantes da laje, pode-se notar com a Figura 5.47 que as quatro lajes analisadas tiveram o mesmo comportamento tendendo a deslocar para cima, mas apenas a laje L09 apresentou valores de deslocamentos positivos nos pontos 4 e 8 pela alta área de armadura de cisalhamento.
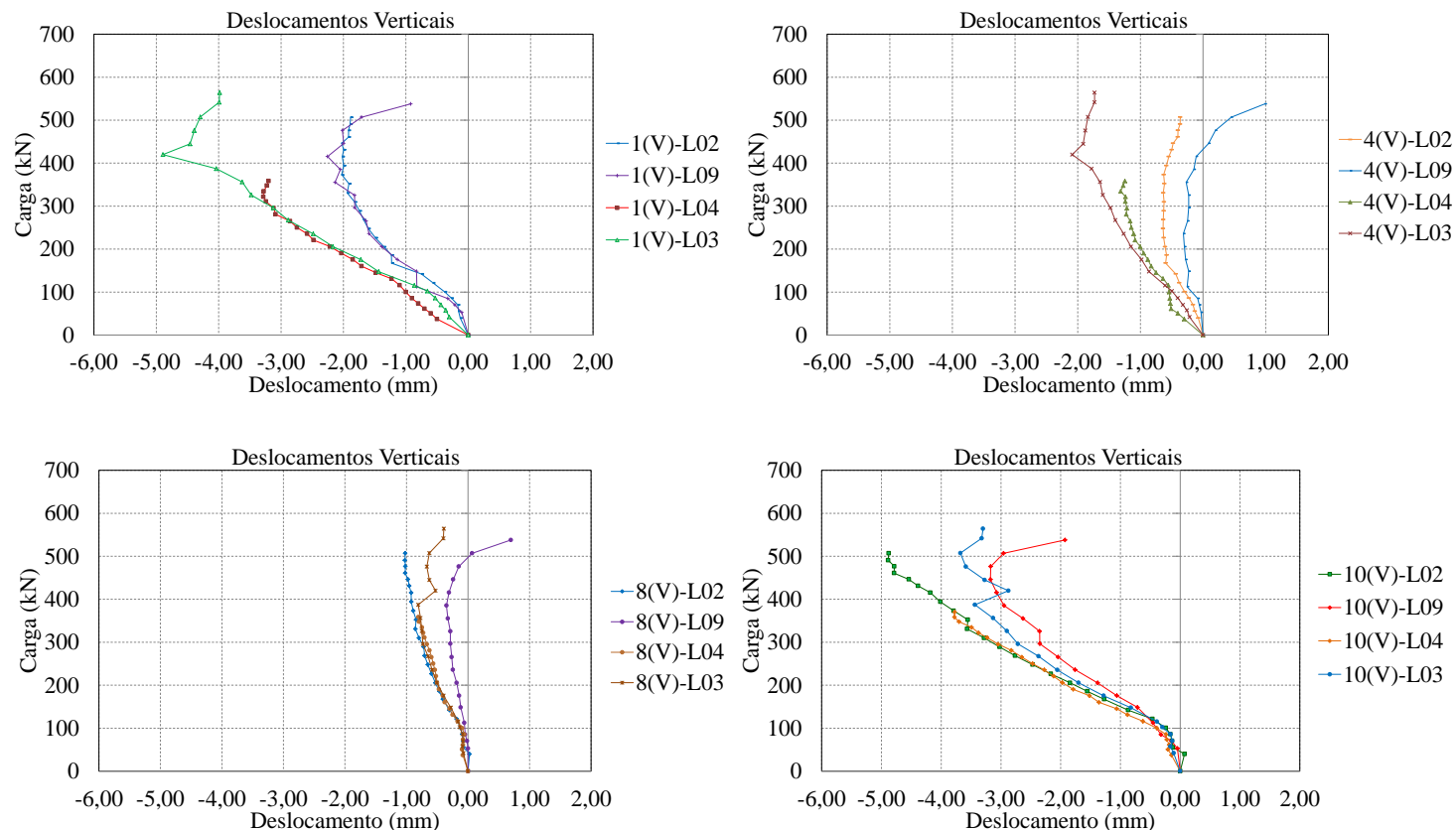

Figura 5.47 - Gráfico de delocamentos verticais x carga das lajes L02, L09, L04 e L03 nos pontos $1,4,8$ e 10 .

Nos pontos 12, 13, 14 e 15, localizados nos cantos do pilar, mostram deslocamentos descentes em sua maioria com exceção da laje L09 que apresentou deslocamento ascendente no extensômetro 13 na ordem de $1,5 \mathrm{~mm}$ aproximadamente e grandes deslocamentos descendentes no ponto 14 por possuir grande área de armadura de cisalhamento, ou seja, à medida que aumenta a área da armadura de cisalhamento maior a tendência do ponto 13 de subir e 14 de descer, pontos estes situados no canto do pilar na parte reentrante e no canto interno respectivamente (Figura 5.48). 

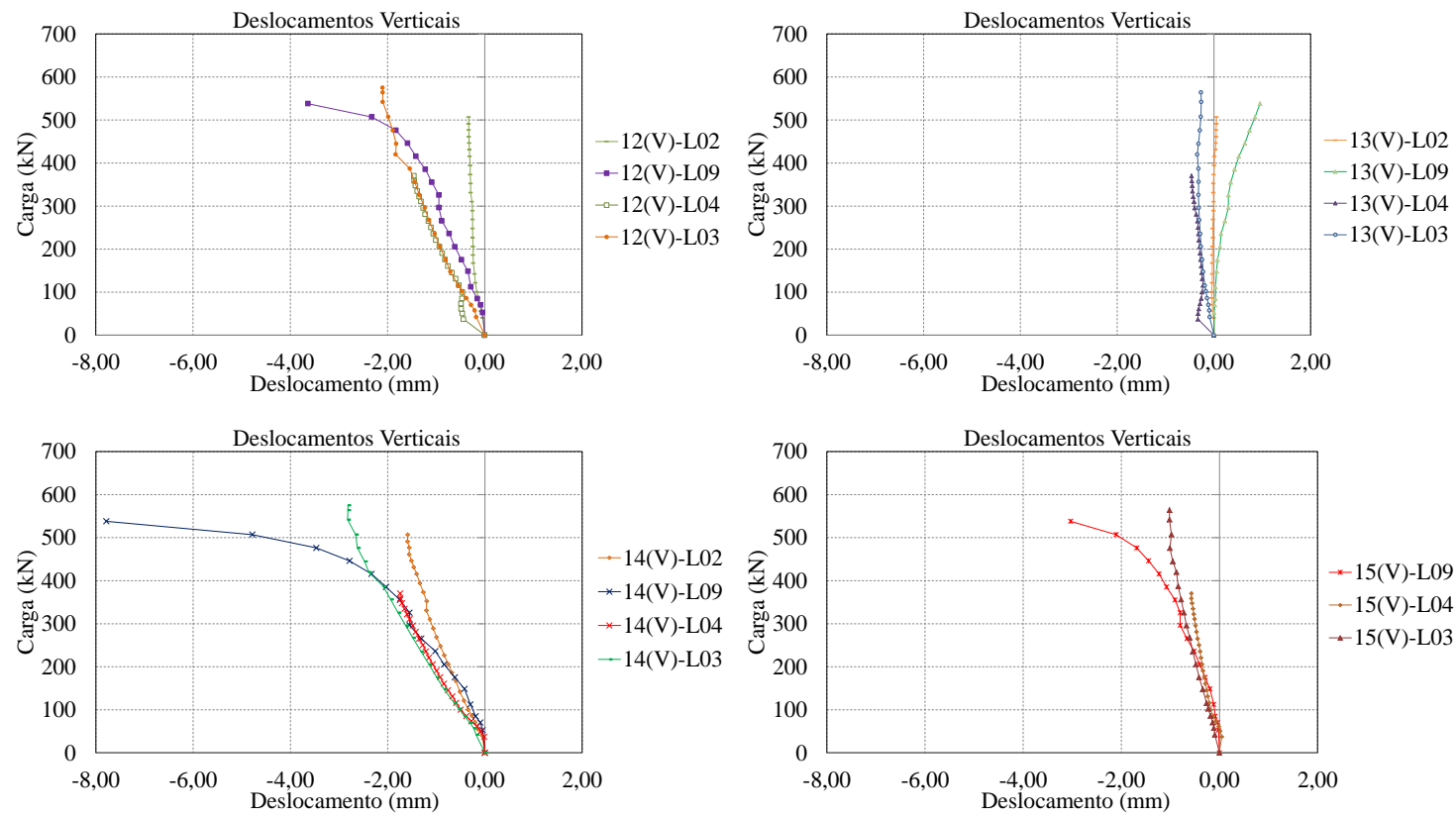

Figura 5.48 - Gráfico de delocamentos verticais x carga das lajes L02, L09, L04 e L03 nos pontos $12,13,14$ e 15 .

Com a Figura 5.49 pode-se notar que nas lajes L02, L09 e L03 escoaram 2, 4 e 4 barras respectivamente. Na laje L02 escoaram as barras 12 e 14 na carga ruptura; na laje L09 escoaram as barras 7, 8, 9 e 10 com uma carga correspondendo $70 \%, 75 \%, 80 \%$, e $90 \%$ da carga de ruptura respectivamente; e na laje L09 escoaram as barras 12, 13, 14 e 15 com uma carga correspondendo $90 \%, 75 \%, 95 \%$, e $75 \%$ da carga de ruptura respectivamente. Já na laje de referência L04, sem armadura de cisalhamento, não escoou nenhuma barra, ou seja, quanto maior a área de armadura de cisalhamento e taxa de armadura de flexão maior foram as deformações antes da ruptura da laje e mais solicitadas será essa armadura.

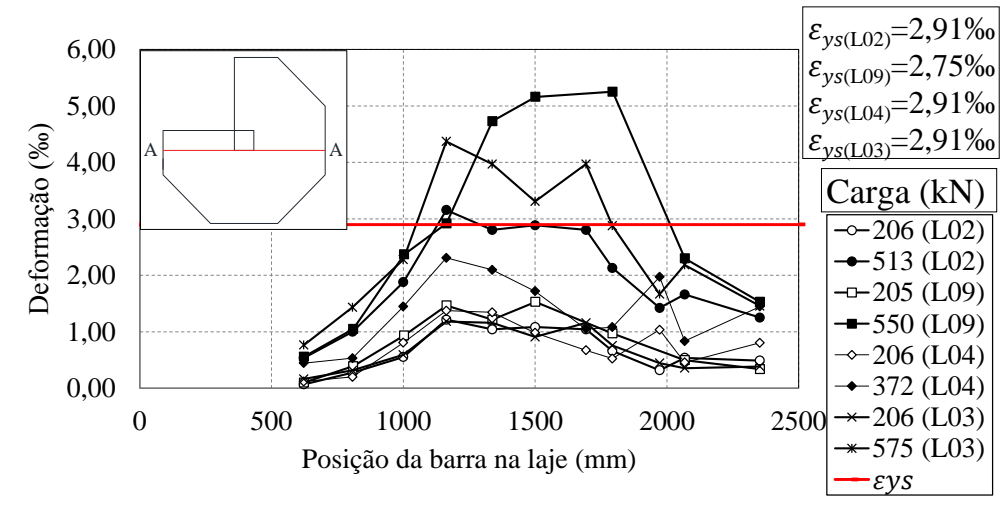

Figura 5.49 - Gráfico de deformações na armadura de flexão das lajes L02, L09, L04 e L03. 
As deformações na superfície do concreto (Figura 5.50) atingiram tensões de compressão de no máximo 2,62 \%. A laje L09 não será comparada aqui por ter pontos monitorados diferentes. As lajes em análise apresentaram comportamento semelhante com deformações de encurtamento com intensidades de no máximo 0,22 \%; a L02 comparada com a L03 deformou menos próxima a ruptura por ter menor área de armadura de cisalhamento.

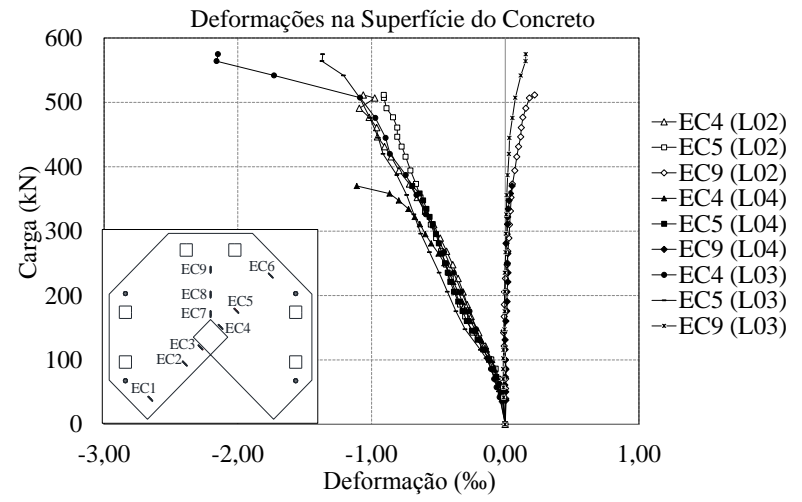

Figura 5.50 - Deformações na superfície do concreto das lajes L02, L04 e L03.

Quanto às cargas de ruptura, pode-se dizer que a laje L04 apresentou menor carga de ruptura $(372 \mathrm{kN})$ e apresentou menores deslocamentos que as demais que possuíam studs. As lajes L02 e L03 apresentaram uma carga de ruptura $38 \%$ e $55 \%$ a mais que a laje L04. Já a laje L09 suportou uma carga de ruptura $48 \%$ a mais que a laje L04, embora tivesse uma área de armadura de cisalhamento maior por perímetro que as demais. Isso ocorreu porque a armadura de cisalhamento não foi efetiva em todo o perímetro.

\subsubsection{Lajes L05 (250 kN), L01 (325 kN) e L10 (500 kN)}

A Tabela 5.12 apresenta o resumo das características das lajes L05, L01 e L10.

Tabela 5.12 - Características das lajes L05, L01 e L10.

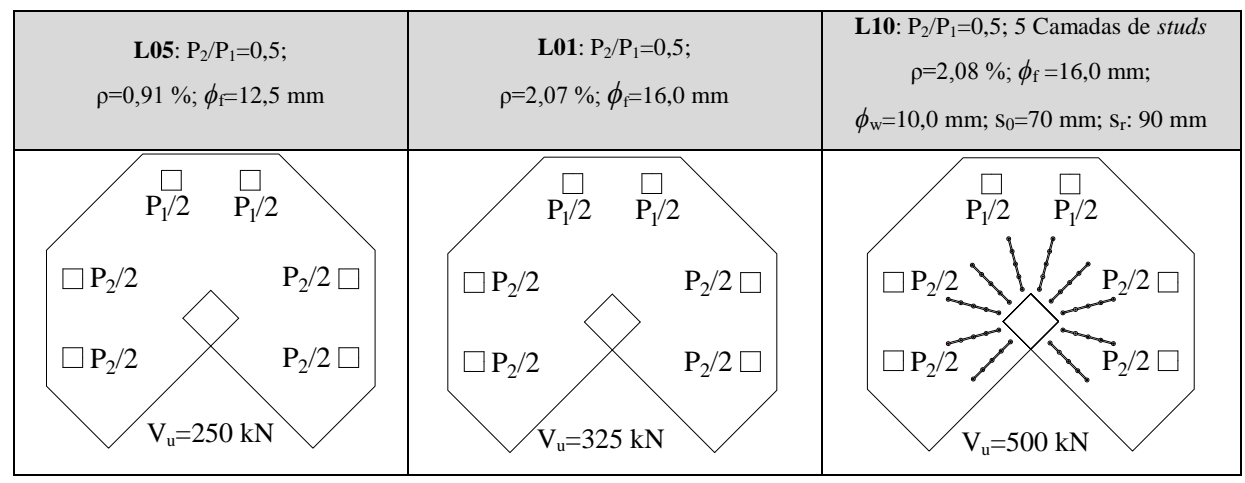


A Figura 5.51 mostra o gráfico da taxa de armadura de flexão em relação à carga de ruptura das lajes L01 e L04 em que pode-se notar que quanto maior a taxa de armadura de flexão maior a carga de ruptura e quanto maior a área de armadura de cisalhamento essa carga de ruptura aumenta mais ainda.

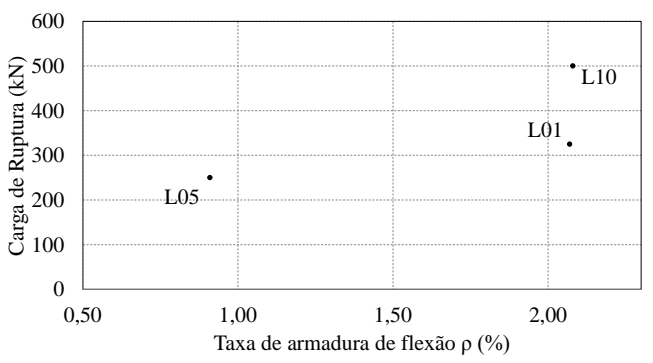

Figura 5.51 - Gráfico de carga de ruptura x taxa de armadura de flexão média das lajes

$$
\text { L05, L01 e L10. }
$$

A Figura 5.52 apresenta o gráfico de deslocamentos das lajes L05, L01 e L10 em relaçao a posição dos LVDT's onde se pode observar o comportamento apenas em um caso, com a carga de $200 \mathrm{kN}$ aproxiamdamente, já que a laje L05 só tem leituras medidas de deslocamentos com carga de no máximo 202 kN. Nota-se uma grande diferença, em que a laje L05 deslocou mais que as demais, fato esse que se deve pela baixa taxa de armadura de flexão.

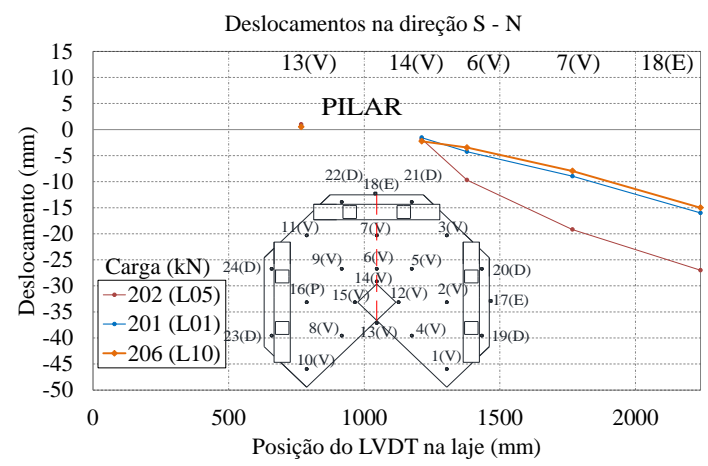

Figura 5.52 - Gráfico de deslocamentos verticais na direção S-N das lajes L05, L01 e L10.

Na Figura 5.53 são apresentados os deslocamentos nos pontos 1, 4, 8 e 10 localizados próximo aos bordos reentrantes, e na Figura 5.54 os deslocamentos nos pontos 12, 13, 14 e 15 localizados próximo os cantos do pilar. 

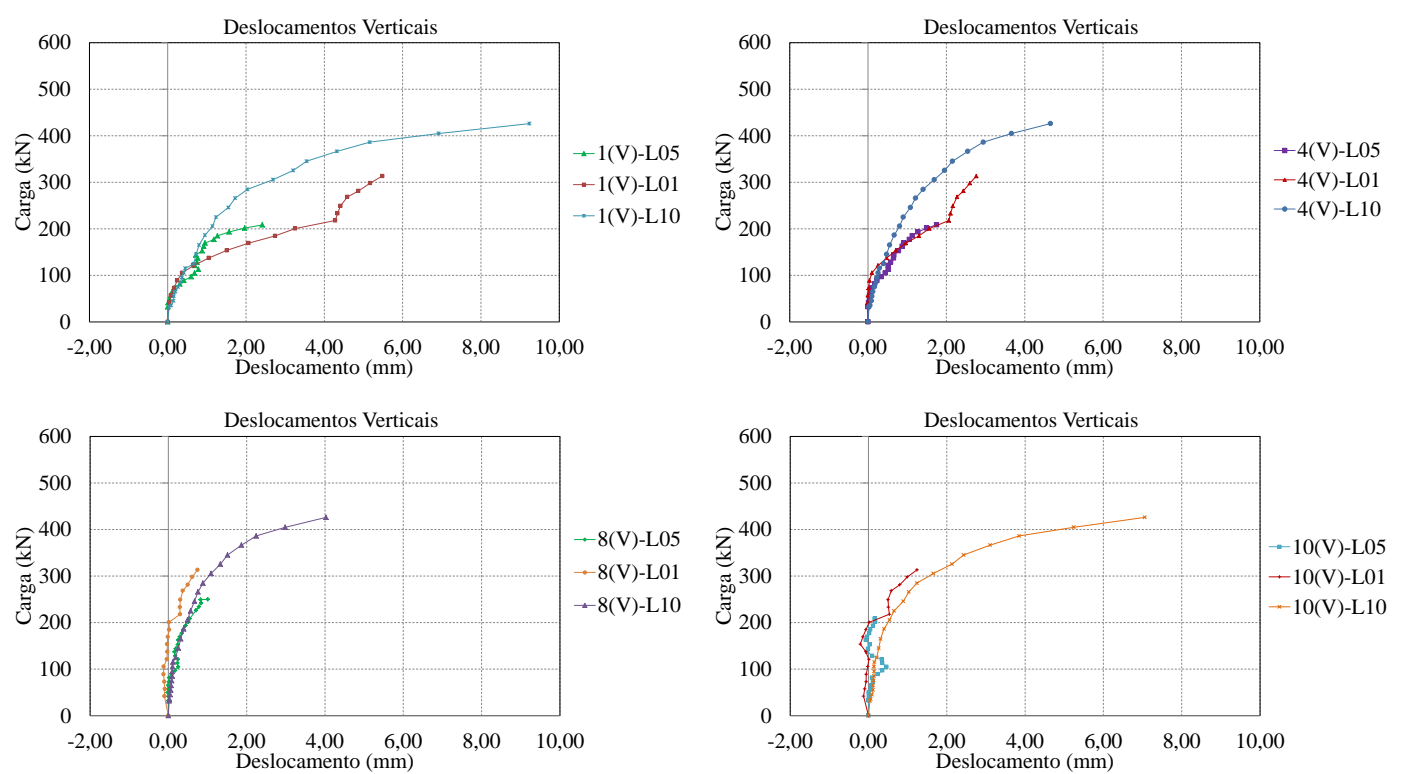

Figura 5.53 - Gráfico de delocamentos verticais x carga das lajes L05, L01 e L10 nos pontos $1,4,8$ e 10 .

Com esses gráficos pode-se observar o mesmo comportamentos devido a semelhança de momento, na laje L10 os deslocamentos foram bem maiores pelo fato da mesma apresentar armadura de cisalhamento e as outras não.
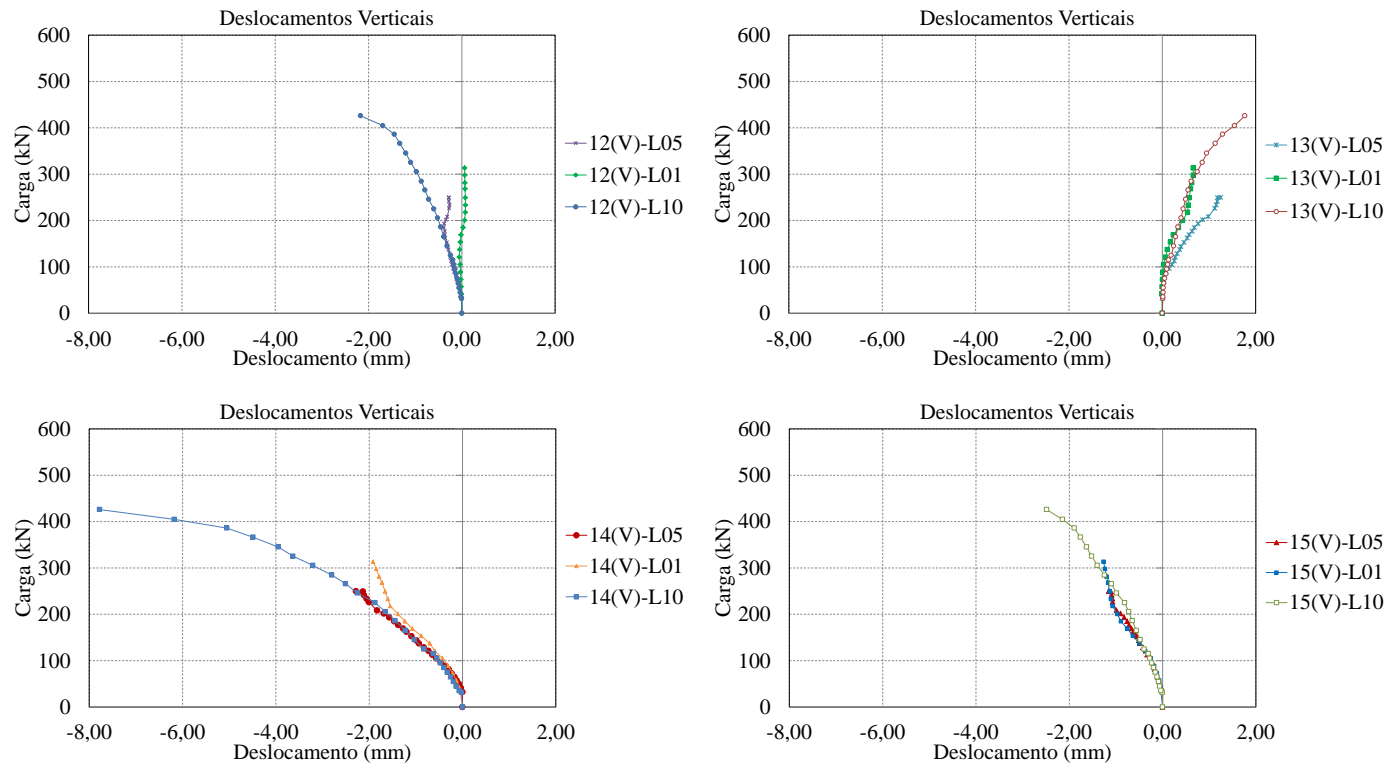

Figura 5.54 - Gráfico de delocamentos verticais x carga das lajes L05, L01 e L10 nos pontos $12,13,14$ e 15 .

Os pontos monitorados próximo ao pilar mostram que as lajes analisadas tiveram o mesmo comportamento e no ponto 13 (localizada no canto do pilar na reentrância da laje) observase uma ascendência de todas as lajes pela alta tranferência de momento. 
Na Figura 5.55 são apresentadas as deformações na armadura de flexão em função do posicionamento na laje.

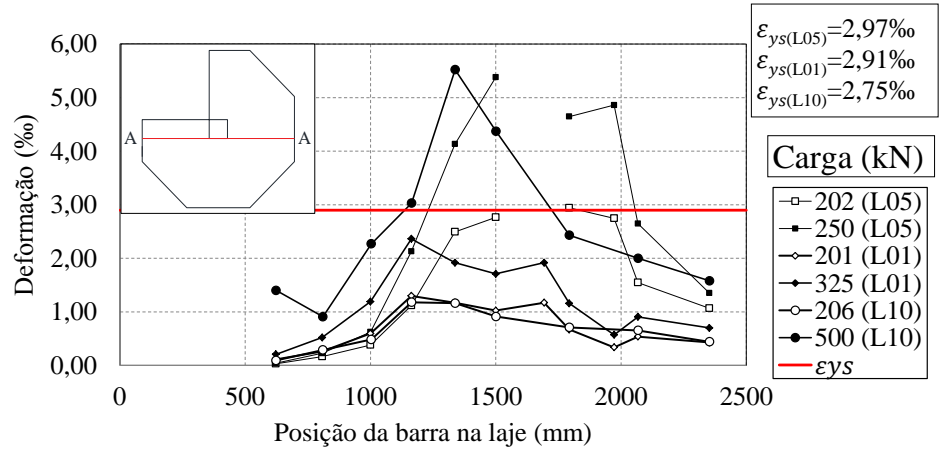

Figura 5.55 - Gráfico de deformações na armadura de flexão das lajes L05, L01 e L10.

A armadura de flexão na laje L05 é muito solicitada próxima à ruptura por ter uma baixa taxa de armadura e na L10 a armadura de flexão trabalha mais com maiores deformações pela presença da armadura de cisalhamento.

Pode-se notar que apenas na laje L01 nenhuma barra escoou. Já as lajes L05 e L10 apresentaram deformações de no máximo 5,38 \% e 5,52 \%o respectivamente, a L05 pelo fato de ter uma baixa taxa de armadura de flexão comparada com a L01 e a L10 pelo fato de ter armadura de cisalhamento.

Na Figura 5.56 são comparadas as deformações na superfície do concreto das lajes L05 e L10, a laje L01 não será comparada aqui por ter pontos monitorados diferentes. É evidente que a presença da armadura de cisalhamento na L10 faz com que seu comportamento mude, tendendo a tracionar (descompressão), ao atingir cerca de $80 \%$ da carga de ruptura.

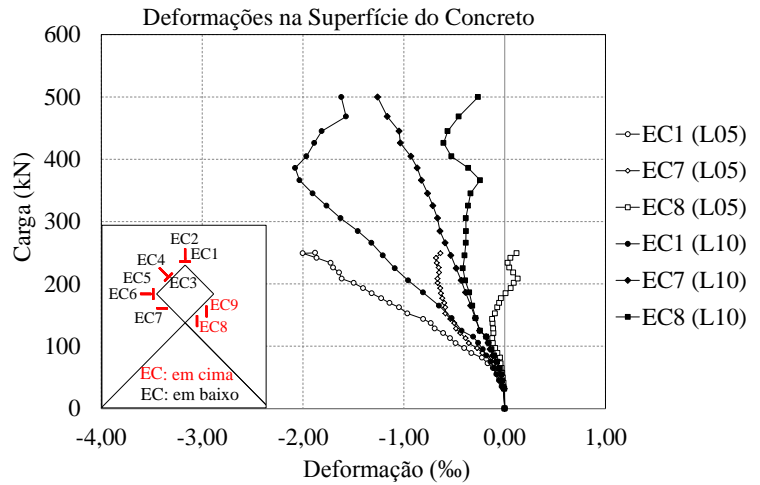

Figura 5.56 - Deformações na superfície do concreto das lajes L05, L01 e L10. 
Quanto às cargas de ruptura, pode-se dizer que a laje L10 apresentou maior carga de ruptura $54 \%$ a mais que a laje L01 e deslocou muito mais. A laje L05 apresentou carga de ruptura $250 \mathrm{kN}$ com deslocamentos menores por não possuir armadura de cisalhamento.

\subsubsection{Lajes L12 (345 kN) e L11 (640 kN)}

A Tabela 5.13 apresenta o resumo das características das lajes L12 e L11.

Tabela 5.13 - Características das lajes L12 e L11.

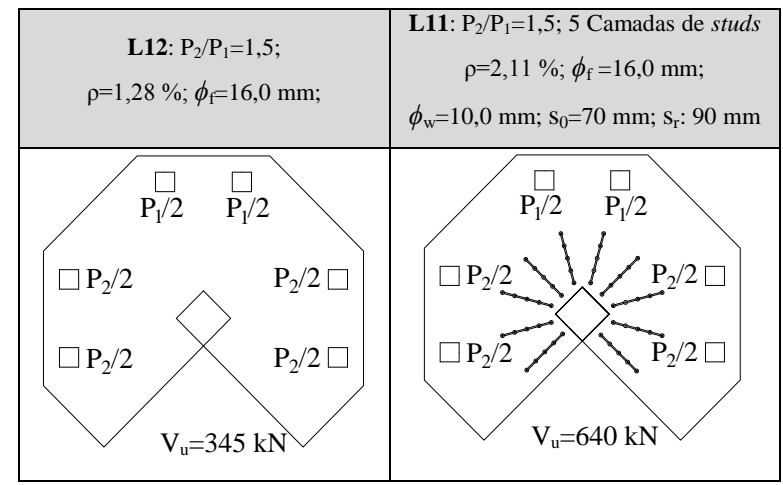

A Figura 5.57 mostra o gráfico da taxa de armadura de flexão em relação à carga de ruptura das lajes L12 e L11 mostrando que quanto maior a taxa de armadura de flexão maior a carga de ruptura da laje e a presença de armadura de cisalhamento faz com que a carga de ruptura da laje L11 aumente mais ainda.

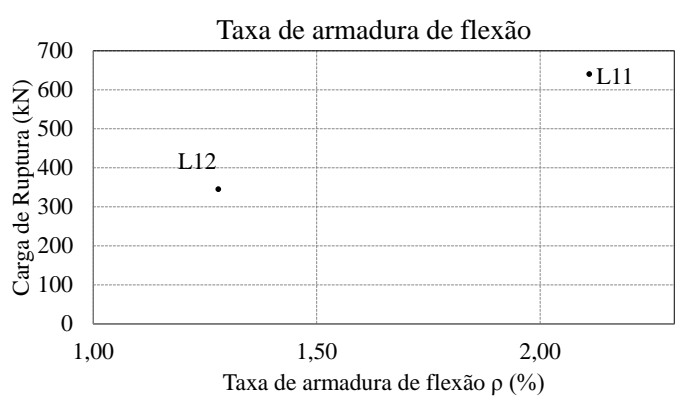

Figura 5.57 - Gráfico de carga de ruptura x taxa de armadura de flexão média das lajes

$$
\text { L12 e L11. }
$$

A Figura 5.58 apresenta o gráfico de deslocamentos das lajes L12 e L11 em relação a posição dos LVDT's onde se pode observar que no primeiro caso, com a carga de $200 \mathrm{kN}$ aproxiamdamente, os deslocamentos são semelhantes nas duas lajes. Já no segundo caso, para cargas próximo a ruptura, a laje L11 deslocou-se muito mais que a L12 por apresentar armadura de cisalhamento e maior taxa de armadura de flexão, tornando-a mais dúctil. 

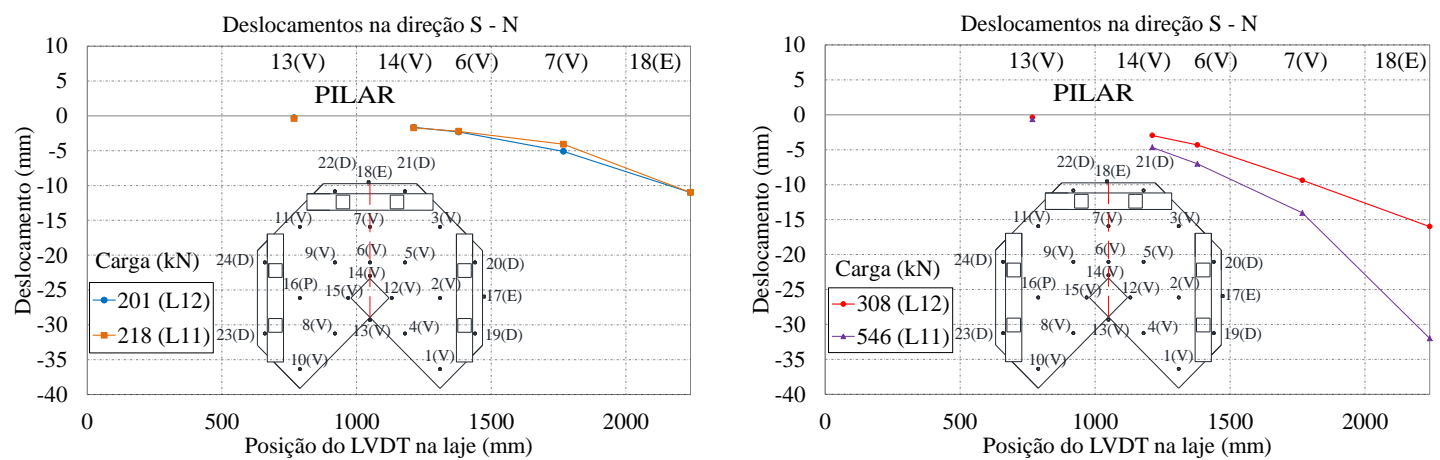

Figura 5.58 - Gráfico de deslocamentos verticais na direção S-N das lajes L12, e L11.

Na Figura 5.59 são apresentados os deslocamentos nos pontos 1, 4, 8 e 10 localizados próximo aos bordos reentrantes, e na Figura 5.43 os deslocamentos nos pontos 12, 13, 14 e 15 localizados próximo os cantos do pilar.
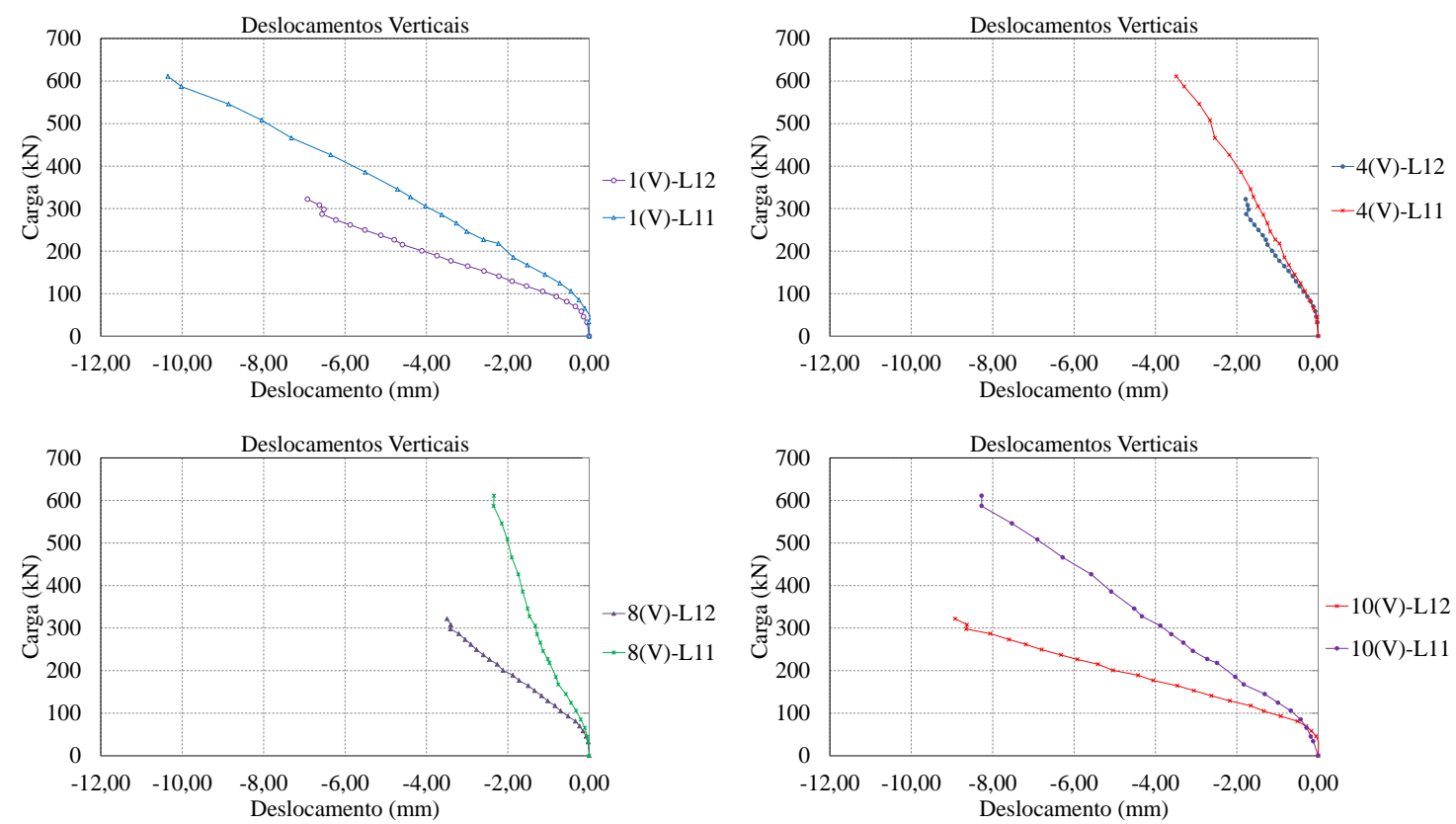

Figura 5.59 - Gráfico de delocamentos verticais x carga das lajes L12 e L11 nos pontos 1, 4,8 e 10.

Com esses gráficos pode-se observar o mesmo comportamentos devido a semelhança de momento, na laje L11 os deslocamentos foram bem maiores. 

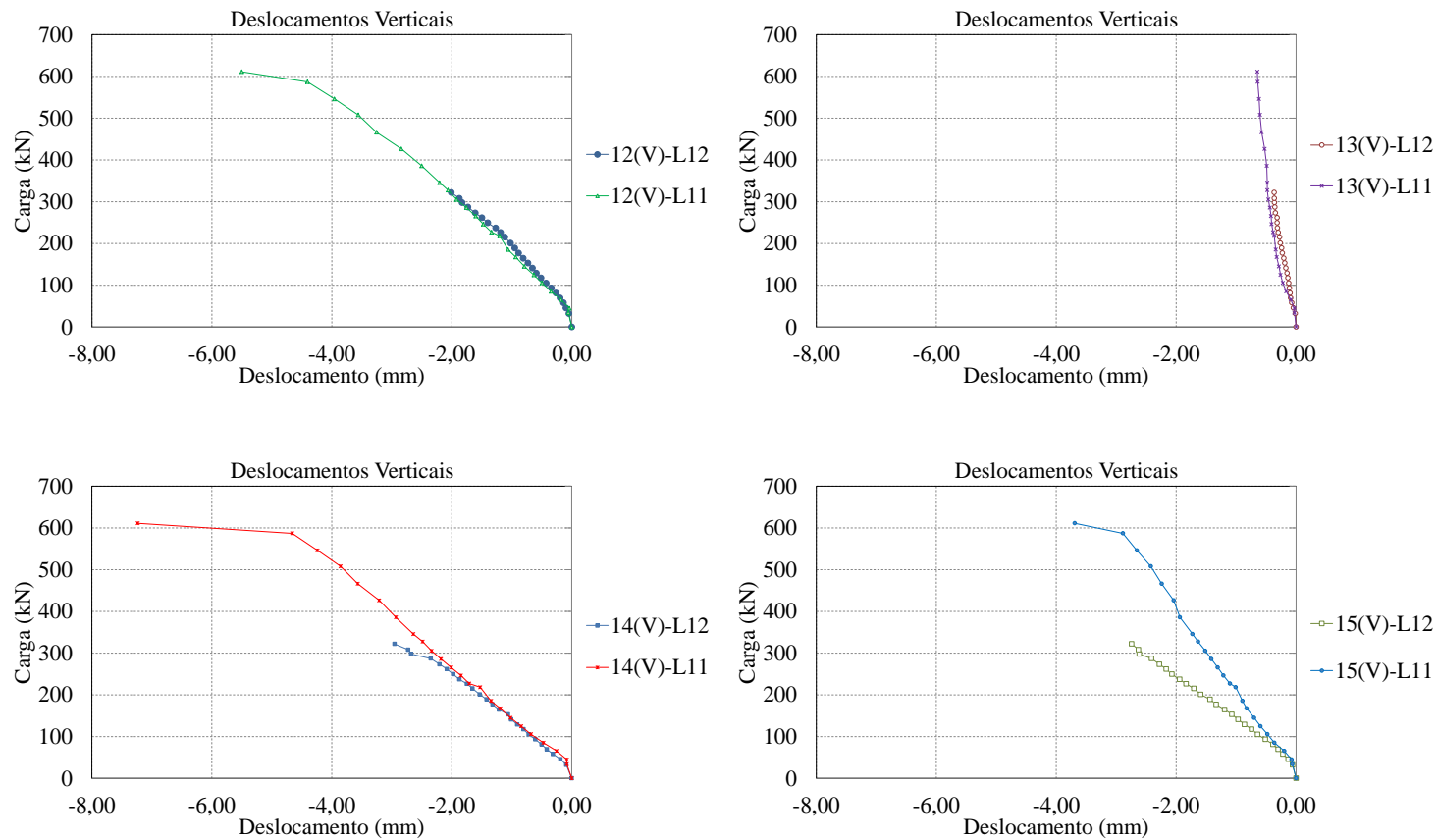

Figura 5.60 - Gráfico de delocamentos verticais x carga das lajes L12 e L11 nos pontos 12, 13,14 e 15.

Os pontos monitorados próximo ao pilar mostram que as lajes analisadas tiveram o mesmo comportamento e mesmo deslocamento para mesmo níveis de carga com excessão dos deslocamentos no ponto 15 , que a partir da carga $100 \mathrm{kN}$ os dislocamentos começaram a divergir no máximo em $1,0 \mathrm{~mm}$.

Na Figura 5.44 são apresentadas as deformações na armadura de flexão em função do posicionamento na laje.

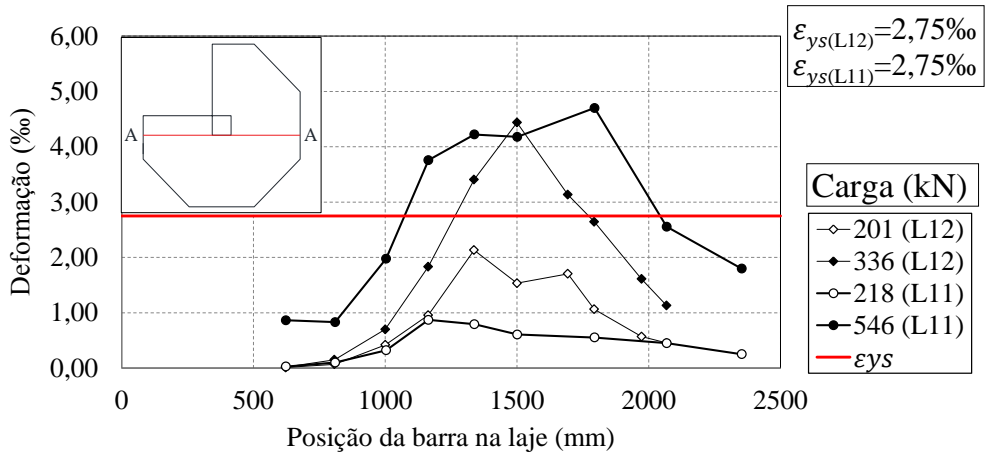

Figura 5.61 - Gráfico de deformações na armadura de flexão das lajes L12 e L11.

Com o gráfico anterior pode-se notar que o momento não é contínuo na linha A-A (Figura 4.167) e os momentos na parte esquerda da linha são menores que os momentos 
localizados na parte direita por se localizarem próximo a reentrância. A armadura de flexão na laje L11 deforma mais próxima à ruptura por ter armadura de cisalhamento.

Comparando as deformações na superfície no concreto (Figura 5.62), observa-se um comportamento semelhante com intensidades maiores na laje L11 por possuir armadura de cisalhamento o que a tornou mais dúctil. Sendo assim, as deformações maiores ocorreram no canto do pilar oposto à reentrância no sentido tangencial.

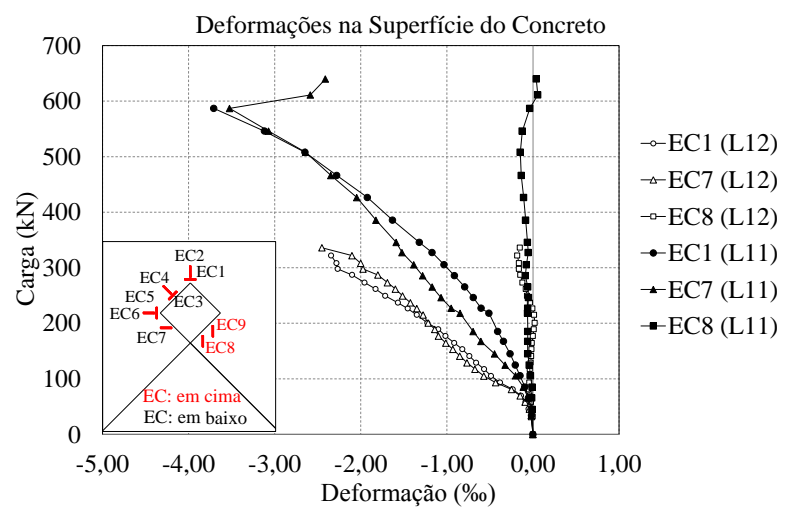

Figura 5.62 - Deformações na superfície do concreto das lajes L12 e L11.

Quanto às cargas de ruptura, pode-se dizer que a laje L11 apresentou uma carga de ruptura $86 \%$ a mais que a laje L12 pela presença da armadura de cisalhemento e excentricidade menor dentre as utilizadas nessa pesquisa.

\subsection{CARGAS E MODO DE RUPTURA}

A Tabela 5.14 apresenta algumas das principais características das lajes em questão junto com o momento último $\mathrm{M}_{\mathrm{u}}$ e superfície de ruptura, ou seja, se rompeu dentro ou fora da armadura de cisalhamento. 
Tabela 5.14 - Carga de ruptura das lajes.

\begin{tabular}{|c|c|c|c|c|c|c|c|c|c|}
\hline LAJES & $\mathrm{P}_{2} / \mathrm{P}_{1}$ & $\begin{array}{c}\mathrm{e} \\
(\mathrm{mm})\end{array}$ & $\begin{array}{l}\text { Atuador1 } \\
(\mathrm{kN})\end{array}$ & $\begin{array}{c}\text { Atuador2 } \\
(\mathrm{kN})\end{array}$ & $\begin{array}{l}\text { Atuador3 } \\
(\mathrm{kN})\end{array}$ & $\begin{array}{c}P_{u} \\
(\mathrm{kN})\end{array}$ & $\begin{array}{c}V_{u} \\
(\mathrm{kN})\end{array}$ & $\begin{array}{c}M_{u} \\
\text { (kN.m) }\end{array}$ & $\begin{array}{c}\text { Superfície de } \\
\text { Ruptura }\end{array}$ \\
\hline L01 & 0,5 & 500 & 148,0 & 76,0 & 76,0 & 300 & 325 & 162 & - \\
\hline L02 & 1,0 & 352 & 164,0 & 162,0 & 162,0 & 488 & 513 & 181 & Fora \\
\hline L03 & 1,0 & 349 & 183,0 & 183,5 & 183,5 & 550 & 575 & 200 & Fora \\
\hline L04 & 1,0 & 349 & 115,6 & 115,7 & 115,7 & 347 & 372 & 130 & - \\
\hline L05 & 0,5 & 504 & 112,0 & 57,0 & 56,0 & 225 & 250 & 126 & - \\
\hline L06 & 1,0 & 343 & 84,0 & 84,0 & 89,0 & 257 & 282 & 97 & - \\
\hline L07 & 1,0 & 349 & 111,0 & 110,5 & 111,5 & 333 & 358 & 125 & - \\
\hline L08 & 1,0 & 347 & 106,0 & 107,0 & 107,0 & 320 & 345 & 120 & - \\
\hline L09 & 1,0 & 349 & 175,0 & 175,0 & 175,0 & 525 & 550 & 192 & Fora \\
\hline L10 & 0,5 & 498 & 225,0 & 125,0 & 125,0 & 475 & 500 & 245 & Dentro \\
\hline L11 & 1,5 & 267 & 155,0 & 230,0 & 230,0 & 615 & 640 & 171 & Fora \\
\hline L12 & 1,5 & 268 & 80,0 & 120,0 & 120,0 & 320 & 345 & 92 & - \\
\hline
\end{tabular}

Para a carga de ruptura $\mathrm{P}_{\mathrm{u}}$ foi considerado apenas a soma das cargas aplicadas pelos cilindros hidráulicos (Figura 5.63); $\mathrm{V}_{\mathrm{u}}$ considera além das cargas aplicadas o peso próprio da laje e dos equipamentos sobre sua superfície. A excentricidade é considerada no instante da ruptura. $\mathrm{O}$ momento último $\mathrm{M}_{\mathrm{u}}$ foi determinado a partir da soma algébrica dos momentos provocados pelas cargas aplicadas como mostra a equação a seguir:

$$
M_{u}=\left(P_{1}\right) \cdot z_{1}+\left(\frac{P_{\text {laje }}}{3}+P_{e q}\right) \cdot z_{2}
$$

onde:

$P_{1}$ : carga aplicada no cilindro na posição indicada na Figura 5.63;

$P_{e q}:$ peso próprio do equipamento sobre a laje;

$P_{\text {laje }}:$ peso próprio da laje;

$z_{1}$ : braço de alavanca entre o ponto de aplicação da carga e o eixo transversal que passa pelo centro do pilar; Para esta pesquisa $z_{1}$ é $1050 \mathrm{~mm}$;

$z_{2}$ : braço de alavanca entre o centro de gravidade da área e o eixo transversal que passa pelo centro do pilar; Para as lajes desta pesquisa $z_{2}$ é $772 \mathrm{~mm}$. 


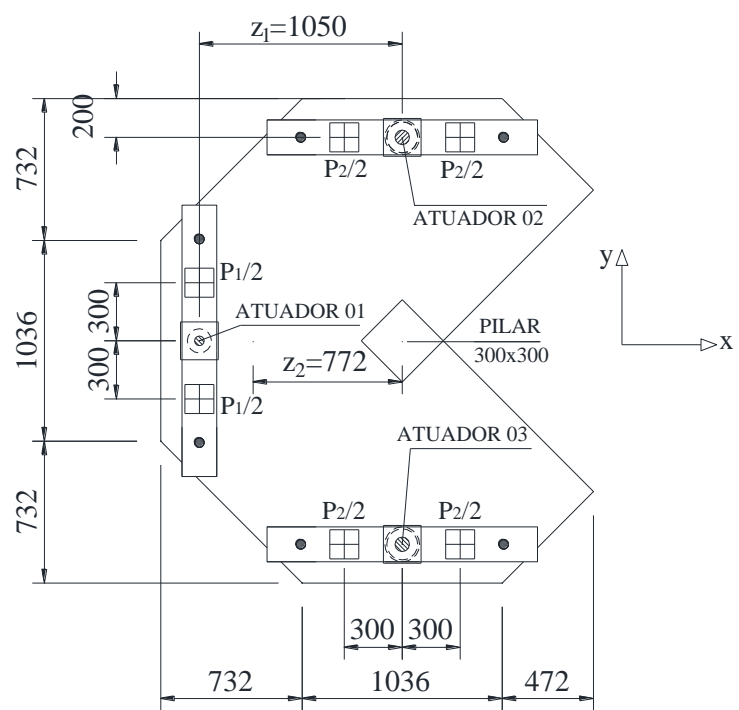

Figura 5.63 - Posição dos atuadores utilizados no ensaio das lajes.

Para esta pesquisa foram adotados alguns critérios para definir o tipo de ruptura e classificá-la em ruptura por: punção (P), flexão seguida por punção (FP) ou punção seguida por flexão (PF). Ruptura por punção é determinado pela ocorrência da formação de uma superfície cônica na região próxima ao pilar. A ruptura por flexão será caracterizada por: formação de rótulas plásticas (yield-line), que dividem a laje em segmentos delimitados por um determinado padrão de fissuração, deformação da armadura de flexão $\varepsilon_{f} \geq 3,5 \%$ e números de barras escoadas na linha A-A maior ou igual a três. Ainda em relação a defoemação da armadura de flexão, $\varepsilon_{f l}$ é a primeira deformação máxima e $\varepsilon_{f l}$ é a segunda deformação máxima dentre os pontos monitorados. O esmagamento do concreto na região inferior da laje adjacente ao pilar ocorrerá quando a deformação nos pontos monitorados forem $\varepsilon_{c} \geq 3,0 \%$. Como em todas as lajes houve formação de cone e poucas barras de flexão atingiram o escoamento, todas foram classificadas por punção. A Tabela 5.15 apresenta o resumo dos resultados experimentais mostrando a classificação do tipo de ruptura para cada laje. Nessa tabela são apresentadas as cargas correspondentes às flechas apresentadas e os extensômetros em que as deformações são apresentadas. 
Tabela 5.15 - Resumo das resultados experimentais analisados.

\begin{tabular}{|c|c|c|c|c|c|c|c|c|c|c|c|c|c|c|c|c|c|c|c|c|c|c|}
\hline & $V_{u}(\mathbf{k N})$ & $\begin{array}{l}V_{\text {flex }} \\
(\mathbf{k N})\end{array}$ & $V_{u} / V_{\text {flex }}$ & $d(\mathbf{m m})$ & $\begin{array}{c}e \\
(\mathbf{m m})\end{array}$ & $\rho(\%)$ & $\begin{array}{c}V_{u} \\
(\mathbf{k N})\end{array}$ & $\begin{array}{c}\delta_{\text {máx } x \text { final }} \\
(\mathbf{m m})\end{array}$ & $\begin{array}{c}V \\
(\mathbf{k N})\end{array}$ & $\begin{array}{l}\delta_{\text {comp }} \\
(\mathbf{m m})\end{array}$ & $\begin{array}{c}\varepsilon_{f 1} \\
(\% 0)\end{array}$ & EF & $\begin{array}{c}\varepsilon_{f 2} \\
(\% 0)\end{array}$ & EF & \begin{tabular}{|c}
$\mathbf{N}^{\mathbf{0}}$ \\
Barras \\
escoadas
\end{tabular} & $\begin{array}{l}\varepsilon_{\text {stud }} \\
\mathbf{( \% )}\end{array}$ & EF & $\begin{array}{c}A_{s w} \\
\left(\mathbf{m m}^{2}\right)\end{array}$ & $\begin{array}{c}\varepsilon_{c} \\
(\% 0)\end{array}$ & EF & $\begin{array}{c}\text { Comportamento } \\
\text { na ruptura }\end{array}$ & $\begin{array}{l}\text { TIPO DE } \\
\text { RUPTURA }\end{array}$ \\
\hline L1 & 325 & 638 & 0,5 & 148,0 & 500 & 2,07 & 278 & 24 & 201 & 16 & 2,22 & 12 & 1,85 & 5 & 0 & - & - & & \begin{tabular}{|l|}
$-0,59$ \\
\end{tabular} & 5 & 1 e 3 & $\mathrm{P}$ \\
\hline $\mathrm{L2}$ & 513 & 718 & 0,7 & 148,0 & 352 & 2,07 & 477 & 22 & 206 & 8 & 4,36 & 5 & 3,16 & 12 & 4 & 5,51 & 11 & 503 & \begin{tabular}{|l|}
$-1,09$ \\
\end{tabular} & 4 & 2 e 4 & $\mathrm{FP}$ \\
\hline $\mathbf{L 3}$ & 575 & 698 & 0,8 & 144,5 & 349 & 2,17 & 507 & 28 & 206 & 8 & 4,82 & 4 & 4,37 & 12 & 4 & 2,31 & 6 & 785 & $-2,62$ & 3 & 2 e 4 & FP \\
\hline L4 & 372 & 712 & 0,5 & 147,0 & 349 & 2,10 & 372 & 17 & 206 & 8 & 2,41 & 4 & 2,31 & 12 & 0 & - & - & - & $-1,11$ & 4 & 1 e 3 & $\mathrm{P}$ \\
\hline L5 & 250 & 282 & 0,9 & 142,5 & 504 & 0,91 & 202 & 27 & 202 & 27 & 5,38 & 6 & 4,86 & 9 & 4 & - & - & - & $-2,00$ & 1 & 1 e 3 & $\mathrm{FP}$ \\
\hline L6 & 282 & 322 & 0,9 & 144,5 & 343 & 0,88 & 226 & 18 & 212 & 16 & 4,55 & 8 & 4,55 & 10 & 3 & - & - & - & $-2,31$ & 1 & $1 \mathrm{e} 4$ & FP \\
\hline L7 & 358 & 431 & 0,8 & 141,0 & 349 & 1,35 & 266 & 20 & 206 & 13 & 5,46 & 6 & 2,99 & 8 & 3 & - & - & - & \begin{tabular}{|l|}
$-2,30$ \\
\end{tabular} & 7 & 2 e 3 & PF \\
\hline L8 & 345 & 447 & 0,8 & 145,5 & 347 & 1,27 & 279 & 22 & 206 & 13 & 3,57 & 7 & 2,48 & 4 & 2 & - & - & - & $-2,30$ & 7 & 2 e 3 & $\mathrm{P}$ \\
\hline L9 & 550 & 721 & 0,8 & 147,5 & 349 & 2,08 & 385 & 39 & 205 & 17 & 5,25 & 10 & 5,16 & 9 & 4 & 1,89 & 11 & \begin{tabular}{|l|}
1021 \\
\end{tabular} & \begin{tabular}{|l|}
$-2,07$ \\
\end{tabular} & 1 & 2 e 4 & FP \\
\hline L10 & 500 & 641 & 0,8 & 147,5 & 498 & 2,08 & 386 & 45 & 205 & 15 & 5,52 & 8 & 3,18 & 3 & 3 & 2,54 & 6 & 785 & $-2,08$ & 1 & 2 e 4 & FP \\
\hline L11 & 640 & 763 & 0,8 & 146,5 & 267 & 2,11 & 546 & 32 & 218 & 11 & 4,70 & 10 & 4,68 & 2 & 4 & 2,92 & 6 & 785 & \begin{tabular}{|l|}
$-3,70$ \\
\end{tabular} & 1 & 2 e 4 & FP \\
\hline L12 & 345 & 476 & 0,7 & 145,0 & 268 & 1,28 & 308 & 16 & 201 & 11 & 4,44 & 6 & 3,83 & 11 & 3 & - & & - & $-2,45$ & 7 & $2 \mathrm{e} 4$ & $\mathrm{PF}$ \\
\hline
\end{tabular}

\section{Tipo de Ruptura:}

P - Punção

FP - Flexão seguida por punção

PF - Punção seguida por flexão

\section{Critérios:}

Flexão - $\varepsilon_{\mathrm{f}} \geq 3,0 \%$ e $\mathrm{N}^{\circ}$ Barras escoadas na linha $\mathrm{A}-\mathrm{A} \geq 3$

$\varepsilon_{\mathrm{f} 1}$ - primeira deformação máxima.

$\varepsilon_{\mathrm{f} 2}$ - segunda deformação máxima.

Esmagamento do concreto $-\varepsilon c \geq 3,5 \%$

\section{Comportamento na ruptura observado com vídeo de aplicação de carga:}

1 - Carga cai subitamente

2 - Carga cai paulatinamente

3- Sem estalos (barulho)

4- Com estalos (barulho)

\section{Modo de Ruptura:}

Fora $=$ ruptura fora da região da armadura de cisalhamento (studs).

Dentro= ruptura dentro da região da armadura de cisalhamento (studs). 


\section{ANÁLISE NUMÉRICA (SOFTWARE ATENA 3D)}

\subsection{INTRODUÇÃO}

O software ATENA (Advanced Tool for Engineering Nonlinear Analysis) 3D foi criado pela empresa Checa, Cervenka Consulting Ltda, a partir de uma evolução do software SBETA e atualmente encontra-se na versão 5. Esse software é destinado a efetuar análises tridimensionais não lineares em estruturas de concreto armado (Červenka et al (2010).

- Descrição do comportamento não linear do concreto, incluindo endurecimento e posterior amolecimento do concreto sob compressão;

- A fratura do concreto é baseada num mecanismo de fratura não linear;

- Critério de ruptura do concreto baseia-se numa ruptura biaxial. O comportamento do material concreto é simulado (para efeitos de cálculo) recorrendo a uma transformação do diagrama biaxial de tensões do concreto num diagrama uniaxial com os devidos ajustes;

- Diferenciação entre estados não fissurado e fissurado. Após fissurado, há uma redução de resistência à compressão, redução da resistência à tração, redução da rigidez de corte;

- O ATENA 3D permite trabalhar com dois modelos de fissuração distribuída "smered crack approach": o "fixed crack model" e o "rotated crack model";

- É possível também trabalhar com vários modelos de "bond-slip", para a aderência entre armadura e concreto;

- A modelagem é feita com diversos elementos sólidos tri-dimensionais, tais como: elementos "brick" e "shell" para concreto. As armaduras foram modeladas como elementos de barra;

\subsection{MODELOS CONSTITUTIVOS DO CONCRETO}

\subsubsection{Relações tensão-deformação do concreto}

O comportamento não linear do concreto no estado de tensão biaxial é descrito por meio da tensão efetiva $\sigma_{c}^{e f}$ e da deformação uniaxial equivalente $\varepsilon^{e q}$. A tensão efetiva é, na maioria dos casos, uma tensão principal (Červenka et al - 2010). 
A tensão uniaxial equivalente é introduzida a fim de eliminar o efeito de Poisson no estado plano de tensão:

$$
\varepsilon^{e q}=\frac{\sigma_{c i}}{E_{c i}}
$$

A deformação uniaxial equivalente pode ser considerada como a deformação que seria produzida pela tensão $\sigma_{c i}$ em um ensaio uniaxial com módulo de elasticidade $E_{c i}$ associado com a direção $i$. Dentro dessa premissa, a não linearidade que representa um dano é causado apenas pela tensão $\sigma_{c i}$.

O diagrama uniaxial equivalente completo de tensão-deformação em concreto é mostrado na Figura 6.1.

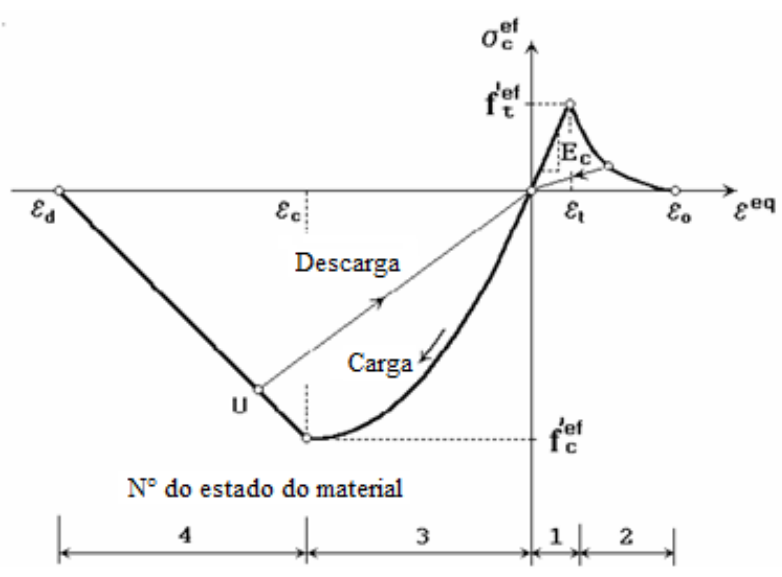

Figura 6.1 - Diagrama de tensão-deformação uniaxial do concreto - adaptado de Červenka et al (2010)

O número do estado do material define os níveis de dano do concreto. Nos estados 1 e 3 o concreto não se encontra fissurado, enquanto, nos estados 2 e 4, o concreto já se encontra fissurado. Nestes últimos estados quando ocorre uma descarga, o diagrama assume uma função linear que vai até à origem, como se pode observar no exemplo a partir do ponto U, no gráfico. Os valores de tensão efetiva de compressão $f_{c}^{\prime e f}$ e tração $f_{t}^{\prime e f}$ são calculados de acordo com o estado de tensões biaxial. 


\subsubsection{Comportamento do concreto à tração}

O comportamento do concreto à tração antes da abertura de fissura é assumido como elástico-linear, com $E_{c}$ igual ao módulo de elasticidade do concreto no estado inicial de compressão. Nesta fase o concreto apresenta um comportamento isotrópico. Este estado termina quando se atinge $f_{t}^{\prime e f}$, tensão efetiva resistente à tração do concreto, sendo definido por:

$$
\sigma_{c}^{e f}=E_{c} \cdot \varepsilon^{e q}, 0 \leq \sigma_{c} \leq f_{t}^{\prime e f}
$$

onde:

$\sigma_{c}^{e f}$ é a tensão efetiva;

$\varepsilon^{e q}$ é deformação uniaxial equivalente.

Quanto à tração, o concreto tem dois comportamentos distintos dependendo do seu estado de fissuração. As formulações utilizadas para abertura de fissuras desses dois tipos são:

- Modelo de fissura fictício baseado na lei da abertura de fissura e energia de fratura. Essa formulação é adequada para modelar propagação de fissura no concreto.

- Relação tensão-deformação num ponto material. Essa formulação não é adequada para casos normais de propagação de fissuras em concretos e deve ser usada somente em casos especiais.

Na Figura 6.2 ilustra-se a função que define a lei de abertura de fissuras de maneira exponencial.

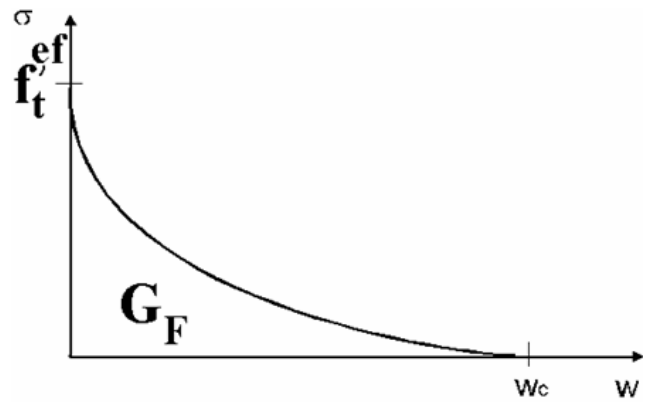

Figura 6.2 - Lei de abertura de fissuras exponencial, desenvolvida por Hodijk. Adaptado de Červenka et al (2010). 
Esta função é definida pela expressão 6.3 e foi obtida experimentalmente:

$$
\frac{\sigma}{f_{t}^{\prime e f}}=\left\{1+\left(c_{1} \cdot \frac{w}{w_{c}}\right)^{3}\right\} \exp \left(-c_{2} \cdot \frac{w}{w_{c}}\right)-\frac{w}{w_{c}} \cdot\left(1+c_{1}^{3}\right) \cdot \exp \left(-c_{2}\right)
$$

em que:

$\sigma$ é a tensão nominal;

$w$ é a abertura de fissura;

$w_{c}$ é a abertura da fissura quando a tensão efetiva de resistência à tração é nula, definida por:

$$
w_{c}=5,14 \cdot \frac{G_{f}}{f_{t}^{\prime e f}}
$$

$c_{1}$ e $c_{2}$ são constantes que tomam o valor de 3 e 6,93 , respectivamente.

Segundo Červenka et al (2010), a energia de fratura, $G_{f}$, foi pré-definida no programa computacional ATENA 3D segundo a expressão 6.5, tendo sido desenvolvido por VOS, em 1983.

$$
G_{f}=0,000025 \cdot f_{t}^{\prime e f}[M N / m]
$$

\subsubsection{Comportamento do concreto à compressão}

Antes da fissuração, o comportamento do concreto quando solicitado à compressão, segue o mesmo princípio adotado pelo CEB-FIP Model Code 1990 (1993), sofrendo algumas modificações de modo a se adaptar à ruptura biaxial, denominada tensão de resistência à compressão média, $f_{c m}$, substituída pela tensão efetiva de resistência à compressão, $f_{c}^{\prime}$ ef .

Na Figura 6.3 ilustra-se o diagrama tensão-deformação, com o comportamento do concreto à compressão assumida pelo software ATENA 3D. 


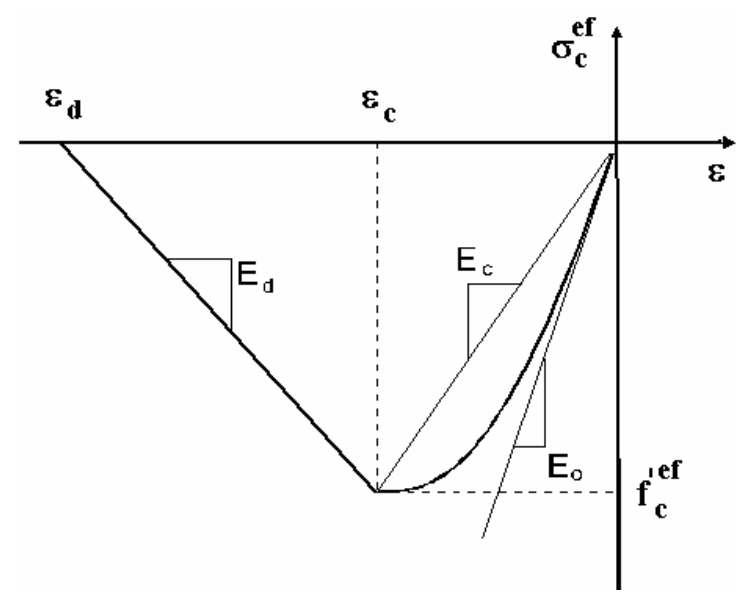

Figura 6.3 - Diagrama tensão de compressão x deformação. Červenka et al (2010).

A expressão 6.6 representa a função que define o ramo ascendente do diagrama representado anteriormente.

$$
\sigma_{t}^{e f}=f_{t}^{\text {ef }} \cdot \frac{k_{x}-x^{2}}{1+(k-2) \cdot x}, \quad x=\frac{\varepsilon}{\varepsilon_{c}}, \quad k=\frac{E_{0}}{E_{c}}
$$

onde:

$\sigma_{t}^{e f}$ é a tensão à tração do concreto;

$f_{t}^{\prime e f}$ é a tensão efetiva de resistência à tração do concreto;

$x$ são as deformações normalizadas;

$\varepsilon_{c}$ é a deformação máxima em $f_{t}^{\prime e f}$;

$k$ é um parâmetro de forma;

$E_{0}$ é o módulo de elasticidade inicial;

$E_{c}$ é o módulo de elasticidade secante.

$\mathrm{O}$ valor de $\mathrm{k}$ deve de ser maior ou igual a 1 . Exemplos: $\mathrm{k}=1$, linear; $\mathrm{k}=2$, parábola.

Nesta fase, em que o concreto ainda não se encontra fissurado, assume os danos como distribuídos, devido à abordagem tomada para o material. 
Após se atingir a tensão máxima efetiva de resistência à compressão, os danos no concreto passam a ser considerados como localizados, e surgem representados por superfícies de esmagamento, Červenka et al (2010).

Como mostrado no diagrama da Figura 6.3, o concreto assume um comportamento linear após atingir o pico da resistência à compressão, ramo linear descendente no diagrama. Ao se atingir a deformação limite por compressão do concreto, $\varepsilon_{d}$, a resistência do concreto é nula. Este ramo foi definido com base num diagrama de amolecimento linear que depende da máxima dimensão das fissuras à compressão, $w_{d}$ (no ATENA 3D tem como valor prédefinido de 0,5 mm para concreto normal); do comprimento de banda, Ld', corrigido quando a fissura se propaga numa direção diferente da paralela ao elemento; e da deformação no ponto de máxima tensão efetiva de compressão:

$$
\varepsilon_{d}=\varepsilon_{c}+\frac{w_{d}}{L_{d}^{\prime}}
$$

onde:

$$
L_{d}^{\prime}=L_{d} \cdot \gamma
$$

$L_{d}$ corresponde à dimensão do elemento finito quando a fissura se propaga na direção paralela a este e $\gamma$ o fator de correção que assume valor de 1,0 quando a fissura se propaga paralela ao elemento finito, e toma valor máximo de 1,5 logo que a fissura faz ângulo de $45^{\circ}$, com o limite do elemento finito. Estes valores são pré-definidos no ATENA 3D, Červenka et al (2010). Estes pressupostos também são válidos quando do estado de tração do concreto, representando-se como $L_{t}^{\prime}$ ou $L_{t}$ dependendo da orientação da fissura.

\subsubsection{Processo de fissuração do concreto}

O processo de fissuração no concreto ocorre em três estágios, segundo Červenka et al (2010): estágio não fissurado (o material ainda não atingiu a tensão de resistência à tração do concreto); estágio de formação de fissura (inicia-se e desenvolve-se o processo de fissuração do material, a tensão de resistência à tração do concreto começa a diminuir com a abertura da fissura); estágio fissurado (a tensão de tração do concreto é nula na face de desenvolvimento de fissura, podendo esta continuar o seu processo de abertura embora não tenha capacidade para resistir a esforços deste tipo). A Figura 6.4 mostra o diagrama 
tensão-deformação da zona de tração do concreto com cada um dos estágios. A abertura de fissura $w$ pode ser obtida segundo a expressão abaixo:

$$
w=\varepsilon_{c r} \cdot L_{t}^{\prime}
$$

onde:

$\varepsilon_{c r}$ é a deformação de abertura de fissura antes da tensão de resistência à tração ser nula;

$L_{t}^{\prime}$ é o comprimento de banda.

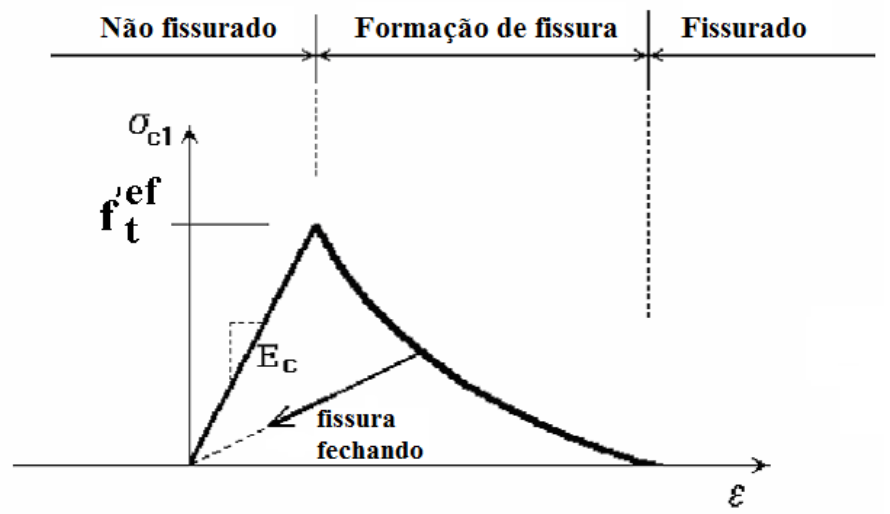

Figura 6.4 - Processo de fissuração do concreto no diagrama tensão-deformação do concreto. Adaptado de Červenka et al (2010).

\subsubsection{Comportamento biaxial do concreto}

O comportamento biaxial do concreto é descrito segundo o diagrama representado na Figura 6.5.

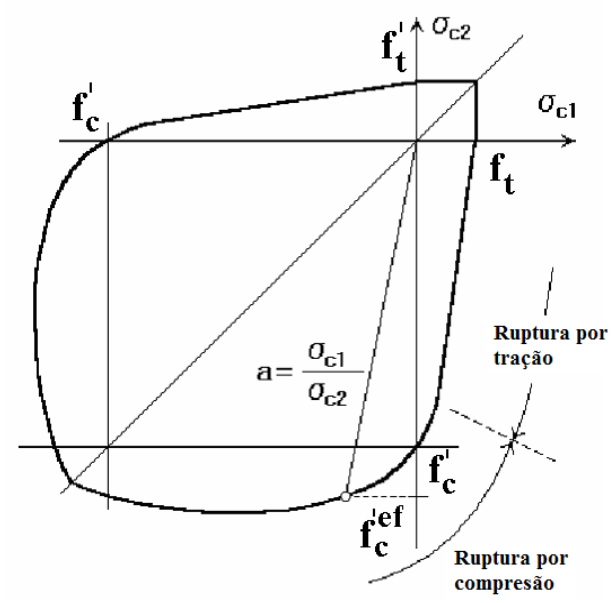

Figura 6.5 - Diagrama de ruptura biaxial do concreto. Adaptado de Červenka et al (2010). 
Os valores de $\sigma_{c 1}$ e $\sigma_{c 2}$ que aparecem no gráfico anterior correspondem aos valores das tensões principais no concreto, e $f_{c}^{\prime}$ é a tensão resistente à compressão para corpos de prova cilíndricos, Červenka et al (2010). Observa-se que o concreto quando sujeito a compressões biaxiais tem maior capacidade resistente que numa abordagem uniaxial, sendo a tensão efetiva de resistência à compressão, $f_{c}^{\text {eef }}$, descrita segundo a expressão 6.10.

No estado tração-compressão, a capacidade de resistência à compressão sofre uma redução, sendo definida segundo a expressão 6.11. Neste caso, a tensão de resistência à compressão é limitada pelo valor da tensão de resistência à compressão em corpos de prova cilíndricos.

$$
\begin{gathered}
f_{c}^{\prime e f}=\frac{1+3,65 \cdot a}{(1+a)^{2}} \cdot f_{c}^{\prime}, a=\frac{\sigma_{c 1}}{\sigma_{c 2}} \\
f_{c}^{\prime e f}=f_{c}^{\prime} \cdot r_{e c}
\end{gathered}
$$

onde:

$r_{e c}=$ fator de redução da tensão de resistência à compressão quando se está no estado tração-compressão (tração numa direção principal e compressão na outra) com valores entre 0,9 e 1,0 .

$$
r_{e c}=1-0,8 \cdot \frac{\sigma_{c 1}}{f_{c}^{\prime}}
$$

No estado tração-tração, a tensão de tração é constante e equivale à tensão de resistência à tração do concreto, $f_{t}^{\prime}$. Quando se entra num estado tração-compressão, a tensão de resistência à tração do concreto é definida segundo a expressão 6.13. No qual, o valor de $r_{e t}$ corresponde ao fator de redução da resistência à tração na direção principal 1, devido às compressões presentes na direção principal 2 (expressão 6.14).

$$
\begin{gathered}
f_{t}^{\prime e f}=f_{t}^{\prime} \cdot r_{e t} \\
r_{e t}=1-0,95 \cdot \frac{\sigma_{c 2}}{f_{c}^{\prime}}
\end{gathered}
$$




\subsubsection{Modelo de físsuração do concreto}

Segundo Červenka et al (2010), na modelagem através do ATENA 3D apenas se pode adotar fissuração distribuída, conhecido por smeared crack approach. Este tipo de abordagem permite modelar a fissura, alterando as relações constitutivas tensãodeformação na vizinhança das mesmas. Tem vantagens para a computação porque a simplifica e admite as microfissuras como distribuídas e sinuosas em vez de retas e concentradas, no volume do material. O desempenho computacional, e por consequente os resultados, dependem da dimensão da malha dos elementos finitos e da sua orientação, tendo a fissuração controlada numa linha ou banda dos elementos finitos.

Duas opções estão disponíveis para os modelos de fissuração: fixed crack model e rotated crack model. Em ambos os modelos, a fissura é formada quando a tensão principal excede a resistência à tração. Desde que a fissura inicie o seu processo de formação, o material adota um comportamento ortotrópico, Červenka et al (2010).

No fixed crack model a direção da fissura é fixa, ou seja, assume a mesma direção desde que se inicia até sua formação. Pode haver aumento de carga e de deformações nas imediações da fenda, mas esta mantém sempre a mesma direção. Na Figura 6.6 ilustram-se o estado de tensões e de deformações deste modelo de fissuração, Červenka et al (2010).

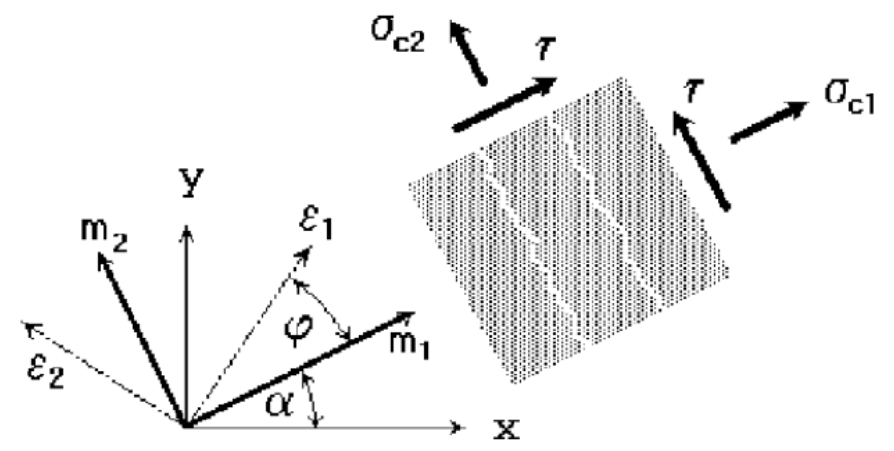

Figura 6.6 - Estado de tensões e deformações do fixed crack model. Adaptado de Červenka et al (2010).

Antes de ocorrer à fissuração as direções das tensões e deformações principais são idênticas (estado de isotropia). Após a abertura das fissuras passa-se a um estado de ortotropia no qual o eixo normal à direção da fissura corresponde ao eixo no qual o material é mais fraco (no exemplo da Figura 6.6 corresponde ao eixo $\mathrm{m}_{1}$ ) e o eixo paralelo 
à fissura corresponde o eixo onde o material é mais forte $\left(\right.$ eixo $\left.\mathrm{m}_{2}\right)$. Se ocorrer uma rotação das deformações principais para os eixos $\varepsilon_{1}$ e $\varepsilon_{2}$, as tensões principais $\sigma_{c 1}$ e $\sigma_{c 2}$, não vão acompanhar a rotação, deixando de ser tensões principais e transformando-se em tensões de cisalhamento na face da fissura, $\tau$.

$\mathrm{Na}$ formação de fissuras segundo o rotated crack model a direção das tensões principais coincidem com a direção das deformações principais. Não há formação de tensões de cisalhamento na face da fissura e as tensões principais são as únicas tensões que devem ser definidas para análise da fissuração, através deste modelo, Červenka et al (2010).

Na Figura 6.7 apresentam-se o estado de tensões e de deformações correspondentes ao rotated crack model. Se os eixos principais da deformação rodam, então, de forma similar, a direção da fissura também roda. A tensão principal na direção do eixo no qual, o material é mais fraco, é sempre normal à fissura, enquanto que na direção em que o material possui maior resistência a tensão principal é sempre paralela à direção da fissura.

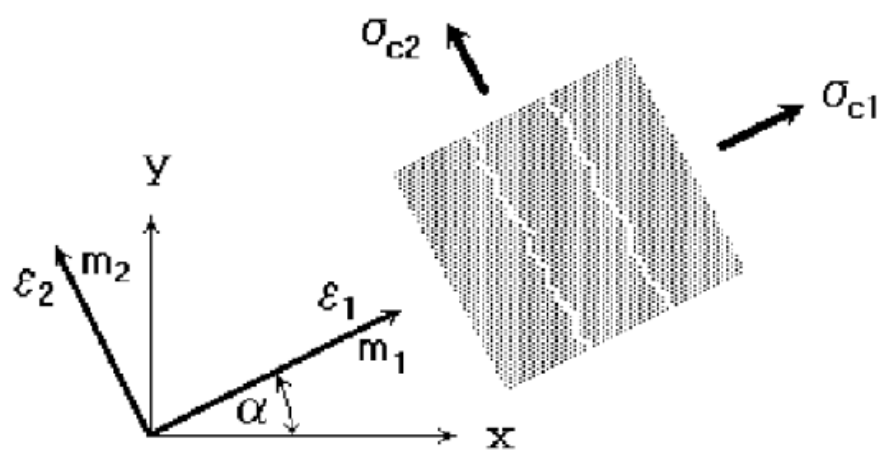

Figura 6.7 - Estado de tensões e deformações do rotated crack model. Adaptado de Červenka et al (2010).

No ATENA 3D, a definição entre um dos modelos de fissuração referidos faz-se através da introdução de um coeficiente, que representa a relação entre o fixed crack model e o rotated crack model. Um coeficiente com valor 1,0 representa o primeiro modelo de fissuração. Para qualquer outro coeficiente, a fissuração inicia o seu processo seguindo a abordagem rotated crack model e quando se atinge o valor correspondente ao produto da tensão de resistência à tração do concreto com o coeficiente definido, as fissuras passam a ter direção fixa, abordando a fissuração segundo o modelo fixed crack model a partir desse ponto. 


\subsubsection{Comportamento do concreto após fissuração}

Após fissurado, o concreto, tem uma menor capacidade de resistência ao cisalhamento, à compressão e à tração, Červenka et al (2010).

Na capacidade de resistência ao cisalhamento, o material sofre uma redução, que no caso do modelo de fissuração fixed crack model é proporcional às deformações normais à fissura. Dá-se uma redução do módulo de distorção do material na face da fissura.

A resistência à compressão sofre um decréscimo segundo o diagrama apresentado na Figura 6.8, esta função tem a forma da função de Gauss.

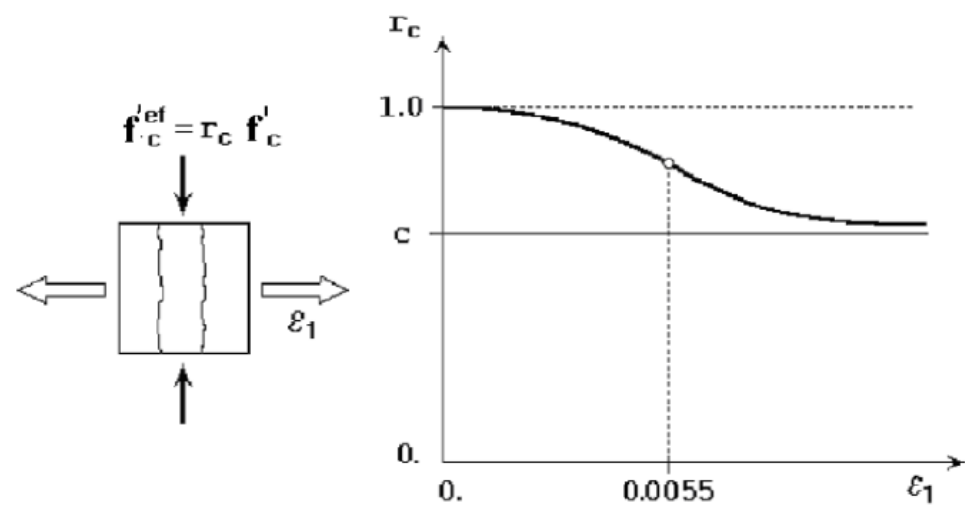

Figura 6.8 - Redução da resistência à compressão com presença de fissuração no material. Červenka et al (2010).

A expressão 6.15 descreve a redução da resistência à compressão do concreto, onde a constante c representa a máxima redução quando o material está sujeito a uma grande deformação.

Esta constante foi definida no ATENA 3D com o valor de 0,8 , sugerido de acordo pesquisas realizadas.

$$
\begin{gathered}
f_{c}^{\prime e f}=r_{c} \cdot f_{c}^{\prime} \\
r_{c}=c+(1-c) \cdot e^{-\left(128 \varepsilon_{u}\right)^{2}}
\end{gathered}
$$




\subsection{MODELOS CONSTITUTIVOS DAS ARMADURAS DE AÇO}

As armaduras de aço que fazem parte da composição do concreto armado podem ser modeladas de duas formas distintas: armadura distribuída ou discreta. A armadura distribuída pode ser definida como elemento de malha especial (camada) de material compósito com uma espessura que leva à área total de armadura da peça. A armadura discreta é simulada com elementos barra, colocando cada barra individualmente, com o respectivo diâmetro, na sua posição correspondente. Em ambos os casos, o estado de tensão uniaxial é assumido e a mesma formulação da lei tensão- deformação é usada em todos os tipos de armadura. Na Figura 6.9 ilustra-se um exemplo de armadura distribuída (smeared), à esquerda, e de armadura discreta, à direita.
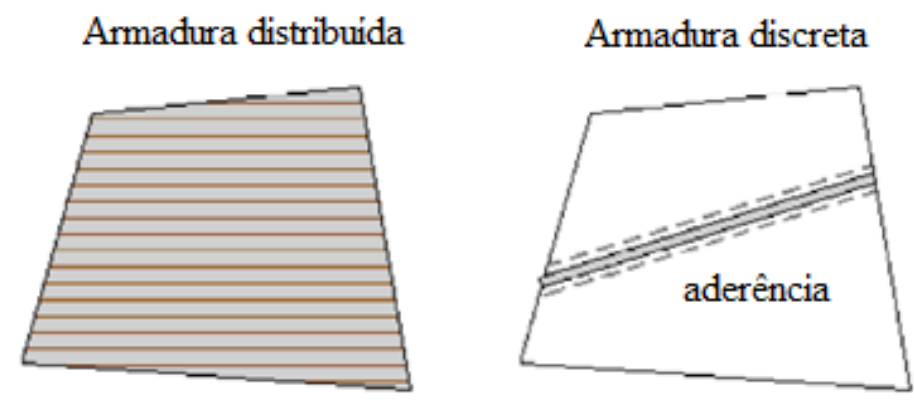

Figura 6.9 - Exemplos de simulação de armaduras no ATENA 3D, à esquerda: armadura distribuída; à direita: armadura discreta. Červenka et al (2010).

\subsubsection{Relações tensão-deformação do aço}

O ATENA 3D suporta vários tipos relação tensão-deformação do aço com endurecimento compatíveis na modelagem numérica: linear, bilinear e multilinear.

O estado bilinear, elástico-plástico perfeito, é ilustrado na Figura 6.10. 


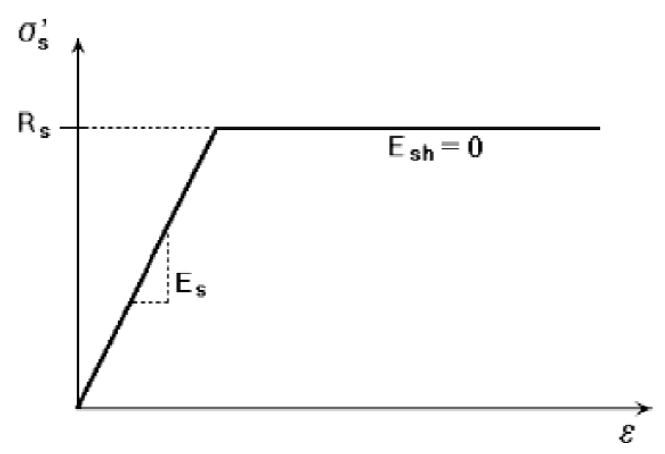

Figura 6.10 - Diagrama tensão-deformação do aço, bilinear, adotado nos modelos simulados. Adaptado de Červenka et al (2010).

No estado linear o comportamento traduz-se por um traço reto, com o módulo de elasticidade sempre constante. No estado bilinear o material assume o mesmo comportamento que o estado anterior, mas quando se atinge a tensão de escoamento o módulo de elasticidade passa a ser nulo, passando a haver deformações plásticas. O estado multilinear é caracterizado por vários pontos, geralmente adquirido em ensaios laboratoriais, traduzindo as várias fases do comportamento do aço: estado elástico, patamar de escoamento, endurecimento e fratura. $\mathrm{O}$ estado bilinear com endurecimento assume comportamento similar ao bilinear, mas após atingir a tensão de escoamento passa para um patamar em que o módulo de elasticidade é muito reduzido em vez de nulo, dando-se o endurecimento, Červenka et al (2010).

O ATENA 3D suporta vários tipos de modelos bond-slip que demonstram a relação entre a tensão de aderência atuante na barra de aço e o escorregamento entre os materiais. $\mathrm{O}$ modelo de aderência armadura-concreto utilizado nessa pesquisa foi bond-slip cujo o objetivo é simular o mecanismo de transferência de esforços das armaduras para o concreto, mantendo a integridade da estrutura de concreto armado. $\mathrm{O}$ modelo bond-slip presente no Model Code 1990 (1993), desenvolvido por Bigaj (1999), depende da qualidade da aderência entre concreto e aço, da resistência à compressão do concreto, diâmetro da barra de aço. Outros parâmetros importantes são: condições de confinamento do concreto e a qualidade da produção do concreto.

Segundo Červenka (2009), estes mecanismos devem ser escolhidos criteriosamente nas análises numéricas porque deles dependem um adequado modelo de fissuração, para que os resultados sejam satisfatórios. 


\subsection{ELEMENTOS FINITOS SÓLIDOS 3D}

No software ATENA 3D a modelagem de elementos sólidos 3D é feita utilizando-se um dos três grupos de elementos finitos disponíveis: tetraedros, com quatro faces; brick, com seis faces ou wedge, com cinco faces. Červenka et al (2010).

O número de nós que constituem cada elemento depende da função interpoladora que se escolhe para a resolução dos problemas numéricos: linear ou quadrática. O número de nós corresponde ao número de pontos a integrar. Ao se escolher uma função interpoladora quadrática o número de nós é superior do que numa função linear, visto que, em cada elemento vão ser considerados e calculados os pontos intermédios aos pontos exteriores. Os elementos tetraedros são compostos por 4 ou 10 nós, dependendo se a função interpoladora é linear ou quadrática, respectivamente. Os elementos brick, também designados por hexaedros, são compostos por 8 ou 20 nós e os elementos wedge são constituídos por 6 ou 15 nós; ambos, dependendo se a função interpoladora é linear ou quadrática, respectivamente. Na Figura 6.11 são mostrados esses três tipos de elementos:

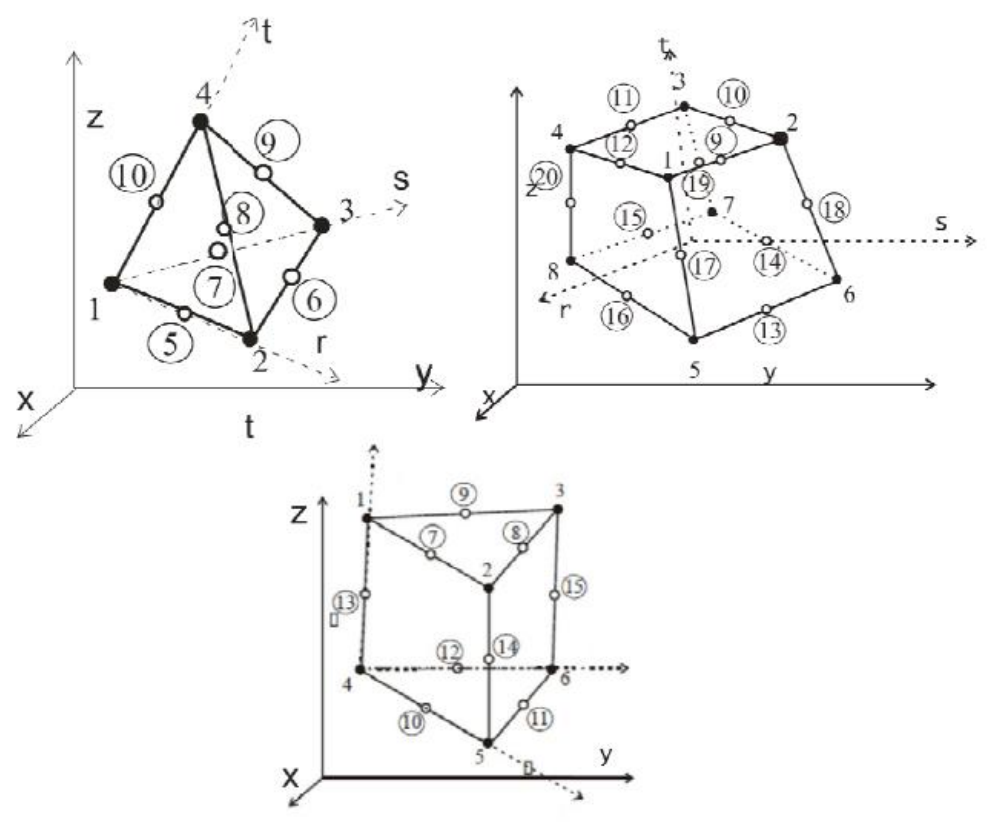

Figura 6.11 - Geometria dos elementos finitos possíveis de modelar no ATENA 3D. Em cima: à esquerda - tetraedro; à direita - brick. Em baixo: elemento wedge. Adaptado

Červenka (2010). 


\subsection{MÉTODO NEWTON-RAPHSON}

No software ATENA 3D, as soluções numéricas podem ser calculadas seguindo dois métodos iterativos não lineares: o método Newton-Raphson e o método Arc- Length.

O método iterativo escolhido no ATENA 3D para a resolução das soluções não lineares foi o Newton-Raphson. As soluções não lineares são obtidas através de um processo interativo seguindo a expressão 6.17 até se obter convergência de resultados.

$$
K\left(p_{i-1}\right) \cdot \Delta p_{p i}=q-f\left(p_{i-1}\right)
$$

onde:

$q$ : é o vetor de carga total aplicada;

$f\left(p_{i-1}\right)$ : é o vetor de forças internas antes do atual incremento de carga.

$\Delta p_{p i}$ : é o incremento de deformações devido ao atual incremento de carga;

$K\left(p_{i-1}\right)$ : é a matriz de rigidez que relaciona o incremento de carga com o incremento de deformações;

$p_{i-1}:$ são deformações da estrutura antes do atual incremento de carga;

A não linearidade da equação deve-se ao fato das forças internas e da matriz de rigidez não serem lineares mostradas nas expressões 6.18 e 6.19, respectivamente, onde k é uma constante.

$$
\begin{gathered}
f\left(k_{p}\right) \neq k \cdot f(p) \\
K(p) \neq K(p-\Delta p)
\end{gathered}
$$

A convergência é regida por quatro critérios, onde o valor de tolerância padrão é de 0,01 , que correspondem: o incremento da deformação, a força residual absoluta, a força residual relativa e a energia dissipada. Quando a diferença destes parâmetros é menor que a tolerância, o processo iterativo pára e passa para o passo seguinte, prescrevendo um novo deslocamento. É necessário fazer uma iteração até que algum critério de convergência seja satisfeito. As seguintes possibilidades são suportadas em ATENA 3D: 


$$
\begin{gathered}
\sqrt{\frac{\Delta \underline{p}_{i}^{T} \cdot \Delta \underline{p}_{i}}{p_{i}^{T} \cdot \underline{p}_{i}}} \leq \varepsilon_{\text {rel.disp }} \\
\sqrt{\frac{\left(\underline{q}-\underline{f}\left(\underline{p}_{i-1}\right)\right)^{T} \cdot\left(\underline{q}-f\left(\underline{p}_{i-1}\right)\right)}{\underline{f}\left(\underline{p}_{i}\right) \cdot \underline{f}\left(\underline{p}_{i}\right)}} \leq \varepsilon_{\text {rel.force }} \\
\sqrt{\frac{\Delta \underline{p}_{i}^{T} \cdot\left(\underline{q}-\underline{f}\left(\underline{p} \underline{p}_{i-1}\right)\right)}{\underline{p}_{i}^{T} \cdot \underline{f}\left(\underline{p}_{i}\right)} \leq \varepsilon_{\text {rel.energy }}} \\
\sqrt{\frac{\max \left(\underline{q}^{k}-\underline{f}^{k}\left(\underline{p}_{i-1}\right)\right) \cdot \max \left(\underline{q}^{k}-\underline{f}^{k}\left(\underline{p}_{i-1}\right)\right)}{\max \left(\underline{f}^{k}\left(\underline{p}_{1}\right)\right) \cdot \max \left(\underline{f}^{k}\left(\underline{p}_{i}\right)\right)}} \leq \varepsilon_{\text {abs.force }}
\end{gathered}
$$

O primeiro verifica se a deformação muda em relação à última iteração enquanto o segundo verifica se as forças estão em equilíbrio. $\mathrm{O}$ terceiro verifica energia relativa e as condições de equilíbrio. A quarta controla se as forças estão equilibradas em termos de componentes máximos. Os valores dos limites de convergência $\varepsilon$ (erro) são definidos por padrão para 0,01 ou pode ser alterado pelo comando de entrada SET.

Na Figura 6.12 apresenta-se uma ilustração gráfica do conceito do método NewtonRaphson.

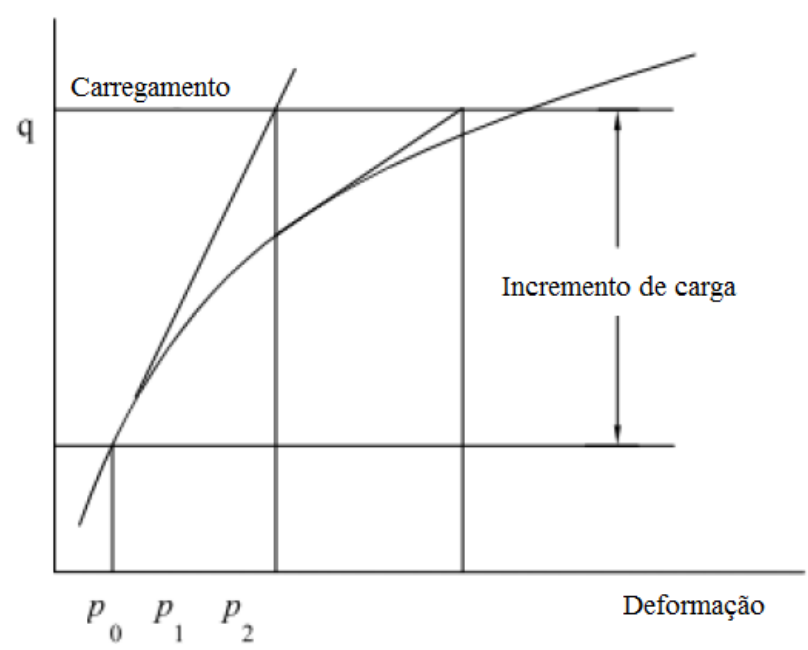

Figura 6.12 - Método de Newton-Raphson. Červenka et al (2010). 


\subsection{DESCRIÇÃO DOS MODELOS NUMÉRICOS}

A modelagem das lajes dessa pesquisa foi realizada na Universidade NOVA de Lisboa em Portugal durante o doutorado sanduíche com duração de seis meses. As propriedades dos materiais e os parâmetros utilizados no programa ATENA 3D para elaboração dos modelos numéricos resultaram dos ensaios experimentais realizados nesta pesquisa de modo a se obter a melhor convergência na comparação com as lajes analisadas. A máquina utilizada para correr os modelos possuía um processador Intel Core i 73930 k, 3.2 GHz e RAM de $16 \mathrm{~GB}$.

\subsubsection{Geometria}

As lajes ensaiadas experimentalmente se caracterizavam por serem lajes lisas com espessura prevista de $180 \mathrm{~mm}$, pilar quadrado de canto reentrante com dimensão de 300 $\mathrm{mm}$ e altura de $1580 \mathrm{~mm}$. Foram modeladas também as placas de aço que simulavam a transmissão de esforços, como se observa na Figura 6.13.

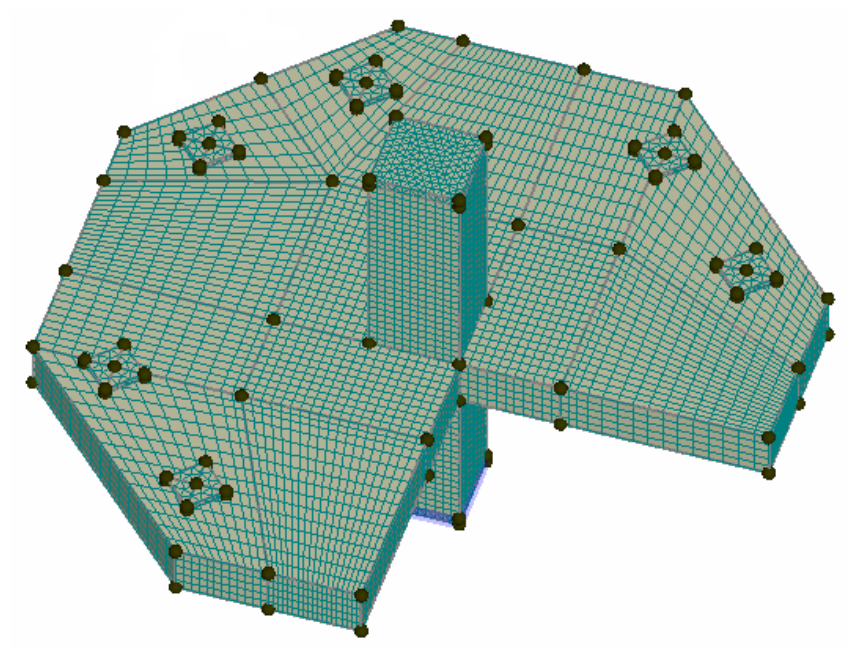

Figura 6.13 - Exemplo da modelagem da laje no Atena 3D (Laje L01).

Em todas as lajes, o carregamento foi simulado com imposição de cargas nas placas de aço com incrementos de $0,4 \mathrm{kN}$ em cada placa. Nas extremidades dos pilares foram colocadas placas de aço de $30 \mathrm{~mm}$ com Perfect-Bond (aderência perfeita) simulando engastamento dos mesmos restringindo deslocamentos verticais, horizontais e rotações.

A laje foi modelada por elementos hexaedros com função interpoladora linear, também designados por brick, e as placas de aço foram simuladas por elementos tetraedros com função interpoladora linear. Os elementos finitos tinham como dimensão máxima $60 \mathrm{~mm}$. $\mathrm{Na}$ zona junto ao pilar, em um perímetro afastado de duas vezes a espessura da laje, 
executou-se o refinamento da malha para metade da dimensão máxima. O número de elementos finitos do concreto é apresentado na Tabela 6.1.

Tabela 6.1 - Tipos de elementos 3D

\begin{tabular}{|c|c|}
\hline LAJE & $\begin{array}{c}\text { N}^{\circ} \text { DE ELEMENTOS } \\
\text { FINITOS }\end{array}$ \\
\hline Laje 1 & 20357 \\
\hline Laje 2 & 20237 \\
\hline Laje 3 & 20237 \\
\hline Laje 4 & 20357 \\
\hline Laje 5 & 20357 \\
\hline Laje 6 & 20357 \\
\hline Laje 7 & 20237 \\
\hline Laje 8 & 20237 \\
\hline Laje 9 & 20237 \\
\hline Laje 10 & 20237 \\
\hline Laje 11 & 20237 \\
\hline Laje 12 & 20237 \\
\hline
\end{tabular}

\subsubsection{Materiais}

Os materiais utilizados nas lajes, concreto e aço, foram caracterizados de acordo com os ensaios de corpo de prova dos mesmos. Para o concreto foram utilizadas amostras de cilindros retificados de $10 \mathrm{~cm}$ x $20 \mathrm{~cm}$ em ensaios de compressão, tração e módulo de elasticidade. $\mathrm{O}$ aço foi ensaiado à tração utilizando amostras de $50 \mathrm{~cm}$ para todos os diâmetros.

\subsubsection{Concreto}

A Tabela 6.2 mostra os valores obtidos experimentalmente, de tensão à compressão do concreto $f_{c}$, os valores de tensão média de ruptura à tração $f_{c t}$ e módulo de elasticidade $E$. Os valores calculados com as expressões a seguir, de tensão média à tração do concreto $f_{c t m}$, módulo de elasticidade médio calculado $E_{c m}$ e energia de fratura $G_{F}$ foram obtidos através das expressões 6.24, 6.25, 6.26 e 6.27 sugeridas pelo EUROCODE2 (2004).

Tabela 6.2 - Parâmetros de entrada no ATENA

\begin{tabular}{|c|c|c|c|c|c|c|}
\hline LAJES & $f_{c}(\mathrm{MPa})$ & $f_{c t}(\mathrm{MPa})$ & $\begin{array}{c}f_{c t m} \\
(\mathrm{MPa})\end{array}$ & $E(\mathrm{GPa})$ & $\begin{array}{c}E_{c m} \\
(\mathrm{GPa})\end{array}$ & $\begin{array}{c}G_{F} \\
(\mathrm{~N} / \mathrm{m})\end{array}$ \\
\hline SÉRIE 1 & 48 & 3,4 & 3,5 & 29,4 & 31,7 & 77,7 \\
\hline SÉRIE 2 & 44 & 3,1 & 3,3 & 30,1 & 30,8 & 72,7 \\
\hline SÉRIE 3 & 43 & 3,5 & 3,2 & 32,9 & 30,6 & 71,7 \\
\hline
\end{tabular}


Resistência compressão média:

$$
f_{c m}=f_{c}
$$

Resistência à tração:

$$
f_{c t m}=0,30 \cdot\left(f_{c m}-8\right)^{2 / 3}
$$

Módulo de Elasticidade a $0,4 \cdot f_{c m}$ do Concreto:

$$
E_{c m}=22 \cdot\left(\frac{f_{c m}}{10}\right)^{0,3}
$$

Energia de fratura específica:

$$
G_{f}=G_{F O} \cdot\left(\frac{f_{c m}}{f_{c m 0}}\right)^{0,7}
$$

onde: $f_{c m 0}=10 M P a$ e $G_{F 0 ; 9,5}=0,0259$

Foi considerado para todas as lajes o peso específico do material $23 \mathrm{kN} / \mathrm{m}^{3}$ e coeficiente de Poisson 0,20.

O modelo de fissuração do concreto foi definido considerando-se um coeficiente de 0,5 para a relação entre o fixed crack model e o rotated crack model. Assim, após a fissuração quando se atinge uma tensão equivalente a metade da tensão de ruptura à tração do concreto, as fendas deixam de rodar constantemente e as tensões principais passam a ter direção fixa.

\subsubsection{Aço}

Para as propriedades do aço nas armaduras de flexão e cisalhamento foram utilizados os resultados obtidas nos ensaios de caracterização mostradas no Capítulo 4.

As barras de aço foram consideradas com comportamento bilinear e introduzida por elementos barra, armadura discreta (armadura desenhada isoladamente, um elemento de cada vez, através de pontos e linhas), utilizando o eixo das mesmas como referência garantindo a altura útil de cada laje. O tipo de aderência entre as barras de aço e o concreto foi assumido como Perfect Bond, ou seja, aderência perfeita. 


\subsection{DESLOCAMENTOS VERTICAIS}

\subsubsection{Instrumentação}

Para comparação entre os valores experimentais e os numéricos foi necessária a monitorização de vários pontos (Figura 6.14) semelhantes aos pontos nas lajes experimentais para acompanhar os deslocamentos nas lajes e deformações nas barras de flexão e cisalhamento que já foram descritos no Capítulo 3.

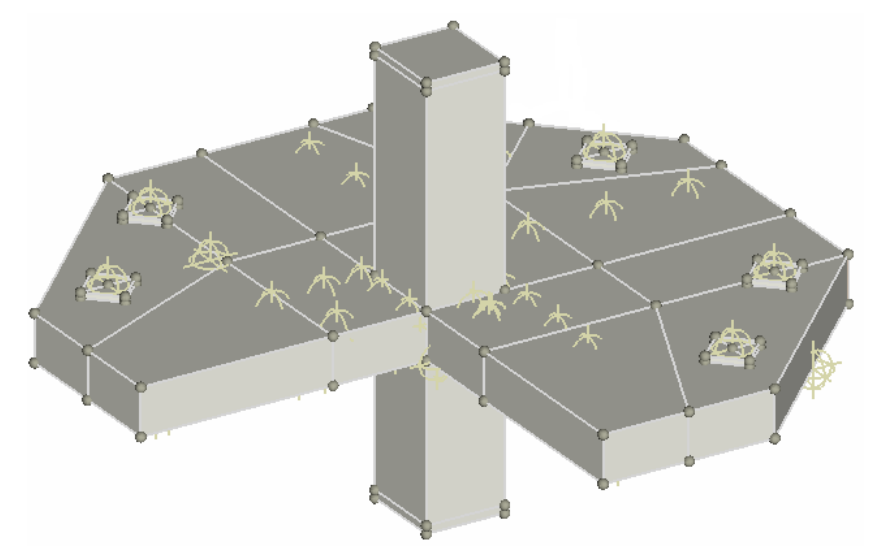

Figura 6.14 - Exemplo da laje com pontos monitorados inseridos no programa Atena 3d (Laje L01).

\subsubsection{Deslocamentos verticais}

Nestas lajes foi possível comparar os deslocamentos verticais em sete pontos como mostra a Figura 6.15. Para avaliação dos deslocamentos verticais foram comparados os deslocamentos experimentais (EXP) e numéricos (MEF) associados a determinados níveis de carga juntamente com a relação de carga de ruptura das lajes.

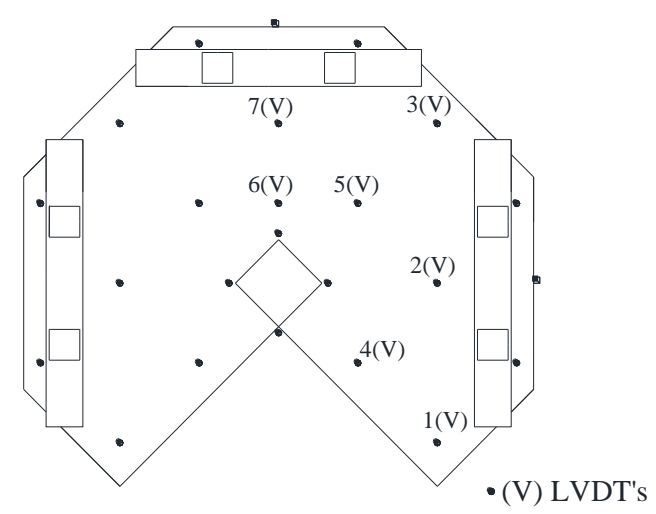

Figura 6.15 - Pontos monitorados no programa ATENA 3D.

Da Figura 6.16 à Figura 6.27 são apresentados os deslocamentos verticais experimentais e numéricos para cada um dos sete pontos das lajes em diferentes passos de carga até próximo à ruptura. 


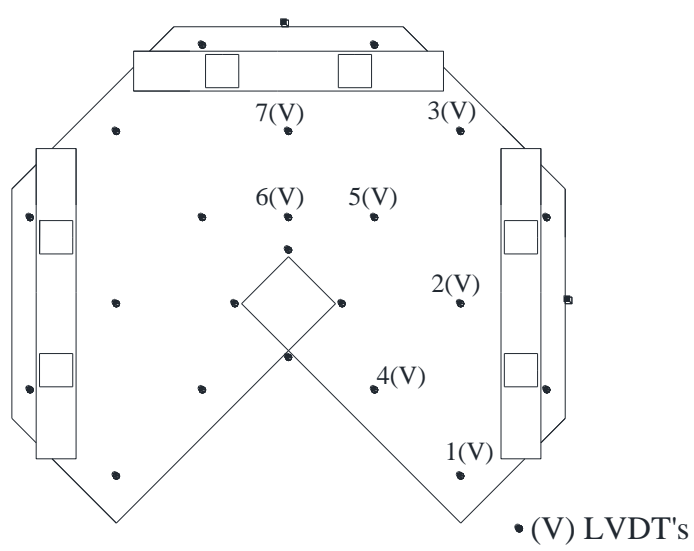

Laje LO1

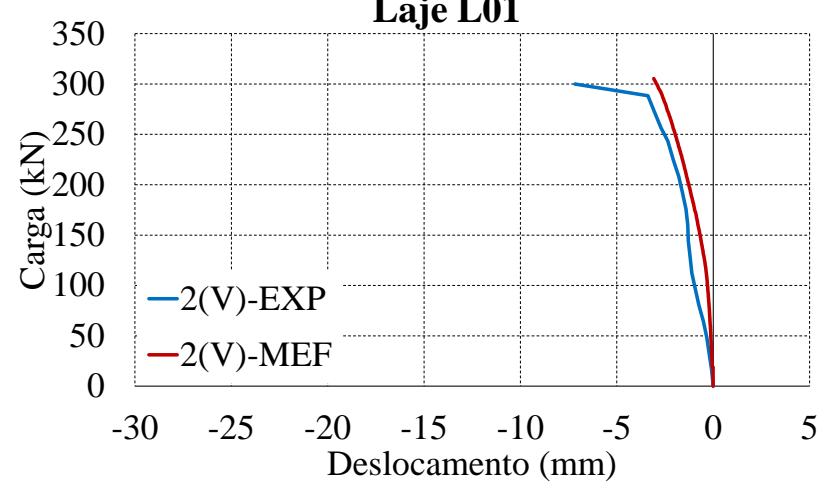

(b) Deslocamentos no ponto 2

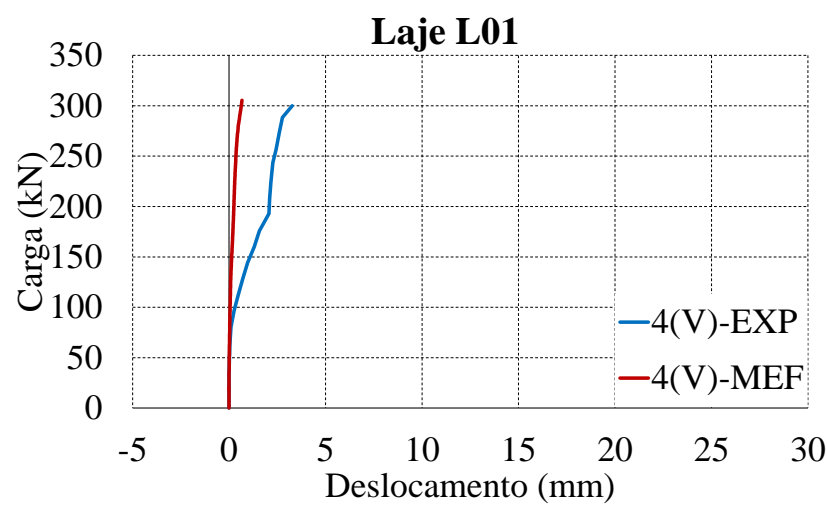

(d) Deslocamentos no ponto 4

\section{Laje L01}

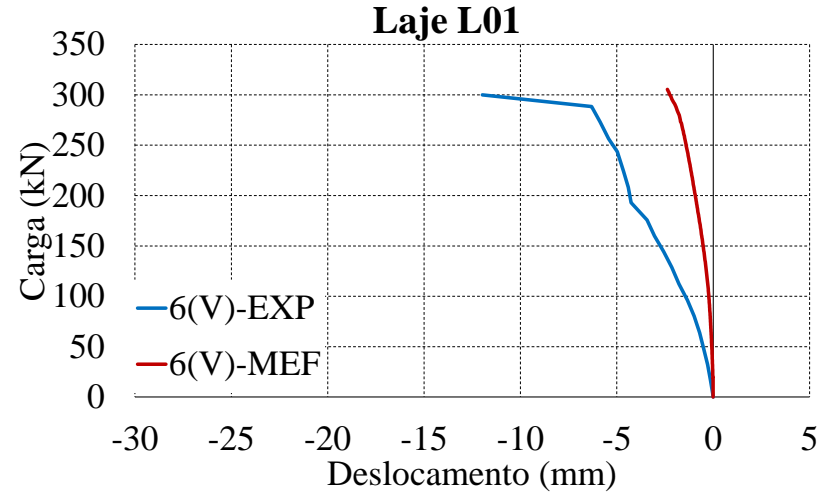

(f) Deslocamentos no ponto 6

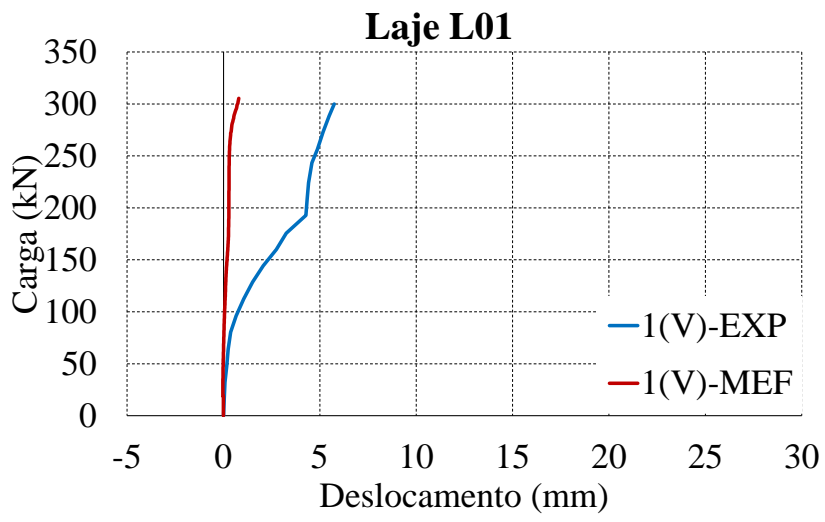

(a) Deslocamentos no ponto 1

\section{Laje L01}

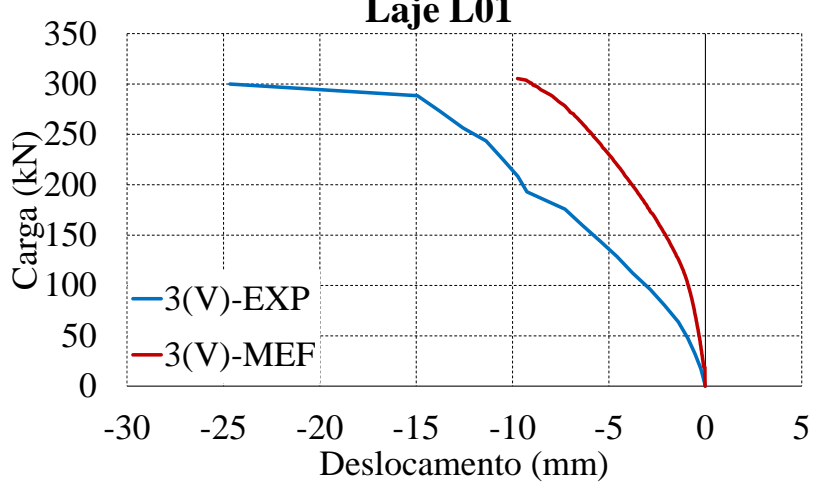

(c) Deslocamentos no ponto 3

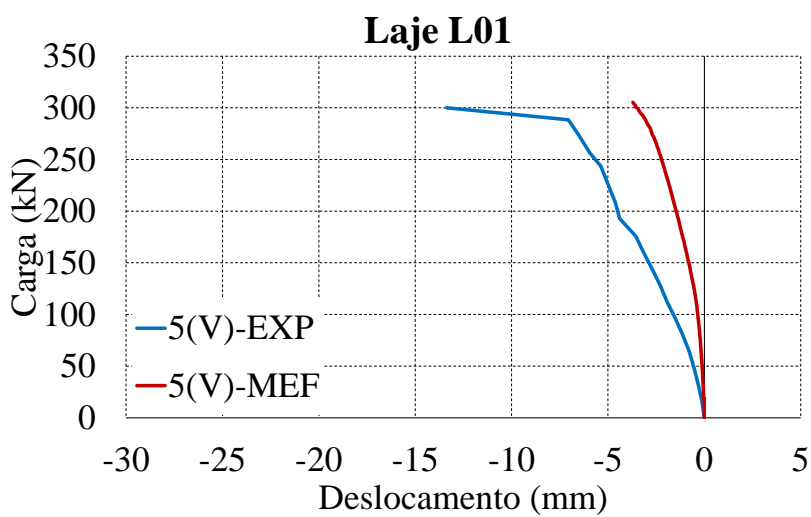

(e) Deslocamentos no ponto 5

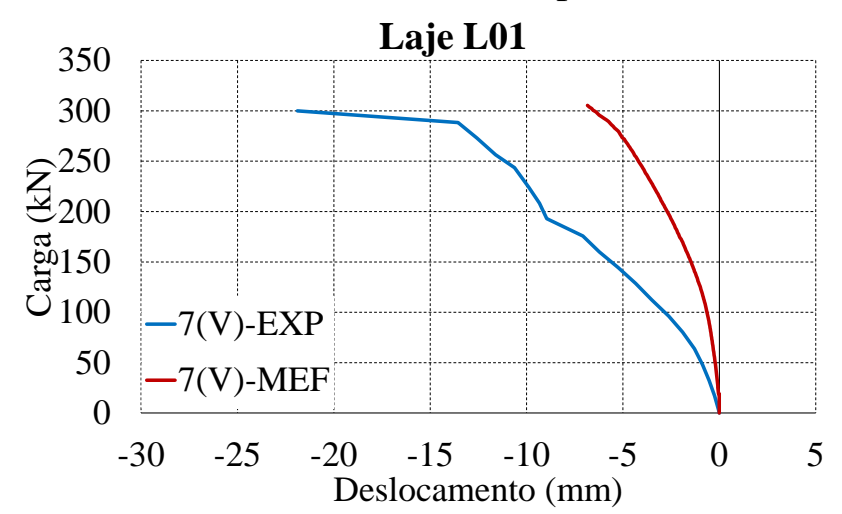

(g) Deslocamentos no ponto 7

Figura 6.16 - Deslocamentos da Laje L01 


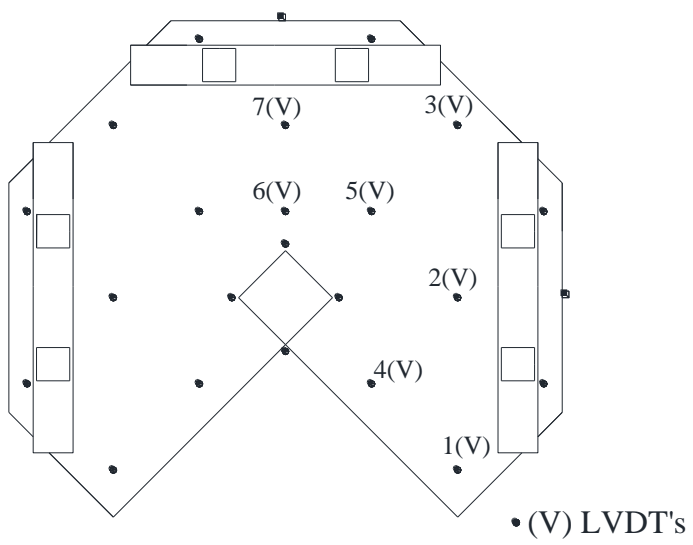

Laje LO2

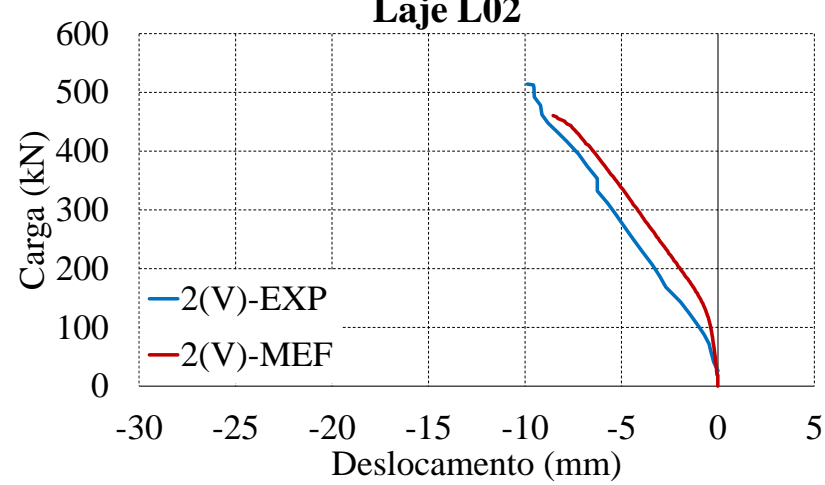

(b) Deslocamentos no ponto 2

\section{Laje LO2}

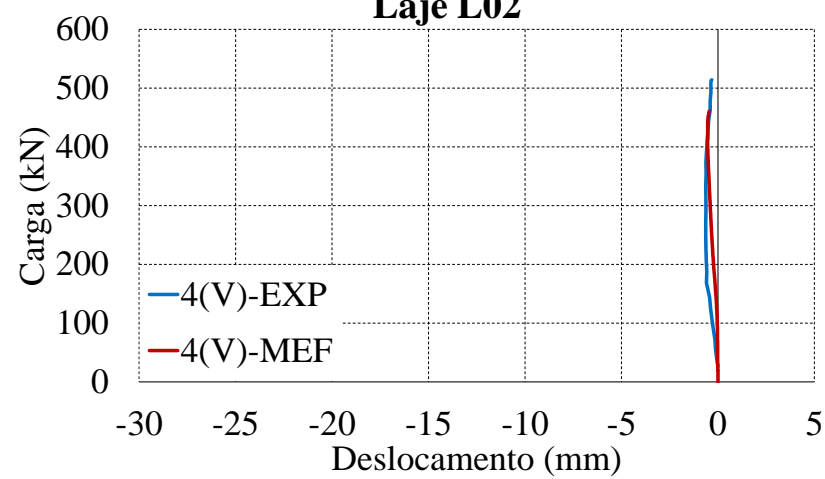

(d) Deslocamentos no ponto 4

Laje LO2

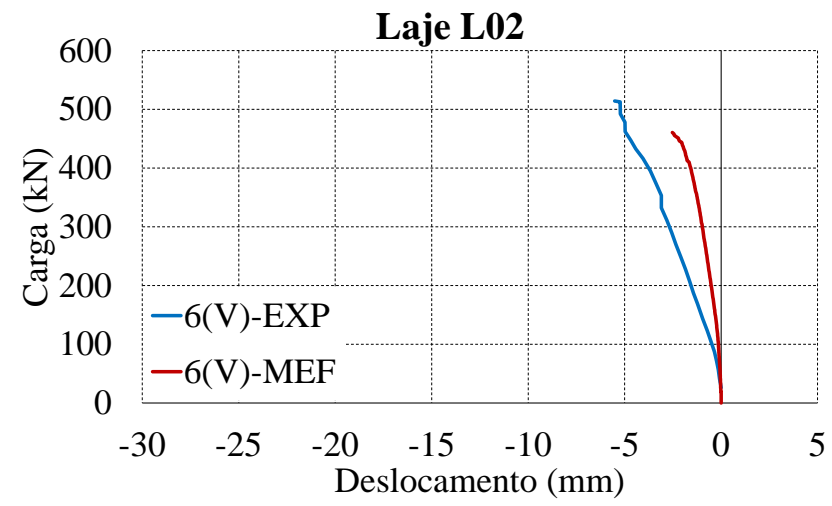

(f) Deslocamentos no ponto 6

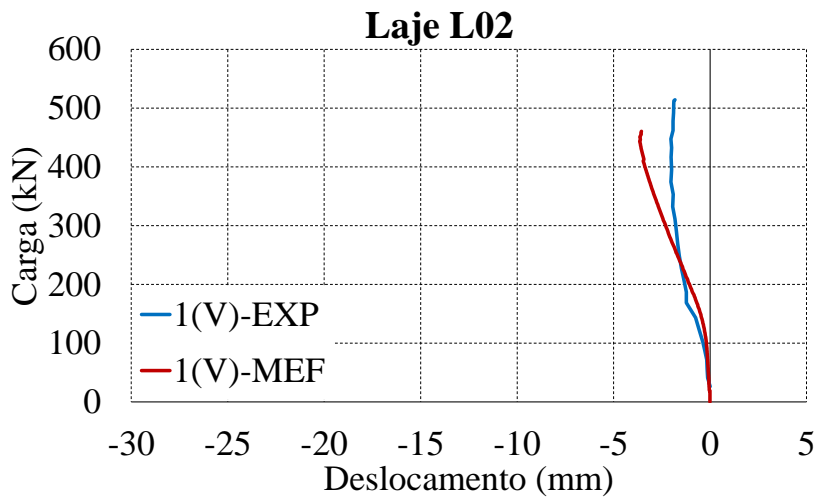

(a) Deslocamentos no ponto 1

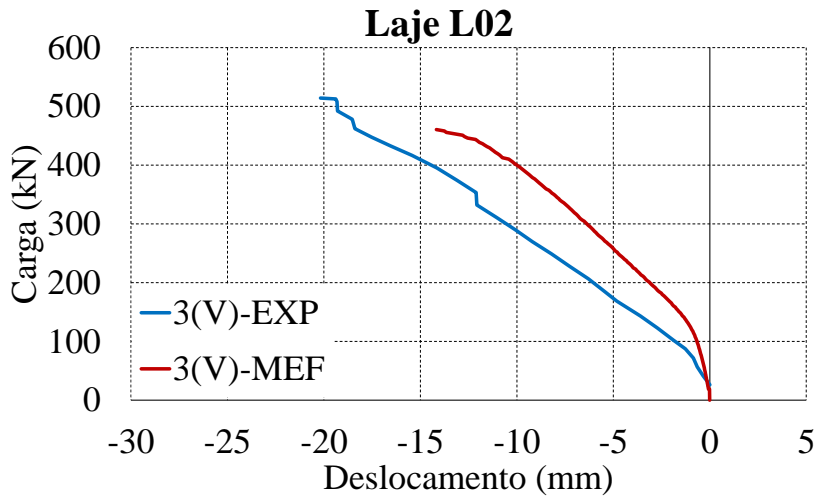

(c) Deslocamentos no ponto 3

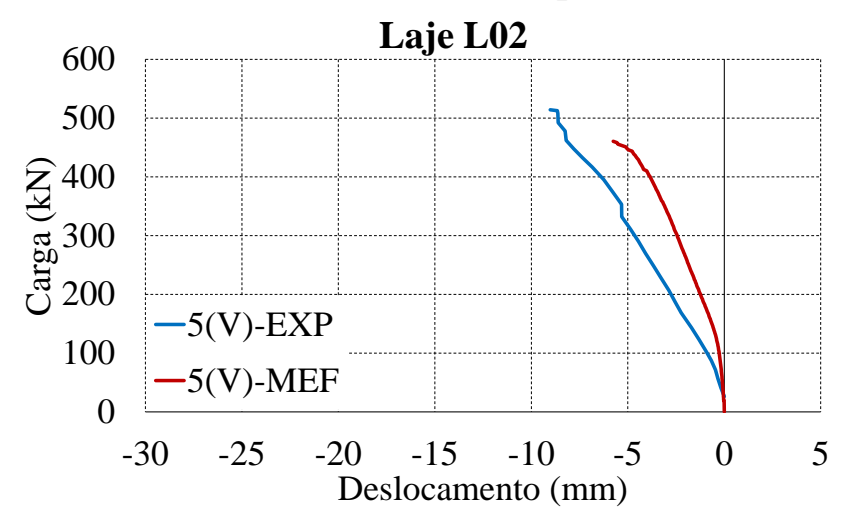

(e) Deslocamentos no ponto 5

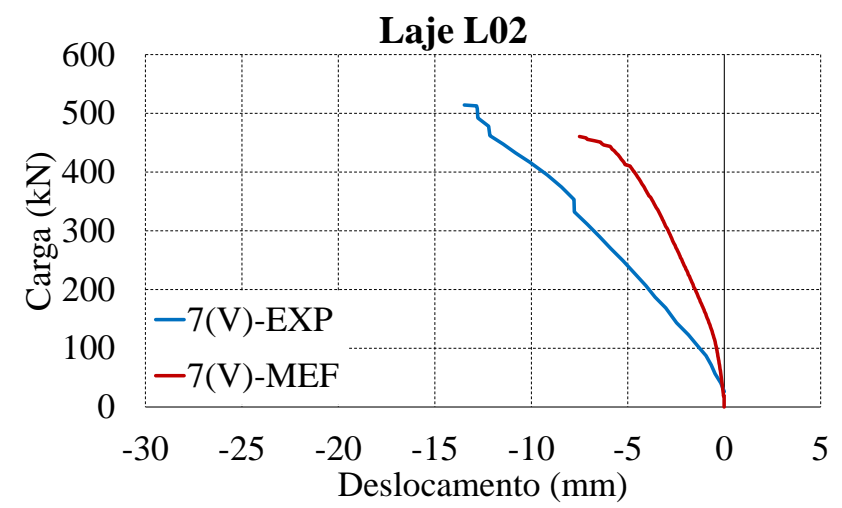

(g) Deslocamentos no ponto 7

Figura 6.17 - Deslocamentos da Laje L02 


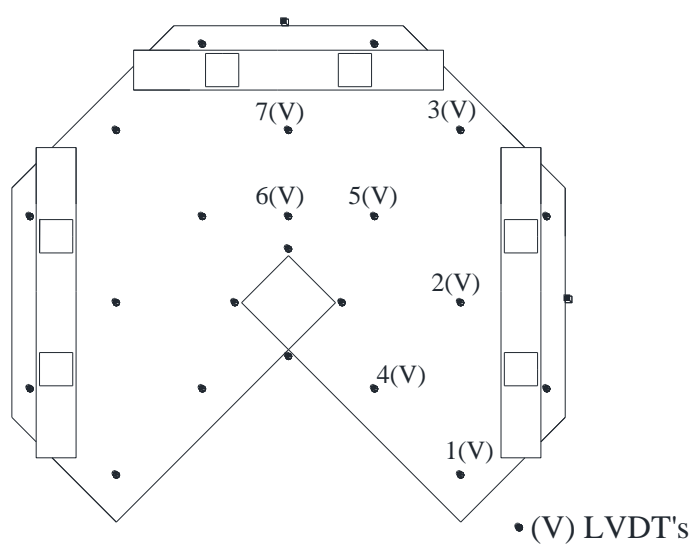

Laje LO3

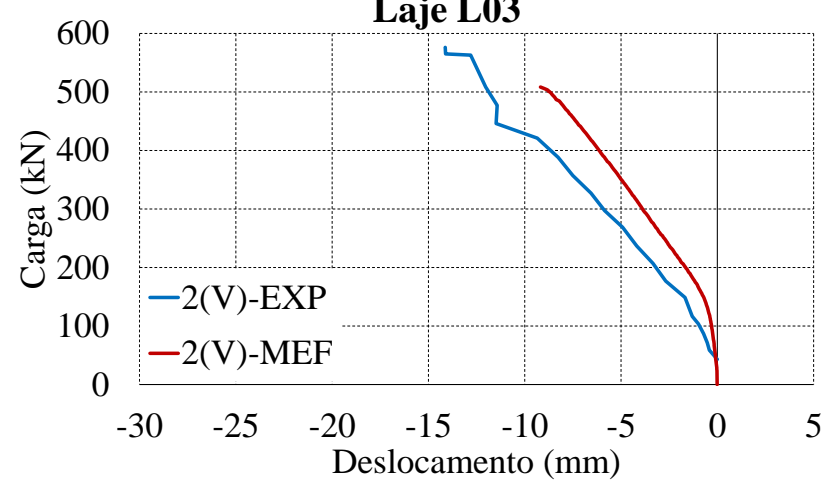

(b) Deslocamentos no ponto 2

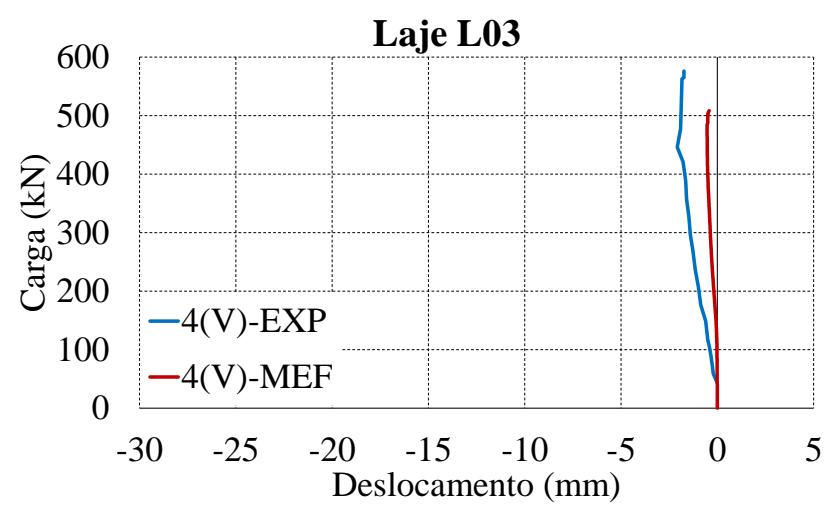

(d) Deslocamentos no ponto 4

Laje LO3

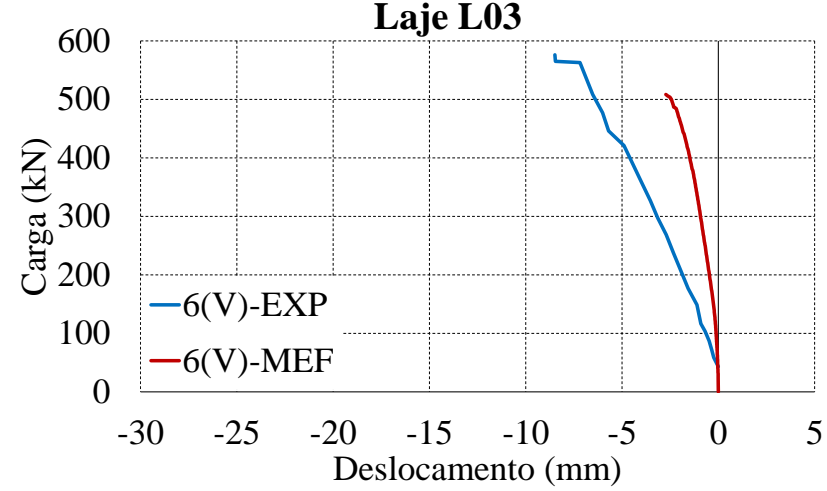

(f) Deslocamentos no ponto 6

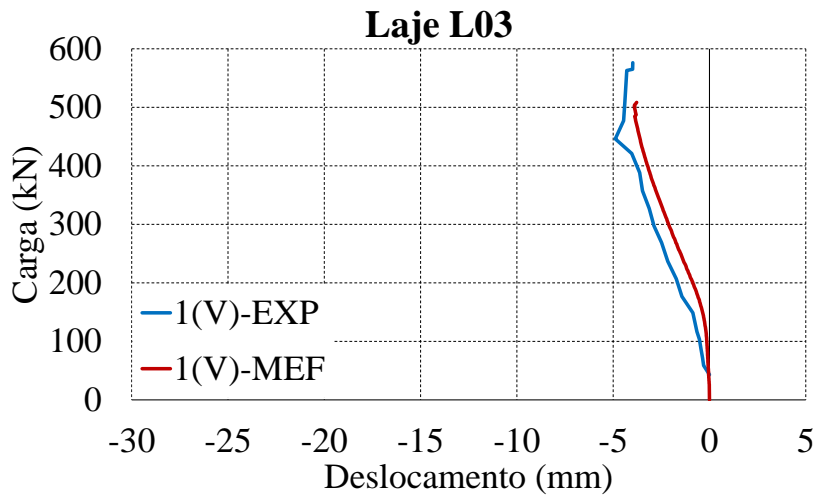

(a) Deslocamentos no ponto 1

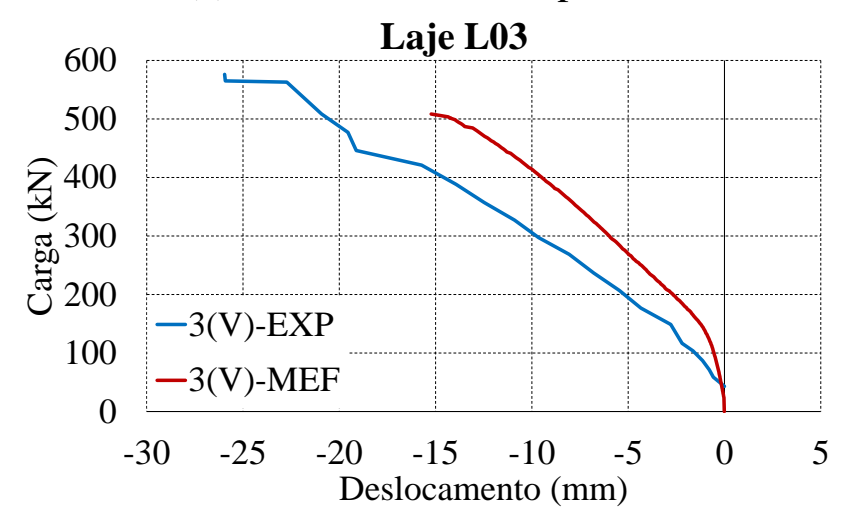

(c) Deslocamentos no ponto 3

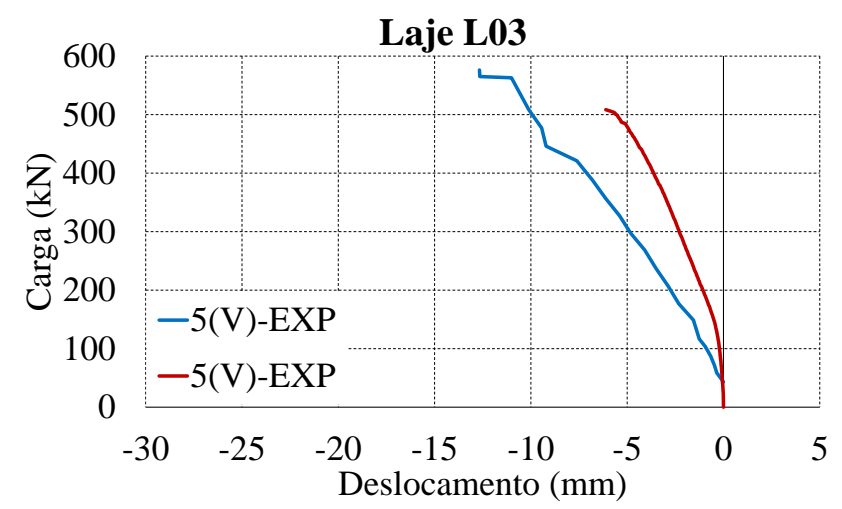

(e) Deslocamentos no ponto 5

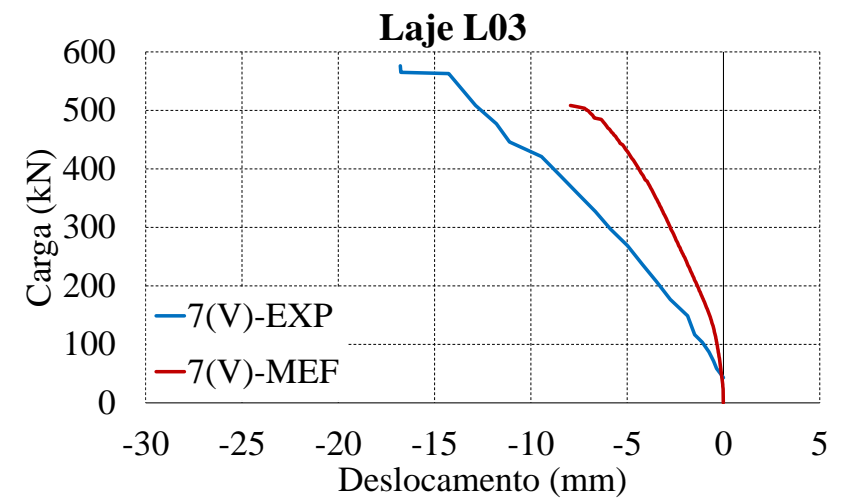

(g) Deslocamentos no ponto 7

Figura 6.18 - Deslocamentos da Laje L03 


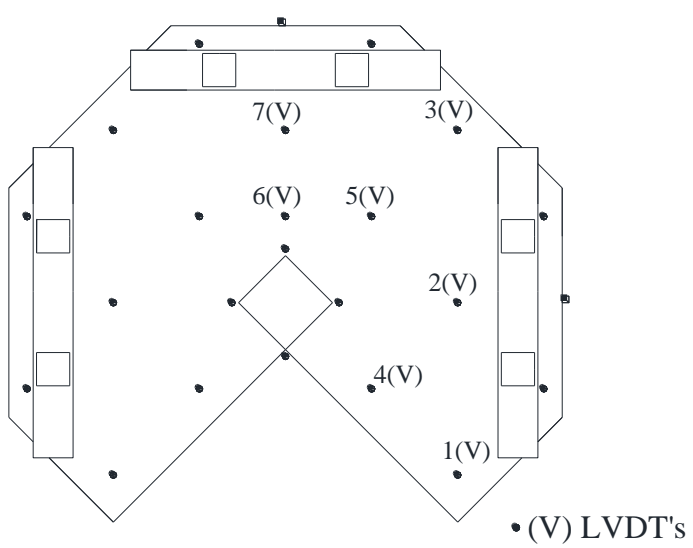

Laje LO4

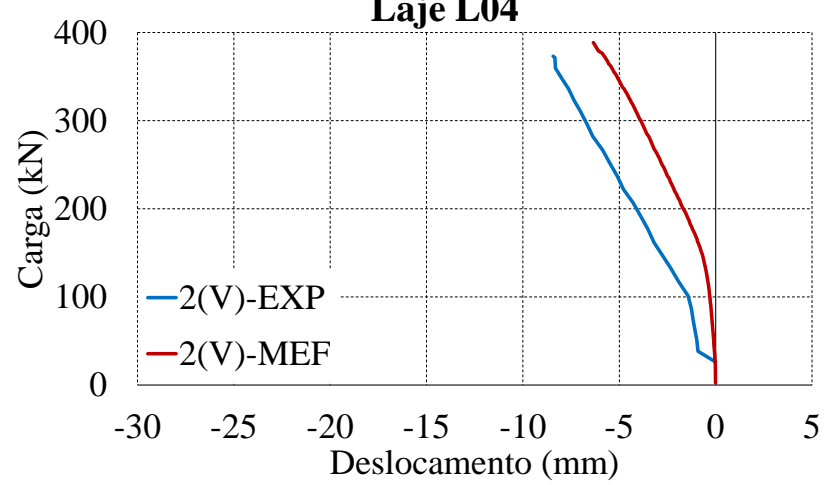

(b) Deslocamentos no ponto 2

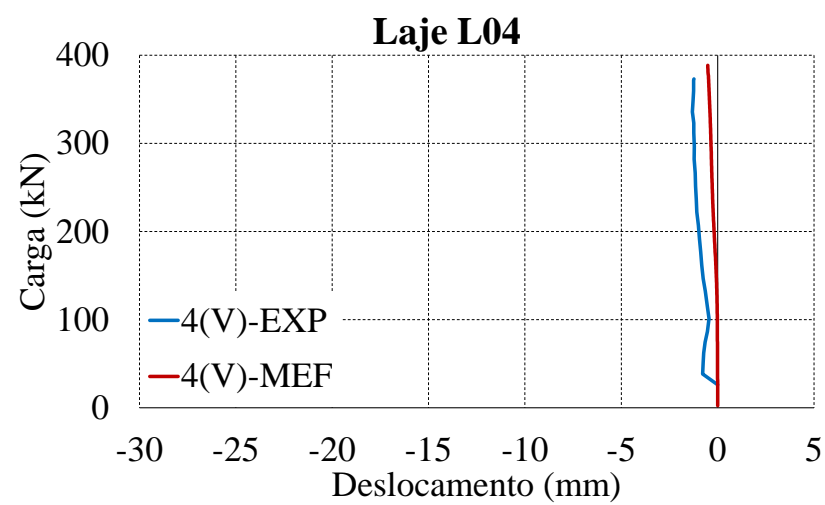

(d) Deslocamentos no ponto 4

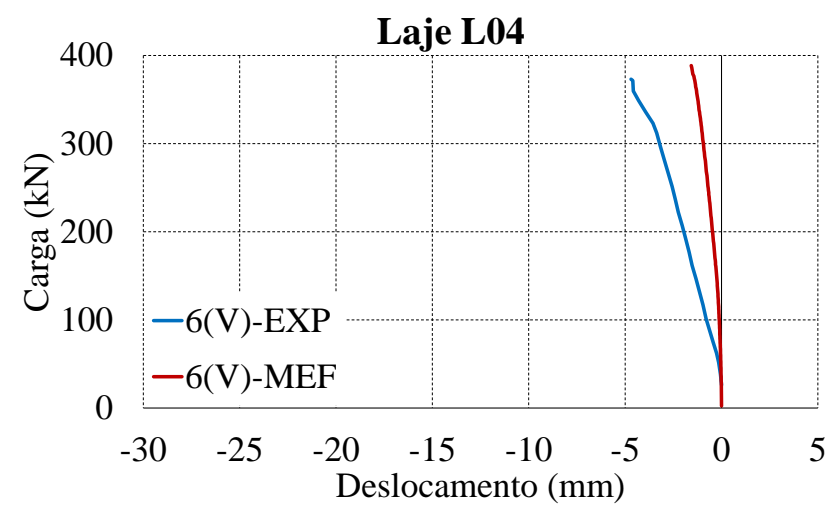

(f) Deslocamentos no ponto 6

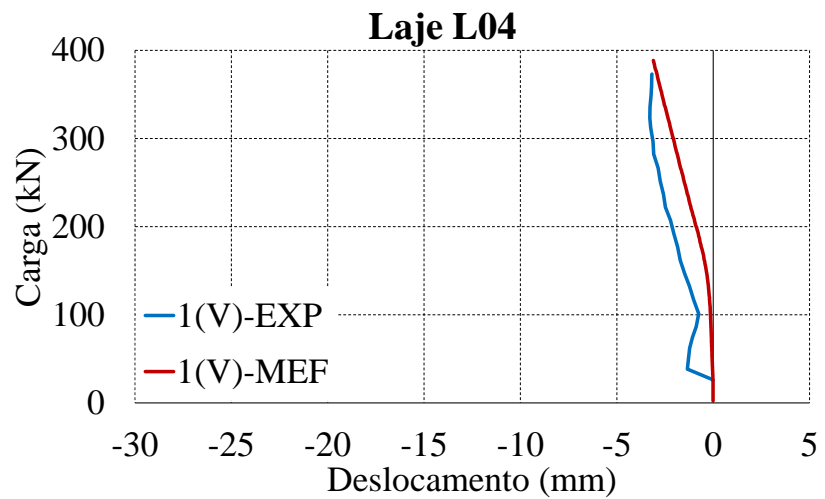

(a) Deslocamentos no ponto 1

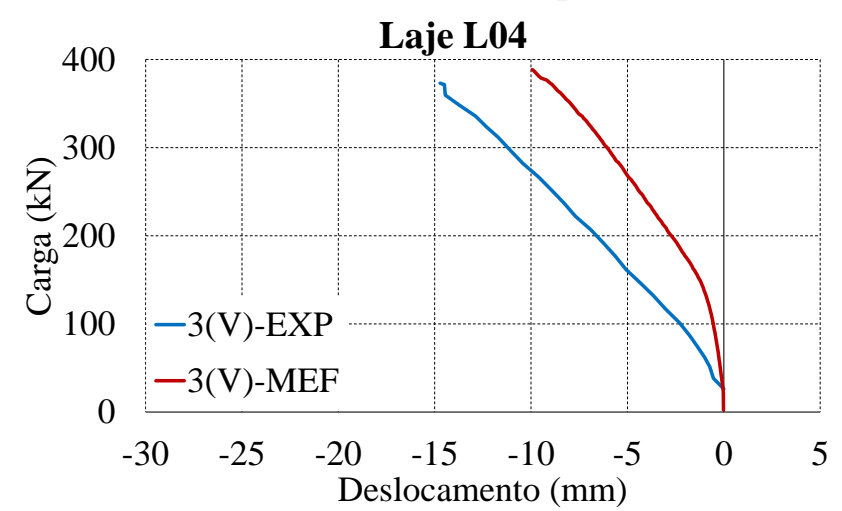

(c) Deslocamentos no ponto 3

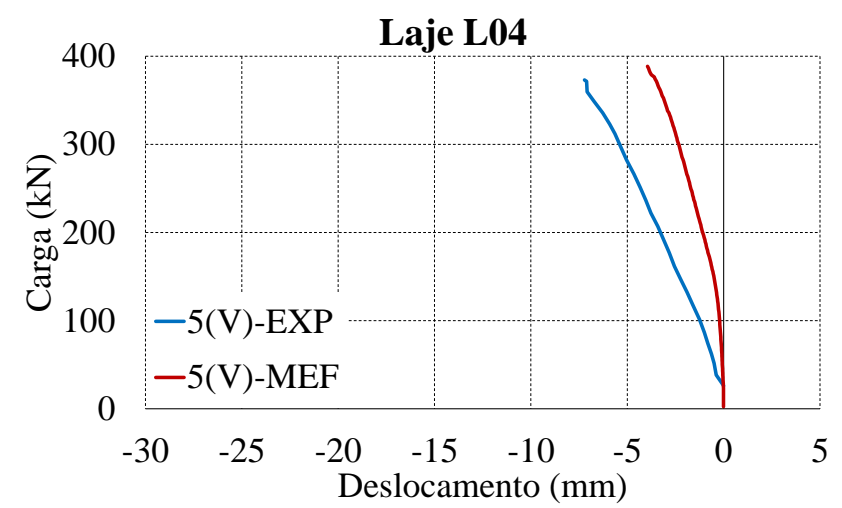

(e) Deslocamentos no ponto 5

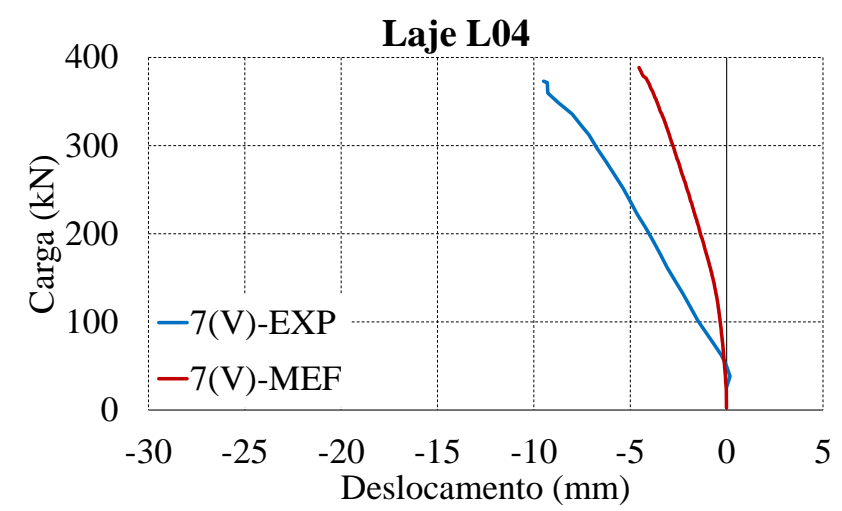

(g) Deslocamentos no ponto 7

Figura 6.19 - Deslocamentos da Laje L04 


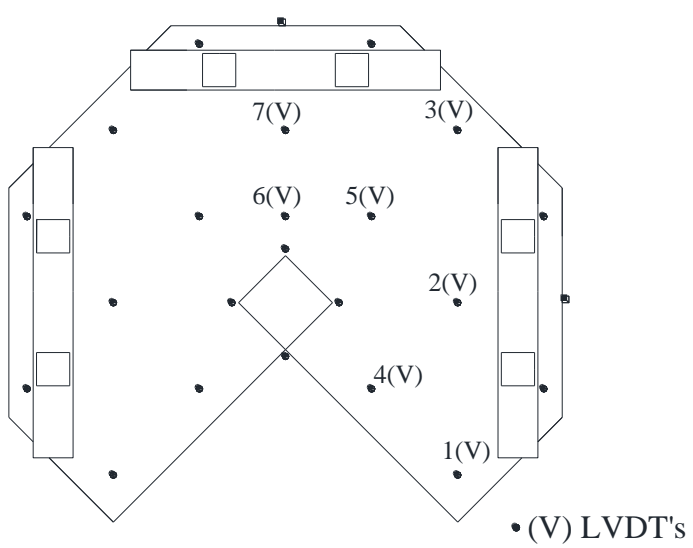

Laje L05

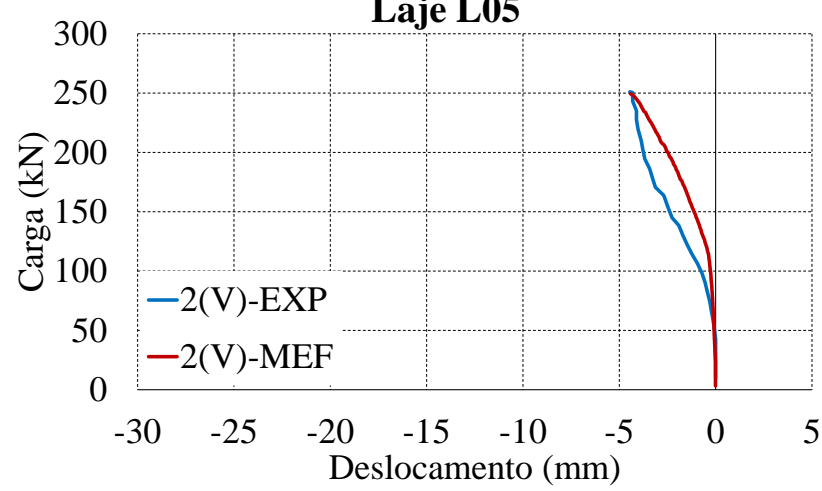

(b) Deslocamentos no ponto 2

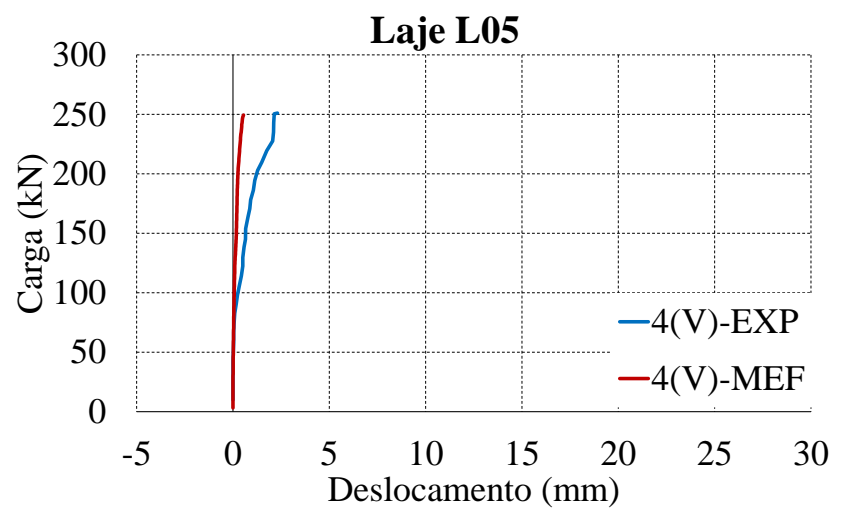

(d) Deslocamentos no ponto 4

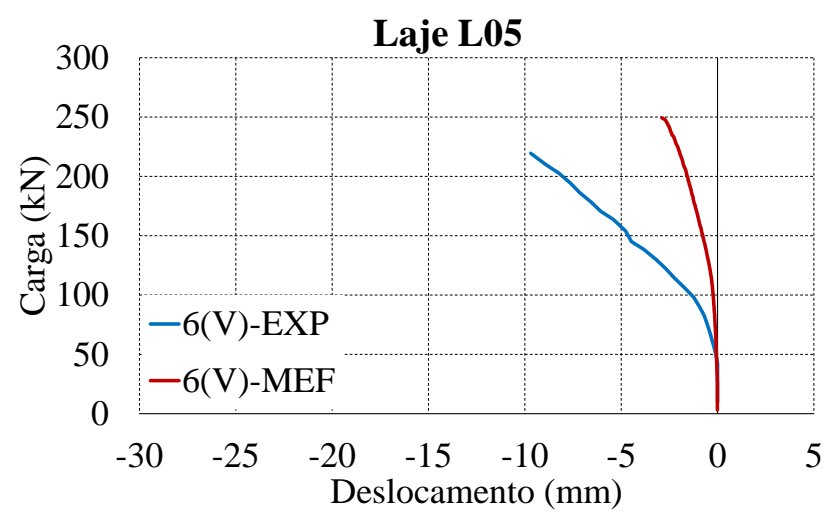

(f) Deslocamentos no ponto 6

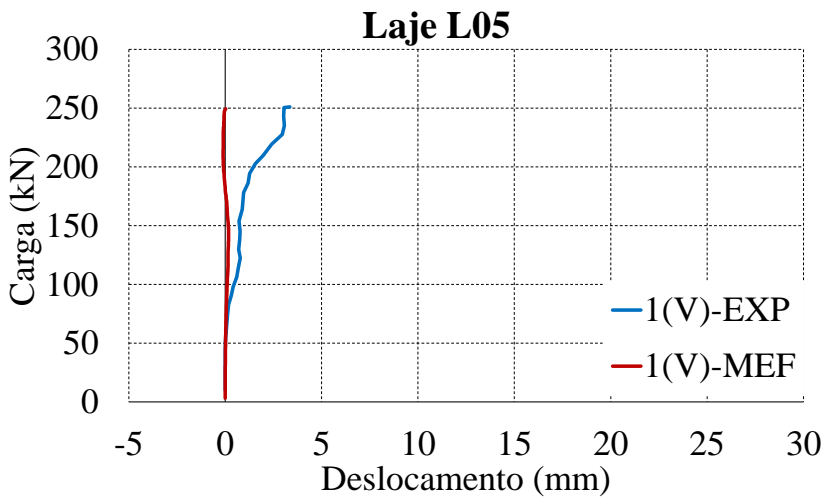

(a) Deslocamentos no ponto 1

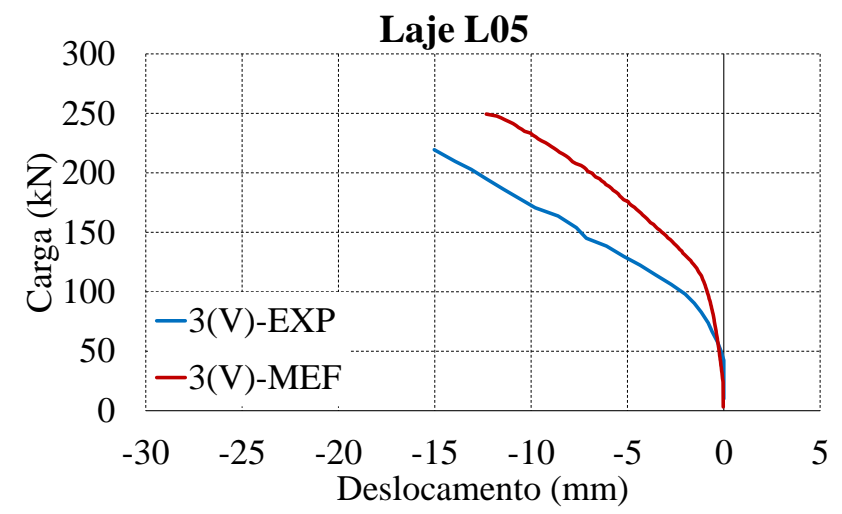

(c) Deslocamentos no ponto 3

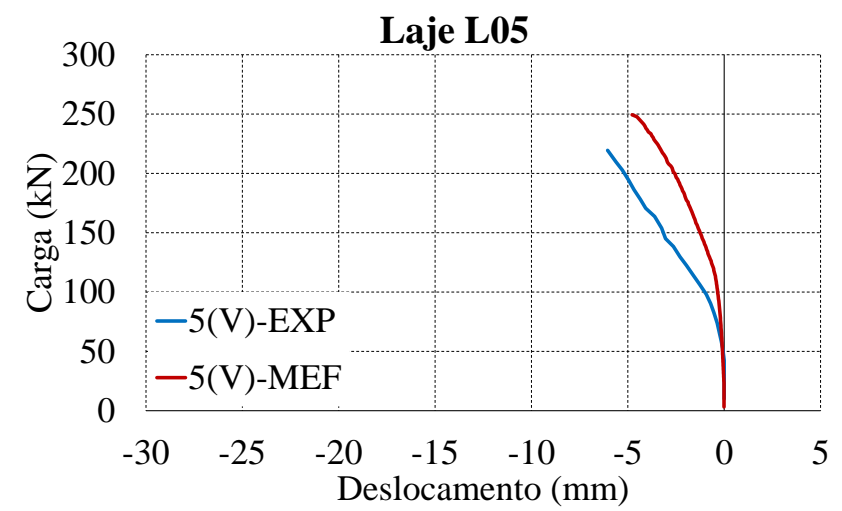

(e) Deslocamentos no ponto 5

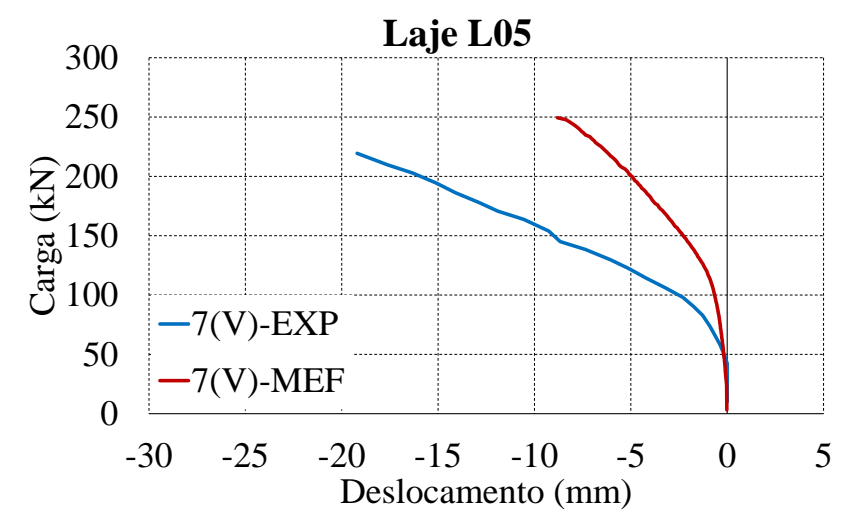

(g) Deslocamentos no ponto 7

Figura 6.20 - Deslocamentos da Laje L05 

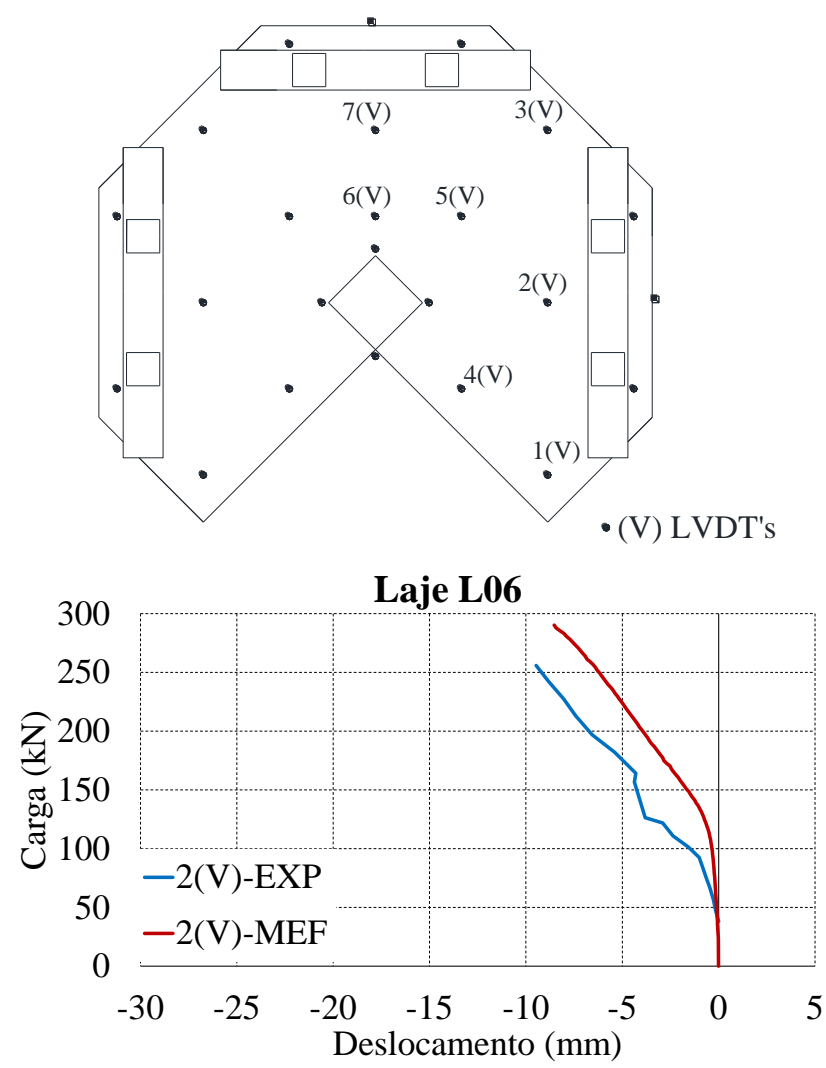

(b) Deslocamentos no ponto 2

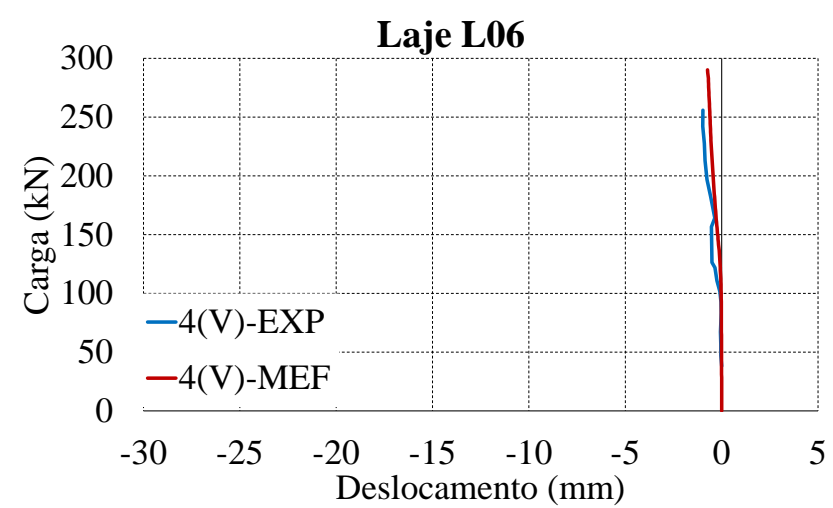

(d) Deslocamentos no ponto 4

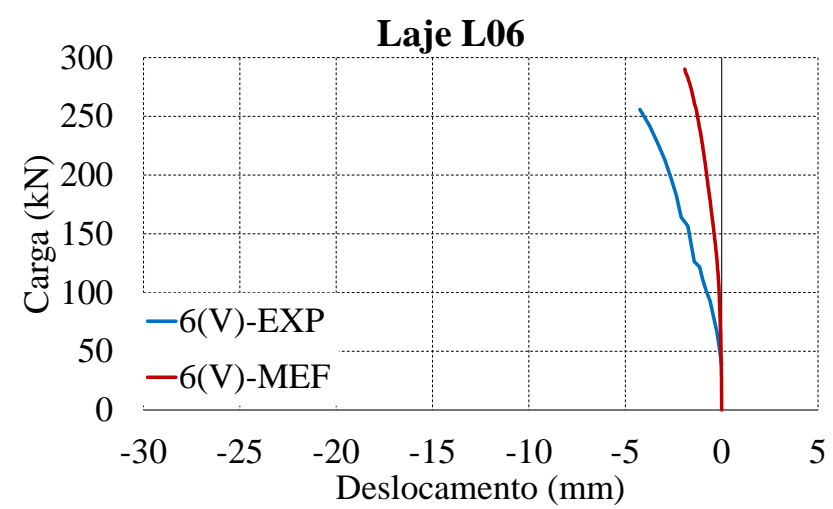

(f) Deslocamentos no ponto 6

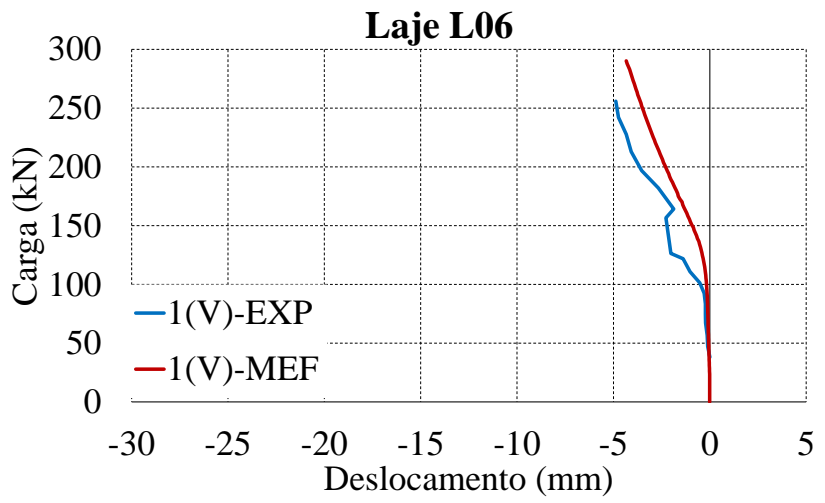

(a) Deslocamentos no ponto 1

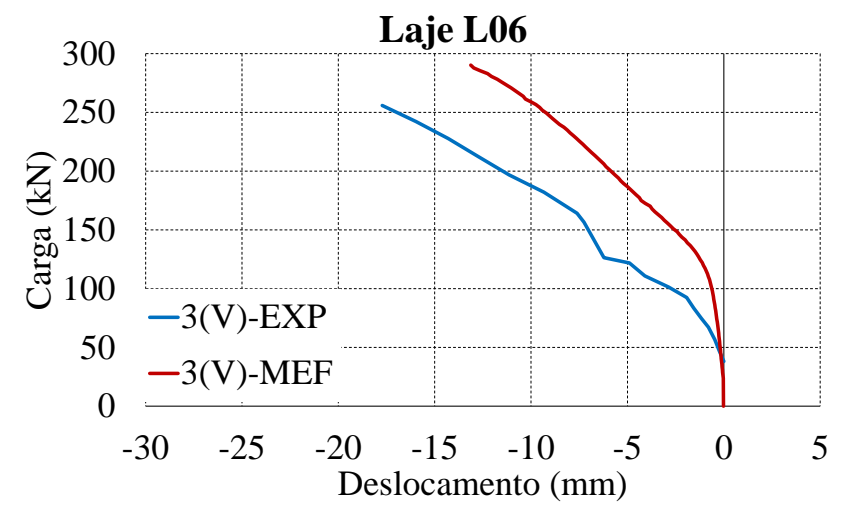

(c) Deslocamentos no ponto 3

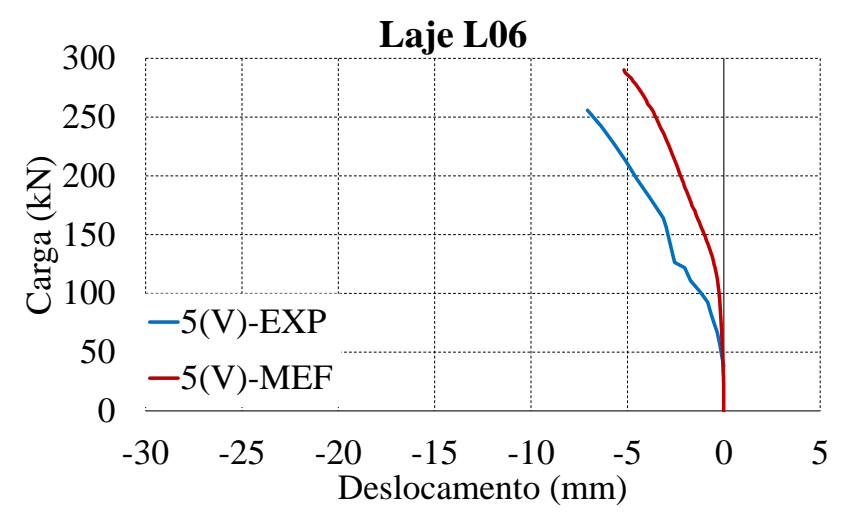

(e) Deslocamentos no ponto 5

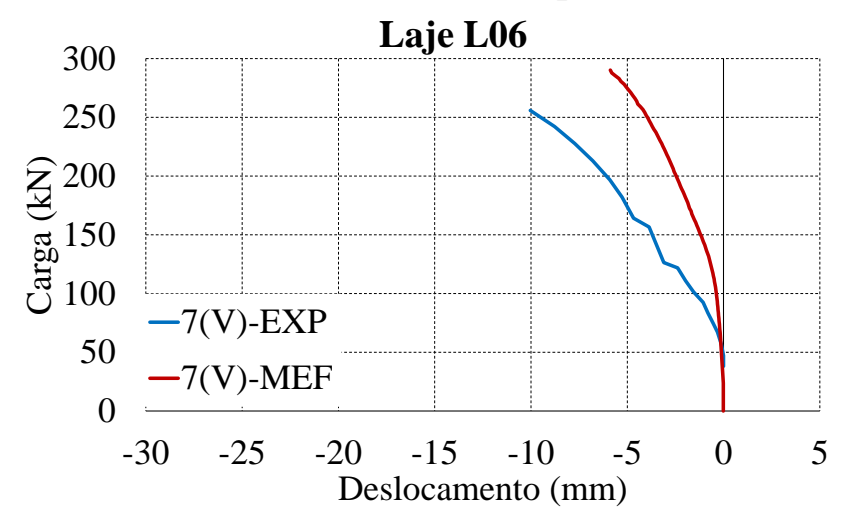

(g) Deslocamentos no ponto 7

Figura 6.21 - Deslocamentos da Laje L06 


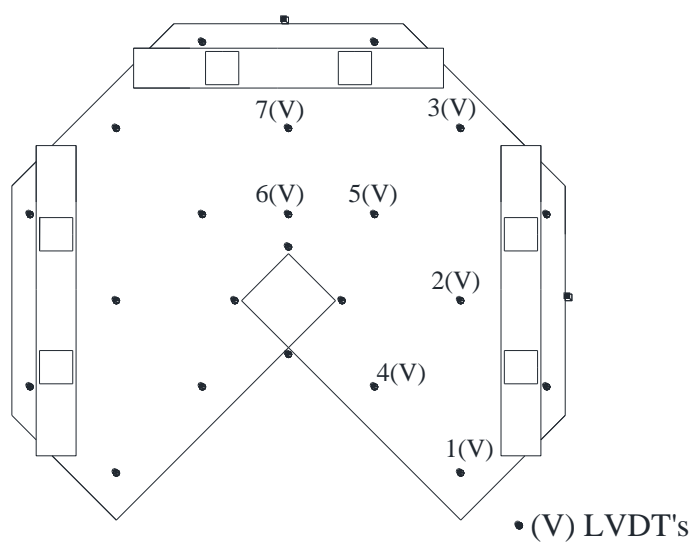

Laje L07

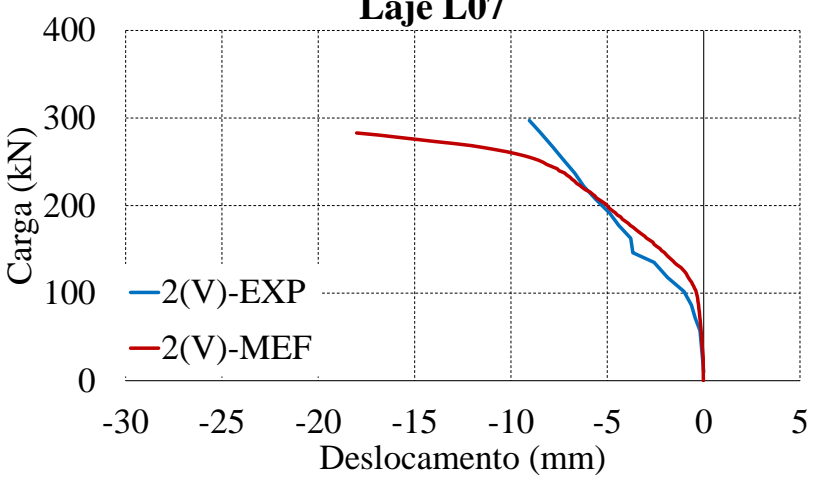

(b) Deslocamentos no ponto 2

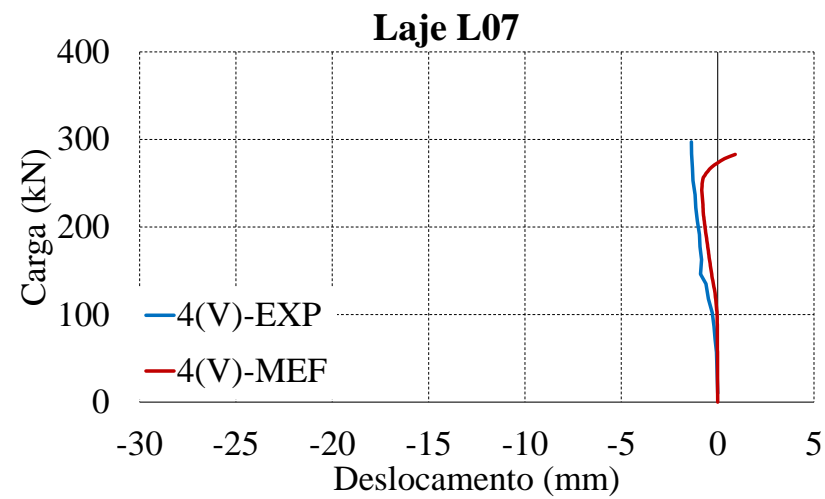

(d) Deslocamentos no ponto 4

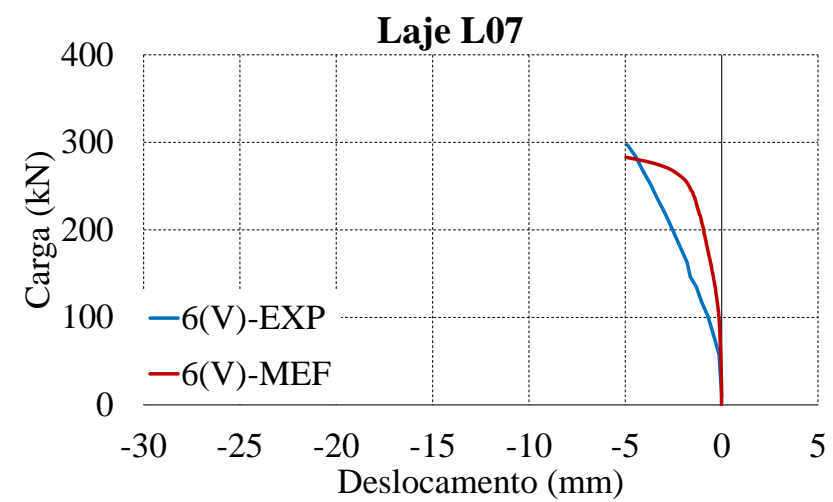

(f) Deslocamentos no ponto 6

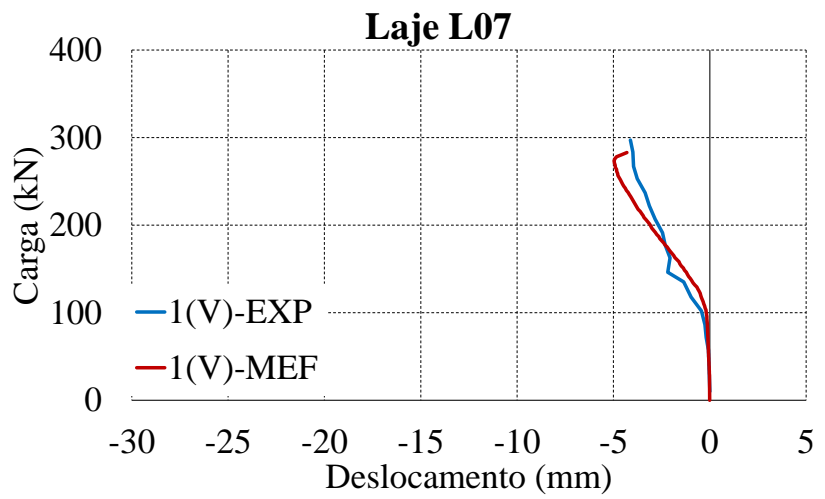

(a) Deslocamentos no ponto 1

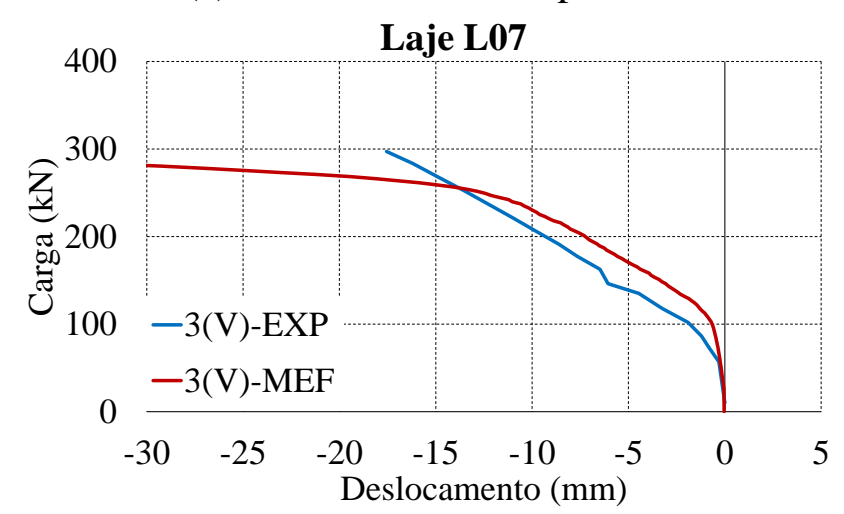

(c) Deslocamentos no ponto 3

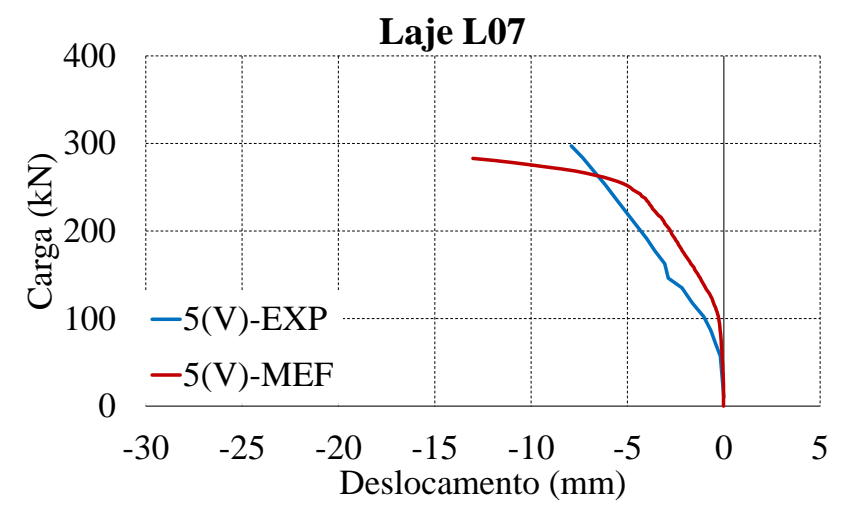

(e) Deslocamentos no ponto 5

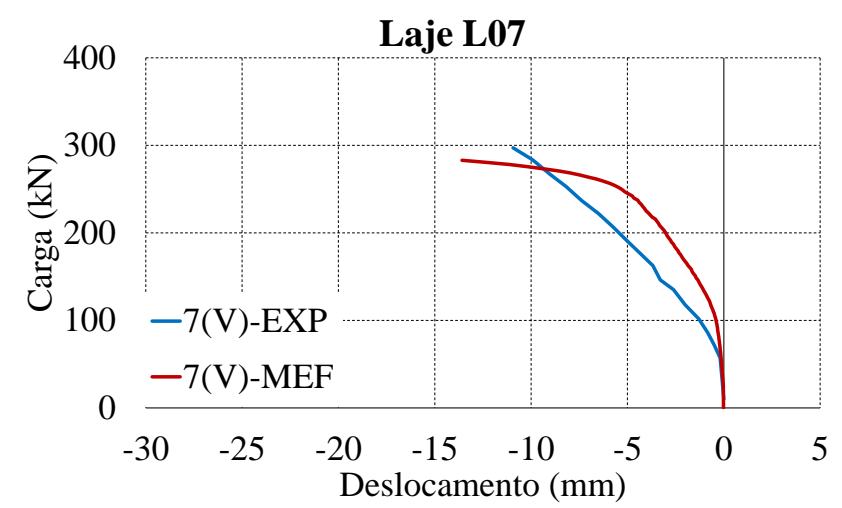

(g) Deslocamentos no ponto 7

Figura 6.22 - Deslocamentos da Laje L07 


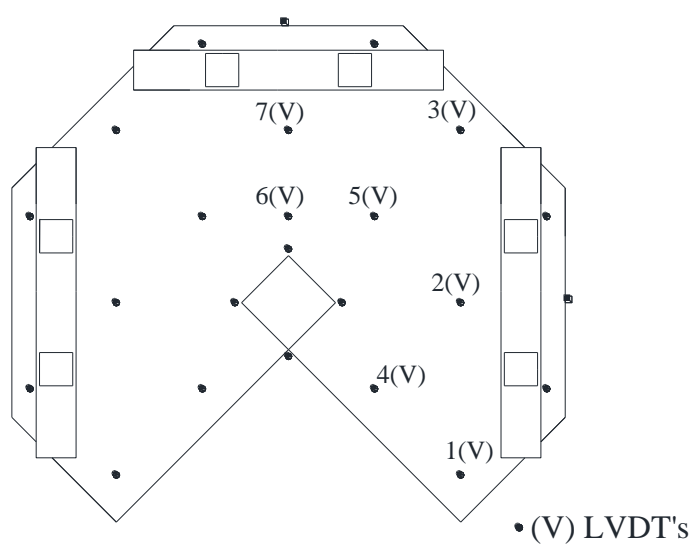

Laje L08

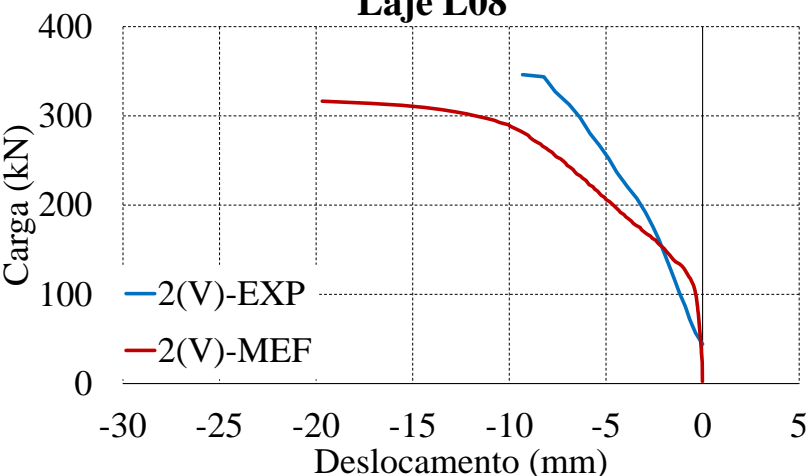

(b) Deslocamentos no ponto 2

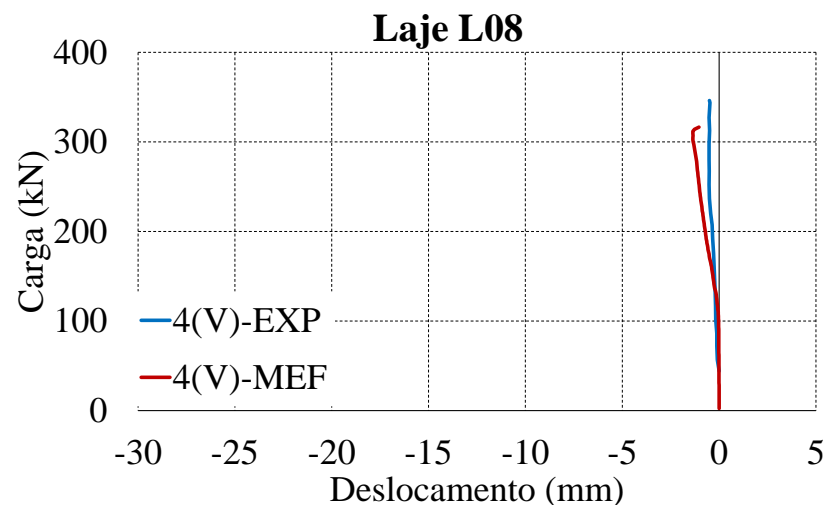

(d) Deslocamentos no ponto 4

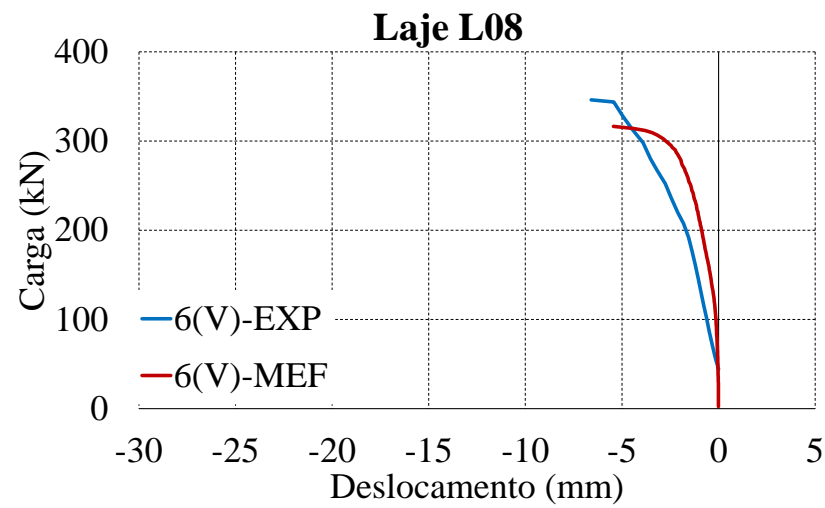

(f) Deslocamentos no ponto 6

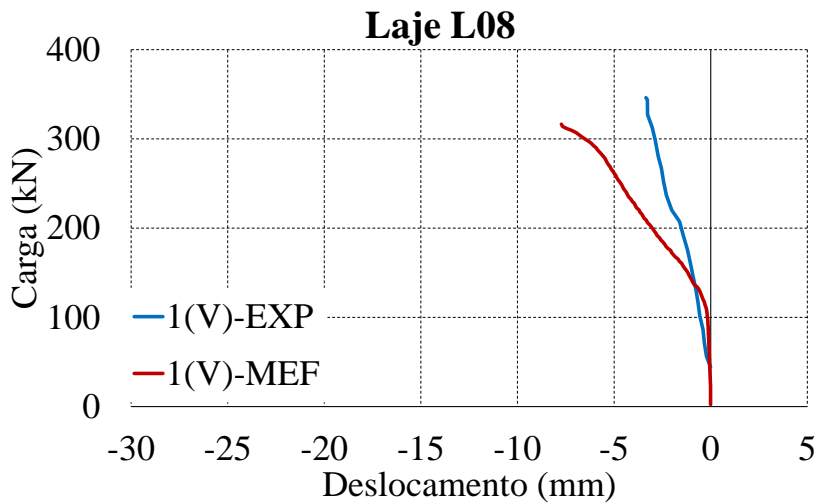

(a) Deslocamentos no ponto 1

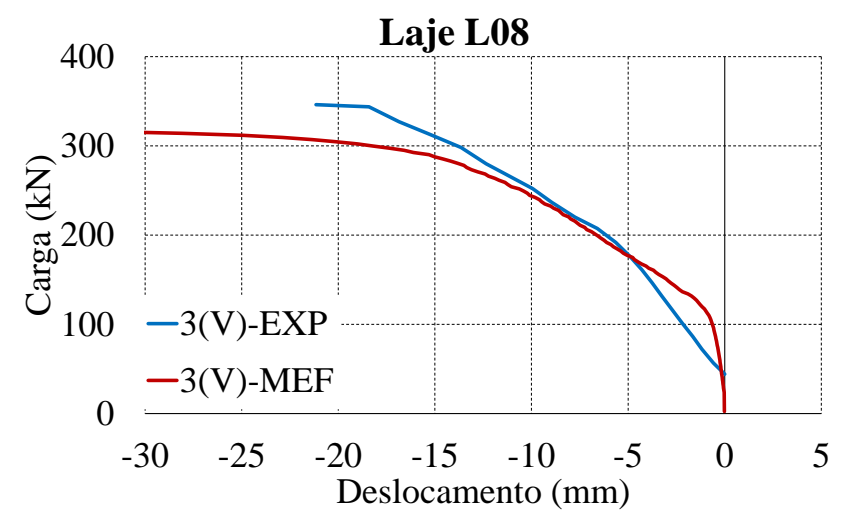

(c) Deslocamentos no ponto 3

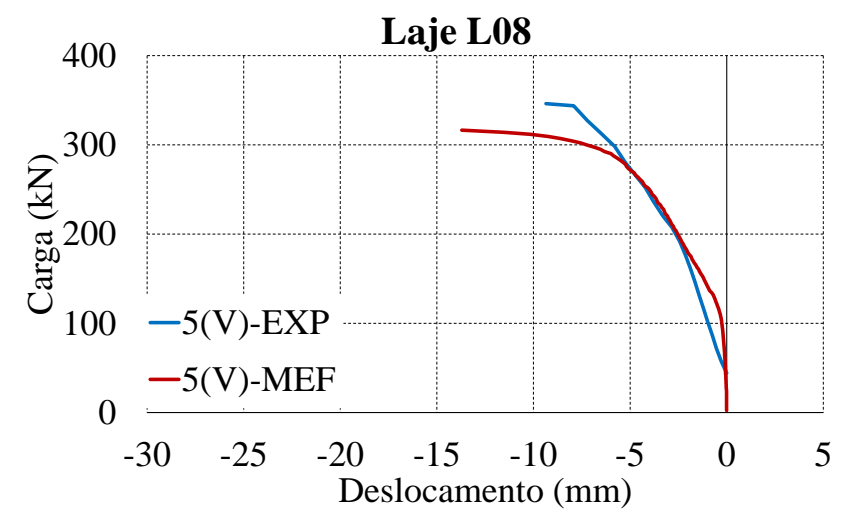

(e) Deslocamentos no ponto 5

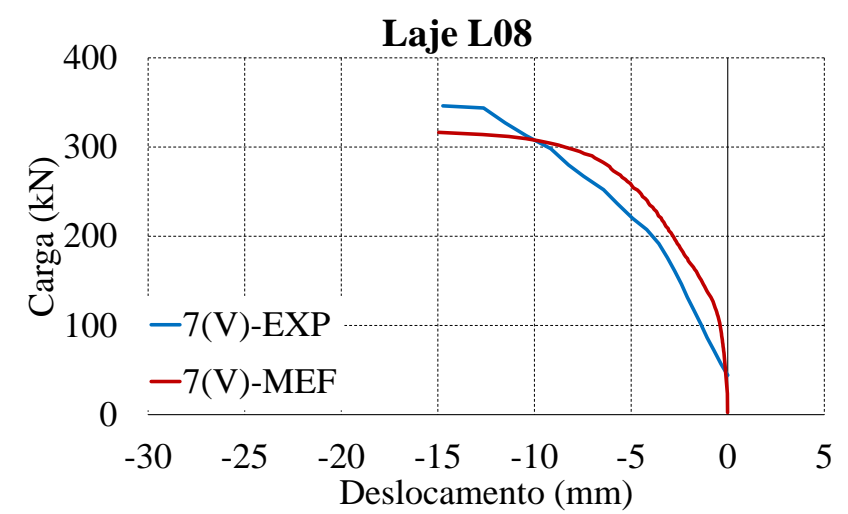

(g) Deslocamentos no ponto 7

Figura 6.23 - Deslocamentos da Laje L08 


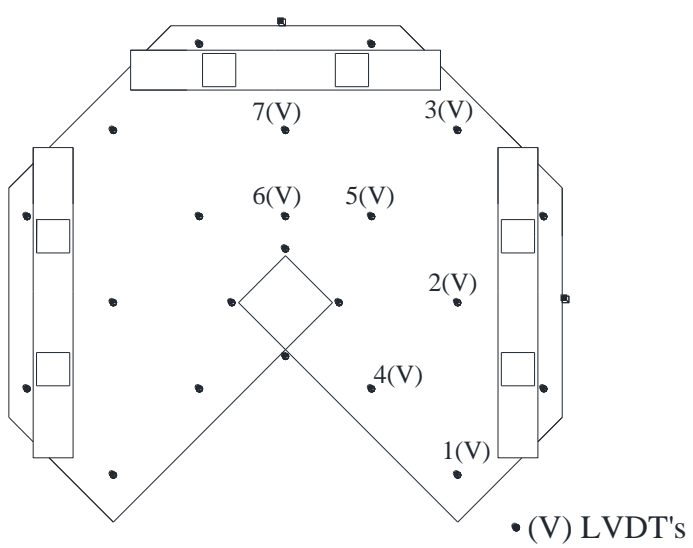

Laje L09

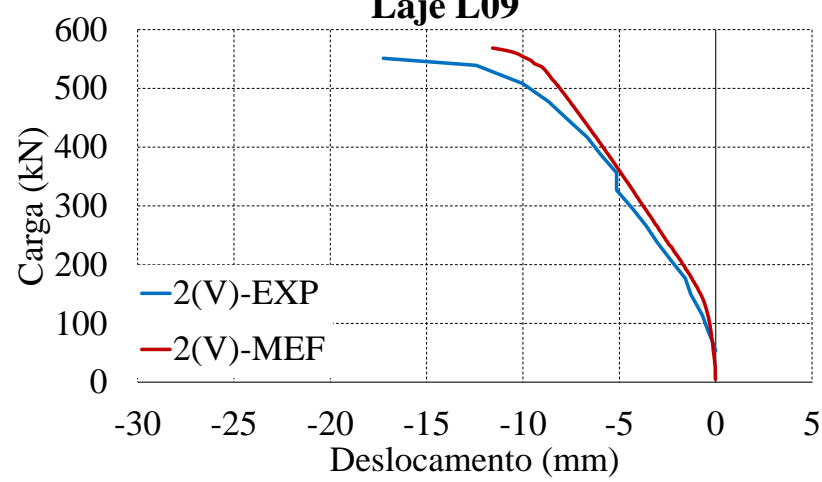

(b) Deslocamentos no ponto 2

Laje L09

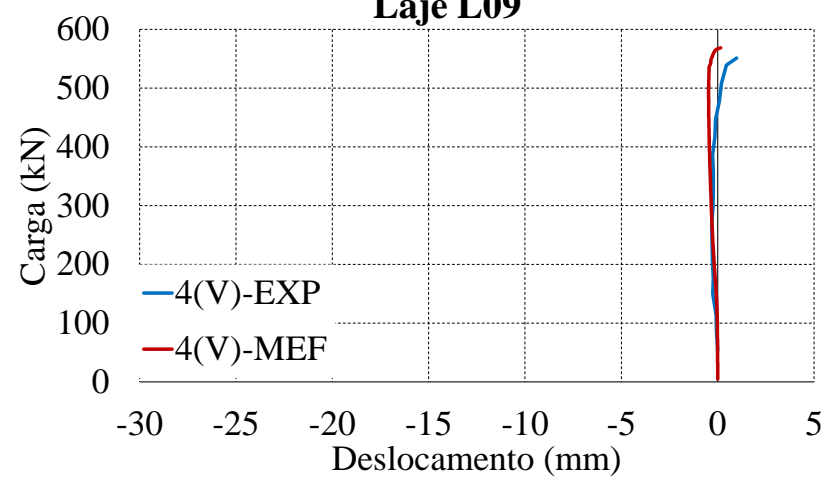

(d) Deslocamentos no ponto 4

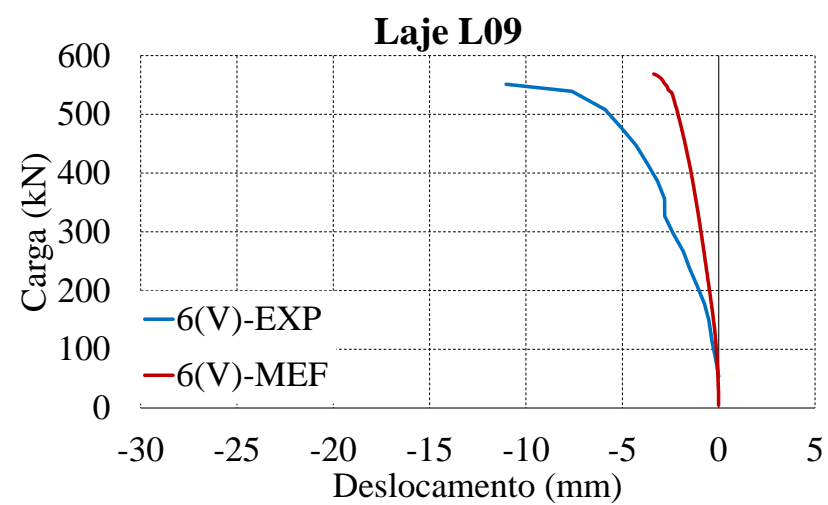

(f) Deslocamentos no ponto 6

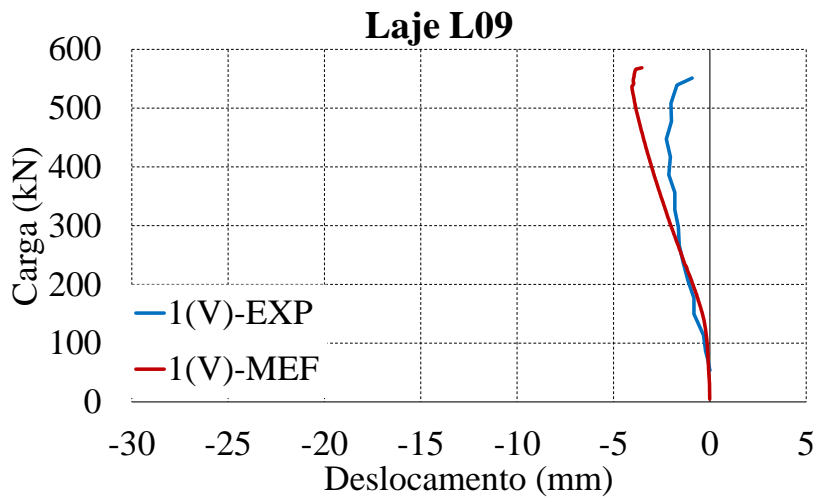

(a) Deslocamentos no ponto 1

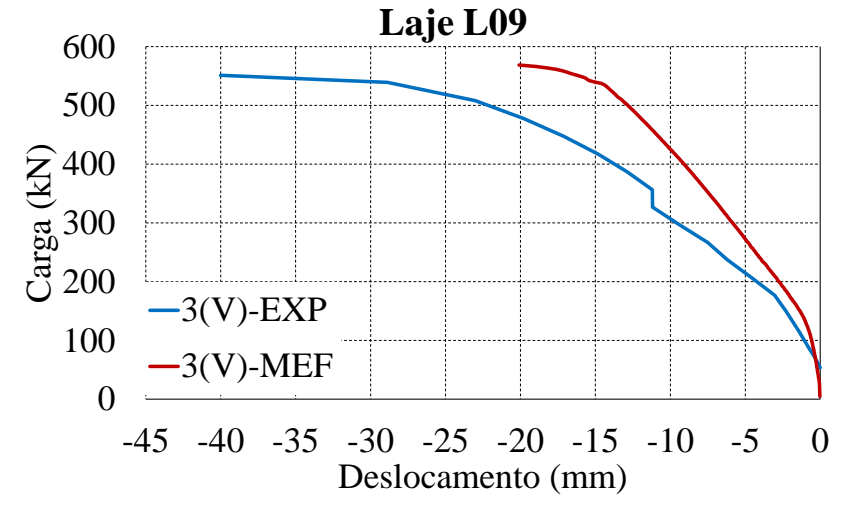

(c) Deslocamentos no ponto 3

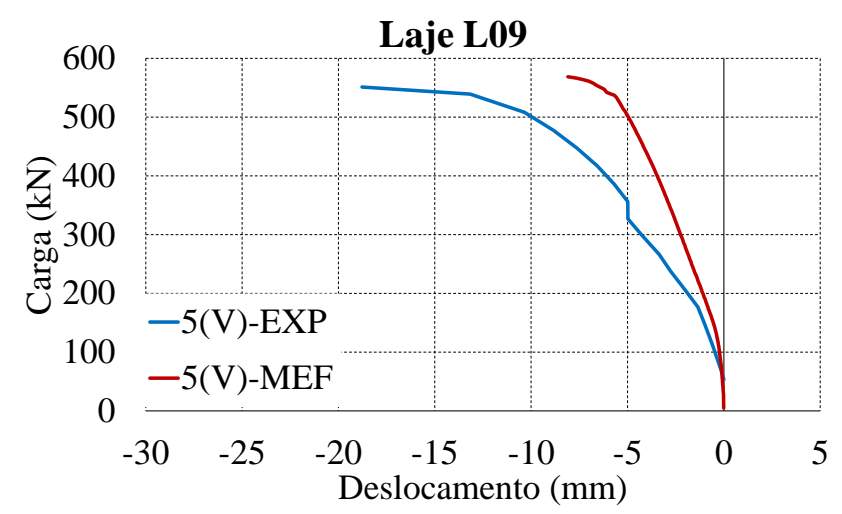

(e) Deslocamentos no ponto 5

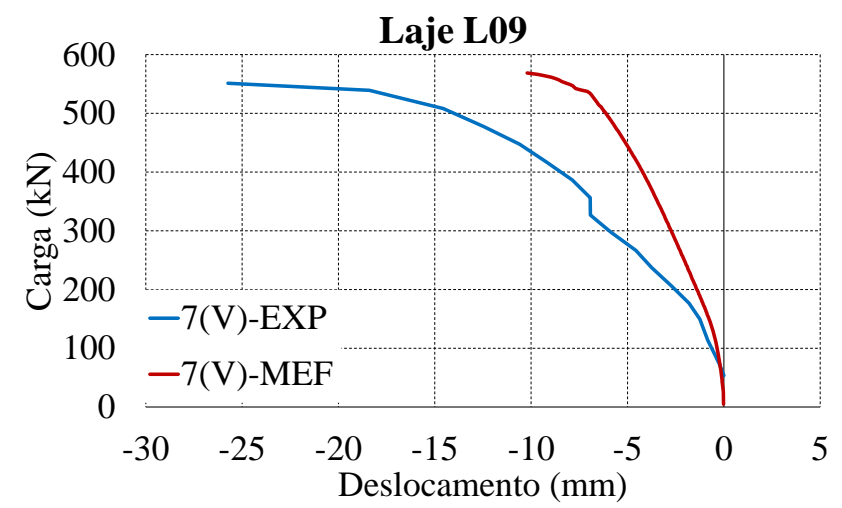

(g) Deslocamentos no ponto 7

Figura 6.24 - Deslocamentos da Laje L09 


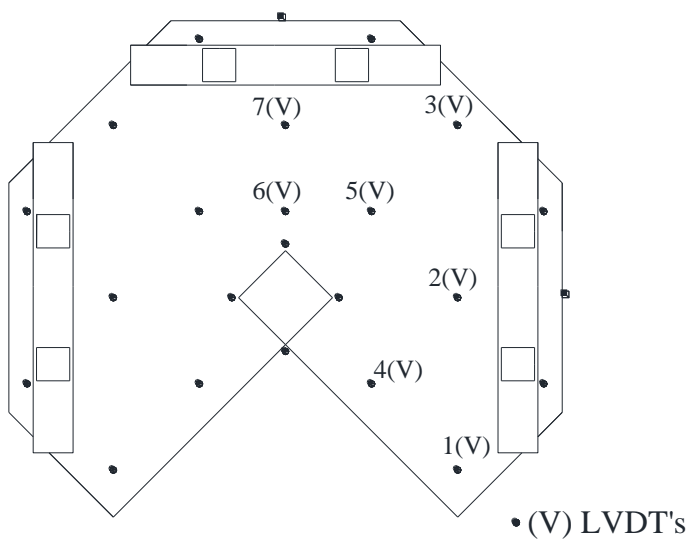

Laje L10

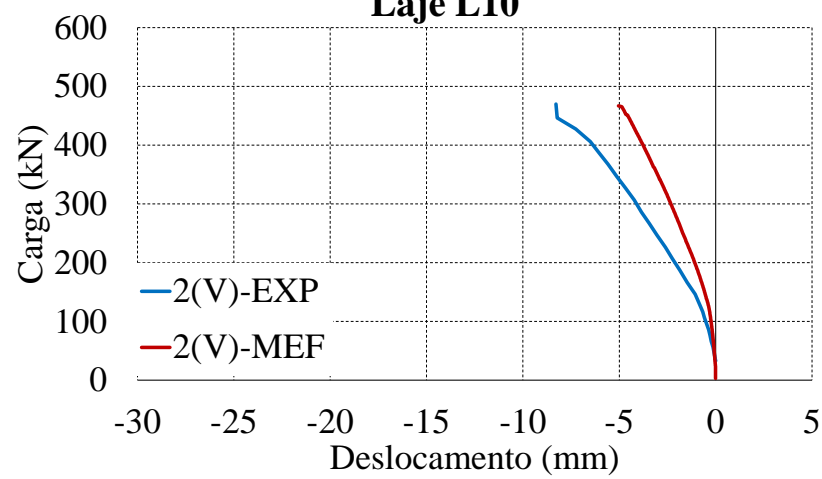

(b) Deslocamentos no ponto 2

Laje L10

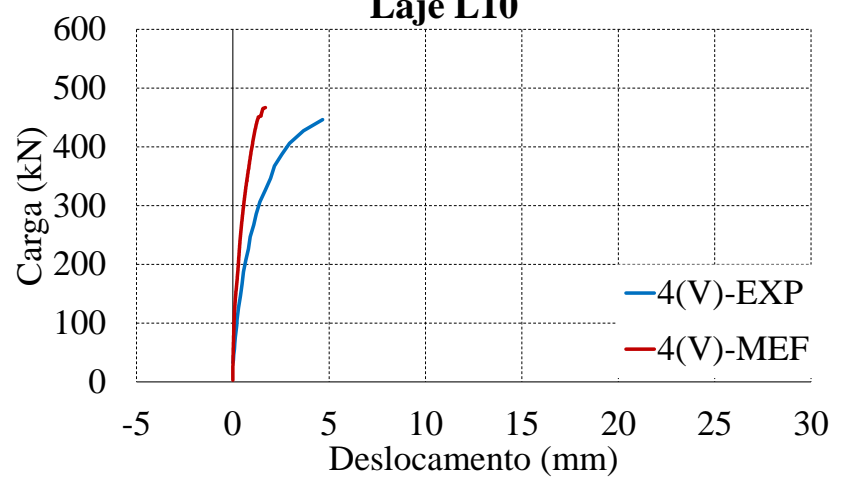

(d) Deslocamentos no ponto 4

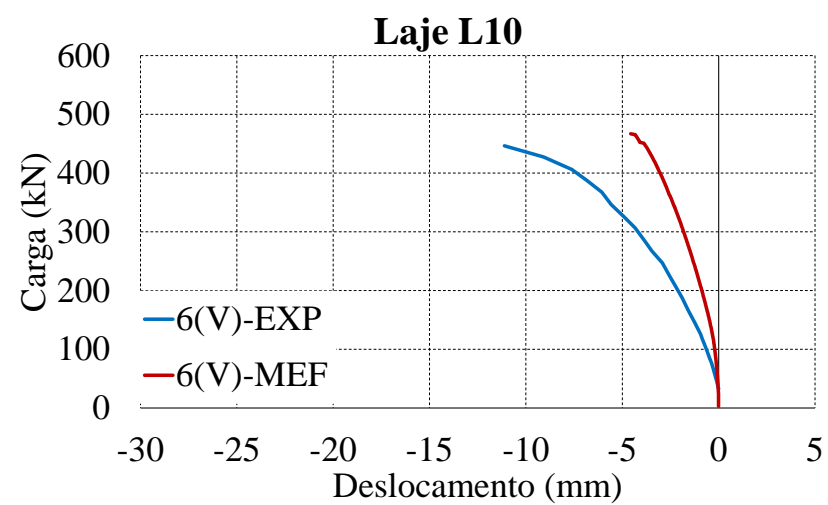

(f) Deslocamentos no ponto 6

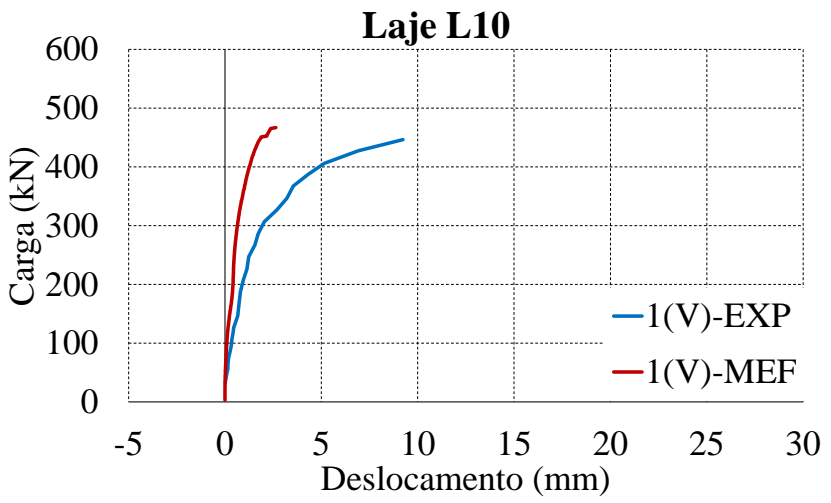

(a) Deslocamentos no ponto 1

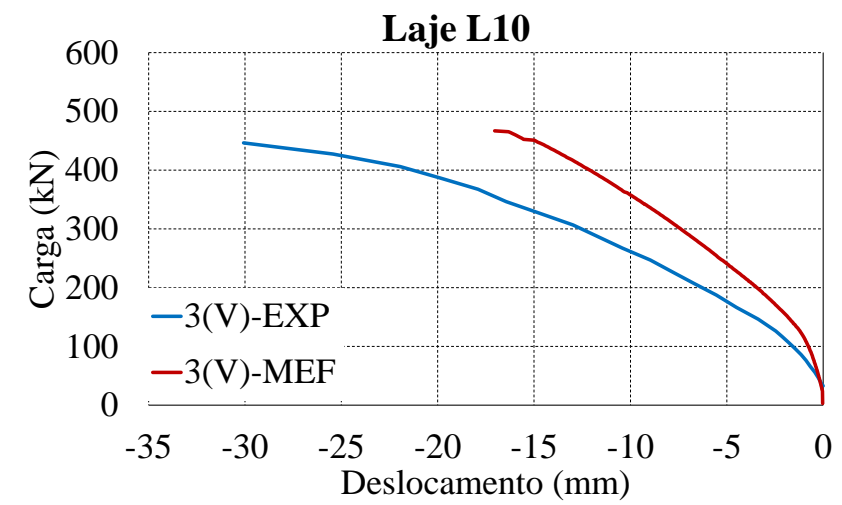

(c) Deslocamentos no ponto 3

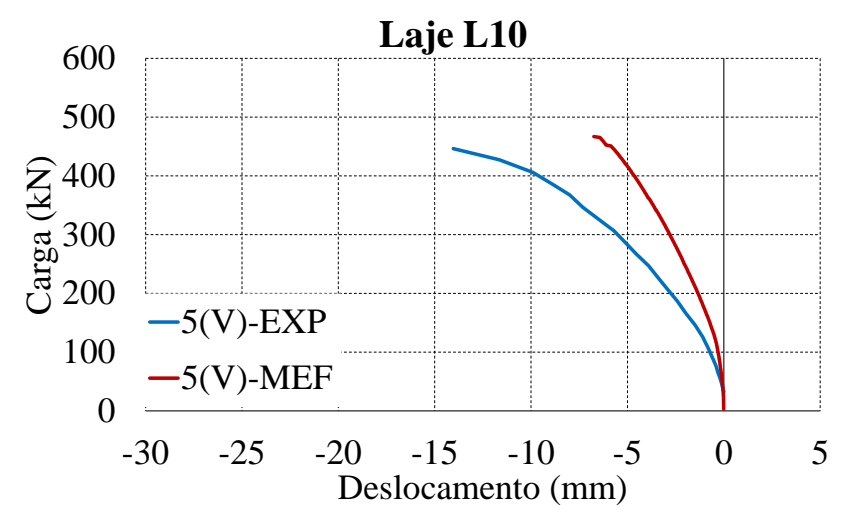

(e) Deslocamentos no ponto 5

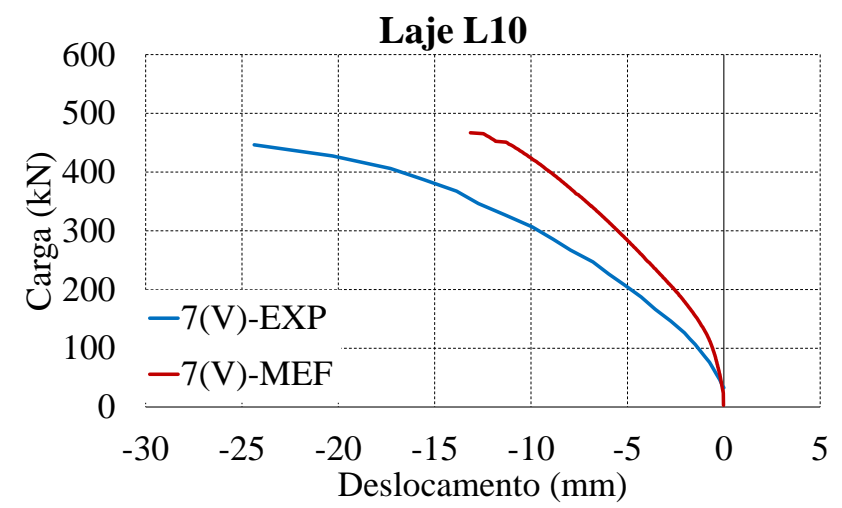

(g) Deslocamentos no ponto 7

Figura 6.25 - Deslocamentos da Laje L10 


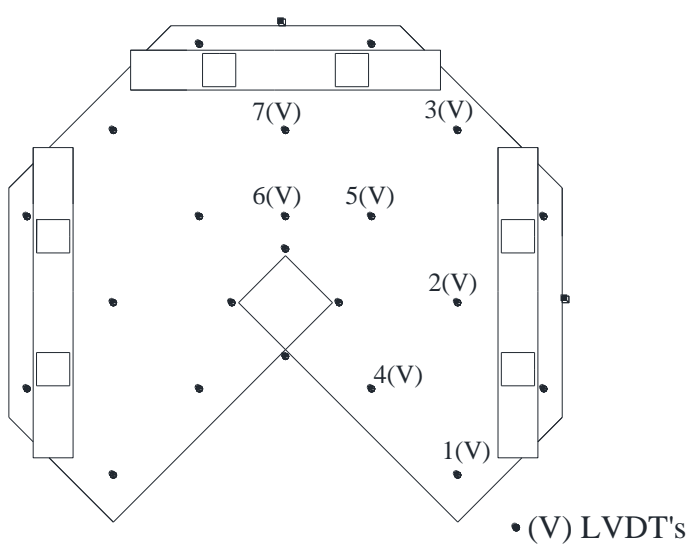

Laje L11

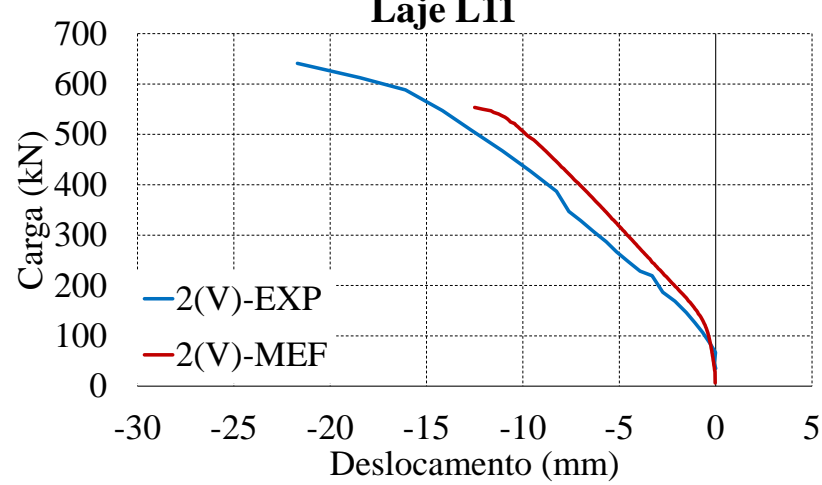

(b) Deslocamentos no ponto 2

Laje L11

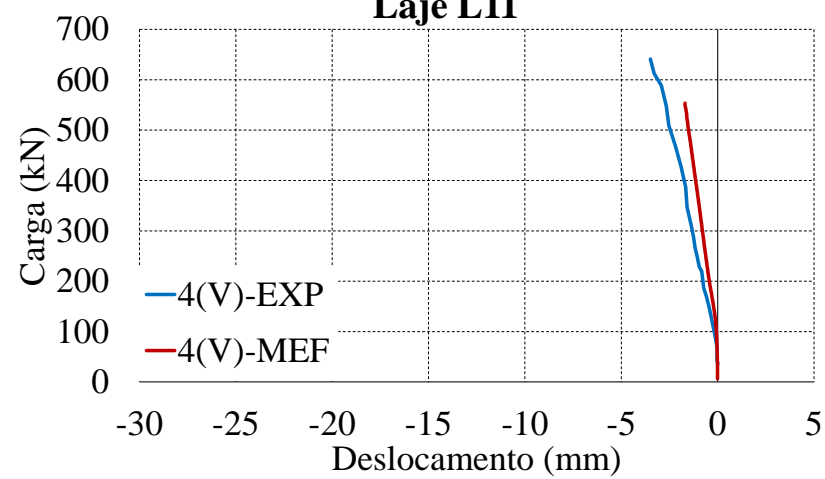

(d) Deslocamentos no ponto 4

Laje L11

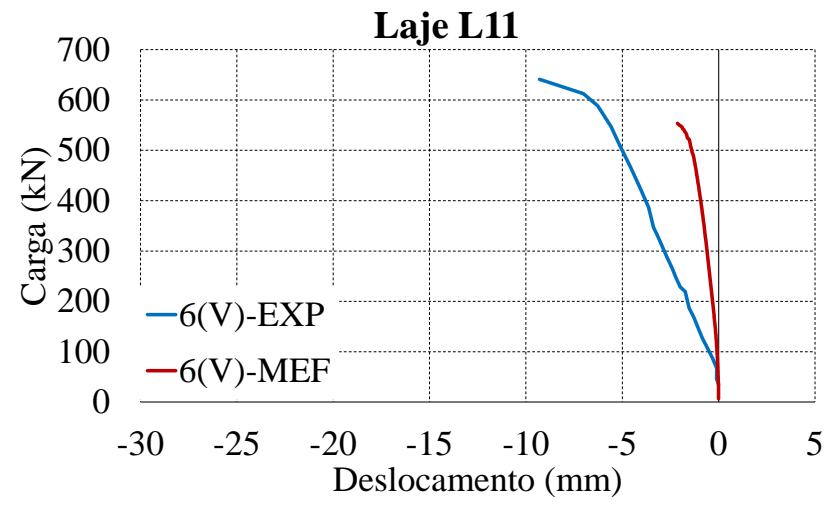

(f) Deslocamentos no ponto 6

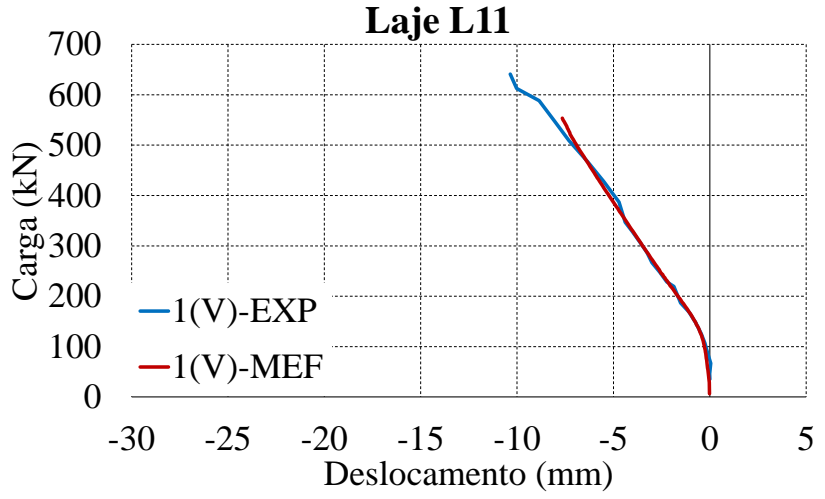

(a) Deslocamentos no ponto 1

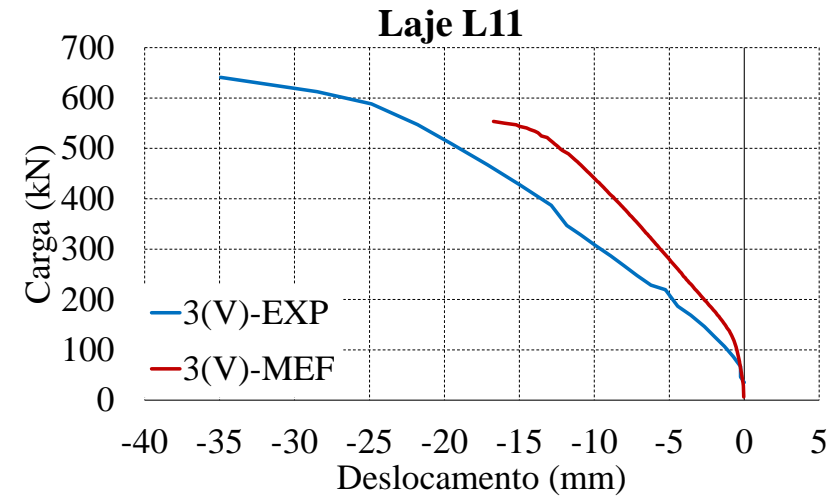

(c) Deslocamentos no ponto 3

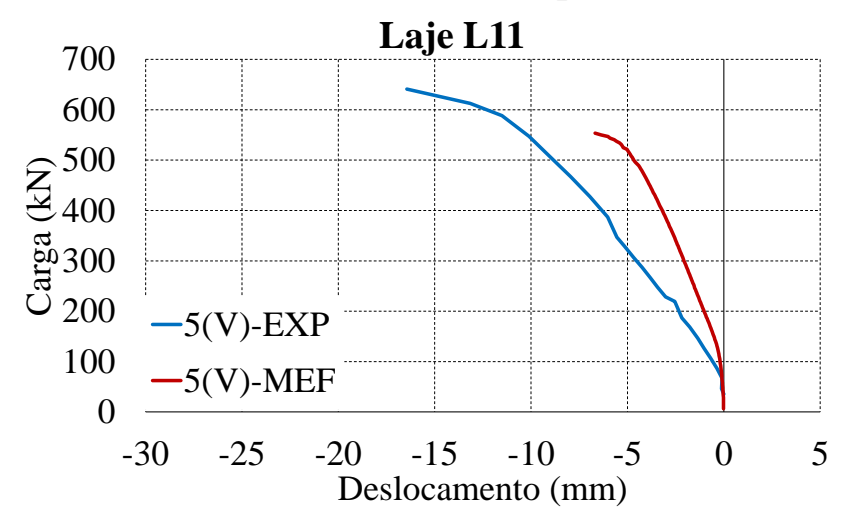

(e) Deslocamentos no ponto 5

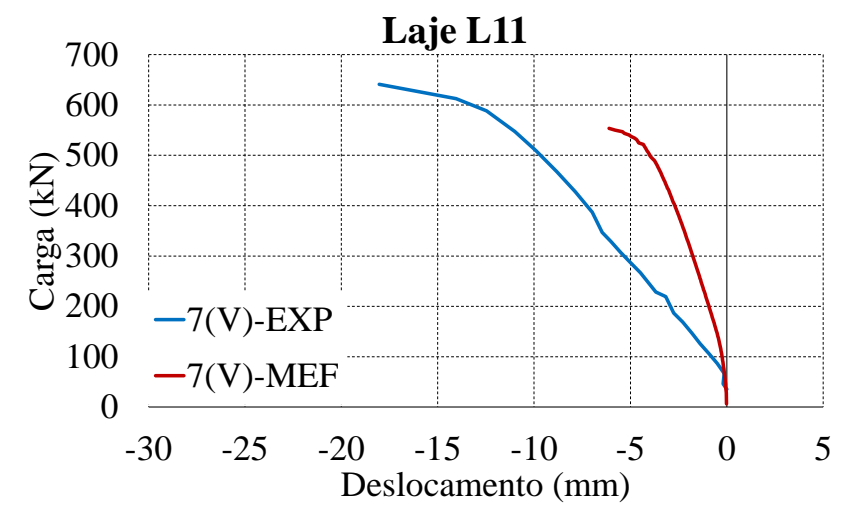

(g) Deslocamentos no ponto 7

Figura 6.26 - Deslocamentos da Laje L11 


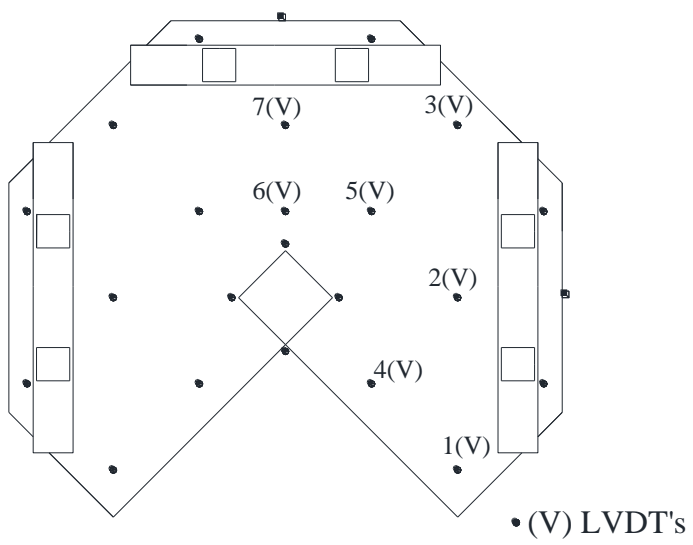

Laje L12

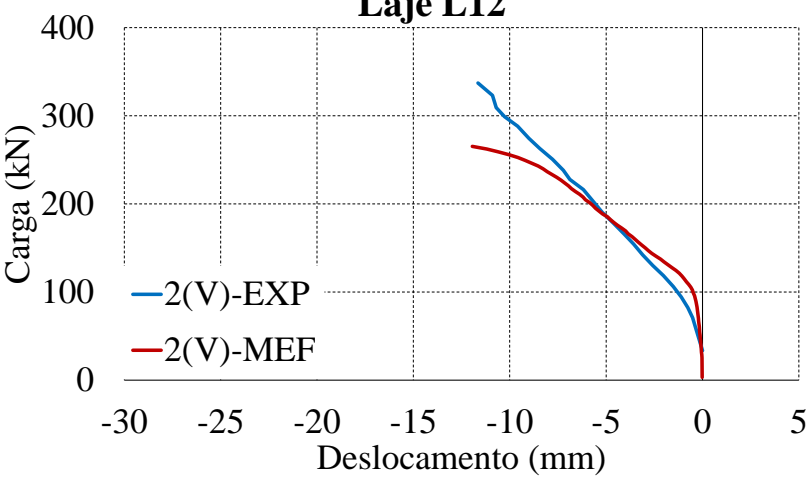

(b) Deslocamentos no ponto 2

Laje L12

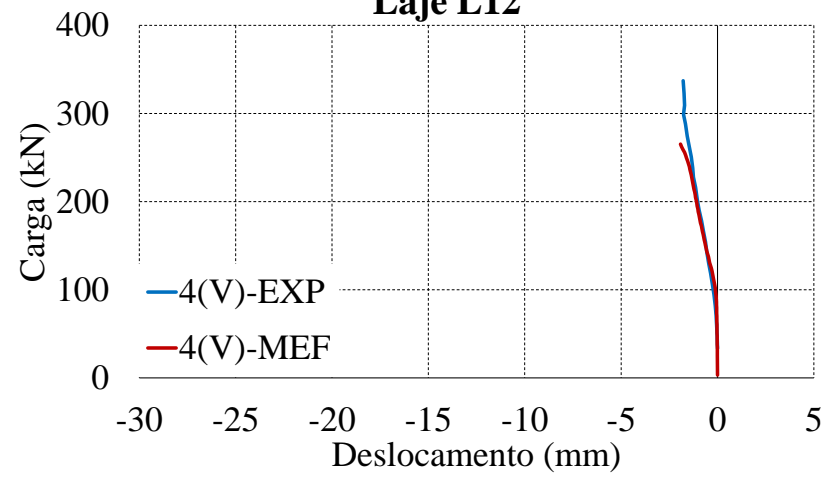

(d) Deslocamentos no ponto 4

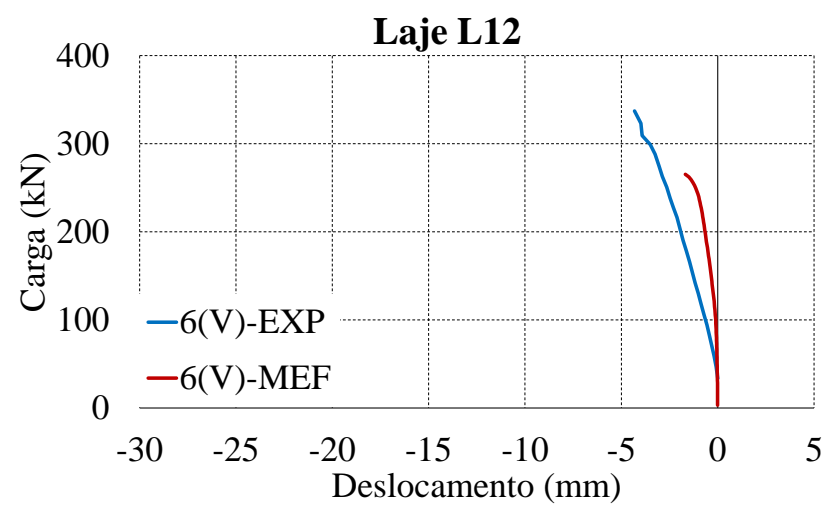

(f) Deslocamentos no ponto 6

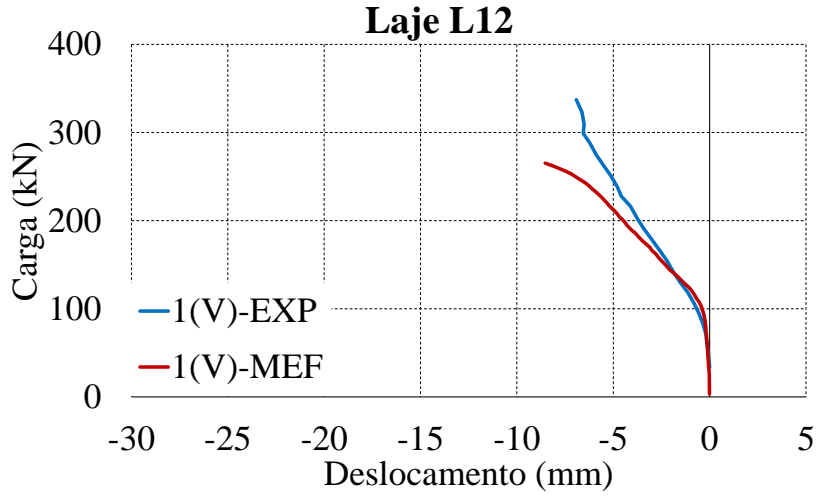

(a) Deslocamentos no ponto 1

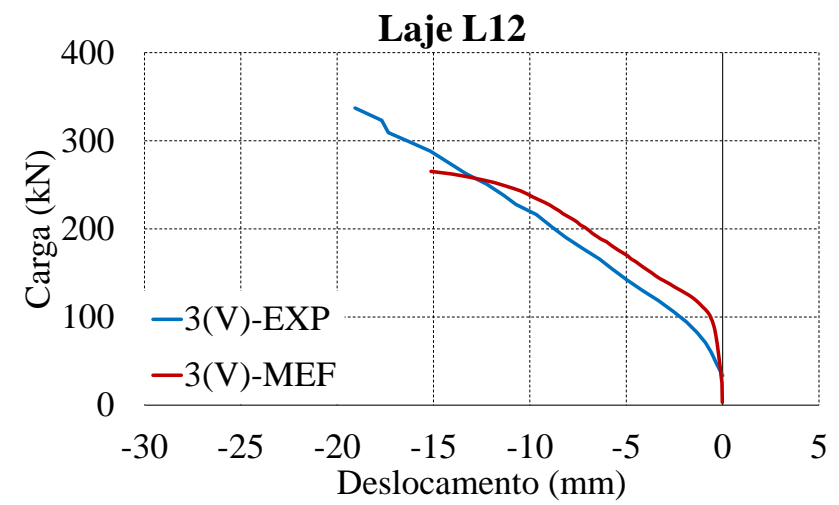

(c) Deslocamentos no ponto 3

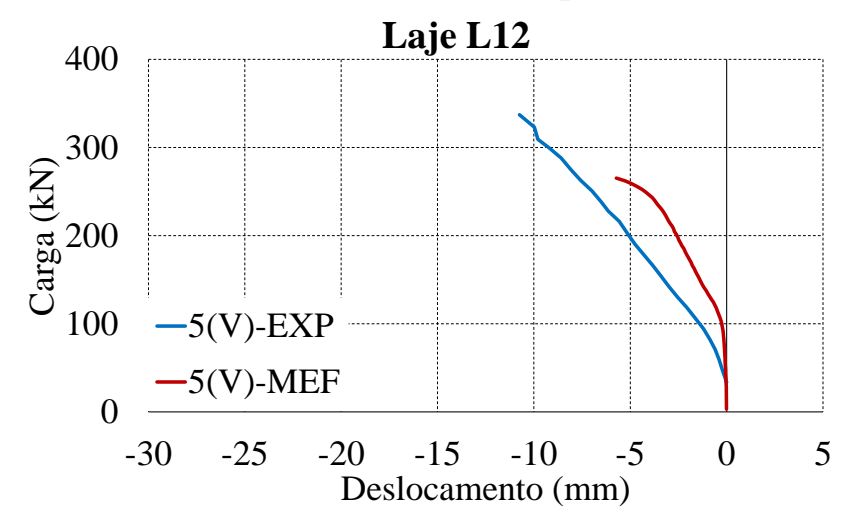

(e) Deslocamentos no ponto 5

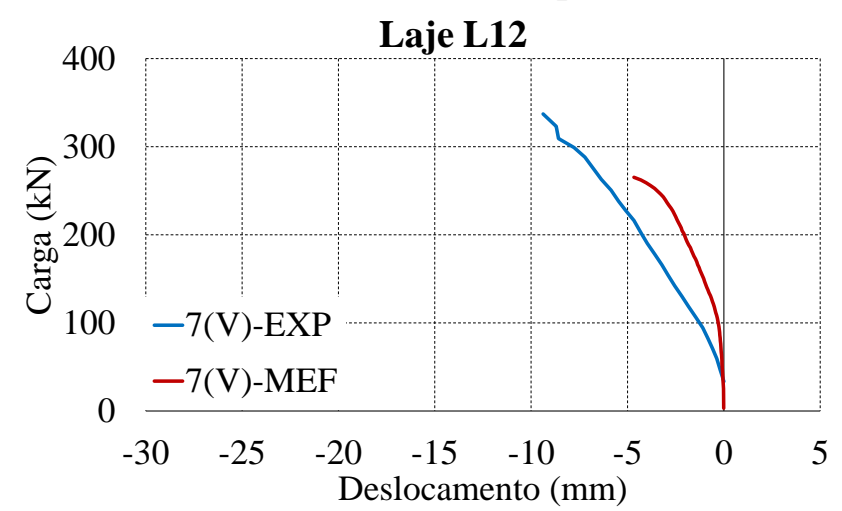

(g) Deslocamentos no ponto 7

Figura 6.27 - Deslocamentos da Laje L12 
Nos deslocamentos obtidos experimentalmente e numericamente nota-se uma concordância razoável com eventual exceção dos deslocamentos nas lajes L01 e L05 que apresentaram diferenças maiores. Esse fato deve-se a uma maior excentricidade atuante (500 mm) nessas lajes e a ausência de armadura de cisalhamento, pois na laje L11 que possui excentricidade também de $500 \mathrm{~mm}$ a diferença entre os deslocamentos é menor.

Com os gráficos de carga x deslocamento dos resultados experimentais e numéricos podese notar um comportamento mais rígido para os resultados numéricos devido ao módulo de elasticidade que o programa admite e o surgimento de microfissuras de flexão mais tardio que no experimental. Nos resultados experimentais, embora as microfissuras tivessem abertura muito pequena causaram um amolecimento no concreto e com o aumento do carregamento surgiram mais microfissuras na superfície da laje propagando-se em direção as extremidades das bordas. Algumas dessas fissuras foram inclinando-se devido à presença da torção.

A Tabela 6.4 apresenta os valores das cargas em que ocorreram as primeiras fissuras determinadas com os gráficos de carga $\mathrm{x}$ deslocamento para os resultados experimentais e numéricos.

Tabela 6.3 - Cargas das primeiras fissuras

\begin{tabular}{|c|c|c|c|c|c|c|}
\hline Laje & $V_{u}(\mathrm{kN})$ & $V_{\text {fis }}(\mathrm{kN})$ & $\%$ de $V_{u}$ & $V_{M E F}(\mathrm{kN})$ & $\begin{array}{c}V_{f i s, M E F} \\
(\mathrm{kN})\end{array}$ & $\%$ de $V_{u}$ \\
\hline L01 & 325 & 70 & 22 & 305,4 & 90 & 29 \\
\hline \begin{tabular}{|l|} 
L02 \\
\end{tabular} & 513 & 90 & 18 & 460,6 & 120 & 26 \\
\hline \begin{tabular}{|l|} 
L03 \\
\end{tabular} & 575 & 90 & 16 & 508,6 & 120 & 24 \\
\hline \begin{tabular}{|l|} 
L04 \\
\end{tabular} & 372 & 70 & 19 & 388,6 & 90 & 23 \\
\hline L05 & 250 & 80 & 32 & 249,4 & 110 & 44 \\
\hline L06 & 282 & 90 & 32 & 292,6 & 120 & 41 \\
\hline \begin{tabular}{|l|} 
L07 \\
\end{tabular} & 358 & 85 & 24 & 283,0 & 100 & 35 \\
\hline \begin{tabular}{|l|} 
L08 \\
\end{tabular} & 345 & 70 & 20 & 316,6 & 100 & 32 \\
\hline L09 & 550 & 90 & 16 & 568,6 & 110 & 19 \\
\hline L10 & 500 & 90 & 18 & 467,0 & 110 & 24 \\
\hline L11 & 640 & 100 & 16 & 553,4 & 100 & 18 \\
\hline L12 & 345 & 80 & 23 & 265,4 & 110 & 41 \\
\hline
\end{tabular}


Os resultados confirmam que os resultados numéricos tem comportamento mais rígido que no experimental, com o surgimento da fissura inicial ocorrendo num nível de carga maior.

Para discutir os resultados numéricos das fissuras e deformada da laje serão mostrados os resultados obtidos do programa para uma laje sem armadura de cisalhamento (L04) e uma laje com armadura de cisalhamento (L02) para um carregamento igual em todos os pontos de aplicação de carga (excentricidade de $350 \mathrm{~mm}$ ).

Na Figura 6.28 e Figura 6.29 são mostradas as fissuras e a deformada na ruptura obtidas numericamente da Laje L04 e L02 respectivamente, com vista em 2D na ruptura.
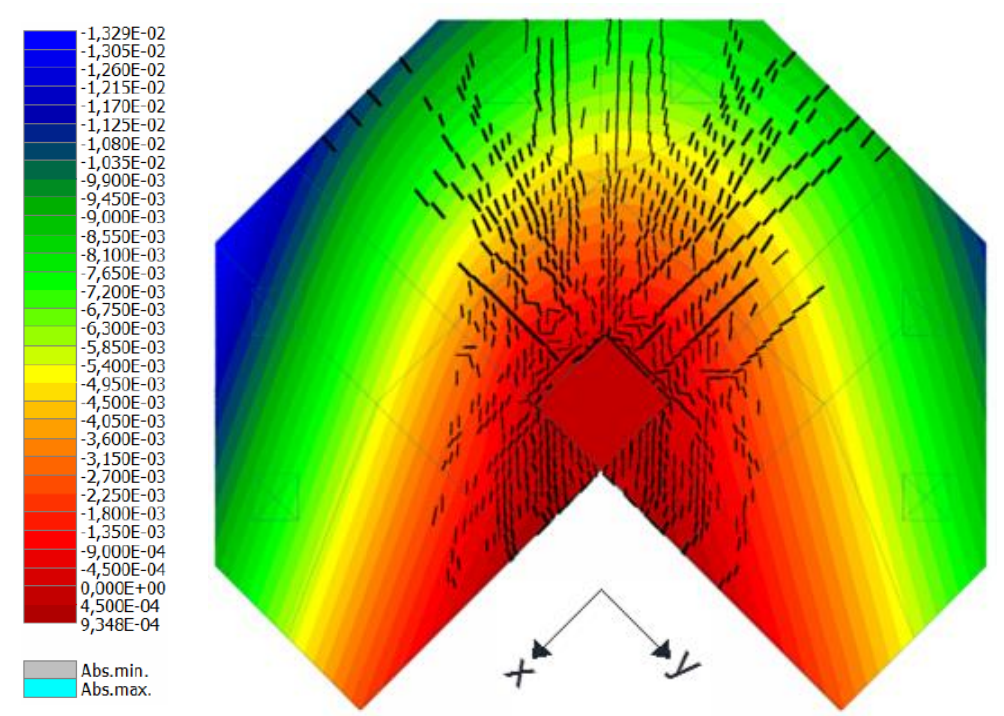

Figura 6.28 -Fissuras e deformada (m) da laje L04 obtida numericamente (vista em 2D)
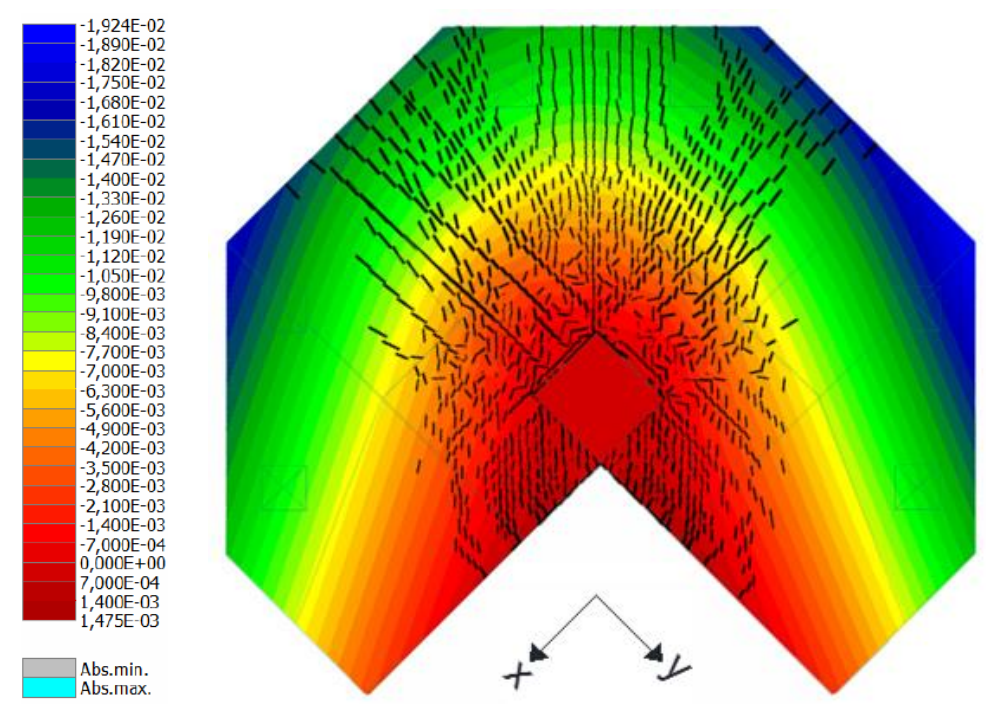

Figura 6.29 -Fissuras e deformada (m) da laje L02 obtida numericamente (vista em 2D) 
As duas lajes possuem a mesma excentricidade, taxa de armadura de flexão e mesma resistência de concreto e diferenciam-se apenas pela presença de armadura de cisalhamento. Essa diferença resultou em deslocamentos maiores na laje L02 (com armadura de cisalhamento) e fissuras superficiais mais distribuídas, cada uma para o nível de carga de ruptura.

Na Figura 6.30 e Figura 6.31 são mostradas as deformadas e fissuras na ruptura obtidas numericamente das lajes L04 e L02 respectivamente com vista em 3D na ruptura.
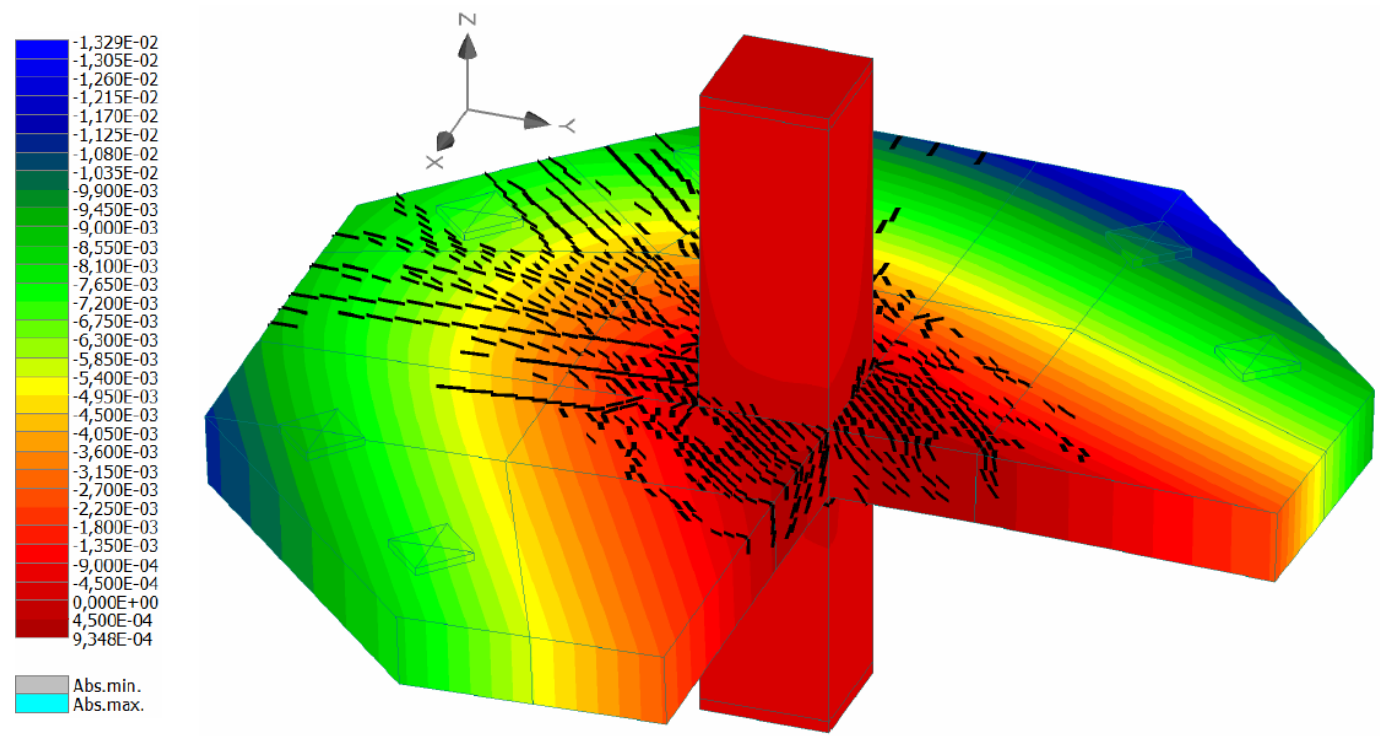

Figura 6.30 -Fissuras e deformada (m) da laje L04 obtida numericamente (vista em 3D)
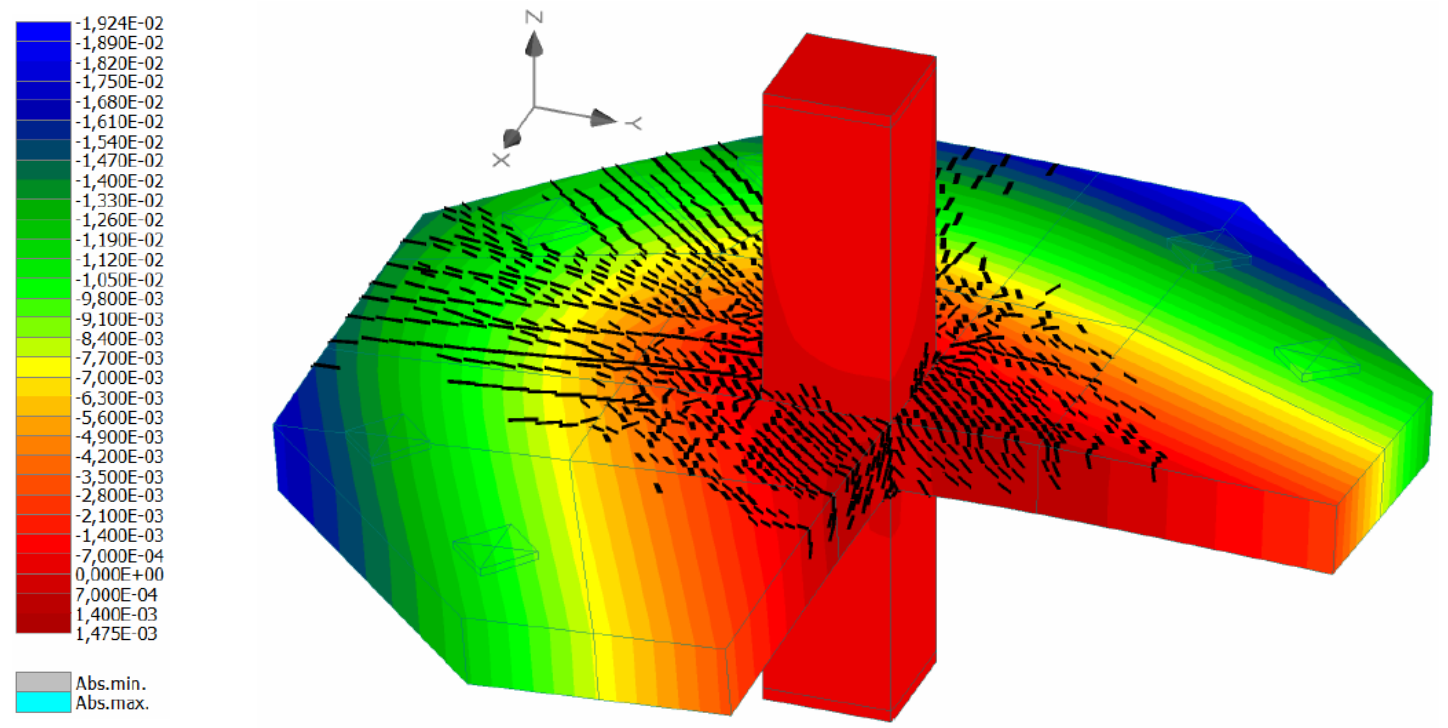

Figura 6.31 -Fissuras e deformada (m) da laje L02 obtida numericamente (vista em 3D) 
Nota-se que os bordos reentrantes da laje sobem enquanto que o restante desce com os valores máximos de deslocamento descendentes situados na borda da laje oposta à reentrância (faixa em azul).

À medida que as fissuras de cisalhamento na superfície superior da laje se propagam ocorre ainda uma redução de rigidez como mostra os gráficos de carga x deslocamento. Estas fissuras seguem em direção à borda reentrante com inclinação em torno de $45^{\circ}$ provocada por momentos de torção. Na Figura 6.34 e Figura 6.35 são mostradas as fissuras obtidas experimentalmente e numericamente das lajes L04 e L02 respectivamente, com vista em 2D.
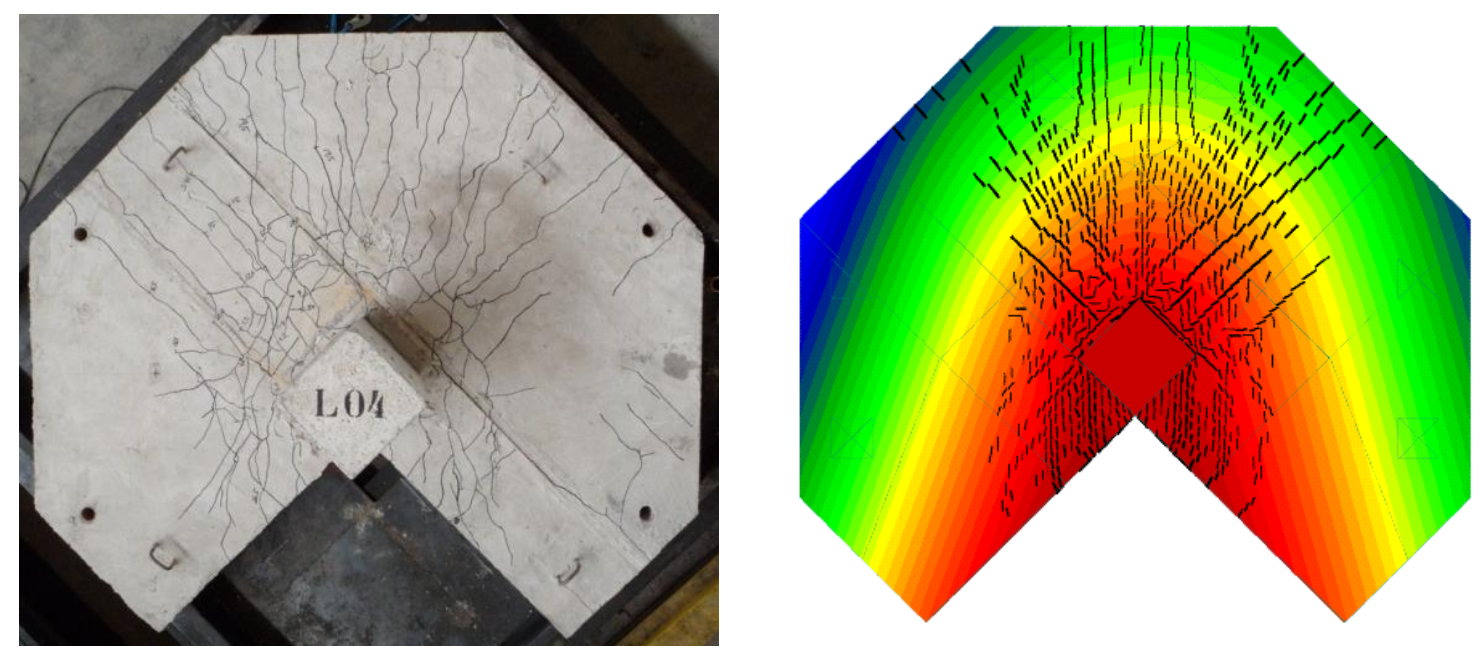

Figura 6.32 - Configuração de fissuras da laje L04 para ensaio experimental (esquerda) e numérico (direita)
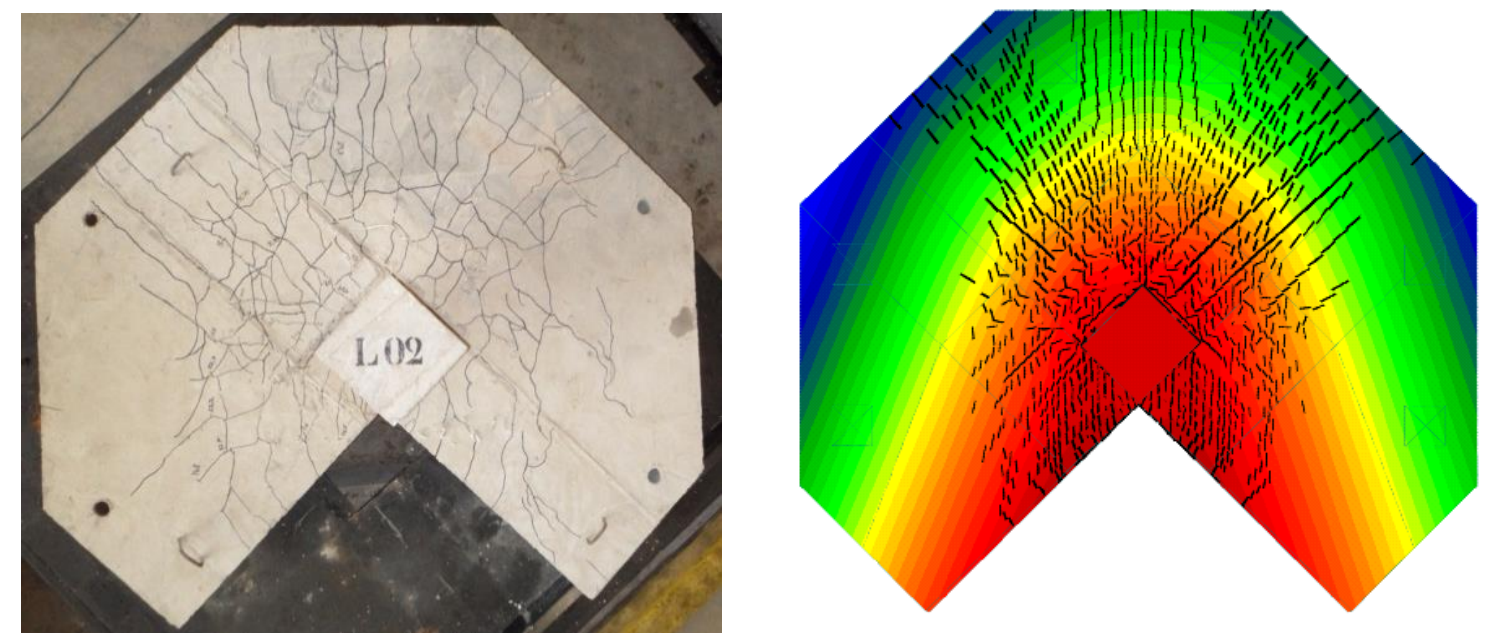

Figura 6.33 - Configuração de fissuras da laje L02 para ensaio experimental (esquerda) e numérico (direita) 
Pode-se observar que em ambas as lajes a configuração é semelhante, com o experimental apresentando pouco mais de fissuras pelo fato de ter sido aplicado cargas de pós puncionamento para melhor visualizar o cone de ruptura, enquanto que no numérico as fissuras mostradas são do momento na ruptura.

\subsection{DEFORMAÇÕES NA ARMADURA DE FLEXÃO}

Nestas lajes foi possível comparar deformações na armadura de flexão em oito pontos para as lajes L01, L02, L03 e L04 como mostra na Figura 6.34.

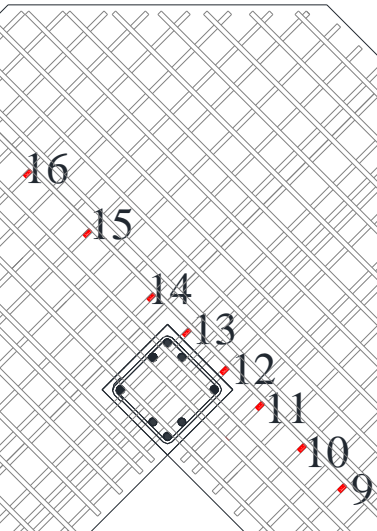

Figura 6.34 - Pontos de deformações monitorados no programa ATENA 3D das lajes L01, L02, L03 e L04

Da Figura 6.35 à Figura 6.38 são apresentadas as deformações na armadura de flexão das lajes da primeira série de concretagem (Série 1) para cada um dos oito pontos das lajes em diferentes passos de carga até próximo à ruptura. 


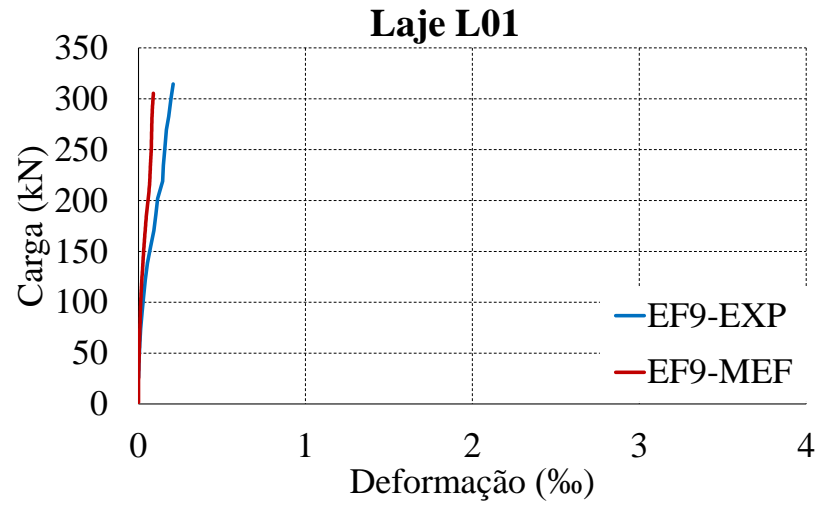

(a) Deformações no ponto 9

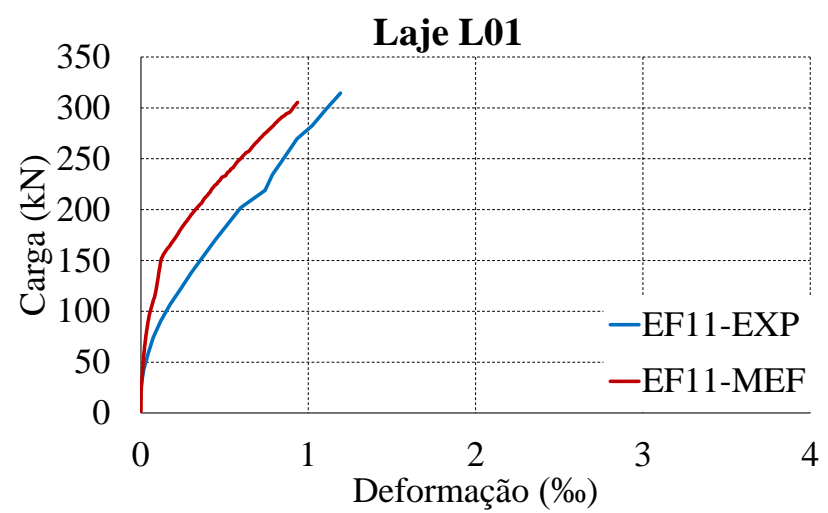

(c) Deformações no ponto 11

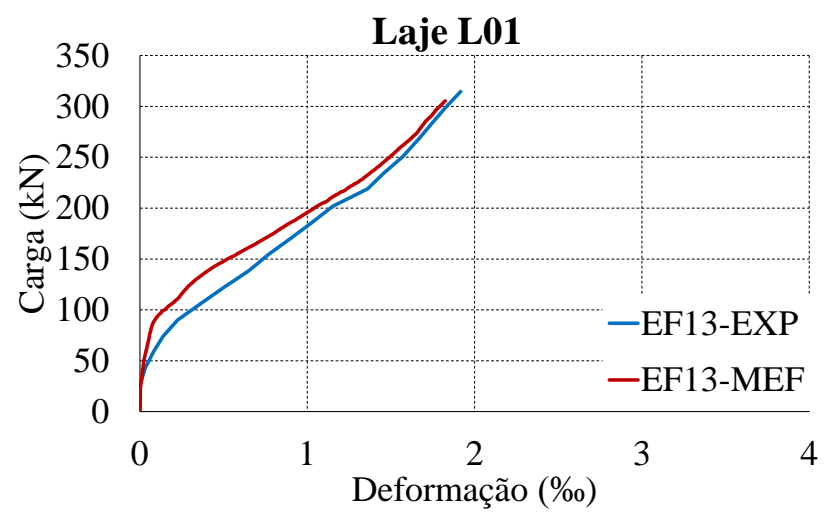

(e) Deformações no ponto 13

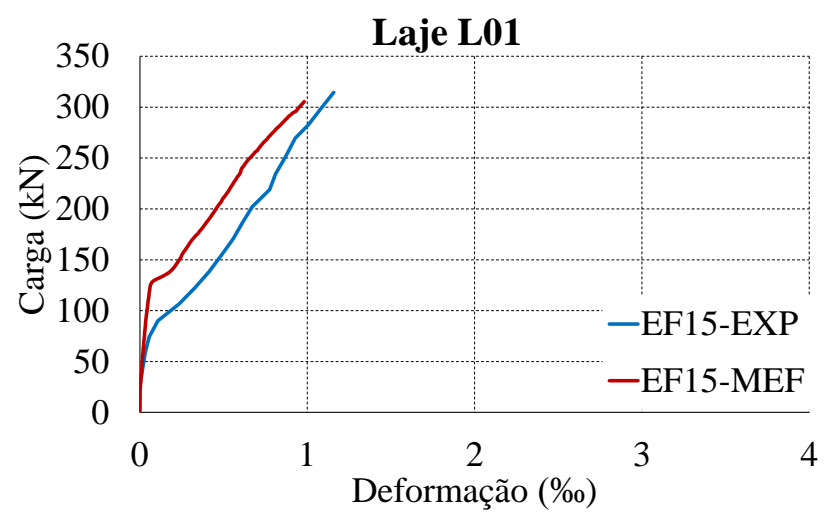

(g) Deformações no ponto 15

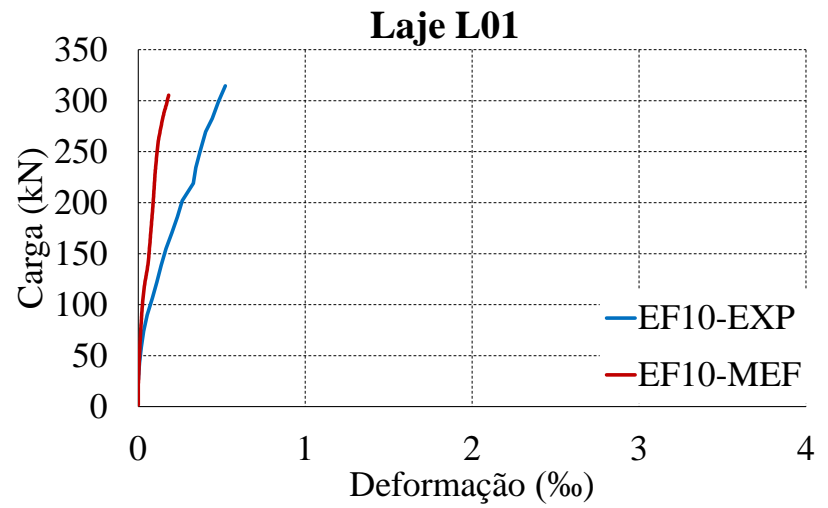

(b) Deformações no ponto 10

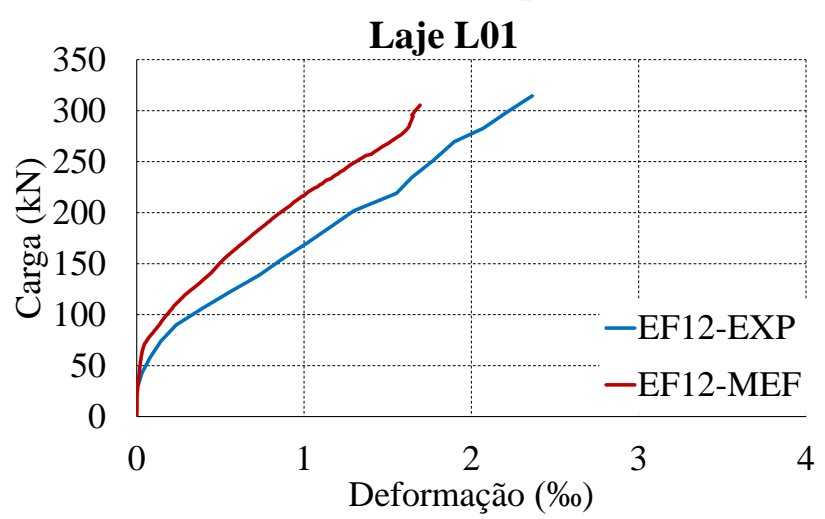

(d) Deformações no ponto 12

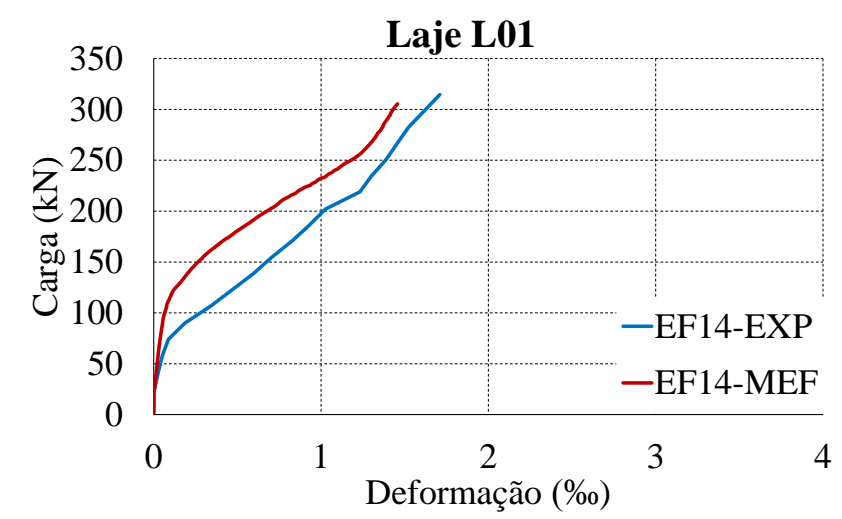

(f) Deformações no ponto 14

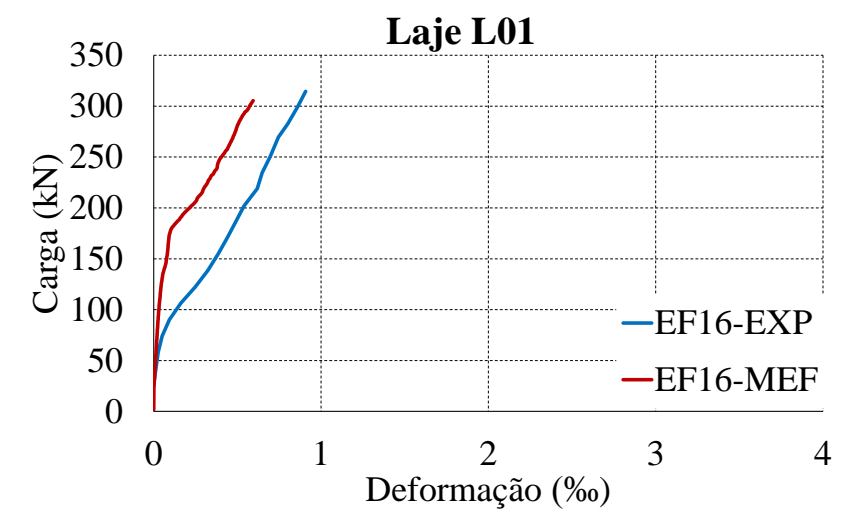

(h) Deformações no ponto 16

Figura 6.35 - Deformações na armadura de flexão da Laje L01 


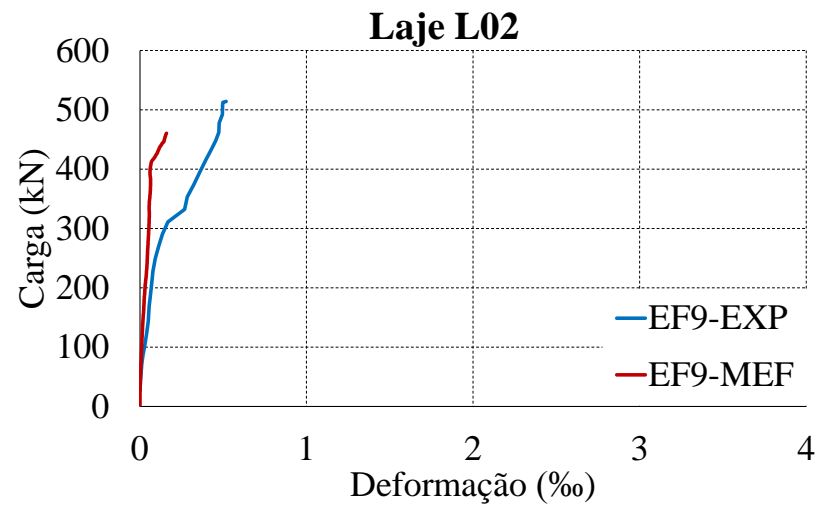

(a) Deformações no ponto 9

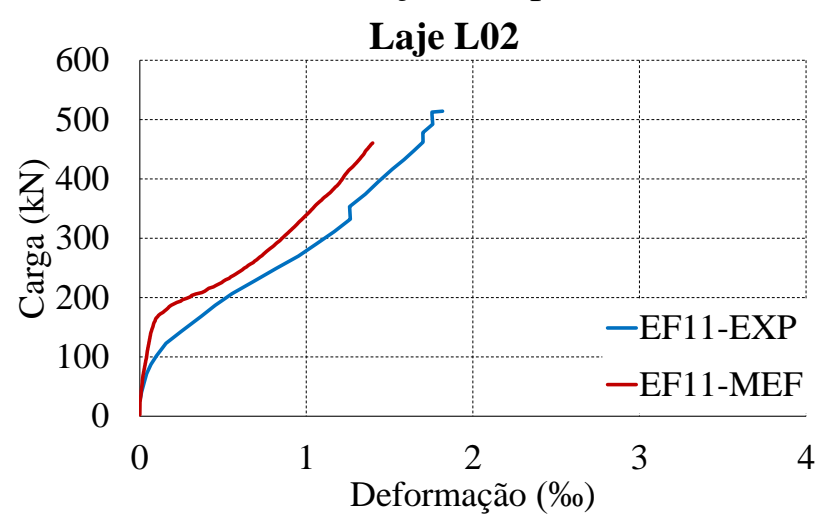

(c) Deformações no ponto 11

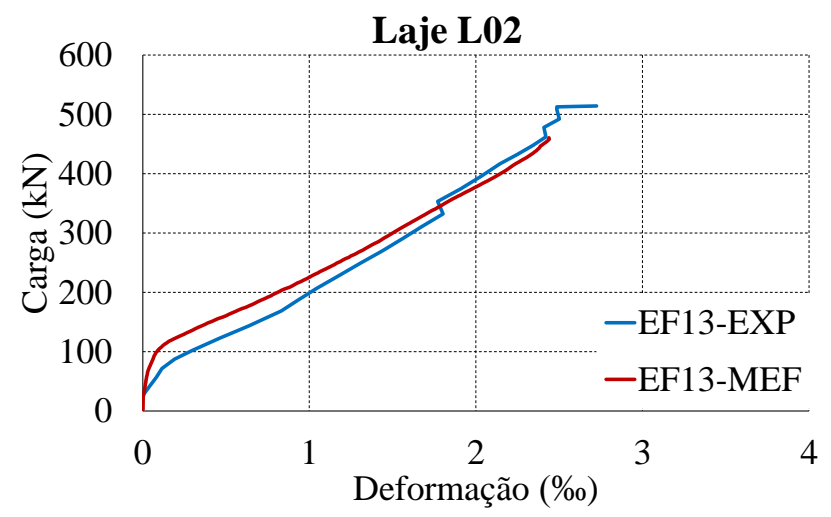

(e) Deformações no ponto 13

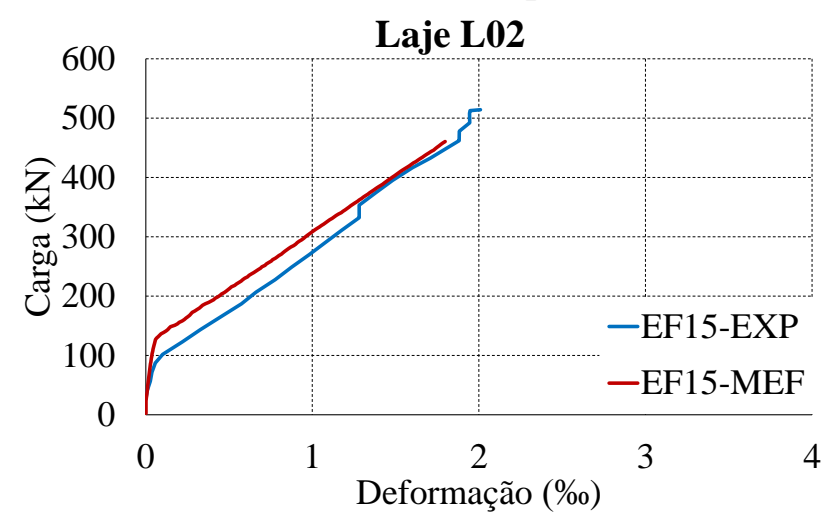

(g) Deformações no ponto 15

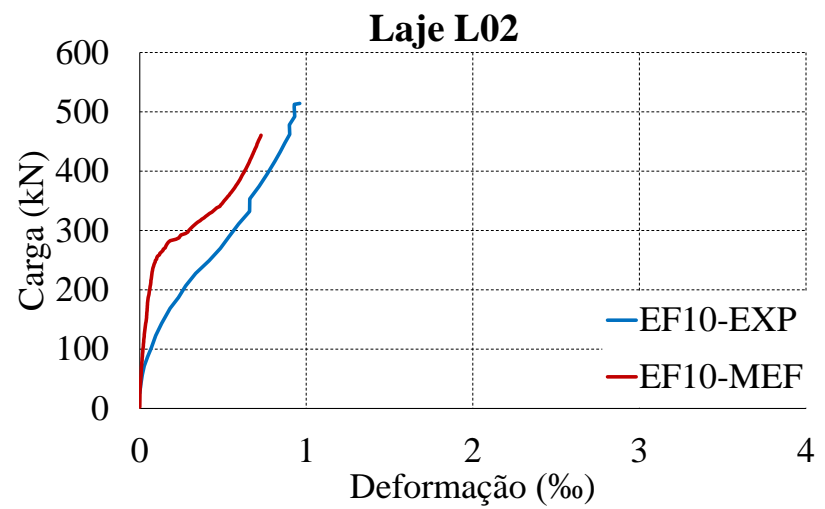

(b) Deformações no ponto 10

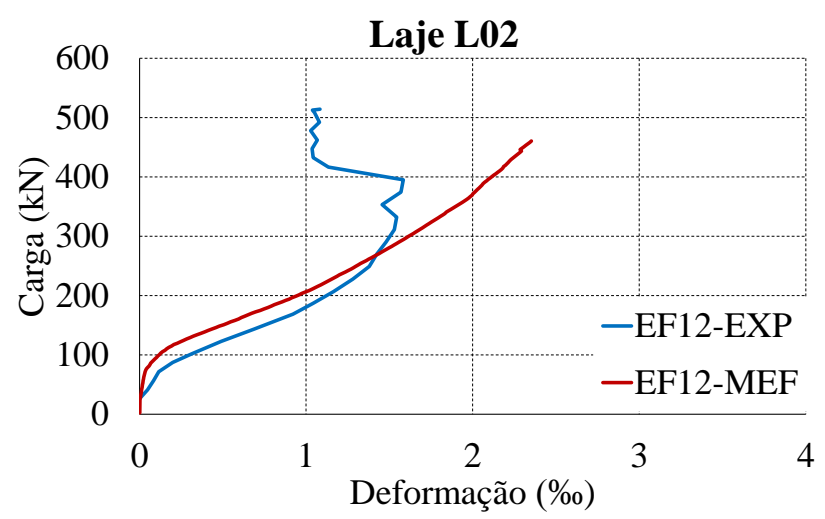

(d) Deformações no ponto 12

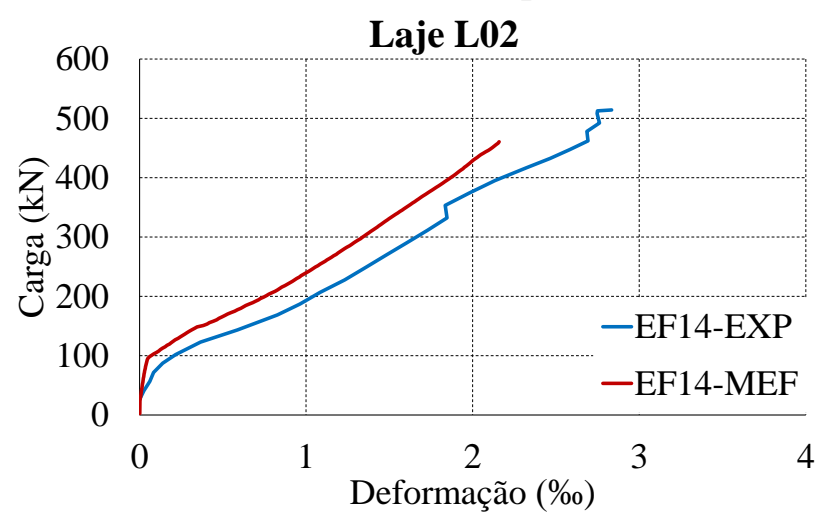

(f) Deformações no ponto 14

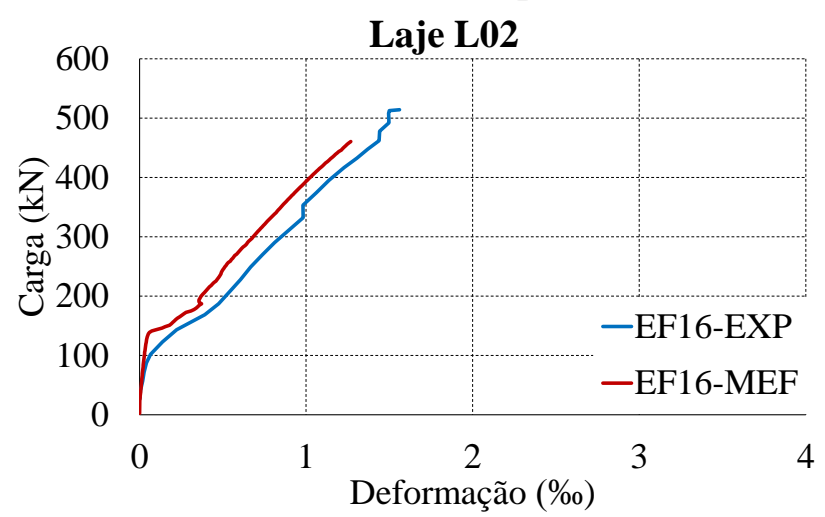

(h) Deformações no ponto 16

Figura 6.36 - Deformações na armadura de flexão da Laje L02 


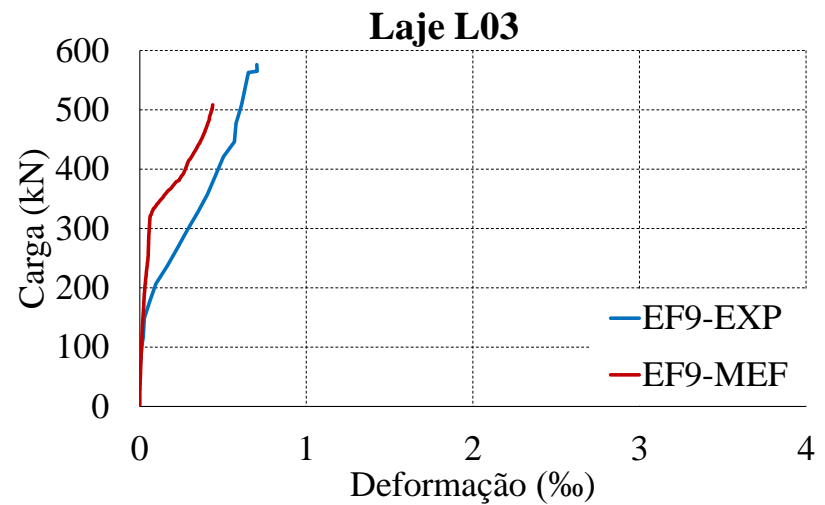

(a) Deformações no ponto 9

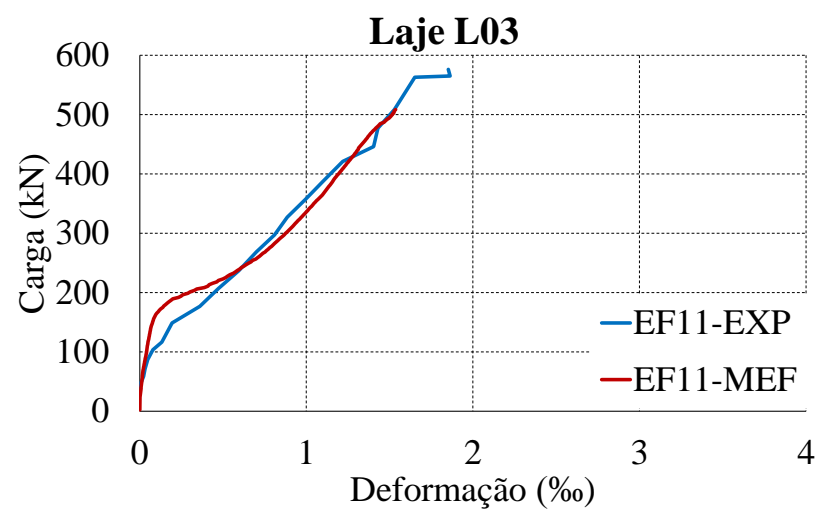

(c) Deformações no ponto 11

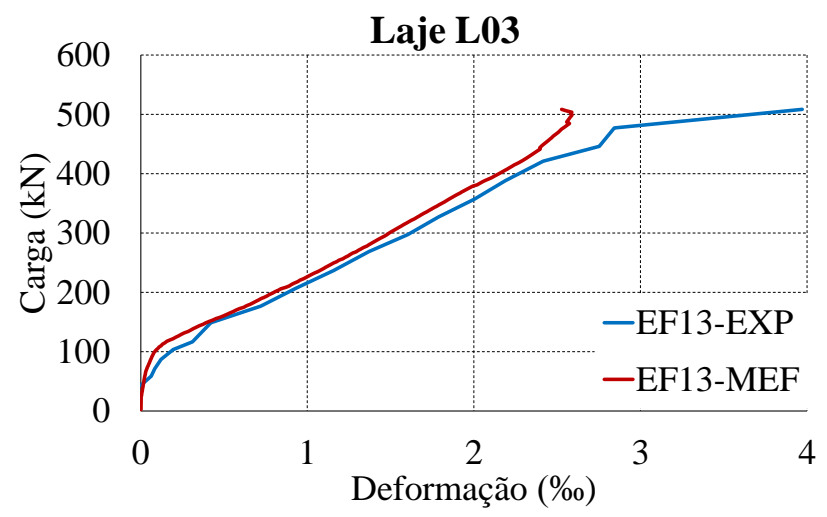

(e) Deformações no ponto 13

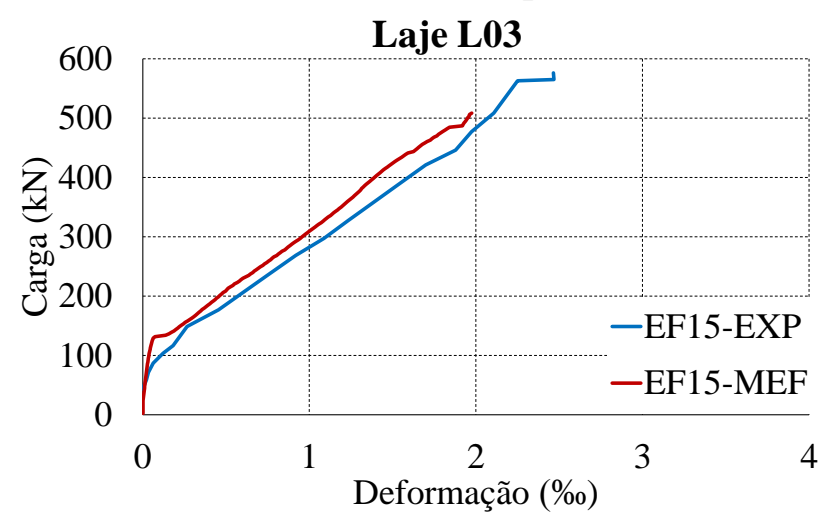

(g) Deformações no ponto 15

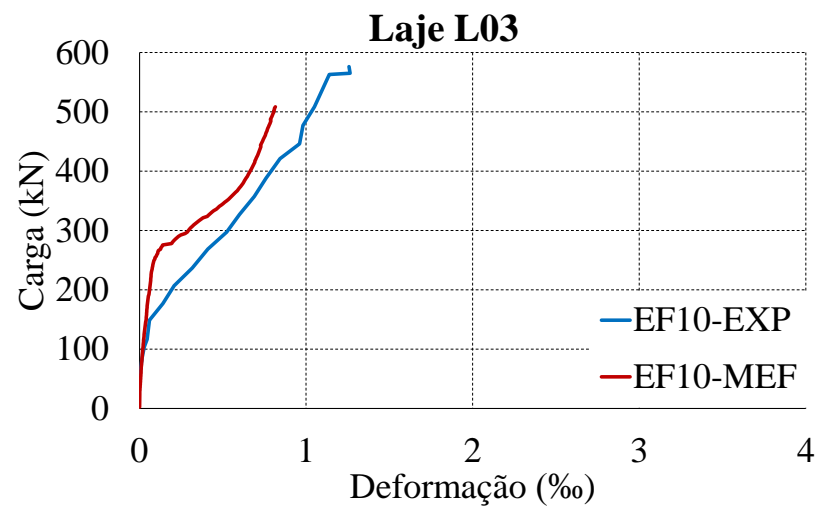

(b) Deformações no ponto 10

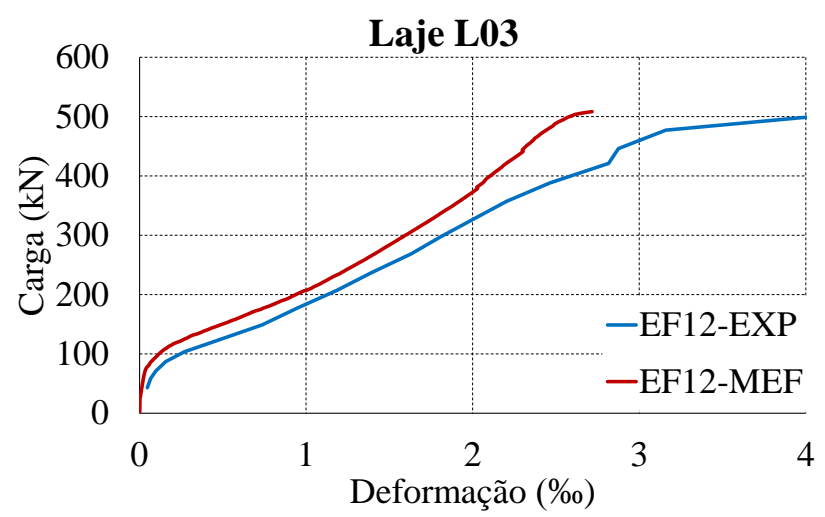

(d) Deformações no ponto 12

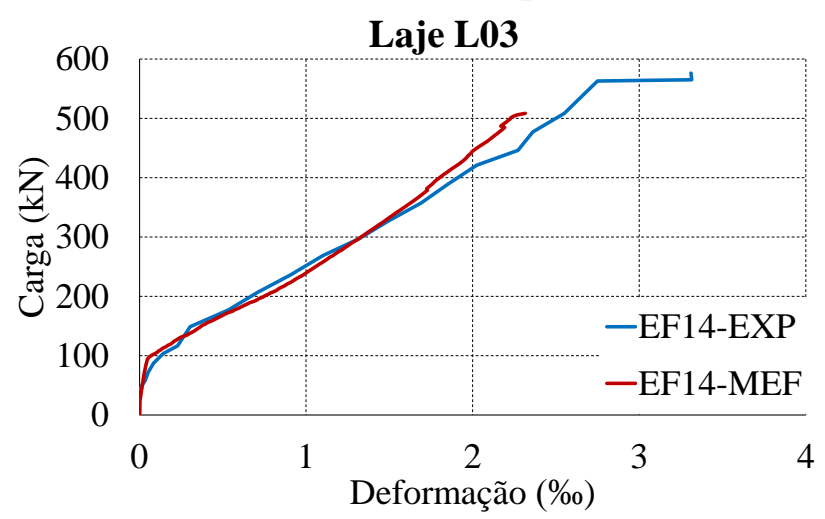

(f) Deformações no ponto 14

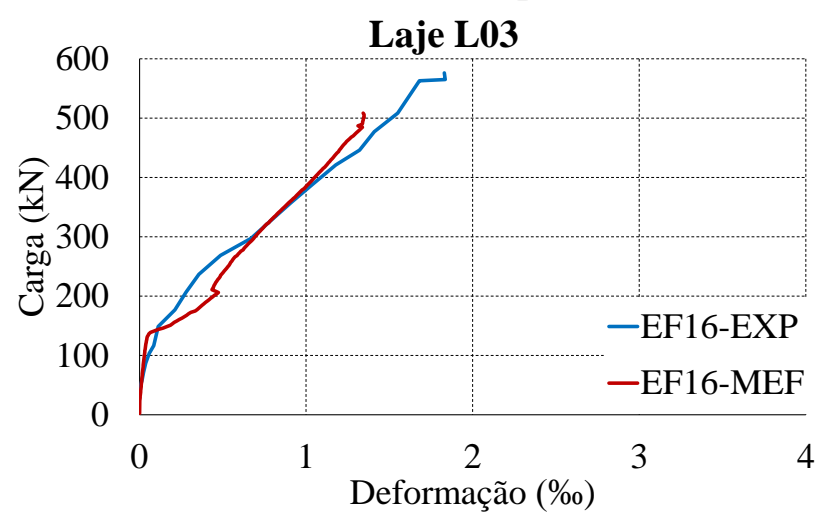

(h) Deformações no ponto 16

Figura 6.37 - Deformações na armadura de flexão da Laje L03 


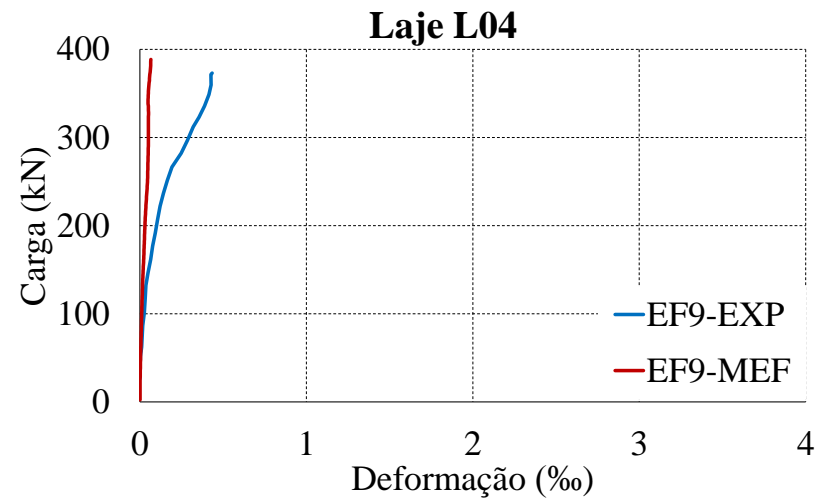

(a) Deformações no ponto 9

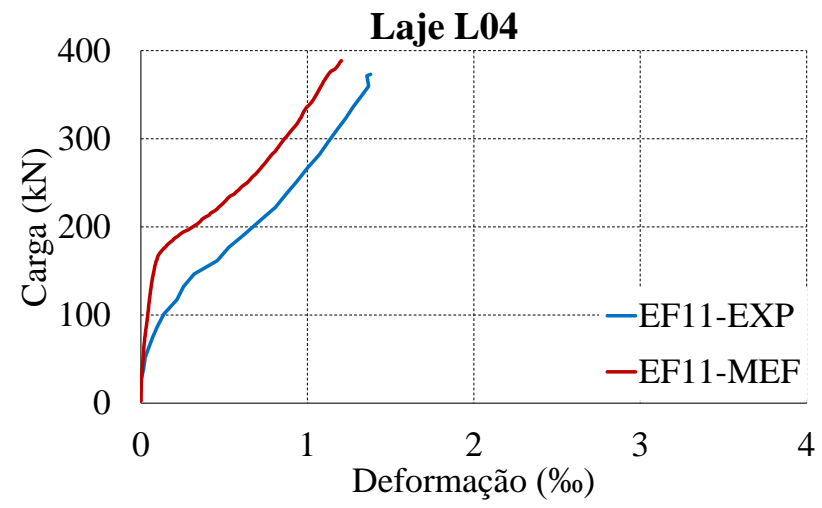

(c) Deformações no ponto 11

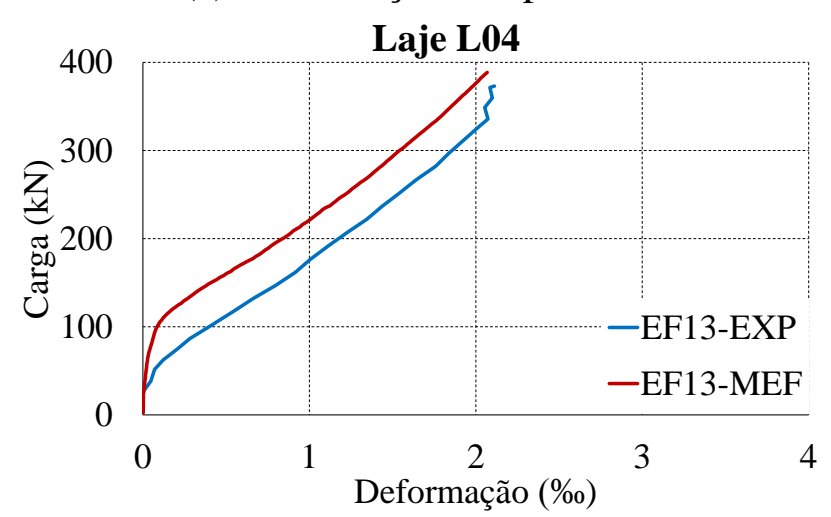

(e) Deformações no ponto 13

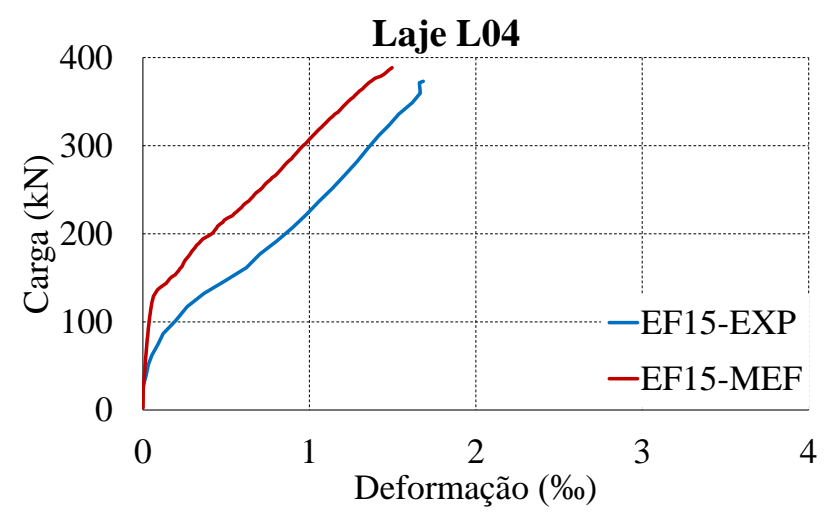

(g) Deformações no ponto 15

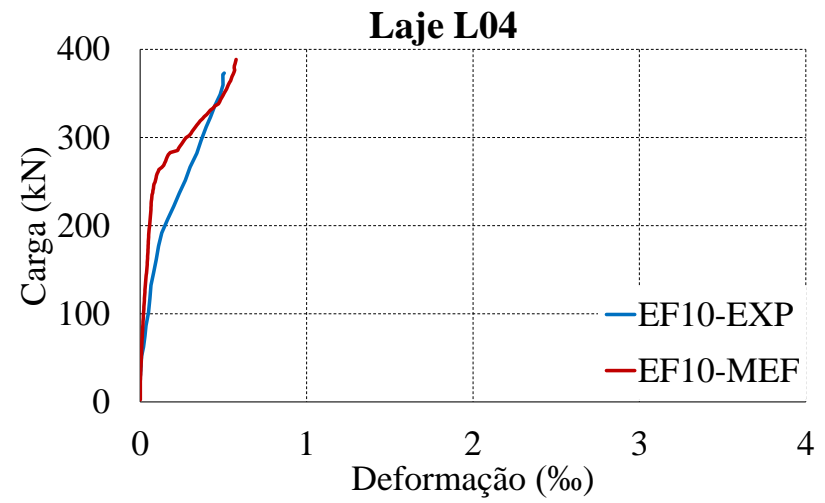

(b) Deformações no ponto 10

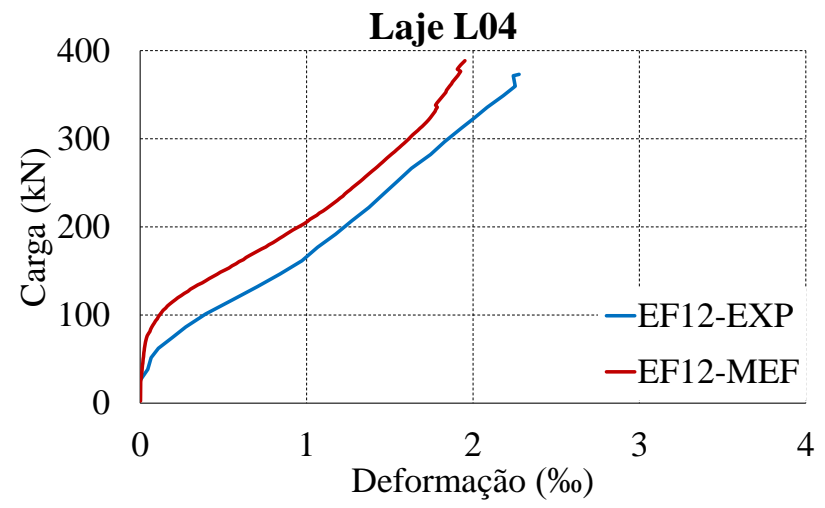

(d) Deformações no ponto 12

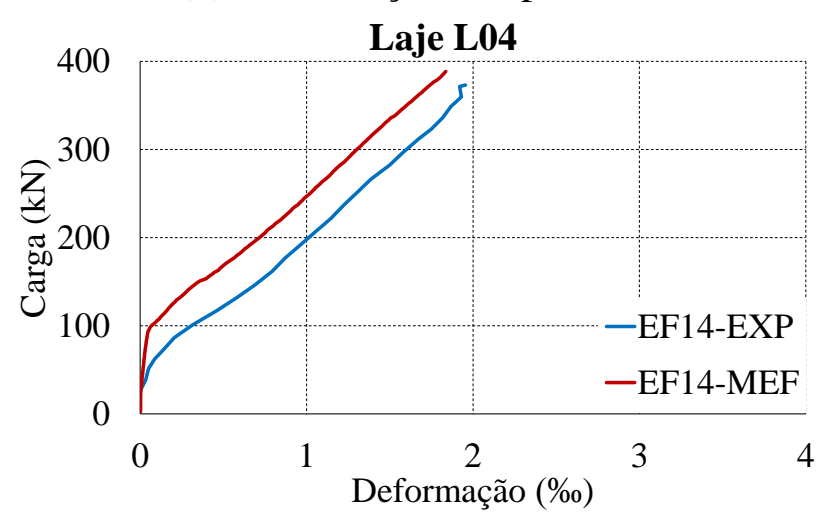

(f) Deformações no ponto 14

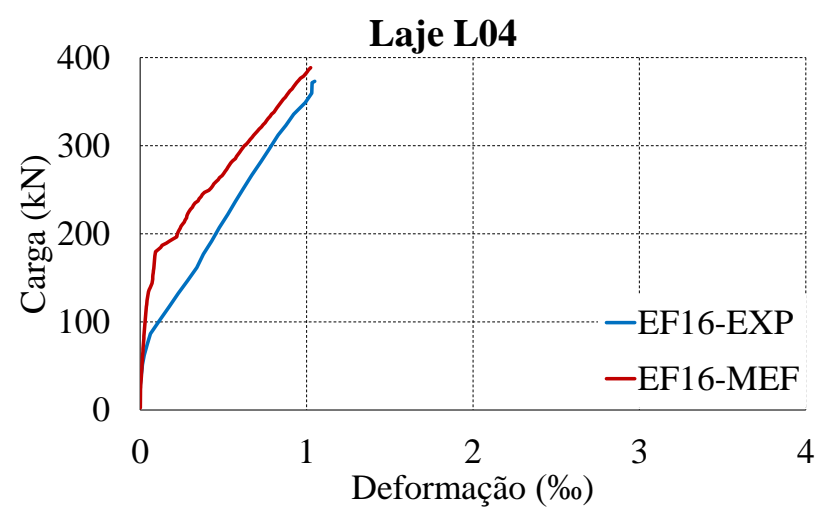

(h) Deformações no ponto 16

Figura 6.38 - Deformações na armadura de flexão da Laje L04 
Para as lajes L05 e L06 foi possível comparar deformações na armadura de flexão em oito pontos como mostra a Figura 6.39.

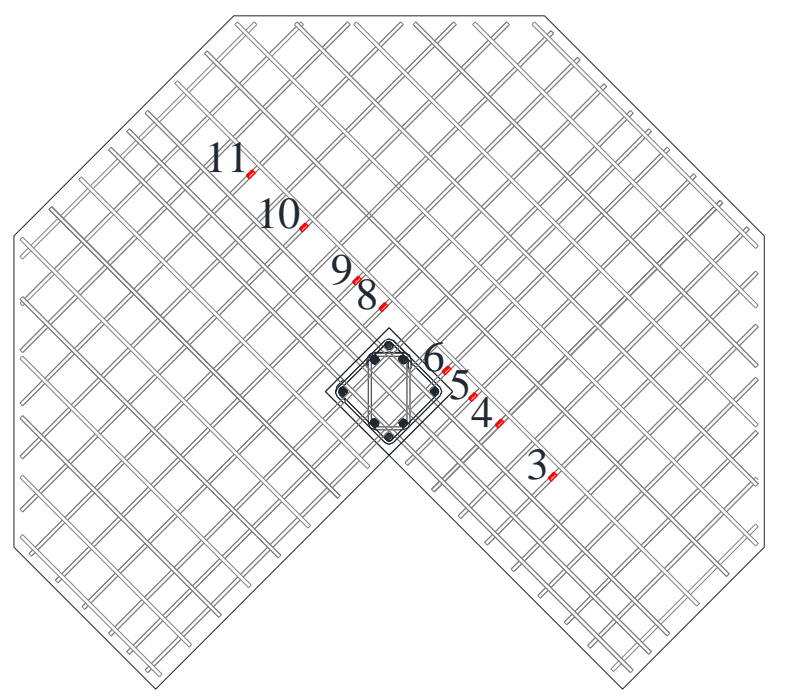

Figura 6.39 - Pontos de deformações monitorados no programa ATENA 3D das lajes L05 e L06

Na Figura 6.40 e Figura 6.41 são apresentadas as deformações na armadura de flexão das lajes L05 e L06 para cada um dos cinco pontos das lajes em diferentes passos de carga até próximo à ruptura. 


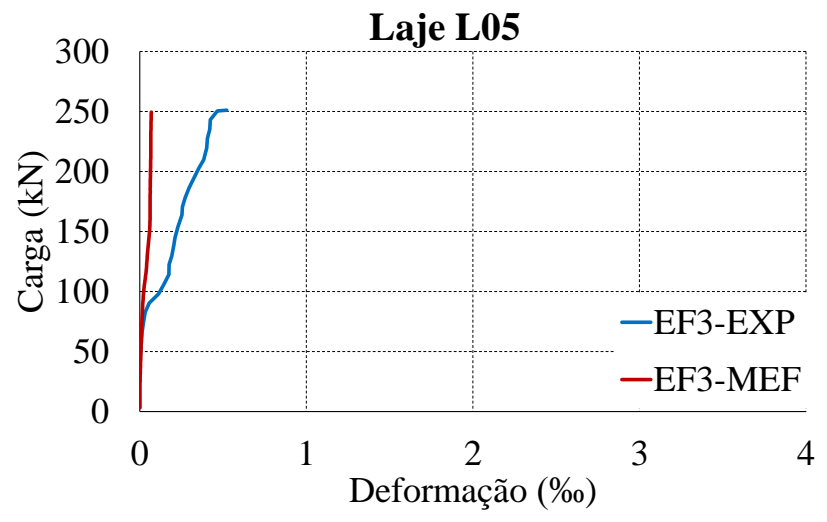

(a) Deformações no ponto 3

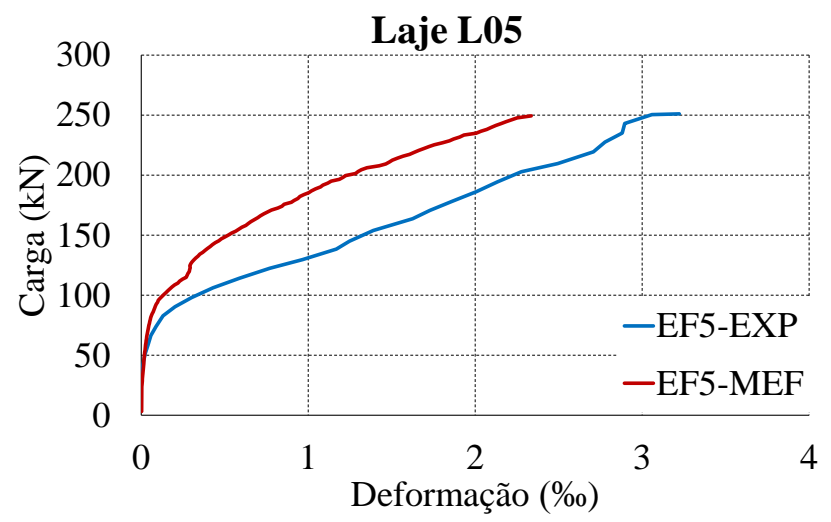

(c) Deformações no ponto 5

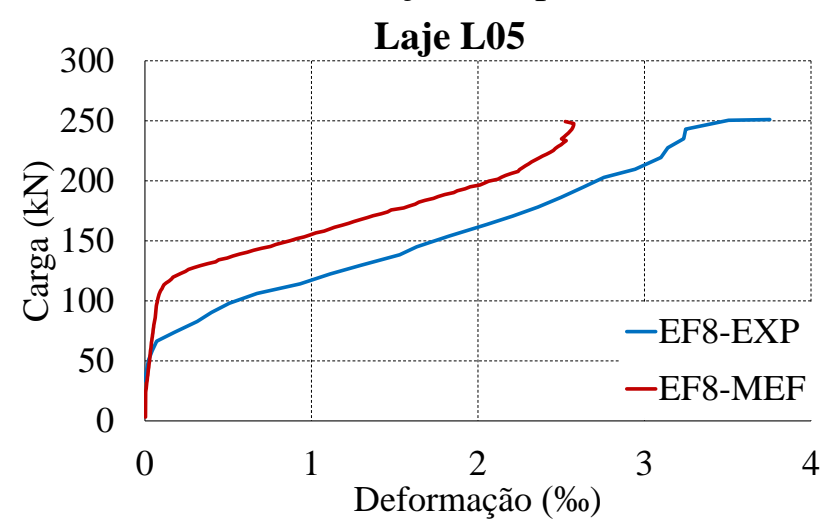

(e) Deformações no ponto 8

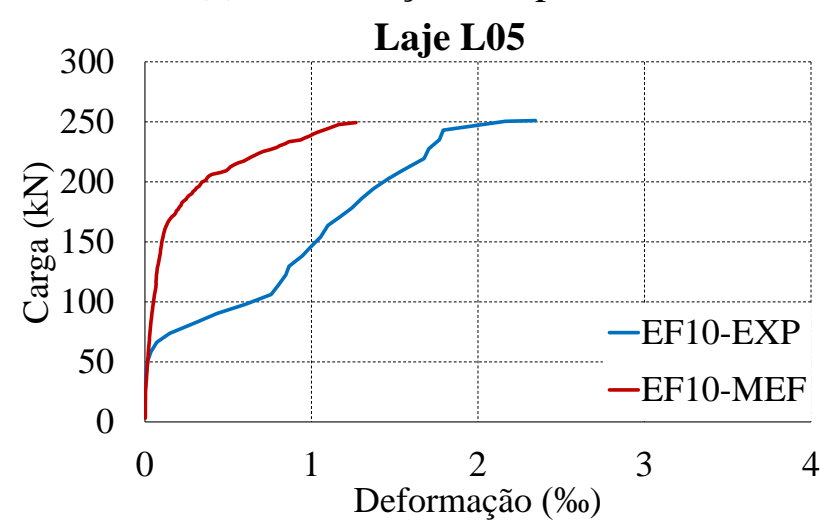

(e) Deformações no ponto 10

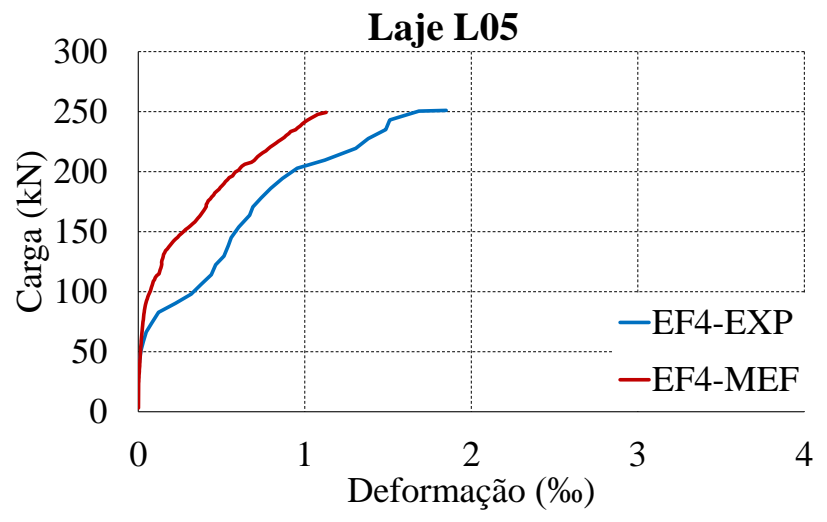

(b) Deformações no ponto 4

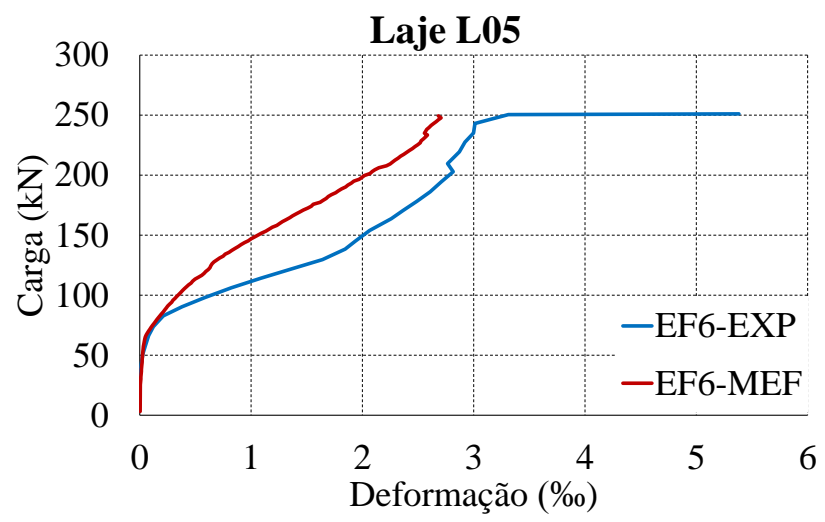

(d) Deformações no ponto 6

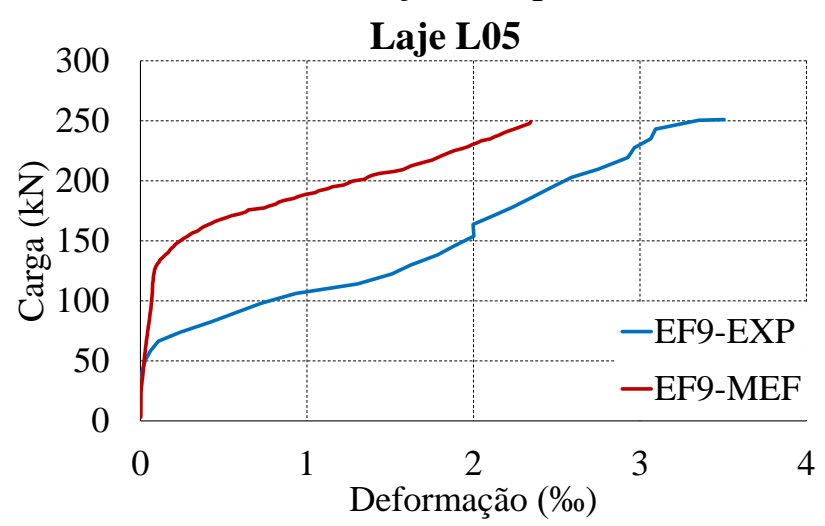

(f) Deformações no ponto 9

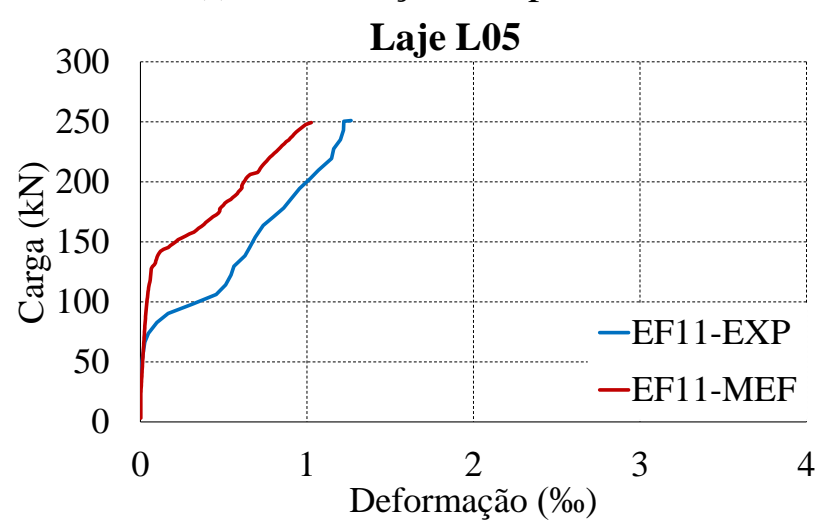

(f) Deformações no ponto 11

Figura 6.40 - Deformações na armadura de flexão da Laje L05 


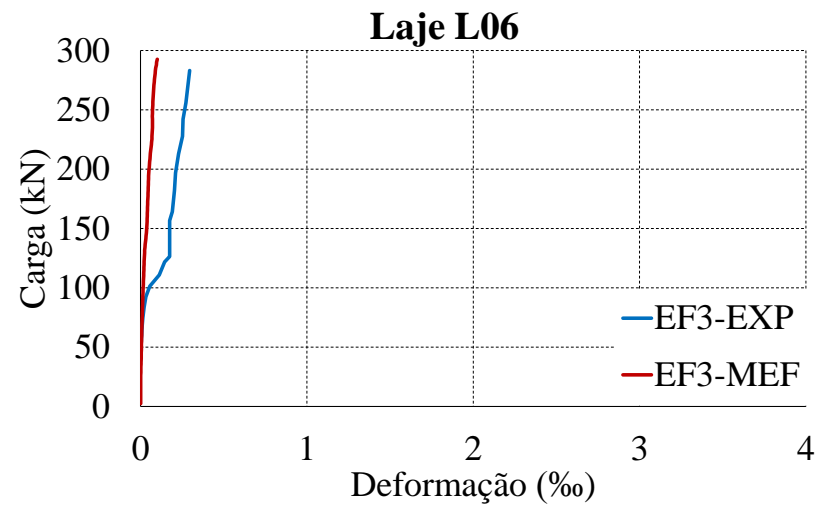

(a) Deformações no ponto 3

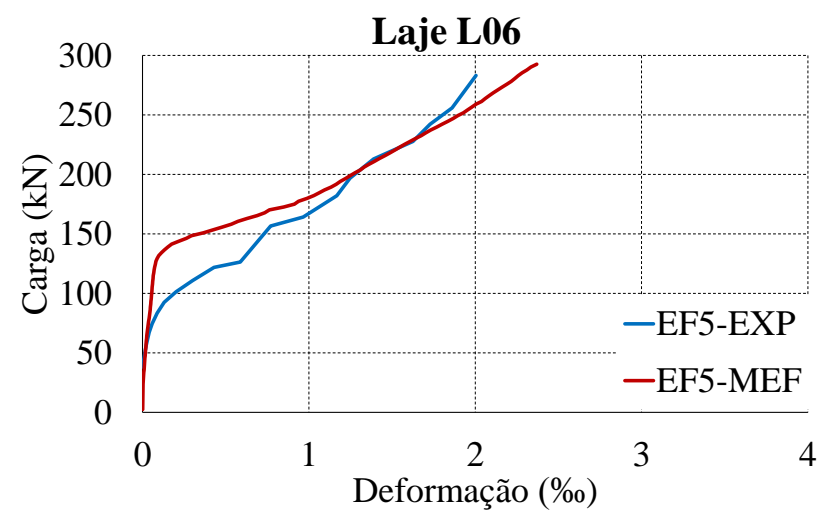

(c) Deformações no ponto 5

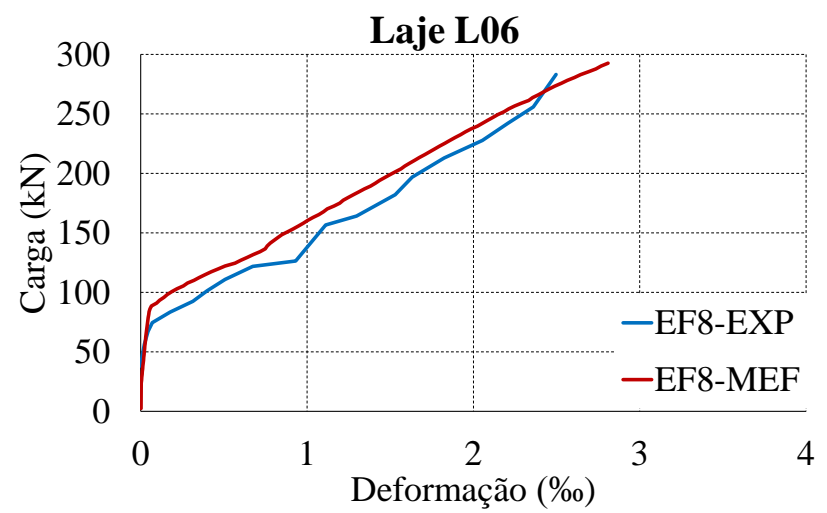

(e) Deformações no ponto 8

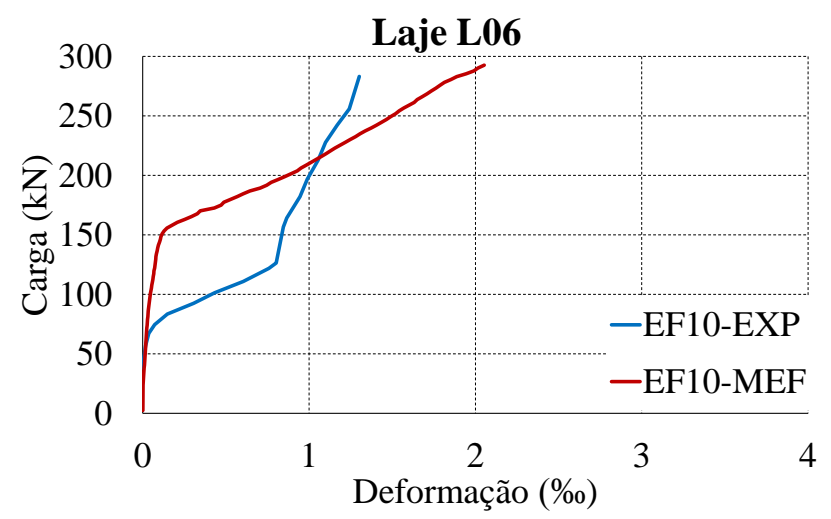

(e) Deformações no ponto 10

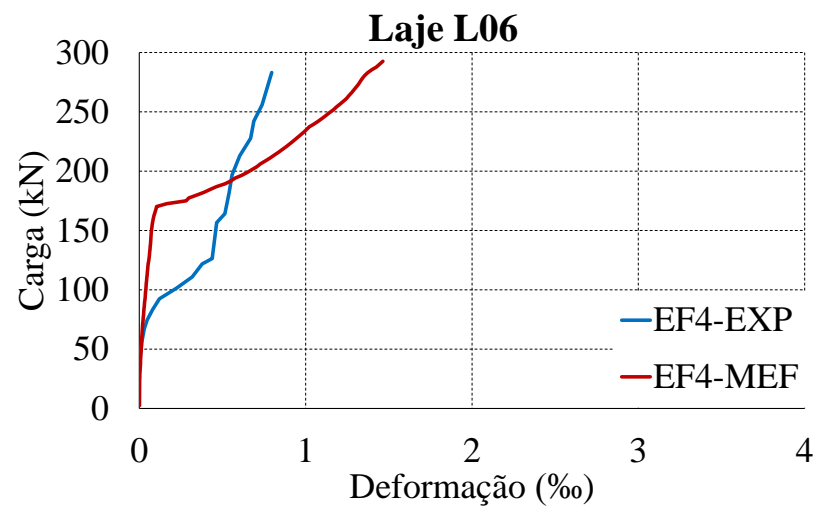

(b) Deformações no ponto 4

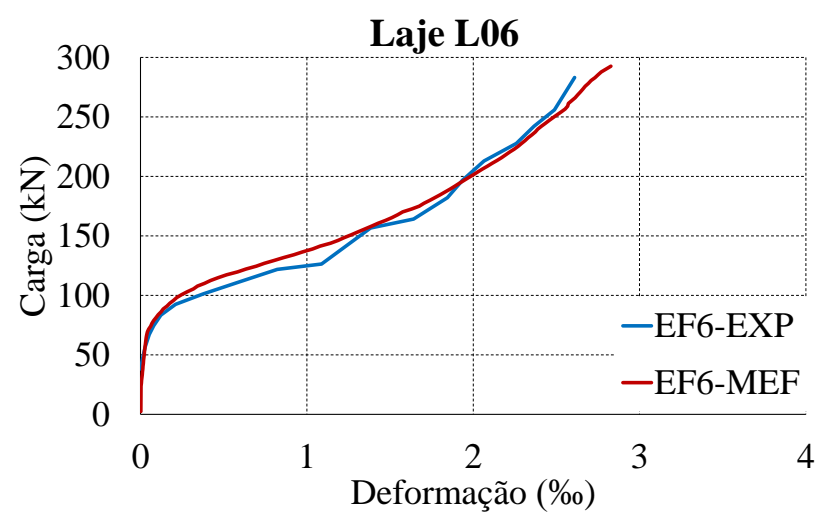

(d) Deformações no ponto 6

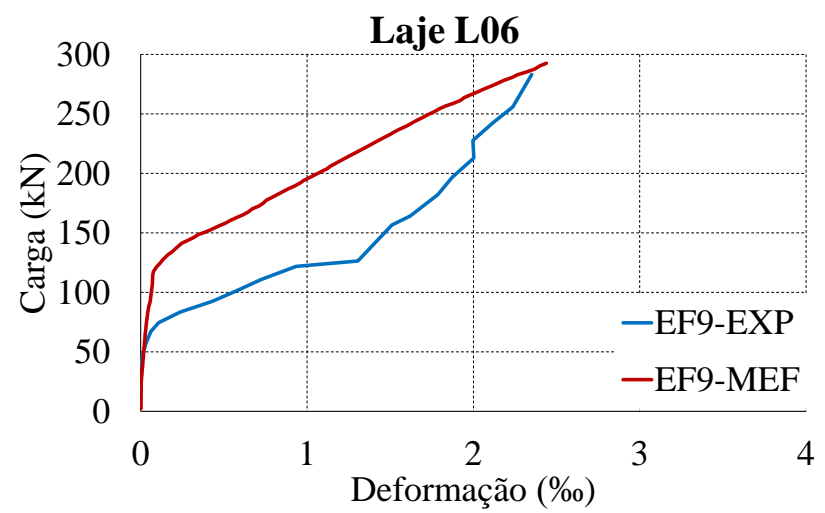

(f) Deformações no ponto 9

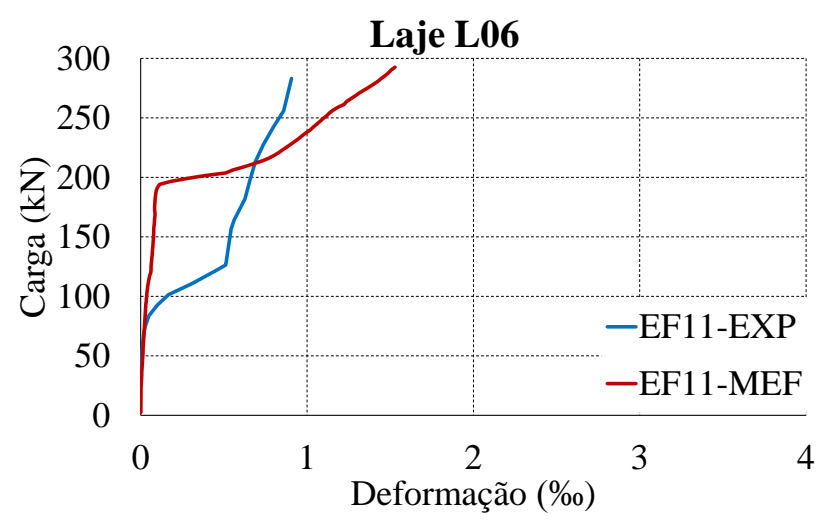

(f) Deformações no ponto 11

Figura 6.41 - Deformações na armadura de flexão da Laje L06 
Para as lajes L07 e L08 foi possível comparar deformações na armadura de flexão em oito pontos como mostra a Figura 6.42.

\section{9.}

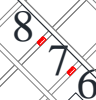<smiles>c1[14cH][14cH][14cH][14cH]n1</smiles>

2.

Figura 6.42 - Pontos de deformações monitorados no programa ATENA 3D das lajes L07 e L08

Na Figura 6.43 e Figura 6.44 são apresentadas as deformações na armadura de flexão das lajes L07 e L08 para cada um dos oito pontos das lajes em diferentes passos de carga até próximo à ruptura. 


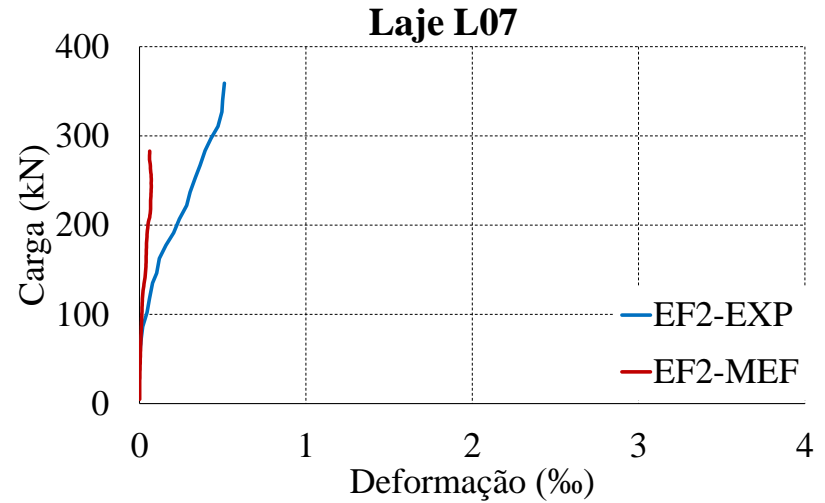

(a) Deformações no ponto 2

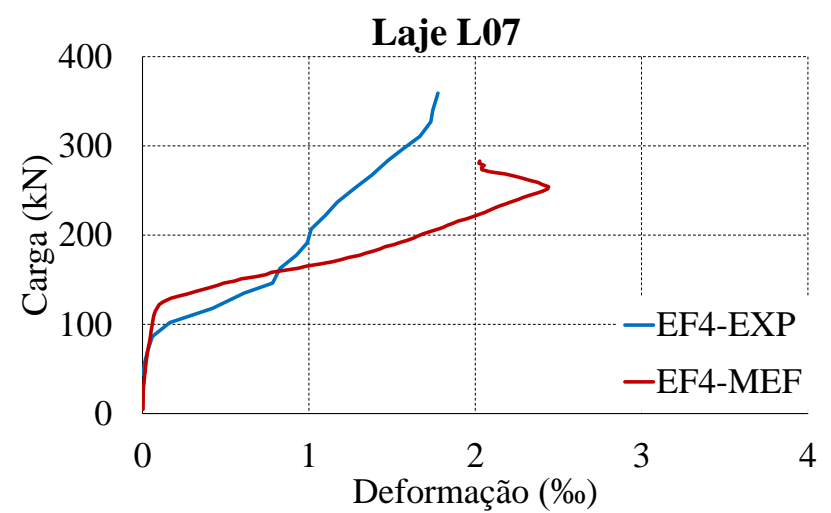

(c) Deformações no ponto 4

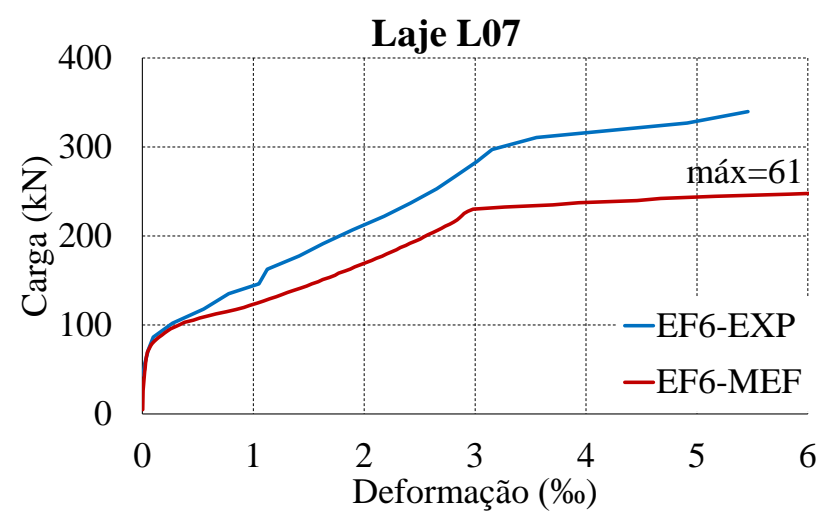

(e) Deformações no ponto 6

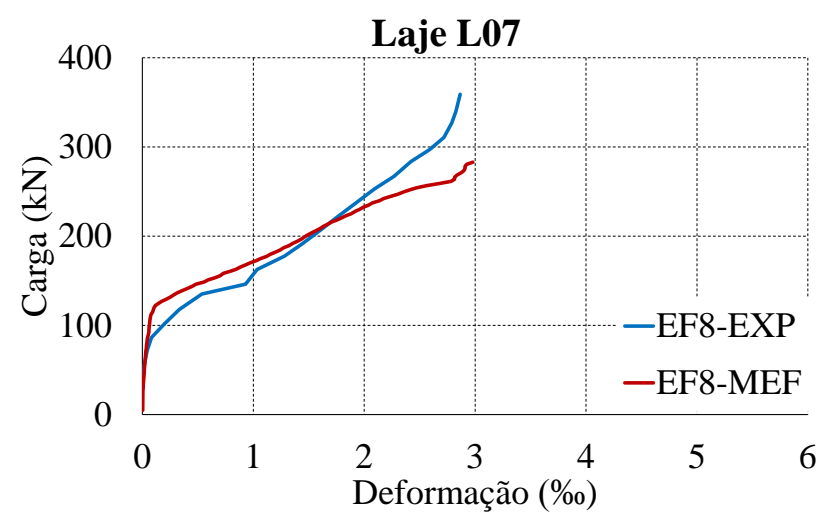

(e) Deformações no ponto 8

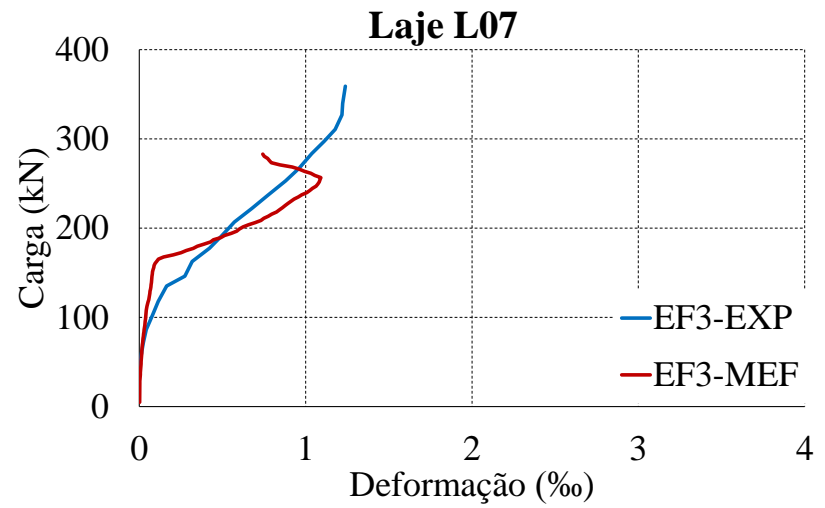

(b) Deformações no ponto 3

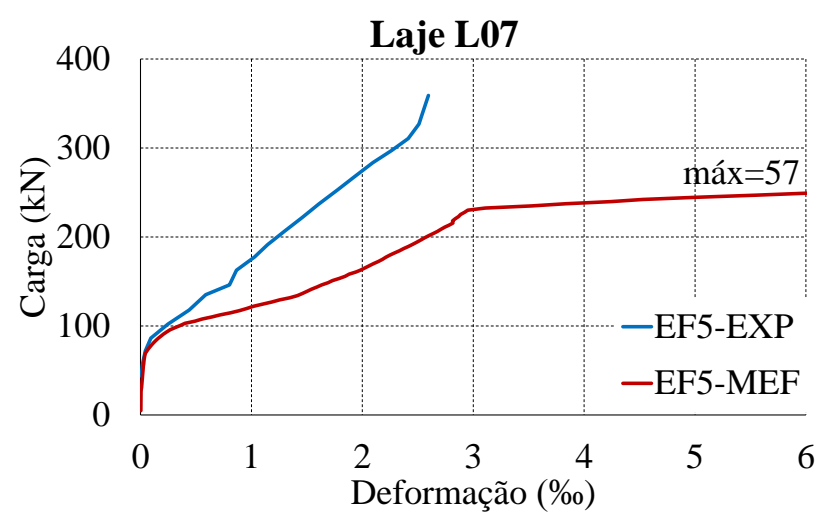

(d) Deformações no ponto 5

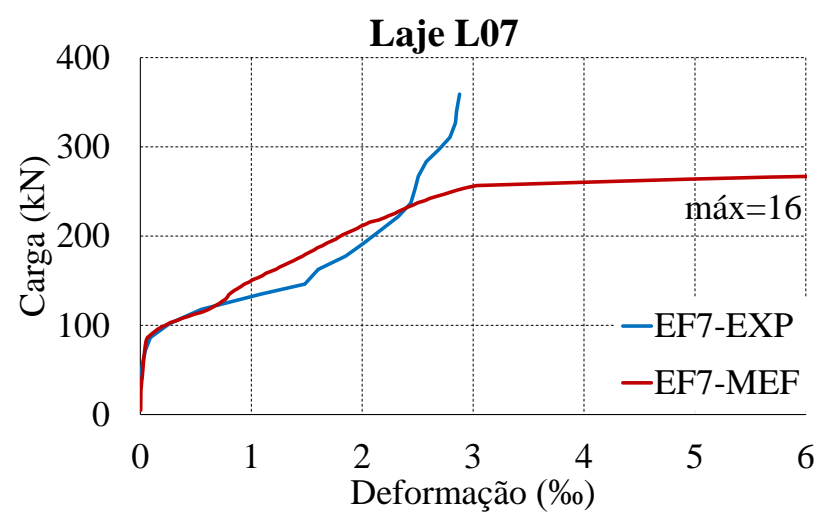

(f) Deformações no ponto 7

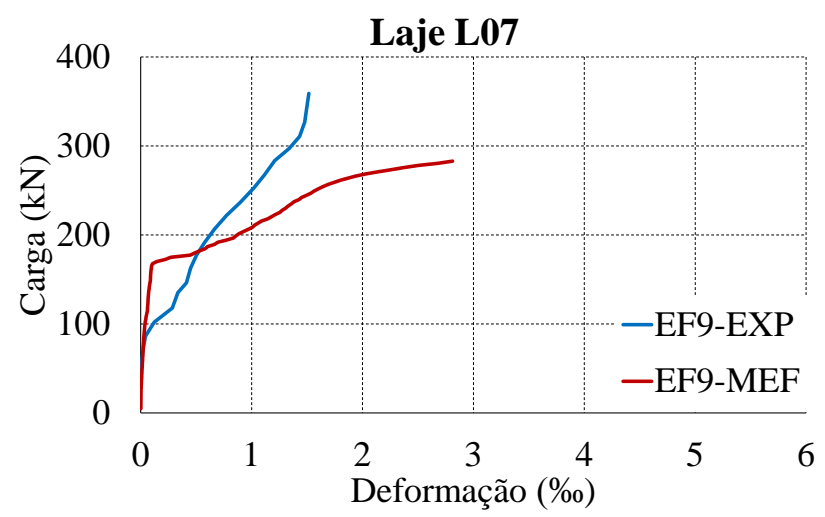

(f) Deformações no ponto 9

Figura 6.43 - Deformações na armadura de flexão da Laje L07 


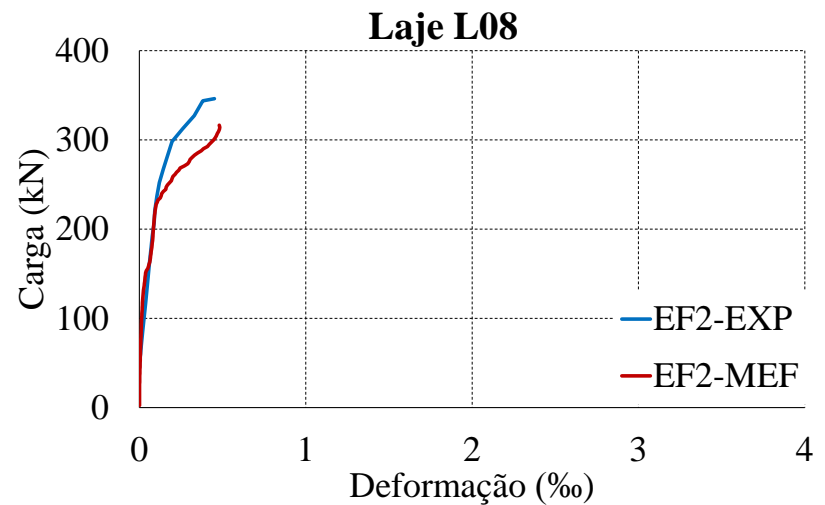

(a) Deformações no ponto 2

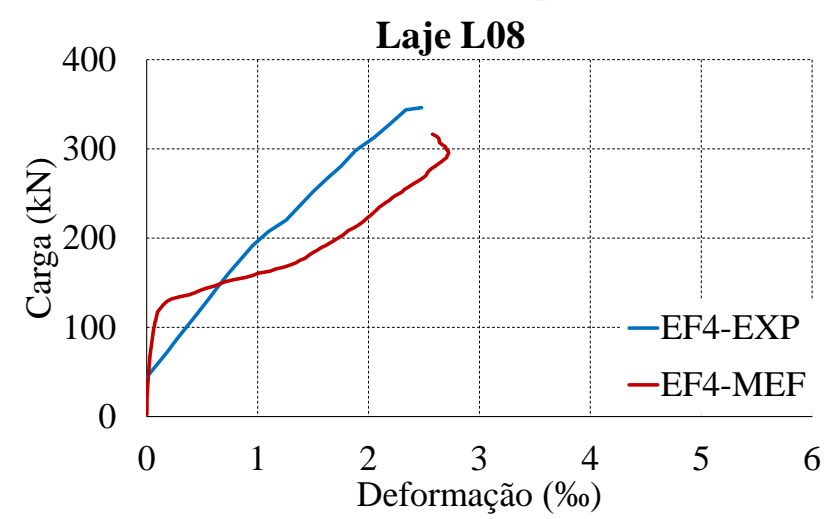

(c) Deformações no ponto 4

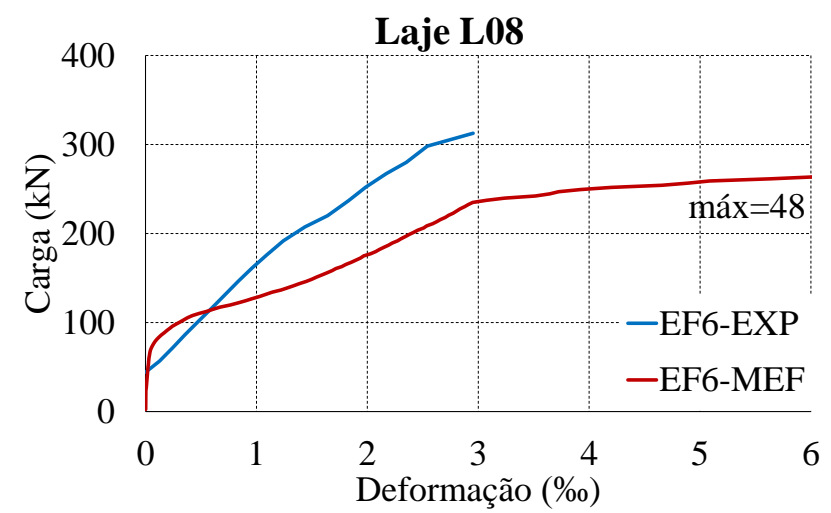

(e) Deformações no ponto 6

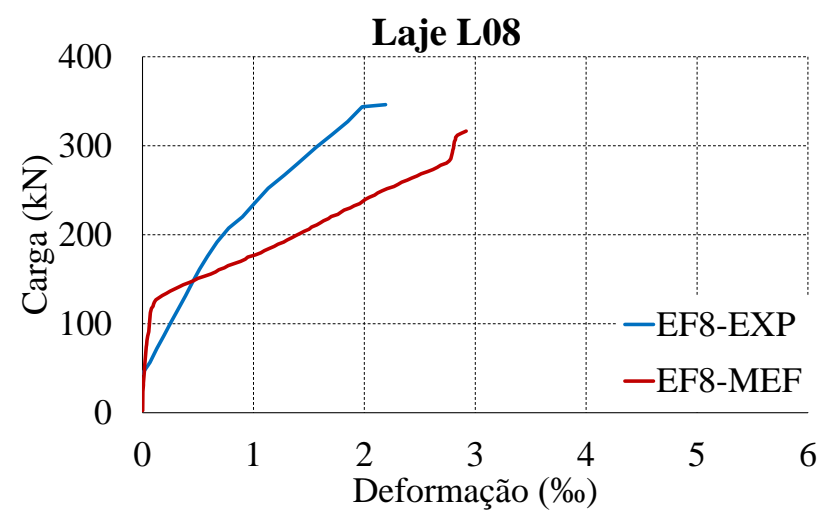

(e) Deformações no ponto 8

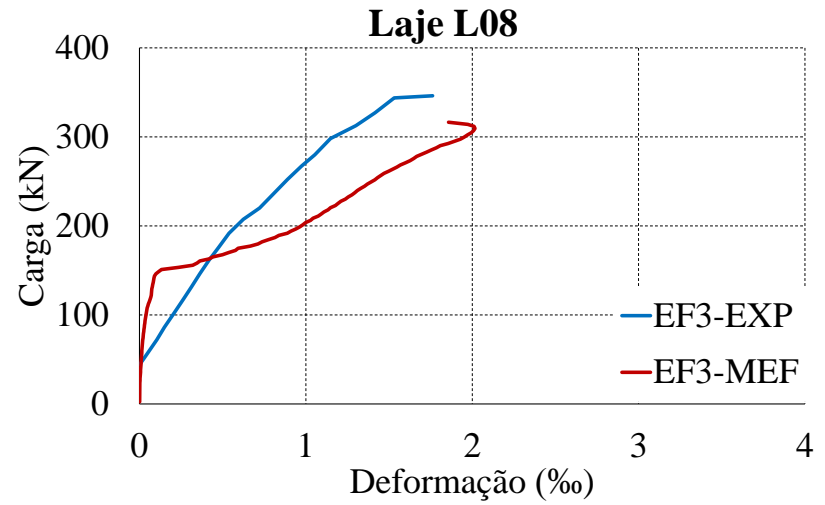

(b) Deformações no ponto 3

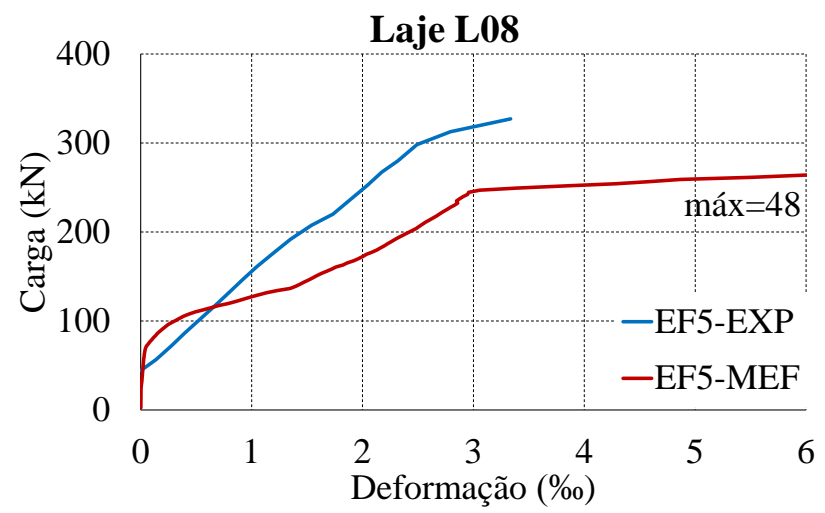

(d) Deformações no ponto 5

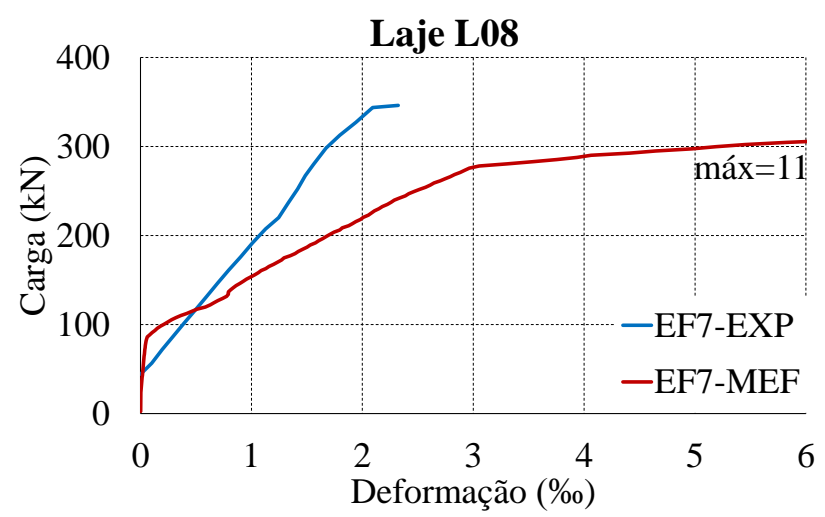

(f) Deformações no ponto 7

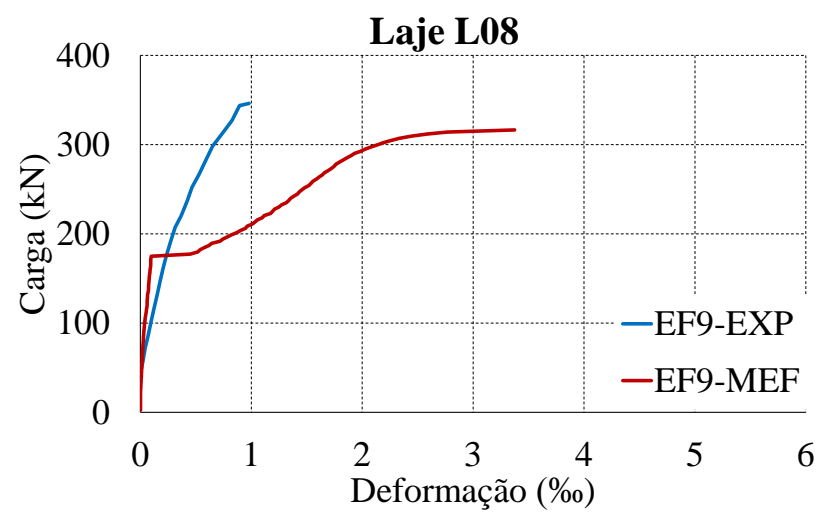

(f) Deformações no ponto 9

Figura 6.44 - Deformações na armadura de flexão da Laje L08 
Nas lajes L09, L10 e L11 foi possível comparar deformações na armadura de flexão em oito pontos como mostra a Figura 6.45.

11.

10.

9

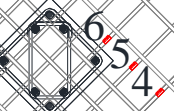

3.

Figura 6.45 - Pontos de deformações monitorados no programa ATENA 3D das lajes L09, L10 e L11

Da Figura 6.46 à Figura 6.49 são apresentadas as deformações na armadura de flexão das lajes L09, L10 e L11 para cada um dos oito pontos das lajes em diferentes passos de carga até próximo à ruptura.

Na laje L12 foi possível comparar deformações na armadura de flexão em oito pontos semelhantes aos das lajes L07 e L08 como mostra a Figura 6.42. Na Figura 6.49 são apresentadas as deformações na armadura de flexão da laje L12 nos oito pontos da laje em diferentes passos de carga até próximo à ruptura. 


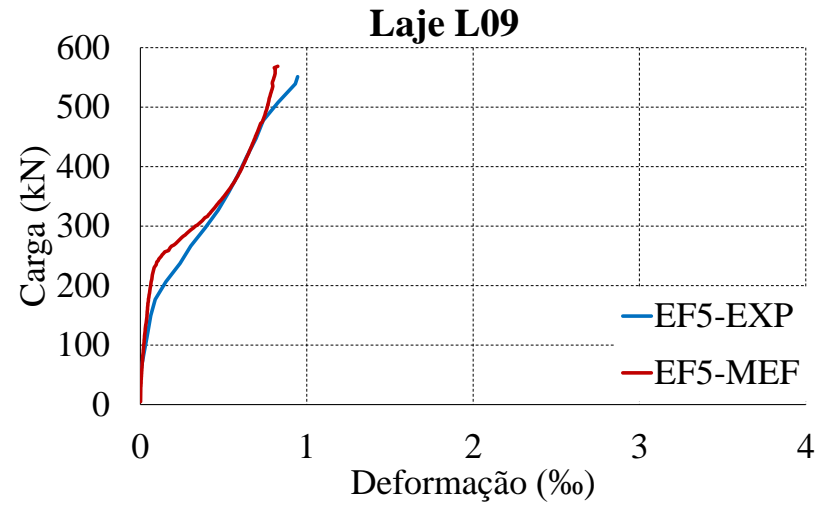

(a) Deformações no ponto 5

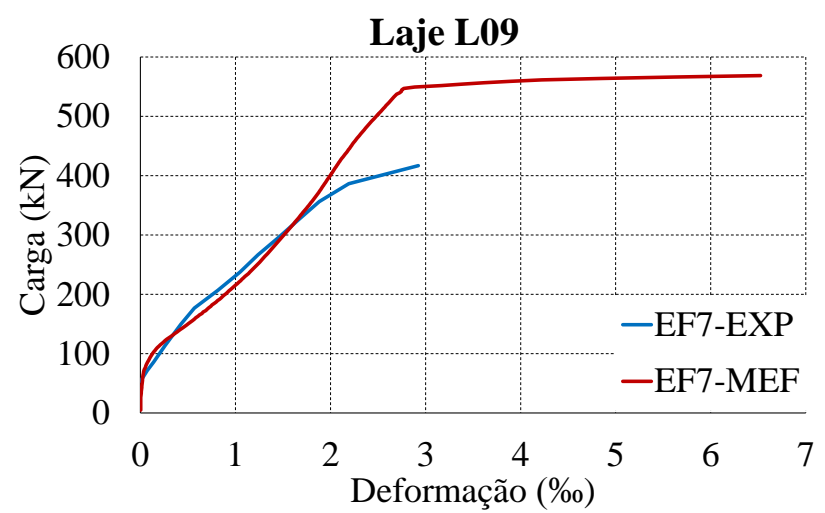

(c) Deformações no ponto 7

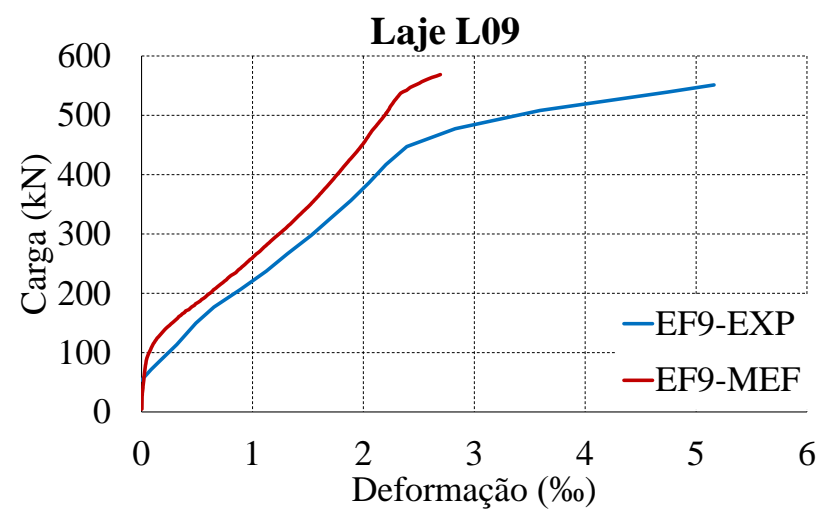

(e) Deformações no ponto 9

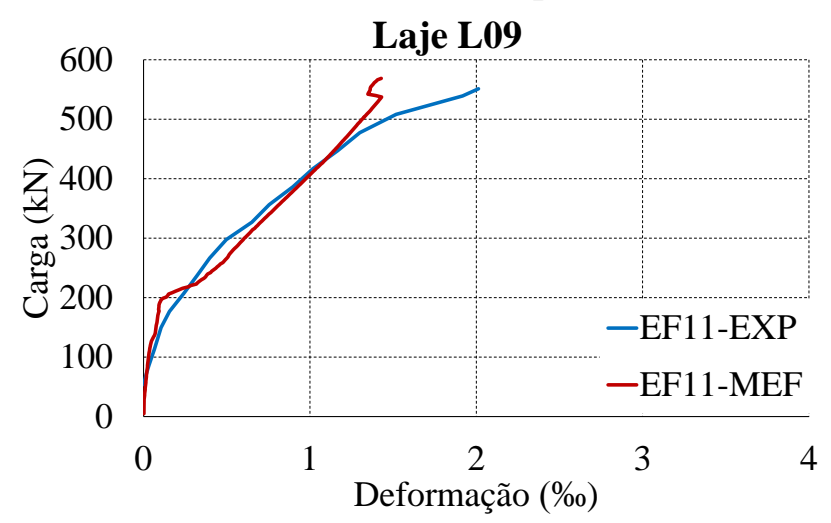

(g) Deformações no ponto 11

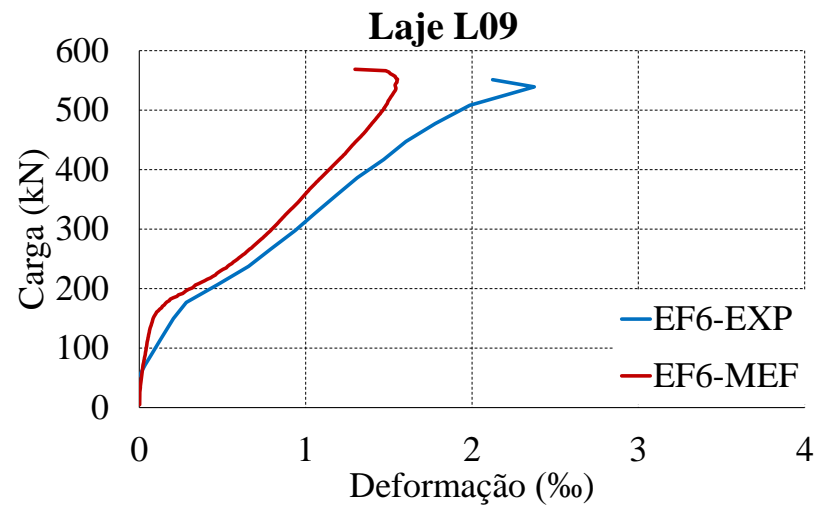

(b) Deformações no ponto 6

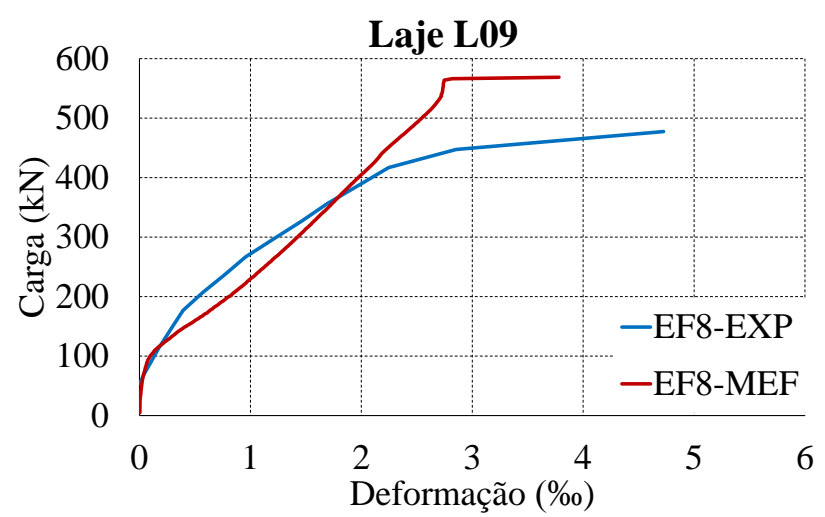

(d) Deformações no ponto 8

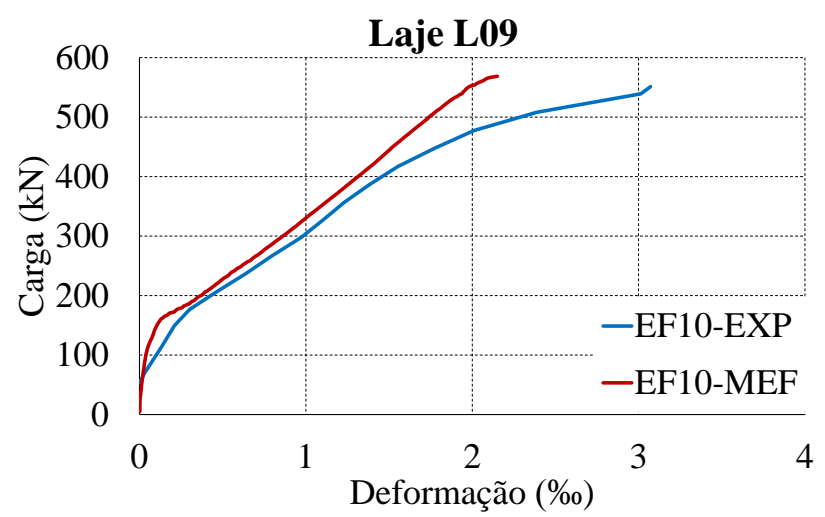

(f) Deformações no ponto 10

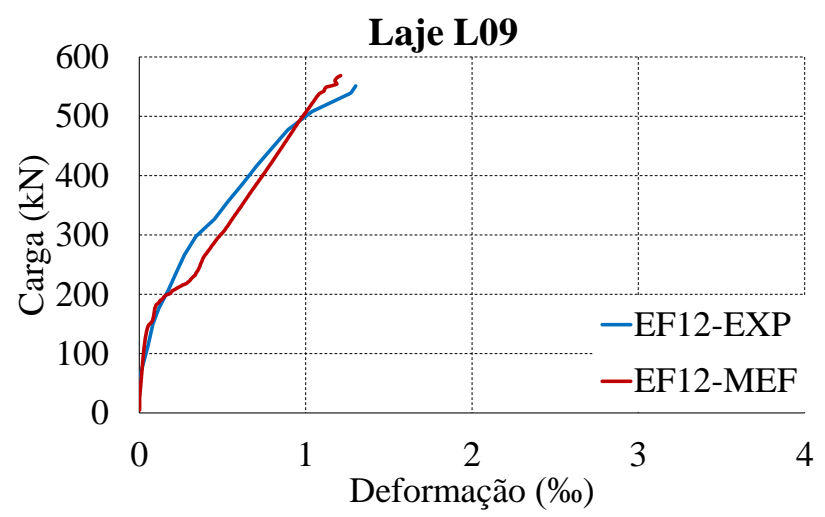

(h) Deformações no ponto 12

Figura 6.46 - Deformações na armadura de flexão da Laje L09 


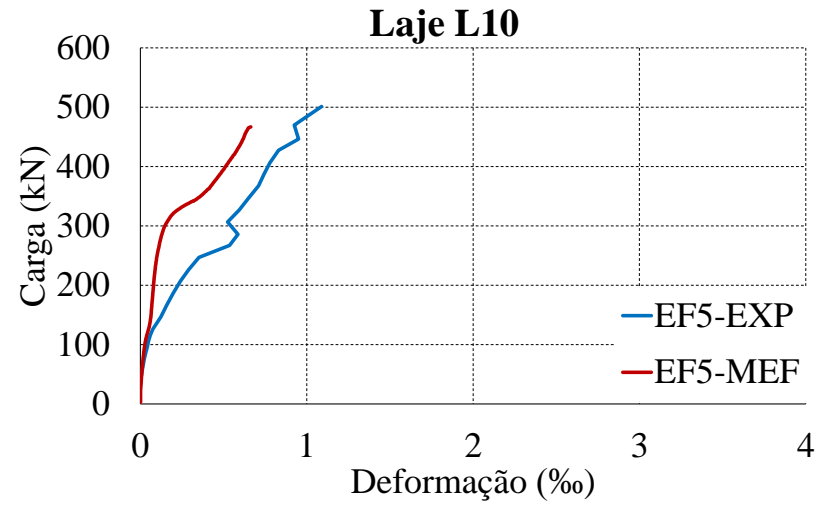

(a) Deformações no ponto 5

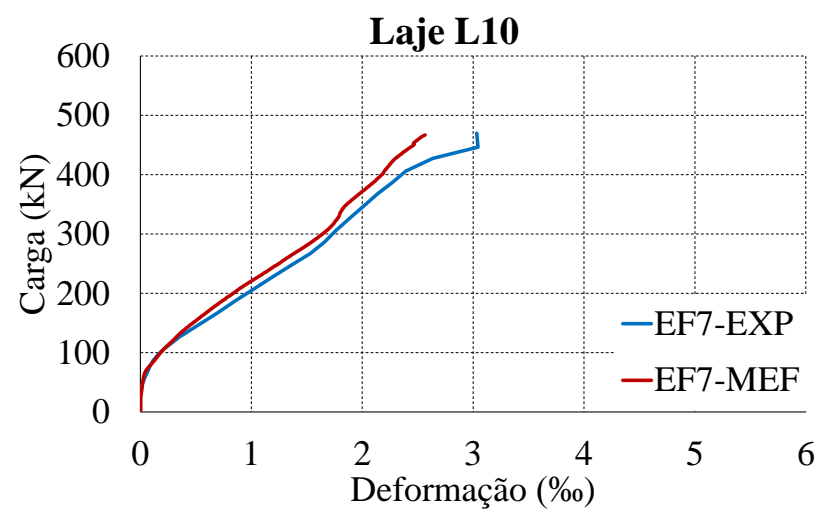

(c) Deformações no ponto 7

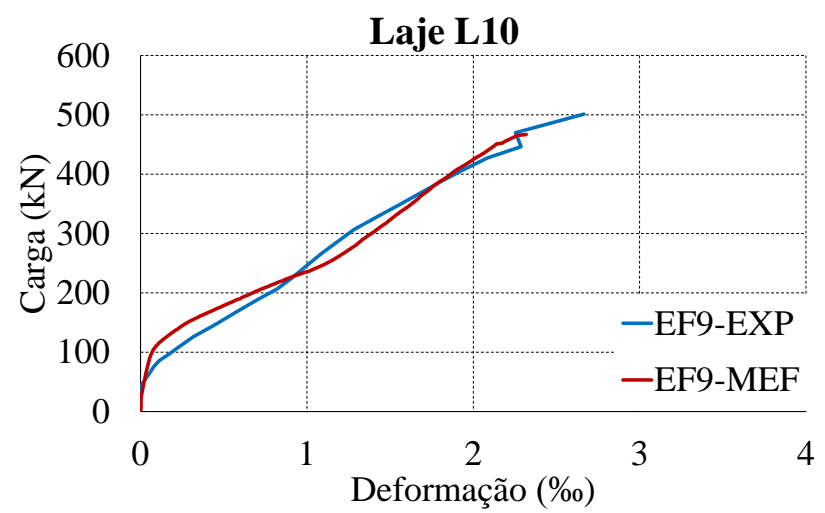

(e) Deformações no ponto 9

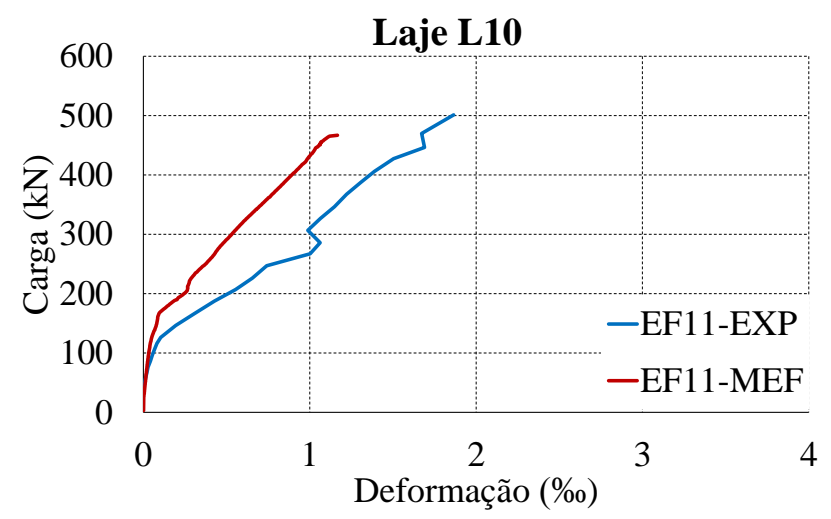

(g) Deformações no ponto 11

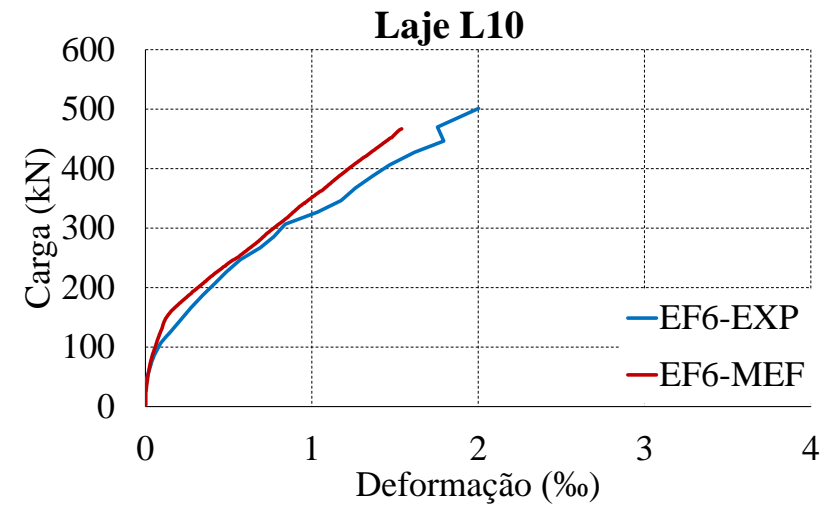

(b) Deformações no ponto 6

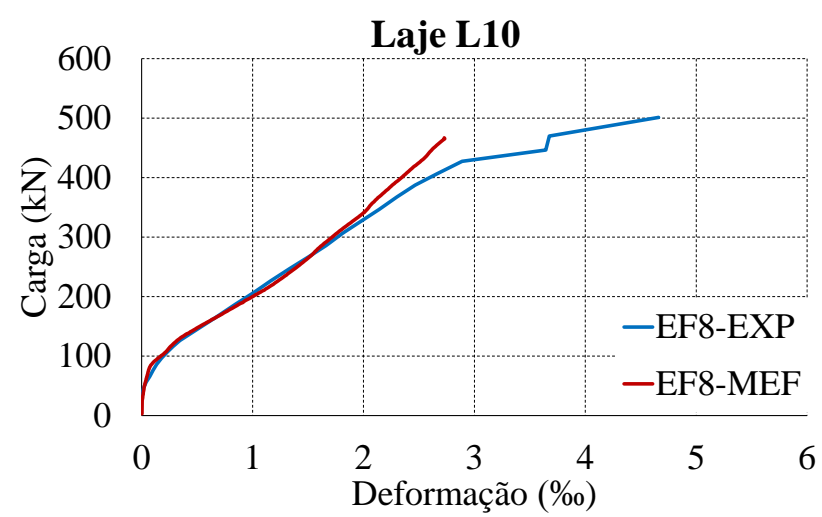

(d) Deformações no ponto 8

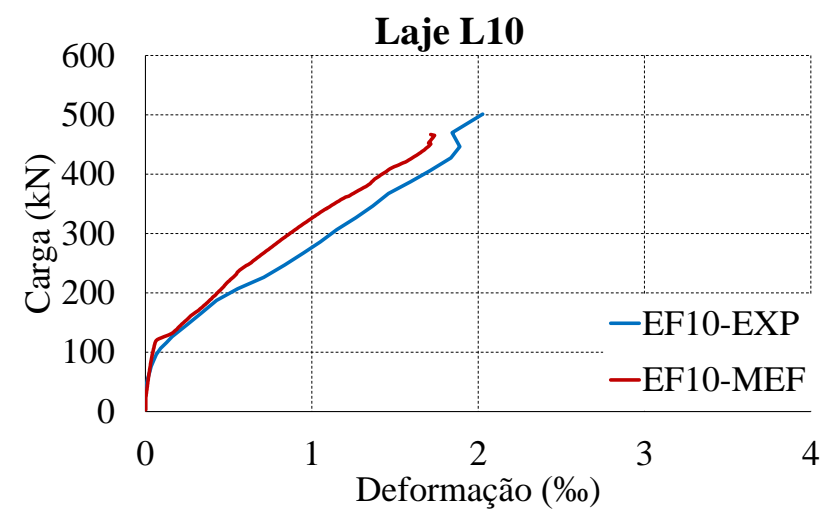

(f) Deformações no ponto 10

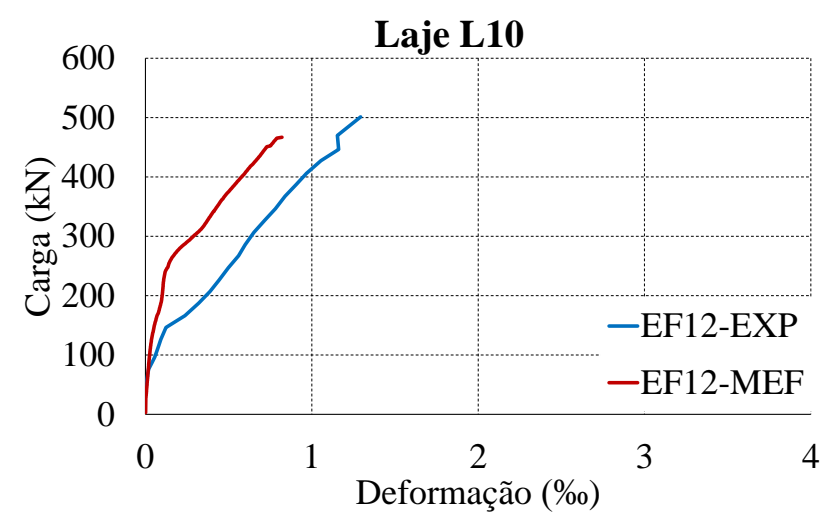

(h) Deformações no ponto 12

Figura 6.47 - Deformações na armadura de flexão da Laje L10 


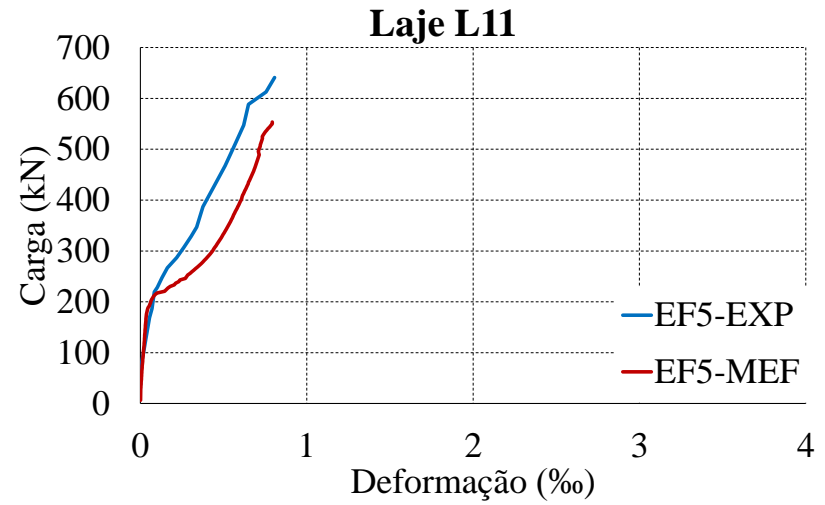

(a) Deformações no ponto 5

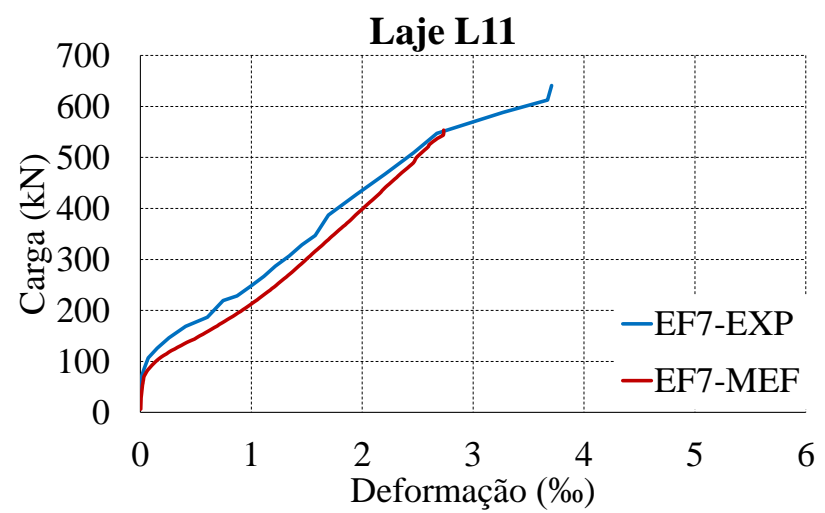

(c) Deformações no ponto 7

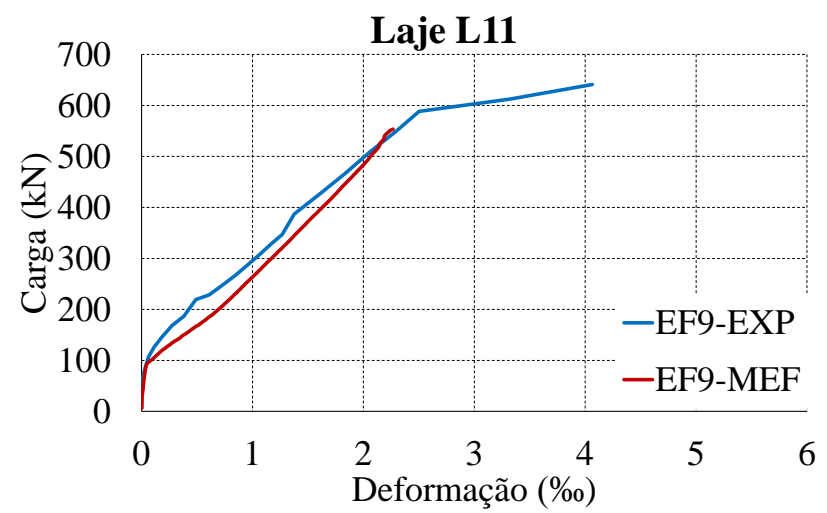

(e) Deformações no ponto 9

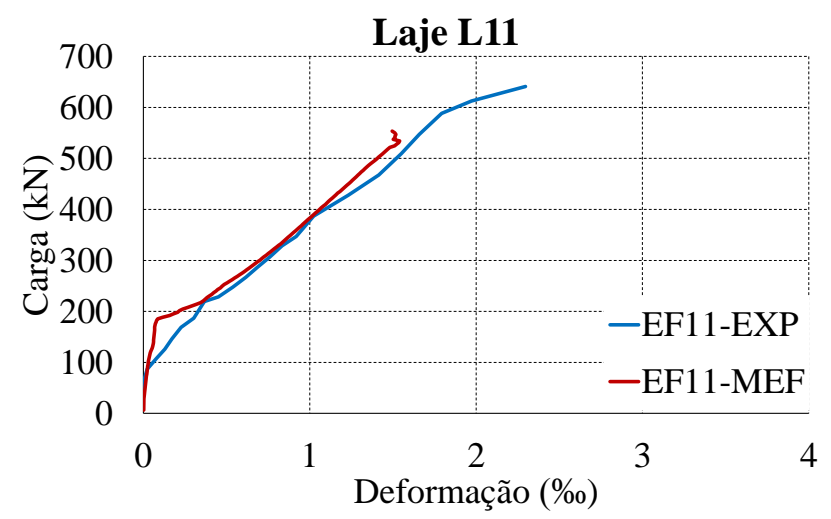

(g) Deformações no ponto 11

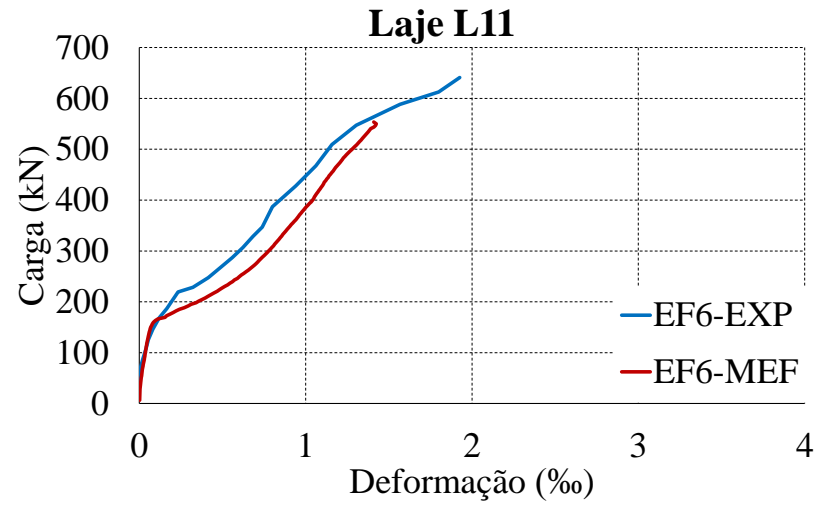

(b) Deformações no ponto 6

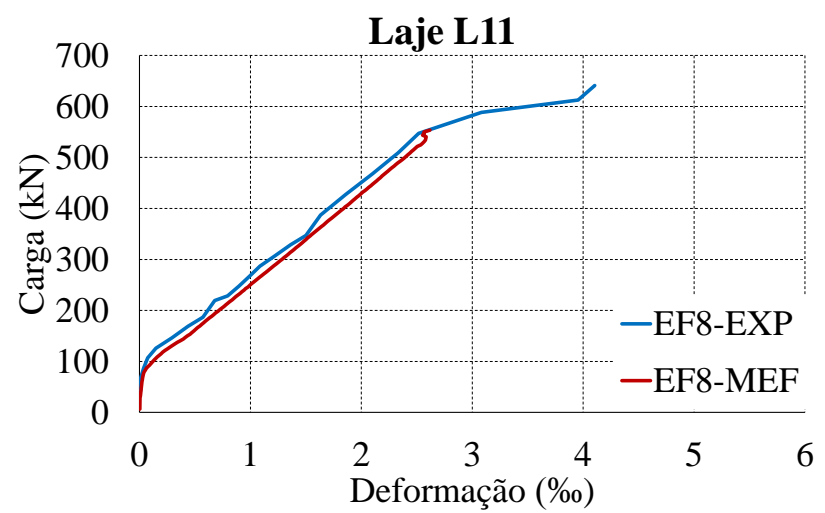

(d) Deformações no ponto 8

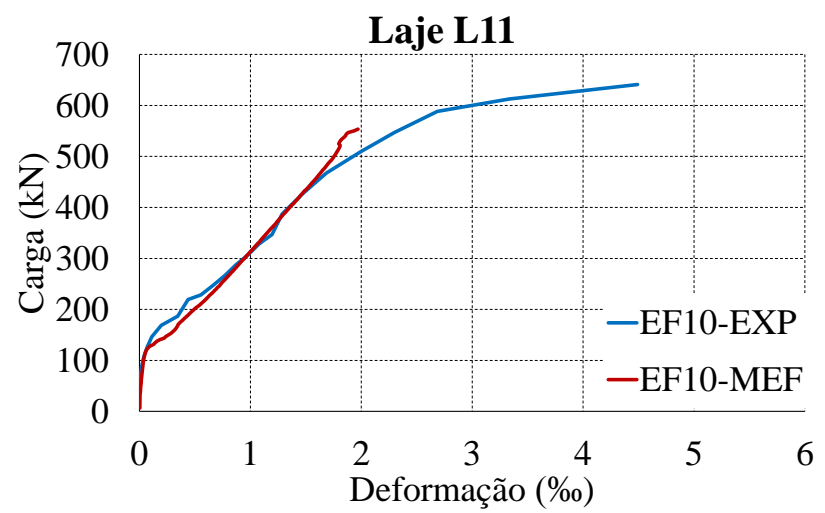

(f) Deformações no ponto 10

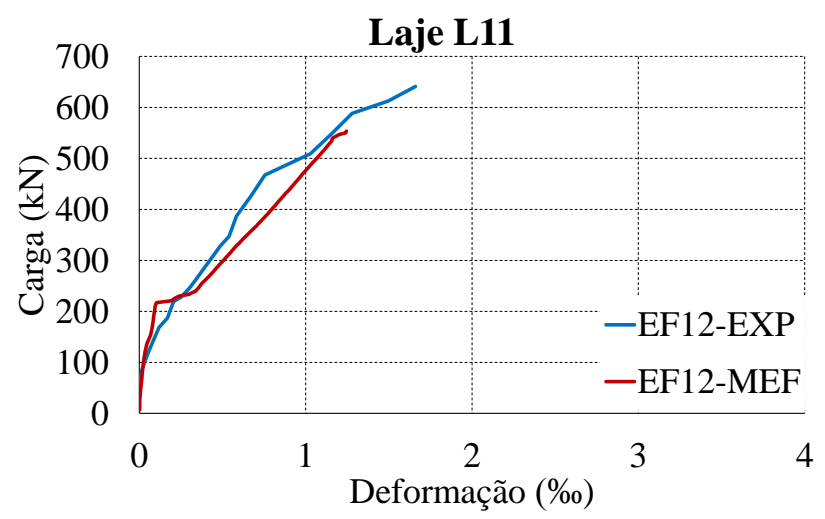

(h) Deformações no ponto 12

Figura 6.48 - Deformações na armadura de flexão da Laje L11 


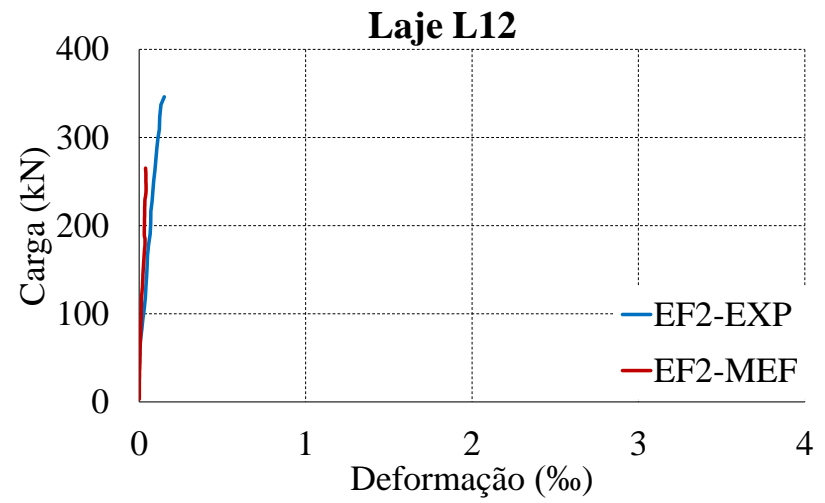

(a) Deformações no ponto 2

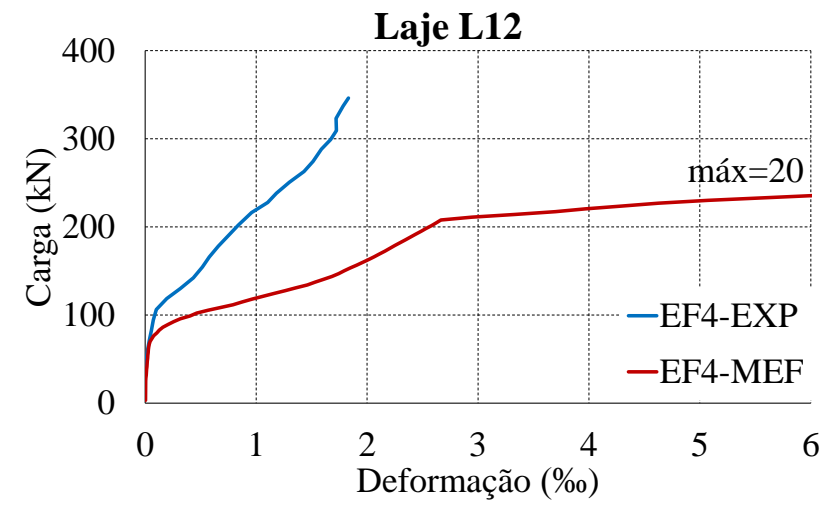

(c) Deformações no ponto 4

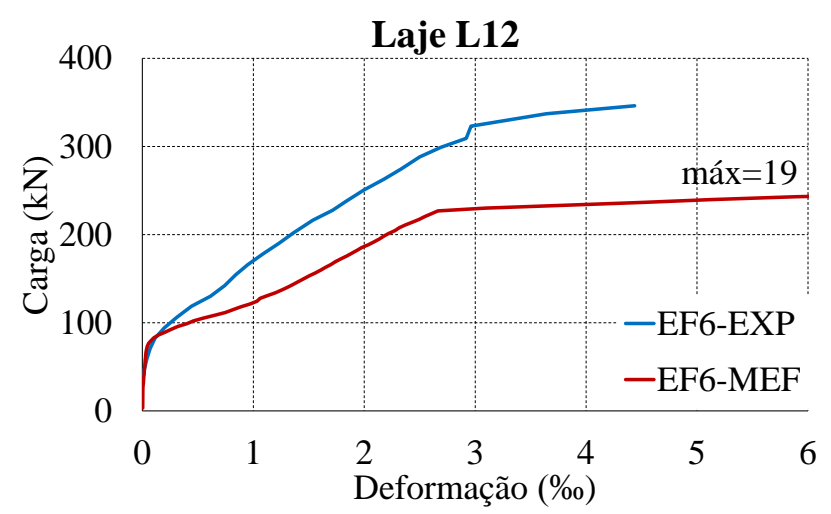

(e) Deformações no ponto 6

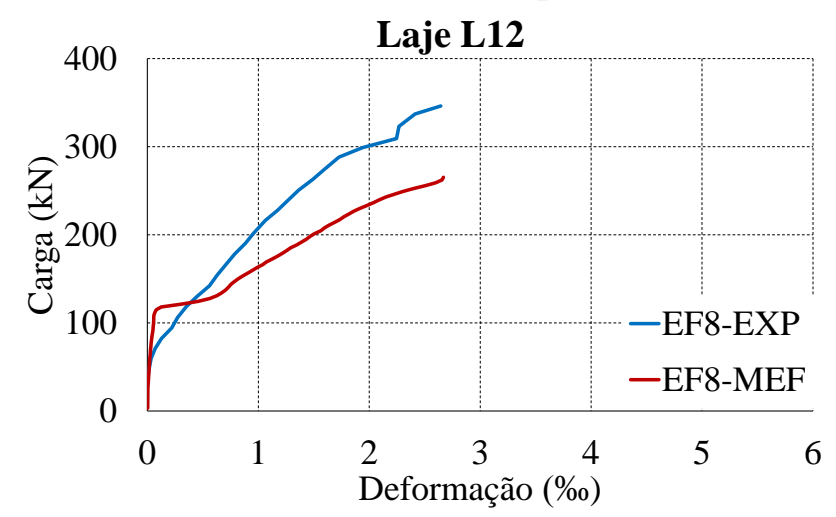

(e) Deformações no ponto 8

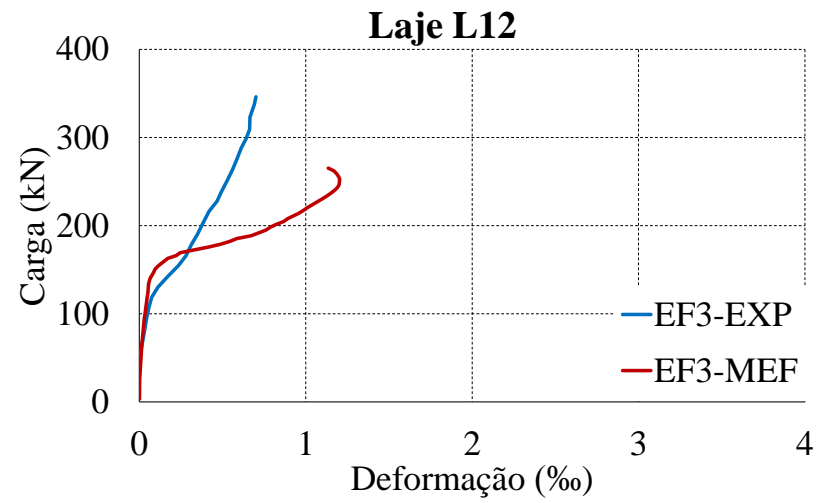

(b) Deformações no ponto 3

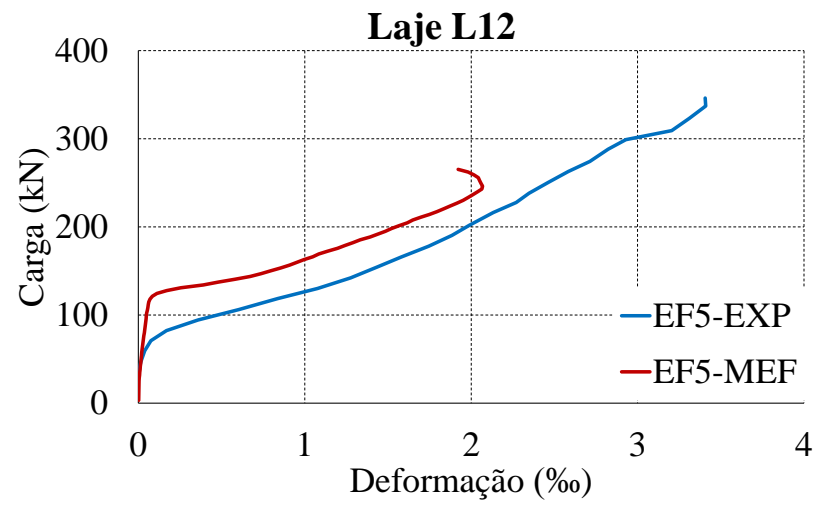

(d) Deformações no ponto 5

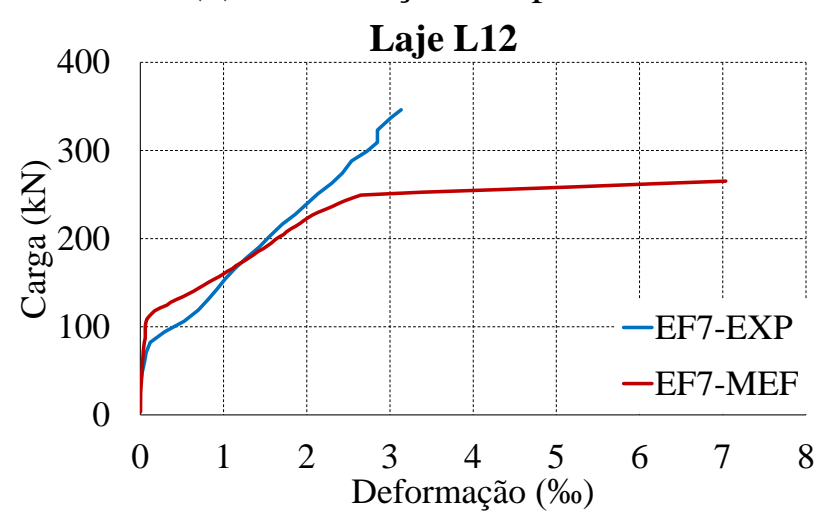

(f) Deformações no ponto 7

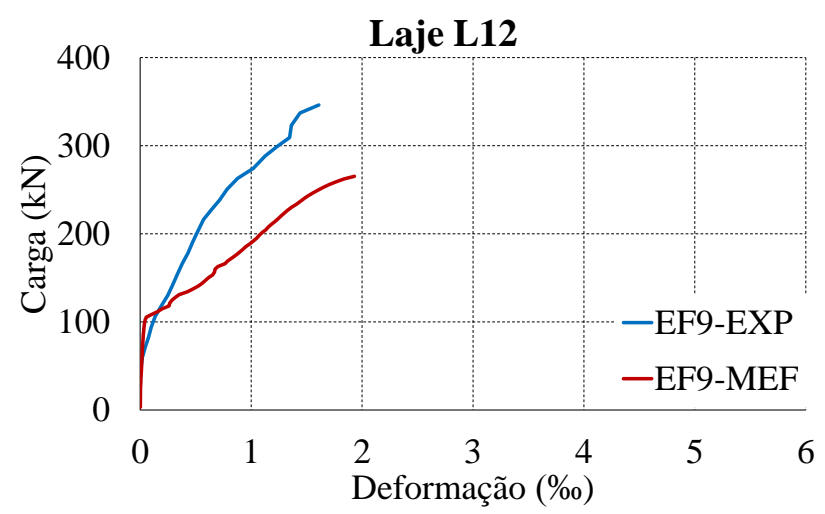

(f) Deformações no ponto 9

Figura 6.49 - Deformações na armadura de flexão da Laje L12 
Com os gráficos de deformações nas armaduras de flexão pode-se notar para todas as lajes uma boa concordância entre os resultados experimentais e numéricos.

\subsection{DEFORMAÇÃO DA ARMADURA DE CISALHAMENTO}

Foi possível comparar deformações na armadura de cisalhamento em quatro pontos mais solicitados para as lajes L02, L03, L09, L10 e L11 como mostra na Figura 6.50.

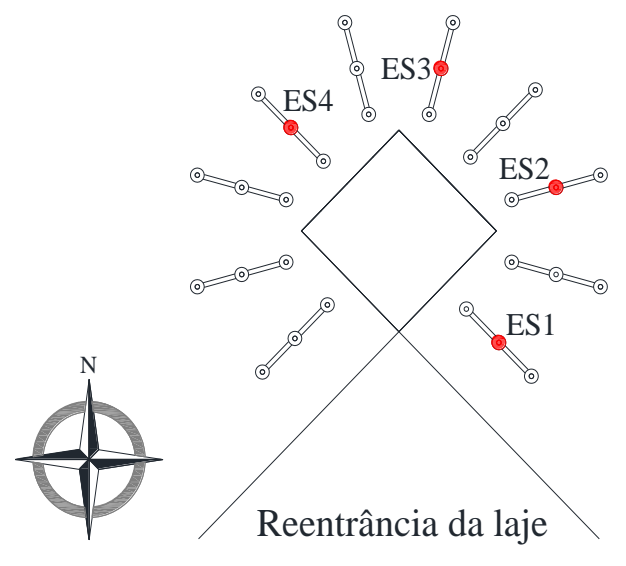

(a) L02

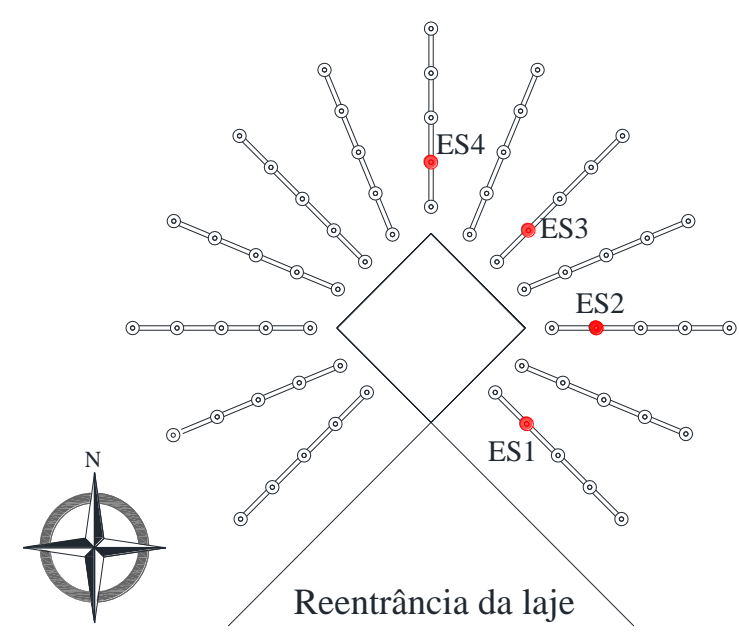

(c) L09

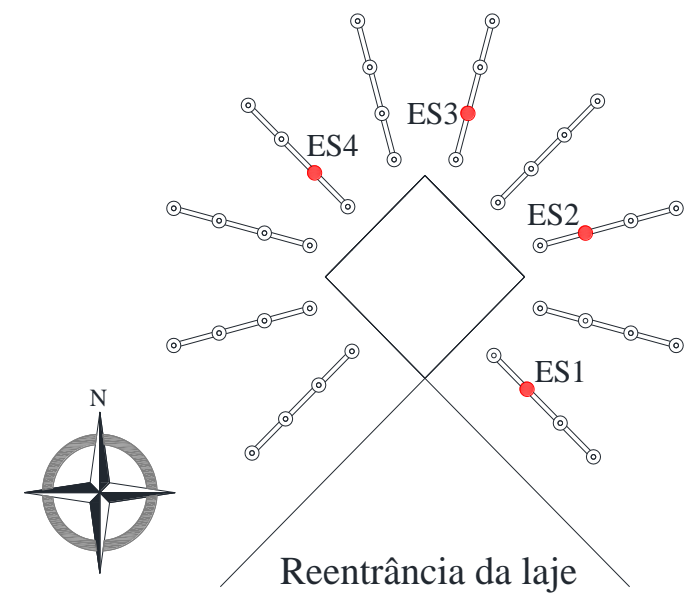

(a) L03

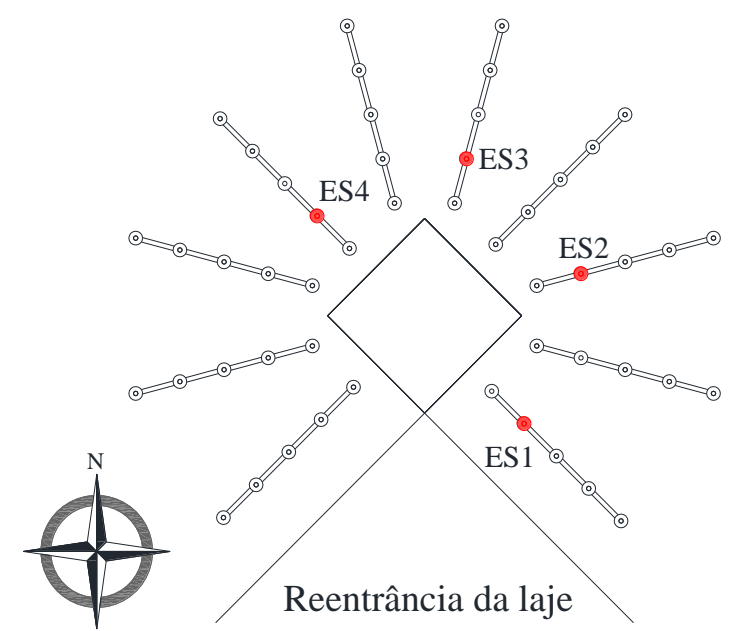

(a) L10 e L11

Figura 6.50 - Pontos de deformações na armadura de cisalhamento monitorados no programa ATENA 3D das lajes L02, L03, L09, L10 e L11.

Da Figura 6.51 à Figura 6.55 são apresentadas as deformações na armadura de cisalhamento das lajes para cada um dos quatro pontos selecionados das lajes em diferentes passos de carga até à ruptura. 


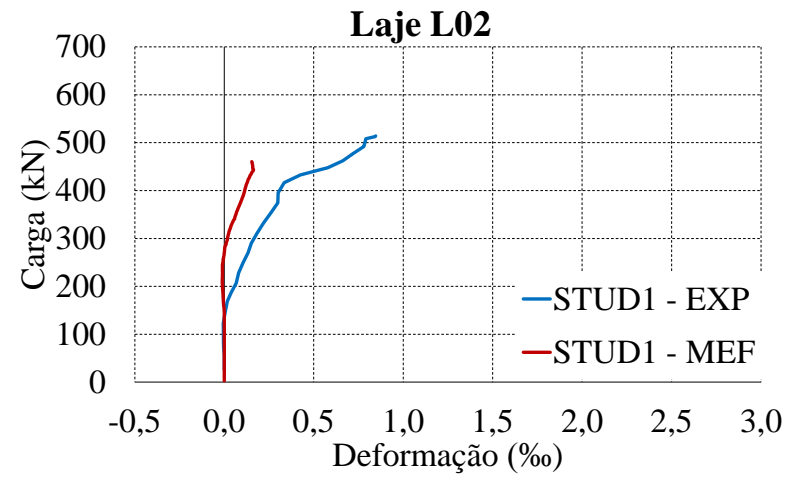

(a) Deformações no ponto 1

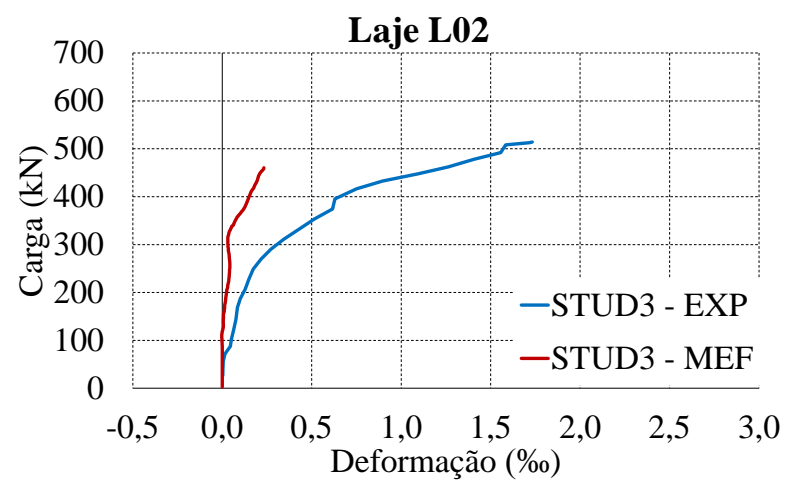

(c) Deformações no ponto 3

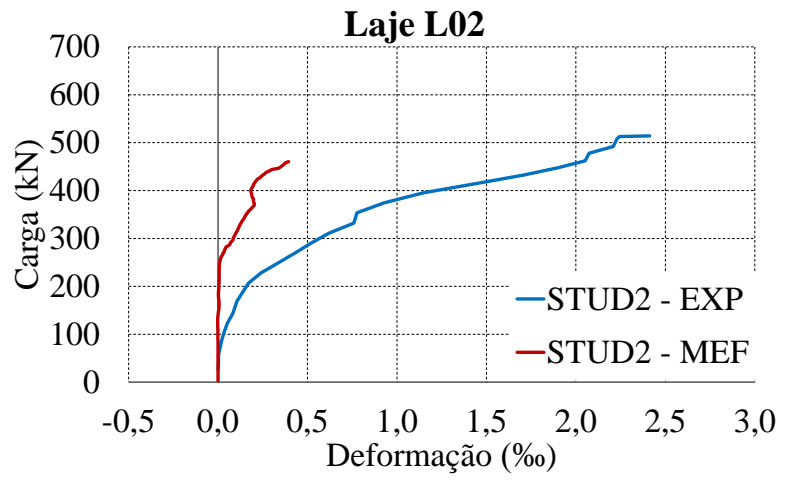

(b) Deformações no ponto 2

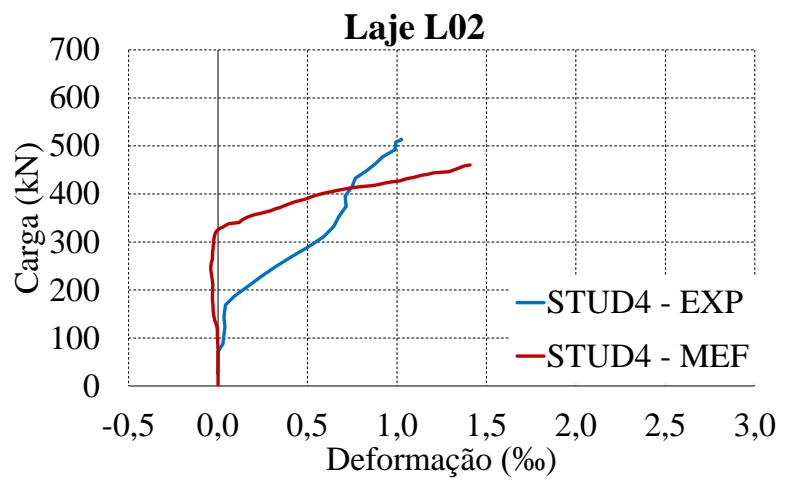

(d) Deformações no ponto 4

Figura 6.51 - Deformações na armadura de cisalhamento da Laje L02

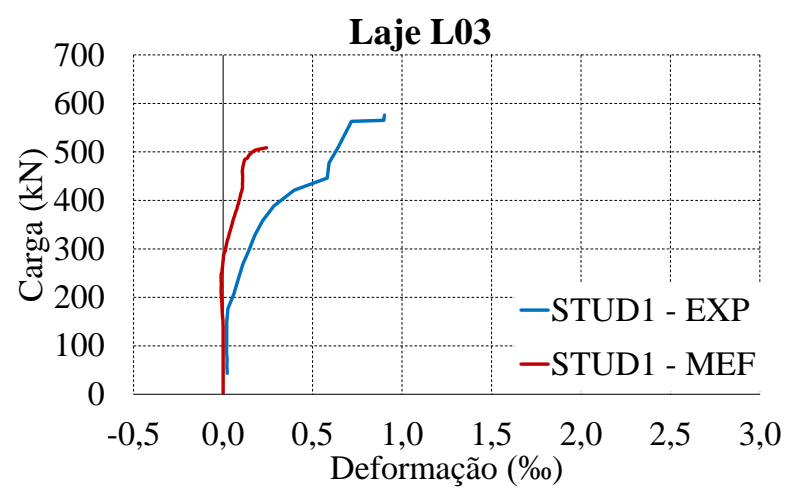

(a) Deformações no ponto 1

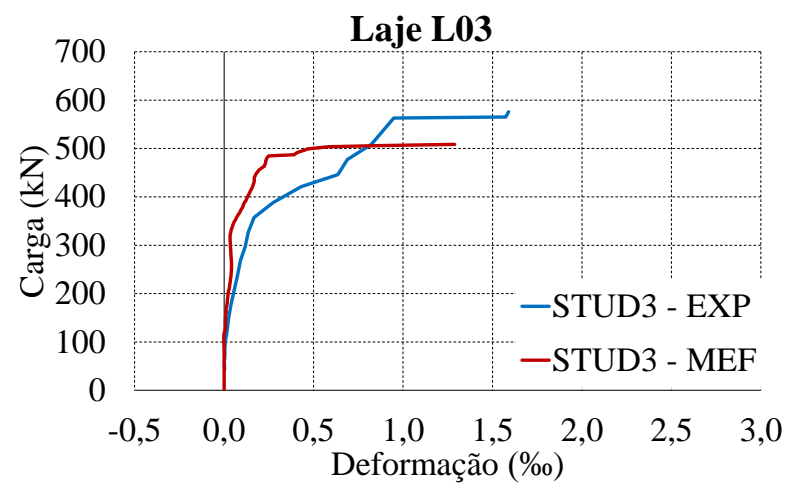

(c) Deformações no ponto 3

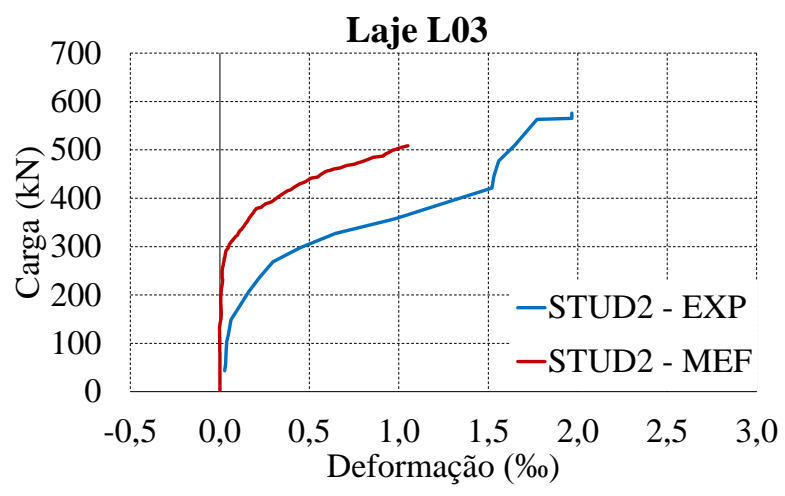

(b) Deformações no ponto 2

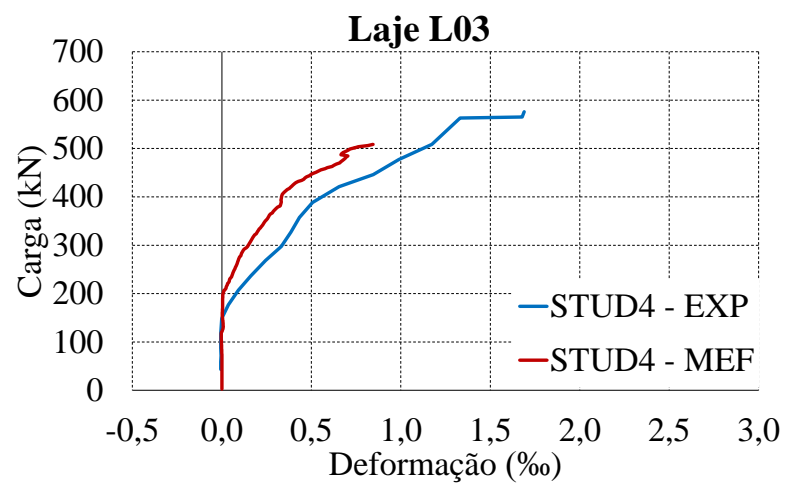

(d) Deformações no ponto 4

Figura 6.52 - Deformações na armadura de cisalhamento da Laje L03 


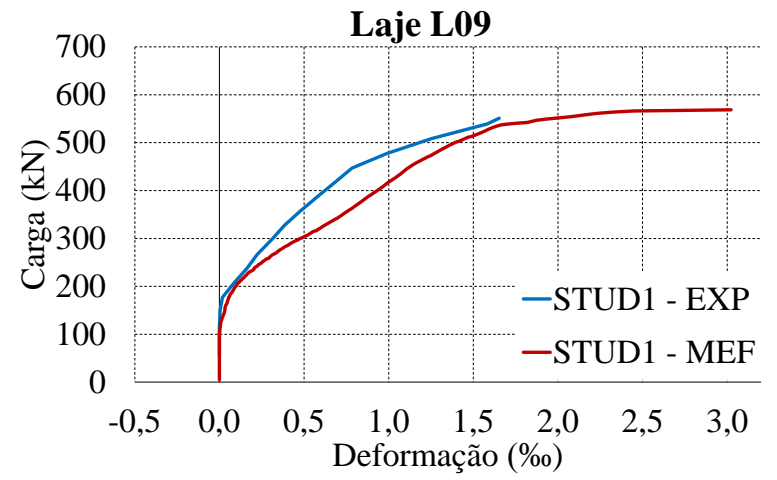

(a) Deformações no ponto 1

\section{Laje L09}

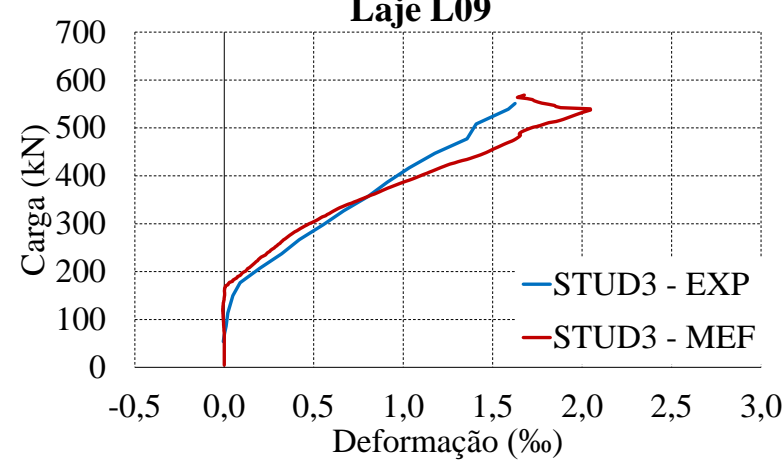

(c) Deformações no ponto 3

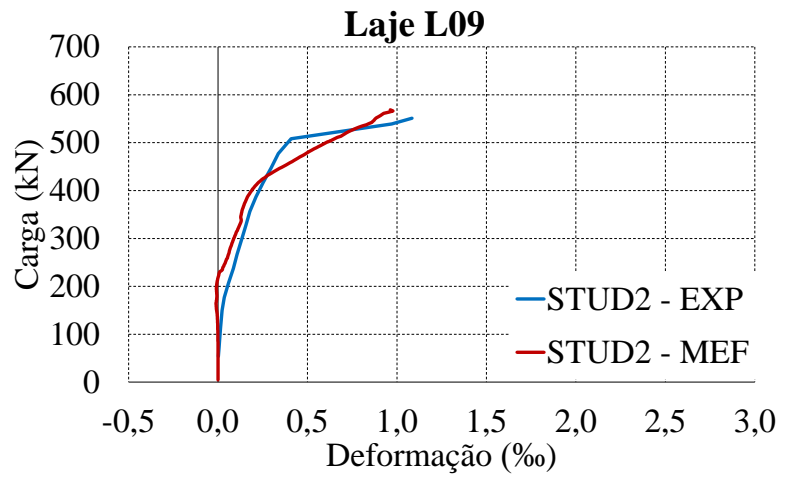

(b) Deformações no ponto 2

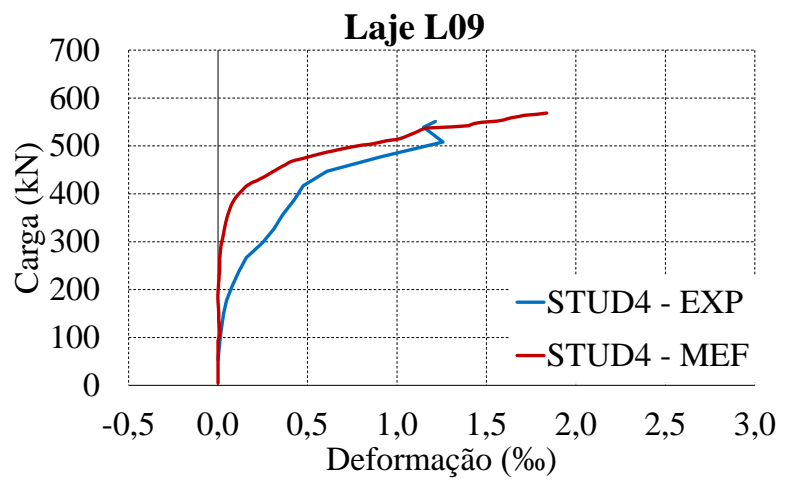

(d) Deformações no ponto 4

Figura 6.53 - Deformações na armadura de cisalhamento da Laje L09

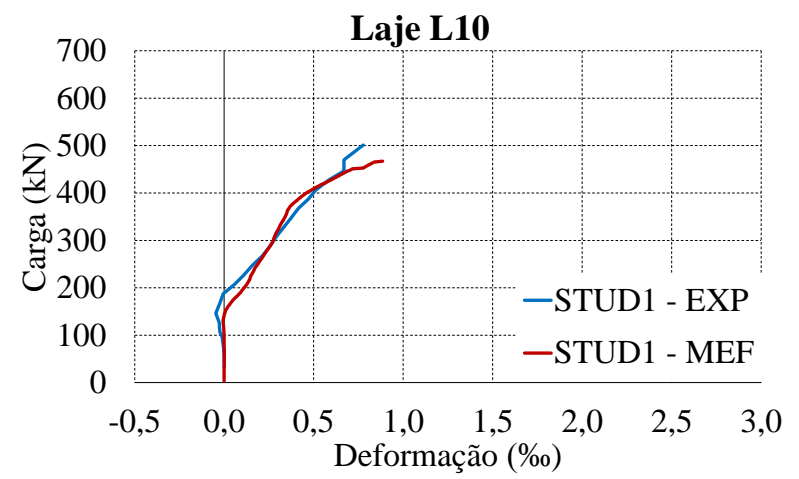

(a) Deformações no ponto 1

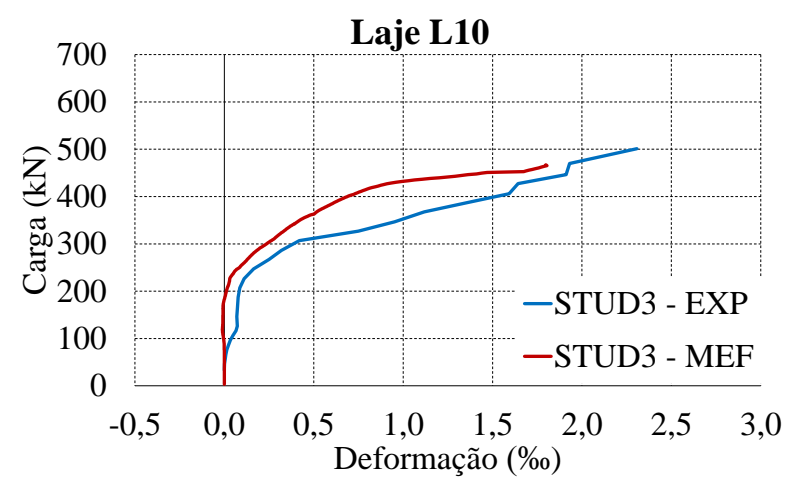

(c) Deformações no ponto 3

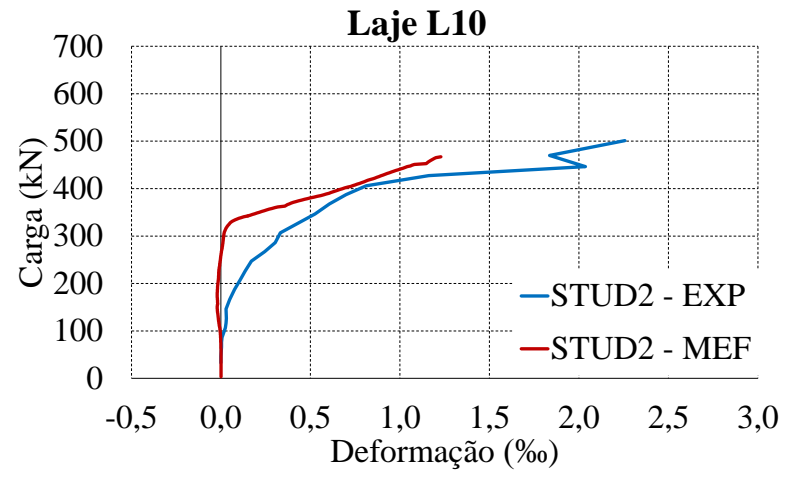

(b Deformações no ponto 2

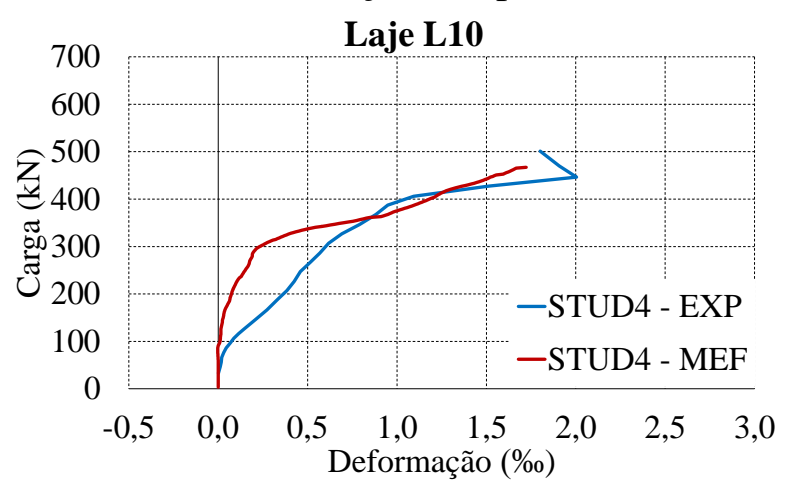

(d) Deformações no ponto 4

Figura 6.54 - Deformações na armadura de cisalhamento da Laje L10 


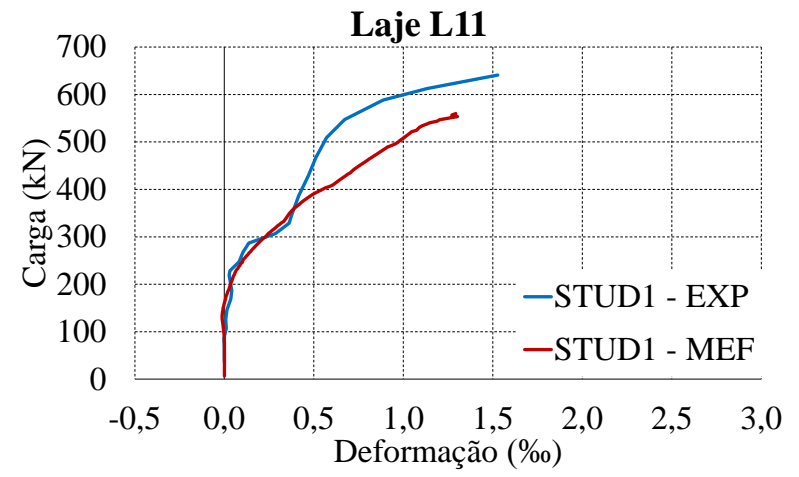

(a) Deformações no ponto 1

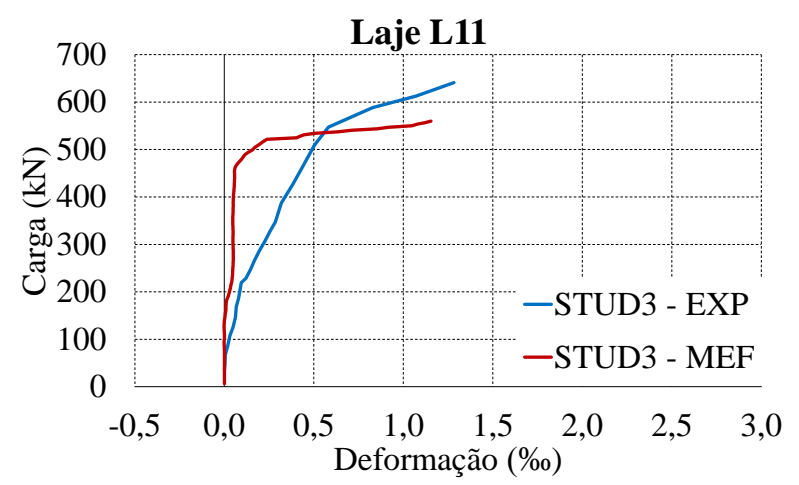

(c) Deformações no ponto 3

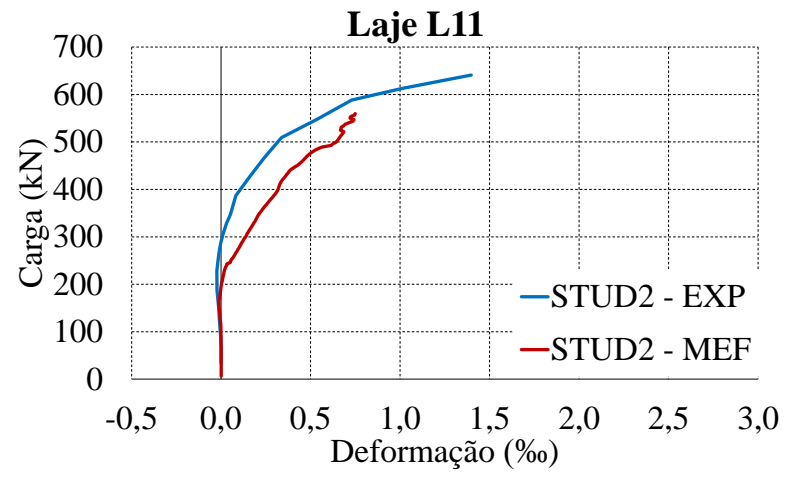

(b) Deformações no ponto 2

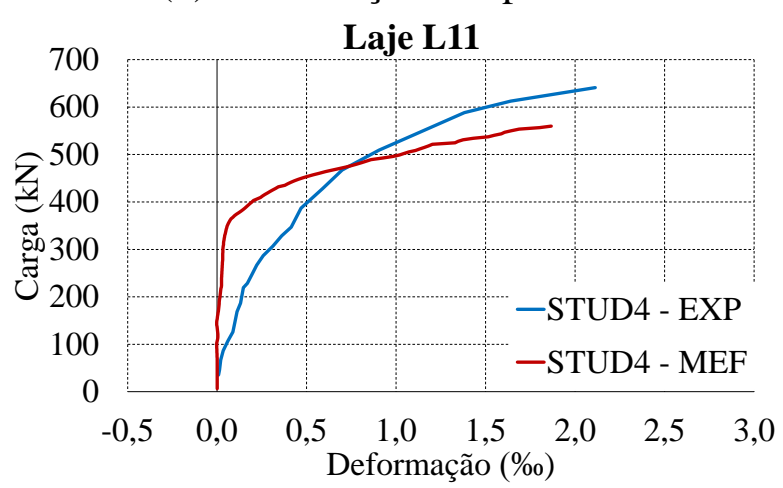

(d) Deformações no ponto 4

Figura 6.55 - Deformações na armadura de cisalhamento da Laje L11

Assim como as deformaçães da armadadura de flexão, as deformações das armaduras de cisalhamento apresentaram para todas as lajes uma boa concordância entre os resultados experimentais e numéricos.

\subsection{DEFORMAÇÃO DO CONCRETO}

Para discutir os resultados numéricos das deformações na superfície do concreto e das tensões na laje serão mostrados os resultados obtidos do programa para uma laje sem armadura de cisalhamento (L04) e uma laje com armadura de cisalhamento (L02) para um carregamento igual em todos os pontos (excentricidade de $350 \mathrm{~mm}$ ).

Nas Figura 6.57 e Figura 6.58 são apresentadas as deformações na superfície de concreto das lajes nos pontos indicados na Figura 6.56. 


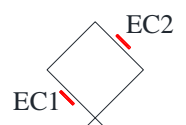

Figura 6.56 - Pontos de deformações monitorados no programa ATENA 3D das lajes L02 e L04

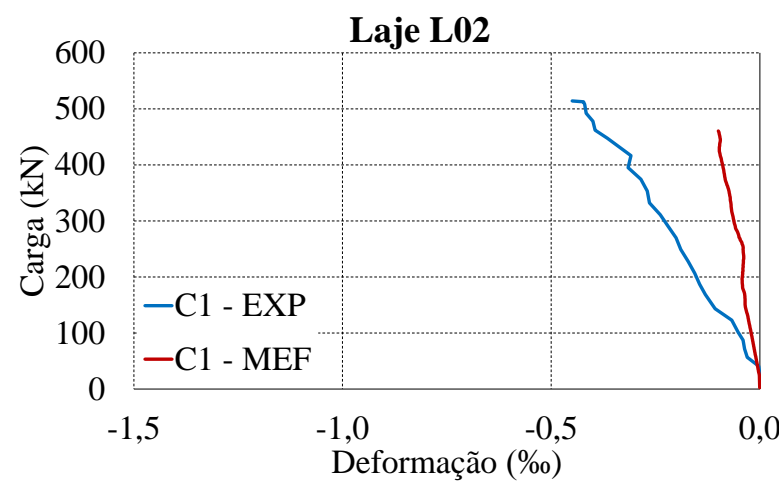

Deformações no ponto 1

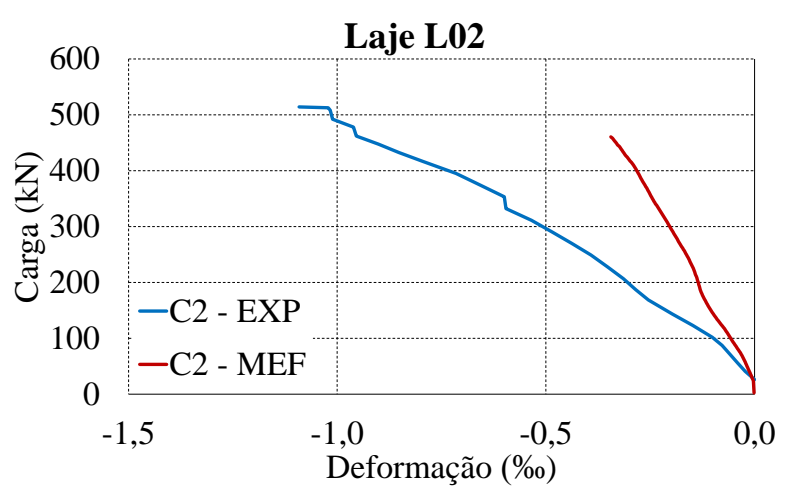

(d) Deformações no ponto 2

Figura 6.57 - Deformações na superfície do concreto da Laje L02

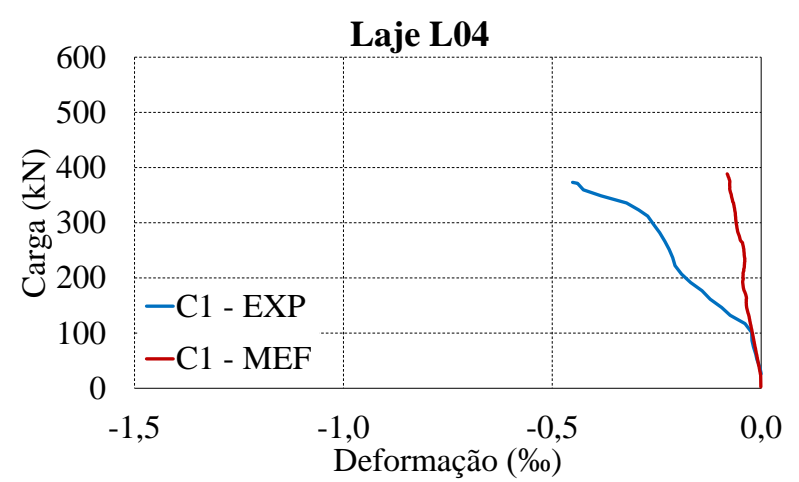

(c) Deformações no ponto 1

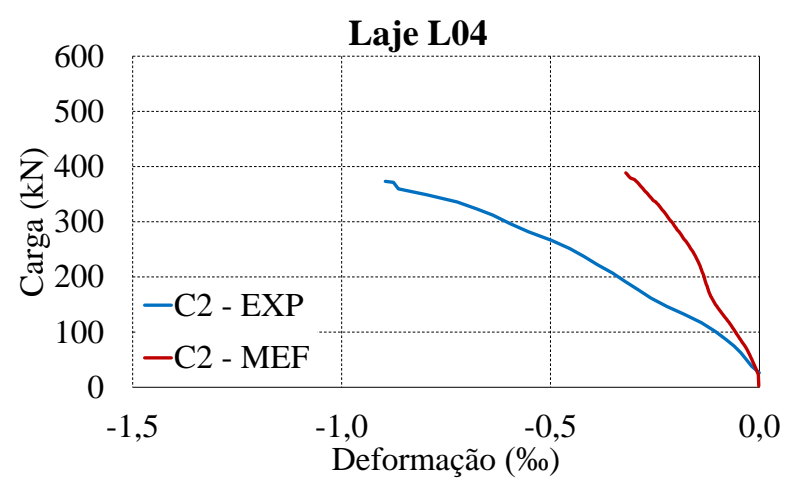

(d) Deformações no ponto 2

Figura 6.58 - Deformações na superfície do concreto da Laje L04

As deformações no concreto apesar de serem difíceis de serem monitorados, pelo surgimento de fissuras na medida em que se carrega a laje, foram coerentes indicando um mesmo comportamento dos resultados experimentais e numéricos. 
A Figura 6.60 e Figura 6.61 apresentam a variação de tensões principais das lajes L04 e L02 respectivamente no corte ilustrado na Figura 6.59.

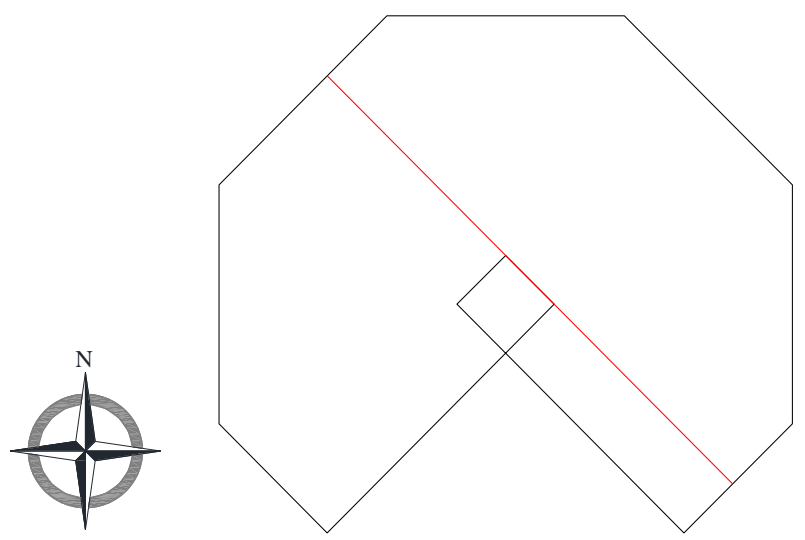

Figura 6.59 - Corte da laje para análise de tensões e deformações

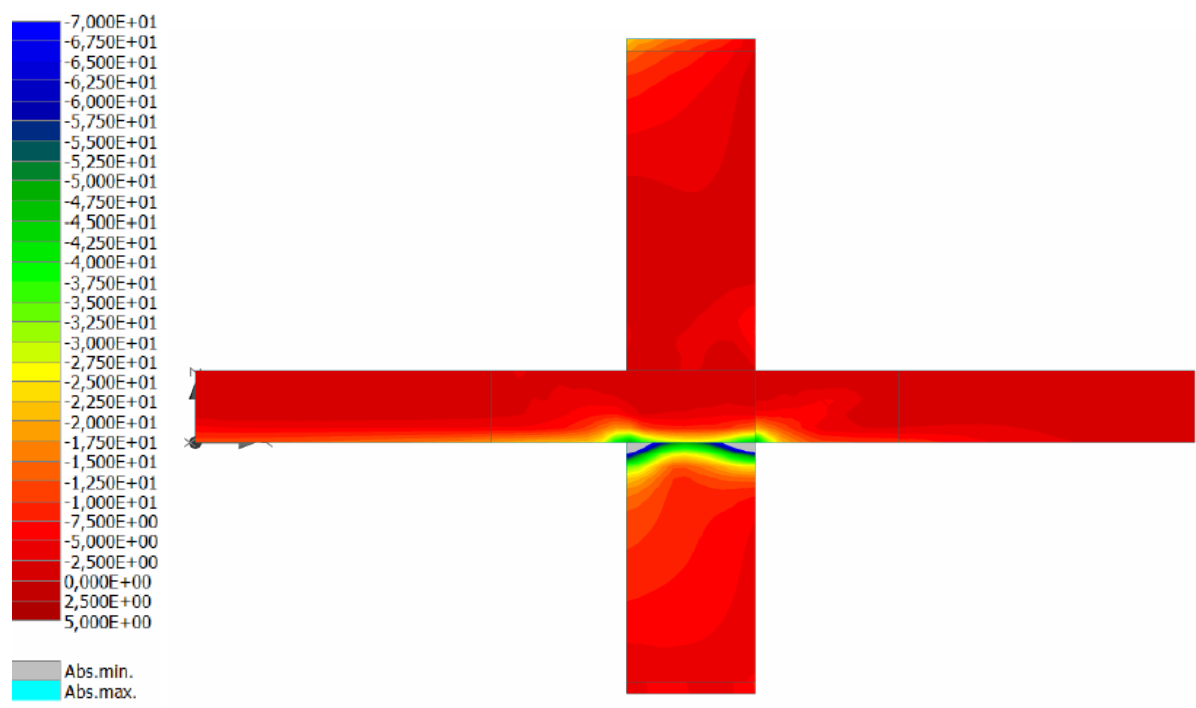

Figura 6.60 - Distribuição das tensões principais (MPa) na laje L04 (corte NO-SE).

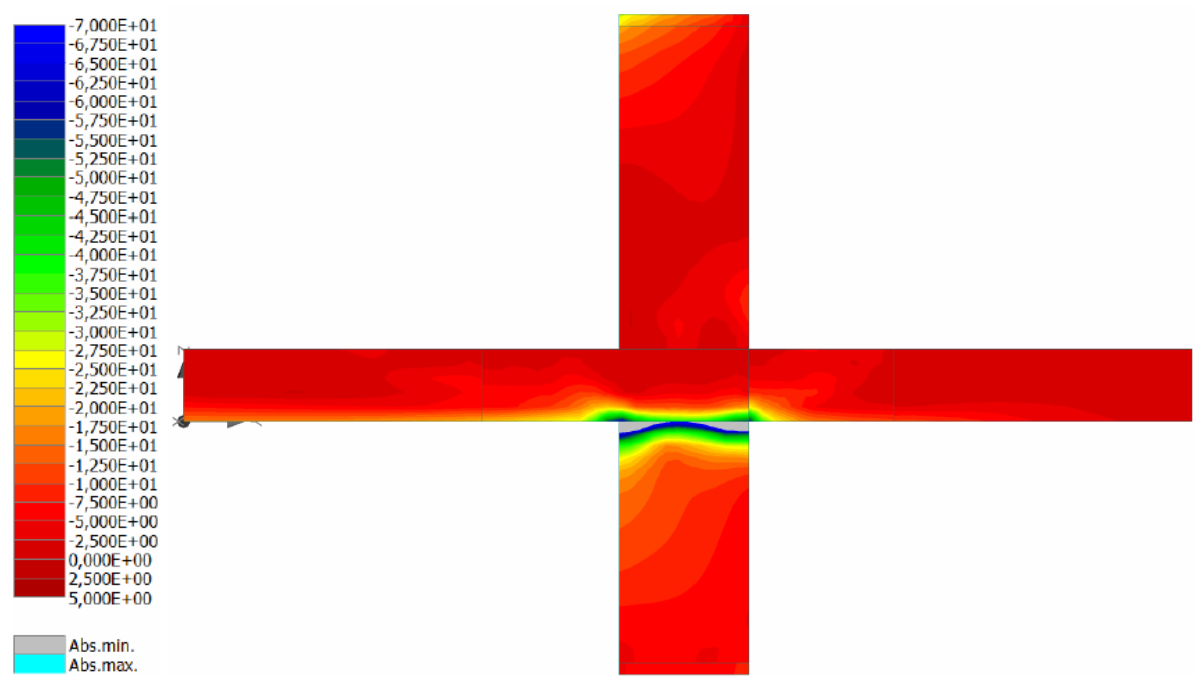

Figura 6.61 - Distribuição das tensões principais (MPa) na laje L02 (corte NO-SE). 
Com os gráficos de tensões principais no corte analisado notam-se bem as compressões na superfície inferior próximo ao pilar. Além disso, o esmagamento do concreto foi iniciado e a região afetada espalhou-se ao longo das faces do pilar representadas pela região cinza (Figura 6.60 e Figura 6.61).

\subsection{COMPARAÇÃO DE RESULTADOS}

\subsubsection{Carga de ruptura}

Para essa pesquisa foram modeladas numericamente doze lajes utilizadas para análise experimental. Foram utilizados os resultados da resistência à compressão de cilindros 10 $\mathrm{cm} \times 20 \mathrm{~cm}$ retificados.

A fim de obter a carga de ruptura foi realizada dois tipos de modelagem: a primeira utilizando elementos shell na região afastada $2 h$ da face do pilar e brick no restante da laje e no pilar (Figura 6.62) para determinar $V_{f c, r e t}$; e a segunda utilizando todos os elementos como brick para determinar $V_{f c, r e t, a b}$. Os resultados das cargas de ruptura por punção obtidos nos ensaios em relação às obtidas pelo programa estão apresentados na Tabela 6.4. Esses resultados foram determinados inicialmente utilizando os gráficos de carga $\mathrm{x}$ deslocamento, porém em alguns casos em que surgiram dúvidas do momento exato da ruptura, então nesses casos foram analisados os critérios de convergência para identificar em que momento houve mudança exata no comportamento da laje e o programa parou de convergir.

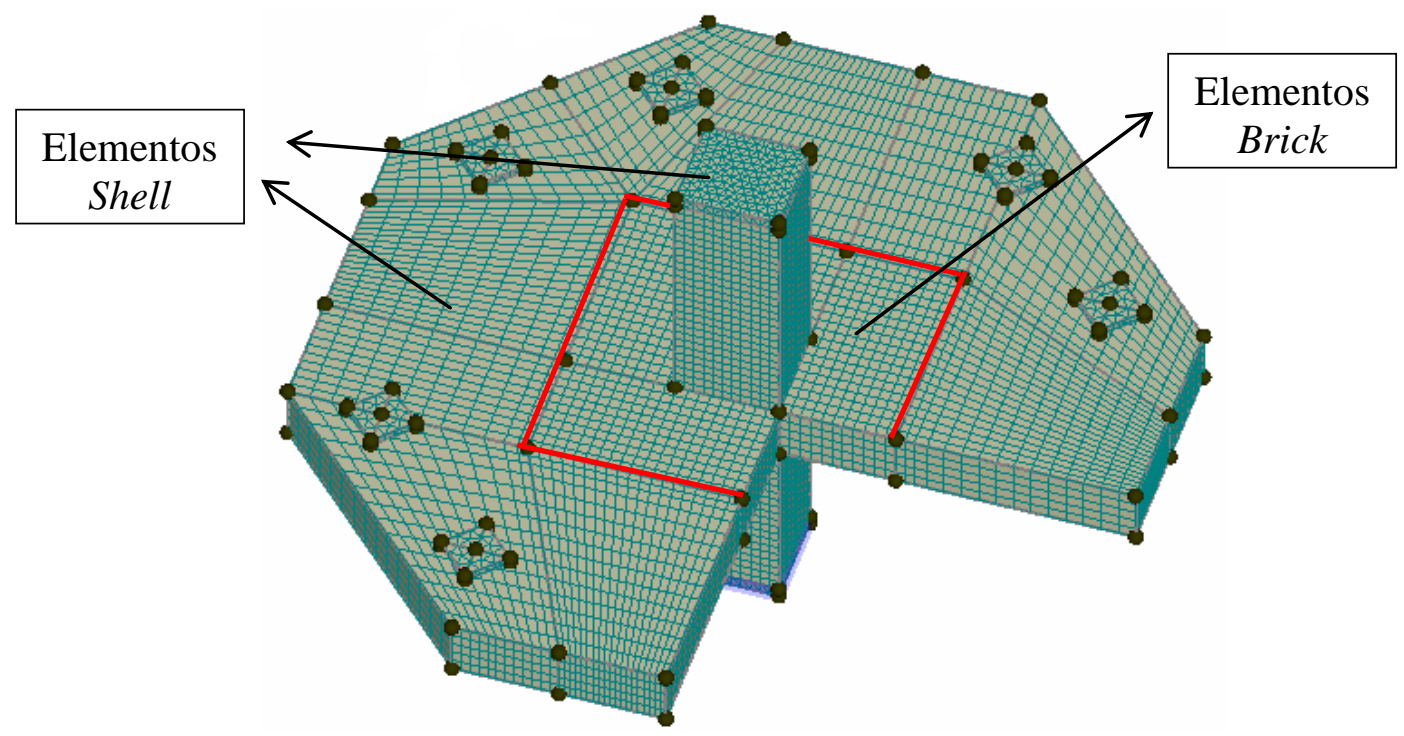

Figura 6.62 - Elementos shell e brick na laje 
Tabela 6.4 - Cargas de ruptura das lajes obtidas experimentalmente e numericamente

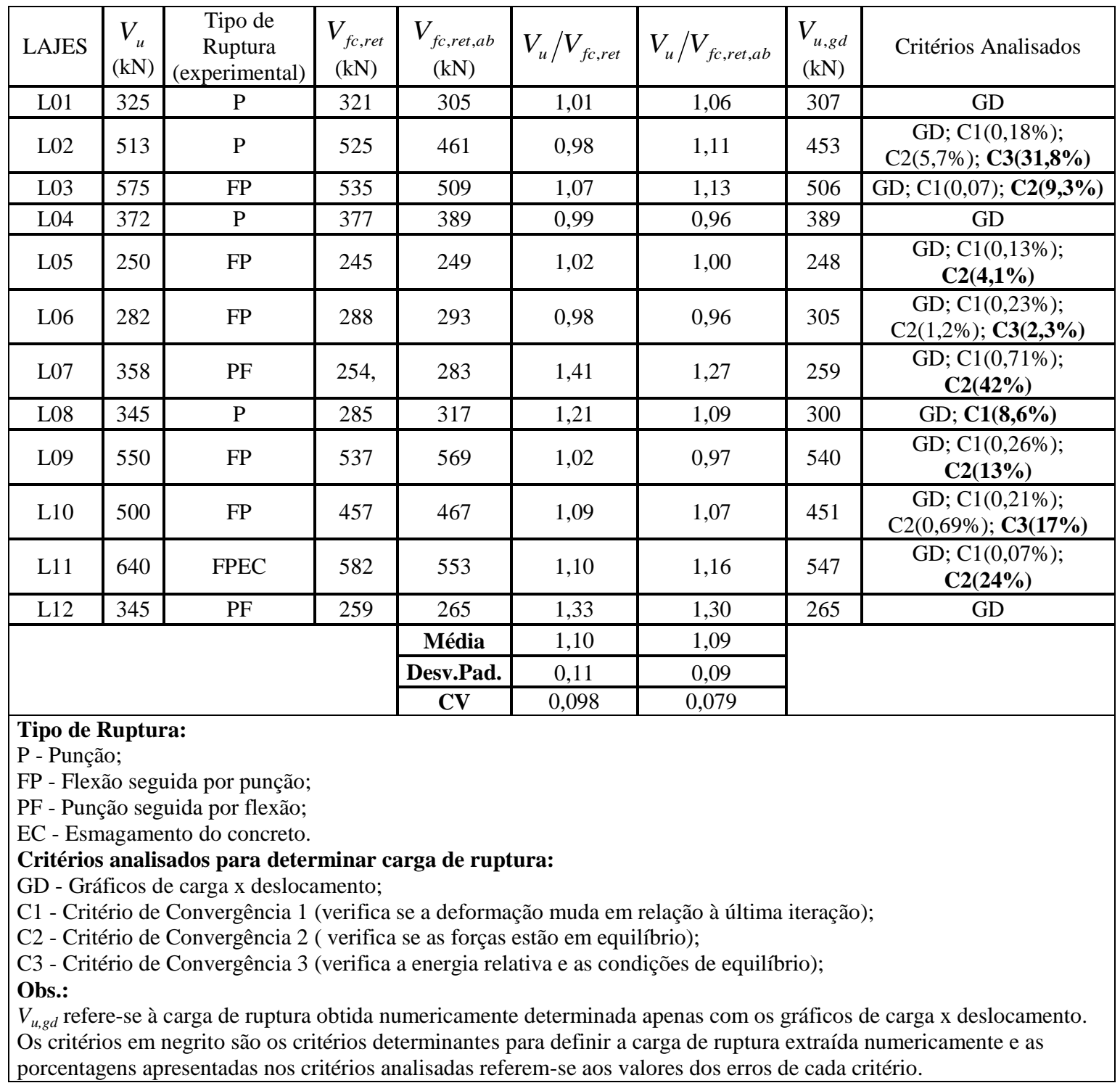

Os resultados das cargas obtidas numericamente são interessantes quando comparadas aos resultados experimentais, pois se observa uma boa aproximação. Os melhores resultados foram para as lajes modeladas com todos os elementos como brick, pois apesar de apresentar uma média da relação $V_{u} / V_{f c, r e t, a b}$ praticamente igual nos dois casos, apresentou um coeficiente de variação menor de 0,079. É apresentado na tabela também $V_{u, g d}$ (carga de ruptura determinada apenas com os gráficos de carga $\mathrm{x}$ deslocamento), que para algumas lajes corresponde a $V_{f c, r e t, a b}$, mas para outras não. Nos casos em que essas cargas não são correspondentes são os casos que utilizaram mais de um critério para determinar as cargas de ruptura pelo fato dos gráficos deixarem incerteza. Nota-se que o valor do erro em cada critério varia de laje para laje, dependendo da carga e do modo de ruptura da mesma. A Figura 6.63 e Figura 6.64 apresentam graficamente a relação entre as cargas 
experimentais e as cargas estimadas pelo programa ATENA $\left(V_{u} / V_{f c, r e t, a b}\right)$ utilizadas nessa pesquisa para lajes sem e com armadura de cisalhamento respectivamente.

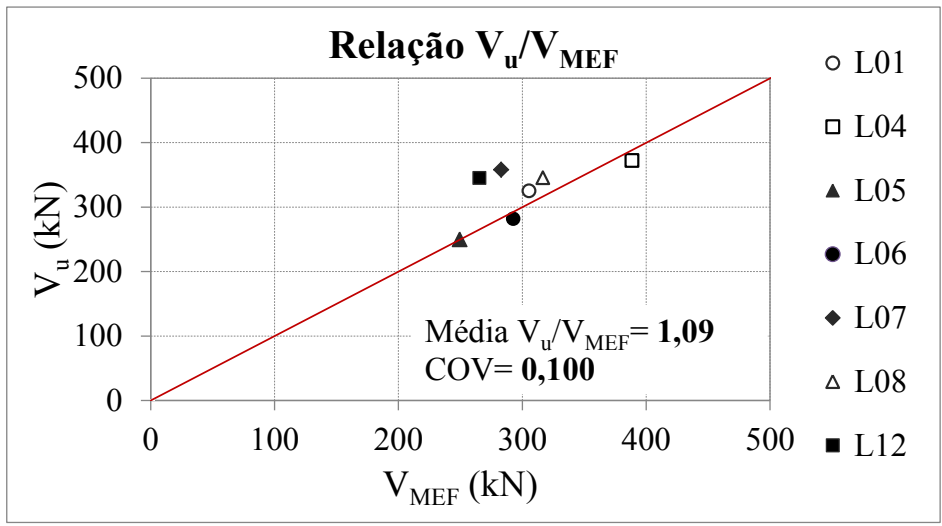

Figura 6.63 - Avaliação da previsão dos resultados para lajes sem armadura de cisalhamento.

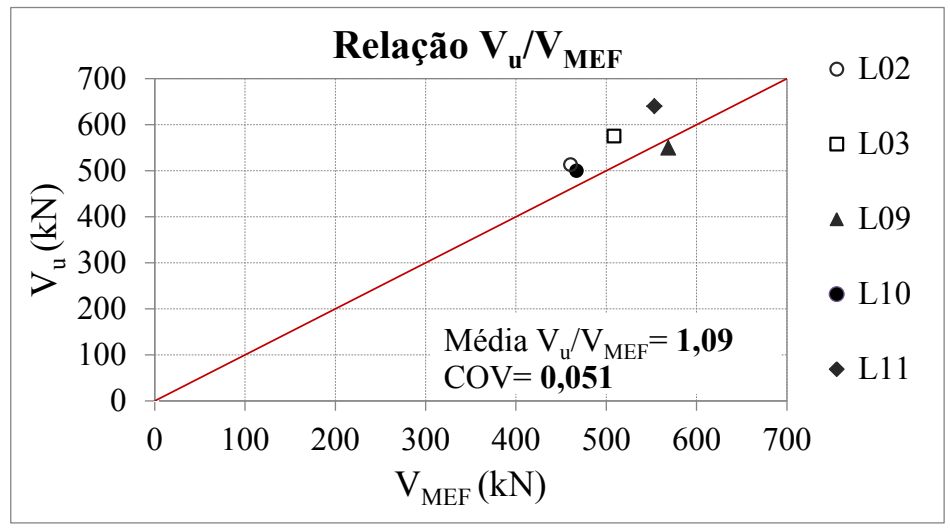

Figura 6.64 - Avaliação da previsão dos resultados para lajes com armadura de cisalhamento.

Ao separar as lajes em dois grupos (lajes sem armadura de cisalhamento e lajes com armadura de cisalhamento) pode-se perceber que os resultados foram precisos em ambos os casos, com as lajes L07 e L12 apresentando um nível de conservadorismo maior, em torno de 30\%. Essas duas lajes tiveram o mesmo tipo de ruptura no experimental, puncionaram seguida de flexão. Em relação ao coeficiente de variação nota-se que as lajes com armadura de cisalhamento tiveram uma dispersão menor com um CV de 0,051.

Para avaliar a carga de ruptura de cada laje foram analisados os critérios de convergência do programa e o comportamento das mesmas em relação aos deslocamentos. A Figura 6.65 e Figura 6.66 mostram os gráficos que relacionam o número do passo de carga com o 
limite de convergência das lajes L04 e L02 respectivamente, nos quais se pode identificar em qual ponto o programa parou de convergir e a laje atingiu sua capacidade resistente.

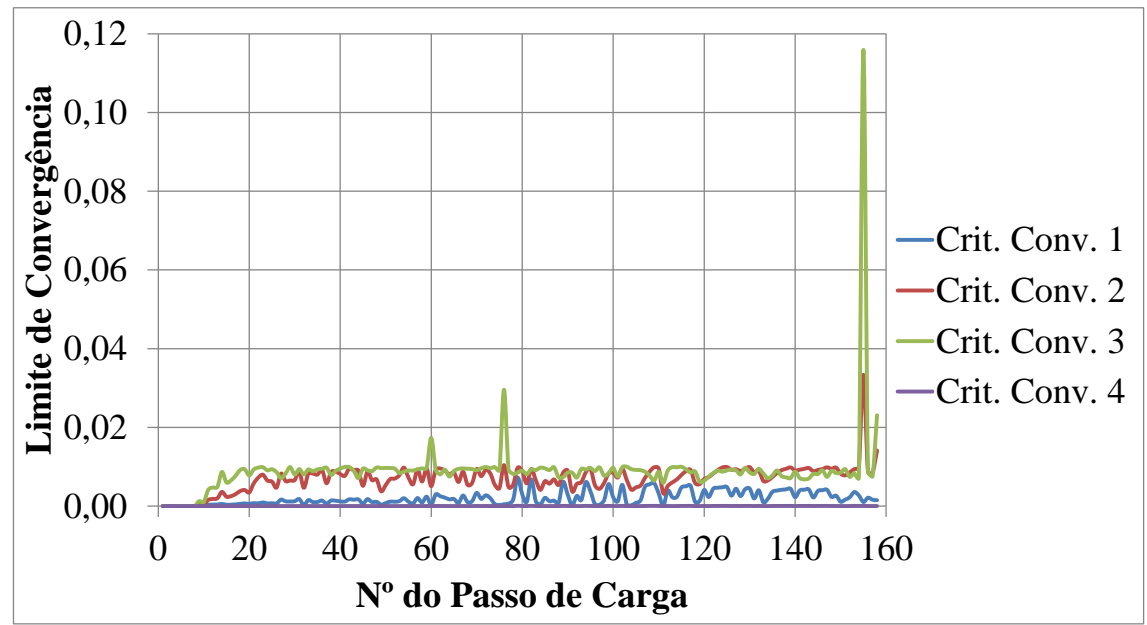

Figura 6.65 - Número do passo de carga x limite de convergência (Laje L04)

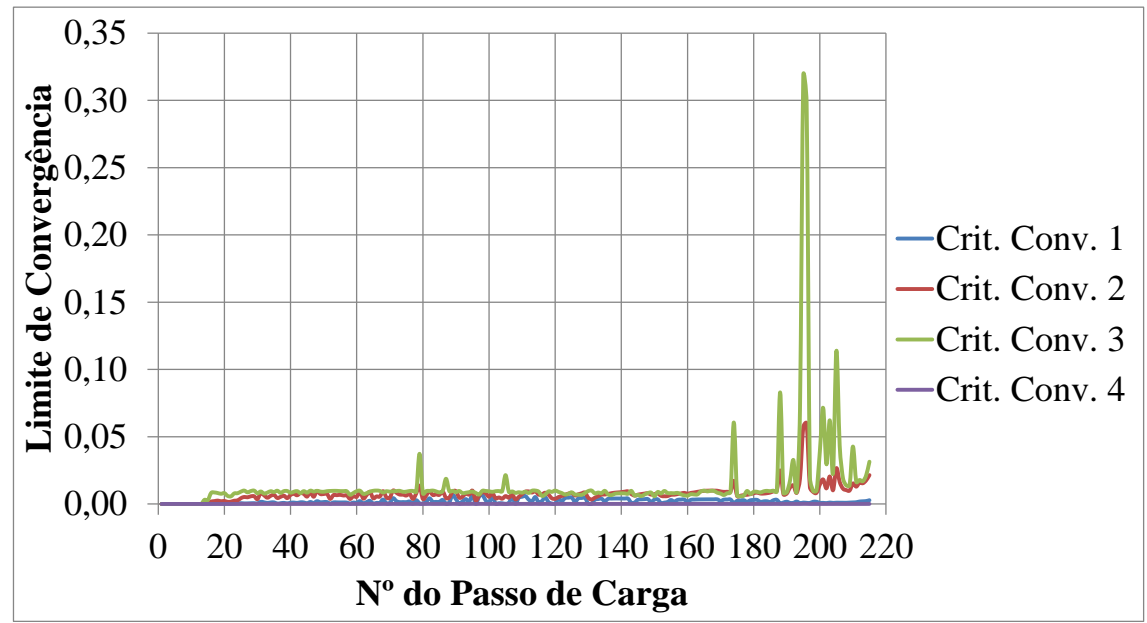

Figura 6.66 - Número do passo de carga x limite de convergência (Laje L02). 


\section{ANÁLISE DAS EXPRESSÕES NORMATIVAS}

Esse capítulo pretende avaliar o desempenho de alguns dos principais métodos teóricos disponíveis para a estimativa da resistência à punção de lajes lisas em concreto armado sem utilizar os coeficientes de segurança. Os métodos teóricos escolhidos para essa análise foram aqueles baseados nas recomendações das normas NBR 6118 (2014), Eurocode 2 (2004), ACI 318 (2014) e MC2010 (2013). No entanto, para a aplicação de cada recomendação normativa foram necessárias algumas adaptações nas formulações propostas porque nenhuma dessas normas aborda o caso de pilar de canto reentrante.

Foi analisada cada norma separadamente fazendo-se uma divisão em dois grupos: lajes sem armadura de cisalhamento e lajes com armadura de cisalhamento. A Tabela $7.1 \mathrm{e}$ Tabela 7.2 apresentam características das lajes dos Grupos 1 e 2 respectivamente necessárias para cálculo das cargas estimadas.

Tabela 7.1 - Características das lajes sem armadura de cisalhamento.

\begin{tabular}{|l|c|c|c|c|c|}
\hline Laje & $e(\mathrm{~mm})$ & $d(\mathrm{~mm})$ & $\rho(\%)$ & $f_{\mathrm{c}}(\mathrm{MPa})$ & $f_{\mathrm{y}}(\mathrm{MPa})$ \\
\hline L01 & 500 & 148 & 2,07 & 48 & 558 \\
\hline L04 & 349 & 147 & 2,10 & 48 & 558 \\
\hline L05 & 504 & 143 & 0,91 & 44 & 561 \\
\hline L06 & 343 & 145 & 0,88 & 44 & 561 \\
\hline L07 & 349 & 141 & 1,35 & 44 & 570 \\
\hline L08 & 347 & 145 & 1,27 & 44 & 570 \\
\hline L12 & 268 & 145 & 1,28 & 43 & 572 \\
\hline
\end{tabular}

Tabela 7.2 - Características das lajes com armadura de cisalhamento.

\begin{tabular}{|c|c|c|c|c|c|c|c|c|c|c|c|c|c|c|}
\hline Laje & $\begin{array}{c}e \\
(\mathrm{~mm})\end{array}$ & $\begin{array}{c}d \\
(\mathrm{~mm})\end{array}$ & $\begin{array}{c}\rho \\
(\%)\end{array}$ & $\begin{array}{c}\phi_{\mathrm{w}} \\
(\mathrm{mm})\end{array}$ & $\begin{array}{l}\mathrm{N}^{\circ} \text { de } \\
\text { linhas }\end{array}$ & $\begin{array}{c}\mathrm{N}^{\circ} \mathrm{de} \\
\text { camadas }\end{array}$ & $\begin{array}{c}\mathrm{s}_{0} \\
(\mathrm{~mm})\end{array}$ & $\begin{array}{c}\mathrm{S}_{\mathrm{r}} \\
(\mathrm{mm})\end{array}$ & $\begin{array}{c}\mathrm{A}_{\mathrm{sw}} \\
\left(\mathrm{mm}^{2}\right)\end{array}$ & $\begin{array}{c}f_{\mathrm{c}} \\
(\mathrm{MPa})\end{array}$ & $\begin{array}{c}f_{\mathrm{yf}} \\
(\mathrm{MPa})\end{array}$ & $\begin{array}{c}\mathrm{E}_{\mathrm{sf}} \\
(\mathrm{GPa})\end{array}$ & $\begin{array}{c}f_{\mathrm{yw}} \\
(\mathrm{MPa})\end{array}$ & $\begin{array}{c}\mathrm{E}_{\mathrm{sw}} \\
(\mathrm{GPa})\end{array}$ \\
\hline L02 & 352 & 148 & 2,07 & 8,0 & 10 & 3 & 70 & 100 & 503 & 48 & 558 & 192 & 587 & 187 \\
\hline L03 & 349 & 145 & 2,17 & 10,0 & 10 & 4 & 10 & 100 & 785 & 48 & 558 & 192 & 560 & 197 \\
\hline L09 & 349 & 148 & 2,08 & 10,0 & 13 & 5 & 60 & 90 & 102 & 43 & 572 & 208 & 528 & 207 \\
\hline L10 & 498 & 148 & 2,08 & 10,0 & 10 & 5 & 70 & 90 & 785 & 43 & 572 & 208 & 528 & 207 \\
\hline L11 & 267 & 147 & 2,11 & 10,0 & 10 & 5 & 70 & 90 & 785 & 43 & 572 & 208 & 528 & 207 \\
\hline \multicolumn{15}{|c|}{$\begin{array}{l}\phi_{\mathrm{w}} \text { é o diâmetro das barras da armadura de cisalhamento; } \\
\mathrm{s}_{0} \text { é a distância do pilar à primeira camada de armadura de cisalhamento; } \\
\mathrm{s}_{\mathrm{r}} \text { é o espaçamento radial da armadura de cisalhamento; } \\
\mathrm{A}_{\mathrm{sw}} \text { é a área radial da armadura de cisalhamento; } \\
\mathrm{E}_{\mathrm{sf}} \text { é o módulo de Elasticidade da armadura de flexão; } \\
\text { frf }_{\mathrm{yf}} \text { é tensão de escoamento da armadura de flexão; } \\
\mathrm{E}_{\mathrm{sw}} \text { é o módulo de Elasticidade da armadura de cisalhamento; } \\
f_{\mathrm{yw}} \text { é a tensão de escoamento da armadura de cisalhamento. }\end{array}$} \\
\hline
\end{tabular}


Para melhor entender as análises a seguir e quantificar o desempenho dos resultados foram considerados alguns critérios de avaliação para classificar os resultados obtidos pelas estimativas das normas quanto à segurança dos mesmos. Essa classificação foi considerada segundo Oliveira (2013) com base na relação $V_{u} / V_{\text {NORMA }}$ (sendo $V_{u}$ a carga última de ensaio e $V_{\text {NORMA }}$ a carga última estimada pela norma), em que os critérios de avaliação e classificação dos resultados normativos podem ser considerados uitlizando uma margem de até $5 \%$ contra a segurança como mostra a Tabela 5.1.

Tabela 7.3 - Critérios de avaliação $V_{u} / V_{\text {NORMA }}$.

\begin{tabular}{|c|c|}
\hline CRITÉRIOS DE AVALIAÇÃO & CLASSIFICAÇÃO \\
\hline$V_{u} / V_{\text {NORMA }}<0,95$ & INSEGURO \\
\hline $0,95 \leq V_{u} / V_{\text {NORMA }} \leq 1,25$ & PRECISO \\
\hline $1,25<V_{u} / V_{\text {NORMA }} \leq 1,40$ & SATISFATÓRIO \\
\hline$V_{u} / V_{\text {NORMA }}>1,40$ & CONSERVADOR \\
\hline
\end{tabular}

\subsection{NBR 6118 (2014)}

7.1.1 Análise de lajes sem armadura de cisalhamento

As lajes desta pesquisa que não utilizaram armadura de cisalhamento tiveram como variáveis principais a excentricidade de carga e a taxa de armadura de flexão. O perímetro crítico para o pilar de canto reentrante $u$ foi considerado como mostra a Figura 7.1 tendo em vista que a norma não prevê esse tipo de ligação.

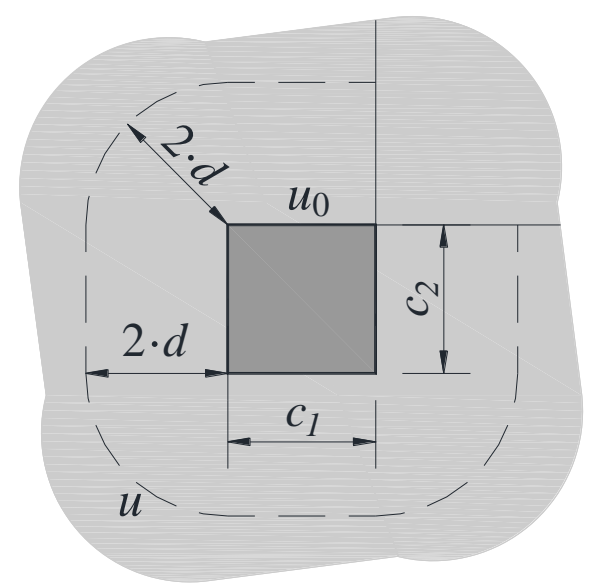

Figura 7.1 - Perímetro crítico $u$ para áreas carregadas perto do canto reentrante. 
A Tabela 7.4 apresenta às previsões da carga de ruptura utilizando as expressões da NBR 6118 (2014) indicando também a relação entre a carga experimental obtida com os ensaios e as cargas de ruptura prevista utilizando as expressões da norma adaptada.

Tabela 7.4 - Previsão da carga de ruptura para lajes sem armadura de cisalhamento pela

NBR 6118 (2014)

\begin{tabular}{|c|c|c|c|c|c|}
\hline Laje & $V_{u}(\mathrm{kN})$ & $V_{R, c}(\mathrm{kN})$ & $V_{\text {máx }}(\mathrm{kN})$ & $V_{\text {NBR6118 }}(\mathrm{kN})$ & $V_{u} / V_{N B R 6118}$ \\
\hline L01 & 325 & 326 & 1861 & 326 & 1,00 \\
\hline L04 & 372 & 387 & 1848 & 387 & 0,96 \\
\hline L05 & 250 & 225 & 1664 & 225 & 1,11 \\
\hline L06 & 282 & 276 & 1687 & 276 & 1,02 \\
\hline L07 & 358 & 304 & 1646 & 304 & 1,18 \\
\hline L08 & 345 & 313 & 1699 & 313 & 1,10 \\
\hline L12 & 345 & 345 & 1666 & 345 & 1,00 \\
\hline & & & MÉDIA & 1,05 \\
\cline { 4 - 5 } & & & CV & 0,074 \\
\cline { 4 - 5 }
\end{tabular}

Com os resultados apresentados, utilizando as expressões da NBR6118 (2014) com adaptações, percebe-se que a carga estimada é precisa em relação à experimental, de acordo com os critérios de avaliação adotados.

A força de punção pode ser considerada uniformemente distribuída ao longo do perímetro crítico reduzido. Pode-se aumentar a média $V_{u} / V_{N B R 6118}$ dos resultados sem sair do limite de precisão utilizando o perímetro crítico reduzido $u^{*}$ como mostrado na Figura 7.2 (Tabela 7.5). Essa adaptação será chamada aqui de Caso 1.

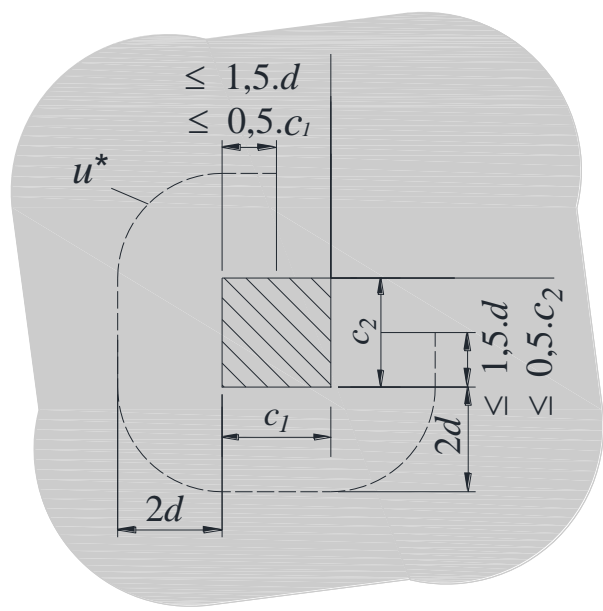

Figura 7.2 - Perímetro crítico reduzido pilar de canto reentrante. 
Tabela 7.5 - Previsão da carga de ruptura dos casos testados para lajes sem armadura de cisalhamento.

\begin{tabular}{|c|c|c|c|}
\hline \multirow{2}{*}{ LAJE } & & \multicolumn{2}{|c|}{ CASO 1 } \\
\cline { 2 - 4 } & $V_{u}(\mathrm{kN})$ & $V_{\text {CASO1 }}(\mathrm{kN})$ & $V_{u} / V_{\text {CASO } 1}$ \\
\hline L1 & 325 & 307 & 1,06 \\
\hline L4 & 372 & 360 & 1,03 \\
\hline L5 & 250 & 212 & 1,18 \\
\hline L6 & 282 & 257 & 1,10 \\
\hline L7 & 358 & 283 & 1,27 \\
\hline L8 & 345 & 291 & 1,18 \\
\hline L12 & 345 & 319 & 1,08 \\
\hline \multirow{2}{*}{} & MÉDIA & 1,13 \\
\cline { 2 - 3 } & CV. & 0,074 \\
\cline { 3 - 4 }
\end{tabular}

Nota-se que com essa modificação foi possível aumentar o conservadorismo dos resultados previstos, ficando ainda alguns resultados precisos. Foi testado ainda utilizar a excentricidade relativa ao perímetro crítico (excentricidade reduzida), mas os valores médios obtidos foram contra a segurança.

7.1.2 Análise de lajes com armadura de cisalhamento

A Tabela 7.9 apresenta às previsões de carga de ruptura utilizando as expressões da NBR 6118 (2014) para as lajes com armadura de cisalhamento indicando também a relação entre a carga experimental obtida com os ensaios e as cargas de ruptura prevista utilizando as expressões da norma.

Tabela 7.6 - Previsão da carga de ruptura para lajes com armadura de cisalhamento pela NBR 6118 (2014).

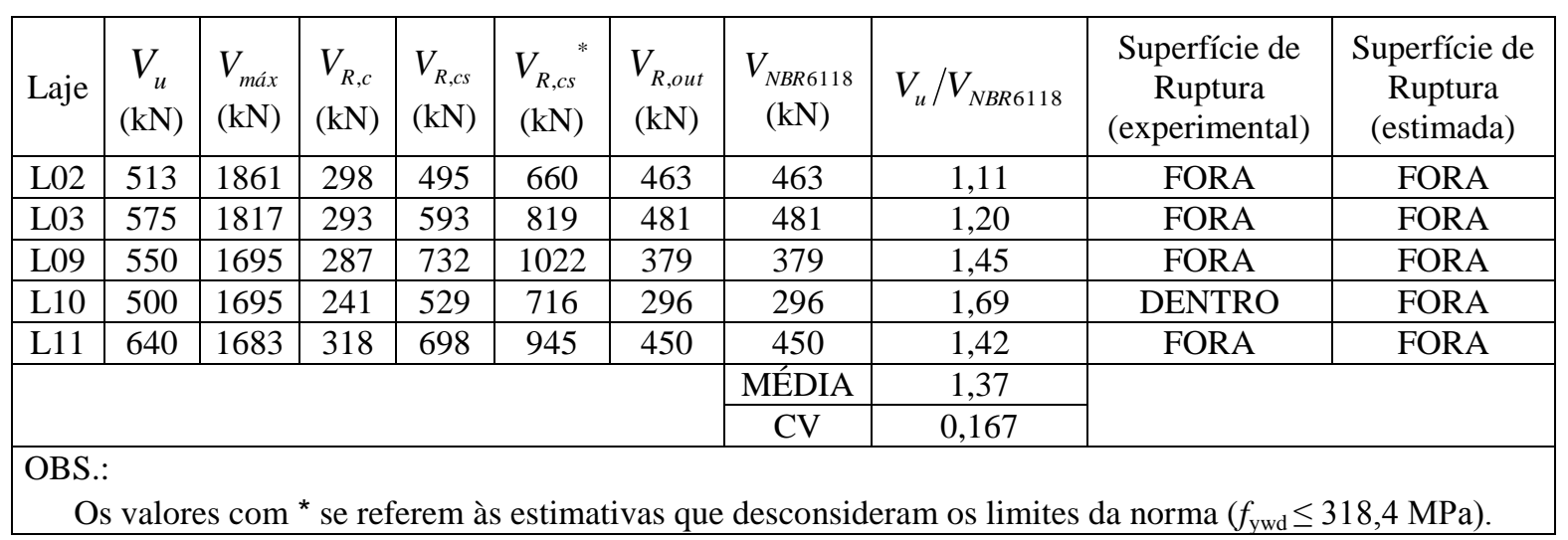

Para as lajes com armadura de cisalhamento os resultados apresentaram valores precisos, satisfatórios e na maioria muito conservadores. 
Como os perímetros críticos normal e fora da armadura de cisalhamento influenciam consideravelmente na previsão da carga de ruptura e a norma utiliza em casos de pilares de borda e canto, foram feitas duas simulações (ver Tabela 7.7 e Figura 7.8):

Caso 1: Foi utilizado um perímetro crítico reduzido $u^{\star}$;

Caso 2: Foi utilizado além do perímetro crítico reduzido o perímetro fora da armadura de cisalhamento reduzido $u^{\prime}$ red (Figura 7.3), tendo em vista que o mapa de fissuração das lajes mostra que as fissuras que caracterizavam a ruptura não atingiam as bordas reentrantes, finalizavam antes.

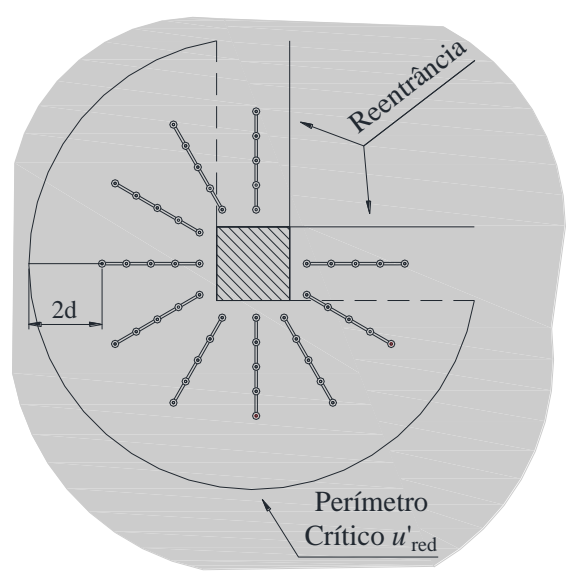

Figura 7.3 - Perímetro fora da armadura de cisalhamento reduzido para pilar de canto reentrante.

Tabela 7.7 - Previsão da carga de ruptura do CASO1 testado para lajes com armadura de cisalhamento.

\begin{tabular}{|c|c|c|c|c|c|c|c|c|}
\hline Laje & $\begin{array}{c}V_{u} \\
(\mathrm{kN})\end{array}$ & $\begin{array}{c}V_{R, c(C A S O 1)} \\
(\mathrm{kN})\end{array}$ & $\begin{array}{c}V_{R, c s(C A S O 1)} \\
(\mathrm{kN})\end{array}$ & $\begin{array}{c}V_{R, \text { out }(\text { CASO })} \\
(\mathrm{kN})\end{array}$ & $\begin{array}{c}V_{C A S O 1} \\
(\mathrm{kN})\end{array}$ & $V_{u} / V_{C A S O 1}$ & $\begin{array}{c}\text { Superfície de } \\
\text { Ruptura } \\
\text { (experimental) }\end{array}$ & $\begin{array}{l}\text { Superfície de } \\
\text { Ruptura } \\
\text { (estimada) }\end{array}$ \\
\hline L02 & 513 & 278 & 486 & 463 & 463 & 1,11 & FORA & FORA \\
\hline L03 & 575 & 273 & 590 & 481 & 481 & 1,20 & FORA & FORA \\
\hline L09 & 550 & 268 & 737 & 482 & 482 & 1,14 & FORA & FORA \\
\hline L10 & 500 & 227 & 534 & 389 & 389 & 1,29 & DENTRO & FORA \\
\hline L11 & 640 & 295 & 691 & 558 & 558 & 1,15 & FORA & FORA \\
\hline & & & & & MÉDIA & 1,18 & & \\
\hline
\end{tabular}


Tabela 7.8 - Previsão da carga de ruptura do CASO2 testado para lajes com armadura de cisalhamento.

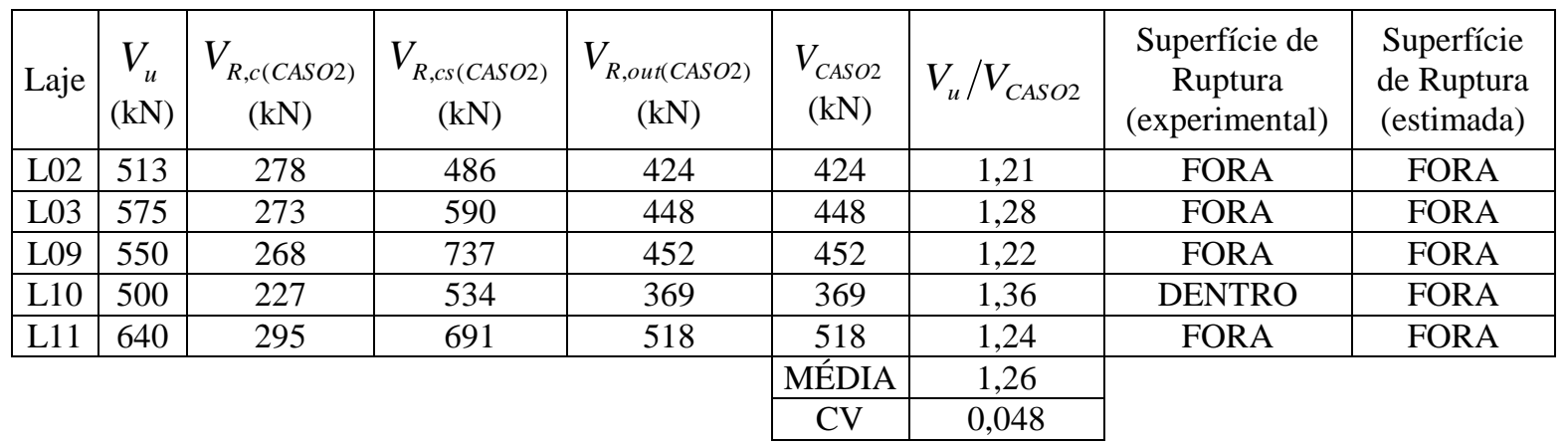

Para as lajes com armadura de cisalhamento, nota-se que, em ambos os casos foi possível reduzir além da relação $V_{u} / V_{C A S O}$ o coeficiente de variação, contudo o Caso 1 mostrou-se mais eficiente por apresentar uma média menor das relações $V_{u} / V_{\text {CASO }}$ de 1,18 , que antes era 1,37 , saindo de satisfatório para preciso. Já em relação da previsão da superfície de ruptura apenas uma laje não condiz com a previsão (laje L10).

Embora os resultados do Caso 2 sejam aparentemente melhor pela menor variação dos resultados, sugere-se com a análise realizada utilizar o perímetro crítico reduzido $u^{\star}$ (Caso 1), tendo em vista que os resultados para lajes sem e com armadura de cisalhamento foram mais satisfatórios e a norma não sugere um perímetro reduzido para o perímetro fora da armadura de cisalhamento considerado no Caso 2.

\subsection{Eurocode 2 (2004)}

\subsubsection{Análise de lajes sem armadura de cisalhamento}

Foram utilizadas as expressões para pilares internos com o perímetro crítico $\mathrm{u}_{1}$ igual ao da Figura 7.1, tendo em vista que a norma não prevê qual seria o perímetro crítico para pilar de canto reentrante.

A Tabela 7.9 apresenta às previsões utilizando as expressões do Eurocode 2 (2004) indicando também a relação entre a carga experimental obtida com os ensaios e as cargas de ruptura prevista utilizando as expressões da norma. 
Tabela 7.9 - Previsão da carga de ruptura das lajes sem armadura de cisalhamento pelo EC2 (2004).

\begin{tabular}{|l|c|c|c|c|c|}
\hline Laje & $V_{u}(\mathrm{kN})$ & $V_{\text {máx }}(\mathrm{kN})$ & $V_{R, c}(\mathrm{kN})$ & $V_{E C 2}(\mathrm{kN})$ & $V_{u} / V_{E C 2}$ \\
\hline L01 & 325 & 2067 & 298 & 298 & 1,10 \\
\hline L04 & 372 & 2053 & 353 & 353 & 1,07 \\
\hline L05 & 250 & 1848 & 204 & 204 & 1,23 \\
\hline L06 & 282 & 1874 & 250 & 250 & 1,13 \\
\hline L07 & 358 & 1829 & 274 & 274 & 1,31 \\
\hline L08 & 345 & 1887 & 285 & 285 & 1,21 \\
\hline L12 & 345 & 1851 & 314 & 314 & 1,10 \\
\hline & & MÉDIA & 1,16 \\
\cline { 4 - 5 } & & CV & 0,074 \\
\cline { 4 - 5 }
\end{tabular}

Os resultados foram precisos e satisfatórios, apresentando uma relação média $V_{u} / V_{E C 2}$ igual a 1,16 e baixo coeficiente de variação, 0,078. Para testar a influência de alguns parâmetros foram feitos alguns testes tendo em vista que alguns parâmetros deixam dúvidas de como devem ser considerados no caso de pilar com canto reentrante (Tabela 7.10):

a) Caso 1: Foi utilizado um perímetro crítico reduzido $u^{\star}$ (Figura 7.2);

b) Caso 2: Foi utilizada uma excentricidade reduzida $e_{E 1}$, relativa ao perímetro crítico $u_{1}$, ao invés de usar a excentricidade do carregamento em relação à laje toda como a norma propõe, tendo em vista que o eixo do perímetro crítico é deslocado do eixo central do pilar e a excentricidade do carregamento em relação ao centróide do perímetro crítico diminui com o aumento da distância em relação ao pilar;

c) Caso 3: Foi desconsiderado o limite da norma $\kappa \leq 2,0$.

Tabela 7.10 - Previsão da carga de ruptura dos casos testados para lajes sem armadura de cisalhamento.

\begin{tabular}{|c|c|c|c|c|c|c|c|}
\hline \multirow{2}{*}{ LAJE } & & \multicolumn{2}{|c|}{ CASO 1} & \multicolumn{2}{|c|}{ CASO 2} & \multicolumn{2}{|c|}{ CASO 3} \\
\hline & $V_{u}(\mathrm{kN})$ & $V_{C A S O 1}(\mathrm{kN})$ & $V_{u} / V_{C A S O 1}$ & $V_{C A S O 2}(\mathrm{kN})$ & $V_{u} / V_{C A S O 2}$ & $V_{C A S O .3}(\mathrm{kN})$ & $V_{u} / V_{\text {CASO } .3}$ \\
\hline L1 & 325 & 281 & 1,16 & 328 & 0,99 & 322 & 1,01 \\
\hline L4 & 372 & 329 & 1,13 & 396 & 0,94 & 382 & 0,97 \\
\hline L5 & 250 & 192 & 1,30 & 224 & 1,12 & 223 & 1,12 \\
\hline L6 & 282 & 233 & 1,21 & 281 & 1,00 & 272 & 1,03 \\
\hline L7 & 358 & 255 & 1,40 & 307 & 1,17 & 300 & 1,19 \\
\hline L8 & 345 & 265 & 1,30 & 319 & 1,08 & 309 & 1,12 \\
\hline L12 & 345 & 290 & 1,19 & 356 & 0,97 & 341 & 1,01 \\
\hline & & MÉDIA & 1,24 & & 1,04 & & 1,07 \\
\hline & & CV. & 0,078 & & 0,082 & & 0,074 \\
\hline
\end{tabular}


Os resultados dos testes mostram que no Caso 1 aumentou-se o conservadorismo das cargas de ruptura. Já nos Casos 2 e 3 os resultados previstos são precisos e satisfatórios, com o Caso 2 mais preciso, porém tendendo a ficar inseguros como mostra a relação $V_{u} / V_{\text {CASO }}$ da laje L04.

7.2.2 Análise de lajes com armadura de cisalhamento

A Tabela 7.11 apresenta as previsões utilizando as expressões do Eurocode 2 (2004) para as lajes com armadura de cisalhamento indicando também a relação entre a carga experimental obtida com os ensaios e as cargas de ruptura prevista pela norma.

Tabela 7.11 - Previsão da carga de ruptura das lajes com armadura de cisalhamento pelo EC2 (2004).

\begin{tabular}{|c|c|c|c|c|c|c|c|c|c|}
\hline Laje & $\begin{array}{c}V_{u} \\
(\mathrm{kN})\end{array}$ & $\begin{array}{l}V_{\text {máx }} \\
(\mathrm{kN})\end{array}$ & $\begin{array}{l}V_{R, c} \\
(\mathrm{kN})\end{array}$ & $\begin{array}{l}V_{R, c s} \\
(\mathrm{kN})\end{array}$ & $\begin{array}{c}V_{R, \text { out }} \\
(\mathrm{kN})\end{array}$ & $\begin{array}{l}V_{E C 2} \\
(\mathrm{kN})\end{array}$ & $V_{u} / V_{E C 2}$ & $\begin{array}{l}\text { Superfície de } \\
\text { Ruptura } \\
\text { (experimental) }\end{array}$ & $\begin{array}{l}\text { Superfície de } \\
\text { Ruptura } \\
\text { (estimada) }\end{array}$ \\
\hline L02 & 513 & 2067 & 354 & 470 & 454 & 454 & 1,14 & FORA & FORA \\
\hline L03 & 575 & 2019 & 346 & 569 & 510 & 510 & 1,16 & FORA & FORA \\
\hline L09 & 550 & 1883 & 341 & 715 & 531 & 531 & 1,05 & FORA & FORA \\
\hline L10 & 500 & 1883 & 287 & 512 & 451 & 451 & 1,12 & DENTRO & FORA \\
\hline L11 & 640 & 1871 & 378 & 675 & 596 & 596 & 1,09 & FORA & FORA \\
\hline & & & & & & MÉDIA & 1,11 & & \\
\hline
\end{tabular}

Os resultados utilizando as expressões do EC2 (2004) para as lajes com armadura de cisalhamento foram considerados todos precisos, com média das relações $V_{u} / V_{E C 2}$ igual a 1,10, CV de 0,036 e nenhum valor contra a segurança. Contudo, para verificar a influência de alguns parâmetros foram feitos alguns testes tendo em vista que alguns parâmetros deixam dúvidas de como devem ser considerados no caso de pilar com canto reentrante (ver Tabela 7.12, Tabela 7.13, Tabela 7.14 e Tabela 7.15):

a) Caso 1: Foi utilizado um perímetro crítico reduzido $u^{\star}$ e a equação 7.1 para cálculo $\beta$;

$$
\beta=1+k \cdot \frac{M_{E d}}{V_{E d}} \cdot\left(\frac{u^{*}}{W_{1}}\right)
$$

b) Caso 2: Foi utilizada uma excentricidade reduzida $e_{E 1}$, relativa ao perímetro crítico $u_{1}$ pois no caso do pilar de canto reentrante a excentricidade do carregamento em relação ao centróide do perímetro crítico diminui com o aumento da distância em relação ao pilar. 
c) Caso 3: Foi utilizado um $\beta_{\text {out }}$ (coeficiente de transferência de momento para força cortante solicitante fora da região da armadura de cisalhamento em função de $u_{\text {out }}$, como mostra a Figura 7.4, e $W_{\text {out }}$ como mostra a equação 7.2) tendo em vista que a utilização de $\beta$ determinado com o perímetro $u_{1}$ utilizado nos cálculos dos perímetros $u_{0}$ e $u_{\text {out }}$ é questionável pois a relação $u / W$ não permanece constante independentemente da distância do pilar para o perímetro considerado.

$$
\beta_{\text {out }}=1+k \cdot \frac{M_{E d}}{V_{E d}} \cdot\left(\frac{u_{\text {out }}}{W_{\text {out }}}\right)
$$

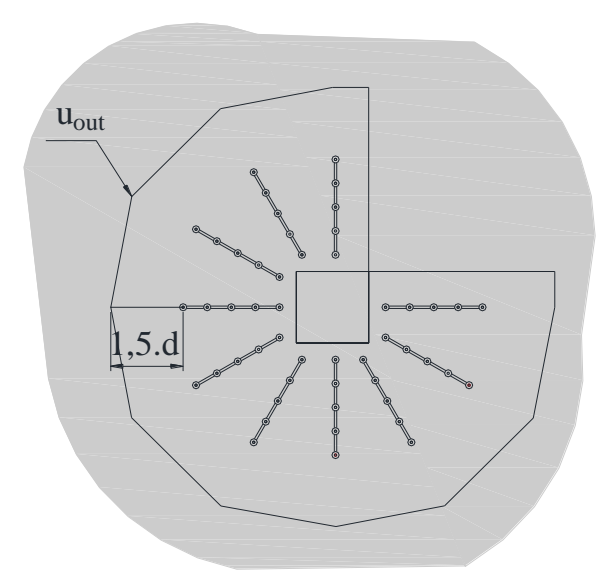

Figura 7.4 - Perímetro crítico fora da armadura de cisalhamento para pilar de canto reentrante.

d) Caso 4: Foi desconsiderado o limite da norma $\kappa \leq 2,0$.

Tabela 7.12 - Previsão da carga de ruptura do CASO 1 testado para lajes com armadura de cisalhamento.

\begin{tabular}{|c|c|c|c|c|c|c|c|c|}
\hline Laje & $\begin{array}{c}V_{u} \\
(\mathrm{kN})\end{array}$ & $\begin{array}{c}V_{R, c(C A S O 1)} \\
(\mathrm{kN})\end{array}$ & $\begin{array}{c}V_{R, c s(C A S O 1)} \\
(\mathrm{kN})\end{array}$ & $\begin{array}{c}V_{R, \text { out }(\text { CASO } 1)} \\
(\mathrm{kN})\end{array}$ & $\begin{array}{c}V_{C A S O 1} \\
(\mathrm{kN})\end{array}$ & $V_{u} / V_{C A S O 1}$ & $\begin{array}{c}\text { Superfície de } \\
\text { Ruptura } \\
\text { (experimental) }\end{array}$ & $\begin{array}{l}\text { Superfície de } \\
\text { Ruptura } \\
\text { (estimada) }\end{array}$ \\
\hline L02 & 513 & 330 & 463 & 479 & 463 & 1,11 & FORA & DENTRO \\
\hline L03 & 575 & 323 & 568 & 538 & 538 & 1,07 & FORA & FORA \\
\hline L09 & 550 & 318 & 723 & 559 & 559 & 0,98 & FORA & FORA \\
\hline L10 & 500 & 270 & 519 & 481 & 481 & 1,04 & DENTRO & FORA \\
\hline L11 & 640 & 350 & 671 & 624 & 624 & 1,03 & FORA & FORA \\
\hline & & & & & MÉDIA & 1,05 & & \\
\hline
\end{tabular}


Tabela 7.13 - Previsão da carga de ruptura do CASO 2 testado para lajes com armadura de cisalhamento.

\begin{tabular}{|c|c|c|c|c|c|c|c|c|}
\hline Laje & $\begin{array}{c}V_{u} \\
(\mathrm{kN})\end{array}$ & $\begin{array}{c}V_{R, c(C A S O 2)} \\
(\mathrm{kN})\end{array}$ & $\begin{array}{c}V_{R, c s(C A S O 2)} \\
(\mathrm{kN})\end{array}$ & $\begin{array}{c}V_{R, \text { out }(\text { CASO2 })} \\
(\mathrm{kN})\end{array}$ & $\begin{array}{c}V_{C A S O 2} \\
(\mathrm{kN})\end{array}$ & $V_{u} / V_{C A S O 2}$ & $\begin{array}{c}\text { Superfície de } \\
\text { Ruptura } \\
\text { (experimental) }\end{array}$ & $\begin{array}{l}\text { Superfície de } \\
\text { Ruptura } \\
\text { (estimada) }\end{array}$ \\
\hline L02 & 513 & 398 & 527 & 510 & 510 & 1,01 & FORA & FORA \\
\hline L03 & 575 & 388 & 637 & 571 & 571 & 1,01 & FORA & FORA \\
\hline L09 & 550 & 383 & 803 & 595 & 595 & 0,92 & FORA & FORA \\
\hline L10 & 500 & 315 & 563 & 496 & 496 & 1,01 & DENTRO & FORA \\
\hline L11 & 640 & 430 & 768 & 678 & 678 & 0,94 & FORA & FORA \\
\hline & & & & & MÉDIA & 0,98 & & \\
\hline
\end{tabular}

Tabela 7.14 - Previsão da carga de ruptura do CASO 3 testado para lajes com armadura de cisalhamento.

\begin{tabular}{|c|c|c|c|c|c|c|c|c|}
\hline Laje & $\begin{array}{c}V_{u} \\
(\mathrm{kN})\end{array}$ & $\begin{array}{c}V_{R, c(C A S O 3)} \\
(\mathrm{kN})\end{array}$ & $\begin{array}{c}V_{R, c s(C A S O 3)} \\
(\mathrm{kN})\end{array}$ & $\begin{array}{c}V_{R, \text { out }(\text { CASO3 })} \\
(\mathrm{kN})\end{array}$ & $\begin{array}{c}V_{C A S O 3} \\
(\mathrm{kN})\end{array}$ & $V_{u} / V_{C A S O 3}$ & $\begin{array}{c}\text { Superfície de } \\
\text { Ruptura } \\
\text { (experimental) }\end{array}$ & $\begin{array}{l}\text { Superfície de } \\
\text { Ruptura } \\
\text { (estimada) }\end{array}$ \\
\hline L02 & 513 & 354 & 470 & 511 & 470 & 1,09 & FORA & DENTRO \\
\hline L03 & 575 & 346 & 569 & 604 & 569 & 1,01 & FORA & DENTRO \\
\hline L09 & 550 & 341 & 715 & 639 & 639 & 0,86 & FORA & FORA \\
\hline L10 & 500 & 287 & 512 & 569 & 512 & 0,98 & DENTRO & DENTRO \\
\hline L11 & 640 & 378 & 675 & 700 & 675 & 0,95 & FORA & DENTRO \\
\hline & & & & & $\frac{\text { MÉDIA }}{\mathrm{CV}}$ & $\begin{array}{c}0,98 \\
0,087\end{array}$ & & \\
\hline
\end{tabular}

Tabela 7.15 - Previsão da carga de ruptura do CASO 4 testado para lajes com armadura de cisalhamento.

\begin{tabular}{|c|c|c|c|c|c|c|c|c|}
\hline Laje & $\begin{array}{c}V_{u} \\
(\mathrm{kN})\end{array}$ & $\begin{array}{c}V_{R, c(C A S O 4)} \\
(\mathrm{kN})\end{array}$ & $\begin{array}{c}V_{R, c S(C A S O 4)} \\
(\mathrm{kN})\end{array}$ & $\begin{array}{c}V_{R, \text { out }(\text { CASO } 4)} \\
(\mathrm{kN})\end{array}$ & $\begin{array}{c}V_{\text {CASO4 }} \\
(\mathrm{kN})\end{array}$ & $V_{u} / V_{C A S O 4}$ & $\begin{array}{c}\text { Superfície de } \\
\text { Ruptura } \\
\text { (experimental) }\end{array}$ & $\begin{array}{c}\text { Superfície de } \\
\text { Ruptura } \\
\text { (estimada) }\end{array}$ \\
\hline L02 & 513 & 383 & 491 & 491 & 491 & 1,04 & FORA & FORA \\
\hline L03 & 575 & 377 & 592 & 555 & 555 & 1,04 & FORA & FORA \\
\hline L09 & 550 & 369 & 736 & 574 & 574 & 0,96 & FORA & FORA \\
\hline L10 & 500 & 310 & 530 & 488 & 488 & 1,02 & DENTRO & FORA \\
\hline L11 & 640 & 410 & 698 & 646 & 646 & 0,99 & FORA & FORA \\
\hline & & & & & MÉDIA & 1,01 & & \\
\hline
\end{tabular}

Com os resultados apresentados pode-se notar que em todos os casos foi possível aumentar a precisão dos resultados, mas nos Casos 2 e 3 surgiram resultados contra a segurança e nos Casos 1 e 4 obtiveram-se melhores resultados, diminuindo a média das relações carga última por carga prevista, contudo a previsão da superfície de ruptura piora com previsão diferente para duas lajes e antes só uma previsão divergia do experimental. 
Contudo, sugere-se obter a carga resistente utilizando as expressões mencionadas no Capítulo 2 referente ao EC2 (2004) sem utilizar os testes mencionados nos casos aqui apresentados.

\subsubsection{Análise do coeficiente $\beta$}

Para um pilar quadrado interno, o EC2 (2004) leva em consideração as distribuições de tensões verticais no perímetro crítico $u_{1}$ devido à força de cisalhameto $V_{E d}$ e o momento $M_{E d}=V_{E d} \cdot e$. A tensão de cisalhamento devido à $V_{E d}$ é $V_{E d} / u_{1} \cdot d$ e devido à $M_{E d}$ é $k \cdot M_{E d} / W_{1} \cdot d$. O cisalhamento máximo é:

$$
\begin{gathered}
\frac{V_{E d}}{u_{1} \cdot d}+\frac{k \cdot M_{E d}}{W_{1} \cdot d}=\beta \cdot \frac{V_{E d}}{u_{1} \cdot d} \\
V_{\text {NORMA }}=\beta \cdot V_{R, c} \\
\beta_{\text {NORMA }}=1+k \cdot \frac{M_{E d}}{V_{E d}} \cdot\left(\frac{u_{1}}{W_{1}}\right)
\end{gathered}
$$

onde:

$\beta$ é fator que considera a parcela de cisalhamento transmitida da laje para o pilar através do momento fletor desbalanceado;

k é o coeficiente representa a parcela de $M_{E d}$ transmitida ao pilar por cisalhamento, que depende das dimensões do pilar;

$W_{1}$ é momento estático do perímetro crítico $u_{1}$ em relação ao eixo passando por $e_{1}$, ou seja, Módulo de Resistência Plástica em função do perímetro crítico $u_{1}$ :

$d l$ é o comprimento elementar do perímetro;

$e_{i}$ é a distância de $d l$ ao eixo em torno do qual atua o momento $M_{E d}$;

$V_{E d}$ é a carga de cisalhamento atuante; 
$V_{\text {NORMA }}$ é a carga total prevista pela norma;

Aternativamente $\beta_{\exp }$ pode ser obtido com a expressão abaixo em que leva-se em consideração o peso próprio da laje:

$$
\beta_{\text {exp }}=\frac{V_{u}}{V_{R, c}}
$$

onde:

$V_{u}$ é a carga de ruptura obtida experimentalmente;

$V_{R, c}$ é a resistência ao cisalhamento advinda do concreto.

A utilização do coeficiente $k=0,6$, que a norma trás para pilares de lados iguais, resultou em previsões de cargas precisas e satisfatórias. A Tabela 7.16 mostra uma comparação entre o $\beta_{\exp }$ e $\beta_{\text {NORMA }}$ obtido em função de $k=0,6$ :

Tabela 7.16 - Comparação dos coeficientes $\beta$.

\begin{tabular}{|c|c|c|c|c|c|}
\hline \multirow{2}{*}{ LAJES } & \multirow{2}{*}{$e(\mathrm{~mm})$} & \multicolumn{2}{|c|}{ Experimental } & \multicolumn{2}{c|}{$\mathrm{EC} 2(2004)$} \\
\cline { 3 - 6 } & & $V_{u}(\mathrm{kN})$ & $\beta_{\exp }$ & $k_{\text {norma }}$ & $\beta_{\text {norma }}$ \\
\hline L01 & 500 & 325 & 1,09 & 0,60 & 2,15 \\
\hline L02 & 352 & 513 & 1,45 & 0,60 & 1,81 \\
\hline L03 & 349 & 575 & 1,66 & 0,60 & 1,81 \\
\hline L04 & 349 & 372 & 1,05 & 0,60 & 1,80 \\
\hline L05 & 504 & 250 & 1,23 & 0,60 & 2,18 \\
\hline L06 & 343 & 282 & 1,13 & 0,60 & 1,80 \\
\hline L07 & 349 & 358 & 1,31 & 0,60 & 1,82 \\
\hline L08 & 347 & 345 & 1,21 & 0,60 & 1,80 \\
\hline L09 & 349 & 550 & 1,61 & 0,60 & 1,80 \\
\hline L10 & 498 & 500 & 1,75 & 0,60 & 2,14 \\
\hline L11 & 267 & 640 & 1,69 & 0,60 & 1,62 \\
\hline L12 & 268 & 345 & 1,10 & 0,60 & 1,62 \\
\hline
\end{tabular}

Os resultados mostram que os coeficientes $\beta_{\text {norma }}$ são maiores que $\beta_{\exp }$ e por isso foram obtidas cargas estimadas com valores a favor da segurança. $\mathrm{O}$ uso aproximado de $\beta$ sugerido pelo EC2 (2004) na seção 6.4.3 não pode ser recomendado para pilar de canto reentrante, embora seja um parâmetro necessário para a análise estrutural de dimensionamento de lajes sujeitas à punção, tendo em vista que o valor de $\beta$ varia muito 
com a excentricidade de carga. Contudo, é mais seguro utilizar o $\beta$ com a expressão que a norma recomenda.

\subsection{ACI 318 (2014)}

7.3.1 Análise de lajes sem armadura de cisalhamento

Foram utilizadas as expressões para pilares internos com o perímetro crítico $b_{0}$ como mostra a Figura 7.5, tendo em vista que a norma não prevê qual seria o perímetro para pilar de canto reentrante.

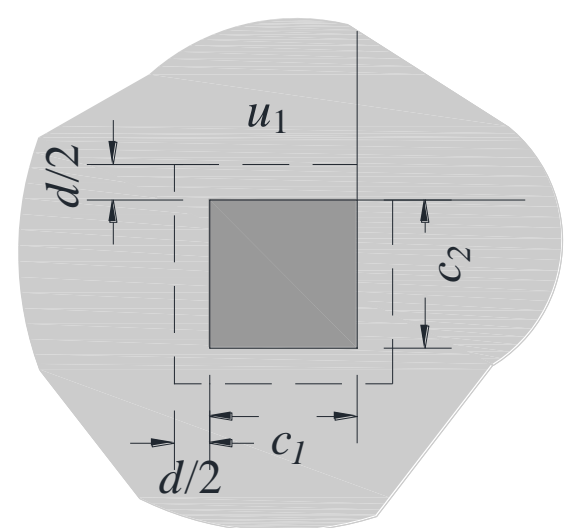

Figura 7.5 - Localização da seção crítica para o pilar de canto reentrante.

A Tabela 7.29 apresenta às cargas previstas utilizando as expressões do ACI318 (2014) com as adaptações necessárias indicando também a relação entre a carga experimental obtida com os ensaios e as cargas

Tabela 7.17 - Previsão da carga de ruptura para lajes sem armadura de cisalhamento pelo ACI 318 (2014)

\begin{tabular}{|c|c|c|c|c|c|}
\hline Laje & $V_{u}(\mathrm{kN})$ & $V_{\text {máx }}(\mathrm{kN})$ & $V_{R, c}(\mathrm{kN})$ & $V_{A C I 318}(\mathrm{kN})$ & $V_{u} / V_{A C I 318}$ \\
\hline L01 & 325 & 843 & 185 & 185 & 1,76 \\
\hline L04 & 372 & 836 & 229 & 229 & 1,63 \\
\hline L05 & 250 & 766 & 166 & 166 & 1,51 \\
\hline L06 & 282 & 780 & 215 & 215 & 1,31 \\
\hline L07 & 358 & 756 & 206 & 206 & 1,74 \\
\hline L08 & 345 & 787 & 216 & 216 & 1,60 \\
\hline L12 & 345 & 775 & 245 & 245 & 1,41 \\
\hline \multicolumn{7}{|r}{} & & MÉDIA & 1,57 \\
\cline { 5 - 6 } & & & CV & 0,107 \\
\cline { 5 - 6 }
\end{tabular}


Os resultados apresentaram valores muito conservadores com relação média de $V_{u} / V_{A C I 318}$ igual a 1,57 e um coeficiente de variação com valor de 0,107 . Pode-se obter resultados com um menor conservadorismo utilizando uma excentricidade reduzida $e_{E 1}$ relativa ao perímetro crítico $b_{0}$, ao invés de usar a excentricidade do carregamento em relação ao centro do pilar como a norma propõe. Foi feito uma simulação (Tabela 7.18) chamada aqui de Caso 1.

Tabela 7.18 - Previsão da carga de ruptura dos casos testados para lajes sem armadura de cisalhamento.

\begin{tabular}{|c|c|c|c|}
\hline \multirow{2}{*}{ LAJE } & & \multicolumn{2}{|c|}{ CASO 1} \\
\cline { 2 - 4 } & $V_{u}(\mathrm{kN})$ & $V_{\text {CASO1 }}(\mathrm{kN})$ & $V_{u} / V_{\text {CASO1 }}$ \\
\hline L1 & 325 & 190 & 1,72 \\
\hline L4 & 372 & 237 & 1,57 \\
\hline L5 & 250 & 170 & 1,47 \\
\hline L6 & 282 & 223 & 1,27 \\
\hline L7 & 358 & 213 & 1,68 \\
\hline L8 & 345 & 223 & 1,55 \\
\hline L12 & 345 & 255 & 1,35 \\
\hline \multirow{2}{*}{} & MÉDIA & 1,51 \\
\cline { 2 - 3 } & CV. & 0,109 \\
\hline
\end{tabular}

Com os resultados do Caso 1 pode-se reduzir a média das relações carga última por carga prevista de 1,57 para 1,51.

7.3.2 Análise de lajes com armadura de cisalhamento

A Tabela 7.19 apresenta às previsões para as lajes com armadura de cisalhamento utilizando as expressões do ACI318 (2014) indicando também a relação entre a carga experimental obtida com os ensaios e as cargas de ruptura prevista pela norma.

Tabela 7.19 - Previsão da carga de ruptura para lajes com armadura de cisalhamento pelo ACI (2014)

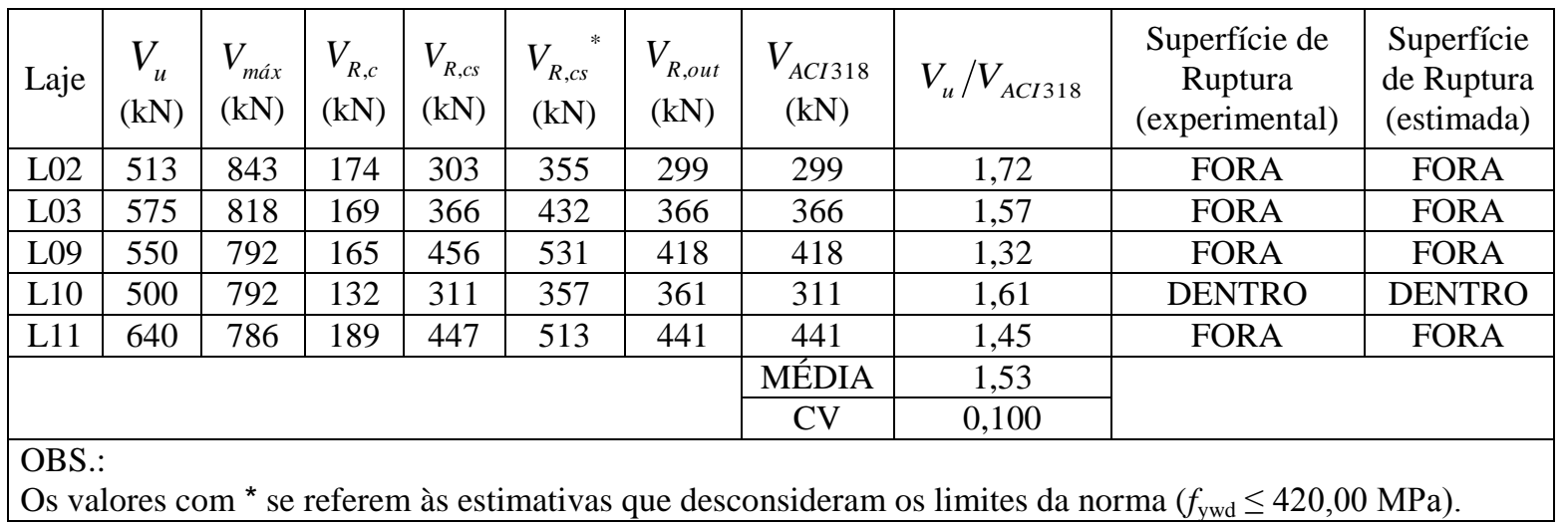


Pode-se obter resultados com um menor conservadorismo utilizando uma excentricidade reduzida $e_{E 1}$ relativa ao perímetro crítico $b_{0}$, ao invés de usar a excentricidade do carregamento em relação ao centro do pilar como a norma propõe. Foi feita uma simulação chamada aqui Caso 1 (Tabela 7.5).

Tabela 7.20 - Previsão da carga de ruptura do CASO 1 testado para lajes com armadura de cisalhamento.

\begin{tabular}{|c|c|c|c|c|c|c|c|c|}
\hline Laje & $\begin{array}{c}V_{u} \\
(\mathrm{kN})\end{array}$ & $\begin{array}{c}V_{R, c(C A S O \mathrm{I})} \\
(\mathrm{kN})\end{array}$ & $\begin{array}{c}V_{R, c s(C A S O \mathrm{l})} \\
(\mathrm{kN})\end{array}$ & $\begin{array}{c}V_{R, \text { out }(\mathrm{CASO})} \\
(\mathrm{kN})\end{array}$ & $\begin{array}{c}V_{\text {CASO1 }} \\
(\mathrm{kN})\end{array}$ & $V_{u} / V_{C A S O 1}$ & $\begin{array}{c}\text { Superfície de } \\
\text { Ruptura } \\
\text { (experimental) }\end{array}$ & $\begin{array}{l}\text { Superfície de } \\
\text { Ruptura } \\
\text { (estimada) }\end{array}$ \\
\hline L02 & 513 & 180 & 314 & 305 & 305 & 1,68 & FORA & FORA \\
\hline L03 & 575 & 175 & 379 & 373 & 373 & 1,56 & FORA & FORA \\
\hline L09 & 550 & 170 & 472 & 425 & 425 & 1,37 & FORA & FORA \\
\hline L10 & 500 & 135 & 320 & 367 & 320 & 1,56 & DENTRO & DENTRO \\
\hline L11 & 640 & 196 & 465 & 449 & 449 & 1,49 & FORA & FORA \\
\hline & & & & & MÉDIA & 1,53 & & \\
\hline
\end{tabular}

Com os resultados do Caso 1 pode-se notar que não ouve alteração na média das relações carga última por carga prevista. A previsão da superfície de ruptura foi exata para todas as lajes.

\subsection{MC $2010(2013)$}

7.4.1 Análise de lajes sem armadura de cisalhamento

Foram utilizadas as expressões para pilares internos com o perímetro crítico $b_{1}$ como mostra a Figura 7.6, tendo em vista que a norma não prevê qual seria o perímetro para pilar de canto reentrante.

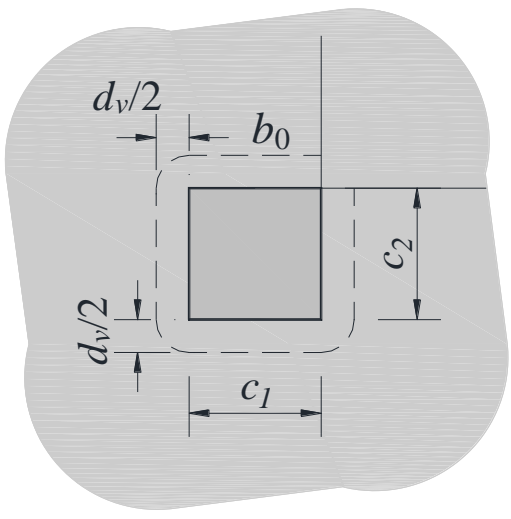

Figura 7.6 - Localização da seção crítica para o pilar de canto reentrante. 
a) Nível de aproximação II

A Tabela 7.21 apresenta as cargas de ruptura previstas utilizando as expressões do MC2010 (2013) no nível de aproximação II com as adaptações necessárias indicando também a relação entre a carga experimental obtida com os ensaios e as cargas de ruptura prevista pela norma.

Tabela 7.21 - Previsão da carga de ruptura para lajes sem armadura de cisalhamento pelo MC 2010 (2013) utilizando o nível de aproximação II.

\begin{tabular}{|c|c|c|c|c|c|}
\hline Laje & $V_{u}(\mathrm{kN})$ & $V_{\text {máx }}(\mathrm{kN})$ & $V_{R, c}(\mathrm{kN})$ & $V_{M C 2010}(\mathrm{kN})$ & $V_{u} / V_{M C 2010}$ \\
\hline L01 & 325 & 998 & 253 & 253 & 1,28 \\
\hline L04 & 372 & 1009 & 303 & 303 & 1,23 \\
\hline L05 & 250 & 628 & 158 & 158 & 1,59 \\
\hline L06 & 282 & 652 & 197 & 197 & 1,43 \\
\hline L07 & 358 & 762 & 228 & 228 & 1,57 \\
\hline L08 & 345 & 790 & 237 & 238 & 1,45 \\
\hline L12 & 345 & 809 & 269 & 269 & 1,28 \\
\hline & & & & MÉDIA & 1,41 \\
\hline
\end{tabular}

Com os resultados apresentados, utilizando as expressões do MC2010 (2013) com adaptações, percebe-se que as previsões resultaram em valores conservadores. Como a norma não propõe qual largura efetiva deve ser utilizada para pilar de canto reentrante foi feita uma simulação aqui chamada de Caso 1, em que foi considerado o momento resistente e o momento solicitante para uma faixa de largura efetiva de 1,7 $\mathrm{m}$, indo atda laje (Tabela 7.22).

Tabela 7.22 - Previsão da carga de ruptura pelo MC 2010 (2013) utilizando o nível de aproximação II.

\begin{tabular}{|l|c|c|c|c|c|}
\hline Laje & $V_{u}(\mathrm{kN})$ & $V_{\text {max }}(\mathrm{kN})$ & $V_{R, c}(\mathrm{kN})$ & $V_{M C 2010}(\mathrm{kN})$ & $V_{u} / V_{M C 2010}$ \\
\hline L01 & 325 & 1069 & 271 & 271 & 1,20 \\
\hline L04 & 372 & 1067 & 320 & 320 & 1,16 \\
\hline L05 & 250 & 694 & 174 & 174 & 1,43 \\
\hline L06 & 282 & 710 & 214 & 214 & 1,32 \\
\hline L07 & 358 & 810 & 242 & 242 & 1,48 \\
\hline L08 & 345 & 839 & 252 & 252 & 1,37 \\
\hline L12 & 345 & 850 & 283 & 283 & 1,22 \\
\hline & & MÉDIA & 1,31 \\
\cline { 4 - 5 } & & CV & 0,087 \\
\cline { 4 - 5 } & & &
\end{tabular}

Com o teste, pode-se reduzir um pouco o conservadorismo dos resultados previstos e o coeficiente de variação dos resultados. A média das relações entre carga experimental e 
carga prevista que era 1,41 passou a ser 1,31, dentro do limite satisfatório do critério adotado.

b) Nível de aproximação III

A Tabela 7.23 apresenta as cargas de ruptura previstas utilizando as expressões do MC2010 (2013) no nível de aproximação III com as adaptações necessárias indicando também a relação entre a carga experimental obtida com os ensaios e as cargas de ruptura prevista pela norma.

Tabela 7.23 - Previsão da carga de ruptura pelo MC 2010 (2013) utilizando o nível de aproximação III.

\begin{tabular}{|l|c|c|c|c|c|}
\hline Laje & $V_{u}(\mathrm{kN})$ & $V_{\text {máx }}(\mathrm{kN})$ & $V_{R, c}(\mathrm{kN})$ & $V_{M C 2010}(\mathrm{kN})$ & $V_{u} / V_{M C 2010}$ \\
\hline L01 & 325 & 975 & 248 & 248 & 1,31 \\
\hline L04 & 372 & 954 & 286 & 286 & 1,30 \\
\hline L05 & 250 & 613 & 154 & 154 & 1,62 \\
\hline L06 & 282 & 608 & 184 & 184 & 1,54 \\
\hline L07 & 358 & 718 & 214 & 214 & 1,67 \\
\hline L08 & 345 & 743 & 223 & 223 & 1,55 \\
\hline L12 & 345 & 727 & 242 & 242 & 1,43 \\
\hline \multicolumn{7}{|l}{} & MÉDIA & 1,49 \\
\cline { 4 - 5 } & & CV & 0,091 \\
\hline
\end{tabular}

Utilizando uma faixa de largura efetiva de 1,7 m da laje, temos (Tabela 7.24):

Tabela 7.24 - Previsão da carga de ruptura dos casos testados para lajes sem armadura de cisalhamento.

\begin{tabular}{|c|c|c|c|}
\hline \multirow{2}{*}{ LAJE } & & \multicolumn{2}{|c|}{ CASO 1 } \\
\cline { 2 - 4 } & $V_{u}(\mathrm{kN})$ & $V_{\text {CASO1 }}(\mathrm{kN})$ & $V_{u} / V_{\text {CASO } 1}$ \\
\hline L1 & 325 & 264 & 1,23 \\
\hline L4 & 372 & 303 & 1,23 \\
\hline L5 & 250 & 169 & 1,47 \\
\hline L6 & 282 & 200 & 1,41 \\
\hline L7 & 358 & 228 & 1,57 \\
\hline L8 & 345 & 237 & 1,45 \\
\hline L12 & 345 & 255 & 1,35 \\
\hline \multirow{2}{*}{} & MÉDIA & 1,39 \\
\cline { 2 - 3 } & CV. & 0,085 \\
\cline { 3 - 3 }
\end{tabular}

Com o teste feito pode-se reduzir a média da relação carga experimental e prevista de 1,49 para 1,39 . 
7.4.2 Análise de lajes com armadura de cisalhamento

a) Nível de aproximação II

A Tabela 7.25 apresenta as previsões utilizando as expressões do MC2010 (2013) indicando também a relação entre a carga experimental obtida com os ensaios e as cargas de ruptura prevista para o nível de aproximação II.

Tabela 7.25 - Previsão da carga de ruptura pelo MC2010 (2013) utilizando o nível de aproximação II

\begin{tabular}{|c|c|c|c|c|c|c|c|c|c|}
\hline Laje & $\begin{array}{c}V_{u} \\
(\mathrm{kN})\end{array}$ & $\begin{array}{l}V_{\text {máx }} \\
(\mathrm{kN})\end{array}$ & $\begin{array}{l}V_{R, c} \\
(\mathrm{kN})\end{array}$ & $\begin{array}{l}V_{R, c s} \\
(\mathrm{kN})\end{array}$ & $\begin{array}{c}V_{R, \text { out }} \\
(\mathrm{kN})\end{array}$ & $\begin{array}{l}V_{E C 2} \\
(\mathrm{kN})\end{array}$ & $V_{u} / V_{E C 2}$ & $\begin{array}{l}\text { Superfície de } \\
\text { Ruptura } \\
\text { (experimental) }\end{array}$ & $\begin{array}{l}\text { Superfície de } \\
\text { Ruptura } \\
\text { (estimada) }\end{array}$ \\
\hline L02 & 513 & 784 & 235 & 411 & 689 & 411 & 1,25 & FORA & DENTRO \\
\hline L03 & 575 & 663 & 199 & 462 & 702 & 462 & 1,24 & FORA & DENTRO \\
\hline L09 & 550 & 622 & 187 & 511 & 766 & 511 & 1,08 & FORA & DENTRO \\
\hline L10 & 500 & 676 & 172 & 383 & 813 & 383 & 1,31 & DENTRO & DENTRO \\
\hline L11 & 640 & 702 & 234 & 511 & 846 & 511 & 1,25 & FORA & DENTRO \\
\hline & & & & & & MÉDIA & 1,23 & & \\
\hline
\end{tabular}

Utilizando uma faixa de largura efetiva de 1,7 m da laje, temos (ver Tabela 7.26):

Tabela 7.26 - Previsão da carga de ruptura do Caso 1 testado para as lajes com armadura de cisalhamento.

\begin{tabular}{|c|c|c|c|c|c|c|c|c|}
\hline Laje & $\begin{array}{c}V_{u} \\
(\mathrm{kN})\end{array}$ & $\begin{array}{c}V_{R, c(C A S O \mathrm{O})} \\
(\mathrm{kN})\end{array}$ & $\begin{array}{c}V_{R, c s(C A S O 1)} \\
(\mathrm{kN})\end{array}$ & $\begin{array}{c}V_{R, o u t(C A S O I)} \\
(\mathrm{kN})\end{array}$ & $\begin{array}{c}V_{C A S O 1} \\
(\mathrm{kN})\end{array}$ & $V_{u} / V_{C A S O 1}$ & $\begin{array}{c}\text { Superfície de } \\
\text { Ruptura } \\
\text { (experimental) }\end{array}$ & $\begin{array}{l}\text { Superfície de } \\
\text { Ruptura } \\
\text { (estimada) }\end{array}$ \\
\hline L02 & 513 & 254 & 430 & 430 & 430 & 1,19 & $\begin{array}{l}\text { FORA } \\
\end{array}$ & DENTRO \\
\hline L03 & 575 & 217 & 481 & 481 & 481 & 1,20 & FORA & DENTRO \\
\hline L09 & 550 & 205 & 529 & 841 & 529 & 1,04 & FORA & DENTRO \\
\hline L10 & 500 & 191 & 401 & 902 & 401 & 1,25 & DENTRO & DENTRO \\
\hline L11 & 640 & 251 & 528 & 908 & 528 & 1,21 & FORA & DENTRO \\
\hline & & & & & MÉDIA & 1,18 & & \\
\hline
\end{tabular}

Com o teste feito pode-se reduzir a média da relação carga experimental e prevista de 1,23 para 1,18 . 
b) Nível de aproximação III

A Tabela 7.27 apresenta as previsões utilizando as expressões do MC2010 (2013) indicando também a relação entre a carga experimental obtida com os ensaios e as cargas de ruptura prevista para o nível de aproximação III.

Tabela 7.27 - Previsão da carga de ruptura pelo MC2010 (2013) utilizando o nível de aproximação III

\begin{tabular}{|c|c|c|c|c|c|c|c|c|c|}
\hline Laje & $\begin{array}{c}V_{u} \\
(\mathrm{kN})\end{array}$ & $\begin{array}{l}V_{\text {máx }} \\
(\mathrm{kN})\end{array}$ & $\begin{array}{l}V_{R, c} \\
(\mathrm{kN})\end{array}$ & $\begin{array}{l}V_{R, c s} \\
(\mathrm{kN})\end{array}$ & $\begin{array}{l}V_{R, \text { out }} \\
(\mathrm{kN})\end{array}$ & $\begin{array}{l}V_{E C 2} \\
(\mathrm{kN})\end{array}$ & $V_{u} / V_{E C 2}$ & $\begin{array}{l}\text { Superfície de } \\
\text { Ruptura } \\
\text { (experimental) }\end{array}$ & $\begin{array}{l}\text { Superfície de } \\
\text { Ruptura } \\
\text { (estimada) }\end{array}$ \\
\hline L02 & 513 & 726 & 217 & 394 & 638 & 394 & 1,30 & FORA & DENTRO \\
\hline L03 & 575 & 605 & 181 & 445 & 641 & 445 & 1,29 & FORA & DENTRO \\
\hline L09 & 550 & 564 & 169 & 493 & 694 & 493 & 1,12 & FORA & DENTRO \\
\hline L10 & 500 & 649 & 165 & 376 & 781 & 376 & 1,33 & DENTRO & DENTRO \\
\hline L11 & 640 & 599 & 200 & 476 & 721 & 476 & 1,34 & FORA & DENTRO \\
\hline & & & & & & MÉDIA & 1,28 & & \\
\hline
\end{tabular}

Utilizando uma faixa de largura efetiva de 1,7 m da laje tem-se (ver Tabela 7.28):

Tabela 7.28 - Previsão da carga de ruptura do Caso 1 testado para as lajes com armadura de cisalhamento.

\begin{tabular}{|c|c|c|c|c|c|c|c|c|}
\hline Laje & $\begin{array}{c}V_{u} \\
(\mathrm{kN})\end{array}$ & $\begin{array}{c}V_{R, c(C A S O 1)} \\
(\mathrm{kN})\end{array}$ & $\begin{array}{c}V_{R, c s(C A S O 1)} \\
(\mathrm{kN})\end{array}$ & $\begin{array}{c}V_{R, \text { out }(\text { CASOl })} \\
(\mathrm{kN})\end{array}$ & $\begin{array}{c}V_{C A S O 1} \\
(\mathrm{kN})\end{array}$ & $V_{u} / V_{C A S O 1}$ & $\begin{array}{c}\text { Superfície de } \\
\text { Ruptura } \\
\text { (experimental) }\end{array}$ & $\begin{array}{l}\text { Superfície de } \\
\text { Ruptura } \\
\text { (estimada) }\end{array}$ \\
\hline L02 & 513 & 236 & 412 & 692 & 412 & 1,24 & FORA & DENTRO \\
\hline L03 & 575 & 199 & 462 & 703 & 462 & 1,24 & FORA & DENTRO \\
\hline L09 & 550 & 187 & 511 & 767 & 511 & 1,08 & FORA & DENTRO \\
\hline L10 & 500 & 183 & 394 & 864 & 394 & 1,27 & DENTRO & DENTRO \\
\hline L11 & 640 & 217 & 493 & 784 & 493 & 1,30 & FORA & DENTRO \\
\hline & & & & & $\frac{\text { MÉDIA }}{\mathrm{CV}}$ & $\frac{1,23}{0,063}$ & & \\
\hline
\end{tabular}

Com os resultados, observa-se que foi possível reduzir o conservadorismo das cargas resistentes, diminuindo a média das relações carga última por carga prevista de 1,28 para 1,23 dentro do limite satisfatório do critério adotado.

Tanto para as lajes sem e com armadura de cisalhamento, os resultados do nível II são melhores que do nível III possivelmente por causa do modelo utilizado no programa SAP. 


\subsection{Avaliação dos resultados estimados}

A Figura 7.7 e Figura 7.8 apresentam graficamente a relação entre as cargas experimentais e as cargas previstas com as expressões das normas, utilizadas nessa pesquisa para lajes sem e com armadura de cisalhamento respectivamente. É importante ressaltar que as normas não abordam o tipo de ligação considerada, pilares de canto reentrante, por isso os cálculos foram realizados com adaptações sugeridas para a determinação da resistência à punção desta situação específica de projeto.

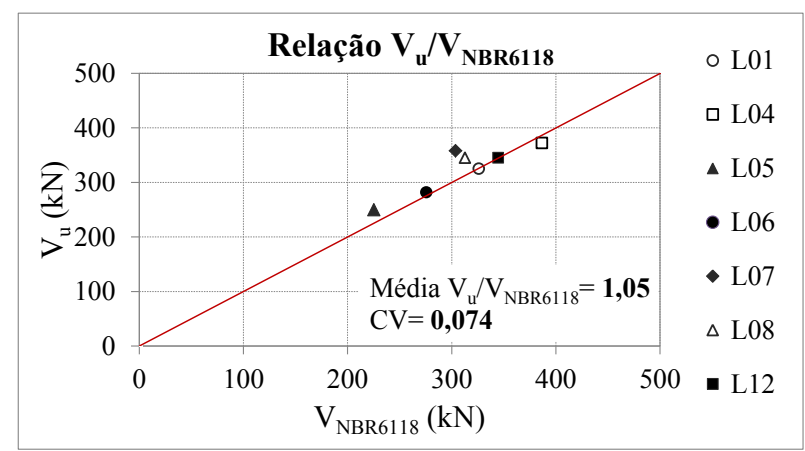

a) NBR 6118 (2014)

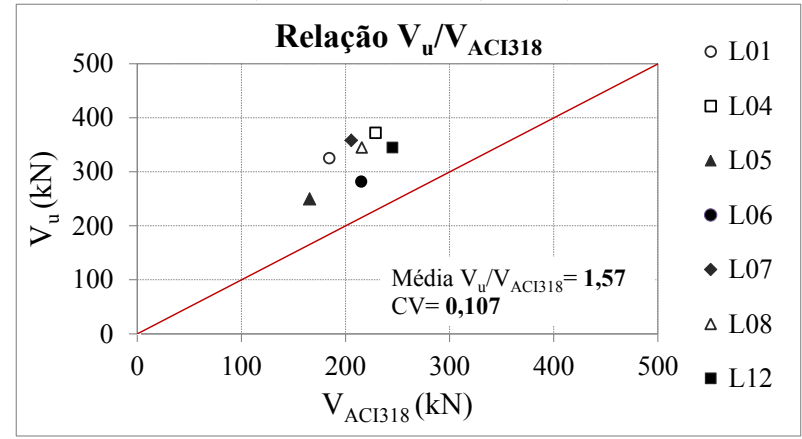

c) ACI 318 (2014)

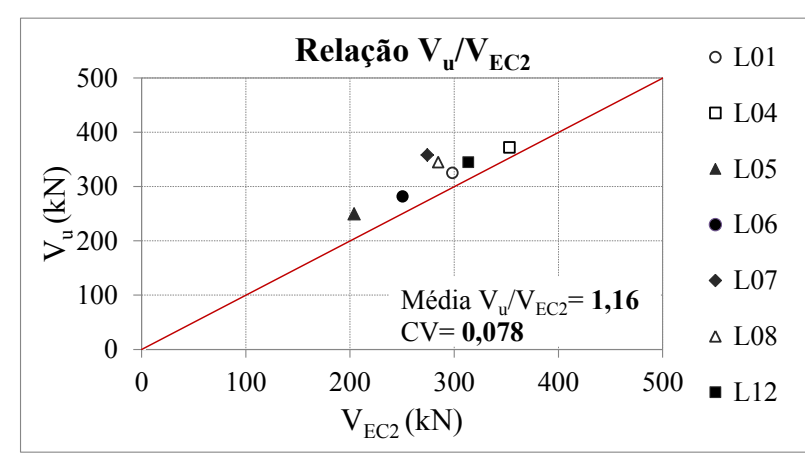

b) EC2 (2004)

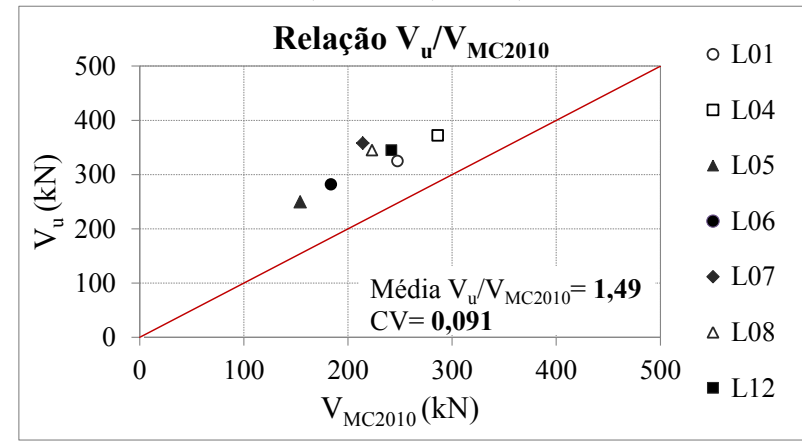

d) MC2010 (2013) - Nível de Aprox. III

Figura 7.7 - Avaliação da previsão dos resultados para lajes sem armadura de cisalhamento. 


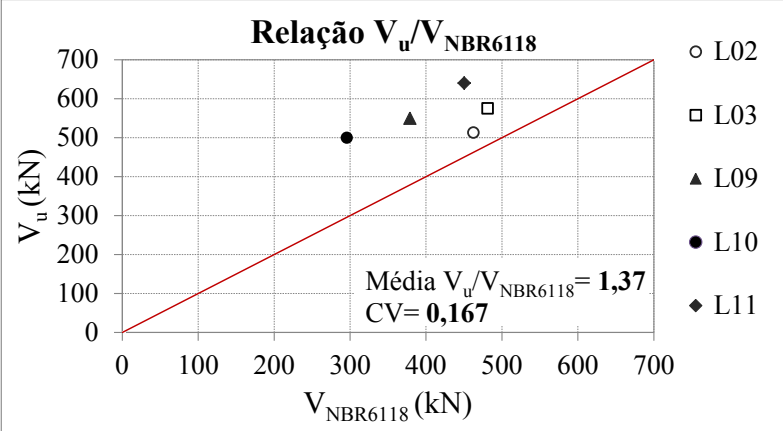

a) NBR 6118 (2014)

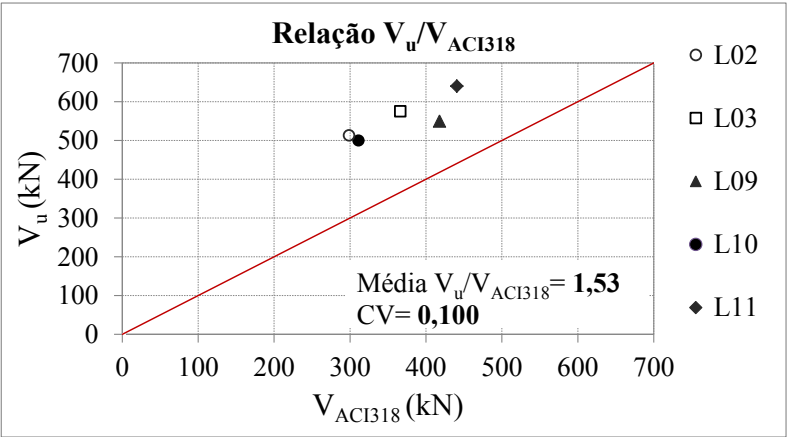

c) ACI 318 (2014)

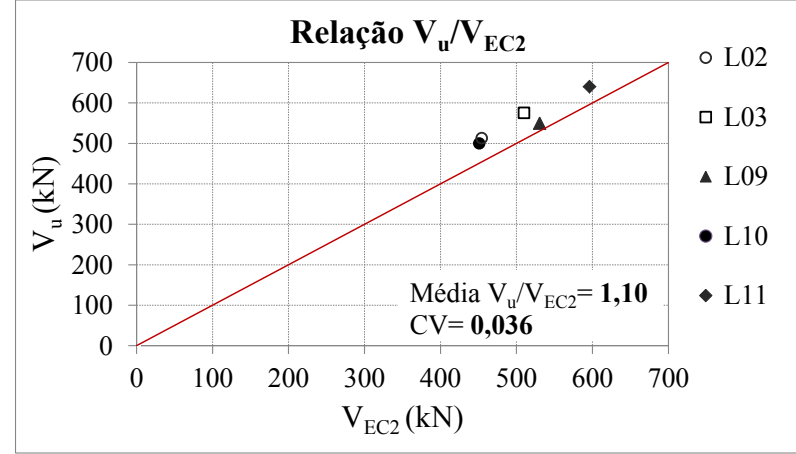

b) EC2 (2004)

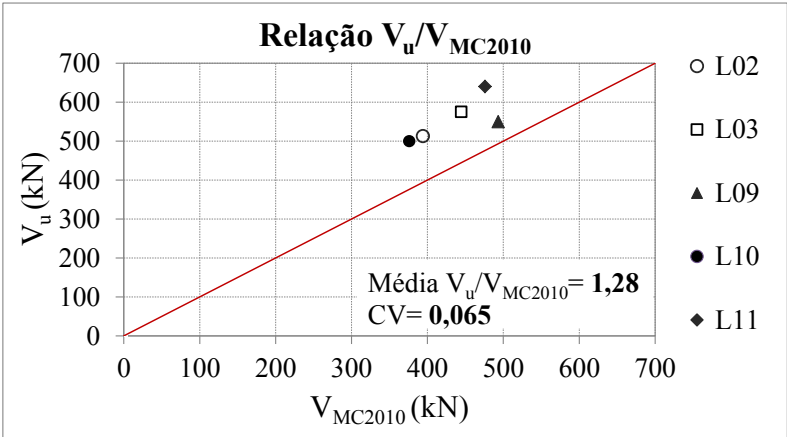

d) MC2010 (2013) - Nível de Aprox. III

Figura 7.8 - Avaliação da previsão dos resultados para lajes com armadura de cisalhamento.

Com os gráficos mostrados, tanto para as lajes sem e com armadura de cisalhamento, notase que ao utilizar as expressões normativas com adaptações, os resultados mais conservadores foram os previstos utilizando as expressões do ACI318 (2014) e MC2010 (2013). Já as previsões que utilizaram as expressões da NBR 6118 (2014) e EC2 (2004) tiveram melhor desempenho.

Com os gráficos do Grupo 1 pode-se notar que a NBR 6118 (2014) e o EC2 (2004) tiveram melhor desempenho com a NBR 6118 (2014) apresentando resultados mais precisos, com uma relação média de $V_{u} / V_{\text {NORMA }} 1,05$ e um coeficiente de variação 0,074 . Já para os resultados do Grupo 2 o EC2 (2004) apresentou resultados mais precisos com uma relação média de $V_{u} / V_{\text {NORMA }} 1,10$ e um coeficiente de variação 0,036 . A Tabela 7.9 apresenta os resultados da previsão de carga de ruptura pelas normas. 
Tabela 7.29 - Previsão da carga de ruptura pelas normas.

\begin{tabular}{|c|c|c|c|c|c|c|c|c|c|c|c|c|c|c|c|c|}
\hline \multirow[b]{2}{*}{ Laje } & \multirow[b]{2}{*}{$V_{u}(\mathrm{kN})$} & \multicolumn{3}{|c|}{ NBR 6118 (2014) } & \multicolumn{3}{|c|}{ EC2 (2004) } & \multicolumn{3}{|c|}{ ACI 318 (2014) } & \multicolumn{3}{|c|}{ MC2010 (2013) - Nível Aprox. II } & \multicolumn{3}{|c|}{ MC2010 (2013) - Nível Aprox. III } \\
\hline & & $V_{c s}(\mathrm{kN})$ & $V_{\text {out }}(\mathrm{kN})$ & $V_{u} / V_{N B R 6118}$ & $V_{c s}(\mathrm{kN})$ & $V_{\text {out }}(\mathrm{kN})$ & $V_{u} / V_{E C 2}$ & $V_{c s}(\mathrm{kN})$ & $V_{\text {out }}(\mathrm{kN})$ & $V_{u} / V_{A C I 318}$ & $V_{c s}(\mathrm{kN})$ & $V_{\text {out }}(\mathrm{kN})$ & $V_{u} / V_{M C 2010}$ & $V_{c s}(\mathrm{kN})$ & $V_{\text {out }}(\mathrm{kN})$ & $V_{u} / V_{M C 2010}$ \\
\hline L01 & 325 & 326 & - & 1,00 & 295 & - & 1,10 & 185 & - & 1,76 & 253 & - & 1,28 & 248 & - & 1,31 \\
\hline L02 & 513 & 495 & 463 & 1,11 & 467 & 449 & 1,14 & 303 & 299 & 1,72 & 411 & 689 & 1,25 & 394 & 638 & 1,30 \\
\hline L03 & 575 & 593 & 481 & 1,20 & 562 & 496 & 1,16 & 366 & 366 & 1,57 & 462 & 702 & 1,24 & 445 & 640 & 1,29 \\
\hline L04 & 372 & 387 & - & 0,96 & 347 & & 1,07 & 229 & - & 1,63 & 303 & - & 1,23 & 286 & - & 1,30 \\
\hline L05 & 250 & 225 & - & 1,11 & 204 & & 1,23 & 166 & - & 1,51 & 158 & - & 1,59 & 154 & - & 1,62 \\
\hline L06 & 282 & 275 & - & 1,02 & 250 & & 1,13 & 215 & - & 1,31 & 197 & - & 1,43 & 184 & - & 1,54 \\
\hline L07 & 358 & 304 & - & 1,18 & 274 & & 1,31 & 206 & - & 1,74 & 228 & - & 1,57 & 214 & - & 1,67 \\
\hline L08 & 345 & 313 & - & 1,10 & 285 & & 1,21 & 216 & - & 1,60 & 238 & - & 1,45 & 223 & - & 1,55 \\
\hline L09 & 550 & 732 & 379 & 1,45 & 712 & 523 & 1,05 & 456 & 418 & 1,32 & 511 & 766 & 1,08 & 493 & 694 & 1,12 \\
\hline L10 & 500 & 529 & 296 & 1,69 & 509 & 445 & 1,12 & 311 & 361 & 1,61 & 383 & 813 & 1,31 & 376 & 781 & 1,33 \\
\hline L11 & 640 & 698 & 450 & 1,42 & 670 & 585 & 1,09 & 447 & 441 & 1,45 & 511 & 846 & 1,25 & 476 & 721 & 1,34 \\
\hline L12 & 345 & 345 & - & 1,00 & 314 & - & 1,10 & 245 & - & 1,41 & 269 & - & 1,28 & 242 & - & 1,43 \\
\hline \multicolumn{4}{|c|}{ Média } & 1,19 & & & 1,14 & & & 1,55 & & & 1,33 & & & 1,40 \\
\hline \multicolumn{4}{|c|}{ Percentil (5\%) } & 0,98 & & & 1,06 & & & 1,31 & & & 1,16 & & & 1,21 \\
\hline
\end{tabular}




\section{CONCLUSÕES}

Essa pesquisa teve como objetivos principais: analisar a influência das principais variáveis (excentricidade de carga, taxa de armadura de flexão, quantidade e disposição da armadura de cisalhamento e armadura de torção) sobre o comportamento das lajes dessa pesquisa; verificar a eficiência da armadura de cisalhamento; verificar a viabilidade na utilização do software ATENA (destinado a efetuar análises tridimensionais não lineares em estruturas de concreto armado) para representar o comportamento de lajes com pilares de canto reentrante; verificar a viabilidade de utilizar recomendações normativas de projeto contra ruptura por punção para o caso dessa pesquisa.

\subsection{PROGRAMA EXPERIMENTAL}

\subsubsection{Sistema de ensaio}

O sistema de ensaio utilizado tornou possível a aplicação e controle de carregamentos assimétricas com diferentes excentricidades, possibilitando a transferência de momento fletor da laje para o pilar, comportando-se de maneira satisfatória para todos os carregamentos e com bom desempenho do sistema hidráulico empregado na aplicação das cargas. O carregamento foi aplicado no sentido de cima para baixo em três bordas da laje e as faces do pilar foram travadas com perfis metálicos a fim de evitar movimentos de corpo rígido das lajes que pudessem influenciar nas medições dos deslocamentos verticais. Apesar do ensaio não ter sido com aplicação de carga contínua, o comportamento foi efetivamente contínuo do início da aplicação das cargas até à ruptura das lajes.

O sistema de aquisição de dados utilizado na pesquisa se mostrou satisfatório quanto à monitoração dos deslocamentos e deformações.

\subsubsection{Deslocamentos e Deformações}

Os deslocamentos verticais das lajes foram monitorados em 18 pontos utilizando-se 15 LVDT's, um potenciômetro e duas escalas. Em todas as lajes esses pontos foram os mesmos a fim de permitir a comparação direta entre os resultados observados. Para as lajes L05 à L12 foram adicionados mais seis pontos monitorados por defletômetros. A quantidade e a distribuição dos pontos monitorados para medir os deslocamentos 
forneceram resultados satisfatórios quanto ao comportamento carga-deslocamento das lajes ensaiadas.

A presença da armadura de cisalhamento possibilitou que a laje se deslocasse mais antes de romper. Já a armadura de torção reduziu os deslocamentos nas bordas reentrantes. Ao analisar as lajes em um mesmo nível de carregamento notou-se que quanto maior a excentricidade maior será os deslocamentos na laje, porém é reduzida a capacidade de carga da mesma. O contrário ocorre quando se aumenta a taxa de armadura de flexão, pois a laje torna-se mais rígida.

As deformações nas armaduras de flexão foram monitoradas nas quatro primeiras lajes em pontos variados e posteriormente reduziu-se essa quantidade de pontos, contudo fixou-se sempre na mesma direção por causa da simetria e da transferência de momento. Considerou-se que o número de barras monitoradas foi satisfatório, possibilitando uma boa noção do comportamento das tensões nestas armaduras ao longo de uma seção da laje. Pode-se concluir com os resultados experimentais que as deformações máximas estão localizadas em pontos próximos à face interna do pilar e a distribuição das deformações ao longo da direção monitorada indica que o momento fletor não é contínuo e que os momentos próximos à reentrância são menores que os momentos localizados na parte contínua.

As deformações no concreto foram monitoradas para as quatro primeiras lajes através de extensômetros distribuídos em toda a laje, e posteriormente foram monitorados pontos somente próximos ao pilar por apresentar maior concentração de tensões nessa região. As deformações monitoradas foram no geral baixas com excessão apenas da laje L11 que mostrou indícios de esmagamento do concreto em sua superfície inferior com deformações relativamente altas em torno de $3,7 \%$.

Para as lajes da primeira série de concretagem, a armadura de cisalhamento foi instrumentada com dois extensômetros em cada ponto em todas as camadas a fim de conhecer quais perímetros eram mais solicitados, já nas próximas lajes foram monitoradas apenas as duas primeiras camadas. Pode-se observar de uma maneira geral que as deformações foram relativamente baixas e as barras que se aproximaram ou atingiram a tensão de escoamento estavam localizadas nas linhas mais próximas do eixo de simetria em direção à excentricidade. Ao observar os resultados da laje L03, que também possuía 
armadura de torção, concluiu-se que mesmo com a armadura de torção (estribos) a armadura de cisalhamento próximo à reentrância ainda atingiu deformações consideráveis. As deformações dos studs foram mais baixas no primeiro perímetro que no segundo, com excessão da laje L09 que possuía mais linhas de studs que as demais lajes, conseguindo redistribuir melhor as tensões na região dos dois primeiros perímetros.

A utilização de armadura de torção no bordo reentrante da laje mostrou-se eficaz, com maior transferência de momento resistente e assim possibilitou a redução de deslocamento nos bordos reentrantes.

\subsubsection{Fissuração e superfícies de ruptura}

A fissuração das lajes foi acompanhada durante intervalos de carregamento até próximo à ruptura marcando-se com pincel a propagação das mesmas. Após a ruptura, foram retiradas fotos superiores das lajes para realizar um mapeamento do nível de fissuração observado nos ensaios. Vale salientar que a laje foi sujeita a cargas de pós puncionamento para que pudesse visualizar melhor o cone de ruptura, ou seja, as fissurações apresentadas são para nível de carga após a ruptura. Os resultados demonstraram que as lajes sem armadura de cisalhamento tiveram formação do cone de punção mais evidente dentro do perímetro $\mathrm{u}_{0}$ (2.d).

A presença de armadura de torção fez com que as fissuras fossem mais distribuídas e quanto maior a taxa de armadura de flexão maior a concentração de fissuras numa mesma região. A baixa excentricidade fez com que as fissuras ficassem distribuídas mais verticalmente (sentido norte-sul) com maior ocorrência de fissuras nas bordas leste e oeste.

Após os ensaios todas as lajes foram cortadas a fim de determinar a inclinação e a posição da superfície de ruptura das lajes. A partir de uma superfície inclinada (vista do corte) que se iniciou na face inferior do pilar até atingir a armadura de flexão superior, que continua ao longo do cobrimento, a fissura da superfície de ruptura apresentou inclinação em torno de $30^{\circ}$ para as lajes com excentricidade de $500 \mathrm{~mm}$ e $265 \mathrm{~mm}$. Já as demais lajes tiveram inclinações variando de $15^{\circ}$ à $60^{\circ}$ em pelo menos uma das faces. Com isso, conclui-se que no caso em que as cargas são aplicadas igualmente nos seis pontos de transmissão de carregamento $(\mathrm{e}=350 \mathrm{~mm}$ ), o comportamento é variável em cada face cortada, ou seja, o cone não tem inclinação uniforme. 
Dentre as cinco lajes com armadura de cisalhamento foi possível evidenciar, com as faces da laje cortada, que apenas uma delas teve a ruptura dentro da região de cisalhamento.

\subsubsection{Influência das variáveis nas cargas de ruptura}

A presença de studs em lajes com cargas iguais em todos os pontos contribuiu para a mesma aumentar sua capacidade resistente em $38 \%$ e $55 \%$ no caso das lajes L02 e L03 respectivamente quando comparadas com a laje L04. A laje L10 apresentou carga de ruptura $54 \%$ a mais que a laje L01 e a laje L11 $86 \%$ a mais que a laje L12. Já a laje L09 suportou uma carga de ruptura $48 \%$ a mais que a laje L04. Essas variações devem-se a quantidade de armadura de cisalhamento. Contudo, a presença da armadura de torção não influenciou na carga de ruptura, fato esse comprovado quando se compara as lajes L07 e L08.

Com os resultados dessa pesquisa pode-se comprovar que quanto maior a excentricidade menor a capacidade de carga e quanto maior a taxa de armadura maior a capacidade de carga. Para as lajes não reforçadas e com cargas iguais nas faixas circundantes ao pilar tivemos que a laje $\operatorname{com} \rho$ de $2,1 \%$ suportou uma carga $4 \%$ a mais que a laje com $\rho$ de 1,3 $\%$ e suportou uma carga $32 \%$ a mais que a laje com $\rho$ de $0,9 \%$.

\subsection{MÉTODO NUMÉRICO}

Com as simulações numéricas computacionais pôde-se observar que em relação à fissuração, a configuração é semelhante nos casos de laje sem e com armadura de cisalhamento. Os resultados experimentais apresentaram um pouco mais de fissuras pelo fato de ter sido aplicada carga de pós-ruptura para melhor visualizar o cone de punção, enquanto que no modelo numérico as fissuras mostradas são do momento da ruptura.

Em relação aos deslocamentos, notou-se nos deslocamentos obtidos experimentalmente e numericamente uma concordância razoável com eventual exceção dos deslocamentos nas lajes sem armadura de cisalhamento. Com os gráficos de carga x deslocamento dos resultados experimentais e numéricos pode-se notar um comportamento mais rígido para os resultados numéricos devido ao módulo de elasticidade que o programa admite e o surgimento de microfissuras de flexão mais tardio que no experimental. 
Já em relação à capacidade resistente da laje e às tensões que nela surgem, observou-se que o programa apresentou uma boa concordância com os resultados experimentais. As cargas de ruptura estimadas com o programa em relação às cargas obtidas nos ensaios apresentaram uma média na relação $V_{u} / V_{M E F}$ de 1,09 e um coeficiente de variação 0,079 . O modelo numérico pode representar bem as tensões de compressão na superfície inferior próximo ao pilar e a evolução das tensões na armadura de flexão.

\subsection{MÉTODOS TEÓRICOS DE CÁLCULO}

\subsubsection{NBR 6118 (2014)}

Para lajes sem e com armadura de cisalhamento, as estimativas de capacidade de carga utilizando as expressões da NBR6118 (2014) foram melhores quando se utiliza o perímetro crítico reduzido. Nas lajes sem armadura de cisalhamento, a NBR 6118 (2014) obteve relação de carga última experimental e carga estimada em média 1,13 e nas lajes com armadura de cisalhamento a média dessa relação foi 1,18 Os resultados são precisos e satisfatórios de acordo com os critérios de avaliação adotados, porém a previsão da superfície de ruptura não foi tão precisa, com a previsão de uma das cinco lajes divergindo da superfície apresentada nos ensaios experimentais.

\subsubsection{EUROCODE 2 (2004)}

Os resultados com melhor desempenho da previsão da carga resistente utilizando as expressões do EC2 (2004) foram utilizando o perímetro crítico indo até a borda reentrante. Para as lajes sem armadura de cisalhamento, a norma obteve relação de carga última experimental e carga estimada em média 1,16 e para as lajes com armadura de cisalhamento a média dessa relação foi 1,10. Os resultados foram precisos e satisfatórios, porém a previsão da superfície de ruptura não foi tão precisa, com a previsão de uma das cinco lajes divergindo da superfície apresentada com os ensaios experimentais.

As conexões como, ligações internas, de borda e de canto, recebem tratamentos pelas normas detalhados com métodos de cálculo conhecidos para determinar a capacidade à punção. Para essas situações o EC2 (2004) leva em consideração a transferência de momento que ocorre na ligação entre a laje e o pilar, abordando métodos de cálculo simplificados em que a carga real de cisalhamento é multiplicada por um coeficiente $(\beta)$ 
dependente da posição do pilar. Porém, esse coeficiente depende da excentricidade de carga em relação ao eixo do pilar, das dimensões do pilar e do coeficiente k (coeficiente que fornece a parcela de $M_{s d}$ transmitida ao pilar por cisalhamento). Essa pesquisa trás três situações, ou seja, três excentricidades diferentes, que resultou em $\beta$ igual a 1,6, 1,8 e 2,2 para lajes com excentricidade de $265 \mathrm{~mm}, 350 \mathrm{~mm}$ e $500 \mathrm{~mm}$ respectivamente. Foi considerado um $\mathrm{k}$ de 0,6 para pilar quadrado.

\subsubsection{ACI318 (2014)}

Nas lajes sem armadura de cisalhamento, a norma obteve relação de carga última experimental e carga estimada em média 1,51 e nas lajes com armadura de cisalhamento a média dessa relação foi 1,53 . Os resultados foram muito conservadores, mas notou-se que é possível reduzir a média das relações carga última por carga prevista em média $5 \%$ utilizando uma excentricidade reduzida, relativa ao perímetro crítico. Contudo, o ACI318 (2014) foi à única norma que acertou a previsão da posição da superfície de ruptura para todas as lajes.

\subsubsection{MC2010 (2013)}

Foram utilizados os níveis de aproximação II e III para obter a previsão de carga para as lajes dessa pesquisa, e os melhores resultados foram os que utilizaram o nível II tanto para lajes sem armadura de cisalhamento quanto para lajes com armadura de cisalhamento.

Nas lajes sem armadura de cisalhamento utilizando o nível de aproximação II, a norma obteve resultados conservadores com relação de carga última experimental e carga estimada em média 1,41. Já para lajes com armadura de cisalhamento os resultados foram satisfatórios com a média dessa relação de 1,23. Utilizando o nível de aproximação III, a norma também obteve resultados conservadores para as lajes sem armadura de cisalhamento, com relação de carga última experimental e carga estimada em média 1,49. Porém, para lajes com armadura de cisalhamento os resultados foram satisfatórios com a média dessa relação de 1,28 .

Quanto à previsão da superfície de ruptura, apenas uma das cinco lajes teve previsão equivalente da superfície apresentada com os ensaios experimentais. 
É possível reduzir o conservadorismo das cargas resistentes em $10 \%$ nas lajes sem armadura e $5 \%$ nas lajes com armadura de cisalhamento, considerando o momento resistente e o momento solicitante em uma faixa de largura de laje carregada ou analisada de $1,7 \mathrm{~m}$ ao invés de $1,25 \mathrm{~m}$.

\subsection{SUGESTÕES PARA TRABALHOS FUTUROS}

Neste item serão apresentadas algumas sugestões para trabalhos futuros baseadas nas observações durante essa pesquisa e que não puderam ser solucionadas por falta de mais ensaios e/ou pesquisas, fato esse que se deve também a ausência de trabalhos com a situação específica de projeto aqui estudado. São elas:

1- Melhorar o sistema de ensaio, aplicando e controlando o carregamento de maneira contínua e com a mesma velocidade. Aplicar cargas de pós-ruptura e monitorar além do carregamento, deslocamentos e deformações, as rotações da laje utilizando inclinômetros.

2- Realizar ensaios em lajes com armadura de torção, variando o diâmetro da barra e distribuição da mesma;

3- Realizar ensaios utilizando armadura de cisalhamento e torção ao mesmo tempo próxima à borda reentrante;

4- Realizar ensaios variando as dimensões do pilar e utilizar pilares retangulares e circulares também.

5- Desenvolver uma equação para quantificar a variação da parcela $k$ de transferência de momento fletor utilizando o método dos elementos finitos e métodos analíticos. 


\section{REFERÊNCIAS}

ACI 318 - AMERICAN CONCRETE INSTITUTE. Building code requirements for structural concrete (ACI 318M-14) and Commentary (ACI 318RM-14). Farmington Hills, 2014.

ACI 421.1R-99, Shear-Reinforcement for Slabs. Reported by Joint ACI-ASCE Committee 421, ACI, Farmington Hills, Michigan, 1999.

AMERICAN SOCIETY FOR TESTING AND MATERIALS. ASTM C 1231/C 1231M Standard practice for use of unbonded caps in determination of compressive strength of hardened concrete cylinders. ASTM Committee C09 on Concrete and concrete Aggregates, 2000.

ANCON Building Products. Shearfix Punching Shear Reinforcement. 2012. Disponível em:http://www.ancon.co.uk/downloads/s1/11/shearfix\%20punching\%20shear\%20reinforce ment.pdf. Acessado em: 02/12/2014.

ASSOCIAÇÃO BRASILEIRA DE NORMAS TÉCNICAS. ABNT NBR 5739 Concreto - Ensaio de compressão de corpos-de-prova cilíndricos. Rio de Janeiro, 1994.

ASSOCIAÇÃO BRASILEIRA DE NORMAS TÉCNICAS. NBR 6118 - Projeto de estruturas de concreto armado e protendido - procedimento. Rio de Janeiro, 2014.

ASSOCIAÇÃO BRASILEIRA DE NORMAS TÉCNICAS. ABNT NBR 7222 Argamassa e concreto - Determinação da resistência à tração por compressão diametral de corpos de prova cilíndricos - Método de ensaio. Rio de Janeiro, 1994-b.

ASSOCIAÇÃO BRASILEIRA DE NORMAS TÉCNICAS. ABNT NBR 8522/8 Concreto - Determinação do módulo de deformação estática e diagrama tensãodeformação - Método de ensaio. Rio de Janeiro, 1984.

BARbOSA, W. C. S. (2012). Punção em Lajes Lisas de Concreto Armado com Pilar de Canto Reentrante. Dissertação de Mestrado em Estruturas e Construção Civil, 
Departamento de Engenharia Civil e Ambiental, Universidade de Brasília, Brasília, DF, $239 \mathrm{p}$.

CARES Technical Approval Report TA7 5041. Assessment of the Ancon SHEARFIX.

Punching Shear Reinforcement System and Quality System for Production. 2012. Disponível em: http://www.ukcares.com/TAPDF/5041.pdf. Acessado em: 01/12/14

CARES Technical Approval Report TA7 5043. FRANK Max Frank Shearail. Punching Shear Reinforcement System. Assessment of the Shearail. Punching Shear Reinforcement System. 2013. Disponível em: http://www.ukcares.com/tapdf/5043.pdf. Acessado em: $01 / 12 / 14$.

CARVALHO, R. C.; PINHEIRO, L. M. Cálculo e detalhamento de estruturas usuais de concreto armado. Volume 2. 1. Ed. São Paulo: Pini, 2009. 589p.

\section{CATMAN 4.5 User's Manual for Windows 95/98/NT en.}

CEB-FIP - Model Code 1990 - Design Code. Thomas Telford, 1993.

ČERVENKA, V.; JENDELE, L.; ČERVENKA, J. - ATENA Program Documentation Part 1 - Theory. Cervenka Consulting Ltd, Praga, 2010.

DILGER, W.H., GHALI, A., Shear Reinforcement for Concrete Slabs, ASCE Journal of Structural Division, Proceedings, V. 107, No. ST12, Dec. 1981, pp. 2403-2420.

DSA Reinforcement against punching failure of slabs. Technical Manual. Peikko Group. Version: US 11/2012. Disponível em:

http://materials.crasman.fi/materials/public/619a39e33f08620b52806e0a9ceed2ac/downloa d?link_id=13360\&folder_id=1380. Acessado em: 01/12/14.

ELGABRY, A.A., GHALI, A. Tests on concrete slab-column connections with studshear reinforcement subjected to shear-moment transfer. ACI Structural Journal, v. 84, n.5, Sept-Oct, 1987 , p. 433-442. 
EUROCODE 2 - EUROPEAN STANDARD. Design of concrete structures - Part 1:

General rules and rules for buildings. European Committee for Standardization. Brussels, 2004.

FERREIRA, M. P. (2010). Punção em Lajes Lisas de Concreto Armado com Armaduras de Cisalhamento e Momentos Desbalanceados. Tese de Doutorado em Estruturas e Construção Civil, Publicação E.TD - 007 A/10 Departamento de Engenharia Civil e Ambiental, Universidade de Brasília, Brasília, DF, 275p.

Fédération Internationale du Béton - Model Code 2010, First Complete Draft. Bulletin 56, Volume 2. Lausanne, 2010.

Fib Model Code for Concrete Structures, Ernst \& Sohn, Berlin, 2013.

GOMES, R. B., Punching Resistance of Reinforced Concrete Flat Slabs with Shear Reinforcement. PhD Thesis, Polytechnic of Central London, London, England, 1991, $185 \mathrm{p}$.

KING, S., and DELATTE, N. (2004). "Collapse of 2000 Commonwealth Avenue: Punching Shear Case Study." J.Perform.Constr.Facil., 18(1), 54-61. Disponível em: http://engagedscholarship.csuohio.edu/cgi/viewcontent.cgi?article $=1025 \&$ context=encee_f acpub. Acessado em: 17/08/15.

KINNUNEN, S.; NYLANDER, H. Punching of concrete slabs without shear reinforcement. Meddelande NR 38. Institutionen för Byggnadsstatik, Kungl. Tekniska Högskolans, Stockholm, 1960.

KINNUNEN, S. Punching of Concrete Slabs With Two-way Reinforcement Whit Special Reference to Dowel Effect and Deviation of Reinforcement from Polar Symmetry. Meddeland $\mathrm{N}^{\mathrm{o}}$ 41, Institutionen för Byggnadsstatik, Kungliga Tekniska Högskolans, Stockholm, 1963. 
LANGOHR, P.H.; GHALI, A.; DILGER, W.H. Special shear reinforcement for concrete flat plates. Journal of the American Concrete Institute, v.73, n.3, 1976, p.141146.

LORD, A.R., A Test of a Flat Slab Floor in a Reinforced Concrete Building. National Association of Cement Users, ACI, No. 67, 1910, pp. 156-179.

MELO, G. S. S. A., Behavior of Reinforced Concrete Flat Slabs after Local Failure. $\mathrm{PhD}$ Thesis, Polytechnic of Central London, London, England, 1990, 214p.

MIRZAEI, Y. Post-Punching Behavior of Reinforced Concret Slabs. Lausane, Suisse, 2010. 137p. Thèse (Doctoral) - École Polytechnique Fédérale de Lausanne.

MOKHTAR, A.; GHALI, A.; DILGER, W. Stud shear reinforcement for flat concrete plates. Journal of the American Concrete Institute, v. 82, n.5, 1985, p.676-683.

MOE, J., Shearing Strength of Reinforced Concrete Slabs and Footings Under Concentrated Loads. Development Bulletin D47, Portland Cement Association, Skokie, Illinois, Apr. 1961, 129p.

OLIVEIRA, M. H. (2013). Punção em lajes lisas com armadura de cisalhamento submetidas a carregamento excêntrico e apoiadas sobre pilares retangulares. Tese de Doutorado em Estruturas e Construção Civil, Departamento de Engenharia Civil e Ambiental, Universidade de Brasília, Brasília, DF, 250p.

REGAN, P. E.; BRAESTRUP, M. W., Punching Shear in Reinforced Concrete. Comité Euro-International du Béton, Bulletin d'Information, No. 168, Jan. 1985, 232 pp.

SEIBLE, F.; GHALI, A.; DILGER, W.H. Preassembled shear reinforcing units for flat plates. Journal of the American Concrete Institute, v.77, n.1, 1980, p.28-35.

TALBOLT, A. N. Reinforced Concrete Wall Footings and Column Footings. Bulletin 67, March 1913. 1-114, University of Ilinois, Engeneering Experiment Station, Urbana, 1913. 
WOOD, J. G. M., Pipers Row Car Park, Wolverhampton: Quantitative Study of the Causes of the Partial Collapse on 20th March 1997. Report presented to Structural Studies \& Design Ltd, England, 1997, 209 p.

https://failures.wikispaces.com/Concrete+System+Collapses+\%26+Failures+During+Cons truction. Acessado em: 17/08/15.

https://reidmiddleton.wordpress.com/2011/03/14/5/. Acessado em: 17/08/15. 
APÊNDICE 


\section{A: ESTIMATIVAS DA CARGA ÚLTIMA DE PUNÇÃO PELAS DIFERENTES NORMAS}

Neste item são apresentadas as estimativas de cargas de ruptura por punção para duas lajes (lajes L01 e L02), utilizando as normas descritas no Capítulo 2. Serão utilizadas aqui as melhores propostas de cálculo apresentado no Capítulo 7.

Na Tabela A.1 é apresentada as características necessárias das lajes que serão utilizadas aqui para demostrar o cálculo da carga de ruptura à punção pelas normas abordadas nessa pesquisa.

Tabela A.1 - Características das lajes L01 e L02

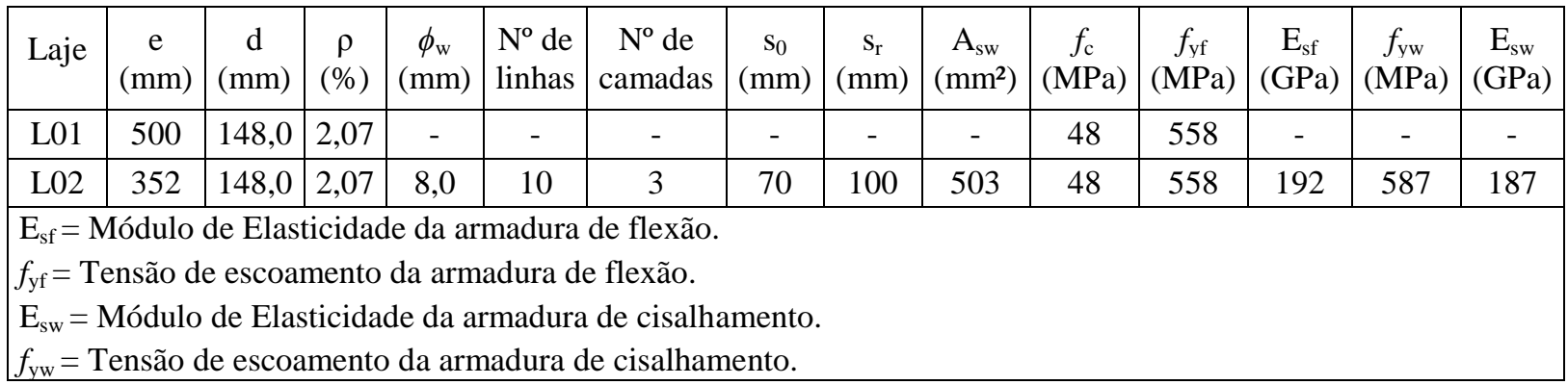

\section{A.1: Estimativas de carga última pela NBR 6118 (2014)}

Para evitar uma ruptura por compressão diagonal do concreto na superfície crítica do perímetro $u_{0}$ (perímetro do pilar ou ponto de carregamento multiplicado pela espessura da laje) uma verificação deve ser feita para lajes com ou sem armadura de punção:

$$
\tau_{s d} \leq \tau_{R d 2}=0,27 \cdot\left(1-\frac{f_{c}}{250}\right) \cdot f_{c}
$$

onde:

$\tau_{s d}$ é a tensão atuante ou de projeto;

$\tau_{R d 2}$ é a tensão resistente;

$f_{c}$ é a resistência à compressão do concreto.

Para evitar uma ruptura por punção da laje na superfície crítica do perímetro $u$ (perímetro crítico $u$ multiplicado pela espessura da laje) em elementos estruturais ou trechos sem armadura de punção deve ser feita uma nova verificação: 


$$
\tau_{s d} \leq \tau_{R d 1}=0,13 \cdot\left(1+\sqrt{\frac{20}{d}}\right) \cdot\left(100 \rho \cdot f_{c k}\right)^{1 / 3}
$$

onde:

$d$ é a altura útil da laje ao longo do perímetro crítico $u$ da área de aplicação da força, em centímetros;

$\rho$ é a taxa geométrica de armadura de flexão aderente (armadura não aderente deve ser desprezada);

$\rho_{x}$ e $\rho_{y}$ são as taxas de armadura nas duas direções ortogonais.

Para evitar uma ruptura por punção da laje na superfície crítica do perímetro $u$ (perímetro crítico u multiplicado pela espessura da laje) em elementos estruturais ou trechos com armadura de punção deve ser feita uma nova verificação:

$$
\tau_{s d} \leq \tau_{R d 1}=0,13 \cdot\left(1+\sqrt{\frac{20}{d}}\right) \cdot\left(100 \cdot \rho \cdot f_{c k}\right)^{1 / 3}+1,5 \cdot \frac{d}{s_{r}} \cdot \frac{A_{s w} \cdot f_{y w d} \cdot \operatorname{sen} \alpha}{u \cdot d}
$$

sendo:

$$
s_{r} \leq 0,75 \cdot d
$$

onde:

$s_{r}$ é o espaçamento radial entre linhas de armadura de punção, não maior do que $0,75 \mathrm{~d}$;

$A_{s w}$ é a área da armadura de punção num perímetro completo paralelo a $u$;

$\alpha$ é o ângulo de inclinação entre o eixo da armadura de punção e o plano da laje;

$u$ é o perímetro crítico ou perímetro crítico reduzido no caso de pilares de borda ou canto.

$f_{y w d}$ é a resistência de cálculo da armadura de punção, não maior do que $300 \mathrm{MPa}$ para conectores ou $250 \mathrm{MPa}$ para estribos (de aço CA50 ou CA60). Para lajes com espessura maior que $15 \mathrm{~cm}$, esses valores podem ser aumentados conforme estabelece o item 19.4.2. da NBR 6118 (2007).

No caso em que, além da força vertical, existe transferência de momento da laje para o pilar, o efeito de assimetria deve ser considerado de acordo com a expressão:

$$
\tau_{s d}=\frac{F_{s d}}{u \cdot d}+\frac{K \cdot M_{s d}}{W_{p} \cdot d}
$$


onde:

$K$ é o coeficiente que fornece a parcela de $M_{s d}$ transmitida ao pilar por cisalhamento, que depende da relação $C_{1} / C_{2}$ (dimensões do pilar, paralela e perpendicular à excentricidade da força respectivamente). $\mathrm{O}$ coeficiente $\mathrm{K}$ assume os valores indicados na Tabela 2.1.

$e_{0}$ é a excentricidade da carga resultante em relação ao centro do pilar;

$W_{p}$ é o módulo resistente da seção crítica e pode ser calculado desprezando a curvatura dos cantos do perímetro crítico, através da expressão:

$$
W_{p}=\int_{0}^{u}\left|e_{i}\right| \cdot d l
$$

onde:

$d l$ é o comprimento infinitesimal no perímetro crítico u;

$e_{i}$ é a distancia de dl ao eixo que passa pelo centro do pilar e sobre a qual atua o momento fletor $M_{s d}$.

A.1.1: Exemplo de cálculo da carga de ruptura à punção pela NBR6118 (2014)

\section{A.1.1.1: Laje L01}

Verificação na superfície crítica do perímetro $u_{0}$ :

$$
\begin{gathered}
\tau_{s d} \leq \tau_{R d 2}=0,27 \cdot \alpha_{v} \cdot f_{c d} \\
\tau_{R 2}=0,27 \cdot\left(1-\frac{48}{250}\right) \cdot 48=10,5 \mathrm{MPa} \\
V_{R, \text { máx }}=\tau_{R 2} \cdot u_{0} \cdot d=10,5 \cdot 1200 \cdot 148=1864,8 \mathrm{kN}
\end{gathered}
$$

Verificação na superfície crítica $u$ :

$$
\begin{gathered}
\tau_{s d} \leq \tau_{R d 1}=0,13 \cdot\left(1+\sqrt{\frac{20}{d}}\right) \cdot\left(100 \rho \cdot f_{c k}\right)^{1 / 3} \\
\tau_{R 1}=1,4 \cdot 0,13 \cdot\left(1+\sqrt{\frac{200}{148}}\right) \cdot(100 \cdot 0,0207 \cdot 48)^{1 / 3}=1,82 \mathrm{MPa}
\end{gathered}
$$

Cálculo da tensão solicitante:

$$
\tau_{s}=\frac{F_{s}}{u^{*} \cdot d}+\frac{K \cdot e \cdot F_{s}}{W_{p} \cdot d}
$$


Para simplificar: $e=\frac{M_{s}}{F_{s}}$;

a) Cálculo da excentricidade da carga resultante em relação ao centro do pilar, em $\mathrm{mm}$.

$$
\begin{gathered}
e=\frac{M_{u}}{V_{u}}=\frac{\left(P_{1}\right) \cdot z_{1}+\left(\frac{P_{\text {laje }}}{3}+P_{e q}\right) \cdot z_{2}}{P_{1}+2 \cdot P_{2}+P_{\text {laje }}+P_{e q}} \\
e=\frac{(149) \cdot 1050+\left(\frac{20}{3}+2\right) \cdot 772}{148+2 \cdot 76+20+3 \cdot 2}=500 \mathrm{~mm}
\end{gathered}
$$

onde:

$P_{1}$ e $P_{2}$ são as cargas externas aplicadas sobre a laje ensaiada no momento de carga de pico (Figura A.1);

$P_{e q}$ é o peso próprio do equipamento sobre a laje;

$P_{\text {laje }}$ é o peso próprio da laje;

$z_{1}$ é o braço de alavanca entre o ponto de aplicação da carga e o eixo transversal que passa pelo centro do pilar. Para esta pesquisa $z_{1}$ é $1050 \mathrm{~mm}$;

$z_{2}$ é o braço de alavanca entre o centro de gravidade da área e o eixo transversal que passa pelo centro do pilar. Para as lajes desta pesquisa $z_{2}$ é $772 \mathrm{~mm}$.

b) Cálculo do perímetro crítico normal e reduzido.

- $u$ é o perímetro crítico normal distante $2 d$ da face do pilar, em $\mathrm{mm}$.

- $u^{*}$ é o perímetro crítico reduzido distante $2 d$ da face do pilar, em $\mathrm{mm}$.

- c é o dimensão do lado do pilar.

$$
\begin{gathered}
u=4 \cdot c+3 \pi d \\
u=4 \cdot 300+3 \pi \cdot 148=2594,9 \mathrm{~mm} \\
u^{*}=4 \cdot c+3 \pi d-2 \cdot(0,5 \cdot c) \\
u^{*}=4 \cdot 300+3 \pi \cdot 148-2 \cdot(0,5 \cdot 300)=2294,9 \mathrm{~mm}
\end{gathered}
$$

c) Cálculo da excentricidade do perímetro de controle $u_{1}$ em relação ao centro do pilar é dada por $e_{1}$, em $\mathrm{mm}$.

$$
e_{1}=\frac{m_{l 1}}{u}
$$


- Propriedades geométricas do perímetro crítico normal $u$ :

Para um arco qualquer, são válidas as fórmulas, todas em mm (Figura A.1).

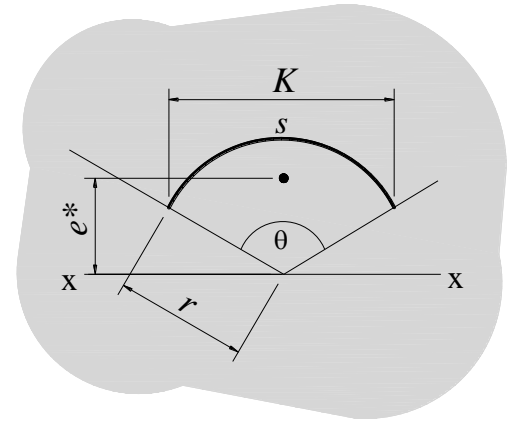

Figura A.1 - Propriedades de um arco genérico.

Para um arco qualquer, as propriedades do mesmo são apresentadas em mm (Figura A.2).

Comprimento do arco:

$$
s=2 \pi \cdot r \cdot\left(\frac{\theta}{360}\right)=2 \pi \cdot(2 \cdot 148) \cdot\left(\frac{90}{360}\right)=465,0 \mathrm{~mm}
$$

Comprimento reto da corda:

$$
K=2 r \cdot \operatorname{sen}\left(\frac{\theta}{2}\right)=2 \cdot(2 \cdot 148) \cdot \operatorname{sen}\left(\frac{90}{2}\right)=418,6 \mathrm{~mm}
$$

Distância do centro do círculo ao centroide do arco:

$$
e^{*}=\frac{r \cdot K}{s}=\frac{(2 \cdot 148) \cdot 418,6}{465}=266,5 \mathrm{~mm}
$$

Momento estático do arco em relação ao eixo xx:

$$
m_{x x}=r \cdot s=(2 \cdot 148) \cdot 465=137640,0 \mathrm{~mm}^{2}
$$

Logo, o momento estático do perímetro $u$ em torno do eixo do pilar em $\mathrm{mm}^{2}$ é:

$$
m_{l 1}=\left(e^{*}+\frac{c \cdot \sqrt{2}}{2}\right) \cdot s=\left(266,5+\frac{300 \cdot \sqrt{2}}{2}\right) \cdot 465=222564 \mathrm{~mm}^{2}
$$

- Com isso, a excentricidade do perímetro de controle $u_{l}$ em relação ao centro do pilar $e_{1}$, em mm é: $e_{1}=\frac{m_{l 1}}{u}=\frac{222564}{2594,9}=85,8 \mathrm{~mm}$.

- Cálculo da excentricidade da carga em relação ao centroide de u é dado por $e_{E, 1}$, em mm:

$$
e_{E, 1}=e-e_{1}=500-85,8=414,2 \mathrm{~mm}
$$

d) Cálculo do momento estático $W_{p}$ do perímetro de controle $\boldsymbol{u}$ em relação ao eixo passando por $e_{1}$, em $\mathrm{mm}^{2}$ é:

$$
W_{1}=\int_{0}^{u_{i}}|e| \cdot d l
$$


A determinação do momento estático do perímetro de controle $u$ pode ser obtida a partir das posições dos seguimentos 1, 2, 2', 3, 3', 4, 4', 5 e 5' como mostra a Figura A.2.

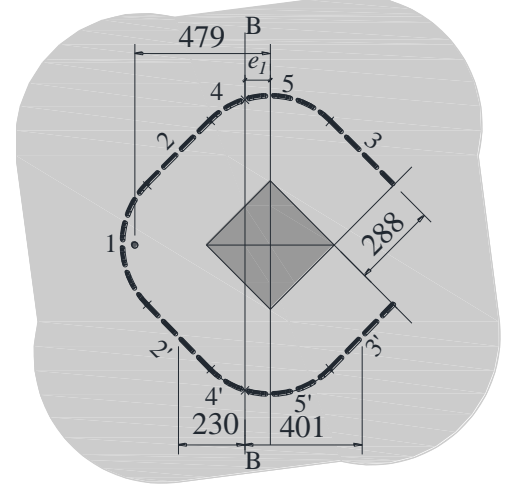

Figura A.2 - Arco 1, 2, 2', 3, 3', 4, 4', 5 e 5'.

As propriedades geométrica do segmento 1 do perímetro de controle $u$ podem ser vistas na Figura A.3, e estas são:

$$
\begin{aligned}
& r=2 \cdot 148=296 \mathrm{~mm} \\
& s=465 \mathrm{~mm} \\
& K=418,6 \mathrm{~mm} \\
& e^{*}=r k / s=266,5 \mathrm{~mm}
\end{aligned}
$$

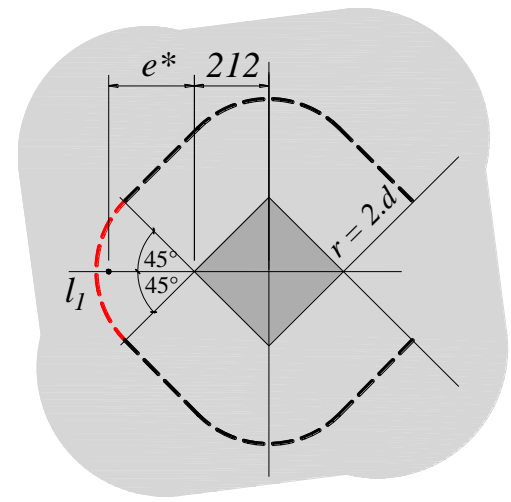

Figura A.3 - Arco 1.

A distância do centroide do segmento 1 para o centro do pilar é igual a $e^{*+212}=479 \mathrm{~mm}$ (ver Figura A.4).

O momento estático do arco sobre o centro do pilar é:

$$
m_{1}=s \cdot d_{1}=465 \cdot 479=212549 \mathrm{~mm}^{2}
$$

A distância do centroide do segmento 1 até o eixo BB (ver Figura 11) é igual a $e_{l l}=e^{*_{-}} e_{1}=$ $393 \mathrm{~mm}$.

Logo, a contribuição do segmento 1 para o momento estático total é:

$$
W_{1}=s \cdot e_{l 1}=465 \cdot 393=182652 \mathrm{~mm}^{2}
$$

O comprimento dos segmentos 2, 2', 3 e 3' são todos iguais a 300 mm. 
Para os segmentos 2 e 2', a distância do centroide até o eixo BB é:

$$
e_{l 2}=\left[\operatorname{sen}\left(45^{\circ}\right) \cdot(2 \cdot d+c / 2)\right] e_{1}=[0,707 \cdot(2 \cdot 148+300 / 2)]-86=230 \mathrm{~mm}
$$

A soma das contribuições dos segmentos 2 e 2' para o momento estático total é:

$$
W_{2}=2 \cdot c \cdot e_{l 2}=2 \cdot 300 \cdot 230=137760 \mathrm{~mm}^{2}
$$

Para os segmentos 3 e 3', a distância do centroide até o eixo BB é:

$$
e_{l 3}=\left[\operatorname{sen}\left(45^{\circ}\right) \cdot(2 \cdot d+\mathrm{c} / 2)\right]+\mathrm{e}_{1}=[0,707 \cdot(2 \cdot 148+300 / 2)]+86=401,2 \mathrm{~mm}
$$

A soma das contribuições dos segmentos 3 e 3' para o momento estático total é:

$$
W_{3}=c \cdot e_{l 3}=2 \cdot 300 \cdot 401=240720 \mathrm{~mm}^{2} .
$$

Para determinar as distâncias dos centroides dos segmentos 4 e 5 até o eixo B-B é necessário conhecer os ângulos $\alpha$ e $\beta$ mostrados na Figura A.4:

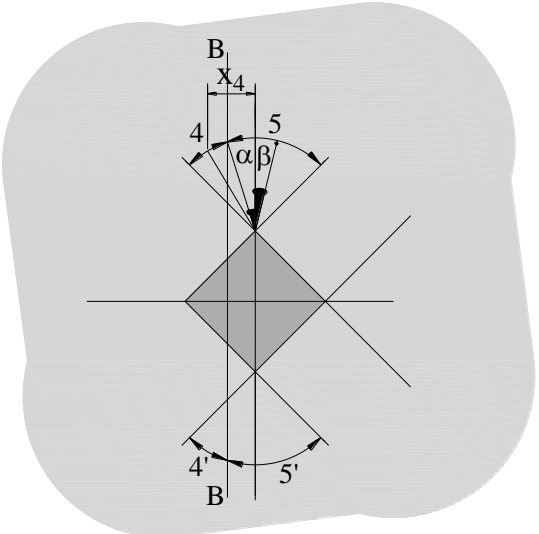

Figura A.4 - Arco 4 e 5.

$$
\alpha=\operatorname{sen}^{-1}(86 / 296)=16,9^{\circ}
$$

Para os segmentos 4 e 4' o ângulo subentendido no canto do pilar é:

$$
45^{\circ}-\alpha=45^{\circ}-16,9^{\circ}=28,1^{\circ}
$$

As propriedades do segmento de $\operatorname{arco} 4$ são:

$$
\begin{gathered}
s=2 \pi \cdot 296 \cdot\left(28,1^{\circ} / 360^{\circ}\right)=145,4 \mathrm{~mm} \\
K=2.296 \cdot \operatorname{sen}\left(28,1^{\circ} / 2\right)=144 \mathrm{~mm} \\
e^{*}=\frac{2 \cdot 148 \cdot 144}{145,4}=293,1 \mathrm{~mm}
\end{gathered}
$$

O centroide do segmento 4 até o centro do pilar é:

$$
x_{4}=293,1 \cdot \operatorname{sen}\left(16,9^{\circ}+28,1^{\circ} / 2\right)=151 \mathrm{~mm}
$$

A distância do centroide do segmento 4 até o eixo BB é:

$$
x_{4}-e_{1}=151-86=65 \mathrm{~mm}
$$


A contribuição dos segmentos 4 e 4' para o momento estático total é:

$$
W_{4}=2 \cdot s \cdot x_{4}=2 \cdot 145,4 \cdot 65=18905,6 \mathrm{~mm}^{2}
$$

Para os segmentos 5 e 5', o ângulo subentendido no canto do pilar é:

$$
45^{\circ}+\alpha=45^{\circ}+16,9^{\circ}=61,9^{\circ}
$$

As propriedades geométricas do segmento 5 são:

$$
\begin{gathered}
s=2 \pi \cdot 296 \cdot\left(61,9^{\circ} / 360^{\circ}\right)=319,5 \mathrm{~mm} \\
K=2 \cdot 296 \cdot \operatorname{sen}\left(61,9^{\circ} / 2\right)=304,2 \mathrm{~mm} \\
e^{*}=\frac{2 \cdot 148 \cdot 304,2}{319,5}=281,9 \mathrm{~mm}
\end{gathered}
$$

$\mathrm{O}$ ângulo $\beta$ foi calculado como: $\beta=0,5 \cdot 61,9^{\circ}-\alpha=0,5 \cdot 61,9^{\circ}-16,9^{\circ}=14,1^{\circ}$

A contribuição dos segmentos 5 e 5' para o momento estático total é:

$$
W_{5}=2 \cdot s \cdot\left[e^{*} \cdot \operatorname{sen}(\beta)+\alpha\right]=2 \cdot 319,5 \cdot\left[281,9 \cdot \operatorname{sen}\left(14,1^{\circ}\right)+86\right]=98709,6 \mathrm{~mm}^{2}
$$

Somando as contribuições de todos os segmentos para o momento estático, tem-se:

$$
\begin{gathered}
W_{1, t o t}=W_{1}+W_{2}+W_{3}+W_{4}+W_{5} \\
W_{1 . t o t}=W_{p}=182652+137760+240720+18905,6+98709,6=678747,2 \mathrm{~mm}^{2} .
\end{gathered}
$$

Com isso, temos que a carga solicitante na superfície crítica do perímetro crítico $u$ é:

$$
\begin{gathered}
\tau_{s d}=\frac{F_{s}}{u^{*} \cdot d}+\frac{K \cdot F_{s} \cdot e_{0}}{W_{p} \cdot d}=\frac{F_{s}}{2294,9 \cdot 148}+\frac{0,6 \cdot F_{s} \cdot 500}{678747,2 \cdot 148}=5,93.10^{-6} \cdot F_{s} \\
\tau_{s d}=1,82 M P a \leq \tau_{R d 1}=5,93.10^{-6} \cdot F_{s} \\
F_{s}=307,4 \mathrm{kN}
\end{gathered}
$$

Logo, a carga estimada de ruptura é $F_{s}=307,4 k N$ e não é feita a verificação no perímetro $u_{\text {out }}$ porque a laje L01 não possui armadura de cisalhamento.

\section{A.1.1.2: Laje L02}

Verificação na superfície crítica do perímetro $u_{0}$ :

$$
\begin{gathered}
\tau_{s d} \leq \tau_{R d 2}=0,27 \cdot \alpha_{v} \cdot f_{c d} \\
\tau_{R 2}=0,27 \cdot\left(1-\frac{48}{250}\right) \cdot 48=10,5 \mathrm{MPa} \\
V_{R, \text { máx }}=\tau_{R 2} \cdot u_{0} \cdot d=10,5 \cdot 1200 \cdot 148=1864,8 \mathrm{kN}
\end{gathered}
$$


Verificação na superfície crítica do perímetro $u$ :

$$
\tau_{s d} \leq \tau_{R d 1}=0,10 \cdot\left(1+\sqrt{\frac{20}{d}}\right) \cdot\left(100 \cdot \rho \cdot f_{c}\right)^{1 / 3}+1,5 \cdot \frac{d}{s_{r}} \cdot \frac{A_{s w} \cdot f_{y w d} \cdot \operatorname{sen} \alpha}{u^{*} \cdot d}
$$

Sabendo que os perímetros críticos, normal e reduzido são:

$$
\begin{gathered}
u=4 \cdot c+3 \pi d \\
u=4 \cdot 300+3 \pi \cdot 148=2594,9 \mathrm{~mm} \\
u^{*}=4 \cdot c+3 \pi d-2 \cdot(0,5 \cdot c) \\
u^{*}=4 \cdot 300+3 \pi \cdot 148-2 \cdot(0,5 \cdot 300)=2294,9 \mathrm{~mm}
\end{gathered}
$$

Temos que a tensão resistente é:

$$
\tau_{R 1}=1,4 \cdot 0,10 \cdot\left(1+\sqrt{\frac{200}{148}}\right) \cdot(100 \cdot 0,0207 \cdot 48)^{1 / 3}+1,5 \cdot\left(\frac{148}{100} \cdot \frac{503 \cdot(277,75 \cdot 1,15) \cdot 1}{2294,9 \cdot 148}\right)=2,45 M P a
$$

Lembrando que a resistência dos estribos pode ser considerada com os seguintes valores máximos, sendo permitida interpolação linear:

— $250 \mathrm{MPa}$, para lajes com espessura até $15 \mathrm{~cm}$;

- $435 \mathrm{MPa}\left(f_{\mathrm{ywd}}\right)$, para lajes com espessura maior que $35 \mathrm{~cm}$.

Temos que para espessura de $18 \mathrm{~cm}, f_{y w d}=277,75 M P a$.

Verificação na superfície crítica fora da armadura de cisalhamento:

$$
\tau_{R 1}=1,4 \cdot 0,13 \cdot\left(1+\sqrt{\frac{200}{148}}\right) \cdot(100 \cdot 0,0207 \cdot 48)^{1 / 3}=1,82 M P a
$$

Cálculo da tensão solicitante:

$$
\tau_{s}=\frac{F_{s}}{u^{*} \cdot d}+\frac{K \cdot e \cdot F_{s}}{W_{p} \cdot d}
$$

a) Cálculo da excentricidade da carga resultante em relação ao centro do pilar, em $\mathrm{mm}$.

$$
e=\frac{M_{u}}{V_{u}}=\frac{\left(P_{1}\right) \cdot z_{1}+\left(\frac{P_{\text {laje }}}{3}+P_{e q}\right) \cdot z_{2}}{P_{1}+2 \cdot P_{2}+P_{\text {laje }}+P_{e q}}=\frac{(166) \cdot 1050+\left(\frac{20}{3}+2\right) \cdot 772}{166+2 \cdot 162+20+3 \cdot 2}=352 \mathrm{~mm}
$$


b) Cálculo de $W_{p}$, em $\mathrm{mm}^{2}$.

Somando todas as contribuições do momento estático, temos o momento estático semelhante ao da laje L01:

$$
W_{p}=182652+137760+240720+18905,6+98709,6=678747,2 \mathrm{~mm}^{2}
$$

Com isso, temos que a carga solicitante na superfície crítica do perímetro $u$ é:

$$
\begin{gathered}
\tau_{s d}=\frac{F_{s}}{u^{*} \cdot d}+\frac{K \cdot F_{s} \cdot e}{W_{p} \cdot d}=\frac{F_{s}}{2294,9 \cdot 148}+\frac{0,6 \cdot F_{s} \cdot 352}{678747,2 \cdot 148}=5,05.10^{-6} \cdot F_{s} \\
\tau_{s d}=2,45 M P a \leq \tau_{R d 1}=5,04.10^{-6} \cdot F_{s} \\
F_{s}=486,1 \mathrm{kN}
\end{gathered}
$$

A carga solicitante na superfície crítica do perímetro $u_{\text {out }}$ :

Sabendo que $u_{\text {out }}=3676,31 \mathrm{~mm}$

$$
\begin{gathered}
\tau_{s d}=\frac{F_{s}}{u_{\text {out }} \cdot d}+\frac{K \cdot F_{s} \cdot e}{W_{p} \cdot d}=\frac{F_{s}}{3676,31 \cdot 148}+\frac{0,6 \cdot F_{s} \cdot 352}{678747,2 \cdot 148}=3,94.10^{-6} \cdot F_{s} \\
\tau_{s d}=1,82 M P a \leq \tau_{R d 1}=3,93.10^{-6} \cdot F_{s} \\
F_{s}=463,0 k N
\end{gathered}
$$

A NBR 6118 (ABNT 2014) define que a resistência à punção de uma laje com armadura de cisalhamento deve ser o menor valor entre as cargas estimadas nos perímetros $u_{0}, u$ e $u_{\text {out }}$ Logo, para a laje L02 a carga resistente a punção é $F_{s}=463,0 \mathrm{kN}$.

\section{A.2: Estimativas de carga última pelo EUROCODE2 (2004)}

A norma europeia exige a comparação entre a tensão atuante e a tensão resistente para a verificação de ligações laje-pilar à punção.

Para verificação no perímetro do pilar ou área carregada a máxima tensão de cisalhamento não deve exceder:

$$
v_{E d}<v_{R d, m a x}
$$

onde:

$v_{E d}$ é a tensão atuante na ligação;

$V_{R d, m a ́ x}$ é o valor de cálculo máximo da resistência ao cisalhamento ao longo da seção considerada. 
Para verificação da necessidade de armadura de punção é necessário que:

$$
v_{E d}<v_{R d, c}
$$

onde:

$V_{R d, c}$ é o valor de cálculo da resistência ao cisalhamento sem armadura de punção ao longo da seção considerada.

No caso de $v_{E d}$ exceder o valor de $v_{R d, c}$ para a seção de controle considerada deverá adotar-se uma armadura de punção.

O valor da máxima tensão de cisalhamento quando a reação for excêntrica com relação ao perímetro crítico é:

$$
v_{E d}=\beta \cdot \frac{V_{E d}}{u_{i} \cdot d}
$$

onde:

$$
\beta=1+k \cdot \frac{M_{E d}}{V_{E d}} \cdot\left(\frac{u_{1}}{W_{1}}\right)
$$

$d$ é a profundidade média efetiva da laje, que pode ser tomada como $\left(d_{y}+d_{z}\right) / 2$;

$d_{y}$ e $d_{z}$ correspondem às profundidades efetivas nos eixos y e z da seção de controle;

$u_{i}$ é o comprimento do perímetro crítico considerado;

$u_{1}$ é o comprimento do perímetro crítico normal distante $2 \mathrm{~d}$ da face do pilar, em $\mathrm{mm}$;

$u_{1}=4 \cdot c+3 \cdot \pi \cdot d$, para um pilar de canto reentrante quadrado;

$M_{E d}$ é o momento de cálculo;

$V_{E d}$ é o esforço normal de cálculo;

Para simplificar: $e=\frac{M_{E d}}{V_{E d}}$;

$e$ é a excentricidade do carregamento;

$k$ é o coeficiente definido em EC2 em função da razão das dimensões do pilar retangular. Este coeficiente representa a proporção do momento que é restrito por cisalhamento 
desigual. É largamente empírico e era destinado a pilares internos. Foi assumido um valor de 0,6 , correspondente a um pilar quadrado interno, e é dado pela Tabela 2.2:

$W_{1}$ é momento estático do perímetro crítico $u_{1}$ em relação ao eixo passando por $e_{1}$, ou seja, Módulo de Resistência Plástica em função do perímetro crítico $u_{1}$ :

$$
W_{i}=\int_{0}^{u_{i}}\left|e_{i}\right| \cdot d l
$$

$d l$ é o comprimento elementar do perímetro;

$e_{i}$ é a distância de $d l$ ao eixo em torno do qual atua o momento $M_{E d}$.

O cálculo detalhado de $W_{1}$ para pilares de canto reentrante será mostrado no Anexo 1.

O Eurocode 2 (2004) define que a resistência à punção de uma laje com armadura de cisalhamento deve ser o menor valor entre $V_{R, \text { máx }}, V_{R, c s}$ e $V_{R, o u t}$, mas não menor que $V_{R, c}$ :

a) Resistência máxima:

$$
V_{R, \text { máx }}=\left[0,3 \cdot f_{c}^{\prime} \cdot\left(1-\frac{f_{c}^{\prime}}{250}\right)\right] \cdot u_{0} \cdot d
$$

onde:

$f_{c}^{\prime}$ é a resistência a compressão do concreto;

$u_{0}$ é o perímetro do pilar;

b) Para lajes sem armadura de cisalhamento, a capacidade resistente de uma laje é:

$$
V_{R, c}=0,18 \cdot\left(100 \cdot \rho \cdot f_{c}^{\prime}\right)^{\frac{1}{3}} \cdot\left(1+\sqrt{\frac{200}{d}}\right) \cdot u_{1} \cdot d \cdot \frac{1}{\beta}
$$

onde:

$\rho=\sqrt{\rho_{x} \cdot \rho_{y}}$ é a taxa de armadura média da laje, devendo ser calculada em uma largura igual com tamanho do pilar mais $3 \cdot d$ para cada lado;

c) Para lajes com armadura de cisalhamento a resistência máxima advinda da combinação da armadura de cisalhamento e do concreto é: 


$$
\begin{gathered}
V_{R, c s}=0,75 \cdot V_{R, c}+V_{R, s} \\
V_{R, s}=\left(1,5 \cdot \frac{d}{s_{r}}\right) \cdot A_{s w} \cdot f_{y w, e f f} \cdot \frac{1}{\beta}
\end{gathered}
$$

onde:

$s_{r}$ é o espaçamento radial das camadas (ou perímetro) de armadura de cisalhamento.

$A_{s w}$ é a área (vertical) da armadura de cisalhamento por camada.

$f_{y w, e f f}=1,15 \cdot(250+0,25 \cdot d)$ no qual o 1,15 substitui $\gamma_{s}$.

d) Resistência da laje na região externa à armadura de cisalhamento:

$$
V_{R, \text { out }}=0,18 \cdot\left(100 \cdot \rho \cdot f_{c}^{\prime}\right)^{\frac{1}{3}} \cdot\left(1+\sqrt{\frac{200}{d}}\right) \cdot u_{\text {out }} \cdot d \cdot \frac{1}{\beta}
$$

onde:

$$
\begin{aligned}
& \kappa=1+\sqrt{\frac{200}{d}} \leq 2,0 \\
& u_{\text {out }}=\beta \cdot V_{E d} /\left(v_{R d, c} \cdot d\right)
\end{aligned}
$$

$u_{\text {out }}$ é o perímetro crítico para o qual não é necessário armadura de cisalhamento.

$u_{\text {out,eff }}$ é a soma dos trechos do perímetro mínimo externos às armaduras de cisalhamento, com perímetro externo da armadura de cisalhamento colocado a uma distância não superior a 1,5d, conforme ilustrado na Figura 2.23.

A.2.1: Exemplo de cálculo da carga de ruptura à punção pelo EC2 (2004).

\section{A.2.1.1: Laje L01}

a) Resistência máxima:

$$
V_{R, \text { máx }}=\left[0,3 \cdot 48 \cdot\left(1-\frac{48}{250}\right)\right] \cdot 1200 \cdot 148=2.066,4 k N
$$


b) Para lajes sem armadura de cisalhamento, a capacidade resistente de uma laje é:

$$
V_{R, c}=0,18 \cdot\left(100 \cdot \rho \cdot f_{c}^{\prime}\right)^{\frac{1}{3}} \cdot\left(1+\sqrt{\frac{200}{d}}\right) \cdot u_{1} \cdot d \cdot \frac{1}{\beta}
$$

Em que, o perímetro crítico é: $u_{1}=4 \cdot 300+3 \pi \cdot 148=2594,9 \mathrm{~mm}$.

E o coeficiente de transferência de momento é:

$$
\beta=1+k \cdot e \cdot\left(\frac{u^{*}}{W_{1}}\right)
$$

onde:

$W_{i}=\int_{0}^{u_{i}}\left|e_{i}\right| \cdot d l=678747,2 \mathrm{~mm}^{2}$ e $e=500 \mathrm{~mm}$ são semelhantes aos valores calculados para a laje L01 na estimativa da carga de ruptura utilizando a NBR6118 (2014).

$$
\begin{gathered}
\beta=1+0,6 \cdot 500 \cdot\left(\frac{2594,9}{678747,2}\right)=2,15 \\
\kappa=1+\sqrt{\frac{200}{148}}=2,16>2,0 \\
V_{R, c}=0,18 \cdot(100 \cdot 0,0207 \cdot 48)^{\frac{1}{3}} \cdot(2,0) \cdot 2594,9 \cdot 148 \cdot \frac{1}{2,15}=297,8 \mathrm{kN}
\end{gathered}
$$

Logo, a resistência à punção da laje L01 (sem armadura de cisalhamento) é 297,8kN .

\section{A.2.1.2: Laje L02}

a) Resistência máxima:

$$
V_{R, \text { máx }}=\left[0,3 \cdot 48 \cdot\left(1-\frac{48}{250}\right)\right] \cdot 1200 \cdot 148=2.066,4 k N
$$

b) Para lajes sem armadura de cisalhamento, a capacidade resistente de uma laje é:

$$
V_{R, c}=0,18 \cdot\left(100 \cdot \rho \cdot f_{c}^{\prime}\right)^{\frac{1}{3}} \cdot\left(1+\sqrt{\frac{200}{d}}\right) \cdot u_{1} \cdot d \cdot \frac{1}{\beta}
$$

Em que, o perímetro crítico é: $u_{1}=4 \cdot 300+3 \pi \cdot 148=2594,9 m m$

E o coeficiente de transferência de momento é: 


$$
\beta=1+k \cdot e \cdot\left(\frac{u^{*}}{W_{1}}\right)
$$

onde:

$W_{i}=\int_{0}^{u_{i}}\left|e_{i}\right| \cdot d l=678747,2 \mathrm{~mm}^{2}$ e $e=352 m m$ são semelhantes aos valores calculados para a laje L01 na estimativa da carga de ruptura utilizando a NBR6118 (2014).

$$
\begin{gathered}
\beta=1+0,6 \cdot 352 \cdot\left(\frac{2594,9}{678747,2}\right)=1,81 \\
\kappa=1+\sqrt{\frac{200}{148}}=2,16>2,0 \\
V_{R, c}=0,18 \cdot(100 \cdot 0,0207 \cdot 48)^{\frac{1}{3}} \cdot(2,0) \cdot 2594,9 \cdot 148 \cdot \frac{1}{1,81}=354,0 \mathrm{kN}
\end{gathered}
$$

c) Para lajes com armadura de cisalhamento a resistência máxima advinda da combinação da armadura de cisalhamento e do concreto é:

$$
\begin{gathered}
V_{R, c s}=0,75 \cdot V_{R, c}+V_{R, s} \\
V_{R, s}=\left(1,5 \cdot \frac{148}{100}\right) \cdot 503 \cdot 330,05 \cdot \frac{1}{1,81}=203,6 \mathrm{kN} \\
f_{y w, e f f}=1,15 \cdot(250+0,25 \cdot 148)=330,05 \mathrm{MPa} \\
V_{R, c s}=0,75 \cdot 354+203,6=469,1 \mathrm{kN}
\end{gathered}
$$

d) Resistência da laje na região externa à armadura de cisalhamento:

Sendo $u_{\text {out }}=3328,15 \mathrm{~mm}$

$$
\begin{aligned}
\kappa= & 1+\sqrt{\frac{200}{148}}=2,16>2,0 \\
& V_{R, \text { out }}=0,18 \cdot(100 \cdot 0,0207 \cdot 48)^{\frac{1}{3}} \cdot(2,0) \cdot 3328,15 \cdot 148 \cdot \frac{1}{1,81}=454,0 \mathrm{kN}
\end{aligned}
$$

O Eurocode 2 (2004) define que a resistência à punção de uma laje com armadura de cisalhamento deve ser o menor valor entre $V_{R, \text { máx }}, V_{R, c s}$ e $V_{R, o u t}$, mas não menor que $V_{R, c}$, logo para a laje L02 a carga resistente é $454,0 \mathrm{kN}$. 


\section{A.3: Estimativas de carga última pelo ACI318 (2014)}

O dimensionamento de qualquer seção de concreto ao cisalhamento, incluindo o dimensionamento de uma ligação laje-pilar à punção, deve satisfazer a seguinte condição:

$$
v_{u} \leq \phi \cdot v_{n}
$$

onde:

$v_{u}$ é a tensão de cisalhamento máxima devido à $M_{u}$ e $V_{u}$;

$v_{n}$ é a tensão de cisalhamento resistente nominal.

Para a tensão de cisalhamento resultante da transferência de momento, a excentricidade de cisalhamento deve ser considerada variável de forma linear sobre o centroide das seções críticas.

Para ligações laje-pilar que realizam transferência de momentos e não apresentam armadura de cisalhamento:

$$
\phi \cdot v_{n}=\frac{\phi \cdot V_{c}}{b_{0} \cdot d}
$$

Para membros com armadura de cisalhamento diferente de shearheads:

$$
\phi \cdot v_{n}=\frac{\phi \cdot\left(V_{c}+V_{s}\right)}{b_{0} \cdot d}
$$

onde $V_{c}$ não deve exceder $0,25 \cdot \lambda \cdot \sqrt{f_{c}^{\prime}} \cdot b_{0} \cdot d$

A resistência à punção de acordo com o ACI 318 (2014), para lajes sem armadura de cisalhamento é:

$$
V_{c}=0,33 \cdot \lambda \cdot \sqrt{f_{c}^{\prime}} \cdot b_{0} \cdot d
$$

onde:

$f_{c}^{\prime}$ é a resistência à compressão do concreto, e é limitada em no máximo $69 \mathrm{MPa}$;

$b_{0}$ é o comprimento de um perímetro crítico à $\mathrm{d} / 2$ da face do pilar; 
$d$ é a altura útil da laje;

Para lajes de concreto armado com armadura de cisalhamento existem três possíveis modos de ruptura: superfície de ruptura passando pela armadura de cisalhamento $\left(V_{R, c s}\right)$; superfície de ruptura fora da região das armaduras de cisalhamento $\left(V_{R, \text { out }}\right)$; e ruptura por esmagamento da biela comprimida nas proximidades do pilar $\left(V_{R, \text { máx }}\right)$.

$$
V_{R, c s}=V_{R, c}+V_{R, s}
$$

A contribuição da armadura de cisalhamento, quando se tem estribos verticais, é dada pela expressão:

$$
V_{s}=\frac{A_{v} \cdot f_{y} \cdot d}{s_{r}}
$$

onde:

$A_{v}$ é a área de armadura de cisalhamento por camada;

$f_{y}$ é a tensão específica de escoamento do aço;

$s_{r}$ é o espaçamento entre camadas sucessivas da armadura de cisalhamento.

O valor máximo de tensão de cisalhamento majorado pode ser calculado através de:

$$
\nu_{u}(A B)=\frac{V_{u}}{A_{c}}+\frac{\gamma_{v} \cdot M_{u} \cdot c_{A B}}{J_{c}}
$$

$\mathrm{ou}$

$$
v_{u}(A B)=\frac{V_{u}}{A_{c}}-\frac{\gamma_{v} \cdot M_{u} \cdot c_{A B}}{J_{c}}
$$

onde:

$V_{u}$ é a força de cisalhamento majorada;

$M_{u}$ é o momento majorado desequilibrado;

$c_{A B}$ é a distância do centroide da seção crítica até o ponto de máximo do cisalhamento;

$\gamma_{v}$ é o coeficiente de transferência de momento fletor pela excentricidade da força cortante. 
Cálculo de $\gamma_{v y}$, fração do momento transferido por excentricidade do cisalhamento da seção crítica de acordo com o ACI 421.1R (1999):

$$
\gamma_{v y}=1-\frac{1}{1+(2 / 3) \cdot \sqrt{b_{1} / b_{2}}}
$$

onde:

$b_{1}=$ projeção da seção crítica no eixo principal, na direção do momento.

$b_{2}=$ projeção da seção crítica perpendicular a $b_{1}$.

De acordo com o ACI 421.1R (1999), o perímetro crítico é geralmente composto por linhas retas. O momento polar de inércia em relação ao eixo $e_{b 0}$ (centroide do perímetro crítico) pode ser aproximado para o momento de inércia pela equação dada abaixo:

$$
\begin{gathered}
A_{c}=d \cdot \sum l \\
I_{y}=d \cdot \sum\left[\frac{l}{3} \cdot\left(x_{i}^{2}+x_{i} \cdot x_{j}+x_{j}^{2}\right)\right] \\
I_{x}=d \cdot \sum\left[\frac{l}{3} \cdot\left(y_{i}^{2}+y_{i} \cdot y_{j}+y_{j}^{2}\right)\right]
\end{gathered}
$$

onde:

$l=$ comprimento do segmento da seção crítica, em mm.

$x_{i}$ e $x_{j}$ coordenadas do segmento da seção crítica, em mm.

A.3.1: Exemplo de cálculo da carga de ruptura à punção pelo ACI318 (2004).

\section{A.3.1.1: Laje L01}

a) Cálculo da máxima carga resistente à punção de acordo com o ACI 318 (2014):

$$
V_{\text {máx }}=0,5 \cdot \lambda \cdot \sqrt{f_{c}^{\prime}} \cdot b_{0} \cdot d=0,5 \cdot 1,0 \cdot \sqrt{48} \cdot 1644 \cdot 148=843,0 \mathrm{kN}
$$

b) A tensão resistente à punção, para lajes sem armadura de cisalhamento é:

$$
b_{0}=2 \cdot(300+300)+3 \cdot 148=1644 m m
$$




$$
V_{c}=0,33 \cdot 1,0 \cdot \sqrt{48} \cdot 1644 \cdot 148=556,3 k N
$$

Para ligações laje-pilar que realizam transferência de momentos e não apresentam armadura de cisalhamento:

$$
\begin{aligned}
& \phi \cdot v_{n}=\frac{\phi \cdot 556,3}{1644 \cdot 148} \\
& v_{n}=2,29 \mathrm{MPa}
\end{aligned}
$$

c) Capacidade resistente da laje ao cisalhamento:

A fração do momento transferido por excentricidade do cisalhamento da seção crítica é:

$$
\begin{aligned}
& l_{x}=(300+148) \cdot(\sqrt{2} / 2)+(300+148 / 2) \cdot(\sqrt{2} / 2)=581,2 \mathrm{~mm} \\
& l_{y}=(300+148) \cdot(\sqrt{2} / 2) \cdot 2=633,6 \mathrm{~mm} \\
& \gamma_{v}=1-\frac{1}{1+(2 / 3) \cdot \sqrt{581,2 / 633,6}}=0,39
\end{aligned}
$$

De acordo com o ACI 421.1R (1999), o perímetro crítico é geralmente composto por linhas retas.

Cálculo de $e_{b}$, em mm (Figura A.5):

A excentricidade do centroide de $u_{l}$ em relação ao centro do pilar é dada por:

$$
e_{b}=\frac{m_{l 1}}{b_{0}}
$$

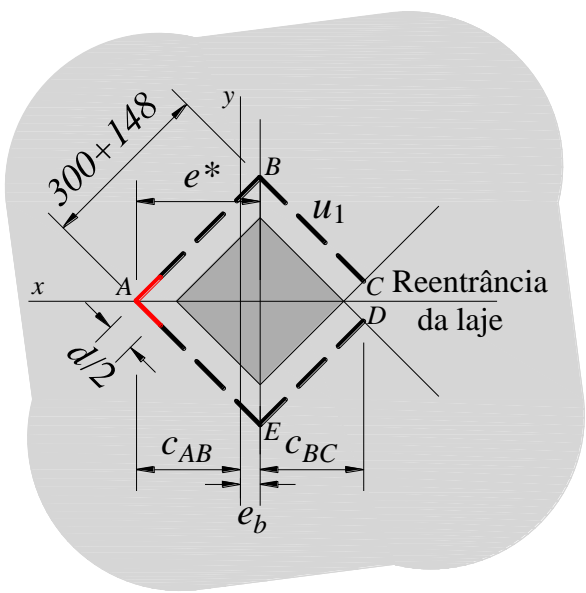

Figura A.5 - Propriedades geométricas do perímetro crítico para cálculo de $e_{b}$. 
- Cálculo de $m_{l 1}$, em mm².

O momento do perímetro $u$ em torno do eixo do pilar é dado por:

$$
\begin{gathered}
e^{*}=(300+148) \cdot(\sqrt{2} / 2)-\frac{2}{3} \cdot\left(\frac{148}{2} \cdot \sqrt{2} / 2\right)=281,9 m m \\
m_{l 1}=e^{*} \cdot s=281,9 \cdot 148=41721,2 \mathrm{~mm}^{2}
\end{gathered}
$$

- Cálculo de $e_{b}$, em mm: $e_{b}=\frac{m_{l 1}}{b_{0}}=\frac{41721,2}{1644}=25,4 m m$.

O momento polar de inércia em relação ao eixo $e_{b}$ (centroide do perímetro crítico) pode ser aproximado para o momento de inércia pela equação dada abaixo:

$$
I_{y}=d \cdot \sum\left[\frac{l}{3} \cdot\left(x_{i}^{2}+x_{i} \cdot x_{j}+x_{j}^{2}\right)\right]
$$

Conhecendo as coordenadas das retas que compõem a superfície crítica (Figura A.6), temse:

$$
\begin{aligned}
& A=(-(300+148) \cdot(\sqrt{2} / 2)+25,4) ;(0)=(-291,4 ; 0) \\
& B=(25,4) ;((300+148) \cdot(\sqrt{2} / 2))=(25,4 ; 316,8) \\
& C=((300+148 / 2) \cdot(\sqrt{2} / 2)+25,4) ;(148 / 2 \cdot(\sqrt{2} / 2))=(289,9 ; 52,3) \\
& D=((300+148 / 2) \cdot(\sqrt{2} / 2)+25,4) ;(-148 / 2 \cdot(\sqrt{2} / 2))=(289,9 ;-52,3) \\
& E=(25,4) ;(-(300+148) \cdot(\sqrt{2} / 2))=(25,4 ;-316,8) \\
& I_{y}=2 \cdot\left\{148 \cdot\left[\left(\frac{448}{3} \cdot\left(291,4^{2}-291,4 \cdot 25,4+25,4^{2}\right)\right)+\left(\frac{374}{3} \cdot\left(25,4^{2}+25,4 \cdot 289,9+289,8^{2}\right)\right)\right]\right\}
\end{aligned}
$$




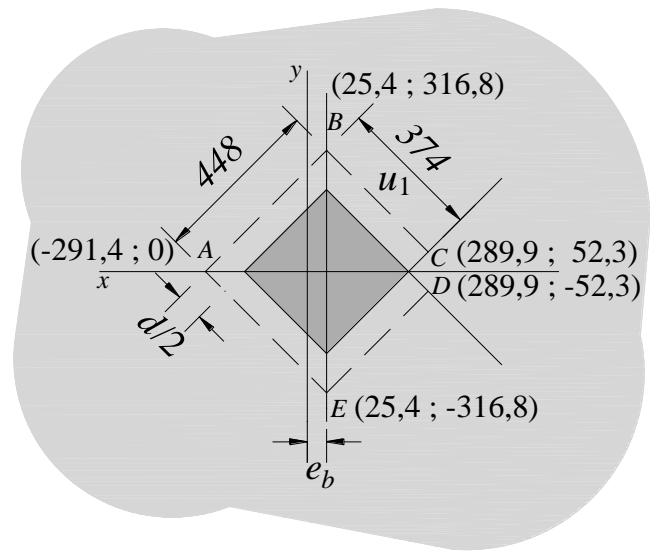

Figura A.6 - Propriedades do perímetro crítico para cálculo do momento polar de inércia

Para simplificar: $M_{u}=V_{u} \cdot e$, em que $e$ é a excentricidade do carregamento total na laje igual a $500 \mathrm{~mm}$.

A distância $c_{A B}$ será (Figura A.6):

$c_{A B}=(300+148) \cdot(\sqrt{2} / 2)-25,4=291,4 \mathrm{~mm}$

O valor máximo de tensão de cisalhamento majorado pode ser calculado através de:

$$
\begin{gathered}
v_{u}(A B)=\frac{V_{u}}{b_{0} \cdot d}+\frac{\gamma_{v} \cdot V_{u} \cdot e \cdot c_{A B}}{J_{c}} \\
v_{u}(A B)=\frac{V_{u}}{1644 \cdot 148}+\frac{0,39 \cdot V_{u} \cdot 500 \cdot 291,4}{6849424383,0}=1,24 \cdot 10^{-5} \cdot V_{u}
\end{gathered}
$$

O dimensionamento de qualquer seção de concreto ao cisalhamento, incluindo o dimensionamento de uma ligação laje-pilar à punção, deve satisfazer a seguinte condição:

$$
v_{u} \leq \phi \cdot v_{n}
$$

Logo, a carga resistente da laje L01 é:

$$
\begin{gathered}
1,24 \cdot 10^{-5} \cdot V_{R, c}=2,29 \\
V_{R, c}=184,7 \mathrm{kN}
\end{gathered}
$$




\section{A.3.1.2: Laje L02}

a) Cálculo da máxima carga resistente à punção de acordo com o ACI 318 (2014):

$$
V_{\text {máx }}=0,5 \cdot \lambda \cdot \sqrt{f_{c}^{\prime}} \cdot b_{0} \cdot d=0,5 \cdot 1,0 \cdot \sqrt{48} \cdot 1644 \cdot 148=843,0 k N
$$

b) A resistência à punção, para lajes com armadura de cisalhamento é:

$$
\begin{gathered}
\phi \cdot v_{n}=\frac{\phi \cdot\left(V_{c}+V_{s}\right)}{b_{0} \cdot d} \\
b_{0}=2 \cdot(300+300)+3 \cdot 148=1644 \mathrm{~mm}
\end{gathered}
$$

onde $V_{c}$ não deve exceder $0,25 \cdot \lambda \cdot \sqrt{f_{c}^{\prime}} \cdot b_{0} \cdot d$

$V_{c}=0,25 \cdot 1,0 \cdot \sqrt{48} \cdot 1644 \cdot 148=421,4 k N$

A contribuição da armadura de cisalhamento, quando se tem estribos verticais, é dada pela expressão:

$$
V_{s}=\frac{A_{v} \cdot f_{y} \cdot d}{s_{r}}=\frac{503 \cdot 420 \cdot 148}{100}=312,7 \mathrm{kN}
$$

$f_{y}$ não deve exceder 420,0MPa.

$\operatorname{Logo:} \phi \cdot v_{n}=\frac{\phi \cdot(421,4+312,7)}{1644 \cdot 148} \rightarrow v_{n}=3,02 M P a$

c) Capacidade resistente da laje ao cisalhamento:

A fração do momento transferido por excentricidade do cisalhamento da seção crítica é:

$$
\gamma_{v}=1-\frac{1}{1+(2 / 3) \cdot \sqrt{581,2 / 633,6}}=0,39
$$

O momento polar de inércia em relação ao eixo $e_{b}$ para a seção crítica afastada a $0,5 \cdot d$ do pilar será o mesmo da laje:

$$
I_{y}=6.849 .424 .383,0 \mathrm{~mm}^{4}
$$

Para simplificar: $M_{u}=V_{u} \cdot e$, em que $e$ é a excentricidade do carregamento total na laje igual a $352 \mathrm{~mm}$. 
A distância $c_{A B}$ será:

$c_{A B}=(300+148) \cdot(\sqrt{2} / 2)-25,4=291,4 \mathrm{~mm}$

O valor máximo de tensão de cisalhamento majorado pode ser calculado através de:

$$
\begin{gathered}
v_{u}(A B)=\frac{V_{u}}{b_{0} \cdot d}+\frac{\gamma_{v} \cdot V_{u} \cdot e \cdot c_{A B}}{J_{c}} \\
v_{u}(A B)=\frac{V_{u}}{1644 \cdot 148}+\frac{0,39 \cdot V_{u} \cdot 352 \cdot 291,4}{6849424383,0}=9,95 \cdot 10^{-6} \cdot V_{u}
\end{gathered}
$$

O dimensionamento de qualquer seção de concreto ao cisalhamento, incluindo o dimensionamento de uma ligação laje-pilar à punção, deve satisfazer a seguinte condição:

$$
\begin{gathered}
v_{u} \leq \phi \cdot v_{n} \\
9,95 \cdot 10^{-6} \cdot V_{R, c s}=3,02 \\
V_{R, c s}=303,5 \mathrm{kN}
\end{gathered}
$$

d) Resistência da laje na região externa à armadura de cisalhamento:

$$
\phi \cdot v_{n}=\frac{\phi \cdot V_{c, o u t}}{b_{\text {out }} \cdot d}
$$

Para a laje L02 $b_{\text {out }}=2722 \mathrm{~mm}$, medido no desenho desenvolvido no software AutoCAD.

$$
\begin{gathered}
V_{c, \text { out }}=\frac{1}{6} \cdot \lambda \cdot \sqrt{f_{c}^{\prime}} \cdot b_{\text {out }} \cdot d=\frac{1}{6} \cdot 1,0 \cdot \sqrt{48} \cdot 2722 \cdot 148=465,2 k N \\
\phi \cdot v_{n}=\frac{\phi \cdot 465,2}{2722 \cdot 148} \rightarrow v_{n}=1,16 \mathrm{MPa}
\end{gathered}
$$

O momento polar de inércia em relação ao eixo $e_{b}$ para a seção crítica afastada a $0,5 \mathrm{~d}$ da armadura de cisalhamento da laje será (Figura A.7): 


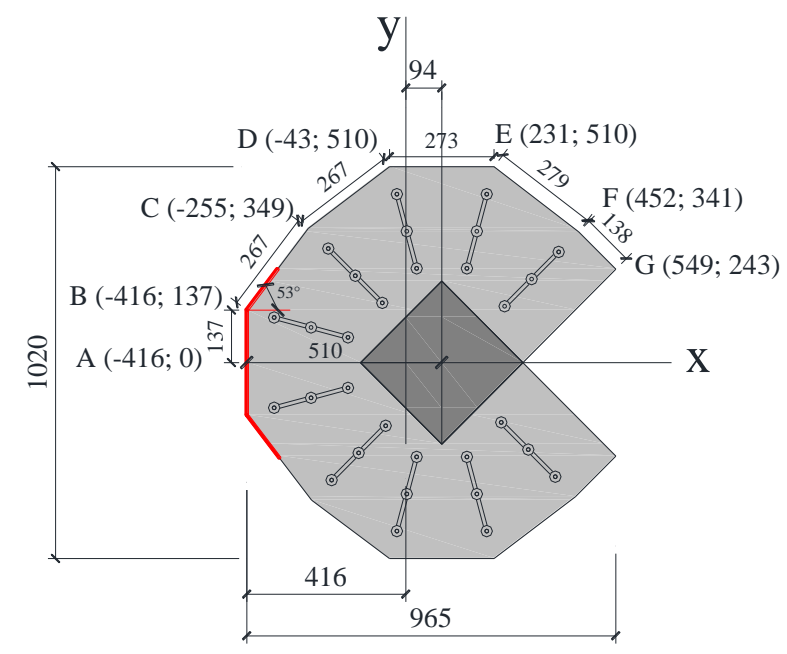

Figura A.7 - Propriedades do perímetro fora da armadura de cisalhamento para cálculo do momento polar de inércia.

- O momento do perímetro fora da armadura de cisalhamento é dado por:

$$
\begin{aligned}
& m_{l 1}=e_{1}^{*} \cdot s=510 \cdot 137=69870 \mathrm{~mm}^{2} \\
& e_{2}^{*}=510-\frac{2}{3} \cdot\left(\frac{267}{2} \cdot \operatorname{sen} .53^{\circ}\right)=439 \mathrm{~mm} \\
& m_{l 2}=e_{2}^{*} \cdot s=439 \cdot \frac{267}{2}=58596 \mathrm{~mm}^{2}
\end{aligned}
$$

- Cálculo de $e_{b, \text { out }}$, em mm: $e_{b, \text { out }}=\frac{m_{l}}{b_{\text {out }}}=\frac{2 \cdot(69870+58596)}{2722}=94 \mathrm{~mm}$.

O momento polar de inércia em relação ao eixo $e_{b}$ (centroide do perímetro crítico) pode ser aproximado para o momento de inércia pela equação dada abaixo:

$$
\begin{aligned}
I_{y}= & 2 \cdot 148 \cdot\left[\left(\frac{137}{3} \cdot\left(416^{2}+416 \cdot 416+416^{2}\right)\right)+\left(\frac{267}{3} \cdot\left(416^{2}+416 \cdot 255+255^{2}\right)\right)+\left(\frac{267}{3} \cdot\left(255^{2}+255 \cdot 43+43^{2}\right)\right)+\ldots\right. \\
& \left.+\left(\frac{273}{3} \cdot\left(43^{2}-43 \cdot 231+231^{2}\right)\right)+\left(\frac{279}{3} \cdot\left(231^{2}+231 \cdot 452+452^{2}\right)\right)+\left(\frac{138}{3} \cdot\left(452^{2}+452 \cdot 549+549^{2}\right)\right)\right] \\
& I_{y}=2 \cdot 148 \cdot\left(2,4 \cdot 10^{7}+3,1 \cdot 10^{7}+0,7 \cdot 10^{7}+0,35 \cdot 10^{7}+3,4 \cdot 10^{7}+3,5 \cdot 10^{7}\right)=4,0 \cdot 10^{10} \mathrm{~mm}^{4}
\end{aligned}
$$

O valor máximo de tensão de cisalhamento majorado pode ser calculado através de:

$$
v_{u}(A B)=\frac{V_{u}}{b_{\text {out }} \cdot d}+\frac{\gamma_{v} \cdot V_{u} \cdot e \cdot c_{A B}}{J_{c, \text { out }}}
$$




$$
\begin{gathered}
\gamma_{v, \text { out }}=1-\frac{1}{1+(2 / 3) \cdot \sqrt{965 / 1020}}=0,39 \\
v_{u}(A B)=\frac{V_{u}}{2722 \cdot 148}+\frac{0,39 \cdot V_{u} \cdot 352 \cdot 416}{4,0 \cdot 10^{10}}=3,9 \cdot 10^{-6} \cdot V_{u}
\end{gathered}
$$

O dimensionamento de qualquer seção de concreto ao cisalhamento, incluindo o dimensionamento de uma ligação laje-pilar à punção, deve satisfazer a seguinte condição:

$$
\begin{gathered}
v_{u} \leq \phi \cdot v_{n} \\
3,9 \cdot 10^{-6} \cdot V_{R, \text { out }}=1,16 \\
V_{R, \text { out }}=297,4 \mathrm{kN}
\end{gathered}
$$

A carga resistente à punção é a menor entre $V_{R, \text { out }}$ e $V_{R, c s}, \operatorname{logo} V_{R}=297,4 k N$.

\section{A.4: Estimativas de carga última pelo MC2010 (2013)}

A resistência à punção é calculada como:

$$
V_{R d}=V_{R d, c}+V_{R d, s} \geq V_{E d}
$$

A resistência à punção atribuída ao concreto pode ser obtida em função da altura efetiva da armadura de flexão para a direção x e y $\left(d_{v}\right)$ e do perímetro crítico $b_{0}$ :

$$
V_{R d, c}=\kappa_{\psi} \cdot \frac{\sqrt{f_{c}}}{\gamma_{c}} \cdot b_{0} \cdot d_{v}
$$

com $f_{c}$ em MPa.

O parâmetro $\kappa_{\psi}$ depende de deformações (rotações) da laje como mostra a equação a seguir:

$$
\kappa_{\psi}=\frac{1}{1,5+0,9 \cdot \psi \cdot d \cdot \kappa_{d g}} \leq 0,6
$$

onde:

$\psi$ : rotação da laje em torno do pilar;

$$
\kappa_{d g}=\frac{32}{16+d_{g}} \geq 0,75
$$


$\operatorname{com} d_{g}$ (diâmetro do agregado) em mm.

O efeito da concentração de tensões devido à transferência de momento entre a laje e a área carregada pode ser obtido aproximadamente multiplicando $b_{1, \text { red }}$ por um coeficiente de excentricidade $\kappa_{e}$ :

$$
b_{0}=\kappa_{e} \cdot b_{1, r e d}
$$

O coeficiente de excentricidade pode ser determinado em função do momento de transferência do pilar para a laje:

$$
\kappa_{e}=\frac{1}{1+e_{u} / b_{u}}
$$

onde $e_{u}$ é a excentricidade resultante da força de cisalhamento com respectivo centroide do perímetro crítico e $b_{u}$ é o diâmetro de um círculo com a mesma superfície da região dentro do perímetro crítico.

A contribuição da armadura de cisalhamento é calculada:

$$
V_{R d, s}=\sum A_{s w} \cdot \kappa_{e} \cdot \sigma_{s w} \cdot \sin \alpha
$$

com:

$$
\sigma_{s w d}=\frac{E_{s} \cdot \psi}{6} \cdot\left(\sin \alpha+\frac{f_{b d}}{f_{y w d}} \cdot \frac{d}{\phi_{w}}\right) \leq f_{y w d}
$$

onde:

$A_{s w}:$ área da seção transversal da armadura de cisalhamento;

$\kappa_{e}$ : fator de redução do perímetro crítico assumindo 0,9 para pilares internos; 0,7 para pilares de bordo e 0,65 para pilares de canto;

$\sigma_{s w}:$ tensão cuja armadura de cisalhamento tem capacidade para mobilizar;

$\alpha$ : ângulo entre as armaduras de cisalhamento e a laje;

$\phi_{w}:$ diâmetro da armadura de cisalhamento;

$f_{y w d}:$ tensão de escoamento;

$f_{b d}$ : tensão de flexão para barras nervuradas pode ser assumido como $3 \mathrm{MPa}$. 
Em lajes com armadura de cisalhamento a resistência mínima da armadura de cisalhamento de ser:

$$
\sum A_{s w} \cdot \kappa_{e} \cdot f_{y w d} \geq 0,5 \cdot V_{E d}
$$

A resistência à punção máxima é limitada pela resistência ao esmagamento do concreto ou área carregada:

$$
V_{R d, \max }=\kappa_{s y s} \cdot \kappa_{\psi} \cdot \frac{\sqrt{f_{c k}}}{\gamma_{c}} \cdot b_{0} \cdot d_{v} \leq \frac{\sqrt{f_{c k}}}{\gamma_{c}} \cdot b_{0} \cdot d_{v}
$$

O coeficiente $\kappa_{s y s}$ é 2,8 para studs, 2,4 para estribos comprimento de ancoragem suficiente e 2,0 pode ser adotado para outros casos.

O cálculo da rotação em torno do pilar na zona externa a ruptura $\psi$, pelo nível de aproximação II e III é respectivamente:

$$
\begin{aligned}
& \psi=1,5 \cdot \frac{r_{s}}{d} \cdot \frac{f_{y d}}{E_{s}} \cdot\left(\frac{m_{s d}}{m_{R d}}\right)^{1,5} \\
& \psi=1,2 \cdot \frac{r_{s}}{d} \cdot \frac{f_{y d}}{E_{s}} \cdot\left(\frac{m_{s d}}{m_{R d}}\right)^{1,5}
\end{aligned}
$$

O valor de $r_{s}$ corresponde à distância do centro do pilar até ao raio onde o momento fletor é nulo, sendo este valor aproximadamente $0,22 \cdot L_{x}$ ou $0,22 \cdot L_{y}$ em lajes regulares em que a razão dos vãos está entre 0,5 e 2,0. $E_{s}$ é o módulo de elasticidade do material das armaduras longitudinais.

$m_{R d}$ é a resistência à flexão média de projeto por unidade de comprimento numa faixa carregada (para a direção considerada).

No nível de aproximação II o valor de $m_{s d}$ (momento médio atuante por unidade de comprimento da armadura de flexão numa faixa) recomendado corresponde a:

- Para pilares reentrantes:

$$
m_{s d}=V_{E d} \cdot\left(\frac{1}{8}+\frac{\left|e_{u, i}\right|}{2 \cdot\left(b_{s} / 2+b_{s r} / 2\right)}\right)
$$


onde o termo $\left|e_{u, i}\right|$ refere-se à excentricidade da força de cisalhamento resultante com respectivo controle de perímetro básico na direção investigada.

A largura da faixa carregada ou analisada para o cálculo de $m_{s d}$ é:

$$
b_{s}=1,5 \cdot \sqrt{r_{s, x} \cdot r_{s, y}} \leq L_{\min }
$$

Para o nível III foi utilizado programa de análise linear SAP para obter a resistência à punção, em que se extraíram as relações de $V / m_{s d}$. Para obter o $M_{R d}$ foi considerando um $\rho$ (taxa de armadura de flexão) na menor direção para uma faixa de 1,25 m que corresponde a $b_{s} / 2+b_{s r} / 2$ (Figura A.8).

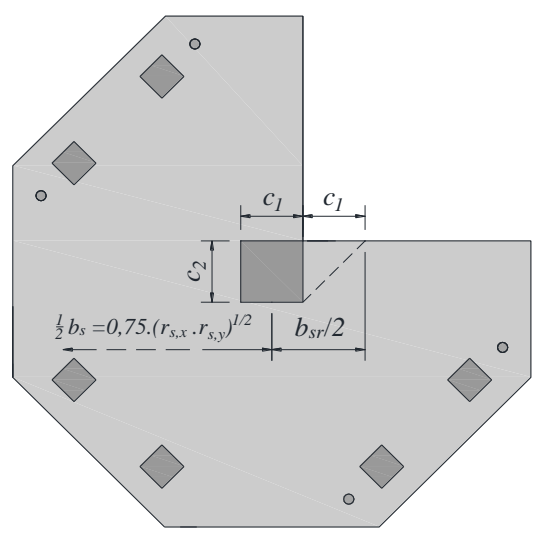

Figura A.8 - Dimensões da área carregada ou analisada para ligação laje pilar reentrante

A resistência à punção fora da armadura cisalhamento pode ser determinada como na expressão a seguir em um perímetro crítico com a distância máxima efetiva de $3 \cdot d_{v}$ entre dois elementos de reforço de cisalhamento:

$$
V_{R d, \text { out }}=\kappa_{\psi} \cdot \frac{\sqrt{f_{c k}}}{\gamma_{c}} \cdot b_{0, \text { out }} \cdot d_{v}
$$

A.4.1: Exemplo de cálculo da carga de ruptura à punção pelo MC2010 (2013).

\section{A.4.1.1: Laje L01}

A resistência à punção é calculada como:

$$
V_{R d}=V_{R d, c}+V_{R d, s} \geq V_{E d}
$$

Como a laje L01 não possui armadura de cisalhamento, $V_{R d}=V_{R d, c}$. 
A resistência à punção atribuída ao concreto será:

$$
\begin{gathered}
V_{R d, c}=\kappa_{\psi} \cdot \frac{\sqrt{f_{c}}}{\gamma_{c}} \cdot b_{0} \cdot d_{v} \\
\kappa_{d g}=\frac{32}{16+9,5}=1,25 \geq 0,75
\end{gathered}
$$

Cálculo de $e_{u}$, em mm.

A excentricidade do centroide de $b_{0}$ em relação ao centro do pilar é dada por:

$$
e_{u}=\frac{m_{l 1}}{b_{0}}
$$

- Propriedades geométricas do perímetro crítico normal $b_{0}$ :

Para um arco qualquer, são válidas as fórmulas, todas em mm (Figura A.9).

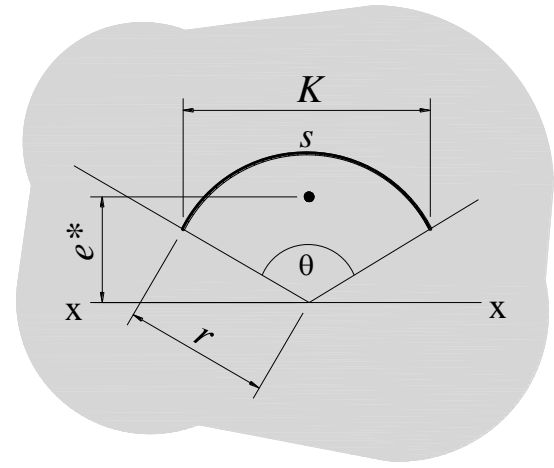

Figura A.9 - Propriedades de um arco genérico.

Comprimento de arco:

$$
s=2 \pi \cdot r \cdot\left(\frac{\theta}{360}\right)=2 \pi \cdot(0,5 \cdot 148) \cdot\left(\frac{90}{360}\right)=116,2 \mathrm{~mm}
$$

Comprimento de corda:

$$
K=2 r \cdot \sin \left(\frac{\theta}{2}\right)=2 \cdot(0,5 \cdot 148) \cdot \sin \left(\frac{90}{2}\right)=104,7 \mathrm{~mm}
$$

Distância do centro do círculo ao centroide do arco:

$$
e^{*}=\frac{r \cdot K}{s}=\frac{(0,5 \cdot 148) \cdot 104,7}{116,2}=66,7 \mathrm{~mm}
$$

Momento do arco em relação à xx :

$$
m_{x x}=r \cdot s=(0,5 \cdot 148) \cdot 116,2=8599 \mathrm{~mm}^{2}
$$

- Cálculo de $m_{l 1}$, em $\mathrm{mm}^{2}$.

O momento do perímetro $b_{0}$ em torno do eixo do pilar é dado por: 


$$
\begin{gathered}
m_{l 1}=\left(e^{*}+\frac{c \cdot \sqrt{2}}{2}\right) \cdot s=\left(66,7+\frac{300 \cdot \sqrt{2}}{2}\right) \cdot 116,2=32400,3 \mathrm{~mm}^{2} \\
b_{0}=4 \cdot 300+2 \pi \cdot \frac{3}{4} \cdot(0,5.148)=1549 \mathrm{~mm}
\end{gathered}
$$

- Cálculo de da excentricidade do perímetro $b_{0}$, em mm: $e_{b 0}=\frac{m_{l 1}}{b_{0}}=\frac{32400,3}{1549}=21,0 \mathrm{~mm}$

- Cálculo da excentricidade da carga em relação ao centroide de $b_{0}$ é dado por $e_{u}$, em mm:

$$
e_{u}=500-21,0=479,0 \mathrm{~mm}
$$

O coeficiente de excentricidade pode ser determinado em função do momento de transferência do pilar para a laje:

$$
\begin{gathered}
A_{b 0}=300 \cdot 300+2 \cdot 300 \cdot 148+\frac{3}{4} \cdot \frac{\pi \cdot 148^{2}}{4}=191703 \mathrm{~mm}^{2} \\
b_{u}=\left(\frac{191703 \cdot 4}{\pi}\right)^{0,5}=494 \mathrm{~mm} \\
\kappa_{e}=\frac{1}{1+479,0 / 494,0}=0,5 \\
b_{0}=0,5 \cdot 1549=775 \mathrm{~mm} \\
\kappa_{\psi}=\frac{1}{1,5+0,9 \cdot \psi \cdot 148 \cdot 1,25}=\frac{1}{1,5+166,5 \cdot \psi} \leq 0,6 \\
V_{R d, c}=\left(\frac{1}{1,5+166,5 \cdot \psi}\right) \cdot \frac{\sqrt{48}}{1,4} \cdot 775 \cdot 148=567612 \cdot\left(\frac{1}{1,5+166,5 \cdot \psi}\right)
\end{gathered}
$$

A resistência à punção máxima é limitada pela resistência ao esmagamento do concreto ou área carregada:

$$
\begin{aligned}
& V_{R d, \max }=2,8 \cdot\left(\frac{1}{1,5+166,5 \cdot \psi}\right) \cdot \frac{\sqrt{48}}{1,4} \cdot 775 \cdot 148 \leq \frac{\sqrt{48}}{1,4} \cdot 775 \cdot 148 \\
& V_{R d, \text { max }}=1589330 \cdot\left(\frac{1}{1,5+166,5 \cdot \psi}\right) \leq 567,6 \mathrm{kN}
\end{aligned}
$$

O cálculo da rotação em torno do pilar na zona externa a ruptura $\psi$, pelo nível de aproximação II é:

$$
\psi=1,5 \cdot \frac{105}{148} \cdot \frac{558}{192} \cdot\left(\frac{m_{s d}}{m_{R d}}\right)^{1,5}
$$


Para calcular o momento resistente na faixa $1,25 \mathrm{~m}$ foi necessário recalcular a taxa de armadura de flexão, pois próximo ao pilar a armadura era mais concetrada. Utilizando a expressão:

$$
m_{R d}=\rho \cdot d^{2} \cdot f_{y} \cdot\left(1-\frac{\rho \cdot f_{y}}{2 \cdot f_{c}}\right)
$$

Em que $\rho_{x}=1,72 \%$

$$
m_{R d}=0,0172 \cdot 140^{2} \cdot 558 \cdot\left(1-\frac{0,0172 \cdot 558}{2 \cdot 48}\right)=169,3 \mathrm{kN} \cdot \mathrm{mm} / \mathrm{mm}
$$

No nível de aproximação II o valor de $m_{s d}$ (momento médio atuante por unidade de comprimento da armadura de flexão numa faixa) recomendado corresponde a:

$$
m_{s d}=V_{E} \cdot\left(\frac{1}{8}+\frac{479}{2 \cdot(788+450)}\right)=0,32 \cdot V_{E}
$$

A largura da faixa carregada ou analisada para o cálculo de $m_{s d}$ é:

$$
\begin{gathered}
b_{s}=1,5 \cdot \sqrt{1050 \cdot 1050}=1575 \mathrm{~mm} \leq L_{\min } \\
b_{s r}=300+2 \cdot 300=900 \mathrm{~mm} \\
\psi=1,5 \cdot \frac{1050}{148} \cdot \frac{558}{192} \cdot\left(\frac{0,32 \cdot V_{E}}{169,3}\right)^{1,5}
\end{gathered}
$$

Foi utilizada a ferramenta macro do Excel para fazer um processo interativo até que a relação $V_{E} / V_{R, c}$ fosse igual a 1,0 .

Logo, a resistência ao cisalhamento é: $V_{R, c}=253,4 k N$.

E a resistência máxima é: $V_{R d, \text { max }}=998,3 k N$.

\section{A.4.1.2: Laje L02}

A resistência à punção é calculada como:

$$
V_{R d}=V_{R d, c}+V_{R d, s} \geq V_{E d}
$$


A resistência à punção atribuída ao concreto será:

$$
\begin{gathered}
V_{R d, c}=\kappa_{\psi} \cdot \frac{\sqrt{f_{c}}}{\gamma_{c}} \cdot b_{0} \cdot d_{v} \\
\kappa_{d g}=\frac{32}{16+9,5}=1,25 \geq 0,75
\end{gathered}
$$

A excentricidade do perímetro $b_{0}$, em mm: $e_{b 0}=21,6 m m$ (semelhante ao da laje L01)

- Cálculo da excentricidade da carga em relação ao centroide de $b_{0}$ é dado por $e_{u}$, em mm:

$$
e_{u}=352-21,0=331,0 \mathrm{~mm}
$$

O coeficiente de excentricidade pode ser determinado em função do momento de transferência do pilar para a laje:

$$
\begin{gathered}
b_{u}=494 \mathrm{~mm} \\
\kappa_{e}=\frac{1}{1+331,0 / 494}=0,6 \\
b_{0}=0,6 \cdot 1549=929,4 \mathrm{~mm} \\
\kappa_{\psi}=\frac{1}{1,5+0,9 \cdot \psi \cdot 148 \cdot 1,25}=\frac{1}{1,5+166,5 \cdot \psi} \leq 0,6 \\
V_{R d, c}=\left(\frac{1}{1,5+166,5 \cdot \psi}\right) \cdot \frac{\sqrt{48}}{1,4} \cdot 929,4 \cdot 148=680102 \cdot\left(\frac{1}{1,5+166,5 \cdot \psi}\right)
\end{gathered}
$$

A contribuição da armadura de cisalhamento é calculada:

$$
V_{R d, s}=\sum 503 \cdot 0,6 \cdot 587=177,2 k N \geq 0,5 \cdot V_{E d}
$$

A resistência à punção máxima é limitada pela resistência ao esmagamento do concreto ou área carregada:

$$
\begin{aligned}
& V_{R d, \max }=2,8 \cdot\left(\frac{1}{1,5+166,5 \cdot \psi}\right) \cdot \frac{\sqrt{48}}{1,4} \cdot 929,4 \cdot 148 \leq \frac{\sqrt{48}}{1,4} \cdot 929,4 \cdot 148 \\
& V_{R d, \max }=1905965 \cdot\left(\frac{1}{1,5+166,5 \cdot \psi}\right) \leq 680,7 \mathrm{kN}
\end{aligned}
$$

O cálculo da rotação em torno do pilar na zona externa a ruptura $\psi$, pelo nível de aproximação II é:

$$
\psi=1,5 \cdot \frac{r_{s}}{d} \cdot \frac{f_{y d}}{E_{s}} \cdot\left(\frac{m_{s d}}{m_{R d}}\right)^{1,5}
$$


O momento resistente é semelhante ao da laje L01:

$$
m_{R d}=169,3 \mathrm{kN} \cdot \mathrm{mm} / \mathrm{mm}
$$

No nível de aproximação II o valor de $m_{s d}$ (momento médio atuante por unidade de comprimento da armadura de flexão numa faixa) recomendado corresponde a:

$$
m_{s d}=V_{E} \cdot\left(\frac{1}{8}+\frac{331}{2 \cdot(788+450)}\right)=0,26 \cdot V_{E}
$$

A largura da faixa carregada ou analisada para o cálculo de $m_{s d}$ é:

$$
\begin{gathered}
b_{s}=1,5 \cdot \sqrt{1050 \cdot 1050}=1575 \mathrm{~mm} \leq L_{\min } \\
b_{s r}=300+2 \cdot 300=900 \mathrm{~mm} \\
\psi=1,5 \cdot \frac{1050}{148} \cdot \frac{558}{192} \cdot\left(\frac{0,26 \cdot V_{E}}{169,3}\right)^{1,5}
\end{gathered}
$$

A resistência à punção fora da armadura cisalhamento é ( $b_{0, \text { out }}$ foi medido no AutoCAD)

$$
V_{R d, \text { out }}=\left(\frac{1}{1,5+166,5 \cdot \psi}\right) \cdot \frac{\sqrt{48}}{1,4} \cdot 2722 \cdot 148=1993620 \cdot\left(\frac{1}{1,5+166,5 \cdot \psi}\right)
$$

Foi utilizada a ferramenta macro do Excel para fazer um processo interativo até que a relação $V_{E} / V_{R}$ fosse igual a 1,0 .

A resistência à punção no perímetro crítico $b_{0}$ é $V_{R, c s}=411,4 k N$.

A resistência à punção fora da armadura cisalhamento é: $V_{R, o u t}=689,2 \mathrm{kN}$.

A resistência máxima é: $V_{R d, \max }=784,2 k N$.

Logo a resistência à punção é $V_{R, c s}=411,4 k N$, menor resistência entre as calculadas. 